\title{
Władysław Jóźwicki
}

Ochrona wyższego niż unijny konstytucyjnego standardu prawa jednostki

i tożsamości konstytucyjnej RP

\section{Trybunał Konstytucyjny}

a Trybunał Sprawiedliwości Unii Europejskiej: ku sekwencji a nie hierarchii orzekania

Wydawnictwo Naukowe UAM 
Ochrona wyższego niż unijny

konstytucyjnego standardu

prawa jednostki

i tożsamości konstytucyjnej RP 

UNIWERSYTET IM. ADAMA MICKIEWICZA W POZNANIU SERIA PRAWO NR 330

WŁADYSŁAW JÓŹWICKI

\section{Ochrona wyższego niż unijny konstytucyjnego standardu prawa jednostki i tożsamości konstytucyjnej RP}

Trybunał Konstytucyjny a Trybunał Sprawiedliwości Unii Europejskiej: ku sekwencji a nie hierarchii orzekania

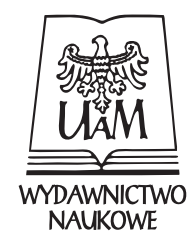

POZNAŃ 2019 


\section{Recenzenci:}

dr hab. Aleksandra Kustra-Rogatka, UMK

prof. dr hab. Krzysztof Wójtowicz, UWr

Publikacja sfinansowana przez

Wydział Prawa i Administracji Uniwersytetu im. Adama Mickiewicza w Poznaniu

(C) Władysław Jóźwicki 2019

This edition (c) Uniwersytet im. Adama Mickiewicza w Poznaniu, Wydawnictwo Naukowe UAM, Poznań 2019

Projekt okładki

Helena Oszmiańska

Redaktor

Adam Pielachowski

Projekt typograficzny i łamanie komputerowe

Reginaldo Cammarano

ISBN 978-83-232-3490-6

ISSN 0083-4262

WYDAWNICTWO NAUKOWE UNIWERSYTETU IM. ADAMA MICKIEWICZA W POZNANIU 61-701 POZNAŃ, UL. ALEKSANDRA FREDRY 10

www.press.amu.edu.pl

Sekretariat: tel. 6182946 46, faks 6182946 47, e-mail: wydnauk@amu.edu.pl

Dział Promocji i Sprzedaży: tel. 6182946 40, e-mail: press@amu.edu.pl

Wydanie I. Ark. wyd. 37,00 Ark. druk. 31,875

DRUK I OPRAWA: VOLUMINA.PL DANIEL KRZANOWSKI, SZCZECIN, UL. KS. WITOLDA 7-9 


\section{Spis treści}

Wykaz skrótów $\ldots \ldots \ldots \ldots \ldots \ldots \ldots \ldots \ldots \ldots \ldots \ldots \ldots \ldots \ldots \ldots \ldots \ldots \ldots \ldots \ldots$

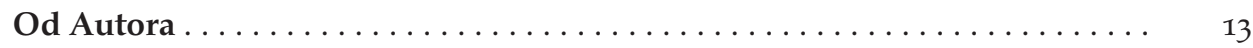

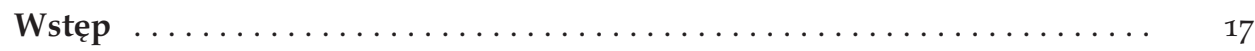

\section{RozDZiAŁ I}

Zakres zastosowania unijnych praw podstawowych wobec państw członkowskich i stanowionego przez nie prawa w świetle orzecznictwa TSUE . . 31

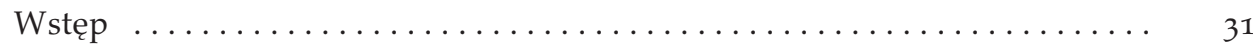

1. Pojęcie stosowania prawa ugruntowane w polskiej tradycji prawnej i jego nieprzystawalność do realiów UE i wykładni art. 51 ust. 1 Karty . . . . .

2. Art. 51 ust. 1 Karty i zakres jej zastosowania wobec państw członkowskich Unii w innych niż polska wersjach językowych Karty . . . . . . . . . .

3. Alternatywne propozycje brzmienia art. 51 ust. 1 Karty pojawiające się w travaux préparatoires . . ...................................... 41

4. Wyjaśnienia dotyczące Karty Praw Podstawowych ............... 44

5. Zakres zastosowania unijnych praw podstawowych wobec państw członkowskich przed wejściem w życie Karty $\ldots \ldots \ldots \ldots \ldots \ldots \ldots \ldots \ldots \ldots \ldots$

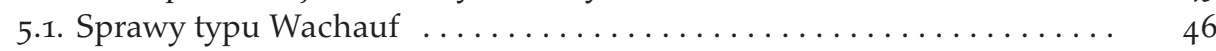

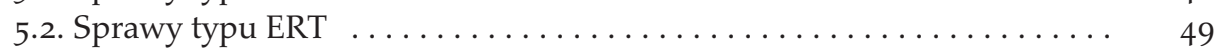

5.3. Innego rodzaju łącznik z prawem unijnym $\ldots \ldots \ldots \ldots \ldots \ldots \ldots \ldots \ldots$

5.4. Typy sytuacji, w których unijne prawa podstawowe znajdowały zastosowanie wobec państw członkowskich .............. 61

6. Zakres zastosowania unijnych praw podstawowych do państw członkowskich po wejściu w życie Karty na gruncie jej art. 51 ust. $1 \ldots \ldots \ldots \ldots \ldots 62$

6.1. Propozycje dotyczące rozszerzenia zakresu zastosowania unijnych praw podstawowych wobec państw członkowskich .............

6.2. Pierwsze przykłady zastosowania art. 51 ust. 1 Karty po jej wejściu w ży-

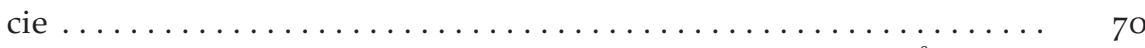

6.3. Pierwsza systemowa interpretacja art. 51 ust. 1 Karty. Sprawa Åkerberg

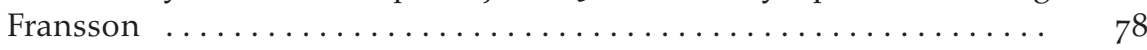


6.3.1. Stanowisko Rzecznika Generalnego Pedra Cruz Villalóna ....

6.3.2. Stanowisko TSUE . . . . . . . . . . . . . . . .

6.3.3. Niektóre inne konsekwencje wyroku w sprawie Åkerberg Fransson i podejścia TSUE do kwestii związania państw członkowskich unijnymi prawami podstawowymi $\ldots \ldots \ldots \ldots \ldots \ldots$

6.3.3.1. Objęcie krajowej regulacji unijnymi prawami podstawowymi a pierwszeństwo, jedność i efektywność prawa Unii

6.3.3.2. Autonomiczność relacji między krajowymi porządkami prawnymi a systemem EKPCz $\ldots \ldots \ldots \ldots \ldots \ldots$

6.3.3.3. Obowiązek zastosowania i ewentualnego wyjaśnienia znajdującego zastosowanie w sprawie krajowej unijnego standardu ochrony praw podstawowych .........

6.4. Ugruntowywanie podejścia do rozumienia art. 51 ust. 1 Karty . . . . . . .

6.4.1. Przykłady ugruntowywania podejścia do rozumienia art. 51 ust. 1

Karty w sprawach typu Wachauf $\ldots \ldots \ldots \ldots \ldots \ldots \ldots \ldots$

6.4.2. Przykłady ugruntowywania podejścia do rozumienia art. 51 ust. 1

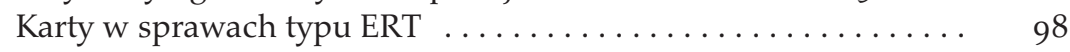

6.4.3. Przykłady ugruntowywania podejścia do rozumienia art. 51 ust. 1

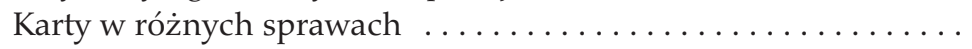

6.4.3.1. Sprawy dotyczące obywatelstwa unijnego . . . . . . . . .

6.4.3.2. Sprawy dotyczące kompetencji Unii. Cel regulacji unijnej i krajowej - znaczenie zasady efektywności prawa unij-

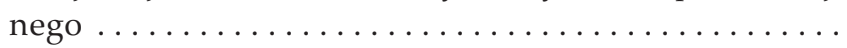

6.4.3.3. Dalsze przykłady ugruntowywania podejścia do rozumie-

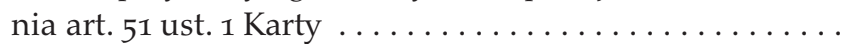

92

93

96

96

101

103

107

119

7. Przykłady innych niż art. 51 ust. 1 zd. pierwsze Karty okoliczności wykluczających zastosowanie unijnych praw podstawowych wobec państw człon-

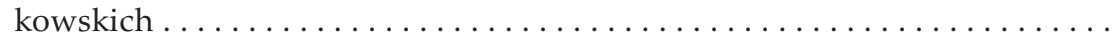

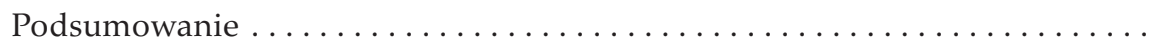

\section{RozDZIAE II}

Stosowanie unijnych praw podstawowych przez polskie sądy i funkcja tych sądów w unijnym systemie ochrony praw podstawowych . . . . . . .

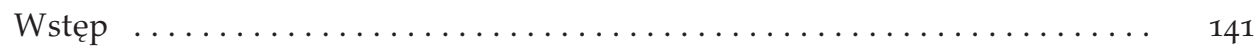

1. Protokół brytyjsko-polski i jego znaczenie dla stosowania Karty w Polsce . 143

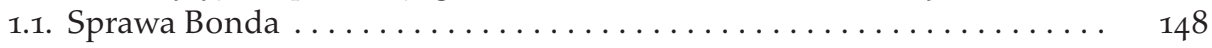

1.2. Sprawa N.S. . . . . . . . . . . . . . . . . . . . . 157

1.3. Praktyka sądów polskich a Protokół $n r z 0 \ldots \ldots \ldots \ldots \ldots \ldots \ldots$

1.4. Znaczenie Protokołu nr 30 dla stosowania Karty w Polsce ......... 164

2. Stosowanie Karty Praw Podstawowych przez sądy polskie . . . . . . . . 172

2.1. Stosowanie Karty przez sądy administracyjne . . . . . . . . . . . 175

2.2. Stosowanie Karty przez sądy powszechne .............. 180 
2.3. Stosowanie Karty przez Sąd Najwyższy $\ldots \ldots \ldots \ldots \ldots \ldots \ldots \ldots$

2.4. Pytania prejudycjalne sądów polskich dotyczące praw podstawowych $\quad 194$

2.4.1. Sprawa Leśniak-Jaworska i Głuchowska-Szmulewicz . . . . . . . . 195

2.4.2. Sprawa Pańczyk ........................ 196

2.4.3. Sprawa Stylinart . . . . . . . . . . . . . . . . . . . . 197

2.4.4. Sprawa Grodecka ....................... 200

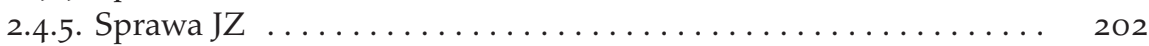

2.4.6. Sprawa El Hassani . . . . . . . . . . . . . . . . . 203

2.5. Nieprawidłowości w stosowaniu Karty przez sądy polskie. Niebezpie-

czeństwo jej niestosowania w sytuacjach tego wymagających ......

3. Rola sądów polskich jako sądów unijnych w procesie stosowania odpowiednich standardów ochrony praw człowieka . . . . . . . . . . . .

3.1. Znaczenie zasady pierwszeństwa prawa unijnego a rola sądów krajowych i ich relacja z TSUE i sądami konstytucyjnymi ...........

3.2. Doniosłość poprawnego i zniuansowanego stosowania przez sądy krajowe unijnych praw podstawowych w kontekście konstytucyjnej ochrony

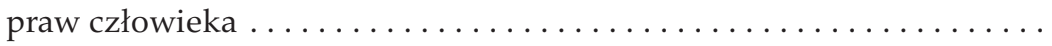

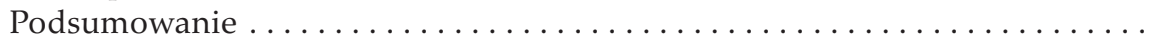

\section{RozDziat III}

Trybunał Konstytucyjny i kontrola prawa obowiązującego w Polsce przez pryzmat zgodności z gwarancjami praw i wolności człowieka w kontekście unijnym

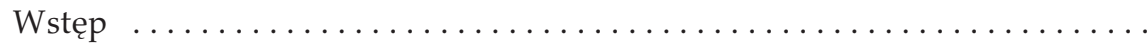

1. Stosowanie Karty Praw Podstawowych przez Trybunał Konstytucyjny . . . .

1.1. Stosunek TK do Karty zanim ta uzyskała moc prawną ...........

1.2. Zmiana stosunku TK do Karty po tym, gdy uzyskała moc prawną ....

1.3. Potencjalne znaczenie Karty w postępowaniach przed TK . . . . . . . . .

2. TK wobec konfliktu między prawem unijnym a Konstytucją RP . . . . . . . 2.1. Kontrola konstytucyjności prawa pierwotnego UE ............

2.2. Kontrola konstytucyjności prawa polskiego mieszczącego się w zakresie zastosowania prawa unijnego . . . . . . . . . . . . . .

2.2.1. Prawo polskie mieszczące się w zakresie zastosowania prawa unijnego jako prawo polskie tout court ...............

2.2.2. Prawo polskie transponujace prawo unijne a znaczenie unijnych wzorców kontroli. Pierwsze pytanie prejudycjalne skierowane przez TK do TSUE . . . . . . . . . . . . . . . . .

2.2.3. Konsekwencje kontroli konstytucyjności prawa polskiego mieszczącego się w zakresie zastosowania prawa unijnego dla zgodnego z Kartą stosowania unijnych praw podstawowych .........

2.3. Kontrola konstytucyjności bezpośrednio skutecznego prawa pochodnego UE pod kątem zgodności z konstytucyjnymi gwarancjami praw

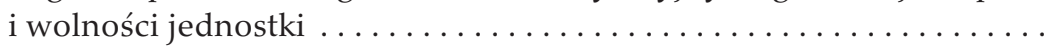


2.4. Skutki orzeczenia TK o niezgodności prawa pochodnego UE z prawami i wolnościami zagwarantowanymi w Konstytucji RP . . . . . . . . .

2.4.1. Zasada pierwszeństwa prawa UE w prawie unijnym i jej odzwierciedlenie w Konstytucji . . . . . . . . . . . . . . . . 280

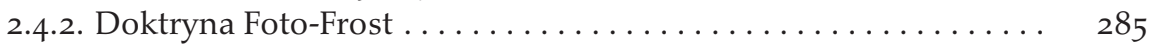

2.4.3. Niedopuszczalność stosowania w Polsce prawa pochodnego UE w związku z jego niezgodnością z Konstytucją . . . . . . . .

3. Pytanie prejudycjalne do TSUE jako jedna z metod niekonfliktowego rozstrzygnięcia potencjalnej kolizji między unijnym a wyższym niż unijny konstytucyjnym standardem ochrony praw jednostki $\ldots \ldots \ldots \ldots \ldots \ldots$

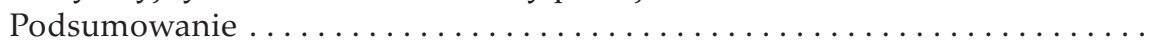

\section{RozDZIAE IV}

Dialog między TK a TSUE w przedmiocie poszanowania tożsamości konstytucyjnej RP i składającego się na nią wyższego niż unijny konstytucyjnego standardu ochrony praw człowieka

Wstęp

1. Powołanie się w pytaniu prejudycjalnym do TSUE na tożsamość konstytucyjną RP

1.1. Tożsamość konstytucyjna z perspektywy Konstytucji RP i orzecznictwa TK

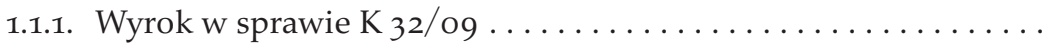

1.1.2. Wewnętrzne znaczenie tożsamości konstytucyjnej RP (dla krajowego systemu prawnego) i zewnętrzne znaczenie tożsamości konstytucyjnej RP (w ramach systemu unijnego) . . . . . . . .

1.2. Tożsamość narodowa/konstytucyjna z perspektywy prawa unijnego

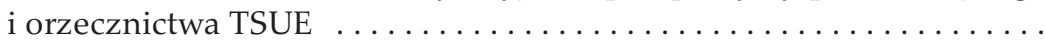

1.2.1. Sprawa Omega . . . . . . . . . . . . . . . . . . .

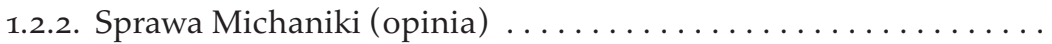

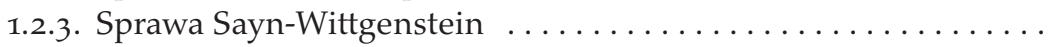

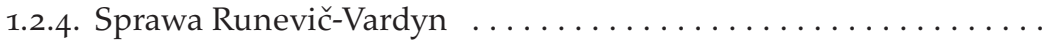

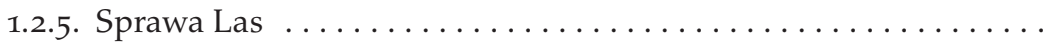

1.2.6. Sprawa Bogendorff von Wolffersdorff ...............

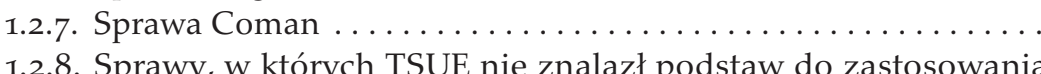

1.2.8. Sprawy, w których TSUE nie znalazł podstaw do zastosowania przepisów dotyczących poszanowania tożsamości narodowej/ konstytucyjnej państw członkowskich ............. 1.2.8.1. Pierwsze przykłady odwołania się TSUE do obowiązku poszanowania przez Unię tożsamości narodowej/konstytucyjnej państw członkowskich ..............

1.2.8.2. Przykłady odwołania się TSUE do obowiązku poszanowania przez Unię tożsamości narodowej/konstytucyjnej państw członkowskich na gruncie art. 4 ust. 2 TUE ..... 
1.2.9. Pytania prejudycjalne trybunałów konstytucyjnych państw członkowskich dotyczące obowiązku poszanowania tożsamości naro-

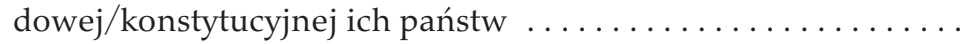

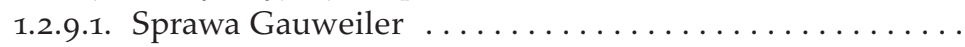
370

1.2.9.2. Saga Taricco na tle sagi Landtová i sprawy Ajos ......

1.2.10. Obowiązek poszanowania przez Unię tożsamości konstytucyjnej państw członkowskich i jego dotychczasowe oraz potencjalne

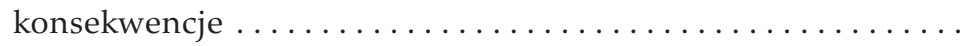

1.3. Art. 4 ust. 2 TUE jako wyjątek od rozumienia art. 53 Karty przedstawionego przez TSUE w sprawie Melloni . . . . . . . . . . . . .

1.3.1. Sprawa Melloni i unijny standard ochrony praw człowieka jako standard maksymalny w zakresie zastosowania prawa unij-

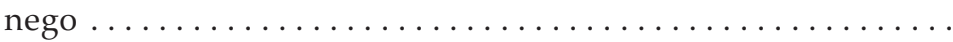

1.3.2. Sprawa Melloni a możliwość powołania się na tożsamość konstytucyjną dla realizacji wyższego niż unijny krajowego standardu ochrony praw człowieka $\ldots \ldots \ldots \ldots \ldots \ldots \ldots \ldots \ldots \ldots \ldots \ldots$

1.3.3. Wyjątki od rozumienia art. 53 Karty a inne przepisy unijnego pra-

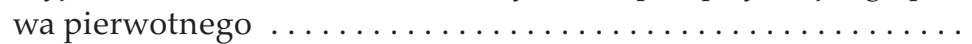

2. Ochrona praw człowieka jako dopuszczalny wyjątek od zasady wzajemnego

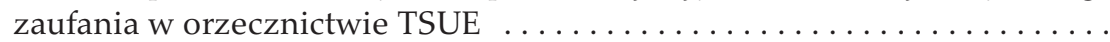

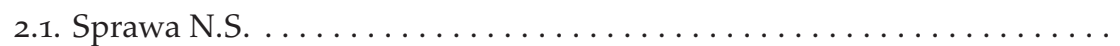

2.2. Sprawa Pál Aranyosi i Robert Căldăraru $\ldots \ldots \ldots \ldots \ldots \ldots \ldots \ldots$

3. Szczególna rola sądów w mechanizmie sekwencyjnego dialogu między TK a TSUE umożliwiającego zapewnienie przestrzegania w Polsce wyższego niż unijny konstytucyjnego standardu ochrony praw człowieka . . . . . . .

3.1. Rola sądów w mechanizmie sekwencyjnego dialogu odnośnie do prawa polskiego mieszczącego się w zakresie zastosowania prawa unijnego .

3.2. Rola sądów w mechanizmie sekwencyjnego dialogu odnośnie do bezpośrednio skutecznego pochodnego prawa unijnego . . . . . . . . . .

3.3. Potencjalna rola innych organów w obliczu ewentualnych trudności ze stosowaniem sekwencyjnego mechanizmu orzekania o tożsamości

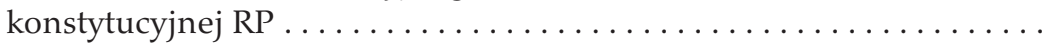

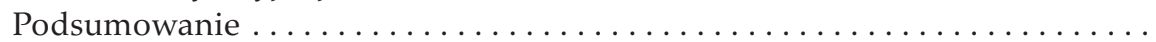

Zakończenie

406

406

410

Orzecznictwo

A. Polskie sądy i trybunały

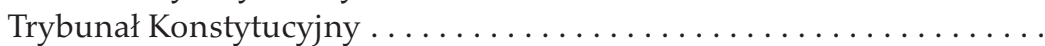

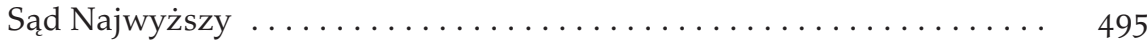

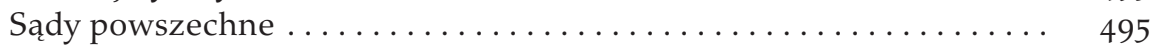

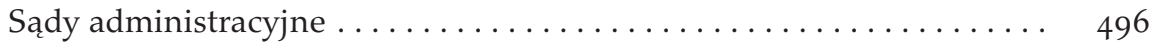




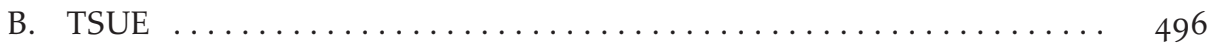

Trybunał Sprawiedliwości UE .......................... 496

Są UE ..................................... 502

Opinie Rzeczników Generalnych TSUE ................ 502

C. Europejska Komisja Praw Człowieka . . . . . . . . . . . . . . . . . . 504

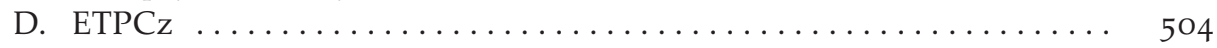

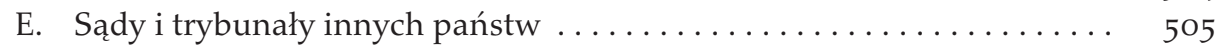

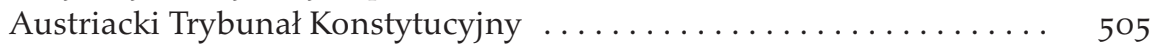

Belgijski Trybunał Konstytucyjny ..................... 505

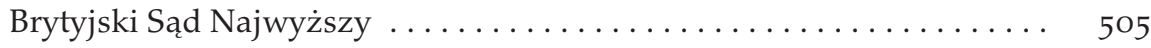

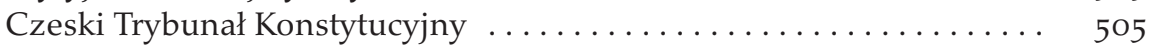

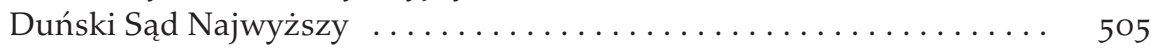

Francuska Rada Konstytucyjna ....................... 505

Hiszpański Trybunał Konstytucyjny $\ldots \ldots \ldots \ldots \ldots \ldots \ldots \ldots \ldots . \ldots \ldots$

Niemiecki Federalny Trybunał Konstytucyjny $\ldots \ldots \ldots \ldots \ldots \ldots . \quad 505$

Węgierski Trybunał Konstytucyjny ..................... 506

Włoski Trybunał Konstytucyjny ..................... 506

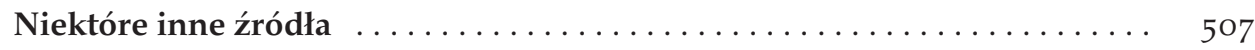

Summary (Protection of a Constitutional Fundamental Rights Standard Higher than European Union's and of Polish Constitutional Identity. Constitutional Tribunal and Court of Justice of the European Union: From a Hierarchical Towards a Sequential Model of Adjudication ...................... 


\title{
Wykaz skrótów
}

\author{
Dz.U. - - Dziennik Ustaw \\ Dz.Urz. $\quad$ - Dziennik Urzędowy (UE i wcześniej WE) \\ EBC - Europejski Bank Centralny \\ EFSF - Europejski Instrument Stabilności Finansowej \\ EFSM - Europejski Mechanizm Stabilizacji Finansowej \\ EKPCz/Konwencja \\ (także: EKPC) - Europejska Konwencja Praw Człowieka (właściwie: Konwencja \\ o ochronie praw człowieka i podstawowych wolności) \\ EMS - Europejski Mechanizm Stabilności \\ ENA - Europejski nakaz aresztowania \\ ETPCz $\quad-$ Europejski Trybunał Praw Człowieka \\ ESP - peseta hiszpańska \\ ETS - Europejski Trybunał Sprawiedliwości \\ FTK/BVerfG _ - (Niemiecki) Federalny Trybunał Konstytucyjny \\ FUE $\quad$ - (Traktat o) Funkcjonowaniu Unii Europejskiej \\ Kpk - Kodeks postępowania karnego \\ KPP/Karta - Karta Praw Podstawowych Unii Europejskiej \\ MPPGSiK - Międzynarodowy Pakt Praw Gospodarczych, Społecznych i Kultu- \\ ralnych \\ MPPOiP — - Międzynarodowy Pakt Praw Obywatelskich i Politycznych \\ NSA - Naczelny Sąd Administracyjny \\ OMT _ - Outright Monetary Transactions \\ RP $\quad-$ Rzeczpospolita Polska \\ SN $\quad$ - Sąd Najwyższy \\ TFUE - Traktat o funkcjonowaniu Unii Europejskiej \\ TK - - Trybunał Konstytucyjny \\ TL - - Traktat lizboński \\ TS - - Trybunał Sprawiedliwości (UE) \\ TSUE - Trybunał Sprawiedliwości Unii Europejskiej \\ TUE - Traktat o Unii Europejskiej \\ UE/Unia - Unia Europejska \\ VAT - value-added tax (podatek od wartości dodanej) \\ WE - Wspólnoty Europejskie \\ WSA - Wojewódzki Sąd Administracyjny
}





\section{Od Autora}

Whosoever hath an absolute authority to interpret any written or spoken laws, it is he who is truly the law-giver to all intents and purposes and not the person who first wrote or spoke them.

Bishop Benjamin Hoadly (1676-1761) (Dictum, 1717)

U nia Europejska u swego zarania nie była organizacja praw człowieka. Te, na poziomie europejskim, pozostawiono Radzie Europy. W wymiarze krajowym prawa człowieka po doświadczeniach drugiej wojny światowej stały się natomiast fundamentem europejskiego konstytucjonalizmu, z pewnym opóźnieniem (jak całego naszego regionu) również polskiego. Z czasem także prawo unijne zaczęło coraz silniej rozpoznawać i orientować się wokół gwarancji praw człowieka, najpierw dzięki orzecznictwu TSUE, który, w dużej mierze pod naciskiem sądów konstytucyjnych państw członkowskich, uniósł je do rangi zasad ogólnych prawa Unii. Od blisko dekady zagwarantowane są natomiast one w równej rangą traktatom Karcie Praw Podstawowych Unii Europejskiej.

W ostatnich latach wokół problematyki praw jednostki zogniskował się spór o charakterze konstytucyjnym. Dotyczył on relacji między prawem unijnym i krajowym, gdzie na szalach stawały zasada pierwszeństwa prawa Unii, jak chciał widzieć ją TSUE, i zasada prymatu konstytucji, na straży której stoją sądy konstytucyjne. Doprowadziło to do powstania różnych koncepcji orzeczniczych, jak włoskie controlimiti czy niemieckie Solange. Pojawienie się w prawnym porządku Unii Karty Praw Podstawowych i sposób, w jaki jej przepisy intepretuje TSUE, zintensyfikowało konflikt, szczególnie w wymiarze potencjalnej kolizji między unijnym i krajowym standardem ochrony praw człowieka w sytuacji, gdy standard krajowy byłby wyższy.

${ }^{1}$ Cyt. za: R.M. Dallen, An Overview of European Community Protection of Human Rights, with Some Special References to the U.K., "Common Market Law Review” 1990, nr 27 (4), s. 761. 
Kwestia ta ponownie wprowadziła TSUE i krajowe sądy konstytucyjne, w tym (choć przynajmniej na razie nie w sposób otwarty) polski TK, na kolizyjną ścieżkę. Stała się podstawą fali orzeczeń, które można sklasyfikować jako swoisty, pełzający bunt sądów konstytucyjnych przeciwko TSUE i prawu unijnemu, a szczególnie przeciwko ekspansji unijnych standardów ochrony praw jednostki. Polski TK wpisał się w tę tendencję, adoptując koncepcję możliwej kontroli działań Unii i stanowionego przez nią prawa w ramach tzw. doktryny ultra vires i zapowiadając skorzystanie $z$ niej w razie potrzeby.

Ten kolizyjny kurs, na którym znalazły się, a w ostatnich latach zaczęły przyspieszać, TSUE i sądy konstytucyjne państw członkowskich, szczególnie w obliczu kryzysu, w jakim znalazła się Unia, legł u podstaw zainteresowania badawczego w rozprawie doktorskiej, której uaktualnioną wersję stanowi niniejsza książka. Badaniom tym przyświecała chęć znalezienia odpowiedzi na pytanie, czy pęd ku owej kolizji można, jeśli nie całkowicie zatrzymać, to chociaż spowolnić albo znaleźć bocznicę, dzięki której przynajmniej niektórych kolizji można by uniknąć, przy jak najdalej idącym poszanowaniu dla prawa unijnego i jego specyfiki, jak i dla prawa krajowego i jego specyfiki. Przedmiotem badania nie było całe szerokie spektrum porządków konstytucyjnych państw członkowskich, lecz polska perspektywa konstytucyjna. Wydaje się jednak, że znaleziona na tym gruncie odpowiedź może mieć zastosowanie w szerszej skali, również na gruncie systemów konstytucyjnych innych państw członkowskich Unii.

Pojęciem centralnym dla rozważań zawartych w tej pracy jest pojęcie tożsamości konstytucyjnej. Pojęcie to w ostatnich latach było odmieniane w orzecznictwie i literaturze przez wszystkie przypadki. Ostatnio jest ono coraz mniej popularne, gdyż przede wszystkim na podstawie orzecznictwa krajowych sądów konstytucyjnych, traktowane bywa jako zagrożenie dla integracji europejskiej. Krytycy tego pojęcia zdają się jednak nie dostrzegać jego pozytywnego potencjału, którego próbę ukazania podjęto w tej pracy. Pojęcie to, jeszcze zanim zostało spopularyzowane w kontekście integracji unijnej, już miało złą prasę. Francuski literat Raymond Queneau, zastanawiając się w latach 40. minionego stulecia, co o pojęciu tym powiedziałby Gustave Flaubert, autor słynnego Słownika komunałów, zdefiniował tożsamość konstytucyjną jako "narodowe, a wręcz nacjonalistyczne delirium, dogmatyczny kaprys profesorów prawa, wizytówkę państw narodowych, współczesną wariację na temat idei suwerenności"2. Być może jednak warto pojęciu temu bliżej się przyjrzeć i dostrzec, że prawidłowo rozumiane i stosowane otwiera ono szansę na wpro-

${ }^{2}$ L. Burgorgue-Larsen, L'identité constitutionnelle en question(s), [w:] L. Burgorgue-Larsen (red.), L'identité constitutionnelle saisie par les juges en Europe, Paryż 2011, s. 155 (tłum. własne). 
wadzenie mechanizmu uelastyczniającego unijną architekturę konstytucyjną, uodparniając ją tym samym na różne wstrząsy i zawirowania, a przez to szansę na wzmocnienie Unii, a nie jej osłabienie. Taka właśnie wizja i propozycja stosowania tożsamości konstytucyjnej znalazła wyraz w tej pracy.

$\mathrm{W}$ miejscu tym chciałbym wyrazić podziękowania promotorowi pracy prof. zw. dr. hab. Zdzisławowi Kędzi z Wydziału Prawa i Administracji UAM w Poznaniu za wsparcie merytoryczne i metodologiczne podczas całych studiów doktoranckich. Ponadto, chciałbym podziękować obojgu recenzentom rozprawy, dr hab. Aleksandrze Kustrze z Wydziału Prawa i Administracji UMK w Toruniu i prof. zw. dr. hab. Krzysztofowi Wójtowiczowi z Wydziału Prawa, Administracji i Ekonomii UWr za wnikliwą lekturę pracy oraz liczne i wartościowe komentarze i uwagi. Podziękowanie chciałbym skierować również do Marcina Barańskiego z Departamentu Prawa EUI we Florencji, dyskusje z którym pozwoliły mi dopracować argumentację za niektórymi zawartymi w książce tezami, szczególnie w konfrontacji z perspektywą unijną. Jeżeli książka ta usatysfakcjonuje Czytelnika, to w dużej mierze będzie to zasługa wspomnianych osób. Wszelkie błędy i niedociągnięcia obciążają w całości autora.

Władysław Jóźwicki

Poznań, listopad 2018 



\section{Wstęp}

Prawa człowieka są współcześnie zagwarantowane w większości porządków 1 konstytucyjnych, a także w wielu umowach międzynarodowych zarówno o zasięgu globalnym, jak i regionalnym ${ }^{3}$. „Nie istnieje teraz »żaden naród, kultura czy człowiek, które nie byłyby w taki czy inny sposób wplątane w systemy praw człowieka «"4. Prawa te stają się też często fundamentem postępujących procesów integracyjnych, wśród których na szczególną uwagę zasługuje integracja europejska. Z licznych aktów prawnych zawierających gwarancje praw jednostki wynikają konkretne modalności prawne (wolności, uprawnienia, kompetencje ${ }^{5}$ ) dotyczące ułożenia stosunków między władzą publiczną a podmiotami, które znalazły się w zasięgu tej władzy, a także stosunków między samymi tymi podmiotami. Normy gwarantujące prawa człowieka kreują konkretne uprawnienia jednostek i podmiotów podobnych o charakterze praw podmiotowych, a w ogólności składają się na zespół norm prawnych w rozumieniu przedmiotowym.

Podstawowym źródłem gwarancji praw człowieka w polskim systemie prawnym jest Konstytucja $\mathrm{RP}^{6} \mathrm{z}$ jej art. 30 na czele. Potwierdza on poszanowanie dla przyrodzonej i niezbywalnej godności człowieka i stanowi źródło rozbudowanego katalogu gwarancji praw i wolności człowieka zawartych w innych przepisach ustawy zasadniczej. Podstawowym organem, dbającym o przestrzeganie praw człowieka i kontrolującym wypełnianie standardów ich ochrony

${ }^{3}$ Już w 1950 roku Hirsh Lauterpacht pisał, że Karta Narodów Zjednoczonych (Dz.U. z 1947 nr 23, poz. 90), uznając podstawowe prawa i wolności człowieka sprawiła, że jednostki w pewnym stopniu stały się podmiotami prawa narodów (H. Lauterpacht, International Law and Human Rights, Londyn 1950, s. 61). Szerzej na temat genezy praw człowieka i zjawiska tzw. ich pozytywizacji, a więc nadawania im charakteru norm prawnych patrz np.: T. Jurczyk, Prawa jednostki w orzecznictwie Europejskiego Trybunału Sprawiedliwości, Warszawa 2009, s. 15 i nast. oraz podana tam literatura.

${ }^{4}$ M. Freeman, Prawa człowieka, Warszawa 2007, s. 10.

${ }^{5}$ Więcej na temat klasyfikacji modalności prawnych w dziedzinie praw człowieka i obywatela, patrz np.: S. Wronkowska, Z. Ziembiński, Zarys teorii prawa, Poznań 2001, s. 100-113.

${ }^{6}$ Konstytucja Rzeczypospolitej Polskiej z dnia 2 kwietnia 1997, Dz.U. nr 78, poz. 483 ze zm. 
przez prawo obowiązujące w Polsce, jest Trybunał Konstytucyjny. Jego główną funkcją jest dbanie o hierarchiczną zgodność norm prawnych niższego rzędu z normami wyższego rzędu, na czele z Konstytucją i zawartymi w niej gwarancjami praw człowieka. Można powiedzieć, że TK jest podstawowym 'trybunałem praw człowieka' dla Polski i prawa polskiego. We współczesnym świecie nie sposób jednak analizować Konstytucji i zawartych w niej gwarancji praw i wolności człowieka, a także aktywności TK mającej służyć ich przestrzeganiu w oderwaniu od szerszego między- i ponadnarodowego kontekstu normatywnego i instytucjonalnego, którego Polska jest częścią.

Powstanie Unii Europejskiej w aktualnej jej formie wykreowało specyficzną i niepowtarzalną rzeczywistość prawną w państwach członkowskich, które przestały być jedynymi prawodawcami na swoich terytoriach. Poprzez przekazanie Unii uprawnień prawotwórczych w niektórych sprawach, to Unia stała się, jeśli nie równorzędnym, to z całą pewnością niemal równorzędnym źródłem regulacji prawnych kształtujących sytuację prawną podmiotów znajdujących się pod władzą państw członkowskich, w tym Polski. W związku z rozwojem kompetencji Unii i coraz szerszym zakresem prawodawstwa unijnego, za pomocą którego Unia kształtuje sytuację prawną jednostek i podmiotów podobnych, nie może dziwić, że coraz bardziej obecna w ramach tego porządku prawnego stawała się kwestia gwarancji praw człowieka. Na początku procesu integracji europejskiej prawa człowieka w ogóle nie były objęte prawem wspólnotowym7 7 . Miało ono ograniczać się do kwestii ekonomicznych i nie wchodzić w kwestie polityczne. Stopniowo jednak prawa człowieka, ich ochrona i poszanowanie stały się jedną z centralnych wartości, wokół których proces integracji się ogniskuje. Całościowa prezentacja tego dość dobrze już opisanego procesu w sposób oczywisty przekraczałaby ramy tej pracyº. Trzeba jednak zauważyć, że ostatecznie wraz z wejściem w życie Traktatu z Lizbony ${ }^{9}$ i uzyskaniem przez Kartę Praw Podstawowych Unii Europejskiej ${ }^{10}$ statusu równego prawu pierwotnemu Unii, ochrona praw człowieka w Unii weszła w nowy etap. Nie ulega wątpli-

\footnotetext{
${ }^{7}$ Choć już u zarania Unii postulowano rozszerzenie integracji o kwestie polityczne, $\mathrm{w}$ tym prawa człowieka. Już w latach 50. propozycja taka znalazła swój wyraz na poziomie projektów traktatów wspólnotowych.Więcej na ten temat, patrz np.: G. de Búrca, The Road Not Taken: The European Union as a Global Human Rights Actor, "American Journal of International Law" 2011, nr 4 (105).

${ }^{8}$ Patrz np.: M. Dybowski, Prawa fundamentalne w orzecznictwie ETS, Warszawa 2007, s. 3 i nast. oraz s. 80 i nast. oraz podana tam literatura; F. Korenica, The EU Accession to the ECHR. Between Luxembourg's Search for Autonomy and Strasbourg's Credibility on Human Rights Protection, Cham-Nowy Jork 2015, s. 35 i nast. oraz podana tam literatura.

${ }_{9}^{9}$ Traktat z Lizbony zmieniający Traktat o Unii Europejskiej i Traktat ustanawiający Wspólnotę Europejska, podpisany 13 grudnia 2007, Dz.Urz. C 306 z 17 grudnia 2007.

${ }^{10}$ Karta praw podstawowych Unii Europejskiej, Dz.Urz. C 326 z 26 października 2012.
} 
wości, że już przynajmniej „od kilku lat TS buduje linię orzeczniczą praw podstawowych na podstawie KPP, stając się tym samym »trybunałem praw człowieka« dla Unii Europejskiej. Karta zajęła pozycję w samym centrum unijnego porządku konstytucyjnego. Świadczy o tym liczba odwołań TS do tego aktu, która systematycznie wzrasta"11.

Członkostwo Polski w Unii sprawia, że nasz kraj jest częścią wielopoziomowej struktury, która wyposażona jest na różnych swych poziomach w kompetencje władcze wobec podmiotów, którym jednocześnie gwarantuje przestrzeganie ich praw fundamentalnych. Oczywista konsekwencją przystąpienia Polski do UE stało się wzbogacenie systemu źródeł prawa obowiązującego w Polsce o akty prawa unijnego - zarówno akty tzw. prawa pierwotnego, jak i pochodnego. Odzwierciedla to znana teza o multicentryczności współczesnego porządku prawnego w Europie i na świecie ${ }^{12}$. W Europie, a co za tym idzie i w Polsce, przyjmuje ona szczególną formę i cechuje się wyjątkową intensywnością. Już na gruncie wyroku dotyczącego zgodności z Konstytucją traktatu akcesyjnego $^{13}$ TK zauważył, że:

Prawną konsekwencją art. 9 Konstytucji jest konstytucyjne założenie, iż na terytorium Rzeczypospolitej Polskiej, obok norm (przepisów) stanowionych przez krajowego

${ }^{11}$ R. Grzeszczak, A. Szmigielski, Sadowe stosowanie Karty Praw Podstawowych UE w odniesieniu do państw członkowskich - refleksje na podstawie orzecznictwa Trybunału Sprawiedliwości i praktyki sądów krajowych, "Europejski Przegląd Sądowy” 2015, nr 10, s. 11; por. też: A. Torres Pérez, The Federalizing Force of the EU Charter of Fundamental Rights, "International Journal of Constitutional Law" 2017, nr 4, s. 1081 oraz G. de Búrca, After the EU Charter of Fundamental Rights: The Court of Justice as a Human Rights Adjudicator?, "Maastricht Journal of European and Comparative Law" 2013, $\mathrm{nr} 20$.

${ }^{12}$ E. Łętowska, Multicentryczność wspótczesnego systemu prawa i jej konsekwencje, „Państwo i Prawo" 2005, z. 4; ukazała się też bardziej rozwinięta wersja tego tekstu: E. Łętowska, Multicentryczność wspótczesnego systemu prawa i wykładnia jej przyjazna, [w:] L. Ogiegło, W. Popiołek, M. Szpunar (red.), Rozprawy prawnicze. Ksiega pamiątkowa Profesora Maksymiliana Pazdana, Kraków 2005. Pojęcie multicentryczności poddawane bywa również krytyce jako nie najtrafniej odzwierciedlające współczesną sytuację prawną (patrz np.: A. Kustra, Polemika. Wokół multicentryczności systemu prawa, „Państwo i Prawo” 2006, z. 6).

${ }^{13}$ Traktat między Królestwem Belgii, Królestwem Danii, Republiką Federalną Niemiec, Republiką Grecką, Królestwem Hiszpanii, Republiką Francuską, Irlandia, Republiką Włoska, Wielkim Księstwem Luksemburga, Królestwem Niderlandów, Republiką Austrii, Republiką Portugalską, Republiką Finlandii, Królestwem Szwecji, Zjednoczonym Królestwem Wielkiej Brytanii i Irlandii Północnej (Państwami Członkowskimi Unii Europejskiej) a Republiką Czeską, Republiką Estońską, Republiką Cypryjską, Republiką Łotewską, Republiką Litewską, Republiką Węgierska, Republiką Malty, Rzecząpospolitą Polską, Republiką Słowenii, Republiką Słowacką dotyczący przystąpienia Republiki Czeskiej, Republiki Estońskiej, Republiki Cypryjskiej, Republiki Łotewskiej, Republiki Litewskiej, Republiki Węgierskiej, Republiki Malty, Rzeczypospolitej Polskiej, Republiki Słowenii i Republiki Słowackiej do Unii Europejskiej, podpisany w Atenach w dniu 16 kwietnia 2003, Dz.Urz. L 236 z 23 września 2003. 
legislatora, obowiązują uregulowania (przepisy) kreowane poza systemem krajowych (polskich) organów prawodawczych. Ustrojodawca konstytucyjny świadomie więc przyjął, że system prawa obowiązujący na terytorium Rzeczypospolitej mieć będzie charakter wieloskładnikowy. Obok aktów prawnych, stanowionych przez krajowe (polskie) organy prawodawcze, w Polsce obowiązują i są stosowane także akty prawa międzynarodowego [...]. Prawo wspólnotowe nie jest przy tym prawem w pełni zewnętrznym w stosunku do państwa polskiego. W części stanowiącej prawo traktatowe, powstaje ono przez akceptowanie traktatów zawartych przez wszystkie państwa członkowskie (w tym: Rzeczpospolitą Polską). W części zaś stanowiącej wspólnotowe prawo stanowione (pochodne), kreowane jest ono przy udziale przedstawicieli rządów państw członkowskich (w tym: Polski) - w Radzie Unii Europejskiej oraz przedstawicieli obywateli europejskich ( w tym: obywateli polskich) - w Parlamencie Europejskim. Na terenie Polski współobowiązują więc podsystemy regulacji prawnych, pochodzące z różnych centrów prawodawczych. Winny one koegzystować na zasadzie obopólnie przyjaznej wykładni i kooperatywnego współstosowania ${ }^{14}$.

Nie można jednak nie zauważyć, że owa koegzystencja może prowadzić również do poważnych problemów w przypadku ewentualnej kolizji. Jeszcze raz oddajmy głos Trybunałowi: „Okoliczność ta w innej perspektywie ukazuje potencjalną kolizję norm oraz pierwszeństwo jednego z wyróżnionych podsystemów"15. Ten potencjalny konflikt nabiera szczególnej wagi, gdy dotyczy kwestii tak fundamentalnych zarówno z perspektywy ustrojowej, jak i z perspektywy jednostki, jaką jest ochrona praw człowieka i ich standardy, których gwarancje mogą być odmiennie ukształtowane w porządku unijnym i krajowym. Jak będzie jeszcze o tym szczegółowo mowa, celem tej pracy nie jest analiza konkretnych praw i wolności człowieka zagwarantowanych zarówno w Konstytucji, jak i w systemie unijnym pod kątem ewentualnej rozbieżności standardu ochrony. Nie jest tym bardziej jej celem próba oceny systemu konstytucyjnego i unijnego en gros pod kątem tego, który z nich ustanawia korzystniejsze standardy ochrony. Należy bowiem zgodzić się, że ze względu na wspólne źródła i aksjologiczną bliskość krajowych gwarancji ochrony praw człowieka i gwarancji unijnych, materialne rozbieżności między wynikającymi z nich standardami nie powinny zdarzać się często. Ze względu na dynamiczny charakter unijnego porządku prawnego i wyposażenie Unii w kompetencje prawotwórcze w niektórych sprawach może jednak zdarzyć się, że taka kolizja, na gruncie konkretnego prawa czy wolności, powstanie. W takim przypadku konflikt będzie miał jednak raczej charakter jednostkowy i będzie mógł zaistnieć na gruncie konkretnego prawa czy wolności, stąd liczba pojedyncza użyta w tytule pracy, gdy mowa o standardzie ochrony "prawa jednostki”. Tym

${ }^{14} \mathrm{TK}$, sprawa K 18/o4, wyrok z 11 maja 2005, pkt III 2.2 uzasadnienia.

${ }^{15}$ Ibidem, pkt III 2.2 uzasadnienia. 
niemniej proponowana w pracy metoda współpracy między TK a TSUE jest uniwersalna, jako że odnosi się do tego rodzaju potencjalnych konfliktów na gruncie każdego z zawartych w Konstytucji i Karcie praw i wolności, stąd w tekście pracy najczęściej używa się liczby mnogiej. Tytuł miał uwypuklić raczej jednostkowy charakter takiego potencjalnego konfliktu, tekst ma pokazywać, że rozwiązanie proponowane $\mathrm{w}$ tej pracy może znaleźć zastosowanie dla każdego z takich konfliktów.

Przystąpienie Polski do UE doprowadziło do zmiany kontekstu funkcjonowania podstawowego aktu prawnego gwarantującego prawa człowieka w Polsce, jakim jest Konstytucja RP. „Konstytucja RP jest obecnie jednym z elementów większej struktury normatywnej obejmującej prawo pierwotne UE, konstytucje krajowe oraz konstytucje lub statuty podpaństwowych jednostek terytorialnych. Ta przemiana znalazła swój wyraz m.in. w terminologii prawniczej: Konstytucja RP z konstytucji tout court stała się konstytucją krajową" ${ }^{\prime \prime 6}$. Jest jedną z szeregu konstytucji krajowych państw członkowskich. Tak samo o państwach należących do Unii mówi się już rzadziej po prostu jako o państwach, a częściej jako o 'państwach członkowskich ${ }^{17}$. Ze względu na fakt członkostwa Polski w Unii Europejskiej w naszym kraju obowiązują więc prawo polskie i prawo unijne, a także polskie gwarancje praw człowieka, jak i unijne gwarancje praw człowieka. Te ostatnie mają jednak znaczenie szerszy zasięg. Wraz z prawem unijnym w sposób jednolity funkcjonują na przestrzeni całej Unii.

Co do zasady Konstytucja rozstrzyga status prawa unijnego w Polsce. Zgodnie z art. 91 ust. 1 i 2 Konstytucji do prawa pierwotnego Unii, ustanowionego w formie traktatów międzynarodowych, stosuje się zawarte w tych przepisach ogólne postanowienia dotyczące prawa międzynarodowego. Stanowią one w związku z tym część krajowego porządku prawnego, podlegają bezpośredniemu stosowaniu i cieszą się statusem pierwszeństwa przed ustawami, a co za tym idzie również krajowymi aktami prawnymi niższego rzędu. Unijne prawo pochodne zaś, a więc takie, które zostało wydane przez instytucje Unii na podstawie przekazanych Unii kompetencji przez państwa członkowskie, jaką to możliwość przewiduje art. 90 ust. 1 Konstytucji, zgodnie z jej art. 91 ust. 3 może być stosowane bezpośrednio i również cieszy się pierwszeństwem przed ustawami i aktami niższego rzędu. W żadnym wypadku Konstytucja RP nie wspomina o prymacie prawa unijnego względem jej samej.

Jak wspomniano jednak prawo unijne i unijne gwarancje praw człowieka nie obowiązują jedynie w Polsce, lecz również w pozostałych państwach

${ }^{16}$ K. Wojtyczek, Trybunat Konstytucyjny w europejskim systemie konstytucyjnym, „Przegląd Sejmowy" 2009, $\mathrm{nr} 4$ (93), s. 177.

${ }^{17}$ N. Lupo, The Advantage of Having the "First Word" in the Composite European Constitution, „Italian Journal of Public Law” 2018, nr 10 (2), s. 187. 
członkowskich. Dla pozycji prawa unijnego w krajowych porządkach prawnych państw członkowskich, w tym Polski, kluczowe znaczenie mają trzy zasady, które nie mają już swego źródła w Konstytucji, lecz wynikają z autonomicznego charakteru unijnego porządku prawnego ${ }^{18}$, a "podporządkowanie którym wynika z samej istoty członkostwa poszczególnych państw w Unii Europejskiej"19. Są to: zasada bezpośredniego skutku, zasada pierwszeństwa i zasada jednolitości ${ }^{20}$, z którymi łączą się również inne zasady, jak np. zasada efektywności prawa unijnego. Zasady te podają w pewną wątpliwość status prawa unijnego wynikający literalnie ze wspomnianych przepisów Konstytucji, gdy chodzi o ich hierarchiczną relację.

W obliczu zaliczenia do źródeł prawa obowiązującego w Polsce prawa unijnego, a szczególnie prawa pochodnego, które cieszy się przymiotami bezpośredniego stosowania i pierwszeństwem przed prawem krajowym, a także w obliczu specyficznego związku z prawem unijnym prawa polskiego stanowiącego przejaw implementacji prawa unijnego w związku z obowiązkami, jakie nakłada na państwo polskie prawo unijne, TK przestał być jedynym organem sądowym weryfikującym prawo kształtujące sytuację prawną podmiotów znajdujących się na terytorium Polski przez pryzmat zgodności z prawem wyższego rzędu, w tym szczególnie zawartymi w nim gwarancjami praw i wolności jednostki, a Konstytucja przestała być w sposób niekwestionowany ostatecznym źródłem gwarancji praw i wolności człowieka wobec prawa obowiązującego w Polsce służącym do tego rodzaju weryfikacji. Przystąpienie Polski do UE

zmieniło nie tylko w zasadniczy sposób system źródeł prawa, ale także pozycję Trybunału Konstytucyjnego w polskim i europejskim systemie konstytucyjnym. Dla wyznaczenia tej pozycji podstawowe znaczenie mają w praktyce dwa czynniki: struktura hierarchiczna systemu prawnego oraz zakres kompetencji TK w zakresie ochrony konstytucji, a w szczególności w zakresie usuwania sprzeczności hierarchicznych z systemu prawnego ${ }^{21}$.

Mówiąc najogólniej, otwierają się tu przynajmniej dwie podstawowe przestrzenie potencjalnego konfliktu związane $\mathrm{z}$ charakterem i statusem prawa unijnego. Po pierwsze chodzi o to, na ile TK i konstytucyjny standard ochrony mogą bezpośrednio ingerować w sferę prawa unijnego, które jest samowyko-

${ }^{18}$ Więcej na temat autonomii prawa unijnego zarówno w relacji do prawa międzynarodowego, jak i do prawa państw członkowskich, patrz np.: K. Wójtowicz, Sądy konstytucyjne wobec prawa Unii Europejskiej, Warszawa 2012, s. 11-28.

${ }^{19}$ A. Biłgorajski, Rozdział II. Źródła prawa, [w:] R.M. Małajny, Polskie prawo konstytucyjne na tle porównawczym, Warszawa 2013, s. 58.

${ }^{20}$ Por.: ibidem, s. 58-59.

${ }^{21}$ K. Wojtyczek, Trybunat Konstytucyjny..., s. 177. 
nalne i nie wymaga implementacji. Po drugie zaś chodzi o to, na ile TK i konstytucyjny standard ochrony mogą pośrednio ingerować w sferę unijnego prawa pochodnego, które wymagało implementacji do krajowego porządku prawnego za pomocą prawa krajowego. $\mathrm{W}$ istocie rzeczy chodzi o to, czy państwa członkowskie, w tym Polska, mogą mieć wyższe standardy ochrony praw człowieka, nawet gdyby prowadziło to do kolizji z prawem unijnym.

Wieloskładnikowość systemu prawa obowiązującego w Polsce, w tym wielość źródeł gwarancji praw człowieka, prowadzi do poważnych problemów co do identyfikacji prawidłowego wzorca ochrony praw i wolności człowieka, jak i podziału kompetencji, kto miałby tego rodzaju kontroli dokonywać. W niniejszej pracy kwestie podziału tych kompetencji zostaną omówione w świetle aktualnego orzecznictwa zarówno TSUE, jak i TK. Posłuży to jak najbardziej precyzyjnej delimitacji kompetencji TSUE i TK w przedmiocie kontroli prawa obowiązującego w Polsce. Będzie to podstawą do dalszych rozważań, dotyczących prób rozwiązania potencjalnych kolizji między wzorcem krajowym i unijnym tam, gdzie w pełni jednoznaczna delimitacja nie jest możliwa. Proponowane metody rozwiązywania tego rodzaju kolizji będą mieć charakter kooperacyjny i będą służyć wypełnieniu w jak najwyższym stopniu zarówno zasad konstytucyjnych, jak i tych, na których opiera się prawo unijne. Nie będą one jednak dotyczyć wszystkich potencjalnych konfliktów. Wiele z rozważań prezentowanych w tej pracy będzie mogło mieć szersze zastosowanie. Wszakże uwaga tej pracy koncentrować się będzie na kwestii dopuszczalności zapewniania przez państwo członkowskie, jakim jest Polska, wyższego niż unijny standardu ochrony praw człowieka, w sytuacji, gdy stałoby to w sprzeczności do prawa unijnego, $w$ tym przede wszystkim do zasad pierwszeństwa, jedności i efektywności tego prawa.

Rozdział I pracy będzie służył ukazaniu zakresu zastosowania unijnych praw podstawowych zawartych w KPP, przede wszystkim nie tyle wobec Unii i jej instytucji, organów i jednostek organizacyjnych, gdyż to zasadniczo nie budzi większych kontrowersji, co wobec państw członkowskich, w tym odnośnie do stanowionego przez nie prawa. $W$ rozdziale tym zaprezentowana zostanie perspektywa unijna oparta na stanowisku TSUE, który dość szeroko zakreślił granice zastosowania Karty wobec państw członkowskich na gruncie jej art. 51 ust. 1. Ponadto w rozdziale tym dokonana zostanie próba oceny prawidłowości powyższego podejścia, a także ukazania konsekwencji, jakie z tego wynikają dla poszerzenia się przestrzeni potencjalnego konfliktu między wyższym niż unijny konstytucyjnym standardem ochrony praw człowieka a standardem unijnym (oraz powiązaną z nim zasadą pierwszeństwa, jedności i efektywności). Rozdział ten będzie miał służyć więc przede wszystkim przedstawieniu zobowiązań, jakie ciążą na państwach członkowskich związanych z obowiązkiem 
stosowania przez nie, $\mathrm{w}$ tym przez ich sądy i trybunały, unijnych praw podstawowych. Prawidłowe rozumienie tych zobowiązań jest bowiem warunkiem wyjściowym dla prawidłowego stosowania proponowanej w tej pracy metody niekonfliktowego rozwiązywania kolizji między wyższymi niż unijne, krajowymi standardami ochrony praw człowieka a standardami unijnymi, jakie mogą się na tym obszarze ujawnić.

Rozdział II pokaże natomiast, jak zagadnienia te odzwierciedlone są w praktyce polskiej. W rozdziale poddana analizie i ocenie zostanie praktyka sądów polskich w przedmiocie stosowania KPP, a także będzie podjęta próba zdefiniowania ich roli, jako sądów unijnych, w architekturze unijnego systemu ochrony praw człowieka, szczególnie w wymiarze, w jakim mają one zapewniać zgodność z Kartą prawa polskiego mieszczącego się w zakresie zastosowania prawa unijnego, a więc w zakresie zastosowania KPP zgodnie z tym, o czym mowa $\mathrm{w}$ rozdziale poprzednim. W rozdziale tym ukazana zostanie faktyczna, jak i wskazana będzie prawidłowa rola, jaką sądy krajowe powinny odgrywać w procesie zapewniania skuteczności Karcie w kontekście konstytucyjnym, a więc również w zakresie ich relacji z TK, szczególnie w obliczu obowiązku poszanowania przez Unię tożsamości konstytucyjnej RP oraz roli współpracy między TK a TSUE w przypadku ewentualnego konfliktu między unijnym a wyższym od niego konstytucyjnym standardem ochrony praw człowieka.

W rozdziale III analizie poddane zostanie podejście TK do unijnych gwarancji praw człowieka i Karty oraz do ich stosowania wobec prawa polskiego, a także szersze tło, istotne z perspektywy pracy, podejścia TK do kwestii relacji między prawem unijnym a Konstytucją RP. W rozdziale ukazane zostanie podejście TK do kwestii potencjalnego pośredniego konfliktu między unijnym a wyższym niż unijny, konstytucyjnym standardem ochrony praw człowieka, jaki może zaistnieć na obszarze opisanym w rozdziale I, gdzie prawo polskie, podlegające jako takie w sposób oczywisty krajowym - konstytucyjnym - gwarancjom praw człowieka, podlega również gwarancjom unijnym, jako że mieści się w zakresie zastosowania prawa unijnego. Ponadto ukazane zostanie podejście TK do kwestii potencjalnego bezpośredniego konfliktu między unijnym a wyższym niż unijny, konstytucyjnym standardem ochrony praw człowieka, jaki może zaistnieć przede wszystkim na obszarze bezpośrednio skutecznego prawa unijnego, które nie musi być w żaden sposób wprowadzane do polskiego porządku prawnego, które podlega jako takie w sposób oczywisty unijnym - zawartym w Karcie - gwarancjom praw człowieka, lecz podlega również gwarancjom krajowym, jako że jest stosowane na terytorium państwa polskiego, gdzie Konstytucja RP jest najwyższym prawem.

Wreszcie w rozdziale IV podjęta zostanie próba zaprezentowania jednego z możliwych do pogodzenia zarówno z prawem unijnym i orzecznictwem 
TSUE, jak i z Konstytucją RP i orzecznictwem TK, rozwiązań konfliktów między unijnym a wyższym niż unijny, konstytucyjnym standardem ochrony praw człowieka. W rozdziale podjęta zostanie próba ukazania roli i znaczenia pojęcia tożsamości konstytucyjnej RP zarówno na podstawie orzecznictwa TK, jak i TSUE, a także zaprezentowania propozycji mechanizmu współpracy, prowadzącego do pewnej specyficznej sekwencji orzekania przez TK i TSUE w sytuacjach, w których wyższy niż unijny, konstytucyjny, stanowiący element tożsamości konstytucyjnej RP, standard ochrony praw był zagrożony przez prawo unijne - czy to bezpośrednio skuteczne czy też wymagające implementacji. W rozdziale tym zaprezentowana będzie główna teza tej pracy, sprowadzająca się do próby zarysowania mechanizmu minimalizującego zaistnienie konfliktu między TK a TSUE oraz prawem krajowym i unijnym w tej materii i maksymalizującego szansę na jednoczesne poszanowanie w jak najwyższym stopniu zasady konstytucjonalizmu i związanej z nią zasady prymatu Konstytucji oraz obowiązku poszanowania tożsamości konstytucyjnej RP, jak i autonomii unijnego porządku prawnego i fundamentalnych dla niego zasad pierwszeństwa, jedności i efektywności prawa unijnego.

Uwaga w tej pracy będzie więc skoncentrowana na problemach, jakie rodzą się na gruncie współobowiązywania w Polsce prawa unijnego i prawa polskiego oraz unijnych i konstytucyjnych gwarancji praw człowieka. Zasadniczym celem pracy będzie próba znalezienia i zaproponowania rozwiązania minimalizującego potencjalny konflikt między standardem unijnym a konstytucyjnym, w sytuacji, w której to ten drugi byłby wyższy, a zobowiązania wynikające z członkostwa Polski w Unii prowadziłyby do jego obniżenia. Mówiąc krótko, w pracy tej podjęta zostanie próba zaproponowania nieco odważniejszego niż do tej pory stosowania przez TK pytania prejudycjalnego do TSUE. Miałoby się ono sprowadzać do powołania się na obowiązek poszanowania przez Unię tożsamości konstytucyjnej państw członkowskich, zawarty w art. 4 ust. 2 TUE ${ }^{22}$ w związku z art. 53 Karty oraz w kontekście innych przepisów unijnego prawa pierwotnego, takich jak Preambuła do Karty czy art. 52 ust. 4 Karty, w pewnych, ściśle określonych kategoriach sytuacji, w których prawo unijne naruszałoby nie tyle jakiekolwiek konstytucyjne standardy ochrony praw człowieka, lecz w których naruszałoby konstytucyjne standardy ochrony praw człowieka składające się na tożsamość konstytucyjną państwa. Rozróżnienie to będzie mogło pozwolić na przyznanie pierwszeństwa bądź to standardom unijnym i zasadom pierwszeństwa jedności i efektywności prawa unijnego, co do zasady, gdy ograniczany standard konstytucyjny nie stanowiłby elementu tożsamości konstytucyjnej RP, bądź to standardom krajowym, gdy będą one elementem skła-

${ }^{22}$ Traktat o Unii Europejskiej (wersja skonsolidowana), Dz.Urz. C 202 z 7 czerwca 2016. 
dowym tożsamości konstytucyjnej. Praca ta będzie próbą wskazania możliwie kooperacyjnego mechanizmu dochodzenia do tego, które standardy powinny przeważyć oraz ukazania jego zalet w porównaniu do sztywnego podejścia, wiążącego tożsamość konstytucyjną RP i obowiązek jej poszanowania przez Unię z doktryną ultra vires. Zaprezentowana w tej pracy propozycja będzie stanowiła próbę pewnego zbalansowania kompetencji TK i TSUE i skłonienia ich do współpracy opierającej się na wzajemnym poszanowaniu swych kompetencji i pozycji ustrojowych w ramach sekwencji orzekania w przedmiotowej materii, a nie tworzenia w ramach Unii nowej hierarchii sądów, na podstawie której, ten który miałby „ostatnie słowo", urastałby do rangi sądu najwyższego czy najważniejszego.

Dzięki skoncentrowaniu uwagi na wymiarze unijnym do wyjątkowej rangi urasta poszukiwanie płaszczyzn współpracy i operacjonalizacji różnego rodzaju rozbieżności i potencjalnych konfliktów. Próba rozstrzygania sporu między TK a TSUE o "ostatnie słowo" ustąpi próbie poszukiwania mechanizmu umożliwiającego im sformułowanie "słowa wspólnego", opartego nie na izolacjonistycznie rozumianym porządku krajowym czy unijnym, lecz na porządku prawnym, jaki ukształtował się w związku z przystąpieniem Polski do Unii. Do sformułowania takiego wspólnego sława mogłoby dojść poprzez rzeczywisty i bezpośredni dialog między TK a TSUE, i taką metodę jego prowadzenia, dzięki której wypowiedź ostatnia czy też ostateczna wcale nie będzie wynikała z hierarchicznej wyższości danego trybunału, co raczej z sekwencji wypowiadania się przez te trybunały w związku z ich rolami ustrojowymi. Sekwencja, o której mowa $w$ tej pracy, będzie $w$ istocie prowadzić do ograniczania swobody orzeczniczej i tym samym, w pewnym sensie odbierać, ze względu na podział ról między nimi i doniosłość sformułowanych na wcześniejszych etapach owej sekwencji orzeczeń, przewagę trybunałowi wypowiadającemu się jako kolejny czy wreszcie ostatni. Praca ta będzie miała prowadzić do wskazania metod poszerzania przestrzeni unijnej integracji poprzez poszerzenie zakresu niekolizyjnego stosowania gwarancji praw człowieka do prawa obowiązującego w Polsce.

Problem relacji między prawem polskim a prawem unijnym i między TK a TSUE jest elementem szerszego problemu, który - jak zostało to powiedziane - określany bywa często mianem zjawiska multicentryczności porządku prawnego czy pluralizmu systemów źródeł prawa ${ }^{23}$, a który w Europie osiągnął szczególnie zaawansowany poziom nota bene nie tylko ze względu na powsta-

${ }^{23}$ Więcej, patrz np.: A. Biłgorajski, Rozdział II..., s. 38 i nast. 
nie UE. Jak pisze Leszek Garlicki, współczesny „wieloszczeblowy konstytucjonalizm”24 czy „pluralizm konstytucyjny”25, doprowadziły do sytuacji, w której

znacznie trudniejsze staje się określanie, komu i w jakim zakresie przysługuje kompetencja do podejmowania decyzji ostatecznych (słynne "prawo ostatniego słowa" w debacie o kontroli konstytucyjności). Umocnienie porządków ponadnarodowych w znacznym stopniu ogranicza tradycyjne pojmowanie suwerenności, bo - w każdym razie w sferze praw jednostki - decyzje narodowe muszą pozostawać w zgodzie z rozbudowaną siatką standardów europejskich i globalnych. Zarazem ta nowa struktura ma o tyle pluralistyczny charakter, że nie istnieje jeden nadrzędny akt czy organ orzekający. Pojawia się zjawisko „zdecentralizowanej suwerenności”, widoczne zarówno w wewnętrznym porządku konstytucyjnym (bo sądy, zwłaszcza konstytucyjne, zyskują tam daleko posuniętą autonomię), jak i w relacjach między państwami narodowymi a porządkami regionalnymi czy globalnymi. Tworzy to konieczność wypracowywania mechanizmów współpracy i koordynacji, w czym sądy mogą odgrywać znaczącą rolę. Tworzy to więc przesłanki dla stałego dialogu sądów narodowych z sądami regionalnymi, a także dialogu między sądami regionalnymi. Odpowiednio, mówi się o wyłanianiu się "globalnej wspólnoty sądów"26.

W kontekście wielości źródeł norm praw człowieka obowiązujących w Polsce i organów odpowiedzialnych za ich implementację, nie należy zapominać o całej liście traktatów międzynarodowych zarówno o zasięgu globalnym, jak i regionalnym, których Polska jest stroną. Ze względu na swój specyficzny charakter i znaczenie, również $\mathrm{w}$ ramach unijnego porządku prawnego, na szczególną uwagę zasługuje w tym kontekście bez wątpienia Europejska Konwencja Praw Człowieka ${ }^{27}$ i jej organ implementacyjny - Europejski Trybunał Praw Człowieka w Strasburgu. Tym niemniej podkreślić należy, że funkcja Konwencji, jak i ETPCz jest nieco inna niż funkcja Karty i Konstytucji RP oraz TSUE i TK.

${ }^{24}$ Patrz np.: M. Kumm, The Cosmopolitan Turn in Constitutionalism: On the Relationship Between Constitutionalism in and Beyond the State, [w:] J.L. Dunhoff, J.P. Trachtmann (red.), Ruling the World? Constitutionalism, International Law and Global Governance, Cambridge 2009.

${ }^{25}$ Patrz np.: A. Stone Sweet, A Cosmopolitan Legal Order: Constitutional Pluralism and Rights Adjudication in Europe, "Journal of Global Constitutionalism" 2012, nr 1 (1); pod kątem UE patrz przed.: M. Avbelj, J. Komárek (red.), Constitutional Pluralism in the European Union and Beyond, Oxford 2012; M.P. Maduro, Interpreting European Law: Judicial Adjudication in a Context of Constitutional Pluralism, "European Journal of Legal Studies” 2007, nr 1 (2); I. Pernice, Multilevel Constitutionalism in the European Union, "European Law Review” 2002, nr 27 (5); N. Walker, The Idea of Constitutional Pluralism, EUI Working Paper, LAW 2002, nr 1.

${ }^{26}$ L. Garlicki, Ochrona praw jednostki w XXI wieku (globalizacja - standardy lokalne - dialog między sądami), [w:] „Abstrakty i tezy” LVI Zjazd Katedr i Zakładów Prawa Konstytucyjnego, Lublin 29-31 maja 2014, s. 5.

${ }^{27}$ Konwencja o ochronie praw człowieka i podstawowych wolności sporządzona w Rzymie dnia 4 listopada 1950, Dz.U. 1993 nr 61, poz. 284 ze zm. 
ETPCz nie jest sądem nad prawem, nie ma kompetencji do eliminowania przepisów prawnych z porządku prawnego ze względu na niezgodność zawartych w nich norm z normami wyższego rzędu, w tym z normami gwarantującymi prawa człowieka. O ile więc Konwencja i oparte na niej orzecznictwo ETCPz odgrywają niezwykle istotną rolę dla wytwarzania się europejskiego standardu ochrony praw i wolności człowieka, i ma ono szersze oddziaływanie niż tylko inter partes w konkretnych sprawach ${ }^{28}$, o tyle co do zasady Konwencja ma służyć jednostce w wymiarze indywidualnym - do dochodzenia przez nią sprawiedliwości, jeśli jej prawa i wolności zostały naruszone. ETPCz co do zasady wymierza sprawiedliwość indywidualna, a nie systemowa, czy jak niektórzy nazywają to - konstytucyjną. Stąd problematyka ta pozostawiona zostanie na marginesie tej pracy.

Głównymi metodami badawczymi przyjętymi w pracy będą metoda dogmatyczna oraz teoretyczno-prawna. Umożliwią one analizę na dwóch płaszczyznach, a więc opisowej, sprowadzającej się do przedstawienia różnych sposobów rozwiązywania wątpliwości i kolizji w zakresie kognicji TK i TSUE w przedmiocie praw człowieka, a także na płaszczyźnie dyrektywalnej, a więc związanej z formułowaniem wniosków, jak w aktualnym stanie prawnym należałoby, zdaniem autora, rozwiązywać niektóre z tych problemów. Rozważania co do przyszłości ograniczać będą się jednak jedynie do wskazywania najwłaściwszych, zdaniem autora, rozwiązań problemów na gruncie aktualnego stanu prawnego i bieżącego orzecznictwa. W pracy tej nie zostaną więc sformułowane żadne wnioski de lege ferenda. Analiza możliwych rozwiązań będzie opierać się na stanie de lege lata.

Podobnie wszelkie rozważania dotyczące przeszłości prowadzone będą tylko o tyle, o ile będzie to przydatne z perspektywy omówienia stanu aktualnego. Przedmiotem analizy nie będzie więc cała ewolucja omawianych

${ }^{28}$ Patrz np.: A. Bodnar, Res Interpretata: Legal Effect of the European Court of Human Rights' Judgments for other States Than Those Which Were Party to the Proceedings, [w:] Y. Haeck, E. Brems (red.), Human Rights and Civil Liberties in the 21 $1^{\text {st }}$ Century, Dordrecht 2014; R. Degener, L. Garlicki, Art. 46 [moc obowiązująca oraz wykonanie wyroków], [w:] L. Garlicki (red.), Konwencja o Ochronie Praw Człowieka i Podstawowych Wolności. Komentarz do artykułów 19-59, Warszawa 2011, s. 361; L. Wildhaber, Precedent in the European Court of Human Rights, [w:] P. Mahoney, H. Petzold (red.), Protecting Human Rights: The European Perspective, Köln 2000; w polskim kontkście konstytucyjnym w wymiarze relacji między art. 9 Konstytucji a obowiązkiem wykonywania wyroków pilotażowych patrz np.: K. Wójtowicz, Art. 9. [Zasada przestrzegania prawa międzynarodowego], [w:] M. Safjan, L. Bosek (red.), Konstytucja. Komentarz, t. 1, Warszawa 2016, s. 334 i nast. i podana tam literatura; nota bene na gruncie Konwencji również powstał mechanizm umożliwiający bezpośredni dialog między TK a ETPCz (patrz np.: W. Jóźwicki, Protocol 16 to the ECHR. A Convenient Tool for Judicial Dialogue and Better Domestic Implementation of the Convention?, [w:] E. Kużelewska, D. Kloza, I. Kraśnicka, F. Strzyczkowski (red.), European Judicial Systems as a Challenge for Democracy, Cambridge-Antwerp-Portland 2015 i podana tam literatura). 
w pracy przepisów i aktualnego stanu orzecznictwa, a jedynie te jej aspekty, które mają znaczenie dzisiaj i które umożliwiają identyfikację i wyjaśnienie obecnego stanu rzeczy i zagadnień, które podejmowane będą w tej pracy. Również gdy mowa będzie o różnych instytucjach czy pojęciach, które z czasem ewoluowały i zmieniały nazwę, jak choćby TSUE (w poprzednim stanie prawnym zwany Europejskim Trybunałem Sprawiedliwości, a aktualnie składający się ściśle rzecz biorąc z Trybunału Sprawiedliwości i Sądu), określane będą na ogół zgodnie z aktualną terminologia, choć czasem, szczególnie w cytowanych starszych dokumentach czy opracowaniach, może pojawić się nomenklatura już nieaktualna. Niektóre pojęcia, takie jak pierwszeństwo czy prymat prawa unijnego, jedność czy jednolitość (stosowania) prawa unijnego albo skuteczność czy efektywność prawa unijnego itp., które bywają stosowane $\mathrm{w}$ literaturze zamiennie, będą używane zamiennie również $\mathrm{w}$ tej pracy. Takie pojęcia, jak prawa człowieka, prawa jednostki czy prawa fundamentalne traktowane będą jako równoznaczne, choć ich stosowanie będzie w miarę możliwości dostosowywane do kontekstu, w którym o nich będzie mowa, a więc w kontekście unijnym najwłaściwsze będzie mówienie o prawach fundamentalnych, a w kontekście konstytucyjnym - o prawach człowieka. 



\section{Zakres zastosowania unijnych praw podstawowych wobec państw członkowskich i stanowionego przez nie prawa w świetle orzecznictwa TSUE}

\section{Wstęp}

Zakres podmiotowy zastosowania praw podstawowych uznawanych w systemie prawnym Unii Europejskiej od dawna budzi wątpliwości. Trybunał Sprawiedliwości Unii Europejskiej (...) początkowo uznawał prawa podstawowe wyinterpretowane z porządków konstytucyjnych państw członkowskich UE i Europejskiej Konwencji Praw Człowieka i Podstawowych Wolności (...) za obowiązujące instytucje Wspólnot (obecnie Unii), a następnie odniósł je także do państw członkowskich. Sytuacja zmieniła się wraz z wejściem w życie Karty Praw Podstawowych UE (...) jako aktu o mocy równej traktatom. Unia Europejska ma obecnie katalog praw podstawowych, a TSUE uzyskał wobec tego katalogu jurysdykcję. Odwołania w orzecznictwie TSUE do Karty od uzyskania przez nią mocy wiążącej są bardzo liczne ${ }^{29}$.

Co do zasady kompetencje TSUE związane z kontrolą przestrzegania unijnych standardów ochrony praw jednostki sprowadzają się do możliwości oceniania prawa stanowionego przez Unię oraz działalności unijnych instytucji, organów i jednostek, co wiąże się z określonym w traktatach statusem i funkcją trybunału luksemburskiego jako sądu unijnego ${ }^{30}$.

${ }^{29}$ N. Półtorak, Zakres zwiazania państw członkowskich Kartą Praw Podstawowych Unii Europejskiej, „Europejski Przegląd Sądowy" 2014, nr 9, s. 17.

${ }^{30}$ Zdaniem niektórych w ten sposób unijny system ochrony praw człowieka odzwierciedla różnice, jakie dzielą Unię od USA, gdzie od połowy XIX w. federalna karta praw może być stosowana zarówno do prawa federalnego, jak i stanowego (A. Rosas, The Applicability of the 
Tę ogólną zasadę potwierdza również expressis verbis sama KPP. Art. 51 ust. 1 Karty, który otwiera jej Tytuł VII poświęcony postanowieniom ogólnym dotyczącym wykładni i stosowania Karty, stwierdza: „Postanowienia niniejszej Karty mają zastosowanie do instytucji, organów i jednostek organizacyjnych Unii przy poszanowaniu zasady pomocniczości". Tym niemniej, jak wynika z dalszej części zawartego w tym ustępie zdania, postanowienia Karty znajdują również zastosowanie do państw członkowskich Unii, jednak "wyłącznie w zakresie, w jakim stosują one prawo Unii. Szanują one zatem prawa, przestrzegają zasad i popierają ich stosowanie zgodnie ze swymi odpowiednimi uprawnieniami i w poszanowaniu granic kompetencji Unii powierzonych jej w Traktatach". Gwarancje praw zawarte w Karcie mają więc w pewnym, ograniczonym zakresie zastosowanie również do państw członkowskich, a nie tylko do działań samej Unii.

Jak wyraźnie wynika z tego przepisu, skoro mowa o związaniu państw unijnymi prawami podstawowymi jedynie wtedy, gdy stosują one prawo unijne, przywoływanie przepisów Karty jako ustanawiających standardy wiążące dla regulacji krajowych nie jest możliwe samo z siebie. Sam fakt istnienia Karty i zagwarantowania przez nią jakiegoś prawa czy wolności nie wystarczy do tego, by państwa członkowskie były zobowiązane stosować unijne standardy ochrony praw człowieka do regulacji krajowych. Karta może być stosowana jedynie wtedy, gdy mamy do czynienia z jakąś normą prawa unijnego niewynikającą z samej Karty, która znajduje w danej sprawie zastosowanie i która stanowi łącznik między działaniem państwa członkowskiego a Unią i jej prawem.

W pewnym sensie można więc powiedzieć, że problem zastosowania Karty do państw członkowskich w pierwszym rzędzie jest problemem stosowania bądź nie przez te państwa wynikających ze źródeł innych niż sama Karta norm prawa unijnego ${ }^{31}$. Stwierdzenie, czy państwa stosują w danej swojej aktywności prawo unijne, jest koniecznym warunkiem do określenia, czy zastosowanie znajdują wobec nich również unijne prawa podstawowe, czy też nie. Jak obrazowo piszą o tym niektórzy autorzy, „Karta jest »cieniem《 prawa Unii Europejskiej. Oznacza to, że KPP i unijna ochrona praw podstawowych podążają

EU Charter of Fundamental Rights at National Level, "European Yearbook of Human Rights” 2013, nr 13, s. 97-98). Jednakże w opinii innych, ostatnie lata i sposób, w jaki TSUE stosuje Kartę w jakimś stopniu upodabnia Unię do USA (patrz np.: A. Torres Pérez, The Federalizing...); więcej nt. Unii oraz jej instytucji, organów i jednostek organizacyjnych jako adresatów Karty patrz np.: A. Ward, Art. 51, [w:] S. Peers, T. Harvey, J. Kenner, A. Ward (red.), The EU Charter of Fundamental Rights. A Commentary, Oxford 2014, s. 1425-1427; A. Wróbel, Art. 51. Zakres zastosowania, [w:] A. Wróbel (red.), Karta Praw Podstawowych Unii Europejskiej. Komentarz, Warszawa 2013, s. 1302-1304.

${ }^{31}$ Por. np.: A. Rosas, The Applicability..., s. 105. 
zawsze tam, gdzie unijne prawo pierwotne lub wtórne. W ślad za prawem unijnym podąża »cień « Karty, która chroni jednostkę przed naruszeniem jej praw przez organy unijne bądź państwowe" ${ }^{32}$. Kwestia oceny kryteriów weryfikacji czy istnieje owa konieczna dla zastosowania Karty więź z prawem unijnym, czy też - jak wolą niektórzy - czy istnieje odpowiedni łącznik ${ }^{33}$ z tym prawem, będzie głównym tematem tego rozdziału ${ }^{34}$.

Już na wstępie należy również wyraźnie podkreślić, że art. 51 ust. 2 Karty stanowi, że: „Niniejsza Karta nie rozszerza zakresu zastosowania prawa Unii poza kompetencje Unii, nie ustanawia nowych kompetencji ani zadań Unii, ani też nie zmienia kompetencji i zadań określonych w Traktatach". Regulacja ta potwierdza expressis verbis wyrażoną jednoznacznie w art. 90 ust. 1 Konstytucji RP, jak i zagwarantowaną w traktatach zasadę przyznania kompetencji Unii przez państwa wchodzące w jej skład, zwaną również zasadac kompetencji powierzonych ${ }^{35}$, a także potwierdza fundamentalne dla unijnego

${ }^{32}$ M. Wróblewski, Ł. Bojarski, D. Schindlauer, K. Wladasch, Karta Praw Podstawowych Unii Europejskiej jako żywy instrument. Podręcznik dla prawników, Warszawa 2014, s. 48.

${ }^{33}$ Czasem niektórzy mówią nawet o "przepisie odpalającym” (triggering rule) możliwość zastosowania Karty (np.: M. Almhofer, J. Hartlieb, Article 53 of the Charter of Fundamental Rights of the EU: Recent Developments, "European Yearbook of Human Rights” 2014, nr 14, s. 157).

${ }^{34}$ Podobne problemy związane z oceną czy normy zawarte w przepisach prawa wspólnotowego są wystarczająco istotne w postępowaniu krajowym do tego, by uzasadnić interwencję trybunału luksemburskiego, były znane od wielu lat. Pojawiały się one również w sprawach, które nie dotyczyły praw podstawowych. Trybunał stawał przed wątpliwościami, takimi jak np. czy powinien odpowiadać na pytanie sądu krajowego, dotyczące interpretacji prawa unijnego, które wszakże nie było stosowane bezpośrednio w postępowaniu krajowym, ale prawo krajowe odwoływało się do prawa unijnego w sposób, który - zdaniem sądu krajowego - sprawiał, że uprzednia wykładnia prawa unijnego była niezbędna, aby prawidłowo zinterpretować prawo krajowe. Chodzi tu przede wszystkim o problem ujawniony w grupie orzeczeń zapoczątkowanych wyrokiem w sprawach połączonych: TSUE, Massam Dzodzi p. państwu belgijskiemu, C-297/88 i C-197/89, wyrok z 18 października 1990. TSUE zgodził się w tej sprawie dokonać interpretacji prawa unijnego w czysto wewnętrznej sprawie ze względu na to, że prawo krajowe odwoływało się do prawa unijnego i regulowało ową wewnętrzną sytuację na podstawie unijnych regulacji swobody przepływu osób. Belgijskie prawo rozszerzało bowiem konsekwencje wynikające z prawa unijnego również na małżonków osób posiadających belgijskie obywatelstwo, którzy jednak sami byli obywatelami państw trzecich. W grupie orzeczeń zapoczątkowanych wyrokiem w innej sprawie (TSUE, Postępowanie karne p. Jean-Pierre Guimont, C-448/98, wyrok z 5 grudnia 2000) TSUE zgodził się natomiast dokonać interpretacji prawa unijnego w sprawie czysto wewnętrznej, ze względu na to, że wykładnia prawa krajowego bez odniesienia do prawa unijnego mogła prowadzić do pogorszenia sytuacji osób, które nie mogłyby powołać się na normę unijną względem osób, które mogłyby to uczynić (por. np.: S. Douglas-Scott, Constitutional Law of the European Union, Harlow-Nowy Jork 2002, s. 240 i nast.; A. Rosas, The Applicability..., s. 106).

${ }^{35}$ Więcej na temat kompetencji Unii patrz np.: R. Adam, M. Safjan, A. Tizzano, Zarys prawa Unii Europejskiej, Warszawa 2014, s. 45-65 i podana tam literatura; P. Craig, G. de Búrca, EU Law: Text, Cases, and Materials, Cambridge 2015, s. 73-104 i podana tam literatura. 
porządku prawnego zasady proporcjonalności i pomocniczości (art. 5 TUE). Wynika z nich brak jakiejkolwiek możliwości modyfikowania zakresu kompetencji UE bez zgody państw członkowskich, w tym przede wszystkim brak po stronie Unii kompetencji do kształtowania własnych kompetencji (kompetenz-kompetenz) $)^{36}$.

Wprawdzie zasady te są dobrze ugruntowane w prawie unijnym - art. 51 ust. 2 stanowi powtórzenie zasady wyrażonej w art. 6 ust. 1, zd. drugie TUE niemniej jednak szczególny charakter Karty, jak i konstytucyjna ze swej istoty materia, jaką są gwarancje praw i wolności człowieka oraz ranga tego dokumentu, usytuowanego na poziomie prawa pierwotnego Unii, mogłyby stwarzać pokusę do podejmowania prób obchodzenia zasady przyznania, opierając się na Karcie. Prowadziłoby to do nieuprawnionego rozszerzania zakresu kompetencji Unii. Art. 51 ust. 2 miał więc służyć wykluczeniu wszelkich wątpliwości w tej kwestii:

Celem art. 51 ust. 2 KPP jest zapobieżenie wyraźnemu powiększeniu kompetencji UE w drodze prawodawstwa unijnego wykonującego postanowienia Karty czy tzw. pełzaniu kompetencji na rzecz Unii w rezultacie aktywnej sądowej reinterpretacji przepisów Karty czy art. 114 i 357 TFUE[ $\left.{ }^{37}\right]$. Nie ma bowiem wątpliwości, że (...) ustanowienie na tym szczeblu przepisów rangi konstytucyjnej, zawierających rozwinięty katalog praw podstawowych, przepisy takie jako przepisy hierarchicznie wyższego rzędu, wywołują silne tendencje centralizacyjne, którym w UE ma przeszkodzić klauzula zawarta w art. $5^{1} \mathrm{KPP}^{38}$.

Karta nie wzięła się w unijnym porządku prawnym z próżni. Jej powstanie poprzedzone było długim procesem odkrywania roli, wypracowywania i umacniania w ramach Unii standardów ochrony praw fundamentalnych, co dokonywało się dzięki rozwojowi orzecznictwa trybunału luksemburskiego w tej materii. Jak wiadomo, traktaty założycielskie ${ }^{39}$ były pozbawione jakie-

${ }^{36}$ Więcej na ten temat patrz np.: G. Beck, The Problem of Kompetenz-Kompetenz: a Conflict Between Right and Right in Which There is no Praetor, "European Law Review" 2005, nr 1.

${ }^{37}$ Traktat o funkcjonowaniu Unii Europejskiej (wersja skonsolidowana), Dz.Urz. C 202 z 7 czerwca 2016.

${ }^{38}$ A. Wróbel, Art. 51.., s. 1302 . Więcej na temat art. 51 ust. 2 patrz np.: A. Ward, Art. 51.., s. 1447-1448; patrz też: TSUE, J. McB. p. L.E., C-400/10, wyrok z 5 października 2010, pkt 51; TSUE, Yoshikazu Iida p. Stadt Ulm, C-4O/11, wyrok z 8 listopada 2012, pkt 78 i nast.; TSUE, Thomas Pringle p. Government of Ireland, Ireland i The Attorney General, C-370/12, wyrok z 27 listopada 2012, pkt 179 .

${ }^{39}$ Traktat ustanawiający Europejską Wspólnotę Węgla i Stali, podpisany w Paryżu 18 kwietnia 1951; Traktat ustanawiający Europejską Wspólnotę Gospodarczą zawarty w Rzymie 25 marca 1957 przez sygnatariuszy Traktatu paryskiego; Traktat ustanawiający Europejską Wspólnotę Energii Atomowej zawarty w Rzymie 25 marca 1957 przez sygnatariuszy Traktatu 
gokolwiek odniesienia do praw człowieka. Taka ich architektura powodowała powstawanie różnych wątpliwości co do prawowitości wspólnotowego projektu. Jednakże raison d'être tego przedsięwzięcia było zapewnienie gospodarczej integracji między państwami, które w tamtym czasie zakładały wspólnotę $i$, jak twierdzono, nie było $w$ związku z tym konieczne rozszerzanie jej na kwestie natury politycznej, takie jak prawa człowieka ${ }^{40}$. Z czasem jednak prawa człowieka stały się jednym z centralnych obszarów prawa wspólnotowego, a ich role stopniowo odkrywał trybunał luksemburski, wyprowadzając obowiązywanie praw podstawowych w unijnym porządku prawnym z zasad ogólnych prawa wspólnotowego, opierając się na wspólnej tradycji konstytucyjnej państw członkowskich oraz EKPC $z^{41}$. Nadanie Karcie mocy prawnej, co nastąpiło wraz z przyjęciem Traktatu lizbońskiego, stanowiło ostatni krok $\mathrm{w}$ tym procesie i ostatecznie potwierdziło rolę praw człowieka w unijnym porządku prawnym oraz nadało gwarancjom je chroniącym status równy traktatom.

Podobnie historia zagadnienia zastosowania unijnych standardów praw fundamentalnych do jej państw członkowskich po tym, gdy prawa te okazały się na podstawie orzecznictwa TSUE być częścią unijnego porządku prawnego jako jego zasady ogólne, nie rozpoczyna się oczywiście od momentu wejścia w życie czy nawet od momentu rozpoczęcia prac nad Kartą, lecz jest znacznie dłuższa i sięga niemal samego początku procesu odnajdowania przez trybunał luksemburski gwarancji praw podstawowych w prawie Unii. „Problem zakresu związania państw członkowskich prawami podstawowymi nie jest nowy" ${ }^{\prime 2}$. Jest to problem dawny, którego rozstrzygnięcie ewoluowało przez lata. Po wejściu w życie Karty, w związku z użytym w niej nie do końca precyzyjnym i rozstrzygającym sformułowaniem, nawarstwione od lat wątpliwości sprawily, że kwestia ta stała się jeszcze bardziej niepewna.

Przełomowe okazało się w tym zakresie wydane 26 lutego 2013 roku orzeczenie w sprawie Åkerberg Fransson ${ }^{43}$, i to właśnie ono oraz jego skut-

paryskiego; nota bene propozycje, aby wprowadzić do wspólnotowego porządku prawnego prawa człowieka sięgają swą historią lat 50. XX wieku. Swój pierwszy w pełni dojrzały wyraz znalazły w projekcie Traktatu ustanawiającego Europejską Wspólnotę Polityczną z 1953 r.; więcej na ten temat patrz np.: G. de Búrca, The Road...; stąd Karta i Konwencja bywają czasem określane mianem bliźniaków rozdzielonych tuż po porodzie (G. Quinn, The European Union and the Council of Europe on the Issue of Human Rights: Twins Separated at Birth?, „McGill Law Journal" 2000-2001, nr 46).

${ }^{40}$ F. Korenica, The EU Accession..., s. 36-37.

${ }^{41}$ Więcej - patrz np.: P. Gragl, The Accession of the European Union to the European Convention on Human Rights, Oxford-Portland 2013, s. 50-81; F. Korenica, The EU Accession..., s. 35-67.

42 A. Wróbel, Art. 51..., s. 1309.

${ }^{43}$ TSUE, Åklagaren p. Hans Åkerberg Fransson, C-617/10, wyrok z 26 lutego 2013. 
$\mathrm{ki}$, a także wynikające $\mathrm{z}$ niego konsekwencje najważniejsze z perspektywy tej pracy, będą głównym przedmiotem zainteresowania w tym rozdziale. Należy wszakże podkreślić, że orzeczenie to, podobnie jak sama Karta, nie wzięło się z próżni i stanowi kolejny etap w rozwoju podejścia TSUE do kwestii stosowania unijnych gwarancji praw podstawowych wobec państw członkowskich $\mathrm{z}$ uwzględnieniem przemian $\mathrm{w}$ systemie prawa UE, $\mathrm{w}$ tym przede wszystkim zmian wynikających z wejścia w życie Traktatu lizbońskiego. Orzeczenie w sprawie Åkerberg Fransson wpisało się w dziedzictwo TSUE i w pewnym sensie podsumowało je, rozstrzygając zasadnicze wątpliwości wokół pytania, czy trybunał luksemburski pod rządami Karty będzie kontynuował swoją wcześniejszą linię orzeczniczą w przedmiotowej materii, czy raczej zerwie z nią i opierając się na art. 51 ust. 1 Karty wypracuje nową zasadę stosowania unijnych praw podstawowych do państw członkowskich. Trybunał luksemburski wybrał tę pierwszą drogę. Orzeczenie to stało się również podstawą do dalszego rozwijania i doprecyzowania przez TSUE rozumienia art. 51 ust. 1 Karty i wynikających z niego konsekwencji w dalszych wyrokach TSUE, najważniejsze z których będą również poddane analizie $w$ tym rozdziale.

Karta, jako obowiązujący dokument prawny, i to dokument o najwyższej randze w ramach unijnego porządku prawnego, zmieniła w istotny sposób status praw podstawowych na przestrzeni Unii. Sam fakt ochrony przez Unię praw podstawowych, jak i realia funkcjonowania prawa Unii oraz zasady, na których było i jest ono oparte, pozostały jednak w dużej mierze niezmienione. Burzliwe czasem negocjacje nad ostatecznym brzmieniem przepisów Karty oraz długa droga, jaką dokument ten musiał przejść od przyjęcia jego ostatecznego brzmienia do nadania mu mocy obowiązującej, pokazują jednak, że wcale niekoniecznie był on jedynie pieczęcią sankcjonującą stan rzeczy, który jest i był powszechnie znany i niekontrowersyjny. Po wejściu w życie Karty konieczna była więc jednoznaczna odpowiedź na pytanie, czy, i jeśli tak, to $\mathrm{w}$ jaki sposób coś zmieniło się w zakresie stosowania unijnych praw podstawowych, w tym przede wszystkim w zakresie ich stosowania wobec państw członkowskich Unii. Odpowiedź na tę kwestę umożliwia bowiem w kategoriach ogólnych odpowiedź na pytanie, w jakich sytuacjach sądy narodowe i organy władzy państwowej powinny stosować unijne gwarancje praw podstawowych. Szczególnie stanowi zaś jeden z elementów odpowiedzi na interesujące nas w tej pracy pytanie dotyczące relacji między Trybunałem Konstytucyjnym a Trybunałem Sprawiedliwości Unii Europejskiej oraz podziału kompetencji pomiędzy nimi w zakresie, w jakim odpowiadają one za kontrolowanie prawa obowiązującego w Polsce pod kątem zgodności z unijnymi i krajowymi gwarancjami praw człowieka. 


\section{Pojęcie stosowania prawa ugruntowane w polskiej tradycji prawnej i jego nieprzystawalność do realiów UE i wykładni art. 51 ust. 1 Karty}

Dokonywanie wykładni pojęcia stosowania prawa Unii przez jej państwa członkowskie zawartego w art. 51 ust. 1 KPP należy oczywiście do TSUE, który ma wyłączną kompetencję do interpretowania prawa Unii. Dla prawidłowego rozumienia tego przepisu konieczna jest więc analiza orzecznictwa TSUE w tej materii. Przed przejściem do omawiania tych szczegółowych zagadnień i zanim uwaga skupiona zostanie na perspektywie unijnej, należy wszakże już w tym miejscu zauważyć, że w kontekście unijnym owo 'stosowanie' prawa Unii nabiera istotnie szerszego znaczenia niż mogłoby to wynikać z intuicji czysto językowej, naturalnej dla zakorzenionego w Polsce rozumienia pojęcia stosowania prawa.

W polskiej tradycji prawnej stosowanie prawa jest pojęciem o specyficznym i dość wąskim znaczeniu. W ujęciu najszerszym stosowanie prawa to korzystanie „z upoważnień, których określona norma prawna udziela jakiemuś podmiotowi"44. Jednakże szczególnie ważne znaczenie, odróżniające stosowanie od stanowienia prawa, jak przyjęło się uważać w polskiej kulturze prawnej, ma indywidualny i konkretny charakter aktów stosowania prawa w przeciwieństwie do generalnego i abstrakcyjnego charakteru aktów stanowienia prawa. Sławomira Wronkowska-Jaśkiewicz przez stosowanie prawa rozumie „czynność konwencjonalną organu państwa (albo podmiotu, który spełnia podobną rolę), przez którą organ ten rozstrzyga jakąś sprawę indywidualną i konkretną, czyniąc to na podstawie obowiązującej normy prawnej" ${ }^{\prime 4}$. Na tej podstawie wyróżnia się cztery podstawowe etapy stosowania prawa, jakimi modelowo są: ustalanie podstawy prawnej rozstrzygnięcia, ustalenie stanu faktycznego, dokonanie subsumpcji i wydanie decyzji finalnej oraz jej uzasadnienie ${ }^{46}$. W ramach tego modelowego ujęcia wyróżnia ona także dwa podstawowe typy stosowania prawa, jakimi są sądowy typ stosowania prawa i kierowniczy typ stosowania prawa ${ }^{47}$.

Jak słusznie zauważył Andrzej Wróbel, należy

przyjąć, że pojęcie "stosowanie” użyte w polskiej wersji językowej przepisu art. 51 ust. 1 Karty ma autonomiczne znaczenie i nie powinno być interpretowane zgodnie ze znaczeniem, jakie temu pojęciu przypisuje się w polskiej kulturze prawnej. Sto-

\footnotetext{
${ }^{44}$ S. Wronkowska, Z. Ziembiński, Zarys..., s. 213.

${ }^{45}$ S. Wronkowska, Podstawowe pojęcia prawa i prawoznawstwa, Poznań 2003, s. 133.

${ }^{46}$ Ibidem, s. 134-136.

${ }^{47}$ Ibidem, s. $138-139$.
} 
sowanie w rozumieniu tego przepisu nie oznacza zatem wyłącznie ustalenia konsekwencji prawnej stosowanej normy prawa do ustalonego stanu faktycznego ${ }^{48}$.

W związku z tym, dokonując wykładni art. 51 ust. 1 Karty i zawartego $\mathrm{w}$ nim pojęcia stosowania prawa UE, należy zdecydowanie

odejść od językowo-logicznej wykładni tego niefortunnego terminu w języku polskim i uwzględniając inne jego wersje językowe przyjąć, że państwa członkowskie są związane przepisami Karty w zakresie, w jakim „implementują" prawo Unii, przy czym pojęcie implementują należy rozumieć jako obejmujące implementację legislacyjną i implementację orzeczniczą, czyli zarówno stanowienie prawa przez państwa członkowskie, jak i stosowanie przez państwa członkowskie prawa UE oraz stosowanie prawa państwa członkowskiego w kontekście prawa UE ${ }^{49}$.

Należy przypomnieć, że w doktrynie prawa unijnego dominuje szerokie rozumienie pojęcia implementowania prawa UE. Zgodnie z jego wąskim rozumieniem pojęcie implementacji oznaczałoby stanowienie prawa przez organy prawodawcze państw członkowskich w celu osiągania rezultatów wskazanych w unijnych dyrektywach (legislacyjna implementacja dyrektyw) oraz w wyjątkowych przypadkach stanowienie przez te organy prawa na podstawie unijnych rozporządzeń, które co do zasady są samodzielnymi źródłami prawa, obowiązującymi bezpośrednio w państwach członkowskich ${ }^{50}$. Zgodnie zaś z szerokim rozumieniem pojęcia implementacji, które przyjęte jest również na potrzeby tej pracy, przez implementację prawa Unii przez państwa członkowskie należy rozumieć

nie tylko transpozycję dyrektyw do krajowego porządku prawnego, lecz także stanowienie przepisów uzupełniających lub wykonujących inne akty prawne UE, np. rozporządzenia. Natomiast implementacja w procesie stosowania prawa polega nie tylko na stosowaniu bezpośrednio skutecznych przepisów prawa UE, lecz także na stosowaniu i wykładni prawa krajowego ustanowionego w wykonaniu prawa UE, w tym zwłaszcza dyrektyw ${ }^{51}$.

Pojęcie implementowania prawa Unii jest więc pojęciem szerokim, obejmującym różnorodne aktywności organów władzy państwowej, zmierzające

${ }^{48}$ A. Wróbel, O niektórych problemach sadowego stosowania Karty Praw Podstawowych, [w:] A. Wróbel (red.), Karta Praw Podstawowych w europejskim i krajowym porzadku prawnym, Warszawa 2009 , s. 88.

${ }^{49}$ Ibidem.

${ }^{50}$ Por.: A. Wróbel, Art. 51..., s. 1309-1311.

${ }^{51}$ A. Wróbel, O niektórych..., s. 86. 
do wykonania obowiązków wynikających z prawa unijnego. „Takie ujęcie implementacji jest zgodne ze sposobami, w jaki prawa (podstawowe) UE moga mieć wpływ na sytuację prawną jednostki"52.

\section{Art. 51 ust. 1 Karty i zakres jej zastosowania wobec państw członkowskich Unii w innych niż polska wersjach językowych Karty}

Sposób sformułowania treści interesującego nas art. 51 ust. 1 KPP odnośnie do zastosowania Karty do państw członkowskich w różnych językach urzędowych Unii nie jest w pełni jednorodny. Łatwo zauważalna niespójność zwrotów użytych w różnych wersjach językowych Karty niewątpliwie nie ułatwia wykładni tego przepisu ${ }^{53}$. Na pierwszy rzut oka może się wydawać, że w niektórych językach nieco lepiej oddano dotyczącą unijnej specyfiki istotę problemu związania państw członkowskich unijnymi prawami podstawowymi i nieco lepiej dopasowano brzmienie art. 51 ust. 1 Karty do lokalnej, lecz także unijnej tradycji prawnej, niż udało się to zrobić w innych wersjach językowych, w tym w polskiej. Zaproponowane przez Andrzeja Wróbla pojęcie implementacji prawa UE, które faktycznie miałoby lepiej oddawać sens art. 51 ust. 1 Karty, a które obudowane jest szerszą doktryną i orzecznictwem ułatwiającymi jego bardziej jednoznaczną wykładnię oraz które pozbawione jest konieczności odchodzenia od utrwalonej w polskiej kulturze prawnej rozumienia pojęcia stosowania prawa, znajduje swoje odbicie w angielskiej wersji językowej Karty (while implementing). Jednakże już wersja francuska (mettent en œuvre) czy niemiecka (Durchführung) od czasownika tego stronią. Poprzez użyte sformułowania odnoszące się do 'realizowania' prawa czy też raczej zobowiązań wynikających z prawa unijnego pozostają jednak w logice szeroko, a nie wąsko rozumianej implementacji prawa unijnego, o której była mowa przed chwila. $Z$ drugiej natomiast strony, jak wskazuje Allan Rosas, niektóre wersje językowe używają pojęcia zbliżonego do polskiego "stosowania”. Najbliższa naszej wersji językowej wydaje się hiszpańska wersja Karty, w której pojawia się sformułowanie o zastosowaniu jej przepisów wobec państw członkowskich: "únicamente cuando apliquen el Derecho de la Unión"54. Podobnych do "stosowania"

\footnotetext{
52 A. Wróbel, Art. $51 \ldots$, s. 1311.

${ }^{53}$ N. Półtorak, Zakres związania..., s. 19.

${ }^{54}$ Por.: A. Rosas, The Applicability..., s. 105; A. Wróbel, Art. 51..., s. 1311-1312.
} 
pojęć używają również np. wersja fińska (soveltaa) czy szwedzka (tillämpa). W języku angielskim odpowiadają one najbliżej słowu apply. Odmiennie do zaprezentowanego tu zawężającego efektu użycia takich słów względem pojęcia implement Angela Ward zwraca uwagę, co wydaje się aktualne jedynie przy ewentualnym przyjęciu wąskiego rozumienia pojęcia implementacji, że z kolei te właśnie sformułowania ułatwiają szerszą interpretację zakresu zastosowania unijnych praw podstawowych do państw członkowskich na gruncie art. 51 ust. 1 niż pojęcie implementacji ${ }^{55}$. Jeszcze bardziej pokazuje to niejednolitość sformułowań użytych w różnych wersjach językowych oraz pewną konfuzję, jaka w związku z tym powstaje.

Te cienie i niuanse kolejnych wersji brzmienia Karty w różnych językach państw członkowskich Unii nie powinny mieć jednak większego znaczenia dla rozumienia pojęcia "stosowania" z art. 51 ust. 1 Karty. Należy przychylić się do poglądu nakazującego traktować je jako pojęcie autonomiczne i dokonywać jego wykładni w oderwaniu od czysto językowo-logicznych metod, a także w oderwaniu od krajowych partykularyzmów pojęciowych. Bez względu na różnorodność nie zawsze szczęśliwie dobranych sformułowań, należy uznać, że pojęcia te powinny uzyskać autonomiczne i spójne w całej Unii znaczenie, które w oczywisty sposób musi mieć uniwersalny charakter i być w związku $\mathrm{z}$ tym rozumiane jednakowo. Dlatego tak ważna jest $\mathrm{w}$ tej materii rola TSUE, odpowiedzialnego za wykładnię prawa unijnego.

Wydaje się, że pojęcie "stosowania” z art. 51 ust. 1 jest wystarczająco przejrzyście wyłożone i obudowane przez - również nie zawsze posługujące się bezpośrednio tym pojęciem, lecz wyrażeniami bliskoznacznymi - orzecznictwo TSUE. Dzięki temu bez względu na język, w którym czyta się Kartę czy najważniejsze orzeczenia, można uzyskać jasność, jak trybunał luksemburski rozumie art. 51 ust. 1 i wynikający z niego zakres stosowania Karty do państw członkowskich. Należy również podkreślić, że od dawna, a więc jeszcze przed wejściem w życie Karty i jej art. 51 ust. 1, gdy oceniał zastosowanie unijnych praw podstawowych do państw członkowskich, TSUE najchętniej używał w swym orzecznictwie zamiennie pojęć „implementowanie” (implementation) prawa UE oraz "działanie w zakresie zastosowania prawa UE" (acting within the scope of EU law $)^{56}$.

${ }^{55}$ A. Ward, Art. 51..., s. 1431; por. także: M. Safjan, Areas of Application of the Charter of Fundamental Rights of the European Union: Fields of Conflict?, EUI Working Paper, LAW 2012, nr 22, s. 5 .

56 A. Rosas, The Applicability..., s. 105. 


\section{Alternatywne propozycje brzmienia art. 51 ust. 1 Karty pojawiające się w travaux préparatoires}

Aby najlepiej odzwierciedlić poprzedzającą wejście w życie Karty tendencję, w ramach której określany był zakres związania państw członkowskich unijnymi prawami podstawowymi, i podkreślić niezmienność tej zasady po wejściu w życie Karty, wydaje się, że najodpowiedniejszym rozwiązaniem byłoby użycie znanego z orzecznictwa TSUE bardziej opisowego sformułowania, wedle którego zobowiązania wynikające z Karty byłyby wiążące dla państw członkowskich UE wtedy, gdy państwa te "działają (...) w zakresie zastosowania prawa UE", albo też powszechne zastosowanie wspomnianego pojęcia implementacji prawa unijnego przy ugruntowanym jego szerokim rozumieniu. Tak się jednak nie stało. Warto więc poświęcić chwilę uwagi procesowi wypracowywania ostatecznego brzmienia art. 51 ust. 1 KPP.

Pewne światło na temat intencji państw członkowskich dotyczących sformułowania użytego ostatecznie w tym przepisie i w związku z tym zakresu, $\mathrm{w}$ jakim chciały one związać się unijnymi prawami podstawowymi, mogą rzucić prace przygotowawcze i proces negocjacji zmierzających do ostatecznego sformułowania brzmienia tego przepisu. Jego proponowane brzmienie podlegało wielokrotnym zmianom i zmiany te często odzwierciedlały pewne obawy, które mogły żywić państwa członkowskie, a które dotyczyły rozszerzania dotychczasowego i znanego im zakresu ich związania przepisami Karty (w skrajnych przypadkach być może nawet nieograniczonego). Skutkowałoby to znaczącym rozszerzeniem kompetencji Unii kosztem państw członkowskich, na co nie chciały się one zgodzić57. Tego typu obawy zostały jednak jednoznacznie wykluczone, jak zostało to już wspomniane, w art. 51 ust. 2 Karty. Niemniej jednak brzmienie art. 51 ust. 1 nie było bez znaczenia, a ostatecznie użyte w nim sformułowania mogły być różne i sprzyjać rozszerzającemu rozumieniu zakresu stosowania Karty skutkującemu szerokim zakreśleniem spektrum aktywności państw, w ramach którego musiałyby one wypełniać unijne gwarancje praw podstawowych albo przeciwnie - wąskiemu jego rozumieniu. Stąd też dyskusja nad ostatecznym brzmieniem tego artykułu była forum ścierania się różnych tendencji i podejść do tej kwestii. Niektóre państwa członkowskie, takie jak Wielka Brytania, były szczególnie niechętne idei stosowania do nich unijnych praw podstawowych. W sytuacji, gdy jej niechęci nie podzielały pozostałe państwa członkowskie, doprowadziła ona

${ }^{57}$ Por.: A. Wróbel, O niektórych..., s. 84-85. 
zresztą $^{58}$ do przyjęcia Protokołu nr $3 \mathrm{O}^{59}$, do którego przystąpiła również Polska, dotyczącego stosowania KPP wobec tych dwóch państw ${ }^{60}$.

W kolejnych wersjach projektu KPP [interesujące nas - przyp. aut.] sformułowanie [...] miało następujące brzmienia: "gdy transponują lub stosują prawo Unii" (transpose or apply the law of the Union), gdy „implementują prawo Wspólnoty” (implementing Community law), "wyłącznie w zakresie, w jakim implementują prawo Wspólnoty" (exclusively within the framework of implementing Community law), "wyłącznie w zakresie prawa Unii" (exclusively within the scope of Union law). Nie ma watpliwości, że najszerszy zakres związania państw członkowskich przepisami Karty wynikał ze sformułowania "w zakresie prawa Unii", a najwęższy - „wyłącznie w zakresie, w jakim implementują prawo Wspólnoty", ewentualnie "gdy transponują lub stosują prawo Unii"61.

Pojęcie „w zakresie prawa Unii” oznaczałoby bowiem wszelkie istotne z punktu widzenia praw podstawowych działania, a także zaniechania państw członkowskich w obszarach uregulowanych przepisami prawa unijnego oraz jego zasadami ogólnymi. Takie sformułowanie mogłoby być nawet ewentualną podstawą do rozszerzenia zakresu związania państw członkowskich do wszelkich ich działań i zaniechań mieszczących się w zakresie kompetencji Unii, choć tak szerokie podejście do zakresu związania państw członkowskich unijnymi prawami podstawowymi, nawet przy takim brzmieniu art. 51 ust. 1 , nie byłoby niekontrowersyjne. Sformułowanie: „wyłącznie w zakresie, w jakim implementuja prawo Wspólnoty", mogłoby być nie w pełni jednoznaczne ze względu na to, czy pojęcie implementacji rozumiano by wąsko - jako legislacyjną implementację dyrektyw, i w wyjątkowych przypadkach stanowienie prawa na podstawie rozporządzeń, czy też szeroko ${ }^{62}$. Równoznaczne z tym ostatnim byłoby sformułowanie: "gdy transponują lub stosują prawo Unii", obejmujące zarówno implementację wymagających tego przepisów prawa unijnego, jak i stosowanie bezpośrednio skutecznych przepisów prawa UE.

Jak więc widać, państwa nie zdecydowały się ostatecznie wprowadzić do tekstu Karty sformułowania najszerszego, a więc właśnie związującego ich unijnymi prawami podstawowymi, gdy działają „w zakresie prawa Unii”. Po niełatwych negocjacjach ${ }^{63}$ wybrały inne sformułowanie, które w dodatku zostało

${ }^{58}$ A. Rosas, The Applicability..., s. 104.

${ }^{59}$ Protokół (nr 30) w sprawie stosowania Karty praw podstawowych Unii Europejskiej do Polski i Zjednoczonego Królestwa, Dz.Urz. C 115 z 9 maja 2008.

${ }^{60} \mathrm{O}$ dokumencie tym i jego znaczeniu dla stosowania postanowień Karty odnośnie do Polski będzie bardziej szczegółowo mowa w następnym rozdziale.

${ }^{61}$ A. Wróbel, O niektórych..., s. 85.

${ }^{62}$ A. Wróbel, Art. 51..., s. 1309-1311.

${ }^{63}$ Więcej na ten temat patrz np.: G. de Búrca, The Drafting of the European Union Charter of Fundamental Rights, "European Law Review” 2001, nr 26, s. 126; P. Eeckhout, The EU Charter 
niejednorodnie przełożone na różne języki urzędowe Unii. Skoro więc tak się stało, można odnieść wrażenie, że intencją państw członkowskich było nadanie zakresowi ich związania unijnymi prawami podstawowymi pod rządami Karty innego zakresu niż wynikać by to miało $z$ utrwalonego do tej pory orzecznictwa TSUE. Podkreślić należy w tym kontekście użycie słowa "wyłącznie”, które uwydatnia ekstraordynaryjny charakter związania państw członkowskich unijnymi prawami podstawowymi jedynie, gdy jest to wyraźnie uzasadnione ${ }^{64}$. Znaczenie owych rozbieżności i sporów co do wykorzystanych w poszczególnych wersjach projektu KPP sformułowań, osłabia w pewnym sensie fakt, że użyte ostatecznie pojęcia nie miały bardzo precyzyjnego charakteru, nie posiadały żadnej legalnej definicji, a ich stosowanie w orzecznictwie bywało często zamienne. Jak się więc okaże, te spory o słowa na etapie ustalania brzmienia Karty, przynajmniej odnośnie do art. 51 ust. 1, i tak w dużej mierze okazały się w ograniczonym stopniu wpływać na interpretację art. 51 ust. 1 Karty, jakiej dokonał TSUE.

Tym niemniej należy pamiętać, że przebieg prac nad art. 51 ust. 1 Karty pokazał, że wolą Herren der Verträge było wyraźne rozgraniczenie sytuacji, w których Karta może mieć zastosowanie do państw członkowskich, od sytuacji czysto wewnętrznych, w których ona zastosowania nie ma ${ }^{65}$.

Podstawowym celem art. 51 KPP jest wyraźne oddzielenie kompetencji państw członkowskich i UE w zakresie ochrony praw podstawowych oraz prawne związanie Unii i państw członkowskich postanowieniami Karty, z tym wszakże zastrzeżeniem, że o ile zakres związania UE jest szeroki, to związanie państw członkowskich tymi postanowieniami jest zdecydowanie węższe ${ }^{66}$.

Jest to widoczne zarówno w art. 51 ust. 1 i art. 51 ust. 2 Karty, jak i w szerszej lizbońskiej architekturze unijnej struktury gwarancji praw człowieka. Można więc stwierdzić, że w istocie: „Karta jest dokumentem kompromisowym. Dominuje w nim element delimitacji i gwarancji obecnego status quo, a nie niekontrolowanej ekspansji i narzucania" ${ }^{67}$. Kompromis ten bywa jednak często przedmiotem i ostatecznie jest wynikiem nie tyle samego brzmienia Karty, co swoistego docierania się orzecznictwa unijnego i krajowego.

of Fundamental Rights and the Federal Question, "Common Market Law Review” 2002, nr 39 (5), s. 954; A. Ward, Art. 51..., s. 1424-1425.

${ }^{64}$ A. Ward, Art. $51 \ldots$, s. 1425.

${ }^{65}$ A. Rosas, The Applicability..., s. 112.

${ }^{66}$ A. Wróbel, Art. 51..., s. 1301.

${ }^{67}$ T.T. Koncewicz, A. Podolska, Karta Praw Podstawowych w sadach polskich. Mit, marzenie czy rzeczywistość, „Palestra” 2014, nr 3-4, s. 248. 


\section{Wyjaśnienia dotyczące Karty Praw Podstawowych}

Wyjaśnienia dotyczące Karty Praw Podstawowych ${ }^{68}$ nie są wprawdzie dokumentem mającym moc prawnie wiążąca, stanowią jednak istotne narzędzie pomocnicze przy dokonywaniu wykładni KPP, szczególnie w obliczu oparcia ich w dużej mierze na wcześniejszym orzecznictwie TSUE, a także w związku z art. 6 ust. 1 zd. trzecie TUE, który stanowi, że „Prawa, wolności i zasady zawarte $\mathrm{w}$ Karcie są interpretowane zgodnie z postanowieniami ogólnymi określonymi w Tytule VII Karty regulującymi jej interpretację i stosowanie oraz z należytym uwzględnieniem wyjaśnień, o których mowa w Karcie, które określają źródła tych postanowień", oraz w obliczu art. 52 ust. 7 samej Karty, który stanowi, że "Wyjaśnienia sporządzone w celu wskazania wykładni niniejszej Karty są należycie uwzględniane przez sądy Unii i Państw Członkowskich". Wyjaśnienia mają więc dość specyficzny status jako dokument interpretacyjny Karty, który jest silnie podparty przez Traktat lizboński ${ }^{69}$.

We fragmencie Wyjaśnień poświęconym art. 51 ust. 1 Karty czytamy, że:

W odniesieniu do Państw Członkowskich z orzecznictwa Trybunału wynika niewątpliwie, że wymóg poszanowania praw podstawowych określonych w kontekście Unii jest wiążący dla Państw Członkowskich wyłącznie wtedy, gdy działają one w zakresie zastosowania prawa Unii [...]. W ostatnim czasie Trybunał Sprawiedliwości potwierdził to orzecznictwo w następujący sposób: „Ponadto należy pamiętać, że wymogi wynikające z ochrony praw podstawowych w ramach wspólnotowego porządku prawnego są wiążące także dla Państw Członkowskich, gdy wykonują one regulacje wspólnotowe..." [... $]^{70}$.

Jak wyraźnie więc widać, „stosowanie prawa UE”, jak formułuje to polska wersja językowa Karty, czy „wykonywanie regulacji wspólnotowych”, jakiego to sformułowania używa się w cytowanym powyżej fragmencie polskiej wersji językowej Wyjaśnień, wyroku w sprawie Karlsson ${ }^{71}$, rozumiane jest szeroko. Zakres związania Kartą miałby więc być oparty nie na formalnym powiązaniu z bezpośrednio wynikającym z prawa unijnego zobowiązaniem kierowanym do państw członkowskich, lecz na fakcie, że państwo działa „w zakresie za-

${ }^{68}$ Wyjaśnienia dotyczące Karty Praw Podstawowych, Dz.Urz. C 303 z 14 grudnia 2007, s. 17.

${ }^{69}$ Więcej na ten temat patrz np.: J-P. Jacqué, The Explanations Relating to the Charter of Fundamental Rights of the European Union, [w: ] S. Peers, T. Harvey, J. Kenner, A. Ward (red.), The EU Charter of Fundamental Rights. A Commentary, Oxford 2014, s. 1715 i nast.

${ }^{70}$ Wyjaśnienia dotyczące Karty Praw Podstawowych, Dz. Urz. C 303 z 14 grudnia 2007, S. 17 .

${ }^{71}$ TSUE, Kjell Karlsson i inni p. Szwecji, C-292/97, wyrok z 13 kwietnia 2000. 
stosowania prawa Unii". Co najistotniejsze, jak zdaje się wynikać z Wyjaśnień, nadanie Karcie mocy prawnej i przyjęcie wraz z nią art. 51 ust. 1, regulującego zakres zastosowania unijnych praw podstawowych do państw członkowskich nie miał służyć, przynajmniej zdaniem Prezydium Konwentu przygotowującego Kartę, któremu to powierzono opracowanie Wyjaśnień, zerwaniu z dotychczasową linią orzeczniczą w tej materii i odejściem od wypracowanych przez TSUE zasad stosowania unijnych praw podstawowych do państw członkowskich.

\section{Zakres zastosowania unijnych praw podstawowych wobec państw członkowskich przed wejściem w życie Karty}

W świetle luksemburskiej jurisprudence constante państwa członkowskie są związane unijnymi prawami podstawowymi, gdy „działają w zakresie zastosowania prawa Unii"72. Sprowadza się to zasadniczo do trzech podstawowych rodzajów sytuacji, z których dwie pierwsze mają znacznie dłuższą historię orzeczniczą i stanowią dziedzictwo orzeczeń TSUE w sprawach Wachauf ${ }^{73}$ i ERT ${ }^{74}$ z przełomu lat 8o. i 9o. XX wieku. Orzeczenia zaliczane do trzeciej grupy pochodza zaś z lat późniejszych. Ma ona również charakter mniej jednorodny i bardziej otwarty niż dwie poprzednie.

Orzeczenia w sprawach Wachauf i ERT stanowiły początek procesu, w ramach którego trybunał luksemburski przestał ograniczać stosowanie unijnych praw podstawowych jedynie do prawa wspólnotowego, rozszerzając ich stosowanie do prawa państw członkowskich. Podobnie jak w latach 1969-1979, w wyniku ewolucji swego orzecznictwa przestał ignorować prawa podstawo-

${ }^{72}$ Patrz np.: TSUE, Friedrich Kremzow p. Republik Österreich, C-299/95, wyrok z 29 maja 1997, pkt 15; TSUE, Daniele Annibaldi p. Sindaco del Comune di Guidonia and Presidente Regione Lazio, C-309/96, wyrok z 18 grudnia 1997, pkt 13; TSUE, Roquette Frères SA p. Directeur général de la concurrence, de la consommation et de la répression des fraudes, and Commission of the European Communities, C-94/oo, wyrok z 22 października 2002, pkt 25; TSUE, Sopropé - Organizações de Calçado Lda p. Fazenda Pública, C 349/o7, wyrok z 18 grudnia 2008, pkt 34; por.: A. von Bogdandy, M. Kottmann, C. Antpöhler, J. Dickschen, S. Hentrei, M. Smrkolj, Reverse Solange - Protecting the Essence of Fundamental Rights against EU Member States, "Common Market Law Review" 2012, nr 2 (49), s. 497.

${ }^{73}$ TSUE, Hubert Wachauf p. Republika Federalna Niemiec, C-5/88, wyrok z 13 lipca 1989.

74 TSUE, Elliniki Radiophonia Tiléorassi AE i Panellinia Omospondia Syllogon Prossopikou p. Dimotiki Etairia Pliroforissis i Sotirios Kouvelas i Nicolaos Avdellas et al., C-260/89, wyrok z 18 czerwca 1991. 
we w prawie wspólnotowym i zaczął orzekać o nich, doszukując się ich źródeł w ogólnych zasadach prawa wspólnotowego, tak w latach 1989-1991 zaczął prawa podstawowe traktować jako parametry stosowalne również wobec prawa państw członkowskich. O ile ta pierwsza faza ewolucji orzecznictwa TSUE w przedmiocie praw człowieka przyjęta była raczej z powszechną aprobata, o tyle ta druga nie była aż tak niekontrowersyjna ${ }^{75}$.

To właśnie o sytuacjach typu Wachauf, jak i sytuacjach typu ERT wspominał Andrzej Wróbel, gdy pisał o dawności problemu wykładni pojęcia stosowania prawa Unii na potrzeby określania zakresu związania państw członkowskich unijnymi prawami podstawowymi:

Jeszcze przed przyjęciem Karty przyjmowano bowiem w orzecznictwie sądów unijnych, że państwa członkowskie są związane prawami podstawowymi rozumianymi jako zasady ogólne prawa wspólnotowego w następujących sytuacjach: 1) państwo członkowskie implementuje prawo UE/WE [sprawy typu Wachauf - przyp. aut.], 2) państwo członkowskie odstępuje od wymagań prawa UE/WE, w szczególności swobód wspólnotowych [sprawy typu ERT - przyp. aut.]: a) odstępstwa przewidziane wyraźnie w traktacie - państwo członkowskie powołuje się na przepis traktatu przewidujący odstępstwo od zasady swobody przemieszczania się, aby uzasadnić ograniczenia tej zasady, b) odstępstwa typu Cassiss de Dijon [...], c) odstępstwa typu podanego w wyr. ETS z 12.6.2003 r. [... $]^{76}$.

\subsection{Sprawy typu Wachauf}

Podstawową sytuacja, w której państwa członkowskie podlegają unijnym prawom podstawowym jest dokonywanie przez nie wąsko rozumianej implementacji prawa wspólnotowego, które nie może być stosowane bezpośrednio i wymaga transpozycji lub innego wprowadzenia do systemu krajowego dla swojej skuteczności. Co do tego, że w takim przypadku państwa członkowskie stosują prawo UE, nie było przed wejściem Karty w życie, przynajmniej po stronie TSUE, większych wątpliwości. Do tej „kategorii spraw należą te, w których państwa członkowskie działają jako »organy« Unii w znaczeniu funkcjonalnym albo wdrażając dyrektywy, albo »operacjonalizując« rozporządzenia, albo wykonując prawo UE"77.

${ }^{75}$ P.C. Villalón, 'All the guidance', ERT and Wachauf, [w:] M.P. Maduro, L. Azoulai (red.), The Past and Future of EU Law: The Classics of EU Law Revisited on the 5oth Anniversary of the Rome Treaty, Oxford-Portland 2010, s. 163.

${ }^{76}$ A. Wróbel, Art. 51..., s. 1309.

77 Ibidem, s. 1341. 
Po raz pierwszy w pełni otwarcie ${ }^{78}$ Trybunał stwierdził to $\mathrm{w}$ wyroku w sprawie Wachauf ${ }^{79}$, a później podtrzymał takie stanowisko w wielu orzeczeniach ${ }^{80}$. Sprawa Wachauf dotyczyła Huberta Wachauf, który prowadził przedsiębiorstwo mleczne w wydzierżawionym gospodarstwie. To on jednak zapewnił niezbędny do jego funkcjonowania żywy inwentarz i maszyny. Po wygaśnięciu dzierżawy pojawiło się pytanie, czy kwoty mleczne lub odszkodowanie za powstrzymywanie się od produkcji powinny powrócić do właściciela, a nie pozostać przy dzierżawcy, co nie w pełni przejrzyście uregulowane było w przepisach prawa wspólnotowego. Prawo niemieckie zezwalało jedynie na to, by dzierżawca zachowywał kwoty, jednakże za zgodą właściciela wyrażoną na piśmie, której to zgody Hubert Wachauf nie uzyskał. Trybunał doszedł do wniosku, że takie rozwiązanie stoi w sprzeczności z prawami podstawowymi chronionymi we wspólnotowym porządku prawnym, jako że pozbawiają dzierżawcę owoców jego pracy i nakładów bez żadnej rekompensaty. Stwierdził ponadto, że te gwarancje są wiążące również dla państw członkowskich, kiedy implemen-

${ }^{78}$ Można wskazać różne przykłady orzeczeń wcześniejszych, w których wspólnotowe prawa podstawowe bywały jeszcze przed wyrokiem w sprawie Wachauf stosowane odnośnie do państw członkowskich, jednakże bez tak jednoznacznego uwidocznienia tej kwestii w samym wyroku. Np. Joseph Weiler (J.H. H. Weiler, Fundamental Rights and Fundamental Boundaries: on the Conflict of Standards and Values in the Protection of Human Rights in the European Legal Space, [w:] J.H. H. Weiler (red.), The Constitution of Europe, Cambridge 1999, s. 199) wskazuje w tym kontekście sprawy takie, jak: TSUE, Roland Rutili p. Ministre de l'intérieur, 36-75, wyrok z 28 października 1975, pkt 36-75; TSUE, Cinéthèque SA and others p. Fédération nationale des cinémas français, C-6o i 61/84, wyrok z 11 lipca 1985, przed. pkt 26; TSUE, Marthe Klensch i inni p. Secrétaire d'État a l'Agriculture et a la Viticulture, C-201/85 i C-202/85, wyrok z 25 listopada 1986, przed. pkt 9-11; Andrzej Wróbel (A. Wróbel, Art. 51.., s. 1341) wskazuje: TSUE, SpA Eridania - Zuccherifici nazionali i SpA Societa italiana per l'industria degli zuccheri p. Ministro per l'agricoltura e le foreste, Ministro per l'industria, il commercio e l'artigianato i SpA Zuccherifici meridionali, 230/78, wyrok z 27 września 1978, pkt 31; TSUE, Zuckerfabrik Franken GmbH p. Republice Federalnej Niemiec, 77/81, wyrok z 18 lutego 1982, pkt 22-27; TSUE, Marthe Klensch i inni p. Secrétaire d'État a l'Agriculture et a la Viticulture, C-201/85 i C-202/85, wyrok z 25 listopada 1986, pkt 10-11.

${ }^{79}$ TSUE, Hubert Wachauf p. Republika Federalna Niemiec, C-5/88, wyrok z 13 lipca 1989, pkt 19.

${ }^{80}$ Np.: TSUE, The Queen p. Ministry of Agriculture, Fisheries and Food, ex parte Dennis Clifford Bostock, C-2/92, wyrok z 24 marca 1994, pkt 16; TSUE, Booker Aquacultur Ltd i Hydro Seafood GSP Ltd p. The Scottish Ministers, C-20/oo i C-64/oo, wyrok z 10 lipca 2003, pkt 8893; więcej na temat dziedzictwa sprawy Wachauf i jego znaczenia dla rozwoju prawa wspólnotowego patrz np.: F.G. Jacobs, Wachauf and the Protection of Fundamental Rights in EC Law, [w:] M.P. Maduro, L. Azoulai (red.), The Past and Future of EU Law: The Classics of EU Law Revisited on the 5oth Anniversary of the Rome Treaty, Oxford-Portland 2010; Z. Kühn, Wachauf and ERT: On the Road from the Centralised to the Decentralised System of Judicial Review, [w:] M.P. Maduro, L. Azoulai (red.), The Past and Future of EU Law: The Classics of EU Law Revisited on the 5oth Anniversary of the Rome Treaty, Oxford-Portland 2010; P.C. Villalón, 'All the guidance'.... 
tują one prawo wspólnotowe i w związku z tym musza, na ile to jest możliwe, dokonywać implementacji również w zgodzie z tymi gwarancjami ${ }^{81}$. Trybunał stwierdził, że możliwa była interpretacja przepisów dyrektywy dotyczących uprawnień dzierżawcy, która nie stałaby w sprzeczności z przysługującymi mu prawami podstawowymi i regulacja taka, jaka została przyjęta w prawie niemieckim, nie wynikała w sposób konieczny z przepisów dyrektywy. Trybunał skonkludował, że państwa członkowskie, cieszące się marginesem swobody w zakresie implementacji prawa unijnego, są ograniczone do wybrania takich środków implementacyjnych, które również nie stałyby w sprzeczności z unijnymi prawami fundamentalnymi ${ }^{82}$.

Grupa orzeczeń typu Wachauf obejmuje sytuacje, w których państwa członkowskie działają w istocie rzeczy jako agent (agency) Unii ${ }^{83}$, czy też jako władza wykonawcza Unii ${ }^{84}$, a więc gdy na przykład wydają przepisy wykonawcze do unijnych rozporządzeń czy implementują unijne dyrektywy. Jak wynika wyraźnie z późniejszego orzecznictwa TSUE, nie ma tu większego znaczenia to, czy korzystają przy tym z dużej swobody i dyskrecjonalności, a więc czy jest im pozostawiona daleko idąca swoboda doboru środków zmierzających do implementacji.

Jak stwierdził TSUE, w przypadku, gdy przepisy dyrektyw „są stosunkowo ogólne [...]. A zatem logicznie zawierają one zasady, które pozostawiają państwom członkowskim niezbędny zakres swobodnego uznania przy określeniu środków mających na celu ich transpozycję, tak by można je było dostosować do różnych możliwych sytuacji [... $]^{\prime 85}$, to

na państwach członkowskich spoczywa obowiązek oparcia się na takiej wykładni tych dyrektyw, która pozwoli na zapewnienie odpowiedniej równowagi między poszczególnymi prawami podstawowymi chronionymi przez wspólnotowy porządek prawny. Następnie przy przyjmowaniu środków mających na celu transpozycję tych dyrektyw, władze i sądy państw członkowskich są zobowiązane nie tylko dokonywać wykładni ich prawa krajowego w sposób zgodny ze wspomnianymi dyrektywami, lecz również nie opierać się na takiej wykładni tych dyrektyw, która pozostawałaby $\mathrm{w}$ konflikcie z wspomnianymi prawami podstawowymi ${ }^{86}$.

${ }^{81}$ TSUE, Hubert Wachauf p. Republika Federalna Niemiec, C-5/88, wyrok z 13 lipca 1989, pkt 19 .

${ }^{82}$ Ibidem, pkt 20-23.

${ }^{83}$ Termin ten do określenia tego rodzaju relacji między Unią a państwami członkowskimi spopularyzował Joseph Weiler (J.H.H. Weiler (red.), The Constitution..., s. 120 i nast.).

${ }^{84}$ J.H.H. Weiler, N.J. S. Lockhart, "Taking rights seriously" Seriously: The European Court and its Fundamental Rights Jurisprudence - part I, "Common Market Law Review” 1995, nr 32 (1), s. 64.

${ }^{85}$ TSUE, Productores de Música de España (Promusicae) p. Telefónica de España SAU, C-275/o6, wyrok z 29 stycznia 2008, pkt 67.

${ }^{86}$ Ibidem, pkt 68. 
Dla obowiązku państw członkowskich odnośnie do unijnych praw podstawowych, gdy implementują one prawo unijne, znaczenia nie ma również to, czy harmonizacja prawa ma kompleksowy i szeroki, czy też jedynie minimalny charakter ${ }^{87}$. Kiedy państwa członkowskie dokonują implementacji prawa unijnego, zawsze podlegają unijnym prawom podstawowym i nie mogą działać w sposób, który prowadziłby do naruszenia unijnych praw podstawowych.

Takie podejście TSUE, wedle którego państwa członkowskie związane były unijnymi prawami podstawowymi nawet $\mathrm{w}$ zakresie, $\mathrm{w}$ jakim prawo unijne pozostawiało im swobodę doboru przez nie środków implementacji, budziło pewne kontrowersje $\mathrm{w}$ doktrynie, ostatecznie jednak należy uznać je za uzasadnione. Swoboda implementacyjna nie jest bowiem przyznawana państwom po to, aby naruszały one prawa podstawowe, ani nie może być do tego wykorzystywana ${ }^{88}$.

\subsection{Sprawy typu ERT}

Zdaniem trybunału luksemburskiego, co wyraził po raz pierwszy w wyroku w sprawie ERT ${ }^{89}$, państwa członkowskie podlegają unijnym prawom podstawowym także wtedy, gdy korzystają z sytuacji derogacyjnych. W wyroku tym, odnoszącym się do tego rodzaju sytuacji, TSUE użył jednak znacznie ogólniejszego sformułowania do określenia kategorii przepisów, do których należy stosować wspólnotowe prawa podstawowe. Stwierdził, że jest to możliwe odnośnie do przepisów, które "mieszczą się w zakresie prawa wspólnotowego" ${ }^{90}$. To określenie stanie się kluczowe dla rozwoju orzecznictwa TSUE w interesującej nas w tym rozdziale kwestii.

${ }^{87}$ Np.: TSUE, Ángel Rodríguez Caballero p. Fondo de Garantía Salarial (Fogasa), C-442/oo, wyrok z 12 grudnia 2002, pkt 31; TSUE, Joachim Steffensen, C-276/o1, wyrok z 10 kwietnia 2003, pkt 69 i nast.; TSUE, Rechnungshof p. Österreichischer Rundfunk i innym oraz Christa Neukomm i Joseph Lauermann p. Österreichischer Rundfunk, C-465/oo, C-138/o1, C-139/o1, wyrok z 20 maja 2003, pkt 31-47, gdzie TSUE przyjął mocno rozszerzającą interpretację zakresu dyrektywy po to, aby móc wdać się w kwestię ochrony praw podstawowych (por. A. von Bogdandy, M. Kottmann, C. Antpöhler, J. Dickschen, S. Hentrei, M. Smrkolj, Reverse Solange..., s. 498).

${ }^{88}$ Por.: A. von Bogdandy, M. Kottmann, C. Antpöhler, J. Dickschen, S. Hentrei, M. Smrkolj, Reverse Solange..., s. 498.

${ }^{89}$ TSUE, Elliniki Radiophonia Tiléorassi AE i Panellinia Omospondia Syllogon Prossopikou p. Dimotiki Etairia Pliroforissis i Sotirios Kouvelas i Nicolaos Avdellas et al., C-26o/89, wyrok z 18 czerwca 1991, pkt 43.

${ }^{90}$ Ibidem, pkt 42. Zasada ta szybko znalazła zastosowanie w orzecznictwie Trybunału i została powtórzona np. w sprawie Grogan (TSUE, The Society for the Protection of Unborn Children Ireland Ltd p. Stephen Grogan and others, C-159/90, wyrok z 4 października 1991, pkt 31). 
W sprawie ERT trybunał luksemburski stwierdził, że państwa członkowskie podlegają unijnym prawom podstawowym również wtedy, gdy polegają na dopuszczalnych w prawie Unii wyjątkach od unijnych swobód rynkowych. Ponadto należy jednak podkreślić, że państwa członkowskie podlegają unijnym prawom podstawowym, gdy dokonują wszelkich dopuszczalnych odstępstw od tych swobód, jako że co najmniej od sprawy Cassis de Dijon ${ }^{91}$ wiadomo, że państwa członkowskie mogą te swobody ograniczać, również chroniąc różnego rodzaju dobra pozaekonomiczne ${ }^{92}$, co rozszerza nieco zakres tej grupy zagadnień, obejmując nią niektóre sytuacje, które mogłyby wymykać się wąskiemu rozumieniu derogacji. Dopuszczalność derogacji może być określana w różnych przepisach prawa unijnego. Na gruncie prawa unijnego państwa członkowskie mogą więc wyłączać się spod pewnych obowiązków nakładanych na nie przez prawo Unii. Owo wyłączenie jednak i jego dopuszczalność są również oparte na prawie Unii, stąd państwa członkowskie w takich sytuacjach też stosują prawo Unii i podlegają tym samym unijnym prawom podstawowym. Również tę konstatację trybunał luksemburski potwierdzał w swym orzecznictwie wielokrotnie, utrwalając poczynione przy okazji tej sprawy ustalenia w całej grupie późniejszych orzeczeń dotyczących tego typu sytuacji ${ }^{93}$.

${ }^{91}$ TSUE, Rewe-Zentral AG p. Bundesmonopolverwaltung für Branntwein, C 120/78, wyrok z 20 lutego 1979.

92 Jak można podsumować za Janem Chmielewskim: „Formuła Cassis de Dijon dopuściła możliwość stosowania środków krajowych ograniczających handel wewnątrz UE wówczas, gdy niemożliwe jest powołanie się przez państwo członkowskie na art. 36 TFUE, ale po kumulatywnym ziszczeniu się następujących warunków: brak jest harmonizacji unijnej, środki krajowe stosowane są w sposób niedyskryminacyjny, tzn. bez rozróżnienia na towary krajowe i zagraniczne, środki krajowe są proporcjonalne i uwzględniają interes UE w swobodnym przepływie towarów, ich wprowadzenie jest konieczne ze względu na ochronę wymogów imperatywnych, a państwo członkowskie wykaże, iż faktycznie istnieje powód (wymóg imperatywny), którego ochrona oznacza konieczność ograniczenia swobodnego przepływu towarów (tzw. ciężar dowodu)" (J. Chmielewski, Pojęcie nadrzędnego interesu publicznego w prawie administracyjnym, Warszawa 2015, s. 4-5).

${ }^{93} \mathrm{~Np}$.: TSUE, Vereinigte Familiapress Zeitungsverlags- und vertriebs GmbH p. Heinrich Bauer Verlag, C-368/95, wyrok z 26 czerwca 1997; TSUE, Bernard Connolly p. Komisji Wspólnot Europejskich, C-274/99, wyrok z 6 marca 2001, pkt 37; TSUE, Roquette Frères SA p. Directeur général de la concurrence, de la consommation et de la répression des fraudes, and Commission of the European Communities, C-94/oo, wyrok z 22 października 2002, pkt 25; TSUE, Eugen Schmidberger, Internationale Transporte und Planzüge p. Republik Österreich, C-112/oo, wyrok z 12 czerwca 2003; TSUE, RTL Television GmbH p. Niedersächsische Landesmedienanstalt für privaten Rundfunk, C-245/o1, wyrok z 23 października 2003; TSUE, Omega Spielhallen- und Automatenaufstellungs-GmbH p. Oberbürgermeisterin der Bundesstadt Bonn, C-36/o2, wyrok z 14 października 2004, pkt 33. Więcej na temat dziedzictwa sprawy ERT i jego znaczenia dla rozwoju prawa wspólnotowego patrz np.: D. Chalmers, Looking Back at ERT and its Contribution to an EU Fundamental Rights Agenda, [w:] M.P. Maduro, L. Azoulai (red.), The Past and Future of 
W pewnym sensie można powiedzieć, że przestrzeganie unijnych praw podstawowych urasta w tych kategoriach spraw do kolejnej przesłanki dopuszczalności derogacji. Korzystając z sytuacji derogacyjnych, państwa członkowskie są więc ograniczone w tej możliwości poprzez różnorodne warunki dopuszczalności derogacji wynikające z prawa Unii ${ }^{94}$, a w tym przez obowiązek przestrzegania unijnych praw podstawowych. Państwo może więc powoływać się na względy interesu ogólnego czy inne dopuszczalne w prawie unijnym względy dla uzasadnienia środka krajowego, który może ograniczyć korzystanie z unijnych swobód jedynie wtedy, gdy środek ten jest zgodny z prawami podstawowymi, nad których przestrzeganiem czuwa Trybunał ${ }^{95}$. Rozumowanie to było kontrowersyjne od samego początku jego stosowania przez Trybunał. Tym bardziej mogło więc budzić pewne wątpliwości w obliczu sformułowania art. 51 ust. 1 Karty ${ }^{96}$. Podobnie jak w przypadku spraw typu Wachauf, podejście zaprezentowane przez TSUE do spraw typu ERT w zakresie związania państw członkowskich unijnymi prawami podstawowymi, wydaje się uzasadnione, gdyż znowu prawo unijne przyznaje państwom pewną swobodę, tym razem do derogowania się ze względu na istotne przyczyny od niektórych zobowiązań, jakie nakłada na nie prawo unijne nie po to, aby naruszały one prawa podstawowe ani wykorzystywały derogacje w celu ich naruszenia lub obejścia, lecz w innych celach.

\subsection{Innego rodzaju łącznik z prawem unijnym}

Te dwa typy nie wyczerpują jednak całego spektrum sytuacji, w których uznaje się, że państwa członkowskie są związane unijnymi prawami podstawowymi. Ponadto wyróżnić można trzecią grupę sytuacji obejmującą przypadki niestanowiące sensu stricto implementowania prawa UE, oraz które nie mieszczą się w kategorii sytuacji derogacyjnych. Mimo to zdaniem TSUE mogą one być uznane za mieszczące się w zakresie prawa unijnego. „Chodzi o sytuacje, gdy

EU Law: The Classics of EU Law Revisited on the 5oth Anniversary of the Rome Treaty, Oxford-Portland 2010; Z. Kühn, Wachauf and ERT...; P.C. Villalón, 'All the guidance'...

${ }^{94}$ Patrz np.: P. Koutrakos, N. Nic Shuibhne, P. Syrpis (red.), Exceptions from EU Free Movement Law Derogation, Justification and Proportionality, Oxford-Londyn-Portland 2016.

${ }^{95}$ Por. np.: TSUE, Elliniki Radiophonia Tiléorassi AE i Panellinia Omospondia Syllogon Prossopikou p. Dimotiki Etairia Pliroforissis i Sotirios Kouvelas i Nicolaos Avdellas et al., C-26o/89, wyrok z 18 czerwca 1991, pkt 43; TSUE, Vereinigte Familiapress Zeitungsverlagsund vertriebs GmbH p. Heinrich Bauer Verlag, C-368/95, wyrok z 26 czerwca 1997, pkt 24; TSUE, Mary Carpenter p. Secretary of State for the Home Department, C-6o/oo, wyrok z 11 lipca 2002, pkt 40 .

${ }^{96}$ Por.: A. von Bogdandy, M. Kottmann, C. Antpöhler, J. Dickschen, S. Hentrei, M. Smrkolj, Reverse Solange..., s. 499. 
istnieje jakiś inny łącznik z prawem UE niebędący wprost wykonywaniem prawa UE lub poleganiem na dopuszczalnych prawem UE odstępstwach"97. Taka kategorię spraw expressis verbis wskazała jeszcze przed wejściem w życie Karty w jednej ze swych opinii Rzeczniczka Generalna Eleanor Sharpston, kiedy pisała, że:

ogólne zasady prawa wspólnotowego, choć mają podstawowe znaczenie dla właściwego funkcjonowania prawa WE, nie działają w oderwaniu. Konkretne krajowe środki mogą być kontrolowane tylko wówczas, jeżeli wchodzą w zakres stosowania prawa wspólnotowego. Aby tak się stało, przepis prawa krajowego, będący przedmiotem sporu, powinien na ogół mieścić się w jednej z trzech następujących kategorii: albo powinien wdrażać prawo wspólnotowe (bez względu na stopień zachowanych przez państwo członkowskie uprawnień dyskrecjonalnych oraz na to, czy środek krajowy wykracza poza to, co jest ściśle niezbędne dla wprowadzenia), albo powinien powoływać się on na jakieś odstępstwo, na które zezwala prawo wspólnotowe, albo też powinien w inny sposób wchodzić w zakres prawa wspólnotowego na tej podstawie, że dana szczegółowa norma materialna prawa wspólnotowego ma zastosowanie w określonym stanie faktycznym ${ }^{98}$.

Zatem oprócz spraw typu Wachauf czy ERT może, po trzecie, istnieć możliwość, że jeszcze jakiś inny łącznik - szczegółowa norma materialna prawa Unii, mająca zastosowanie w określonym stanie faktycznym - sprawi, że dana sytuacja będzie mogła być uznana za mieszczącą się w zakresie stosowania prawa Unii i przez to państwo członkowskie będzie również związane unijnymi prawami fundamentalnymi. Jak słusznie wskazuje Nina Półtorak, dobrym przykładem takiej sytuacji może być sprawa Mangold ${ }^{99}$ czy sprawa Kücükdeveci ${ }^{100}$, „w których pomimo braku bezpośredniego skutku dyrektyw unijnych, badano zgodność mieszczących się w ramach regulacji tych dyrektyw przepisów krajowych z prawami podstawowymi"101. W przypadku obu tych spraw potrzebnym łącznikiem okazała się być obowiązująca, choć nieimplementowana dyrektywa Unii. Nota bene sprawy te nie były w pełni analogiczne. Sytuacja różniła się tym, że w momencie orzekania przez TSUE w sprawie Mangold, termin na implementację jeszcze nie upłynął, zaś w sprawie Kücükdeveci termin ten już upłynął. O wyrokach tych będzie mowa za chwilę.

${ }^{97}$ N. Półtorak, Zakres zwiazania..., s. 19.

${ }^{98}$ TSUE, Birgit Bartsch p. Bosch und Siemens Hausgeräte (BSH) Altersfürsorge GmbH, C-427/o6, opinia Rzecznika Generalnego Eleanor Sharpston przedstawiona w dniu 22 maja 2008 , pkt 69 .

99 TSUE, Werner Mangold p. Rüdiger Helm, C-144/o4, wyrok z 22 listopada 2005, pkt 78 . 100 TSUE, Seda Kücükdeveci p. Swedex GmbH \& Co. KG, C-555/o7, wyrok z 19 stycznia 2010.

${ }^{101}$ N. Półtorak, Zakres zwiazania..., s. 23. 
Już teraz należy zwrócić uwagę, że w innej istotnej w tym kontekście sprawie, jaką jest sprawa Navarro ${ }^{102}$, TSUE wskazał wyraźnie pewną cezurę. W sprawie tej Trybunał

uznał, że przepisy dyrektywy o funduszu gwarancyjnym nie są bezpośrednio skuteczne wobec sytuacji, które wystapily przed upływem terminu na implementacje dyrektywy, ale od momentu wejścia w życie dyrektywy, przepisy krajowe dotyczące funduszy gwarancyjnych wchodzą $\mathrm{w}$ zakres prawa UE, a więc przepisy te muszą być zgodne z prawami podstawowymi, gdyż sam fakt obowiązywania dyrektywy (regulującej ten sam przedmiot co prawo krajowe) jest wystarczającym łącznikiem z prawem UE dla możliwości zastosowania unijnych praw podstawowych ${ }^{103}$.

Sytuacja w tej sprawie była jednak o tyle specyficzna, że przepisy krajowe nie zostały wydane w celu wykonania dyrektywy, gdyż ustanawiając ogólnie obowiązki po stronie państw spłaty pracownikom kwot wynikających z umowy o pracę lub stosunku pracy, nie wprowadzała obowiązku ustanowienia funduszu gwarancyjnego wypłaty odszkodowań należnych w przypadku rozwiązania umowy o pracę przez pracodawcę. Państwa były więc swobodne w jego ustanowieniu bądź nie. Co więcej, przepisy krajowe ustanawiające taki fundusz w przedmiotowej sprawie zostały wprowadzone przed wejściem w życie dyrektywy ${ }^{104}$. Mimo to TSUE stwierdził,

że ten przepis krajowy, począwszy od dnia wejścia w życie dyrektywy 2002/74, wchodzi w zakres stosowania art. 3 akapit pierwszy dyrektywy 8o/987, a tym samym wchodzi w zakres prawa wspólnotowego. Począwszy od tego dnia, jest on podporządkowany obowiązkowi poszanowania zasad ogólnych i praw podstawowych, uznanych we wspólnotowym porządku prawnym $(\ldots)^{105}$.

Jak może się wydawać, specyfika sytuacji w tej sprawie polegała na tym, że przepisy krajowe obowiązywały jeszcze przed wejściem w życie dyrektywy i nie stanowiły jej implementacji w sensie formalnym, co więcej, implementacja dyrektywy wcale nie musiałaby prowadzić do ustanowienia takich właśnie regulacji. Tym niemniej miały one co do zasady ten sam cel co przepisy dyrektywy i w obliczu ich istnienia nie było konieczności ustanawiania ich na nowo bądź też tworzenia innych przepisów w ich miejsce. Choć tego rodzaju rozważań brak w wyroku Trybunału, należy zauważyć, że niestosowanie do

102 TSUE, Josefa Velasco Navarro p. Fondo de Garantía Salarial (Fogasa), C-246/o6, wyrok z 17 stycznia 2008.

${ }^{103}$ N. Półtorak, Zakres zwiazania..., s. 23.

104 TSUE, Josefa Velasco Navarro p. Fondo de Garantía Salarial (Fogasa), C-246/o6, wyrok z 17 stycznia 2008, pkt 32-33.

${ }^{105}$ Ibidem, pkt 34. 
nich unijnych praw podstawowych prowadziłoby więc do powstania swoistej luki - w krajach, w których regulacji zmierzających do realizacji podobnych celów by wcześniej nie było i przepisy je ustanawiające dopiero byłyby wprowadzane, jednostki mogłyby korzystać z ochrony unijnych praw podstawowych. W krajach, w których przedmiotowe przepisy funkcjonowałyby już wcześniej, jednostki nie mogłyby korzystać z ochrony unijnych praw podstawowych, gdyby takie przepisy krajowe miałyby im nie podlegać.

Pewne wątpliwości mogło jednak budzić to, czy unijne prawa podstawowe należy faktycznie zawsze stosować do państw członkowskich już od momentu wejścia w życie dyrektywy, ale jeszcze przed upłynięciem terminu na jej implementację. Zgodnie z zaprezentowanym powyżej stanowiskiem mogłoby się wydawać, że samo objęcie zakresem prawa unijnego danej kwestii poprzez jej uregulowanie $w$ formie dyrektywy, wystarczy do stwierdzenia zaistnienia niezbędnego łącznika dla objęcia kwestii unijnymi prawami podstawowymi (a przynajmniej zawierającą się w nich zasadą niedyskryminacji, gdyż to właśnie tej kwestii dotyczyła sprawa $)^{106}$. Rozumowanie takie nie okazało się w pełni słuszne. Jak wynika z wyroku w sprawie Bartsch ${ }^{107}$, bezwzględnie wiążącym dla państw momentem dla oceny sytuacji z perspektywy jej objęcia zakresem prawa unijnego jest termin wykonania dyrektywy, a nie moment jej wejścia w życie. TSUE stwierdził w sprawie Bartsch, która również dotyczyła unijnej zasady niedyskryminacji, że zasada ta nie znajduje zastosowania przed upłynięciem terminu na transpozycję dyrektywy. Nota bene w sprawie tej Trybunał nie poruszał expressis verbis kwestii praw podstawowych i ich zastosowania wobec państw członkowskich. Koncentrował się jedynie na zasadzie niedyskryminacji i dyrektywie wydanej w celu jej ochrony. Trybunał odmówił więc oceny przez pryzmat zasady niedyskryminacji przepisów krajowych, które funkcjonowały już przed wejściem w życie dyrektywy, a także po jej wejściu w życie, lecz przed upływem terminu na jej transpozycję $e^{108}$.

Choć tego rodzaju rozważań brak w wyroku, podejście takie wydaje się wcale nie być sprzeczne z zaprezentowanym w sprawie Navarro. Tam wcześniejsze przepisy krajowe realizowały cel przewidziany w prawie unijnym. Trudno więc byłoby spodziewać się dalszej jego implementacji. Stąd można te istniejące wcześniej przepisy uznać za rodzaj przepisów implementujących, które powinny zatem również odpowiadać unijnym prawom podstawowym. Tym razem przepisy krajowe miały jednak inny charakter i były oderwane od prawa unijnego, i zarówno formalnie, jak i materialnie w żaden sposób nie

${ }^{106}$ Por.: N. Półtorak, Zakres zwiazania..., s. 23.

107 TSUE, Birgit Bartsch p. Bosch und Siemens Hausgeräte (BSH) Altersfürsorge GmbH, C-427/o6, wyrok z 23 września 2008.

${ }^{108}$ Ibidem, pkt 17 i nast. 
zmierzały do realizacji celów w nim przewidzianych. Nawet jeśli byłyby niezgodne z dyrektywa, to państwo miało czas na wykonanie dyrektywy i ewentualne usunięcie tej niezgodności. Przed upływem tego terminu nie mogło być jednak mowy o zastosowaniu unijnej zasady niedyskryminacji do tego rodzaju przepisów krajowych.

Interesujący w tym kontekście wydaje się wyrok w sprawie Mangold ${ }^{109}$, w której Trybunał orzekł o możliwości zastosowania unijnych praw podstawowych do przepisów krajowych wydanych już wprawdzie po wejściu w życie dyrektywy, lecz przed upływem terminu na jej implementację. Co do zasady nie powinno to dziwić, skoro państwo implementując unijną dyrektywę, jak wiadomo, musi to czynić w sposób zgodny z unijnymi prawami podstawowymi. Wątpliwości w tej sprawie może budzić jednak fakt sklasyfikowania przepisów krajowych, które znajdowały zastosowanie w sprawie Mangold, jako implementujących unijną dyrektywę. Jak słusznie zauważa bowiem Nina Półtorak,

sporna regulacja prawa niemieckiego w sprawie Mangold została wprowadzona raczej po to, aby postanowienia dyrektywy nie były skuteczne aż do dnia upływu terminu na jej implementację, a nie w celu wykonania dyrektywy. Można wobec tego uznać, że regulacja krajowa "weszła w zakres zastosowania prawa UE” z tego powodu, iż zmierzała ku ograniczeniu efektywności przyjętej przez Unię dyrektywy (realizacja celów dyrektywy po upływie terminu jej implementacji byłaby osłabiona przez działania podjęte po jej wejściu w życie, a przed upływem terminu implementacji). Takie odczytanie orzeczenia w sprawie Mangold potwierdza tezę, że działanie państw mieszczące się w zakresie zasady efektywności prawa UE (zarówno pozytywne - służące wykonaniu prawa UE, jak i negowane - służące osłabieniu efektywności prawa UE) będzie stanowiło "stosowanie" prawa UE w rozumieniu art. 51 ust. 1 KPP110.

Takie podejście, łączące fakt związania państw członkowskich unijnymi prawami podstawowymi poprzez ich działanie w zakresie prawa unijnego, a właściwie poprzez działanie mające wpływ na szeroko rozumianą efektywność prawa unijnego, jak się wydaje, znajduje również potwierdzenie w zaprezentowanej powyżej ocenie spraw Navarro czy Bartsch.

Takie odczytanie sprawy Mangold zdaje się potwierdzać także logika przyjęta w sprawie Kücükdeveci ${ }^{111}$. Należy podkreślić, że dyrektywa, która miała zastosowanie $w$ tej sprawie, nie została implementowana do krajowego porządku prawnego mimo upływu przewidzianego terminu na implementację. Fakt istnienia tej dyrektywy wystarczył jednak Trybunałowi do tego, by uznać,

109 TSUE, Werner Mangold p. Rüdiger Helm, C-144/o4, wyrok z 22 listopada 2005.

${ }^{110}$ N. Półtorak, Zakres zwiazania..., s. 23.

${ }^{111}$ TSUE, Seda Kücükdeveci p. Swedex GmbH \& Co. KG, C-555/o7, wyrok z 19 stycznia 2010. 
że sprawa "mieściła się w zakresie zastosowania prawa Unii"112. Jak stwierdził trybunał luksemburski, „dyrektywa spowodowała, że w zakres zastosowania prawa Unii weszło uregulowanie będące przedmiotem sporu przed sądem krajowym, obejmujące materię uregulowaną w dyrektywie"113. Nie dość więc, że dyrektywa unijna, która nie stanowi prawa bezpośrednio skutecznego, jest zdaniem TSUE wystarczającym łącznikiem z prawem unijnym do tego, aby stosować unijne prawa podstawowe, to także prawa te znajdują zastosowanie nawet jeśli dyrektywa ta nie zostanie wykonana i implementowana do krajowego porządku prawnego. Podejście takie zdaje się zmierzać do uniknięcia luki. Tym razem takiej, która mogłaby pozwolić państwom na wymknięcie się od związania unijnymi prawami podstawowymi w najbardziej podstawowej sytuacji, w której są one nimi związane, jaką jest sytuacja, kiedy państwa implementują prawo Unii. Dlatego też niektórzy zaliczają tę sprawę do pierwszej z omawianych tutaj kategorii spraw, a więc spraw typu Wachauf ${ }^{114}$. Fakt, że państwo nie wykonuje obowiązku implementacji nie sprawia, że się z niego zwalnia ani nie wyłącza innych konsekwencji wynikających z tego obowiązku. Nie wyłącza więc także konsekwencji, jaką jest związanie państw w zakresie uregulowanym przez dyrektywę unijnymi prawami podstawowymi.

Z omawianych powyżej spraw można wyciągnąć wniosek, że co do zasady państwa są związane unijnymi prawami podstawowym, gdy implementują dyrektywę unijną od momentu, kiedy po jej wejściu w życie wydadzą przepisy ją implementujące w szerokim tego słowa rozumieniu, a więc mające wpływ na realizację celu dyrektywy (w tym zmierzające do opóźnienia jej wykonania), albo od momentu, kiedy nie wydadzą żadnych tego rodzaju przepisów, ale termin na implementację upłynie. Wtedy wszelkie przepisy mieszczące się w zakresie regulacji dyrektywy muszą być zgodne nie tylko z nią, ale również $\mathrm{z}$ unijnymi prawami podstawowymi. $Z$ tym że jeśli mowa o przepisach realizujących kwestie związane z celami dyrektywy, a więc takich, które mogłyby być wydane w celu jej implementacji, lecz zostały wydane przed jej wejściem w życie, to możliwość ich oceny pod kątem zgodności z unijnymi prawami podstawowymi rozpoczyna się od momentu wejścia w życie dyrektywy. Takie podejście wydaje się uzasadnione oraz zdaje się sprzyjać unikaniu różnego rodzaju luk w obejmowaniu przepisów krajowych unijnymi prawami podstawowymi, a także ewentualnemu unikaniu przez państwa nie tylko wykonywania dyrektyw, lecz również związania ich unijnymi prawami podstawowymi z zakresie regulacji dyrektyw.

${ }^{112}$ Ibidem, pkt 23.

${ }^{113}$ Ibidem, pkt 25.

${ }^{114}$ Por. np.: A. von Bogdandy, M. Kottmann, C. Antpöhler, J. Dickschen, S. Hentrei, M. Smrkolj, Reverse Solange..., s. 498-499. 
Trzecia grupa sytuacji, w których państwa są związane unijnymi prawami podstawowymi, nie jest jednorodna. Można wskazać różne inne przypadki istnienia, zdaniem TSUE, odpowiedniego łącznika z prawem UE, uzasadniającego zastosowanie do państw unijnych praw podstawowych. Szczególne wątpliwości mogło budzić swoiste rozciąganie zastosowania praw podstawowych w niektórych przypadkach, które trudno było objąć jednym z dwóch podstawowych rodzajów spraw sprawiających, że państwa członkowskie objęte są unijnymi prawami podstawowymi, a w których TSUE i tak uznawał, że jest on wystarczający. Tak jak omawiane przed chwilą orzeczenia są w pewnym sensie rozwinięciem spraw typu Wachauf, tak orzeczenia omawiane poniżej są swoistym rozwinięciem rozumienia spraw typu ERT i w zależności od przyjmowanej metodologii mogą być zaliczane również do tej kategorii spraw ${ }^{115}$.

W sprawie Carpenter ${ }^{116}$ Trybunał zdecydował się przyznać ochronę prawu do życia rodzinnego powodowi, mimo że, jak twierdziło wielu komentatorów, sprawa miała charakter czysto wewnętrzny ${ }^{117}$. Pan Carpenter prowadził działalność polegającą na świadczeniu usług w znacznym stopniu również w innych państwach członkowskich niż Wielka Brytania, gdzie mieściła się jego firma. Jego żona, która była obywatelką państwa trzeciego, nie korzystała jednak z żadnej z unijnych swobód, jako że nie podróżowała w celu świadczenia usług. Pozostawała w domu, zajmując się rodziną. Tym niemniej Trybunał podjął się oceny możliwości jej deportacji ze Zjednoczonego Królestwa, opartej na przepisach krajowych regulujących tę materię, i stwierdził, że:

(...) separacja małżonków Carpenter zaszkodziłaby ich życiu rodzinnemu, a co za tym idzie również warunkom wykonywania jednej z podstawowych swobód przez Petera Carpentera. Swoboda ta nie mogłaby bowiem w pełni wywoływać swych skutków, gdyby uwaga Petera Carpentera była odwrócona od jej wykonywania za sprawą przeszkód stawianych jego małżonce w odniesieniu do wjazdu i pobytu w jego państwie pochodzenia $(. . .)^{118}$.

Powiązanie sytuacji w sprawie z zasadą swobody przepływu usług było dość odległe. Sprawa nie dotyczyła bowiem obywatela Unii, któremu takie prawo przysługuje, lecz jego współmałżonka, będącego obywatelem państwa trzeciego, niebędącego podmiotem tego prawa. Mimo to TSUE nawiązał do

\footnotetext{
${ }^{115}$ Por. ibidem, s. 499.

116 TSUE, Mary Carpenter p. Secretary of State for the Home Department, C-6o/oo, wyrok z 11 lipca 2002.

117 A. von Bogdandy, M. Kottmann, C. Antpöhler, J. Dickschen, S. Hentrei, M. Smrkolj, Reverse Solange..., s. 499.

${ }_{118}$ TSUE, Mary Carpenter p. Secretary of State for the Home Department, C-6o/oo, wyrok z 11 lipca 2002, pkt 39.
} 
możliwości derogowania się państw członkowskich z wynikających z niej obowiązków. Można rzec, że przepisy określające warunki wydalenia obywatela państwa trzeciego uznał w tym przypadku za derogację od zasady swobody przepływu usług. TSUE stwierdził, „iż państwo członkowskie może powołać się na względy interesu ogólnego dla uzasadnienia środka krajowego, który może ograniczyć korzystanie ze swobody świadczenia usług jedynie wtedy, gdy środek ten jest zgodny z prawami podstawowymi, nad których przestrzeganiem czuwa Trybunał (...)"119.

Zdaniem Trybunału:

art. $49 \mathrm{WE}$, analizowany w świetle prawa podstawowego do poszanowania życia rodzinnego, należy interpretować w ten sposób, iż stoi on na przeszkodzie temu, aby w sytuacji takiej, jak będąca przedmiotem postępowania przed sądem krajowym państwo członkowskie pochodzenia usługodawcy, który ustanowił działalność gospodarczą w tym państwie i świadczy usługi usługobiorcom, którzy ustanowili działalność gospodarczą w innych państwach członkowskich, odmawiało prawa pobytu na jego terytorium małżonkowi owego usługodawcy, będącemu obywatelem państwa trzeciego ${ }^{120}$.

Trybunał oparł się tu na rozumowaniu, zgodnie z którym małżonek obywatela Unii powinien otrzymać prawo pobytu, skoro opiekuje się jego dziećmi, umożliwiając mu przez to świadczenie usług w innych państwach członkowskich.

W sprawie tej TSUE oparł się wyraźnie na zasadzie efektywności prawa unijnego. Przyjął bowiem, że swoboda świadczenia usług, z której korzystał obywatel brytyjski, a więc obywatel państwa członkowskiego Unii, nie byłaby efektywna, gdyby jego żona, nielegalnie przebywająca na terytorium Zjednoczonego Królestwa, została stamtąd wydalona na podstawie stosownych regulacji krajowych. Jej wydalenie zniechęciłoby bowiem obywatela Wielkiej Brytanii do świadczenia usług w innych państwach przez to, że jego żona nie mogłaby już się zajmować jego dziećmi, co, zdaniem Trybunału było warunkiem koniecznym, by mógł on takie transgraniczne usługi świadczyć121.

O ile w tym wypadku TSUE zdecydował się na szeroką ochronę swobody świadczenia usług i poprzez nią rozszerzył zakres zastosowania unijnych praw podstawowych wobec państw członkowskich, o tyle w przypadku sprawy Kremzow ${ }^{122}$ nie znalazł podstaw do zastosowania wobec przepisów krajowych unijnych praw podstawowych, opierając się na zasadzie swobody przepływu

\footnotetext{
${ }^{119}$ Ibidem, pkt 40.

${ }^{120}$ Ibidem, pkt 46.

${ }^{121}$ Por.: D. Miąsik, 5.6 Zasada efektywności a interpretacja przepisów prawa, [w:] A. Wróbel (red.), Stosowanie prawa Unii Europejskiej przez sądy, t. 1, Warszawa 2010, s. 239.

${ }^{122}$ TSUE, Friedrich Kremzow p. Republik Österreich, C-299/95, wyrok z 29 maja 1997.
} 
osób. Trybunał uznał, że osoba skazana na więzienie na podstawie wyłącznie przepisów krajowych nie jest ograniczona w możliwości korzystania z prawa do swobodnego przepływu osób w rozumieniu prawa unijnego. Każde ograniczenie wolności może zakłócać możliwość korzystania z prawa do swobodnego przepływu osób, dlatego też zdaniem Trybunału czysto hipotetyczna możliwość stania się podmiotem tego prawa (w sytuacji braku ograniczenia wolności) nie jest wystarczającym łącznikiem, uzasadniającym zastosowanie prawa wspólnotowego ${ }^{123}$.

W sprawie Karner ${ }^{124}$ natomiast Trybunał nie stwierdzając naruszenia swobody przepływu towarów, uznał jednak, że mimo to unijne prawa podstawowe znajdowały zastosowanie. $W$ ten sposób zasada swobody przepływu towarów stała się koniecznym łącznikiem z prawem unijnym, choć nie mieliśmy do czynienia z derogacją od tej zasady, jako że nie miało miejsca zastosowanie środka o charakterze ograniczającym tę swobodę. Trybunał oparł się w tej sprawie na tzw. doktrynie Keck, w której przełamał swoje wcześniejsze orzecznictwo i stwierdził, że:

(...) zastosowanie do produktów pochodzących z innych państw członkowskich krajowych przepisów, które ograniczają niektóre sposoby sprzedaży bądź ich zakazują, o ile tylko obowiązują one wszystkie zainteresowane podmioty gospodarcze prowadzące działalność na terytorium krajowym i dotyczą w ten sam sposób, z prawnego i faktycznego punktu widzenia, obrotu produktami krajowymi i produktami pochodzącymi z innych państw członkowskich, nie utrudnia, bezpośrednio ani pośrednio, rzeczywiście ani potencjalnie wymiany handlowej między państwami członkowskimi $(\ldots)^{125}$.

Z taką właśnie sytuacją mieliśmy do czynienia w sprawie Karner. Trybunał przypomniał w niej, że doktryna Keck sformułowała dwa warunki, które regulacje krajowe musiały spełnić, aby mogły one być uznane za nieutrudniające wymiany handlowej między państwami członkowskimi i w związku z tym za niesprzeczne z prawem unijnym. Trybunał uznał w tej sprawie, że obowiązujący w Austrii zakaz reklamy opierającej się na rozpowszechnianiu informacji, iż sprzedawane towary pochodzą z masy upadłościowej, gdy nie stanowią one już części masy upadłościowej, z której pochodziły, nie narusza wspomnianych warunków zawartych w formule Keck i tym samym nie ma związku z zasadą swobody przepływu towarów. Tym niemniej Trybunał podkreślił znaczenie

${ }^{123} \mathrm{Ibidem}$, pkt 16 .

124 TSUE, Herbert Karner Industrie-Auktionen GmbH p. Troostwijk GmbH, C-71/o2, wyrok z 25 marca 2004.

${ }^{125}$ Patrz: TSUE, Bernard Keck i Daniel Mithouard, C-267/91 i C-268/91, wyrok z 24 listopada 1994, pkt 16. 
unijnych gwarancji praw podstawowych, w tym wypadku wolności słowa ${ }^{126}$. Ponadto Trybunał przypomniał swoje wcześniejsze orzecznictwo dotyczące zobowiązania państw do ochrony unijnych praw podstawowych, gdy działaja w zakresie zastosowania prawa Unii i w związku z tym przedstawił niezbędne wyjaśnienia związane $z$ unijnymi gwarancjami wolności słowa, które były - jego zdaniem - niezbędne sądowi krajowemu dla oceny krajowych regulacji pod kątem zgodności z tymi gwarancjami ${ }^{127}$.

Sprawę Karner i przyjęte w niej rozumowanie w stosunku do możliwości zastosowania unijnych praw podstawowych można jednak wskazać jako swoisty wyjątek, który nie znalazł potwierdzenia w dalszym orzecznictwie TSUE, szczególnie już po wejściu w życie Karty. Kwestie rozstrzygnięte w tym orzeczeniu, dotyczące takich zagadnień, jak treść prawa do wolności słowa i dopuszczalności jej ograniczeń, czy też dotyczące relacji między zasadami swobody przepływu towarów i swobody przepływu usług albo dotyczące dopuszczalności ograniczeń w handlu niestanowiących utrudnień $\mathrm{w}$ stosowaniu unijnych swobód i kryteria oceny takich ograniczeń, znajdowały zastosowanie w późniejszym orzecznictwie Trybunału ${ }^{128}$. Jednakże kwestia dopuszczalności zastosowania unijnych praw podstawowych do regulacji krajowych w sytuacji, gdy należy je uznać za niestanowiące derogacji od unijnych swobód, nie znalazła potwierdzenia w późniejszym orzecznictwie. Przeciwnie, po wejściu w życie Karty pojawiły się orzeczenia, które, wprawdzie nie expressis verbis, ale implicite można uznać za zrywające z tym sposobem myślenia. Mam tu na myśli przede wszystkim wyrok w sprawie Pelckmans ${ }^{129}$, o którym będzie jeszcze mowa.

126 TSUE, Herbert Karner Industrie-Auktionen GmbH p. Troostwijk GmbH, C-71/o2, wyrok z 25 marca 2004, przede wszystkim pkt 37 i nast.

${ }^{127}$ Ibidem, pkt 49 i nast.

${ }^{128}$ Mam tu na myśli sprawy takie jak: TSUE, Omega Spielhallen- und Automatenaufstellungs-GmbH p. Oberbürgermeisterin der Bundesstadt Bonn, C-36/o2, wyrok z 14 października 2004, pkt 26; TSUE, Postępowanie karne przeciwko Marcel Burmanjer, René Alexander Van Der Linden i Anthony De Jong, C-20/o3, wyrok z 26 maja 2005, pkt 22-23; TSUE, Wolff \& Müller GmbH \& Co. KG p. José Filipe Pereira Félix, C-6o/o3, wyrok z 12 października 2004, pkt 30; TSUE, Republika Federalna Niemiec p. Parlamentowi Europejskiemu i Rada Unii Europejskiej, C-38o/o3, wyrok z 12 grudnia 2006, pkt 142, 154-155; TSUE, A-Punkt Schmuckhandels GmbH p. Claudia Schmidt, C-441/o4, wyrok z 23 lutego 2006, pkt 12-15; TSUE, Fidium Finanz AG p. Bundesanstalt für Finanzdienstleistungsaufsicht, C-452/o4, wyrok z 3 października 2006, pkt 34; TSUE, Laserdisken ApS p. Kulturministeriet, C-479/o4, wyrok z 12 września 2006, pkt 64; TSUE, Postępowanie karne przeciwko Frede Damgaard, C-421/o7, wyrok z 2 kwietnia 2009, pkt 26-27; TSUE, Marc Michel Josemans p. Burgemeester van Maastricht, C-137/o9, wyrok z 16 grudnia 2010, pkt 50 .

129 TSUE, Pelckmans Turnhout NV p. Walter Van Gastel Balen NV i inni, C-483/12, wyrok z 8 maja 2014 . 


\subsection{Typy sytuacji, w których unijne prawa podstawowe znajdowały zastosowanie wobec państw członkowskich}

Kwestia związania państw członkowskich unijnymi prawami podstawowymi pojawiała się w orzecznictwie TSUE przed 1.12.2009 r. stosunkowo rzadko, gdyż TSUE raczej koncentrował się na określeniu praw podstawowych wiążących samą Unię, a pytania sądów krajowych dotyczące zastosowania unijnych praw podstawowych w państwach członkowskich rzadko były kierowane, gdyż TSUE nie był - co do zasady - traktowany przez sądy krajowe jako sąd zajmujący się prawami podstawowymi ${ }^{130}$.

Tym niemiej, że już przed wejściem Karty w życie ${ }^{131}$ TSUE wyodrębnił trzy rodzaje sytuacji, w których państwa członkowskie były w swych działaniach związane unijnymi prawami podstawowymi ${ }^{132}$ :

1) kiedy implementuja prawo unijne (grupa spraw typu Wachauf);

2) kiedy polegają na unijnych wyjątkach od swobód rynkowych w tzw. sytuacjach derogacyjnych (grupa spraw typu ERT);

3) kiedy istnieje jakiś inny łącznik z prawem Unii, niebędący wprost wykonywaniem prawa UE ani poleganiem na dopuszczalnych przez prawo UE odstępstwach, który wszakże sprawia, że sytuacja mieści się w zakresie zastosowania prawa Unii. W dużej mierze, choć nie jedynie, sprawy mieszczace się w tej grupie są swoistymi pochodnymi spraw z grupy pierwszej i drugiej, a więc służą unikaniu luk w stosowaniu unijnych praw podstawowych w sytuacjach wymykających się kryteriom w ramach dwu poprzednich grup.

Wszystkie te trzy kategorie spraw wynikały wyłącznie z orzecznictwa Trybunału. Zwłaszcza ten ostatni rodzaj sytuacji pozostawiał otwartą drogę Trybunałowi do rozwijania zakresu związania państw członkowskich unijnymi prawami podstawowymi i dość swobodnego określania sytuacji mieszczacych się, jego zdaniem, w zakresie prawa Unii. Wraz z wejściem w życie Karty i wyrażeniu $\mathrm{w}$ art. 51 ust. 1 zakresu związania państw członkowskich unijnymi prawami podstawowymi, mogło zrodzić się pytanie, czy przedstawione powyżej ustalenia, poczynione na podstawie wcześniejszego orzecznictwa TSUE, pozostają w mocy i jeśli tak, to w jakim zakresie oraz jak ma się to do sformułowań użytych w nowym dokumencie, którego historia negocjacyjna pokazuje, że państwa członkowskie nie były skłonne do szerokiego ujmowania zastosowania praw podstawowych wobec nich.

${ }^{130}$ N. Półtorak, Zakres zwiazzania..., s. 19.

${ }^{131}$ Nota bene wyrok w sprawie Kücükdeveci został wydany w styczniu 2010, a więc tuż po uzyskaniu przez Kartę mocy prawnej.

132 Por.: N. Półtorak, Zakres zwiazania..., s. 18-19; A. Wróbel, Art. 51..., s. 1340-1342; M. Wróblewski, Karta Praw Podstawowych Unii Europejskiej w polskim sądownictwie - problemy i wyzwania, „Krajowa Rada Sądownictwa” 2015, nr 2 (27), s. 17-18. 


\section{Zakres zastosowania unijnych praw podstawowych do państw członkowskich po wejściu w życie Karty na gruncie jej art. 51 ust. 1}

„Uzyskanie przez KPP mocy wiążącej nie tylko (...) nie wyjaśniło problemu zakresu zastosowania praw podstawowych do państw członkowskich, ale dodatkowo skomplikowało sytuację"133. Wspomniany sposób, w jaki art. 51 ust. 1 Karty określił zakres zastosowania Karty, nie był w pełni jednoznaczny szczególnie w obliczu różnorodności jego brzmienia w różnych wersjach językowych, a także sporów co do jego redakcji podczas prac nad Kartą. Ta niejednoznaczność prowadziła do formułowania różnych propozycji wykładni art. 51 ust. 1 i zakresu zastosowania unijnych praw podstawowych do państw członkowskich zarówno przez Rzeczników Generalnych w formułowanych przez nich opiniach, jak i przede wszystkim $\mathrm{w}$ doktrynie ${ }^{134}$. Niektóre $\mathrm{z}$ tych propozycji miały dość zachowawczy charakter, niektóre jednak postulowały daleko idącą zmianę podejścia do tego zagadnienia i znaczące rozszerzenie zakresu zastosowania Karty względem państw członkowskich. Nadanie Karcie mocy prawnej mogło być więc pewnego rodzaju przełomem w stosowaniu unijnych praw podstawowych do państw członkowskich.

\subsection{Propozycje dotyczące rozszerzenia zakresu zastosowania unijnych praw podstawowych wobec państw członkowskich}

Rzeczniczka Eleanor Sharpston w opinii do sprawy Zambrano ${ }^{135}$ postulowała zasadę, by unijne prawa podstawowe znajdowały zastosowanie we wszystkich sprawach, w których istnieje kompetencja po stronie Unii. Miałoby nie mieć przy tym znaczenia, czy byłaby to kompetencja wyłączna, czy dzielo-

${ }^{133}$ N. Półtorak, Zakres zwiazania..., s. 17 .

${ }^{134}$ Patrz np.: B. van Bockel, P. Wattel, New Wine into Old Wineskins: the Scope of the Charter of Fundamental Rights of the EU after Åkerberg Fransson, "European Law Review” 2013, nr 38; K. Lenaerts, Trybunał Sprawiedliwości Unii Europejskiej a ochrona praw podstawowych, „Europejski Przegląd Sądowy” 2013, nr 1; idem, Exploring the Limits of the EU Charter of Fundamental Rights, "European Constitutional Law Review" 2012, nr 3; M. Safjan, Areas of...; A. Knook, The Court, the Charter, and The Vertical Division Of Powers in The European Union, "Common Market Law Review" 2005, nr 42; A. Wróbel, O niektórych...; idem, Art. 51..., A. Rosas, When is the EU Charter of Fundamental Rights Applicable at National Level?, "Jurisprudence" 2012, nr 19; por. także: N. Półtorak, Zakres zwiazania..., s. 19-20.

135 TSUE, Gerardo Ruiz Zambrano p. Office national de l'emploi (ONEm), C-34/o9, opinia Rzecznika Generalnego Eleanor Sharpston przedstawiona w dniu 30 września 2010. 
na, ani to, czy została ona zrealizowana przez Unię, czy też nie została jeszcze zrealizowana. Wystarczający byłby sam fakt objęcia danej kategorii spraw kompetencją Unii. Takie podejście miałoby wynikać z faktu, że „Przyznanie Unii kompetencji przez państwa członkowskie oznacza bowiem przeniesienie odpowiedzialności za realizację praw podstawowych"136. Eleanor Sharpston pisała:

Ze względu na wymogi przejrzystości i jasności każdy powinien być w stanie ustalić z całą pewnością, co z punktu widzenia celów praw podstawowych Unii Europejskiej oznacza „zakres zastosowania prawa Unii”. Wydaje się, że w dłuższej perspektywie najczytelniejszą regułą byłaby taka, która nie uzależniałaby dostępności ochrony ustanowionej prawami podstawowymi Unii Europejskiej ani od tego, czy postanowienia traktatu mają bezpośrednie zastosowanie, ani od tego, czy prawo wtórne zostało uchwalone, ale raczej od istnienia i zakresu materialnej kompetencji Unii Europejskiej. Innymi słowy reguła stanowiłaby, że jeżeli Unii Europejskiej przysługuje kompetencja w danej dziedzinie prawa (wyłączna lub dzielona), prawa podstawowe Unii Europejskiej powinny chronić obywatela Unii, nawet gdyby kompetencja ta nie została jeszcze wykonana ${ }^{137}$.

Przyjęcie takiego podejścia prowadziłoby do rozszerzenia zakresu zastosowania unijnych praw podstawowych do państw członkowskich. Możliwość ich zastosowania wiązałaby się bowiem z potencjalnym, a nie faktycznym zakresem prawa unijnego. Unijne prawa podstawowe należałoby stosować, nawet jeśli prawo unijne nie regulowałoby w żaden sposób kwestii w przewidzianym dla Unii w ramach jej kompetencji zakresie ${ }^{138}$. Związanie państw członkowskich unijnymi prawami podstawowymi w zakresie kompetencji Unii rozszerzałoby zakres związania państw w porównaniu do opisywanego wcześniej stanu rzeczy sprzed wejścia w życie Karty, co trudno byłoby uzasadnić, opierając się na przyjętym brzmieniu art. 51 ust. 1 Karty. Szczególnie trudno w takim wypadku byłoby mówić o „stosowaniu” przez państwa prawa unijnego, skoro prawo to w danej dziedzinie w ogóle mogłoby nie istnieć. Trudno byłoby również doszukiwać się powiązania z efektywnością prawa unijnego i związku z realizowanym przez nie celem. Dostrzegała to sama Rzeczniczka, która wyraźnie

136 N. Półtorak, Zakres związania..., s. 20.

137 TSUE, Gerardo Ruiz Zambrano p. Office national de l'emploi (ONEm), C-34/o9, opinia Rzecznika Generalnego Eleanor Sharpston przedstawiona w dniu 30 września 2010, pkt 163.

138 Jak wiadomo, w ramach kompetencji dzielonych zarówno UE, jak i państwa członkowskie mogą stanowić prawo, jednak Unii przysługuje uprzywilejowanie (art. 2 ust. 2 TFUE). Dopóki Unia nie zdecydowała się ze swej kompetencji skorzystać, dopóty państwa korzystają z pełnej swobody w możliwości wprowadzania własnych regulacji, w zakresie, w jakim Unia kompetencję swoją zrealizuje, państwa swą kompetencję tracą (więcej - patrz np.: P. Craig, G. de Búrca, EU Law..., s. 84-85). 
zastrzegła, że nie sądzi, aby zaproponowane przez nią podejście mogłoby być przyjęte na ówczesnym (tak samo jak i obecnym) etapie rozwoju prawa Unii poprzez orzecznictwo TSUE. Trybunał nie mógłby po prostu przyjąć takiego punktu widzenia wbrew swemu wcześniejszemu orzecznictwu i wbrew brzmieniu traktatów, a także, jak można sądzić, wbrew woli państw członkowskich, które przyjęły Kartę w takim, a nie innym ostatecznym brzmieniu. Do tego, aby przyjąć taki zakres związania państw członkowskich unijnymi prawami podstawowymi, konieczna byłaby dalsza reforma prawa Unii ${ }^{139}$. Eleanor Sharpston stwierdziła: „nie sądzę, aby już miał miejsce niezbędny rozwój konstytucyjny podstaw Unii Europejskiej - taki, który uzasadniałby twierdzenie, że na prawa podstawowe wynikające z prawa Unii Europejskiej można było powoływać się niezależnie jako na prawa samodzielne ${ }^{\prime 140}$. Potwierdził to Trybunał, który w wyroku w sprawie Zambrano nie podążył w tej materii śladem propozycji Rzeczniczki i nie znalazł w tej sprawie podstaw do zastosowania praw podstawowych.

Sprawa Zambrano, w której TSUE nie powołał przepisów Karty, pokazała wyraźnie, że nie jest on skłonny, przynajmniej na razie, w sposób istotny odejść od dotychczasowej linii orzeczniczej. Sprawa ta dotyczyła sytuacji prawnej rodziców dziecka mającego obywatelstwo Unii, którzy jednak sami nie byli obywatelami Unii. TSUE nie znalazł w tej sytuacji wystarczających podstaw do zastosowania w tej sprawie unijnych praw podstawowych. TSUE ograniczył się do stwierdzenia, że prawo państw członkowskich nie może naruszać obywatelstwa unijnego. W swej argumentacji oparł się więc na art. 20 TFUE, ustanawiającym obywatelstwo unijne i na tej podstawie sprzeciwił się przepisom krajowym, „których skutkiem byłoby pozbawienie obywateli Unii skutecznego korzystania $\mathrm{z}$ istoty praw przyznanych im $\mathrm{w}$ związku ze statusem obywatela Unii"141. Trybunał stwierdził, że:

wykładni art. 20 TFUE należy dokonywać w ten sposób, że sprzeciwia się on temu, by państwo członkowskie, po pierwsze, odmówiło obywatelowi państwa trzeciego sprawującemu opiekę nad swoimi małymi dziećmi, będącymi obywatelami Unii, prawa pobytu w państwie członkowskim zamieszkania tych dzieci, którego są one też obywatelami, a po drugie, odmówiło temu obywatelowi państwa trzeciego zezwolenia na pracę, ponieważ takie decyzje faktycznie pozbawiałyby te dzieci możności korzystania z istoty praw związanych ze statusem obywatela Unii ${ }^{142}$.

139 TSUE, Gerardo Ruiz Zambrano p. Office national de l'emploi (ONEm), C-34/o9, opinia Rzecznika Generalnego Eleanor Sharpston przedstawiona w dniu 30 września 2010, pkt 171-177.

${ }^{140}$ Ibidem, pkt 175 .

${ }^{141}$ TSUE, Gerardo Ruiz Zambrano p. Office national de l'emploi (ONEm), C-34/o9, wyrok z 8 marca 2011, pkt 42.

${ }^{142}$ Ibidem, pkt 45. 
Tak więc TSUE nie zdecydował się w tej sytuacji na powołanie przepisów Karty, mimo że pytanie skierowane doń przez sąd krajowy dotyczyło tych przepisów, a konkretnie art. 21, 24 i 34 Karty, a więc odpowiednio prawa do nie bycia dyskryminowanym, gwarancji praw dziecka oraz prawa do zabezpieczenia społecznego i pomocy społecznej ${ }^{143}$.

Mimo to, że TSUE „miał wiele razy okazję stwierdzić, że status obywatela Unii ma stanowić podstawowy status obywateli państw członkowskich"144, nie doszedł jednak nigdy do wniosku, że posiadanie obywatelstwa unijnego wystarczy do zastosowania unijnych praw podstawowych. Dobrym uzupełnieniem w tej materii wyroku w sprawie Zambrano jest wyrok w sprawie Dereci. W sprawie Zambrano TSUE zignorował trzecie pytanie sądu odsyłającego, dotyczące możliwości zastosowania unijnych praw podstawowych, jako że dla rozstrzygnięcia sprawy wystarczyły inne przepisy. Nie należy tego jednak traktować jako uniku ze strony Trybunału ${ }^{145}$. W sprawie Dereci odniósł się do tej kwestii wprost. Podobnie jak pan Zambrano, pan Dereci (i inne osoby, których dotyczył ten wyrok w sprawach połączonych) był obywatelem państwa trzeciego, który nielegalnie zamieszkiwał w państwie członkowskim, którego obywatelami były jego dzieci. Podobnie jak dzieci pana Zambrano, dzieci pana Dereci były nieletnie i nigdy nie skorzystały ze swobody przepływu osób ${ }^{146}$. Zdaniem TSUE tym razem nie doszło jednak do naruszenia istoty praw wynikających z obywatelstwa unijnego. Trybunał stwierdzil, że "kryterium dotyczące pozbawienia istoty praw przyznanych w związku ze statusem obywatela Unii odnosi się do sytuacji zdefiniowanych przez okoliczność, że obywatel Unii jest faktycznie zmuszony do opuszczenia nie tylko terytorium państwa członkowskiego, którego jest obywatelem, lecz również terytorium całej Unii" ${ }^{\prime 17}$. Jeśli nie mamy do czynienia z tego typu okolicznościa, to prawa pobytu obywatelowi państwa trzeciego można odmówićic ${ }^{148}$ Zdaniem TSUE:

${ }^{143}$ Ibidem, pkt 35. Por.: N. Półtorak, Zakres zwiazzania..., s. 20.

${ }^{144}$ TSUE, Gerardo Ruiz Zambrano p. Office national de l'emploi (ONEm), C-34/o9, wyrok z 8 marca 2011, pkt 41; por.: TSUE, Rudy Grzelczyk p. Centre public d'aide sociale d'Ottignies-Louvain-la-Neuve, C-184/99, wyrok z 20 września 2001, pkt 31; TSUE, Baumbast i R p. Secretary of State for the Home Department, C-413/99, wyrok 17 września 2002, pkt 82; TSUE, Carlos Garcia Avello p. państwu belgijskiemu, C-148/o2, wyrok z 2 października 2003, pkt 22; TSUE, Kunqian Catherine Zhu i Man Lavette Chen p. Secretary of State for the Home Department, C-200/02, wyrok z 19 października 2004, pkt 25; TSUE, Janko Rottman p. Freistaat Bayern, C-135/o8, wyrok z dnia 2 marca 2010, pkt 43.

${ }^{145}$ Por.: K. Lenaerts, EU Citizenship and the European Court of Justice's 'stone-by-stone' Approach, "International Comparative Jurisprudence" 2015, $\mathrm{nr}$ 1, s. 3 i nast.

146 TSUE, Murat Dereci i inni p. Bundesministerium für Inneres, C-256/11, wyrok z 15 listopada 2011, pkt 22-27.

${ }^{147}$ Ibidem, pkt 66.

${ }^{148}$ Ibidem, pkt 67. 
sam fakt, że dla obywatela państwa członkowskiego mogłoby wydawać się pożądane

- ze względów ekonomicznych lub w celu utrzymania jedności rodziny na terytorium Unii - aby członkowie jego rodziny, którzy nie posiadają obywatelstwa państwa członkowskiego mogli z nim przebywać na terytorium Unii, jest niewystarczający dla stwierdzenia, że obywatel Unii byłby zmuszony do opuszczenia terytorium Unii $\mathrm{w}$ razie nieprzyznania takiego prawa ${ }^{149}$.

Jeśli więc sytuacja nie oznacza konieczności opuszczenia terytorium Unii przez jej obywatela, ze względu na niemożność przebywania na jej terytorium przez będącego obywatelem państwa trzeciego członka jego rodziny, przepisy dotyczące unijnego obywatelstwa nie znajdują zastosowania. Na podstawie tych rozważań Trybunał odniósł się również do kwestii unijnych praw podstawowych. W obliczu braku możliwości zastosowania przepisów o obywatelstwie unijnym, nie ma odpowiedniego łącznika z prawem unijnym, aby objąć taką sytuację unijnymi prawami podstawowymi. Jak dobrze pokazuje to wyrok w tej sprawie, unijne prawa podstawowe nie są okolicznością determinującą zakres zastosowania Traktatów, a odwrotnie, to zakres zastosowania prawa unijnego jest determinujący dla zakresu zastosowania unijnych praw podstawowych. Gdyby było inaczej, stałoby to w sprzeczności z podziałem kompetencji między Unię a państwa członkowskie, art. 6 ust. 1 TUE oraz art. 51 ust. 2 Karty ${ }^{150}$. Sytuacje takie podlegają więc krajowym i międzynarodowym gwarancjom, którymi dane państwo jest związane, z EKPCz na czele ${ }^{151}$ nie podlegają jednak prawu unijnemu.

Ważną okolicznością, która mogłaby zmienić sytuację w kwestii zastosowania unijnych praw podstawowych, jest zaistnienie elementu transgranicznego, a więc skorzystanie przez osoby, których sprawa dotyczy, z zagwarantowanych w traktatach swobód. To jednak sprawia, że mamy do czynienia z koniecznym łącznikiem, co TSUE potwierdził w różnych omawianych w tej pracy wyrokach. W podobną logikę wpisuje się wyrok w sprawie Coman ${ }^{152}$, która szerzej omawiana będzie $\mathrm{w}$ dalszej części pracy. W sprawie tej Trybunał nie oparł się wprawdzie na Karcie i zawartych w niej gwarancjach poszanowania życia rodzinnego, lecz na swobodzie przemieszczania się i art. 21 ust. 1 TFUE ${ }^{153}$. Niemniej jednak przywołał Kartę ${ }^{154}$, a także podkreślił znaczenie definicji rele-

${ }^{149}$ Ibidem, pkt 68 .

${ }^{150}$ K. Lenaerts, EU Citizenship..., s. 4-5.

${ }^{151}$ TSUE, Murat Dereci i inni p. Bundesministerium für Inneres, C-256/11, wyrok z 15 listopada 2011, pkt 70-72.

152 TSUE, Relu Adrian Coman i in. p. Inspectoratul General pentru Imigrări i Ministerul Afacerilor Interne, C-673/16, wyrok 5 z czerwca 2018.

${ }^{153}$ Ibidem, pkt 51 .

${ }^{154}$ Ibidem, pkt 48. 
wantnych pojęć, rozumianych w sposób, który w swym orzecznictwie wypracował ETPCz ${ }^{155}$ (w obliczu art. 52 ust. 3 Karty, nadającego gwarancjom wynikającym z art. 7 Karty „takie same znaczenie i zakres, jak prawa gwarantowane w art. 8 europejskiej Konwencji"156). Określając zakres zastosowania prawa unijnego, TSUE określił tym samym potencjalny zakres zastosowania Karty, choć w danej sprawie nie było to konieczne.

Jeśli chodzi o propozycje formułowane przez przedstawicieli doktryny, to na szczególną uwagę zasługuje wypracowana przez Armina von Bogdandy'ego i jego zespół koncepcja, jak nazwali ją sami autorzy - "odwróconego Solange” (Reverse Solange $)^{157}$. Propozycja ta szła jeszcze dalej niż wspomniana przed chwila, sformułowana przez Rzeczniczkę Sharpston na gruncie sprawy Zambrano. To wyrok w tej sprawie stanowił grunt dla jej wypracowania. Zespół Armina von Bogdandy'ego postulował, by zastosowanie Karty mogło wykraczać nawet poza szeroko rozumiany zakres prawa UE w sytuacjach, gdy państwa członkowskie w sposób poważny i systematyczny naruszałyby istotę praw podstawowych. Autorzy ci nie opierali jednak swojej koncepcji sensu stricto na art. 51 ust. 1 Karty, lecz wywodzili ją z innych przepisów, związanych z szerszą reformą Unii i jej systemu ochrony praw człowieka, jaka dokonała się wraz z wejściem w życie Traktatu lizbońskiego. To na jego mocy Karta uzyskała moc prawną. Nie było to jednak jedynym skutkiem tej reformy, odnoszacym się do unijnej ochrony praw podstawowych. Dla zespołu von Bogdandy'ego kluczowy był po pierwsze, art. 2 TUE, ustanawiający podstawowe wartości Unii, wśród których znajduja się: poszanowanie godności osoby ludzkiej, wolności, demokracji, równości, państwa prawnego, jak również poszanowania praw człowieka oraz po drugie, art. 9 TUE ustanawiający obywatelstwo unijne. Zdaniem autorów tej koncepcji stopniowe rozszerzanie rozumienia art. 51 ust. 1 Karty poprzez rozszerzanie zakresu rozumienia działania przez państwa w zakresie prawa Unii, jednakże ograniczone przez brzmienie tego przepisu, czego dokonywał w swym orzecznictwie TSUE, nie dawało możliwości odpowiedniej reakcji na pewne problemy w zakresie ochrony praw podstawowych i zbytnio krępowało kompetencję Unii w tym zakresie ${ }^{158}$.

Nazwa koncepcji nawiązywała w sposób oczywisty do znanego orzecznictwa FTK w kwestii ochrony praw człowieka przez Unię, zgodnie z którym Trybunał w Karlsruhe dopuścił uznanie pierwszeństwa prawa wspólnotowego, jednakże jedynie tak długo, jak długo ETS będzie zapewniał skuteczną ochronę

\footnotetext{
${ }^{155}$ Ibidem, pkt 50.

${ }^{156}$ Ibidem, pkt 49 .

157 A. von Bogdandy, M. Kottmann, C. Antpöhler, J. Dickschen, S. Hentrei, M. Smrkolj, Reverse Solange....

${ }^{158}$ Ibidem, s. 497 i nast.
} 
praw podstawowych w prawie unijnym (tzw. Solange II ${ }^{159}$. W nowej, "odwróconej" wersji zasada Solange miała oznaczać, że dopóki państwa członkowskie nie naruszają praw podstawowych w sposób poważny i systematyczny, dopóty pozostają one swobodne w stosowaniu, poza zakresem zastosowania prawa unijnego, czyli poza zakresem przewidzianym w art. 51 ust. 1, swoich praw podstawowych. Jednakże w sytuacjach, gdyby takiego naruszenia unijnych praw podstawowych się dopuszczały, to prawo unijne pozwala na reagowanie na to, nawet w sytuacjach pozostających poza zakresem prawa Unii, czyli poza zakresem związania państw przewidzianym w art. 51 ust. 1 Karty. Jak ujęli to autorzy:

Naruszenie przez państwo członkowskie, nawet w sytuacjach całkowicie wewnętrznych, może być uznane za naruszenie istoty obywatelstwa Unii. Aby zachować pluralizm konstytucyjny, który jest zagwarantowany w art. 4 ust. 2 TUE, proponujemy zawarcie tego [podejścia - przyp. aut.] w doktrynie „odwróconego" Solange, stosowanego odnośnie do państw członkowskich z poziomu unijnego. Można to ująć krótko w sposób następujący: poza zakresem art. 51 ust. 1 KPP państwa członkowskie pozostają swobodne w ochronie praw podstawowych tak długo, jak można uznać, że zapewniają istotę praw podstawowych chronioną na podstawie art. 2 TUE. Jednakże jeśli w skrajnym przypadku doszłoby do sytuacji, w której naruszenia miałyby charakter systemowy, to domniemanie jest obalane. W takich sytuacjach jednostki mogą korzystać ze swego statusu jako obywatele Unii i wnosić sprawę do sądu krajowego ${ }^{160}$.

Koncepcja ta powstała w dużej mierze w obliczu krytycznej oceny skuteczności procedury zawartej w art. 7 TUE, która miała być podstawowym mechanizmem chroniącym przestrzeganie wartości wyrażonych w art. 2 TUE przez państwa członkowskie. Koncepcja ta miała dość rewolucyjny charakter i dalece rozszerzałaby stosowanie unijnych praw podstawowych poza zakres art. 51 ust. I KPP. Wzbudziła ona spore zainteresowanie, głównie w doktrynie, nie znalazła jednak zastosowania.

Koncepcja 'odwróconego Solange' w dużej mierze wiązała się z pewnym poczuciem braku realizacji pełnego potencjału, jaki drzemie w instytucji obywatelstwa unijnego ${ }^{161}$. Z kwestią obywatelstwa związana była również sprawa Zambrano, na gruncie której Rzeczniczka Sharpston sformułowała swoją pro-

${ }^{159}$ FTK, 2 BvR 197/83, orzeczenie z 22 października 1986.

160 A. von Bogdandy, M. Kottmann, C. Antpöhler, J. Dickschen, S. Hentrei, M. Smrkolj, Reverse Solange..., s. 491 (tłum. własne).

161 Więcej na ten temat patrz np.: G. Baranowska, A. Bodnar, A. Gliszczyńska-Grabias (red.), Ochrona praw obywatelek i obywateli Unii Europejskiej. 20 lat - osiagnięcia i wyzwania na przyszłość, Warszawa 2015. 
pozycję rozszerzenia zakresu unijnych praw podstawowych. Do zastosowania praw wynikających z obywatelstwa unijnego koniecznym warunkiem jest bowiem istnienie tzw. elementu transgranicznego albo jakichś innych łączników, które by to uzasadniały. Sam fakt posiadania obywatelstwa nie wiąże się z żadnymi konkretnymi prawami. Ma to swoje konsekwencje również dla możliwości stosowania unijnych praw podstawowych:

Dotychczasowe orzecznictwo TSUE wskazuje, że obywatelstwo Unii nie może być traktowane samo w sobie jako uzasadniające zastosowanie prawa unijnego, a więc i KPP. Innymi słowy - musi istnieć jakieś unijne prawo wynikające z obywatelstwa, aby uznać, że sprawa mieści się w zakresie zastosowania prawa UE i Karty. Ani obywatelstwo Unii samo w sobie nie jest łącznikiem wystarczającym dla zastosowania KPP, ani Karta nie rozszerza praw przysługujących obywatelom UE ${ }^{162}$.

Stanowisko takie wyraźnie potwierdził w swym orzecznictwie TSUE. Będzie o tych sprawach mowa w dalszej części tego rozdziału.

Powyższe propozycje określenia zakresu KPP i praw podstawowych w stosunku do państw członkowskich (...) prowadziły do rozszerzenia zakresu stosowania praw podstawowych poza prawo UE, a więc mogły mieć efekt federalizacyjny polegający na zastosowaniu praw podstawowych UE także poza zakresem prawa unijnego, a więc w tych sytuacjach, gdy państwa członkowskie wykonują własne kompetencje $\mathrm{e}^{163}$.

Tymczasem to przecież obawy przed federalizacyjnym efektem jej wprowadzenia do unijnego porządku prawnego, były jedną z głównych przeszkód hamujaccych przez wiele lat proces nadania Karcie mocy prawnej ${ }^{164}$. Pomijajacc rozważania nad charakterem Unii oraz jej ewentualną federalizacja, jako przekraczające zakres tego opracowania, należy wyraźnie podkreślić, że takie, jak zaprezentowane powyżej rozszerzające podejście, byłyby trudne do zaakceptowania w aktualnym stanie prawnym i w świetle gwarancji przewidzianych zarówno w traktatach (przede wszystkim w art. 6 ust. 1, zd. drugie TUE), jak i w samej KPP (przede wszystkim w art. 51 ust. 2) ${ }^{165}$. Byłyby także sprzeczne z brzmieniem art. 51 ust. 1 Karty, na które zgodziły się ostatecznie państwa członkowskie, przyjmując Kartę.

${ }^{162}$ N. Półtorak, Zakres związania..., s. 20.

${ }^{163}$ Ibidem, s. 20.

164 Por. np.: K. Lenaerts, Respect for Fundamental Rights as a Constitutional Principle of EU, "Columbia Journal of European Law" 2000, nr 1; P. Eeckhout, The EU...; jak się okazuje obawy wcale nie całkiem płonne: A. Torres Pérez, The Federalizing....

165 Por.: N. Półtorak, Zakres zwiazania..., s. 20. 


\subsection{Pierwsze przykłady zastosowania art. 51 ust. 1 Karty po jej wejściu w życie}

Podobnie jak Wyjaśnienia dotyczące Karty opierały się na wcześniej zarysowanej linii orzeczniczej trybunału luksemburskiego, tak i sam TSUE po wejściu w życie Karty dawał przykłady kontynuowania wyznaczonej przedtem linii orzeczniczej i raczej ewolucyjnie, a nie rewolucyjnie rozwijał swoje podejście do kwestii stosowania unijnych praw podstawowych do państw członkowskich. Tak np. w sprawie N.S. ${ }^{166}$ wybrał wyraźnie drogę kontynuacji i potwierdził aktualność swego wcześniejszego orzecznictwa w ramach grupy spraw typu Wachauf. Sprawa N.S. dotyczyła wspólnego europejskiego systemu azylowego, a konkretnie pewnej swobody pozostawionej państwom do odstępstw od zasad odpowiedzialności państw za przeprowadzenie procedury azylowej przewidzianej przez tzw. Rozporządzenie Dublin II ${ }^{167}$. Wprawdzie nie mieliśmy tu do czynienia z dyrektywa, lecz rozporządzeniem unijnym, problem należał jednak do kategorii spraw typu Wachauf, ponieważ wiązał się z pozostawioną państwom w pewnym zakresie swobodą $\mathrm{w}$ implementacji postanowień rozporządzenia.

Sprawa dotyczyła obywatela Afganistanu, który ubiegał się o azyl w Zjednoczonym Królestwie, po tym jak dotarł do niego, podróżując uprzednio przez wiele państw Unii, w tym Grecję, gdzie przekroczył granicę Unii. Zgodnie z rozporządzeniem, państwem odpowiedzialnym za przeprowadzenie procedury azylowej obywatela państwa trzeciego, bez względu na to, w którym państwie złożył on odpowiedni wniosek, było państwo, w którym przekroczył on granicę Unii. Dlatego też N.S. powinien być wydany władzom greckim w tym celu. Tym niemniej N.S. zwrócił się do władz brytyjskich (Secretary of State) o rozpatrzenie jego wniosku azylowego, powołując się na art. 3 ust. 2 Rozporządzenia. Stanowił on m.in., że „każde państwo członkowskie może rozpatrzyć wniosek o udzielenie azylu wniesiony do niego przez obywatela państwa trzeciego, nawet jeżeli za takie rozpatrzenie nie jest odpowiedzialne na podstawie kryteriów ustanowionych w niniejszym rozporządzeniu". N.S. twierdził, że wydanie go władzom greckim wiązałoby się z wysokim ryzykiem naruszenia praw podstawowych zagwarantowanych w prawie Unii, EKPCz i Konwencji genewskiej

166 TSUE, N.S. p. Secretary of State for the Home Department oraz M.E., A.S.M., M.T., K.P., E.H. p. Refugee Applications Commissioner, Minister for Justice, Equality and Law Reform, C-411/10 i C-493/10, wyrok z 21 grudnia 2011.

${ }^{167}$ Rozporządzenie Rady (WE) nr 343/2003 z dnia 18 lutego 2003 ustanawiające kryteria i mechanizmy określania państwa członkowskiego właściwego dla rozpatrywania wniosku o azyl, wniesionego w jednym z państw członkowskich przez obywatela państwa trzeciego, Dz.Urz. L 50 z 25 lutego 2003. 
dotyczącej statusu uchodźców ${ }^{168}$. Szczególnie podnosił niebezpieczeństwo naruszenia art. 4 Karty zakazującego nieludzkiego i poniżającego traktowania. Secretary of State odmówił skorzystania z uprawnienia do rozpatrzenia sprawy i trafiła ona do sądu, który skierował do TSUE serię pytań prejudycjalnych, z których pierwsze brzmiało następująco:

Czy decyzja podjęta przez państwo członkowskie na mocy art. 3 ust. 2 rozporządzenia $\mathrm{nr} 343 / 2003$ (...) w przedmiocie rozpatrzenia wniosku o udzielenie azylu, który to wniosek nie należy do zakresu odpowiedzialności tego państwa zgodnie z kryteriami określonymi w rozdziale III rozporządzenia, podlega prawu UE dla potrzeb art. 6 [TUE - przyp. aut.] lub art. 51 [Karty - przyp. aut.]? ${ }^{169}$

Odnośnie do kwestii zastosowania unijnych praw podstawowych, Trybunał wprost odniósł się w tej sprawie do sprawy Wachauf, przyznając rację Komisji, która powoływała się w tej mierze w swoim stanowisku na tę właśnie sprawę $e^{170}$. Przypomniawszy, że "Artykuł 51 ust. 1 Karty przewiduje, że jej postanowienia mają zastosowanie do państw członkowskich wyłącznie w zakresie, w jakim stosują one prawo Unii"171, i stwierdziwszy, że "Analiza art. 3 ust. 2 rozporządzenia nr 343/2003 wskazuje, że w rozporządzeniu tym przyznano państwom członkowskim zakres uznania, który stanowi integralną część wspólnego europejskiego systemu azylowego przewidzianego w TFUE i opracowanego przez prawodawcę Unii" ${ }^{172}$, przyznał, że "Jak podkreśliła Komisja, korzystając ze wspomnianego zakresu uznania, państwa członkowskie powinny przestrzegać innych przepisów rzeczonego rozporządzenia"173. Doprowadziło go to do konkluzji, że:

zakres uznania przyznany państwom członkowskim w art. 3 ust. 2 rozporządzenia $\mathrm{nr} 343 / 2003$ stanowi część przewidzianego w tym rozporządzeniu mechanizmu określania państwa członkowskiego odpowiedzialnego za rozpatrzenie wniosku o udzielenie azylu i w konsekwencji stanowi jeden z elementów wspólnego europejskiego systemu azylowego. W związku z tym należy uważać, że państwo członkowskie, które korzysta z tego zakresu uznania, stosuje prawo Unii w rozumieniu art. 51 ust. 1 Karty ${ }^{174}$.

${ }^{168}$ Konwencja dotycząca statusu uchodźców, podpisana w Genewie w dniu 28 lipca 1951, Dz.U. 1991 nr 119 poz. 515.

169 TSUE, N.S. p. Secretary of State for the Home Department oraz M.E., A.S.M., M.T., K.P., E.H. p. Refugee Applications Commissioner, Minister for Justice, Equality and Law Reform, C-411/10 i C-493/10, wyrok z 21 grudnia 2011, pkt 50.

${ }^{170}$ Ibidem, pkt 6 o.

${ }^{171}$ Ibidem, pkt 64 .

172 Ibidem, pkt 65 .

${ }^{173}$ Ibidem, pkt 66.

${ }^{174}$ Ibidem, pkt 68; por. także: TSUE, Raffinerie Mediterranee (ERG) SpA, Polimeri Europa SpA i Syndial SpA p. Ministero dello Sviluppo economico and Others oraz ENI SpA p. Ministero 
Trybunał potwierdził więc w tej sprawie, że możliwość zastosowania unijnych praw podstawowych nie zależy od tego, czy przy działaniu w ramach prawa unijnego państwo członkowskie działało $\mathrm{w}$ ramach przyznanej mu przez nie dyskrecjonalności ${ }^{175}$, co wszakże może mieć znaczenie w sytuacji nakładania się unijnego i krajowego standardu ochrony ${ }^{176}$, o czym będzie jeszcze mowa.

Podobną logikę Trybunał zastosował w sprawie $\mathrm{McB}^{177}$, w której nie doszedł wprawdzie wprost do wniosku o możliwości zastosowania unijnych praw podstawowych wobec regulacji krajowej i tego nie uczynił. Jednakże nie wprost zastosował wobec niej unijne prawa podstawowe, formalnie dokonując jedynie oceny i wykładni unijnego rozporządzenia. Trybunał zastrzegł się, że nie ocenia regulacji krajowej, a jedynie bada, dokonując wykładni rozporządzenia, czy odniesienie do prawa krajowego, które w zakresie, jaki regulowało, mieściło się w kompetencji krajowej, nie zagrażało odpowiedniej ochronie praw podstawowych ${ }^{178}$. TSUE stwierdził, że:

w niniejszej sprawie kartę należy uwzględnić wyłącznie dla potrzeb wykładni rozporządzenia nr 2201/2003, bez dokonywania wykładni prawa krajowego jako takiego. Chodzi tu raczej o ustalenie, czy postanowienia karty stoją na przeszkodzie wykładni tego rozporządzenia przedstawionej w pkt 44 niniejszego wyroku, z uwzględnieniem w szczególności odesłania do prawa krajowego, z którym taka wykładnia się wiąże $\mathrm{e}^{179}$.

Ocena ta była pozytywna. To znaczy TSUE nie doszedł do wniosku o naruszeniu praw podstawowych przez rozporządzenie. Można jednak przypuszczać, że gdyby regulacje krajowe były sprzeczne z unijnymi prawami podstawowymi, to TSUE doszedłby do konkluzji, że są one sprzeczne z prawidłową (zapewniającą realizację praw podstawowych) interpretacją przedmiotowego prawa UE ${ }^{180}$. Warto zwrócić także uwagę, że Unia nie ma kompetencji harmonizacyjnych w odniesieniu do kwestii, których dotyczyła sprawa (prawo rodzinne). Dlatego też prawo unijne mogło zmierzać jedynie do pewnej koordynacji, a nie harmonizacji regulacji krajowych. Dlatego też rozgraniczenie dokonane przez Trybunał w oparciu o art. 51 ust. 1 , ale i ust. 2 - w tej sprawie jest tak istotne ${ }^{181}$.

Ambiente e Tutela del Territorio e del Mare and Others, C-379/o8 i 38o/o8, wyrok z 9 marca 2010, pkt 79 .

${ }^{175}$ Por. też: TSUE, Jiří Sabou p. Finanční ředitelství pro hlavní město Prahu, C-276/12, wyrok z 22 października 2013, pkt 25-26.

176 Tak samo: N. Półtorak, Zakres zwiazania..., s. 23.

177 TSUE, J. McB. p. L.E., C-40o/10, wyrok z 5 października 2010.

${ }^{178}$ Ibidem, pkt 44, 51-55 i nast.

${ }^{179}$ Ibidem, pkt 52.

180 Tak np.: M. Safjan, Areas of..., s. 10-11.

${ }^{181}$ E. Spaventa, The Interpretation of Article 51 of the EU Charter of Fundamental Rights: the Dilemma of Stricter or Broader Application of the Charter to National Measures, European Parliament 
Przez pewien czas po wejściu w życie Karty Trybunał a casu ad casum przybliżał kryteria, które należy brać pod uwagę podczas dokonywania oceny, czy istnieje odpowiedni łącznik z prawem unijnym, wymagany przez art. 51 ust. 1 Karty, i czy w związku z tym dana sprawa podlega Karcie. Kontynuował w ten sposób swą linię orzeczniczą w poszczególnych przypadkach. Przez długi czas brak było jednak wyroku, który w kategoriach ogólnych odnosiłby się do wykładni art. 51 ust. 1 Karty w kontekście szerszego dziedzictwa orzeczniczego TSUE w tej materii. Tak np. w sprawie Iida ${ }^{182}$ Trybunał wskazał, że:

Aby ustalić, czy odmowa przez władze niemieckie przyznania Y. Iidzie „karty pobytu członka rodziny obywatela Unii" mieści się w granicach stosowania prawa Unii w rozumieniu art. 51 karty, należy między innymi zbadać, czy omawiane uregulowanie krajowe ma na celu wykonanie przepisu prawa Unii, jaki jest charakter tego uregulowania, oraz to, czy zmierza ono ku realizacji celów innych niż te objęte prawem Unii, nawet jeżeli może ono w sposób pośredni wpływać na to ostatnie, a także to, czy istnieją przepisy prawa Unii regulujące daną dziedzinę w sposób szczególny lub mogące mieć dla niej znaczenie ${ }^{183}$.

Również w tym wyroku daje się więc dostrzec kontynuację linii orzeczniczej sprzed wejścia w życie Karty, a nawet jej pewne rozwinięcie. Trybunał nie rezygnuje z trzeciej kategorii opisanych wcześniej sytuacji, w których państwa były związane unijnymi prawami podstawowymi i podkreśla, że również pod rządami art. 51 ust. 1 Karty dla stwierdzenia zastosowania unijnych praw podstawowych wobec państw członkowskich związek z prawem unijnym wcale nie musiał być bezpośredni, a więc wynikający wprost $\mathrm{z}$ jakiegoś przepisu prawa unijnego. Wystarczy, aby sytuacja miała związek z niewyrażoną wprost zasadą efektywności prawa unijnego, a więc by prawo Unii "miało znaczenie" dla określonej sytuacji, choćby poprzez cele przez nie realizowane. Powyższe stanowisko w sprawie Iida było próbą „wskazania pewnych rodzajów sytuacji pojawiających się dotychczas w orzecznictwie, w których uznano, że państwa członkowskie działały w zakresie prawa unijnego, lecz nie wyjaśnia [ono - przyp. aut.] wprost, jakie są kryteria zastosowania KPP w prawie krajowym"184. Nie jest to też wskazanie w pełni jednoznaczne. O ile można było z tego wyroku odczytać pewną wskazówkę w tej materii, o tyle ostatecznie nie zostało rozstrzygnięte kluczowe - w obliczu sformułowania zawartego w art. 51 ust. 1 Karty po jej wejściu w życie - pytanie, czy dla zastosowania KPP do państw członkowskich konieczne jest "wskazanie przepisu prawa UE, z którego bez-

STUDY, PE 556.930, s. 18-19.

182 TSUE, Yoshikazu Iida p. Stadt Ulm, C-40/11, wyrok z 8 listopada 2012.

${ }^{183}$ Ibidem, pkt 79.

${ }^{184}$ N. Półtorak, Zakres zwiazania..., s. 22. 
pośrednio wynika zobowiązanie do danego działania lub zaniechania państwa członkowskiego"185, czy też istnienie takiego przepisu nie jest konieczne.

Ponadto należy podkreślić, że w sprawie tej Trybunał wskazał również, że dodatkowym warunkiem koniecznym do zastosowania w danej sytuacji unijnych praw podstawowych jest to, aby w sprawie nie tylko spełniony był warunek podstawowy, jakim jest objęcie sprawy zakresem prawa unijnego, ale także, żeby stan faktyczny w sprawie temu prawu podlegał. Ostatecznie bowiem w sprawie Iida Trybunał nie uznał, że mieści się ona w zakresie zastosowania prawa Unii nawet odnośnie do przepisów, które były bezpośrednim wykonaniem regulacji unijnych. Stanął on na takim stanowisku ze względu na fakt, że skarżący nie spełniał przesłanek do zastosowania wobec niego przepisów unijnych, co uniemożliwiało sądowi zastosowanie zasady pierwszeństwa w tej sprawie $^{186}$. Trybunał stwierdził wyraźnie:

Jakkolwiek $\S 5$ FreizügG/EU, przewidujący wydanie „karty pobytu członka rodziny obywatela Unii", w sposób oczywisty ma na celu wykonanie prawa Unii, nie zmienia to faktu, że sytuacja skarżącego w postępowaniu głównym nie jest regulowana przez prawo Unii, ponieważ nie spełnia on przesłanek wymaganych do uzyskania tej karty na podstawie art. 10 dyrektywy 2004/38. Ponadto wobec niewystąpienia przez skarżącego w postępowaniu głównym z wnioskiem o przyznanie mu statusu rezydenta długoterminowego zgodnie z dyrektywą 2003/109, jego sytuacja nie wykazuje żadnego łącznika z prawem Unii ${ }^{187}$.

O ile więc TSUE już w pierwszych wyrokach po wejściu w życie Karty, nie dokonywał tak radykalnych rozszerzeń zastosowania unijnych praw podstawowych w oparciu o zmianę, jaką przyniosło ze sobą wejście w życie Karty, jak proponowali to niektórzy, i raczej dość restrykcyjnie kontynuował swoją wcześniejszą linię orzeczniczą i trzymał się wypracowanych wcześniej kryteriów oceny związania państw członkowskich unijnymi prawami podstawowymi, o tyle zdarzało mu się także znajdować podstawy do zastosowania unijnych praw podstawowych $\mathrm{w}$ sytuacjach, w których związek z prawem unijnym bywał bardzo luźny ${ }^{188}$. Za przykład takiej sprawy może posłużyć sprawa DEB ${ }^{189}$. Wskazywano, że stanowi ona istotny przełom w rozumieniu przedmiotowej kwestii ${ }^{190}$. Co do zasady bowiem w sprawach, w których mamy do czynienia

\footnotetext{
${ }^{185}$ Ibidem, s. 22.

186 Por.: ibidem, s. 22.

187 TSUE, Yoshikazu lida p. Stadt Ulm, C-40/11, wyrok z 8 listopada 2012, pkt 80.

188 Por.: T.T. Koncewicz, A. Podolska, Karta Praw..., s. 255.

189 TSUE, DEB Deutsche Energiehandels- und Beratungsgesellschaft $\mathrm{mbH}$ p. Bundesrepublik Deutschland, C-279/o9, wyrok z 22 grudnia 2010.

${ }^{190}$ Np.: M. Safjan, Areas of..., s. 9.
} 
z dochodzeniem uprawnień wynikających z prawa unijnego przed organami krajowymi, dzieje się to w ramach autonomii proceduralnej przysługującej państwom członkowskim ${ }^{191}$ :

Zgodnie z autonomią proceduralną, dochodzenie takich roszczeń odbywa się na podstawie przepisów prawa krajowego. Rzadko bowiem się zdarza, aby prawo UE w sposób wyczerpujący regulowało kwestie procesowe w postępowaniu przed organami krajowymi. Przepisy krajowe, które w konkretnym stanie faktycznym służą realizacji roszczeń wynikających z prawa UE, muszą być [zgodne] z zasadą równoważności [przepisy służące dochodzeniu roszczeń nie mogą być mniej korzystne dla osoby uprawnionej, aniżeli w przypadku realizacji porównywalnych roszczeń opartych wyłącznie na prawie krajowym] i zasadą skuteczności (efektywności) [przepisy służące dochodzeniu roszczeń nie mogą powodować, że realizacja roszczeń opartych na prawie UE byłaby nadmiernie utrudniona lub praktycznie niemożliwa] ${ }^{192}$.

W sprawie DEB chodziło o zastosowanie gwarancji procesowych przewidzianych w art. 47 Karty, a konkretnie kwestii dotyczących prawa do skorzystania z pomocy prawnej. Niemiecka spółka wniosła powództwo w celu pociągnięcia do odpowiedzialności państwa niemieckiego z powodu naruszenia prawa UE. W toku postępowania odmówiono powodowi prawa do skorzystania z pomocy prawnej z urzędu, mimo że w takich sytuacjach jak ta, która miała miejsce w przedmiotowej sprawie, prawo niemieckie przewidywało przymus adwokacki. TSUE zdecydował podjąć się oceny, czy niemieckie przepisy dotyczące przesłanek warunkujących ustanowienie pełnomocnika dla osób prawnych naruszaja przepisy Karty, czy nie. Trybunał stanął na takim stanowisku, mimo że nie mamy tu do czynienia z przypadkiem bezpośredniego stosowania prawa UE, jako że przepisy dotyczące zasad ustanawiania pełnomocnika z urzędu nie wynikały z prawa unijnego, lecz jedynie z prawa niemieckiego. Tym niemniej, w sprawie tej gwarancje wynikające z Karty powinny być zdaniem TSUE wypełnione w postępowaniu krajowym. Trybunał wywiódł taki wniosek z faktu, że roszczenie w prawie krajowym wynikało z prawa Unii (a właściwie z faktu jego niewykonania przez państwo członkowskie). Nie miało zdaniem TSUE znaczenia to, że prawo UE ani wprost nie nakazuje państwom członkowskim realizacji takich roszczeń (nakaz taki wynikał natomiast z orzecznictwa

${ }^{191}$ Autonomia proceduralna państw członkowskich jest rozumiana (zgodnie z tzw. formułą Rewe/Comet) jako kompetencja tych państw do regulowania właściwości sądów i procedur sądowych służących rozpoznawaniu roszczeń opartych na prawie UE (patrz przed.: TSUE, Rewe-Zentralfinanz eG i Rewe-Zentral AG p. Landwirtschaftskammer für das Saarland, C-33/76, wyrok z 16 grudnia 1976).

${ }^{192}$ M. Szpunar, Kilka uwag systematyzujacych na temat zakresu zastosowania Karty Praw Podstawowych UE, "Europejski Przegląd Sądowy” 2015, nr 10, s. 7 . 
TSUE), ani nie reguluje kwestii pomocy prawnej w ramach roszczeń odszkodowawczych. Skoro roszczenie nie mogło powstać, gdyby nie prawo unijne, to kwestia jego dochodzenia, w tym regulacje krajowe dotyczące warunków uzyskania pomocy prawnej, mieszczą się w zakresie prawa unijnego. Muszą więc odpowiadać unijnym standardom ochrony praw podstawowych. Bardzo wyraźnie widać więc $w$ tej sprawie powiązanie zastosowania unijnych praw podstawowych wobec regulacji wprowadzonych przez państwa członkowskie $\mathrm{z}$ ich wpływem na efektywność prawa unijnego ${ }^{193}$. Jak pokazała ta sprawa, regulacje krajowe nie mogą blokować skutecznego egzekwowania uprawnień wynikających z dyrektywy. Zagrażałoby to zasadzie effet utile ${ }^{194}$.

Z drugiej strony w sprawie Winkow ${ }^{195}$ TSUE podkreślił, że związek umożliwiający zastosowanie Karty nie może mieć charakteru czysto teoretycznego. Pan Anton Winkow twierdził, że związek ten polegać miałby na tym, że odebranie mu w Bułgarii prawa jazdy za punkty karne uniemożliwi mu prowadzenie pojazdów również w innych państwach członkowskich UE, co miałoby być wystarczającą podstawą do zastosowania Karty, a konkretnie jej art. 47 i 48 i wynikających z nich gwarancji prawa do skutecznego odwołania, którego prawo bułgarskie w tej kategorii spraw miało nie zapewniać. TSUE uznał jednak pytanie prejudycjalne, z którym wystąpił w tej kwestii sąd bułgarski, za niedopuszczalne ze względu na brak związku z prawem UE.

Na gruncie spraw dotyczących tematyki obywatelstwa unijnego należy w tym miejscu wspomnieć raz jeszcze o sprawie Dereci ${ }^{196}$. Trybunał przypomniał w niej w ogólnym tonie, że:

postanowienia karty, zgodnie z jej art. 51 ust. 1, skierowane są do państw członkowskich wyłącznie w zakresie, w jakim stosują one prawo Unii. Na podstawie art. 51 ust. 2 karta nie rozszerza zakresu zastosowania prawa Unii poza kompetencje Unii ani nie ustanawia nowych kompetencji, ani zadań Unii, ani też nie zmienia kompetencji i zadań określonych w traktatach. Trybunał dokonuje zatem, w świetle karty, wykładni prawa Unii w granicach przyznanych jej kompetencji ${ }^{197}$.

Rozważanie to niewiele jednak wniosło do wyjaśnienia interesującej nas kwestii jako poczynione niejako przy okazji i nieznajdujące rozwinięcia

\footnotetext{
${ }^{193}$ M. Safjan, Areas of..., s. 8-9.

${ }^{194} \mathrm{~K}$. Lenaerts, The Court of Justice of the European Union and the Protection of Fundamental Rights, "Polish Yearbook of International Law” 2011, nr XXXI, s. 86; A. Ward, Art. 51..., s. 1445.

195 TSUE, Anton Winkow p. Naczałnik Administratiwno-nakazatełna dejnost, C-27/11, wyrok z 7 czerwca 2012.

196 TSUE, Murat Dereci i inni p. Bundesministerium für Inneres, C-256/11, wyrok z 15 listopada 2011.

${ }^{197}$ Ibidem, pkt 71.
} 
w przedmiotowej sprawie. TSUE de facto pozostawił bowiem kwestię rozstrzygnięcia problemu zastosowania unijnych praw podstawowych sądowi krajowemu. Sprawa ta dotyczyła krajowych regulacji państwa członkowskiego Unii, umożliwiających odmowę przyznania obywatelowi państwa trzeciego pobytu na terytorium tego państwa członkowskiego, w sytuacji, gdy chciał on przebywać wraz z członkiem swojej rodziny, który obywatelstwo tego państwa ma. Zdaniem Trybunału jednak sam fakt posiadania przez członka rodziny obywatela państwa trzeciego obywatelstwa państwa członkowskiego Unii, a tym samym obywatelstwa unijnego, to jednak za mało do zastosowania unijnych praw podstawowych ( $w$ tym wypadku art. 7 KPP dotyczącego ochrony życia prywatnego i rodzinnego), jeśli z faktem posiadania tego obywatelstwa nie wiązały się żadne inne uprawnienia wynikające z prawa unijnego.

Trybunał stwierdził, że:

prawo Unii, a w szczególności jego przepisy dotyczące obywatelstwa Unii, należy interpretować w ten sposób, że nie sprzeciwia się odmowie przez państwo członkowskie obywatelowi państwa trzeciego pobytu na swoim terytorium, podczas gdy ten obywatel zamierza przebywać z członkiem swojej rodziny, który jest obywatelem Unii mieszkającym w tym państwie członkowskim, którego obywatelstwo posiada i który nigdy nie skorzystał ze swojego prawa do swobodnego przemieszczania się, o ile taka odmowa nie pociaga za sobą dla tego obywatela Unii pozbawienia skutecznego korzystania $\mathrm{z}$ istoty praw przyznanych $\mathrm{w}$ związku ze statusem obywatela Unii, czego zbadanie należy do sądu krajowego ${ }^{198}$.

Dlatego też, jeśli chodzi o zastosowanie unijnych praw podstawowych w takich sytuacjach:

jeżeli sąd krajowy uzna w świetle okoliczności sporów w postępowaniu przed sądem krajowym, że przedstawiona mu sytuacja skarżących w postępowaniu przed sądem krajowym podlega zakresowi prawa Unii, to będzie musiał zbadać, czy odmowa prawa pobytu tym skarżącym w postępowaniu przed sądem krajowym narusza prawo do ochrony życia prywatnego i rodzinnego, o którym mowa w art. 7 karty. Jeżeli natomiast uzna, że ta sytuacja nie podlega zakresowi zastosowania prawa Unii, to będzie wówczas musiał dokonać analizy w świetle art. 8 ust. 1 EKPC ${ }^{199}$.

Jak widać więc Trybunał trzymał się w tej sprawie ogólnej zasady dotyczącej kwestii obywatelstwa unijnego i konsekwencji, jakie ono ze sobą niesie dla stosowania unijnych praw podstawowych wobec państw członkowskich. Potwierdził tym samym swe wcześniejsze orzecznictwo, że obywatelstwo unijne

\footnotetext{
${ }^{198}$ Ibidem, pkt 74 .

${ }^{199}$ Ibidem, pkt 72.
} 
nie może być traktowane samo w sobie jako uzasadniające zastosowanie prawa unijnego, a więc i KPP. Musi istnieć i mieć w danej sprawie zastosowanie jakieś unijne prawo wynikające z obywatelstwa, aby uznać, że sprawa mieści się w zakresie zastosowania prawa UE i Karty.

Należy zwrócić uwagę, że w sprawie tej Trybunał użył nieco mylącego sformułowania: „podlega zakresowi prawa Unii” ${ }^{200}$. Takie sformułowanie, o czym będzie jeszcze mowa, wydaje się nieuzasadnione i mylące. Słusznie Trybunał porzucił je w innych orzeczeniach i zastąpił pozornie tylko podobnym sformułowaniem, że dana regulacja mieści się „w zakresie prawa Unii” (jak np. w omawianej w następnym podrozdziale sprawie Åkerberg Fransson). Jak wyraźnie pokazuje bowiem omawiane tu orzecznictwo, sam fakt objęcia danej kwestii prawem unijnym ani nawet sam fakt istnienia $\mathrm{w}$ danej materii prawa unijnego, które wszakże nie znajduje związku ze stanem faktycznym, nie jest wystarczającym łącznikiem dla zastosowania unijnych praw podstawowych. Normy prawa unijnego muszą w danej sprawie znajdować zastosowanie in concreto (choćby przez znaczenie dla ich efektywności), nie wystarczy zaś, jeśli maja jedynie potencjalną wagę in abstracto ${ }^{201}$.

\subsection{Pierwsza systemowa interpretacja art. 51 ust. 1 Karty. Sprawa Åkerberg Fransson}

Pierwszą systemową interpretację art. 51 ust. 1 KPP odnośnie do zakresu zastosowania Karty do państw członkowskich Trybunał sformułował 26 lutego 2013 r. w wyroku w sprawie Åkerberg Fransson ${ }^{202}$. Sprawa ta została zainicjowana wnioskiem w trybie pytania prejudycjalnego, skierowanym do TSUE przez sąd szwedzki (Haparanda tingsrätt) w związku z toczącą się przed nim sprawą przedsiębiorcy rybnego Hansa Åkerberga Franssona, który prowadził działalność w Szwecji, ale swój towar sprzedawał zarówno w Szwecji, jak i Finlandii. Dopuścił się on oszustw podatkowych w postaci niedopełnienia obowiązków informacyjnych w dziedzinie podatków w latach 2004 i 2005, co skutkowało narażeniem skarbu państwa na uszczuplenie wpływów z tytułu podatku dochodowego i podatku VAT. Hans Åkerberg Fransson był również ścigany z powodu niezłożenia deklaracji dotyczących składek pracodawcy za październik 2004 i październik 2005 r., w związku z czym zakład ubezpieczeń społecznych nie otrzymał należnych składek ${ }^{203}$.

\footnotetext{
${ }^{200}$ Ibidem, pkt 72.

${ }^{201}$ Por.: A. Rosas, The Applicability..., s. 108.

202 TSUE, Åklagaren p. Hans Åkerberg Fransson, C-617/10, wyrok z 26 lutego 2013.

${ }^{203}$ Ibidem, pkt 12.
} 
W związku z tym nałożono na niego na podstawie prawa szwedzkiego sankcje zarówno o charakterze karnym, jak i administracyjnym. W maju $2007 \mathrm{r}$. szwedzkie organy podatkowe zadecydowały o nałożeniu sankcji podatkowych za lata 2004 i $2005 \mathrm{w}$ postaci dodatkowych zobowiązań podatkowych z tytułu dochodów z działalności gospodarczej z tytułu podatku VAT oraz z tytułu składek pracodawcy. W 2009 r. wszczęto przed sądem rejonowym (tingsrätt) w miejscowości Haparanda postępowanie karne przeciwko niemu, gdyż czyny przez niego popełnione, a za które nałożone zostały na niego wspomniane wcześniej sankcje podatkowe, wypełniały także znamiona przestępstw skarbowych, za które prawo szwedzkie przewidywało karę pozbawienia wolności do lat sześciu. Zgodnie z aktem oskarżenia, przestępstwa te zostały uznane za szczególnie niebezpieczne, po pierwsze ze względu na znaczną wysokość należnych kwot, a po drugie dlatego, że stanowily przestępstwo o znacznych rozmiarach i o charakterze ciągłym ${ }^{204}$.

Należy w tym miejscu podkreślić, że sankcje przewidziane przez prawo szwedzkie za naruszenie przepisów podatkowych były przewidziane bez względu na to, czy źródłem owych przepisów podatkowych byłoby prawo unijne, czy prawo szwedzkie. Prawo UE jedynie częściowo reguluje kwestie podatkowe, "podatki obrotowe (VAT i akcyza) są zharmonizowane na poziomie unijnym, podczas gdy podatki dochodowe objęte są jedynie punktową harmonizacją. Dodatkowo, prawo unijne nie nakazuje wprost państwom członkowskim wprowadzenia sankcji karnych czy administracyjnych za naruszenie reguł podatkowych ustanowionych w przepisach Unii"205. Dlatego też szwedzkie przepisy wprowadzające sankcje za nieprzestrzeganie przepisów podatkowych w znacznie większym stopniu odnosiły się do regulacji krajowych i sankcji za ich niewykonywanie, gdyż to właśnie krajowe regulacje podatkowe, dla przestrzegania których ustanawiano sankcje, były znacznie rozleglejsze. W zakresie, w jakim sankcje dotyczyły zaś nieprzestrzegania unijnych regulacji podatkowych nie miały charakteru realizacji zobowiązań unijnych, gdyż prawo Unii nie formułowało obowiązku po stronie państw członkowskich do ustanawiania sankcji za naruszanie unijnych regulacji podatkowych.

Pytanie skierowane przez szwedzki sąd do TSUE było zbliżone co do meritum do pytania skierowanego do TSUE przez polski Sąd Najwyższy w sprawie Bonda ${ }^{206}$. Nieco inny był jednak kontekst obu spraw. Zaistnienie stanu faktycznego w sprawie Bonda miało miejsce przed wejściem w życie Karty, a także zakres pytania, z jakim zwrócił się w sprawie SN, był znacznie węższy - nie-

\footnotetext{
${ }^{204}$ Ibidem, pkt 12-13.

${ }^{205}$ N. Półtorak, Zakres zwiazania..., s. 21.

206 TSUE, Postępowanie karne przeciwko Łukasz Marcin Bonda, C-489/10, wyrok z 5 czerwca 2012.
} 
uwzględniający w ogóle Karty i unijnych gwarancji praw podstawowych - niż zakres pytań sformułowanych przez Haparanda tingsrätt. Będzie o tym mowa w następnym rozdziale.

W swej istocie sprawa zainicjowana skierowanym do TSUE pytaniem prejudycjalnym przez Haparanda tingsrätt dotyczyła dwóch kwestii. Primo, chodziło o dokonanie przez TSUE wykładni zasady ne bis in idem w prawie UE, a więc o precyzyjne wyjaśnienie jednego z fundamentalnych praw człowieka, jakim jest prawo do nie bycia karanym więcej niż raz za to samo przewinienie, zagwarantowanego w art. 50 Karty. Oczywiście prawo to, ze względu na swój niekwestionowany w europejskiej tradycji prawnej status znajduje swój wyraz także $\mathrm{w}$ wielu innych dokumentach, w tym w art. 4 Protokołu dodatkowego nr 7 do EKPC $z^{207}$, którego również dotyczyły pytania sądu. Jest ono zagwarantowane także w Konstytucji RP, nawet jeśli nie jest w niej wyrażone expressis verbis, to jednak w dość oczywisty sposób wynika z jej art. 2 i zawartej w nim zasady demokratycznego państwa prawnego ${ }^{208}$. Prawo to zagwarantowane jest także w systemach innych państw członkowskich, w tym w systemie szwedzkim, choć w sposób powiązany z EKPCz, poprzez wymóg istnienia ugruntowanej linii orzeczniczej ETPCz, koniecznej dla uznania naruszenia tego prawa, co wzbudziło wątpliwości sądu w kontekście zasady effet utile ${ }^{209}$. Secundo, w spra-

${ }^{207}$ Protokół nr 7 do Konwencji o Ochronie Praw Człowieka i Podstawowych Wolności, przyjęty w Strasburgu dnia 22 listopada 1984, Dz.U. z 2003 nr 42 poz. 364.

${ }^{208}$ Zgodnie z ugruntowanym orzecznictwem TK zasada ne bis in idem należy do fundamentalnych zasad prawa karnego i w związku z tym jest konieczną cechą państwa prawnego. Odstępstwo od tej zasady, a w szczególności stworzenie organowi władzy publicznej kompetencji do dwukrotnego zastosowania środka represyjnego wobec tego samego podmiotu za ten sam czyn, byłyby niezgodne z Konstytucją (TK, sprawa K 18/o3, wyrok z 3 listopada 2004). TK wielokrotnie potwierdził w swoim orzecznictwie, że zasada ne bis in idem jako podstawowa zasada prawa karnego wynika z art. 2 Konstytucji RP i stanowi jeden z elementów demokratycznego państwa prawnego (patrz np.: TK, sprawa K 36/oo, wyrok z 8 października 2002). Więcej na temat zasady ne bis in idem patrz np.: A. Sakowicz, Zasada ne bis in idem w prawie karnym w ujęciu paneuropejskim, Białystok 2011.

${ }^{209}$ Pytania skierowane do TSUE przez Haparanda tingsrätt brzmiały następująco:

„1. Zgodnie z prawem szwedzkim sąd tego państwa może nie zastosować przepisu prawa krajowego, co do którego podejrzewa, że narusza on zasadę ne bis in idem, o której mowa w art. 4 Protokołu nr 7 do [EKPC], a w związku z tym również art. 50 [Karty], tylko pod warunkiem istnienia po temu wyraźnej podstawy w EKPC lub orzecznictwie Europejskiego Trybunału Praw Człowieka. Czy tego rodzaju warunek obowiązujący w prawie krajowym dla niestosowania przepisów tego prawa jest zgodny z prawem Unii Europejskiej, a w szczególności jego zasadami ogólnymi, w tym zasadą pierwszeństwa i zasadą bezpośredniej skuteczności?

2. Czy dopuszczalność oskarżenia o przestępstwo skarbowe, w sytuacji gdy na podatnika nałożono już uprzednio, w postępowaniu administracyjnym, określone sankcje finansowe (dodatkowe zobowiązanie podatkowe) za ten sam czyn, polegający na podaniu informacji niezgodnych z prawda, podlega zasadzie ne bis in idem, o której mowa w art. 4 Protokołu nr 7 do EKPC i w art. 50 Karty? 
wie Åkerberg Fransson chodziło o rozumienie art. 51 ust. 1, a przede wszystkim o określenie wynikającego z niego zakresu zastosowania Karty wobec państw członkowskich, choć takiego pytania sąd odsyłający wprost nie postawił. Rozstrzygnięcie tego problemu było jednak konieczne, pod kątem dopuszczalności pytania prejudycjalnego, adresowanego do TSUE. Ze względu na temat tej pracy szczególnie istotny będzie problem drugi i to jemu właśnie poświęcona będzie uwaga.

Fakt, że kwestia ta nie była oczywista i niekontrowersyjna odzwierciedla to, że państwa członkowskie UE, które zdecydowały się przystąpić do sprawy i przedstawić swoje uwagi na piśmie bądź też ustnie podczas rozprawy (wśród których nie było Polski) z wyjątkiem Austrii ${ }^{210}$, jak i Komisja Europejska - opowiedziały się za brakiem właściwości trybunału luksemburskiego.

Należy podkreślić, że w sprawie tej nie mieliśmy do czynienia ani z sytuacją implementacji prawa unijnego, ani też z sytuacją derogacyjna, które stanowią dwa najbardziej podstawowe w świetle ugruntowanego orzecznictwa TSUE i najmniej kontrowersyjne w obliczu sformułowania art. 51 ust. 1 Karty

3. Czy na odpowiedź na pytanie drugie ma wpływ okoliczność, że sankcje te muszą zostać dostosowane $\mathrm{w}$ taki sposób, iż sądy mają prawo obniżyć karę nałożoną w postępowaniu karnym z tego względu, że na podatnika nałożono już dodatkowe zobowiązanie podatkowe za ten sam czyn, polegający na podaniu informacji niezgodnych z prawdą?

4. W pewnych okolicznościach zasada ne bis in idem [...] dopuszcza nałożenie dodatkowych sankcji w nowym postępowaniu dotyczącym tego samego czynu, który był już przedmiotem postępowania i doprowadził do nałożenia sankcji na jednostkę. Czy w przypadku twierdzącej odpowiedzi na pytanie drugie warunki dopuszczające nałożenie wielu sankcji w oddzielnych postępowaniach zgodnie z zasadą ne bis in idem są spełnione, jeżeli w nowym postępowaniu rozpatrywane są ponownie i w sposób niezależny od okoliczności sprawy?

5. Szwedzki system polegający na nakładaniu dodatkowych zobowiązań podatkowych i rozpatrywaniu odpowiedzialności karnoskarbowej w odrębnych postępowania uzasadniony jest licznymi względami interesu ogólnego [...]. Czy w razie twierdzącej odpowiedzi na pytanie drugie system tego rodzaju jak system szwedzki jest zgodny z zasadą ne bis in idem, jeżeli możliwe jest ustanowienie systemu niepodlegającego zasadzie ne bis in idem bez konieczności rezygnacji z nakładania dodatkowego zobowiązania podatkowego albo z rozstrzygania o odpowiedzialności karnoskarbowej, poprzez, jeżeli odpowiedzialność karnoskarbowa wchodzi w grę, przeniesienie orzekania o dodatkowym zobowiązaniu podatkowym ze Skatteverket i ewentualnie sądów administracyjnych i powierzenie tego zadania sądom powszechnym przy okazji rozpatrywania oskarżenia o przestępstwa skarbowe?" (TSUE, Åklagaren p. Hans Åkerberg Fransson, C-617/10, wyrok z 26 lutego 2013, pkt 15).

${ }^{210}$ Swoje uwagi na piśmie przedstawiły Królestwo Szwecji, Królestwo Niderlandów, Królestwo Danii, Republika Czeska, Republika Austrii oraz Irlandia, zaś na rozprawie, która miała miejsce w dniu 24 stycznia 2012 r., stawili się celem ustnego przedstawienia swoich stanowisk przedstawiciele Republiki Czeskiej, Królestwa Danii, Republiki Federalnej Niemiec, Irlandii, Republiki Greckiej, Republiki Francuskiej, Królestwa Niderlandów (TSUE, Åklagaren p. Hans Åkerberg Fransson, TSUE, C-617/10, opinia Rzecznika Generalnego Pedra Cruza Villalóna przedstawiona w dniu 12 czerwca 2012, pkt 20 i 21). 
rodzaje sytuacji stosowania prawa unijnego przez państwa członkowskie. Jak zostało to opisane, $\mathrm{w}$ dotychczasowym orzecznictwie Trybunału można było jednak wyodrębnić jeszcze trzecią grupę orzeczeń dotyczących możliwości zastosowania unijnych praw podstawowych do państw członkowskich, które w inny sposób mieściły się w zakresie zastosowania prawa Unii. Około dwa lata od nadania Karcie mocy prawnej ${ }^{211}$ i narosłych przez ten czas wątpliwości wokół kwestii jej stosowania do państw członkowskich, sprawa Åkerberg Fransson dawała doskonałą sposobność do wypracowania przez TSUE nieco bardziej systemowego podejścia do wykładni jej art. 51 ust. 1 oraz odniesienia się do dziedzictwa orzeczniczego Trybunału w tej materii. Najistotniejszym było w obliczu tej sprawy pytanie, czy w związku z brzmieniem art. 51 ust. 1 KPP Trybunał będzie skłonny do trzymania się najbardziej podstawowych typów sytuacji, które wcześniej klasyfikował jako mieszczące się w zakresie zastosowania prawa Unii. Czy też będzie - opierając się na istnieniu innego rodzaju związków z prawem unijnym, sprawiających, że dana regulacja krajowa będzie uznawana za spełniającą kryteria art. 51 ust. 1 Karty - szeroko podchodził do zakresu związania państw członkowskich unijnymi prawami podstawowymi.

\subsubsection{Stanowisko Rzecznika Generalnego Pedra Cruz Villalóna}

Rzecznik Generalny Pedro Cruz Villalón, który przygotował opinię w tej sprawie, opowiedział się za węższą wykładnią art. 51 ust. 1 Karty i węższym zakresem zastosowania unijnych praw podstawowych do państw członkowskich niż mogłoby to wynikać z uprzedniego orzecznictwa TSUE. Rzecznik zwrócił uwagę, że pojawiające się w przepisach i orzecznictwie sformułowania, takie jak „zakres”, "zakres zastosowania”, „stosowanie” prawa Unii łączy wynikające z nich wszystkich określone wymaganie wobec prawa Unii:

Abstrakcyjny opis rozpatrywanego przez nas fenomenu może prowadzić do wniosku, że wspólną cechą tych różnorodnych stanowisk jest konieczność obecności prawa Unii u źródła wykonywania władzy publicznej. Należy dodać, że chodzi tu o obecność jako prawa, to jest prawa mogącego określić lub wpłynąć w mniejszym lub większym stopniu na treść tych przejawów władzy publicznej w państwach członkowskich. Jednakże "obecność" nie staje się jednak nigdy „ustaleniem z góry”, gdyż ta ostatnia sytuacja nie powinna budzić wątpliwości ${ }^{212}$.

${ }^{211}$ Należy wszakże pamiętać, że o ile wyrok w sprawie został wydany 26 lutego 2013, o tyle wniosek o wydanie orzeczenia w trybie prejudycjalnym został złożony 27 grudnia 2010.

${ }^{212}$ TSUE, Åklagaren p. Åkerberg Hans Fransson, TSUE, C-617/10, opinia Rzecznika Generalnego Pedra Cruza Villalóna przedstawiona w dniu 12 czerwca 2012, pkt 33. 
Zwrócił on więc uwagę, że prawo Unii powinno, niekoniecznie bezpośrednio, ale leżeć u źródła regulacji krajowej, aby można mówić, że ta ostatnia jest przejawem stosowania prawa unijnego. Ponadto stwierdził, że w jego ocenie:

właściwość Unii do przyjęcia roli gwaranta praw podstawowych w odniesieniu do przejawów wykonywania władzy przez państwa członkowskie, w sytuacji, gdy stosują one prawo Unii, musi znaleźć wytłumaczenie w kontekście szczególnego interesu Unii, by takie wykonywanie uprawnień władczych było dostosowane do takiego rozumienia praw podstawowych, jakie przyjmuje Unia. Okoliczność, że takie wykonywanie uprawnień władczych ma swoje ostateczne źródło w prawie Unii, nie jest sama w sobie wystarczająca, by przyjąć, że zachodzi przypadek "stosowania"213.

Jak skonkludował swoje rozważania Rzecznik, interpretacja art. 51 ust. 1 KPP nie powinna mieć charakteru ogólnego i statycznego, lecz wymaga ona wykładni, dokonywanej przez TSUE a casu ad casum i przejawiającej się w określaniu przezeń przypadków, w których to właśnie organ Unii, jakim jest TSUE, a nie instytucje państw członkowskich, miałby przyjmować rolę gwaranta praw podstawowych wobec prawa państw członkowskich, niemającego na celu bezpośredniego wykonania, a więc transpozycji czy implementacji prawa UE, a jedynie znajdującego się $\mathrm{w}$ zakresie zastosowania prawa $\mathrm{UE}^{214}$. W pewnym sensie postulował on uelastycznienie podejścia do kwestii stosowania Karty wobec państw członkowskich i zakorzeniania go w realiach każdej sprawy, a nie konstruowania w orzecznictwie ogólnych typologizacji zakresów zastosowania Karty. Stanął on na stanowisku, że w przypadku transpozycji prawa unijnego, a więc wąsko rozumianej implementacji, gdzie, jak była mowa, państwa działają w zasadzie jak organy Unii, nie ma wątpliwości, kto jest odpowiedzialny za przestrzeganie praw podstawowych i czyje regulacje powinny w związku z tym znajdować zastosowanie. $W$ innych przypadkach sprawa nie jest już jednak tak oczywista. To właśnie wokół pytania o ciężar odpowiedzialności za prawa podstawowe i ich przestrzeganie zbudował on swoją koncepcję wykładni art. 51 ust. 1 Karty.

Kluczową kwestią było według niego pytanie o to, kto - czy Unia, czy państwo członkowskie - $\mathrm{w}$ danej sprawie powinno być uznane za odpowiedzialne za zapewnienie przestrzegania praw podstawowych, i to właśnie ten test miał służyć odpowiedzi na pytanie, jakie - krajowe czy unijne - gwarancje praw podstawowych powinny znajdować zastosowanie. Zdaniem Rzecznika sytuacja w sprawie Åkerberg Fransson nie uzasadniała przeniesienia takiej odpowiedzialności z państwa członkowskiego, które jest pierwotnym jej nosicielem, na

${ }^{213}$ Ibidem, pkt 40.

${ }^{214}$ Por.: ibidem, przed. pkt 45. 
Unię, a tym samym stwierdzenia właściwości TSUE. Sam fakt, że podatek VAT jest regulowany przez prawo unijne i dochody z niego wpływają do unijnego budżetu, to jeszcze za mało, by uznać, że polityka karna i regulacje w tej materii przyjmowane przez państwa członkowskie miałyby być zakwalifikowane jako stosowanie prawa Unii. Jak twierdzi Rzecznik Generalny:

Problem z ustaleniem zakresu zasady ne bis in idem w prawie szwedzkim, o ile w ogóle występuje, stanowi ogólny problem architektury szwedzkich regulacji w zakresie nakładania sankcji. Jako taki występuje on zatem całkowicie niezależnie od poboru podatku VAT, a co za tym idzie, niniejszy przypadek nałożenia sankcji za przedkładanie fałszywych informacji wydaje się jedynie prostą occasio ${ }^{215}$. Skoro tak jest, to pojawia się pytanie, czy ta occasio powinna skutkować tym, że w ostateczności to sąd unijny rozstrzygnie, z wszystkimi tego nieuniknionymi konsekwencjami w zakresie ogólnego charakteru takiego wyroku, jaki jest zasięg zasady ne bis in idem w prawie szwedzkim, z pierwszeństwem przed rozstrzygnięciem wynikającym z jego struktur konstytucyjnych i zobowiązań międzynarodowych ${ }^{216}$.

Zdaniem Rzecznika przyjęcie, że taka, jak to ujął, occasio wystarczy do uznania właściwości sądu unijnego, byłoby w związku z testem ciężaru odpowiedzialności nieuprawnione. Doszedł on do wniosku, że w takiej sytuacji, z jaką mamy do czynienia w przedmiotowej sprawie, przeniesienie odpowiedzialności za przestrzeganie praw podstawowych z państwa członkowskiego na Unię poprzez stwierdzenie kognicji TSUE wynikającej z uznania, że ustalając sankcje za nieprzestrzeganie przepisów podatkowych, Szwecja stosuje prawo UE i podlega przez to Karcie zgodnie z jej art. 51 ust. 1, byłoby nieproporcjonalne i jest w związku z tym niedopuszczalne ${ }^{217}$.

\subsubsection{Stanowisko TSUE}

TSUE zajął jednak w swym wyroku odmienne stanowisko i orzekł o swej właściwości do wydania w tej sprawie orzeczenia. Stwierdził, że przedmiotowa kwestia znajdowała się w zakresie zastosowania Karty w rozumieniu jej art. 51 ust. 1. Trybunał postanowił bezpośrednio wpisać się w prezentowaną przez siebie wcześniej linię orzecznicza, i kwestię zastosowania Karty oraz zawartych w niej unijnych praw podstawowych potraktować szeroko. Potwierdził znaną sprzed uzyskania przez Kartę mocy prawnej zasadę, że unijne prawa podstawowe znajdują zastosowanie do państw członkowskich, gdy działają

\footnotetext{
${ }^{215}$ Ibidem, pkt 61.

${ }^{216}$ Ibidem, pkt 62.

${ }^{217}$ Por.: ibidem, pkt 63 i 64 .
} 
one w zakresie zastosowania prawa unijnego i stosowanie prawa unijnego, o którym mowa w art. 51 ust. 1 Karty, tak właśnie należy rozumieć.

W wyroku w sprawie Åkerberg Fransson TSUE przypomniał wyrażane przez siebie wcześniej wielokrotnie stanowisko i podkreślił:

Z utrwalonego orzecznictwa Trybunału wynika bowiem co do zasady, że prawa podstawowe chronione w porządku prawnym Unii znajdują zastosowanie we wszystkich sytuacjach podlegających prawu Unii, ale nie poza takimi sytuacjami. Z tego względu Trybunał przypomniał już, że nie jest władny oceniać zgodności z Kartą przepisów krajowych, które nie mieszczą się w zakresie zastosowania prawa Unii. Natomiast jeżeli przepisy takie wchodzą w zakres zastosowania tego prawa, Trybunał, rozpatrując pytanie prejudycjalne, powinien udzielić wszelkich wyjaśnień interpretacyjnych koniecznych do oceny przez sąd krajowy zgodności tych przepisów z prawami podstawowymi, których ochronę zapewnia [... $]^{218}$.

Trybunał, podkreślając ciągłość podejścia prezentowanego w przyjętej przezeń linii orzeczniczej, przypomniał także przytoczone wcześniej Wyjaśnienia dotyczące Karty w zakresie, jakim dotyczą one art. 51 ust. 1 Karty ${ }^{219}$, i stwierdził, że:

Poszanowanie praw podstawowych chronionych na mocy karty jest [...] konieczne w sytuacji, gdy przepisy krajowe mieszczą się w zakresie zastosowania prawa Unii. Nie mogą więc występować sytuacje podlegające prawu Unii, w których wspomniane prawa podstawowe nie miałyby zastosowania. Stosowanie prawa Unii oznacza więc jednoczesne zastosowanie praw podstawowych chronionych na mocy karty ${ }^{220}$.

W dalszej części wyroku Trybunał skonstatował, że: „W niniejszej sprawie należy na wstępie zauważyć, że dodatkowe zobowiązania podatkowe nałożone na H. Åkerberga Franssona i wszczęte przeciwko niemu postępowanie karne są po części związane z niedopełnieniem przez niego obowiązku przekazania prawidłowych informacji dotyczących podatku VAT"221. Po stwierdzeniu tego faktu Trybunał podkreślił, że:

Jak zaś wynika z art. 2, art. 250 ust. 1 i art. 273 dyrektywy Rady 2006/112/WE z dnia 28 listopada 2006 r. w sprawie wspólnego systemu podatku od wartości dodanej (...), które przejmują sformułowanie między innymi art. 2 i art. 22 ust. 4 i 8 szóstej dyrektywy, w brzmieniu wynikającym z jej art. 28h, a także z art. 4 ust. 3 TUE, w dziedzi-

${ }^{218}$ TSUE, Åklagaren p. Åkerberg Hans Fransson, TSUE, C-617/10, wyrok z 26 lutego 2013, pkt 19 .

${ }^{219}$ Ibidem, pkt 20.
${ }^{220}$ Ibidem, pkt 21.
${ }^{221}$ Ibidem, pkt 24. 
nie podatku VAT każde państwo członkowskie jest zobowiązane podjąć wszelkie działania ustawodawcze i administracyjne niezbędne do zapewnienia na jego terytorium poboru w pełnej wysokości należnego podatku VAT i zwalczania przestępczości podatkowej $[\ldots]^{222}$.

Prawo unijne zobowiązuje więc państwa do zapewniania skuteczności poborowi podatku VAT, nie określa jednak, jakie środki miałoby państwo w tym celu zastosować.

Ponadto, jak przypomniał Trybunał, art. 325 TFUE zobowiązuje państwa członkowskie do zwalczania nielegalnych działań naruszających interesy finansowe Unii poprzez stosowanie środków odstraszających podobnych do tych, które państwa stosują przy zwalczaniu działań naruszających ich interesy.

Zasobami własnymi Unii są zaś [...] dochody wynikające z zastosowania jednolitej stawki do zharmonizowanej podstawy opodatkowania podatkiem VAT określonej zgodnie z normami Unii. Istnieje zatem bezpośredni związek między poborem zgodnie z obowiązującym prawem Unii należności z tytułu podatku VAT a wpłatą do budżetu Unii odpowiednich środków pochodzących z tego podatku, ponieważ wszelkie braki w poborze owych należności mogą powodować uszczuplenie wskazanych środków budżetowych $[\ldots]^{223}$.

O ile więc regulacje szwedzkie wprowadzające sankcje za niedopełnienie obowiązków związanych z odprowadzaniem podatku VAT nie wynikały z prawa Unii, o tyle służyły interesowi Unii, a także związane były z ogólnym zobowiązaniem państw członkowskich do zwalczania nielegalnych działań naruszajacych interesy finansowe Unii.

W związku z tym Trybunał doszedł do wniosku, że:

dodatkowe zobowiązania podatkowe i postępowanie karnoskarbowe, a więc tego rodzaju środki, jak stosowane wobec oskarżonego w sprawie głównej z powodu nieprawdziwych informacji podanych przez niego w odniesieniu do podatku VAT, stanowią wykonanie (...) [wspomnianych zobowiązań wynikających z prawa UE], a zatem akt stosowania prawa Unii w rozumieniu art. 51 ust. 1 karty ${ }^{224}$.

Trybunał skonkludował w odniesieniu do stanu faktycznego i prawnego w tej sprawie, że:

Okoliczność, że przepisy krajowe służące za podstawę tych zobowiązań podatkowych i postępowania karnego nie zostały wydane w celu transpozycji dyrektywy [...],

\footnotetext{
222 Ibidem, pkt 25 .

${ }^{223}$ Ibidem, pkt 26.

${ }^{224}$ Ibidem, pkt 27.
} 
nie podważa powyższego wniosku, ponieważ ich zastosowanie stanowi sankcję za naruszenie przepisów owej dyrektywy, ma więc na celu wypełnienie nałożonego na państwa członkowskie w traktatach obowiązku skutecznego sankcjonowania działań mogących naruszać interesy finansowe Uniii ${ }^{225}$.

Wydaje się, że w obliczu przedstawionej przez trybunał luksemburski argumentacji oraz na podstawie zaprezentowanego wcześniej orzecznictwa, dotyczącego stosowania unijnych praw podstawowych do państw członkowskich, stwierdzenie możliwości zastosowania Karty w tej sprawie, a tym samym właściwości Trybunału, nie powinno zostać uznane za zaskakujące. Wpisuje się ono w linię orzeczniczą budowaną przez Trybunał jeszcze przed wejściem w życie Karty, a więc, że państwa członkowskie są związane unijnymi prawami podstawowymi wtedy, gdy „działają w zakresie zastosowania prawa unijnego" $^{\prime 226}$, a więc gdy stosują je w szerokim tego słowa znaczeniu, nie tylko poprzez bezpośrednie wykonywanie zobowiązań wynikających z prawa unijnego, ale poprzez działania, które związane są z prawem unijnym i poprzez wpływ na jego efektywność.

W obliczu tych ustaleń co do zakresu związania państw członkowskich unijnymi prawami podstawowymi pamiętać należy jednak o wspomnianej dwuwątkowości pytań skierowanych do TSUE przez sąd szwedzki. Ustaliwszy swoją właściwość do orzekania w tej sprawie w związku z objęciem sprawy zakresem art. 51 ust. 1 KPP, w sentencji wyroku w sprawie Åkerberg Fransson TSUE orzekł także co do meritum, a więc co do wykładni zasady ne bis in idem w prawie Unii, czyli ustanowił standard ochrony wynikającego z tej zasady prawa, jaki gwarantuje Karta.

Zasada ne bis in idem ujęta w art. 50 Karty praw podstawowych Unii Europejskiej nie stoi na przeszkodzie stosowaniu przez państwo członkowskie kolejno sankcji podatkowej i sankcji karnej za ten sam czyn polegający na niedopełnieniu obowiązku przekazania prawidłowych informacji dotyczących podatku od wartości dodanej, pod warunkiem, że pierwsza z tych sankcji nie ma charakteru karnego, co ustalić winien sąd krajowy 227 .

W tym wymiarze tej sprawy TSUE wpisał się więc w klasyczny podział ról między sądem Unii a sądem krajowym, gdzie ten pierwszy dokonał wykładni unijnej gwarancji praw człowieka, odnoszącej się jednocześnie zgodnie z wynikającymi z Karty zobowiązaniami do standardu strasburskiego, ten drugi zaś

${ }^{225}$ Ibidem, pkt 28.

${ }^{226}$ Por.: N. Półtorak, Zakres zwiazania..., s. 21.

227 TSUE, Åklagaren p. Hans Åkerberg Fransson, TSUE, C-617/10, wyrok z 26 lutego 2013, pkt 50 . 
ma ją stosować w swych rozstrzygnięciach, o ile sprawa mieści się w zakresie prawa UE, do stwierdzenia czego kryteria wypracował i uszczegóławia stopniowo TSUE.

Za pomocą wyroku w tej sprawie odnośnie do kwestii stosowania unijnych praw podstawowych do państw członkowskich, TSUE dość jednoznacznie wybrał drogę kontynuacji swego wcześniejszego podejścia. Wyrok w tej sprawie rozwiał więc istotne wątpliwości co do ewentualnej modyfikacji podejścia Trybunału, którego podstawą miałoby stać się wejście w życie Karty. Jak ujęli to obrazowo Bas van Bockel i Peter Wattel, orzeczenie w sprawie Åkerberg Fransson było jak napełnienie starych bukłaków nowym winem ${ }^{228}$. W pewnym sensie jednak Karta, przynajmniej w kwestii stosowania unijnych praw podstawowych do państw członkowskich, stała się nowym bukłakiem, a więc ubraniem w nową treść normatywna, dla starego wina, jakim była dawno zarysowana przez Trybunał linia orzecznicza odnośnie do stosowania unijnych praw podstawowych względem państw członkowskich.

W kontekście tym pamiętać należy, że przełom, jakim było ostateczne nadanie Karcie bezdyskusyjnej mocy prawnej, a więc rok 2009, wcale nie pokrywał się z przyjęciem Karty, które przecież nastąpiło znacznie wcześniej229. Rozwijając swe orzecznictwo przynajmniej od 2000 r., kiedy to Karta została przyjęta, Trybunał zdawał sobie więc sprawę, że kiedyś może uzyskać ona status prawny w znanym brzmieniu. Dlatego też pewnie, chociaż nie przyznawał tego wprost, był przygotowany na takie kształtowanie orzecznictwa w przedmiocie zastosowania unijnych praw podstawowych do państw członkowskich, które będzie mogło być później kontynuowane już pod rządami Karty. Co więcej, w kontekście materialnego znaczenia Karty, część doktryny twierdzi nawet, że Karta nie wnosi żadnego novum normatywnego, a jedynie krystalizuje i umacnia istniejące wcześniej prawa, nie dodając niczego nowego ${ }^{230}$. Podobnie

${ }^{228}$ B. van Bockel, P. Wattel, New Wine....

${ }^{229}$ Kartę uchwalono i podpisano 7 grudnia 2000 podczas szczytu Rady Europejskiej w Nicei w imieniu trzech organów UE: Parlamentu, Rady UE oraz Komisji, powtórnie, z pewnymi poprawkami, została podpisana przez przewodniczących tych samych organów Unii podczas szczytu w Lizbonie 12 grudnia 2007. Moc wiążąca dokumentu została mu nadana przez TL podpisany 13 grudnia 2007, który wszedł w życie 1 grudnia 2009.

${ }^{230}$ Por. np.: X. Groussot, L. Pech, Fundamental Rights Protection in the European Union post Lisbon Treaty, Robert Schuman Fondation Policy Paper, "European Issue” nr 173 z 14 czerwca 2010, [online] <http://www.robert-schuman.eu/en/doc/questions-d-europe/qe-173-en.pdf> [dostęp: 28.12.2018]. Wielu badaczy uważa, że Karta rozszerzyła jednak katalog praw podstawowych chronionych przez prawo Unii. Jak twierdzą Tomasz Tadeusz Koncewicz i Anna Podolska: „Lektura Karty pozwala postawić tezę, że Karta jest dokumentem kompromisowym. Dominuje w nim element delimitacji i gwarancji obecnego status quo, a nie niekontrolowanej ekspansji i narzucania. Karta ma węższy zakres regulacji ratione materiae w porównaniu 
miałaby nie wnosić niczego nowego do zakresu jej zastosowania względem państw członkowskich. Wydaje się jednak, że trudno Kartę traktować jako superfluum prawodawcze, niczego niezmieniające w zakresie unijnej ochrony praw podstawowych. Nawet więc jeśli nie pójdziemy w ocenie Karty aż tak daleko, jak chcieliby tego niektórzy, jako dokumentu jedynie wyrażającego unijną ochronę praw człowieka, w zakresie, w jakim i tak ona obowiązywała już przed nadaniem jej mocy prawnej, to $\mathrm{w}$ zakresie, w jakim została wypowiedziana, a więc odnośnie do art. 51 ust. 1 KPP, konstatacja taka nie powinna zaskakiwać, co potwierdzi orzecznictwo TSUE, które będzie przedmiotem analizy w tym rozdziale. Przynajmniej w zakresie podejścia do kwestii stosowania Karty do państw członkowskich jej obowiązywanie nie doprowadziło do żadnej rewolucji. Tym niemniej, jak okaże się w dalszej części tego rozdziału, w orzecznictwie już po wydaniu wyroku w sprawie Åkerberg Fransson, Trybunał będzie wprowadzał lekkie modyfikacje do swego wcześniejszego orzecznictwa, cechujące się pewną powściągliwością.

\subsubsection{Niektóre inne konsekwencje wyroku w sprawie Åkerberg Fransson i podejścia TSUE do kwestii związania państw członkowskich unijnymi prawami podstawowymi}

6.3.3.1. Objęcie krajowej regulacji unijnymi prawami podstawowymi a pierwszeństwo, jedność i efektywność prawa Unii

Konsekwentnie, bazując na dokonanej przez siebie wykładni art. 51 ust. 1 Karty i zakresu zastosowania unijnych praw podstawowych do państw członkowskich, w sprawie Åkerberg Fransson TUSE wyraził ponadto jeszcze jedno istotne stanowisko, które w szerszym zakresie będzie przedmiotem rozważań w rozdziale IV przy okazji omawiania sprawy Melloni, rozstrzygniętej tego samego dnia co sprawa Åkerberg Fransson. Trybunał podkreślił, że:

gdy sąd państwa członkowskiego przystępuje do kontroli zgodności z prawami podstawowymi przepisu prawa krajowego lub działania organów krajowych stanowiącego akt stosowania prawa Unii w rozumieniu art. 51 ust. 1 karty - a dotyczy to sytuacji, w której działanie państw członkowskich nie jest w pełni określone przepisami prawa Unii - organy i sądy krajowe są uprawnione do stosowania krajowych standardów ochrony praw podstawowych, o ile zastosowanie owych standardów nie podważa

\footnotetext{
z EKPC i Konstytucją RP. Z drugiej jednak strony Karta wykracza poza katalog praw fundamentalnych uznanych przez Trybunał Sprawiedliwości, ale nie wychodzi poza potencjalny zasięg acquis communautaire w kontekście praw fundamentalnych" (T.T. Koncewicz, A. Podolska, Karta Praw..., s. 248).
} 
poziomu ochrony wynikającego z karty stosownie do wykładni Trybunału ani pierwszeństwa, jednolitości i skuteczności prawa Unii [... $]^{231}$.

Stwierdzenie to otwiera cała gamę problemów, do których trybunał luksemburski bardziej szczegółowo odniósł się w przywoływanej sprawie Melloni.

Już teraz należy jednak podkreślić, co wynika z przytoczonego powyżej fragmentu, że gwarancje praw i wolności zawarte w Karcie stanowią minimalny standard ochrony, które regulacje krajowe muszą spełniać, kiedy mieszczą się one w zakresie jej zastosowania w związku z art. 51 ust. 1 Karty. Jeśli więc państwa mają swobodę we wprowadzaniu regulacji krajowych, mieszczących się w zakresie zastosowania prawa unijnego, muszą dbać, aby spełniały one unijne standardy praw podstawowych. Jest to oczywista konsekwencja, jaka wynika z Karty jako unijnego dokumentu gwarantującego prawa i wolności jednostki. Jak mogłoby się jednak na pierwszy rzut oka wydawać, państwa mają również wolną rękę do ustanawiania takich regulacji, które będą spełniały także dalej idące standardy ochrony jakiegoś prawa czy wolności niż wynikałoby to z Karty. Podejście takie znane jest różnym międzynarodowym reżimom ochrony praw człowieka. Klauzule gwarantujace to, że dana umowa międzynarodowa zawierająca gwarancje praw człowieka nie może negatywnie wpływać na standardy chronione przez dane państwo czy to na podstawie jego wewnętrznych regulacji, czy to na podstawie innych umów międzynarodowych, występują np. w art. 53 Europejskiej Konwencji Praw Człowieka² ${ }^{232}$ art. 5 ust. 2 Międzynarodowego Paktu Praw Obywatelskich (Osobistych) i Politycznych ${ }^{233}$, art. 5 ust. 2 Międzynarodowego Paktu Praw Gospodarczych, Socjalnych i Kulturalnych ${ }^{234}$

${ }^{231}$ TSUE, Åklagaren p. Hans Åkerberg Fransson, TSUE, C-617/10, wyrok z 26 lutego 2013, pkt 29.

${ }^{232}$ Więcej na temat tego przepisu patrz np.: L. Garlicki, Art. 53. [Ochrona uznanych praw człowieka], [w:] L. Garlicki (red.), Konwencja o Ochronie Praw Człowieka i Podstawowych Wolności. Komentarz do artykułów 19-59 oraz protokołów dodatkowych, Warszawa 2011.

${ }^{233}$ Międzynarodowy Pakt Praw Obywatelskich (Osobistych) i Politycznych z 16 grudnia 1966, Dz.U. z 1977 nr 38, poz. 167; więcej na temat tego przepisu patrz przed.: R. Wieruszewski, Artykut 5. Podstawowe zasady interpretacji postanowień Paktu, [w:] R. Wieruszewski (red.), Międzynarodowy Pakt Praw Obywatelskich (Osobistych) i Politycznych. Komentarz, Warszawa 2012; por. także: S. Joseph, M. Castan, The International Covenant on Civil and Political Rights: Cases, Materials, and Commentary, Oxford 2013; M. Nowak, U.N. Covenant on Civil and Political Rights: CCPR Commentary, Kehl 2005.

${ }^{234}$ Międzynarodowy Pakt Praw Gospodarczych, Społecznych i Kulturalnych otwarty do podpisu w Nowym Jorku 19 grudnia 1966, Dz.U. z 1977 nr 38, poz. 169; por. także komentarz do art. 5 Paktu w: B. Saul, D. Kinley, J. Mowbray, The International Covenant on Economic, Social and Cultural Rights. Commentary, Cases Materials, Oxford 2014 oraz W. Jóźwicki, Art. 5. Zakaz nadużywania postanowień Paktu oraz ochrona uznanych praw i wolności człowieka, [w:] Z. Kędzia, A. Hernandez-Połczyńska (red.), Międzynarodowy Pakt Praw Gospodarczych, Socjalnych i Kulturalnych. Komentarz, Warszawa 2018. 
czy art. 29 ust. b Amerykańskiej Konwencji Praw Człowieka ${ }^{235}$. Analogiczny przepis znajduje się również w Karcie. Jej art. 53 stanowi, że:

Żadne z postanowień niniejszej Karty nie będzie interpretowane jako ograniczające lub naruszające prawa człowieka i podstawowe wolności uznane, we właściwych im obszarach zastosowania, przez prawo Unii i prawo międzynarodowe oraz konwencje międzynarodowe, których Unia lub wszystkie Państwa Członkowskie są stronami, w szczególności przez europejską Konwencję o ochronie praw człowieka i podstawowych wolności oraz przez konstytucje Państw Członkowskich.

Karta jest jednak specyficznym aktem prawnym. Nie jest umową międzynarodowa, nie została podpisana jako dodatkowy traktat, choć ma na mocy traktatów moc prawną im równą. Jest wewnętrznym dokumentem specyficznej - wyposażonej w kompetencję do wydawania prawa wiążącego wszystkie państwa wchodzące w jej skład, które to prawo cieszy się przymiotem pierwszeństwa, służącym zachowaniu jego jedności i efektywności - organizacji, jaką jest Unia. Stąd jej art. 51 ust. 1 w unikalny sposób regulujący jej stosowalnośćc ${ }^{236}$. Ze względu na to art. 53 Karty nie może być odczytywany wprost, analogicznie do podobnych tego typu regulacji zawieranych we wspomnianych międzynarodowych instrumentach gwarantujących prawa człowieka. Karta i zawarte w niej gwarancje skierowane są przede wszystkim do samej Unii. Służy jako zbiór gwarancji praw i wolności, które wiążą Unię w jej działaniach, przede wszystkim w jej aktywności prawotwórczej. Karta stosuje się do państw członkowskich jedynie w ograniczonym zakresie - kiedy te działają w obrębie prawa unijnego. W tym ograniczonym zakresie stosuje się do nich jednak w specyficzny sposób. Ustanawia minimalny i nieograniczalny standard ochrony praw jednostki. Jednakże nie może to prowadzić do wniosku, że wszelkie inne działania państw powyżej tego standardu są dopuszczalne. Oczywiście poza zakresem prawa unijnego są dopuszczalne - w tym wymiarze Karta państw członkowskich Unii w ogóle nie wiąże. W zakresie prawa unijnego jednak państwa mogą swobodnie działać jedynie, kiedy respektują minimalny poziom ochrony praw i wolności przewidziany w Karcie, a także kiedy szanują inne podstawowe zasady prawa unijnego, jakimi są jego pierwszeństwo, jedność i efektywność.

O ile więc w sytuacji takiej, jaka miała miejsce w sprawie Åkerberg Fransson, państwa członkowskie są swobodne w ustanawianiu regulacji krajowych mieszczących się w zakresie prawa unijnego zgodnie z ewentualnymi wyższymi niż unijne standardami praw człowieka, o tyle Trybunał przypomniał, że co do zasady mogą to czynić jedynie, jeśli nie stoi to w sprzeczności z zasadami

${ }^{235}$ Amerykańska Konwencja Praw Człowieka przyjęta w San José w dniu 22 listopada 1969.

${ }^{236}$ Por.: A. Ward, Art. 51..., s. 1422-1423. 
pierwszeństwa, jedności i efektywności prawa unijnego. $W$ tej sprawie rozważanie to miało teoretyczny charakter. Jego zawarcie w tym wyroku oraz powtórzenie i zastosowanie w sprawie Melloni sprawiło jednak, że znaczenie art. 51 ust. 1 Karty i opartego na nim określania czy państwa członkowskie stosują prawo Unii w jego rozumieniu stały się jeszcze istotniejsze. Wiadomo bowiem, że jeśli zarzut naruszenia praw człowieka będzie odnosił się do kwestii mieszczącej się w zakresie prawa unijnego i w pełni rządzonej unijnymi gwarancjami praw podstawowych, jakakolwiek regulacja krajowa, nawet korzystniejsza dla jednostki, a więc ustanawiająca wyższy standard ochrony danego prawa, nie będzie mogła być zastosowana ${ }^{237}$. Zatem w scenariuszu takim, jak w sprawie Åkerberg Fransson, unijne prawa podstawowe znajdowały zastosowanie i stanowiły standard minimalny dla państw członkowskich, gdyż ze względu na stopień harmonizacji prawa w tej dziedzinie, państwa były swobodne do stosowania swoich standardów ochrony, odpowiadających temu minimum, w tym standardów dowolnie wyższych, gdyż nie zagrażało to pierwszeństwu, jedności i efektywności prawa unijnego. Tymczasem w scenariuszu takim, jak w sprawie Melloni, w którym harmonizacja prawa unijnego wymagała poszanowania pierwszeństwa, jedności i efektywności prawa unijnego, unijny standard ochrony praw podstawowych urastał dla państw do poziomu standardu maksymalnego ${ }^{238}$. Można więc powiedzieć, że w zakresie zastosowania Karty mamy czasem do czynienia $z$ bezwzględnym zastosowaniem unijnych praw podstawowych jako minimalnego i maksymalnego standardu ochrony, albo zastosowaniem ich jedynie jako standardu minimalnego, dopuszczającego stosowanie standardów krajowych, w tym wyższych niż unijne standardów krajowych, którą to sytuację można nazwać sytuacją stosowania "mieszanych" (mixed) standardów ochrony ${ }^{239}$.

6.3.3.2. Autonomiczność relacji między krajowymi porządkami prawnymi a systemem EKPCz

Należy także zauważyć, że w wyroku w sprawie Åkerberg Fransson TSUE stwierdził również, że:

Prawo Unii nie reguluje stosunków między europejską Konwencją o ochronie praw człowieka i podstawowych wolności a porządkami prawnymi państw członkowskich,

${ }^{237}$ Ibidem, s. 1419.

${ }^{238}$ Por. np.: P. Gragl, The Reasonableness of Jealousy: Opinion 2/13 and EU Accession to the ECHR, „European Yearbook on Human Rights”, Wiedeń 2015; A. Ward, Art. 51..., s. 1418-1419.

${ }^{239}$ Por.: A. Ward, Art. 51..., s. 1432. 
ani nie określa skutków, jakie sąd krajowy powinien łączyć ze sprzecznością między normą prawa krajowego a prawami chronionymi na mocy tej konwencji ${ }^{240}$.

Trybunał podkreślił więc, że prawo Unii w żaden sposób nie wpływa na relacje między Konwencją a państwami członkowskimi, ani na konsekwencje, jakie miałyby w porządkach tych państw wynikać z niewypełniania przez prawo tych państw czy też przez praktykę stosowania przez nie swojego prawa gwarancji wynikających z Konwencji. Tematyka relacji między EKPCz a krajowymi systemami prawnymi, w tym kwestia relacji między TK a ETPC z, nie mieści się w zakresie tej pracy. W miejscu tym należy jedynie podkreślić, że Unia nie powinna wpływać na relacje między państwami a Konwencją, a fakt pokrywania się niektórych praw zagwarantowanych w Karcie i Konwencji wcale nie sprawia, że TSUE poprzez swoje generalne kompetencje staje się sądem nad prawem państw członkowskich przez pryzmat standardów konwencyjnych. Standardy konwencyjne są minimalnymi standardami unijnymi tam, gdzie prawa zagwarantowane w Karcie pokrywają się z prawami zagwarantowanymi w Konwencji. Wynika to jasno zarówno z art. 6 ust. 1 TUE, Preambuły, jak i art. 52 ust. 3 oraz art. 53 Karty, a potwierdzone zostało także w Deklaracji nr 1 dołączonej do Traktatu lizbońskiego ${ }^{241}$. Nie powinno to jednak prowadzić do rozszerzenia kompetencji TSUE do zastępowania ETPC z w zakresie interpretowania praw zagwarantowanych w Konwencji.

\subsubsection{Obowiązek zastosowania i ewentualnego wyjaśnienia znajdującego zastosowanie w sprawie krajowej unijnego standardu ochrony praw podstawowych}

Ponadto w wyroku w sprawie Åkerberg Fransson TSUE orzekł, że:

Prawo Unii stoi na przeszkodzie krajowej praktyce sądowej, która uzależnia obowiązek niezastosowania przez sąd krajowy przepisu sprzecznego z prawem podstawowym chronionym na mocy Karty praw podstawowych Unii Europejskiej od spełnienia warunku, by sprzeczność ta wynikała w sposób oczywisty z karty lub z dotyczącego jej orzecznictwa, ponieważ praktyka ta uniemożliwia sądowi krajowemu dokonanie, z ewentualnym udziałem Trybunału Sprawiedliwo-

${ }^{240}$ TSUE, Åklagaren p. Hans Åkerberg Fransson, TSUE, C-617/10, wyrok z 26 lutego 2013, pkt 48 i 50.

${ }^{241}$ Deklaracja w sprawie Karty praw podstawowych Unii Europejskiej dołączona do Traktatu z Lizbony zmieniającego Traktat o Unii Europejskiej i Traktat ustanawiający Wspólnotę Europejską podpisany w Lizbonie dnia 13 grudnia 2007, C 306 z 17 grudnia 2007. 
ści Unii Europejskiej, kompletnej oceny zgodności owego przepisu krajowego z kartą ${ }^{242}$.

Jeśli więc dana sprawa mieści się w zakresie prawa UE, tak jak zakres ten rozumie TSUE, sąd krajowy powinien co do zasady zastosować unijny standard praw człowieka, taki, jaki wynika z Karty, której interpretatorem jest TSUE, a jeśli ma on wątpliwości co do rozumienia danego prawa podstawowego, to powinien je wyjaśnić w ramach istniejących w Unii procedur, a więc przez zadanie pytania prejudycjalnego. Wątpliwości co do treści konkretnego, zagwarantowanego w Karcie prawa czy wolności nie zwalniają sądu państwa członkowskiego z jego stosowania, lecz zobowiązują go do wyjaśnienia ewentualnych wątpliwości, i gdy to nastąpi, zastosowania unijnych praw podstawowych. To samo dotyczy zresztą watpliwości co do obowiązku zastosowania unijnych praw podstawowych, co wiąże się z interpretacją art. 51 ust. 1 Karty. Również takie wątpliwości sąd krajowy, jeśli je ma, zobowiązany jest wyjaśnić przed TSUE. Sytuacja ta w pewnym sensie pozwala sądom krajowym na uzyskanie swoiście konstytucyjnej roli. „Wiąże się to [...] z bezspornym faktem częściowego decentralizowania kontroli hierarchicznej zgodności norm w państwach członkowskich, czego następstwem jest wzmocnienie roli sądów powszechnych, administracyjnych oraz sądów najwyższych"243. Sądy uzyskują kompetencję do dokonywania oceny prawa krajowego przez pryzmat zgodności z prawami człowieka zagwarantowanymi w Karcie, podczas gdy co do zasady takiej kompetencji one nie mają, odnośnie do praw zagwarantowanych w Konstytucji ${ }^{244}$. Będzie jeszcze o tym mowa w następnych rozdziałach.

${ }^{242}$ TSUE, Åklagaren p. Hans Åkerberg Fransson, TSUE, C-617/10, wyrok z 26 lutego 2013, pkt 50 .

${ }^{243}$ A. Kustra, Kelsenowski model kontroli konstytucyjności prawa a integracja europejska. Studium wptywu, Toruń 2015, s. 34; por. także: M. Bobek, The Impact of the European Mandate of Ordinary Courts on the Position of Constitutional Courts, [w:] M. de Visser, C. van de Heyning (red.), Constitutional Conversations in Europe, Cambridge 2012, s. 287 i nast.

${ }^{244}$ Należy zauważyć, że ostatnio zaczęły się znowu pojawiać w doktrynie głosy dotyczące dopuszczalności dokonywania przez sądy, a szczególnie przez Sąd Najwyższy, tzw. rozproszonej kontroli konstytucyjności prawa, opartej na bezpośredniem stosowaniu Konstytucji (patrz np.: L. Garlicki, Sądy a Konstytucja Rzeczypospolitej Polskiej, „Przegląd Sądowy” 2016, nr 7-8; M. Gutowski, P. Kardas, Sądowa kontrola konstytucyjności prawa. Kilka uwag o kompetencjach sądów powszechnych do bezpośredniego stosowania konstytucji, „Palestra” 2016, nr 4; W. Sanetra, Bezpośrednie stosowanie Konstytucji RP przez Sąd Najwyższy , "Przegląd Sądowy” 2017, nr 2). Aktualnie jest za wcześnie jednak, aby mówić o odejściu od dominującego dotychczas poglądu co do skoncentrowanego charakteru kontroli konstytucyjności w Polsce. Pogląd ten jest silnie ugruntowany nie tylko w doktrynie (patrz np.: A. Kustra, Kelsenowski..., s. 18 i nast.), ale także w orzecznictwie zarówno sądów, w tym Sądu Najwyższego, jak i Trybunału Konstytucyjnego. Jak w 2015 r. podsumował Sąd Najwyższy: „Zgodnie z utrwaloną linią orzecznictwa zarówno Trybunału Konstytucyjnego, jak i Sądu Najwyższego, sądy i inne organy stosowania prawa nie mają kompetencji 
Należy podkreślić, że obowiązek wyjaśniania wątpliwości (co do zastosowania unijnych praw podstawowych oraz co do ich treści) dotyczy wszystkich organów władzy sądowniczej państw członkowskich, a więc nie tylko sądów powszechnych - również Trybunału Konstytucyjnego ${ }^{245}$. Pozostaje to w zgodzie $z$ tezą stawianą $w$ tej pracy zmierzającą do zaproponowania dialogicznej drogi rozwiązywania potencjalnego konfliktu między TK a TSUE w związku z wyższym niż unijny konstytucyjnym standardem ochrony praw człowieka a zasadą pierwszeństwa, jedności i efektywności prawa unijnego. Wynikająca stąd obowiązkowość pewnej sekwencji orzekania, umożliwiającej prawidłowe stosowanie prawa unijnego, która wpisana jest w unijny porządek sądowy i zawarta jest przede wszystkim w procedurze pytania prejudycjalnego, jest kluczową cechą sędziowskiego dialogu w ramach unijnego porządku prawnego, na której chciałbym oprzeć swą główną argumentację w dalszej części pracy. Zostanie ona zaprezentowana przede wszystkim w rozdziale IV.

do orzekania o niekonstytucyjności przepisu ustawy i odmowy jego stosowania. Domniemanie zgodności ustawy z Konstytucją może być obalone jedynie wyrokiem Trybunału Konstytucyjnego, a związanie sędziego ustawa, o którym mowa w art. 178 ust. 1 Konstytucji, obowiązuje dopóty, dopóki ustawie tej przysługuje moc obowiązująca. Jeżeli sąd jest przekonany o niezgodności przepisu z Konstytucją lub ma w tym względzie wątpliwości, powinien - na podstawie art. 193 Konstytucji - zwrócić się do Trybunału Konstytucyjnego z odpowiednim pytaniem prawnym. Brak w Konstytucji przepisu przyznającego sądom i innym organom powołanym do stosowania prawa kompetencji do kontroli, na użytek rozpoznawanej sprawy, konstytucyjności aktów ustawowych nie pozwala - ze względu na wyrażoną w art. 7 Konstytucji zasadę działania organów władzy publicznej na podstawie i w granicach prawa - domniemywać tej kompetencji (zob. wyroki Trybunału Konstytucyjnego z dnia 31 stycznia 2001 r., P 4/99, OTK 2001, nr 1, poz. 5 i z dnia 4 grudnia 2001 r., SK 18/oo, OTK 2001, nr 8, poz. 256, wyroki Sądu Najwyższego z dnia 30 października 2002 r., V CKN 1456/oo, nie publ., z dnia 27 marca 2003 r., V CKN 1811/oo, nie publ., z dnia 6 listopada 2003 r., II CK 184/o2, nie publ., z dnia 16 kwietnia 2004 r., I CK 291/o3, OSNC 2005, nr 4,9 poz. 71, z dnia 24 czerwca 2004 r., III CK 536/02, nie publ., i z dnia 3 grudnia 2008 r., V CSK 310/o8, nie publ.)" (SN, Izba Cywilna, II CSK 517/14, wyrok z 24 listopada 2015). Należy przy tym zauważyć, że również sam TK jeszcze w marcu 2016 r. stwierdził, że „jest jedynym organem państwa, który może ostatecznie i z mocą powszechnie obowiązującą oceniać hierarchiczną zgodność prawa [...]. W obecnym stanie prawnym żaden inny organ państwa, w tym Sąd Najwyższy lub Naczelny Sąd Administracyjny, nie jest władny Trybunału z tego obowiązku zwolnić bądź przejąć jego funkcji do własnego zakresu działania" (TK, sprawa K 47/15, wyrok z 9 marca 2016, pkt III 1.4 uzasadnienia). Jak podsumowywał Leszek Garlicki: „Sędzia nie może odmawiać stosowania ustaw w oparciu o zarzut ich niekonstytucyjności, może jedynie uruchamiać stosowną procedurę przed Trybunałem Konstytucyjnym, kierując do niego pytanie prawne" (L. Garlicki, Polskie prawo konstytucyjne. Zarys wykładu, Warszawa 2014, s. 335).

${ }^{245}$ Co TK przyznał w odniesieniu do luksemburskiej doktryny Foto-Frost, chociażby w sprawie Sk 45/o9 (pkt III 8.1 uzasadnienia). Więcej na temat praktyki sądów konstytucyjnych państw członkowskich w tej materii patrz np.: A. Kustra, Sady konstytucyjne a procedura prejudycjalna przed Trybunałem Sprawiedliwości Unii Europejskiej, "Przegląd Sejmowy” 2012, nr 4; idem, The First Preliminary Questions to the Court of Justice of the European Union Referred by Italian Corte Costituzionale, Spanish Tribunal Constitucional, and French Conseil Constitutionnel, "Comparative Law Review" 2013, nr 16. 


\subsection{Ugruntowywanie podejścia do rozumienia art. 51 ust. 1 Karty}

Wyrok w sprawie Åkerberg Fransson pokazał, że TSUE konsekwentnie trzyma się zasady daleko idącego związania państw członkowskich unijnymi prawami podstawowymi w sytuacjach, gdy stosują one prawo unijne, co rozumie jako działanie państw w zakresie zastosowania prawa unijnego. To ostatnie ma miejsce nie tylko w sytuacjach, gdy dokonują one transpozycji prawa Unii, czy też, gdy korzystają z sytuacji derogacyjnych, lecz również w sytuacjach, kiedy działania państw członkowskich, w tym ich działania prawotwórcze niewynikające z prawa unijnego, mają wpływ na efektywność regulacji unijnych. Tym samym Trybunał podtrzymał swoje wcześniejsze orzecznictwo co do trzech kategorii sytuacji, w których unijne prawa podstawowe stosują się do państw członkowskich, o których była mowa wcześniej. Wyraźnie wskazał ponadto, że kryterium decydującym o działaniu w zakresie prawa unijnego przez państwo, co szczególnie istotne dla trzeciej kategorii spraw, jest związek z efektywnością prawa unijnego.

Podstawowym [...] kryterium, którym kieruje się luksemburski Trybunał, przesądzając o możliwości wzięcia pod uwagę Karty, jest konieczność zapewnienia skuteczności przepisów prawa UE w porządkach krajowych państw członkowskich. Jeśli zatem w szczególności związek (łącznik) między przepisami prawa UE a przepisami prawa krajowego nie wydaje się oczywisty (jest trudny do ustalenia), kryterium potrzeby zapewnienia efektywności będzie dla TS przesądzające w decyzji o możliwości zastosowania Karty. Trybunał zachowuje się więc nadal jako sąd integracyjny, dla którego integracja europejska, polegająca na zachowaniu spójności i efektywności jest wartością nadrzędną ${ }^{246}$.

\subsubsection{Przykłady ugruntowywania podejścia do rozumienia art. 51 ust. 1 Karty w sprawach typu Wachauf}

W obliczu tego, co powiedziano powyżej, nie powinno zaskakiwać, że TSUE stwierdził także, że wszelkiego rodzaju regulacje wprowadzane przez państwa członkowskie podlegają unijnym prawom podstawowym w sytuacjach, kiedy dystrybuują one unijne środki. Sprawa Liivimaa Lihaveis ${ }^{247}$ dotyczyła niemożności odwołania się od decyzji komitetu, utworzonego przez państwo członkowskie, nadzorującego wdrożenie unijnego programu operacyjnego (Seirekomitee), która to możliwość nie była przewidziana przez przewodnik programowy, określający kompetencje komitetu. W sprawie tej Trybunał podkre-

${ }^{246}$ M. Wróblewski, Karta Praw Podstawowych Unii Europejskiej w polskim..., s. 20-21.

${ }^{247}$ TSUE, Liivimaa Lihaveis MTÜ p. Eesti-Läti programmi 2007-2013 Seirekomitee, C-562/12, wyrok z 17 września 2014. 
ślił, że: „Zgodnie z utrwalonym orzecznictwem Trybunału pojęcie »stosowania prawa Unii w rozumieniu wspomnianego postanowienia karty wymaga istnienia powiązania określonego stopnia, wykraczającego poza bliskość danych dziedzin lub pośredni wpływ jednej dziedziny na drugą $[\ldots]^{\prime 248}$. Skoro więc prawo unijne nałożyło na dwa państwa członkowskie, jakimi w tym wypadku były Łotwa i Estonia, obowiązek wdrożenia programu operacyjnego, to wszelkie regulacje dotyczące jego wdrożenia mieszczą się w zakresie prawa unijnego i podlegają unijnym prawom podstawowym. Dotyczy to w takim samym stopniu ustaw, jak i wszelkiego rodzaju innych dokumentów, które nie mają charakteru legislacyjnego ${ }^{249}$. Takim dokumentem w przedmiotowej sprawie był przewodnik programowy. TSUE doszedł więc do wniosku, że "w zakresie, w jakim przewodnik programowy przewiduje, iż decyzja Seirekomitee odrzucająca wniosek o dofinansowanie nie podlega zaskarżeniu, nie przestrzega on zasady skutecznej ochrony sądowej przewidzianej w art. 47 akapit pierwszy karty"250.

Powiązanie zakresu zastosowania Karty z efektywnością prawa unijnego i wprowadzaniem z pomocą krajowych przepisów sankcji mających na celu zapewnienie tej efektywności uwidacznia także sprawa Texdata Software ${ }^{251}$. Sankcja za nieprzestrzeganie dyrektywy unijnej przewidziana była przez przepisy krajowe. Jednakże to przepisy unijne upoważniały państwo członkowskie do wprowadzenia sankcji w prawie krajowym, co znacznie bardziej wiązało dokonujące tego przepisy krajowe z prawem unijnym niż miało to miejsce w sprawie Åkerberg Fransson i wpisywało sytuację w grupę spraw typu Wachauf, choć Trybunał się do niej w orzeczeniu nie odniósł.

W niniejszym przypadku spór rozstrzygany w postępowaniu głównym dotyczy sankcji
nałożonej z uwagi na niezachowanie obowiązku ujawnienia przewidzianego w jede-
nastej dyrektywie [...], prawodawca Unii na mocy art. 12 jedenastej dyrektywy powie-
rzył państwom członkowskim zadanie określenia właściwych sankcji, to znaczy sank-
cji skutecznych, proporcjonalnych i odstraszających w celu zapewnienia wykonania
obowiązku ujawnienia. W prawie austriackim sankcje te zostały przewidziane [... $]^{252}$.

W obliczu znanego orzecznictwa TSUE nie dziwi więc, że w sprawie tej trybunał luksemburski skonkludował, że: „Wynika stąd, że austriackie przepisy będące przedmiotem postępowania głównego stanowią stosowanie prawa Unii w rozumieniu art. 51 ust. 1 karty" 253 .

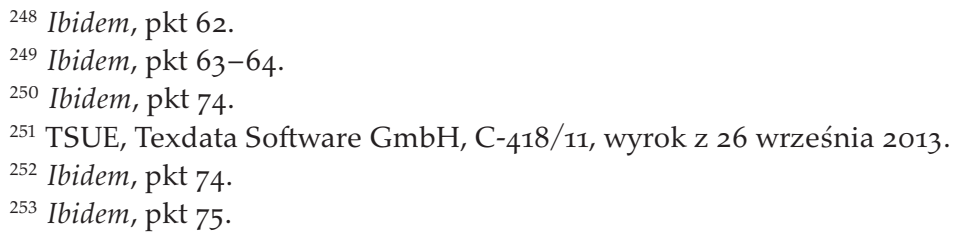




\subsubsection{Przykłady ugruntowywania podejścia do rozumienia art. 51 ust. 1 Karty w sprawach typu ERT}

W sprawie Pfleger ${ }^{254}$ TSUE znalazł podstawy do zastosowania unijnych praw podstawowych, potwierdzając wprost aktualność doktryny ERT. Kwestia ta po wejściu w życie Karty pozostawała w pewnym sensie wątpliwa. Niektórzy twierdzili, że w obliczu brzmienia art. 51 ust. 1 sprawy typu ERT powinny wypaść spod zakresu zastosowania unijnych praw podstawowych ${ }^{255}$. Pewna powściągliwość po wejściu w życie Karty, co do zastosowania unijnych praw podstawowych $\mathrm{w}$ związku z unijnymi swobodami, choć nie odnośnie do sytuacji stricte derogacyjnych, ujawniła się w sprawie Pelckmans, o której będzie jeszcze mowa. W obliczu Wyjaśnień dotyczących Karty, w których sprawa ERT pojawia się expressis verbis, a także omawianego wcześniej orzecznictwa, w tym sprawy Åkerberg Fransson oraz chęci unikania pewnego rozdwojenia czy wręcz schizmy ${ }^{256} \mathrm{w}$ kwestii stosowania unijnych praw podstawowych w sytuacjach derogacyjnych, rozstrzygnięcie w tej materii, jakiego dokonał TSUE w sprawie Pfleger nie powinno zaskakiwać. Sprawa ta dotyczyła restrykcji w dostępie do użytku maszyn do gier losowych. Kwestią sporną było czy przepisy zakazujące obsługiwania automatów do gry przy braku uzyskania uprzedniego zezwolenia organów administracyjnych, wprowadzone w Austrii, miały jedynie wewnętrzny charakter, czy też nie, i czy w związku z tym muszą one spełniać gwarancje praw podstawowych zagwarantowanych w Karcie. Zarówno rządy austriacki, jak i belgijski, niderlandzki oraz polski wyraziły stanowisko, „że karta nie znajduje zastosowania w postępowaniach głównych, gdyż w niezharmonizowanej dziedzinie gier losowych przepisy krajowe dotyczące tej dziedziny nie stanowią stosowania prawa Unii w rozumieniu art. 51 ust. 1 karty"257.

Po przypomnieniu swego wcześniejszego orzecznictwa, ze szczególnym uwzględnieniem sprawy Åkerberg Fransson, oraz tego, „że prawa podstawowe chronione w porządku prawnym Unii znajdują zastosowanie we wszystkich

${ }^{254}$ TSUE, Postępowanie zainicjowane przez Robert Pfleger i inni, C-39o/12, wyrok z 30 kwietnia 2014.

${ }^{255}$ Np.: Lord Goldsmith Q.C., A Charter of Rights, Freedoms and Principles, "Common Market Law Review" 2001, nr 38 (5), s. 1205; F. Jacobs, Human Rights in the European Union: the Role of the Court of Justice, "European Law Review" 2001, nr 26, s. 331; por.: K. Lenaerts, J.A. Gutiérrez-Fons, The Place of the Charter in the EU Constitutional Edifice, [w:] S. Peers, T. Harvey, J. Kenner, A. Ward (red.), The EU Charter of Fundamental Rights. A Commentary, Oxford 2014, s. 1425-1427;

A. Wróbel, Art. 51..., s. 1568-1569.

256 A. Ward, Art. $51 \ldots$, s. 1429.

${ }^{257}$ TSUE, Postępowanie zainicjowane przez Robert Pfleger i inni, C-39o/12, wyrok z 30 kwietnia 2014, pkt 30. 
sytuacjach podlegających prawu Unii, ale nie poza takimi sytuacjami"258, a także, że „Poszanowanie praw podstawowych chronionych na mocy karty jest [...] konieczne, w sytuacji gdy przepisy krajowe mieszczą się w zakresie stosowania prawa Unii. Nie mogą więc występować sytuacje podlegające prawu Unii, w których wspomniane prawa podstawowe nie miałyby zastosowania" ${ }^{259}$, TSUE zwrócił uwagę na fakt, że właścicielem maszyn do gier było czeskie przedsiębiorstwo i wynikający stąd transgraniczny charakter świadczonych przez nie usług. Sprawa dotyczy w związku z tym jednej z podstawowych unijnych swobód, jaką jest swoboda świadczenia usług ${ }^{260}$. Trybunał zaliczył sytuację w tej sprawie do kategorii spraw typu ERT. TSUE przypomniał, że:

jeżeli państwo członkowskie powołuje się na nadrzędne względy interesu ogólnego w celu uzasadnienia przepisów, które mogą ograniczać korzystanie ze swobody świadczenia usług, takie uzasadnienie, przewidziane w prawie Unii, powinno być interpretowane w świetle ogólnych zasad prawa Unii, a w szczególności praw podstawowych zagwarantowanych obecnie w karcie. Odnośne przepisy krajowe mogą zatem być objęte przewidzianymi wyjątkami wyłącznie, jeżeli są zgodne z prawami podstawowymi, nad których przestrzeganiem czuwa Trybunał [... $]^{261}$.

To wszystko doprowadziło Trybunał do wniosku, że sprawa ta mieści się w zakresie prawa unijnego, skoro:

przepisy krajowe mogą ograniczać korzystanie z jednej lub kilku podstawowych swobód gwarantowanych traktatem, mogą one być objęte wyjątkami przewidzianymi w prawie Unii w celu uzasadnienia takiego ograniczenia wyłącznie w zakresie, w jakim jest to zgodne z prawami podstawowymi, nad których przestrzeganiem czuwa Trybunał. Ten obowiązek zapewnienia zgodności z prawami podstawowymi objęty jest w sposób oczywisty zakresem stosowania prawa Unii i w rezultacie zakresem stosowania karty. Korzystanie przez państwo członkowskie z wyjątków przewidzianych w prawie Unii w celu uzasadnienia ograniczenia podstawowej swobody zagwarantowanej traktatem należy zatem uznać [...] za "stosowanie prawa Unii” w rozumieniu art. 51 ust. 1 karty ${ }^{262}$.

Rozważania Trybunału co do meritum na gruncie unijnych gwarancji praw człowieka, a więc co do zgodności zakwestionowanych regulacji z przepisami Karty, a mianowicie z art. 15, 16 i 17 Karty, gwarantującymi wolność wyboru zawodu i prawo do podejmowania pracy, wolność prowadzenia działalności

\footnotetext{
${ }^{258}$ Ibidem, pkt 33.

${ }^{259}$ Ibidem, pkt 34 .

260 Ibidem, pkt 23.

261 Ibidem, pkt 35.

${ }^{262}$ Ibidem, pkt 36.
} 
gospodarczej i prawo własności, były wszakże dość skromne. W pierwszym rzędzie Trybunał ocenił bowiem przepisy austriackie przez pryzmat zgodności z art. 56 TFUE, gwarantującym swobodę świadczenia usług oraz dopuszczalności wyjątków od tej swobody, w ramach których państwa mogą ją ograniczać na zasadzie odstępstw wyraźnie przewidzianych w art. 51 TFUE i 52 TFUE, a więc ze względu na porządek publiczny, bezpieczeństwo publiczne i zdrowie publiczne, mających zastosowanie $w$ dziedzinie swobody świadczenia usług na podstawie art. 62 TFUE lub uzasadnionych zgodnie z orzecznictwem Trybunału nadrzędnymi względami interesu ogólnego ${ }^{263}$. Doszedł przy tym do wniosku, że:

art. 56 TFUE należy interpretować w ten sposób, że sprzeciwia się on obowiązywaniu przepisów krajowych, takich jak będące przedmiotem postępowań głównych, w sytuacji gdy przepisy te nie dążą w rzeczywistości do realizacji celu w postaci ochrony graczy lub zwalczania przestępczości i nie są one rzeczywiście podyktowane troską o ograniczenie okazji do gry lub chęcią zwalczania przestępczości związanej z takimi grami w sposób spójny i systematyczny ${ }^{264}$.

W obliczu skonstatowania niezgodności austriackich przepisów z art. 56 TFUE Trybunał stwierdził, że „W okolicznościach takich, jak będące przedmiotem postępowań głównych nieuzasadnione lub nieproporcjonalne ograniczenia swobody świadczenia usług w świetle art. 56 TFUE nie są również dopuszczalne na mocy wskazanego art. 52 ust. 1 w związku z art. 15-17 karty"265. Unijne prawa podstawowe zostały tu więc użyte w pewnym sensie pomocniczo - jako dodatkowe uzasadnienie niedopuszczalności nieproporcjonalnego ograniczenia swobody świadczenia usług.

Wniosek, do jakiego doszedł w tej sprawie TSUE, ,jest koherentny z dotychczasowym orzecznictwem, zgodnie z którym wszelkie rozwiązania prawa krajowego, które ograniczają korzystanie ze swobód rynkowych, wchodzą w zakres zastosowania prawa unijnego. Jednocześnie skutki zastosowania tego podejścia (spójnego z dotychczasowym, ale obecnie stosowanego wobec KPP) będą poważne"266. Faktycznie bowiem państwa ograniczają swobody rynkowe również ze względu na potrzebę ochrony partykularnie rozumianej ochrony praw człowieka w związku z ochroną tożsamości konstytucyjnej tych państw, na którą składają się gwarancje praw człowieka. Być może potencjalne komplikacje, jakie mogą się z tym wiązać, mogły doprowadzić

\footnotetext{
${ }^{263}$ Ibidem, pkt 38-56.

${ }^{264}$ Ibidem, pkt 56.

${ }^{265}$ Ibidem, pkt 59.

${ }^{266}$ N. Półtorak, Zakres zwiazzania..., s. 23.
} 
TSUE do nieco bardziej powściągliwego podejścia do możliwości stosowania unijnych praw podstawowych do regulacji krajowych mogących naruszać swobody rynkowe ${ }^{267}$.

Zasadnicze pytanie w tego rodzaju sprawach nie powinno się jednak sprowadzać do tego, czy działanie państwa znajduje się w zakresie zastosowania KPP, lecz powinno dotyczyć tego, czy możliwość zastosowania Karty wyklucza stosowanie krajowego standardu ochrony praw podstawowych, a więc jak pogodzić, w praktyce orzeczniczej, stosowanie Karty ze stosowaniem konstytucyjnych praw podstawowych ${ }^{268}$.

To właśnie temu pytaniu nie tylko na gruncie zastosowania Karty wobec państw członkowskich, lecz również odnośnie do prawa unijnego poświęcony będzie rozdział IV, w którym przedstawiona zostanie potencjalna funkcja pojęcia tożsamości konstytucyjnej RP dla możliwości stosowania konstytucyjnego standardu ochrony praw człowieka w przestrzeni zastosowania Karty. Należy także pamiętać, w szerszym wymiarze różnego rodzaju unijnych przepisów, na co na gruncie aktualnego orzecznictwa TSUE zwracał uwagę Maciej Szpunar, że:

$\mathrm{w}$ wielu wypadkach nie jest łatwo przesądzić, czy mamy do czynienia z przepisem umożliwiającym derogację - rozumianą jako odstępstwo od materii objętej prawem UE, czy też z przepisem, który jedynie delimituje kompetencje Unii Europejskiej i państw członkowskich. Ponadto, w praktyce bardzo trudno oddzielić te sytuacje, w których prawo Unii wyłącza pewne zagadnienia z zakresu swego stosowania i pozostawia je przepisom krajowym od tych, w których prawo UE pozwala przepisom krajowym współtworzyć pewne "byty prawne” regulowane na poziomie unijnym $[\ldots]^{269}$.

Sytuacje derogacyjne pozostają więc nadal zagadnieniem, które może budzić wątpliwości w kontekście stosowania Karty wobec państw członkowskich.

\subsubsection{Przykłady ugruntowywania podejścia do rozumienia art. 51 ust. 1 Karty $w$ różnych sprawach}

Nawet po wydaniu tak wielu orzeczeń na gruncie art. 51 ust. 1, cały czas aktualne pozostawały pewne wątpliwości co do tego, jak ścisła musi być więź między prawem unijnym a prawem krajowym, aby można było zastosować Kartę. O ile

\footnotetext{
${ }^{267}$ Ibidem, s. 23-24.

${ }^{268}$ Ibidem, s. 24.

${ }^{269}$ M. Szpunar, Kilka uwag..., s. 7 .
} 
sprawy typu Wachauf czy ERT budziły stosunkowo mało wątpliwości, o tyle po wyroku w sprawie Åkerberg Fransson, w obliczu szerokiego i nie w pełni jednoznacznego zakreślenia granic wystarczającego powiązania sprawy z prawem unijnym poprzez jego efektywność, pewne sytuacje, nawet jeśli nie były one zupełnie nowe na gruncie orzecznictwa Trybunału sprzed wejścia Karty w życie, mogły budzić jakieś wątpliwości. Do ich wyjaśnienia szczególnie istotne okazały się następujące po wyroku w sprawie Åkerberg Fransson orzeczenia o braku zastosowania Karty do państw członkowskich.

Wyrok w sprawie Åkerberg Fransson był więc, jak zostało to powiedziane, pierwszym przejawem systemowego podejścia do kwestii zastosowania Karty wobec państw członkowskich. Nie stał się jednak podstawą do sformułowania uniwersalnego testu czy też uniwersalnej metodologii, którą można by zawsze zastosować z związku z art. 51 ust. 1 Karty. Jak się jednak wydaje, „Problem ten jest na tyle złożony, że TS nie jest w stanie skonstruować uniwersalnego testu poprzez podanie dokładnych i abstrakcyjnych wytycznych, określających sprawę unijną (tj. z elementem unijnym)"270. Konieczne jest tu bardziej zniuansowane podejście, przejawiające się budowaniem linii orzeczniczej w szeregu spraw. Oczekiwanie sformułowania takiego uniwersalnego testu w jednej sprawie i stosowania go we wszystkich następnych byłoby nierealne.

Można więc powiedzieć, że gdy jedna grupa spraw z wyrokiem w sprawie Åkerberg Fransson na czele pokazała w pewnym sensie awers wypracowanej przez TSUE zasady określania kryteriów pozwalających stwierdzić, co mieści się $\mathrm{w}$ zakresie zastosowania prawa unijnego w rozumieniu art. 51 ust. 1 Karty i dlaczego tak jest, tak druga grupa, w tym wiele wyroków następujących po sprawie Åkerberg Fransson, z których część zostanie omówiona poniżej, w istotny sposób ukazała nam jej rewers. Wydaje się, że rację mieli ci, którzy dostrzegali w tym orzeczeniu znaczenie systemowe ${ }^{271}$, choćby przez to, że było ono zawsze punktem odniesienia, również w sprawach z grupy, w której TSUE nie dopatrywał się możliwości zastosowania Karty wobec państw członkowskich ${ }^{272}$.

Tego rodzaju rewers obecny był rzecz jasna również w orzecznictwie TSUE znacznie przed wejściem w życie Karty. To, że unijne prawa podstawowe nie mogą być stosowane wobec działań państw członkowskich, gdy te nie wykonują zobowiązań ciążących na nich ze względu na wiążące je prawo unijne,

${ }^{270}$ R. Grzeszczak, A. Szmigielski, Sądowe stosowanie..., s. 14.

${ }^{271}$ N. Półtorak, Zakres zwiazania..., s. 26.

${ }^{272}$ Tym niemniej zdaniem niektórych wyrok w sprawie Siragusa, o którym będzie mowa poniżej, przesądził, że wyrok w sprawie Hans Åkerberg Fransson należy uznać za wyjątkowy, dotyczący jedynie specyficznej sytuacji unijnego VAT; por. np.: D. Denman, The EU Charter of Fundamental Rights: How Sharp are its Teeth?, "Judicial Review" 2014, nr 3. 
TSUE podkreślał wyraźnie przynajmniej od momentu wydania wyroku w sprawie Annibaldi ${ }^{273}$. Potwierdzał to także w wielu późniejszych orzeczeniach ${ }^{274}$, np. w sprawie Dereci ${ }^{275}$, o której była mowa wcześniej. Wydaje się więc, że sprawa Siragusa i inne, o których będzie mowa poniżej, nie są zaprzeczeniem czy ograniczeniem konsekwencji wynikających z wyroku w sprawie Åkerberg Fransson, lecz stanowią przykłady doprecyzowania zasad w niej sformułowanych.

\subsubsection{Sprawy dotyczące obywatelstwa unijnego}

Kontrowersje dotyczące zakresu zastosowania unijnych praw podstawowych wobec państw członkowskich ujawniały się nadal w różnych sprawach, jak chociażby w sprawie O. ${ }^{276} \mathrm{~W}$ swej opinii do tej sprawy Rzeczniczka Sharpston stwierdziła, że:

jeżeli nie ma możliwości wskazania mającego zastosowanie przepisu prawa Unii, to karta nie zadziała. Ujmując rzecz nieco odmiennie, zachodzi konieczność spojrzenia na sytuację prawną poprzez pryzmat karty wtedy i tylko wtedy, gdy przepis prawa Unii nakłada pozytywne bądź negatywne zobowiązanie na państwo członkowskie (niezależnie od okoliczności czy zobowiązanie to wynika z traktatów, czy też z prawa wtórnego Unii $)^{277}$.

Rozumowanie takie, jakże odmiennie do innych propozycji Rzeczniczki Sharpston, o których była mowa wcześniej, jeśli miałoby zostać przyjęte jako zasada, oznaczałoby tym razem istotne zawężenie podejścia prezentowanego przez TSUE. Byłoby jednak trudne do obrony również na gruncie omawianego już wcześniej orzecznictwa. Trybunał wydał w tej sprawie ${ }^{278}$ ostateczne rozstrzygnięcie bez jakiegokolwiek odniesienia do Karty. Nie było to konieczne, gdyż żadne z pytań prejudycjalnych nie odnosiło się do kwestii praw fun-

273 TSUE, Daniele Annibaldi p. Sindaco del Comune di Guidonia, Presidente Regione Lazio, C-309/96, wyrok z 18 grudnia 1997.

${ }^{274}$ Por. np.: K. Lenaerts, J.A. Gutiérrez-Fons, The Place..., s. 1570 i nast. oraz podane tam orzecznictwo.

275 TSUE, Murat Dereci i inni p. Bundesministerium für Inneres, C-256/11, wyrok z 15 listopada 2011.

276 TSUE, O. p. Minister voor Immigratie, Integratie en Asiel, oraz Minister voor Immigratie, Integratie en Asiel p. B., C-456/12, wyrok z 12 marca 2014.

277 TSUE, O. p. Minister voor Immigratie, Integratie en Asiel i Minister voor Immigratie, Integratie en Asiel p. B., C-456/12 oraz S. p. Minister voor Immigratie, Integratie en Asiel i Minister voor Immigratie, Integratie en Asiel p. G., C-457/12, opinia Rzecznika Generalnego Eleanor Sharpston przedstawiona w dniu 12 grudnia 2013, pkt 61.

278 TSUE, O. p. Minister voor Immigratie, Integratie en Asiel, oraz Minister voor Immigratie, Integratie en Asiel p. B., C-456/12, wyrok z 12 marca 2014. 
damentalnych. Nie oznacza to jednak, że Trybunał w żaden sposób nie ustosunkował się przez to do kwestii rozumienia art. 51 ust. 1 Karty. Formułując odpowiedzi co do zakresu zastosowania dyrektywy, de facto udzielił również odpowiedzi co do potencjalnego zastosowania praw podstawowych, gdyby sąd odsyłający uznał to za zasadne.

Sprawa ta znowu dotyczyła kwestii prawa pobytu obywatela państwa trzeciego, członka rodziny obywatela Unii, w państwie członkowskim, którego przynależność państwową posiada obywatel Unii. Trybunał potwierdził swą wcześniejszą linię, przyjmowaną we wspominanych wcześniej sprawach związanych z obywatelstwem Unii, z których wynikało, że obywatelstwo Unii nie może być samo w sobie traktowane jako wystarczające uzasadnienie do zastosowania prawa unijnego, a więc i KPP. Do tego, aby uznać, że sprawa mieści się w zakresie zastosowania prawa UE i Karty, musi istnieć i znajdować zastosowanie jakieś konkretne unijne prawo wynikające $\mathrm{z}$ unijnego obywatelstwa. Trybunał powtórzył, że:

dyrektywa 2004/38 wprowadza pochodne prawo pobytu na rzecz obywateli państw trzecich będących członkami rodziny obywatela Unii [...] tylko wówczas, gdy ten ostatni skorzystał z prawa do swobodnego przemieszczania się, osiedlając się w państwie członkowskim innym niż państwo członkowskie, którego obywatelstwo posiada $[\ldots]^{279}$.

Ponadto:

Pozostałe przepisy dyrektywy 2004/38, [...] odnoszą się do prawa pobytu obywatela Unii i pochodnego prawa pobytu przysługującego członkom ich rodzin w „innym państwie członkowskim”, czyli w "przyjmującym państwie członkowskim”, potwierdzając zatem, że obywatel państwa trzeciego będący członkiem rodziny obywatela Unii nie może powoływać się na podstawie tej dyrektywy na pochodne prawo pobytu w państwie członkowskim, którego przynależność państwową posiada ów obywatel Unii $[\ldots]^{280}$.

Mówiąc krótko, dyrektywa reguluje jedynie zasady możliwości uzyskania pobytu przez będącego obywatelem państwa trzeciego członka rodziny obywatela państwa członkowskiego w innym niż rodzinne państwo członkowskie tego ostatniego. Dopiero wtórnie, po ewentualnym uzyskaniu pochodnego prawa pobytu i utrwaleniu pożycia rodzinnego podczas pobytu w kraju członkowskim, którego obywatelstwa połączony więzami rodzinnymi z obywatelem państwa trzeciego obywatel Unii nie posiada, dyrektywa może stosować się do obywatela państwa trzeciego, powracającego wraz z będącym członkiem ro-

\footnotetext{
279 Ibidem, pkt 39 .

${ }^{280}$ Ibidem, pkt 40.
} 
dziny obywatelem państwa członkowskiego Unii, do jego rodzinnego państwa członkowskiego. Trybunał skonkludował, że:

w sytuacji, w której obywatel Unii rozwinął lub umocnił życie rodzinne z obywatelem państwa trzeciego przy okazji odbywania [...] oraz w poszanowaniu określonych w nich warunków efektywnego pobytu w państwie członkowskim innym niż państwo członkowskie jego przynależności państwowej, przepisy tej dyrektywy znajdują zastosowanie przez analogię także wówczas, gdy wspomniany obywatel Unii powraca wraz z zainteresowanym członkiem swej rodziny do państwa członkowskiego swojego pochodzenia. $\mathrm{W}$ rezultacie warunki przyznania pochodnego prawa pobytu obywatelowi państwa trzeciego będącemu członkiem rodziny tego obywatela Unii w państwie członkowskim pochodzenia tego ostatniego nie powinny być co do zasady bardziej rygorystyczne niż te przewidziane przez wspomnianą dyrektywę dla przyznania pochodnego prawa pobytu obywatelowi państwa trzeciego będącemu członkiem rodziny obywatela Unii, który skorzystał z przysługującego mu prawa do swobodnego przemieszczania się, osiedlając się w państwie członkowskim innym niż państwo, którego obywatelstwo posiada ${ }^{281}$.

Określając precyzyjnie zakres zastosowania dyrektywy, Trybunał sformułował tym samym precyzyjnie zakres zastosowania unijnych praw podstawowych. To właśnie w związku z uprawnieniem po stronie obywateli unijnych, z których korzystać mogą oni na podstawie dyrektywy, mogłoby ewentualnie dojść do zastosowania unijnych praw podstawowych wobec państw członkowskich. Jednak nie w związku z samym posiadanym przez nich obywatelstwem unijnym ${ }^{282}$.

W kontekście tym warto wskazać również na wyrok w sprawie Delvigne $^{283}$. Sprawa ta dotyczyła obywatela francuskiego, który w związku z ogra-

${ }^{281}$ Ibidem, pkt 61.

282 Ostatecznie więc, przynajmniej na aktualnym etapie rozwoju prawa unijnego, Trybunał odrzucił możliwość, aby sam fakt bycia obywatelem unijnym wystarczał do powołania się na unijne prawa podstawowe. Powiedzieć: Civis europeus sum (por. np. już: TSUE, Christos Konstantinidis p. Stadt Altensteig - Standesamt i Landratsamt Calw - Ordnungsamt, C-168/91, opinia Rzecznika Generalnego Francisa Jacobsa przedstawiona w dniu 9 grudnia 1992, pkt 46) i powołać się na unijne prawa podstawowe może obywatel Unii korzystający z konkretnych związanych z tym faktem uprawnień, szczególnie w wymiarze transgranicznym. Bez spełnienia takich warunków, w sytuacjach czysto wewnętrznych, na unijne prawa podstawowe powoływać się nie może. Tym niemniej kwestia obywatelstwa pozostaje jedną z powszechniejszych wśród proporcji rozszerzania zastosowania unijnych praw podstawowych wobec państw członkowskich, również w związku z petycjami dotyczącymi tej materii, napływającymi do Parlamentu Europejskiego (patrz np.: E. Spaventa, The Interpretation..., s. 9, 15 i nast.).

${ }^{283}$ TSUE, Thierry Delvigne p. Commune de Lesparre Médoc i Préfet de la Gironde, C-650/13, wyrok z 6 października 2015. 
niczeniami prawa do głosowania przewidzianymi przez prawo francuskie, nie mógł uczestniczyć w wyborach do Parlamentu Europejskiego. Został on

wykreślony z list wyborców, ponieważ z powodu skazania go [...] za zbrodnię, wymieniony jest wśród osób, które [...] na podstawie przepisów ordynacji [...] nie spełniają przesłanek bycia wyborcą na szczeblu krajowym. Tymczasem, jak Parlament zaznaczył w uwagach, art. 2 loi du 7 juillet 1977, relative à l'élection des représentants au Parlement européen (ustawy z dnia 7 lipca 1977 r. dotyczącej wyborów przedstawicieli do Parlamentu Europejskiego), przewidzianych aktem z 1976 r., wyraźnie odsyła do tych przesłanek szczególnie w odniesieniu do prawa głosowania w wyborach do Parlamentu Europejskiego ${ }^{284}$.

Mamy tu więc do czynienia z sytuacją wydawałoby się wewnętrzną. Obywatel Unii posiada wynikające $z$ tego faktu prawa wyborcze do Parlamentu Europejskiego, brak jednak jakiegokolwiek elementu transgranicznego. Jest to obywatel jednego z państw członkowskich, znajdujący się w tym państwie i podlegający prawu tego państwa w sytuacji, gdy prawo unijne stanowi, z pewnymi zastrzeżeniami, że procedura wyborcza do Parlamentu Europejskiego w każdym państwie członkowskim podlega przepisom krajowym ${ }^{285}$.

Katalog osób, którym przysługuje prawo wyborcze, nie znajdował się wśród wspomnianych zastrzeżeń zawartych w przywołanym prawie unijnym regulującym przedmiotową kwestię. Trybunał to dostrzegł:

Wprawdzie w odniesieniu do osób, którym przysługuje prawo głosowania w wyborach do Parlamentu Europejskiego, Trybunał orzekł [wcześniej - przyp. aut.] [...], że art. 1 ust. 3 i art. 8 aktu z 1976 r. nie wskazują w sposób wyraźny i szczegółowy osób, którym przysługuje to prawo, i że zatem na obecnym etapie rozwoju prawa Unii określenie osób, którym przysługuje wspomniane prawo, należy - z poszanowaniem prawa Unii - do kompetencji każdego państwa członkowskiego ${ }^{286}$.

Tym niemniej, jak zauważył Trybunał, „na państwach członkowskich spoczywa przy wykonywaniu tej kompetencji określony w art. 1 ust. 3 aktu z 1976 r. w związku z art. 14 ust. 3 TUE, obowiązek zapewnienia, by wybory członków Parlamentu Europejskiego odbywały się w powszechnych wyborach bezpośrednich, w głosowaniu wolnym i tajnym"287.

Dlatego też, przypomniawszy, „że zakres stosowania karty w odniesieniu do działań państw członkowskich został określony w jej art. 51 ust. 1, zgodnie

${ }^{284}$ Ibidem, pkt 30.
${ }^{285}$ Ibidem, pkt 29.
${ }^{286}$ Ibidem, pkt 31.
${ }^{287}$ Ibidem, pkt 32. 
z którym postanowienia karty mają zastosowanie do państw członkowskich tylko w sytuacji, gdy stosują one prawo Unii [...]"288 oraz, że „art. 51 ust. 1 karty potwierdza utrwalone orzecznictwo Trybunału, zgodnie z którym prawa podstawowe chronione w porządku prawnym Unii znajdują zastosowanie we wszystkich sytuacjach podlegających prawu Unii, ale nie poza takimi sytuacjami [...]"289, TSUE stwierdził, że przedmiotowe regulacje francuskie znajdowały się w zakresie zastosowania prawa unijnego i powinny w związku z tym odpowiadać unijnym gwarancjom praw podstawowych. Należy podkreślić, że podstawą do stwierdzenia zastosowania przepisów Karty nie był sam fakt posiadania obywatelstwa unijnego i wynikających z niego praw politycznych, lecz konkretne przepisy regulujące charakter wyborów do Parlamentu Europejskiego (art. 14 ust. 3 TUE wyrażony w art. 1 Aktu dotyczącego wyborów członków Parlamentu Europejskiego ${ }^{290}$ ). Takie podejście podtrzymuje po raz kolejny sformułowane wcześniej orzecznictwo ograniczające zakres zastosowania unijnych praw podstawowych ze względu na sam tylko fakt posiadania unijnego obywatelstwa ${ }^{291}$.

\subsubsection{Sprawy dotyczące kompetencji Unii. \\ Cel regulacji unijnej i krajowej - \\ znaczenie zasady efektywności prawa unijnego}

W grupie spraw ukazujących, jak zostało to określone, rewers zasady sformułowanej w wyroku w sprawie Åkerberg Fransson, na szczególną uwagę zasługuje wyrok w sprawie Siragusa ${ }^{292}$. W sprawie tej TSUE nie doszedł do wniosku o właściwości zastosowania KPP. Dzięki zawartej w niej precyzyjnej analizie i odesłaniu do wcześniejszego swego orzecznictwa, w tym do sprawy Åkerberg

${ }^{288}$ Ibidem, pkt 25.

289 Ibidem, pkt 26.

290 Akt dotyczący wyborów członków Parlamentu Europejskiego w powszechnych wyborach bezpośrednich, dołączony do decyzji Rady 76/787/EWWiS, EWG, Euratom z 20 września 1976, Dz.Urz. L 278, zmieniony decyzją Rady 2002/772/WE, Euratom z 25 czerwca 2002 i 23 września 2002, Dz.Urz. L 283.

${ }^{291}$ Co do meritum Trybunał stwierdził, że „że art. 39 ust. 2 i art. 49 ust. 1 zdanie ostatnie karty należy interpretować w ten sposób, że nie stoją one na przeszkodzie temu, by przepisy krajowe państwa członkowskiego, takie jak będące przedmiotem postępowania głównego, wykluczały z mocy prawa spośród osób, którym przysługuje prawo głosowania w wyborach do Parlamentu Europejskiego, osoby, które, podobnie jak T. Delvigne, zostały skazane w trybie karnym za zbrodnię wyrokiem, który stał się prawomocny przed dniem 1 marca 1994 r." (TSUE, Thierry Delvigne p. Commune de Lesparre Médoc i Préfet de la Gironde, C-650/13, wyrok z 6 października 2015, pkt 58).

292 TSUE, Cruciano Siragusa p. Regione Sicilia, C-206/13, wyrok z 6 marca 2014. 
Fransson, $\mathrm{w}$ istotny sposób przyczyniła się ona do zakreślania granic związania państw członkowskich unijnymi prawami podstawowymi.

Wyrok w tej sprawie poprzedzony był orzeczeniem w sprawie Gueye ${ }^{293}$. Wprawdzie brak w nim otwartego odniesienia do art. 51 ust. 1 Karty, pojawiają się jednak rozważania co do zakresu prawa unijnego regulującego przedmiotową kwestię, co jak wiadomo ma decydujące znaczenie dla możliwości zastosowania unijnych praw podstawowych do przepisów prawa krajowego. Trybunał zważył, że decyzja ramowa, o której była mowa w tej sprawie, nie zawierała żadnego przepisu dotyczącego kwestii uregulowanej w prawie krajowym (dotyczącego rodzaju kar i ich wymiaru, jakie państwa członkowskie powinny zawrzeć w swoich ustawodawstwach w celu karania przestępstw, o których mowa była w decyzji ramowej) ${ }^{294}$. Ponadto podkreślił, że „decyzja ramowa w żaden sposób nie wskazuje, by prawodawca Unii, w granicach przyznanych mu traktatem kompetencji, zmierzał do zharmonizowania lub przynajmniej zbliżenia ustawodawstw państw członkowskich co do rodzaju i wymiaru sankcji karnych"295.

Celem decyzji ramowej było raczej ustanowienie "minimalnych norm w celu ochrony ofiar przestępstw i zaoferowania im wysokiego poziomu ochrony, w szczególności w zakresie ich dostępu do wymiaru sprawiedliwości"296. Przy czym przepisy decyzji ramowej pozostawiały państwom daleko idącą swobodę, i choć nakładały one "na państwa członkowskie obowiązek zapewnienia ofiarom możliwości wysłuchania ich w trakcie postępowania oraz możliwości dostarczania dowodów, to jednak pozostawia[ły] władzom krajowym szeroki zakres uprawnień dyskrecjonalnych co do konkretnych mechanizmów realizacji tych celów"297. Ponadto, nie ustanawiały "dla państw członkowskich żadnego obowiązku wprowadzenia do krajowego prawa karnego przepisów pozwalających ofierze wpływanie na kary, jakie sąd krajowy może wymierzać sprawcom przestępstw" ${ }^{\prime 298}$. Doprowadziło to Trybunał do wniosku, że przepisy krajowe ustanawiające obowiązek orzekania o zakazie zbliżania się, w związku z przestępstwami, których dotyczyła decyzja ramowa, nie wchodzą „w zakres zastosowania decyzji ramowej, a tym samym nie może w każdym razie być oceniany w świetle postanowień Karty praw podstawowych Unii Europejskiej"299.

293 TSUE, Postępowania karne przeciwko Magatte Gueye i Valentín Salmerón Sánchez, C-483/og i C-1/10, wyrok z 15 września 2011.

${ }^{294}$ Ibidem, pkt 50.

${ }^{295}$ Ibidem, pkt 51.

${ }^{296}$ Ibidem, pkt 52.

${ }^{297} \mathrm{Ibidem}$, pkt 57.

${ }^{298}$ Ibidem, pkt 65.

${ }^{299}$ Ibidem, pkt 69. 
Objęcie danej kwestii kompetencją Unii i zrealizowanie tej kompetencji przez nią, nie jest więc samo z siebie wystarczające do objęcia wszelkich regulacji krajowych w tej dziedzinie unijnymi prawami podstawowymi. Sama okoliczność, że środek krajowy należy do dziedziny objętej kompetencją Unii, nie oznacza jeszcze, iż jest on objęty zakresem stosowania prawa Unii, a więc również Karty. Unijne prawa podstawowe powinny być stosowane tylko do tych regulacji krajowych, które wchodzą w zakres w jakimś stopniu zharmonizowany przez prawo unijne, a nie ten, który wyraźnie prawo unijne pozostawiło nieuregulowany. Takie okoliczności należy jednak wyraźnie odróżnić od sytuacji, w której państwa członkowskie korzystają ze swobody implementacyjnej wynikającej z przepisów prawa unijnego, obejmujących kwestię, w której pozostawiają swobodę państwom, tak jak np. miało to miejsce w sprawie N.S. ${ }^{300} \mathrm{~W}$ sytuacji takiej, jak w sprawie Gueye, państwa korzystają ze swobody, która wynika jednak z braku objęcia danej kwestii regulacją unijną ${ }^{301}$, co zmienia postać rzeczy.

W sprawie Siragusa Trybunał wyraźnie sformułował ogólne kryteria, jakimi należy się kierować przy ocenie, czy Karta znajduje zastosowanie do państw członkowskich, i bardzo dobitnie powiązał je z efektywnością prawa unijnego, a więc realizacją celów przewidzianych w tym prawie. Jak twierdzą niektórzy, kryteria te na tyle ograniczają wcześniejsze podejście prezentowane przez Trybunał, że mogłaby wręcz powstać wątpliwość, czy sytuacja w sprawie Åkerberg Fransson spełnia te kryteria ${ }^{302}$. Trybunał podkreślił:

\begin{abstract}
Aby określić, czy uregulowanie krajowe mieści się w granicach stosowania prawa Unii w rozumieniu art. 51 karty, należy między innymi zbadać, czy omawiane uregulowanie krajowe ma na celu wykonanie przepisu prawa Unii, jaki jest charakter tego uregulowania oraz czy zmierza ono ku realizacji celów innych niż te objęte prawem Unii, nawet jeżeli może ono w sposób pośredni wpływać na to ostatnie, a także czy istnieją przepisy prawa Unii regulujące daną dziedzinę w sposób szczególny lub mogące mieć dla niej znaczenie $e^{303}$.
\end{abstract}

W sprawie tej Pan Cruciano Siragusa, właściciel nieruchomości położonej na terenie podlegającym ochronie krajobrazu, dokonał zmian, na które nie uzyskał uprzedniego pozwolenia, i wystąpił do Comune di Trabia (gminy Trabia) o wydanie pozwolenia na budowę legalizującego samowolę budowlaną, po uzyskaniu uprzedniej zgody Soprintendenza Beni Culturali e Ambientali

300 TSUE, N.S. p. Secretary of State for the Home Department oraz M.E., A.S.M., M.T., K.P., E.H. p. Refugee Applications Commissioner, Minister for Justice, Equality and Law Reform, C-411/10 i C-493/10, wyrok z 21 grudnia 2011.

${ }^{301}$ Por.: A. Ward, Art. $51 \ldots$, s. 1450.

302 E. Spaventa, The Interpretation..., s. 20-21.

303 TSUE, Cruciano Siragusa p. Regione Sicilia, C-206/13, wyrok z 6 marca 2014, pkt 25. 
di Palermo ${ }^{304}$. Organ ten wydał jednak, opierając się na prawie włoskim, nakaz zobowiązujący skarżącego w postępowaniu głównym do przywrócenia terenu do stanu poprzedniego poprzez rozebranie wszystkich wykonanych bezprawnie obiektów w terminie 120 dni od dnia doręczenia tego nakazu ${ }^{305}$. Cruciano Siragusa wniósł do sądu administracyjnego skargę przeciwko temu nakazowi, a sąd ten zdecydował się skierować do TSUE pytanie prejudycjalne o następującej treści:

Czy art. 17 [karty] oraz zasada proporcjonalności jako ogólna zasada prawa Unii [...] stoją na przeszkodzie stosowaniu przepisu krajowego, [...], który wyklucza możliwość wydania, w celu zalegalizowania samowoli budowlanej, pozwolenia stwierdzającego zgodność z wymogami ochrony krajobrazu w zakresie wszystkich działań człowieka powodujących zwiększenie powierzchni i kubatury, niezależnie od faktu, czy zostało przeprowadzone konkretne badanie zgodności tych działań z wartościami związanymi z ochroną krajobrazu danego miejsca? $?^{306}$

Tribunale amministrativo regionale per la Sicilia zdawał sobie sprawę, „że w prawie Unii zagadnienie ochrony krajobrazu nie jest niezależne i nie różni się pod względem konceptualnym od zagadnienia ochrony środowiska, lecz stanowi jego część" ${ }^{\prime 307}$, oraz z tego, że w związku z tym mieści się ono w zakresie kompetencji Unii ${ }^{308}$, stąd też uznał za właściwe wystąpienie do TSUE z powyższym pytaniem prejudycjalnym. TSUE nie uznał się jednak w tej sprawie za właściwy do udzielenie odpowiedzi. Stwierdził bowiem, że sprawa nie mieści się w zakresie prawa Unii. Trybunał potwierdził tym samym po raz kolejny swoje wcześniejsze stanowisko, powtarzane również w późniejszych wyrokach, jak choćby w sprawie Hernández ${ }^{309}$, że sam fakt objęcia danej sprawy kompetencją Unii, nawet jeśli kompetencja ta byłaby w jakimś zakresie wykonana, to za mało, aby można było mówić o automatycznym zastosowaniu przepisów Karty ${ }^{310}$.

Podobnie Trybunał orzekł już, że art. 13 WE (obecnie art. 19 TFUE) nie może sam w sobie włączyć w zakres stosowania prawa Unii - w celu stosowania praw podstawowych jako ogólnych zasad prawa Unii - środka krajowego, który nie mieści się w ramach środków przyjętych na podstawie tego artykułu [...]. Z tego względu sama okoliczność, że środek krajowy należy do dziedziny objętej kompetencją Unii, nie

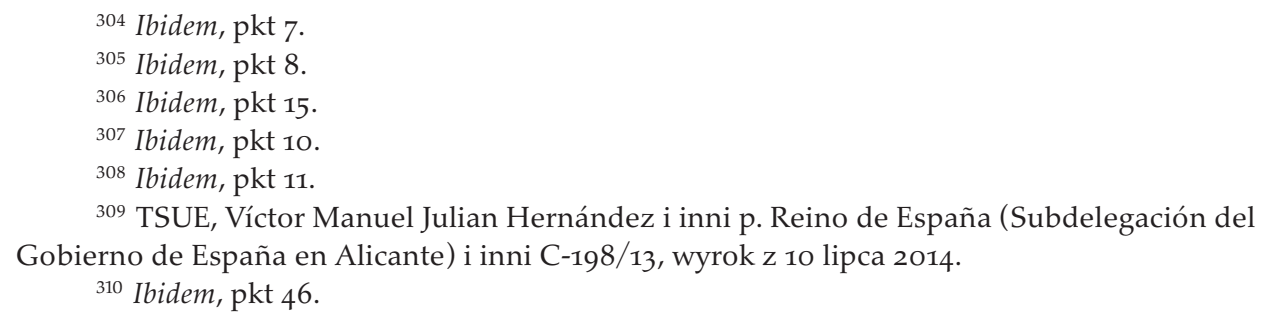


oznacza jeszcze, iż jest on objęty zakresem stosowania prawa Unii, a więc również karty $[\ldots]^{311}$.

W sprawie tej chodziło o regulacje krajowe, które przyznawały określonej grupie podmiotów (pracownikom) większy poziom ochrony niż przewidziane było to w prawie unijnym (dyrektywie), będący rezultatem wykonywania przez państwa członkowskie ich kompetencji wyłącznej, co znajdowało potwierdzenie w samym prawie unijnym ${ }^{312}$. Jej przepisy wprost stanowiły, że nie narusza ona "prawa państw członkowskich do stosowania lub wprowadzenia przepisów ustawowych, wykonawczych bądź administracyjnych korzystniejszych dla pracowników" $w^{\prime \prime 13}$. Cel regulacji krajowej jest więc inny niż cel regulacji unijnej. Celem tej ostatniej było zapewnienie minimalnej ochrony pracownikom na wypadek niewypłacalności pracodawcy. Regulacja krajowa szła jednak dalej i miała na celu umożliwienie dochodzenia od państwa hiszpańskiego odszkodowania za szkodliwe konsekwencje przewlekłości postępowań sądowych przekraczających 60 dni roboczych ${ }^{314}$. Sama bliskość dziedzin przedmiotu regulacji lub pośredni wpływ jednej dziedziny na drugą to za mało, aby można było zastosować unijne prawa podstawowe do prawa krajowego: „pojęcie »stosowania prawa Unii« w rozumieniu art. 51 karty wymaga istnienia związku między aktem prawa Unii a rozpatrywanym środkiem krajowym, który wykracza poza bliskość danych dziedzin"315. Dlatego też TSUE potwierdził w tej sprawie „brak możliwości zastosowania praw podstawowych Unii w kontekście uregulowań krajowych ze względu na okoliczność, że przepisy Unii w danej dziedzinie nie nakładały żadnych zobowiązań na państwa członkowskie w odniesieniu do sytuacji, której dotyczyło postępowanie główne [...]"316.

Co istotne z perspektywy tej pracy - w sprawie tej Trybunał podkreślił także znaczenie zasad pierwszeństwa, jedności i efektywności prawa Unii oraz ich powiązanie z ochroną unijnych praw podstawowych. Uczynił to jednak w dość specyficzny sposób, który uwydatnia wspomniany w podrozdziale 6.3.3.1. swoisty dualizm sytuacji zastosowania unijnych standardów praw podstawowych i ograniczeń wobec państw członkowskich do stosowania standardów wyższych niż unijne, gdy działają one w zakresie prawa unijnego. Sytuację w tej sprawie należy sklasyfikować jako sytuację „harmonizacji minimalnej”317 ze

\footnotetext{
${ }^{311}$ Ibidem, pkt 36 .

312 Ibidem, pkt 45 .

313 Ibidem, pkt 44.

${ }^{314}$ Ibidem, pkt 41.

315 Ibidem, pkt 34.

${ }^{316}$ Ibidem, pkt 35 .

${ }^{317}$ M. Szpunar, Kilka uwag..., s. 6.
} 
wszystkimi wynikającymi stąd konsekwencjami. W sprawie tej TSUE zauważył, że:

Należy wreszcie przypomnieć, że cel ochrony praw podstawowych w prawie Unii, jeśli chodzi zarówno o działania na szczeblu Unii, jak też o stosowanie prawa Unii przez państwa członkowskie, znajduje uzasadnienie w konieczności uniknięcia sytuacji, w której poziom ochrony praw podstawowych będzie różny w zależności od danego prawa krajowego, co niesie ze sobą ryzyko naruszenia jednolitości, pierwszeństwa i skuteczności prawa Unii [...]. Tymczasem [...] w przypadku uregulowania rozpatrywanego w postępowaniu głównym ryzyko takie nie zachodzi ${ }^{318}$.

Przy czym w sprawie tej w ogóle nie było możliwości zastosowania unijnych praw podstawowych wobec regulacji krajowych, jako że ze względów, o których była mowa wcześniej, TSUE nie stwierdził, aby regulacje te były przejawem zastosowania prawa unijnego ${ }^{319}$.

Wracając do sprawy Siragusa należy podkreślić, że TSUE przypomniał w niej po raz kolejny, że:

nie jest władny oceniać zgodności z kartą przepisów krajowych, które nie wchodzą w zakres prawa Unii. Natomiast jeżeli przepisy takie wchodzą w zakres stosowania tego prawa, Trybunał, rozpatrując pytanie prejudycjalne, powinien udzielić wszelkich wyjaśnień interpretacyjnych koniecznych do oceny przez sąd krajowy zgodności tych przepisów z prawami podstawowymi, których ochronę zapewnia [... $]^{320}$.

TSUE swe rozważania poparł również odwołaniem do Wyjaśnień dotyczących Karty i jej art. 51 ust. $1^{321}$. Sam fakt, że ochrona krajobrazu, której dotyczy przedmiotowe uregulowanie krajowe, na podstawie którego wydany został nakaz rozbiórki, wchodzi w zakres ochrony środowiska, a Unia posiada i wykonała na różne sposoby kompetencje w tej dziedzinie, to za mało, by uznać tę sprawę za mieszczącą się w zakresie zastosowania prawa Unii ${ }^{322}$. Trybunał podkreślił, że „pojęcie »stosowania prawa Unii« w rozumieniu art. 51 karty wymaga istnienia powiązania określonego stopnia, które wykracza poza bliskość odnośnych dziedzin lub pośredni wpływ jednej dziedziny na drugą [...]"323.

Trybunał jeszcze raz zaakcentował w kategoriach ogólnych znaną z przytaczanych wcześniej spraw formułę, że:

${ }^{318}$ TSUE, Víctor Manuel Julian Hernández i inni p. Reino de España (Subdelegación del Gobierno de España en Alicante) i inni, C-198/13, wyrok z 10 lipca 2014, pkt 47.

319 Ibidem, pkt 48.

320 TSUE, Cruciano Siragusa p. Regione Sicilia, C-206/13, wyrok z 6 marca 2014, pkt 21.

321 Ibidem, pkt 22.

322 Ibidem, pkt 23.

${ }^{323}$ Ibidem, pkt 24 . 
Aby określić, czy uregulowanie krajowe mieści się w granicach stosowania prawa Unii w rozumieniu art. 51 karty, należy między innymi zbadać, czy omawiane uregulowanie krajowe ma na celu wykonanie przepisu prawa Unii, jaki jest charakter tego uregulowania oraz czy zmierza ono ku realizacji celów innych niż te objęte prawem Unii, nawet jeżeli może ono w sposób pośredni wpływać na to ostatnie, a także czy istnieją przepisy prawa Unii regulujące daną dziedzinę w sposób szczególny lub mogące mieć dla niej znaczenie $[\ldots]^{324}$.

Jak widać tym razem Trybunał nie zadowolił się oschłym powtarzaniem krótkich formuł stanowiących cytaty bądź parafrazy sformułowań z art. 51 ust. 1 Karty lub prostego stwierdzania, że aby Kartę zastosować wobec państw członkowskich muszą one działać w zakresie zastosowania prawa Unii. Po pierwsze, TSUE expressis verbis podkreślił konieczność istnienia powiązania określonego stopnia, które wykracza poza bliskość odnośnych dziedzin lub pośredni wpływ jednej dziedziny (uregulowanej prawem unijnym) na drugą (uregulowaną prawem krajowym). Po drugie zaś wskazał, że dla stwierdzenia możliwości zastosowania wobec niego unijnych praw podstawowych, wystarczające jest to, że omawiane uregulowanie krajowe ma na celu wykonanie przepisu prawa Unii. Wreszcie wyjaśnił, że jeśli regulacja zmierza ku realizacji celów innych niż te objęte prawem Unii, a także jeśli nie istnieją przepisy prawa Unii regulujące daną dziedzinę w sposób szczególny, to prawo krajowe pozostaje poza zakresem zastosowania KPP. Powiązaniem uzasadniającym zastosowanie unijnych praw podstawowych wobec prawa krajowego jest więc to, że prawo to wiąże się z celem realizowanym przez jakieś istniejące normy prawa unijnego.

Ta lista warunków w sposób dość istotny krystalizuje krąg spraw mieszczących się w zakresie prawa Unii, i o ile cały czas nie można mówić tu o pełnej przejrzystości kryteriów kwalifikacji danej sprawy jako podpadającej pod art. 51 ust 1 Karty, to jednak nie mamy też do czynienia z pełną swobodą. Wypracowując powyższe kryteria, sam Trybunał w istotny sposób tę swoją swobodę ograniczył, i można się spodziewać, że efekty tego ograniczenia będziemy obserwować w kolejnych sprawach, które, tak jak sprawa Siragusa, pozwola a casu ad casum coraz bardziej doprecyzowywać zakres związania państw członkowskich unijnymi prawami podstawowymi. W tej sprawie Trybunał ocenił, że skoro to prawo włoskie było jedynym źródłem szczegółowych regulacji dotyczących ochrony krajobrazu, i nawet jeśli ochrona krajobrazu mieści się w objętym przez prawo UE prawie ochrony środowiska, to przy braku uregulowania w jego ramach kwestii ochrony krajobrazu, nie można mówić o regulacjach krajowych w tej mierze, jako o mieszczących się w zakresie prawa UE. Dlatego też doszedł do wniosku o braku swojej właściwości w tej sprawie.

\footnotetext{
${ }^{324}$ Ibidem, pkt 25 .
} 
Co istotne z perspektywy tej pracy trybunał luksemburski zwrócił także uwagę, że należy również uwzględnić w tej i podobnych sprawach, gdy chodzi o zakres zastosowania unijnych praw podstawowych do państw członkowskich, "cel ochrony praw podstawowych w prawie Unii, jakim jest zapewnienie, że prawa te nie będą naruszane $\mathrm{w}$ obszarach działalności Unii, czy to z powodu działań Unii, czy też z powodu stosowania prawa Unii przez państwa członkowskie" ${ }^{\prime 25}$. Trybunał dostrzegł więc po raz kolejny i podkreślił swoisty podział odpowiedzialności między państwami działającymi poza zakresem prawa Unii i związanych swoimi gwarancjami ochrony praw człowieka a Unią działającą $\mathrm{w}$ ramach swoich kompetencji i związaną swoimi gwarancjami praw człowieka. Nie zapomniał jednak o tym wymiarze wykonywania przez Unię swych kompetencji, w którym współdziałają z nią państwa członkowskie. Ten współudział prowadzi do związania państw unijnymi prawami podstawowymi.

W wyroku w sprawie Siragusa przy okazji podkreślenia celu ochrony praw podstawowych w prawie Unii, Trybunał jeszcze raz uwydatnił także znaczenie podstawowych zasad, którymi kieruje się w swym orzecznictwie i które znajdują zastosowanie również przy ochronie unijnych praw podstawowych. W duchu wyroku w sprawie Internationale Handelsgesellschaft ${ }^{326}$ i podobnie jak w sprawie Åkerberg Fransson ${ }^{327}$ i Melloni ${ }^{328}$, ochronę unijnych standardów praw podstawowych wymienił w jednym szeregu $\mathrm{z}$ innymi zasadami prawa unijnego, jakimi są pierwszeństwo, jednolitość i skuteczność prawa UE. W ten sposób jeszcze raz podkreślił specyficzny charakter unijnej ochrony praw człowieka względem zwykłych międzynarodowych reżimów ochrony praw człowieka. Te ostatnie ustanawiają pewne standardy minimalne. Pozostawiają jednak państwom swobodę do stosowania standardów wyższych. Unijne gwarancje praw człowieka ustanawiają standard minimalny dla Unii. Nie odnoszą się co do zasady do państw, chyba, że te stosują prawo Unii. Wtedy musza, tak samo jak Unia, spełniać minimalny standard przez nie przewidziany, jeśli jednak Unia zdecyduje się na ich dopuszczalne (powyżej standardu minimalnego) ograniczenie, to one również są do tego zobowiązane. Nie mogą podważać unijnego porządku prawnego poprzez podważanie prawa unijnego przez niestosowanie się do zawartych $\mathrm{w}$ tym prawie ograniczeń w możliwości korzystania z praw człowieka, w obszarze objętym zakresem prawa unijnego. Podważałoby to harmonizującą funkcję prawa unijnego i jego autonomiczność.

${ }^{325}$ Ibidem, pkt 31.

${ }^{326}$ TSUE, Internationale Handelsgesellschaft $\mathrm{mbH}$ p. Einfuhr- und Vorratsstelle für Getreide und Futtermittel, 11/70, wyrok z 17 grudnia 1970, pkt 3 .

${ }^{327}$ TSUE, Åklagaren p. Hans Åkerberg Fransson, TSUE, C-617/10, wyrok z 26 lutego 2013, pkt 29.

${ }^{328}$ TSUE, Stefano Melloni p. Ministerio Fiscal, C-399/11, wyrok z 26 lutego 2013, pkt 60. 
To ograniczenie swobody państw wynika więc ze zobowiązań, jakie na siebie przyjęły, przystępując do Unii, i z tego, że przekazały jej kompetencję prawotwórczą w określonych kwestiach. W sprawie Siragusa TSUE podkreślił wyraźnie, że:

Dążenie do tego celu [ochrony praw podstawowych w prawie Unii, jakim jest zapewnienie, że prawa te nie będą naruszane w obszarach działalności Unii, czy to z powodu działań Unii, czy też z powodu stosowania prawa Unii przez państwa członkowskie - przyp. aut.] jest uzasadnione koniecznością uniknięcia naruszenia pierwszeństwa, jednolitości i skuteczności prawa Unii w wyniku ochrony praw podstawowych, która może różnić się w zależności od danego prawa krajowego [...] $]^{329}$.

Dość specyficznej i istotnej z perspektywy tego rozdziału kwestii dotyczyła sprawa Pringle ${ }^{330}$. Również w tej sprawie TSUE stwierdził, że nie może być mowy o zastosowaniu unijnych praw podstawowych w związku $z$ art. 51 ust. 1 Karty, tym razem do umów międzynarodowych, zawieranych przez państwa członkowskie Unii, w materii nie mieszczącej się w zakresie traktatów unijnych. Sprawa ta dotyczyła ustanowienia mechanizmu stabilności dla państw, których walutą jest euro w związku z kryzysem gospodarczym, jaki dotknął Europę w 2008 r. i latach następnych. Omawianie całej złożoności mechanizmu i procesu zmierzającego do jego powstania przekraczałoby ramy tego opracowania, tak samo jak omawianie całej sprawy Pringle, w której badano zgodność mechanizmu z prawem pierwotnym Unii.

Na potrzeby tej pracy wystarczy stwierdzić, że Europejski Mechanizm Stabilności (EMS) zmierza do konsolidacji i połączenia dwu wcześniejszych instrumentów, ustanowionych tymczasowo w następstwie kryzysu związanego z zadłużeniem niektórych krajów, jakimi są Europejski Mechanizm Stabilizacji Finansowej (EFSM) ${ }^{331}$ oraz Europejski Instrument Stabilności Finansowej (EFSF) ${ }^{332}$, z którymi obecnie współistnieje. EMS stanowi jeden z elementów mających na celu zapewnienie stabilności finansowej w ramach strefy euro. Jest to mechanizm zawierający różne instrumenty wsparcia, takie jak pożyczki, możliwość dokapitalizowania instytucji finansowych czy możliwość zakupu

${ }^{329}$ TSUE, Cruciano Siragusa p. Regione Sicilia, C-206/13, wyrok z 6 marca 2014, pkt 32.

330 TSUE, Thomas Pringle p. Government of Ireland, Ireland i The Attorney General, C-370/12, wyrok z 27 listopada 2012.

${ }^{331}$ Rozporządzenie Rady (UE) nr 407/2010 z 11 maja 2010 ustanawiające europejski mechanizm stabilizacji finansowej, Dz.Urz. L 118 z 12 maja 2010 oraz Rozporządzenie Rady (UE) 2015/1360 z 4 sierpnia 2015 zmieniające rozporządzenie (UE) nr 407/2010 ustanawiające europejski mechanizm stabilizacji finansowej, Dz.Urz. L 210 z 7 sierpnia 2015.

${ }^{332}$ Spółka („société anonyme”) założona na podstawie prawa luksemburskiego z siedzibą w Luksemburgu założona 7 czerwca 2010 przez 17 udziałowców (państwa strefy euro). 
obligacji na rynku pierwotnym lub wtórnym, dla państw członkowskich Unii wchodzących w skład strefy euro, w celu walki ze skutkami światowego kryzysu gospodarczego. Jego prawny charakter jest jednak dość szczególny. Powstał on na podstawie decyzji Rady Europejskiej ${ }^{333}$, w której dokonano zmiany art. 136 TFUE w ramach tzw. procedury uproszczonej zmiany traktatów w oparciu o art. 48 ust. 6 TUE ${ }^{334}$, dodając do art. 136 TFUE ust. 3, zgodnie z którym:

Państwa Członkowskie, których walutą jest euro, mogą ustanowić mechanizm stabilności uruchamiany, jeżeli będzie to niezbędne do ochrony stabilności strefy euro jako całości. Udzielenie wszelkiej niezbędnej pomocy finansowej w ramach takiego mechanizmu będzie podlegało rygorystycznym warunkom.

Sam Mechanizm został jednak ustanowiony poza Unią i nie jest jej instytucją. Jego podstawą była umowa międzynarodowa, zawarta przez państwa członkowskie Unii, wchodzące w skład strefy euro, jednakże bez udziału wspólnoty. 11 lipca 2011 r. państwa te podpisały Traktat o utworzeniu Europejskiego Mechanizmu Stabilności, który został następnie skierowany do ratyfikacji przez odpowiednie organy zgodnie z wewnętrznymi procedurami poszczególnych krajów, a Unia Europejska nie jest jego stroną. Traktat ten był później modyfikowany. Procedura wejścia w życie traktatu ustanawiającego EMS wymagała podpisu i ratyfikacji ze strony wszystkich państw strefy euro. Na jego mocy EMS został ustanowiony jako organizacja międzynarodowa na podstawie prawa międzynarodowego publicznego ${ }^{335}$.

Zdaniem TSUE decyzja 2011/199 nie naruszyła kompetencji Unii w dziedzinie koordynacji polityki gospodarczej państw członkowskich, ponieważ art. 2 ust. 3 TFUE i art. 5 ust. 1 TFUE ograniczają rolę Unii $w$ dziedzinie polityki gospodarczej do podejmowania działań koordynacyjnych, w związku z czym postanowienia traktatów UE i FUE nie powierzają Unii szczególnej kompetencji

${ }^{333}$ Decyzja Rady Europejskiej 2011/199/UE z dnia 25 marca 2011 w sprawie zmiany art. 136 Traktatu o funkcjonowaniu Unii Europejskiej w odniesieniu do mechanizmu stabilności dla państw członkowskich, których walutą jest euro, Dz.Urz. z 5 lipca 2013.

${ }^{334}$ Pozwala on Radzie Europejskiej stanowiącej jednomyślnie po konsultacji z Parlamentem Europejskim, Komisja, a także w pewnych przypadkach z Europejskim Bankiem Centralnym, przyjąć decyzję zmieniającą wszystkie lub niektóre postanowienia części trzeciej Traktatu o funkcjonowaniu Unii Europejskiej (TFUE); decyzja taka nie może jednak prowadzić do zwiększenia kompetencji przyznanych Unii w Traktatach, a jej wejście w życie jest uzależnione od późniejszego jej zatwierdzenia przez państwa członkowskie zgodnie z odpowiednimi procedurami wewnętrznymi.

${ }^{335}$ Więcej na temat ESM i kontrowersji wokół niego patrz np.: Co to jest EFSF $i$ ESM?, [online] <http://www.mf.gov.pl/documents/764034/1417826/23_efsf-esm.pdf> [dostęp: 28.12.2018]; A. Trzcińska, Europejski Mechanizm Stabilności jako stabilizator w planowanej unii finansowej, [online] $<$ https://www.nbp.pl/badania/seminaria/10iv2013.pdf> [dostęp: 28.12.2018]. 
do utworzenia takiego mechanizmu stabilności jak przewidziany w omawianej decyzji ${ }^{336}$. Może ona koordynować tę politykę na różne inne sposoby. Ponadto Trybunał stwierdził, że:

Wprawdzie art. 122 ust. 2 TFUE uprawnia Unię do udzielania jednostkowej pomocy finansowej państwom członkowskim napotykającym trudności lub zagrożonym poważnymi trudnościami z powodu klęsk żywiołowych lub nadzwyczajnych okoliczności pozostających poza ich kontrola, jednakże, jak podkreśla Rada Europejska [...], art. 122 ust. 2 TFUE nie stanowi właściwej podstawy prawnej utworzenia takiego mechanizmu stabilności, jak przewidziany w tej decyzji. Zarówno bowiem stały charakter tego mechanizmu, jak i cel w postaci zapewnienia stabilności finansowej strefy euro jako całości, stoją na przeszkodzie jego powołaniu na podstawie wskazanego postanowienia traktatu FUE ${ }^{337}$.

Ponadto art. 143 ust. 2 TFUE dotyczy pomocy państwom nienależącym do strefy euro ${ }^{338}$. Art. 352 TFUE daje Unii możliwość ustanowienia mechanizmu podobnego do EMS, nie nakłada on jednak na wspólnotę takiego obowiązku ${ }^{339}$. Wobec powyższego, zdaniem Trybunału, „biorąc pod uwagę art. 4 ust. 1 TUE i art. 5 ust. 2 TUE, państwa członkowskie, których walutą jest euro, mają prawo zawrzeć między sobą umowę o utworzeniu takiego mechanizmu stabilności, jak przewidziany w art. 1 decyzji 2011/199" ${ }^{\prime 340}$. Tym niemniej TSUE zauważył, że:

Państwa członkowskie pozostają jednak związane obowiązkiem poszanowania prawa Unii przy wykonywaniu swojego uprawnienia w tej dziedzinie [...]. Rygorystyczne warunki, jakim podlega przyznanie pomocy finansowej z mechanizmu stabilności zgodnie z wprowadzonym w drodze omawianej zmiany traktatu FUE art. 136 ust. 3 TFUE, ma właśnie na celu zapewnienie, że mechanizm ten będzie funkcjonował w zgodzie w prawem Unii, w tym z działaniami podjętymi przez Unię w ramach koordynacji polityki gospodarczej państw członkowskich ${ }^{341}$.

Kluczowe z perspektywy oceny kwestii ewentualnego objęcia EMS zakresem zastosowania Karty okazało się dla Trybunału to, „że ani art. 122 ust. 2 TFUE, ani żadne inne postanowienie traktatu UE lub FUE nie powierza Unii szczególnej kompetencji do utworzenia stałego mechanizmu stabilności tego

${ }^{336}$ TSUE, Thomas Pringle p. Government of Ireland, Ireland i The Attorney General, C-370/12, wyrok z 27 listopada 2012, pkt 64 .

${ }^{337}$ Ibidem, pkt 65 .

${ }^{338}$ Ibidem, pkt 66.

${ }^{339} \mathrm{Ibidem}$, pkt 67.

${ }^{340}$ Ibidem, pkt 68

${ }^{341}$ Ibidem, pkt 69. 
rodzaju, jak EMS [...], państwa członkowskie są w świetle art. 4 ust. 1 TUE i art. 5 ust. 2 TUE uprawnione do podejmowania działań w tej dziedzinie" ${ }^{342}$. Swoboda po stronie państw i brak udziału Unii wystarczyły Trybunałowi do stwierdzenia braku zastosowania unijnych praw podstawowych do EMS. Przypomniał on, że:

zgodnie z art. 51 ust. 1 Karty jej postanowienia mają zastosowanie do państw członkowskich wyłącznie w sytuacji, gdy stosują one prawo Unii. Zgodnie z ust. 2 tego artykułu Karta nie rozszerza zakresu zastosowania prawa Unii poza kompetencje Unii, nie ustanawia nowych kompetencji ani zadań Unii, nie zmienia też kompetencji i zadań określonych w traktatach. Zatem Trybunał dokonuje wykładni w świetle Karty prawa Unii w granicach powierzonych jej kompetencji $[\ldots]^{343}$.

Tym samym, zdaniem TSUE, „państwa członkowskie nie stosują prawa Unii w rozumieniu art. 51 ust. 1 Karty, ustanawiając mechanizm stabilności tego rodzaju jak EMS, dla którego utworzenia traktaty UE i FUE nie przewidują żadnej kompetencji Unii" ${ }^{344}$. Nieobjęcie EMS zakresem zastosowania unijnych praw podstawowych i rozumowanie zaprezentowane przez Trybunał budziło daleko idące kontrowersje również z perspektywy przejrzystości tego mechanizmu, możliwości jego kontrolowania oraz zagrożenia dla ochrony praw człowieka. Pojawiły się nawet zarzuty, że wyrok Trybunału miał bardziej polityczny niż prawny charakter ${ }^{345}$. Najpoważniejsza obawa, jaka może się na gruncie tego wyroku zrodzić, wiąże się z możliwością obchodzenia przez państwa członkowskie gwarancji praw podstawowych, wykorzystując przyjęte przez TSUE ograniczenie zakresu ich zastosowania. Na razie ma ona jednak głównie hipotetyczny charakter. Odnośnie do najważniejszej z perspektywy tej pracy kwestii, jaka jest zakres zastosowania KPP wobec państw członkowskich, należy podkreślić, że jeśli przyjąć za zasadę, że samo objęcie danej kwestii kompetencją Unii, która nawet częściowo byłaby wykonana, to za mało, aby można było mówić o stosowaniu prawa unijnego w danej dziedzinie, to wyrok ten to potwierdza.

${ }^{342}$ Ibidem, pkt 105 .

${ }^{343}$ Ibidem, pkt 179 .

${ }^{344}$ Ibidem, pkt 180.

${ }^{345}$ Patrz np.: G. Beck, The Court of Justice, Legal Reasoning, and the Pringle Case - Law as the Continuation of Politics by other Means, "European Law Review" 2014, nr 39 (2); D. O'Donovan, 'The Way of the World', International Economic Law and National Constitutions: Irish Constitutional Sovereignty and the Eurozone Crisis, [w:] F. De Londras, S. Mullally (red.), „The Irish Yearbook of International Law" 2013, t. 8, s. 65 i nast.; K.H. Tuori, The European Financial Crisis: Constitutional Aspects and Implications, EUI Working Paper, LAW 2012, nr 28. 
6.4.3.3. Dalsze przykłady ugruntowywania podejścia do rozumienia art. 51 ust. 1 Karty

Po utrwaleniu i opisaniu w nieco ogólniejszych kategoriach rozumienia art. 51 ust. 1 w wyroku w sprawie Åkerberg Fransson i innych omówionych powyżej orzeczeniach, trybunał w Luksemburgu kontynuował także linię zarysowaną już we wspominanej, wcześniejszej sprawie DEB, potwierdzając, że przepisy proceduralne wprowadzane przez państwa członkowskie podlegają unijnym prawom podstawowym, nawet jeśli mają ogólny charakter i nie zostały wprowadzone ze względu na obowiązki implementacyjne, ale jeśli służą egzekwowaniu prawa unijnego. W sprawie Stojanow ${ }^{346}$ uznał, że kwestia właściwości sądów, które rozpatrują sprawy dotacji rolnych podlega KPP. Trybunał podkreślił, że:

Zgodnie z utrwalonym orzecznictwem Trybunału w braku uregulowań unijnych w danej dziedzinie zadaniem wewnętrznego porządku prawnego każdego z państw członkowskich, zgodnie z zasadą ich autonomii proceduralnej, jest wyznaczenie właściwych sądów i określenie zasad postępowania w sprawach skarg mających na celu zapewnienie ochrony praw, które jednostki wywodzą z prawa Unii, przy czym państwa członkowskie ponoszą jednakże odpowiedzialność za zapewnienie w każdym przypadku skutecznej ochrony tych praw ${ }^{347}$.

Obowiązek państw do stworzenia procedur służących zapewnieniu ochrony praw, które to prawa wynikają z prawa Unii, niemający wprost podstawy normatywnej w unijnym prawie, lecz wyprowadzony w orzecznictwie TSUE, po raz kolejny został uznany za wystarczający łącznik z prawem Unii do tego, aby uznać, że krajowe regulacje ustanawiajace tego rodzaju procedury podlegajac unijnym prawom podstawowym (w tym wypadku zawartym w art. 47 Karty). Znów widoczne jest tu powiązanie regulacji krajowych nie tyle $\mathrm{z}$ materialnym przepisem prawa unijnego, co raczej z efektywnością tego prawa. Autonomia proceduralna państw nie może się tej efektywności sprzeniewierzyć. Musi jej służyć. Służąc jej, musi również odpowiadać unijnym prawom podstawowym. Zasadę tę TSUE potwierdził i orzekł w związku z tym o zastosowaniu art. 47 Karty również w sprawie Sánchez Morcillo ${ }^{348}$.

Zgodnie $\mathrm{z}$ tym tokiem myślenia $\mathrm{w}$ innych sprawach Trybunał stwierdzał również, że jeśli roszczenie krajowe nie dotyczy roszczenia wywodzonego

${ }^{346}$ TSUE, ET Agrokonsulting-O4-Velko Stoyanov p. Izpalnitelen direktor na Darzhaven fond «Zemedelie» - Razplashtatelna agentsia, C-93/12, wyrok z 27 czerwca 2013.

${ }^{347}$ Ibidem, pkt 35 .

${ }^{348}$ Patrz np.: TSUE, Juan Carlos Sánchez Morcillo i María del Carmen Abril García p. Banco Bilbao Vizcaya Argentaria SA, C-169/14, wyrok z 17 lipca 2014, pkt 35. 
z prawa UE, to nie ma potrzeby oceniania postępowania zmierzającego do realizacji tego roszczenia przez pryzmat KPP ${ }^{349}$. Na przykład w sprawie Torralbo Marcos $^{350}$ TSUE nie odnalazł wystarczającego związku z prawem UE postępowania, które dotyczyło skierowania ugody sądowej do egzekucji, którego ostatecznym celem było postawienie spółki w stan upadłości i skorzystanie w związku z tym z funduszu gwarancyjnego regulowanego unijną dyrektywą:

Okoliczność, że poprzez swoje działania E. Torralbo Marcos usiłuje - zgodnie ze wskazówkami udzielonymi przez sąd odsyłający - uzyskać [...] stwierdzenie niewypłacalności w celu skorzystania z interwencji Fogasy zgodnie z art. 3 dyrektywy 2008/94, nie jest wystarczająca, by już w obecnym stadium postępowania uznać, że sytuacja rozpatrywana w postępowaniu głównym wchodzi w zakres stosowania dyrektywy, a w konsekwencji prawa Unii ${ }^{351}$.

Postępowanie, na którego etapie znajdowała się sprawa, miało charakter krajowy, ponieważ poprzedzało ewentualne stwierdzenie niewypłacalności. Nie mieściło się więc w zakresie objętym dyrektywa, dotyczącą funduszu gwarancyjnego. Pozostawało zatem poza zakresem prawa unijnego i unijne prawa podstawowe nie mogły znaleźć zastosowania do przepisów krajowych regulujących procedurę tego etapu postępowania. TSUE zauważył, że:

Postanowienie to [dotyczące stwierdzenia niewypłacalności - przyp. aut.] nie przesądza kwestii niewypłacalności spółki Korota ani ewentualnego prawa zainteresowanego do uzyskania od instytucji gwarancyjnej pokrycia jego nieodzyskanych wierzytelności socjalnych zgodnie z dyrektywą 2008/94 w przypadku uznania spółki Korota za niewypłacalną w rozumieniu właściwych przepisów krajowych ${ }^{352}$.

Dlatego też uznał, że „sytuacja prawna leżąca u podstaw postępowania głównego nie wchodzi w zakres stosowania prawa Unii"353.

W sprawie Érsekcsanádi Mezőgazdasági, dotyczącej regulacji zmierzających do zwalczania ptasiej grypy, TSUE również nie znalazł podstaw do zastosowania unijnych praw podstawowych. Opierając się na wyrokach w sprawie Åkerberg Fransson i wspominanej również wcześniej sprawie Sociedade Agrícola, TSUE doszedł do wniosku, że skoro prawo unijne nie przewidywało żadnych odszkodowań z tytułu środków wprowadzanych w prawie krajowym

${ }^{349}$ TSUE, Sociedade Agrícola e Imobiliária da Quinta de S. Paio Lda p. Instituto da Segurança Social IP, C-258/13, postanowienie z 28 listopada 2013.

350 TSUE, Emiliano Torralbo Marcos p. Korota SA and Fondo de Garantía Salarial, C-265/13, wyrok z 27 marca 2014.

${ }^{351} \mathrm{Ibidem}$, pkt 40.

${ }^{352}$ Ibidem, pkt 42.

${ }^{353}$ Ibidem, pkt 43 . 
$\mathrm{w}$ wyniku wykonania regulacji unijnych dotyczących ochrony przed ptasią grypa, to regulacje krajowe dotyczące odszkodowań, które w przypadku szkód związanych ze zwalczaniem ptasiej grypy mogły mieć jedynie częściowy charakter, nie mieszczą się w zakresie prawa unijnego i tym samym nie podlegają unijnym prawom podstawowym ${ }^{354}$.

W sprawie Willems ${ }^{355}$ Trybunał uznał, że brak jest podstaw do zastosowania unijnych praw podstawowych do przepisów regulujących możliwości wykorzystywania przez państwa danych biometrycznych do celów innych niż przewidziane $\mathrm{w}$ unijnym rozporządzeniu, zobowiązującym państwa do gromadzenia takich danych w określonych w nim celach. Trybunał stwierdził, że:

Artykuł 4 ust. 3 rozporządzenia nr 2252/2004 wymaga w celu wydania paszportu lub dokumentu podróży pobrania danych biometrycznych, które mają być "gromadzone" $i$ "przechowywane” na nośniku pamięci w tych dokumentach. Jeśli chodzi o "wykorzystywanie" tych danych, przepis ten stanowi, że do celów tego rozporzadzenia dane te wykorzystywane są wyłącznie $\mathrm{w}$ celu sprawdzania autentyczności paszportu lub tożsamości jego posiadacza, w przypadkach gdy okazanie paszportu lub dokumentu podróży wymagane jest zgodnie z przepisami ${ }^{356}$.

Zgodność tych regulacji z unijnymi gwarancjami praw człowieka w tym zakresie została już wcześniej zbadana i TSUE orzekł, że ich one nie naruszają ${ }^{357}$. Tymczasem:

Jeśli chodzi o wszelkie inne przypadki wykorzystywania i przechowywania tych danych, z art. 4 ust. 3 rozporządzenia nr 2252/2004, który dotyczy wykorzystywania tych danych tylko "do celów [tego - przyp. aut.] rozporządzenia”, w związku z motywem 5 rozporządzenia $\mathrm{nr}$ 444/2009, którym zmieniono rozporządzenie nr 2252/2004, wynika, że przypadki te nie zostały uregulowane w tym rozporządzeniu. W myśl tego motywu bowiem rozporządzenie $\mathrm{nr}$ 2252/2004 pozostaje bez uszczerbku dla jakiegokolwiek innego wykorzystywania lub przechowywania takich danych zgodnie z przepisami krajowymi państw członkowskich i nie wprowadza podstawy prawnej dla tworzenia lub utrzymywania baz danych dla przechowywania tych danych w państwach członkowskich, co jest kwestią należącą wyłącznie do prawa krajowego $0^{358}$.

354 TSUE, Érsekcsanádi Mezőgazdasági Zrt p. Bács-Kiskun Megyei Kormányhivatal, C-56/13, wyrok z 22 maja 2014, pkt 54-57.

355 TSUE, W.P. Willems i in. p. Burgemeester van Nuth i in, C-446/12 do C-449/12, wyrok z 16 kwietnia 2015.

${ }^{356}$ Ibidem, pkt 45.

357 Ibidem, pkt 46; patrz też TSUE, Michael Schwarz p. Stadt Bochum, C-291/12, wyrok z 17 października 2013.

${ }^{358}$ TSUE, W.P. Willems i in. p. Burgemeester van Nuth i in, C-446/12 do C-449/12, wyrok z 16 kwietnia 2015, pkt 47. 
Dlatego też prowadzenie takich baz danych i wykorzystywanie zawartych w nich informacji podlegać może jedynie krajowym, ewentualnie międzynarodowym gwarancjom praw człowieka, którymi związane jest dane państwo. Nie wchodzi jednak w zakres zastosowania prawa Unii i unijne prawa człowieka nie mają do nich zastosowania.

W sprawie Dano ${ }^{359}$ Trybunał również nie znalazł podstaw do zastosowania Karty. Oparł się tu na zasadzie potwierdzonej już po wejściu w życie Karty, ale jeszcze przed wyrokiem w sprawie Åkerberg Fransson w kilku postanowieniach, w których orzekł o swej oczywistej niewłaściwości do wydania wyroku ze względu na brak związku z prawem Unii. Chodzi tu przede wszystkim o postanowienie w sprawie Chartry ${ }^{360}$, dotyczącej uregulowania krajowego przewidującego priorytetowy charakter postępowania wpadkowego w zakresie kontroli zgodności z konstytucją ustaw krajowych oraz analogicznych postanowieniach w sprawach Nagy ${ }^{361}$, dotyczącej przepisów prawa krajowego odnoszącego się do statusu urzędników państwa regulujących kwestię zwolnienia urzędników organu administracji publicznej zezwalających na zwolnienie bez przedstawienia powodu, czy w sprawie Cholakova ${ }^{362}$, dotyczącej krajowych przepisów zezwalających na zatrzymanie osoby w celu weryfikacji tożsamości. Podobnych postanowień - o oczywistej niewłaściwości TSUE do wydania wyroku - było zresztą więcej ${ }^{363}$. Postanowienia te łączyło użycie specyficznego sformułowania, zdaniem niektórych niestosownego ${ }^{364}$, które TSUE potraktował synonimicznie czy wręcz zastępczo do pojęcia "stosowania" prawa unijnego z art. 51 ust. 1 Karty, czy używanego od lat jako z nim równoznacznego: „działania w zakresie (zastosowania) prawa Unii”. Chodzi tu o określanie krajowych środków w przedmiotowych sprawach jako "niemających żadnego związku z prawem unijnym” czy jako "pozbawionych odpowiedniego

${ }^{359}$ TSUE, Elisabeta Dano i Florin Dano p. Jobcenter Leipzig, C-333/13, wyrok z 11 listopada 2014.

360 TSUE, Claude Chartry p. państwu belgijskiemu, C-457/o9, postanowienie z 1 marca 2011, pkt 25-27.

${ }^{361}$ TSUE, Nagy Sándor p. Hajdú-Bihar Megyei Kormányhivatal, Lajos Tiborné Böszörményi, Róbert Gálóczhi-Tömösváry, Magdolna Margit Szabadosné Bay p. Mezőgazdasági és Vidékfejlesztési Hivatal i Józsefné Ványai p. Nagyrábé Község Polgármesteri Hivatal, C-488/12, C-489/12, C-49o/12, C-491/12 i C-526/12, postanowienie z 1o października 2013, pkt 15.

362 TSUE, Gena Ivanova Cholakova p. Osmo rayonno upravlenie pri Stolichna direktsia na vatreshnite raboti, C-14/13, postanowienie z 6 czerwca 2013, pkt 32-33.

${ }^{363}$ Np.: TSUE, Krasimir Asparuhov Estov i inni p. Ministerski savet na Republika Bulgaria, C-339/10, postanowienie z 12 listopada 2010, pkt 14; TSUE, André Rossius i Marc Collard p. państwu belgijskiemu - Service public fédéral Finances, C-267/1o i C-268/1o postanowienie z 23 maja 2011, pkt 19; TSUE, Hubert Pagnoul p. państwu belgijskiemu, C-314/10, postanowienie z 22 września 2011, pkt 24.

${ }^{364}$ A. Rosas, The Applicability..., s. 110. 
łącznika z prawem unijnym". Wydaje się jednak, że o ile sformułowania takie faktycznie nie do końca odpowiadają terminologii użytej w odpowiednich przepisach prawnych, $\mathrm{w}$ tym przede wszystkim $\mathrm{w}$ art. $5^{1}$ ust. 1 Karty, to jednak dobrze oddają istotę problemu, jakim jest badanie czy do danych środków krajowych należy stosować unijne prawa podstawowe, czy nie. Jest to szczególnie widoczne w obliczu powiązania zakresu zastosowania prawa unijnego z jego efektywnościa, skutkującego istnieniem bądź nieistnieniem właśnie odpowiedniego związku przepisów krajowych z prawem unijnym. Faktycznie TSUE w warstwie językowej

nie jest tu konsekwentny i używa wielu różnych pojęć w celu określenia związania państw członkowskich postanowieniami Karty. W orzecznictwie polizbońskim pojawiły się m.in. takie określenia, jak: „sytuacje podlegające prawu Unii”, „wykonywanie prawa Unii", „w zakresie prawa Unii". Zasadniczo nie zmienia to jednak głównego problemu, jakim jest potrzeba znalezienia punktu stycznego z tym prawem - aby móc zastosować prawa podstawowe gwarantowane w Karcie ${ }^{365}$.

Sama sprawa Dano dotyczyła, w interesującym nas tu wymiarze, prawodawstwa unijnego odnoszącego się do koordynacji systemów zabezpieczenia społecznego państw członkowskich oraz prawa obywateli Unii oraz ich rodzin do swobodnego przemieszczania się i zamieszkiwania na terytorium państw należących do Unii. Trybunał nie stwierdził jednak swej właściwości do wypowiadania się $\mathrm{w}$ tej sprawie $\mathrm{w}$ przedmiocie unijnych gwarancji praw podstawowych. Zauważył bowiem, że określanie warunków do korzystania z pomocy społecznej nie wynikało z prawa unijnego, lecz z prawa państw członkowskich. Na podstawie swego wcześniejszego orzecznictwa TSUE stwierdził, że:

w [...] wyroku Brey [...] Trybunał potwierdził, iż art. 7 o rozporządzenia nr 883/2004, który definiuje pojęcie "specjalnych nieskładkowych świadczeń pieniężnych", nie ma na celu ustanowienia materialnych warunków, od których zależy istnienie prawa do wspomnianych świadczeń. Ustalenie tych warunków należy do ustawodawcy każdego z państw członkowskich ${ }^{366}$.

Trybunał podkreślił, że:

Z tego względu, jako że wspomniane warunki nie wynikają [...] z [...] aktów prawa wtórnego, a państwa członkowskie są zatem uprawnione do regulowania warunków przyznawania takich świadczeń, państwa te są [...] również uprawnione do

${ }^{365}$ R. Grzeszczak, A. Szmigielski, Sadowe stosowanie..., s. 14.

366 TSUE, Elisabeta Dano i Florin Dano p. Jobcenter Leipzig, C-333/13, wyrok z 11 listopada 2014, pkt 89 . 
określenia zakresu objęcia zabezpieczeniem społecznym w przypadku tego rodzaju świadczenia ${ }^{367}$.

Doprowadziło to Trybunał do następującego wniosku: „W rezultacie państwa członkowskie, ustalając warunki i zakres przyznawania specjalnych nieskładkowych świadczeń pieniężnych, nie stosują prawa Unii" ${ }^{\prime 368}$, co sprawia, że nie może być w takim wypadku mowy o zastosowaniu do tego rodzaju regulacji krajowych unijnych praw podstawowych.

W kontekście ewolucji podejścia do kwestii zastosowania unijnych praw podstawowych w orzecznictwie TSUE należy wskazać sprawę Pelckmans ${ }^{369}$. Jak się bowiem wydaje, opierając się na art. 51 ust. 1 Karty i na rozwijanym już na jego gruncie orzecznictwie dotyczącym zakresu zastosowania przepisów Karty do państw członkowskich, Trybunał zastosował w niej bardziej restrykcyjne podejście do zakresu zastosowania unijnych praw podstawowych niż jeszcze przed wejściem w życie Karty uczynił to w sprawie Karner ${ }^{370}$. Nota bene w wyroku w sprawie Pelckmans do sprawy Karner Trybunał się w ogóle nie odniósł, być może więc wąsko potraktował zakres sytuacji określonych w tej ostatniej (mieszczących się w ramach formuły Keck). Tym niemniej można odnieść wrażenie, że kwestia w sprawie Pelckmans była na tyle podobna do sytuacji w sprawie Karner, że można ją uznać za przykład odejścia w pewnym zakresie od rozszerzającego rozumienia zakresu stosowania unijnych praw podstawowych do państw członkowskich. Sprawa Pelckmans dotyczyła regulacji krajowych ustanawiających ograniczenia handlu w niedzielę, wprowadzonych przez ustawodawstwo belgijskie odnośnie do sklepów działających na terenie tego kraju. Pojawiło się pytanie czy przepisy te są zgodne z prawami zagwarantowanymi w Karcie (konkretnie z zasadą równości ustanowioną w art. 6 (3) TEU oraz w art. 20 i 21 Karty w związku z jej art. 15 i 16, gwarantującymi wolność wyboru zawodu i prawo do podejmowania pracy oraz wolność prowadzenia działalności gospodarczej).

Trybunał przypomniał po raz kolejny potwierdzoną przez siebie już wielokrotnie zasadę (z wyrokiem w sprawie Åkerberg Fransson na czele), że „zakres stosowania karty w odniesieniu do działań państw członkowskich został określony w jej art. 51 ust. 1, zgodnie z którym postanowienia karty mają zastosowanie do państw członkowskich tylko w sytuacji, gdy stosują one prawo

${ }^{367}$ Ibidem, pkt 90.

${ }^{368}$ Ibidem, pkt 91.

369 TSUE, Pelckmans Turnhout NV p. Walter Van Gastel Balen NV i inni, C-483/12, wyrok z 8 maja 2014 .

${ }_{370}$ TSUE, Herbert Karner Industrie-Auktionen GmbH p. Troostwijk GmbH, C-71/o2, wyrok z 25 marca 2004 . 
Unii $[\ldots]^{\prime \prime 371}$, oraz że: „Przepis ten potwierdza również utrwalone orzecznictwo, zgodnie z którym prawa podstawowe chronione w porządku prawnym Unii znajdują zastosowanie we wszystkich sytuacjach podlegających prawu Unii, ale nie poza takimi sytuacjami [... $]^{\prime 372}$. Przywołując także Wyjaśnienia dotyczące Karty"373, Trybunał jeszcze raz potwierdził, że „jeżeli stan prawny nie jest objęty zakresem stosowania prawa Unii, Trybunał nie jest właściwy do jego oceny, a przytaczane ewentualnie postanowienia karty nie mogą stanowić samodzielnej podstawy do nadania mu takiej właściwości $[\ldots]^{\prime \prime 374}$. Ponadto Trybunał zwrócił także uwagę na art. 6 ust. 1 TEU oraz art. 51 ust. 2 Karty podkreślające niemożność poszerzania zakresu kompetencji Unii na podstawie Karty. Trybunał przypomniał, że zgodnie $\mathrm{z}$ art. 6 ust. 1 TUE, postanowienia Karty w żaden sposób nie rozszerzają kompetencji Unii określonych w traktatach. „Podobnie na podstawie art. 51 ust. 2 karty nie rozszerza ona zakresu zastosowania prawa Unii poza kompetencje Unii, nie ustanawia nowych kompetencji ani zadań Unii, ani też nie zmienia kompetencji i zadań powierzonych jej w traktatach $[\ldots]^{\prime \prime 375}$. Poczyniwszy te wszystkie zastrzeżenia, Trybunał doszedł do konkluzji o braku swojej właściwości do orzekania w przedmiocie zgodności regulacji krajowych wprowadzających ograniczenia w handlu niedzielnym jako niemieszczących się w zakresie zastosowania prawa unijnego $^{376}$. Taki wniosek sformułował ze względu na to, że:

jeśli chodzi o stosowanie wskazanych przez ów sąd [odsyłający - przyp. aut.] art. 3436 TFUE w dziedzinie swobodnego przepływu towarów, należy przypomnieć, że Trybunał wielokrotnie orzekał, iż postanowienia te nie mają zastosowania do przepisów krajowych w zakresie zamykania sklepów, które obowiązują wszystkie podmioty gospodarcze prowadzące działalność na terytorium danego kraju i które mają zastosowanie bez rozróżnienia, de iure i de facto, do sprzedaży produktów pochodzenia krajowego i do produktów pochodzących z innych państw członkowskich [... $]^{377}$.

Odnośnie do swobody przepływu usług TSUE stwierdził natomiast:

Podobnie jeśli chodzi o art. 56 TFUE i 57 TFUE w dziedzinie swobodnego świadczenia usług, także przywołane przez sąd odsyłający, wystarczy stwierdzić, że rozpatrywane przepisy obowiązują wszystkie podmioty gospodarcze wykonujące działalność na terytorium kraju, które ponadto nie mają na celu uregulowania warunków

${ }^{371}$ TSUE, Pelckmans Turnhout NV p. Walter Van Gastel Balen NV i inni, C-483/12, wyrok z 8 maja 2014, pkt 17 .

372 Ibidem, pkt 18.

${ }^{373}$ Ibidem, pkt 19.

${ }^{374}$ Ibidem, pkt 20.

375 Ibidem, pkt 21.

${ }^{376}$ Ibidem, pkt 22-23.

${ }^{377}$ Ibidem, pkt 24. 
dotyczących świadczenia usług zainteresowanych przedsiębiorstw, oraz wreszcie że ograniczające skutki, jakie mogą one wywierać na swobodne świadczenie usług, są zbyt niepewne i zbyt pośrednie, aby ustanowiony przez nie obowiązek mógł być uważany za naruszający tę swobodę $[\ldots]^{378}$.

Sposób rozumowania odnośnie do kwestii związania państw członkowskich unijnymi prawami podstawowymi w tej sprawie wydaje się odmienny do tego, który Trybunał przyjął w sprawie Karner. Tym razem uznał, że skoro ograniczenia w handlu wprowadzane przez regulacje krajowe, nie mają charakteru utrudnień w funkcjonowaniu unijnych swobód, co zostało potwierdzone orzecznictwem TSUE w tej materii, to należy uznać, że pozostają one poza zakresem prawa unijnego i unijne prawa podstawowe nie znajdują do nich zastosowania. W sprawie Karner zaś dokonał wykładni unijnych praw podstawowych, co uznał wtedy za niezbędne sądowi krajowemu dla oceny krajowych regulacji, które również, z bardzo podobnych, choć formalnie nietożsamych powodów (wynikających z zastosowania formuły Keck) ${ }^{379}$, nie stanowiły utrudnienia dla funkcjonowania unijnych swobód. Być może Trybunał w sprawie Karner orzekł w taki, a nie inny sposób ze względu na to, że przepisy krajowe w tamtym przypadku miały pewien, choć bardzo ograniczony skutek dla handlu w wymiarze transgranicznym, nawet jeśli nie był to wpływ, do którego stosowałby się art. $34 \mathrm{TFUE}^{380}$.

Dostrzegając jednak fakt poczynienia przez TSUE tak wielu wspomnianych powyżej zastrzeżeń, których dokonał on w wyroku w sprawie Pelckmans, zanim doszedł on do wniosku o braku zastosowania Karty do przepisów krajowych, być może można sądzić, że dla zmiany podejścia Trybunału nie bez znaczenia była lizbońska struktura nadana unijnej ochronie praw człowieka, skłaniająca Trybunał do pewnej powściągliwości w wykładni art. 51 ust. 1 Karty. Po wyroku w sprawie Pelckmans za zasadę należy uznać, że Karta nie stosuje się do przepisów krajowych, które dotyczą wprawdzie unijnych swobód, ale w taki sposób, który pozostaje poza zakresem unijnych gwarancji tych swobód, a więc który na gruncie prawa unijnego nie może być uznany za ich ograniczenie ${ }^{381}$.

${ }^{378}$ Ibidem, pkt 25.

${ }^{379}$ Niektórzy twierdza, że TSUE błędnie nie powołał się w sprawie Pelckmans na formułę Keck, de facto stosując te same co zawarte w niej kryteria oceny krajowych środków pod kątem unijnych swobód. Odwołanie się do formuły Keck jeszcze bardziej upodobniłoby sprawy Pelckmans i Karner. Jednak nawet bez tego są one wystarczająco podobne, aby dostrzec rozbieżność w podejściu do interesującej nas w tym rozdziale kwestii, zaprezentowanym przez TSUE. Por. np.: T. Horsley, EU Law, Sunday Trading Restrictions ... and the Charter? [online] <http:// europeanlawblog.eu/?p=2372> [dostęp: 28.12.2018].

${ }^{380}$ Por.: D. Denman, The EU Charter..., s. 165.

${ }^{381}$ Por. też: N. Półtorak, Zakres związania..., s. 24. 


\section{Przykłady innych niż art. 51 ust. 1 zd. pierwsze Karty okoliczności wykluczających zastosowanie unijnych praw podstawowych wobec państw członkowskich}

Na zakończenie należy zauważyć, że art. 51 ust. 1 Karty i określony w nim zakres jej zastosowania wobec państw członkowskich, gdy stosują one prawo unijne, nie jest jedynym ograniczeniem zakresu zastosowania KPP. Na przykład w wyroku w sprawie $\mathrm{AMS}^{382}$, w której Trybunał orzekł o niemożności zastosowania Karty odnośnie do regulacji krajowej nie ze względu na art. 51 ust. 1 KPP i problem jej stosowalności do państw członkowskich, gdyż Karta jako taka była stosowalna. Sporna regulacja stanowiła wykonanie dyrektywy unijnej, co ze względów, o których wielokrotnie była już mowa, jest wystarczającym łącznikiem z prawem unijnym do zastosowania unijnych praw podstawowych do prawa krajowego ${ }^{383}$. Tym niemniej Trybunał nie zastosował w sprawie art. 27 Karty, gwarantującego prawo pracowników do informacji i konsultacji w ramach przedsiębiorstwa, mieszczący się w Tytule IV Karty („Solidarność”), jako że gwarancje w nim przewidziane nie mogą stanowić samodzielnego źródła uprawnień. „Z brzmienia art. 27 karty wynika [...] jasno, że aby artykuł ten wywierał w pełni zamierzone skutki prawne, musi zostać doprecyzowany przez przepisy prawa Unii lub prawa krajowego"384. Tymczasem tego rodzaju regulacji nie było. Jak podkreślił Trybunał:

okoliczności sprawy stanowiącej przedmiot postępowania głównego różnią się od okoliczności sprawy, w której wydany został [...] wyrok w sprawie Kücükdeveci, ponieważ zasada niedyskryminacji ze względu na wiek, której dotyczyła ta ostatnia sprawa, ustanowiona w art. 21 ust. 1 karty, wystarcza sama w sobie dla przyznania jednostkom prawa podmiotowego, które może być powoływane jako takie ${ }^{385}$.

Dlatego tė̇, mimo iż przepisy implementujące dyrektywę zostały uznane za niezgodne z prawem unijnym, ze względu na brak możliwości ich wykładni w zgodzie z brzmieniem dyrektywy, TSUE uznał jednak, że:

art. 27 karty, sam bądź w związku z przepisami dyrektywy 2002/14, należy interpretować w ten sposób, że gdy przepis prawa krajowego dokonujący transpozycji tej dyrektywy [...] okazuje się niezgodny z prawem Unii, to ten artykuł karty nie może

382 TSUE, Association de médiation sociale p. Union locale des syndicats CGT i inni, C-176/12, wyrok z 15 stycznia 2014.

${ }^{383}$ Ibidem, pkt $42-43$.

${ }^{384}$ Ibidem, pkt 45 .

${ }^{385}$ Ibidem, pkt 47 . 
być powoływany w sporze między jednostkami w celu spowodowania odstąpienia od stosowania tego przepisu prawa krajowego ${ }^{386}$.

Rozumowanie takie ma wyraźny związek z art. 51 ust. 1 Karty, lecz z jego zdaniem drugim, które brzmi: „Szanują one zatem prawa, przestrzegają zasad i popierają ich stosowanie zgodnie ze swymi odpowiednimi uprawnieniami i w poszanowaniu granic kompetencji Unii powierzonych jej w Traktatach". Przepis ten uwydatnia różnicę między prawami a zasadami zawartymi w Karcie. Te pierwsze są szanowane, a drugie przestrzegane. Jak przewiduje art. 52 ust. 5 Karty:

„Zasady mogą być wykonywane poprzez akty prawodawcze lub wykonawcze (przyjęte przez Unię zgodnie z jej uprawnieniami oraz Państwa Członkowskie jedynie gdy wykonują prawo Unii); stają się one zatem istotne dla sądów i trybunałów jedynie wtedy, gdy akty takie są interpretowane lub poddawane kontroli. Nie stanowią one podstawy do żadnych praw bezpośrednich do podejmowania działań pozytywnych przez instytucje Unii lub władze Państw Członkowskich" (Wyjaśnienia do art. 52 ust. $5 \mathrm{KPP})^{387}$.

Art. 51 ust. 1 ma niewątpliwie kluczowy charakter dla określania, kto i w jakich przypadkach jest zobowiązany do wypełniania unijnych gwarancji praw podstawowych. Należy wszakże zauważyć, że niektóre przepisy Karty sformułowane są w ten sposób, że dalej ograniczają jego zakres ratione materiae. Niektóre zagwarantowane w Karcie prawa są ograniczone przez zastrzeżenie, że są chronione "zgodnie z prawem Unii oraz ustawodawstwami i praktykami krajowymi” (art. 16 gwarantujaccy wolność prowadzenia działalności gospodarczej, art. 28 gwarantujący prawo do rokowań i działań zbiorowych, art. 30 gwarantujący ochronę w przypadku nieuzasadnionego zwolnienia z pracy). Podobne, choć nieco inne ograniczenia zawarto w art. 27 (Prawo pracowników do informacji i konsultacji w ramach przedsiębiorstwa) i 34 (Zabezpieczenie społeczne i pomoc społeczna). Dlatego też nawet jeśli spełnione zostaną kryteria art. 51 ust. 1, prawa zagwarantowane w tych przepisach moga podlegać pewnym wpływom je osłabiającym wynikającym zarówno z prawa i praktyki Unii, jak i jej państw członkowskich. Jeszcze bardziej enigmatyczne sformułowania pojawiają się w art. 35 (Ochrona zdrowia) i 36 (Dostęp do usług świadczonych w ogólnym interesie gospodarczym), których realizacja podporządkowana jest warunkom przewidzianym w ustawodawstwach i praktykach krajowych. Art. 52 ust. 6 Karty

${ }^{386}$ Ibidem, pkt 51.

${ }^{387}$ A. Wróbel, Art. 51..., s. 1329, patrz też s. 1330 i nast. Taką samą zasadę jak w sprawie EMS Trybunał zastosował np. także w sprawie Glatzel (TSUE, Wolfgang Glatzel p. Freistaat Bayern, C-356/12, wyrok z 22 maja 2014). 
stanowi w tym kontekście, że: „Ustawodawstwa i praktyki krajowe uwzględnia się w pełni, jak przewiduje to niniejsza Karta”. Równie mało przejrzyste są w tej materii wyjaśnienia do tego przepisu, które mówią jedynie, że „Ustęp 6 odnosi się do różnych artykułów Karty, które w duchu pomocniczości odsyłają do krajowych ustawodawstw i praktyk" ${ }^{\prime 388}$.

Należy więc pamiętać, że dla możliwości stosowania przepisów Karty znaczenie ma nie tylko sam jej art. 51 ust. 1 zd. pierwsze, lecz także powiązany z jego drugim zdaniem charakter normy ustanawianej przez Kartę, a mianowicie to, czy i w jakim zakresie stanowi ona prawo, a więc czy wynika z niej bezpośrednio uprawnienie dla jednostki, czy też ustanawia jedynie zasadę, dla skuteczności której muszą zostać wydane przepisy zmierzające do jej wykonania $^{389}$. Ponadto należy również pamiętać o innych okolicznościach, takich jak ograniczenia ratione materiae zawarte w poszczególnych przepisach Karty, a także o tym, że:

niektóre prawa (wolności, zasady) nie są jednoznacznie powiązane z wykonywaniem kompetencji UE. Nie ma bowiem wątpliwości, że w sytuacji, gdy przedmiot prawa podstawowego nie należy do kompetencji UE, wówczas tym bardziej państwo członkowskie nie ma kompetencji do wykonywania prawa UE w tym przedmiocie i nie jest związane przepisem ustanawiającym dane prawo podstawowe. Tego typu prawa zawarte w Karcie mają znaczenie głównie polityczne w tym sensie, że przyczyniają się do rozwoju wspólnych wartości narodów Europy wynikających ze wspólnych konstytucyjnych tradycji państw członkowskich (np. prawo do nauki, gwarantowane art. $14 \mathrm{KPP}[\ldots])^{390}$.

\section{Podsumowanie}

Zagadnienie zakresu zastosowania unijnych praw podstawowych wobec państw członkowskich Unii zostało rozwinięte i ugruntowane w rozległym orzecznictwie TSUE na przestrzeni lat. Wiele z tych orzeczeń omówiono albo wspominano w tym rozdziale. Omówienie czy nawet wyliczenie ich wszystkich nie byłoby jednak z perspektywy tego opracowania możliwe ani potrzebne. Kluczowe orzeczenie w sprawie Åkerberg Fransson było przywoływane przez TSUE i jego rzeczników generalnych w kilkudziesięciu orzeczeniach i opiniach. W większości z nich Trybunał doszedł do wniosku, że Karta nie znajduje zastosowania. Wiele z tych orzeczeń nie wnosi nic nowego do kwestii rozumienia

\footnotetext{
${ }^{388}$ Więcej na ten temat patrz np.: A. Ward, Art. 51..., s. 1415-1416.

${ }^{389}$ Por. także: A. Ward, Art. 51..., s. 1416-1417.

390 A. Wróbel, Art. $51 \ldots$, s. 1314 .
} 
art. 51 ust. 1 Karty, może poza wyrazem pewnej tendencji do - w miarę możliwości - powściagliwego stosowania zasady sformułowanej w tym wyroku w późniejszych sprawach ${ }^{391}$. Celem tego rozdziału było ukazanie na podstawie najważniejszych orzeczeń, ogólnych wniosków dotyczących zakresu związania państw członkowskich Unii unijnymi prawami podstawowymi w związku z brzmieniem art. 51 ust. 1 Karty. Celem tego rozdziału nie było także omówienie rozległej dyskusji, jaka na różnych etapach rozwoju orzecznictwa w tej materii toczyła się w doktrynie ${ }^{392}$.

Rozdział ten miał służyć do zarysowania swoistej linii demarkacyjnej między sytuacjami, w których do aktywności państw członkowskich zastosowanie powinny znajdować unijne prawa podstawowe, zgodnie ze zobowiązaniami, jakie państwa nałożyły na siebie, nadając Karcie status prawny, w tym szczególnie do aktywności polegającej na stanowieniu przez nie prawa, gdyż to właśnie kontrola prawa obowiązującego w Polsce jest tematem tej pracy, a sytuacjami, w których zastosowanie znajdują krajowe gwarancje praw człowieka. $\mathrm{W}$ rozdziale tym przedstawiono unijną perspektywę w tej materii, nie w pełni podzielaną w praktyce przez krajowe, w tym polskie, sądy i trybunały. O perspektywie polskiej mowa będzie w następnych rozdziałach. Zakres związania państw członkowskich, w tym Polski, unijnymi prawami podstawowymi określany jest jednak przez prawo unijne, którym Polska jest związana ze względu na swoje członkostwo tej organizacji. Dlatego też to właśnie analiza prawa unijnego jest w tej materii kluczowa.

Jak wynika z analizy przedstawionej w tym rozdziale zakres, w jakim unijne standardy praw podstawowych znajdują zastosowanie do prawa krajowego, jest szerszy niż mogłoby to wynikać z czysto językowej analizy brzmienia art. 51 ust. 1 KPP. Trybunał luksemburski wypracował w swym orzecznictwie różne kategorie sytuacji, w których unijne prawa podstawowe stosują się również do państw członkowskich. Składają się na nie przede wszystkim sprawy typu Wachauf, w których państwa członkowskie sensu stricto implementują prawo unijne, a więc wprowadzają je w sposób niezbędny dla jego skuteczności do systemu krajowego, sprawy typu ERT, w których państwa korzystają z sytuacji derogacyjnych, oraz inne sprawy, w których sytuacja podlega zakresowi prawa

${ }^{391}$ N. Półtorak, Zakres zwiazania..., s. 25.

392 Więcej na ten temat, oprócz pozycji przywoływanych w tym rozdziale, patrz np.: T. von Danwitz, K. Paraschas, A Fresh Start for the Charter: Fundamental Questions for the Application of the European Charter of the Fundamental Rights, "Fordham International Law Journal" 2012, 35, s. 1403-1413; F. Fontanelli, The Implementation of European Union Law by Member States Under Article 51(1) of the Charter of Fundamental Rights, "Columbia Journal of European Law" 2014, nr 20 (2); H. Kaila, The Scope of Application of the Charter of Fundamental Rights of the European Union in the Member States, [w:] P. Cardonnel, A. Rosas, N. Wahl (red.), Constitutionalizing the EU Judicial System: Essays in Honour of Pernilla Lindh, Oxford 2012; A. Knook, The Court..., s. 369-370. 
unijnego ze względu na inny łącznik z prawem unijnym i związek prawa krajowego z celem realizowanym przez prawo unijne. Co wszystkie te sytuacje łączy, to zasada efektywności prawa unijnego. Z orzecznictwa TSUE odnośnie do art. 51 ust. 1 Karty wynika wyraźnie, że zastosowanie KPP będzie miało miejsce w sytuacjach, „w których państwo członkowskie działa nie [tylko - przyp. aut.] w zakresie konkretnego przepisu unijnego zobowiązującego lub uprawniającego do danego działania, ale gdy działa w zasięgu zasady efektywności prawa unijnego" ${ }^{393}$. Wydaje się, "że podstawową wytyczna, którą miał na względzie TS, była potrzeba zapewnienia efektywności (effet utile) i jednolitości prawu unijnemu"394. Nawet jeśli można było przez moment mieć pewne wątpliwości, co do ewentualnego wahania się TSUE w tej materii, to późniejsze orzecznictwo, w tym to najaktualniejsze ${ }^{395}$, wątpliwości takie eliminuje.

Można podsumować, że:

dla zastosowania KPP wobec państw członkowskich - po stronie Unii musi istnieć kompetencja wyłączna lub zrealizowana kompetencja dzielona lub koordynacyjna, a po stronie państw członkowskich musi istnieć przepis krajowy pozostający w ramach tej kompetencji UE lub sytuacja faktyczna, mieszcząca się w tej kompetencji; przy czym przepis krajowy czy działanie państwa członkowskiego nie muszą stanowić bezpośredniego wykonania legislacji UE (wystarczy, że niezależnie od intencji państwa, służą lub przeszkadzają wykonaniu prawa UE), a także nie muszą regulować dokładnie tej samej kwestii, jaka występuje w legislacji unijnej ${ }^{396}$.

Niektórzy komentatorzy twierdzili, że utrzymanie takiej linii orzeczniczej i jej wyraz w sprawie Åkerberg Fransson po wejściu w życie Karty, było raczej nietrudne do przewidzenia w świetle wcześniejszego orzecznictwa TSUE ${ }^{397}$. Inni stali na stanowisku, że takie rozstrzygnięcie wcale nie w pełni jednoznacznie wynika z poprzedniego orzecznictwa Trybunału ${ }^{398}$. Jak jednak to pokazano $\mathrm{w}$ tym rozdziale, nawet jeśli wyrok w tej sprawie nie był koniecznym następ-

${ }^{393}$ N. Półtorak, Zakres związania..., s. 22.

${ }^{394}$ M. Wróblewski, Karta Praw Podstawowych Unii Europejskiej w polskim..., s. 20.

395 TSUE, Postępowanie karne przeciwko Gianpaolowi Paolettiemu i in., C-218/15, wyrok z 6 października 2016.

${ }^{396}$ N. Półtorak, Zakres zwiazania..., s. 22.

397 Patrz np.: M. Dougan, Judicial Review of Member State Action under the General Principles and the Charter: Defining the "Scope of Union Law", "Common Market Law Review" 2015, nr 52 (5), s. 1214-1215; P. Koutrakos, Does the United Kingdom Have a General Opt out from the EU Charter of Fundamental Rights?, "European Law Review” 2014, nr 39, s. 1.

${ }^{398}$ B. van Bockel, P. Wattel, New Wine..., s. 871; por. także: A.-L. Chané, A. Hauser, J. Jaraczewski, W. Jóźwicki, Z. Kędzia, M.A. Šimáková, H. Suchocka, S. Wallace, EU Engagement with Other European Regional Organisations (Work Package No. 5 - Deliverable No. 5.2), Fostering Human Rights Among European Policies, Large-Scale FP7 Collaborative Project GA No. 3200oo, s. 92, [online] <http://www.fp7-frame.eu/frame-reps-5-2/> [dostęp: 28.12.2018]. 
stwem wcześniejszego orzecznictwa, to był w nim dobrze osadzony. Co najważniejsze, sprawa Åkerberg Fransson i następujące po niej orzeczenia, rozstrzygnęły wiele wątpliwości dotyczących zakresu zastosowania unijnych praw podstawowych wobec państw członkowskich. Dokonały tego nie na zasadzie rewolucji, ale ewolucji.

Na obecnym etapie rozwoju orzecznictwa TSUE nie może być już wątpliwości co do szerokiej, a nie zawężającej interpretacji zakresu zastosowania wobec państw członkowskich unijnych praw podstawowych, nawet jeśli literalne brzmienie art. 51 ust. 1 Karty, szczególnie w polskiej wersji językowej, mogłoby sugerować inaczej. W swym orzecznictwie TSUE najszerzej jak to możliwe de lege lata zakreślił ramy zastosowania Karty do państw członkowskich. Jeśli chodzi o ocenę takiego podejścia, to należy zgodzić się z Niną Półtorak, której zdaniem:

Szeroka interpretacja art. 51 ust. 1 KPP, przyjęta przez TSUE w wyroku w sprawie Åkerberg Fransson, jest słuszna. Po pierwsze, potwierdza ciągłość dotychczasowego rozumienia związania państw członkowskich zakresem praw podstawowych; po drugie, pozwala na zrównanie zakresu obowiązywania praw podstawowych w Karcie i praw podstawowych jako zasad ogólnych Unii; po trzecie, jest najszerszą z możliwych - na podstawie treści art. 51 ust. 1 - wykładnią zakresu związania państw członkowskich unijnymi prawami podstawowymi (powstrzymującą się [przy] tym od zobowiązania państw do przestrzegania Karty poza zakresem prawa UE), a takie szerokie związanie jest pożądane dla wypracowania wspólnych standardów interpretacji i stosowania praw podstawowych w państwach członkowskich $\mathrm{UE}^{399}$.

Interpretacja taka pozwala także na uchwycenie funkcjonalnego, a nie tylko formalnego związku prawa krajowego z prawem unijnym, sprzyjającego integracji, nie podważając jednak przy tym zasady pomocniczości i autonomii systemów krajowych ${ }^{400}$.

Owo szerokie, nawet jeśli nie nieograniczone (co wyraźnie widać w orzecznictwie TSUE, szczególnie tym już z okresu po wyroku w sprawie Åkerberg Fransson) podejście prowadzić jednak może do powiększenia ryzyka zaistnienia pewnych kolizji czy nieporozumień między tym trybunałem a sądami czy trybunałami państw członkowskich. Przy takim rozumieniu art. 51 ust. 1 Karty, jakie zaprezentował TSUE, właściwie każde prawo krajowe może w jakimś zakresie okazać się podległe unijnym prawom podstawowym. $\mathrm{Na}$ podstawie wypracowanych przez TSUE kryteriów oceny, powiązanych z zasadą efektywności prawa unijnego, potencjalnie każdy przepis krajowy może

\footnotetext{
${ }^{399}$ N. Półtorak, Zakres zwiazania..., s. 21.

${ }^{400}$ M. Safjan, Areas of..., s. 5.
} 
być $\mathrm{w}$ pewnych sytuacjach uznany za mieszczący się w zakresie zastosowania prawa unijnego, szczególnie $\mathrm{w}$ związku z jego transgranicznym wymiarem, i jeśli będzie niezgodny z unijnymi prawami podstawowymi, nie będzie mógł być $\mathrm{w}$ tych sytuacjach stosowany (oczywiście odnośnie do sytuacji czysto wewnętrznych będzie mógł nadal funkcjonować). Patrząc z perspektywy państw członkowskich, tak szerokie stosowanie unijnych praw podstawowych może wiązać się z zagrożeniem dla ich kompetencji, jako że potencjalnie żadna dziedzina prawa krajowego nie może być uznana za w pełni niedostępną dla unijnych praw podstawowych ${ }^{401}$.

Obawy te mogą być szczególnie aktualne w obliczu tego, że zasada ogólna zawarta w sprawie Åkerberg Fransson nie jest w pełni precyzyjna i zawiera pewne półcienie, dopuszczające otwartość interpretacyjną, co pokazały wątpliwości wynikłe w różnych następujących po tym wyroku sprawach. Wątpliwości te związane były głównie $\mathrm{z}$ intensywnością koniecznego dla uznania zastosowania Karty powiązania prawa krajowego z prawem UE. Należy wszakże wyraźnie podkreślić, że jak pokazało wiele rozstrzygnięć Trybunału, wydanych w omówionych w tym rozdziale sprawach, w dość istotny sposób ograniczył on w nich zakres zastosowania Karty do państw członkowskich i złagodził potencjalne skutki zasady wyrażonej w sprawie Åkerberg Fransson ${ }^{402}$. Jeśli więc zgodzić się z niektórymi komentatorami, którzy dostrzegli pewien chłodzący efekt, jaki dla stosowania unijnych praw podstawowych wobec państw członkowskich przyniosło ze sobą uzyskanie przez Kartę mocy prawnejej ${ }^{403}$, to można w tym kontekście wskazać sprawy związane z unijnym obywatelstwem, przy braku jakiegoś związanego z jego posiadaniem uprawnienia wynikającego z prawa Unii, sytuacje o mniejszej intensywności związku regulacji krajowych ze swobodami wolnego rynku oraz sprawy, w których prawo unijne ma jedynie koordynujący, a nie harmonizujący charakter. W tego rodzaju przypadkach Karta nie znajduje zastosowania. Ponieważ jednak sprawy te trudno sklasyfikować jako otwarcie odstępujące od linii orzeczniczej sprzed wejścia w życie Karty, trudno jednoznacznie skonkludować, że to właśnie Karta skłoniła TSUE do ograniczenia zakresu zastosowania unijnych praw podstawowych wobec państw członkowskich.

Nie ulega natomiast wątpliwości, że na gruncie Karty aktualność zachowują wszystkie trzy rodzaje sytuacji, o których była mowa, w których unijne prawa podstawowe znajdują zastosowanie wobec państw członkowskich, a więc za-

${ }^{401}$ E. Spaventa, The Interpretation..., s. 12-13.

402 Por. np.: C. Murphy, Bulletin on the EU Charter of Fundamental Rights: An Introduction (Part 1), "European Human Rights Law Review" 2016, nr 21(1), s. 28; B. van Bockel, P. Wattel, New Wine..., s. 866.

${ }^{403}$ E. Spaventa, The Interpretation..., s. 32. 
równo sytuacje typu Wachauf $\mathrm{i}$ ich pochodne, sytuacje typu ERT i ich pochodne, oraz sytuacje, $w$ których mamy do czynienia $z$ innego rodzaju związkiem z prawem unijnym, charakteryzowanym głównie przez zasadę efektywności prawa unijnego.

Przy czym ta kategoria sytuacji jest najtrudniejsza do zdefiniowania z uwagi m.in. na niejednoznaczność orzecznictwa w przedmiocie wagi i ścisłości związku (łącznika [...]), jaki musi występować w danej sytuacji. [...] Szczegółowa analiza orzecznictwa TS dokonywana w literaturze wykazuje, że jednoznaczne ustalenie tego związku jest niekiedy niezwykle trudne, a judykatury TS w tym obszarze nie można uznać za ustabilizowaną ${ }^{404}$.

Liczba i różnorodność orzeczeń dotyczących zakresu zastosowania Karty $\mathrm{z}$ jednej strony pomogła $\mathrm{w}$ rekonstrukcji znaczenia jej art. 51 ust. 1. Z drugiej jednak strony być może nieco zaciemniła obraz faktycznego zakresu zastosowania unijnych praw podstawowych do państw członkowskich, otwierając w ten sposób przestrzeń do potencjalnego konfliktu również w tej materii, a więc już na etapie rozstrzygania czy $w$ danej sytuacji zastosowanie znajdują unijne prawa podstawowe, czy też nie, między TSUE a innymi sądami ${ }^{405}$. Co jednak najważniejsze z perspektywy tej pracy szeroka interpretacja art. 51 ust. 1 Karty zwiększyła pole potencjalnego konfliktu między krajowymi a unijnymi standardami ochrony praw człowieka, szczególnie w sytuacji, w której standardy krajowe byłyby wyższe niż unijne, co jest głównym przedmiotem zainteresowania tej pracy.

Recepcja wyroku w sprawie Åkerberg Fransson w systemach prawnych państw członkowskich pokazała, że państwa członkowskie i ich sądy wcale nie są skłonne w pełni przyjmować linii zaprezentowanej w tej sprawie przez TSUE i godzić się na tak szeroki zakres związania unijnymi prawami podstawowymi. Stąd być może to późniejsze ograniczanie zakresu związania państw członkowskich unijnymi prawami podstawowymi, jakie cechowało orzecznictwo TSUE. Faktycznie bowiem

niektóre państwa członkowskie oczekiwały innego, bardziej powściągliwego stanowiska TSUE. To, że spośród różnych określeń zakresu zastosowania unijnych praw podstawowych, używanych dotychczas w orzecznictwie TSUE (często używane były zwroty: sytuacji mieszczącej się w zakresie prawa UE; przepisów krajowych mieszczących się w zakresie zastosowania prawa UE; same zaś Wyjaśnienia do KPP posługują się zwrotem: działania państw w zakresie zastosowania prawa UE), wybrano

\footnotetext{
${ }^{404}$ M. Wróblewski, Karta Praw Podstawowych Unii Europejskiej w polskim..., s. 18.

${ }^{405}$ Por. np.: A.-L. Chané, A. Hauser, J. Jaraczewski, W. Jóźwicki, Z. Kędzia, M.A. Šimáková, H. Suchocka, S. Wallace, EU Engagement..., s. 92-93.
} 
W art. 51 ust. 1 KPP "stosowanie” (ang. implementing, fr. mettent en oeuvre), a więc zwrot, który można wąsko interpretować, może wskazywać na wolę państw jak najskromniejszego związania Kartą ${ }^{406}$.

Negatywna recepcja wyroku w tej sprawie szczególnie bezpośrednią formę przybrała w Niemczech, jednak nie tylko. Podobnie odniósł się do tego wyroku również brytyjski Sąd Najwyższy (Supreme Court) ${ }^{407}$, a także Izba Gmin, która wydała specjalny raport poświęcony Karcie i orzecznictwu z nią związanemu ${ }^{408}$.

Wydaje się, że TSUE wybierając drogę kontynuacji swojej wcześniejszej linii orzeczniczej, zlekceważył te wątpliwości bądź też chciał utwierdzić swoją pozycję wśród europejskich sądów i trybunałów, mimo pewnych tendencji zmierzających ku jej osłabieniu, i zamiast ograniczyć zakres sytuacji, w których Karta miałaby być podstawowym instrumentem determinującym standardy ochrony praw człowieka, rozszerzył go najdalej, jak to tylko było możliwe ${ }^{409}$.

Na to, że interpretacja art. 51 KPP dokonana przez TSUE może wychodzić poza oczekiwania państw członkowskich, wskazuje reakcja niemieckiego Bundesverfassungsgericht, który w wyroku z 24.04.2013 r. uznał, że orzeczenie Åkerberg Fransson należy interpretować jako odnoszące się do specyficznego przypadku regulacji VAT, gdyż gdyby miało zasięg szerszy, należałoby je uznać za wydane ultra vires i naruszające tożsamość konstytucyjną państw członkowskich ${ }^{410}$.

Chodzi tu o orzeczenie FTK, w którym uznał on za stosowne odnieść się do wyroku w sprawie Åkerberg Fransson, choć sytuacja wcale tego nie wymuszała. To nawiązanie należy więc odczytywać jako wyraźną deklarację w obliczu wspomnianego orzeczenia TSUE.

W przedmiotowej sprawie FTK stwierdził brak podstaw do tego, aby kwestię tworzenia baz danych w celu zwalczania terroryzmu poddawać prawu unijnemu i tym samym unijnym, a nie krajowym prawom podstawowym ${ }^{411}$. Wyrok

${ }^{406}$ N. Półtorak, Zakres związania..., s. 21.

407 Brytyjski Sąd Najwyższy, HS2 Action Alliance Limited v The Secretary of State for Transport, (2014) UKSC 3, wyrok z 22 stycznia 2013; więcej na ten temat patrz np.: J. Skrzydło, Karta Praw Podstawowych UE w praktyce brytyjskiej, "Europejski Przegląd Sądowy” 2015, nr 10.

${ }^{408}$ House of Commons, European Scrutiny Committee, The Application of the EU Charter of Fundamental Rights in the UK: A State of Confusion. Forty-third Report of Session 2013-14. Report, together with Formal Minutes, HC 979, Londyn 2014, [online] <http://www.publications.parliament.uk/pa/cm201314/cmselect/cmeuleg/979/979.pdf> [dostęp: 28.12.2018].

${ }^{409}$ A. Ward, Art. $51 \ldots$, s. 1425.

${ }^{410}$ N. Półtorak, Zakres związania..., s. 21.

${ }^{411}$ FTK, 1 BvR 1215/o7, orzeczenie z 24 kwietnia 2013; nota bene wydaje się to pozostawać $\mathrm{w}$ zgodzie $\mathrm{z}$ rozumowaniem przyjętym przez TSUE $\mathrm{w}$ wyroku w sprawie Willems (TSUE, 
ten FTK wydał niecałe dwa miesiące po wyroku w sprawie Åkerberg Fransson. W pewnym sensie prewencyjnie Trybunał z Karlsruhe podkreślił w tej sprawie, że wyrok w sprawie Åkerberg Fransson nie może być rozumiany jako rozszerzający zastosowanie unijnych praw podstawowych zawsze, gdy istnieje jakikolwiek związek przedmiotowej kwestii z abstrakcyjnym jedynie zakresem prawa Unii albo z jedynie incydentalnymi skutkami dla prawa unijnego. To byłoby za mało, aby związać państwa członkowskie unijnymi prawami podstawowymi zawartymi w Karcie. FTK stwierdził brak potrzeby zwracania się w tej sprawie z pytaniem prejudycjalnym do TSUE ${ }^{412}$ i podkreślił konieczność harmonijnego współistnienia (kooperatives Miteinanders) między oboma sądami, w ramach którego TSUE nie może być uznany za prawowitego arbitra w kwestiach, do których zastosowanie znajdują jedynie niemieckie - krajowe - gwarancje praw podstawowych ${ }^{413}$. Trybunał w Karlsruhe podkreślił też, wyrażone przez sam TSUE w wyroku Åkerberg Fransson, i później wielokrotnie przytaczane, szczególnie w sprawach, w których TSUE nie dochodził do wniosku o zastosowaniu unijnych praw podstawowych, zdanie, "że prawa podstawowe chronione w porządku prawnym Unii znajdują zastosowanie we wszystkich sytuacjach podlegajacych prawu Unii, ale nie poza takimi sytuacjami"414. Poza nimi znaleźć muszą się takie, które w sposób jedynie incydentalny łączą się z prawem unijnym, a więc pozostają całkowicie w gestii państw członkowskich. Bogate orzecznictwo FTK dotyczace kwestii unijnych i skomplikowana relacja z TSUE ${ }^{415}$, a także jego pokaźne dziedzictwo dotyczące doktryny ultra vires odnośnie do działań Unii, w tym aktywności trybunału luksemburskie$\mathrm{go}^{416}$, zostanie w dalszych częściach tej pracy przywołane jedynie o tyle, o ile

W.P. Willems i in. p. Burgemeester van Nuth i in, C-446/12 do C-449/12, wyrok z 16 kwietnia 2015), o której była mowa wcześniej.

${ }^{412}$ FTK, 1 BvR 1215/o7, orzeczenie z 24 kwietnia 2013, pkt 88

${ }^{413}$ Ibidem, pkt 91.

${ }^{414}$ Ibidem, pkt 91 (TSUE, Åklagaren p. Hans Åkerberg Fransson, TSUE, C-617/10, wyrok z 26 lutego 2013, pkt 19).

${ }^{415}$ Patrz np.: R. Arnold, Germany. The Federal Constitutional Court of Germany in the Context of the European Integration, [w:] P. Popelier, C. van de Heyning, P. van Nuffel (red.), Human Rights Protection in the European Legal Order: the Interaction Between the European and the National Courts, Cambridge-Antwerp-Portland 2011.

${ }^{416}$ Doktrynę tę, budowaną w swym orzecznictwie, FTK przeformułował nieco w wyroku w sprawie Honeywell (FTK, 2 BvR 2661/o6, orzeczenie z 6 lipca 2010, patrz przed. pkt 58 i nast.), dotyczącym omawianego w tej pracy wyroku TSUE w sprawie Mangold, i nadał jej nieco bardziej przyjazną Unii i jej prawu tonację, stwierdzając, że działanie TSUE mogłoby być uznane za działanie ultra vires jedynie, gdyby jego orzecznictwo prowadziło do zmiany traktatów lub przeniesienia kompetencji pozostających przy państwach członkowskich na Unię. Podkreślał w niej również kwestię harmonijnej współpracy między BVG a TSUE w ramach ich kompetencji, do czego nawiązał również we wspominanym tu wyroku 24 kwietnia 2013. Doktryna ta pozostaje jednak w rozumieniu Trybunału w Karlsruhe, mechanizmem oceny orzecznictwa 
będzie to istotne z perspektywy prezentowanej w niej tezy. Dość powiedzieć, że natychmiastowa reakcja FTK na wyrok w sprawie Åkerberg Fransson mogła mieć na celu skłonienie TSUE do pewnej powściągliwości w późniejszych wyrokach dotyczących art. 51 ust. 1 Karty ${ }^{417}$, co też nastąpiło.

Głównym celem, postawionym przed tą praca, jest jednak próba zaproponowania konkurencyjnego i - zdaniem autora - bardziej kooperacyjnego i być może nieco mniej kolizyjnego, sytuującego się - można powiedzieć - na przedpolu doktryny ultra vires, podejścia do relacji między TK a TSUE w zakresie kontroli prawa obowiązującego w Polsce przez pryzmat zgodności z prawami człowieka niż czyni to za pomocą doktryny ultra vires (we wspomnianym wyroku wymienionej jednym tchem z tożsamością konstytucyjną Republiki Federalnej Niemiec) niemiecki FTK.

O recepcji wyroku w sprawie Åkerberg Fransson przez polskie sądy, a szczególnie przez Trybunał Konstytucyjny, czy też szerzej o ich podejściu do kwestii stosowania unijnych praw podstawowych do prawa wydanego przez polskie organy do tego uprawnione, będzie mowa w następnym rozdziale. $\mathrm{Z}$ analizy przedstawionej $\mathrm{w}$ tym rozdziale wynikają istotne $\mathrm{z}$ perspektywy tezy formułowanej w tej pracy wnioski, sprowadzające się do tego, że określając zakres zastosowania Karty do państw członkowskich, TSUE wskazał linię delimitacji kompetencji do kontrolowania pod kątem zgodności z gwarancjami praw człowieka prawa obowiązującego w państwach członkowskich, w tym Polsce, między sobą a odpowiednimi organami krajowymi - w polskim przypadku jest to Trybunał Konstytucyjny. Obok klasycznego podziału na prawo unijne i jego kontrolę przez TSUE oraz na prawo polskie i jego kontrolę przez TK, TSUE dość daleko zakreślił zakres swojej kompetencji odnośnie do prawa, które należy jego zdaniem uznawać za stosowanie prawa Unii w rozumieniu art. 51 ust. 1 Karty i które w związku z tym musi spełniać zagwarantowane w Karcie standardy praw człowieka, których to on jest interpretatorem.

Dla prawidłowego zarysowania linii demarkacyjnej między unijnymi gwarancjami praw podstawowych a krajowymi, konstytucyjnymi gwarancjami praw człowieka kluczowa wydaje się ścisła współpraca między sądami krajowymi a TSUE i stosowanie przez te pierwsze unijnych praw podstawowych zawsze, gdy jest to uzasadnione, a więc w tych przypadkach, które mieszczą się w zakresie stosowania prawa UE $w$ rozumieniu art. 51 ust. 1 Karty. W razie watpliwości co do tego, czy właśnie z takim przypadkiem mamy do czynienia, sądy krajowe są zobowiązane do skorzystania z procedury pytania prejudycjalnego, które

TSUE i jego interpretacji prawa unijnego, w której FTK usiłuje w wyjątkowych sytuacjach zachować ostatnie słowo.

${ }^{417}$ Por. np.: Editorial Comments: Ultra vires - has the Bundesverfassungsgericht shown its teeth?, "Common Market Law Review" 2013, nr 50 (4), s. 925 i nast. 
pomoże rozwiać ewentualne wątpliwości, primo co do tego, czy dana sprawa mieści się w zakresie zastosowania prawa UE i ewentualnie, jeśli odpowiedź będzie twierdząca, secundo co do tego, jak należy rozumieć dane prawo podstawowe. Dialog i współpraca między sądami i trybunałami państw członkowskich i TSUE są więc wpisane we wspólnotowy porządek prawny. Bezwzględne stosowanie unijnych gwarancji praw człowieka do wszystkich sytuacji objętych zakresem prawa unijnego mogłoby okazać się jednak nie do zaakceptowania z perspektywy krajowej w przypadku konfliktu wyższego, krajowego standardu z niższym unijnym. Poprzez tak szerokie określenie zakresu zastosowania unijnych praw podstawowych wobec państw członkowskich, w tym wobec prawa polskiego, kosztem polskich standardów ochrony praw człowieka odnośnie do tego prawa i kompetencji TK w tym zakresie, TSUE powiększył potencjalną przestrzeń konfliktu.

Przestrzeń ta została w pewnym stopniu ograniczona przez sam TSUE poprzez, jak zostało to określone, mieszane (mixed) stosowanie unijnych i krajowych praw podstawowych w zakresie zastosowania Karty. Zarówno wyroki w sprawach Åkerberg Fransson ${ }^{418}$, jak i Siragusa ${ }^{419}$, które były przedmiotem analizy w tym rozdziale, a także wyrok w sprawie Melloni ${ }^{420}$, o którym bardziej szczegółowo będzie mowa w dalszych częściach pracy, ukazują pewną różnicę, jaka wiąże się z samym stwierdzeniem, że dana sytuacja mieści się w zakresie zastosowania prawa Unii i uruchomienia tym samym działania Karty wobec państw członkowskich, a jej rzeczywistym zastosowaniem w danej sprawie zamiast standardu krajowego.

Zakres zastosowania Karty do państw członkowskich (art. 51 ust. 1 KPP) powinien być definiowany szeroko, jako obejmujący wszystkie te sprawy, w których państwa członkowskie działają w zakresie zasady pierwszeństwa lub efektywności prawa UE. Określenie zastosowania ratione personae Karty powinno być niezależne od tego, jakie skutki dla prawa unijnego ma jej zastosowanie. Innymi słowy, ryzyko naruszenia unijnych praw podstawowych nie powinno mieć znaczenia dla określenia zakresu zastosowania KPP (interpretacji art. 51 ust. 1 KPP); a więc zakres zastosowania Karty nie powinien być rozumiany wąsko, gdy nie ma zagrożenia dla prawa UE, a szeroko, gdy takie ryzyko występuje $\mathrm{e}^{421}$.

Jak słusznie dodaje jednak Nina Półtorak, używając w kolejnej konfiguracji metafory opartej na pojawiających się niezwykle często w analizach kwepkt 29.

${ }^{418}$ TSUE, Åklagaren p. Hans Åkerberg Fransson, TSUE, C-617/10, wyrok z 26 lutego 2013,

419 TSUE, Cruciano Siragusa p. Regione Sicilia, C-206/13, wyrok z 6 marca 2014, pkt 32.

${ }^{420}$ TSUE, Stefano Melloni p. Ministerio Fiscal, C-399/11, wyrok z 26 lutego 2013, pkt 6o.

${ }^{421}$ N. Półtorak, Zakres zwiazania..., s. 26. 
stiach związanych z prawami człowieka i relacjach między różnymi reżimami je chroniącymi, i pisząc o „unijnym Solange”:

odmienną kwestią jest uzasadnienie potrzeby interwencji KPP - jej zastosowania zamiast krajowego standardu ochrony praw podstawowych. Uznanie, że dana sprawa mieści się w zakresie zastosowania KPP ratione personae, daje tylko możliwość jej zastosowania, a nie powoduje, że Karta musi być zastosowana w zastępstwie krajowych praw podstawowych. Karta powinna być bowiem uruchamiana subsydiarnie w stosunku do krajowych standardów ochrony praw podstawowych. W sytuacjach, gdy krajowe standardy są odpowiednie, nie stanowią zagrożenia dla standardu Karty ani dla wykonywania zobowiązań unijnych przez państwa członkowskie, powinny korzystać z pierwszeństwa stosowania ${ }^{422}$.

Unijne Solange miałoby więc polegać na tym, że jeżeli prawo krajowe, mieszczące się w zakresie zastosowania prawa Unii, nie narusza standardów ochrony unijnych praw podstawowych, ani nie zagraża zasadom pierwszeństwa, jedności i efektywności prawa unijnego, to uruchomienie Karty i niejako interwencja unijnego standardu nie jest potrzebna. Istnieje więc możliwość, ale brak jest potrzeby zastosowania Karty zamiast standardu konstytucyjnego ${ }^{423}$. Jak konkluduje Nina Półtorak:

kwestia zakresu zastosowania KPP powinna być oddzielona od kwestii potrzeby jej zastosowania (faktycznego uruchomienia w sprawie i zastąpienia prawa krajowego). Zakres podmiotowy Karty powinien być definiowany szeroko i obejmować wszystkie sprawy, w których istnieje jakikolwiek łącznik z prawem UE (jak stwierdza TS: nie mogą występować sytuacje podlegające prawu Unii, w których KPP nie będzie mogła zostać zastosowana). Natomiast łącznikiem powodującym jej uruchomienie (zastosowanie w konkretnej sprawie zamiast standardu krajowego) powinno być zagrożenie dla unijnego standardu ochrony praw podstawowych lub pierwszeństwa, jednolitości i efektywności prawa UE ${ }^{424}$.

Państwa są więc swobodne do zapewniania w swym prawie wyższego standardu ochrony niż prawo unijne nie tylko poza zakresem jego zastosowania, ale również w jego zakresie, jeśli nie wiąże się to z ograniczeniem wynikającym z pierwszeństwa, jednolitości i efektywności prawa unijnego. Przestrzeń potencjalnego konfliktu w przedmiocie stosowania unijnych bądź krajowych praw podstawowych sprowadza się więc w istocie rzeczy do tego zakresu zastosowania Karty, w którym wymusza ona swoje zastosowanie wraz z zasadami pierwszeństwa, jednolitości i efektywności prawa unijnego.
${ }^{422}$ Ibidem
${ }^{423}$ Ibidem.
${ }^{424}$ Ibidem. 
Próba wskazania drogi ku dalszemu zminimalizowaniu przestrzeni takiego konfliktu i znalezieniu kooperacyjnych, a nie kolizyjnych jego rozwiązań, zgodnej zarówno z prawem unijnym i orzecznictwem TSUE, jak i z prawem polskim i orzecznictwem TK, jest właśnie podstawowym celem tej pracy i zaprezentowana zostanie w następnych jej rozdziałach. Art. 51 ust. 1 Karty, i zawarta w nim zasada, powstał jako wypadkowa rozwoju unijnego systemu ochrony praw podstawowych, a szczególnie z dialogu między sądami krajowymi i TSUE na temat, jak zapewnić ochronę tym prawom przy jednoczesnym zachowaniu zasady pierwszeństwa ${ }^{425}$. Tak samo próby rozwiązywania problemów, jakie mogą powstać na gruncie potencjalnego konfliktu między krajowymi i unijnymi standardami ochrony praw człowieka w związku z autonomią prawa unijnego, powinny się opierać na dialogu między sądami. Jak słusznie zauważa Daniel Sarmiento, wyroki w sprawach Åkerberg Fransson, który był przedmiotem zainteresowania w tym rozdziale, oraz Melloni, o którym będzie mowa bardziej szczegółowo w rozdziale IV, legły u podstaw nowej architektury systemu ochrony praw podstawowych w Unii Europejskiej. Ta struktura nie opiera się jednak na wyłącznej władzy trybunału luksemburskiego, lecz na złożonym systemie mechanizmów kontroli i równowagi (checks and balances), które wymagają współpracy i zaangażowania zarówno ze strony TSUE, jak i najwyższych sądów i trybunałów, w tym sądów konstytucyjnych państw członkowskich $^{426}$. Propozycja, która przedstawiona zostanie w tej pracy, może być kolejną płaszczyzną dialogu i współpracy w ramach tego złożonego systemu, eliminująca, czy chociaż minimalizującą niebezpieczeństwo ujawnienia się pewnych jego sprzeczności i faktycznej kolizji między unijnymi a krajowymi gwarancjami praw człowieka.

${ }^{425}$ A. Ward, Art. 51..., s. 1450, por. też s. 1454.

${ }^{426}$ D. Sarmiento, Who's Afraid of the Charter? The Court of Justice, National Courts and the New Framework of Fundamental Rights Protection in Europe, "Common Market Law Review" 2013, nr 50 (5). 


\title{
Stosowanie unijnych praw podstawowych przez polskie sądy i funkcja tych sądów w unijnym systemie ochrony praw podstawowych
}

\section{Wstęp}

\begin{abstract}
A rt. 51 ust. 1 Karty oraz bogate orzecznictwo TSUE w tej materii i forAmułowane na jego podstawie wnioski delimitujące z perspektywy prawa unijnego strefy wpływu unijnych i krajowych standardów ochrony praw człowieka powinny być odzwierciedlane w aktywności sądów krajowych. Te ostatnie są przecież również sądami unijnymi i jako takie są odpowiedzialne za stosowanie prawa polskiego i prawa unijnego, w tym krajowych i unijnych gwarancji praw człowieka w sposób, w jaki odpowiada to krajowej i unijnej architekturze ochrony tych praw związanej ze specyfiką obu tych reżimów prawnych. „Dalsza ewolucja unijnych praw podstawowych na podstawie Karty trwa i stanowi wyraźny sygnał dla sądów krajowych o istotnym i rosnącym znaczeniu unijnego bill of rights. Sędziowie krajowi mają więc przed sobą trudne zadanie. W celu realizacji swojej roli jako gwaranta unijnych praw podstawowych muszą zmierzyć się z "prawną enigmą " 427 , jaką w pewnym sensie wciąż pozostaje zakres zastosowania unijnych praw podstawowych określony w art. 51 ust. 1 Karty. Jak najprecyzyjniejszemu wyjaśnieniu tej „enigmy” służył rozdział poprzedni. Dzięki opisanym w nim kryteriom, wypracowanym w orzecznictwie TSUE, sądy krajowe będą mogły lepiej odgrywać swą rolę.
\end{abstract}

${ }^{427}$ R. Grzeszczak, A. Szmigielski, Sądowe stosowanie..., s. 12. 
To właśnie „Sędziowie krajowi są głównymi aktorami zapewniającymi efektywność prawom i wolnościom uwzględnionym w Karcie" ${ }^{\prime \prime 28}$. Już w wyroku w sprawie Simmenthal trybunał luksemburski stwierdził, że:

sąd krajowy, mający w ramach swoich kompetencji za zadanie zastosować przepisy prawa wspólnotowego, zobowiązany jest zapewnić pełną skuteczność tych norm, nie stosując w razie konieczności, z mocy własnych uprawnień, wszelkich, nawet późniejszych, sprzecznych z nimi przepisów ustawodawstwa krajowego, i nie można przy tym wymagać od niego wnioskowania ani oczekiwania na zniesienie tych przepisów w drodze ustawodawczej lub w jakimkolwiek innym trybie konstytucyjnym $^{429}$.

Mówiąc krótko, jak wynika to z ugruntowanego orzecznictwa TSUE, „sędzia krajowy jest powołany do zapewnienia skuteczności prawa unijnego $\mathrm{w}$ tej roli staje się on sędzią europejskim" ${ }^{\prime 30}$. W związku z tym sądowe stosowanie Karty w Polsce, czy mówiąc szerzej, jej status w prawie polskim, w tym w interesującym nas $w$ tej pracy wymiarze relacji między TK i TSUE odnośnie do kontrolowania prawa obowiązującego w Polsce pod kątem zgodności z prawami człowieka, jest w dużej mierze uwarunkowany „zasadami ogólnymi prawa UE, w tym zasadą bezpośredniego skutku, zasadą pierwszeństwa i zasadą efektywności prawa UE"431.

W tym rozdziale uwaga będzie poświęcona praktyce sądów polskich w kwestii stosowania przez nie unijnych praw podstawowych. Praktyka sądów powszechnych, sądów administracyjnych i Sądu Najwyższego przedstawiona tu będzie w zakresie pozwalającym ukazać tendencję występująca w tych sądach odnośnie do interesującej nas tu materii. Pełna analiza czy nawet wyliczenie wszystkich spraw, w których pojawiało się odwołanie do Karty, znacznie przekraczałoby zakres tej pracy. Orzecznictwo sądów powszechnych, sądów administracyjnych i Sądu Najwyższego będzie zaprezentowane w tym rozdziale jako tło dla dalszych rozważań na temat zastosowania unijnych standardów praw człowieka w Polsce, a także jako ilustracja aktualnego stanu praktyki w tej materii, który odbiega od ideału, co może utrudniać prawidłowe stosowanie mechanizmu współpracy między TSUE a TK w sytuacji zaistnienia konfliktu między unijnym a wyższym niż unijny konstytucyjnym

\footnotetext{
${ }^{428}$ Cyt. za: M. Wróblewski, Ł. Bojarski, D. Schindlauer, K. Wladasch, Karta Praw..., s. 129.

${ }^{429}$ TSUE, Amministrazione delle Finanze dello Stato p. Simmenthal SA, C- 106/77, wyrok z 9 marca 1978, pkt 24.

${ }^{430} \mathrm{~J}$. Maliszewska-Nienartowicz, Naruszenie obowiązku notyfikacji przepisów technicznych a zasada pierwszeństwa prawa UE - glosa do postanowienia SN z 28.11.2013 r. (I KZP 15/13), „Europejski Przegląd Sądowy" 2014, nr 6, s. 46.

${ }^{431}$ A. Wróbel, O niektórych..., s. 83.
} 
standardem ochrony praw człowieka, który prezentowany będzie w dalszych rozdziałach. Nie sposób przecenić roli sądów polskich z perspektywy postulatów, jakie zostaną sformułowane w dalszych częściach pracy, co do podziału ról między TK a TSUE w tej delikatnej materii, sprowadzającego się do konieczności zachowania dość wrażliwej relacji między nimi w ramach specyficznej sekwencji orzekania zapewniającej im możliwość dialogu i współpracy. Bez świadomego udziału sądów powszechnych, sądów administracyjnych i Sądu Najwyższego, a także bez właściwego rozpoznania przez nie podstawowych zasad, na jakich opiera się podział kompetencji między TSUE a TK odnośnie do kontroli prawa obowiązującego w Polsce przez pryzmat zgodności z prawami człowieka, prawidłowe funkcjonowanie mechanizmu, który zaprezentowany zostanie $\mathrm{w}$ rozdziale IV, nie będzie możliwe, a przynajmniej będzie znacznie utrudnione.

Gdy mowa o stosowaniu unijnych praw podstawowych w Polsce nie można zapominać również o tzw. protokole brytyjsko-polskim ${ }^{432}$, dotyczącym kwestii zastosowania unijnych praw podstawowych w tych dwu państwach. Zgodnie z art. 51 TUE Protokół ten stanowi integralną część traktatów i wywiera te same co one skutki prawne, przynależy więc do korpusu prawa pierwotnego Unii. Dokument ten wzbudził liczne kontrowersje i wątpliwości co do ewentualnej modyfikacji zakresu zastosowania Karty wobec Polski i Wielkiej Brytanii w porównaniu do zasad zastosowania Karty względem innych państw członkowskich. Dlatego w rozdziale tym podjęta zostanie również próba odpowiedzi na pytanie, czy faktycznie Protokół ma wpływ na ogólne zasady zastosowania Karty. Analiza ta ograniczy się jedynie do perspektywy polskiej. Specyfika brytyjska, która w dużej mierze go ukształtowała, jako że to właśnie Wielka Brytania była głównym promotorem i negocjatorem tego dokumentu, a Polska jedynie się do niego przyłączyła, będzie tylko tłem dla oceny znaczenia Protokołu dla Polski.

\section{Protokół brytyjsko-polski i jego znaczenie dla stosowania Karty w Polsce}

Powstanie protokołu brytyjsko-polskiego wiązało się z kontrowersjami ujawnionymi w procesie prac nad KPP, a szczególnie nad jej art. 51 ust. 1. U źródeł powstania tego dokumentu legł opór, jaki Wielka Brytania prezentowała podczas tych prac względem szerokiego zakresu zastosowania unijnych praw

${ }^{432}$ Protokół (nr 30) w sprawie stosowania Karty praw podstawowych Unii Europejskiej do Polski i Zjednoczonego Królestwa, Dz.Urz. C 115 z 9 maja 2008. 
podstawowych wobec państw członkowskich oraz związanych z tym obaw dotyczących rozszerzenia kompetencji po stronie Unii. W obliczu braku pełnego sukcesu w forsowaniu swego stanowiska odnośnie do brzmienia art. 51 ust. 1 Karty Wielka Brytania uzyskała dołączenie do TUE i TFUE specjalnego protokołu dotyczącego szczególnych zasad zastosowania Karty względem niej. Do Protokołu, gdy był on już gotowy, zdecydowała się przystąpić również Polska. Możliwość przystąpienia do niego zarezerwowały sobie również Czechyy33, choć później zrezygnowały z jej wykorzystania ${ }^{434}$.

Rząd polski zdecydował się ponadto podkreślić swoje stanowisko dotyczące obaw co do potencjalnego wzrostu kompetencji po stronie Unii po nadaniu Karcie mocy prawnej poprzez dołączenie do Aktu Końcowego Konferencji przedstawicieli rządów państw członkowskich, która przyjęła Traktat lizboński, specjalnej deklaracji. Stwierdził w niej, że „Karta w żaden sposób nie narusza prawa Państw Członkowskich do stanowienia prawa w zakresie moralności publicznej, prawa rodzinnego, a także ochrony godności ludzkiej oraz poszanowania fizycznej i moralnej integralności człowieka"435. Deklaracja, odmiennie do Protokołu, jest jedynie wyrazem stanowiska i ze względu na swój prawny charakter nie może mieć innej wartości, jak sama nazwa wskazuje - deklaratoryjnej. Tym niemniej należy o tej deklaracji pamiętać jako o przejawie atmosfery politycznej, która towarzyszyła przyjęciu TL i nadaniu Karcie mocy prawnie wiążącej, której efektem było przyjęcie Protokołu nr 30. Treść deklaracji wyraźnie wskazuje na to, w jakiej materii rozszerzenia kompetencji Unii szczególnie obawiała się Polska i jakiego rodzaju obawy legły u podstaw przystąpienia do Protokołu. Może więc rzucać pewne światło na interpretację tych jego przepisów, które były szczególnie istotne z perspektywy brytyjskiej związane z prawami socjalnymi i pracowniczymi - a co do których strona polska miała znacznie mniej obaw.

Nawet jeśli nie było to intencją autorów Protokołu, a pamiętać należy, że już na etapie prac nad tym dokumentem, rozpoczętych w wyniku niezadowolenia delegacji brytyjskiej po tym jak w 2004 r. podjęta została decyzja o nadaniu Karcie mocy prawnej, Lord Goldsmith przyznawał, że:

${ }^{433}$ A. Rosas, The Applicability..., s. 104; por. także: M. Książkiewicz, Stosowanie Karty Praw Podstawowych Unii Europejskiej: Protokót brytyjski i Sprawozdania ze stosowania KPP UE, „Rocznik Integracji Europejskiej" 2012, nr 6, s. 339-340.

${ }^{434}$ R. Schütze, European Union Law, Cambridge 2015, s. 464.

${ }^{435}$ Deklaracja (nr 61) Rzeczypospolitej Polskiej w sprawie Karty praw podstawowych Unii Europejskiej, dołączona do Aktu Końcowego Konferencji przedstawicieli rządów państw członkowskich zwołanej w Brukseli w dniu 23 lipca 2007 roku w celu przyjęcia za wspólnym porozumieniem zmian do Traktatu o Unii Europejskiej, Traktatu ustanawiającego Wspólnotę Europejską oraz Traktatu ustanawiającego Europejską Wspólnotę Energii Atomowej, Dz.Urz. C 306 z 17 grudnia 2007. 
Protokołu nie należy traktować jako instrumentu wyłączającego stosowanie Karty (opt-out), lecz raczej jako gwarancję - potwierdzenie, że w relacjach z Wielką Brytanią i jej porządkiem prawnym ograniczenia z niej wynikające będą ściśle przestrzegane. W istocie protokół - pod warunkiem prawidłowej interpretacji i prawidłowego stosowania Karty - był zbędny ${ }^{436}$.

Jednakże w rozumieniu znacznej części opinii publicznej oraz w intencjach albo chociaż wrażeniu, jakie chciały one stworzyćc ${ }^{437}$ części elit politycznych w obu państwach, miał on

spowodować wyłączenie względem nich stosowania postanowień Karty (tzw. mechanizm derogacji, ang. opt-out). Także sposób relacjonowania treści Protokołu przez środki masowego przekazu, zarówno w Polsce, jak i w Wielkiej Brytanii, utrwalał to przekonanie. Tymczasem pobieżna nawet lektura postanowień Protokołu brytyjskiego nakazuje podać w wątpliwość takie - mocno uproszczone - jego rozumienie ${ }^{438}$.

Damian Chalmers, Gareth Davies i Giorgio Monti dostrzegają w Protokole chłodzący zamysł (chilling effect), kierujący do TSUE ostrzeżenie przed potencjalnym aktywizmem w stosowaniu Karty ${ }^{439}$. Protokół miałby mieć więc bardziej polityczną niż ściśle prawną wymowę. Jak zauważyła Anna Wyrozumska: „Traktat z Lizbony mocno akcentuje obawy państw członkowskich wobec aktywizmu ETS i wkraczania prawa UE w obszary zastrzeżone dla prawa krajowego"440. Wraz z Protokołem nr 30 również na gruncie Karty TSUE otrzymał kolejny „jasny sygnał wrażliwości państw członkowskich w tej sprawie"441. Od początku większość badaczy, którzy poświęcali swoją uwagę tematowi Protokołu, nie dostrzegała w nim waloru opt-out od postanowień Karty i wynikających stąd zobowiązań wiążących państwa członkowskie, w tym Polskę ${ }^{442}$. Ich zdaniem, ze względu na brzmienie zawartych w Protokole postanowień, miał on mieć interpretacyjny, doprecyzowujący czy też wręcz deklaratoryjny charakter ${ }^{443}$.

${ }^{436}$ Cyt. za: J. Skrzydło, Karta Praw..., s. 26.

${ }^{437}$ W 2007 r. premier Rządu Jej Królewskiej Mości Tony Blair mówił w Izbie Gmin, że „jest absolutnie jasne, że Wielka Brytania skorzystała z mechanizmu opt-out w stosunku do Karty w sprawach wewnętrznych" (cyt. za: J. Skrzydło, Karta Praw..., s. 26).

${ }^{438}$ J. Skrzydło, Karta Praw..., s. 25.

${ }^{439}$ D. Chalmers, G. Davies, G. Monti, European Union Law: Cases and Materials, Cambridge 2010, s. 258.

${ }^{440}$ A. Wyrozumska, Inkorporacja Karty Praw Podstawowych do prawa UE: status Karty w prawie UE, zakres obowiazywania i stosowania, główne problemy interpretacyjne z uwzględnieniem stanowiska polskiego, [w:] J. Barcz (red.), Ochrona praw podstawowych w Unii Europejskiej, Warszawa 20o8, s. 111.

${ }^{441}$ Ibidem, s. 112.

${ }_{442}$ A. Rosas, The Applicability..., s. 104.

${ }^{443}$ Patrz np.: W. Czapliński, Kilka uwag w kwestii możliwości wycofania się przez Polskę z protokołu polsko-brytyjskiego, "Studia Europejskie” 2012, nr 1, s. 89 i nast.; T.T. Koncewicz, A. Podolska, 
Tym niemniej pojawiali się również komentatorzy, którzy dostrzegali w nim mniej lub bardziej ograniczony potencjał derogacyjny ${ }^{444}$. Jak zauważa Angela Ward, dokument ten ma pewien potencjał do modyfikacji zakresu zastosowania Karty ratione materiae do spraw toczących się w Polsce, nawet jeśli ogólne kryteria z art. 51 ust. 1 Kary zostałyby spełnione ${ }^{445}$. Wyrażająca podobne obawy Catherine Barnard w ogólnym rozrachunku nazwała jednak Protokół w nieco publicystycznym stylu "picem na wodę" (smoke and mirrors) ${ }^{446}$, który miał pomóc przekonać brytyjską opinię publiczną, że TL różnił się od ostatecznie nieratyfikowanego Traktatu Konstytucyjnego, i zachęcić do jego poparcia. W obliczu częstego mieszania rozważań czysto prawnych z politycznymi Protokół dostarczył różnych wątpliwości, i jak twierdzi Vojtech Belling, urósł wręcz do rangi jednej z najtrudniejszych do interpretacji zmian unijnego prawa pierwotnego, jakie przyniósł ze sobą $\mathrm{TL}^{447}$. Ocenę tę uwiarygadnia burzliwa dyskusja w doktrynie prawa unijnego, jaka rozgorzała od razu po powstaniu Protokołu ${ }^{448}$.

Karta Praw..., s. 250-251; I. Pernice, The Treaty of Lisbon and Fundamental Rights, [w:] S. Griller, J. Ziller (red.), The Lisbon Treaty. EU Constitutionalism without Constitutional Treaty, Wiedeń-Nowy Jork 2008, s. 247-248; R. Wieruszewski, Rola i znaczenie Karty Praw Podstawowych Unii Europejskiej dla ochrony praw człowieka, "Przegląd Sejmowy” 2008, nr 2 (85), s. 56 i nast.; A. Wyrozumska, Znaczenie prawne zmiany statusu Karty Praw Podstawowych Unii Europejskiej w Traktacie lizbońskim oraz Protokołu polsko-brytyjskiego, „Przegląd Sejmowy” 20o8, nr 2 (85), s. 32 i nast.; A. Wyrozumska, Inkorporacja Karty..., s. 112.

${ }^{444}$ Patrz np.: L. Bosek, Ochrona godności człowieka w prawie Unii Europejskiej a konstytucyjne granice przekazywania kompetencji państwa, "Przegląd Sejmowy” 2008, nr 2; M. Jaśkowski, Konsekwencje prawne Protokołu nr 30 w sprawie stosowania Karty praw podstawowych Unii Europejskiej do Polski i Zjednoczonego Królestwa, "Zeszyty Prawnicze Biura Analiz Sejmowych" 2013, nr 4 (40); J. Jirásek, Application of the Charter of Fundamental Rights of the EU in the United Kingdom and Poland according to the Lisbon Treaty, Brno 2008; C. Mik, Karta Praw Podstawowych: wyznaczniki standardów ochrony, [w:] J. Barcz (red.), Ochrona praw podstawowych w Unii Europejskiej, Warszawa 2008; Opinia [Rady Legislacyjnej] z 17 marca 2008 r. w sprawie skutków prawnych Karty Praw Podstawowych, RL-0303-8/o8, [online] <http://radalegislacyjna.gov.pl/dokumenty/opinia-z-17-marca2008-r-w-sprawie-skutkow-prawnych-karty-praw-podstawowych> [dostęp: 28.12.2018].

${ }^{445}$ A. Ward, Art. $51 \ldots$, s. 1420.

${ }^{446}$ C. Barnard, The 'Opt-Out' for the UK and Poland from the Charter of Fundamental Rights: Triumph of Rhetoric over Reality? [w:] S. Griller, J. Ziller (red.), The Lisbon Treaty. EU Constitutionalism without Constitutional Treaty, Wiedeń-Nowy Jork 2008, s. 281.

${ }^{447}$ V. Belling, Supranational Fundamental Rights or Primacy of Sovereignty? Legal Effects of the So-Called Opt-Out from the EU Charter of Fundamental Rights, "European Law Journal” 2012, nr 18 (2), s. 251.

${ }^{448}$ Więcej na temat dyskusji nad charakterem Protokołu zarówno bezpośrednio po jego powstaniu, jak i później patrz też np.: A. Arnull, Protocol (No 30) on the Application of the Charter of Fundamental Rights of the European Union to Poland and the United Kingdom, [w:] S. Peers, T. Harvey, J. Kenner, A. Ward (red.), The EU Charter of Fundamental Rights. A Commentary, Oxford 2014, s. 1596-1597 i nast. oraz podana tam literatura; S. Biernat, Czy Karta Praw Podstawowych Unii Europejskiej obowiązuje w Polsce? [w:] P. Kardas, T. Sroka, W. Wróbel (red.), Państwo prawa 
Protokół składa się z dwóch artykułów, zawierających trzy przepisy. Stanowią one, po pierwsze, że:

Karta nie rozszerza zdolności Trybunału Sprawiedliwości Unii Europejskiej ani żadnego sądu lub trybunału Polski lub Zjednoczonego Królestwa do uznania, że przepisy ustawowe, wykonawcze lub administracyjne, praktyki lub działania administracyjne Polski lub Zjednoczonego Królestwa są niezgodne z podstawowymi prawami, wolnościami i zasadami, które są w niej potwierdzone [art. 1 ust. 1 ].

Po drugie, że:

W szczególności i w celu uniknięcia wszelkich wątpliwości nic, co zawarte jest w Tytule IV Karty nie tworzy praw, które mogą być dochodzone na drodze sądowej, mających zastosowanie do Polski lub Zjednoczonego Królestwa, z wyjątkiem przypadków, gdy Polska lub Zjednoczone Królestwo przewidziały takie prawa w swoim prawie krajowym [art. 1 ust. 2].

\section{Oraz po trzecie, że:}

Jeżeli dane postanowienie Karty odnosi się do ustawodawstw i praktyk krajowych, ma ono zastosowanie do Polski lub Zjednoczonego Królestwa wyłącznie w zakresie, $\mathrm{w}$ jakim prawa i zasady zawarte $\mathrm{w}$ tym postanowieniu są uznane przez ustawodawstwo lub praktyki Polski lub Zjednoczonego Królestwa [art. 2].

Protokół został poprzedzony znacznie obszerniejszą Preambułą, w której zawarto motywy leżące u źródeł jego powstania ${ }^{449}$. Preambuła nie ma charakte-

i prawo karne. Ksiega jubileuszowa Profesora Andrzeja Zolla, Warszawa 2012, s. 61-77; K. Kowalik-Bańczyk, Konsekwencje przyjęcia protokołu polsko-brytyjskiego dotyczącego stosowania Karty Praw Podstawowych, [w:] A. Wróbel (red.), Karta Praw Podstawowych w europejskim i krajowym porządku prawnym, Warszawa 2009, s. 137-139 i przywoływana tam literatura; idem, Protokół w sprawie stosowania Karty Praw Podstawowych Unii Europejskiej do Polski i Zjednoczonego Królestwa, [w:] A. Wróbel (red.), Karta Praw Podstawowych Unii Europejskiej. Komentarz, Warszawa 2013, s. 14161417 i przywoływana tam literatura.

${ }^{449}$ Stwierdzono w niej, że: „W SPRAWIE STOSOWANIA KARTY PRAW PODSTAWOWYCH UNII EUROPEJSKIEJ DO POLSKI I ZJEDNOCZONEGO KRÓLESTWA WYSOKIE UMAWIAJĄCE SIĘ STRONY, MAJĄC NA UWADZE, że w artykule 6 Traktatu o Unii Europejskiej Unia uznaje prawa, wolności i zasady określone w Karcie praw podstawowych Unii Europejskiej, MAJĄC NA UWADZE, że Karta ma być stosowana w ścisłej zgodności z postanowieniami wspomnianego wyżej artykułu 6 i tytułu VII samej Karty, MAJĄC NA UWADZE, że wspomniany artykuł 6 stanowi, że Karta jest stosowana i interpretowana przez sądy Polski i Zjednoczonego Królestwa w ścisłej zgodności z wyjaśnieniami, o których mowa w tym artykule, MAJĄC NA UWADZE, że Karta zawiera zarówno prawa, jak i zasady, MAJĄC NA UWADZE, że Karta zawiera zarówno postanowienia o charakterze obywatelskim i politycznym, jak i postanowienia o charakterze gospodarczym i społecznym, MAJĄC NA UWADZE, że Karta potwierdza prawa, 
ru wiążącego i oczywiście w żadnym sensie nie może być uznana za podstawę podważenia któregokolwiek z przepisów Protokołu ${ }^{450}$. Nie można jednak nie brać jej pod uwagę przy interpretacji tych ostatnich, szczególnie w obliczu ich niejednoznaczności.

\subsection{Sprawa Bonda}

Być może dogodną okazją do rozwiania wątpliwości narosłych wokół interpretacji Protokołu i jego znaczenia była zainicjowana przez Sąd Najwyższy w trybie pytania prejudycjalnego sprawa Bonda ${ }^{451}$. Na jej gruncie Rzeczniczka Generalna Juliane Kokott poczyniła w swej opinii przedstawionej w sprawie pewne uwagi dotyczące Protokołu, a szczególnie jego art. 1 ust. 1, jako niemającego charakteru opt-out'u od postanowień Karty i tym samym niewpływającego na jej zakres zastosowania wobec państw, które do Protokołu przystąpiły. Trybunał z okazji tej jednak nie skorzystał i nie odniósł się ani szczegółowo do kwestii Protokołu, ani nawet do możliwości zastosowania w tej sprawie unijnych praw podstawowych w związku ze znajdującymi w niej zastosowanie przepisami krajowymi.

Sprawa Bonda dotyczyła charakteru sankcji wynikających z unijnego rozporządzenia dotyczącego dopłat rolnych. SN powoływał się w tej sprawie na konieczność rozstrzygnięcia przez TSUE o charakterze tych, przewidzianych przez prawo unijne sankcji, ze względu na znaczenie tej oceny dla ochrony standardów praw jednostki zagwarantowanych w prawie polskim oraz EKPCz.

wolności i zasady uznawane w Unii oraz sprawia, że są one bardziej widoczne, nie tworzy jednak nowych praw ani zasad, PRZYPOMINAJĄC zobowiązania Polski i Zjednoczonego Królestwa wynikające z Traktatu o Unii Europejskiej, Traktatu o funkcjonowaniu Unii Europejskiej, jak również ogólnie pojętego prawodawstwa Unii, PRZYJMUJĄC DO WIADOMOŚCI pragnienie Polski i Zjednoczonego Królestwa sprecyzowania pewnych aspektów stosowania Karty, PRAGNĄC zatem sprecyzować stosowanie Karty w stosunku do przepisów prawnych i działań administracyjnych Polski i Zjednoczonego Królestwa oraz możliwość rozpoznawania na podstawie postanowień Karty spraw na drodze sądowej w Polsce i Zjednoczonym Królestwie, POTWIERDZAJĄC, że zawarte w niniejszym Protokole odniesienia do wprowadzania w życie poszczególnych postanowień Karty pozostają ściśle bez uszczerbku dla wprowadzania w życie innych postanowień Karty, POTWIERDZAJĄC, że niniejszy Protokół pozostaje bez uszczerbku dla stosowania Karty w stosunku do innych Państw Członkowskich, POTWIERDZAJĄC, że niniejszy Protokół pozostaje bez uszczerbku dla innych zobowiązań Polski i Zjednoczonego Królestwa wynikających z Traktatu o Unii Europejskiej, Traktatu o funkcjonowaniu Unii Europejskiej oraz ogólnie pojętego prawodawstwa Unii, UZGODNIŁY następujące postanowienia, które są dołączone do Traktatu o Unii Europejskiej i do Traktatu o funkcjonowaniu Unii Europejskiej".

${ }^{450}$ C. Mik, Karta Praw..., s. 78.

${ }^{451}$ TSUE, Postępowanie karne przeciwko Łukasz Marcin Bonda, C-489/10, wyrok z 5 czerwca 2012. 
Pytanie skierowane przezeń do TSUE brzmiało: „Jaki jest charakter prawny sankcji przewidzianej w art. 138 [rozporządzenia nr 1973/2004], polegającej na pozbawieniu rolnika dopłat bezpośrednich w kolejnych latach następujących po roku, w którym rolnik złożył nieprawdziwe oświadczenie co do wielkości areału stanowiącego podstawę [jednolitej płatności obszarowej]?"452. Rozstrzygnięcie charakteru tych sankcji miało być konieczne dla zbadania, czy w postępowaniu głównym nie doszło do naruszenia zasady ne bis in idem. SN chciał wiedzieć, czy art. 138 rozporządzenia

należy interpretować w ten sposób, że środki przewidziane w akapitach drugim i trzecim tego przepisu, polegające na wykluczeniu rolnika z pomocy w roku, w którym złożył nieprawdziwe oświadczenie co do wielkości kwalifikującego się areału, i na obniżeniu pomocy, do której byłby uprawniony w trzech kolejnych latach kalendarzowych, do kwoty, która odpowiada różnicy między areałem zadeklarowanym a wyznaczonym, stanowią sankcje o charakterze karnym ${ }^{453}$.

Wyjaśnienie takie zdaniem SN było konieczne do tego, by ocenić, czy zakaz podwójnego karania za ten sam czyn, a więc zasada ne bis in idem, "ujęta $\mathrm{w}$ art. 17 ust. 1 pkt 7 Kodeksu postępowania karnego, może być zastosowana w zawisłym przed nim postępowaniu" 454 dotyczącym Łukasza Bondy, w obliczu objęcia czynu, jakiego się on dopuścił również sankcją, która już bez wątpienia miała charakter karny, przewidzianą w polskim Kodeksie karnym. Zdaniem SN art. 17 par. 1 pkt 7 Kpk mógłby jednak zostać zastosowany "tylko wtedy, gdy środki przewidziane $w$ tym art. 138 ust. 1 można uznać za sankcje o charakterze karnym" ${ }^{\prime \prime 5}$.

Wątpliwość SN wynikała z faktu, że pan Łukasz Bonda, zgodnie z art. 138 przedmiotowego rozporządzenia unijnego, został ukarany decyzją kierownika Biura Powiatowego Agencji Restrukturyzacji i Modernizacji Rolnictwa za złożenie nieprawdziwego oświadczenia dotyczącego ilości uprawianych gruntów rolnych i prowadzonych upraw na tych gruntach, zawyżającego deklarację dotyczącą powierzchni użytkowanej rolniczo ${ }^{456}, \mathrm{w}$ postaci, z jednej strony odmowy przyznania mu jednolitej płatności obszarowej w 2005 r., z drugiej zaś nałożenia na niego sankcji w postaci utraty uprawnień do jednolitej płatności obszarowej w wysokości kwoty odpowiadającej różnicy między powierzchnią rzeczywistą a zadeklarowaną w trzech kolejnych latach następujących po

\footnotetext{
452 Ibidem, pkt 25.

${ }^{453}$ Ibidem, pkt 26.

${ }^{454}$ Ibidem, pkt 26.

455 Ibidem, pkt 27.

${ }^{456}$ Ibidem, pkt 17.
} 
roku, w którym nastąpiło złożenie nieprawdziwego oświadczenia ${ }^{457}$. Spotkała go więc sankcja przewidziana przez prawo unijne. Ponadto jednak:

Sąd Rejonowy w Goleniowie wyrokiem z dnia 14 lipca 2009 r. skazał Ł. Bondę za popełnienie przestępstwa oszustwa subwencyjnego przewidzianego w art. 297 $\S$ I Kodeksu karnego, polegającego na tym, że w celu uzyskania dotacji poświadczył nieprawdę co do okoliczności o istotnym znaczeniu dla uzyskania jednolitej płatności obszarowej. Z tego tytułu wymierzono mu karę pozbawienia wolności w wymiarze 8 miesięcy z warunkowym zawieszeniem jej wykonania na okres 2 lat, a nadto karę grzywny w rozmiarze 80 stawek dziennych po 20 PLN każda ${ }^{458}$.

\section{Od tego wyroku Łukasz Bonda się odwołał}

do Sądu Okręgowego w Szczecinie, który uchylił wyrok Sądu Rejonowego w Goleniowie i stwierdził, że postępowanie karne jest niedopuszczalne z tego powodu, iż Ł. Bondzie wymierzono już sankcję o charakterze administracyjnym za ten sam czyn. W konsekwencji sąd ten, opierając się na art. $17 \S 1$ pkt 11 Kodeksu postępowania karnego, stwierdził niedopuszczalność postępowania i umorzył je wyrokiem z dnia 19 marca 2010 r. ${ }^{459}$

Wyrok ten został zaskarżony kasacją przez Prokuratora Generalnego ${ }^{460}$.

SN odrzucił możliwość umorzenia postępowania karnego przeciwko Łukaszowi Bondzie na podstawie art. 17 par. 1 pkt 11 mówiącego o innych okolicznościach wyłączających ściganie. Nie można bowiem do nich zaliczyć sankcji administracyjnych ${ }^{461}$. SN uznał jednak, że jeśli sankcja przewidziana w unijnym rozporządzeniu miała charakter karny, do stwierdzenia czego kompetentny jest TSUE, to istniała możliwość zastosowania art. 17 par. 1 pkt 7 Kodeksu postępowania karnego ${ }^{462} \mathrm{i}$ umorzenia postępowania karnego za ten sam czyn, za który sprawca został już ukarany. Jeśli jednak sankcja przewidziana przez prawo unijne miała charakter administracyjny, to w związku z literalnym brzmieniem art. 17 par. 1 pkt 7 za podstawę do umorzenia na podstawie tego przepisu nie mogła być uznana. Przepis ten stanowi bowiem, że: „Nie wszczyna się postępowania, a wszczęte umarza, gdy: [...] postępowanie karne co do tego samego czynu tej samej osoby zostało prawomocnie zakończone albo wcześniej wszczęte toczy się". SN wyjaśnił w tym kontek-

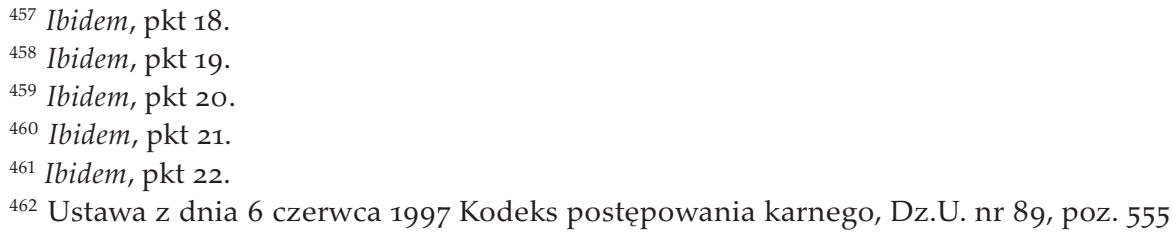


ście także, „że choć literalna wykładnia tego przepisu prowadzi do negatywnej odpowiedzi na to pytanie, to jednak przepis ten musi być interpretowany w świetle art. 4 ust. 1 protokołu nr 7 [do EKPCz - przyp. aut.]"463. Art. 4 ust. 1 Protokołu nr 7 stanowi, że: „Nikt nie może być ponownie sądzony lub ukarany w postępowaniu przed sądem tego samego państwa za przestępstwo, za które został uprzednio skazany prawomocnym wyrokiem lub uniewinniony zgodnie z ustawą i zasadami postępowania karnego tego państwa"464. Należało więc nie tylko zastanowić się, jaka była podstawa i tryb wymierzania sankcji, ale czy ze względu na swój charakter nie urastała do sankcji karnej, choć formalnie nawet by takiej nie stanowiła.

Sprawa ta dotyczyła zasady ne bis in idem w ograniczonym zakresie, a więc tego, jak została ona wyrażona w art. 17 ust. 1 pkt 7 Kodeksu postępowania karnego w związku z Protokołem dodatkowym nr 7 do EKPCz. SN pominął w swym pytaniu kwestię Karty i unijnych praw podstawowych, które zasadę tę również obejmują. Kwestii tej nie podniósł także TSUE. Stwierdził, że sankcje przewidziane w rozporządzeniu nie mają charakteru karnego, o czym orzekał już w swym wcześniejszym orzecznictwie ${ }^{465}$ i podkreślił ich znaczenie dla prawidłowego funkcjonowania systemu pomocy w rolnictwie ${ }^{466}$ oraz konieczność wypełniania przez podmioty z pomocy tej korzystające wysokich standardów wiarygodności ${ }^{467}$. Skonkludował, że „kary administracyjne ustanowione zgodnie z celami wspólnej polityki rolnej stanowią integralną część systemów pomocy; mają własny cel i mogą być stosowane niezależnie od ewentualnych sankcji karnych, jeżeli i w zakresie, w jakim nie są równoważne z tymi karami" ${ }^{\prime 468}$. TSUE doszedł również do wniosku, że nie stoi to w sprzeczności z EKPCz, a miano-

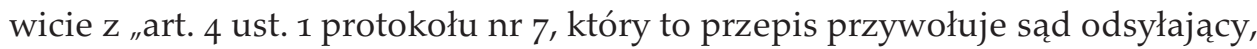
nie podważa w niniejszej sprawie administracyjnego charakteru środków przewidzianych art. 138 ust. 1 akapity drugi i trzeci rozporządzenia nr 1973/2004"469. TSUE podkreślił, że sankcja przewidziana w rozporządzeniu odpowiada trzem kryteriom sformułowanym w tej materii przez orzecznictwo ETPC ${ }^{470}$. Nie jest więc po pierwsze, przez prawo krajowe (w tym wypadku prawo Unii) uznawa-

${ }^{463}$ TSUE, Postępowanie karne przeciwko Łukasz Marcin Bonda, C-489/10, wyrok z 5 czerwca 2012, pkt 23.

${ }^{464}$ Protokół nr 7 do Konwencji o Ochronie Praw Człowieka i Podstawowych Wolności, przyjęty w Strasburgu dnia 22 listopada 1984, Dz.U. z 2003 nr 42, poz. 364.

${ }^{465}$ TSUE, Postępowanie karne przeciwko Łukasz Marcin Bonda, C-489/10, wyrok z 5 czerwca 2012, pkt 28.

${ }^{466}$ Ibidem, pkt 29.

${ }^{467}$ Ibidem, pkt 30.

${ }^{468}$ Ibidem, pkt 35 .

${ }^{469}$ Ibidem, pkt 36.

${ }^{470}$ Ibidem, pkt 37 . 
na za sankcję karną ${ }^{471}$. Po drugie, nie ma celu represyjnego, lecz co do istoty ma na celu ochronę zarządzania funduszami Unii poprzez czasowe wykluczenie beneficjenta, który złożył nieprawdziwe oświadczenia ${ }^{472}$ oraz, że może ona okazać się bezskuteczna, jeśli np. beneficjent nie złoży w następnych latach wniosku o dofinansowanie, nie ma więc charakteru bezwzględnego ${ }^{473}$. Po trzecie wreszcie, TSUE stwierdził, że jedynym skutkiem sankcji przewidzianej $\mathrm{w}$ rozporządzeniu jest pozbawienie zainteresowanego rolnika perspektywy uzyskania pomocy, co nie spełnia wymogów co do charakteru oraz rygoryzmu sankcji, która miałaby mieć charakter karny ${ }^{474}$. Stosując strasburskie kryteria oceny sankcji pod kątem tego, czy należy je uznać za sankcje karne na potrzeby zasady ne bis in idem, Trybunał w ogóle nie odniósł się do unijnych gwarancji praw podstawowych zawartych w Karcie.

Z propozycją odmiennego podejścia w tej sprawie wyszła Rzeczniczka Generalna Juliane Kokott. Zaproponowała ona Trybunałowi przeformułowanie pytania zadanego przez Sąd Najwyższy i skoncentrowanie się właśnie na wyrażonej w prawie unijnym (art. $50 \mathrm{KPP}$ ) zasadzie ne bis in idem. Jej zdaniem „kwestię, czy sankcje na podstawie art. 138 rozporządzenia nr 1973/2004 stoją na przeszkodzie późniejszemu ściganiu karnemu z powodu oszustwa subwencyjnego, należy rozstrzygnąć na podstawie unijnej zasady ne bis in idem" ${ }^{\prime \prime 75}$. Co prawda, co do istoty odpowiedź na tak postawione pytanie nie prowadziłaby zapewne do odmiennego rezultatu niż na pytanie postawione przez SN. Zdaniem Rzeczniczki również unijna zasada ne bis in idem jest oparta na jej strasburskim rozumieniu. Swej oceny sankcji przewidzianej w rozporządzeniu również dokonała ona, opierając się na wypracowanych w strasburskim orzecznictwie tzw. "kryteriach Engela" ${ }^{\prime 76}$, i oceniła, że sankcja przewidziana w rozporządzeniu nie powinna zostać uznana za sankcję karną, i w związku z tym za uniemożliwiającą wymierzenie oprócz niej również sankcji karnej przewidzianej przez

${ }^{471}$ Ibidem, pkt 38 .

${ }^{472}$ Ibidem, pkt 39-40.

${ }^{473}$ Ibidem, pkt 41.

${ }^{474}$ Ibidem, pkt 43-44. Takie podejście do sankcji przewidzianej przez rozporządzenie za słuszne i odpowiadające również polskiemu standardowi uznał zresztą i powołał się na nie w podobnej sprawie Trybunał Konstytucyjny (TK, sprawa P 50/13, wyrok z 21 października 2014, pkt III.5.2 i nast. uzasadnienia); por. także: TK, sprawa P 32/12, wyrok z 21 października 2015, pkt III.3.4 uzasadnienia; TK, sprawa P 40/13, wyrok z 21 kwietnia 2015, pkt III.3.2 uzasadnienia).

475 TSUE, Postępowanie karne przeciwko Łukasz Marcin Bonda, C-489/10, opinia Rzecznika Generlanego Juliane Kokott przedstawiona w dniu 15 grudnia 2011, pkt 24.

${ }^{476}$ Patrz: ETPCz, Engel i in. p. Niderlandom, skargi nr 5100/71, 5101/71, 5102/71, 5354/72, 5370/72, wyrok z 8 czerwca 1976, para. 82; por.: TSUE, Postępowanie karne przeciwko Lukasz Marcin Bonda, C-489/10, opinia Rzecznika Generlanego Juliane Kokott przedstawiona w dniu 15 grudnia 2011, pkt 45 i nast. 
prawo polskie za czyn, jakiego dopuścił się Pan Bonda ${ }^{477}$. Czy więc przepisy unijne ocenione zostałyby na podstawie przepisów Karty, opartych na EKPCz, czy też na podstawie EKPCz nie prowadziłoby to do różnicy w wymiarze materialnym - standard ochrony byłby za każdym razem ten sam. $Z$ formalnego punktu widzenia - który wzorzec kontroli byłby faktycznie zastosowany różnica byłaby jednak zasadnicza. Podążenie za głosem Rzeczniczki mogłoby przyczynić się do podniesienia świadomości sądów krajowych, w tym wypadku szczególnie polskiego SN, co do zasad zastosowania Karty.

Co istotne, i na co należy zwrócić szczególną uwagę w związku z tematem tej pracy, Rzeczniczka doszła na gruncie tej sprawy do wniosku o potrzebie przeformułowania pytania ze względu na konieczność zastosowania w niej KPP. Wysunęła taki wniosek ze względu na to, że nawet w obliczu braku w momencie powstawania Opinii przejrzystych wskazówek TSUE co do rozumienia art. 51 ust. 1 Karty wiadomo było, że unijne prawa podstawowe mogą być stosowane wobec państw członkowskich, gdy te stosują prawo Unii, a więc co do zasady wtedy, gdy działają w jego zakresie ${ }^{478}$. Sytuacja w tej sprawie spełniała kryteria nawet wąsko rozumianego "stosowania" zarówno na gruncie Karty, jak i tym bardziej „działania w zakresie prawa Unii” na gruncie zasad ogólnych prawa unijnego ${ }^{479}$. Jak słusznie zauważyła Rzeczniczka:

Co się tyczy sankcji administracyjnej przeciw Ł.M. Bondzie, to została ona nałożona w bezpośrednim wykonaniu art. 138 ust. 1 rozporządzenia nr 1973/2004. Druga sankcja, którą wymierzył sąd krajowy za popełnienie przestępstwa oszustwa subwencyjnego, oparta jest wprawdzie na krajowym przepisie karnym, ale również i ona ma swoje źródło w prawie Unii. Polska norma karna służy bowiem w tym konkretnym przypadku ukaraniu za naruszenie przepisów prawa rolnego Unii. Służy ona zatem wykonaniu wynikającego z prawa pierwotnego zobowiązania państw członkowskich do skutecznego i odpowiedniego karania za naruszenia interesów finansowych Unii ${ }^{480}$.

Dalsze jej rozważania, dotyczące obowiązku po stronie państw do zwalczania nielegalnych działań naruszających interesy finansowe Unii za pomocą odstraszających i skutecznych środków na gruncie art. 325 TFUE, jako żywo przypominają te, które w wydanym około półtora roku później wyroku, doprowadziły TSUE w sprawie Åkerberg Fransson do wniosku o możliwości zastosowania unijnych praw podstawowych ${ }^{481}$.

477 TSUE, Postępowanie karne przeciwko Łukasz Marcin Bonda, C-489/10, opinia Rzecznika Generlanego Juliane Kokott przedstawiona w dniu 15 grudnia 2011, pkt 31 i nast.

${ }^{478}$ Ibidem, pkt 14-15.

${ }^{479}$ Ibidem, pkt 15-16.

${ }^{480}$ Ibidem, pkt 17 .

${ }^{481}$ Ibidem, pkt 18-20. 
Ponadto Rzeczniczka zaprezentowała w swej opinii w sprawie Bonda stanowisko, zgodnie z którym wpływu na możliwość zastosowania unijnych praw podstawowych nie powinien mieć art. 1 ust. 1 Protokołu nr $3 \mathrm{O}^{482}$, który stanowi, że Karta nie rozszerza kompetencji Trybunału ani żadnego sądu lub trybunału Polski lub Zjednoczonego Królestwa do uznania, że przepisy ustawowe, wykonawcze lub administracyjne, praktyki lub działania administracyjne Polski lub Zjednoczonego Królestwa są niezgodne z podstawowymi prawami, wolnościami i zasadami, które są w niej potwierdzone ${ }^{483}$. Zdaniem Rzeczniczki:

Przepis ten nie wyróżnia się dużą jasnością. W każdym razie protokół nr 30 nie oznacza wyłączenia Zjednoczonego Królestwa i Rzeczypospolitej Polskiej z karty praw podstawowych [...]. Motywy ósmy i dziewiąty preambuły do protokołu przemawiają raczej za tym, że protokół nie zawiera dla obu wspomnianych krajów odstępstwa od karty, lecz że ma charakter precyzujący i ma być pomocny przy wykładni [...]. Sam art. 51 ust. 2 karty stanowi, że nie rozszerza ona zakresu zastosowania prawa Unii poza kompetencje Unii ani nie ustanawia nowych kompetencji, ani zadań Unii, ani też nie zmienia kompetencji i zadań określonych w traktatach. Ponieważ unormowany w art. 50 karty zakaz podwójnego karania był jednak już wcześniej uznany za ogólną zasadę prawa Unii, a zgodnie z dotychczasowym orzecznictwem ona również miałaby zastosowanie do niniejszego przypadku i jej zakres zastosowania byłby otwarty - jak wykazano powyżej - także przy ścisłej wykładni art. 51 karty, nie może być mowy o rozszerzeniu kompetencji Trybunału w rozumieniu protokołu ${ }^{484}$.

Na gruncie sprawy Bonda Trybunał mógł więc już ponad pół roku wcześniej niż ostatecznie to uczynił w wyroku w sprawie Åkerberg Fransson, dokonać podobnie systemowo doniosłej wykładni art. ${ }_{51}^{1}$ ust. 1 Karty. Jak to już zauważono w poprzednim rozdziale, nieco inny był kontekst tych spraw. Zaistnienie stanu faktycznego w sprawie Bonda miało miejsce przed wejściem w życie Karty, a także zakres pytania, z jakim zwrócił się w tej ostatniej sprawie sąd odsyłający, był znacznie węższy - nieuwzględniający w ogóle Karty i unijnych gwarancji praw podstawowych - niż zakres pytań sformułowanych w sprawie Åkerberg Fransson. Wreszcie sytuację w sprawie Bonda potencjalnie komplikowała również kwestia Protokołu nr 3o. Jak się wydaje wszystkie te kwestie można było jednak rozwiązać. Możliwe było przeformułowanie pytania zgodnie z sugestią Rzeczniczki Generalnej. Jak pokazał to bowiem wyrok w sprawie Åkerberg Fransson i inne omówione w poprzednim rozdziale orzeczenia TSUE, przepisy krajowe znajdujące zastosowanie w sprawie Bonda, przynajmniej w zakresie, w jakim odnosiły się do sankcji wymierzonej za

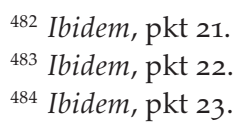


przestępstwo popełnione w związku z korzystaniem z uprawnienia wprost wynikającego z prawa unijnego, mieściły się w zakresie zastosowania prawa unijnego i można było zastosować do nich unijne gwarancje praw podstawowych. Nawet jeśli stan faktyczny miał miejsce przed wejściem w życie Karty, można było zastosować unijne prawa podstawowe jako zasady ogólne prawa unijnego, co nie niosłoby ze sobą zasadniczej różnicy dla interesującej nas tu kwestii, a nawet mogłoby posłużyć Trybunałowi do zaprezentowania wniosków związanych z ewentualną modyfikacją albo kontynuacjac stanowiska w tej materii w obliczu uzyskania przez Kartę mocy prawnej i rozwiania tym samym dotyczących tego przełomu wątpliwości. Zaletą przyjęcia rozwiązania proponowanego przez Rzeczniczkę byłaby nie tylko możliwość sformułowania ogólniejszych wniosków co do wykładni art. 51 ust. 1 Karty i zasady zastosowania unijnych praw podstawowych wobec państw członkowskich w związku z nadaniem jej mocy prawnej w odniesieniu do orzecznictwa w tej materii sprzed tego momentu, pół roku wcześniej niż to ostatecznie nastąpiło, lecz także w związku z tym, że sprawa dotyczyła Polski, można byłoby również wykorzystać tę sprawę do rozwiania wątpliwości interpretacyjnych dotyczących Protokołu nr 30 w związku z art. 51 ust. 1 Karty.

Nawet jeśli z szans tych nie skorzystano, wydaje się jednak dość oczywiste, że orzeczenie Trybunału w tej sprawie, nieodnoszące się do Karty, szczególnie w obliczu tego, co TSUE powiedział na ten temat we wcześniejszym wyroku w sprawie N.S. ${ }^{485}$, nie wynikało z przekonania o jakimś głębszym wpływie Protokołu na ogólne zasady zastosowania Karty wobec państw członkowskich ${ }^{486}$. TSUE w pewnym sensie nie wprost wypowiedział się na temat unijnego standardu, poprzez analizę zasady ne bis in idem w rozumieniu strasburskim. Jak przecież wiadomo, zgodnie z art. 52 ust. 3 Karty: „W zakresie, w jakim niniejsza Karta zawiera prawa, które odpowiadaja prawom zagwarantowanym w europejskiej Konwencji o ochronie praw człowieka i podstawowych wolności, ich znaczenie i zakres są takie same jak praw przyznanych przez tę konwencję. Niniejsze postanowienie nie stanowi przeszkody, aby prawo Unii przyznawało szerszą ochronę". Także przed wejściem w życie Karty unijne prawa podstawowe jako zasady ogólne brały swe źródło właśnie również w Konwencji. Wyrok ten w pewnym sensie potwierdził więc i uwydatnił status, jaki w prawie unijnym ma EKPCz jako źródło minimalnego standardu ochrony praw w niej zawartych ${ }^{487}$.

${ }^{485}$ TSUE, N.S. p. Secretary of State for the Home Department oraz M.E., A.S.M., M.T., K.P., E.H. p. Refugee Applications Commissioner, Minister for Justice, Equality and Law Reform, C-411/10 i C-493/10, wyrok z 21 grudnia 2011.

${ }^{486}$ Tak samo np.: B. Thorson, Individual Rights in EU Law, Cham 2016, s. 201.

487 A. Andreangeli, Ne bis in idem and Administrative Sanctions: Bonda, "Common Market Law Review" 2013, nr 50 (6), s. 1839. 
Pewną niepoprawność oparcia stanowiska TSUE wyłącznie na EKPCz bez odniesienia do Karty w sytuacji, gdy Konwencja stanowi minimalny standard w zakresie, w jakim prawa zagwarantowane w Karcie pokrywają się z prawami zagwarantowanymi w Konwencji, można w jakimś stopniu usprawiedliwić również charakterem tej sprawy. Ze względu na stopień harmonizacji przedmiotowej materii w zakresie, w jakim dotyczyła ona państwa członkowskiego (a więc w zakresie, w jakim sprawa dotyczyła polskich przepisów karnych), można byłoby mówić co najwyżej o takiej samej intensywności zastosowania unijnych praw podstawowych, z jaką mieliśmy do czynienia w sprawie Åkerberg Fransson. Intensywność ta w poprzednim rozdziale została określona jako skutkująca mieszanym (mixed) zastosowaniem unijnych i krajowych gwarancji praw człowieka. Sprowadza się ona to tego, że standard unijny jest, podobnie jak co do zasady ma to miejsce w przypadku standardów strasburskich, jedynie standardem minimalnym. Należy przypomnieć, że w sprawie Åkerberg Fransson TSUE stwierdził, że:

Państwom członkowskim przysługuje bowiem swoboda wyboru sankcji w celu zapewnienia poboru w pełnej wysokości dochodów z podatku VAT, a tym samym ochrony interesów finansowych Unii [...]. Sankcje te mogą więc mieć postać sankcji administracyjnych, sankcji karnych lub obu tych rodzajów sankcji łącznie. Dopiero jeżeli sankcja podatkowa ma charakter karny w rozumieniu art. 50 karty i jest ostateczna, zasada wyrażona w tym przepisie staje na przeszkodzie prowadzeniu przeciwko tej samej osobie kolejnego postępowania karnego ${ }^{488}$.

$\mathrm{Z}$ materialnego punktu widzenia istotnie nie miało większego znaczenia to, $\mathrm{w}$ jaki sposób ten minimalny standard $\mathrm{w}$ ramach zasady ne bis in idem zostanie przez TSUE zidentyfikowany. Możliwe więc, że podobnie jak w kontekście przystąpienia Unii do EKPCz, czy też szerzej, w kontekście relacji między luksemburskimi a strasburskimi gwarancjami praw człowieka zauważyła na jej gruncie Arianna Andreangeli, również w kontekście zastosowania unijnych praw podstawowych wobec państw członkowskich sprawa Bonda była w pewnym sensie "sprawą testową" (test case) zmierzającą do wyczucia nastrojów (sounding the mood), i stąd pewna powściągliwość trybunału luksemburskiego $^{489}$ sprowadzająca się do osiągnięcia tego samego efektu bez konieczności wdawania się w różne zawiłości, którym uwagę poświęciła Rzeczniczka. Być może po tym teście TSUE łatwiej było pół roku później wydać systemowy wyrok w kwestii zastosowania unijnych praw podstawowych wobec państw członkowskich, w sprawie Åkerberg Fransson, szczególnie że nie musiało to wiązać się

${ }_{488}$ TSUE, Åklagaren p. Hans Åkerberg Fransson, C-617/10, wyrok z 26 lutego 2013, pkt 34. 489 A. Andreangeli, Ne bis..., s. 1841. 
z przeformułowaniem pytania, które sąd szwedzki sformułował przychylniej unijnemu systemowi ochrony praw podstawowych, niż uczynił to SN w sprawie Bonda.

Można jednak zaryzykować twierdzenie, że wyrok w sprawie Bonda, w którym TSUE nie odniósł się do powyższych rozważań Rzeczniczki Generalnej i ostatecznie nie zastosował w sprawie unijnych praw podstawowych, nieco zaciemnił, zamiast rozjaśnić, kwestię zastosowania Karty wobec państw członkowskich, a także kwestię znaczenia Protokołu nr 30. Mimo stanowiska zaprezentowanego przez Rzeczniczkę i mimo dobrych racji stojących za wykorzystaniem tej sprawy do systemowego rozwiązania kwestii zastosowania Karty wobec Polski w związku z Protokołem nr 30, "W sprawie Bonda, TSUE ostatecznie nie dał polskiemu sądowi wskazówek w tym zakresie ani też nie zwrócił uwagi, że sprawa może być rozpatrywana w świetle przepisów Karty" ${ }^{\prime \prime 90}$. Jak zauważa Nina Półtorak: „Niestety, TSUE nie odniósł się do zakresu pytania polskiego sądu ani do samej Karty. Być może znaczenie miało to, że sprawa dotyczyła stanu faktycznego sprzed wejścia w życie KPP, oraz to, iż w odniesieniu do Polski sprawę zastosowania KPP dodatkowo komplikuje Protokół nr $3 \mathrm{O}^{\prime \prime 491}$. Nawet jeśli tak było, to pierwsza wątpliwość mogła zostać rozwiana poprzez wskazanie przez Trybunał na kontynuację jego linii orzeczniczej sprzed wejścia w życie Karty odnośnie do zastosowania unijnych praw podstawowych wobec państw członkowskich już po tym, kiedy Karta i jej art. 51 ust. 1 uzyskały moc prawnie wiążąca, z ewentualnym uwzględnieniem pewnych modyfikacji, które ujawniały się stopniowo w późniejszym orzecznictwie, o czym szczegółowo była mowa w poprzednim rozdziale. Druga wątpliwość mogła zaś zostać rozwiana, opierając się na rozwinięciu i doprecyzowaniu podejścia zaprezentowanego przez TSUE $\mathrm{w}$ wyroku w sprawie N.S., który pozostaje do tej pory podstawowym przejawem luksemburskiego podejścia do Protokołu nr 30, potwierdzającym przekonanie, że nie można uznać, aby wyłączał on lub ograniczał zastosowanie przepisów KPP w Polsce i w Wielkiej Brytanii.

\subsection{Sprawa N.S.}

Zasadnicze wątpliwości, jakie mogły się rodzić na gruncie interpretacji postanowień Protokołu, a przynajmniej jego art. 1 ust. 1, rozwiał TSUE w sprawie N.S., która dotyczyła wspólnego europejskiego systemu azylowego. O tym wyroku była już mowa przy okazji omawiania kontynuowania przez TSUE linii orzeczniczej w grupie spraw typu Wachauf i wyrażonego w tym wyroku sta-

\footnotetext{
${ }^{490}$ N. Półtorak, Zakres zwiazania..., s. 17.

${ }^{491}$ Ibidem, s. 17 .
} 
nowiska, że unijne prawa podstawowe powinny być stosowane wobec państw członkowskich niezależnie od zakresu swobody implementacyjnej, jaki pozostawia im prawo unijne. Kwestię Protokołu i ewentualnej, wynikającej z niego modyfikacji postanowień ogólnych, zawartych w art. 51 ust. 1 Karty, a co za tym idzie również konieczności modyfikacji odpowiedzi udzielonych przez TSUE na pięć poprzednich pytań, podniósł w pytaniu siódmym sam sąd odsyłający (Court of Appeal [England \& Wales] [Civil Division] [Zjednoczone Królestwo]). Brzmiało ono: „W zakresie, w jakim pytania poprzedzające dotyczą obowiązków ciążących na Zjednoczonym Królestwie, czy uwzględnienie protokołu (nr 30) ma jakikolwiek wpływ na odpowiedzi [udzielone na pytania od drugiego do szóstego]?"492

Trybunał przypomniał w związku z tym, że:

art. 1 ust. 1 protokołu (nr 30) stanowi, iż karta nie rozszerza kompetencji Trybunału Sprawiedliwości Unii Europejskiej ani żadnego sądu lub trybunału Polski lub Zjednoczonego Królestwa do uznania, że przepisy ustawowe, wykonawcze lub administracyjne, praktyki lub działania administracyjne Polski lub Zjednoczonego Królestwa są niezgodne z podstawowymi prawami, wolnościami i zasadami, które są w niej potwierdzone ${ }^{493}$.

W odpowiedzi Trybunał przywołał zarówno motywy, jakimi kierowały się strony i jakie zawarte zostały w Preambule do Protokołu, a także przypomniał charakter Karty jako dokumentu potwierdzającego jedynie istniejące w unijnym porządku prawnym jako jego zasady ogólne gwarancje praw podstawowych, a nie je ustanawiającego ${ }^{494}$. Trybunał stwierdził, że:

Z brzmienia tego [art. 1 ust. 1 Protokołu nr 30 - przyp. aut.] przepisu wynika, że jak zauważyła rzecznik generalna w pkt 169 i 170 swojej opinii ${ }^{495}[\ldots]$ protokół (nr 30) nie

${ }^{492}$ TSUE, N.S. p. Secretary of State for the Home Department oraz M.E., A.S.M., M.T., K.P., E.H. p. Refugee Applications Commissioner, Minister for Justice, Equality and Law Reform, C-411/10 i C-493/10, wyrok z 21 grudnia 2011, pkt 50.

${ }^{493}$ Ibidem, pkt 118.

${ }^{494}$ Tak samo np.: N. Półtorak, Zakres zwiazania..., s. 28; M. Pyziak-Szafnicka, Karta Praw Podstawowych UE w orzecznictwie Trybunału Konstytucyjnego, "Europejski Przegląd Sądowy" 2016, nr 8, s. 23; A. Wróbel, Art. 51..., s. 1324-1325.

${ }^{495}$ Nota bene w swojej opinii Rzeczniczka Generalna Verica Trstenjak odnosiła się do wszystkich przepisów Protokołu w kontekście ich potencjalnego derogacyjnego charakteru. Nie ograniczyła się, tak jak zrobił to w wyroku Trybunał jedynie do art. 1 ust. 1 Protokołu (TSUE, N.S. p. Secretary of State for the Home Department oraz M.E., A.S.M., M.T., K.P., E.H. p. Refugee Applications Commissioner, Minister for Justice, Equality and Law Reform, C-411/10 i C-493/10, wyrok z 21 grudnia 2011, opinia Rzecznika Generalnego Vericy Trstenjak przedstawiona w dniu 22 września 2011, pkt 165-177). 
podważa zastosowania karty wobec Zjednoczonego Królestwa czy wobec Polski, co znajduje potwierdzenie w motywach tego protokołu. Tak więc, zgodnie z motywem 3 protokołu (nr 3o) art. 6 TUE stanowi, że karta jest stosowana i interpretowana przez sądy Polski i Zjednoczonego Królestwa w ścisłej zgodności z wyjaśnieniami, o których mowa w tym artykule. Ponadto zgodnie z motywem 6 wspomnianego protokołu karta potwierdza prawa, wolności i zasady uznawane w Unii oraz sprawia, że są one bardziej widoczne, nie tworzy jednak nowych praw ani zasad ${ }^{496}$.

Doprowadziło to Trybunał do następującej konkluzji: „W takiej sytuacji art. 1 ust. 1 protokołu ( $\mathrm{nr}$ 30) potwierdza treść art. 51 karty dotyczącego jej zakresu stosowania, a nie ma na celu zwolnienia Rzeczypospolitej Polskiej i Zjednoczonego Królestwa z obowiązku przestrzegania postanowień karty ani uniemożliwienia sądom i trybunałom w tych państwach [...] czuwania nad przestrzeganiem tych postanowien'" ${ }^{\prime \prime 97}$. Trybunał nie odniósł się natomiast do art. 1 ust. 2 ze względu na to, że prawa, których dotyczyły postępowania główne nie były objęte zakresem Tytułu IV Karty, a art. 1 ust. 2 dotyczy tylko przepisów zawartych w tym tytule ${ }^{498}$. Dlatego też na pytanie siódme, skierowane doń przez Court of Appeal, TSUE odpowiedział, „że w zakresie, w jakim pytania poprzedzające dotyczą obowiązków ciążących na Zjednoczonym Królestwie, uwzględnienie protokołu ( $\mathrm{nr} 30$ ) w sprawie stosowania karty do Rzeczypospolitej Polskiej i Zjednoczonego Królestwa nie ma wpływu na odpowiedzi udzielone na pytania od drugiego do szóstego [...]"499.

Tak więc nawet jeśli być może istnieją możliwe do pomyślenia odczytania, szczególnie art. 1 ust. 1 Protokołu, które sprawiałyby, że zawiera on w sobie pewne elementy opt-out'u, związane przede wszystkim z potraktowaniem Karty nie jedynie jako potwierdzenia praw i wolności i tak zawartych w prawie unijnym jako jego zasad ogólnych, lecz jako dokumentu tworzącego nowe prawa ${ }^{500}$, to wydaje się, że w obliczu tego, co zostało powiedziane powyżej, szczególnie w związku ze stanowiskiem przyjętym w sprawie N.S. przez TSUE, który to przecież jest interpretatorem prawa unijnego, w tym prawa pierwotnego, do którego zalicza się zarówno Protokół, jak i Karta, dokument ten nie modyfikuje zakresu zastosowania Karty wobec Polski względem tego, co wynika $\mathrm{z}$ art. 51 ust. 1 KPP.

${ }^{496}$ TSUE, N.S. p. Secretary of State for the Home Department oraz M.E., A.S.M., M.T., K.P., E.H. p. Refugee Applications Commissioner, Minister for Justice, Equality and Law Reform, C-411/10 i C-493/10, wyrok z 21 grudnia 2011, pkt 119.

${ }^{497}$ Ibidem, pkt 120.

${ }^{498}$ Ibidem, pkt 121.

${ }^{499}$ Ibidem, pkt 122.

${ }^{500}$ Patrz np.: C. Barnard, The 'Opt-Out'..., s. 266 i nast. 


\subsection{Praktyka sądów polskich a Protokół nr 30}

Jeśli chodzi o orzecznictwo sądów polskich dotyczących Karty i unijnych praw podstawowych, to nie jest ono pozbawione ułomności, o czym będzie mowa bardziej szczegółowo w dalszej części tego rozdziału. Ta ułomność sprowadza się do częstego pomijania fundamentalnej kwestii, jaką jest to, czy w danej sprawie w ogóle można zastosować Kartę w związku z jej art. 51 ust. 1 oraz dość powszechnej praktyki ornamentacyjno-argumentacyjnego wykorzystywania Karty w orzeczeniach w sprawach czysto wewnętrznych jako wsparcia wywodu opartego na prawie polskim. Skoro brak tak podstawowych rozważań co do stosowalności Karty w ogóle, trudno spodziewać się, by sądy polskie poświęcały swoją uwagę sprawie bardziej szczegółowej i wymagającej głębszej analizy prawa unijnego, jaką byłoby odnoszenie się do wpływu Protokołu nr 30 na zakres zastosowania Karty wobec Polski. Tym bardziej, że jak już wspomniano, Protokół faktycznie jest sformułowany w sposób niejednoznaczny i jego prawidłowa wykładnia nie jest łatwa.

Dodatkowo na sądowe wykorzystanie Karty w kontekście Protokołu nr 30 wpływ mogą mieć także rozbieżności co do znaczenia tego ostatniego, jakie prezentowane było przez różne organy władzy państwowej w Polsce. Pomijając burzliwa, często niejasną z prawniczego punktu widzenia, dyskusję na poziomie politycznym towarzyszącą pracy nad Protokołem i przystąpieniu do niego przez Polskę w ramach lizbońskiej reformy Unii ${ }^{501}$, również na poziomie prawnym, już po tym, jak Protokół stał się częścią unijnego prawa pierwotnego, formułowane były różne, często sprzeczne stanowiska. Żadne z tych stanowisk nie ma wprawdzie charakteru normatywnego ani prawnie wiążącego, ich sprzeczny charakter potęguje jednak konfuzję. W dodatku, jako że pochodzą one od organów polskich, są łatwiej dostępne polskim sądom i mogą łatwiej wpływać na ich wątpliwości w tej materii niż np. orzecznictwo TSUE. Tym niemniej należy podkreślić, że stanowiska te pochodzą sprzed wyroku w sprawie N.S., o którego znaczeniu była już mowa, który, jak się wydaje, wiele z wątpliwości narosłych wokół Protokołu rozwiał.

Rada Legislacyjna, która jest organem doradczym przy Radzie Ministrów, stanęła na stanowisku, że wprawdzie celem Protokołu nie jest wyeliminowanie skutku Karty wobec Polski, lecz doprecyzowanie zakresu jej zastosowania, szczególnie jeśli chodzi o możliwość powoływania się na Kartę przed sądami

${ }^{501}$ Por. np.: M. Wyrzykowski, Wiele hałasu o nic? Racjonalizowanie irracjonalności na przykładzie Protokołu polsko-brytyjskiego do Karty Praw Podstawowych UE, [w:] J. Wawrzyniak, M. Laskowska (red.), Instytucje prawa konstytucyjnego w dobie integracji europejskiej. Księga jubileuszowa Marii Kruk-Jarosz, Warszawa 2009. 
polskimi, to jednak „Karta nie będzie działała w pełni efektywnie w stosunku do Polski"502. Zdaniem Rady:

Jej [Karty - przyp. aut.] ogólny charakter normatywny nie zostanie wyłączony, ale zostanie ograniczony w niektórych aspektach.

Protokół:

- uniemożliwia wnoszenie przez Komisję lub inne państwo członkowskie skarg przeciwko Polsce o naruszenie Karty do Trybunału Sprawiedliwości,

- uniemożliwia powoływanie się na postawienia Karty przez jednostki przed sądami polskimi, w celu orzekania o niezgodności prawa krajowego z Karta,

- podważa kompetencje sądów krajowych do wnoszenia pytań prejudycjalnych w zakresie w jakim mogłyby prowadzić do stwierdzenia niezgodności prawa krajowego z Karta,

- zakazuje sądom krajowym przyznawania skutków bezpośrednich przepisom Karty i blokuje zasadę pierwszeństwa,

- zakazuje Trybunałowi UE stwierdzania istnienia sprzeczności między systemem polskiego prawa krajowego i Kartą. Ogranicza w ten sposób dochodzenie, zdolność interpretacyjną i proces tworzenia oraz kształtowania prawa polskiego poprzez jego orzecznictwo. Pozwala państwu-stronie protokołu na swobodne tworzenie prawa w zakresie chronionym Karta, a w ten sposób przerzuca na ustawodawcę krajowego rolę ewentualnego kształtowania prawa w zgodzie z zakresem ochrony przez Kartę,

- w przypadku, gdy Karta odsyła do prawa lub praktyk krajowych, Karta będzie stosowana tylko w zakresie, $\mathrm{w}$ jakim prawa i zasady są już znane w prawie i praktyce krajowej ${ }^{503}$.

Tymczasem wedle opinii Doradczego Komitetu Prawnego przy Ministrze Spraw Zagranicznych ${ }^{504}$ Protokół stanowi dodatkową gwarancję zakresu stosowania Karty w Polsce, związaną z art. 52 samej Karty oraz z art. 6 ust. 1 TUE. Opinia ta zbliża się $\mathrm{w}$ tej materii do stanowiska prezentowanego przez Komitet Konstytucyjny brytyjskiej Izby Lordów ${ }^{505}$. Wedle autorów opi-

${ }^{502}$ Opinia [Rady Legislacyjnej] z 17 marca 2008 r. w sprawie skutków prawnych Karty Praw Podstawowych, RL-0303-8/o8, pkt III.1, [online] <http://radalegislacyjna.gov.pl/dokumenty/ opinia-z-17-marca-2008-r-w-sprawie-skutkow-prawnych-karty-praw-podstawowych> [dostęp: 28.12.2018].

${ }^{503}$ Ibidem, pkt III.1.

${ }^{504}$ Opinia Doradczego Komitetu Prawnego przy Ministrze Spraw Zagranicznych z 21 maja 2008 r. dotyczacej skutku prawnego Protokolu w sprawie stosowania Karty Praw Podstawowych Unii Europejskiej w stosunku do Polski i Zjednoczonego Królestwa, „Przegląd Legislacyjny” 2011, nr 1.

${ }^{505}$ House of Lords Constitution Committee, Session 2007-08: $6^{\text {th }}$ Report, European Union (Amendment) Bill and the Lisbon Treaty: Implications for the UK Constitution, Cm 7417, Londyn 2008, s. 5, [online] <https://www.gov.uk/government/uploads/system/uploads/attachment_data/ file/243382/7417.pdf> [dostęp: 28.12.2018]. 
nii Protokół nie prowadzi do wyłączenia kompetencji TSUE i polskich sądów do orzekania o niezgodności prawa krajowego, mieszczącego się w zakresie prawa unijnego, z prawami podstawowymi, ani nie wyłącza możliwości występowania z pytaniami prejudycjalnymi do TSUE. W 2013 r. do Ministra Spraw Zagranicznych skierowana została interpelacja dotycząca stanowiska Rządu w sprawie Karty. W odpowiedzi odnośnie do Protokołu stwierdzono, że: „Protokół nie przyznaje obu państwom odstępstwa od karty, lecz ma charakter precyzujący i może mieć znaczenie dla jej wykładni. Można argumentować, że prawne znaczenie protokołu ogranicza się do podkreślenia normatywnego brzmienia art. 51 ust. 2 karty" ${ }^{\prime \prime 06}$. W ostatnich latach pojawiały się też różne, zarówno na poziomie politycznym (w parlamencie), jak i na poziomie naukowym (w literaturze przedmiotu) propozycje odstąpienia Polski od Protokołu, co jednak nie jest łatwe do zrealizowania ze względu na rangę prawną Protokołu, który jest elementem unijnego prawa pierwotnego ${ }^{507}$. Jak zauważa Mirosław Wróblewski:

Te rozbieżne wypowiedzi organów państwowych miały i mają z pewnością wpływ na sądowe wykorzystanie Karty w Polsce. Świadczy o tym fakt, że strony wolą nie odnosić się do protokołu nr $30 \mathrm{w}$ postępowaniach sądowych, choć z drugiej strony nie powinno to dziwić, gdyż jego przytoczenie nie leżałoby raczej w interesie strony żądającej stwierdzenia naruszenia prawa wynikającego z KPP508.

Owa niepewność co do statusu Karty w Polsce w związku z Protokołem nr 30 odzwierciedlona jest w orzecznictwie sądów polskich. WSA w Warszawie stwierdził w wyroku z 2010 r., że:

zakres obowiązywania Karty jest ograniczony. Bezpośrednie obowiązywanie Karty Praw Podstawowych wyłączone zostało na podstawie Protokołu w sprawie stosowania Karty Praw Podstawowych Unii Europejskiej do Polski i Zjednoczonego Królestwa. Stosownie do treści art. 1 Protokołu wykluczone jest powoływanie się przez jednostki przed sądami polskimi na postanowienia Karty w celu orzekania o niezgodności tak przepisów ustawowych, wykonawczych lub administracyjnych, jak też praktyki lub działania administracyjnego ${ }^{509}$.

${ }^{506}$ Odpowiedź sekretarza stanu w Ministerstwie Spraw Zagranicznych - z upoważnienia prezesa Rady Ministrów - na interpelację nr 18706 w sprawie zastrzeżeń do Karty Praw Podstawowych, [online] <http://www.sejm.gov.pl/sejm7.nsf/InterpelacjaTresc.xsp?key=6CD471D2> [dostęp: 28.12.2018].

${ }^{507}$ Patrz np.: ibidem; W. Czapliński, Kilka uwag...

${ }^{508}$ M. Wróblewski, Karta Praw Podstawowych Unii Europejskiej w polskim..., s. 23.

${ }^{509}$ WSA w Warszawie, sprawa IV SA/Wa 1968/o9, wyrok z 29 kwietnia 2010, cyt. za: LEX nr 707138 
Na marginesie w obliczu rozważań czynionych w dalszych częściach tego rozdziału podkreślić należy, że w wyroku tym brak rozważań co do zakresu zastosowania Karty w związku z jej art. 51 ust. 1, a sprawa ma zdecydowanie charakter wewnętrzny, i Karta tak czy owak nie mogłaby być w niej zastosowana. Stąd też sformułowanie tak stanowczego stanowiska dotyczącego Protokołu może szczególnie zaskakiwać.

$Z$ drugiej strony należy przytoczyć $z$ aprobata, przynajmniej gdy chodzi o kwestię Protokołu, wyrok WSA w Kielcach, w którym sąd ten stwierdził:

W kontekście zarzutów naruszenia przepisów Karty Praw Podstawowych Unii Europejskiej [...], wskazać należy, że Rzeczpospolita Polska przystąpiła do tzw. Protokołu Brytyjskiego - Protokołu nr 30 dołączonego do Traktatu z Lizbony [...]. Zgodnie jednak z orzecznictwem Trybunału Sprawiedliwości Unii Europejskiej - jego wyrokiem z dnia 21 grudnia $2011 \mathrm{r}$. w sprawach połączonych C-411/10 i C-493/10, Karta Praw Podstawowych nie jest ograniczona co do swej skuteczności w polskim porządku prawnym, ponieważ "art. 1 ust. 1 protokołu ( $\mathrm{nr}_{30}$ ) [...] potwierdza treść art. 51 karty dotyczącego jej zakresu stosowania, a nie ma na celu zwolnienia Rzeczypospolitej Polskiej i Zjednoczonego Królestwa z obowiązku przestrzegania postanowień karty ani uniemożliwienia sądom i trybunałom w tych państwach członkowskich czuwania nad przestrzeganiem tych postanowień" $[\ldots]^{510}$.

W swej ocenie opartej na Karcie sąd odwołał się także do postanowień ogólnych Karty z art. 53 i 54, zawartych w Tytule VII Karty. Mimo podjęcia tematu Protokołu, a nawet przywołania sprawy N.S., co jest przejawem pogłębionej analizy tej problematyki po stronie sądu, podkreślić należy jednak brak odniesienia do art. 51 ust. 1, który jest kluczowy w przedmiocie zastosowania Karty, a Protokół ma dla niego ewentualnie wtórne znacznie. Należy przy tym zauważyć, że sprawa znowu miała charakter wewnętrzny i nie uzasadniała zastosowania unijnych praw podstawowych. Obniża to ogólną ocenę stanowiska sądu.

Do kwestii Protokołu przez długi czas nie odnosił się w żaden sposób Sąd Najwyższy. Po raz pierwszy zrobił to dopiero w 2016 r., jednakże w sposób, który można odczytywać jako sugestię traktowania Protokołu jako dodatkowego potwierdzenia zasad zastosowania Karty wynikających z niej samej, ze wszystkimi przewidzianymi w niej ograniczeniami, szczególnie w art. 51 ust. 2, a więc wykluczający traktowanie Protokołu jako opt-out $t^{511}$. Zważywszy te wszystkie okoliczności, wydaje się, że można skonkludować za Mirosławem Wróblewskim, że:

${ }^{510}$ WSA w Kielcach, sprawa I SA/Ke 496/14, wyrok z 29 grudnia 2014, cyt. za: LEX nr 1947813 .

${ }^{511}$ SN, Izba Cywilna, sprawa IV CSK 270/15, wyrok z 16 marca 2016. 
wpływ treści protokołu na orzecznictwo sądów powszechnych jest bardzo ograniczony. Protokół odgrywa obecnie bardziej rolę polityczną niż prawną; jest niewidoczny na salach sądowych, a sądy nie powołują się na jego przepisy. Nieobecność protokołu w polskim orzecznictwie może prowadzić do konkluzji, że prawne znaczenie protokołu jest przeceniane zarówno przez jego zwolenników, jak i przeciwników ${ }^{512}$.

\subsection{Znaczenie Protokołu nr 30 dla stosowania Karty w Polsce}

O ile TSUE w sprawie Bonda nie wykorzystał szansy na rozstrzygnięcie wątpliwości związanych z Protokołem nr 30 i jego ewentualnym znaczeniem dla stosowania Karty w Polsce, o tyle sprawa N.S. w dużej mierze, przynajmniej odnośnie do potencjalnie posiadającego największy ładunek derogacyjny art. 1. ust. 1 Protokołu, je rozstrzygnęła. To właśnie ten przepis był najbardziej problematyczny w obliczu wątpliwości co do charakteru Karty. Skoro jednak należy uznać, że Karta nie rozszerza katalogu praw podstawowych chronionych sądowo ponad te, które już podlegają takiej ochronie na innej podstawie (w szczególności jako zasady ogólne prawa unijnego/wspólnotowego), art. I ust. 1 Protokołu nie może być traktowany jako w jakiś sposób ograniczający zastosowanie Karty. Jak podkreśla jednak Marek Jaśkowski, przy dokładnej analizie katalogu praw i wolności zagwarantowanych w Karcie założenie, że potwierdza ona jedynie prawa, wolności i zasady uznawane w Unii oraz sprawia, że są one bardziej widoczne, nie tworzy jednak nowych praw ani zasad, nie znajduje potwierdzenia w rzeczywistości.

Jak wyliczyli Xavier Groussot i Laurent Pech, jedynie około połowa z praw zagwarantowanych w Karcie to uznane wcześniej w orzecznictwie unijnych sądów za zasady ogólne prawa podstawowe $\mathrm{e}^{513}$. Pozostałe prawa zagwarantowane w Karcie są wprawdzie zawarte w innych dokumentach gwarantujących prawa człowieka, do których odnosi się Preambuła, zgodnie z którą Karta:

potwierdza, przy poszanowaniu kompetencji i zadań Unii oraz zasady pomocniczości, prawa wynikające zwłaszcza z tradycji konstytucyjnych i zobowiązań międzynarodowych wspólnych Państwom Członkowskim, europejskiej Konwencji o ochronie praw człowieka i podstawowych wolności, Kart Społecznych przyjętych przez Unię i Radę Europy oraz z orzecznictwa Trybunału Sprawiedliwości Unii Europejskiej i Europejskiego Trybunału Praw Człowieka [...].

${ }^{512}$ M. Wróblewski, Karta Praw Podstawowych Unii Europejskiej w polskim..., s. 23.

${ }^{513}$ X. Groussot, L. Pech, Fundamental Rights..., s. 5. 
Jak twierdzi Marek Jaśkowski:

patrząc z perspektywy prawa Unii, nie sposób zgodzić się z zawartą w preambule Karty deklaracja, jakoby KPP jedynie potwierdzała określone w niej prawa podstawowe. Trudno bowiem uznać, aby źródło prawa Unii Europejskiej (jakim jest Karta) mogło jedynie "potwierdzać” obowiązywanie w ramach unijnego porządku prawnego norm prawnych wobec niego zewnętrznych i dotychczas w tym porządku nieobowiązujących. Jakkolwiek więc można mówić o potwierdzeniu przez Kartę tych praw podstawowych, które stanowią element prawa "pisanego" Unii lub zostały uprzednio uznane w orzecznictwie Trybunału Sprawiedliwości i w ten sposób wprowadzone do unijnego porządku prawnego jako zasady ogólne prawa unijnego (wspólnotowego), to uznanie, że KPP rzekomo potwierdza prawa zawarte w aktach prawnych niezaliczających się do prawa unijnego, prowadziłoby do zatarcia granic porządku prawnego Unii Europejskiej ${ }^{514}$.

Dlatego tė̇, zdaniem Marka Jaśkowskiego: „Należy żałować, że Trybunał nie zdecydował się na dokonanie własnej oceny, w jakim stopniu Karta stanowi jedynie »kodyfikację« zasad ogólnych prawa unijnego, ograniczając się do zacytowania fragmentów preambuły" ${ }^{\prime 515}$. W tym zakresie w sprawie N.S. TSUE faktycznie przytoczył właściwie jedynie Preambułę do Karty.

Nic nie stoi jednak na przeszkodzie, aby TSUE takiego uszczegółowienia dokonał w przyszłości, w razie potrzeby uzasadnionej konkretną sprawą. Tego rodzaju rozstrzygnięcie bądź też ich seria pozwoliłyby rozwiać wszelkie wątpliwości w tej materii, do czego mogłaby posłużyć procedura pytania prejudycjalnego. Być może więc wyrok w sprawie N.S. nie wykluczył interpretacji Protokołu, jaką dopuszczała po jego powstaniu Catherine Barnard, sprowadzającą się do wyłączenia zastosowania wobec Polski i Zjednoczonego Królestwa praw zagwarantowanych w Karcie, które wcześniej nie byłyby uznane za zasady ogólne prawa unijnego lub wyłączenia zastosowania pewnego zakresu praw, które były uznane za zasady ogólne prawa unijnego, ale w zakresie węższym niż uczyniła to Karta ${ }^{516}$. Mówiąc krótko, cały czas mogą istnieć pewne wątpliwości, dotyczące takiej interpretacji „art. 1 ust. 1 protokołu, zgodnie z którą Karta nie ma zastosowania do Polski i Zjednoczonego Królestwa, w zakresie w jakim wprowadza ona nowe elementy, wykraczające poza kodyfikację"517, a więc poza to, co TSUE uznał już przed wejściem w życie Karty za zasady ogólne prawa unijnego.

\footnotetext{
${ }^{514}$ M. Jaśkowski, Konsekwencje prawne..., s. 32.

515 Ibidem, s. 50.

516 C. Barnard, The 'Opt-Out'..., s. 257.

${ }^{517}$ M. Jaśkowski, Konsekwencje prawne..., s. 40.
} 
Aby tego dokonać, TSUE musiałby jednak zmodyfikować nieco linię przyjętą w wyroku w sprawie N.S. Wydaje się to jednak mało prawdopodobne i byłoby trudne do uzasadnienia, szczególnie w obliczu motywu 3 i 6 zawartego przez Polskę i Wielką Brytanię w Preambule do Protokołu, o których będzie jeszcze mowa. "Co więcej, nawet gdyby przyjąć takie rozumienie art. 1 ust. 1 protokołu, Trybunał mógłby odwołać się do zasad ogólnych prawa w celu zastosowania nowych praw podstawowych do wskazanych państw członkowskich" ${ }^{\prime 18}$. Nie chodzi tu oczywiście o całkiem nowe prawa podstawowe gdyż powstanie Karty zdaje się, że wykluczyło możliwość dalszego rozwijania katalogu unijnych praw podstawowych przez TSUE w oderwaniu od Karty lecz te, które zawarte są w Karcie ${ }^{519}$. Z faktu, że TSUE nie miał okazji, przed wejściem w życie Karty wypowiedzieć się na temat niektórych praw później w niej zawartych wcale nie musi wynikać też jednoznaczny wniosek, że zanim Karta nie uzyskała mocy prawnej prawa te nie były zagwarantowane w prawie unijnym jako jego zasady ogólne. Skoro brak było takiego katalogu, TSUE jedynie a casu ad casum mógł stwierdzać ochronę poszczególnych praw czy wolności człowieka. Powstanie tego katalogu ograniczyło tę swobodę Trybunału, która wcześniej też nie była nieograniczona, brak było jedynie takiego, zamkniętego katalogu praw i wolności ją ograniczającego. Mogło być więc tak, że prawa te były chronione wcześniej w unijnym porządku prawnym, nie było jedynie odpowiedniej okazji (sprawy), w której mogłoby to zostać potwierdzone przez TSUE.

Jeśli chodzi o art. 1 ust. 2 oraz art. 2 Protokołu to niosą one ze sobą mniejszy potencjał derogacyjny. Na ostateczne rozstrzygnięcie wątpliwości, co do ich skutku będziemy jednak musieli poczekać, aż kwestię tę podejmie w swym orzecz-

${ }^{518}$ Ibidem, s. 41; por. także: J. Baquero Cruz, What's Left of the Charter? Reflections on Law and Political Mythology, "Maastricht Journal of European and Comparative Law" 2008, t. 15, s. 71 .

${ }^{519} \mathrm{KPP}$ potwierdza czy też uznaje prawa zawarte w zasadach ogólnych prawa unijnego. To one właśnie, wypracowane na podstawie tradycji konstytucyjnych państw członkowskich w orzecznictwie TSUE stanowiły przed wejściem w życie Karty źródło obowiązywania w prawie unijnym praw podstawowych. Jak słusznie zauważa w tym kontekście Andrzej Wróbel: „Zasadniczym problemem w kontekście wyodrębnienia tych dwóch kategorii praw podstawowych jest jednak to, czy prawa podstawowe zawarte w zasadach ogólnych prawa unijnego stanowią katalog zamknięty w tym sensie, że w związku z uznaniem i potwierdzeniem tego dorobku orzeczniczego przez Kartę Trybunał został pozbawiony kompetencji do »odkrywania« innych praw podstawowych niż określone w Karcie i uzupełniania w drodze orzecznictwa katalogu praw podstawowych określonych w KPP. Biorąc pod uwagę cel przyjęcia Karty, jej status oraz stanowisko państw członkowskich i prace przygotowawcze, należy przyjąć, że Trybunał nie może rozszerzać - w drodze orzecznictwa - katalogu praw podstawowych określonych w Karcie (zob. komentarz do art. 51 ust. 2 i art. 52), co nie oznacza, że nie może korzystać z dorobku orzeczniczego w tym zakresie, przy stosowaniu i wykładni odnośnych jej postanowień" (A. Wróbel, Art. 51..., s. 1324-1325). 
nictwie TSUE. Warto jednak zwrócić uwagę, że TSUE dostrzega specyficzny i wymagający konkretyzacji w prawie unijnym lub krajowym, zależnie od podziału kompetencji między Unią a państwami członkowskimi, charakter praw zagwarantowanych w Tytule IV Karty, którego dotyczy art. 1 ust. 2 Protokołu. Była o tym mowa w poprzednim rozdziale. Dlatego też wynikający z tego przepisu wniosek, że wyklucza on możliwość dochodzenia na podstawie Karty wskazanych w Tytule IV KPP praw podstawowych na drodze postępowania sądowego, jeśli nie zostały one zagwarantowane w konkretnych przepisach prawnych przez państwa członkowskie lub Unię zgodnie z podziałem kompetencji między nimi, w zasadzie jest powtórzeniem tego, co i tak wynika z art. 52 ust. 5 Karty.

Tym niemniej trzeba pamiętać, że niektóre przepisy zawarte w tym Tytule Karty zawierają w sobie prawa, a nie jedynie ustanawiają zasadę, a delimitacja odnośnie do niektórych z nich co do tego, w jakim stopniu zawierają prawo, a w jakim zasadę, czasem może rodzić pewne wątpliwości. Zgodnie z Wyjaśnieniami dotyczącymi Karty bezsporne jest, że art. 25 (prawa osób starszych), art. 26 (integracja osób niepełnosprawnych) i art. 37 (ochrona środowiska) to wyłącznie zasady, choć wyliczenie to nie jest kompletne ${ }^{520}$. "W praktyce granice między prawami a zasadami są płynne. Niektóre przepisy Karty zawierają zarówno elementy praw, jak i zasad"521. W razie uznania, że niektóre przepisy Tytułu IV Karty ustanawiają konkretne prawa, przepis 1 ust. 2 Protokołu może być uznany za nie tyle derogujący od postanowień Karty, ale warunkujący możliwość dochodzenia tych praw na drodze sądowej, jeśli prawa te nie byłyby przewidziane $\mathrm{w}$ prawie krajowym (polskim albo brytyjskim). W zasadzie więc to nie obowiązywanie Karty jako takiej podlegać miałoby pewnemu ograniczeniu, lecz byłoby ono zawieszone do momentu, w którym prawo krajowe potwierdziłoby te zasady a nawet prawa (jeśli z przepisów tego Tytułu jakieś prawa wynikają ${ }^{522}$ ). Mówiąc krótko, jak zauważa Krystyna Kowalik-Bańczyk, przepis ten wyklucza bezpośredni skutek tych postanowień zawartych w Tytule IV KPP, z których treści lub charakteru wynika odesłanie do prawa krajowego. Oznacza to niemożliwość dochodzenia wynikających z nich uprawnień bezpośrednio na podstawie Karty i konieczność inkorporacji tych praw do prawa krajowego dla ich skuteczności. Jednak w ocenie tej autorki zastrzeżenie zawarte $\mathrm{w}$ art. 1 ust. 2 Protokołu jest w stosunku do Polski bezprzedmiotowe, ponieważ doszło

${ }^{520}$ A. Arnull, Protocol (No 30)..., s. 1608.

${ }^{521}$ M. Wróblewski, Ł. Bojarski, D. Schindlauer, K. Wladasch, Karta Praw..., s. 58.

${ }^{522}$ Stanowiska są w tej materii podzielone. Patrz np.: A. Arnull, Protocol (No 30)..., s. 16o8; np. Michael Dougan twierdzi, że art. 1 ust. 2 należy uznać za deklaratoryjny, ponieważ żaden z przepisów Tytułu IV Karty nie ustanawia żadnych samodzielnych (freestanding) praw, które mogłyby być dochodzone (justiciable) (M. Dougan, The Treaty of Lisbon 2007: Winning Minds, Not Hearts, "Common Market Law Review” 20o8, nr 45, s. 669-670). 
już do pełnej implementacji praw pracowniczych z Tytułu IV KPP w polskim porządku prawnym ${ }^{523}$.

Dodatkowo, jeśli chodzi o intencje po stronie Polski związane z art. 1 ust. 2, należy zauważyć, że akurat odnośnie do Tytułu IV Karty i zagwarantowanych w nim praw Polska nie wyrażała szczególnego sceptycyzmu, być może właśnie w związku z szerokim zakresem ochrony praw zawartych $w$ tym rozdziale w prawie polskim. Wyraźnym przejawem braku sceptycyzmu w tej materii była kolejna (nr 62) Deklaracja dołączona do Aktu końcowego Konferencji przedstawicieli rządów państw członkowskich, która przyjęła Traktat lizboński. Zgodnie z tą deklaracją:

Rzeczpospolita Polska oświadcza, że ze względu na tradycję ruchu społecznego „Solidarność" i jego znaczący wkład w walkę o prawa społeczne i pracownicze, w pełni szanuje prawa społeczne i pracownicze ustanowione prawem Unii Europejskiej, w szczególności prawa potwierdzone w Tytule IV Karty praw podstawowych Unii Europejskiej ${ }^{524}$.

Zdaje się to potwierdzać sformułowaną powyżej tezę co do bezprzedmiotowości tego przepisu w odniesieniu do Polski. Deklaracja nr 62, jakby stojąca w opozycji do sensu przystępowania przez Polskę do Protokołu, przynajmniej W związku z jego art. 1 ust. 2, dobitnie odzwierciedla również fakt, że dokument ten "był autorską koncepcją Wielkiej Brytanii, do której Polska tylko się przyłączyła"525. Nie zmienia to faktu, że przystąpiła doń, mówiąc w przenośni, z dobrodziejstwem inwentarza, gdyż jak się czasem podkreśla: „nie wykorzystała szansy odpowiednio wcześniej, na autorskie opracowanie podobnego protokołu, co skutkowało zaakceptowaniem oraz brakiem możliwości wpływu na treść dokumentu"526. Intencją Polski nie było więc raczej wykorzystywanie art. 1 ust. 2 jako opt-out'u w kwestiach związanych z prawami socjalnymi i pracowniczymi zagwarantowanymi w Tytule IV Karty. Jak już wspomniano, obawy te koncentrowały się raczej wokół kwestii obyczajowych i wrażliwych światopoglądowo, takich jak zagadnienia związane z małżeństwem czy aborcją. Karta jednak zagadnień takich nie obejmuje, jako że sprawy te w ogóle nie należą

${ }^{523}$ K. Kowalik-Bańczyk, Protokół w sprawie..., s. 1432.

${ }^{524}$ Deklaracja (nr 62) Rzeczypospolitej Polskiej dotycząca Protokołu w sprawie stosowania Karty praw podstawowych Unii Europejskiej w odniesieniu do Polski i Zjednoczonego Królestwa dołączona do Aktu Końcowego Konferencji przedstawicieli rządów państw członkowskich zwołanej w Brukseli w dniu 23 lipca 2007 roku w celu przyjęcia za wspólnym porozumieniem zmian do Traktatu o Unii Europejskiej, Traktatu ustanawiającego Wspólnotę Europejską oraz Traktatu ustanawiającego Europejską Wspólnotę Energii Atomowej, Dz.Urz. C 306 z 17 grudnia 2007.

${ }^{525}$ J. Skrzydło, Karta Praw..., s. 25.

${ }^{526}$ M. Książkiewicz, Stosowanie Karty..., s. 333-334. 
do materii wspólnotowej, stąd trudno byłoby wykorzystywać Kartę i jej postanowienia do narzucania państwom członkowskim jakichkolwiek rozwiązań w tych sprawach ${ }^{527}$. Tak więc znowu wydaje się, że Protokół potwierdza jedynie to, co i tak wynika z samej Karty, w tym wypadku szczególnie z jej art. 52 ust. 5. Gdyby na gruncie art. 52 ust. 5 Karty mogły być co do tego jakiekolwiek wątpliwości, to art. 1 ust. 2 Protokołu przesądza, że przepisy zawarte w Tytule IV Karty należy traktować jako zasady w rozumieniu art. 52 ust. 5 Karty, a nie jako indywidualne prawa, których można dochodzić na drodze sądowej ${ }^{528}$.

Wreszcie, jeśli chodzi o art. 2 Protokołu, to odnosi się on zasadniczo do praw zagwarantowywanych w Karcie, które odsyłają do prawa krajowego, a więc takich, które zawierają zastrzeżenie, że podlegają regulacjom krajowym. Niektóre przepisy Karty wprost wskazują, że pewne kwestie zarezerwowane są dla prawodawstwa krajowego. Ma to również wpływ na możliwość stosowania Karty wobec państw członkowskich ratione materiae, o czym też wspomniano w poprzednim rozdziale. Znowu więc Protokół nie wydaje się wnosić nic nowego ponad to, co i tak wynika z przepisów samej Karty i potwierdza zarówno to, co zawarto w niektórych przepisach Karty, gwarantujących konkretne prawa i odsyłających przy tym do regulacji krajowych (jak np. art. 16, 27 czy 28 Karty), a także to, co wynika z art. 52 ust. 6 Karty.

Nie można również zapominać o preambule do Protokołu, a szczególnie o zawartych w niej motywach 8 i 9, potwierdzających w swej wymowie jego interpretacyjny charakter, oraz motywach 3, 9 i 10, podkreślających, że celem Protokołu nie jest wyłączenie obowiązywania Karty względem państw przystępujących do Protokołu i podkreślających znaczenie Wyjaśnień dotyczących Karty i zasad jej stosowania ${ }^{529}$. W motywie 6 Polska i Wielka Brytania przyznają wprost to, co Karta stwierdza w Preambule, a TSUE potwierdził w sprawie N.S., a więc, „że Karta potwierdza prawa, wolności i zasady uznawane w Unii oraz sprawia, że są one bardziej widoczne, nie tworzy jednak nowych praw ani zasad". Motywy 7 i 12 podkreślają też związanie Polski i Zjednoczonego Królestwa prawem unijnym i wynikającymi stąd dla nich konsekwencjami, w tym i dotyczącymi ochrony praw podstawowych oraz fakt, że Protokół nie ma wpływu na te zobowiązania, których Karta jest przecież, choć kluczowym, ale jednak

${ }^{527}$ C. Barnard, The 'Opt-Out'..., s. 276. Choć jak zauważa Mirosław Wyrzykowski: „Nie znaczy to, że sytuacje będące źródłem odrzucenia Karty Praw Podstawowych, a mające swoje zakorzenienie $\mathrm{w}$ ogólnych zasadach prawa oraz w fundamentalnym zakazie wszelkiej dyskryminacji, w tym ze względu np. na orientację seksualna, nie spowodują koniecznych konsekwencji prawnych dotyczących pewnych zagadnień transgranicznych" (M. Wyrzykowski, Wprowadzenie: granice władzy i granice interpretacji, [w:] J. Barcz (red.), Ochrona praw podstawowych w Unii Europejskiej, Warszawa 2008, s. 29-30).

${ }^{528}$ Por.: S. Biernat, Czy Karta Praw..., s. 67 i 75; M. Pyziak-Szafnicka, Karta Praw..., s. 23.

${ }^{529}$ Por.: M. Jaśkowski, Konsekwencje prawne..., s. 35 i podana tam literatura. 
jedynie elementem. Dlatego też, co należy zauważyć - obszerna i odnosząca się do wielu istotnych z perspektywy zakresu obowiązywania Karty kwestii preambuła do Protokołu, choć niewiążąca, ze wspomnianymi motywami na czele sprawia, że traktowanie Protokołu jako opt-out'u byłoby z nią niespójne ${ }^{530}$. Odnośnie do postanowień Protokołu nr 30 można więc skonkludować, że:

Po pierwsze, Karta nie rozszerza zdolności Trybunału Sprawiedliwości [...] ani żadnego sądu lub trybunału Polski lub Zjednoczonego Królestwa do uznania, że przepisy ustawowe, wykonawcze lub administracyjne, praktyki lub działania administracyjne Polski lub Zjednoczonego Królestwa są niezgodne z podstawowymi prawami, wolnościami i zasadami, które są w niej potwierdzone (art. 1 ust. 1 Protokołu nr 30). Po drugie, nic, co zawarte jest w tytule [IV] Karty nie tworzy praw, które mogą być dochodzone na drodze sądowej, mających zastosowanie do Polski lub Zjednoczonego Królestwa, z wyjątkiem przypadków, gdy Polska lub Zjednoczone Królestwo przewidziały takie prawa w swoim prawie krajowym (art. 1 ust. 2 Protokołu nr 30 ). Po trzecie, jeżeli dane postanowienie Karty odnosi się do ustawodawstw i praktyk krajowych, to ma ono zastosowanie do Polski lub Zjednoczonego Królestwa wyłącznie w zakresie, $w$ jakim prawa i zasady zawarte w tym postanowieniu są uznane przez ustawodawstwo lub praktyki Polski lub Zjednoczonego Królestwa (art. 2 Protokołu nr 30$)^{531}$.

W zasadzie więc, mimo że Protokół dotyczy jedynie Polski i Wielkiej Brytanii, jak sam przyznawał jeszcze przed wydaniem przez TSUE wyroku w sprawie N.S. jeden z negocjatorów Protokołu ze strony Zjednoczonego Królestwa - Daniel Denman, dokument ten czyni niewiele więcej ponad to, że określa pewne implikacje sposobu, w jaki prawo Unii nadaje Karcie efektywność, co - choć w Protokole mowa jedynie o dwóch krajach - jest tak samo prawdziwe dla wszystkich państw członkowskich ${ }^{532}$.

W pewnym sensie pozorność problemu związanego z interpretacją Protokołu jako opt-out'u od postanowień Karty jeszcze dobitniej ukazuje fakt, że jeśli nawet Protokół w jakimkolwiek wymiarze mógłby skutkować derogacją od jej postanowień, to i tak nie zmieniałoby to faktu, że unijne prawa podstawowe zagwarantowane jako zasady ogólne prawa unijnego mogłyby być jako takie do Polski stosowane, tak jak miało to miejsce przed wejściem Karty w życie ${ }^{533}$. Jak zauważa Anna Wyrozumska, nawet jeśli więc „nie bezpośrednio Karta, to prawa w niej zawarte mogą być powoływane (bezpośrednio) m.in. dlatego, że

${ }^{530}$ A. Arnull, Protocol (No 30)..., s. 1603-1604.

${ }^{531}$ J. Skrzydło, Karta Praw..., s. 25.

532 D. Denman, (Opinion) The Charter of Fundamental Rights, „European Human Rights Law Review" 2010, nr 4, s. 355; por. także: V. Belling, Supranational Fundamental..., s. 267.

${ }^{533}$ Por.: C. Barnard, The 'Opt-Out'..., s. 267. 
stanowią jednocześnie prawa zawarte w EKPCz lub wynikają z tradycji konstytucyjnej państw członkowskich. Będzie to w zdecydowany sposób minimalizowało konsekwencje Protokołu" ${ }^{\prime 534}$. Karta, co wyraźnie podkreślił w wyroku N.S. TSUE, potwierdza prawa podstawowe obecne w prawie Unii jako zasady ogólne tego prawa, wynikające $\mathrm{z}$ tych dwu źródeł. W tym wymiarze więc wyrok N.S., choć ograniczony sensu stricto do art. 1 ust. 1 Protokołu sensu largo podważa jego derogacyjny potencjał. Konieczność uciekania się przez TSUE do, w pewnym sensie, obchodzenia Protokołu, tak jak o tym mowa powyżej, mogłoby jednak nieść ze sobą negatywne konsekwencje. Byłoby to szczególnie widoczne z perspektywy jednostki, ponieważ "konieczność powołania się na zasady ogólne prawa unijnego w miejsce Karty byłaby mniej korzystna dla skarżącego. Łatwiej bowiem odwołać się do prawa ujętego w Karcie, niż wykazać, że dane prawo podstawowe rzeczywiście podlega ochronie w Unii Europejskiej na mocy zasad ogólnych prawa" ${ }^{\prime 35}$. Mogłoby też prowadzić do osłabienia potencjalnej aktywności Komisji Europejskiej i stawiania przez nią w razie potrzeby zarzutów przeciwko Polsce czy Zjednoczonemu Królestwu (póki jeszcze jest ono w Unii) związanych z naruszaniem praw podstawowych, opierając się na naruszeniu zasad ogólnych prawa Unii, a nie Karty. Mogłoby to bowiem spotkać się ze szczególnie politycznie nośnym zarzutem obchodzenia Protokołu.

Jak zauważają Tomasz Tadeusz Koncewicz i Anna Podolska: „Treść protokołu nie daje jednak jednoznacznej odpowiedzi co do jego rzeczywistego wpływu na stosowanie Karty"536, co wprowadza pewną konfuzję wśród przedstawicieli doktryny, jak i wśród praktyków, szczególnie wśród sędziów sądów krajowych. Jeśli okaże się więc, że Protokół w jakimś ograniczonym wymiarze może modyfikować zastosowanie unijnych praw podstawowych wobec Polski, nawet jeśli miałoby to mieć miejsce jedynie w pewnych kategoriach spraw czy sytuacji, to będzie musiało to zastać doprecyzowane w orzecznictwie. Dobrym poligonem do tego rodzaju rozstrzygnięć jest procedura pytania prejudycjalnego. Potencjalny zakres tych modyfikacji nie wydaje się jednak mieć zasadniczego wpływu na podstawowe zasady zastosowania zagwarantowanych w Karcie unijnych praw podstawowych wobec państw członkowskich wynikających samej z Karty i mających oparcie w traktatach kształtujących unijny porządek prawny. Mówiąc ogólniej, co szczególnie istotne w kontekście tej pracy, potencjalny zakres tych modyfikacji nie wydaje się mieć wpływu na podział kompetencji między TSUE a TK, gdy chodzi o kontrolę prawa obowiązującego w Polsce pod kątem jego zgodności z prawami człowieka. Skoro tak, to nie powinien mieć on również wpływu na możliwość wykorzystania procedury

\footnotetext{
${ }^{534}$ A. Wyrozumska, Inkorporacja Karty..., s. 96-97.

${ }_{535}$ M. Jaśkowski, Konsekwencje prawne..., s. 48.

536 T.T. Koncewicz, A. Podolska, Karta Praw..., s. 250.
} 
pytania prejudycjalnego do prowadzenia dialogu między tymi dwoma sądami w celu obrony konstytucyjnych standardów ochrony praw człowieka, które byłyby wyższe niż standardy unijne, o czym będzie mowa w rozdziale IV, a co jest głównym przedmiotem zainteresowania w tej pracy.

\section{Stosowanie Karty Praw Podstawowych przez sądy polskie}

Stosowanie sensu stricto Karty, a więc branie jej za podstawę orzekania w orzeczeniach indywidualnych i konkretnych, przez polskie sądy jest zjawiskiem rzadkim. Praktyka sądów polskich w tej materii jest dość ułomna i znamionuje ją słabe rozumienie zasad zastosowania Karty zawartych w jej art. 51 ust. 1. Być może po części jest to związane z pewnymi niejasnościami, jakie pozostawił po sobie wyrok w sprawie Åkerberg Fransson, który o ile miał zasadnicze znaczenie dla rozumienia art. 51 ust. 1 Karty i zakresu jej zastosowania do państw członkowskich, o tyle przyjęta w nim

definicja zastosowania Karty nie rozwiązuje problemów sądów krajowych, jakie te mają i będą mieć w przyszłości co do uznania w konkretnej sprawie, iż znajduje się ona w zakresie zastosowania prawa UE, a więc i KPP. Po orzeczeniu w sprawie Åkerberg Fransson jest jasne, jak to sformułowała rzeczniczka generalna E. Sharpston, że: „Karta nie przyznaje 'autonomicznych' praw podstawowych, to jest praw niemających punktu stycznego ze sferą należącą do właściwości Unii". Natomiast nadal pozostaje pytanie, na czym ma polegać ten punkt styczny (łącznik) pozwalający na uznanie, że sprawa mieści się w zakresie zastosowania KPP?537.

Jak zostało to ukazane w poprzednim rozdziale, orzecznictwo następujące już po wyroku w sprawie Åkerberg Fransson w sposób istotny doprecyzowywało rozumienie zasad rządzących stosowaniem unijnych praw podstawowych wobec państw członkowskich w związku z art. 51 ust. 1 Karty. Jednakże jego liczba, wielowątkowość, a czasem dość kazuistyczne, trudne do ekstrapolacji podejście zaprezentowane w niektórych sprawach przez TSUE, niekoniecznie musiało się przyczynić do powstania powszechnej jasności co do tego, kiedy należy stosować unijne prawa podstawowe zagwarantowane w Karcie, a kiedy stosować należy gwarancje krajowe.

Nie ulega wątpliwości, że w związku z członkostwem w Unii sądy krajowe państw członkowskich Unii Europejskiej, a więc także sądy polskie, są również

${ }^{537}$ N. Półtorak, Zakres zwiazania..., s. 21. 
sądami unijnymi ${ }^{538}$. Stosują one obowiązujące w tych krajach prawo Unii i ciąży na nich obowiązek stosowania unijnych praw podstawowych i pilnowania zarówno tego, by prawom tym odpowiadały regulacje unijne, jak i prawo krajowe mieszczące się w zakresie zastosowania prawa unijnego. Art. 19 ust. 1 TUE stanowi, że Trybunał Sprawiedliwości Unii Europejskiej obejmuje Trybunał Sprawiedliwości, Sąd i sądy wyspecjalizowane. Zapewnia on poszanowanie prawa w wykładni i stosowaniu Traktatów. W zdaniu trzecim stanowi jednak, że to państwa członkowskie ustanawiają środki niezbędne do zapewnienia skutecznej ochrony prawnej w dziedzinach objętych prawem Unii.

Oznacza to, że w sposób funkcjonalny sądy państw członkowskich należą do systemu sądownictwa UE, gdyż rozstrzygają sprawy, których przedmiot jest objęty zakresem zastosowania prawa UE (tzw. sprawy unijne). Dodatkowo, szczególne znaczenie sądów krajowych jest wzmocnione skromną ilością postępowań bezpośrednio przed sądami unijnymi, z których może skorzystać jednostka, a zwłaszcza restrykcyjnymi warunkami, które należy spełnić w celu unieważnienia aktu prawa unijnego ${ }^{539}$.

Dlatego też:

Sąd krajowy, który jest właściwy do rozstrzygnięcia sprawy przed nim zawisłej, powinien zawsze dokonywać oceny, jaki charakter ma owa sprawa. Powyższa analiza jest konieczna z punktu widzenia prawidłowego zastosowania przepisów oraz wydania orzeczenia zgodnego z prawem. W przypadku ustalenia, że sprawa ma charakter unijny, sąd krajowy obowiązany jest do rozpatrzenia danej kwestii pod kątem zgodności z unijnymi standardami praw podstawowych, które nie są badane w przypadku sprawy „czysto wewnętrznej”540.

Jak zauważają jednak Tomasz Tadeusz Koncewicz i Anna Podolska, jeśli chodzi o polskie sądy, a przynajmniej o sądy powszechne i Sąd Najwyższy, którym poświęcili oni swą uwagę, to dość „nieśmiało odnoszą się one do postanowień Karty, raczej nie zauważając jej regulacji" ${ }^{541}$. Liczba orzeczeń, które w ogóle wskazują na istnienie tego aktu, jest dość skromna, szczególnie jeśli będziemy pamiętać, ile orzeczeń rocznie wydają polskie sądy powszechne (liczba ta oscyluje w okolicach piętnastu milionów rocznie ${ }^{542}$ ). „Dodatkowo jedynie

${ }^{538}$ Szerzej patrz np.: M. Claes, The National Courts' Mandate in the European Constitution, Oxford, Portland 2006.

${ }^{539}$ R. Grzeszczak, A. Szmigielski, Sądowe stosowanie..., s. 12.

${ }^{540}$ Ibidem, s. $12-13$.

${ }^{541}$ T.T. Koncewicz, A. Podolska, Karta..., s. 252.

${ }^{542}$ E. Kania, MS: w zeszłym roku do sądów trafito ponad 14 mln spraw, "Rzeczpospolita”, [online] <http://www.rp.pl/artykul/990665-MS--w-zeszlym-roku-do-sadow-trafilo-ponad14-mln-spraw.html\#ap-1> [dostęp: 28.12.2018]. 
nieliczne z tych nielicznych orzeczeń, w których Karta się pojawia, uwzględniają Kartę jako podstawę rozstrzygnięcia, nie zaś wyłącznie informacyjny element uzasadnienia" ${ }^{543}$. Nawet jeśli odniesienia w orzecznictwie polskich sądów do Karty są relatywnie nieliczne, to należy zauważyć, że z czasem pojawia się ich coraz więcej. Kluczowym z perspektywy tej pracy problemem, z tych, na które uwagę zwrócili wspomniani autorzy, zdaje się być ten drugi. Orzeczenia sądów polskich dotyczące Karty bardzo często nie mają oparcia w art. 51 ust. 1 Karty i zasadach zastosowania unijnych praw podstawowych. Mają więc na ogół charakter ornamentacyjny, a w najlepszym wypadku argumentacyjny. Bardzo rzadko jednak Karta i jej przepisy stają się faktyczną podstawą orzeczenia. Tymczasem, jak pisze Mirosław Wróblewski:

Trzeba podkreślić, że ustalenie na podstawie art. 51 ust. 1 KPP, czy Karta będzie mogła mieć zastosowanie w odniesieniu do państwa członkowskiego, przesądza, czy powołanie w orzeczeniu prawa albo wolności ustanawianej Kartą jako podstawy wyroku bądź w warstwie argumentacyjnej będzie w ogóle zasadne. Dlatego też bardzo liczne odniesienia do KPP niespełniające tego wymagania, które można odnaleźć w dotychczasowym orzecznictwie polskich sądów, można ocenić wyłącznie w perspektywie ornamentacyjnego wzbogacania zawartości uzasadnienia orzeczeń. [...] Dekoracyjne zamieszczenie w uzasadnieniu orzeczenia przepisu Karty będzie, w najlepszym wypadku, wskazywało, że porządek unijny rozpoznaje dane wartości prawne, które najczęściej chronione są także w konstytucyjnym systemie państwa ${ }^{544}$.

Fakt ten - pomocniczego wykorzystywania Karty jako wsparcia argumentacji opierającej się na prawie polskim - nie powinien budzić zaskoczenia w obliczu tego, o czym wielokrotnie już wspominano, a więc zakorzenienia unijnych praw podstawowych we wspólnych tradycjach konstytucyjnych państw członkowskich. Nie usprawiedliwia on jednak ignorowania problematyki zakresu zastosowania Karty i orzekania na jej podstawie.

[W] orzecznictwie polskich sądów analiza problemu zakresu podmiotowego zastosowania unijnych praw podstawowych i samej KPP w zasadzie nie występuje. Dzieje się tak, pomimo że Karta jest stosunkowo często przywoływana w sprawach sądowych przez strony. Jednak powoływana jest nieadekwatnie, bez odpowiedniego uzasadnienia, jako dodatkowe i generalne poparcie argumentacji. W takich przypadkach sądy traktują Kartę jako uzupełniające uzasadnienie dokonanego - na podstawie prawa polskiego - rozstrzygnięcia. W niektórych przypadkach rozpatrują zarzuty naruszenia KPP, jednak bez analizy dotyczącej możliwości jej zastosowania w sprawie ${ }^{545}$.

\footnotetext{
543 T.T. Koncewicz, A. Podolska, Karta..., s. 252.

${ }^{544}$ M. Wróblewski, Karta Praw Podstawowych Unii Europejskiej w polskim..., s. 18.

545 N. Półtorak, Zakres zwiazania..., s. 17.
} 
Na marginesie można zauważyć, że podobną rolę, mimo zasadniczej różnicy, jaka dzieli ten dokument od KPP, pełni często w orzecznictwie sądów polskich EKPCz. Mimo że Karta w przeciwieństwie do Konwencji jest ograniczona w swym zastosowaniu do Unii oraz jedynie do sytuacji, w których państwa członkowskie stosują prawo unijne, właściwie zasadą jest, że w przypadku wspierania się przez sąd w uzasadnieniu orzeczenia szerszym lub węższym odniesieniem do innych niż polskie standardów ochrony praw człowieka, Karta i Konwencja przywoływane są jednym tchem, często również w towarzystwie dokumentów takich, jak Powszechna Deklaracja Praw Człowieka ${ }^{546}$, Międzynarodowy Pakt Praw Obywatelskich (Osobistych) i Politycznych ${ }^{547}$, Międzynarodowy Pakt Praw Gospodarczych, Społecznych ${ }^{548}$ i Kulturalnych ${ }^{549}$ i inne. Jeszcze dobitniej pokazuje to niezrozumienie przez polskie sądy specyfiki Karty i wynikającego z niej zakresu zastosowania zagwarantowanych w niej praw i wolności.

\subsection{Stosowanie Karty przez sądy administracyjne}

Orzecznictwo sądów administracyjnych wpisuje się w trend ornamentacyjno-argumentacyjnego używania Karty. Jak zauważa Mirosław Wróblewski, „W polskim sądownictwie administracyjnym Karta powoływana jest stosunkowo często" 550 . Jak policzył, w latach 2011-2013 w ponad 20\% wszystkich analizowanych przez niego wyroków (choć oczywiście nie były to wszystkie wyroki sądów administracyjnych, lecz jedynie wybrana ich grupa, szczególnie doniosła w kontekście ochrony praw człowieka) „sądy administracyjne podzielały opinię strony powołującej się na naruszenie przepisów Karty. Najczęściej stwierdzano naruszenie prawa do dobrej administracji, określonego przez art. $41 \mathrm{KPP}^{\prime \prime 51}$. Jednakże większość tych odniesień nie wiązało się z orzekaniem na podstawie Karty, lecz powielało schemat opisany wcześniej i przybierało charakter w dużej mierze ornamentacyjno-argumentacyjny. Jak zostało to podkreślone

\footnotetext{
${ }^{546}$ Powszechna Deklaracja Praw Człowieka uchwalona w dniu 10 grudnia 1948 roku w Paryżu.

${ }^{547}$ Międzynarodowy Pakt Praw Obywatelskich (Osobistych) i Politycznych z 16 grudnia 1966, Dz.U. 1977 nr 38, poz. 167.

${ }^{548}$ Użyte w oficjalnej polskiej nazwie Paktu pojęcie praw społecznych błędnie oddaje charakter praw, do których Pakt się odnosi. Prawidłowo należałoby mówić o prawach socjalnych, por. np.: Z. Kędzia, Wprowadzenie, [w:] Z. Kędzia, A. Hernandez-Połczyńska (red.), Międzynarodowy Pakt Praw Gospodarczych, Socjalnych i Kulturalnych. Komentarz, Warszawa 2018, s. 2.

${ }^{549}$ Międzynarodowy Pakt Praw Gospodarczych, Społecznych i Kulturalnych otwarty do podpisu w Nowym Jorku 19 grudnia 1966, Dz.U. z 1977 nr 38, poz. 169.

${ }^{550}$ M. Wróblewski, Karta Praw Podstawowych Unii Europejskiej w polskim..., s. 18.

${ }^{551}$ Ibidem.
} 
w sprawozdaniu z orzecznictwa sądów administracyjnych za rok 2015, sporządzonym przez Biuro Orzecznictwa NSA, jeśli chodzi o Kartę, to

sądy administracyjne powoływały KPP przede wszystkim, by wskazać, że określone prawa jednostki są gwarantowane nie tylko w Konstytucji RP czy EKPC, ale również w ramach systemu prawa UE. W szczególności dotyczyło to prawa do sądu, prawa własności, zasady legalności oraz proporcjonalności kar do czynów zabronionych pod groźbą kary - w kontekście charakteru sankcji administracyjnych ${ }^{552}$.

Podobnie rzecz się miała w roku $2014^{553}$. Praktyka ta była również charakterystyczna dla aktywności sądów administracyjnych w latach poprzednich ${ }^{554}$. Należy także podkreślić, że żadne z pytań prejudycjalnych wystosowanych przez polskie sądy administracyjne do TSUE nie dotyczyło Karty ani tym bardziej jej zakresu zastosowania w związku z jej art. 51 ust. 1, chociaż procedura pytania prejudycjalnego jest przez sądy te stosowana dość aktywnie ${ }^{555}$.

W wyroku z 21 października 2011 w sprawie dotyczącej przepisów podatkowych NSA poświęcił sporo uwagi art. 20 Karty, gwarantującemu równość wobec prawa. Odmówił jednak jego zastosowania ze względu na fakt, że zdaniem sądu ustanawia on zasadę interpretacyjna,

w świetle której należy dokonywać wykładni kolejnych przepisów zawartych w tym rozdziale dotyczących takich kwestii, jak: niedyskryminacja, równość kobiet i mężczyzn, poszanowania zróżnicowania kulturalnego, religijnego i językowego. Z tej konstatacji można wywieść, że art. 20 Karty Praw Podstawowych nie może być samodzielną podstawą do skutecznego wniesienia środka zaskarżenia bez wskazania, który przepis regulujący problematykę równości został konkretnie naruszony ${ }^{556}$.

${ }^{552}$ Naczelny Sąd Administracyjny, Informacja o działalności sądów administracyjnych w 2015 roku, Warszawa 2016, s. 217, [online] <www.nsa.gov.pl/download.php?id=335\&mo$\mathrm{d}=\mathrm{m} / 11 /$ pliki_edit.php $>$ [dostęp: 28.12.2018].

${ }_{553}$ Sprawozdanie roczne, Biuro Orzecznictwa Naczelnego Sądu Administracyjnego, Warszawa, kwiecień 2015, s. 261 i nast., [online] <http://www.nsa.gov.pl/sprawozdania-roczne. php> [dostęp: 28.12.2018].

${ }^{554}$ Por. np.: Naczelny Sąd Administracyjny, Informacja o działalności sądów administracyjnych w 2013 roku, Biuro Orzecznictwa Naczelnego Sądu Administracyjnego, Warszawa, 23 kwietnia 2014, s. 227-253, [online] <http://www.nsa.gov.pl/sprawozdania-roczne.php> [dostęp: 28.12.2018]; Sprawozdanie roczne, Biuro Orzecznictwa Naczelnego Sądu Administracyjnego, Warszawa, kwiecień 2013, s. 242-267, [online] <http://www.nsa.gov.pl/sprawozdania-roczne.php> [dostęp: 28.12.2018].

${ }_{555}$ Patrz np.: Naczelny Sąd Administracyjny, Informacja o działalności sądów administracyjnych w 2015 roku, Warszawa 2016, s. 217, 219 i nast., [online] <www.nsa.gov.pl/download. php?id=335\&mod=m/11/pliki_edit.php $>$ [dostęp: 28.12 .2018$]$.

${ }^{556}$ NSA, sprawa II FNP 3/11, wyrok z 21 października 2011 [cyt. za: LEX 1069792]. 
Tymczasem we wniosku nie wskazano takich przepisów. Abstrahując od poprawności tego rozumowania, należy podkreślić, że w wywodzie NSA brak jakichkolwiek rozważań na temat, czy w ogóle sprawa mieści się w zakresie zastosowania prawa Unii i czy w związku z tym można stosować w niej unijne prawa podstawowe.

Za przykłady orzeczeń sądów administracyjnych wpisujących się w tendencję ornamentacyjno-argumentacyjną mogą posłużyć wyroki NSA z 19 lipca 2012, w którym podniesione zostały, odrzucone przez sąd, zarzuty związane $\mathrm{z}$ art. 17 ust. 1 Karty gwarantującym prawo własności oraz zasadą proporcjonalności ${ }^{57}$ oraz WSA w Lublinie z 7 listopada 2013, w którym pojawiła się kwestia przewidzianych w Karcie gwarancji prowadzenia działalności gospodarczej $^{558}$. Brak w nich jakiejkolwiek analizy dotyczącej możliwości zastosowania w tych sprawach unijnych praw podstawowych. Podobnych przykładów nie brak również wśród orzeczeń nowszych, takich jak judykaty WSA w Warszawie z 6 sierpnia $2015^{559}$ oraz 12 sierpnia tego samego roku ${ }^{560}$, w których to sąd ten odwołał się do chronionej przez prawo unijne zasady ne bis in idem oraz legalności i proporcjonalności kar do czynów zabronionych pod groźbą kary w kontekście charakteru sankcji administracyjnych. Uczynił to znowu bez refleksji nad możliwością zastosowania Karty i zawartej w niej zasady ne bis in idem. W sprawach tych brak zresztą podstaw do zastosowania Karty. Wobec tego wspomniane sądy, nawet gdyby chciały, Karty sensu stricto zastosować by nie mogły. Mogłyby jednak zrobić to, co zrobiły, a więc przywołać Kartę pomocniczo. Wyraźne stwierdzenie jedynie pomocniczego jej przywołania oparte na prawidłowym zastosowaniu art. 51 ust. 1 KPP pomyślnie wpłynęłoby na przejrzystość uzasadnienia i stanowiłoby świadectwo świadomego, a nie innego użycia Karty, dającego również rękojmię faktycznego zastosowania Karty jako podstawę orzekania w sprawach, w których byłoby to uzasadnione. Tymczasem brak takiej praktyki może budzić poważne wątpliwości.

W miejscu tym wskazać można także wyrok NSA z 24 lutego 2015, w którym Karta pojawiła się w kontekście ochrony prawa własności ${ }^{561}$, oraz wyroki dotyczące prawa do sądu z 22 maja $2015^{562}$ oraz z 24 września $2015^{563}$. Podobnych orzeczeń można by wskazać znacznie więcej ${ }^{564}$. W każdym z tych orze-

${ }^{557}$ NSA, sprawa I OSK 810/11, wyrok z 19 lipca 2012.

558 WSA w Lublinie, sprawa III SA/Lu 476/13, wyrok z 17 listopada 2013.

${ }^{559}$ WSA w Warszawie, sprawa V SA/Wa 1217/15, wyrok z 6 sierpnia 2015.

${ }^{560}$ WSA w Warszawie, sprawa V SA/Wa 1214/15, wyrok z 12 sierpnia 2015.

${ }^{561}$ NSA, sprawa I OSK 1502/13, wyrok z 24 lutego 2015.

${ }^{562}$ NSA, sprawa II GSK 935/14, wyrok z 22 maja 2015.

${ }^{563}$ NSA, sprawa II OSK 107/14, wyrok z 24 września 2015.

${ }^{564}$ Patrz np.: M. Wróblewski, Karta Praw Podstawowych Unii Europejskiej w polskim..., s. 18-19 i podane tam orzecznictwo. 
czeń brak jakiegokolwiek odniesienia się do art. 51 ust. 1 Karty i pogłębionej analizy związanej z zakresem zastosowania Karty. W większości stanowią one dobre przykłady ornamentacyjno-argumentacyjnego przywołania postanowień Karty i zawartych w niej gwarancji dla poparcia stanowiska sądu opartego na prawie polskim lub też pozbawione rozważań na temat stosowalności unijnych praw podstawowych przykłady odrzucenia argumentacji nawiązującej do Karty jako nieuzasadnionej. To ostatnie nie jest jednak oparte na zasadach stosowalności Karty, które nie są spełnione, lecz na przekonaniu sądu, że sytuacja spełnia zarówno wymagania standardu polskiego, jak i standardu unijnego.

Celem tej pracy nie jest szczegółowa i przekrojowa analiza orzecznictwa sądów administracyjnych odnoszącego się w jakikolwiek sposób do Karty, a jedynie zilustrowanie pewnej tendencji związanej z pomijaniem zasadniczej kwestii, jaką jest art. 51 ust. 1 Karty oraz ewentualne wskazanie wybranych, zasługujących na szczególną uwagę, przejawów jej przełamywania. Dlatego też, przechodząc do tej drugiej kategorii orzeczeń, należy w tym miejscu wskazać postanowienie NSA z 22 sierpnia $2014^{565}$, w którym sąd ten wyczerpująco podniósł kwestię art. 51 ust. I KPP. Sprawa ta dotyczyła skargi o stwierdzenie niezgodności z prawem ostatecznego wyroku NSA w związku z zarzutem naruszenia art. 17 ust. 1 KPP. NSA stwierdził, że niewystarczające jest przytoczenie przez skarżącego jedynie tego przepisu $\mathrm{w}$ obliczu braku powiązania go $\mathrm{z}$ innym przepisem prawa UE, który był stosowany lub powinien być stosowany w tej sprawie.

W wyroku tym:

NSA wskazał, że żaden taki przepis prawa UE, z którym zaskarżone orzeczenie jest niezgodne, nie został wskazany przez skarżącego. Wprawdzie skarżący powołał się na art. 6 ust. 1 TUE, lecz pominął kwestię zakresu stosowania praw i zasad zawartych w KPP. NSA wskazał, że zakres zastosowania praw i zasad zawartych w KPP został uregulowany w art. 51 ust. 1 KPP, w świetle którego prawa i zasady określone w KPP są wiążące dla państw członkowskich wyłącznie w zakresie, w jakim stosują one prawo Unii. NSA przypomniał, że TSUE w wyroku w sprawie [...] Åkerberg Fransson przyjąl, że poszanowanie praw podstawowych chronionych na mocy Karty jest konieczne w sytuacji, gdy mające zastosowanie w sprawie przepisy mieszczą się w zakresie stosowania prawa Unii. Podobne stanowisko zostało wyrażone w wyroku w sprawie [...] Siragusa, w którym TSUE wskazał, że pojęcie stosowania prawa Unii w rozumieniu art. 51 KPP wymaga istnienia powiązania określonego stopnia z prawem Unii Europejskiej. Oznacza to, że co prawda KPP jako prawo pierwotne jest częścią porządku prawnego UE, ale zarzut naruszenia postanowień tej Karty może być podnoszony tylko w sytuacji, gdy w sprawie mają zastosowanie lub powinny mieć zastosowanie inne niż KPP przepisy prawa Unii Europejskiej. Zdaniem NSA wniosku

${ }^{565}$ NSA, sprawa I ONP 3/14, postanowienie z 22 sierpnia 2014. 
tego nie podważa brzmienie art. 6 ust. 1 TUE. NSA stwierdził, że zarzut naruszenia przepisów KPP nie może stanowić samodzielnej podstawy skargi o stwierdzenie niezgodności z prawem orzeczeń NSA, ponieważ KPP znajduje zastosowanie jedynie wtedy, kiedy w sprawie mogą mieć zastosowanie inne przepisy prawa UE i wskazanie tych przepisów jest wymogiem skargi o stwierdzenie niezgodności z prawem orzeczenia NSA określonym w art. 285e $\S 1$ pkt 3 p.p.s.a., którego niedopełnienie skutkuje odrzuceniem skargi na podstawie art. 285 h $\S$ 1 p.p.s.a. ${ }^{566}$

W sprawie tej NSA poprawnie wskazał art. 51 ust. 1 Karty jako klucz do rozstrzygnięcia o możliwości zastosowania unijnych praw podstawowych w danej sprawie oraz właściwie zidentyfikował fundamentalne z tej perspektywy orzecznictwo TSUE, rozstrzygające o tym, co mieści się w zakresie stosowania prawa Unii w rozumieniu tego przepisu, a co nie. Właściwie też określił skutki możliwości bądź też braku możliwości zastosowania unijnych praw podstawowych w postępowaniu polskim. Podobne, wręcz bliźniacze stanowisko NSA wyraził w dwóch analogicznych postanowieniach $z$ tego samego dnia $^{567}$. Ze względu na wspomniane orzeczenia należy zgodzić się z Mirosławem Wróblewskim, że: „Ogólna dosyć krytyczna ocena dotychczasowego polskiego orzecznictwa dotyczącego Karty, odnosząca się do braku odpowiedniej analizy możliwości jej zastosowania w świetle art. 51 ust. 1 KPP, musi być skorygowana przez pozytywną ocenę orzecznictwa NSA, wydawanego w ostatnim czasie [...]"568. Wspomniane orzeczenia NSA dobrze korespondują z zasadami dotyczącymi zastosowania Karty, o których była mowa w poprzednim rozdziale, i można je uznać za zwiastun rozwijającej się świadomości sądów administracyjnych co do zasad zastosowania KPP ${ }^{569}$. Orzeczenia te są więc świadectwem, że NSA wreszcie dostrzegł znaczenie tego przepisu oraz orzecznictwa TSUE w tej materii i zaczął brać je pod uwagę. "Co prawda, weryfikacja przedstawionej przez NSA wykładni deklaracji konieczności występowania łącznika między zastosowaniem przepisów prawa Unii a możliwością relewant-

566 Sprawozdanie roczne, Biuro Orzecznictwa Naczelnego Sądu Administracyjnego, Warszawa, kwiecień 2015, s. 298, [online] <http://www.nsa.gov.pl/sprawozdania-roczne.php> [dostęp: 28.12.2018].

${ }^{567} \mathrm{NSA}$, sprawa II ONP 4/14, postanowienie z 22 sierpnia 2014, oraz NSA, sprawa II ONP 5/14, postanowienie z 22 sierpnia 2014.

${ }^{568}$ M. Wróblewski, Karta Praw Podstawowych Unii Europejskiej w polskim..., s. 21.

${ }^{569} \mathrm{~W}$ szerszym kontekście tej problematyki, wymykającym się jednak poza obszar głównego zainteresowania tej pracy, można zauważyć również, że w postanowieniu z 30 maja 2014 NSA poprawnie podkreślił wiążący charakter Karty po TL, a także prawidłowo określił relację między Kartą a Konwencją na podstawie art. 52 ust. 3 Karty oraz to, że mimo iż ustanawia standard minimalny ochrony praw w niej zagwarantowanych również w unijnym porządku prawnym, sama nie jest jego elementem, jako że Unia nie jest jej stroną (NSA, sprawa I ONP 1/14, postanowienie z 30 maja 2014). 
nego postawienia zarzutu naruszenia Karty będzie wyzwaniem dla dalszego orzecznictwa, warto jednak zwrócić uwagę, że sądy administracyjne wreszcie zauważyły ten problem" ${ }^{\prime 570}$. Test sformułowany przez NSA odbiega jednak nieco od tego, jaki sformułował TSUE. NSA zdaje się wymagać istnienia przepisów unijnych znajdujących zastosowanie w sprawie, podczas gdy TSUE wystarczy powiązanie przepisów krajowych z celami realizowanymi przez prawo unijne, a więc z szeroko rozumianym kontekstem efektywności prawa unijnego. Wydaje się więc, że stanowisko NSA wymaga dalszego doprecyzowywania $\mathrm{w}$ dalszych orzeczeniach, stanowi jednak niewątpliwie ważny krok w dobrym kierunku i zwraca uwagę na najważniejsze kwestie związane ze stosowaniem Karty wobec prawa polskiego.

Jeszcze większym wyzwaniem dla sądów polskich, w tym dla NSA, będzie jednak prawidłowe rozróżnienie kwestii zakresu zastosowania Karty do państw członkowskich od potrzeby uruchomienia jej działania, „a więc oddzielenie kwestii możliwości zastosowania KPP i potrzeby jej rzeczywistego zastosowania zamiast standardu krajowego. Zakres zastosowania Karty do państw członkowskich (art. 51 ust. I KPP) powinien być definiowany szeroko [...]. Natomiast odmienną kwestią jest uzasadnienie potrzeby interwencji KPP [...]. Karta powinna być bowiem uruchamiana subsydiarnie w stosunku do krajowych standardów ochrony praw podstawowych"571, o czym szerzej była mowa w poprzednim rozdziale ( $w$ podrozdziałach: 6.3.3.1. oraz 6.4.3.2. $)^{572}$. Po uporaniu się z tymi trudnościami, jeszcze trudniejszą kwestią będzie dla sądów rozstrzygnięcie i właściwe wybranie dalszych kroków orzeczniczych w sytuacji konieczności zastosowania, czy też konieczności umożliwienia zastosowania sekwencji orzekania prowadzącej do ograniczenia potencjalnego konfliktu między TK a TSUE, o której będzie mowa w rozdziale IV tej pracy, w sytuacji potencjalnego zagrożenia dla wyższego niż unijny, konstytucyjnego standardu ochrony praw człowieka przez prawo Unii.

\subsection{Stosowanie Karty przez sądy powszechne}

Można wskazać wiele przykładów orzeczeń sądów powszechnych wpisujących się w przedstawione powyżej podejście do Karty i zawartych w niej gwarancji praw człowieka. Poniżej wspomnianych będzie kilka ich przykładów, wystarczających dla zilustrowania konstatacji co do dominującego również w sądach powszechnych, w najlepszym razie, ornamentacyjno-argumentacyjnego wy-

\footnotetext{
${ }^{570}$ M. Wróblewski, Karta Praw Podstawowych Unii Europejskiej w polskim..., s. 21.

${ }^{571}$ N. Półtorak, Zakres zwiazzania..., s. 26.

572 Por. także: M. Wróblewski, Karta Praw Podstawowych Unii Europejskiej w polskim..., s. 21.
} 
korzystania Karty. Większa uwaga poświęcona zostanie nielicznym, wybranym przykładom prawidłowego zastosowania unijnych praw podstawowych i Karty, które mogą służyć za wzór innym sądom w Polsce albo przynajmniej być uznane za znamiona pewnego przełamywania tendencji do ignorowania zasad zastosowania Karty.

Jako przykłady orzeczeń wpisujących się w ogólną tendencję ornamentacyjno-argumentacyjnego używania Karty wskazać można orzeczenie Sądu Apelacyjnego we Wrocławiu z 2012 r., który oprócz przepisów polskich, które stosował w sprawie odwołał się, obok gwarancji przewidzianych w prawie polskim, również do prawa do ochrony zdrowia oraz prawa do życia zagwarantowanych w Karcie, jak i w innych regulacjach międzynarodowych wymienionych obok niej w jednym rzędzie ${ }^{573}$; postanowienie Sądu Apelacyjnego w Białymstoku z 2013 r., w którym uwzględniony został zawarty w Karcie wymóg humanitarnego traktowania skazanych oraz wynikający stąd obowiązek zapewnienia warunków urzeczywistniających skazanym realne prawo do opieki zdrowotnej ${ }^{574}$; czy też wyrok Sądu Apelacyjnego w Gdańsku z tego samego roku, w którym powołał się on na zagwarantowane również w Karcie prawo do zabezpieczenia społecznego ${ }^{575}$. Jak podsumowują te judykaty Tomasz Tadeusz Koncewicz i Anna Podolska, żadna z tych „spraw nie miała elementu transgranicznego uzasadniającego stosowanie Karty, z drugiej jednak strony jej powołanie miało jedynie charakter informacyjny" ${ }^{\prime \prime 76}$. Regulacje międzynarodowe służyły tylko wsparciu czy też dodatkowemu uzasadnieniu charakteru gwarancji wynikających przede wszystkim z Konstytucji RP i przewidzianych przez prawo polskie, a także dopuszczalności ich pewnych ograniczeń. Karta, mimo zasadniczych różnic, jakie cechują ją względem EKPCz czy Paktów praw człowieka wymieniana była z nimi jednym tchem i służyła jedynie jako dodatkowe poparcie konstatacji sądu opartych na prawie polskim. Podobnych orzeczeń można by wskazać wiele ${ }^{577}$. Sądy dość swobodnie sięgają do różnych praw i wolności zagwarantowanych w Karcie i innych dokumentach gwarantujących prawa człowieka, chcąc poprzeć ich autorytetem regulacje krajowe, wskazując na ich uniwersalność. „Rozpiętość odesłań do wielu postanowień Karty jest wręcz zaskakująca, jednak - co trzeba podkreślić - sądy polskie nie dokonywały w swoich wyrokach podstawowego ustalenia, czy powołując dane

${ }^{573}$ Sąd Apelacyjny we Wrocławiu, Wydział I Cywilny, sprawa I ACa 1337/11, wyrok z 29 października 2012.

574 Sąd Apelacyjny w Białymstoku, II Wydział Karny, sprawa II AKzw 665/13, postanowienie z 17 kwietnia 2013.

${ }^{575}$ Sąd Apelacyjny w Gdańsku, III Wydział Pracy i Ubezpieczeń Społecznych, sprawa III AUa 208/13, wyrok z 19 kwietnia 2013.

${ }^{576}$ T.T. Koncewicz, A. Podolska, Karta..., s. 254.

577 Patrz np.: M. Wróblewski, Ł. Bojarski, D. Schindlauer, K. Wladasch, Karta Praw..., s. 141-143. 
prawo zawarte w Karcie, możliwe jest zastosowanie jej postanowień w świetle art. 51 ust. $1 \mathrm{KPP}^{\prime \prime 578}$.

Czasem sądy powszechne wprost negują Kartę jako źródło prawa je obowiązującego, "twierdząc, że polskich obywateli obowiązuje prawo stanowione przez polski parlament, i to ono jest podstawą orzekania sądów, chyba że zostanie zmienione bądź unieważnione przez Trybunał Konstytucyjny"579. Sąd Apelacyjny w Katowicach w 2012 r., a więc już dość długo po uzyskaniu przez Kartę niekwestionowanej mocy prawnej, odmówił jej wartości normatywnej ${ }^{580}$. Nawet jeśli takie stanowisko znajdowało oparcie w wybranym orzecznictwie Sądu Najwyższego, to należy podkreślić, o czym będzie jeszcze mowa w dalszej części tego rozdziału, że Sąd Najwyższy stał na takim stanowisku przed tym, jak Karta uzyskała moc prawną na mocy TL. Zmiana statusu Karty, jaką przyniósł ze sobą ten traktat, została prawidłowo odzwierciedlona w orzecznictwie SN, tymczasem sąd w Katowicach nie dostrzegł tej zmiany.

W orzecznictwie sądów powszechnych w Polsce można wskazać również przykłady najpoważniejszego błędu, jaki może wiązać się ze stosowaniem unijnych praw podstawowych zagwarantowanych w Karcie, jakim jest odmowa zastosowania Karty w sytuacjach, w których spełnione są warunki przewidziane w art. 51 ust. 1 Karty. Co gorsza zdarza się to w sytuacjach, w których sądy te są świadome, że co do zasady można powoływać przed nimi na Kartę i że ma ona wiążącą moc prawna, tym niemniej bez pogłębionej analizy art. 51 ust. 1 Karty czy ogólnie zasad zastosowania unijnych praw podstawowych, stwierdzaja błędnie, że warunki te w danej sprawie nie są spełnione. Za przykład może tu posłużyć wyrok Sądu Apelacyjnego w Szczecinie z 26 marca 2009. Jako pewne usprawiedliwienie sądu można wskazać, że wyrok wydany został na kilka miesięcy przed wejściem Karty w życie. Nie to jednak skłoniło sąd do odmowy jej zastosowania. W wyroku tym sąd oparł się na konstytucyjnych gwarancjach praw człowieka oraz EKPCz, mimo że sprawa dotyczyła odmowy wydania osoby w ramach europejskiego nakazu aresztowania ${ }^{581}$, co sprawia, że istniał odpowiedni łącznik do zastosowania unijnych praw podstawowych i sprawa mieściła się w zakresie zastosowania Karty ${ }^{582}$. Zdaniem sądu prawo unijne nie wnosiło nic nowego do niezmiennych i trwałych demokratycznych zasad dotyczacych ochrony praw przysługujaccych osobie podejrzanej i ściganej za popełnienie

\footnotetext{
${ }^{578}$ M. Wróblewski, Karta Praw Podstawowych Unii Europejskiej w polskim..., s. 19.

${ }^{579}$ M. Wróblewski, Ł. Bojarski, D. Schindlauer, K. Wladasch, Karta Praw..., s. 131.

580 Sąd Apelacyjny w Katowicach, III Wydział Pracy i Ubezpieczeń Społecznych, sprawa
} III AUa 497/12, wyrok z 15 listopada 2012.

${ }^{581}$ Sąd Apelacyjny w Szczecinie, sprawa II AKa 1/o9, wyrok z 26 marca 2009.

${ }^{582}$ M. Wróblewski, Ł. Bojarski, D. Schindlauer, K. Wladasch, Karta Praw..., s. 131. 
przestępstwa w wymiarze, w jakim zarzuty ona podnosiła. Sąd nie zignorował więc zupełnie unijnych gwarancji praw człowieka, uznał je jednak w wymiarze, w jakim znajdowały one potencjalnie zastosowanie za pokrywajacce się z gwarancjami przysługującymi jednostce na gruncie Konstytucji i Konwencji.

Ponadto należy zauważyć, że sąd przeprowadził w uzasadnieniu pewne rozważania na temat unijnych praw podstawowych, które są warte podkreślenia w kontekście ewolucji podejścia TSUE do "klauzuli praw fundamentalnych” i możliwości oparcia na niej odmowy wykonania ENA, jaką zawiera decyzja ramowa dotycząca $\operatorname{ENA}^{583}$ (w jej art. 1 ust. 3), która dokonała się w wyroku w sprawie Pál Aranyosi i Robert Căldăraru, który znacznie bardziej szczegółowo omówiony będzie w rozdziale IV. Na ówczesnym etapie rozwoju orzecznictwa TSUE sąd w Szczecinie stwierdził zdecydowanie na wyrost, że decyzja ramowa w związku z unijnymi gwarancjami praw człowieka:

pozwala [...] państwom członkowskim odmówić przekazania osoby ściganej ENA w sytuacji, gdy zostaną naruszone jej prawa, i to zarówno te wynikające z Konwencji o ochronie praw człowieka i podstawowych wolności, Karty Praw Podstawowych UE, jak i zasad ogólnych prawa wspólnotowego. Zatem art. 1 ust. 3 decyzji ramowej stanowi swoistą gwarancję dla poszanowania praw jednostki. [...] Jest oczywiste, że organ sądowy danego państwa członkowskiego ma prawo odmówić wykonania ENA, gdy stwierdzi, że procedura ta łączy się z naruszeniem art. 6 TUE i praw podstawowych wynikających z tradycji konstytucyjnych wspólnych dla państw członkowskich ${ }^{584}$.

Na szczególną uwagę, jeśli chodzi o orzecznictwo polskich sądów powszechnych, zasługuje stanowisko, jakie Sąd Apelacyjny w Białymstoku wyraził 5 grudnia $2013^{585}$. W sprawie tej Karta stała się już nie jedynie ornamentem, dodatkowym argumentem za tezą sądu, czy też potwierdzeniem doniosłości poprzez uniwersalność jej ochrony wartości chronionej przez dane prawo człowieka, lecz była faktyczną podstawą rozstrzygnięcia. Regulacje zawarte w Karcie zostały w tej sprawie potraktowane przez sąd nie tylko jako ogólna gwarancja, wymagająca konkretyzacji w przepisach krajowych, lecz jako normy bezpośrednio kształtujące postępowania krajowe. Przedmiotem sprawy było uchylenie postanowienia sądu pierwszej instancji, odrzucającego zażalenie ze względu na wniesienie środka odwoławczego po terminie. W rzeczywistości został on złożony (a więc nadany) w odpowiednim czasie, ale w urzędzie pocztowym w Niem-

${ }^{583}$ Decyzja ramowa Rady z dnia 13 czerwca 2002 w sprawie europejskiego nakazu aresztowania i procedury wydawania osób między Państwami Członkowskimi, Dz.Urz. L 190 z 18 lipca 2002 ze zm.

${ }^{584}$ Cyt za: LEX 508307.

585 Sąd Apelacyjny w Białymstoku, Wydział I Cywilny, sprawa I Acz 1479/13, postanowienie z 5 grudnia 2013 . 
czech i doręczony po upływie terminu. Sąd oparł się w swym orzeczeniu na art. 47 Karty i ocenił, że art. $165 \S 2$ Kodeksu postępowania cywilnego ${ }^{586}$ w brzmieniu obowiązującym w tamtym czasie, które wykluczało możliwość nadania pisma w placówce pocztowej w innym państwie członkowskim UE dla skutecznego dochowania terminu, był sprzeczny z art. 1 ust. 1 Rozporządzenia 1393/200 $7^{587}$ interpretowanym zgodnie $z$ wykładnia, jakiej dokonał trybunał luksemburski w sprawie Szyrocka ${ }^{58}$, oraz że był sprzeczny z gwarancją rzetelnego procesu przewidzianą w art. 47 akapit 2 KPP. Dlatego też w przedmiotowej sprawie:

Sąd Apelacyjny ocenił, że także w okresie przed wejściem w życie art. 165 § 2 k.p.c. $\mathrm{w}$ brzmieniu obowiązującym od 17 sierpnia 2013 r., nadanie pisma procesowego w placówce pocztowej operatora świadczącego powszechne usługi pocztowe w innym państwie członkowskim Unii Europejskiej było równoznaczne z wniesieniem go do sądu. Przepis ten w dawnej redakcji był bowiem sprzeczny z art. 1 ust. 1 Rozporządzenia 1393/2007, rozumianego w sposób wyłożony w wyroku ETS [...] C-215/11 oraz niezgodny z realizacją prawa do rzetelnego procesu, pozostającego pod ochroną art. 47 akapit 2 Karty praw podstawowych i art. 6 ust. 1 EKPCz i PW ${ }^{589}$.

Wyrok ten należy docenić jako rzadki przykład prawidłowego zastosowania Karty przez sąd polski odnośnie do prawa polskiego, choć nie jest on pozbawiony pewnych wad. Wydaje się, że jako najpoważniejsza, choć nie jedyną, można wskazać brak jakiegokolwiek odniesienia się do art. 51 Karty i kwestii jej stosowalności do przepisów krajowych. Brak więc postawienia "kropki nad i", jeśli chodzi o przejrzystość rozumowania sądu. Wyrok ten jest kolejnym świadectwem, że nawet jeśli Karta stosowana jest poprawnie, sądom brak nawyku analizy zasad jej zastosowania.

Mimo pewnych braków w przyjętej terminologii oraz uznania, że Unia związana jest Konwencją, stanowisko Sądu należy w pełni podzielić. Prawa podstawowe zawarte w Karcie oraz Konwencji były bezpośrednią i wyraźnie wskazaną podstawą rozstrzygnięcia. Regulacje Karty zostały zauważone przez sędziów, właściwie zinterpretowane i odpowiednio zastosowane dla dobra uczestników postępowania ${ }^{590}$.

${ }^{586}$ Ustawa z 17 listopada 1964 Kodeks postępowania cywilnego, Dz.U. nr 43, poz. 296 ze zm.

587 Rozporządzenie nr 1393/2007 Parlamentu Europejskiego i Rady z 13 listopada 2007 dotyczące doręczania w państwach członkowskich dokumentów sądowych i pozasądowych w sprawach cywilnych i handlowych oraz uchylające rozporządzenie Rady (WE) nr 1348/2000, Dz.Urz. L 324 z 10 grudnia 2007.

${ }^{588}$ TSUE, Iwona Szyrocka p. SiGer Technologie GmbH, C-215/11, wyrok z 19 grudnia 2012.

589 Sąd Apelacyjny w Białymstoku Wydział I Cywilny, sprawa I Acz 1479/13, postanowienie z 5 grudnia 2013, [online] <http://orzeczenia.bialystok.sa.gov.pl/content/\$N/150500000000503_I_ACz_001479_2013_Uz_2013-12-05_001> [dostęp: 28.12.2018].

590 T.T. Koncewicz, A. Podolska, Karta..., s. 254. 
Podobny przykład stanowić może wyrok Sądu Rejonowego we Wrocławiu, w którym sprawa dotyczyła zwolnienia pracowniczki ze względu na ciążę. Sąd zauważył, że:

Zarówno w orzeczeniach Trybunału Sprawiedliwości, jak i Sądu Najwyższego wskazuje się, że rozwiązanie umowy o pracę właśnie z powodu ciąży, stanowi niedozwoloną dyskryminację ze względu na płeć [...]. W świetle treści art. 33 Karty Praw Podstawowych macierzyństwo obejmuje okres od poczęcia do zakończenia karmienia piersią. Karta Praw Podstawowych wprost uznaje stabilizację zatrudnienia w okresie macierzyństwa za istotny aspekt godzenia życia rodzinnego z zawodowym. Zgodnie z treścią art. 30 KPP każdy pracownik ma prawo do ochrony w przypadku nieuzasadnionego zwolnienia z pracy. Kobietom w okresie ciąży powinna przysługiwać ochrona szczególna, zwiększona w porównaniu z ochroną przysługującą wszystkim zatrudnionym. Ciąża oraz macierzyństwo nie mogą stanowić przyczyny rozwiązania umowy o pracę. Wynika to również z art. 10 dyrektywy 92/85/EWG. Swoboda wypowiedzenia umowy o pracę z kobietą w okresie ciąży powinna być ograniczona do sytuacji wyjątkowych, np. likwidacji przedsiębiorstwa $[\ldots]^{591}$.

Sąd prawidłowo ocenił więc sytuację pod kątem gwarancji praw człowieka zagwarantowanych w Karcie. Prawidłowo odnalazł także konieczny łącznik z prawem unijnym, niezbędny do zastosowania Karty, jakim była w tym wypadku Dyrektywa 92/85/EWG ${ }^{592}$. Nie przywołał jednak art. 51 ust. 1 Karty i nie uzasadnił odpowiednio zastosowania Karty. Dyrektywę potraktował jako dodatkowy przejaw ochrony wartości chronionych w Karcie i jak się wydaje, to właśnie na podstawie samej dyrektywy dokonał oceny sytuacji. Nie potraktował jej jednak, przynamniej nie w sposób otwarty, jako warunku umożliwiajacego zastosowanie Karty i zawartych w niej gwarancji praw człowieka.

\subsection{Stosowanie Karty przez Sąd Najwyższy}

Jeśli chodzi o Sąd Najwyższy, to należy zauważyć, że w obliczu wejścia Karty w życie wraz z Traktatem lizbońskim tracą na aktualności jego wyrok z 7 mar-

${ }^{591}$ Sąd Rejonowy Wrocław Śródmieście we Wrocławiu, sprawa X P 20/16, wyrok z 3 sierpnia 2016, [online] <http://orzeczenia.ms.gov.pl/content/Karta\$oo2oPraw\$oo2oPodstawowych/155025500005021_X_P_000020_2016_Uz_2016-08-03_002> [dostęp: 28.12.2018].

${ }_{592}$ Dyrektywa 92/85/EWG z 19 października 1992 w sprawie wprowadzenia środków służących wspieraniu poprawy w miejscu pracy bezpieczeństwa i zdrowia pracownic w ciąży, pracownic, które niedawno rodziły i pracownic karmiących piersią (dziesiąta dyrektywa szczegółowa w rozumieniu art. 16 ust. 1 dyrektywy 89/391/EWG), Dz.Urz. L 348 z 28 listopada 1992. 
ca $2005^{593}$ oraz postanowienia z 8 czerwca $2004^{594}$ i 28 czerwca $2005^{595}$, przynajmniej w zakresie, w którym stanął on w nich na stanowisku, że regulacje Karty nie są bezpośrednio skuteczne, i co za tym idzie, że jednostki nie mogą się na nie powoływać w postępowaniach przed sądami polskimi oraz że prawa zawarte w Karcie nie mogą być podstawą oceny prawa krajowego, gdyż Karta stanowi jedynie deklarację polityczna, a nie jest aktem prawnym. Stanowisko zawarte w tych orzeczeniach nie powinno zaskakiwać w obliczu tego, że pochodzą one z czasu, kiedy Karta faktycznie nie miała jeszcze niekwestionowanej mocy prawnej. Po Traktacie lizbońskim taka teza byłaby niemożliwa do utrzymania, czego zresztą SN nie próbował czynić.

Jednakże już w czasie poprzedzającym uzyskanie przez Kartę niepodważalnej mocy prawnej w wyniku reformy lizbońskiej, niejako równolegle do prezentowanego powyżej podejścia, można w orzecznictwie Sądu Najwyższego odnaleźć charakterystyczne dla całego sądownictwa polskiego odwołania do Karty, najczęściej w towarzystwie różnych międzynarodowych - uniwersalnych i regionalnych - dokumentów gwarantujących prawa człowieka, które określone zostały jako ornamentacyjno-argumentacyjne. Za przykład może tu posłużyć postanowienie SN z 2007 r. dotyczące Prawa prasowego ${ }^{596}$ i wymogów szczególnej staranności, nakładanych na dziennikarzy w kontekście karalności zniesławienia, gdzie podczas rozważań nad prawem do wolności słowa Sąd przywołał pomocniczo Kartę ${ }^{597}$. Ten swoisty dualizm może pokazywać, że ornamentacyjno-argumentacyjne wykorzystywanie Karty może mieć miejsce nawet wtedy, gdy organ to czyniący jest przekonany o niemożności jej stosowania z powodów nawet tak fundamentalnych jak jej brak mocy wiążącej. Uwypukla to niebezpieczeństwo związane z niepogłębionym odwoływaniem się do Karty o takim właśnie charakterze, bez jakiejkolwiek refleksji nad jej zakresem zastosowania w związku z jej art. 51 ust. 1 teraz, kiedy jej status prawny i wiążący charakter nie mogą już budzić żadnych wątpliwości. Przyzwyczajenie związane z traktowaniem Karty jako wyrazu pewnych patetycznych i górnolotnych wartości ${ }^{598}$, nieprzydatnych sądowi jako podstawa orzekania bez ich skonkretyzowania w przepisach ustawowych ${ }^{599}$, które i tak nie mogą być zastosowane, bo Karta jest dokumentem politycznym (jakie to podejście do niej było dominujące przed TL), albo dlatego, że jej zasady zasto-

${ }^{593}$ SN, Izba Pracy, Ubezpieczeń Społecznych i Spraw Publicznych, sprawa III PK 83/o4, wyrok z 7 marca 2005.

${ }^{594}$ SN, Izba Karna, sprawa II KZ 27/o4, postanowienie z 8 czerwca 2004.

${ }^{595}$ SN, Izba Cywilna, sprawa I CK 834/o4, postanowienie z 28 czerwca 2005.

${ }^{596}$ Ustawa z 26 stycznia 1984 Prawo prasowe, Dz.U. nr 5, poz. 24 ze zm.

597 SN, Izba Karna, sprawa III KK 243/o6, postanowienie z 7 lutego 2007.

${ }^{598}$ Podobnie: T.T. Koncewicz, A. Podolska, Karta..., s. 254-255.

${ }^{599}$ Por.: ibidem, s. 256-257. 
sowania są niejasne i być może jeszcze ograniczone równie niejasnym Protokołem nr 30 (po Lizbonie) lub w ogóle ze względu na brak świadomości zasad zastosowania Karty - może prowadzić do poważnych uchybień obowiązków wynikających z członkostwa Polski w Unii. Ornamentacyjno-argumentacyjne przywoływanie Karty i zawartych w niej gwarancji tam, gdzie Karta nie może być stosowana, nie jest samo w sobie błędem. Jednakże jeśli towarzyszy mu brak refleksji nad zasadami zastosowania Karty lub wręcz brak ich świadomości, może być elementem tendencji prowadzącej do znacznie gorszych konsekwencji, jaką byłoby niestosowanie Karty w przypadkach, w których powinna ona zostać zastosowana.

Sposób podejścia do Karty przez SN uległ dość istotnym zmianom wraz z wejściem Karty w życie, szczególnie, gdy chodzi o niemożność podważania jej wiążącego charakteru. Jak zauważa Mirosław Wróblewski, w orzecznictwie Sądu Najwyższego „odwołania do Karty są sporadyczne" ${ }^{\prime 60}$. Jednakże „W rzadkich przypadkach powoływania się na Kartę SN najczęściej zastosował ją poprawnie, w kontekście prawa unijnego" ${ }^{\prime 601}$. Po raz pierwszy zmianę podejścia tego sądu względem orzecznictwa sprzed nadania Karcie mocy prawnej zauważyć można w wyroku z 14 kwietnia $2010^{602}$. Tym niemniej odwołanie do Karty nie było w tym wyroku rozległe ani znaczące dla werdyktu. Raczej dość zdawkowo SN odniósł się do Karty i wskazał jej art. 47 oraz podkreślił zasadę ogólną prawa UE ochrony praw podstawowych i „uzasadnił konieczność uwzględniania w postępowaniu z odwołania od decyzji Prezesa Urzędu Komunikacji Elektronicznej gwarancji oskarżonego w postępowaniu karnym" ${ }^{\prime 603}$.

W wydanym nieco ponad rok później (7 lipca 2011) wyroku ${ }^{604} \mathrm{SN}$ znowu powołał się na zasadę ogólną prawa UE ochrony praw podstawowych i art. 47 Karty, tym razem w związku z interpretacją przepisów prawa polskiego wydanych w celu implementacji dyrektywy unijnej dotyczącej zezwoleń na udostępnianie sieci i usług łączności elektronicznej, co skutkowało wykładnią przepisów dotyczących dopuszczalności kar nakładanych przez prezesa Urzędu Komunikacji Elektronicznej w sposób uniemożliwiający pogorszenie sytuacji przedsiębiorcy w związku ze zmianą unijnej dyrektywy. W obydwu tych przypadkach należy podkreślić zasadność zastosowania Karty w związku z faktem, że przepisy polskie były przepisami implementującymi prawo Unii. W obydwu

\footnotetext{
${ }^{600}$ M. Wróblewski, Karta Praw Podstawowych Unii Europejskiej w polskim..., s. 19.

${ }^{601}$ Ibidem.

${ }^{602}$ SN, Izba Pracy, Ubezpieczeń Społecznych i Spraw Publicznych, sprawa III SK 1/10, wyrok z 14 kwietnia 2010.

${ }^{603}$ T.T. Koncewicz, A. Podolska, Karta..., s. 253.

${ }^{604}$ SN, Izba Pracy, Ubezpieczeń Społecznych i Spraw Publicznych, sprawa III SK 52/10, wyrok z 7 lipca 2011.
} 
orzeczeniach brak było jednak rozstrzygnięć opartych wprost na art. 51 ust. 1 KPP, choć w wyroku z 14 kwietnia 2010 Sąd zauważył, że postępowanie ma „charakter sprawy unijnej z uwagi na stosowanie przez sądy przepisów prawa krajowego implementujących dyrektywy Unii Europejskiej"605 , a w wyroku z 7 lipca 2011 podkreślił, że „w niniejszej sprawie chodzi o zastosowanie przepisów prawa krajowego wdrażających art. 10 dyrektywy 2002/20"606. Należy wszakże podkreślić, że w obydwu tych wypadkach SN potraktował standard zawarty w Karcie jako potwierdzenie standardów przewidzianych przez EKPCz i stanowiących minimalny standard ochrony w danym przypadku w związku z art. 52 ust. 3 Karty, co jak wiadomo nie wyczerpuje konsekwencji wobec państw członkowskich, wynikających Karty w obliczu art. 51 ust. 1 Karty.

W uchwale z 29 października $2012^{607}$ SN powołał się na Kartę, mimo że inaczej niż w dwóch wspomnianych wcześniej przypadkach, gdzie odwołanie do Karty związane było ze stosowaniem w sprawie przepisów implementujących prawo UE, przepisy w niej stosowane nie miały takiego charakteru. Sprawa ta odnosiła się do pytania prawnego skierowanego w toku postępowania karnego dotyczącego przestępstwa z art. 196 Kodeksu karnego ${ }^{608}$, a więc obrazy uczuć religijnych, dokonanego w toku występu o charakterze artystycznym, przejawiającego się w znieważeniu przedmiotu czci religijnej. SN stanął przed pytaniem czy przestępstwo ze wspomnianego artykułu może być popełnione jedynie w zamiarze bezpośrednim czy również w zamiarze ewentualnym. Rozstrzygając ten dylemat, SN powołał się na różne fundamentalne akty prawne gwarantujące wolność religijna, a także wolność wypowiedzi oraz regulujące możliwości ograniczania korzystania z tych praw. Wykorzystał Kartę wśród tych różnych dokumentów do poparcia swych ustaleń dokonanych na gruncie prawa polskiego i przewidzianych w Konstytucji gwarancji wolności religii, sumienia i wyznania oraz wolności słowa. Wpisał się więc w ten sposób w ornamentacyjno-argumentacyjną tendencję traktowania Karty cechująca polskie sądy. Chęć jak najbardziej przekonującego uzasadnienia, ukazującego zgodność nie tylko z polskimi, ale również z europejskimi, jak i uniwersalnymi standardami ochrony praw człowieka wiązać mogła się z dość głośnym medialnie charakterem sprawy.

${ }^{605}$ SN, Izba Pracy, Ubezpieczeń Społecznych i Spraw Publicznych, sprawa III SK 1/10, wyrok z 14 kwietnia 2010, [online] <http://sn.pl/Sites/orzecznictwo/Orzeczenia1/III\%20SK\%2O 1-10-1.pdf> [dostęp: 28.12.2018].

${ }^{606}$ SN, Izba Pracy, Ubezpieczeń Społecznych i Spraw Publicznych, sprawa III SK 52/10, wyrok z dnia 7 lipca 2011, [online] <http://www.lexlege.pl/orzeczenie/68844/iii-sk-52-10-wyrok-sadu-najwyzszego-izba-pracy-ubezpieczen-spolecznych-i-spraw-publicznych/> [dostęp: 28.12.2018].

${ }^{607}$ SN, Izba Karna, sprawa I KZP 12/12, uchwała z 29 października 2012.

${ }^{608}$ Ustawa z 6 czerwca 1997 Kodeks karny, Dz.U. nr 88, poz. 553 ze zm. 
Nie jest to odosobniony przypadek wpisania się SN w tendencję ornamentacyjno-argumentacyjną. Podobnie pomocniczo SN potraktował Kartę w wyroku z 23 maja 2014 $4^{609}$. Jako szczególnie wymowny przykład wpisania się przez SN w tę tendencję może posłużyć postanowienie SN z 21 sierpnia $2013^{610}$, gdzie ornamentacyjne użycie Karty poszło tak daleko, że została ona przywołana w uzasadnieniu orzeczenia w sprawie karnej dotyczącej pracownika służby bezpieczeństwa i znęcania się nad więźniami w latach 5o. XX wieku, co jako żywo wyklucza jakikolwiek związek z prawem unijnym i przewidzianymi w nim gwarancjami praw człowieka oraz możliwością ich zastosowania ratione temporis.

W wyroku z 9 maja 2014 SN dość obszernie odniósł się natomiast do ewolucji zasady równego traktowania w kontekście zatrudnienia zarówno w prawie polskim, jak i w systemie EKPC $z$, a także w prawie unijnym, najpierw poprzez przywołanie orzecznictwa trybunału luksemburskiego $w$ tej materii i jej rozwoju w orzecznictwie, które poprzedziło zawarcie tego prawa w Karcie. Ostatecznie stwierdził jednak, że: „Polskie unormowania kodeksowe mają [...] szerszy kontekst europejski od wskazanego w niniejszej skardze kasacyjnej w sposób ogólnikowy”, a zastosowanie Karty nie jest możliwe "bez adekwatnego wskazania, jaki wpływ mają przepisy europejskie na rozstrzygnięcie niniejszej sprawy oraz w jaki sposób wykładnia przyjazna prawu unijnemu korygowałaby dotychczasową wykładnię polskich przepisów"611. Faktycznie, o ile prawo unijne przewiduje regulacje antydyskryminacyjne w zatrudnieniu, o tyle w przedmiotowej sprawie nie mieliśmy do czynienia z dyskryminacją ze względu na religię lub przekonania, niepełnosprawność, wiek lub orientację seksualną ${ }^{612}$, czy też ze względu na pochodzenie rasowe lub etniczne ${ }^{613}$, które to kwestie znajdują się w centrum zainteresowania unijnego prawa dotyczącego dyskryminacji w zatrudnieniu. Nie mieliśmy też do czynienia z żadnym innym przejawem dyskryminacji w zatrudnieniu objętym przez prawo unijne, które w tej materii nie sprowadza się jedynie do wspomnianych kwestii ${ }^{614}$. Nie

${ }^{609}$ SN, Izba Pracy, Ubezpieczeń Społecznych i Spraw Publicznych, sprawa II PK 273/13, wyrok z 23 maja 2014.

${ }^{610}$ SN, Izba Karna, sprawa III KK 74/13, postanowienie z 21 sierpnia 2013.

${ }^{611}$ SN, Izba Pracy, Ubezpieczeń Społecznych i Spraw Publicznych, sprawa I PK 276/13, wyrok z 9 maja 2014.

${ }^{612}$ Dyrektywa Rady 2000/78/WE z 27 listopada 2000 ustanawiająca ogólne warunki ramowe równego traktowania w zakresie zatrudnienia i pracy, Dz.Urz. L 303 z 2 grudnia 2000.

${ }^{613}$ Dyrektywa Rady 2000/43/WE z 29 czerwca 2000 wprowadzająca w życie zasadę równego traktowania osób bez względu na pochodzenie rasowe lub etniczne, Dz.Urz. L 180 z 19 lipca 2000.

${ }^{614}$ Patrz np.: Podręcznik europejskiego prawa o niedyskryminacji, Fundamental Rights Agency, s. 71 i nast., [online] <fra.europa.eu/sites/default/files/fra.../1510-FRA_CASE_LAW_HANDBOOK_PL.pdf> [dostęp: 28.12.2018]. 
było więc w tej sprawie podstaw, jak słusznie zauważył to SN, do zastosowania unijnych praw podstawowych.

Nie wszystkie orzeczenia SN były przykładami, choć pozbawionego rozważań na temat zakresu ich zastosowania, to jednak ostatecznie nie niepoprawnego zastosowania unijnych praw podstawowych. Można wskazać również takie, przynajmniej jedno orzeczenie, w którym wydaje się, że SN nie dostrzegł, że w danej sprawie Karta mogła mieć zastosowanie. Chodzi tu o postanowienie SN dotyczące rozstrzygania o odpowiedzialności karnej z tytułu naruszenia ustawy o grach hazardowych z 28 listopada $2013^{615}$, w którym orzekł, że sądy karne powinny stosować nienotyfikowane Komisji Europejskiej przepisy prawa polskiego przy rozstrzyganiu o odpowiedzialności karnej z tytułu naruszenia ustawy o grach hazardowych ${ }^{616}$, do czasu ewentualnego stwierdzenia ich niezgodności z Konstytucją przez Trybunał Konstytucyjny. W postanowieniu tym SN stwierdził, że:

Naruszenie wynikającego z dyrektywy 98/34/WE1 [...] obowiązku notyfikacji przepisów technicznych ma charakter naruszenia trybu ustawodawczego, którego konstytucyjność może być badana wyłącznie w postępowaniu przed Trybunałem Konstytucyjnym. Jeżeli w konkretnym postępowaniu sąd dochodzi do wniosku, że doszło do takiej wadliwości trybu ustawodawczego, może nie stosować tych przepisów tylko w ten sposób, że zawiesi prowadzone postępowanie, w którym miałyby one zostać zastosowane i skieruje stosowne pytanie prawne do Trybunału Konstytucyjnego. Jednak do czasu zainicjowania tej kontroli lub podjęcia przez Trybunał Konstytucyjny stosownego rozstrzygnięcia, brak jest podstaw do odmowy stosowania przepisów ustawy o grach hazardowych, w tym jej art. 6 ust. 1 i art. 14 ust. $1^{617}$.

Stanowisko to SN podtrzymał w wyrokach z 3 grudnia $2013^{618}$ oraz 8 stycznia $2014^{619}$. Spotkało się ono z wieloma krytycznymi komentarzami doktryny ${ }^{620}$.

${ }^{615}$ SN, Izba Karna, sprawa I KZP 15/13, postanowienie z 28 listopada 2013.

${ }^{616}$ Ustawa z 19 listopada 2009 o grach hazardowych, Dz.U. nr 201, poz. 1540.

${ }^{617}$ SN, Izba Karna, sprawa I KZP 15/13, postanowienie z 28 listopada 2013, cyt. za: LEX 1393793.

${ }^{618}$ SN, Izba Karna, sprawa V KK 82/13, wyrok z 3 grudnia 2013.

${ }^{619}$ SN, Izba Karna, sprawa IV KK 183/13, wyrok z 8 stycznia 2014.

${ }^{620}$ Patrz np.: M. Domańska, Implementacja dyrektyw unijnych przez sady krajowe, Warszawa 2014, s. 167; M. Górski, Glosa do postanowienia SN z dnia 28 listopada 2013 r., I KZP 15/13, LEX 188532; W. Gontarski, G. Grabowska, Glosa do postanowień Sądu Najwyższego z dnia 28 listopada 2013 r.: I KZP 14/13 i I KZP 15/13 oraz do wyroków Sądu Najwyższego: z dnia 3 grudnia 2013 r., V KK 82/13 i z dnia 8 stycznia 2014 r., IV KK 183/13, LEX 193496; J. Maliszewska-Nienartowicz, Naruszenie obowiazku...; M.J. Szewczyk, Glosa do postanowienia SN z dnia 28 listopada 2013 r., I KZP 15/13, LEX 195443. Pojawily się jednak również głosy aprobujące, patrz np.: A. Krzywoń, Glosa do postanowienia Sądu Najwyższego z dnia 28 listopada 2013 r. (sygn. akt I KZP 15/13), "Zeszyty Naukowe Sądownictwa Administracyjnego" 2014, $\mathrm{nr}_{1}$ (52). 
Problem, z jakim mieliśmy do czynienia w tej sprawie, sprowadzał się do odpowiedzi na pytanie, czy ze względu na orzecznictwo TSUE ${ }^{621}$ należy stwierdzić nieistnienie zakazu urządzania określonych gier hazardowych poza kasynami, w szczególności na automatach, tzn. czy poza kasynami obowiązuje wolność gospodarcza oraz czy w związku z tym dopuszczalne jest karanie za urządzanie tych gier poza kasynami, co przewidywało prawo polskie, które wprowadzało taki zakaz (w ustawie o grach hazardowych), a także przewidywało kary (w Kodeksie karnym) za jego złamanie, a które nie zostało notyfikowane Komisji. Zdaniem TSUE: „[...] przepis tego rodzaju jak art. 14 ust. 1 ustawy o grach hazardowych, zgodnie z którym urządzanie gier na automatach dozwolone jest jedynie w kasynach gry, należy uznać za "przepis techniczny« w rozumieniu art. 1 pkt 11 dyrektywy 98/34"622. Jak zauważa Nina Półtorak:

W postanowieniu z 2013 r. SN uznał, że sądy karne - przy rozstrzyganiu o odpowiedzialności karnej z tytułu naruszenia ustawy o grach hazardowych - powinny stosować nienotyfikowane Komisji Europejskiej [...] przepisy prawa polskiego - do czasu stwierdzenia ich niekonstytucyjności (naruszenia procedury wydania) przez TK. W sprawie tej Karta nie została powołana, a rozstrzygnięcie oparte jest na prawie polskim. Natomiast KPP przewiduje $\mathrm{w}$ art. 49 zasadę nullum crimen sine lege [...] i wydaje się, że kwestia odpowiedzialności karnej z tytułu naruszenia przepisów prawa polskiego niezgodnych z prawem UE (z pewnością jest to kwestia podlegająca prawu UE jako element zasady pierwszeństwa i efektywności) powinna zostać zbadana też w świetle przepisów Karty ${ }^{623}$.

Bez wchodzenia w dalsze rozważania na temat obowiązku notyfikacyjnego i skutków, jakie wiążą się z jego niedotrzymaniem, należy szczególnie podkreślić - co jest najważniejsze w związku z tematem tej pracy, a także w kontekście problematyki poruszanej w tym rozdziale i praktyki sądów polskich dotyczącej stosowania KPP - bezdyskusyjny fakt, że obowiązek notyfikacyjny projektów przepisów technicznych wynika z prawa unijnego ${ }^{624}$. Skoro tak, to należy uznać, że działania państw w przedmiocie objętym tym prawem, a więc działanie państw w przedmiocie objętym obowiązkiem notyfikacji oznacza, że działają one w zakresie zastosowania prawa unijnego. Dlatego też sądy krajowe powinny oceniać takie nienotyfikowane przepisy prawa krajowego pod

${ }^{621}$ TSUE, Fortuna sp. z o.o. i in. p. Dyrektorowi Izby Celnej w Gdyni, C-213/11, C-214/11 i C-217/11, wyrok z 19 lipca 2012.

${ }^{622}$ Ibidem, pkt 25.

${ }^{623}$ N. Półtorak, Zakres zwiazzania..., s. 18.

${ }^{624}$ Aktualnie jest to Dyrektywa (UE) 2015/1535 Parlamentu Europejskiego i Rady z 9 września 2015 ustanawiająca procedurę udzielania informacji w dziedzinie przepisów technicznych oraz zasad dotyczących usług społeczeństwa informacyjnego, Dz.Urz. L 241 z 17 września 2015, która zmieniła i ujednoliciła wcześniejsze regulacje w tej materii. 
kątem zgodności z prawem unijnym przez pryzmat konsekwencji, jakie wiążą się z obowiązkiem notyfikacji, a o których była mowa powyżej, lecz także pod kątem zgodności z zagwarantowanymi w unijnym prawie gwarancjami praw podstawowych ze względu na art. 51 ust. 1 Karty. Błędne stanowisko SN w przedmiocie stosowania krajowych przepisów nienotyfikowanych, mimo obowiązku ich notyfikacji, było więc jeszcze pogłębione poprzez niezastosowanie wobec nich unijnych praw podstawowych. Nawet jeśli i tak (bez względu na ewentualną niezgodność z unijnymi prawami podstawowymi, lecz ze względu na sam brak notyfikacji) nie powinny być one stosowane, to takie orzeczenie, w którym SN uznał, że należy je stosować, a nie stwierdził zastosowania unijnych praw podstawowych, jest przejawem nie tylko błędnego zinterpretowania przez ten sąd konsekwencji niewypełnienia obowiązków notyfikacyjnych, lecz również przejawem błędnej interpretacji art. 51 ust. 1 Karty i zakresu zastosowania unijnych praw podstawowych.

Przechodząc do dalszego orzecznictwa SN dotyczącego stosowania Karty, tym razem zasługującego na aprobatę, szczególną uwagę należy zwrócić na stosunkowo niedawne orzeczenie SN - z 16 marca 2016, w którym to wyroku szczegółowo odniósł się on do zarzutów związanych z naruszeniem Karty w kontekście możliwości jej zastosowania. Można mieć nadzieję, że orzeczenie to będzie przełomowe, gdy chodzi o orzecznictwo samego SN, który zacznie art. 51 ust. 1 Karty jako określający warunki możliwości zastosowania Karty traktować jako element każdego rozstrzygnięcia dotyczącego Karty. Ponadto można również żywić nadzieję, że orzeczenie to stanie się też czynnikiem podnoszącym świadomość sądów powszechnych co do zasad zastosowania Karty i zapoczątkuje proces bardziej refleksyjnego jej stosowania.

W przedmiotowym wyroku SN stwierdził wyraźnie, że:

Zarzut naruszenia prawa materialnego może odnosić się tylko do przepisów, które były objęte podstawą prawną orzeczenia albo do przepisów, które - zdaniem skarżacego - powinny być, a nie zostały, zastosowane. Zarzuty naruszenia art. 23 k.c. oraz wymienionych postanowień Karty Praw Podstawowych Unii Europejskiej zostały podniesione bez wykazania tego koniecznego powiązania, jak również bez wymaganego wskazania formy naruszenia ${ }^{625}$.

Odnośnie do Karty SN zauważył w przedmiotowym orzeczeniu trafnie, że:

Wadliwe jest powiązanie zarzutu naruszenia art. 23 k.c. z zarzutami naruszenia wskazanych postanowień Karty Praw Podstawowych Unii Europejskiej, bez

${ }^{625}$ SN, Izba Cywilna, sprawa IV CSK 270/15, wyrok z 16 marca 2016, s. 4 uzasadnienia, [online] <http://www.sn.pl/sites/orzecznictwo/orzeczenia3/iv\%20csk\%20270-15-1.pdf> [dostęp: 28.12.2018]. 
uwzględnienia dopuszczalnego zakresu jej zastosowania i bez elementarnej nawet próby wykazania, że powołanie się na kartę jest uzasadnione ratione materiae ${ }^{626}$.

Konstatację tę Sąd Najwyższy poparł prawidłową rekonstrukcją zasad zastosowania Karty, opartą na orzecznictwie TSUE, a nawet dostrzeżeniem Protokołu nr 30, choć temu ostatniemu nie poświęcił szczególnej uwagi, jeśli chodzi o jego potencjalny wpływ na ogólne zasady zastosowania Karty. Wydaje się jednak, że sposób, w jaki Sąd odniósł się do Protokołu, można odczytać jako sugestię traktowania go jako ekwiwalent art. 51 ust. 2 Karty, a więc potwierdzenie jego interpretacyjnego, a nie derogacyjnego charakteru.

SN podkreślił w uzasadnieniu omawianego wyroku, że:

Karta Praw Podstawowych Unii Europejskiej [...], zgodnie z art. 6 ust. 1 Traktatu o Unii Europejskiej, jest zrównana z aktami prawa pierwotnego UE i ma taką samą moc prawna, jak traktaty; stosowanie Karty jest elementem stosowania przez sądy krajowe prawa Unii Europejskiej. Ocena, czy w danej sprawie możliwe jest powołanie się na prawo wynikające z Karty, wymaga uwzględnienia zakresu jej stosowania określonego w art. 51 ust. 1 [...]. Jak wyjaśnił Trybunał Sprawiedliwości Unii Europejskiej w wyrokach [...] w sprawie [...] Akeberg Fransson [...] Siracusa [...], chociaż Karta Praw Podstawowych jako prawo pierwotne jest częścią porządku prawnego Unii Europejskiej, zarzut naruszenia jej postanowień może być podnoszony tylko w sytuacji, gdy w sprawie mają lub powinny mieć zastosowanie inne niż Karta przepisy prawa Unii Europejskiej. Pojęcie stosowania prawa w rozumieniu art. 51 ust. 1 Karty wymaga istnienia powiązania z prawem UE, co oznacza, że zastosowanie Karty przez sąd może nastąpić w sprawie „unijnej”, tj. takiej, której stan faktyczny podlega prawu UE, natomiast Karta nie ma zastosowania w sprawie mającej czysto krajowy charakter. W okolicznościach niniejszej sprawy nie ma podstaw ani potrzeby podjęcia dokładniejszych rozważań dotyczących wykładni art. 51 ust. 2 Karty (lub tzw. protokołu polsko-brytyjskiego, nr 30, stanowiącego załącznik do Traktatu o UE i traktatu o funkcjonowaniu UE), gdyż brak w niej powiązania z prawem Unii mogącego uzasadniać stosowanie Karty ${ }^{627}$.

Jak można skonkludować, w swym orzecznictwie przez pewien czas po uzyskaniu przez Kartę niekwestionowanej mocy prawnej, „Sąd Najwyższy regulacje Karty umieszczał obok norm umów międzynarodowych dotyczących praw człowieka, zwłaszcza Konwencji. Traktował je raczej jako inspirację dla swojego stanowiska, nie zaś jako akt, który jest rzeczywistą i konkretną podstawą orzeczenia" ${ }^{628}$. Tym niemniej w orzecznictwie SN można wskazać przykłady prawidłowego zastosowania Karty, szczególnie w sprawach, które dotyczyły

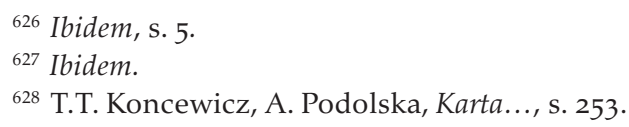


przepisów prawa unijnego i implementujących je przepisów wydanych przez polskie organy legislacyjne, choć pozbawione były one pogłębionej analizy zasad zastosowania Karty. SN nie ustrzegł się jednak pewnych błędów, gdy chodzi o stosowanie Karty, o których również była mowa. Przez długi czas brak było w orzecznictwie SN jednoznacznego stanowiska w sprawie możliwości stosowania Kary w ramach jej wiążącej mocy związanej z jej art. 51 ust. 1 odnośnie do państw członkowskich, a także do Protokołu nr 30. Stosowanie przez SN Karty nie miało charakteru rozstrzygającego i nie wynikało z faktu, że Karta była świadomie stosowaną przez sąd podstawą rozstrzygnięcia, jako akt prawny znajdujący w związku ze swym art. 51 ust. 1 zastosowanie w danej sprawie. Sytuacja ta uległa jednak ostatnio zmianie, choć jak się okazuje zmiana ta nie jest w pełni ugruntowana i w nowszym orzecznictwie SN można wskazać kolejne przejawy niepewności co do zakresu zastosowania Karty, również w obliczu Protokołu nr $30^{629}$. W ogólnym rozrachunku można jednak mieć nadzieję, że tendencja zapoczątkowana wyrokiem w sprawie IV CSK 270/15 zostanie utrzymana, a dzięki orzecznictwu SN w tej materii kwestia prawidłowego stosowania Karty będzie coraz powszechniej znana, co zostanie także odzwierciedlone w orzecznictwie sądów powszechnych w Polsce.

\subsection{Pytania prejudycjalne sądów polskich dotyczace praw podstawowych}

Rzadkie odwołania do KPP i swoista niepewność w jej stosowaniu przez sądy polskie, jaka wyłania się z opisanego powyżej orzecznictwa odzwierciedlona jest również, gdy chodzi o pytania prejudycjalne sądów polskich kierowane do TSUE, które dotyczyły Karty i praw podstawowych. Jak do tej pory wszystkie pytania prejudycjalne dotyczące praw podstawowych zostały skierowane do TSUE jedynie przez sądy powszechne. Pytań takich nie kierowały sądy administracyjne ani SN, choć ten ostatni miał po temu okazję w sprawie Bonda, o której była mowa wcześniej. Jedno pytanie, w którym kwestia praw podstawowych się pojawiła, choć w bardzo ograniczonej formie, skierował też do TSUE TK w swym jedynym dotychczas pytaniu prejudycjalnym jakie w ogóle wystosował do trybunału luksemburskiego. Będzie o nim mowa w dalszej części pracy, poświęconej Trybunałowi Konstytucyjnemu i jego orzecznictwu. W tym miejscu mowa będzie zaś o sześciu pytaniach prawnych do TSUE skierowanych w tej materii przez sądy powszechne, które również w zdecydowanej większości stanowią przejaw braku świadomości po stronie sądów polskich co

${ }^{629}$ SN, Izba Pracy, Ubezpieczeń Społecznych i Spraw Publicznych, sprawa II PK 199/16, wyrok z 12 lipca 2017. 
do zakresu zastosowania unijnych praw podstawowych. Ostatnie z nich może być jednak uznane za zwiastun pozytywnej zmiany.

\subsubsection{Sprawa Leśniak-Jaworska i Głuchowska-Szmulewicz}

Po raz pierwszy polski sąd z pytaniem dotyczącym interpretacji przepisów Karty i zgodności z nimi polskiego prawa, wystąpił dopiero w roku $2013 \mathrm{w}$ sprawie Leśniak-Jaworska i Głuchowska-Szmulewicz. Pytanie Sądu Rejonowego w Płocku koncentrowało się w znacznej mierze na unijnej dyrektywie dotyczącej równego traktowania w zakresie zatrudnienia i pracy ${ }^{630}$. Tym niemniej sąd odsyłający podniósł również kwestię art. 21 ust. 1 KPP. Pytanie sformułowane przez sąd brzmiało:

Czy prawo [Unii], a w szczególności art. 21 Karty praw podstawowych Unii Europejskiej oraz art. 1 i 2 dyrektywy [2000/78] należy interpretować w ten sposób, że stoi ono na przeszkodzie uregulowaniu krajowemu, które prowadzi do sytuacji, iż pracownicy zatrudnieni na takich samych stanowiskach i z takim samym stażem pracy otrzymują wynagrodzenia różnej wysokości przy braku okoliczności uzasadniających tego typu zróżnicowanie? ${ }^{631}$.

Przepisami krajowymi, które miały w tej sprawie zastosowanie, były nowo wprowadzone przepisy ustawy o ustroju sądów powszechnych zmieniające przepisy ustawy o prokuraturze ${ }^{632}$, które doprowadziły do sytuacji, w której wynagrodzenie U. Leśniak-Jaworskiej i M. Głuchowskiej-Szmulewicz było niższe niż wynagrodzenie części prokuratorów z mniejszym stażem pracy niż one ${ }^{633}$. Sąd odsyłający uznał, że takie zróżnicowanie nie jest uzasadnione i że stoi to w sprzeczności ze wspomnianą dyrektywą, jak i art. 21 Karty. Jak stwierdził jednak TSUE, we wniosku złożonym przez sąd odsyłający nie spełnił on ciążących na nim obowiązków i nie zawarł sprecyzowanych w sposób dostateczny ani okoliczności faktycznych, ani okoliczności prawnych postępowania głównego skutkujących istnieniem związku między przepisami krajowymi a przywołany-

${ }^{630}$ Dyrektywa Rady 2000/78/WE z 27 listopada 2000 ustanawiająca ogólne warunki ramowe równego traktowania w zakresie zatrudnienia i pracy, Dz.Urz. L 303 - wyd. spec. w jęz. polskim, rozdz. 5, t. 4, s. 79 .

${ }^{631}$ TSUE, Urszula Leśniak-Jaworska i Małgorzata Głuchowska-Szmulewicz p. Prokuratura Okręgowa w Płocku, C-520/13, postanowienie z 27 marca 2014, pkt 15.

${ }^{632}$ Ustawa z 20 czerwca 1985 o Prokuraturze Polskiej Rzeczypospolitej Ludowej (Dz.U. nr 31, poz. 138 ze zm.), w brzmieniu nadanym jej ustawą z dnia 20 marca 2009 o zmianie ustawy - Prawo o ustroju sądów powszechnych oraz niektórych innych ustaw (Dz.U. nr 56, poz. 459).

${ }^{633}$ TSUE, Urszula Leśniak-Jaworska i Małgorzata Głuchowska-Szmulewicz p. Prokuratura Okręgowa w Płocku, C-520/13, postanowienie z 27 marca 2014, pkt 14. 
mi regulacjami unijnymi. Przepisy krajowe nie miały charakteru implementacji dyrektywy i nie można było uznać ich za mieszczące się w zakresie prawa unijnego. Wniosek nie wyjaśniał także powodów, dla których żądana wykładnia prawa Unii miałaby być konieczna do wydania rozstrzygnięcia w postępowaniu głównym. Wreszcie wniosek był niejasny i nieprecyzyjny, co uniemożliwiło TSUE wydanie orzeczenia ${ }^{634}$. Dlatego też TSUE wydał w tej sprawie postanowienie o oczywistej niedopuszczalności wydania orzeczenia w trybie prejudycjalnym na podstawie art. $53 \S 2$ regulaminu postępowania przed Trybunałem ${ }^{635}$.

\subsubsection{Sprawa Pańczyk}

Drugą sprawą, która już w pełni koncentrowała się na kwestii praw człowieka, stąd bywa traktowana jako pierwsze pytanie prejudycjalne polskiego sądu do TSUE wprost dotyczące Karty ${ }^{636}$, była sprawa Pańczyk ${ }^{637}$. Cała seria (pięciu) pytań Sądu Okręgowego w Częstochowie - Sądu Pracy ${ }^{638}$, dotyczyła przepisów ustawy obniżającej wysokość emerytur byłym funkcjonariuszom komunistycznych służb bezpieczeństwa ${ }^{639} \mathrm{i}$ ich zgodności z całą listą przepisów Karty i zagwarantowanych $\mathrm{w}$ nich praw również $\mathrm{w}$ związku $\mathrm{z}$ różnymi przepisami TUE, a także w związku z przepisami EKPCz gwarantującymi odpowiednie prawa do tych, które przywołano z Karty ${ }^{640}$. Tym niemniej w bardzo obszernym uzasadnieniu wystąpienia z tymi pytaniami, jakie wystosował sąd odsyłający, kwestia tego, czy w ogóle można odnośnie do podanych w wątpliwość przepisów prawa polskiego zastosować Kartę się nie pojawiła. Zresztą trudno byłoby sądowi wykazać, że przepisy te mieściły się w zakresie zastosowania prawa Unii. Brak bowiem jakiejkolwiek więzi między uregulowaniami polski-

${ }^{634}$ Ibidem, pkt 16-28.

${ }^{635} \mathrm{Ibidem}$, pkt 29.

${ }^{636}$ N. Półtorak, Zakres zwiazania..., s. 18.

${ }^{637}$ TSUE, Ryszard Pańczyk p. Dyrektor Zakładu Emerytalno-Rentowego Ministerstwa Spraw Wewnętrznych i Administracji w Warszawie, C-28/14, postanowienie z 12 czerwca 2014.

${ }^{638}$ Pytanie Sądu Okręgowego w Częstochowie - Sądu Pracy z 20.12.2013 (IV U 1470/12), [online] <http://orzeczenia.ms.gov.pl/content/\$N/151510000002021_IV_U_001470_2012_ Uz_2013-12-2O_001> [dostęp: 28.12.2018].

${ }^{639}$ Ustawa z 23 stycznia 2009 o zmianie ustawy o zaopatrzeniu emerytalnym żołnierzy zawodowych oraz ich rodzin oraz ustawy o zaopatrzeniu emerytalnym funkcjonariuszy Policji, Agencji Bezpieczeństwa Wewnętrznego, Agencji Wywiadu, Służby Kontrwywiadu Wojskowego, Służby Wywiadu Wojskowego, Centralnego Biura Antykorupcyjnego, Straży Granicznej, Biura Ochrony Rządu, Państwowej Straży Pożarnej i Służby Więziennej oraz ich rodzin, Dz.U. nr 24, poz. 145 .

${ }^{640}$ TSUE, Ryszard Pańczyk p. Dyrektor Zakładu Emerytalno-Rentowego Ministerstwa Spraw Wewnętrznych i Administracji w Warszawie, C-28/14, postanowienie z 12 czerwca 2014, pkt 16. 
mi znajdującymi zastosowanie w postępowaniu głównym a prawem Unii. Nie sposób więc się dziwić, że trybunał luksemburski w odpowiedzi na pytanie, zgodnie ze swoim, zaprezentowanym w poprzednim rozdziale orzecznictwem, doszedł do wniosku, że jest oczywiście niewłaściwy do udzielenia odpowiedzi na pytania Sądu Okręgowego w Częstochowie i że postanowienie o odesłaniu w trybie art. 267 TFUE nie zawiera żadnej informacji pozwalającej dojść do wniosku, że sprawa w postępowaniu głównym dotyczy przepisów krajowych, które sa przejawem stosowania prawa Unii w rozumieniu art. 51 ust. 1 KPP 641. Obowiązek uzasadnienia, że pytanie związane jest z postępowaniem głównym, które ma charakter unijny, a nie wewnętrzny, leży bowiem po stronie sądu odsyłającego. Również i tym razem TSUE wskazał taką samą podstawę stwierdzenia swej oczywistej niewłaściwości jak w sprawie Leśniak-Jaworska i Głuchowska-Szmulewicz.

\subsubsection{Sprawa Stylinart}

Podobnym rezultatem zakończyły się dwie kolejne sprawy dotyczące zastosowania Karty Praw Podstawowych, które w trybie pytania prejudycjalnego skierowały do TSUE polskie sądy. Jak więc widać, poprzednie dwa postanowienia nie odbiły się w polskim wymiarze sprawiedliwości wystarczająco głośnym echem, aby zapobiec powielaniu podobnych błędów. Sprawa Stylinart ${ }^{642}$ dotyczyła odszkodowania za szkodę wynikającą z wywłaszczenia. Stylinart, spółka prawa handlowego, która w zakresie prowadzonej działalności zajmuje się przewozem i dostawą mebli do sklepów meblowych w Niemczech, została zgodnie z prawem polskim ${ }^{643}$ wywłaszczona z części swej nieruchomości na realizację drogi obwodowej Przemyśla. Odszkodowanie za wywłaszczenie, jakie zostało jej przyznane, odpowiadało wartości działek niezbędnych do budowy wspomnianej drogi obwodowej, z których została ona wywłaszczona ${ }^{644}$. Nie obejmowało zaś szkody związanej z utratą funkcjonalności działek sąsiadujących z działką wywłaszczona, co wynikało z prawa krajowego i praktyki jego stosowania przez polskie sądy, które nie przewidywały odszkodowania za tego rodzaju szkodę ${ }^{645}$. Skłoniło to sąd odsyłający do zadania TSUE pytania:

${ }^{641}$ Ibidem, pkt 17-28.

${ }^{642}$ TSUE, Stylinart sp. z o.o. p. Skarb Państwa - Wojewoda Podkarpacki i Skarb Państwa Prezydent Miasta Przemyśla, C-282/14, postanowienie z 11 grudnia 2014.

${ }^{643}$ Ustawa z 10 kwietnia 2003 o szczególnych zasadach przyznawania i realizacji inwestycji w zakresie dróg publicznych, Dz.U. nr 80, poz. 721.

${ }_{644}$ TSUE, Stylinart sp. z o.o. p. Skarb Państwa - Wojewoda Podkarpacki i Skarb Państwa Prezydent Miasta Przemyśla, C-282/14, postanowienie z 11 grudnia 2014, pkt 7 .

${ }^{645}$ Ibidem, pkt 5-6, 8. 
Czy przepisy art. 16 i 17 Karty praw podstawowych Unii Europejskiej należy rozumieć w taki sposób, że nie stoi [im] na przeszkodzie zasądzenie na rzecz właściciela wywłaszczonej nieruchomości odszkodowania za szkodę, jaką poniósł on w wyniku tego wywłaszczenia przy korzystaniu z pozostałych sąsiadujących nieruchomości, pomimo że polskie ustawodawstwo nie przewiduje takiego uregulowania w krajowym porządku prawnym, a jedynie odszkodowanie odpowiadające wartości wywłaszczonej nieruchomości? ${ }^{646}$.

TSUE w postanowieniu przypomniał brzmienie art. 51 ust. 1 Karty ${ }^{647}$, a także swoje orzecznictwo, które co do istoty omówione zostało w poprzednim rozdziale. Stwierdził, że:

Z utrwalonego orzecznictwa Trybunału wynika [...], że prawa podstawowe chronione w porządku prawnym Unii znajdują zastosowanie we wszystkich sytuacjach podlegających prawu Unii, ale nie poza takimi sytuacjami. Z tego względu Trybunał przypomniał już, że nie jest władny oceniać zgodności z kartą przepisów krajowych, które nie mieszczą się w zakresie zastosowania prawa Unii. Natomiast, jeżeli przepisy takie wchodzą w zakres zastosowania tego prawa, Trybunał, rozpatrując pytanie prejudycjalne, powinien udzielić wszelkich wyjaśnień interpretacyjnych koniecznych do oceny przez sąd krajowy zgodności tych przepisów z prawami podstawowymi, których ochronę zapewnia $[\ldots]^{648}$.

Trybunał przytoczył też liczną grupę spraw, w których odmawiał wydania orzeczenia w trybie prejudycjalnym w przedmiocie unijnych praw podstawowych, gdy brak było związku między prawem znajdującym zastosowanie w postępowaniu głównym a prawem unijnym, innym niż sama Karta. Trybunał przypomniał, że „wielokrotnie odmawiał uznania swej właściwości, w sytuacji gdy postanowienie odsyłające nie zawierało żadnego konkretnego elementu pozwalającego przyjąć, że przedmiotem postępowania głównego jest wykładnia lub stosowanie przepisu prawa Unii innego niż postanowienia zawarte w karcie [... $]^{\prime 649}$.

Wreszcie TSUE powołał się na art. 94 lit. c) regulaminu postępowania przed Trybunałem ${ }^{650}$, zgodnie z którym „wniosek o wydanie orzeczenia w trybie prejudycjalnym winien zawierać omówienie powodów, dla których sąd odsyłający rozpatruje kwestię wykładni lub ważności określonych przepisów

${ }^{646}$ Ibidem, pkt 14 .

${ }^{647}$ Ibidem, pkt 16 .

${ }^{648}$ Ibidem, pkt 17 .

${ }^{649}$ Ibidem, pkt 18 .

${ }^{650}$ Regulamin postępowania przed Trybunałem Sprawiedliwości, Dz.Urz. L 265 z 29 września 2012. 
prawa Unii, jak również związku, jaki dostrzega on między tymi przepisami a uregulowaniami krajowymi, które znajdują zastosowanie w postępowaniu głównym"651. Tymczasem tego rodzaju wyjaśnień we wniosku nie było. Nawet więc gdyby związek, o jakim mowa powyżej, istniał, to bez należytego uzasadnienia tego związku TSUE nie mógłby się tą sprawą zająć. Dobitnie ukazuje to istotność dokonywania przez sądy krajowe pogłębionych analiz sytuacji i precyzyjnych rozstrzygnięć dotyczących zakresu zastosowania Karty w toczących się przed nimi sprawach. Nawet jeśli czasem bez tego rodzaju rozważań prawidłowo stosują one unijne prawa podstawowe, to brak takiego nawyku może skutkować niemożnością odpowiedzi przez TSUE na pytania prejudycjalne w tej materii w sytuacjach, w których taka odpowiedź byłaby potrzebna.

Podobnie jak w omawianej sprawie Pańczyk, również i w tej sprawie trudno byłoby jednak wskazać taki odpowiedni łącznik. Jak zauważa Maciej Szpunar, sąd odsyłający

wskazał na fakt, że działalność gospodarcza prowadzona przez spółkę powodową polegała na przewozie międzynarodowym i dostawie mebli do sklepów meblowych w Niemczech. Jest jednak oczywiste, że fakt współpracy z podmiotami gospodarczymi z Niemiec nie ma jakiegokolwiek związku ze stosowaniem ustawy [...] o szczególnych zasadach przygotowania i realizacji inwestycji w zakresie dróg publicznych. A przypomnijmy, że to właśnie uregulowania tej ustawy skłoniły Sąd Rejonowy w Rzeszowie do zwrócenia się z pytaniem prejudycjalnym ${ }^{652}$.

Jak skonkludował TSUE:

pytanie zadane przez sąd odsyłający ogranicza się do przytoczenia postanowień karty bez powołania się na inne przepisy prawa Unii. Nie ulega wątpliwości, że zgodnie z opisem przedstawionym przez sąd odsyłający działalność gospodarcza prowadzona przez skarżącą w postępowaniu głównym polega na zajmowaniu się przewozem międzynarodowym i dostawą mebli do sklepów meblowych w Niemczech. Jednakże wniosek o wydanie orzeczenia w trybie prejudycjalnym nie zawiera żadnego konkretnego elementu, który doprowadził do powstania w tym sądzie wątpliwości w przedmiocie wykładni lub stosowania przepisu prawa Unii innego niż postanowienia zawarte $\mathrm{w}$ karcie $[\ldots]^{653}$.

${ }^{651}$ TSUE, Stylinart sp. z o.o. p. Skarb Państwa - Wojewoda Podkarpacki i Skarb Państwa Prezydent Miasta Przemyśla, C-282/14, postanowienie z 11 grudnia 2014, pkt 19.

${ }_{652}$ M. Szpunar, Kilka uwag..., s. 5.

${ }^{653}$ TSUE, Stylinart sp. z o.o. p. Skarb Państwa - Wojewoda Podkarpacki i Skarb Państwa Prezydent Miasta Przemyśla, C-282/14, postanowienie z 11 grudnia 2014, pkt 20. 
Dlatego też: „Z uwagi na to, że wniosek o wydanie orzeczenia w trybie prejudycjalnym nie zawiera minimum wyjaśnień w odniesieniu do związku, jaki sąd odsyłający dostrzega między prawem Unii a uregulowaniami krajowymi, nie wykazano właściwości Trybunału do udzielenia odpowiedzi na pytanie przedstawione $\mathrm{w}$ niniejszym wniosku o wydanie orzeczenia $\mathrm{w}$ trybie prejudycjalnym" ${ }^{\prime 65}$. TSUE stwierdził, że jest oczywiście niewłaściwy do udzielenia odpowiedzi na pytanie ${ }^{655}$ postawione mu przez Sąd Rejonowy w Rzeszowie ${ }^{656}$.

\subsubsection{Sprawa Grodecka}

Sprawa Grodecka ${ }^{657}$ dotyczyła kwestii szczególnego reżimu dziedziczenia gospodarstw rolnych. Konkretnie chodziło o nabycie przez Panią Halinę Grodecką spadku po zmarłym w dniu 10 października 2000 r. K. Konieczce, w którego skład wchodziło między innymi gospodarstwo rolne o powierzchni przekraczającej 1 ha ${ }^{658}$.

Artykuły 1058 i nast. kodeksu cywilnego, w brzmieniu mającym zastosowanie do okoliczności faktycznych postępowania głównego, przewidywały szczególny reżim ustawowego dziedziczenia gospodarstw rolnych obejmujących grunty rolne o powierzchni przekraczającej 1 ha. Artykuł 1059 kodeksu cywilnego stanowił zasadniczo, że gospodarstwo rolne dziedziczyli z ustawy tylko spadkobiercy, którzy w chwili otwarcia spadku pracowali przy produkcji rolnej lub mieli w szczególności przygotowanie zawodowe do prowadzenia produkcji rolnej, z wyłączeniem spadkobierców niespełniających tych warunków ${ }^{659}$.

Ponadto zgodnie $\mathrm{z}_{\text {" }}$ art. 1063 kodeksu cywilnego gospodarstwo rolne spadkobiercy dziedziczyli na zasadach ogólnych tylko wtedy, gdy ani małżonek spadkodawcy, ani żaden z jego krewnych powołanych do dziedziczenia z ustawy nie spełniali warunków przewidzianych dla dziedziczenia gospodarstwa rolnego"660.

${ }^{654}$ Ibidem, pkt 21.

${ }^{655}$ Ibidem, pkt 22.

${ }^{656}$ Na marginesie można zauważyć, że spółka Stylinart wystąiła w tej sprawie także ze skargą konstytucyjną do Trybunału Konstytucyjnego. TK orzekł jednak o niedopuszczalności wydania wyroku ze względu na niespełnienie w skardze jej wymogów poprzez to, że przedmiotem skargi nie były wskazane w petitum skargi przepisy, ale sposób ich zastosowania w konkretnej sprawie (TK, sprawa Sk 17/13, postanowienie z 13 stycznia 2015).

657 TSUE, Halina Grodecka p. Józefowi Konieczce i in., C-50/16, postanowienie z 2 czerwca 2016.

${ }^{658}$ Ibidem, pkt 22.

${ }^{659}$ Ibidem, pkt 3.

${ }^{660}$ Ibidem, pkt 4. 
Trybunał Konstytucyjny unieważnił przepisy ustanawiające ten szczególny reżim dziedziczenia jako niezgodne z Konstytucją i utraciły one w związku z tym moc. Jednakże otwarcie spadku miało miejsce zanim to nastąpiło, w związku z czym na podstawie art. $925 \mathrm{Kc}$ zostały one do niego zastosowane ${ }^{661}$.

Sąd Rejonowy w Koninie w obawie, że przepisy ustanawiające wymóg posiadania konkretnych cech od spadkobierców gospodarstw rolnych niesłusznie różnicują sytuację prawną spadkobierców oraz w sytuacji, gdy nie posiadają oni wymaganych cech prowadzą faktycznie do ich wywłaszczenia i że w efekcie naruszają prawa zagwarantowane w Karcie Praw Podstawowych, jak i w EKPC $z^{662}$, zwrócił się do TSUE z pytaniem:

Czy art. 2 TFUE i 8 TFUE, art. 1 protokołu nr 1, art. 14 EKPC i art. 17 ust. 1 karty - statuujące zasadę rządów prawa, równości i niedyskryminacji oraz ochrony własności - należy interpretować w ten sposób, że sprzeciwiają się przepisom krajowym ograniczającym dziedziczenie gospodarstwa rolnego z uwagi na brak cech przedmiotowych określonych przez ustawę i sprecyzowanych w akcie podstawowym po stronie spadkobiercy będącego obywatelem polskim lub cudzoziemcem? ${ }^{663}$.

Co nie powinno zaskakiwać, opierając się na swoim wcześniejszym orzecznictwie, jak i wprost na przepisach Karty, TSUE stwierdził, że jest oczywiście niewłaściwy do rozpoznania sprawy ${ }^{664}$. Tym razem jednak było jeszcze więcej powodów do takiego stwierdzenia niż w przytoczonych wcześniej pytaniach prejudycjalnych. Po pierwsze, sytuacja w sprawie wymyka się z właściwości Trybunału ratione temporis, jako że stan faktyczny miał miejsce przed przystąpieniem Polski do UE ${ }^{665}$, czyli przedtem zanim prawo unijne w ogóle mogło być dla Polski wiążące. Pomijam już w tym miejscu moment uzyskania mocy wiążącej przez Kartę. Ponadto, jak również zauważył Trybunał, w związku z art. 51 ust. 2 Karty, TSUE nie może rozszerzać swych kompetencji i wydać wyroku odnośnie do interpretacji przepisów prawa unijnego, o których interpretację zwraca się sąd odsyłający, gdy przepisy w postępowaniu głównym nie stanowią zastosowania praw Unii w rozumieniu art. 51 ust. 1 Karty ${ }^{666}$, a z taką sytuacją bezspornie (jako że Polska nie była w momencie ustanowienia przedmiotowych przepisów członkiem Unii) mieliśmy do czynienia w przedmiotowej sprawie.

\footnotetext{
${ }^{661}$ Ibidem, pkt 5, 7 .

${ }^{662}$ Ibidem, pkt 8-9.

${ }^{663}$ Ibidem, pkt 10.

${ }^{664}$ Ibidem, pkt 12-13.

665 Ibidem, pkt 14-15.

${ }^{666}$ Ibidem, pkt 16-17.
} 


\subsubsection{Sprawa JZ}

Pewnym zwiastunem poprawy sposobu, w jaki w pytaniach prejudycjalnych polskich sądów funkcjonuje Karta, jest sprawa JZ ${ }^{667}$. Sprawę tę skierował do TSUE Sąd Rejonowy dla Łodzi-Śródmieścia, a dotyczyła ona wykładni przepisów regulujących ENA. Sąd chciał wiedzieć, czy przepisy decyzji ramowej w związku z art. 6 ust. 1 i 3 TUE nadającym Karcie moc prawną i określającym podstawy gwarancji praw człowieka w Unii, a także w związku z art. 49 ust. 3 Karty, gwarantującym, że surowość kar nie może być nieproporcjonalna do popełnionych czynów, należy interpretować w ten sposób, że sformułowanie „zatrzymanie" obejmuje także środki stosowane przez państwo wykonujące nakaz, polegające na elektronicznej kontroli miejsca pobytu osoby, której nakaz dotyczy, połączonej z aresztem domowym, jakie to środki były przewidziane przez prawo polskie ${ }^{668}$.

Trybunał nie podzielił stanowiska wyrażonego przez sąd odsyłający, że stosowanie tego rodzaju środków prowadzi do kumulacji różnych środków zapobiegawczych, które - uwzględniane łącznie - mogłyby być rozpatrywane jako pozbawienie wolności. Stosowanie tych środków przez okres kilkunastu miesięcy mogłoby zdaniem sądu w konsekwencji zostać uznane za dodatkową karę odbytą w związku z tym samym przestępstwem, za które skazanemu wymierzono już długoterminową karę pozbawienia wolności ${ }^{669}$. Zdaniem TSUE:

środki takie, jak areszt domowy w wymiarze dziewięciu godzin na dobę (w godzinach nocnych), połączony z dozorem elektronicznym danej osoby za pomocą opaski elektronicznej, z obowiązkiem stawiennictwa codziennie lub kilka razy w tygodniu $\mathrm{w}$ komisariacie policji w określonych godzinach, a także z zakazem występowania o wydanie dokumentów umożliwiających podróż za granicę, nie są co do zasady uwzględniając rodzaj, czas trwania, skutki i sposób wykonania całokształtu tych środków - do tego stopnia ograniczające, by wywierały skutek w postaci pozbawienia wolności porównywalny z osadzeniem i tym samym by zostały zakwalifikowane jako "zatrzymanie" w rozumieniu wspomnianego przepisu, czego sprawdzenie należy jednak do sądu odsyłającego ${ }^{670}$.

Należy podkreślić, że sąd odsyłający prawidłowo zidentyfikował problem, jakim jest ocena środków krajowych przez pryzmat decyzji ramowej oraz unij-

${ }^{667}$ TSUE, JZ p. Prokuraturze Rejonowej Łódź-Śródmieście, C-294/16 PPU, wyrok z 28 lipca 2016.

${ }^{668}$ Ibidem, pkt 25.

${ }^{669} \mathrm{Ibidem}$, pkt 24.

${ }^{670}$ Ibidem, pkt 57 . 
nych gwarancji praw człowieka. Dla wywodu TSUE kluczowe znaczenie miało rozróżnienie między środkami krajowymi, które należy sklasyfikować jako ograniczenie albo pozbawienie wolności, gdzie tylko te ostatnie mogłyby być uznane za "zatrzymanie" w rozumieniu decyzji ramowej ${ }^{671}$. TSUE zauważył, że pozbawienie wolności nie zawsze musi mieć charakter osadzenia w zakładzie penitencjarnym ${ }^{672}$, i obszernie odnosząc się do standardów konwencyjnych ${ }^{673}$, podkreślił w tym kontekście znaczenie przewidzianych w prawie unijnym gwarancji praw człowieka dla klasyfikacji zastosowanych środków jako ograniczających albo pozbawiających wolności. Pozwoliło mu to uzasadnić tezę, że „oprócz osadzenia w zakładzie penitencjarnym, każdy środek lub każdy całokształt środków nałożonych na daną osobę, które ze względu na ich rodzaj, czas trwania, skutki i zasady wykonywania pozbawiają tę osobę wolności w sposób porównywalny z osadzeniem w zakładzie penitencjarnym" ${ }^{\prime 674}$, należy uznawać za równoważne z pozbawieniem wolności. Ocenę konkretnych środków pod tym kątem i sprawdzenie, czy urastają one do rangi pozbawiających wolność, czy nie, TSUE zostawił sądom krajowym ${ }^{675}$. Unijne gwarancje praw człowieka powinny być jednak dla nich narzędziem niezbędnym do dokonania tej oceny. Stąd pytanie sądu odsyłającego było zasadne.

\subsubsection{Sprawa El Hassani}

Kolejnym przykładem dostrzeżenia unijnego charakteru sprawy i możliwości zastosowania Karty odnośnie do prawa krajowego, a także prawidłowego skierowania w tej materii pytania prejudycjalnego do TSUE, jest sprawa El Hassani ${ }^{676}$. Sprawę tę zainicjował Naczelny Sąd Administracyjny. „Soufiane El Hassani wystąił do Konsula Rzeczypospolitej Polskiej w Rabacie o wydanie mu wizy Schengen dla celów odwiedzenia swojej żony i swojego dziec$\mathrm{ka}$, będących obywatelami polskimi. W przedmiocie tego wniosku konsul wydał decyzję odmowną"677. Zgodnie z polskimi przepisami proceduralnymi Pan El Hassani złożył wniosek o ponowne rozpatrzenie sprawy przez konsula. Decyzja ponownie była odmowna ${ }^{678}$. Wówczas wniósł skargę do

\footnotetext{
${ }^{671}$ Ibidem, pkt 31-45.

672 Ibidem, pkt 46.

${ }^{673}$ Ibidem, pkt 48-52.

${ }^{674}$ Ibidem, pkt 47 .

${ }^{675}$ Ibidem, pkt 57 in fine.

676 TSUE, Soufiane El Hassani p. Ministrowi Spraw Zagranicznych, C-403/16, wyrok Z 13 grudnia 2017.

${ }^{677}$ Ibidem, pkt 10.

${ }^{678}$ Ibidem, pkt 11.
} 
WSA w Warszawie, w której podniósł między innymi, „że chociaż jego żona i dziecko są obywatelami polskimi, ustawodawstwo polskie nie zezwala mu w przeciwieństwie do będących cudzoziemcami małżonków obywateli innych państw członkowskich Unii - na wniesienie skargi do sądu administracyjnego w przypadku odmowy wydania wizy" ${ }^{\prime 679}$. WSA odrzucił jednak "skargę na podstawie art. 5 pkt 4 prawa o postępowaniu przed sądami administracyjnymi, orzekając, że sprawa ze skargi wniesionej na decyzję o odmowie wydania przez konsula wizy Schengen nie należy do właściwości sądu administracyjnego" ${ }^{\prime 60}$. Pan El Hassani wniósł więc "skargę kasacyjną do Naczelnego Sądu Administracyjnego, podnosząc w istocie, że [...] został pozbawiony prawa do skutecznego środka odwoławczego do sądu, co stanowi naruszenie art. 13 EKPC oraz art. 32 ust. 3 [unijnego - przyp. aut.] kodeksu wizowego w związku z art. 47 Karty praw podstawowych Unii Europejskiej [...], które gwarantują prawo do skutecznego środka odwoławczego do sądu"681. Doprowadziło to NSA do skierowania do TSUE pytania: "Czy art. 32 ust. 3 [kodeksu wizowego], z uwagi na motyw 29 preambuły [do tego kodeksu] i art. 47 akapit pierwszy [karty], należy rozumieć w ten sposób, że nakłada na państwo członkowskie obowiązek zagwarantowania środka zaskarżenia (odwołania) do sądu?"682

Odpowiedź TSUE była twierdząca. Trybunał stwierdził, że:

Artykuł 32 ust. 3 rozporządzenia Parlamentu Europejskiego i Rady (WE) nr 810/2009 z dnia 13 lipca 2009 r. ustanawiającego Wspólnotowy kodeks wizowy, zmienionego rozporządzeniem Parlamentu Europejskiego i Rady (UE) nr 610/2013 z dnia 26 czerwca 2013 r., w świetle art. 47 Karty praw podstawowych Unii Europejskiej należy interpretować w ten sposób, że nakłada on na państwa członkowskie obowiązek ustanowienia procedury odwoławczej od decyzji o odmowie wydania wizy, której szczegółowe zasady należą do porządku prawnego każdego państwa członkowskiego, przy poszanowaniu zasad równoważności i skuteczności. Procedura ta musi gwarantować na pewnym etapie postępowania środek odwoławczy do sądu.

Autonomia proceduralna państw w przedmiocie ustanawiania procedur dotyczących uzyskiwania wiz i trybu odwoławczego nie dopuszcza ustanawiania procedur wykluczających możliwość odwołania do sądu.

\footnotetext{
${ }^{679}$ Ibidem, pkt 13.

${ }^{680}$ Ibidem, pkt 16.

${ }^{681}$ Ibidem, pkt 17.

${ }^{682}$ Ibidem, pkt 21.
} 


\subsection{Nieprawidłowości w stosowaniu Karty przez sądy polskie. Niebezpieczeństwo jej niestosowania w sytuacjach tego wymagających}

Wydaje się, że praktyka polskich sądów odnośnie do kwestii stosowania unijnych praw podstawowych pozostawia wiele do życzenia. Cechuje ja, a przynajmniej przez wiele lat cechowało, ornamentacyjno-argumentacyjne używanie Karty oraz brak pogłębionej refleksji nad możliwością rzeczywistego stosowania Karty w związku z jej zakresem zastosowania określonym w jej art. 51 ust. 1. Należy wszakże zauważyć, że odpowiedzialność za ten stan rzeczy nie leży wyłącznie po stronie sądów. Ma słuszność Mirosław Wróblewski, gdy zauważa, że obiektywnie rzecz biorąc „szeroki zakres zastosowania praw gwarantowanych w Karcie rodzi wiele wątpliwości związanych z egzekwowaniem ich treści. Przedstawiciele zawodów prawniczych i osoby pragnące wykorzystać Kartę w swojej działalności wciąż uczą się, jak prawidłowo ocenić rolę Karty i w pełni ją stosować" 683 . Pewne braki w wiedzy na temat Karty cechują nie tylko sądy, ale i przedstawicieli pozostałych zawodów prawniczych i często to ci ostatni generują opisywaną w tym rozdziale tendencję do ornamentacyjno-argumentacyjnego traktowania Karty. W wielu przypadkach:

strony i ich profesjonalni pełnomocnicy nie ułatwiają zadania sądom powszechnym oraz administracyjnym. Faktycznie jest bowiem tak, że Karta jest dość nowym i specyficznym aktem prawnym, nie znajdującym precedensu w polskim porządku prawnym. Strony stosunkowo często powołują Kartę, jednak zwykle jako jeden z kilku bądź kilkunastu dokumentów prawnomiędzynarodowych, których stwierdzenia naruszenia żąda się od wymiaru sprawiedliwości. Odniesienia do Karty nie są najczęściej relewantne, pomijają analizę możliwości zastosowania jej przepisów w świetle art. 51 ust. 1 KPP ${ }^{684}$.

Należy więc pamiętać, że ważną rolę w prawidłowym stosowaniu Karty mają również pełnomocnicy stron. Jak ujęła to kiedyś obrazowo Ewa Łętowska, to oni "podają piłkę" sędziom, ułatwiając im bądź utrudniając celny strzał do bramki ${ }^{685}$.

Nie powinno więc szczególnie dziwić, że w takiej sytuacji:

${ }^{683}$ M. Wróblewski, Ł. Bojarski, D. Schindlauer, K. Wladasch, Karta Praw..., s. 62.

${ }^{684}$ M. Wróblewski, Karta Praw Podstawowych Unii Europejskiej w polskim..., s. 19.

${ }^{685} \mathrm{~Np}$. podczas konferencji „Sędzia a konstytucja. Kryzys sądownictwa konstytucyjnego a rozproszona kontrola zgodności prawa z Konstytucją", która odbyła się 3 marca 2017 w Katowicach. 
Wymienianie postanowień Karty wśród wielu innych aktów prawnych, bez pogłębionej argumentacji, spotyka się w praktyce z obojętnością sądów, które nie odnoszą się do tych zarzutów w ogóle bądź też stwierdzają niezasadność zarzutów, bądź brak jakiejkolwiek argumentacji na rzecz przedstawianych tez procesowych. W najlepszym przypadku, w ślad za argumentacją przedstawianą przez strony lub niekiedy z urzędu, sądy wymieniają przepisy Karty wśród naruszonych polskich przepisów prawa materialnego lub procesowego. Jest to technika orzecznicza, która jest równie częsta w przypadku Konwencji o ochronie praw człowieka. Akty prawa międzynarodowego nie stanowią bowiem zwykle w wyrokach podstawy rozstrzygnięcia, lecz powoływane są jako dodatkowy argument decyzji orzeczniczej opartej w istocie wyłącznie na polskich przepisach ${ }^{686}$.

Pewnym dodatkowym nieporozumieniem, które praktyka sądów polskich ujawnia, jest wymienianie Karty i Konwencji jednym tchem bez dostrzegania ich zasadniczo różnego charakteru - Karty jako aktu prawa unijnego oraz Konwencji jako aktu prawa międzynarodowego. Świadczy to o głęboko zakorzenionym niezrozumieniu charakteru Karty, czego jedynie funkcją jest brak powszechnej świadomości co do zakresu jej zastosowania, widoczny szczególnie dobitnie w aktywności sądów krajowych.

Szczególnie krytyczne wnioski co do oceny świadomości sądów polskich odnośnie do zakresu zastosowania unijnych praw podstawowych można wyciągnać na podstawie skierowanych przez nie do tej pory pytań prejudycjalnych do TSUE dotyczących Karty. Pytania te zawierają przykłady prawie wszystkich możliwych błędów dotyczących właściwości TSUE do zajmowania się prawami podstawowymi wynikającej zarówno z zakresu związania państw członkowskich tymi prawami w obliczu art. 51 ust. 1 Karty, jak i jego właściwości czasowej, a nawet związanych z niewiedzą o obowiązku wskazania podstaw właściwości TSUE jako warunku prawidłowego zainicjowania postępowania w trybie pytania prejudycjalnego. Tych niepowodzeń nie należy traktować jednak jako podstaw do zniechęcenia. Przeciwnie, powinny one służyć jako pewnego rodzaju zbiór wskazówek co do tego, w jakich sytuacjach i w jaki sposób prawidłowo kierować pytania do TSUE w przedmiocie praw podstawowych, do czego, jak wspomniano, polskie sądy są uprawnione i zobowiązane. Można jednak wskazać aktualnie również godne pochwały przykłady poprawy tego stanu rzeczy.

Zdecydowana większość dotychczasowych pytań sądów polskich dotyczących Karty świadczy o

pominięciu rozważenia przez polski sąd treści art. 51 ust. 1 KPP bądź też o błędnym przekonaniu, że materia rozpoznawanej sprawy mieści się w zakresie prawa UE. W postanowieniu odmawiającym odpowiedzi w [...] sprawie Stylinart TS podkreślił,

${ }^{686}$ M. Wróblewski, Karta Praw Podstawowych Unii Europejskiej w polskim..., s. 19. 
że „wniosek o wydanie orzeczenia w trybie prejudycjalnym nie zawiera nawet minimum wyjaśnień w odniesieniu do związku, jaki sąd odsyłający dostrzega między prawem Unii a uregulowaniami krajowymi". Trudno o bardziej jaskrawy dowód na to, że zauważenie i właściwe zastosowanie art. 51 ust. 1 KPP jest kwestią fundamentalną dla stosowania Karty przez polskie sądownictwo ${ }^{687}$.

Owo zauważanie i właściwe stosowanie art. 51 ust. 1 Karty nie może jednak mieć miejsca jedynie w wyjątkowych sytuacjach, a więc wtedy, kiedy sądy chcą zwrócić się z pytaniem prejudycjalnym. Powinno ono mieć charakter powszechny. Tylko wtedy bowiem możliwe będzie prawidłowe w skali powszechnej stosowanie Karty, którego funkcją będzie prawidłowe kierowanie pytań $\mathrm{w}$ tej materii do TSUE w sytuacjach, gdy będzie to uzasadnione.

O ile ornamentacyjno-argumentacyjne używanie Karty może być bardziej zrozumiałe, również ze względu na postawy uczestników postępowań i ich pełnomocników, o tyle jednak nie wydaje się, aby zasługiwało na pełną aprobatę. Sama praktyka przywoływania Karty w roli ornamentacyjno-argumentacyjnej, kiedy formalnie orzeczenie oparte jest wyłącznie na przepisach polskich, nie powinno być oceniane wyłącznie negatywnie.

W takich przypadkach wykładnia przepisów polskiej ustawy w świetle Konwencji czy właśnie Karty może [...] pozytywnie wpłynąć na prawidłowość procesów interpretacji prawa, a w konsekwencji przyczynić się do zapewnienia odpowiedniej ochrony praw jednostki. Warto tylko [...] się zastanowić, czy w takiej sytuacji sądy nie powinny jednak wyraźnie zaznaczać pomocniczej roli interpretacyjnej Karty, zapobiegając ewentualnej konfuzji co do tego, czy w danej sprawie może być ona zasadnie powołana w świetle art. 51 ust. 1 KPP688.

Takie podejście mogłoby pomóc w popularyzacji rzeczywistego znaczenia Karty i zapobiegać ewentualnym poważniejszym błędom w jej stosowaniu, za jakie niewątpliwie należałoby uznać niezastosowanie Karty w sprawach, w których powinna zostać zastosowana.

Ornamentacyjno-argumentacyjne powoływanie Karty nie jest samo w sobie złe, jako że sprzyja tworzeniu przyjaznej atmosfery wokół Karty i unijnych praw podstawowych i ich stopniowego wprowadzania do świadomości obywateli oraz do obrotu prawnego. Jak słusznie twierdzi Nina Półtorak, „pomocnicze powołanie KPP - nawet w sprawach pozostających poza zakresem prawa UE - dla wyznaczenia standardu ochrony praw podstawowych, nie wydaje się uchybieniem. Karta tworzy bowiem europejski standard ochrony praw podstawowych, który może i powinien być uwzględniany przy in-

${ }^{687}$ Ibidem, s. 22.

${ }^{688}$ Ibidem, s. 19. 
terpretacji polskiego standardu"689. Prawa podstawowe w Unii wywodzą się przecież ze wspólnej tradycji konstytucyjnej państw członkowskich, w tym Polski, i jednocześnie ją formują oraz przyczyniają się do jej dalszego rozwoju. Ich możliwie powszechne przestrzeganie w obrębie Unii powinno być zadaniem wszystkich podmiotów władzy na tym obszarze, również sądów polskich, które sensu largo są przecież również sądami unijnymi. Podkreślanie tej wspólnoty wartości, leżącej u źródła ochrony praw człowieka, i przywoływanie regulacji unijnych, nawet jeśli te nie mogą być bezpośrednio zastosowane, a jedynie służą uwydatnieniu argumentacji opartej na prawie polskim, nie powinno więc samo w sobie być oceniane negatywnie. Nic nie stoi jednak na przeszkodzie, aby takie używanie Karty miało świadomy i opierający się na art. 51 ust. 1 charakter.

Najistotniejszym problemem, jaki wyłania się z orzecznictwa sądów polskich dotyczącego Karty Praw Podstawowych, nie jest przywoływanie jej w sprawach, w których wprawdzie nie znajduje ona zastosowania, a może jedynie służyć jako analogia. Jest nim ewentualne jej nieprzywoływanie w sprawach, w których byłoby to uzasadnione ${ }^{690}$. Niebezpieczeństwo takie wydaje się realne w obliczu dość niskiego poziomu świadomości sądów polskich co do zakresu zastosowania KPP, które wyłania się z ich orzecznictwa w tej materii. Przykłady jego ziszczenia się były również wskazywane.

Należy więc podsumować, że zarówno stosowanie unijnych praw podstawowych w konkretnych sprawach, jak i pytania prejudycjalne dotyczące Karty kierowane do TSUE przez polskie sądy, wskazują na raczej słabo rozpowszechnioną wiedzę na temat zasad zastosowania Karty, szczególnie w wymiarze, w jakim może być ona stosowana wobec państw członkowskich w związku z jej art. 51 ust. 1 . Tymczasem nie ulega wątpliwości, że: „Dla zastosowania przez sąd Karty na poziomie krajowym fundamentalne znaczenie ma właściwa wykładnia art. 51 ust. 1 KPP”691. Mimo to "polskie sądy często pomijają analizę, która powinna być oparta na postanowieniach ogólnych Karty i przesądzać, czy możliwe jest na poziomie krajowym powołanie się na prawo wynikające z KPP" ${ }^{\prime \prime 92}$. Nie jest to zreszta problem charakterystyczny tylko dla Polski. Ma on wymiar znacznie szerszy. $\mathrm{O}$ ile w niektórych państwach członkowskich sytuacja jest nieco lepsza, a w innych nieco gorsza, to jednak ogólnie rzecz biorąc, w orzecznictwie sądów krajowych państw członkowskich Unii Europejskiej, w którym pojawia się Karta i gwarantowane w niej prawa, kwestia art. 51 i tego, czy prawa te znajdują faktyczne zastosowanie, czy ich wykorzystanie ma cha-

\footnotetext{
${ }^{689}$ N. Półtorak, Zakres zwiazania..., s. 18.

${ }^{690}$ Tak samo: ibidem.

${ }^{691}$ M. Wróblewski, Karta Praw Podstawowych Unii Europejskiej w polskim..., s. 18.

${ }^{692}$ Ibidem.
} 
rakter bardziej symboliczny lub argumentacyjny, bardzo często bywa pomijana właściwie we wszystkich państwach członkowskich ${ }^{693}$. Sytuacja ta powinna więc ulec poprawie nie tylko w Polsce.

\section{Rola sądów polskich jako sądów unijnych w procesie stosowania odpowiednich standardów ochrony praw człowieka}

Szczególny status jaki uzyskały sądy polskie wraz z wejściem w życie KPP w przedmiocie kontroli prawa obowiązującego w Polsce najlepiej obrazują problemy, po pierwsze, możliwości stosowania przez nie prawa unijnego, w tym przede wszystkim prawa bezpośrednio skutecznego nawet wbrew konstytucyjnym standardom ochrony praw człowieka (szczególnie jeśli wyrażone byłyby one w aktach rangi niekonstytucyjnej) bez angażowania TK do weryfikacji możliwości stosowania takiego prawa unijnego, a po drugie, problem sposobu postępowania przez sądy w sytuacji orzekania na podstawie prawa krajowego, któremu można jednocześnie zarzucić niezgodność zarówno z unijnymi prawami podstawowymi (gdy jest to prawo mieszczące się w zakresie zastosowania prawa unijnego), jak i z konstytucyjnymi gwarancjami tych samych praw (skoro jest to prawo wydane przez polskie organy prawotwórcze). Problem ten ujawniony został w orzecznictwie TSUE szczególnie wyraźnie w ostatnich latach w wyrokach w sprawach Melki i Abdeli ${ }^{694}$ oraz A. p. B. ${ }^{695}$ TSUE co do zasady potwierdzając swe wcześniejsze orzecznictwo, wykluczył w nich, aby prawo krajowe, na podstawie którego sądy krajowe orzekają na poziomie ostatniej instancji, co do którego są przekonane o jego niezgodności zarówno z unijnymi, jak i konstytucyjnymi gwarancjami praw podstawowych, badane było w wyniku odpowiedniego wniosku kierowanego przez sądy zwykłe do sądu konstytucyjnego, aby ten usunął ten przepis z porządku prawnego. Stałoby to bowiem w sprzeczności z obowiązkami sądów do stosowania Karty i ewentualnego występowania do

${ }^{693}$ Patrz np.: European Union Agency for Fundamental Rights, Fundamental Rights Report 2016, Luxembourg: Publications Office of the European Union, 2016, s. 39 i nast., [online] <http://fra.europa.eu/sites/default/files/fra_uploads/fra-2016-fundamental-rights-report-2016-2_en.pdf> [dostęp: 28.12.2018]; European Union Agency for Fundamental Rights, Fundamental rights: challenges and achievements in 2014, Luxembourg: Publications Office of the European Union, 2015, s. 153 i nast., [online] <http://fra.europa.eu/sites/default/files/fra-annual-report-2014_en.pdf> [dostęp: 28.12.2018].

${ }_{694}$ TSUE, Aziz Melki i Sélim Abdeli, C-188/10 i C-189/10 wyrok z 22 czerwca 2010.

${ }^{695}$ TSUE, A. p. B. i in., C-112/13, wyrok z 11 września 2014. 
TSUE z pytaniami prejudycjalnymi. O ile co do zasady konkluzja ta może być uznana za uzasadnioną $\mathrm{w}$ świetle charakteru unijnej ochrony praw podstawowych, o tyle należy zauważyć, że zasada ta jest bardziej skomplikowana i można pomyśleć o pewnych od niej wyjątkach.

Wyjątki takie, o różnym charakterze, zdaje się zresztą dopuszczać sam TSUE, o czym będzie jeszcze mowa w dalszych częściach pracy. Dlatego tak istotne jest, aby sądy krajowe zgłębiły i prawidłowo stosowały zasady zastosowania unijnych praw podstawowych, o których była mowa wcześniej, a co, jak zostało to również wcześniej pokazane, nie zawsze ma miejsce. Bez dogłębnego poznania zasad stosowania unijnych praw podstawowych oraz nabycia tej umiejętności, pójście o krok dalej i stosowanie zaanonsowanych tu wyjątków od podstawowych zobowiązań wynikających z prawa unijnego i przez to współuczestniczenie, czy też ułatwianie sekwencyjnego dialogu orzeczniczego między TK a TSUE w sytuacji, gdy tożsamość konstytucyjna RP wymusza zastosowania wyższego niż unijny standardu ochrony praw człowieka stojącego wszakże w sprzeczności z prawem unijnym, byłoby znacznie utrudnione, jeśli nie niemożliwe.

\subsection{Znaczenie zasady pierwszeństwa prawa unijnego a rola sądów krajowych i ich relacja z TSUE i sądami konstytucyjnymi}

Przy okazji omawiania roli sądów krajowych jako sądów unijnych i ich roli w funkcjonowaniu unijnego systemu ochrony praw człowieka, należy zwrócić uwagę na ich specyficzną pozycję, która urasta wręcz do rangi konstytucyjnej. Aby ten specyficzny status sądów krajowych przejrzyście naświetlić, trzeba zacząć od zaprezentowania stanowiska TSUE w kwestii uprawnień, jak i obowiązków, jakie wraz z wejściem w życie Karty, szczególnie w związku z procedurą pytania prejudycjalnego uzyskały sądy krajowe, w tym sądy polskie. Znane przynajmniej od wyroku w sprawie Simmenthal ${ }^{696}$ napięcie między scentralizowanym modelem kontroli konstytucyjności prawa (który nazywany bywa też modelem kelsenowskim, europejskim czy też kontynentalnym), jaki właściwy jest również dla polskiego porządku konstytucyjnego, a zasadą pierwszeństwa prawa unijnego, w ostatnich latach nabrało szczególnej intensywności ${ }^{697}$. Głów-

${ }^{696}$ TSUE, Amministrazione delle Finanze dello Stato p. Simmenthal SpA, C-106/77, wyrok z 9 marca 1978.

${ }^{697}$ D. Paris, Case Note: Constitutional Courts as Guardians of EU Fundamental Rights? Centralised Judicial Review of Legislation and the Charter of Fundamental Rights of the EU European Court of Justice (Fifth Chamber), Judgment of 11 September 2014, "European Constitutional Law Review” 2015, nr 11, s. 389 . 
ną osią problemu jest tu zakwestionowanie przez zasadę pierwszeństwa prawa unijnego procedury zwracania się do odpowiednich sądów konstytucyjnych państw członkowskich przez inne sądy krajowe.

W scentralizowanym modelu kontroli konstytucyjności sądy krajowe nie mają prawa unieważniać czy też nie stosować przepisów prawa, gdy uważają je za niekonstytucyjne, a więc również za sprzeczne z konstytucyjnymi gwarancjami praw człowieka, lecz zwracają się one w tym celu, w odpowiedniej procedurze, jaką w Polsce jest pytanie prawne z art. 193 Konstytucji, do sądów konstytucyjnych, które posiadają kompetencję do eliminowania takich przepisów z porządku prawnego ze skutkiem erga omnes. W sytuacji, w której prawo krajowe mieszczące się w zakresie zastosowania prawa unijnego (a więc spełniające wymogi z art. 51 ust. 1 Karty) ma jednocześnie naruszać prawo unijne ( $w$ tym zagwarantowane $\mathrm{w}$ nim prawa podstawowe, co jest przedmiotem zainteresowania $w$ tej pracy), jak i prawo krajowe ( $w$ tym konstytucyjne gwarancje praw człowieka), zasada pierwszeństwa ogranicza istotnie możliwość stosowania mechanizmów scentralizowanej kontroli konstytucyjności takich przepisów $w^{698}$.

W praktyce, na gruncie regulacji konstytucyjnych i orzecznictwa sądów konstytucyjnych państw członkowskich wypracowane zostały zasadniczo dwa modele radzenia sobie z tym problemem: model francuski i model austriacki. Nie brak też rozwiązań pośrednich. Modele francuski i austriacki zostaną tu wspomniane, nie będą jednak poddane szczegółowej analizie, gdyż praca ta koncentruje się na Polsce, a wątki porównawcze są w niej obecne jedynie, gdy jest to uzasadnione $z$ perspektywy stawianych $w$ niej tez lub konieczne dla przejrzystości wywodu. Polskie regulacje konstytucyjne i stanowisko TK w tej materii omówione będzie $\mathrm{w}$ następnym rozdziale. $\mathrm{W}$ tym miejscu uwaga poświęcona zostanie orzecznictwu TSUE, w którym ten, nie odrzucając ani nie preferując żadnego z tych modeli, wyraźnie postawił jednak pewne granice, które mają charakter uniwersalny dla wszystkich państw członkowskich Unii i funkcjonujących w nich rozwiązań. Ustalenia poczynione na gruncie tego orzecznictwa mają więc znaczenie również dla sądów polskich. Problematyka ta ujawniała się w różnych orzeczeniach TSUE. Najważniejszą parę orzeczeń - bliźniaczych - choć wydanych w wyniku zetknięcia się przez TSUE ze wspomnianymi, różnymi modelami podejścia do przedmiotowej kwestii, stanowią wyroki w sprawach Melki i Abdelii ${ }^{699}$ oraz A. p. $B^{700}$, które zostaną poniżej omówione przede wszystkim w zakresie konsekwencji, jakie z nich wynikają w kwestii stosowania przez sądy krajowe praw podstawowych.

${ }^{698}$ Ibidem, s. 390.

699 TSUE, Aziz Melki i Sélim Abdeli, C-188/10 i C-189/10, wyrok z 22 czerwca 2010.

${ }^{700}$ TSUE, A. p. B. i in., C-112/13, wyrok z 11 września 2014. 
W postępowaniu głównym w sprawie A. p. B chodziło o odszkodowanie, jakiego B. i inne kobiety dochodzili od A. przed sądem okręgowym w Wiedniu (Landesgericht Wien). Podnosiły one, że A. porwał ich mężów bądź ich ojców w Kazachstanie ${ }^{701}$. Jurysdykcja sądu wiedeńskiego miała wynikać stąd, że A. posiadał miejsce zwykłego pobytu w okręgu sądu, do którego wniesiono sprawę $e^{702}$. Bezskuteczne próby doręczenia pozwu dowiodły, że A. nie przebywał już pod adresem do doręczeń. W dniu 27 sierpnia 2010 r. ów sąd, na wniosek B. i in., ustanowił na podstawie prawa austriackiego kuratora dla nieznanego z miejsca pobytu pozwanego ${ }^{703}$. Kurator złożył odpowiedź na pozew, w której wniósł o oddalenie pozwu i podniósł liczne zarzuty merytoryczne, nie kwestionując jednak jurysdykcji krajowej sądów austriackich ${ }^{704}$. Po tym, gdy to nastąpiło, A. umocował inną kancelarię prawną do reprezentowania go, która to kancelaria podniosła zarzut braku jurysdykcji krajowej sądów austriackich, opierając się na tym, że A. definitywnie opuścił Austrię przed wniesieniem pozwu przeciwko niemu ${ }^{705}$. „Landesgericht Wien stwierdził brak swojej jurysdykcji krajowej i odrzucił pozew. Sąd ten uznał, że A. przebywa na terytorium Republiki Malty oraz że wdanie się w spór kuratora dla pozwanego nieznanego z miejsca pobytu nie stanowi wdania się w spór w rozumieniu art. 24 rozporządzenia $\mathrm{nr} 44 / 2001^{\prime \prime 706}$. Strona powodowa odwołała się do sądu wyższej instancji (Oberlandesgericht Wien), który przychyliwszy się do odwołania, oddalił zarzut braku jurysdykcji krajowej. Według tego sądu na podstawie art. 26 rozporządzenia nr 44/2001 sądy krajowe muszą badać swoją jurysdykcję krajową wyłącznie $\mathrm{w}$ wypadku niewdania się w spór przez pozwanego. Zaś w prawie austriackim czynności procesowe kuratora pozwanego nieznanego z miejsca pobytu, zobowiązanego do ochrony interesów tego pozwanego, wywołują takie same skutki prawne jak czynność pełnomocnika procesowego ustanowionego na podstawie umowy ${ }^{707}$. A. wniósł jednak do tego sądu skargę rewizyjna, w której powołał się na naruszenie jego prawa do obrony określonego w art. $6 \mathrm{EKPCz}$ oraz $\mathrm{w}$ art. 47 KPP. Natomiast B. i in. podniosły, że owe przepisy EKPCz i Karty gwarantują także ich prawo podstawowe do skutecznego środka prawnego, wymagając powołania kuratora dla pozwanego nieznanego z miejsca pobytu, co przewidywało prawo austriackie ${ }^{708}$.

\footnotetext{
${ }^{701}$ Ibidem, pkt 15 .

${ }^{702}$ Ibidem, pkt 16.

${ }^{703}$ Ibidem, pkt 17 .

${ }^{704}$ Ibidem, pkt 18.

${ }^{705}$ Ibidem, pkt 19.

${ }^{706}$ Ibidem, pkt 20

${ }^{707}$ Ibidem, pkt 21.

${ }^{708}$ Ibidem, pkt 22.
} 
W miejscu tym należy zwrócić uwagę na pewną specyfikę austriackiego systemu konstytucyjnego oraz status, jaki ma w nim Karta. Należy podkreślić, że austriacki system konstytucyjny w sposób szczególny podchodzi do europejskich mechanizmów ochrony praw człowieka, co odzwierciedla również specyficzna, szczególnie eksponowana na tle innych państw europejskich - równa prawu konstytucyjnemu - ranga, jaką posiada w nim od $1964 \mathrm{r}$. $\mathrm{EKPCz}^{709}$. W 2012 r. austriacki Trybunał Konstytucyjny (Verfassungsgerichtshof) wydał przełomowe orzeczenie w kwestii statusu Karty w austriackim porządku prawnym ${ }^{710}$ :

Uznał on bardzo szczególną rolę Karty w ramach systemu prawnego Unii oraz podkreślił jej odmienny charakter w porównaniu ze zbiorem praw i przepisów, które Trybunał wypracowywał na przestrzeni lat. Przyjął pogląd, że Karta stanowi podstawę zaskarżenia w postępowaniach wszczynanych przed austriackim Trybunałem Konstytucyjnym, w celu przeprowadzenia kontroli sądowej krajowego ustawodawstwa - a zatem podmioty indywidualne mogą powoływać się na prawa i przepisy uznane w Karcie, gdy podnoszą niezgodność z prawem ustawodawstwa krajowego. Austriacki Trybunał Konstytucyjny dostrzegł wyraźne podobieństwa między rolą jaką Karta odgrywa w systemie prawnym Unii, a rola, jaką odgrywa Konwencja [EKPCz przyp. aut.], która ma w Austrii moc prawa konstytucyjnego ${ }^{711}$.

Jak podkreślają niektórzy komentatorzy, orzeczenie to zasługuje na szczególnie pozytywną ocenę, jeśli chodzi o postrzeganie Karty w krajowym porządku prawnym. Również niektórzy politycy unijni przyjęli je z entuzjazmem, określając mianem „austriackiego modelu inkorporacji Karty”, który mógłby stanowić wzór dla innych państw ${ }^{712}$. Jak jednak pokazała reakcja TSUE na to orzeczenie, sytuacja wcale nie jest aż tak jednoznaczna. Jak słusznie zauważa Aleksandra Kustra, aprobata austriackiego Trybunału Konstytucyjnego dla szerokiego rozumienia art. 51 ust. 1 Karty oraz jego otwartość na międzynarodowe standardy ochrony praw człowieka jako posiadające status konstytucyjny "może jednak zostać uznana przez pozostałe najwyższe instancje sądownicze za próbę "monopolizacji« stosowania Karty"713.

Model austriacki stanowi w pewnym sensie kontrapunkt do modelu wypracowanego przez francuską Radę Konstytucyjna, która w swej ugruntowanej linii orzeczniczej odmawia kontroli prawa krajowego przez pryzmat prawa międzynarodowego i prawa unijnego, $w$ tym przez pryzmat zawartych w nim gwa-

\footnotetext{
${ }^{709}$ D. Paris, Case Note..., s. 393 i nast.

${ }^{710}$ Austriacki TK, sprawa U 466/11 ua, wyrok z 14 marca 2012.

711 T.T. Koncewicz, A. Podolska, Karta Praw..., s. 256.

712 Ibidem, s. 256.

713 A. Kustra, Kelsenowski..., s. 475.
} 
rancji praw podstawowych, zostawiając tę kwestię sądom krajowym ${ }^{714}$. Obydwa te modele mają swoje wady i zalety. Szersza analiza tej problematyki i orzecznictwa z tym związanego w kontekście podejścia prezentowanego zarówno przez austriacki Trybunał Konstytucyjny ${ }^{715}$, jak i francuską Radę Konstytucyjną ${ }^{716}$ przekraczałaby ramy tego opracowania. Dość powiedzieć, że oba te modele mają swoje granice, których wspólny mianownik określił TSUE w wyrokach w sprawach Melki i Abdeli oraz A. p. B.

Na gruncie modelu austriackiego wątpliwości, jakie dostrzegł sąd odsyłający, koncentrowały się wokół tego, że

zgodnie z utrwalonym orzecznictwem odstępuje on w poszczególnych wypadkach od stosowania przepisów prawa niezgodnych z prawem Unii, zgodnie z zasadą pierwszeństwa tego prawa. Zaś w orzeczeniu z dnia 14 marca 2012 r., U 466/11, Verfassungsgerichtshof odstąpił od tej linii orzecznictwa, orzekając, że sprawowana przez niego kontrola zgodności ustaw krajowych z konstytucją - w ramach procedury ogólnej kontroli ustaw [...] na podstawie art. 140 B-VG ${ }^{717}$ - powinna zostać rozszerzona na przepisy karty. W ramach tej procedury na prawa gwarantowane przez EKPC można byłoby bowiem powołać się przed nim jako na prawa o randze konstytucyjnej. A zatem według Verfassungsgerichtshof [austriackiego Trybunału Konstytucyjnego przyp. aut.] zasada równoważności, taka jak wynika ona z orzecznictwa Trybunału [TSUE - przyp. aut.], wymaga, aby owa ogólna kontrola ustaw dotyczyła także praw gwarantowanych przez kartę $e^{718}$.

Co więcej, według sądu odsyłającego, przywoływane orzeczenie austriackiego Trybunału Konstytucyjnego

skutkuje tym, że sądy austriackie nie mogą z własnej inicjatywy odstąpić od stosowania ustawy niezgodnej z karta, lecz muszą one - „bez uszczerbku dla możliwości wniesienia pytania prejudycjalnego do Trybunału" - przedłożyć wniosek do Verfassungsgerichtshof o uchylenie tej ustawy ze skutkiem erga omnes. Ponadto ten ostatni sąd orzekł, że - w sytuacji, gdy prawo gwarantowane przez konstytucję austriacką ma taki sam zakres zastosowania jak prawo gwarantowane przez kartę - nie należy przedstawiać Trybunałowi [TSUE - przyp. aut.] pytania prejudycjalnego na

${ }^{714}$ D. Paris, Case Note..., s. 391-393 i nast.

${ }^{715}$ Więcej - patrz np.: A. Orator, The Decision of the Austrian Verfassungsgerichtshof on the EU Charter of Fundamental Rights: An Instrument of Leverage or Rearguard Action?, "German Law Journal" 2015, vol. 16, nr 6; D. Paris, Case Note..., s. 394-399.

${ }^{716}$ Więcej - patrz np.: Paris, Case Note..., s. 394-399.

${ }^{717}$ Federalna Ustawa konstytucyjna Republiki Austrii z 1 października 1920 według tekstu jednolitego Federalnej Ustawy Konstytucyjnej z 1 stycznia 1930, ostatnio zmieniona przez ustawę z 28 czerwca 2002 - w jęz. polskim patrz: Konstytucja Austrii, tłum. P. Czarny, B. Naleziński, Warszawa 2004.

718 TSUE, A. p. B. i in., C-112/13, wyrok z 11 września 2014, pkt 24. 
podstawie art. 267 TFUE. W tej sytuacji wykładnia karty nie jest istotna dla orzekania w przedmiocie wniosku o uchylenie ustawy ze skutkiem erga omnes, ponieważ orzeczenie to może zostać wydane w oparciu o prawa zagwarantowane przez konstytucję austriacką ${ }^{719}$.

Takie rozumienie stanowiska austriackiego Trybunału Konstytucyjnego prowadzić może zdaniem sądu odsyłającego do powstania różnych wątpliwości, związanych z zasadą równoważności czy też kwestii istnienia obowiązku do zwrócenia się z pytaniem prejudycjalnym do TSUE $w$ sytuacji, gdy prawo gwarantowane przez konstytucję austriacką i prawo wywodzone z Karty mają ten sam zakres zastosowania ${ }^{720}$. Watelpliwości te doprowadziły Oberster Gerichtshof do skierowania do TSUE trzech pytań, z których dla naszych rozważań, szczególne znaczenia ma pytanie pierwsze:

Czy z unijnoprawnej zasady „ekwiwalencji” [równoważności] przy stosowaniu prawa Unii w systemie postępowania [do systemu postępowania], w którym sądy zwykłe [powszechne] orzekające co do istoty mają wprawdzie obowiązek badać także konstytucyjność ustaw, nie mają jednak ogólnie uprawnienia do uchylania [ze skutkiem erga omnes] ustaw, które jest zastrzeżone dla sądu [trybunału] konstytucyjnego zorganizowanego w szczególny sposób, należy wnioskować, że zwykłe sądy [powszechne], w przypadku gdy ustawa narusza art. 47 [karty], zobowiązane są w trakcie postępowania także do zwrócenia się do sądu konstytucyjnego w celu ogólnego uchylenia tej ustawy [ze skutkiem erga omnes], nie mogą zaś jedynie odstąić od jej stosowania w konkretnej sprawie? ${ }^{721}$.

Pozostałe dwa pytania miały charakter merytoryczny i sprowadzały się do tego, czy w świetle art. 47 Karty, art. 24 Rozporządzenia nr 44/2001 należy interpretować w ten sposób, że stawiennictwo ustanowionego przez sąd kuratora jest równoznaczne ze stawiennictwem pozwanego dla potrzeb ustanowienia międzynarodowej jurysdykcji sądu krajowego ${ }^{722}$.

Stanowisko sądu odsyłającego, oparte na orzecznictwie austriackiego Trybunału Konstytucyjnego, w sposób dość oczywisty rodzi doniosły problem z perspektywy zasady pierwszeństwa prawa unijnego. To właśnie sąd konstytucyjny miałby dokonać, choć sformułowanie to nie jest w pełni jednoznaczne „bez uszczerbku dla możliwości wniesienia pytania prejudycjalnego"723 - oceny

${ }_{119}$ Ibidem, pkt 25 .
${ }^{720}$ Ibidem, pkt 26.
${ }^{721}$ Ibidem, pkt 27.
${ }^{722}$ Ibidem, pkt 27 .
${ }^{723}$ Być może w razie wątpliwości sam miałby wystąpić z odpowiednim pytaniem prejudycjalnym; jak można by też domniemywać, w obliczu przywoływania przez austriacki Trybunał Konstytucyjny sprawy Melki i Abdeli i świadomości stanowiska w tej materii TSUE, austriacki 
konkretnych przepisów przez pryzmat zgodności z prawami i wolnościami zagwarantowanymi w Karcie, które w Austrii mają status konstytucyjny, i ewentualnie orzec o usunięciu przedmiotowej legislacji z porządku prawnego, a więc dokonać orzeczenia ze skutkiem erga omnes, a nie jedynie w formie jednostkowego aktu niestosowania tego prawa przez sąd zwykły. Jak ujął to TSUE:

Poprzez pytanie pierwsze sąd odsyłający dąży w istocie do ustalenia, czy prawo Unii, a w szczególności art. 267 TFUE, należy interpretować w ten sposób, że stoi ono na przeszkodzie uregulowaniu krajowemu, takiemu jak to rozpatrywane w postępowaniu głównym, zgodnie z którym sądy powszechne orzekające w drugiej lub w ostatniej instancji muszą - w wypadku gdy uważaja, że ustawa krajowa jest niezgodna z art. 47 karty - wnieść w ramach toczącego się przed nimi postępowania wniosek do trybunału konstytucyjnego o uchylenie ustawy ze skutkiem erga omnes w miejsce ograniczenia się do odstąpienia od jej stosowania w danej sprawie ${ }^{724}$.

TSUE podkreślił, że centralnym problemem nie jest tu zasada ekwiwalentności, jak mogłoby to wynikać ze stanowiska sądu austriackiego, ale właśnie zasada pierwszeństwa prawa unijnego ${ }^{725}$.

Swą argumentację Trybunał oparł na wcześniejszym wyroku w sprawie Melki i Abdeli. Dotyczyła ona badania zgodności przepisu krajowego zarówno z prawem Unii, jak i krajową konstytucją w sytuacji, gdy uregulowanie krajowe zawarte w tamtym wypadku w konstytucji francuskiej, przewidywało priorytetowy charakter postępowania wpadkowego w sprawie kontroli zgodności przepisów krajowych (w tym wypadku francuskiego Kodeksu karnego) z konstytucja, a nie $z$ prawem unijnym. TSUE przypomniał w tym kontekście przede wszystkim brzmienie art. 267 TFUE, zgodnie z którym to trybunał luksemburski jest właściwy

do orzekania w trybie prejudycjalnym zarówno o wykładni traktatów i aktów przyjętych przez instytucje, organy lub jednostki Unii, jak i o ważności tych aktów. [...]

TK wcale nie sformułował sztywnego obowiązku kierowania przez sądy austriackie doń wszystkich spraw dotyczących niezgodności prawa austriackiego mieszczącego się w zakresie zastosowania prawa unijnego pod kątem zgodności z Kartą, lecz pozostawił im wybór do tego, aby kierowały one doń kwestie związane z niezgodnością z Kartą prawa austriackiego nie mieszczącego się w zakresie zastosowania prawa unijnego pod kątem zgodności z Kartą (skoro ta niezależnie od swego zakresu zastosowania uzyskała w Austrii rangę konstytucyjną), oraz aby nie stosowały niezgodnego z Kartą prawa austriackiego mieszczącego się w zakresie zastosowania Karty po ewentualnym uprzednim zwróceniu się do TSUE z pytaniem prejudycjalnym. Oba te rozwiązania miałyby jednak również swoje wady (D. Paris, Case Note..., s. 398-399). Tym niemniej w sprawie A. p. B. ujawniło się ścisłe odczytanie wyroku austriackiego Trybunału Konstytucyjnego, sprowadzające się do tego, że sąd zwykły musi zwrócić się do niego w celu kontroli zgodności z prawami człowieka prawa austriackiego mieszczącego się w zakresie prawa unijnego.

${ }^{724}$ TSUE, A. p. B. i in., C-112/13, wyrok z 11 września 2014, pkt 28.

${ }^{725}$ Ibidem, pkt 29. 
[art. 267 TFUE - przyp. aut.] w akapicie drugim przewiduje, że sąd krajowy może się zwrócić z takimi kwestiami do Trybunału, jeżeli uzna, że decyzja w tym względzie jest niezbędna do wydania wyroku, a w akapicie trzecim - że jest zobowiązany to uczynić, jeżeli jego orzeczenia nie podlegają zaskarżeniu według prawa wewnętrznego ${ }^{726}$.

TSUE przypomniał także swe ugruntowane orzecznictwo, zgodnie z którym sądy krajowe każdej instancji mogą i powinny występować z pytaniami prejudycjalnymi do TSUE, i że „sądy krajowe mają jak najszersze możliwości, jeśli chodzi o wystąpienie do Trybunału, gdy uznaja, że w zawisłej przed nimi sprawie pojawiły się pytania związane z wykładnią lub oceną przepisów prawa Unii wymagające rozstrzygnięcia z ich strony"727. Zatem również sądy, które nie orzekają w najwyższej instancji, nawet jeśli prawo krajowe sprawiałoby, że są one związane oceną prawną dokonaną przez sąd wyższego stopnia, nie moga być pozbawione przez to uprawnienia do skorzystania z procedury $z$ art. 267 TFUE. „Sąd, który nie orzeka w ostatniej instancji, powinien mieć swobodę wystąpienia do Trybunału z nurtującymi go zagadnieniami, w szczególności jeśli uzna, że ocena prawa dokonana przez wyższą instancję mogłaby doprowadzić go do wydania orzeczenia sprzecznego z prawem Unii [...]"728.

W kontekście tym pamiętać należy szczególnie o zasadzie ugruntowanej w wyroku w sprawie Foto-Frost ${ }^{729}$, którą Trybunał przypomniał również w obu omawianych tu sprawach, zgodnie z którą:

jeśli chodzi o równoległe stosowanie praw podstawowych gwarantowanych przez konstytucję krajową oraz praw gwarantowanych przez kartę do ustawodawstwa krajowego wdrażającego prawo Unii w rozumieniu art. 51 ust. 1 karty, należy wskazać, że priorytetowy charakter postępowania wpadkowego w sprawie kontroli zgodności z konstytucją ustawy krajowej, której treść ogranicza się do transpozycji bezwzględnie wiążących przepisów dyrektywy Unii, nie może naruszać kompetencji Trybunału, który jako jedyny jest właściwy do stwierdzenia nieważności aktu Unii, w szczególności dyrektywy, kompetencji mającej na celu zagwarantowanie pewności prawa poprzez jednolite stosowanie prawa Unii $(\ldots)^{730}$.

Trybunał słusznie zauważył bowiem, że:

priorytetowy charakter postępowania wpadkowego w sprawie kontroli zgodności z konstytucją mógłby doprowadzić do uchylenia ustawy krajowej, której treść

726 TSUE, Aziz Melki i Sélim Abdeli, C-188/10 i C-189/10, wyrok z 22 czerwca 2010, pkt 40.

${ }^{727}$ Ibidem, pkt 41.

${ }^{728}$ Ibidem, pkt 42.

${ }^{729}$ TSUE, Foto-Frost, z siedzibą w Ammersbek p. Hauptzollamt Lübeck-Ost, C-314/85, wyrok z 22 października 1987, przed. pkt 15-20.

${ }^{730}$ TSUE, A. p. B. i in., C-112/13, wyrok z 11 września 2014, pkt 41. 
ograniczałaby się do transpozycji wiążących przepisów dyrektywy Unii, z powodu sprzeczności tej ustawy z krajową konstytucją. W takiej sytuacji Trybunał luksemburski mógłby praktycznie zostać pozbawiony możliwości przeprowadzenia - na wniosek orzekających co do istoty sądów zainteresowanego państwa członkowskiego - kontroli ważności tej dyrektywy w świetle tych samych zarzutów dotyczących wymogów prawa pierwotnego, a w szczególności praw uznanych w karcie praw podstawowych Unii Europejskiej, której art. 6 TUE przyznaje taką samą moc prawną, jaką mają traktaty ${ }^{731}$.

Dlatego też zgodnie z zasadą wynikającą z wyroku w sprawie Foto-Frost:

Zanim wpadkowa kontrola zgodności z konstytucją ustawy krajowej, której treść ogranicza się do transpozycji wiążących przepisów dyrektywy Unii, będzie mogła zostać przeprowadzona w świetle tych samych zarzutów kwestionujących ważność dyrektywy, sądy krajowe, których orzeczenia nie podlegają zaskarżeniu według prawa wewnętrznego, są co do zasady zobowiązane, na podstawie art. 267 akapit trzeci TFUE, do wystąpienia do Trybunału Sprawiedliwości z pytaniem o ważność tej dyrektywy, a następnie do wyciągnięcia konsekwencji wynikających z wyroku Trybunału wydanego w trybie prejudycjalnym, chyba że sąd, który wszczyna postępowanie wpadkowe w sprawie kontroli zgodności z konstytucją, sam wystąpi z tym pytaniem do Trybunału Sprawiedliwości na podstawie akapitu drugiego tego postanowienia. Co się bowiem tyczy krajowej ustawy transponującej o takiej treści, kwestia ważności dyrektywy w świetle obowiązku jej transpozycji - nabiera charakteru wstępnego. Ponadto fakt ograniczenia czasu badania przez sądy krajowe ścisłym terminem nie uniemożliwia odesłania prejudycjalnego dotyczącego ważności danej dyrektywy ${ }^{732}$.

TSUE znowu opierając się na swoim ugruntowanym orzecznictwie, przypomniał w tej sprawie również fundamentalną zasadę pierwszeństwa prawa unijnego, zgodnie z którą:

sąd krajowy, do którego należy w ramach jego kompetencji stosowanie przepisów prawa Unii, zobowiązany jest zapewnić pełną skuteczność tych norm, w razie konieczności z własnej inicjatywy nie stosując wszelkich sprzecznych z nimi przepisów prawa krajowego, także późniejszych, bez potrzeby zwracania się o ich uprzednie usunięcie w drodze ustawodawczej lub w ramach innej procedury konstytucyjnej ani oczekiwania na usunięcie wspomnianych przepisów $[\ldots]^{733}$.

Odmowa takiej możliwości sądowi, w którego kompetencji leży stosowanie prawa Unii, byłaby sprzeczna zdaniem TSUE z wymogami wynikającymi

\footnotetext{
${ }^{731}$ TSUE, Aziz Melki i Sélim Abdeli, C-188/10 i C-189/10, wyrok z 22 czerwca 2010, pkt 55.

${ }^{732}$ Ibidem, pkt 56.

${ }^{733}$ Ibidem, pkt 43 .
} 
z samej natury prawa Unii. Sąd krajowy nie może być nawet przejściowo ograniczony w stosowaniu prawa unijnego przez jakiekolwiek elementy krajowej praktyki sądowej, administracyjnej czy legislacyjnej ${ }^{734}$.

Wreszcie, Trybunał stwierdził, że:

jeżeli sąd krajowy rozpoznaje spór dotyczący prawa Unii i uważa, że przepis krajowy jest nie tylko sprzeczny z prawem Unii, ale ponadto niezgodny z konstytucja, to fakt, że stwierdzenie niezgodności z konstytucją przepisu prawa krajowego następuje w drodze obligatoryjnej skargi do trybunału konstytucyjnego, nie pozbawia go uprawnienia lub nie zwalnia z obowiązku - przewidzianych w art. 267 TFUE - polegających na wystąpieniu do Trybunału z pytaniami o wykładnię lub ocenę ważności prawa Unii. Skuteczność prawa Unii byłaby bowiem zagrożona, gdyby istnienie obligatoryjnej skargi do trybunału konstytucyjnego mogło uniemożliwić sądowi krajowemu rozpoznającemu spór dotyczący prawa Unii wykonanie uprawnienia przyznanego mu w art. 267 TFUE, a polegającego na wystąpieniu do Trybunału Sprawiedliwości z pytaniami o wykładnię lub ocenę ważności prawa Unii w celu umożliwienia mu stwierdzenia, czy przepis prawa krajowego jest zgodny z prawem Unii $[\ldots]^{\prime \prime 735}$.

To wszystko doprowadziło Trybunał do sformułowania wniosku, że:

art. 267 TFUE stoi na przeszkodzie istnieniu przepisów państwa członkowskiego, które wprowadzają wpadkową kontrolę zgodności z konstytucją ustaw krajowych, o ile priorytetowy charakter tego postępowania skutkuje uniemożliwieniem - zarówno przed skierowaniem pytania o zgodność z konstytucją do sądu krajowego sprawującego kontrolę nad zgodnością ustaw z konstytucją, jak i, ewentualnie, po wydaniu orzeczenia w tej kwestii przez ten sąd - wszystkim pozostałym sądom krajowym skorzystania $\mathrm{z}$ ich uprawnienia lub spełnienia obowiązku polegających na wystąpieniu do Trybunału z pytaniami prejudycjalnymi. Natomiast art. 267 TFUE nie stoi na przeszkodzie istnieniu takiego uregulowania krajowego, o ile pozostałe sądy krajowe zachowują swobodę: - zwrócenia się do Trybunału Sprawiedliwości z każdym pytaniem prejudycjalnym, jakie uważa za niezbędne i to na każdym etapie postępowania, nawet po zakończeniu postępowania wpadkowego w sprawie kontroli zgodności z konstytucją, - stosowania wszelkich niezbędnych środków w celu zapewnienia tymczasowej ochrony sądowej praw gwarantowanych w porządku prawnym Unii oraz - odstąpienia od stosowania, po zakończeniu takiego postępowania wpadkowego, tego krajowego przepisu ustawowego, jeżeli uważa go za sprzeczny z prawem Unii. Do sądu odsyłającego należy ustalenie, czy przepisy krajowe, których dotyczy sprawa główna, moga być interpretowane zgodnie z tymi wymogami prawa Unii ${ }^{736}$.

\footnotetext{
${ }^{734}$ Ibidem, pkt 44

${ }^{735}$ Ibidem, pkt 45 .

${ }^{736}$ Ibidem, pkt 57 .
} 
W późniejszej sprawie Kernkraftwerke Lippe ${ }^{737}$ TSUE podkreślił, opierając się na orzecznictwie w sprawach Melki Abdeli i A. p. B., a także na wyroku w sprawie Simmenthal, że ponadto sąd krajowy nie może być ograniczony w prawie wniesienia pytania prejudycjalnego do TSUE również ze względu na to, że wpadkowe postępowanie w sprawie zbadania konstytucyjności jest w toku. Zdaniem TSUE „skuteczność prawa Unii byłaby zagrożona, a effet utile art. 267 TFUE osłabiony, gdyby ze względu na trwające postępowanie wpadkowe w sprawie kontroli zgodności z konstytucją sąd krajowy nie mógł zwrócić się do Trybunału z pytaniami prejudycjalnymi i bezpośrednio nadać prawu Unii stosowania zgodnego z decyzją lub orzecznictwem Trybunału [...]"738.

Dokładnie to samo rozumowanie, jak i konkluzję ze sprawy Melki Abdeli powtórzył TSUE w sprawie A. p. B. ${ }^{739} \mathrm{~W}$ gruncie rzeczy gdy chodzi o rozumowanie zaprezentowane $w$ tych dwu sprawach przez TSUE to są one bliźniacze. Paragrafy 34-43 wyroku w sprawie Melki Abdeli zostały właściwie skopiowane do paragrafów 40-41, 43-45 i 52-56 wyroku w sprawie A. p. B. Należy pamiętać, że w obu tych sprawach mieliśmy do czynienia z rozporządzeniami unijnymi, a więc aktami prawa unijnego stosowanymi bezpośrednio i niewymagającymi implementacji. Stąd ich relacja do sprzecznych z nimi przepisów prawa krajowego, a także do wzorców kontroli, jakim podlegają pod względem standardów praw człowieka, jak i tego, kto powinien dokonywać ich weryfikacji przez ten pryzmat jest bardziej oczywista niż miałoby do miejsce w sytuacji oceny przez pryzmat zgodności z Kartą przepisów prawa krajowego w sytuacjach, o których była mowa w poprzednim rozdziale, a więc gdy państwa członkowskie stosują prawo Unii w rozumieniu art. 51 ust. 1 Karty. Obie te sprawy rozstrzygnięte zostały na gruncie odmiennych, rzec by można - rozpiętych na dwu biegunach skali modeli konstytucyjnych przyjętych w państwach członkowskich. Te modele to francuski podział ról między Radą Konstytucyjna, która ocenia prawo krajowe przez pryzmat zgodności z Konstytucją, a sprawę rozstrzygania o zgodności prawa krajowego z prawem międzynarodowym, w tym EKPCz i Karta, i ewentualnym niestosowaniu przez nie niezgodnego z nimi prawa krajowego pozostawia sądom zwykłym, oraz austriacka integracja Karty do porządku konstytucyjnego skutkująca ocenianiem przez Trybunał Konstytucyjny prawa austriackiego przez pryzmat prawa unijnego (Karty) tak jakby było to prawo konstytucyjne. Wnioski z nich wypływające mają więc charakter uniwersalny w kontekście różnych modeli scentralizowanej kon-

${ }^{737}$ TSUE, Kernkraftwerke Lippe-Ems GmbH p. Hauptzollamt Osnabrück, C-5/14, wyrok z 4 czerwca 2015.

${ }^{738}$ Ibidem, pkt 36 .

739 TSUE, A. p. B. i in., C-112/13, wyrok z 11 września 2014, pkt 33-40, 46. 
troli hierarchicznej zgodności prawa, jakie funkcjonują na przestrzeni państw członkowskich UE.

Obowiązki sądów krajowych odnośnie do stosowanych przez nie przepisów (zarówno bezpośrednio skutecznych przepisów prawa unijnego, jak i przede wszystkim przepisów krajowych mieszczących się w zakresie zastosowania prawa unijnego) opierać się muszą zawsze na takich samych zasadach i sądy te nie mogą zostać pozbawione określonego minimum uprawnień wynikających z prawa unijnego związanych z zapewnianiem pierwszeństwa prawu unijnemu. Można zaryzykować stwierdzenie, że model scentralizowanej kontroli prawa wybrany przez państwa członkowskie nie ma znaczenia dla TSUE dopóty, dopóki nie zagraża możliwości sądów krajowych do zwracania się z pytaniami prejudycjalnymi do TSUE i niestosowania prawa krajowego, które uzna on za niezgodne z prawem unijnym oraz, gdy nie zagraża możliwości po stronie TSUE do interpretowania i przede wszystkim weryfikowania ważności aktów prawa unijnego niezgodnych z unijnym prawem pierwotnym, w tym z KPP ${ }^{740}$. W wyrokach w sprawach Melki i Abdeli oraz A. p. B. uwydatniają więc znaczenie zasady pierwszeństwa prawa unijnego, podobnie zresztą jak w kontekście praw podstawowych uczyniły to, znajdujące się w centrum uwagi w tej pracy, wyroki w sprawach Åkerberg Fransson i Melloni. Należy silnie podkreślić, że wynikająca z tych ostatnich kwestia mieszanego (mixed) stosowania unijnych i konstytucyjnych gwarancji praw człowieka w sytuacjach, w których Karta gra jedynie rolę minimalnego standardu ochrony, znalazła odzwierciedlenie również w sprawach Melki i Abdeli oraz A. p. B. TSUE wyraźnie podkreślił, że

w wypadku, gdy prawo Unii przyznaje państwom członkowskim swobodę uznania w ramach wdrażania aktu prawa Unii, organy i sądy krajowe są uprawnione do zapewnienia poszanowania praw podstawowych zagwarantowanych przez konstytucję krajowa, o ile zastosowanie krajowych standardów ochrony praw podstawowych nie podważa poziomu ochrony wynikającego z karty, stosownie do wykładni Trybunału, ani pierwszeństwa, jednolitości i skuteczności prawa Unii $[\ldots]^{741}$.

Wydaje się więc, że poprzez wyroki w sprawach Melki i Abdeli oraz A. p. B., nawet $w$ związku $\mathrm{z}$ uwypukloną $\mathrm{w}$ nich zasadą pierwszeństwa prawa unijnego, TSUE wpisał się jednak w logikę podziału ról między unijnymi i krajowymi standardami ochrony praw człowieka oraz podziału stref wpływów między TSUE i TK w tej materii. Należy zwrócić uwagę, że TSUE nie wykluczył możliwości wniesienia przez sąd zwykły do sądu konstytucyjne-

${ }^{740}$ D. Paris, Case Note..., s. 403.

741 TSUE, A. p. B. i in., C-112/13, wyrok z 11 września 2014, pkt 44. 
go sprawy zgodności prawa krajowego mieszczącego się w zakresie prawa unijnego z Kartą ani tym bardziej z konstytucją. Wyjątkiem od tej możliwości, o którym mowa wprost w sprawach Melki i Abdeli oraz A. p. B., są takie ustawy krajowe, których treść ogranicza się do transpozycji bezwzględnie wiążących przepisów dyrektyw unijnych ${ }^{742}$. Nawet odnośnie do takiego prawa jednak sądy krajowe mogą wystąpić do sądu konstytucyjnego. Muszą wszakże przedsięwziąć środki zapewniające ochronę prawa Unii, w tym unijnych praw podstawowych, a gdy ostatecznie sąd konstytucyjny nie orzeknie o usunięciu danego prawa z porządku prawnego, mogą zlekceważyć takie orzeczenie bądź to poprzez zwrócenie się do TSUE z pytaniem prejudycjalnym, bądź to przez niestosowanie go, jako niezgodnego z Kartą ${ }^{743}$. O tym aspekcie wyroku w sprawie Melki i Abdeli oraz A. p. B. i wynikających z niego konsekwencjach będzie jeszcze mowa w następnym rozdziale. Ustalenia te umożliwiają bowiem, zdaniem autora, powstanie przestrzeni po stronie krajowej - sądów polskich i polskiego TK - do zyskania momentu potrzebnego do zainicjowania odpowiedniej sekwencji orzekania, pozwalającej na dialog między TK a TSUE w sytuacji, gdy prawo polskie (lecz także prawo unijne), do którego należy stosować Kartę, pozostawałoby w sprzeczności z wyższymi niż zagwarantowane w Karcie konstytucyjnymi standardami ochrony praw człowieka, które to konstytucyjne standardy składałyby się na polską tożsamość konstytucyjną.

\subsection{Doniosłość poprawnego i zniuansowanego stosowania przez sądy krajowe unijnych praw podstawowych w kontekście konstytucyjnej ochrony praw człowieka}

Jak słusznie zauważa Nina Półtorak, tak szeroki zakres zastosowania unijnych praw podstawowych wobec państw członkowskich, jak ten, który został opisany w poprzednim rozdziale, a który wynika ze sposobu, w jaki TSUE interpretuje art. 51 ust. 1 Karty oraz specyfika prawa unijnego z zawartą $w$ nim zasadą pierwszeństwa na czele i wynikającymi z niej konsekwencjami, o jakich była mowa powyżej, powoduja,

że sądy krajowe uzyskują rolę sądów konstytucyjnych - badających nie tylko zgodność prawa krajowego z prawem unijnym, lecz także zgodność prawa krajowego z prawami podstawowymi uznanymi w systemie UE. Mogą pominąć krajowe prawa podstawowe $\mathrm{w}$ ich rozumieniu ustalonym $\mathrm{w}$ prawie konstytucyjnym i orzecznictwie, czyli - poprzez

\footnotetext{
${ }^{742}$ Ibidem, pkt 43.

${ }^{743}$ D. Paris, Case Note..., s. 403.
} 
zastosowanie KPP - odmówić stosowania konstytucji lub wkroczyć w kompetencje sądów konstytucyjnych co do rozstrzygania o prawach podstawowych ${ }^{744}$.

W ten sposób unijne prawa podstawowe mogą uzyskać dominującą rolę również w ramach krajowego systemu prawnego i zostać zastosowane w sytuacjach, w których nie powinno tak być, i w których Trybunał Konstytucyjny, gdyby to on, a nie sądy zajmował się oceną danych przepisów, by ich nie zastosował. Tak samo jak jedno z fundamentalnych orzeczeń dla unijnego porządku prawnego, jakim był wyrok w sprawie van Gend and Loos ${ }^{745}$, dało sądom państw członkowskich prawo do oceniania regulacji krajowych pod kątem ich zgodności z prawem Unii, Karta dała im prawo do oceniania regulacji krajowych pod kątem zgodności z unijnymi prawami podstawowymi ${ }^{746}$.

Oczywiście uprawnienie to dała im jedynie w zakresie, w jakim regulacje krajowe są przejawem zastosowania prawa unijnego. Granica oddzielająca przepisy, które należy za takie uznać w związku z przyjęciem przez TSUE opartego na kryterium efektywności rozumienia pojęcia stosowania prawa Unii jako działanie w jego zakresie zastosowania, jak pokazywał to rozdział poprzedni, została przesunięta dość daleko na korzyść unijnych praw podstawowych. Co więcej, ze względu na wielość i różnorodność orzecznictwa TSUE w tej materii, granica ta nie jest wcale wyraźna i oczywista. Tym gorzej więc, że sądy polskie często nawet nie próbują się w tę problematykę zagłębić, a czasem sprawiają wręcz wrażenie, że są nieświadome jej istnienia. Może to rodzić poważne wątpliwości w sytuacji, gdy poprzez tę swoją nową, wynikającą z nadania Karcie mocy prawnej pozycję, sądy krajowe w pewnym sensie obchodziłyby kompetencję sądów konstytucyjnych. Faktycznie bowiem kompetencja do badania zgodności prawa obowiązującego w Polsce pod kątem zgodności z prawami człowieka „w państwach członkowskich z reguły jest podstawową kompetencją sądów konstytucyjnych. Szeroki zakres zastosowania KPP może prowadzić do redukowania tej kompetencji, skoro będzie ona wykonywana przez każdy sąd krajowy w konkretnych sprawach, w razie potrzeby korzystający z dialogu z TSUE w procederze prejudycjalnej"747. Zagrożenie to jest szczególnie aktualne w polskim systemie prawnym, gdzie podział ról między sądami a TK w tej materii jest zakorzeniony w porządku konstytucyjnym, i gdzie to ten ostatni jest pełnoprawnym sądem nad prawem, które to prawo te pierwsze jedynie stosują (w klasycznym dla polskiej kultury prawnej tego słowa rozumieniu).

${ }^{744}$ N. Półtorak, Zakres zwiazania..., s. 24.

${ }^{745}$ TSUE, NV Algemene Transport- en Expeditie Onderneming van Gend \& Loos p. Netherlands Inland Revenue Administration, ETS, 26/62, wyrok z 5 lutego 1963.

${ }^{746}$ N. Półtorak, Zakres zwiazania..., s. 24.

${ }^{747}$ Ibidem. 
Z perspektywy tej pracy należy szczególnie podkreślić, że stosowanie Karty przez sądy polskie oraz zasady, na których to stosowanie się opiera, a przede wszystkim zakres sytuacji objętych art. 51 Karty, a więc zakres przypadków, gdy Karta znajduje zastosowanie do państw członkowskich, ukazują niezwykle wrażliwą przestrzeń potencjalnego sporu między TK a TSUE co do tego, który z tych sądów miałby być sądem kompetentnym do oceny danego prawa przez pryzmat zgodności z prawami człowieka. Sądy w toczących się przed nimi postępowaniach muszą sobie za każdym razem odpowiadać na pytanie quis iudicabit, a więc kto ostatecznie powinien rozstrzygać w kwestii oceny danej regulacji przez pryzmat zgodności z prawami człowieka i który z tych sądów w razie wątpliwości należy pytać o dokonanie takiej oceny czy interpretacji, i wreszcie które - krajowe czy unijne - standardy ochrony praw człowieka powinny zostać zastosowane. Czy tym sądem powinien być TK, do którego należy skierować pytanie prawne w trybie art. 193 Konstytucji, czy może TSUE, do którego należy zwrócić się z pytaniem prejudycjalnym w trybie art. 267 TFUE, a może samemu należy odmówić zastosowania prawa krajowego, jako niezgodnego z prawem unijnym i zawartymi w nim gwarancjami praw podstawowych?

Zasygnalizowany $\mathrm{w}$ tym miejscu problem jest istotny nawet $\mathrm{w}$ sytuacji, gdy standardy - konstytucyjny i unijny - będą ze sobą zbieżne, co ze względu na ich aksjologiczną bliskość oraz rodowód unijnej ochrony praw człowieka, zakorzenionej przede wszystkim we wspólnych tradycjach konstytucyjnych państw członkowskich, wydaje się być sytuacją najpowszechniejszą. Należy wszakże wyraźnie podkreślić, że

nawet przy zbieżności krajowych i unijnych praw podstawowych, sądy krajowe mogą polegać na Karcie. Stosowanie KPP pozwala bowiem sądom krajowym na uzyskanie kompetencji oceny zgodności prawa krajowego z Karta, podczas gdy z reguły nie mają takiej kompetencji - do samodzielnej oceny zgodności z prawami konstytucyjnymi - w prawie krajowym. Uznając, że KPP znajduje zastosowanie, sąd krajowy może zbadać samodzielnie, czy wymogi praw podstawowych regulowanych Kartą zostały zachowane, i nie musi występować w tym zakresie do sądu konstytucyjnego. Prawo UE przyznaje bowiem sądowi krajowemu mechanizmy oceny niezależne od przewidzianych w prawie krajowym, wynikające z zasady bezpośredniego skutku i pierwszeństwa. Potwierdza tę tezę orzeczenie Åkerberg Fransson, w którym TSUE wykluczył stosowanie krajowych rozwiązań w zakresie oceny zgodności prawa z prawami podstawowymi. Uznał, że prawo szwedzkie nie może uzależniać zastosowania KPP przez sąd od tego, czy niezgodność z prawami podstawowymi jest oczywista, „ponieważ praktyka ta uniemożliwia sądowi krajowe dokonanie, z ewentualnym udziałem Trybunału Sprawiedliwości Unii Europejskiej, kompletnej oceny zgodności owego przepisu krajowego z Kartą"748.

${ }^{748}$ Ibidem. 
Wydaje się jednak, że TSUE zawarł w wyrokach w sprawach Åkerberg Fransson, Melloni czy Siragusa różne wskazówki dla sądów krajowych w sytuacji zbieżności unijnych i konstytucyjnych standardów ochrony praw człowieka. Stąd tak ważne, aby zasady zastosowania Karty opierały się nie jedynie na prostym rozumieniu jej art. 51 ust. 1, ale na zniuansowanej jego wykładni, jakiej dokonał TSUE. Sąd krajowy powinien wiedzieć, kiedy ma stosować unijne prawa podstawowe nie tylko w związku z samym art. $5^{1}$ ust. 1 , ale również w związku z dopuszczonym przez TSUE, jak zostało to nazwane w poprzednim rozdziale, mieszanym (mixed) stosowaniem unijnych praw podstawowych i krajowych gwarancji praw człowieka wobec państw członkowskich, w przypadku którego, przy braku zagrożenia dla pierwszeństwa, jedności i efektywności prawa unijnego preferencja przysługuje standardom konstytucyjnym. Takie stanowisko TSUE może w pewnym sensie być uznane za próbę pogodzenia standardów konstytucyjnych i unijnych w praktyce stosowania prawa. Zastosowanie krajowych i unijnych standardów zależne jest od intensywności regulacji unijnej i poziomu harmonizacji, jaki się z nią wiąże, co sprawia, że dana regulacja krajowa, mieszcząca się w zakresie zastosowania unijnych praw podstawowych w zależności od sytuacji, musi jedynie spełniać standardy ochrony tych praw (standard unijny staje się wtedy standardem minimalnym, a państwa są swobodne w możliwości zapewniania standardu wyższego), gdyż nie może zagrozić to prymatowi, jedności i efektywności tego prawa, albo też musi spełniać wszystkie te cztery warunki łącznie i standard unijny urasta wtedy do standardu maksymalnego wiążącego państwa członkowskie.

Podobnie wskazówki te odczytuje Nina Półtorak, która twierdzi, że

sądy krajowe w sprawach nieregulowanych w całości prawem UE zasadniczo powinny stosować krajowy standard praw podstawowych i co za tym idzie - krajowe procedury oceny zgodności z tym standardem, a KPP ma wkraczać wyjątkowo, gdy zagrożone jest pierwszeństwo, jednolitość lub efektywność prawa UE [...]. Sądy powinny więc przede wszystkim stosować standard konstytucyjny i procedury jego stwierdzania ( w tym pytania do sądów konstytucyjnych), a dopiero jeśli dostrzegą zagrożenie dla pierwszeństwa lub efektywności prawa UE - standard unijny i procedurę prejudycjalną ${ }^{749}$.

Należy więc zgodzić się z konkluzją, że co do zasady

prawo UE i działania państw członkowskich, będące wprost wykonaniem jednoznacznych zobowiązań wynikających z prawa UE („działanie państw członkowskich

${ }^{749}$ Ibidem, s. 25 . 
jest w pełni określone przepisami prawa Unii"), podlegają ocenie ze względu na KPP, a jurysdykcja wobec tej oceny przysługuje TSUE. Natomiast prawo krajowe, także to mieszczące się $\mathrm{w}$ zakresie prawa UE, ale wydane $\mathrm{w}$ ramach swobody legislacyjnej państwa, podlega przede wszystkim krajowym prawom podstawowym oraz orzecznictwu sądów konstytucyjnych, a KPP i jurysdykcja TSUE znajduje zastosowanie pomocniczo - w sytuacjach zagrożenia dla prawa unijnego (jego jednolitości, pierwszeństwa i efektywności) $)^{750}$.

Takie podejście, które wydaje się najlepiej odzwierciedlać wielopoziomowy charakter porządku prawnego powstałego w wyniku integracji w ramach Unii Europejskiej, wiąże się jednak z dość trudnym wyzwaniem stającym przed sądami krajowymi.

Sądy musiałyby ocenić nie tylko, czy sprawa mieści się w zakresie zastosowania prawa unijnego, zgodnie z niełatwymi w praktyce kryteriami orzeczenia Åkerberg Fransson, lecz także czy mieści się w zakresie uzasadniającym stosowanie unijnego standardu, czyli czy „działanie państw członkowskich jest w pełni określone przepisami prawa Unii"; a jeśli nie - czy zagrożona jest zasada pierwszeństwa, jednolitości i efektywności prawa UE ${ }^{751}$.

De facto i de iure bowiem nie ma znaczenia z perspektywy prawa unijnego, jeśli zostanie zastosowany równy mu standard konstytucyjny. Prawo unijne dopuszcza przecież, w związku z art. 53 KPP, także stosowanie wyższego standardu ochrony praw podstawowych zagwarantowanych w Karcie przez państwa członkowskie, również wtedy, gdy działają w zakresie prawa unijnego, pod warunkiem wszakże, że ten wyższy standard nie stoi w sprzeczności z zasadami pierwszeństwa, jedności i efektywności prawa unijnego. Uwzględnianie w orzecznictwie tej specyfiki unijnej architektury systemu ochrony praw podstawowych przez sądy państw członkowskich Unii, w tym przez sądy polskie, wydaje się ich podstawowym zadaniem, gdy chodzi o prawa człowieka.

Wydaje się, że trudności te nie są nie do przezwyciężenia przez sądy krajowe. Szczególnie jeśli odpowiedniego wsparcia dostarczą im zarówno TSUE, jak i TK. „Wsparcie TSUE powinno polegać zarówno na jasnym określeniu kryteriów podmiotowego zastosowania Karty, jak i jednoznacznym ustaleniu kryteriów uruchomienia działania KPP ( w tym sposobu postępowania sądu w przypadku zbieżnych standardów ochrony praw podstawowych w Karcie i prawie krajowym)"752. Z drugiej strony:

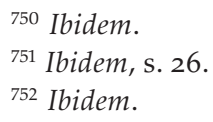


Wsparcie sądów konstytucyjnych i najwyższych powinno w tym zakresie polegać na uwzględnianiu KPP przy ocenie konstytucyjności prawa krajowego mieszczącego się w zakresie prawa UE i odpowiednim dialogu z TSUE uwzględniającym tezę o szerokim zastosowaniu Karty wynikającą z Åkerberg Fransson. Pozytywne przykłady takiego dialogu można już dostrzec w praktyce niektórych sądów krajowych ${ }^{753}$.

W dłuższej perspektywie mogłoby to prowadzić do dalszego ujednolicania się unijnych i krajowych standardów ochrony praw człowieka i zmniejszenia znaczenia problemu, jakim jest rozgraniczanie zakresu zastosowania standardów unijnych i krajowych oraz jurysdykcji TSUE i krajowych sądów konstytucyjnych, który stawałby się zagadnieniem czysto teoretycznym, skoro standardy ochrony de facto by się ujednoliciły ${ }^{754}$.

\section{Podsumowanie}

Trudności dotyczące stosowania Karty i unijnych praw podstawowych, przed jakimi staja polskie sądy, są bez wątpienia bardzo poważne. Wynikają one przede wszystkim ze złożoności unijnej architektury ochrony praw człowieka związanej z wyjątkowym charakterem tej organizacji (jak przyjęło się to o niej mówić sui generis ). Członkostwo Polski w niej potęguje zjawisko multicentryczności porządku prawnego w naszym kraju. W istocie trudność ta sprowadza się jednak głównie do kwestii poprawnego zinternalizowania przez sądy polskie zasad zastosowania Karty wraz z różnymi wiążącymi się z tym niuansami, które opisane zostały w tym i poprzednim rozdziałach oraz do prawidłowego stosowania unijnych gwarancji praw podstawowych lub krajowych gwarancji praw człowieka, a także do prawidłowego korzystania przez nie z mechanizmów współpracy z TSUE (poprzez pytanie prejudycjalne) i z TK (poprzez pytanie prawne).

Dziać się to powinno na podstawie przede wszystkim art. 51 ust. 1 Karty, lecz także innych jej przepisów oraz zasad pierwszeństwa, jedności oraz efektywności prawa unijnego z jednej strony, oraz przepisów prawa krajowego z drugiej, dotyczących podziału stref wpływu między unijnymi i krajowymi standardami ochrony praw człowieka. Na styku tych dwu przestrzeni pojawiajac się jednak rozległe obszary wspólne, wymagające bardziej zniuansowanego podejścia oraz zależnego od różnych czynników mieszanego (mixed) stosowania jednych i drugich standardów. Propozycja jeszcze dalszego zniuansowania

753 Ibidem.

${ }^{754}$ Ibidem, s. 27. 
tych delimitacji, wymagająca pogłębionej świadomości złożoności problemu i współpracy sądów powszechnych, administracyjnych i Sądu Najwyższego, zawarta jest $\mathrm{w}$ rozdziale IV tej pracy. $\mathrm{W}$ obliczu wysokiego poziomu skomplikowania tej materii niepokoić może pozbawiona pogłębionej refleksji nad tymi zagadnieniami, dominująca w polskich sądach powszechnych, sądach administracyjnych, a nawet do pewnego stopnia w Sądzie Najwyższym, praktyka ornamentacyjno-argumentacyjnego wykorzystywania Karty bez względu na to, czy może ona znaleźć w sprawie zastosowanie, czy też nie, oraz lekceważenie, a czasem wręcz nieświadomość zasad zastosowania Karty.

Należy również silnie podkreślić, że sądy krajowe wszystkich szczebli jako sądy unijne, gdy stosują prawo krajowe mieszczące się w zakresie zastosowania prawa unijnego, mają nieograniczone prawo zwracać się do TSUE z pytaniami prejudycjalnymi dotyczącymi zgodności z prawami podstawowymi zagwarantowanymi w unijnym porządku prawnym na dowolnym etapie postępowania i żadne okoliczności krajowe, nawet rangi konstytucyjnej, nie mogą ich tego prawa pozbawiać. Mają one również obowiązek korzystania z procedury pytania prejudycjalnego w sytuacjach, w których nieskorzystanie z niej mogłoby ograniczyć kompetencję TSUE do wypowiadania się w kwestiach prawa unijnego, a więc gdy orzekają w ostatniej instancji. Nadaje to sądom krajowym w pewnym sensie status konstytucyjny i umożliwia im ocenę prawa polskiego przez pryzmat zgodności z prawami człowieka bez uciekania się do TK, na podstawie unijnych praw podstawowych. Nadużywanie przez nie tej kompetencji byłoby jednak sprzeczne z prawem, zarówno unijnym, jak i przede wszystkim polskim.

Pamiętać należy również, że prawo unijne przewiduje różnego rodzaju wyjątki, np. gdy chodzi o możliwość zwracania się przez sądy krajowe do sądów konstytucyjnych w ramach scentralizowanego systemu kontroli konstytucyjności prawa w tych państwach. Co do zasady sądy krajowe mogą zwracać się do krajowego sądu konstytucyjnego o kontrolę stosowanego przez nie $\mathrm{w}$ danej sprawie prawa krajowego mieszczącego się w zakresie zastosowania prawa unijnego, dopiero po ustaleniu kwestii unijnych praw podstawowych i wynikających stąd konsekwencji jak ewentualne niestosowanie tego prawa. Jednakże nawet, gdy chodzi o prawo krajowe służące jedynie transpozycji dyrektyw mogą zwrócić się do krajowego sądu konstytucyjnego, oczywiście przy zachowaniu wszelkich niezbędnych środków w celu zapewnienia tymczasowej ochrony sądowej praw gwarantowanych w porządku prawnym Unii oraz zachowania możliwości odstąpienia od stosowania tego krajowego przepisu ustawowego po zakończeniu takiego postępowania wpadkowego, jeżeli uważać go będą za sprzeczny z prawem Unii. 
Konstytucyjna w pewnym sensie rola sądów krajowych, które są również sądami unijnymi, wydaje się być nieunikniona. Odzwierciedla ona specyfikę unijnego porządku prawnego. Co więcej, sprzyja ona nawet w pewnym sensie dialogowi, choć prowadzonemu nie wprost, a za pośrednictwem sądów krajowych, między TSUE a TK. Pozwala bowiem temu drugiemu mieć pewność co do ewentualnej niezgodności przepisów prawa polskiego będących przejawem stosowania prawa unijnego $\mathrm{w}$ rozumieniu art. 51 ust. 1 Karty i prawidłowego ich traktowania w związku z tym na gruncie Konstytucji, gdyby wcześniej sąd krajowy ich nie zastosował (ewentualnie upewniając się co do słuszności swej decyzji poprzez pytanie prejudycjalne do TSUE), a później sprawa konstytucyjności takich przepisów trafiałaby przed TK. Należy wszakże pamiętać, że o ile opisane tu zasady ogólne stosowania przez sądy unijnych praw człowieka zasługują na zaakceptowanie jako sprzyjające jednolitemu i spójnemu kształtowaniu się unijnej ochrony praw człowieka w zakresie zastosowania prawa unijnego, a także sprzyjające harmonizacji prawnej, będącej głównym celem integracji w ramach UE, o tyle powinny również dopuszczać pewne wyjątki. Tego rodzaju wyjątki czy też niuanse wyraźnie wynikające z orzecznictwa były już omawiane (jak mieszane - mixed - stosowanie unijnych i krajowych praw człowieka). Na innych wyjątkach niewykluczonych przez dotychczasowe orzecznictwo, umożliwiających dalsze zniuansowanie podejścia do zastosowania unijnych albo krajowych gwarancji praw człowieka, opiera się zaś proponowana w tej pracy sekwencja współpracy między TK a TSUE w sytuacji konfliktu wyższego niż unijny konstytucyjnego standardu ochrony z prawem unijnym.

Co szczególnie istotne w kontekście tematu tej pracy, bezwzględne stosowanie kryteriów zakresu zastosowania unijnych praw podstawowych opisanych w poprzednim rozdziale, nawet jeśli miałoby miejsce jedynie w sytuacjach bezspornie spełniających kryteria wynikające z art. 51 ust. 1 Karty przez sądy krajowe wobec regulacji krajowych, mogłoby prowadzić do istotnego ograniczenia roli i funkcji TK, a także do nieuzasadnionego obniżania krajowych standardów ochrony praw człowieka, szczególnie w obszarach, w których mamy do czynienia $\mathrm{z}$ daleko posuniętą harmonizacją prawa unijnego, a więc w sytuacjach, gdzie nie ma mowy o mieszanym (mixed) stosowaniu unijnych i krajowych gwarancji praw człowieka z dopuszczalną preferencją tych drugich. Wyroki TSUE w sprawach Åkerberg Fransson i Melloni wyraźnie pokazały stosunek tego trybunału do swobody państw członkowskich do przestrzegania wyższych standardów ochrony praw podstawowych w zakresie zastosowania prawa unijnego i dopuściły go jedynie w sytuacji, gdy nie jest to sprzeczne z zasadami pierwszeństwa, jedności i efektywności prawa Unii. W przypadku, gdy te war- 
tości są zagrożone, państwa członkowskie nie mają już swobody zapewniania w swym prawie standardu wyższego niż minimalny standard unijny.

Tymczasem, jak będzie o tym mowa w następnych rozdziałach, byłoby to niedopuszczalne ze względu na zasadę prymatu konstytucji i obowiązek po stronie Unii do poszanowania tożsamości konstytucyjnej państw członkowskich. W pewnych wyjątkowych sytuacjach, związanych z poszanowaniem tożsamości konstytucyjnej państwa członkowskiego, taki wyższy standard ochrony jakiegoś prawa czy wolności człowieka powinien móc przeważyć nad zasadami pierwszeństwa, jedności i efektywności prawa Unii i znaleźć wyraz w regulacjach krajowych mieszczących się w zakresie nawet w pełni zharmonizowanego prawa unijnego. Ponadto, taki wyższy standard ochrony jakiegoś prawa czy wolności człowieka powinien również znaleźć zastosowanie do samego prawa unijnego, obowiązującego w danym państwie bezpośrednio i cieszącego się pierwszeństwem względem prawa krajowego, skutkując jego niestosowaniem w Polsce w zakresie niezgodnym z takim standardem.

Decyzje w tego rodzaju sytuacjach nie powinny mieć charakteru jednostronnego. Nie powinny wynikać z wyizolowanych aktów orzeczniczych krajowych albo unijnych sądów czy trybunałów. Powinny być efektem współpracy między TK a TSUE w ramach sekwencji orzekania, o której będzie mowa w dalszych częściach tej pracy. Polskie sądy mogą odegrać niezwykle istotną rolę $\mathrm{w}$ tej sekwencji, pamiętając, że to TK wydaje się być podmiotem najbardziej kompetentnym do określania tożsamości konstytucyjnej RP i identyfikowania standardów ochrony praw człowieka mieszczących się w jej zakresie oraz zabiegania o jej poszanowanie w ramach unijnego porządku prawnego w ramach współpracy i dialogu sędziowskiego maksymalizującego możliwość poszanowania zarówno prawa Unii, jak i prawa polskiego z Konstytucją RP na czele, poprzez procedurę pytania prejudycjalnego, tak jak będzie o tym mowa w rozdziale IV. Sądy polskie powinny więc umożliwiać mu postawienie tego pierwszego kroku i zainicjowania współpracy z TSUE w tej materii.

Sądy polskie powinny dokonywać za każdym razem bardzo rzetelnej analizy i w jej wyniku prawidłowo oceniać, czy dana sprawa i stosowane w niej przepisy wymagają weryfikacji przez pryzmat zgodności z gwarancjami praw człowieka zawartymi w unijnym czy polskim porządku prawnym. Co do zasady więc, we wszystkich sprawach mieszczących się w zakresie zastosowania prawa unijnego, a więc takich, które spełniają kryteria opisane w poprzednim rozdziale, powinny one stosować unijne prawa podstawowe i zwracać się w razie wattpliwości do TSUE z pytaniem prejudycjalnym. Przy tym powinny jednak zdawać sobie sprawę z konsekwencji wynikajacych z wyroków w sprawach Åkerberg Fransson, Melloni i Siragusa, o których była mowa jako o mieszanym 
(mixed) stosowaniu unijnych i krajowych gwarancji praw człowieka. W pozostałych sytuacjach powinny zaś kierować pytanie do TK dotyczące zgodności stosowanych przez nie przepisów krajowych z konstytucyjnymi gwarancjami praw człowieka.

Ponadto wydaje się, że w celu poszanowania zasady konstytucjonalizmu (art. 8 Konstytucji) i prymatu konstytucji, jednakże tak, aby pozostawało to w zgodzie z art. 51 ust. 1 oraz art. 53 Karty i obowiązku po stronie Unii do poszanowania tożsamości konstytucyjnej państw członkowskich, w pewnych przypadkach, dotyczących gwarancji najważniejszych z perspektywy ustroju państwa polskiego praw i wolności jednostki, stanowiących o tożsamości konstytucyjnej Rzeczypospolitej Polskiej, również za właściwego adresata pytania należałoby uznać Trybunał Konstytucyjny. Dotyczy to prawa polskiego mieszczącego się w zakresie zastosowania prawa unijnego, a nawet bezpośrednio skutecznego prawa unijnego. To TK bowiem, w dialogu z TSUE będzie móg1, opierając się na art. 4(2) TUE, 53 KPP i 267 TFUE, ustalić status danej gwarancji praw człowieka jako stanowiącej element tożsamości konstytucyjnej RP, a także ostatecznie umożliwić określenie skutków tego faktu w kontekście prawa unijnego. Tego rodzaju dialogiczne postępowanie, zmierzające do minimalizacji, choć zapewne nie pełnej eliminacji niebezpieczeństwa związanego z potencjalnym konfliktem między unijnym a krajowym, w tym przypadku polskim, standardem konstytucyjnym, zostanie przedstawione w następnych rozdziałach tej pracy. Warunkiem jego zaistnienia jest jednak pogłębiona świadomość po stronie sądów polskich co do zakresu zastosowania unijnych praw podstawowych wraz ze wszystkimi wiążącymi się z tym niuansami, jedynie wtedy będą mogły one umożliwić dalsze zniuansowanie, oparte na kolejnych wyjątkach od opisanych zasad.

Dlatego tak niepokojąca jest praktyka sądów polskich przejawiająca się w dominującym ornamentacyjno-argumentacyjnym stosowaniu Karty w sprawach, w których nie może być ona stosowana jako rzeczywista podstawa orzekania w związku z jej art. 51 ust. 1, a przede wszystkim brak powszechnej świadomości co do zasad jej zastosowania oraz brak nawyku badania w sprawach stających przed sądami polskimi, czy Karta powinna znajdować w nich zastosowanie, czy nie. Na szczęście, jak pokazały omawiane w tym rozdziale orzeczenia, ta silnie zakorzeniona tendencja zaczyna się zmieniać i coraz częściej pojawiają się orzeczenia zarówno sądów powszechnych, administracyjnych, jak i SN, charakteryzujące się prawidłowym stosowaniem Karty. Dalsze komplikacje problematyki związanej ze stosowaniem Karty, jakie wiążą się z mieszanym (mixed) stosowaniem unijnych i krajowych praw podstawowych, czy jakie w kontekście polskim mogłyby pozornie wynikać z Protokołu nr 30, jeszcze wyżej podnoszą poprzeczkę sądom, w zadaniu prawidłowego stoso- 
wania KPP. Na domiar tego wszystkiego, rola sądów w możliwości prawidłowego funkcjonowania mechanizmu relacji między TK a TSUE w przedmiocie współpracy odnośnie do zapewniania poszanowania przez prawo unijne wyższego niż unijny, konstytucyjnego standardu ochrony praw człowieka, która jest również bardzo doniosła (będzie o niej mowa w rozdziale IV), jeszcze bardziej sprawę komplikuje. 


\section{Trybunał Konstytucyjny i kontrola prawa obowiązującego w Polsce przez pryzmat zgodności z gwarancjami praw i wolności człowieka w kontekście unijnym}

\section{Wstęp}

T Tobliczu tego, co powiedziano w poprzednich rozdziałach, wyraźnie widać ekspansję unijnych gwarancji praw człowieka i roli TSUE, związaną z wynikającym z TUE i TFUE charakterem prawa unijnego i zasadami, na których jest ono oparte. Ekspansywność ta jest głęboko zakorzeniona w procesie integracji europejskiej i w praktyce stosowania unijnych praw podstawowych wobec państw członkowskich. Interpretacja art. 51 ust. 1 Karty, jakiej trzyma się TSUE, prowadzi do zachwiania najbardziej oczywistego podziału ról między TK i TSUE do kontrolowania prawa polskiego przez ten pierwszy i prawa unijnego przez ten drugi pod kątem ich zgodności z odpowiednio polskimi i unijnymi gwarancjami praw człowieka.

Ta unijna perspektywa musi zostać uzupełniona i w pewnym sensie zrównoważona perspektywą krajową - konstytucyjną. W tym rozdziale uwaga poświęcona będzie więc stanowisku prezentowanemu przez polski Trybunał Konstytucyjny w tej materii. W związku z obszernym i wielowątkowym orzecznictwem polskiego TK związanym z członkostwem Polski w Unii i konsekwencjami prawnymi, jakie się z tym wiąża, uwaga w tym rozdziale koncentrować się będzie na próbie rekonstrukcji i prezentacji konsekwencji wynikających z orzecznictwa TK, szczególnie istotnych z perspektywy tej pracy, a więc związanych z kwestią ochrony wyższych niż unijne krajowych - polskich - standardów praw człowieka w sytuacji, gdy prawo unijne obowiązujące w Polsce bezpośrednio, a więc wtedy, gdy samodzielnie kształtuje sytuację jednostki, czy też pośrednio, a więc również w związku 
z prawem polskim służącym implementacji prawa unijnego, czy mówiąc szerzej, mieszczącym się w zakresie zastosowania prawa unijnego, prowadziłoby do obniżenia tych standardów. Rozważania ogólniejsze, związane ze statusem prawa unijnego $\mathrm{w}$ polskim porządku konstytucyjnym zostaną zaprezentowane jedynie $\mathrm{w}$ zakresie koniecznym z perspektywy problematyki poruszanej w tej pracy.

\section{Stosowanie Karty Praw Podstawowych przez Trybunał Konstytucyjny}

TK dość rzadko, choć sytuacja ta ulega stopniowej zmianie, powołuje się na $\mathrm{KPP}^{755}$. Jego orzecznictwo $\mathrm{w}$ tej materii przeszło pewną ewolucję prowadzącą do zniuansowania jego podejścia, odzwierciedlającego również najważniejsze zmiany, jakie towarzyszyły samemu statusowi prawnemu Karty, jak i odzwierciedlającego rozwój opartego na gruncie Karty orzecznictwa TSUE.

\subsection{Stosunek TK do Karty zanim ta uzyskała moc prawną}

W wyroku dotyczącym traktatu akcesyjnego z 2005 r., a więc przed uzyskaniem przez Kartę mocy prawnej, Trybunał podkreślił jej niewiążący charakter. Stwierdził, że:

Karta ta w postaci, w jakiej została proklamowana w Nicei, jest do tej pory porozumieniem, bliższym w obecnym statusie naturze deklaracji niż aktu prawa obowiązującego. Jej postanowienia nie mają zatem charakteru prawnie wiążącego. W płaszczyźnie prawnej nie skutkują powstaniem konkretnych uprawnień po stronie jednostek. Nie mogą one - jako wyłącznej podstawy roszczeń - przywoływać praw, o których stanowi Karta ${ }^{756}$.

Co nie jest zaskakujące, podobnie do wspomnianego wcześniej podejścia prezentowanego przez Sąd Najwyższy. „Trybunał Konstytucyjny [...] przed wejściem w życie Traktatu z Lizbony odmawiał orzekania o zgodności prze-

755 Por.: M. Wróblewski, Ł. Bojarski, D. Schindlauer, K. Wladasch, Karta Praw..., s. 129; M. Wróblewski, Karta Praw Podstawowych UE w orzecznictwie Trybunatu Konstytucyjnego - stan obecny i perspektywy, „Europejski Przegląd Sądowy” 2015, nr 10, s. 19 i nast.

756 TK, sprawa K 18/o4, wyrok z 11 maja 2005, pkt III 18.7 uzasadnienia. 
pisów prawa polskiego z KPP, uznając przede wszystkim, że nie ma ona mocy wiążącej"757.

Tak też np. w postanowieniu z 9 maja $2007^{758}$ Trybunał zdecydował się umorzyć postępowanie w sprawie, w której skarżący zarzucił przepisom Ustawy o Służbie Celnej ${ }^{759}$ niezgodność z licznymi przepisami gwarantującymi prawa i wolności jednostki zawartymi w Konstytucji, a także niezgodność $z$ EKPCz oraz z art. 47 Karty, w zakresie, w jakim chodziło o Kartę, ze względu na niedopuszczalność wydania wyroku. Wynikało to oczywiście głównie z faktu, że w trybie skargi konstytucyjnej zgodnie z art. 79 Konstytucji dopuszczalna jest jedynie kontrola zgodności zakwestionowanych przepisów przez pryzmat zgodności z konstytucyjnymi gwarancjami praw i wolności człowieka ${ }^{760}$. Trybunał zauważył jednak również, że badanie przepisów prawa polskiego przez pryzmat zgodności z KPP nie byłoby możliwe również np. w trybie pytania prawnego, który to tryb nie ogranicza wzorców kontroli tak, jak czyni to tryb skargi konstytucyjnej, gdyż: „Karta praw podstawowych Unii Europejskiej nie stanowi ratyfikowanej umowy międzynarodowej. Już z tego powodu orzekanie w sprawie zgodności z nią norm ustawowych jest niedopuszczalne" ${ }^{\prime \prime 61}$.

Dość niekontrowersyjną tezę związaną z niedopuszczalnością traktowania Karty jako wzorca kontroli w postępowaniu zainicjowanym skargą konstytucyjną TK potwierdził w swym orzecznictwie z okresu już po Traktacie lizbońskim $^{762}$. Nie może ulegać wątpliwości, „że wzorcem kontroli konstytucyjnej dokonywanej w trybie skargowym, a zatem kontroli konkretnej inicjowanej przez podmioty praw i wolności, mogą być tylko normy konstytucyjne. Wynika to wprost z treści art. 79 ust. 1 Konstytucji RP"763.

Jeszcze zanim ta uzyskała moc prawną i powyższe orzecznictwo odnośnie do jej prawnego statusu straciło aktualność, 2 lipca $2007 \mathrm{r}$. TK odniósł się do Karty w wyroku, w którym oceniał zgodność z konstytucyjnymi gwarancjami praw i wolności jednostki implementujących unijną dyrektywę polskich przepisów dotyczących prania brudnych pieniędzy ${ }^{764}$. TK odwołał się przy tym do

${ }^{757}$ N. Półtorak, Zakres zwiazania..., s. 17-18.

758 TK, sprawa SK 98/o6, postanowienie z 9 maja 2007.

${ }^{759}$ Ustawa z 24 lipca 1999 o Służbie Celnej, Dz.U. z 2004 nr 156, poz. 1641 ze zm.

${ }^{760}$ TK, sprawa SK 98/o6, postanowienie z 9 maja 2007, pkt II.6 uzasadnienia.

${ }^{761} \mathrm{Ibidem}$, pkt II.6 uzasadnienia; por. także: TK, sprawa Tw 26/o5, postanowienie z 27 września 2005.

${ }^{762} \mathrm{TK}$, sprawa Ts 350/14, postanowienie z 5 maja 2015 oraz postanowienie z 1 października 2015.

${ }^{763}$ M. Pyziak-Szafnicka, Karta Praw..., s. 22.

${ }^{764}$ Ustawy z 16 listopada 2000 o przeciwdziałaniu wprowadzaniu do obrotu finansowego wartości majątkowych pochodzących z nielegalnych lub nieujawnionych źródeł oraz o przeciwdziałaniu finansowaniu terroryzmu, Dz.U. z 2003 nr 153, poz. 1505 ze zm. 
Karty, podkreślając zgodność z nią unijnych przepisów regulujących tę kwestię $e^{765}$, potwierdzając tym samym na podstawie orzecznictwa TSUE, że dyrektywa unijna nie narusza praw podstawowych i jest zgodna z zasadami prawa unijnego dotyczącymi ochrony praw podstawowych, uznanymi w szczególności w Karcie. TK podkreślił także, że żaden z przepisów dyrektywy nie powinien być interpretowany lub wykonywany w sposób, który nie byłby zgodny z EKPCz ${ }^{766}$. Należy jednak zauważyć, że Trybunał nie rozważył w tej sprawie zasad zastosowania unijnych praw podstawowych wobec państw członkowskich. Nie zbadał kwestii, czy badane prawo polskie mieści się w zakresie zastosowania prawa unijnego w związku z istnieniem wspomnianej dyrektywy. Tak jak cechowało to jego orzecznictwo przez długi czas po wejściu Polski do Unii Europejskiej, TK potraktował mieszczące się w zakresie zastosowania prawa unijnego prawo wydane przez polskiego prawodawcę jako prawo polskie tout court i ograniczył się do zastosowania wobec niego jedynie konstytucyjnych wzorców kontroli.

Wyrok w tej sprawie nie doprowadził do jakichś poważnych konsekwencji, jak np. niedotrzymanie przez Polskę zobowiązań wynikających z członkostwa w UE, do czego mogłoby doprowadzić unieważnienie przepisów implementujących. W sprawie tej TK nie doszedł do wniosku o niezgodności żadnego z tych przepisów z Konstytucją, zachował więc je wszystkie w mocy. Ponadto, należy zauważyć, że akurat $\mathrm{w}$ tym wypadku, szczególnie w świetle późniejszego rozwoju orzecznictwa TSUE w tej materii, można uznać, że zastosowanie wzorców konstytucyjnych ochrony praw człowieka nie było nieuzasadnione, zgodnie z zasadą tzw. mieszanego (mixed) stosowania unijnych i krajowych gwarancji praw człowieka. Standardy konstytucyjne nie były niższe niż standardy przewidziane w Karcie, a dyrektywa stanowiła przykład jedynie minimalnej harmonizacji. To ostatnie zresztą TK dostrzegł w swym orzeczeniu, oceniając, że przedmiotowa dyrektywa "nie dąży do ujednolicenia prawodawstw państw członkowskich w dziedzinie przeciwdziałania korzystania z systemu finansowego w celu prania pieniędzy oraz finansowania terroryzmu, gdyż nie ustanawia identycznego poziomu regulacji we wszystkich państwach"767. Zastosowanie standardów konstytucyjnych, które nie były niższe niż standardy unijne, było więc możliwe swobodnie, gdyż nie mogło doprowadzić do podważenia zasad pierwszeństwa, jedności i efektywności prawa unijnego.

${ }^{765}$ Dyrektywa 2005/60/WE Parlamentu Europejskiego i Rady z 26 października 2005 $\mathrm{w}$ sprawie przeciwdziałania korzystaniu $\mathrm{z}$ systemu finansowego $\mathrm{w}$ celu prania pieniędzy oraz finansowania terroryzmu, Dz.Urz. L 309 z 25 listopada 2005.

766 TK, sprawa K 41/05, wyrok z 2 lipca 2007, pkt III 11.4 uzasadnienia.

${ }^{767}$ Ibidem, pkt III 9.2 uzasadnienia. 


\subsection{Zmiana stosunku TK do Karty po tym, gdy uzyskała moc prawną}

Co ciekawe, w wyroku TK dotyczącym TL, w wyniku którego to traktatu, jak wiadomo, Karta uzyskała moc prawna, pojawiła się ona jedynie raz - w kontekście stwierdzenia, że „Wartości znajdujące wyraz w Konstytucji i w Traktacie z Lizbony wyznaczają tożsamość aksjologiczną Polski i Unii Europejskiej"768. Jest to stwierdzenie niewątpliwie ważne, ale ani nie nowe, ani nie wnoszace wiele do oceny statusu Karty z perspektywy polskiego porządku prawnego. Po uzyskaniu przez Kartę mocy prawnej, TK najszerzej odniósł się do niej w wyroku z 16 listopada $2011^{769}$, w którym podjął się kontroli konstytucyjności unijnego prawa pochodnego. Jako że sprawa ta będzie miała szczególne znaczenie dla rozważań nad proponowanym w tej pracy mechanizmem sekwencji orzekania, prowadzącej do minimalizacji niebezpieczeństwa zaistnienia konfliktu, ze wszystkimi tego konsekwencjami między unijnym a wyższym niż unijny, polskim standardem ochrony praw człowieka, szerzej omówiona zostanie w dalszej części pracy. W tym miejscu wystarczy zauważyć, że brak w niej analizy kwestii związanych z art. 51 ust. 1 Karty i zakresem jej zastosowania oraz wynikającymi stąd konsekwencjami dotyczącymi identyfikacji standardów praw człowieka, którym dana regulacja powinna podlegać.

Jeśli chodzi o rzadkie odniesienia do Karty w orzecznictwie TK już z okresu po tym, kiedy uzyskała ona moc prawna, to można zauważyć, że w uzasadnieniu do wyroku z 5 lipca $2011^{770}$, w sprawie, w której Trybunał badał art. 114 ust. 2 pkt 4 ustawy o postępowaniu kompensacyjnym w podmiotach o szczególnym znaczeniu dla polskiego przemysłu stoczniowego ${ }^{771}$, który to przepis różnicował sytuację kobiet i mężczyzn uprawnionych do uzyskania zagwarantowanego w ustawie świadczenia pod katem zgodności z art. 32 ust. 1 i 2 Konstytucji, podkreślając wagę konstytucyjnej zasady równości, zauważył, że „kierunkowy wymóg zapewnienia równości kobiet i mężczyzn we wszystkich dziedzinach, w tym w zakresie zatrudnienia, pracy oraz wynagrodzenia, wynika również z art. 21 i art. 23 Karty Praw Podstawowych Unii Europejskiej. Wyraża ona generalny standard europejski w zakresie zwalczania przejawów dyskryminacji i nieusprawiedliwionego nierównego traktowania"772. TK wsparł więc stanowisko opar-

${ }^{768}$ TK, sprawa K 32/o9, wyrok z 24 listopada 2010, pkt III 2.2 uzasadnienia.

769 TK, sprawa Sk 45/o9, wyrok z 16 listopada 2011.

770 TK, sprawa P 14/10, wyrok z 5 lipca 2011.

${ }^{771}$ Ustawa z 19 grudnia 2008 o postępowaniu kompensacyjnym w podmiotach o szczególnym znaczeniu dla polskiego przemysłu stoczniowego, Dz.U. nr 233, poz. 1569.

772 TK, sprawa P 14/10, wyrok z 5 lipca 2011, pkt III 4.3 uzasadnienia. 
te na Konstytucji odwołaniem do Karty, choć nie była ona bezpośrednio wzorcem kontroli.

W wyroku z 22 maja 2013, w którym Trybunał badał konstytucyjność Kodeksu pracy ${ }^{773}$, sędzia Teresa Liszcz w swym zdaniu odrębnym powołała się na art. 30 Karty w kontekście rozumienia ochrony prawa do pracy, wiążącego się również z gwarancją, że człowiek nie może być pozbawiony pracy bez powodu lub z naruszeniem prawa. Odwołanie do Karty miało jednak jedynie argumentacyjny charakter i było elementem przywołania szerszego kontekstu międzynarodowych gwarancji praw człowiekaa ${ }^{774}$, zawartych w Powszechnej Deklaracji Praw Człowieka, Międzynarodowym Pakcie Praw Gospodarczych, Społecznych i Kulturalnych ${ }^{775}$ i Europejskiej Karcie Społecznej ${ }^{776}$. Z kolei w wyroku z 25 czerwca $2013^{777}$, który dotyczył przepisu ustawy o rencie socjalnej ${ }^{778}$, $\mathrm{w}$ zakresie $\mathrm{w}$ jakim uzależniał on przyznanie i realizację prawa do renty od przebywania beneficjenta na terytorium Polski, TK doszedł do wniosku o jego niezgodności z Konstytucją. Ponieważ wniosek ograniczał wzorce kontroli jedynie do przepisów Konstytucji, TK nie mógł ocenić ewentualnej niezgodności tego przepisu z Kartą. Tym niemniej w uzasadnieniu do wyroku zauważył, że nie ma

żadnych wątpliwości, że ustawowy warunek przebywania na terytorium Rzeczypospolitej Polskiej, jako przesłanka nabycia prawa do renty socjalnej i jej wypłaty, dotyka zarówno konstytucyjnie chronionych praw wnioskodawczyni, takich jak prawo do zabezpieczenia społecznego, jak i gwarantowanych prawem Unii Europejskiej praw podstawowych, w tym prawa wnioskodawczyni, jako obywatelki Unii Europejskiej, do swobodnego przemieszczania się i przebywania na terytorium państw członkowskich Unii (art. 21 ust. 1 Traktatu o funkcjonowaniu Unii Europejskiej; art. 45 ust. 1 Karty Praw Podstawowych Unii Europejskiej... $)^{779}$.

Brak jednak jakiegokolwiek odniesienia do zagadnień takich, jak zakres, w jakim Karta może być wzorcem kontroli dla prawa polskiego, ani tym bardziej do samego art. 51 ust. 1 Karty.

Wreszcie w wyroku z 25 lutego $2014^{780}$ TK przypomniał, że zasada nullum crimen, nulla poena sine lege poenali anteriori jest zakorzeniona nie tylko w Kon-

${ }^{773}$ Ustawa z 26 czerwca 1974 Kodeks pracy, Dz.U. nr 24, poz. 141 ze zm.

774 TK, sprawa P 46/11, wyrok z 22 maja 2013, zdanie odrębne sędzi TK Teresy Liszcz, pkt 3.

${ }_{775}$ Międzynarodowy Pakt Praw Gospodarczych, Społecznych i Kulturalnych otwarty do podpisu w Nowym Jorku 19 grudnia 1966, Dz.U. z 1977 nr 38, poz. 169.

${ }^{776}$ Europejska Karta Społeczna, Dz.U. z 1999 nr 8, poz. 67 ze zm.

777 TK, sprawa P 11/12, wyrok z dnia 25 czerwca 2013.

778 Art. 2 pkt 1 ustawy z 27 czerwca 2003 o rencie socjalnej, Dz.U. nr 135, poz. 1268 ze zm.

779 TK, sprawa P 11/12, wyrok z 25 czerwca 2013, pkt III 3.1 uzasadnienia.

${ }^{780}$ TK, sprawa Sk 65/12, wyrok z 25 lutego 2014. 
stytucji, lecz także w KPP. Znowu TK przywołał Kartę, wśród innych regulacji międzynarodowych, jako dodatkowy argument za swoją tezą opartą na prawie polskim i konstytucyjnych gwarancjach praw człowieka ${ }^{781}$, bez jakiegokolwiek jej rozróżnienia od innych dokumentów międzynarodowych i bez żadnej refleksji na temat zasad jej zastosowania. Na gruncie tych orzeczeń można więc zauważyć, że, choć czyni to znacznie rzadziej niż ma to miejsce w przypadków sądów powszechnych, administracyjnych i Sądu Najwyższego, TK również czasem wpisuje się w tendencję do ornamentacyjno-argumentacyjnego wykorzystywania Karty. Jak już wspomniano, tego rodzaju wykorzystywanie Karty nie jest jako takie nieprawidłowe, gdyż sprzyja konwergencji unijnych i krajowych standardów, a wynika ze wspólnoty wartości i tradycji konstytucyjnych na przestrzeni Unii, którą zresztą sam TK niejednokrotnie podkreślał, jednocześnie ją utwierdzając i pogłębiając. Co szczególnie wyraźnie pokazał wyrok w sprawie retencji danych ${ }^{782}$, o którym będzie jeszcze mowa, „Trybunał Konstytucyjny skłonny jest aprobująco powoływać wyroki Trybunału Sprawiedliwości, w którym ten uznał za nieważny akt prawa wtórnego UE z powodu jego niezgodności z Kartą Praw Podstawowych UE, nie powołując jednak w ogóle w tym kontekście samej Karty" ${ }^{\prime \prime 83}$. Jednakże, jak pokazuje choćby wyrok w sprawie dotyczącej organizacji rynku rybnego ${ }^{784}$, o którym też będzie jeszcze mowa, Trybunałowi zdarzało się nie odnieść do Karty tam, gdzie powinien był to zrobić $^{785}$. Jak zostało to wskazane na gruncie orzecznictwa sądów powszechnych i administracyjnych dotyczących Karty, jest to błąd poważny, w przeciwieństwie do pomocniczego przywoływania Karty, gdy nie ma ona zastosowania, co samo w sobie błędem nie jest.

Po tym, gdy Karta uzyskała moc prawna, TK nie miał jeszcze okazji, a być może nie skorzystał z żadnej z tych, które miał, aby merytorycznie rozstrzygnąć sprawy, w której Karta byłaby wzorcem kontroli, ani „wyraźnie przesądzić, jaką rolę Karta może odgrywać jako wzorzec kontroli polskich aktów normatywnych"786, czy mówiąc szerzej - jaki jest jej status z pespektywy pol-

${ }^{781}$ Ibidem, pkt III 4.7 uzasadnienia.

${ }^{782}$ TK, sprawa K 23/11, wyrok z 30 lipca 2014 w związku z: TSUE, Digital Rights Ireland Ltd p. Minister for Communications, Marine and Natural Resources i inni oraz Kärntner Landesregierung i inni, C-293/12, C-594/12, wyrok z 8 kwietnia 2014.

${ }^{783}$ M. Wróblewski, Karta Praw Podstawowych UE w orzecznictwie Trybunału Konstytucyjnego..., s. 20.

${ }^{784}$ TK, sprawa Kp 1/o9, wyrok z 13 października 2010.

${ }^{785}$ M. Górski, Skutek Karty Praw Podstawowych Unii Europejskiej po wejściu w życie Traktatu z Lizbony w orzecznictwie Europejskiego Trybunału Praw Człowieka, Trybunału Konstytucyjnego Rzeczypospolitej Polskiej i Trybunału Sprawiedliwości Unii Europejskiej, [w:] S. Dudzik, N. Półtorak (red.), Prawo Unii Europejskiej a prawo konstytucyjne państw członkowskich, Warszawa 2013, s. 330.

${ }^{786}$ M. Wróblewski, Karta Praw Podstawowych UE w orzecznictwie Trybunału Konstytucyjnego..., s. 24 . 
skiego porządku prawnego i jaką rolę może i powinien pełnić TK dla zapewnienia jej skuteczności. Trybunał stanął już przed pytaniem prawnym, skierowanym doń przez Sąd Rejonowy w Dąbrowie Górniczej, w którym sąd ten podniósł zarzut niezgodności przepisów Kodeksu karnego w zakresie, w jakim pozwala on na warunkowe zawieszenie kary łącznej tylko w wypadku określonym w art. 69 Kodeksu ${ }^{787}$ zarówno z gwarancjami praw i wolności człowieka zawartymi w Konstytucji, EKPCz, jak i w Karcie. TK zdecydował się jednak umorzyć postępowanie w tej sprawie ze względu na niespełnienie przez sąd pytający trzeciej, obok podmiotowej i przedmiotowej, które zostały spełnione, przesłanki dopuszczalności pytania prawnego, jaką jest przesłanka funkcjonalna, zgodnie z którą: „musi zachodzić związek pomiędzy rozstrzygnięciem Trybunału a rozstrzygnięciem konkretnej sprawy zawisłej przed sądem wnoszącym pytanie prawne. Ten ostatni wymóg oznacza, że sąd pytający ma obowiązek wykazać, że »rozstrzygnięcie zawisłej przed nim sprawy będzie odmienne w przypadku uznania przez Trybunał niezgodności z Konstytucją kwestionowanych przepisów «"788 oraz ze względu na niespełnienie również innych obowiązków ciążących na sądzie pytającym ${ }^{789}$. Do problematyki związanej z KPP, w tym z zakresem jej zastosowania, TK nie odniósł się wcale.

Na szczególną uwagę w kontekście zastosowania przez TK Karty jako wzorca kontroli zasługują dwie sprawy, które zostały zainicjowane przed TK przez RPO, i w których Rzecznik wskazywał przepisy Karty jako wzorce kontroli. Pierwsza z tych spraw dotyczyła kwestii uboju rytualnego ${ }^{790}$, druga zaś unijnych przepisów o VAT ${ }^{791}$. W obu wnioskach o kontrolę abstrakcyjną Rzecznik zarzucał kwestionowanym przepisom polskim niezgodność z Kartą. W pierwszej w tych spraw TK wydał postanowienie o umorzeniu postępowania w obliczu rozstrzygnięcia we wcześniejszym wyroku ${ }^{792}$, dotyczącym zgodności z Konstytucją i EKPCz zaskarżonych przepisów regulujących ubój rytualny, tych samych kwestii, co podniesione przez Rzecznika. Kwestia zgodności kwestionowanych przepisów z postanowieniami Karty w tym wcześniejszym rozstrzygnięciu w ogóle się nie pojawiła, jako że Karta nie była w tamtej sprawie wskazana jako wzorzec kontroli. Mimo umorzenia postępowania, w uzasadnieniu postanowienia z 3 listopada 2015 TK stwierdził obiter, że wniosko-

${ }^{787}$ Ustawa z dnia 6 czerwca 1997 Kodeks karny, Dz.U. nr 88, poz. 553 ze zm., w brzmieniu obwiązującym do 30 czerwca $2015 \mathrm{r}$.

${ }^{788} \mathrm{TK}$, sprawa P 102/15, postanowienie z 4 listopada 2015, pkt II 3 uzasadnienia.

${ }^{789}$ Ibidem, pkt II 4 i nast. uzasadnienia.

790 TK, sprawa K 32/14, postanowienie z 3 listopada 2015.

${ }^{791}$ TK, sprawa K 61/13, wszczęta wnioskiem RPO z 6 grudnia 2013 (RPO-697281-I/12) $\mathrm{NC}$ ), w trakcie której RPO pismem procesowym z 19 listopada 2014 (VII.715.11.2014.MW/NC) zarzucił niezgodność przepisów unijnych o VAT z art. 20 KPP.

792 TK, sprawa K 52/13, wyrok z 10 grudnia 2014. 
dawca niewłaściwie wskazał potencjalny, wynikający z Karty wzorzec kontroli (RPO wskazał art. 10 ust. 1, podczas gdy zdaniem Trybunału powinien był wskazać art. 10 ust. 2 i na tym tle uzasadnić naruszenie $)^{793}$. Zdaniem niektórych może to oznaczać, że TK nie wykluczał możliwości kontroli zakwestionowanych przepisów krajowych przez pryzmat zgodności z Kartą ${ }^{794}$, ale z różnych względów nie mógł takiej kontroli podjąć, czego ostatecznie nie zrobił i wątpliwości tych nie rozwiał. Jest to wniosek wątpliwy, co zostanie bardziej szczegółowo wyjaśnione w dalszej części tego rozdziału. Sprawa dotycząca unijnych regulacji podatku VAT również omówiona będzie trochę dalej. O ile bowiem nie doprowadziła ona TK do jakichś istotnych ustaleń w kwestii Karty, szczególnie w kontekście jej zakresu zastosowania jako wzorca kontroli wobec prawa polskiego, to stała się podstawą pierwszego pytania prejudycjalnego skierowanego przez TK do TSUE ${ }^{795}$, w którym wszakże kwestie dotyczące Karty pojawiały się jedynie zdawkowo.

Pewien potencjał miała sprawa skierowana do TK przez Sąd Apelacyjny w Gdańsku dotycząca tego, czy art. 92a Kodeksu karnego ${ }^{796}$, zakazujący obejmowania wyrokiem łącznym orzeczeń skazujących wydanych w innych państwach członkowskich, jest zgodny z art. 32 Konstytucji oraz art. 20 Karty ${ }^{797}$. Sąd pytający zarzucił zakwestionowanym przepisom, że ukształtowały one nierówną sytuację prawną osób skazanych przez sądy państw niebędących członkami Unii względem osób, które są obywatelami państw członkowskich. Zdaniem Mirosława Wróblewskiego, sprawa ta wydawała się być „najbardziej zaawansowaną do rozpoznania przez TK sprawa, w której jako wzorzec kontroli wskazano postanowienie Karty" ${ }^{\prime \prime 9}$. Faktycznie otwierała ona przed TK szansę na odniesienie się do różnych istotnych zagadnień związanych ze stosowaniem Karty, jej statusem, a także jej potencjalną rolą w postępowaniach przed TK. Szczególnie do kwestii takich, jak to, czy Karta może być wzorcem kontroli dla TK, a jeśli tak, to w jakim zakresie, a także jaki wpływ na stosowanie Karty w Polsce miałby mieć Protokoł nr 30. Jest to kolejna kwestia związana z Karta, której TK do tej pory nie podjął. Tymczasem została ona silnie podniesiona

${ }_{793}$ TK, sprawa K 32/14, postanowienie z 3 listopada 2015, pkt II 2 uzasadnienia.

${ }^{794}$ M. Pyziak-Szafnicka, Karta Praw..., s. 25.

795 TSUE, RPO, C-39o/15, wyrok z 7 marca 2017.

${ }^{796}$ Ustawa z 6 czerwca 1997 Kodeks karny, Dz.U. nr 88, poz. 553 ze zm.

${ }^{797}$ TK, sprawa P 19/14 zainicjowana postanowieniem Sądu Apelacyjnego w Gdańsku z 7 maja 2014, zmodyfikowanym postanowieniem z 29 lipca 2015 tak, że przedmiotem zaskarżenia stał się art. 84 \& 4 Kodeksu karnego, co zostało spowodowane wejściem w życie ustawy z 20 lutego 2015 o zmianie ustawy - Kodeks karny oraz niektórych innych ustaw (Dz.U. poz. 396), która uchyliła art. 92 Kodeksu karnego.

${ }^{798}$ M. Wróblewski, Karta Praw Podstawowych UE w orzecznictwie Trybunału Konstytucyjnego..., s. 21 . 
w stanowiskach uczestników postępowania ${ }^{799}$. Sprawa ta otwierała także potecjalnie pole do rozważań, czy mamy w niej do czynienia z przepisami prawa polskiego mieszczącymi się w zakresie zastosowania prawa unijnego czy też nie, co będzie skutkowało zastosowaniem wobec nich Karty albo Konstytucji jako wzorca kontroli, a w związku z tym do rozstrzygnięcia, czy ze względu na ewentualny stopień harmonizacji zastosowanie powinny znaleźć jednak krajowe, a nie unijne gwarancje praw człowieka. Wreszcie otwierała przestrzeń do ewentualnego skierowania pytania prejudycjalnego do TSUE.

Warto w tym miejscu nadmienić, że w stanowisku wystosowanym $w$ tej sprawie $S j^{800}{ }^{80}$ od początku reprezentował pogląd, że postępowanie w sprawie powinno zostać umorzone. W pierwszym swoim stanowisku stwierdzil, że postępowanie w zakresie kontroli zgodności Kodeksu karnego z Kartą powinno zostać umorzone ze względu na zbędność wydania wyroku. Zdaniem Sejmu Karta nie może być wzorcem kontroli, ponieważ nie jest ratyfikowaną umową międzynarodową. Na poparcie tej tezy Sejm wymienia wiele argumentów, na czele z tym, że Karta została proklamowana przez unijne instytucje (Komisję Europejska, Parlament Europejski i Radę Unii Europejskiej), a nie przez państwa członkowskie. Zdaniem Sejmu art. 6 ust. 1 TUE nie rozwiązuje sprawy, jako że jedynie nadaje Karcie moc prawną równą unijnym traktatom, a nie czyni jej częścią traktatów (tak jak było to planowane na gruncie tzw. Traktatu konstytucyjnego). Sejm stanął na stanowisku, że pokazuje to wyraźną intencję państw członkowskich, aby zachować odrębność Karty i traktatów ${ }^{801}$. Z drugiej strony, Prokurator Generalny również wyraził pogląd, że Karta nie jest umową międzynarodową. Nie doprowadziło go to jednak do wniosku, że uniemożliwia to oceny zgodności Kodeksu z Kartą. Prokurator dostrzegł również znaczenie art. 51 ust. 1 Karty ${ }^{802}$. Podkreślić należy jednak, że w żadnym ze stanowisk, nawet jeśli pojawiają się odniesienia do tej kluczowej kwestii, gdy chodzi o zakres zastosowania Karty, to nie są one pogłębione. Tymczasem jak się wydaje to właśnie rozstrzygnięcie czy zachodzi konieczna więź między prawem krajowym a prawem unijnym jest okolicznością rozstrzygająca, czy Karta może i powinna znaleźć w sprawie zastosowanie, czy też nie. Kwestią dalszą jest zaś to, kto powinien ją zastosować jako wzorzec kontroli w takiej sytuacji: TK czy TSUE.

${ }^{799}$ TK, sprawa P 19/14, Stanowisko Prokuratora Generalnego z 27 października 2014 (PG VIII TK 44/14); Postanowienie SA w Gdańsku z dnia 8 września 2015 dotyczące podtrzymania pytania prawnego.

800 TK, sprawa P 19/14, Stanowisko Marszałka Sejmu z 22 października 2015 (BAS-WPTK-1166/14).

${ }^{801}$ TK, sprawa P 19/14, Stanowisko Marszałka Sejmu z 18 grudnia 2014 (BAS-WPTK-1166/14).

802 TK, sprawa P 19/14, Stanowisko Prokuratora Generalnego z 27 października 2014 (PG VIII TK 44/14). 
Ostatecznie jednak, w obliczu faktu, że sąd pytający "W związku z cofnięciem apelacji przez obrońcę skazanego - postanowił pozostawić bez rozpoznania apelację w sprawie, w związku z którą zostało przedstawione pytanie prawne" 803 , Trybunał orzekł o umorzeniu postępowania w trybie pytania prawnego. Oparł się w tej materii na swym ugruntowanym orzecznictwie dotyczącym konieczności istnienia przesłanki funkcjonalnej pytania prawnego:

Rozstrzygnięcie sądu pytającego [...] przesądza o niedopuszczalności rozpoznania pytania prawnego. Przedmiotem kontroli w trybie pytania prawnego może być jedynie akt normatywny, który ma bezpośrednie znaczenie dla rozstrzygnięcia konkretnej sprawy toczącej się przed tym sądem. Chodzi więc o taki przepis czy też przepisy aktu normatywnego, które będą miały zastosowanie lub chociaż wywierały bezpośredni wpływ na rozstrzygnięcie danej sprawy zawisłej przed sądem pytającym ${ }^{804}$.

\subsection{Potencjalne znaczenie Karty w postępowaniach przed TK}

Niektórzy komentatorzy twierdza, że Karta nie jest traktowana przez TK na równi z EKPCz ${ }^{805}$. Faktycznie EKPCz pojawia się w orzecznictwie TK znacznie częściej zarówno jako źródło inspiracji przy rekonstrukcji konstytucyjnych standardów ochrony poszczególnych praw czy wolności, a także jako podstawa orzekania, a więc jako wzorzec kontroli ${ }^{806}$. Jak zauważa Mirosław Wróblewski:

Chociaż Trybunał Konstytucyjny podkreśla aksjologiczny wspólny rdzeń Konwencji, Konstytucji i Karty [...], nigdy zagadnienia tego szczegółowo nie analizowano. Można jednak dodać, że jednym z powodów takiego stanu rzeczy jest niewielka liczba wniosków i skarg opartych na Karcie. Oczywiste jest, że gdy strony powołują się na Kartę sporadycznie, Trybunał Konstytucyjny ma mniejsze szanse orzekania na podstawie jej treści. Karta z pewnością znajdzie jednak swoje miejsce w skomplikowanych relacjach pomiędzy acquis communautaire i polskim acquis constitutionnel ${ }^{807}$.

Jeśli chodzi o zagadnienie stosowania Karty przez TK, to wydaje się jednak, że nawet po uzyskaniu przez nią niekwestionowanej mocy prawnej nie należy

${ }^{803}$ TK, sprawa P 19/14, postanowienie z dnia 15 grudnia 2016, pkt. II.3 uzasadnienia.

${ }^{804}$ Ibidem, pkt. II.3 uzasadnienia.

${ }^{805}$ M. Górski, Skutek Karty..., s. 328.

${ }^{806} \mathrm{Gdy}$ chodzi o rok 2015 patrz np.: Informacja o istotnych problemach wynikajacych $z$ działalności i orzecznictwa Trybunału Konstytucyjnego w 2015 roku, Trybunał Konstytucyjny Wydawnictwa, Warszawa 2016, s. 131 i nast., [online] <http://trybunal.gov.pl/fileadmin/content/dokumenty/ publikacje/informacje_o_problemach/Informacja2015.pdf> [dostęp: 18.01.2019].

${ }^{807}$ M. Wróblewski, Ł. Bojarski, D. Schindlauer, K. Wladasch, Karta Praw..., s. 130. 
się spodziewać, aby TK uznał Kartę za generalnie dopuszczalny wzorzec kontroli dla prawa polskiego w procedurach kontroli hierarchicznej zgodności prawa w Polsce. Jak wspomniano Karta nie jest w sensie ścisłym umową międzynarodowa, która mogłaby w związku z tym zgodnie z art. 188 pkt 2 i 3 czy art. 193 Konstytucji stanowić wzorzec kontroli dla ustaw i aktów niższego rzędu. Jak już podkreślano w poprzednich rozdziałach, Karta różni się w tej mierze od EKPCz, która właśnie taki charakter ma i w związku z tym służy TK jako wzorzec hierarchicznej kontroli norm $\mathrm{w}$ ramach jego kompetencji wynikających z art. 188 pkt 2 i 3 i art. 193 Konstytucji. Karta ma status równy prawu pierwotnemu Unii, nie jest jednak traktatem sensu stricto. Co więcej, jak szczegółowo to wyjaśniono $\mathrm{w}$ rozdziale I tej pracy art. 51 ust. 1 Karty określa jej zakres zastosowania i ogranicza go do instytucji, organów i jednostek organizacyjnych Unii oraz do państw członkowskich wyłącznie w zakresie, w jakim stosują one prawo Unii.

Kwestia ta może jednak rodzić pewne wątpliwości, co odzwierciedlają głosy w doktrynie i absolutną pewność będziemy mogli w tej materii uzyskać dopiero, gdy TK konkluzywnie się na ten temat wypowie. Zdaniem niektórych badaczy TK nie wykluczał takiej możliwości, a w jego orzecznictwie można dostrzec nawet pewne wskazówki sugerujące, że traktuje on Kartę na równi z Konwencją jako potencjalny wzorzec kontroli dla prawa polskiego. Jak twierdzi Małgorzata Pyziak-Szafnicka, na gruncie postanowienia TK z 3 listopada 2015 ${ }^{808}$ : „Niezależnie od konkretnego rozstrzygnięcia, które - ostatecznie - nie zawiera oceny przepisu prawa polskiego przez pryzmat art. 10 ust. 2 Karty, istotne jest potraktowanie przez TK tego wzorca kontroli jako mającego tę samą rangę, co wolności i prawa statuowane w Konstytucji $\mathrm{RP}^{\prime 809}$. Jej zdaniem, w ramach postępowań kontroli abstrakcyjnej TK może badać, czy prawo polskie spełnia międzynarodowy standard ochrony praw człowieka, w tym ten przewidziany w Konwencji, jak i w Karcie, jak się wydaje, bez względu na to, czy będzie ono mieściło się w zakresie zastosowania prawa unijnego, czy też nie ${ }^{810}$. Konstatacja ta może budzić pewne wątpliwości ze względu na zdawkowy charakter argumentacji TK $\mathrm{w}$ tej materii $\mathrm{w}$ uzasadnieniu do wspomnianego postanowienia, a także ze względu na brak jednoznacznego wskazania powodów, dla których TK zdecydował się na marginesie rozważań zasadniczych odnieść się również do tego, który z przepisów Karty mógłby mieć potencjalne znaczenie $\mathrm{w}$ tej sprawie. Nie wiadomo też w jaki sposób TK by się do niego odniósł. Czy przywołałby go jako argument dodatkowy wzmacniający argumentację opartą na Konstytucji, czy też wykorzystałby go jako faktyczny wzorzec kontroli. Ewentualny wybór tego drugiego rozwiąza-

${ }^{808}$ TK, sprawa K 32/14, postanowienie z 3 listopada 2015.

${ }^{809}$ M. Pyziak-Szafnicka, Karta Praw..., s. 25.

${ }^{810}$ Ibidem, s. 23. 
nia byłby przejawem podążenia przez TK drogą podobną do austriackiego Trybunału Konstytucyjnego, a być może jeszcze dalej idącej introdukcji Karty do polskiego systemu prawnego ${ }^{811}$.

Na gruncie aktualnego orzecznictwa TK nie można takiej ewentualności z całą stanowczością wykluczyć, wydaje się ona jednak mało prawdopodobna i trudno byłoby ją zalecać. Gdy chodzi o skargę konstytucyjna, to przepisy Konstytucji jasno wykluczają Kartę jako wzorzec kontroli. Gdy chodzi o kontrolę abstrakcyjną na gruncie art. 188 pkt 2 i $3^{812}$, a także o kontrolę konkretną $\mathrm{w}$ ramach procedury pytania prawnego na gruncie art. 193 Konstytucji, to wykluczenie nie jest aż tak oczywiste. Należy jednak przyznać rację Andrzejowi Mączyńskiemu i Janowi Podkowikowi, którzy twierdza, że odmiennym

problemem jest dopuszczalność wskazywania KPP jako wzorca kontroli w postępowaniach przez TK, a odmiennym jest dopuszczalność wskazywania - jako wzorca kontroli - przepisów umów międzynarodowych zawierających gwarancję wolności i praw człowieka. W praktyce nie budzi wątpliwości badanie zgodności polskiego prawa z EKPC i z ratyfikowanymi umowami międzynarodowymi przyjętymi w ramach systemu ONZ, jakkolwiek kontrola ta wykonywana jest przy zachowaniu powściągliwości i w duchu dialogu orzeczniczego ${ }^{813}$.

Szczególnie status Konwencji, lecz także Paktów praw człowieka czy innych umów międzynarodowych nie może bowiem budzić kontrowersji w kontekście wzorców kontroli, jakie wskazuje w art. 188 pkt 2 i 3 czy art. 193 Konstytucji, co uwzględnia również w swym orzecznictwie $\mathrm{TK}^{814}$.

Większe kontrowersje dotyczą dopuszczalności stosowania jako wzorca kontroli KPP [...]. Wynikają one z dwóch okoliczności: niejasnego statusu prawnego tego aktu w ramach polskiego systemu źródeł prawa, a w szczególności możliwości zakwalifikowania jej jako „ratyfikowanej umowy międzynarodowej” w rozumieniu art. 188

${ }^{811}$ Na marginesie można też zauważyć, że niektóre sądy konstytucyjne korzystają z prawa unijnego jako wzorca kontroli dla prawa krajowego w postępowaniach przez nimi, choć nie jest to tendencja w pełni ustabilizowana (więcej - patrz: D. Paris, Constitutional Courts as European Union Courts: The Current and Potential Use of EU Law as a Yardstick for Constitutional Review, "Maastricht Journal of European and Comparative Law" 2017, $\mathrm{nr} 24$ (6).

812 Por. np.: M. Wróblewski, Karta Praw Podstawowych UE w orzecznictwie Trybunału Konstytucyjnego..., s. 21.

${ }^{813}$ A. Mączyński, J. Podkowik, Art. 188. [Trybunat Konstytucyjny; właściwość rzeczowa], [w:] M. Safjan, L. Bosek (red.), Konstytucja. Komentarz, t. II, Warszawa 2016, s. 1161; por. też: A. Kustra, Kelsenowski..., s. 351 i nast.

${ }^{814}$ Odnośnie do EKPCz patrz np.: A. Paprocka, Wplyw orzecznictwa ETPCz na rozumienie konstytucyjnych praw i wolności w Polsce - kilka uwag na marginesie orzecznictwa Trybunału Konstytucyjnego, [w:] M. Zubik (red.), XV lat obowiazywania Konstytucji RP z 1997 r. Ksiega jubileuszowa dedykowana Zdzisławowi Jaroszowi, Warszawa 2012. 
pkt 2 i 3 Konstytucji RP oraz oceny wpływu tzw. protokołu polsko-brytyjskiego na jej zastosowanie w Polsce [...]. Wyrażane w literaturze poglądy aprobujące stosowanie KPP jako wzorca kontroli prawa nie wydają się uzasadnione. KPP - jako akt stworzony i wydany przez instytucje UE - nie może zostać uznana za odrębną ratyfikowaną umowę międzynarodową ani za część traktatu podlegającego procedurze ratyfikacyjnej. Nie znajduje się ponadto, z wyjątkiem deklaracji dotyczącej jej stosowania, w oficjalnym spisie protokołów i załączników do Traktatu lizbońskiego. W tym sensie, w świetle prawa międzynarodowego, stanowi ona tzw. akt okołotraktatowy [...]. Zmiany treści tego aktu normatywnego nie wymagają ponadto przeprowadzenia w państwach członkowskich procedur ratyfikacyjnych. Znajdują się zatem poza zakresem bezpośredniego oddziaływania państw członkowskich. Jakkolwiek w świetle art. 6 ust. 1 TUE KPP ma "taką samą moc prawną jak Traktaty”, to sformułowanie to należy odnosić raczej do określenia pozycji KPP w ramach wewnętrznego porządku prawnego UE, a nie w hierarchii systemów prawnych państw członkowskich. Wynika stąd, że nie ma podstaw do traktowania KPP jako umowy międzynarodowej w rozumieniu art. 188 pkt 2 i 3 Konstytucji RP ${ }^{815}$.

Te wszystkie argumenty są bez wątpienia bardzo istotne. Co jednak wydaje się najważniejsze, to specyficzny charakter Karty jako unijnego dokumentu gwarantującego poszanowanie praw podstawowych we wspólnocie. "Nawet gdyby uznać KPP za dopuszczalny wzorzec kontroli, to zakres jej zastosowania w postępowaniu przed TK byłby ograniczony. Zgodnie z art. 51 ust. 1 KPP ma zastosowanie do państw członkowskich wyłącznie w zakresie, w jakim stosują one prawo unijne. W praktyce mogłaby być ona powołana w sprawach, w których przepis krajowy dotyczy materii regulowanej prawem unijnym"816, czy mówiąc ściślej, gdy spełnione są przesłanki zastosowania Karty wynikające $z$ jej art. 51 ust. 1 .

[W] sytuacji, gdy wadliwość przepisu krajowego spowodowana jest niezgodnością aktu prawa pochodnego z prawem pierwotnym, wyłączną kompetencję do zbadania ważności takiego aktu prawa pochodnego ma TSUE. Orzekanie w sprawie zgodności przepisów implementujących prawo UE z przepisami KPP mogłoby zatem wkraczać w kompetencję TSUE, choć - czego nie można wykluczyć - mogłoby się stać polem współpracy między TSUE, mającym wyłączną kompetencję wiążącej wykładni KPP, a krajowymi sądami konstytucyjnymi, które mogłyby ją stosować z uwzględnieniem ustaleń TSUE ${ }^{817}$.

Należy więc skonkludować, że Karta nie jest dokumentem podobnym do Konwencji, gdy chodzi o jej charakter i znaczenie w krajowym porządku praw-

\footnotetext{
815 A. Mączyński, J. Podkowik, Art. 188..., s. 1161-1162.

${ }^{816}$ Ibidem, s. 1162.

${ }^{817}$ Ibidem.
} 
nym. W przeciwieństwie do Konwencji nie stanowi ona samodzielnego systemu referencyjnego dla rozwiązań krajowych ${ }^{818}$. Jest ona samodzielnym systemem referencyjnym dla rozwiązań unijnych oraz ewentualnie dla rozwiązań krajowych, jeśli wynika to z jej zakresu zastosowania w związku z regulacjami unijnymi, stanowiącymi konieczny łącznik z prawem krajowym, co dookreślił w swym orzecznictwie sam TSUE i co było szczegółowo omawiane w rozdziale I. Samodzielność tego systemu przejawia się również w niechęci TSUE do ewentualnego zbyt integracyjnego podejścia do Karty w ramach systemów krajowych i monopolizowania jej jako wzorca kontroli względem mieszczącego się w jej zakresie prawa krajowego, co pokazał wyrok w sprawie Melki i Abdeli ${ }^{819}$.

Ustalenia TSUE, dotyczące zakresu zastosowania Karty, są bardzo wielowątkowe i złożone. W ramach tej złożoności TK ma jednak pewne pole manewru, którego jeszcze inna, nowa przestrzeń zostanie ukazana w następnym rozdziale w ramach możliwej, i jak się wydaje koniecznej, współpracy między TK a TSUE w kwestii stosowania Karty w Polsce w związku z obowiązkiem poszanowania tożsamości konstytucyjnej RP przejawiającej się w dalej idących niż unijne, konstytucyjnych gwarancjach praw człowieka. Co do tej już znanej z poprzednich rozdziałów przestrzeni współpracy, czy też pola manewru, to po pierwsze pamiętać należy o konsekwencjach, jakie wynikają z wyroków w sprawie Melki i Abdeli oraz A. p. B. ${ }^{820}$. Była o tym szerzej mowa w poprzednim rozdziale. W kontekście tego rozdziału podkreślić należy na gruncie tego orzecznictwa szczególnie, że:

Uwieńczeniem [...] rozumowania TS jest stwierdzenie, że zanim kontrola zgodności z konstytucją ustawy krajowej, której treść ogranicza się do transpozycji wiążących przepisów dyrektywy unijnej, będzie mogła zostać przeprowadzona w świetle tych samych zarzutów kwestionujących ważność dyrektywy, sądy krajowe, których orzeczenia nie podlegają zaskarżeniu według prawa wewnętrznego [co może obejmować również TK - przyp. aut.], sa, co do zasady, zobowiązane, na podstawie art. 267 ak. 3 Traktatu o funkcjonowaniu Unii Europejskiej, do wystąpienia do TS z pytaniem o ważność tej dyrektywy, a następnie do wyciągnięcia konsekwencji wynikających z wyroku TS wydanego w trybie prejudycjalnym, chyba że sąd, który wszczyna postępowanie wpadkowe w sprawie kontroli zgodności z konstytucja, sam wystąi z tym pytaniem do $\mathrm{TS}^{821}$.

${ }^{818}$ Por.: M. Safjan, Wprowadzenie, [w:] M. Safjan, L. Bosek (red.), Konstytucja RP. Komentarz, t. 1, Warszawa 2016, s. 103-104.

819 TSUE, Aziz Melki i Sélim Abdeli, C-188/10 i C-189/10, wyrok z 22 czerwca 2010.

${ }^{820}$ TSUE, A. p. B. i in., C-112/13, wyrok z 11 września 2014.

${ }^{821}$ M. Wróblewski, Karta Praw Podstawowych UE w orzecznictwie Trybunału Konstytucyjnego..., s. 22. 
Jak mocno podkreślił bowiem w tej sprawie TSUE: „Co się [...] tyczy krajowej ustawy transponującej o takiej treści, kwestia ważności dyrektywy - w świetle obowiązku jej transpozycji - nabiera charakteru wstępnego" ${ }^{122}$. Nic nie stoi na przeszkodzie, aby z takim wnioskiem wystąpił sam TK, który dostrzega taką możliwość, co potwierdził najdobitniej, występując z pytaniem prejudycjalnym do TSUE w sprawie K 61/13, która była w tym rozdziale wspomniana, a o której będzie jeszcze mowa w szerszym kontekście podejścia TK do kwestii kontroli prawa polskiego przez pryzmat zgodności z prawem unijnym. Sądy mogą więc wystąpić z pytaniem prawnym do TK odnośnie do prawa polskiego mieszczącego się $\mathrm{w}$ zakresie prawa unijnego, gdyż jeśli będzie to uzasadnione, z pytaniem prejudycjalnym do TSUE będzie zawsze mógł wystąpić TK, naprawiając ewentualne niedotrzymanie tego obowiązku przez sąd.

Po drugie pamiętać należy o konsekwencjach, jakie wynikają z - jak zostało to nazwane - mieszanego (mixed) stosowania unijnych i krajowych standardów praw człowieka wobec prawa polskiego mieszczącego się w zakresie zastosowania prawa unijnego, a wraz z nim Karty. Szerokiemu zakresowi zastosowania KPP opartemu na jej art. 51 ust. 1 powinno towarzyszyć rozgraniczenie tej kwestii od problemu uruchomienia działania Karty w konkretnych przypadkach i odnośnie do konkretnych przepisów wydanych przez organy krajowe.

To, że sprawa mieści się w zakresie zastosowania KPP nie oznacza, iż przepisy Karty powinny być stosowane zamiast krajowego standardu ochrony. Karta powinna działać subsydiarnie, wkraczać jedynie w tych sytuacjach, gdy istnieje zagrożenie dla ochrony danego prawa podstawowego (standard ochrony w prawie krajowym jest niższy niż na poziomie europejskim) lub gdy istnieje zagrożenie dla wykonywania prawa UE. Możliwość zastosowania Karty powinna istnieć w jak najszerszej grupie sytuacji (tak szerokiej, jak szeroki jest zakres zastosowania prawa unijnego), lecz potrzeba jej zastosowania występuje jedynie wtedy, gdy krajowe standardy i mechanizmy ochrony praw podstawowych nie są wystarczające i odpowiednie dla realizacji prawa Unii Europejskiej ${ }^{823}$.

Podobnie konsekwencje związane z mieszanym (mixed) stosowaniem unijnych i krajowych standardów ochrony praw człowieka, jakie wynikają przede wszystkim z wyroków TSUE w sprawach Åkerberg-Fransson, Siragusa i Melloni, zdaje się odczytywać Marek Safjan, który przyznaje, że poprzez nie trybunał luksemburski

jednoznacznie wskazał na celowość elastycznego, a w istocie zróżnicowanego, stosowania standardów praw podstawowych w obszarze stosowania prawa europej-

822 TSUE, Aziz Melki i Sélim Abdeli, C-188/10 i C-189/10, wyrok z 22 czerwca 2010, pkt 56. ${ }^{823}$ N. Półtorak, Zakres zwiąania..., s. 28. 
skiego, co najmniej wtedy, gdy regulacje krajowe implementujące normy europejskie operują znaczącym marginesem swobody pozostawionym przez prawodawcę europejskiego co do sposobu i kształtu tej implementacji. Stanowisko to zdaje się mieć charakter zasadniczy dla przyszłej kooperacji sądów konstytucyjnych i TSUE, zważywszy na to, że w ten sposób został usunięty swoisty "monopol interpretacyjny" TSUE w odniesieniu do praw podstawowych, przyjmowany dotychczas w obszarze stosowania prawa europejskiego. Takie podejście, co warto podkreślić, pozwala w konsekwencji na bardziej elastyczną wykładnię art. 53 KPP, umożliwiając poszerzenie pola stosowania odpowiedniego standardu konstytucyjnego. Pojawia się natomiast w tym kontekście pytanie, czy wskazane wyżej przesłanki - pierwszeństwa, jedności, spójności prawa europejskiego są wymagane także wówczas, gdy odmienny standard konstytucyjny znajduje swoje oparcie w koncepcji tożsamości konstytucyjnej państwa członkowskiego ${ }^{824}$.

Próba odpowiedzi właśnie na to ostatnie pytanie podjęta zostanie w następnym rozdziale. Zdaniem autora tej pracy tożsamość konstytucyjna i obowiązek jej poszanowania otwierają bowiem kolejną przestrzeń manewru dla TK i współpracy z TSUE w ramach wspólnego - unijnego - systemu ochrony praw człowieka.

Na podstawie wskazanych w tym podrozdziale orzeczeń TK dotyczących Karty trudno stwierdzić, aby TK rzadko odnosząc się do Karty, w jakiś istotny sposób sprzeniewierzył się ciążącym na nim obowiązkom wynikającym z jej charakteru i zakresu zastosowania. $Z$ aktualnego orzecznictwa TK odnoszącego się do Karty nie sposób jednak jednoznacznie odczytać, jaki jest jego ostateczny stosunek względem zagadnień, o których była mowa w dwu poprzednich rozdziałach dotyczących statusu Karty i zakresu jej zastosowania. Dość jednak powiedzieć, że podejście prezentowane dotychczas przez TK nie jest otwarcie nie do pogodzenia $z$ tym, o czym była w mowa w poprzednich rozdziałach, ani - jak można sądzić - z tym, o czym jeszcze będzie mowa w tym i następnym rozdziale. Przeciwnie, wydaje się być otwarte na specyficzny status Karty jako unijnej - ale nie paneuropejskiej, a więc ograniczonej w swym zakresie - bill of rights.

\section{TK wobec konfliktu między prawem unijnym a Konstytucją RP}

TK sam podkreśla otwartość polskiego systemu prawnego na prawo UE skutkującą tym, co często określane bywa jako cechująca współczesny porządek

${ }^{824}$ M. Safjan, Wprowadzenie..., s. 107. 
prawny w Europie, w tym w Polsce, multicentryczność ${ }^{825}$. Sam TK używa terminu wieloskładnikowość. Trybunał zdaje sobie sprawę, że „współcześnie porządek prawny w Europie jest - dla państw należących do UE - porządkiem wieloskładnikowym: obejmujacym normy traktatowe i stanowione przez instytucje unijne oraz w porządku krajowym. Jest to przy tym system dynamiczny: relacja między porządkiem unijnym i krajowym podlega ewolucji, wraz ze zmianami w prawie unijnym" ${ }^{826}$. Specyfika porządku prawa obowiązującego w Polsce, który w dobie integracji europejskiej w ramach UE nie pochodzi już z jednego wyłącznie źródła, nie unieważnia jednak zasady prymatu Konstytucji RP. Nie może też wpływać na jej zasadniczą treść, która - jak niejednokrotnie podkreślał TK - stanowi o tożsamości konstytucyjnej RP:

Konstytucja określa relacje między prawem międzynarodowym i prawem krajowym przede wszystkim zgodnie z zasadami dobra wspólnego, suwerenności, demokracji, państwa prawnego oraz przychylności prawa krajowego prawu międzynarodowemu. W oparciu o te zasady można wyprowadzić wniosek, że Polska otwiera się na porządek międzynarodowy. Efektem przekazania kompetencji jest zazwyczaj skomplikowany układ zależności między państwem, jego organami a organizacją międzynarodową. Dlatego przekazanie kompetencji zawsze należy oceniać z punktu widzenia zasad kształtujących tożsamość konstytucyjną. Gwarancją zachowania tożsamości konstytucyjnej Rzeczypospolitej pozostaje art. 9o Konstytucji i określone w nim granice przekazywania kompetencji ${ }^{827}$.

Otwartość polskiego systemu prawnego na integrację europejską nie modyfikuje też zakresu kompetencji TK i nie zwalnia go z podstawowego jego obowiązku, jakim jest badanie zgodności z Konstytucją aktów normatywnych obowiązujących w RP i troski tym samym o zapewnienie hierarchicznej zgodności prawa obowiązującego w Polsce. Szczególny, zarówno pod względem doniosłości, jak i rangi tej funkcji Trybunału, wymiar aktywności TK stanowi dbanie o to, aby prawo obowiązujące w Polsce respektowało zagwarantowane w Konstytucji prawa i wolności człowieka. Pewne granice otwartości TK na prawo unijne wyłaniały się już z omówionego przed chwilą stosunku TK, jaki wyrażał on wobec KPP. Teraz ukazany zostanie szerszy kontekst stosunku TK do prawa unijnego oraz prawa polskiego mieszczącego się w zakresie zastosowania prawa unijnego w wymiarze, w jakim pozwoli to w następnym rozdziale przejść do zasadniczej tezy tej pracy, związanej z metodą zapewniania poszanowania wyższego niż unijny konstytucyjnego standardu ochrony praw czło-

\footnotetext{
825 Patrz np.: E. Łętowska, Multicentryczność....

826 TK, sprawa K 32/o9, wyrok z 24 listopada 2010, pkt III 2.3 uzasadnienia.

827 TK, sprawa K 33/12, wyrok z 26 czerwca 2013, pkt III 6.4.1 uzasadnienia.
} 
wieka, gdyby był on zagrożony przez prawo unijne lub prawo polskie mieszczące się w zakresie zastosowania prawa unijnego.

\subsection{Kontrola konstytucyjności prawa pierwotnego UE}

Jak się wydaje, nie powinno być większych wątpliwości co do dopuszczalności badania zgodności z Konstytucją prawa pierwotnego Unii, które stanowi $\mathrm{w}$ istocie rzeczy traktaty międzynarodowe i jako takie może być badane w trybie przewidzianym dla tego właśnie rodzaju aktów normatywnych, co wprost wynika przede wszystkim z art. 188 pkt 1 Konstytucji, gdy chodzi o kontrolę następczą umów międzynarodowych, lecz również z art. 133 ust. 2 ustawy zasadniczej, gdy chodzi o kontrolę prewencyjną umów międzynarodowych, zanim zostaną ratyfikowane przez prezydenta. Zgodnie z art. 188 pkt 1 Konstytucji przedmiotem kontroli konstytucyjności mogą być wszelkie umowy międzynarodowe bez względu na tryb, w jakim wyrażana byłaby zgoda na ich ratyfikację. Jak podkreślił przy okazji kontroli konstytucyjności traktatu akcesyjnego TK: „Trybunał Konstytucyjny nie jest upoważniony do dokonywania samoistnej oceny konstytucyjności prawa pierwotnego Unii Europejskiej. Taka kompetencja służy mu natomiast wobec Traktatu akcesyjnego jako ratyfikowanej umowy międzynarodowej (art. 188 pkt 1 Konstytucji)" 828 - i to bez względu na to, w jakim trybie doszło do zgody na ratyfikację takiej umowy, nawet jeśli było to referendum ogólnokrajowe ${ }^{829}$.

Zasadniczo nie odróżnia to polskiego porządku konstytucyjnego od innych państw należących do Unii Europejskiej. Tego rodzaju kontrola prawa pierwotnego jest najbardziej powszechną formą badania przez sądy konstytucyjne państw członkowskich prawa $\mathrm{UE}^{830}$. W Polsce miało to miejsce dwukrotnie: w związku z przystąpieniem Polski do UE ${ }^{831}$ oraz w związku z reformą prawa pierwotnego Unii przez Traktat lizboński ${ }^{832}$. W uzasadnieniu do tego drugiego wyroku TK podkreślił, że:

zarówno samo przystąpienie do Unii, jak i poszczególne dalsze etapy zmian w procedurach (mechanizmie) tworzenia prawa unijnego, wywołują w państwach członkowskich reakcję w postaci zainicjowania kontroli zgodności z konstytucją krajową. Relacja między prawem unijnym i prawem krajowym jest bowiem mechanizmem,

${ }^{828}$ TK, sprawa K 18/04, wyrok z 11 maja 2005, pkt III 1.2 uzasadnienia.

${ }^{829}$ Ibidem, pkt III 1.3 i nast. uzasadnienia.

${ }^{830}$ Więcej - patrz np.: K. Wójtowicz, Sady konstytucyjne..., s. 55-69; więcej na temat specyfiki kontroli prawa pierwotnego Unii - patrz przed.: A. Kustra, Kelsenowski.., s. 302 i nast.

${ }^{831} \mathrm{TK}$, sprawa K 18/o4, wyrok z 11 maja 2005.

832 TK, sprawa K 32/o9, wyrok z 24 listopada 2010. 
w którym organy państwa członkowskiego, z jednej strony uczestniczą (w różnych formach i stadiach) w formowaniu treści przyszłego prawa unijnego oraz w podejmowaniu decyzji instytucjonalizujących to prawo. Tak więc, z jednej strony na płaszczyźnie europejskiej, a z drugiej strony - w porządku krajowym powstają podstawy kompetencyjne, mechanizmy i procedury zapewniające udział w tworzeniu prawa unijnego i zarazem tworzące gwarancje zachowania pożądanej równowagi. Każdorazowa zmiana mechanizmu unijnego wymaga zatem sprawdzenia pozostającego z nim w korelacji sytemu mechanizmów i gwarancji w prawie krajowym. Kontrola konstytucyjności zapewnia taką właśnie weryfikację, co potwierdza praktyka europejskich trybunałów i sądów konstytucyjnych ${ }^{833}$.

Na potrzeby tej pracy dość powiedzieć, że pierwotne prawo unijne, a wraz z nim Karta Praw Podstawowych, która ma tę samą moc prawną co traktaty, nie są sprzeczne z Konstytucją RP, co potwierdził we wspominanych wyrokach TK. Ramy czy też warunki tej zgodności, sprowadzające się do pewnych granic dla prawa unijnego czy jego interpretacji, dookreślone przez TK przy okazji tych wyroków, będą brane pod uwagę w tej pracy. Ich całościowa analiza znacznie przekraczałaby jednak jej ramy, szczególnie że była ona przedmiotem dość rozbudowanej i dogłębnej analizy doktryny ${ }^{834}$. W obliczu stwierdzenia zgodności z Konstytucją prawa pierwotnego Unii należy stwierdzić, że nie jest to podstawowa płaszczyzna, na której mógłby się ziścić problem, jaki jest głównym przedmiotem zainteresowania w tej pracy, a więc kolizja między unijnym a wyższym niż unijny konstytucyjnym standardem ochrony. Kolizja taka może natomiast powstać w wyniku jego stosowania.

Do konfliktu z prawem pierwotnym mogłoby dojść przy ewentualnej zmianie traktatów unijnych. Taka sytuacja zapewne prowadziłaby do skierowania odpowiedniego wniosku do TK w ramach procedury wymaganej przez polskie prawo do ratyfikacji takiego traktatu. Otwierałoby to przestrzeń dla TK do zbadania zmian w unijnym prawie pierwotnym przez pryzmat zgodności z Konstytucja, w tym z zawartymi w niej gwarancjami praw i wolności człowieka w trybie prewencyjnym - czyli już po wyrażeniu zgody na ratyfikację przez Sejm, ale jeszcze przed złożeniem podpisu przez prezydenta. Abstrahując od tego, w jakim trybie kontrola taka dokonywana była w przypadku akcesji czy reformy lizbońskiej, wydaje się, że słusznie zauważa Krzysztof Wójtowicz, iż prewencyjna kontrola zgodności z Konstytucja, a więc dokonywana w trybie art. 133 ust. 2, „zmian w unijnym traktatowym prawie pierwotnym wydaje się

${ }^{833}$ Ibidem, pkt I 2.3 uzasadnienia.

${ }^{834}$ Patrz np.: K. Wójtowicz, Traktat akcesyjny, [w:] M. Derlatka, L. Garlicki, M. Wiącek (red.), Na straży państwa prawa. Trzydzieści lat orzecznictwa Trybunału Konstytucyjnego, Warszawa 2016 i podana tam literatura. 
być najbardziej pożądanym środkiem do unikania w przyszłości kolizji między prawem unijnym i krajowym. Jest to metoda tym bardziej zasadna, że często zmiany $\mathrm{w}$ traktatowym prawie pierwotnym dotykają materii par excellence konstytucyjnej. Polegają np. na przyznaniu Unii nowych kompetencji czy też na zmianie w zakresie praw i obowiązków jednostki" ${ }^{\prime 335}$. Choć nie można jej wykluczyć, kontrola następcza wydaje się tu rozwiązaniem znacznie gorszym, szczególnie ze względu na zasadę pacta sunt servanda ${ }^{836}$, która znalazła swój normatywny wyraz w art. 26 Konwencji wiedeńskiej o prawie traktatów ${ }^{837}$, a która wyrażona jest również w art. 9 Konstytucji ${ }^{838}$.

W aktualnym stanie prawnym należy więc stwierdzić, że nie występuje niezgodność z unijnym prawem pierwotnym a Konstytucją RP, a jeśli pojawiłaby się ona w przyszłości, to istnieją mechanizmy umożliwiające jej wyeliminowanie - poprzez zmianę Konstytucji, nieprzyjęcie zmian prawa pierwotnego czy wpływ na modyfikację tych zmian, tak aby niezgodności nie było. Czym innym natomiast może być kwestia prowadzącego do sprzeczności z Konstytucją stosowania pierwotnego prawa unijnego, które mogłoby urosnąć do działania ultra vires ze strony instytucji i organów Unii. Jest to problematyka od dawna obecna w orzecznictwie sądów konstytucyjnych państw członkowskich UE ${ }^{839}$. W pracy tej uwaga poświęcona jest co do zasady prawidłowemu stosowaniu unijnego prawa pierwotnego w zakresie ochrony praw człowieka, a więc zgodnego z zawartymi w Karcie gwarancjami praw i wolności człowieka, które mimo to w zakresie zastosowania Karty - a więc poprzez bezpośrednio skuteczne prawo pochodne czy też wymogi wobec mieszczącego się w zakresie zastosowania prawa unijnego prawa krajowego - może, ze względu na rozumienie art. 53 Karty, jakie w swym orzecznictwie zawarł TSUE (co będzie szczegółowo omówione w następnym rozdziale), prowadzić do podważenia wyższego niż unijny konstytucyjnego standardu ochrony praw człowieka. Metoda rozwiązania takiego potencjalnego konfliktu, której istota zaprezentowana zostanie $\mathrm{w}$ następnym rozdziale, również ma być, zdaniem autora, z unijnym prawem pierwotnym zgodna i mieścić się w jego aktualnym kształcie, co według autora ma być jedną z jej najważniejszych zalet.

\footnotetext{
${ }^{835}$ K. Wójtowicz, Sady konstytucyjne..., s. 62.

${ }^{836}$ Por.: ibidem, s. 65 i nast.

${ }^{837}$ Konwencja wiedeńska o prawie traktatów sporządzona w Wiedniu 23 maja 1969, Dz.U. nr 74 (załącznik), poz. 439 .

${ }^{838}$ K. Wójtowicz, Art. 9..., s. 328; P. Sarnecki, Artykuł 9, [w:] L. Garlicki, M. Zubik (red.), Konstytucja Rzeczpospolitej Polskiej. Komentarz, t. 1, Warszawa 2016, s. 325.

${ }^{839}$ Więcej - patrz np.: K. Wójtowicz, Sądy konstytucyjne..., s. 95 i nast.
} 


\subsection{Kontrola konstytucyjności prawa polskiego mieszczącego się w zakresie zastosowania prawa unijnego}

\subsubsection{Prawo polskie mieszczące się w zakresie zastosowania prawa unijnego jako prawo polskie tout court}

Gdy chodzi o kontrolę konstytucyjności prawa polskiego mieszczącego się w zakresie prawa unijnego, to w kategoriach ogólnych należy stwierdzić, jak można było to już zauważyć, kiedy była mowa o stosowaniu Karty przez TK, że Trybunał traktuje, a przynajmniej przez wiele lat traktował, takie prawo i jego kontrolę jako coś normalnego i ignorował kontekst unijny. „Ustawy i rozporządzenia implementujące prawo pochodne Unii Europejskiej są uważane przez polski Trybunał Konstytucyjny za akty normatywne będące dziełem wyłącznie krajowego prawodawcy. W związku z tym podlegają one pełnej kontroli konstytucyjności, zarówno co do trybu dojścia do skutku, jak i postanowień merytorycznych" ${ }^{840}$. Dotyczy to zarówno aktów implementacyjnych, w których implementacja sprowadza się do powtórzenia regulacji zawartych w przepisach implementowanych, jak i takich aktów implementacyjnych, co do których prawodawstwo unijne pozostawiło swobodę państwom członkowskim. W pewnym zakresie sytuacja ta uległa modyfikacji wraz z pierwszym pytaniem prejudycjalnym, jakie TK skierował do TSUE, o którym będzie mowa w dalszej części tego rozdziału. Co do zasady jednak w orzecznictwie TK dominuje podejście, że skoro przepisy takie podlegają pełnej kontroli konstytucyjności, podlegają także kontroli przez pryzmat ich zgodności z konstytucyjnymi gwarancjami praw człowieka. Przez długi czas w orzecznictwie TK odnośnie do prawa polskiego implementującego prawo unijne nie odgrywało większej roli, może poza podkreślanym przekonaniem o najdalej posuniętym $\mathrm{w}$ takich przypadkach zobowiązaniu do dokonywania prounijnej wykładni prawa polskiego, w tym Konstytucji, że „implementacja jest jednym z kluczowych elementów zapewnienia pełnej skuteczności prawa UE"841.

Zagadnienie kontroli konstytucyjności prawa pochodnego, w tym kontroli prawa krajowego implementującego prawo unijne, jest przedmiotem ożywionej dyskusji w doktrynie ${ }^{842}$. Niejednolite jest też podejście do tych kwestii są-

840 J. Maśnicki, Kontrola konstytucyjności instrumentów implementujących prawo pochodne Unii Europejskiej, „Państwo i Prawo” 2015, z. 6, s. 67.

${ }^{841}$ Ibidem; por. też np.: F. Snyder, The Effectiveness of European Community Law: Institutions, Processes, Tools and Techniques, "The Modern Law Review" 1993, nr 56 (1), s. 21.

${ }^{842}$ Patrz np.: A. Chmielarz, Kontrola konstytucyjności prawa pochodnego Unii Europejskiej, "Przegląd Sejmowy" 2012, nr 4 (111); D. Leczykiewicz, "Effective Judicial Protection" of Human Rights After Lisbon: Should National Courts be Empowered to Review EU Secondary Law?, "European Law Review" 2010, nr 3, s. 326-348; M. Olszówka, A. Zinkiewicz, Kompetencje Trybunału Konstytucyj- 
dów konstytucyjnych państw członkowskich ${ }^{843}$. Stąd poniżej zostanie jedynie zarysowane stanowisko polskiego TK odnośnie do kontroli prawa polskiego, implementującego prawa Unii, w kontekście tego, co najważniejsze dla tematu tej pracy.

Trybunał wielokrotnie dawał wyraz temu, że jego podstawową funkcją ustrojową jest badanie zgodności aktów normatywnych z Konstytucją, a obowiązek ten obejmuje także sytuację, gdy zarzut niekonstytucyjności dotyczy tego zakresu ustawy, który służy implementacji prawa UE. „TK stoi na stanowisku, że posiada pełne instrumentarium prawne do dokonania kontroli konstytucyjności ustaw i rozporządzeń implementujących, bez względu na ich częściowo unijny charakter"844. Uważa się więc za właściwy do dokonywania takiej kontroli. Po raz pierwszy dał temu wyraz przy okazji kontroli zgodności z Konstytucją RP regulacji związanych z ENA, co ostatecznie zakończyło się nowelizacją ustawy zasadniczej tak, aby ENA mógł być zgodny z Konstytucją ${ }^{845}$. TK dokonywał w tej sprawie kontroli zgodności z Konstytucją prawa polskiego, które zostało zmienione w celu implementacji wydanej przez Radę UE decyzji ramowej regulującej ENA ${ }^{846}$. Decyzje ramowe w ówczesnym tzw. trzecim filarze stanowiły odpowiednik dyrektyw i konieczna była ich implementacja do porządków krajowych. W związku z tym doszło do zmiany Kodeksu postępowania karnego ${ }^{847} \mathrm{w}$ zakresie, $\mathrm{w}$ jakim zezwolił on na przekazanie obywatela polskiego do państwa członkowskiego Unii na podstawie ENA. Pojawił się na tym tle zarzut niezgodności z art. 55 Konstytucji, zakazującym ekstradycji polskich obywateli.

TK potwierdził przy okazji tego wyroku jedną z najważniejszych zasad, na jakich winna jego zdaniem opierać się relacja między prawem unijnym a prawem polskim w ogóle, a która jest istotna dla omawianej w tej pracy problematyki i która wypełnia treścią konstytucyjną zasadę przychylności procesowi integracji wyprowadzoną przez TK z preambuły i art. 9 Konstytucji ${ }^{848}$, jaką jest zasada prounijnej wykładni prawa polskiego. W szerszym kontekście, obo-

nego w zakresie orzekania w sprawie konstytucyjności prawa Unii Europejskiej, [w:] D. Harasimiuk, M. Olszówka, A. Zinkiewicz (red.), Prawo Unii Europejskiej i porzadek konstytucyjny państw członkowskich. Problem konkurencji i wzajemnych relacji, Warszawa 2014, s. 72-82; J. Maśnicki, Kontrola konstytucyjności....

${ }^{843}$ Patrz np.: J. Maśnicki, Kontrola konstytucyjności..., s. 72-77.

${ }^{844}$ Ibidem, s. 73.

${ }^{845}$ TK, sprawa P 1/05, wyrok z 27 kwietnia 2005.

${ }^{846}$ Decyzja ramowa Rady z 13 czerwca 2002 w sprawie europejskiego nakazu aresztowania i procedury wydawania osób między Państwami Członkowskimi, Dz.Urz. L 190 z 18 lipca 2002 ze zm.

${ }^{847}$ Ustawa z dnia 6 czerwca 1997 Kodeks postępowania karnego, Dz.U. nr 89, poz. 555 ze zm.

${ }^{848}$ TK, sprawa K 11/o3, wyrok z 27 maja 2003; por. też: K. Wójtowicz, Traktat..., s. 507. 
wiązek ten wiąże się ściśle ze znaną z orzecznictwa luksemburskiego zasadą pośredniego skutku prawa unijnego ${ }^{849}$, zgodnie z którą "sądy krajowe mają obowiązek wykładni prawa wewnętrznego zgodnie z prawem UE. [...] zasada skutku pośredniego nie ma [jednak - przyp. aut.] charakteru absolutnego, tzn. sąd krajowy może odmówić jej zastosowania [szczególnie - przyp. aut.] w przypadku gdy prounijna wykładnia wywoływałaby skutki contra legem ${ }^{\prime \prime 50}$. Obowiązek wykładni prounijnej jest również zakorzeniony w samej Konstytucji, a konkretnie w jej art. 9, który stanowi, że Polska przestrzega wiążących ją umów międzynarodowych. Już na gruncie wyroku w sprawie traktatu akcesyjnego TK stwierdził, że norma zakodowana w art. 9 Konstytucji "wyraża jedną $\mathrm{z}$ istotnych cech polskiego porządku konstytucyjnego, którą jest internacjonalizacja systemu krajowego, rozumiana szerzej jako obowiązek zapewnienia odpowiednich warunków w systemie prawnym dla możliwie pełnego urzeczywistnienia i stosowania obowiązujących norm prawa międzynarodowego" ${ }^{151}$. Warto jednak podkreślić, że wykładnię przyjazną prawu unijnemu TK stosował w swym orzecznictwie jeszcze wcześniej, nawet przed przystąpieniem Polski do Unii ${ }^{852}$.

Wagę prounijnej wykładni, szczególnie odnośnie do prawa polskiego będącego przejawem implementacji prawa unijnego, co, jak dostrzega to TK, prowadzi do tego, że sprawa taka ma "charakter unijny", TK podkreślał wielokrotnie również w swym późniejszym orzecznictwie ${ }^{853}$. Należy wszakże pamiętać, że TK silnie akcentuje z drugiej strony, że „obowiązek prounijnej wykładni prawa krajowego ma swoje granice - nota bene wskazane przez sam Europejski Trybunał Sprawiedliwości - a mianowicie kiedy to jej skutkiem byłoby pogorszenie położenia jednostek, a zwłaszcza wprowadzenie lub zaostrzenie odpowiedzialności karnej" ${ }^{\prime \prime 54}$. TK wskazał jej granice, szczególnie na gruncie orzeczeń dotyczących akcesji i Traktatu lizbońskiego. Nie wchodząc w tym miejscu w szczegóły ${ }^{855}$, należy pamiętać, że TK przesądził, iż wykładnia prounijna nie może prowadzić również do wyników sprzecznych z wyraźnym brzmieniem norm

${ }^{849}$ Po raz pierwszy do przedmiotowej zasady TSUE odniósł się: TSUE, Sabine von Colson i Elisabeth Kamann p. Land Nordrhein-Westfalen, C-14/83, wyrok z 10 kwietnia 1984.

850 B. Capik, A. Łazowski, Art. 91. [Pierwszeństwo ratyfikowanej umowy przed ustawami], [w:]

M. Safjan, L. Bosek (red.), Konstytucja. Komentarz, t. II, Warszawa 2016, s. 168.

${ }^{851}$ M. Safjan, Wprowadzenie..., s. 106.

${ }^{852}$ Patrz np.: TK, sprawa 33/o3, wyrok z dnia 21 kwietnia 2004.

${ }^{853}$ Patrz np.: TK, sprawa P 40/13, wyrok z 21 kwietnia 2015, pkt III 4.2 uzasadnienia, lecz także inne, również te wymienione w: M. Safjan, Wprowadzenie..., s. 105-106.

${ }^{854} \mathrm{TK}$, sprawa P 1/O5, wyrok z 27 kwietnia 2005, pkt III 3.3 uzasadnienia.

${ }^{855}$ Więcej - patrz np.: M. Safjan, Konstytucja a Karta Praw Podstawowych. Dylematy wyboru właściwego standardu ochrony, [w:] P. Radziewicz, J. Wawrzyniak (red.), Konstytucja, rzą, parlament: ksiegga jubileuszowa Profesora Jerzego Ciemniewskiego, Warszawa 2014, s. 306-311; por. także: A. Mączyński, J. Podkowik, Art. 188..., s. 1145. 
konstytucyjnych i niemożliwych do uzgodnienia z minimum funkcji gwarancyjnych realizowanych przez Konstytucję $\mathrm{RP}^{856}$, a także, że nie może prowadzić chociażby pośrednio - do naruszenia tożsamości konstytucyjnej państwa ${ }^{857}$.

W sprawie P 1/o5 TK nie znalazł wyjścia, a więc takiej dopuszczalnej prounijnej wykładni, które umożliwiłoby mu orzeczenie zgodności przepisów Kodeksu postępowania karnego $\mathrm{w}$ zakresie, $\mathrm{w}$ jakim zezwalały one na przekazanie obywatela polskiego do państwa członkowskiego Unii na podstawie ENA $\mathrm{z}$ art. 55 Konstytucji w ówczesnym jego brzmieniu ${ }^{858}$. W związku z tym stwierdził ich niezgodność $z$ tym przepisem ${ }^{859}$. TK rozważył różne konsekwencje takiego orzeczenia - szczególnie te związane z nieprzestrzeganiem przez Polskę wiążącego ją prawa międzynarodowego (i.e. unijnego) - i doszedł ostatecznie do wniosku, że najbardziej pożądanym rozwiązaniem byłaby zmiana Konstytucji, taka, aby ENA i związane z nim zobowiązania ciążące na Polsce były z nią zgodne. W celu umożliwienia takiego stanu rzeczy TK skorzystał z przysługującego mu prawa do odroczenia skutków swego wyroku, dając tym samym czas parlamentowi na przeprowadzenie rzeczonej zmiany. Jak stwierdził:

Odroczenie terminu utraty mocy obowiązującej art. 6o7t § 1 k.p.k. ma ten skutek, że w okresie 18 miesięcy od ogłoszenia wyroku Trybunału Konstytucyjnego przepis ten (o ile wcześniej nie zostanie uchylony bądź zmieniony przez ustawodawcę), mimo że obalone w stosunku do niego zostało domniemanie konstytucyjności, winien być stosowany przez wymiar sprawiedliwości. Sądy polskie nie mogą więc odmawiać przekazania obywateli polskich ściganych ENA ${ }^{860}$.

Odroczenie wyroku TK powiązał także z obowiązkami, jakie ciążą na Polsce w związku z członkostwem w Unii. TK podkreślił, że „w okresie odroczenia wejścia w życie wyroku państwo polskie wypełnia obowiązek implementacji decyzji ramowej" 861 .

Zauważył także, że: „Zmiana konstytucji od lat stosowana bywa jako niezbędny środek zapewniający skuteczność prawu UE w krajowych porządkach

${ }^{856}$ TK, sprawa K 18/o4, wyrok z 11 maja 2005, pkt III 6.4 uzasadnienia.

857 TK, sprawa K 32/o9, wyrok z 24 listopada 2010; TK, sprawa P 4/14, wyrok z dnia 11 marca 2015, pkt III 4.5 uzasadnienia; więcej - patrz np.: M. Laskowska, M. Taborowski, Obowiazzek wykładni przyjaznej prawu Unii Europejskiej - między otwartościa na proces integracji a ochroną tożsamości konstytucyjnej, [w:] S. Dudzik, N. Półtorak (red.), Prawo Unii Europejskiej a prawo konstytucyjne państw członkowskich, Warszawa 2013.

858 "1. Ekstradycja obywatela polskiego jest zakazana. 2. Zakazana jest ekstradycja osoby podejrzanej o popełnienie bez użycia przemocy przestępstwa z przyczyn politycznych. 3. W sprawie dopuszczalności ekstradycji orzeka sąd" (Konstytucja RP, Dz.U. 1997, nr 78, poz. 483).

${ }_{859}$ TK, sprawa P 1/05, wyrok z dnia 27 kwietnia 2005, pkt III 4.4 uzasadnienia.

${ }^{860}$ Ibidem, pkt III 5.4 uzasadnienia.

${ }^{861} \mathrm{Ibidem}$, pkt III 5.2 uzasadnienia. 
prawnych państw członkowskich"862 oraz wskazał kilka przykładów takich precedensów w państwach członkowskich ${ }^{863}$. Ostatecznie w wyniku zmiany art. $55^{864}$ Konstytucji przepisy dotyczące ENA mogły pozostać w obiegu prawnym bez zmian i bez negatywnych konsekwencji dla Polski, jakie wiązałyby się z ich usunięciem z polskiego porządku prawnego, w związku z ich niezgodnością z Konstytucja, a także bez konieczności zmiany regulacji dotyczących ENA, która to możliwość też była wskazywana jako jedno z potencjalnych rozwiązańn $^{865}$, zgodnie z zarysowaną już na gruncie wyroku dotyczącego akcesji zasada, że w razie niezgodności prawa unijnego z prawem krajowym istnieją co do zasady trzy możliwe rozwiązania sytuacji: zmiana Konstytucji, zmiana prawa unijnego oraz wystąpienie Polski z Unii. W uzasadnieniu do wyroku TK w sprawie akcesji stwierdził jednoznacznie:

Taka sprzeczność nie może być w polskim systemie prawnym w żadnym razie rozwiązywana przez uznanie nadrzędności normy wspólnotowej w relacji do normy konstytucyjnej. Nie mogłaby też prowadzić do utraty mocy obowiązującej normy konstytucyjnej i zastąpienia jej normą wspólnotową ani do ograniczenia zakresu stosowania tej normy do obszaru, który nie został objęty regulacją prawa wspólnotowego. $\mathrm{W}$ takiej sytuacji do polskiego ustawodawcy należałoby podjęcie decyzji albo o zmianie Konstytucji, albo o spowodowaniu zmian w regulacjach wspólno-

${ }^{862}$ Ibidem, pkt III 5.7 uzasadnienia.

${ }^{863}$ Ibidem, pkt III 5.7 uzasadnienia.

${ }^{864}$ Uzyskał on brzmienie: „1. Ekstradycja obywatela polskiego jest zakazana, z wyjątkiem przypadków określonych w ust. 2 i 3.

2. Ekstradycja obywatela polskiego może być dokonana na wniosek innego państwa lub sądowego organu międzynarodowego, jeżeli możliwość taka wynika z ratyfikowanej przez Rzeczpospolitą Polską umowy międzynarodowej lub ustawy wykonującej akt prawa stanowionego przez organizację międzynarodowa, której Rzeczpospolita Polska jest członkiem, pod warunkiem że czyn objęty wnioskiem o ekstradycję:

1) został popełniony poza terytorium Rzeczypospolitej Polskiej, oraz

2) stanowił przestępstwo według prawa Rzeczypospolitej Polskiej lub stanowiłby przestępstwo według prawa Rzeczypospolitej Polskiej w razie popełnienia na terytorium Rzeczypospolitej Polskiej, zarówno w czasie jego popełnienia, jak i w chwili złożenia wniosku.

3. Nie wymaga spełnienia warunków określonych w ust. 2 pkt 1 i 2 ekstradycja mająca nastąić na wniosek sądowego organu międzynarodowego powołanego na podstawie ratyfikowanej przez Rzeczpospolitą Polską umowy międzynarodowej, w związku z objętą jurysdykcją tego organu zbrodnią ludobójstwa, zbrodnią przeciwko ludzkości, zbrodnią wojenną lub zbrodnią agresji.

4. Ekstradycja jest zakazana, jeżeli dotyczy osoby podejrzanej o popełnienie bez użycia przemocy przestępstwa z przyczyn politycznych lub jej dokonanie będzie naruszać wolności i prawa człowieka i obywatela.

5. W sprawie dopuszczalności ekstradycji orzeka sąd". [art. $55 \mathrm{w}$ brzmieniu ustawy z dnia 8 września 2006 (Dz.U. nr 200, poz. 1471), która weszła w życie dnia 7 listopada 2006].

865 TK, sprawa P 1/o5, wyrok z dnia 27 kwietnia 2005, pkt II 5 uzasadnienia. 
towych, albo - ostatecznie - decyzji o wystąpieniu z Unii Europejskiej. Decyzję tę winien podjać suweren, którym jest Naród Polski, lub organ władzy państwowej, który w zgodzie z Konstytucją może Naród reprezentować ${ }^{866}$.

Stanowisko w przedmiocie dopuszczalności kontroli konstytucyjności prawa polskiego mieszczącego się w zakresie zastosowania prawa unijnego zostało przez TK powtórzone $\mathrm{w}$ wyroku z 2 lipca 2007, we wspominanej już w kontekście stosowania przez TK KPP sprawie, w której badał on regulacje krajowe o przeciwdziałaniu praniu brudnych pieniędzy, które zostały wprowadzone w celu implementacji prawa unijnego w tej materii. TK stwierdził przy tym, że:

Zważywszy kontekst prawa wspólnotowego, w jakim osadzone są przepisy ustawy o przeciwdziałaniu praniu pieniędzy, należy przypomnieć, że zgodnie ze stanowiskiem Trybunału Konstytucyjnego w pełnym składzie, zajętym w sprawie o sygn. P 1/o5, implementacja wtórnego prawa Wspólnot Europejskich jest wymogiem wynikającym z art. 9 Konstytucji, jednak jego realizacja nie zapewnia automatycznie i w każdym wypadku materialnej zgodności przepisów tego prawa wtórnego oraz ustaw je implementujących do prawa krajowego z normami Konstytucji. Podstawową funkcją ustrojową Trybunału Konstytucyjnego jest badanie zgodności aktów normatywnych z Konstytucją, a obowiązek ten odnosi się także do sytuacji, gdy zarzut niekonstytucyjności dotyczy tego zakresu ustawy, który służy implementacji prawa wspólnotowego ${ }^{867}$.

Trybunał ponownie doszedł więc do wniosku, potwierdzając aktualność swego wcześniejszego orzecznictwa w tej materii, że „również na gruncie niniejszej sprawy, [...] zakwestionowane przepisy ustawy o przeciwdziałaniu praniu pieniędzy, stanowią - niezależnie od ich implementacyjnego charakteru - dopuszczalny przedmiot kontroli konstytucyjności"868.

W wyroku z 3 grudnia 2009 pojawił się problem dopuszczalności kontroli prewencyjnej ustaw implementujących prawo pochodne UE. Nie odstępując od swej wcześniejszej linii orzeczniczej, TK pokreślił w tej sprawie, że „nie ulega wątpliwości, że przepisy implementujące prawo UE stanowią dopuszczalny przedmiot również w trybie kontroli prewencyjnej - przedmiotem wniosku Prezydenta skierowanego do Trybunału na podstawie art. 122 ust. 3 Konstytucji może być bowiem każda ustawa, która została przedstawiona mu do podpisu" 869 . W październiku 2010 TK wydał wyrok ${ }^{870}$, w którym znowu ba-

${ }^{866}$ TK, sprawa K 18/o4, wyrok z 11 maja 2005, pkt III 6.4 uzasadnienia.

867 TK, sprawa K 41/o5, wyrok z 2 lipca 2007, pkt III 5.4 uzasadnienia.

${ }^{868}$ Ibidem, pkt III 3.3 uzasadnienia.

${ }^{869}$ TK, sprawa Kp 8/o9, wyrok z 3 grudnia 2009, pkt I 4 uzasadnienia.

${ }^{870}$ TK, sprawa Sk 26/o8, wyrok z 5 października 2010. 
dał zgodność przepisów implementujących prawo unijne i podtrzymał swoje stanowisko w tej materii, wyraźnie odrzucając głosy wyrażane w doktrynie, jakoby Trybunał nie był kompetentny do kontroli konstytucyjności przepisów będących następstwem implementacji. TK nie sformułował jednak żadnych nowych argumentów w tej materii, lecz dodatkowo powołał się na orzecznictwo sądów konstytucyjnych innych państw członkowskich, które również wypowiedziały się za "za dopuszczalnością kontroli konstytucyjności przepisów wewnętrznych implementujących decyzje ramowe, również w kontekście decyzji ramowej w sprawie europejskiego nakazu aresztowania"871.

Nieco bardziej rozwinięte stanowisko w tej materii TK przedstawił w rozstrzygniętej tydzień później sprawie Kp 1/o9 ${ }^{872}$. Tym razem przedmiotem kontroli była dopuszczalność zawarcia w ustawie upoważnienia do wydania rozporządzenia, którego treść miała mieć charakter blankietowy ${ }^{873}$. Upoważnienie zawarte w ustawie ${ }^{874}$ miało dotyczyć uregulowania przez ministra kwestii związanych z połowem, sprzedażą i wyładunkiem ryb, które wymagają wzmożonej ochrony. Przepis ten miał na celu implementację wymogów dotyczących tych kwestii, które zostały określone w unijnym rozporządzeniu ${ }^{875}$. TK doszedł do wniosku, opierając się na zasadzie niedopuszczalności zawierania w ustawach upoważnień blankietowych do wydania rozporządzenia, że przepis ten jest z Konstytucją niezgodny. TK dostrzegł kontekst unijny w tej sprawie. Podkreślił, że:

kompetencje w zakresie prowadzenia wspólnej polityki rybołówstwa należą wyłącznie do organów Unii Europejskiej. Regulacje prawne Unii Europejskiej odnoszące się do rynku rybnego zawarte są przede wszystkim w rozporządzeniach, które [...] obowiązują wprost i są stosowane bezpośrednio. W wyjątkowych przypadkach i tylko na mocy konkretnych przepisów unijnych zawierających odpowiednie upoważnienia państwa członkowskie mogą wprowadzać odpowiednie regulacje na tym obszarze. W niektórych przypadkach państwa członkowskie zobowiązane są do wprowadzenia określonych krajowych ram instytucjonalnych lub kompetencyjnych, umożliwiających wykonywanie unijnej regulacji prawnej ${ }^{876}$.

Zaskarżona regulacja miała na celu realizację takiego właśnie upoważnienia zawartego we wspomnianym rozporządzeniu unijnym, które zresztą

${ }^{871}$ Ibidem, pkt I 2.1 uzasadnienia.

${ }^{872}$ TK, sprawa Kp 1/o9, wyrok z 13 października 2010.

${ }^{873}$ J. Maśnicki, Kontrola konstytucyjności..., s. 74.

874 Art. 23 ust. 1 ustawy z dnia 5 grudnia 2008 o organizacji rynku rybnego, Dz.U. z 2013 r., poz. 1389 .

875 Rozporządzenie Rady (WE) nr 2371/2002 w sprawie ochrony i zrównoważonej eksploatacji zasobów rybołówstwa w ramach wspólnej polityki rybołówstwa, Dz.Urz. L 358.

${ }^{876} \mathrm{TK}$, sprawa Kp 1/o9, wyrok z 13 października 2010, pkt III 2.1 uzasadnienia. 
zostało w międzyczasie zmienione. TK podkreślił jednak, że nie ma „kompetencji do badania zgodności aktów polskiego prawa stanowionego (w tym także ustaw) z aktami prawnymi prawa stanowionego przez organy Unii Europejskiej (w tym także z rozporządzeniami Rady)" ${ }^{\prime 877}$. Na marginesie można zauważyć, że jednym ze wskazanych w tej sprawie wzorców kontroli był art. 22 Konstytucji, gwarantujący wolność gospodarczą, co wprowadza w tej sprawie problematykę kontroli zakwestionowanych przepisów przez pryzmat zgodności z gwarancjami praw i wolności człowieka - zarówno krajowymi, jak i unijnymi ${ }^{878}$. Tym niemniej, kwestia art. 51 ust. 1 Karty nie pojawiła się w rozważaniach TK, mimo że ta potencjalnie (gdyby obejmował ją wniosek) mogłaby znaleźć w tej sprawie zastosowanie. Nawet jeśli TK nie mógł zbadać zgodności prawa polskiego z unijnym prawem pochodnym, powinien zdawać sobie sprawę, że prawidłowym wzorcem gwarancji praw człowieka dla prawa polskiego mieszczącego się $\mathrm{w}$ zakresie zastosowania prawa unijnego, i to w wysokim stopniu zharmonizowanego, jest właśnie Karta, i odnieść się do niej czy to samodzielnie, czy to zwracając się do TSUE. W podobnym kierunku, jak się wydaje, choć kwestia Karty się w nim nie pojawiła, szło zdanie odrębne sędziego TK Stanisława Biernata, w którym podnosił on decydujące znaczenie dla sprawy przepisów unijnych, a nie krajowych ${ }^{879}$.

W kategoriach ogólnych TK podkreślił w uzasadnieniu do tego wyroku także, że obowiązywanie bezpośrednio skutecznego prawa unijnego „przy zachowaniu pierwszeństwa w przypadku kolizji z ustawami, nie uchyla wynikającej z Konstytucji kompetencji Trybunału Konstytucyjnego do orzekania o niezgodności zaskarżonego przepisu ustawy z Konstytucją. Nie uchyla obowiązku Trybunału zbadania zgodności zaskarżonego przepisu ustawy z Konstytucją"880. TK wyraźnie rozgraniczył więc dwie sfery, jakimi są: po pierwsze sądowe stosowanie prawa, gdzie w razie sprzeczności z prawem unijnym sądy

${ }^{877}$ Ibidem, pkt III 5 uzasadnienia.

${ }^{878} \mathrm{O}$ wolności działalności gospodarczej w kontekście konstytucyjnych i unijnych gwarancji praw człowieka patrz np.: M. Szydło, Art. 22. [Dopuszczalność ograniczenia wolności dziatalności gospodarczej], [w:] M. Safjan, L. Bosek (red.) Konstytucja RP. Komentarz, t. 1, Warszawa 2016, s. 599-601.

${ }^{879}$ Nota bene, sędzia Biernat nie wypowiedział się w tym zdaniu odrębnym co do możliwości zastosowania Karty ani w kwestii możliwości kontroli prawa polskiego przez pryzmat zgodności z prawem unijnym w tym, co przede wszystkim istotne z perspektywy tej pracy, z Kartą. Podkreślił on: „W sprawie nie chodzi o zgodność prawa unijnego z prawem polskim ani odwrotnie - zgodność prawa polskiego z prawem unijnym. Prawo unijne służy tu jedynie prawidłowemu określeniu zakresu i treści norm prawnych wyznaczających dopuszczalność ograniczeń konstytucyjnej wolności gospodarczej i wymagań stawianych normom ustawowym" (TK, sprawa Kp 1/o9, wyrok z 13 października 2010, zdanie odrębne Sędziego TK Stanisława Biernata, pkt 5).

${ }^{880} \mathrm{TK}$, sprawa Kp 1/o9, wyrok z 13 października 2010, pkt III 5 uzasadnienia. 
nie powinny stosować prawa krajowego z ustawami włącznie, oraz po drugie, kontrola konstytucyjności prawa polskiego, w tym ustaw mieszczących się w zakresie prawa unijnego, które TK może kontrolować przez pryzmat zgodności z Konstytucją. Takie rozgraniczenie ma istotne znaczenie dla kwestii stosowania unijnych praw podstawowych. W pewnym sensie oddala ono potencjalny konflikt między polskim a unijnym standardem tych praw poprzez opisaną w poprzednim rozdziale w związku z wyrokami w sprawach Melki i Abdeli oraz A. p. B., rolę w tej materii sądów krajowych. Nawet jeśli bowiem TK utrzymałby jakiś przepis krajowy mieszczący się w zakresie zastosowania prawa unijnego w mocy, to sądy i tak mogłyby go nie stosować, jako sprzecznego $\mathrm{z}$ prawem unijnym, $\mathrm{w}$ tym $\mathrm{z}$ unijnymi prawami podstawowymi.

Linię orzeczniczą dotyczącą swej kompetencji do kontroli konstytucyjności prawa krajowego mieszczącego się w zakresie zastosowania prawa unijnego TK podtrzymał w wyroku z 30 lipca $2014^{881}$, który był już przywoływany w kontekście stosowania przez TK Karty. Należy zauważyć, że zaskarżone $\mathrm{w}$ tej sprawie liczne przepisy ustawowe, które dotyczyły udostępniania danych telekomunikacyjnych, nie stanowiły przepisów, które wydane były w celu transpozycji dyrektywy UE ${ }^{882}$, tym niemniej, jak podkreślił to sam TK, pozostawały z nią "w funkcjonalnym związku" ${ }^{\prime \prime 83 . ~ M o z ̇ n a ~ w ~ t y m ~ m i e j s c u ~ z a u w a z ̇ y c ́, ~}$ że pamiętając orzecznictwo TSUE w przedmiocie zastosowania Karty na podstawie jej art. 51 ust. 1, należałoby to uznać za wystarczający łącznik z prawem unijnym dla jej zastosowania. Tym niemniej, zgodnie z zaznaczonym przy okazji omawiania poprzedniego wyroku TK i zgodnie z zarysowanym w poprzednim rozdziale podziałem ról między sądami TK, TSUE i sądami, stosowanie sensu stricto Karty należy uznać za domenę tych ostatnich. Do kwestii tej wrócimy jeszcze za chwilę. Jeśli zaś chodzi o wyrok w sprawie K 23/11, to należy zauważyć, że jeszcze przed wydaniem wyroku przez TK, TSUE stwierdził nieważność wspomnianej dyrektywy ${ }^{884}$. Fakt ten został odnotowany przez TK, który zaznaczył, że orzeczenie TSUE stanowi dla niego "tło decyzyjne" 885 . TK stwierdził w związku z tym dość enigmatycznie, że skoro: „Zakwestionowane w niniejszej sprawie przepisy ustawowe regulujące przesłanki udostęp-

${ }^{881}$ TK, sprawa K 23/11, wyrok z 30 lipca 2014.

${ }^{882}$ Dyrektywa 2006/24/WE Parlamentu Europejskiego i Rady z dnia 15 marca 2006 w sprawie zatrzymywania generowanych lub przetwarzanych danych w związku ze świadczeniem ogólnie dostępnych usług łączności elektronicznej lub udostępnianiem publicznych sieci łączności oraz zmieniająca dyrektywę 2002/58/WE, Dz.Urz. L 105.

${ }_{883}$ TK, sprawa K 23/11, wyrok z 30 lipca 2014, pkt I 3.2.3 uzasadnienia.

884 TSUE, Digital Rights Ireland Ltd p. Minister for Communications, Marine and Natural Resources i inni oraz Kärntner Landesregierung i inni, C-293/12 i C-594/12, wyrok z 8 kwietnia 2014.

${ }^{885}$ TK, sprawa K 23/11, wyrok z 30 lipca 2014, pkt I 3.2.3 uzasadnienia. 
niania właściwym służbom zatrzymanych danych telekomunikacyjnych nie stanowią bezpośrednio implementacji dyrektywy (...) [to] wyrok TSUE (...) nie wiąże zatem bezpośrednio Trybunału Konstytucyjnego w procedurze kontroli konstytucyjności przepisów krajowych" ${ }^{\prime 886}$. Może się zrodzić więc pytanie, jakie konsekwencje dla TK i jego swobody decyzyjnej miałby fakt, że badane przez niego przepisy byłyby wydane w celu transpozycji prawa unijnego? Choć brak odpowiedzi wprost, to interesującej nas w tym miejscu materii TK powtórzył raz jeszcze, utrwalając przyjętą przez siebie linię orzeczniczą, że: „Zarówno w trakcie obowiązywania, jak i po uchyleniu dyrektywy Trybunał [Konstytucyjny - przyp. aut.] ma kognicję do kontroli konstytucyjności obowiązujących przepisów prawa polskiego mających związek z implementacją prawa UE" 887 . Nie należy więc tego wyroku traktować jako zapowiedzi zmiany podejścia TK do tej kwestii.

\subsubsection{Prawo polskie transponujące prawo unijne a znaczenie unijnych wzorców kontroli. Pierwsze pytanie prejudycjalne skierowane przez TK do TSUE}

Pewną nowość w podejściu TK do prawa polskiego wydanego w celu implementacji prawa pochodnego Unii można dostrzec w postanowieniu TK we wspominanej już sprawie skierowanej doń przez RPO, dotyczącej regulacji podatku VAT. Sprawa ta jest po pierwsze przełomowa, jeśli chodzi o sam fakt zastosowania przez TK procedury pytania prejudycjalnego do TSUE, w ramach której wystąpił on w roli sądu pytającego. Uczynił to po raz pierwszy, po ponad jedenastu latach członkostwa Polski w Unii i w pewnym sensie wpisał się w ten sposób w tendencję wzrostu zaufania i współpracy między TSUE a sądami konstytucyjnymi państw członkowskich, które stopniowo przełamują swoją niechęć do kierowania pytań prejudycjalnych do Luksemburga. W ostatnich latach z takimi pytaniami zwróciły się nawet takie spośród nich, które wcześniej otwarcie taką możliwość wykluczały ${ }^{888}$. Nota bene TK nigdy tak niechętnego tej procedurze ze swoim udziałem stanowiska nie prezentował, przeciwnie - już od wyroku w sprawie traktatu akcesyjnego ${ }^{889}$ podkreślał dopuszczalność takiej ewentualności ${ }^{890}$. Co więcej sprawa

${ }^{886}$ Ibidem, pkt I 3.2.3 uzasadnienia.

${ }^{887}$ Ibidem, pkt I 3.2.4 uzasadnienia.

${ }^{888}$ A. Kustra, The First...; więcej na temat praktyki sądów konstytucyjnych państw członkowskich w przedmiocie pytań prejudycjalnych do TSUE patrz np.: K. Wójtowicz, Sądy konstytucyjne..., s. 129-146.

${ }^{889}$ TK, sprawa K 18/o4, wyrok z 11 maja 2005, pkt III 11.1 uzasadnienia.

${ }^{890}$ Więcej na ten temat patrz np.: K. Wójtowicz, Sądy konstytucyjne..., s. 145-146. 
ta stanowi również pewien przełom, jeśli chodzi o podejście do prawa polskiego, implementującego, a więc mieszczącego się w zakresie zastosowania prawa unijnego.

Sprawa dotyczy zbadania zgodności z Konstytucja, w tym z zawartymi w niej gwarancjami praw i wolności jednostki (zasadą równości) przepisów załącznika do ustawy z dnia 11 marca 2004 roku o podatku od towarów i usług w związku z przepisami tej ustawy w zakresie, w jakim wyłączają stosowanie obniżonych stawek podatku do książek wydawanych w formie cyfrowej i innych publikacji elektronicznych, podczas gdy takie stawki są stosowane do książek wydanych w formie fizycznej (czy to na papierze, czy na jakimś innym nośniku ${ }^{891}$. Jako że przepisy te zostały wydane w celu transpozycji prawa unijnego, TK zdecydował się skierować w tej materii dwa pytania prejudycjalne, w których wnosi o zweryfikowanie ważności przepisów dyrektywy, podnosząc zarzuty jej niezgodności z prawem unijnym ${ }^{892}$. Jak podsumowuje Stanisław Biernat:

Wątpliwości Trybunału są dwojakie. Po pierwsze, TK zakwestionował zachowanie $\mathrm{w}$ procesie legislacyjnym istotnego wymogu proceduralnego, jakim była konsultacja z Parlamentem Europejskim. Rzecz w tym, że projekt dyrektywy został zaakceptowany przez Parlament, ale następnie został zmieniony (zdaniem TK: istotnie), ale już bez udziału Parlamentu w procedurze. Po drugie, TK zarzucił przepisom dyrektywy naruszenie zasady neutralności podatkowej wskutek zastosowania różnych stawek podatkowych do książek dostarczanych drogą elektroniczną i książek na nośnikach fizycznych. Natomiast - jak argumentuje TK - książki obu rodzajów są podobne: mają analogiczne właściwości i zaspokajają te same potrzeby konsumenta; są też wzajemnie konkurencyjne ${ }^{893}$.

${ }^{891}$ Poz. 72-75 załącznika nr 3 do ustawy z dnia 11 marca 2004 r. o podatku od towarów i usług (Dz.U. z 2011 r. nr 177, poz. 1054 ze zm.) w związku z art. 41 ust. 2 tej ustawy oraz poz. 3235 załącznika nr 10 do tej ustawy w związku z art. 41 ust. 2a tej ustawy.

892 "1) Czy pkt 6 załącznika III do dyrektywy Rady 2006/112/WE z dnia 28 listopada 2006 r. w sprawie wspólnego systemu podatku od wartości dodanej (Dz.Urz. L 347 z 11.12.2006, s. 1, ze zm.), w brzmieniu zmienionym przepisami dyrektywy Rady 2009/47/WE z dnia 5 maja 2009 r. zmieniającej dyrektywę 2006/112/WE w zakresie stawek obniżonych podatku od wartości dodanej (Dz.Urz. L 116 z 9.05.2009, s. 18) jest nieważny, ponieważ w procesie prawodawczym naruszono istotny wymóg proceduralny konsultacji z Parlamentem Europejskim?

2) Czy art. 98 ust. 2 dyrektywy 2006/112/WE powołanej w punkcie 1 w związku z pkt 6 załącznika III do tej dyrektywy jest nieważny, ponieważ narusza zasadę neutralności podatkowej w zakresie, w jakim wyłącza stosowanie obniżonych stawek podatku do książek wydawanych w formie cyfrowej i innych publikacji elektronicznych?" (TK, sprawa K 61/13, postanowienie z 7 lipca 2015).

${ }^{893}$ S. Biernat, Pierwsze pytanie prejudycjalne Trybunału Konstytucyjnego, „Europejski Przegląd Sądowy" 2015, nr 9, s. 1 . 
Jak wyraźnie widać, oba zarzuty sformułowane przez TK mają charakter czysto unijny. TK zakwestionował ważność dyrektywy, zarzucając niezgodność z unijnymi regułami procedury prawodawczej trybu jej dojścia do skutku, a także zarzucając jej niezgodność z materialnymi normami prawa unijnego wyższego rzędu. Należy również podkreślić, że Trybunałowi nie przeszkadzał w skierowaniu pytania do TSUE fakt, że wniosek RPO nie wskazywał wśród wzorców kontroli prawa unijnego. Sam dostrzegł unijny charakter sprawy.

Ponadto należy zauważyć, że TK nawiązał w uzasadnieniu swego postanowienia o skierowaniu pytania prejudycjalnego do omawianej wcześniej sprawy Melki i Abdeli. Zdaniem TK:

Dodatkowo należy wskazać, że zgodnie ze stanowiskiem Trybunału Sprawiedliwości, „jeżeli sąd krajowy rozpoznaje spór dotyczący prawa Unii i uważa, że przepis krajowy jest nie tylko sprzeczny z prawem Unii, ale ponadto niezgodny z konstytucja, to fakt, że stwierdzenie niezgodności z konstytucją przepisu prawa krajowego następuje w drodze obligatoryjnej skargi do trybunału konstytucyjnego, nie pozbawia go uprawnienia lub nie zwalnia z obowiązku - przewidzianych w art. 267 TFUE - polegających na wystąpieniu do Trybunału z pytaniami o wykładnię lub ocenę ważności prawa Unii" $[\ldots]^{894}$.

Jak była o tym mowa wcześniej, zarówno wyrok w sprawie Melki i Abdeli, jak i wyrok w sprawie A. p. B. nakierowane były raczej na określenie pewnych minimalnych uprawnień przysługujących sądom zwykłym w państwach członkowskich $w$ ich relacji do sądów konstytucyjnych w zakresie procedury kontroli konstytucyjności prawa przez ten ostatni w kontekście faktu, że sądy krajowe są również sądami unijnymi w takim sensie, że odpowiadają za stosowanie prawa unijnego w państwach członkowskich i nie mogą przez ewentualne obowiązki związane z tzw. scentralizowaną kontrolą konstytucyjności funkcjonującą w tych państwach być w tej funkcji ograniczone. Skierowanie takiego pytania przez TK mogłoby być pewnego rodzaju próbą naprawienia ewentualnego błędu sądu zwykłego, który z takim pytaniem do TSUE by nie wystąpił, w sytuacji, gdy powinien był to zrobić, a jedynie skierował sprawę do TK (mogłoby to być jedno z rozwiązań mieszczących się w ramach tego, o czym była mowa w wyroku w sprawie A. p. B., kiedy sąd odsyłający twierdził, że sąd konstytucyjny miałby dokonywać kontroli konstytucyjności takich zakwestionowanych przepisów „bez uszczerbku dla możliwości wniesienia pytania prejudycjalnego" ${ }^{\prime \prime 95}$ ). W świetle wspomnianego orzecznictwa TSUE i „dominującego stanowiska doktryny sądy konstytucyjne państw członkow-

${ }^{894} \mathrm{TK}$, sprawa K 61/13, postanowienie z 7 lipca 2015, pkt 3.1.3 uzasadnienia.

895 TSUE, A. p. B. i in., C-112/13, wyrok z 11 września 2014, pkt 25. 
skich - orzekające w sposób ostateczny w sprawach hierarchicznej zgodności norm - mają ograniczoną kompetencję w dokonywaniu wykładni prawa unijnego oraz są zobowiązane do występowania z pytaniami prejudycjalnymi do TSUE, jeśli spełniono warunki określone w m.in. art. 267 TFUE" ${ }^{\prime \prime 96}$. TK obowiązkowi temu się więc podporządkował.

Skierowanie tego pytania do TSUE przez TK może mieć jednak jeszcze szerszy wymiar. Była już mowa o tym, że TK dostrzegł rolę sądów zwykłych w zapewnianiu skuteczności prawa unijnego i związane $z$ tym orzecznictwo TSUE, i zauważył, że sądy te zachowują prawo do niestosowania prawa krajowego, mieszczącego się w zakresie zastosowania prawa unijnego, nawet jeśli TK uzna je za zgodne z Konstytucją i utrzyma w mocy, ale one dojdą do wniosku, przy ewentualnej współpracy z TSUE, o niezgodności tego prawa (ustawowego) z prawem unijnym ciszącym się przymiotem pierwszeństwa. W ten sposób nawet w przypadku utrzymania tego prawa w mocy przez TK, sądy zwykłe mogłyby uczynić zadość unijnym gwarancjom praw człowieka. Co więcej jednak, dzięki zadaniu tego pytania prejudycjalnego, co należy uznać za godną pozytywnej oceny i zgodną z systemowym wymiarem wyroku w sprawie Melki Abdeli i A. p. B., ewolucję podejścia TK w przedmiocie kontroli prawa polskiego, implementującego prawo unijne, TK zapobiegł innemu zagrożeniu dla unijnych gwarancji praw podstawowych. Dzięki zadaniu pytania TK zapobiegł sytuacji, w której TSUE „mógłby zostać pozbawiony możliwości zbadania ważności dyrektywy transponowanej za pomocą tej ustawy z punktu widzenia zgodności z prawem pierwotnym, a w szczególności z prawami podstawowymi chronionymi na mocy Karty" ${ }^{\prime 897}$. Chodzi tu o sytuację, "gdy niezgodność ustawy z konstytucją krajowa, a konkretnie z zawartymi w niej prawami podstawowymi, wynika z naruszenia przez wdrażaną poprzez tę ustawę dyrektywę tych samych praw podstawowych, chronionych w systemie prawa UE" ${ }^{\prime \prime 98}$.

Jak słusznie podkreśla Mirosław Wróblewski, należy zwrócić uwagę, że stwierdzenie przez trybunał krajowy niezgodności z Konstytucją takiej ustawy

mogłoby mieć negatywne skutki - zarówno dla jednolitości i spójności prawa unijnego, jak i dla poziomu ochrony praw podstawowych w całej Unii. Uwagi te należy uzupełnić także o refleksję, że zarówno tezy wyroku w sprawie Melki i Abdeli, jak i do-

${ }^{896}$ A. Mączyński, J. Podkowik, Art. 188..., s. 1133; por. także: A. Kustra, Kelsenowski..., s. 81 i nast.; M. Safjan, Dialog czy konflikt? O relacji Trybunału Sprawiedliwości Unii Europejskiej i sądów konstytucyjnych w dziedzinie zastosowania praw podstawowych, "Zeszyty Naukowe Sądownictwa Administracyjnego" 2015, rok XI, nr 1 (58), s. 75 i nast.; K. Wójtowicz, Sądy konstytucyjne..., s. 65 i nast.

${ }^{897}$ M. Jarosz, Pierwszeństwo kontroli konstytucyjności a prawo UE - uwagi na tle wyroku TS w sprawach Melki i Abdeli, "Europejski Przegląd Sądowy” 2011, nr 8, s. 28.

${ }^{898}$ Ibidem, s. 28. 
tyczące tych wywodów komentarze doktryny, odnoszą się do procedury, w której to odpowiedni sąd krajowy kieruje pytanie prawne do krajowego sądu konstytucyjnego. Logika wywodu TS opiera się na założeniu, że po stwierdzeniu konstytucyjności zaskarżonej ustawy krajowej sąd a quo nie będzie już zainteresowany skierowaniem późniejszego pytania prejudycjalnego do TS. Tymczasem w przypadku wydania orzeczenia przez krajowy sąd konstytucyjny na skutek wniosku abstrakcyjnego (tak jak w przedmiotowej sprawie na skutek wniosku RPO) podmiot wnioskujący nie będzie miał nawet szansy (nie będąc sądem) na późniejsze uruchomienie procedury prejudycjalnej. Odmowa skierowania pytania do TS przez TK skutkowałaby definitywnym pozbawieniem okazji sędziów luksemburskich do potwierdzenia bądź oddalenia zarzutów naruszania praw podstawowych przez przepisy dyrektywy ${ }^{899}$.

Można więc stwierdzić, że TK wsłuchał się w orzecznictwo TSUE, szczególnie w wyrok w sprawie Melki i Abdeli ${ }^{900}$, i zaakceptował

zasadę, zgodnie z którą sądy konstytucyjne państw członkowskich powinny zwracać się do niego z pytaniem prejudycjalnym w kwestii ważności dyrektywy, kiedy rozstrzygają w przedmiocie konstytucyjności ustawy krajowej wdrażającej wiążące przepisy owej dyrektywy, a zarzuty wobec tej ustawy oparte są na prawach podstawowych, chronionych zarówno w prawie krajowym, jak i w prawie unijnym ${ }^{901}$.

Takie podejście doskonale współgra z propozycją sekwencyjnego mechanizmu orzekania i dialogu między TK a TSUE w sytuacji konfliktu między wyższym niż unijny konstytucyjnym standardem ochrony praw człowieka a standardem unijnym powiązanym z zasadami pierwszeństwa, jedności i efektywności prawa unijnego, o czym będzie mowa w następnym rozdziale.

Należy mocno podkreślić, że takie pytania prejudycjalne, jak te skierowane do TSUE przez TK na gruncie sprawy K 61/13 mogą być jedną z metod minimalizacji różnego rodzaju niebezpieczeństw, jakie wiążą się z doktryną co do kontroli konstytucyjności przepisów polskich implementujących prawo unijne, jaką prezentował do tej pory konsekwentnie TK. Uznanie przez TSUE nieważności dyrektyw zdjęłoby z Polski obowiązek jej implementacji i ułatwiłoby kwestię orzeczenia o niezgodności z Konstytucją przepisów krajowych tę dyrektywę implementujących. Można więc uznać kierowanie tego rodzaju pytań za, w pewnym sensie, działanie prewencyjne. $\mathrm{O}$ innej formie takiego prewencyjnego działania będzie mowa przy okazji omawiania wyroku TK w sprawie Sk 45/og, gdzie - jak się wydaje - przyjął on podobną logikę

${ }^{899}$ M. Wróblewski, Karta Praw Podstawowych UE w orzecznictwie Trybunału Konstytucyjnego..., s. 24 .

900 Por.: ibidem.

${ }^{901}$ M. Jarosz, Pierwszeństwo..., s. 29. 
i jeszcze bardziej wprost wyraził jej doniosłość. Należy wszakże podkreślić, że sam fakt skierowania do TSUE pytań w sprawie takiej, jak K 61/13, wcale nie oznacza podważenia opisanej wcześniej linii orzeczniczej TK w przedmiocie jego kompetencji do badania zgodności z Konstytucją przepisów prawa polskiego wydanych w celu implementacji prawa unijnego. TK może bowiem nawet w sytuacji, jaka zaistniała w sprawie K 61/13, a więc w sytuacji utrzymania przez TSUE dyrektywy w mocy ${ }^{902}$, podjąć się kontroli polskich przepisów ją implementujących, zgodnie z ugruntowaną w swym orzecznictwie linią.

Jak w kontekście omawianego postanowienia TK w sprawie K 61/13 słusznie zauważają Andrzej Mączyński i Jan Podkowik:

w razie gdy przedmiotem kontroli jest ustawa implementująca, a zarzut odnosi się do istoty rozwiązania wynikającego z aktu prawa pochodnego, którego wprowadzenie nastąpiło bezpośrednio w związku z obowiązkiem wykonania prawa UE, TK powinien wystąpić do TSUE o zbadanie ważności prawa pochodnego, które zostało implementowane zaskarżoną ustawą [...]. Stwierdzenie ważności przepisów prawa pochodnego nie zamyka natomiast Trybunałowi drogi do zbadania konstytucyjności ustawy. Ewentualne orzeczenie o jej niezgodności z Konstytucją RP uzasadniałoby natomiast skorzystanie z kompetencji wynikającej z art. 190 ust. 3 Konstytucji RP i odroczenie terminu utraty mocy obowiązującej, tak by dać czas właściwym organom na wypracowanie porozumienia w ramach UE lub stosowne zmiany Konstytucji $\mathrm{RP}^{903}$.

Należy jednak podkreślić, że podejście zaprezentowane przez TK na gruncie sprawy K 61/13 może być uznane za pewien zwrot czy też ukłon w stronę TSUE i współpracy z nim, uprawdopodabniający również możliwość skorzystania w przyszłości z jeszcze jednej metody czy też drogi do jak najmniej kolizyjnego rozstrzygania o kwestiach praw człowieka na styku polskiego i unijnego porządku prawnego, jaka zaproponowana zostanie w dalszej części tego rozdziału. Pełna ocena tej sprawy nie jest jednak łatwa. TSUE negatywnie odpowiedział na oba pytania $\mathrm{TK}^{904}$, otwierając pewną przestrzeń dla zaistnienia potencjalnego konfliktu, ten ostatni nie miał jednak okazji się do tego odnieść. Dalsze postępowanie TK był bowiem zmuszony umorzyć ze względu na wycofanie wniosku przez $\mathrm{RPO}^{905} \mathrm{~W}$ związku z pracami nad zmianą unijnych przepisów zmierzającymi do skutków satysfakcjonujących Rzecznika ${ }^{906}$.

902 TSUE, RPO, C-390/15, wyrok z 7 marca 2017.

903 A. Mączyński, J. Podkowik, Art. 188..., s. 1152-1153.

904 TSUE, RPO, C-39o/15, wyrok z 7 marca 2017.

905 TK, sprawa K 61/13, postanowienie z 17 maja 2017.

906 TK, sprawa K 61/13, Stanowisko Rzecznika Praw Obywatelskich z 22 kwietnia 2017 (VII.715.11.2014.AG). 
W obliczu charakteru prawa unijnego, a także w związku z zakresem zastosowania Karty, o czym była mowa wcześniej, należy docenić podejście zaprezentowane przez TK w sprawie K 61/13, które można uznać za przejaw odzwierciedlenia przezeń związku z prawem unijnym prawa krajowego, stanowiącego przejaw implementacji tego pierwszego. Nawet jeśli na razie za wcześnie mówić o zmianie linii orzeczniczej przez TK w przedmiocie zakresu jego kompetencji do kontrolowania prawa polskiego, które służy implementacji prawa unijnego, szczególnie w związku z brakiem jakiejkolwiek swobody po stronie państw członkowskich, jakie prawo implementowane pozostawiło im w tym przypadku, to wydaje się, że postanowienie o skierowaniu w tej sprawie pytania prejudycjalnego do TSUE jest krokiem w kierunku uwzględnienia specjalnego charakteru prawa implementującego i jego związku z prawem Unii, co ma także istotne znacznie dla kwestii stosowania unijnych albo krajowych gwarancji praw człowieka.

\subsubsection{Konsekwencje kontroli konstytucyjności prawa polskiego mieszczącego się $\mathrm{w}$ zakresie zastosowania prawa unijnego dla zgodnego z Kartą stosowania unijnych praw podstawowych}

Podejście TK do prawa polskiego wydanego w celu implementacji prawa unijnego czy też szerzej - do prawa polskiego, które mieści się w zakresie zastosowania prawa unijnego, albo - jak ujął to TK - „pozostaje z nim w funkcjonalnym związku", sprowadza się do tego, że Trybunał traktuje je jak prawo polskie i bada przez pryzmat zgodności z Konstytucja, prawo unijne i orzecznictwo TSUE traktując jedynie jako "tło decyzyjne". W skrajnym przypadku w sytuacji unieważnienia takiego prawa ze względu na niezgodność z Konstytucją mogłyby to doprowadzić do odpowiedzialności Polski za niewykonanie przez nią obowiązków wynikających z prawa unijnego ${ }^{907}$, choć taka sytuacja nie miała do tej pory miejsca. Na potrzeby tej pracy należy natomiast zauważyć, że podejście TK nie niesie ze sobą jakiegoś zasadniczego zagrożenia dla unijnej ochrony praw człowieka odnośnie do takiego prawa w związku z zasadami zastosowania Karty wobec państw członkowskich. O ile bowiem TK unieważniłby takie prawo krajowe, to jego ewentualna niezgodność z unijnymi gwarancjami praw człowieka nie mogłaby zaistnieć (chyba że prawo implementujące miałoby służyć wprowadzeniu do porządku krajowego prawa unijnego, które zmierzałoby do realizacji jakichś praw czy wolności człowieka), a więc co do zasady nie mogłoby ono wprowadzać niedopuszczalnych ograniczeń tych praw. Zagrożenie dla unijnego systemu ochrony praw człowieka minimalizuje się w obliczu

907 Więcej na temat zasady odpowiedzialności państw członkowskich za naruszenie prawa UE patrz np.: B. Capik, A. Łazowski, Art. 91 ..., s. 169 i nast. 
podejścia TK do wniosków wypływających ze sprawy Melki i Abdeli, które zmaterializowały się w pierwszym pytaniu prejudycjalnym TK do TSUE. Gdyby zaś TK nie unieważnił takiego prawa, to zgodnie $\mathrm{z}$ ich rolą $\mathrm{w}$ ramach unijnego systemu ochrony praw człowieka, o której była mowa w poprzednim rozdziale, szczególnie przy okazji omawiania wyroków w sprawach Melki i Abdeli oraz A. p. B., to sądy polskie i tak mogłyby tego prawa nie stosować, gdyby doszły do przekonania, ewentualnie opierając się na współpracy z TSUE w ramach procedury pytania prejudycjalnego, o jego niezgodności z gwarancjami praw podstawowych przewidzianymi w Karcie. Jeszcze raz podkreślić więc należy znaczenie sądów zwykłych dla prawidłowego funkcjonowania unijnego systemu ochrony praw człowieka. Sądy krajowe muszą zdawać sobie sprawę z tej swojej roli i muszą posiąść umiejętność rozróżniania sytuacji, w których zastosowanie powinny znaleźć unijne, a w których krajowe gwarancje praw człowieka, co silnie podkreślono w poprzednim rozdziale.

Co najważniejsze z perspektywy tej pracy i co należy w związku z tym zaakcentować już teraz, korzystając z tej roli nie mogą jednak pozbawiać TK możliwości uczestnictwa w mechanizmie ochrony wyższego niż unijny konstytucyjnego standardu ochrony praw człowieka, o czym będzie mowa w następnym rozdziale, gdy zostanie poruszona ich rola w ramach proponowanej w nim sekwencji orzekania przez TK i TSUE. Jeśli bowiem niestosowałyby prawa krajowego ze względu na to, że spełnia ono wprawdzie minimalny standard unijny, ale w zakresie, w jakim chroni wyższego standardu konstytucyjnego sprzeczne jest z zasadami pierwszeństwa, jedności i efektywności prawa unijnego, to w ten sposób mogłyby naruszyć konstytucyjny standard ochrony praw jednostki i tożsamość konstytucyjną RP. Jeśli stanowiłby on element tego, co można określić tożsamością konstytucyjną RP, to prowadziłoby to do bardzo poważnego naruszenia zarówno Konstytucji, jak i prawa unijnego (art. 4 ust. 2 TUE). Oczywiście w takich sytuacjach sądy krajowe mogłyby same powoływać się na tożsamość konstytucyjną RP w pytaniach prejudycjalnych do TSUE. Jak się jednak wydaje, organem do czynienia tego ze wszech miar najodpowiedniejszym - ze względu na jego pozycję ustrojowa, funkcję i zakres kompetencji określony w Konstytucji, a także najodpowiedniejszą ekspertyzę - jest TK. Sądy krajowe powinny być więc jak najbardziej świadome wszelkich niuansów w stosowaniu unijnych praw podstawowych, o których była mowa wcześniej. Ponadto powinny zdawać sobie sprawę z tego, o czym będzie jeszcze mowa później, że jeśli wyższy niż unijny, sprzeczny z zasadami pierwszeństwa, jedności i efektywności prawa unijnego konstytucyjny standard ochrony jakiegoś prawa czy wolności człowieka może być uznany za element tożsamości konstytucyjnej RP, to zasługuje on na ochronę zarówno na gruncie prawa polskiego, jak i unijnego. 


\subsection{Kontrola konstytucyjności bezpośrednio skutecznego prawa pochodnego UE pod kątem zgodności z konstytucyjnymi gwarancjami praw i wolności jednostki}

Kontrola konstytucyjności pochodnego prawa unijnego, które działa w Polsce bezpośrednio jest zagadnieniem jeszcze bardziej kontrowersyjnym, jeśli chodzi o kompetencję w tej materii po stronie TK. Pochodne prawo unijne nie jest w żadnej mierze prawem polskim. Jest ono stanowione przez Unię w ramach przysługujących jej uprawnień prawodawczych i w ramach określonego w pierwotnym prawie unijnym trybu postępowania. Jako takie, prawo pochodne Unii mieści się w hierarchicznej strukturze prawa unijnego i w jej ramach może być poddawane kontroli zgodności z normami wyższego rzędu, jakie są zawarte w unijnym prawie pierwotnym. Jak zostało to już powiedziane pierwotne prawo unijne, które to właśnie reguluje zakres kompetencji oraz tryb uchwalania prawa pochodnego, jest zgodne z Konstytucją RP, co potwierdził TK, gdy badał zgodność z Konstytucją traktatów akcesyjnego i lizbońskiego. Tym niemniej należy pamiętać, że proces tworzenia prawa pochodnego jest dynamiczny, obejmuje bardzo liczne i złożone kwestie prawne. Korpus prawa pochodnego rozwija się cały czas, a prawo to może być skuteczne w państwach członkowskich bezpośrednio, a więc bez ich udziału implementacyjnego, w ramach którego moga one w różnym stopniu je modyfikować czy dostosowywać do swoich porządków prawnych. Istnieje więc możliwość, że takie prawo pochodne w jakiś sposób naruszy czy też podważy prawo krajowe, w tym Konstytucję. Podstawowa, obecna zarówno w orzecznictwie sądów konstytucyjnych państw członkowskich z niemieckim FTK na czele, a także w doktrynie próba ochrony krajowych porządków prawnych i ich konstytucyjnej struktury przed tego rodzaju zagrożeniami wiąże się z tzw. doktryną ultra vires. Doktryna ta pozostaje jednak głównie tłem (czy raczej zagrożeniem, którego próbuje się uniknąć - „opcją atomową" - która cały czas pozostaje w pamięci jako możliwa do zastosowania przez TK) dla rozważań centralnych w tej pracy. Celem, jaki praca ta sobie stawia, jest próba wskazania potencjalnych metod rozwiązywania potencjalnych konfliktów między unijnymi a wyższymi od nich konstytucyjnymi standardami ochrony praw i wolności człowieka, bez konieczności uciekania się do zarzutu działania Unii z przekroczeniem kompetencji, a więc próba jak najdalszego rozszerzenia przestrzeni bezkolizyjnych rozwiązań pozwalających na pogodzenie zasad pierwszeństwa, jedności i efektywności prawa unijnego oraz zasady konstytucjonalizmu. Uwaga w tej pracy skoncentrowana jest na takich działaniach Unii, których nie należy uznawać za przekraczające jej kompetencję, a które mimo to mogą w pewnym zakresie stać w sprzeczności do Konstytucji, a konkretnie w zagwarantowanym w niej wyższym niż unijne gwarancje praw człowieka. 
Po przystąpieniu Polski do Unii Europejskiej możliwość kontroli konstytucyjności prawa pochodnego UE była kwestionowana, szczególnie $\mathrm{z}$ perspektywy prawa unijnego ${ }^{908} \mathrm{~W}$ związku $\mathrm{z}$ autonomicznym charakterem unijnego porządku prawnego. Jak jednak jednoznacznie wynika z wyroku w sprawie Sk 45/o9 ${ }^{909}$, TK stoi na stanowisku, że - choć w ograniczonym zakresie i w ograniczonych trybach - jest on kompetentny do tego, by badać, przynajmniej pod kątem jego zgodności z prawami i wolnościami zagwarantowanymi w Konstytucji, prawo pochodne UE, które nie wymaga transpozycji do polskiego systemu prawnego i które jest skuteczne bezpośrednio oraz cieszy się statusem pierwszeństwa przed prawem krajowym. Należy wszakże mocno podkreślić, że zdaniem samego TK nie jest to kompetencja uniwersalna, lecz szczególna - ograniczona do szczególnego trybu kontroli, jakim w przedmiotowej sprawie było postępowanie zainicjowane wniesieniem do TK skargi konstytucyjnej. Stąd też i zakres wzorców kontroli przez pryzmat zgodności, z którymi TK mógł w tej sprawie badać prawo pochodne Unii, był odpowiednio węższy. Tym niemniej wydaje się, że - jak będzie o tym jeszcze mowa - zgodnie z logiką przyjętą przez TK w sprawie Sk 45/o9, kontrola zgodności z Konstytucją RP prawa pochodnego Unii może mieć miejsce również $\mathrm{w}$ ramach innych procedur, a szczególnie $\mathrm{w}$ ramach pytania prawnego, co zasadniczo rozszerza potencjalny zakres kontroli prawa pochodnego Unii przez TK.

Trybunał od dość dawna stoi na stanowisku, zaznaczonym już obiter dicta we wcześniejszym orzecznictwie ${ }^{910}$, że nie ma ogólnej kognicji do kontrolowania prawa pochodnego UE i nie jest możliwe wszczynanie takiej kontroli, opierając się na art. 188 pkt 1-3 Konstytucji, który w sposób enumeratywny wymienia rodzaje aktów prawnych, które mogą podlegać hierarchicznej kontroli abstrakcyjnej. Prawo pochodne UE nie znajduje się wśród nich. Inną jednak sytuację kreuje art. 188 pkt 5 Konstytucji, który nadaje Trybunałowi kompetencję do orzekania w sprawach skargi konstytucyjnej, odsyłając do art. 79, który precyzuje dopuszczalny zakres takiej skargi. Zgodnie z brzmieniem art. 79, który ustanawia jeden $z$ fundamentalnych środków ochrony wolności i praw jednostki w Polsce, przedmiotem kontroli przez pryzmat zgodności z konstytucyjnie zagwarantowanymi prawami i wolnościami jednostki może być „ustawa lub inny akt normatywny", na podstawie którego sąd lub organ administracji

${ }^{908}$ Patrz np.: J. Barcz, Traktat z Lizbony. Wybrane aspekty prawne działań implementacyjnych, Warszawa 2012, s. 179 i nast.; S. Biernat, Członkostwo Polski w Unii Europejskiej w świetle orzecznictwa Trybunału Konstytucyjnego, [w:] S. Biernat, S. Dudzik, Doświadczenia prawne pierwszych lat członkostwa Polski w Unii Europejskiej, Warszawa 2011, s. 104-105.

909 TK, sprawa Sk 45/o9, wyrok z 16 listopada 2011.

910 TK, sprawa U 6/o8, postanowienie z 17 grudnia 2009. 
publicznej orzekł ostatecznie o wolnościach lub prawach jednostki, albo o jej obowiązkach określonych w Konstytucji.

Pojęcie aktu normatywnego znalazło w polskiej doktrynie powszechnie uznaną definicję, którą już w 1989 r. przyjął również w swym orzecznictwie TK, stwierdzając, że „akt normatywny jest aktem ustanawiającym normy prawne o charakterze generalnym (a więc skierowane do pewnej klasy adresatów wyróżnionych z uwagi na jakąś ich wspólną cechę) i abstrakcyjnym (to znaczy ustanawiającym pewne wzory zachowań)" ${ }^{\prime \prime 11}$. Oczywiście pamiętać należy również o tym, by akt ten był wydany przez podmiot posiadający kompetencję prawotwórczą oraz w przewidzianym przez prawo trybie. Kwestie kompetencyjne i formalne mają znaczenie głównie dla oceny ważności jego dojścia do skutku. Dla oceny charakteru aktu pod kątem sklasyfikowania go bądź nie jako aktu normatywnego, kluczowy jest co do zasady jego abstrakcyjny i generalny charakter $^{912}$. W uzasadnieniu wyroku w sprawie Sk 45/og Trybunał podkreślił, że:

Analiza dotychczasowego orzecznictwa Trybunału [Konstytucyjnego - przyp. aut.] wskazuje, że zakres aktów normatywnych, których kwestionowanie w trybie skargi konstytucyjnej było uznawane za dopuszczalne, jest szerszy, niż to wynika z art. 188 pkt 1-3 Konstytucji. Stanowisku takiemu dawano jednak wyraz wyjątkowo. Na przykład Trybunał Konstytucyjny dopuścił do merytorycznego rozpoznania skargę konstytucyjna, w której były kwestionowane przepisy prawa miejscowego, jednakże sprawa nie zakończyła się wydaniem wyroku [...]. [Zaś w innym - przyp. aut.] postanowieniu [...] Trybunał uznał możliwość wniesienia skargi konstytucyjnej na akty prawa miejscowego, o ile mają one charakter normatywny ${ }^{913}$.

Wynika stąd wniosek, że zakres przepisów podlegających zaskarżeniu $\mathrm{w}$ trybie skargi konstytucyjnej jest ustalony autonomicznie przez art. 79 i nie musi on mieścić się w zakresie rodzajów aktów wymienionych w art. 188 pkt $1-3^{914}$. Każdy zatem akt prawny spełniający kryteria definicyjne aktu normatywnego obowiązujący na terenie RP, na podstawie którego sąd lub organ administracyjny orzeka ostatecznie o czyichkolwiek wolnościach, prawach lub obowiązkach, może być badany przez TK w trybie skargi konstytucyjnej, a więc przez pryzmat jego zgodności z konstytucyjnymi gwarancjami praw i wolności. Wynika to z systematyki Konstytucji i rozdzielnego unormowania kompeten-

911 TK, sprawa U 15/88, wyrok z 7 czerwca 1989, uzasadnienie.

912 Więcej na ten temat patrz np.: A. Mączyński, J. Podkowik, Art. 188..., s. 1148; na temat kognicji TK do badania prawa unijnego patrz: ibidem, s. 1158.

913 TK, sprawa Sk 45/o9, wyrok z 16 listopada 2011, pkt III 1.2 uzasadnienia.

914 Takie podejście nie jest jednoznacznie akceptowane w doktrynie, szczególnie odnośnie do aktów prawa UE. Więcej na ten temat patrz np.: T. Jaroszyński, Rozporządzenie Unii Europejskiej jako składnik systemu prawa obowiazującego w Polsce, Warszawa 2011, s. 337-338 lub K. Wojtyczek, Przekazywanie kompetencji państwa organizacjom międzynarodowym, Kraków 2007, s. 323-328. 
cji TK w zakresie abstrakcyjnej, hierarchicznej kontroli prawa, o którym mowa $\mathrm{w}$ art. 188 pkt $1-3$ oraz kompetencji do orzekania w sprawie skargi konstytucyjnej na podstawie art. 188 pkt 5 w związku z art. 79, która to kontrola nie ma charakteru stricte abstrakcyjnego ${ }^{915}$, lecz mieszany, zawierający również elementy kontroli konkretnej. Nie może być wątpliwości, że bezpośrednio skuteczne w Polsce prawo pochodne Unii spełnia kryteria aktu normatywnego jako posiadające generalny i abstrakcyjny charakter, i że może stawać się podstawą ostatecznych decyzji administracyjnych i orzeczeń sądowych.

Na podkreślenie zasługuje również fakt, silnie zaakcentowany też przez TK w omawianym wyroku, że

podstawową funkcją skargi konstytucyjnej jest ochrona konstytucyjnych wolności i praw jednostek. Nieusprawiedliwiona więc byłaby taka interpretacja art. 188 Konstytucji, która zawężałaby przedmiot kontroli w postępowaniu ze skargi konstytucyjnej. Nie służyłaby ona bowiem efektywnej ochronie praw i wolności jednostki. Natomiast stanowisko, zgodnie z którym przedmiotem kontroli Trybunału może być każdy akt normatywny, który był podstawą orzeczenia przez sąd lub organ administracji o czyichś prawach lub wolnościach, znajduje silne uzasadnienie w wartościach konstytucyjnych ${ }^{916}$.

Zasada przyrodzonej godności człowieka jest centralną zasada, wokół której zbudowany jest nie tylko Rozdział II Konstytucji, ale cała polska ustawa zasadnicza ${ }^{917}$, a to przecież właśnie z godności człowieka wynikają wszystkie gwarancje praw i wolności jednostki i to jej ochronie służą. Stąd też pozostawienie jednostki, znajdującej się pod władzą Konstytucji i korzystającej z zawartych w niej gwarancji praw i wolności człowieka bez możliwości ochrony przed naruszeniami jej praw i wolności przez wiążące ją prawo unijne byłoby nie tylko nie do pogodzenia z zasadą suwerenności czy też zasadą konstytucjonalizmu, ale również byłoby sprzeczne $\mathrm{z}$ fundamentalną wartością konstytucyjną, jaką jest ochrona godności człowieka. Co warte podkreślenia i o czym będzie jeszcze mowa, godność człowieka i wynikająca z niej ochrona praw człowieka jest również fundamentalną wartością, chronioną przez prawo unijne (nie tylko przez KPP w jej art. 1, lecz także przez traktaty - przede wszystkim art. 2 i 6 TUE). Odrzucenie możliwości kontroli prawa pochodnego przez TK przez pryzmat zgodności z gwarancjami praw i wolności jednostki na podsta-

${ }^{915}$ Por.: A. Mączyński, J. Podkowik, Art. 188..., s. 1127.

916 TK, sprawa Sk 45/o9, wyrok z 16 listopada 2011, pkt III 1.2 uzasadnienia.

${ }^{917} \mathrm{~Np}$. w uzasadnieniu wyroku w sprawie K 11/oo z 4 kwietnia 2001 TK stwierdził: „Ustrojodawca nadał godności człowieka znaczenie konstytucyjne, czyniąc z niej płaszczyznę odniesienia do systemu wartości, wokół którego zbudowano Konstytucję, a zarazem fundament całego porządku prawnego w państwie" (pkt III A.2 uzasadnienia). 
wie zasady prounijnej wykładni Konstytucji prowadziłoby więc zarazem do naruszenia granic prounijnej jej wykładni wytyczonych przez TK, czyli zakazu wykładni contra legem, naruszenia funkcji gwarancyjnej Konstytucji, jak i naruszenia tożsamości konstytucyjnej RP.

W obliczu rangi godności człowieka wśród wartości konstytucyjnych może pojawić się pytanie, czy ochrona konstytucyjnych praw i wolności nie powinna być okolicznością stanowiącą podstawę dla szerszej aktywności TK w kontekście kontroli prawa obowiązującego w Polsce, w tym tego ustanowionego przez instytucje UE. Trudno jednak domniemywać, że mogłaby ona wpłynać na rozszerzenie zakresu kompetencji TK wynikających z art. 188 pkt 1-3 Konstytucji. W obliczu precyzyjnych sformułowań zawartych $w$ tych przepisach takie rozszerzenie kompetencji TK miałoby więc znowu charakter contra legem. Katalog kompetencji Trybunału Konstytucyjnego w zakresie kontroli hierarchicznej zgodności prawa w trybie abstrakcyjnym ogranicza się do możliwości kontrolowania wymienionych w punktach od 1 do 3 artykułu 188 kategorii aktów prawnych przez pryzmat zgodności z normami zawartymi w również tam wskazanych kategoriach aktów prawnych. Wyliczenie to ma charakter enumeratywny. Niemożliwe jest więc bez zmiany brzmienia przepisu dodanie w tym zakresie kompetencji nowej, nie wymienionej w tym artykule. Próba rozszerzającej wykładni przepisów art. 188 pkt 1-3 zmierzająca do rozszerzenia kompetencji TK do powszechnej kontroli prawa pochodnego Unii byłaby także niewątpliwie sprzeczna z istotą integracji europejskiej i podziałem kompetencji między instytucje UE i państwa członkowskie poprzez przypisanie TK kompetencji przyznanej w pierwotnym prawe unijnym trybunałowi luksemburskiemu.

Z drugiej strony w obliczu powyższych rozważań zasadne wydaje się pytanie o analogiczne jak w art. 79 sformułowanie katalogu aktów prawnych podlegających kognicji TK w przypadku konstytucyjnej regulacji pytań prawnych, jakie mogą do TK kierować sądy opierające się na art. 193 Konstytucji. Pytanie prawne do TK, jak stanowi Konstytucja, może dotyczyć zgodności z Konstytucją (tym razem z całą Konstytucją, a więc również, choć nie tylko, z zawartymi w niej gwarancjami praw i wolności człowieka) aktu normatywnego, od którego zależy rozstrzygnięcie sprawy toczącej się przed sądem. Co więcej, pytanie takie może dotyczyć zgodności każdego aktu normatywnego, jeżeli od odpowiedzi na pytanie prawne zależy rozstrzygnięcie sprawy toczącej się przed sądem, nie tylko z Konstytucją, ale także z ratyfikowanymi umowami międzynarodowymi lub ustawami. Jeśli chodzi o ustawy, to problem niezgodności z nimi unijnego prawa pochodnego rozwiązuje art. 91 ust. 3 Konstytucji, który przesądza, że jeżeli wynika to $\mathrm{z}$ ratyfikowanej przez Polskę umowy konstytuującej organizację międzynarodowa, prawo przez nią stanowione jest stosowane bezpośrednio, 
mając pierwszeństwo w przypadku kolizji z ustawami. Jednakże pewnych wątpliwości może dostarczyć kwestia ewentualnej dopuszczalności kontroli przez TK w trybie pytania prawnego zgodności pochodnego prawa unijnego, które - jak wynika z wyroku w sprawie Sk 45/o9 - bez wątpienia należy uznawać za akt normatywny, z unijnym prawem pierwotnym, które - znowu bez wątpienia - jest ratyfikowaną umową międzynarodowa, a także, co godne odnotowania w kontekście tematu tej pracy, z umowami międzynarodowymi zawierającymi gwarancje praw człowieka, takimi jak EKPCz, MPPOiP czy MPPGSiK, przy jednoczesnym braku możliwości, w obliczu tego, o czym była mowa wcześniej, kontroli jego zgodności z Kartą, która sensu stricto traktatem międzynarodowym nie jest. Teoretycznie nie jest więc wykluczone, aby TK badał w trybie pytania prawnego pochodne prawo unijne przez pryzmat zgodności nie tylko z krajowymi gwarancjami praw człowieka, lecz również z międzynarodowymi gwarancjami tych praw, którymi związana jest Polska. Byłoby to swoiste spełnienie się złego snu TSUE, odnośnie do Karty i potencjalnego ziszczenia się zagrożenia dla autonomii prawa UE poprzez obchodzenie art. $53 \mathrm{KPP}$ - przed czym obawa, choć w nieco innym kontekście, doprowadziła między innymi do odrzucenia przez TSUE wynegocjowanych już instrumentów akcesji Unii do $\mathrm{EKPC}^{918}$. Problematyka ta jest niewątpliwie ciekawa. Dalsze jej rozważanie przekraczałoby jednak ramy tej pracy, której tematem jest konflikt prawa unijnego lub mieszczącego się w jego zakresie prawa krajowego z wyższymi niż unijne, konstytucyjnymi gwarancjami praw człowieka. Aktualnie brak też judykatów TK, które mogłyby sugerować jego skłonność do badania w trybie pytania prawnego zgodności pochodnego prawa unijnego z wiążącymi Polskę międzynarodowymi gwarancjami praw człowieka.

Nie wchodząc głębiej w rozważania dotyczące możliwości kontroli pochodnego prawa unijnego przez pryzmat zgodności z Konstytucją, których TK nie miał jeszcze okazji rozstrzygnąć, na potrzeby tej pracy należy jednak podkreślić, że jeśli chodzi o kontrolę zgodności z Konstytucją bezpośrednio obowiązującego w Polsce pochodnego prawa unijnego, to - zgodnie ze stanowiskiem reprezentowanym przez TK - jest bez wątpienia możliwa kontrola unijnego prawa pochodnego w trybie skargi konstytucyjnej, a więc przez pryzmat zgodności tego prawa z zagwarantowanymi w Konstytucji prawami i wolnościami człowieka, a także, jak się wydaje, w trybie pytania prawnego, a więc przez pryzmat zgodności z całą Konstytucją, w tym przez pryzmat zgodności z zagwarantowanymi w niej prawami i wolnościami człowieka. Oba te przepisy ze względu na użyte w nich sformułowanie, że przedmio-

918 TSUE, Opinia 2/13 wydana w dniu 18 grudnia 2014, pkt 185-190. 
tem kontroli może być "akt normatywny”, wyznaczają autonomiczny katalog przedmiotów kontroli względem art. 188 pkt 1-3 Konstytucji.

Obok art. 188 pkt 5 w zw. z art. 79 oraz art. 193 Konstytucji należy w tym kontekście pamiętać jeszcze o art. 186 ust. 2 Konstytucji, który stanowi, że: „Krajowa Rada Sądownictwa może wystąpić do Trybunału Konstytucyjnego z wnioskiem w sprawie zgodności z Konstytucją aktów normatywnych w zakresie, w jakim dotyczą one niezależności sądów i niezawisłości sędziów". Jak zauważa Marek Zubik w omawianym tu kontekście, przepisy te należy postawić w jednym szeregu. Podsumowując dotychczasowe ustalenia nauki prawa oraz orzecznictwo TK

co do zakresu przedmiotowego kognicji polskiego sądu konstytucyjnego [...] art. 79, 193 oraz, jak się wydaje 186 ust. 2 Konstytucji wyznaczają autonomiczne w odniesieniu do art. 188 pkt 1-3, zakres przedmiotowy hierarchicznej kontroli norm. Jest on generalnie szerszy co do zakresu kwestionowanych aktów normatywnych. Modyfikują również zakres dopuszczalnych wzorców kontroli dla kwestionowanych aktów normatywnych ${ }^{919}$.

W kontekście tej pracy art. 186 ust. 2 Konstytucji ma jednak mniejsze znacznie, jako że dotyczy jedynie kontroli zgodności z Konstytucją aktów normatywnych przez pryzmat zawartych w niej gwarancji niezależności sądów i niezawisłości sędziów, które nie są sensu stricto gwarancjami praw i wolności człowieka. Tym niemniej znaczenie tego przepisu dla tematyki tej pracy nie jest nieistotne, jako że bez wątpienia gwarancje niezależności sądów i niezawisłości sędziów należą do absolutnie fundamentalnych wartości konstytucyjnych, a także są warunkiem dla możliwości dochodzenia praw i wolności jednostki, a więc pośrednio stanowią ich gwarancję ${ }^{920}$. Wśród praw i wolności człowieka figuruje także prawo do sądu, którego elementem jest, aby sąd ten był niezależny, a sędziowie niezawiśli, co wyrażone zostało w art. 45 ust. 1 Konstytucji RP. Można więc sobie wyobrazić, aby proponowana tu sekwencja orzekania w przedmiocie naruszenia przez bezpośrednio skuteczne prawo unijne, wyższych niż unijne konstytucyjnych gwarancji praw człowieka, znalazła zastosowanie $\mathrm{w}$ ramach procedury toczącej się w oparciu o art. 186 ust. 2 Konstytucji RP. Z drugiej jednak strony należy pamiętać, że procedura kontroli zawarta w art. 186 ust. 2 Konstytucji RP ma charakter abstrakcyjny i silniej niż

${ }^{919}$ M. Zubik, "Akt normatywny" jako przedmiot kontroli Trybunału Konstytucyjnego, "Gdańskie Studia Prawnicze" 2014, t. XXXI, s. 743-744.

${ }^{920}$ Kwestia ta jest też coraz częściej dostrzegana w praktyce: Relacja z konferencji "Niezależność sądów i niezawistość sędziów gwarancja praworządności i praw człowieka”, "Krajowa Rada Sądownictwa. Kwartalnik" 2012, nr 2 (15); J. Sędek, Konferencja "Niezależność sądów i trybunałów jako gwarancja praw i wolności człowieka”, Warszawa, 5 marca 2016 r., "Palestra” 2016, nr 5. 
inne powiązana jest przez to $\mathrm{z}$ art. 188 pkt $1-3$, co może jej potencjał ograniczyć. Rozstrzygnięcie tej kwestii pozostaje w gestii TK.

Z perspektywy tej pracy najistotniejsze jest natomiast znane już stanowisko TK wobec możliwości kontrolowania prawa pochodnego UE w trybie skargi konstytucyjnej. Zostało ono wyrażone przez TK wprost. Co więcej, dotyczy również bezpośrednio problematyki dla tej pracy centralnej, jaką są relacje między konstytucyjnymi i unijnymi gwarancjami praw człowieka. Nie bez znaczenia jest jednak także potencjalna możliwość zastosowania na potrzeby współpracy między tymi dwoma trybunałami, o której będzie mowa później, także procedury pytania prawnego. Ów szerszy zakres przepisów, jakie w jej ramach mogą być badane przez pryzmat zgodności z Konstytucją, w tym z zawartymi w niej gwarancjami praw i wolności człowieka, otwiera przestrzeń dla sądów krajowych, w obliczu ich roli w ramach unijnego i krajowego systemu ochrony praw człowieka, a także na styku tych dwu porządków.

Na marginesie rozważań centralnych dla tego opracowania można zauważyć również, że ten profesjonalny (zarezerwowany dla inicjatywy sądu) i wąski (dopuszczalny tylko wobec przepisu, od którego faktycznie zależy rozstrzygnięcie konkretnej sprawy) tryb kontroli aktów normatywnych przez pryzmat zgodności z Konstytucją, może stanowić bardzo ważne uzupełnienie ograniczonej na podstawie art. 188 pkt 1-3 Konstytucji kognicji TK do badania zgodności z Konstytucją prawa pochodnego UE. Uzupełnienie to mogłoby być wolne od niebezpieczeństwa realizowania pokus składania wniosków wynikających z politycznej inspiracji zmierzającej do podważania prawa UE i całego procesu integracji, co mogłoby być przypadłością różnych podmiotów uprawnionych do inicjowania kontroli abstrakcyjnej prawa (przede wszystkim takich, jak grupy posłów czy senatorów, marszałek Sejmu czy Senatu, prezydent czy prezes Rady Ministrów), a także wolne od niebezpieczeństwa pojawienia się natłoku wniosków związanych z rozstrzyganiem potencjalnej niezgodności bardzo przecież rozbudowanego prawa pochodnego UE z Konstytucją, co nie dość, że paraliżowałoby TK, to stałoby w jawnej sprzeczności z zasadami prymatu, jedności i skuteczności prawa europejskiego i podważało sens procesu integracji europejskiej, co mogłoby się ziścić w związku z abstrakcyjnym charakterem kontroli w ramach art. 188 pkt 1-3 w przeciwieństwie do kontroli opartej na art. 193, mającej charakter konkretny.

W zakresie, $\mathrm{w}$ jakim pytanie prawne dotyczyłoby konstytucyjnie zagwarantowanych praw i wolności, przedstawiona w dalszej części tego rozdziału argumentacja oparta na pojęciu tożsamości konstytucyjnej znajduje $\mathrm{w}$ pełni zastosowanie. $\mathrm{W}$ pozostałym zakresie materii konstytucyjnej istotne byłoby precyzyjne rozgraniczenie tych jej elementów, które składają się na tożsamość konstytucyjną RP od tych, które nie wchodzą w jej zakres. Taka 
całościowa analiza pojęcia tożsamości konstytucyjnej przekraczałaby jednak zakres tego opracowania, stąd nie będzie w niej podjęta. Celem tej pracy nie jest bowiem próba zarysowania definicji i zidentyfikowania wszelkich elementów składających się na tożsamość konstytucyjną RP, lecz jedynie ocena pod tym kątem konstytucyjnych gwarancji praw i wolności człowieka.

\subsection{Skutki orzeczenia TK o niezgodności prawa pochodnego UE z prawami i wolnościami zagwarantowanymi w Konstytucji RP}

W omawianej sprawie Sk 45/og TK nie doszedł do wniosku, by przepisy unijnego rozporządzenia, które stały się podstawą wniesionej skargi konstytucyjnej stały w sprzeczności z prawami i wolnościami zagwarantowanymi w Konstytucji. Sam fakt badania ich pod tym kątem oznacza jednak, że taka ewentualność nie może być wykluczona a priori. Nie ma więc wątpliwości, że TK uważa się za kompetentny do tego, by badać cieszące się statusem prymatu i bezpośrednio stosowane w Polsce prawo pochodne UE, jakim bez wątpienia jest unijne rozporządzenie, pod kątem zgodności z konstytucyjnie zagwarantowanymi prawami i wolnościami jednostki. Pozostaje więc pytanie, jak Trybunał zachowałby się w sytuacji, gdyby doszedł jednak do wniosku o niezgodności badanych przepisów pochodnego prawa unijnego z Konstytucją oraz jakie konsekwencje niósłby ze sobą ewentualny wyrok Trybunału.

TK dostrzega znaczenie zasady pierwszeństwa prawa UE, dostrzega także wyłączną kompetencję TSUE do orzekania o ważności aktów pochodnego prawa UE i akceptuje wynikający stąd podział ról między TK badającym hierarchiczną zgodność prawa krajowego oraz TSUE badającym hierarchiczną zgodność prawa UE.

Wynikiem tego podziału funkcji jest przypisanie Trybunałowi Sprawiedliwości Unii Europejskiej kompetencji do ostatecznej interpretacji prawa unijnego i zapewnienia jednolitości jego stosowania we wszystkich państwach członkowskich, jak również wyłączność ostatecznego decydowania o zgodności aktów prawa pochodnego z traktatami i ogólnymi zasadami prawa unijnego ${ }^{921}$.

Zgodnie z prawem pierwotnym $\mathrm{UE}^{922}$ oraz ugruntowanym orzecznictwem TSUE sądy krajowe nie mają kompetencji do orzekania o nieważności aktów unijnego prawa pochodnego, a wyłączną kompetencję w tej kwestii ma

${ }_{921}$ TK, sprawa Sk 45/o9, wyrok z 16 listopada 2011, pkt III 2.6 uzasadnienia.

922 Art. 263 i 267 TFUE. 
TSUE $\mathrm{i}$ to do niego sądy krajowe powinny się w tej materii zwrócić. $\mathrm{W}$ ramach tzw. doktryny Foto-Frost ${ }^{923}$ sądy krajowe, w tym TK, mają kompetencję jedynie do ewentualnego stwierdzania ważności prawa pochodnego UE i tym samym stosowania go w konkretnej sprawie, nie zaś do stwierdzania jego nieważności i jego niestosowania. W sprawie Sk 45/og TK powołał się na doktrynę Foto-Frost i stwierdził, że w „niniejszej sprawie Trybunał Konstytucyjny nie miał wątpliwości co do zgodności zaskarżonego rozporządzenia nr 44/2001 z unijnym prawem pierwotnym, wobec czego - w myśl doktryny Foto-Frost - nie było potrzeby występowania z pytaniem prejudycjalnym do Trybunału Sprawiedliwości Unii Europejskiej"924.

\subsubsection{Zasada pierwszeństwa prawa UE $w$ prawie unijnym i jej odzwierciedlenie w Konstytucji}

Zasada pierwszeństwa prawa UE (zwana również zasadą supremacji czy nadrzędności) była już kilkakrotnie przywoływana we wcześniejszych częściach tej pracy. W tym miejscu należy dla porządku przypomnieć, że choć zasada ta ma fundamentalne znaczenie dla unijnego porządku prawnego, to nie wynika bezpośrednio z prawa Unii. Próżno szukać jej w Traktatach, choć pośrednio można ją wyprowadzać $\mathrm{z}$ różnych regulacji prawa pierwotnego UE, takich jak art. 4 ust. 3 i art. 19 ust. 1 TUE czy art. 291 ust. 1 oraz art. 258-260 TFUE. Próba wprowadzenia zasady pierwszeństwa do prawa pierwotnego UE podjęta była w projekcie Traktatu Konstytucyjnego ${ }^{925}$, który jak wiadomo nie wszedł jednak ostatecznie w życie. Tym niemniej podkreślić należy, że w Deklaracji nr 17 dołączonej do Aktu końcowego konferencji międzyrządowej, która przyjęła Traktat z Lizbony, państwa uczestniczące w tej konferencji przypomniały, „że zgodnie z utrwalonym orzecznictwem Trybunału Sprawiedliwości Unii Europejskiej Traktaty i prawo przyjęte przez Unię na podstawie Traktatów mają pierwszeństwo przed prawem Państw Członkowskich na warunkach ustanowionych przez wspomniane orzecznictwo" ${ }^{\prime \prime 2}$.

${ }_{923}$ TSUE, Foto-Frost p. Hauptzollamt Lübeck-Ost, C-314/85, wyrok z 22 października 1987.

${ }_{924}$ TK, sprawa Sk 45/o9, wyrok z 16 listopada 2011, pkt III 8.1 uzasadnienia.

925 Art. I-6, Traktat Ustanawiający Konstytucję dla Europy, Dz.Urz. C 310 z 16 grudnia 2004.

${ }^{926}$ Jak czytamy w dalszej części Deklaracji: „Ponadto Konferencja postanowiła, że do niniejszego Aktu końcowego Konferencji zostanie załączona opinia Służby Prawnej Rady dotycząca pierwszeństwa, w wersji zawartej w dokumencie 11197/o7 (JUR 260): Opinia Służby Prawnej Rady z 22 czerwca 2007. Z orzecznictwa Trybunału Sprawiedliwości wynika, że pierwszeństwo prawa wspólnotowego stanowi podstawową zasadę tego prawa. Według Trybunału zasada ta jest nieodłącznie związana ze szczególną naturą Wspólnoty Europejskiej. Kiedy wydawany był pierwszy wyrok zapoczątkowujący to obecnie już utrwalone orzecznictwo (wyrok z 15 lipca 1964 w sprawie 6/64, Costa przeciwko ENEL), w Traktacie nie było żadnej wzmianki 
Zasada pierwszeństwa została od podstaw wypracowana przez trybunał w Luksemburgu, który oparł się przede wszystkim na argumentacji teleologicznej, a więc na celu i funkcji prawa unijnego ${ }^{927}$. Przełomowe znaczenie miał w tej kwestii wyrok w sprawie Costa/ENEL ${ }^{928}$, w którym Trybunał bezpośrednio odniósł się do kwestii ewentualnej niezgodności prawa unijnego (wówczas wspólnotowego) z prawem krajowym i stwierdził, że państwa, które zdecydowały się stworzyć Wspólnotę Europejską, tworząc tym samym nowy, szczególny system prawny, ograniczyły w sposób trwały swoje suwerenne prawa i nie mogą wprowadzać regulacji, które stałyby w sprzeczności z istotą prawa wspólnotowego. Istota tego porządku wymaga, by prawo wspólnotowe miało jednolitą moc we wszystkich państwach członkowskich. Inaczej nie można byłoby mówić o integracji prawnej między tymi państwami.

Trybunał wywiódł, że:

w odróżnieniu od zwyczajnych umów międzynarodowych traktat EWG ustanowił własny porządek prawny, który został włączony do systemu prawnego państw członkowskich po jego wejściu w życie i który ma charakter wiążący dla sądów krajowych; bowiem państwa, ustanawiając na czas nieokreślony Wspólnotę wyposażoną we własne instytucje, w osobowość i zdolność prawna, [...] a w szczególności w rzeczywiste uprawnienia władcze, wynikające z ograniczenia kompetencji i przeniesienia uprawnień z tych państw na Wspólnotę, ograniczyły, jakkolwiek w wąskich dziedzinach, swoje suwerenne prawa i stworzyły $\mathrm{w}$ ten sposób system prawa mający zastosowanie do nich samych oraz do pochodzących z nich jednostek; zważywszy, że w związku z włączeniem do prawa każdego z krajów członkowskich przepisów pochodzenia wspólnotowego, a bardziej ogólnie ze względu zarówno na brzmienie, jak ducha traktatu, państwa nie mogą uznawać pierwszeństwa przed porządkiem prawnym, jaki przyjęły na zasadach wzajemności, jednostronnego, późniejszego przepisu, którego w związku z tym nie mogą temu porząadkowi prawnemu przeciwstawiać; moc wiążąca prawa wspólnotowego nie może bowiem różnić się w poszczególnych państwach w zależności od ich późniejszego wewnętrznego ustawodawstwa, gdyż zagroziłoby to realizacji celów traktatu [...]; że zobowiązania podjęte na podstawie traktatu ustanawiającego Wspólnotę nie miałyby charakteru bezwarunkowego, lecz jedynie ewentualny, gdyby mogły zostać zakwestionowane w drodze późniejszych aktów ustawodawczych umawiających się

o zasadzie pierwszeństwa. Sytuacja ta do dziś nie uległa zmianie. Fakt, że zasada pierwszeństwa nie zostanie włączona do przyszłego Traktatu, w żaden sposób nie narusza samej zasady ani obowiązującego orzecznictwa Trybunału Sprawiedliwości" (Deklaracja [nr 17] odnosząca się do pierwszeństwa dołączona do Aktu Końcowego Konferencji przedstawicieli rządów państw członkowskich zwołanej w Brukseli w dniu 23 lipca 2007 w celu przyjęcia za wspólnym porozumieniem zmian do Traktatu o Unii Europejskiej, Traktatu ustanawiającego Wspólnotę Europejską oraz Traktatu ustanawiającego Europejską Wspólnotę Energii Atomowej, Dz.Urz. C 306/o2 z dnia 17 grudnia 2007).

927 B. Capik, A. Łazowski, Art. 91 ..., s. 159 i nast.

928 TSUE, Flaminio Costa p. ENEL, C-6/64, wyrok z 15 lipca 1964. 
stron; że prawo do jednostronnego działania jest państwom członkowskim przyznawane jedynie na mocy wyraźnego, szczególnego postanowienia [...]; że ponadto wnioski państw o przyznanie odstępstw poddane są procedurom zezwoleniowym [...], które byłyby bezprzedmiotowe, gdyby państwa te mogły zwolnić się ze swoich zobowiązań za pomocą zwykłej ustawy; zważywszy, że pierwszeństwo prawa wspólnotowego [...], zgodnie z którym rozporządzenie "wiąże w całości” i jest "bezpośrednio stosowane we wszystkich państwach członkowskich"; że postanowienie to, do którego nie zgłoszono zastrzeżeń, zostałoby pozbawione skuteczności, gdyby jego skutki mogły zostać jednostronnie cofnięte przez jedno z państw w drodze aktu ustawodawczego, który miałby moc wyższą od aktów wspólnotowych; zważywszy, że jak wynika z całości powyższych rozważań, prawu utworzonemu na podstawie traktatu, pochodzącemu z niezależnego źródła, nie można, ze względu na jego wynikającą stąd szczególną naturę, przeciwstawiać w postępowaniu sądowym jakiegokolwiek wewnętrznego aktu prawnego, gdyż oznaczałoby to utratę przez to prawo charakteru wspólnotowego i zakwestionowanie samych podstaw prawnych Wspólnoty; że wskutek dokonanego przez państwa przeniesienia, z ich wewnętrznych porządków prawnych do wspólnotowego porządku prawnego, praw i obowiązków odpowiadających postanowieniom traktatu, nastąpiło ostateczne ograniczenie ich praw suwerennych, którego nie może podważyć późniejszy akt jednostronny sprzeczny z istotą Wspólnoty ${ }^{929}$.

O ile wyrok ten odnosił się w zasadzie do prawa ustanawianego przez państwa już po przystąpieniu do Wspólnoty i o randze ustawowej, o tyle w wyroku w sprawie Internationale Handelsgesellschaft ${ }^{930}$ Trybunał poszedł o krok dalej w budowaniu zasady pierwszeństwa i przesądził, że za niedopuszczalne należy uznać unieważnianie aktów prawa stanowionego przez Wspólnotę ze względu na niezgodność z jakimikolwiek przepisami prawa krajowego, gdyż podważałoby to jednolitość i efektywność tego prawa oraz ze względów wyrażonych już w wyroku w sprawie Costa/ENEL. Ważność prawa wspólnotowego może być oceniana jedynie w ramach prawa wspólnotowego. Zdaniem TSUE nie można kwestionować jego ważności i skuteczności nawet przy użyciu zarzutów sprzeczności z prawami podstawowymi sformułowanymi w konstytucjach państw członkowskich, ani przy użyciu zarzutów sprzeczności z wynikającymi z konstytucji tych państw zasadami ustrojowymi. Prawo wspólnotowe nie może być więc uchylane przez prawo krajowe bez względu na jego rangę, włączając w to prawo konstytucyjne.

Wreszcie podstawowe konsekwencje wynikające z zasady pierwszeństwa zostały dookreślone w wyroku w sprawie Simmenthal ${ }^{931}$. Trybunał wskazał

${ }_{929}$ Ibidem.

930 TSUE, Internationale Handelsgesellschaft mbH p. Einfuhr- und Vorratsstelle für Getreide und Futtermittel, 11/70, wyrok z 17 grudnia 1970.

931 TSUE, Amministrazione delle Finanze dello Stato p. Simmenthal SpA, C-106/77, wyrok z 9 marca 1978 . 
w nim, że w konsekwencji zasady pierwszeństwa prawa wspólnotowego przepisy prawa pierwotnego, a także bezpośrednio obowiązujące akty prawa wydane przez instytucje WE, a więc wywołujące bezpośrednie skutki przepisy prawa pochodnego ${ }^{932}$, po tym jak wejdą w życie automatycznie wykluczają stosowanie sprzecznych z nimi aktów prawa krajowego bez względu na to, czy zostałyby one przyjęte przed, czy też już po wejściu w życie prawa wspólnotowego. Takie sprzeczne z prawem wspólnotowym przepisy powinny być niestosowane, a także stopniowo usuwane z obiegu prawnego przez odpowiednie organy legislacyjne państw członkowskich.

Jak wynika z powyższego, zgodnie z orzecznictwem trybunału luksemburskiego nie może być wątpliwości, że zasada pierwszeństwa prawa UE dotyczyć ma wszystkich krajowych aktów prawnych bez względu na ich rangę, włączając w to konstytucje państw członkowskich, a także bez względu na to, czy dana regulacja krajowa została wydana przed czy po wejściu w życie danego prawa UE. TSUE w swym orzecznictwie doszedł do wniosku, że „porządek prawny UE charakteryzuje się w szczególności autonomicznością oraz jednolitościa jego stosowania we wszystkich państwach członkowskich, a zatem podstawowym założeniem skutecznego funkcjonowania systemu prawa UE jest zapewnienie mu prymatu nad porządkiem wewnętrznym państw członkowskich"933. Jak konkluduje Dagmara Kornobis-Romanowska, zasada prymatu prawa EU „musi stanowić i stanowi konstytutywny element ponadnarodowego charakteru Unii Europejskiej oraz istotę jej porządku prawnego"934.

Nie ulega wątpliwości, że zasada pierwszeństwa największe kontrowersje budzi, gdy chodzi o jej stosowanie wobec konstytucji państw członkowskich.

${ }^{932}$ Abstrahuję w tym tekście od nieistotnych z jego perspektywy kwestii, jakie kryteria musi spełnić prawo pochodne, by mogło być bezpośrednio stosowane. Pominięte zostały więc takie kwestie, jak jasność i bezwarunkowość normy, nałożenie na określony podmiot obowiązków podjęcia lub zaniechania określonych działań oraz możliwość stosowania bez wprowadzania dodatkowych środków. Kryteria te wynikają z orzecznictwa TSUE i są powszechnie znane (patrz głównie: TSUE, NV Algemene Transport- en Expeditie Onderneming van Gend \& Loos p. Netherlands Inland Revenue Administration, ETS, 26/62, wyrok z 5 lutego 1963). Należy pamiętać także o wyroku w sprawie Becker (TSUE, Ursula Becker p. Finanzamt Münster-Innenstadt, C-8/81, wyrok z 19 stycznia 1982), w którym Trybunał Sprawiedliwości odmawia stosowania zasady bezpośredniego skutku, jeśli państwo posiada pewien najmniejszy nawet margines działania dotyczący wprowadzenia danego przepisu (TSUE, Peter Kaefer i Andréa Procacci p. Państwu Francuskiemu, C-100/89 i C-101/89, wyrok z 12 grudnia 1990). Więcej na ten temat patrz np.: B. Capik, A. Łazowski, Art. 91..., s. 161 i nast.

${ }^{933}$ B. Capik, A. Łazowski, Art. $91 \ldots$, s. 158.

${ }^{934}$ D. Kornobis-Romanowska, Kompetencje wspólnotowe sądów krajowych - przeglad zagadnień, [w:] D. Kornobis-Romanowska (red.), Stosowanie prawa wspólnotowego w prawie wewnętrznym z uwzględnieniem prawa polskiego, Warszawa 2004, s. 23. 
Na tym tle powstało wiele sporów doktrynalnych, a co więcej, tak szerokie zastosowanie zasady pierwszeństwa nie spotkało się raczej z aprobatą sądów konstytucyjnych oraz najwyższych w wielu państwach członkowskich. W praktyce tylko w Niderlandach oraz w Estonii (formalnie) zagwarantowane jest pierwszeństwo prawa UE przed przepisami prawa krajowego rangi konstytucyjnej ${ }^{935}$.

W pozostałych państwach członkowskich, co do zasady, przymiotem pierwszeństwa cieszą się konstytucje tych państw, „zaś aby zapobiec otwartym konfliktom w tej sferze, sądy krajowe podejmują próby niwelowania ewentualnych sprzeczności między konstytucjami a prawem UE za pomocą wykładni" ${ }^{\prime \prime 36}$. Takie podejście, związane z obowiązkiem prounijnej wykładni, bliskie jest również polskiemu TK i była już o nim mowa.

Specyfika prawa europejskiego i jego preferencja względem prawa polskiego znajduje swoje odzwierciedlenie w Konstytucji RP. Zgodnie z art. 90 ust. 1 Konstytucji Polska może przekazać na podstawie umowy międzynarodowej organizacji międzynarodowej kompetencje organów władzy państwowej w niektórych sprawach. Dotyczy to również możliwości tworzenia przez tę instytucję prawa obowiązującego na terenie naszego kraju. Jednocześnie, prawo na podstawie takiej umowy utworzone, jak stanowi art. 91 ust. 3 Konstytucji, stosowane jest bezpośrednio i ma pierwszeństwo w przypadku kolizji z ustawami. Z takiego brzmienia tego przepisu należy wnioskować, że ma więc ono a maiori pierwszeństwo przed całym prawem krajowym, które w hierarchii źródeł prawa w Polsce znajduje się poniżej ustawy. Konstytucja natomiast, co wielokrotnie podkreślał Trybunał Konstytucyjny, również w kontekście integracji europejskiej ${ }^{937}$ pozostaje nadrzędnym prawem na terenie RP. Wynika to z zasady konstytucjonalizmu sformułowanej w art. 8 Konstytucji, który stanowi jednoznacznie w swym ustępie 1, że: „Konstytucja jest najwyższym prawem Rzeczypospolitej Polskiej". Ta ogólna konstatacja obniża rangę prawa unijnego i podnosi rangę Konstytucji. Ze względu na zakres tej pracy, nie będzie możliwe przedstawienie całościowej analizy zagadnień związanych z relacją między zasadą pierwszeństwa prawa Unii a zasadą konstytucjonalizmu i wszystkimi aspektami tego problemu czy też metodami jego rozwiązywania i minimalizowania. Późniejsze rozważania sprowadzać się będą do kwestii najważniejszych z perspektywy tej pracy, a więc do kwestii związanych z prawami człowieka oraz stanowiących tło dla propozycji pogodzenia wyższego niż unijny konstytucyjnego standardu ochrony praw człowieka w przypadku jego kolizji z zasadami pierwszeństwa, jedności i efektywności prawa unijnego.

935 B. Capik, A. Łazowski, Art. 91..., s. 162.

936 Ibidem.

937 Mam tu na myśli przede wszystkim wyroki w sprawie K 18/o4 z 11 maja 2005 oraz w sprawie K 32/og z 24 listopada 2010. 


\subsubsection{Doktryna Foto-Frost}

Doktryna Foto-Frost została wypracowana przez trybunał luksemburski w obliczu faktu, co przyznał sam TSUE, że art. 267 TFUE (wówczas 177) „nie rozstrzygnął kwestii uprawnienia [...] [krajowych - przyp. aut.] sądów do samodzielnego orzekania o nieważności aktów wydawanych przez instytucje wspólnotowe" ${ }^{\prime \prime 38}$. Można było więc twierdzić, że kompetencję taką one posiadają. TSUE postanowił więc rozwiać te wątpliwości i stwierdził po pierwsze, że: „Sacdy krajowe mogą badać ważność aktów wspólnotowych, a jeśli nie uznajac za uzasadnione zgłaszanych przez strony zarzutów dotyczących ich nieważności, mogą odrzucić te zarzuty, stwierdzając, że akt prawny jest w pełni ważny. Działając w ten sposób, nie podważają bowiem istnienia aktu wspólnotowego"939. Po drugie jednak podkreślił, że biorąc pod uwagę wynikający z art. 267 TFUE „podział kompetencji między Trybunał Sprawiedliwości a sądy krajowe, wyłącznie Trybunał jest uprawniony do orzekania o nieważności aktów wydanych przez instytucje wspólnotowe" ${ }^{\prime 940}$. TSUE zaakcentował, że spójność systemu prawa unijnego wymaga, aby uprawnienie do orzekania o nieważności aktów prawa unijnego, jeśli jest ona podnoszona przed sądem krajowym, było zarezerwowane wyłącznie dla niego, a służyć temu ma procedura pytania prejudycjalnego ${ }^{941}$. Właśnie to funkcjonalne czy też systemowe kryterium stało się główną przyczyną odmowy przyznania sądom krajowym kompetencji do orzekania o nieważności aktów prawa wspólnotowego. „Wymóg jednolitości ma szczególne znaczenie, w przypadku gdy kwestionowana jest ważność aktu wspólnotowego. Rozbieżności w zakresie ważności tych aktów między sądami krajowymi groziłyby naruszeniem jedności samego wspólnotowego porządku prawnego i podstawowego wymogu pewności prawa"942.

Konkluzje, do jakich doszedł w wyroku w sprawie Foto-Frost TSUE zostały przez niego wielokrotnie potwierdzone w późniejszym orzecznictwie i są w nim silnie ugruntowane. „Analiza materiału orzeczniczego odwołującego się do wyroku w sprawie Foto-Frost prowadzi do wniosku, że częstokroć służy on podkreśleniu, że sądy krajowe nie są uprawnione do samodzielnego orzekania o nieważności aktów prawa pochodnego. Kiedy jednak TSUE przyznaje, że sądy krajowe mogą kontrolować prawo pochodne, czyni to - wydawałoby się - z nieukrywaną niechęcią"943. Oddajmy głos samemu

${ }^{938}$ TSUE, Foto-Frost p. Hauptzollamt Lübeck-Ost, C-314/85, wyrok z 22 października 1987, pkt 13.

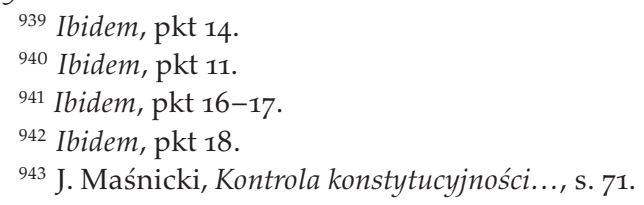


TSUE: „O ile sądy krajowe mogą co do zasady być zmuszone do zbadania ważności aktu wspólnotowego, o tyle nie są one właściwe, aby samodzielnie stwierdzić nieważność aktów instytucji wspólnotowych [...]. W związku z tym Trybunał jest jako jedyny właściwy do stwierdzenia nieważności aktu wspólnotowego" ${ }^{\prime 944}$.

Co do zasady więc podniesienie przed sądem krajowym zarzutu wadliwości skutkującej nieważnością prawa wspólnotowego, powinno prowadzić do skierowania przez ten sąd pytania prejudycjalnego do TSUE, szczególnie w obliczu braku możliwości kwestionowania aktów prawa unijnego przez osoby fizyczne i prawne w systemie środków odwoławczych oraz procedur służących zapewnieniu kontroli legalności aktów instytucji unijnych ${ }^{945}$. Tym niemniej sąd krajowy nie jest bezwzględnie zobowiązany do skierowania pytania do TSUE i może sam taki wniosek odrzucić, stwierdzając ważność aktu prawa wspólnotowego ${ }^{946}$. Należy także podkreślić, że zgodnie ze stanowiskiem prezentowanym przez TSUE, z doktryny Foto-Frost, w zakresie odrzucania przez sądy krajowe zarzutu wadliwości prawa wspólnotowego, powinny korzystać przede wszystkim sądy, których orzeczenia podlegają zaskarżeniu. Zdaniem TSUE:

W przypadku sądów, których orzeczenia podlegają zaskarżeniu według prawa wewnętrznego, Trybunał orzekł, iż sądy te mogą dokonywać oceny aktu wspólnotowego i jeżeli nie uznają za zasadne podnoszonych przed nimi argumentów stron dotyczących nieważności tych aktów, sądy te mogą oddalić te zarzuty, stwierdzając, że akt ten jest ważny w całości. Postępując bowiem w ten sposób, sądy te nie podważają istnienia aktu wspólnotowego ${ }^{947}$.

Z drugiej strony: „Natomiast gdy sądy te uznają, że zarzut lub więcej zarzutów nieważności, czy to podniesionych przez strony, czy to zbadanych $z$ urzędu [...], są zasadne, ciąży na nich obowiązek zawieszenia postępowania

${ }^{944}$ TSUE, Ministero dell'Industria, del Commercio e dell'Artigianato p. Lucchini SpA, C-119/o5, wyrok z 18 lipca 2007; por. także np.: TSUE, Zuckerfabrik Süderdithmarschen AG p. Hauptzollamt Itzehoe i Zuckerfabrik Soest GmbH p. Hauptzollamt Paderborn, C-143/88 i C-92/89, wyrok z 21 lutego 1991, pkt 17; TSUE, The Queen, na wniosek International Air Transport Association i European Low Fares Airline Association p. Department for Transport, C-344/o4, wyrok z 10 stycznia 2006, pkt 27.

${ }^{945}$ Por. np.: TSUE, Unión de Pequeños Agricultores p. Radzie Unii Europejskiej, C-50/oo P, wyrok z 25 lipca 2002, pkt 40.

${ }^{946}$ Por. np.: Sąd UE, Manfred Danzer i Hannelore Danzer p. Radzie Unii Europejskiej, T-47/o2, wyrok z 21 czerwca 2006, pkt 37.

947 TSUE, The Queen, na wniosek International Air Transport Association i European Low Fares Airline Association p. Department for Transport, C-344/o4, wyrok z 10 stycznia 2006, pkt 29 . 
i zwrócenia się do Trybunału o wydanie orzeczenia w trybie prejudycjalnym dokonującego oceny ważności" ${ }^{\prime \prime 48}$.

Jak natomiast już wspomniano wcześniej sądy, których wyroki nie podlegają zaskarżeniu powinny zwracać się do TSUE z pytaniem prejudycjalnym w sprawie ważności aktów prawa unijnego, nawet wtedy, kiedy potwierdzają ich ważność i nawet jeśli czynią to nie wprost, a jedynie dokonując kontroli konstytucyjności krajowego aktu implementującego akt unijny. Jak podkreślił TSUE:

Zanim wpadkowa kontrola zgodności z konstytucją ustawy krajowej, której treść ogranicza się do transpozycji wiążących przepisów dyrektywy Unii, będzie mogła zostać przeprowadzona w świetle tych samych zarzutów kwestionujących ważność dyrektywy, sądy krajowe, których orzeczenia nie podlegają zaskarżeniu według prawa wewnętrznego, są co do zasady zobowiązane, na podstawie art. 267 akapit trzeci TFUE, do wystąienia do Trybunału Sprawiedliwości z pytaniem o ważność tej dyrektywy ${ }^{949}$.

Przy czym należy pamiętać, że nawet po uzyskaniu takiej odpowiedzi wciąż otwarta pozostanie sprawa kontroli prawa transponującego przez pryzmat zgodności z Konstytucją. Skierowanie pytania prejudycjalnego w takiej sytuacji znowu można więc uznać za kolejny środek prowadzący do zminimalizowania niebezpieczeństwa konfliktu między prawem polskim a unijnym (jeśli doszłoby do unieważnienia dyrektywy, to ewentualne uznanie za niekonstytucyjny aktu ją implementującego nie wiązałoby się z doprowadzaniem do stanu, w którym Polska znajdowałaby się w stanie niewypełniania obowiązku implementacji, wynikającego z tej unieważnionej dyrektywy).

Zdaniem niektórych wynikające z doktryny Foto-Frost upoważnienie do kontroli ważności prawa unijnego przez sądy krajowe jest pozorne. „Wnioski wywiedzione z orzeczenia w sprawie Foto-Frost prowadzą do konkluzji, że sądy krajowe - jak się wydaje - jedynie pozornie są upoważnione do dokonywania kontroli aktów prawa pochodnego, co wyraża się w tym, iż samo jej podjęcie musi się wiązać z założeniem co do jej jedynego dopuszczonego przez TSUE wyniku" ${ }^{\prime \prime 50}$. Chyba jednak lepiej byłoby powiedzieć, że nie jest ona pozorna, lecz, że jest to kompetencja do dokonywania swoistego przed-sądu i o ile jego efekt sprzyja spójności systemu prawa unijnego i potwierdza ważność wydanych w jego ramach przez instytucje Unii aktów prawnych, to prowadzi on do braku konieczności angażowania w ten proces TSUE i przedłużania sprawy, szczególnie na etapach, kiedy ich orzeczenie nie jest niepodważalne. Sądy kra-

\footnotetext{
${ }_{948}$ Ibidem, pkt 30.

${ }_{949}$ TSUE, Aziz Melki i Sélim Abdeli, C-188/10 i C-189/10, wyrok z 22 czerwca 2010, pkt 56.

950 J. Maśnicki, Kontrola konstytucyjności..., s. 72.
} 
jowe, które, jak była już o tym mowa, są też sądami unijnymi, jako takie mogą ten problem rozwiązywać same. Jeśli zaś w wyniku owego przed-sądu dojdą one do przekonania o na tyle poważnych wadach aktów prawa unijnego, że powinny one skutkować ich nieważnością, to uzasadnia to zaangażowanie TSUE, jako jedynego organu uprawnionego do unieważniania takich aktów prawa unijnego.

\subsubsection{Niedopuszczalność stosowania $w$ Polsce prawa pochodnego UE w związku z jego niezgodnością z Konstytucją}

TK dostrzega zarówno istnienie zasady pierwszeństwa prawa unijnego, jak i doktryny Foto-Frost. Co do zasady TK ich nie kwestionuje, choć czasem interpretuje je dość specyficznie ${ }^{951}$. TK dostrzega i nie kwestionuje także podziału ról między sobą a TSUE, gdy chodzi o hierarchiczną kontrolę prawa unijnego i prawa krajowego. Również i tu prezentuje jednak podejście, w którym uzupełnia perspektywę unijną spojrzeniem konstytucyjnym. Dlatego też należy zauważyć, że TK w dalszej części uzasadnienia do wyroku w sprawie Sk 45/og podkreśla i „zwraca uwagę na konieczność rozróżnienia, z jednej strony, badania zgodności aktów unijnego prawa pochodnego $z$ traktatami, czyli prawem pierwotnym Unii, a z drugiej strony, badania ich zgodności z Konstytucją" ${ }^{\prime \prime 52}$. O ile ta pierwsza pozostaje w domenie TSUE, o tyle ta druga musi pozostać zarezerwowana dla TK.

Ta ostatnia miałaby mieć charakter wyjątkowy i subsydiarny, jako wymykająca się podstawowej hierarchii, w ramach której funkcjonują akty unijnego prawa pochodnego. Nie można jej jednak wykluczyć, a nie sposób przypisać kompetencji do jej wykonywania komukolwiek innemu niż TK. Trybunał już we wcześniejszym swym orzecznictwie podkreślał, że rolą TSUE jest stanie na straży prawa unijnego, zaś rolą TK jest stanie na straży Konstytucji ${ }^{953}$. To TK w sprawach ustrojowych widzi siebie jako "sąd ostatniego słowa” w odniesieniu do polskiej Konstytucji. Jak wynika z tego stanowiska TSUE i TK nie są sądami konkurującymi ze soba, a cechują je odmienne role i wynikające z nich kompetencje. TK dostrzega więc konieczność zachowania daleko posuniętej ostrożności i powściągliwości w sytuacji podejmowania przezeń kontroli prawa pochodnego UE. Nie może jednak pozostawać bierny tam, gdzie jego aktywność jest uzasadniona i konieczna ze względu na rangę Konstytucji w polskim porządku prawnym ${ }^{954}$.

W związku z powyższym skutki ewentualnego orzeczenia TK o niezgodności pochodnego prawa unijnego z Konstytucją RP nie mogłyby mieć, co sam

\footnotetext{
${ }^{951}$ Por.: ibidem, s. 7 o.

952 TK, sprawa Sk 45/o9, wyrok z 16 listopada 2011, pkt III 2.3 uzasadnienia.

953 TK, sprawa P 37/o5, wyrok z 19 grudnia 2006.

954 TK, sprawa Sk 45/o9, wyrok z 16 listopada 2011, pkt III 2.4 uzasadnienia.
} 
przyznaje, charakteru analogicznego do skutków orzeczenia TK o niezgodności przepisów prawa krajowego z Konstytucją. Nie mogłyby mieć też skutku analogicznego do orzeczenia TSUE o niezgodności pochodnego prawa unijnego z prawem pierwotnym, a więc wiązać się z unieważnieniem badanego prawa. Jak stwierdza TK: „W odniesieniu do aktów unijnego prawa pochodnego tego rodzaju skutek byłby niemożliwy, ponieważ o mocy obowiązującej takich aktów nie decydują organy polskie. Konsekwencją orzeczenia Trybunału Konstytucyjnego byłoby tylko pozbawienie aktów unijnego prawa pochodnego możliwości stosowania przez organy polskie i wywierania skutków prawnych w Polsce ${ }^{\prime \prime 955}$. Skoro TK może skontrolować zgodność pochodnego prawa unijnego z Konstytucja, ale nie może go unieważnić, to jaki miałby być skutek ewentualnego stwierdzenia takiej niezgodności? TK udziela jednoznacznej odpowiedzi: „Skutkiem wyroku Trybunału Konstytucyjnego byłoby zatem zawieszenie stosowania na terytorium Rzeczypospolitej Polskiej niezgodnych z Konstytucją norm prawa unijnego" ${ }^{\prime \prime 56}$. Prawo to pozostawałoby więc w mocy i obowiązywało oraz bez przeszkód funkcjonowało na terytorium pozostałych państw Unii. W Polsce nie mogłoby być jednak stosowane.

Oczywiście konsekwencja taka wydaje się trudna do pogodzenia z art. 4 ust. 3 TUE, który formułuje zasadę lojalnej współpracy państw członkowskich UE w realizowaniu celów Uni9 ${ }^{957}$. Byłaby ona niewątpliwie również sprzeczna z omawianą powyżej zasadą pierwszeństwa oraz jedności i skuteczności prawa UE. Podważałaby więc fundamenty procesu integracji europejskiej opisane powyżej. Wydanie podobnego wyroku przez TK, co podkreśla również sam Trybunał ${ }^{958}$, doprowadziłoby zapewne również do wszczęcia wobec Polski postępowania przez Komisję Europejską i w jego efekcie złożenia przez nią do TSUE skargi z tytułu naruszenia przez nasz kraj zobowiązań traktatowych w trybie przewidzianym przez art. 258-26o TFUE. Zdając sobie sprawę z tych wszystkich negatywnych konsekwencji, w przypadku braku innego wyjścia, TK nie tylko stoi na stanowisku, że mógłby taki wyrok wydać, ale że byłby do tego zobowiązany.

Ze względu na powagę potencjalnych negatywnych konsekwencji takiego wyroku TK w uzasadnieniu wyroku w sprawie Sk 45/og zdecydował

955 Ibidem, pkt III 2.7 uzasadnienia.

956 Ibidem, pkt III 2.7 uzasadnienia.

957 Stanowi on, że: „Zgodnie z zasadą lojalnej współpracy Unia i Państwa Członkowskie wzajemnie się szanują i udzielają sobie wzajemnego wsparcia w wykonywaniu zadań wynikających z Traktatów. Państwa Członkowskie podejmują wszelkie środki ogólne lub szczególne właściwe dla zapewnienia wykonania zobowiązań wynikających z Traktatów lub aktów instytucji Unii. Państwa Członkowskie ułatwiają wypełnianie przez Unię jej zadań i powstrzymują się od podejmowania wszelkich środków, które mogłyby zagrażać urzeczywistnieniu celów Unii".

958 TK, sprawa Sk 45/o9, wyrok z 16 listopada 2011, pkt III 2.7 uzasadnienia. 
się ponadto obiter przypomnieć i podtrzymać sformułowane przez siebie w wyroku w sprawie traktatu akcesyjnego (K 18/o4) ustalenia co do ostatecznych - systemowych - konsekwencji niezgodności pochodnego prawa unijnego z Konstytucją. Powtórzył w tym kontekście raz jeszcze, że ostatecznie

istnieją trzy możliwości reakcji Polski na wystąpienie niezgodności między Konstytucją a prawem unijnym: a/ dokonanie zmian w Konstytucji, b/ podjęcie działań zmierzających do wprowadzenia zmian w przepisach unijnych albo c/ podjęcie decyzji o wystąpieniu z Unii Europejskiej. Decyzję taką winien podjąć suweren, którym jest Naród polski, lub organ władzy państwowej, który w zgodzie z Konstytucją może reprezentować Naród ${ }^{959}$.

Jak była już o tym mowa przy okazji wyroku w sprawie P 1/05, istnieją również metody, takie jak odroczenie skuteczności wyroku, którymi może się TK posłużyć w celu stworzenia możliwości do zrealizowania któregoś z tych scenariuszy. Ostatecznie jednak wyczerpują one spektrum dostępnych możliwości i o ile po ewentualnym odroczeniu wejścia w życie wyroku o niezgodności z Konstytucją prawa pochodnego żaden z nich by się nie ziścił, przedmiotowe prawo pochodne nie mogłoby w Polsce być stosowane, a Polska znajdowałaby się $\mathrm{w}$ stanie naruszenia swych traktatowych zobowiązań. Przypomnienie tych trzech dróg w kontekście tej sprawy świadczy o daleko posuniętej jednoznaczności TK w obronie swej kompetencji do stania na straży Konstytucji jako najwyższego prawa w Polsce. Dostrzec można, mówiąc kolokwialnie, opierając się także na przedstawionym w poprzednich rozdziałach orzecznictwie TSUE, kurs kolizyjny, na jakim znajdują się, bez wskazywania z czyjej przyczyny, ani też bez wskazywania racji po żadnej ze stron, polski TK oraz TSUE. Kurs ten wynika w dużej mierze z powodów obiektywnych, a więc z charakteru prawa Unii oraz statusu Konstytucji.

\section{Pytanie prejudycjalne do TSUE jako jedna z metod niekonfliktowego rozstrzygnięcia potencjalnej kolizji między unijnym a wyższym niż unijny konstytucyjnym standardem ochrony praw jednostki}

Wyjątkowy i subsydiarny charakter kompetencji TK do orzekania o niezgodności prawa pochodnego UE z prawami i wolnościami jednostki zagwarantowanymi w Konstytucji, musi zdaniem TK wiązać się z koniecznością podejmowania

\footnotetext{
${ }^{959}$ Ibidem, pkt III 2.7 uzasadnienia.
} 
prób możliwie niekonfliktowego rozstrzygania tej kolizji, a zatem eliminowania jej bez konieczności uciekania się do orzeczenia o niestosowaniu tego prawa na terenie Polski. TK stara się więc szukać rozwiązań, zmierzających do rozwijania współpracy w ramach wspólnoty europejskiej i niepodważających procesu integracji ${ }^{960}$. Jak podkreślił w uzasadnieniu wyroku w sprawie Sk 45/o9 TK: „Niewątpliwie orzeczenie o niezgodności prawa unijnego z Konstytucją powinno mieć zatem charakter ultima ratio i wystąić jedynie wówczas, kiedy zawiodłyby wszystkie inne sposoby rozstrzygnięcia konfliktu z normami należącymi do unijnego porządku prawnego" ${ }^{\prime \prime 61}$.

Należy więc zastanowić się, jakie środki mogłyby zostać przedsięwzięte dla znalezienia takich niekonfliktowych rozwiązań i uniknięcia stanowiących ostateczność rozwiązań konfliktowych, które zdaniem samego Trybunału w skrajnej sytuacji mogłyby wiązać się z zakończeniem członkostwa RP w UE. O procedurze wykluczenia nie wspominając, można zauważyć, że niedawne referendum w Wielkiej Brytanii i rozpoczęcie przez to państwo procedury wyjścia z Unii pokazuje, że we współczesnej rzeczywistości politycznej jest to rozwiązanie coraz bardziej możliwe, a nie jedynie hipotetyczne, jak przez wiele lat się wydawało ${ }^{962}$, a stanowi jedno $\mathrm{z}$ triady przypomnianych w uzasadnieniu do wyroku w sprawie Sk 45/og rozwiązań nieusuwalnego w inny sposób konfliktu między prawem unijnym a Konstytucją RP.

Gdy chodzi o takie niekonfliktowe rozwiązania, to jak zauważa sam TK: „Służyć temu może wystąpienie do Trybunału Sprawiedliwości z pytaniem prejudycjalnym na podstawie art. 267 TFUE w kwestii interpretacji lub ważności przepisów budzących wątpliwości" ${ }^{\prime \prime 63}$. TK trafnie zauważa, że takie odesłanie

${ }^{960}$ Na podobnym stanowisku stoją zresztą w tej materii sądy konstytucyjne innych państw członkowskich; więcej - patrz np.: D. Paris, Limiting the 'Counter Limits'. National Constitutional Courts and the Scope of the Primacy of EU Law, "Italian Journal of Public Law" 2018, nr 10 (2), s. 223.

961 TK, sprawa Sk 45/o9, wyrok z 16 listopada 2011, pkt III 2.7 uzasadnienia.

962 Jak wiadomo art. 50 ust. 1 TUE stanowi: „Każde Państwo Członkowskie może, zgodnie ze swoimi wymogami konstytucyjnymi, podjąć decyzję o wystąpieniu z Unii". Polska Konstytucja $\mathrm{w}$ art. 90 ust. 1 stanowi jedynie o warunkach przystąpienia do organizacji międzynarodowej, na mocy której następuje przeniesienie kompetencji organów władzy państwowej na organizację międzynarodową - milczy jednak o trybie ewentualnego wystąpienia z takiej organizacji. Odnośnie do wystąpienia z takiej organizacji, a także z UE, zastosowanie znajdują postanowienia Ustawy o umowach międzynarodowych (Ustawa z 14 kwietnia 2000 o umowach międzynarodowych, Dz.U. nr 39, poz. 442 ze zm.), która w art. 22a ust. 2 stwierdza, że: „Przedłożenie Prezydentowi Rzeczypospolitej Polskiej projektu decyzji o wystąpieniu z Unii Europejskiej jest dokonywane po uzyskaniu zgody wyrażonej w ustawie". Do wystąpienia z Unii Europejskiej wystarczy więc zgoda wyrażona w ustawie zwykłej. Rozwiązanie takie znajduje jednak niepozbawioną pewnych racji krytykę w doktrynie (zob. np. J. Barcz, Traktat z Lizbony. Wybrane aspekty..., s. 497 i nast.; A. Kustra, "Euronowelizacja” w projektach ustaw o zmianie Konstytucji RP. Próba oceny, "Przegląd Sejmowy” 2011, nr 3, s. 45 i nast.).

963 TK, sprawa Sk 45/o9, wyrok z 16 listopada 2011, pkt III 2.6 uzasadnienia. 
i następujące po nim orzeczenie TSUE mogłoby wyeliminować problem na przynajmniej dwa sposoby. Po pierwsze, w wyniku wykładni przepisów prawa pochodnego UE, dokonywanej przez TSUE mogłoby się okazać, że treść kwestionowanej normy jest $w$ istocie inna niż mogłoby się to wydawać na pierwszy rzut oka i że w rzeczywistości jest jednak zgodna z Konstytucją, a sprzeczność wynikała jedynie z błędnego jej odczytania. Dzięki prawidłowej interpretacji prawa unijnego mogłoby się więc okazać, że faktycznie nie jest ono z Konstytucją sprzeczne, co rozwiązywałoby problem. Po drugie zaś TSUE mógłby dopatrzyć się naruszenia przez badane prawo pochodne prawa pierwotnego UE - w interesującym nas przypadku naruszenia przez nie zagwarantowanych w Karcie standardów ochrony praw i wolności jednostki - i ze względu na to je unieważnić. To również rozwiązywałoby problem i sprawiałoby, że ewentualne orzeczenie TK o niestosowaniu prawa unijnego w Polsce, byłoby zbędne, gdyż w wyniku orzeczenia TSUE, przestawałby on obowiązywać.

Ziszczenie się tych scenariuszy wydaje się zresztą wysoce prawdopodobne zważywszy na wspólną tradycję konstytucyjną państw członkowskich, z której wyrasta unijna ochrona i tym samym rozumienie praw podstawowych. Jak podkreślił to sam TK, „ze względu na podobieństwo wartości znajdujących wyraz w Konstytucji i traktatach [...], istnieje duże prawdopodobieństwo, że ocena Trybunału Sprawiedliwości będzie podobna do oceny Trybunału Konstytucyjnego"964. W uzasadnieniu omawianego tu wyroku owa bliskość aksjologiczna była przez TK wielokrotnie i wyraźnie akcentowana. TK podkreślił, „że konsekwencją wspólnej dla wszystkich państw członkowskich aksjologii systemów prawnych jest to, że prawo unijne nie powstaje w przestrzeni europejskiej, abstrakcyjnej oraz wolnej od wpływu państw członkowskich i ich społeczności" ${ }^{\prime \prime 65}$. Można więc liczyć, że zaproponowane przez TK drogi niekonfliktowego rozwiązania dostrzeżonej przez niego niezgodności bezpośrednio skutecznego w Polsce prawa pochodnego Unii z konstytucyjnymi prawami i wolnościami człowieka mogłyby doprowadzić do usunięcia takiego stanu, a nawet przyczynić się do usunięcia na przestrzeni całej Unii prawa naruszającego prawa i wolności obywateli Unii. Rozwiązanie takie doprowadziłoby więc do pożądanego efektu usunięcia z systemu norm prawnych naruszających prawa człowieka $\mathrm{w}$ ramach całego unijnego porządku prawnego, a nie tylko w Polsce.

Należy zauważyć, że oba te rozwiązania zakładają jednak w swej istocie, że kontrolowane prawo pochodne było albo ab inicio zgodne z Konstytucja, tylko źle je rozumiano, albo też było ab inicio niezgodne nie tylko z Konstytucją $R P$, lecz również z prawem pierwotnym UE, a niezgodność ta nie została

\footnotetext{
${ }^{964}$ Ibidem, pkt III 2.6 uzasadnienia.

${ }^{965}$ Ibidem, pkt III 2.10 uzasadnienia.
} 
jedynie wcześniej dostrzeżona. Tymczasem pytaniem zasadniczym, jakie postawione zostało w pracy, jest pytanie o rozwiązanie sytuacji, w której prawo pochodne UE wydane zgodnie $\mathrm{z}$ zasadami prawa pierwotnego UE, a więc odpowiadające również unijnym gwarancjom praw i wolności jednostki, pozostaje w sprzeczności z wyższym standardem ochrony tych praw i wolności, który byłby przewidziany przez krajową konstytucję. Należy zgodzić się z TK, że pytanie prejudycjalne do TSUE, o jakim wspomniał w uzasadnieniu wyroku w sprawie Sk 45/og, byłoby jak najbardziej wskazane i z dużą dozą prawdopodobieństwa doprowadziłoby do zgodnego rezultatu zarówno z prawem unijnym, jak i polskim. Tym niemniej nie można wykluczyć, że mogą istnieć również takie scenariusze, w których oba te rozwiązania nie prowadziłyby do wyeliminowania problemu, jakim byłaby sprzeczność zgodnego z pierwotnym prawem unijnym i prawidłowo zinterpretowanego, pochodnego prawa unijnego z wyższymi niż unijne, konstytucyjnymi gwarancjami praw człowieka.

\section{Podsumowanie}

Jak to przedstawiono w poprzednich rozdziałach i o czym będzie jeszcze mowa, TSUE twardo stoi na stanowisku, jakie wynika z jego roli w ramach unijnej architektury konstytucyjnej i szeroko zakreśla zakres zastosowania Karty i unijnych praw podstawowych, w specyficzny sposób wiążąc go również z zasadami pierwszeństwa, jednolitości i efektywności prawa unijnego, jak to ukazano w tym rozdziale. Podobnie TK twardo stoi na stanowisku wynikającym z jego roli i pozycji w ramach polskiego ustroju konstytucyjnego i w żadnym wymiarze nie jest skłonny do kapitulacji i rezygnacji ze swych kompetencji odnośnie do hierarchicznej kontroli prawa obowiązującego w Polsce zgodnie z uprawnieniami, a jednocześnie zobowiązaniami, jakie nakłada na niego Konstytucja $\mathrm{RP} w$ tej materii.

TK jest otwarty na prawo unijne, dostrzega multicentryczność, czy jak sam woli - wieloskładnikowość - systemu prawnego obowiązującego w Polsce w związku z członkostwem naszego kraju w Unii. Nie godzi się jednak na to, aby prowadziło to $\mathrm{w}$ jakimkolwiek stopniu do osłabienia jego roli jako arbitra nad prawem obowiązującym w Polsce w kontekście jego zgodności z Konstytucją. W tym szczególnie podkreśla swą rolę jako strażnika konstytucyjnych gwarancji praw i wolności człowieka, które stanowią fundamentalne wartości chronione konstytucyjnie. Wieloskładnikowość polskiego systemu prawnego i jego otwartość na prawo unijne obarczona jest różnymi ograniczeniami, z których część bardziej szczegółowo omówiona zostanie w następnym rozdziale. Na 
podstawie tego, o czym była mowa w tym rozdziale, należy podkreślić przede wszystkim, że główny mechanizm umożliwiający funkcjonowanie Polski w Unii, a co za tym idzie, prawa unijnego w Polsce, jakim jest prounijna wykładnia prawa polskiego, w tym Konstytucji RP, do czego TK czuje się zobowiązany, nie może jednak być niegraniczony. Nie może więc on prowadzić do pogorszenia położenia jednostek, a zwłaszcza wprowadzenia lub zaostrzenia ich odpowiedzialności karnej, nie może prowadzić do wyników sprzecznych z wyraźnym brzmieniem norm konstytucyjnych, nie może być więc contra legem, wreszcie nie może prowadzić do rezultatów niemożliwych do uzgodnienia z minimum funkcji gwarancyjnych realizowanych przez Konstytucję RP, a zwłaszcza nie może prowadzić do naruszenia tożsamości konstytucyjnej Polski.

TK stoi też na stanowisku, że jest kompetentny do kontrolowania prawa polskiego, stanowiącego przejaw implementacji prawa unijnego, czy też mówiąc szerzej, mieszczącego się w zakresie prawa unijnego, przez pryzmat zgodności z Konstytucja, tak jakby było to po prostu prawo polskie. Przepisy takie tout court, niezależnie od ich unijnego charakteru stanowią zdaniem TK dopuszczalny przedmiot kontroli konstytucyjności. Stanowisko to nieco ewoluuje, czego przejawem było pierwsze odesłanie prejudycjalne, jakie TK skierował do TSUE w sprawie RPO, odzwierciedlając w ten sposób zobowiązania, jakie nakłada na niego prawo unijne i sposób, w jaki zobowiązania te interpretuje TSUE. Odesłanie to trudno jednak uznać za odejście od przekonania TK co do możliwości kontrolowania prawa polskiego mieszczącego się w zakresie prawa unijnego przez pryzmat zgodności z Konstytucją. Można je traktować jedynie jako zadośćuczynienie pewnym konsekwencjom, jakie towarzyszą związkowi takiego prawa z prawem unijnym, którego implementacji ono służy i jako zadośćuczynienie uprawnieniom TSUE do badania tegoż prawa przez pryzmat zgodności z unijnymi normami wyższego rzędu, w ramach unijnej hierarchii normatywnej. To ostatnie zdaje się jednak zgodnie z podejściem TK w żaden sposób nie ograniczać kompetencji tego trybunału do kontrolowania prawa polskiego, mieszczącego się w zakresie prawa unijnego w ramach polskiej hierarchii normatywnej. Orzeczenie TSUE będzie dla TK swoistym przed-sądem w ramach innego układu odniesienia, i - jak ujął to on w jednej z omawianych w tym rozdziale spraw - "tłem decyzyjnym" dla orzeczenia na gruncie Konstytucji RP.

Co więcej, TK stoi na stanowisku, że w ograniczonym zakresie i w ograniczonych trybach, jest on również kompetentny do tego, aby badać zgodność z Konstytucją nawet bezpośrednio skutecznego unijnego prawa pochodnego, które pozostaje poza konstytucyjną hierarchią źródeł prawa. Czuje się on do tego kompetentny w trybie skargi konstytucyjnej, a jak wydaje się z uzasadnienia, które go do takiego wniosku doprowadziło, również w trybie pytania praw- 
nego (a może także w trybie art. 186 ust. 2 Konstytucji) ze względu na szersze niż w pozostałych trybach określenie zakresu dopuszczalnych przedmiotów kontroli poprzez kategorię generalną - aktu normatywnego. Tryb skargi konstytucyjnej umożliwia mu badanie aktów pochodnego prawa unijnego przez pryzmat zgodności z konstytucyjnie zagwarantowanymi prawami i wolnościami człowieka. Pytania prawne zaś umożliwiałyby mu już kontrolę aktów pochodnego prawa unijnego przez pryzmat zgodności z całą Konstytucją a więc również, choć nie tylko, z zawartymi w niej gwarancjami praw i wolności człowieka.

Oprócz takich metod, jak prounijna wykładnia TK stara się szukać wszelkich sposobów unikania kolizji ze zobowiązaniami wynikającymi z prawa unijnego i kompetencjami TSUE, w tym również unikania jej poprzez pytania prejudycjalne, zarówno te, które już zadał, jak i te, do których zadania się zobowiązał, szczególnie w przypadku rozważania ewentualności orzeczenia o niezgodności z Konstytucją bezpośrednio skutecznego w Polsce unijnego prawa pochodnego. Szukając tych dróg podkreśla jednak, że ostatecznie nierozwiązywalna kolizja może zakończyć się orzeczeniem o niestosowalności danego aktu prawa unijnego w Polsce ze wszystkimi tego konsekwencjami, jak wszczęcie przeciwko Polsce procedury naruszeniowej, aż po rozwiązania ostateczne, takie jak wykluczenie czy wystąienie Polski z Unii. Jak widać zarówno TSUE, jak i TK, o ile starają się znajdować możliwie niekolizyjne sposoby współistnienia, o tyle w pewnym zakresie znajdują się jednak na kursie kolizyjnym. Jedną z centralnych potencjalnych kości niezgody, której uwaga poświęcona jest w tej pracy, jest stanie na straży gwarancji praw człowieka, szczególnie jeśli prawo unijne miałoby w związku ze swym pierwszeństwem, jednolitością i efektywnością prowadzić do obniżenia standardu konstytucyjnego.

W tym kontekście można zauważyć, że nieuszanowanie konstytucyjnych standardów ochrony praw i wolności człowieka mogłoby być uznane za działanie Unii ultra vires. W orzecznictwie sądów konstytucyjnych państw członkowskich, szczególnie w okresie polizbońskim, ale i wcześniej, zarysowała się bowiem wyraźnie linia, choć oczywiście nie w pełni jednorodna, związana z założeniem o nieprzekazywalności pewnych kompetencji na rzecz Unii, które stanowią o ich tożsamości konstytucyjnej, w tym składających się na nią konstytucyjnych gwarancji praw i wolności człowieka ${ }^{966}$. W nurt ten wpisał się również nasz TK. Propozycja nowej płaszczyzny współpracy między TK a TSUE dotyczącej wyższych niż unijne standardów ochrony praw człowieka, które składają się na tożsamość konstytucyjną RP będzie przedmiotem następnego rozdziału. Propozycja ta nie będzie całkowitym i ostatecznym rozwiązaniem tego problemu ani nie doprowadzi do wyeliminowania problemu

966 Więcej - patrz np.: K. Wójtowicz, Poszanowanie tożsamości..., s. 15 i nast. 
ewentualnego działania Unii poza swymi kompetencjami oraz konsekwencji, jakie $z$ tego wynikają $\mathrm{i}$ jakie zostały ujawnione między innymi w orzecznictwie sądów konstytucyjnych państw członkowskich, nawiązującym do doktryny ultra vires. Odsunie ona jednak ewentualne zastosowanie tego ostatecznego argumentu i pozwoli na podjęcie próby zgodnego zarówno z prawem unijnym, jak i krajowym dialogicznego i niekonfliktowego uszanowania wyższego niż unijny, krajowego standardu ochrony praw człowieka, który stanowi element tożsamości konstytucyjnej tego państwa.

Oprócz wszystkich analizowanych podstaw normatywnych, którym uwaga poświęcana jest w pracy, można dodatkowo zauważyć, że wspólna ochrona takiego standardu, jak i szerzej - wspólna odpowiedzialność unijnych i krajowych organów za skuteczne funkcjonowanie Unii i unikanie konstytucyjnych konfliktów - poprzez stosowanie przydatnych do tego mechanizmów, w tym przede wszystkim mechanizmów sądowego dialogu, jest zobowiązaniem tych instytucji wobec obywateli państw członkowskich, którzy są przez to również obywatelami Unii ${ }^{967}$. Autonomiczność unijnego porządku prawnego, ale również autonomiczność porządków krajowych, które przecież też tę cechę posiadają, sprawia, że przez fakt członkostwa w Unii autonomiczności te są współzależne i przy braku ostatecznego arbitra, pozostaje wspólna odpowiedzialność organów krajowych i unijnych względem wspólnego punktu odniesienia, a zarazem suwerena, a więc vis-à-vis obywateli ${ }^{968}$.

${ }^{967}$ I. Pernice, The Autonomy of the EU Legal Order - Fifty Years After Van Gend, [w:] Van Gend en Loos 1963-2013. Conference Proceedings, Luxemburg 13 May 2013, s. 64.

${ }^{968}$ R. Barents, The Autonomy of Community Law, Haga-Londyn 2004, s. 18, 176 i nast., przed. 268 i nast., 299 i nast.; I. Pernice, The Autonomy..., s. 64-65. 


\section{Dialog między TK a TSUE w przedmiocie poszanowania tożsamości konstytucyjnej RP i składającego się na nią wyższego niż unijny konstytucyjnego standardu ochrony praw czlowieka}

\section{Wstęp}

Tak wynika z jej art. 53, Karta nie może doprowadzić do obniżenia standardów ochrony praw i wolności jednostki, które podlegają ochronie przez prawo Unii, a którymi jednostka ta cieszyć się może na podstawie innych regulacji. Art. 53 Karty na pierwszy rzut oka wygląda jak typowa klauzula, zwana czasem zastrzegająca, czy mówiąc precyzyjnej, klauzula zapewniająca ochronę uznanych na podstawie innych źródeł praw i wolności człowieka. Klauzule tego rodzaju, co dobrze oddaje ich istotę, bywają nazywane klauzulami najwyższego uprzywilejowania jednostki ${ }^{969}$. Są one powszechnie obecne w międzynarodowych aktach gwarantujących prawa człowieka ${ }^{970}$. Karta nie jest typową umową międzynarodową zawierającą gwarancje praw człowieka, którą wiążą się państwa do niej przystępujące, lecz jest wewnętrznym aktem Unii, jako sui generis organizacji międzynarodowej, wyposażonej w bogate kompetencje, w tym prawotwórcze. To właśnie Unia i jej instytucje są podstawowym adresatem postanowień Karty, a nie państwa członkowskie, które są związane Kartą w ograniczonym zakresie. Kwestia specyfiki Karty na tle międzynarodowych aktów praw człowieka w kontekście jej art. 53 była już zasygnalizowana w poprzednich rozdziałach. $W$ tym rozdziale zyska rozwinięcie w kontekście

${ }_{969}$ Por. np.: R. Wieruszewski, Artykuł 5..., s. 96.

970 Patrz np.: art. 53 EKPCz, art. 5 ust. 2 Międzynarodowego Paktu Praw Obywatelskich (Osobistych) i Politycznych, art. 5 ust. 2 Międzynarodowego Paktu Praw Gospodarczych, Socjalnych i Kulturalnych czy art. 29 ust. b Amerykańskiej Konwencji Praw Człowieka. 
istotnym z perspektywy tej pracy. Art. 53 zostanie poddany szczegółowej analizie jako przepis uzupełniający charakter Karty jako dokumentu ustanawiającego minimalny standard ochrony praw i wolności w niej zagwarantowanych $\mathrm{w}$ zakresie jej zastosowania, przede wszystkim w wymiarze, $w$ jakim nadaje on Karcie w pewnych przypadkach status dokumentu ustanawiającego maksymalny dopuszczalny standard ochrony praw i wolności w niej zagwarantowanych. Przedstawienie tego rodzaju roli Karty będzie konieczne po to, aby przejść do analizy dopuszczalnych wyjątków od tej zasady, związanych z konstytucyjnymi gwarancjami praw człowieka oraz z tożsamością konstytucyjną Rzeczypospolitej Polskiej.

Na gruncie art. 53 KPP szczególna rola przypisana została standardom zagwarantowanym w EKPCz, obok porządków konstytucyjnych państw członkowskich. Wyróżnienie roli Konwencji nie ogranicza się jednak wyłącznie do postanowień art. 53. UE jest zobowiązana do przestrzegania standardów ochrony praw jednostki wypracowanych przez Europejski Trybunał Praw Człowieka w Strasburgu, mimo że formalnie nie jest stroną Konwencji, a jedynie jest zobowiązana do przystąpienia do niej, opierając się na art. 6 ust. 2 TUE ${ }^{971}$. Standardy konwencyjne stanowią bezwzględny minimalny standard ochrony praw i wolności w niej zagwarantowanych dla prawa unijnego. Zgodnie z art. 52 ust. 3 Karty „w zakresie, w jakim niniejsza Karta zawiera prawa, które odpowiadają prawom zagwarantowanym w Europejskiej konwencji o ochronie praw człowieka i podstawowych wolności, ich znaczenie i zakres są takie same jak praw przyznanych przez tę konwencję. Niniejsze postanowienie nie stanowi przeszkody, aby prawo Unii przyznawało szerszą ochronę". Przepis ten uzupełnia art. 53 Karty, podnosząc rangę Konwencji i wynikających z jej postanowień standardów ochrony zagwarantowanych w niej praw względem pozostałych, wymienionych w art. 53 źródeł gwarancji praw człowieka ${ }^{972}$. Standard strasburski jawi się dla prawa unijnego jako standard minimalny, który zawsze musi być przestrzegany, a wszelka dalej idąca ochrona jest dozwolona, a nawet wskazana. Jest to dobrze znana rola, w jakiej występuje EKPCz i wyznaczane przez nią standardy ochrony praw i wolności jednostki. Podobne znaczenie mają one dla krajowych systemów ochrony praw jednostki.

${ }^{971}$ Więcej na temat procesu przystąpienia Unii do Konwencji oraz statusu Konwencji w unijnym porządku prawnym patrz np.: A.-L. Chané, A. Hauser, J. Jaraczewski, W. Jóźwicki, Z. Kędzia, M.A. Šimáková, H. Suchocka, S. Wallace, EU Engagement..., s. 58 i nast.; P. Gragl, The Accession....

972 Prawnie wykluczona jest więc sytuacja, w której prawo Unii obniżałoby strasburski standard ochrony praw jednostki. Kwestia, czy faktycznie do podobnych kolizji dochodzi, nie będzie wchodziła w zakres tematyczny tego opracowania (więcej - patrz np.: E. Ravasi, Human Rights Protection by the ECtHR and the ECJ. A Comparative Analysis in Light of the Equivalency Doctrine, Leiden 2017). 
Inna jest natomiast relacja między standardem unijnym i standardem krajowym, o czym będzie mowa w tym rozdziale. Jednym z pytań, na które próba odpowiedzi zostanie w nim podjęta, koncentrować się będzie wokół tego, jak należy podchodzić do sytuacji, w których prawo UE i prawo krajowe mieszczące się w zakresie jego zastosowania spełniałoby wymogi stawiane mu w kwestii ochrony praw jednostki przez prawo unijne, a więc byłoby zgodne ze standardami ochrony wynikającymi z KPP, nie wypełniając jednak krajowego standardu ochrony jakiegoś prawa czy wolności, który w danym państwie członkowskim byłby wyższy niż w prawie Unii.

Co do zasady, należy zgodzić się, że ze względu na wspólne źródła i aksjologiczną bliskość gwarancji ochrony praw człowieka w Unii i państwach członkowskich, materialne rozbieżności pomiędzy wynikającymi z nich standardami nie powinny zdarzać się ani często, ani być bardzo istotne ${ }^{973}$. Wspólne tradycje konstytucyjne państw członkowskich były przecież jednym z podstawowych źródeł unijnej ochrony praw podstawowych, gdy ta była wyinterpretowywana przez trybunał luksemburski z zasad ogólnych prawa wspólnotowego. Do wspólnych tradycji konstytucyjnych państw członkowskich jako źródła wspólnotowej ochrony praw człowieka TSUE odwoływał się przynajmniej od czasu fundamentalnego, gdy chodzi o ochronę praw podstawowych w unijnym porządku prawnym, wyroku w sprawie Internationale Handelsgesellschaft ${ }^{974}$. Jak podkreśla to również Preambuła do KPP, w której ostatecznie skodyfikowane zostały unijne gwarancje praw człowieka:

Karta potwierdza, przy poszanowaniu kompetencji i zadań Unii oraz zasady pomocniczości, prawa wynikające zwłaszcza z tradycji konstytucyjnych i zobowiązań międzynarodowych wspólnych Państwom Członkowskim, europejskiej Konwencji o ochronie praw człowieka i podstawowych wolności, Kart Społecznych przyjętych przez Unię i Radę Europy oraz z orzecznictwa Trybunału Sprawiedliwości Unii Europejskiej i Europejskiego Trybunału Praw Człowieka.

Także sądy konstytucyjne państw członkowskich za trudne do wyobrażenia uznają rozwój prawa unijnego, który prowadziłby do podważenia fundamentalnych, składających się na tożsamość konstytucyjną państw członkowskich, regulacji konstytucyjnych, w tym przede wszystkim gwarancji praw

${ }^{973}$ Por. np.: M. Pyziak-Szafnicka, Karta Praw..., s. 23-24; A. Rosas, The Applicability..., s. 100; A. Ward, Art. 51..., s. 1453; R. Wieruszewski, Postanowienia Karty Praw Podstazwowych w świetle wiążących Polskę umów międzynarodowych i postanowień Konstytucji RP z 1997 r., [w:] J. Barcz (red.), Ochrona praw podstawowych w Unii Europejskiej, Warszawa 2008.

974 TSUE, Internationale Handelsgesellschaft mbH p. Einfuhr- und Vorratsstelle für Getreide und Futtermittel, 11/70, wyrok z 17 grudnia 1970. 
człowieka ${ }^{975}$. Nie oznacza to jednak, że ewentualność taką wykluczają, co dobitnie przejawia się $w$ rozwijanych przez nie doktrynach, takich jak controlimiti, ultra vires czy tożsamość konstytucyjna.

Sytuacja rozbieżności standardów ochrony między państwami a Unią nie ma wyłącznie charakteru hipotetycznego również w zakresie istotnym z perspektywy tej pracy, a więc w wymiarze, w którym państwa członkowskie zapewniałyby dalej idącą ochronę pewnych praw niż Unia. Lista praw i wolności, które w konkretnych państwach członkowskich UE mają zagwarantowany wyższy poziom ochrony niż wynikałoby to z prawa UE, zdaniem różnych badaczy wcale nie jest krótka. Leonard F.M. Besselink wskazuje takie kwestie, jak absolutny zakaz uprzedniej cenzury wypowiedzi w Niemczech czy Holandii, niektóre prawa mniejszości etnicznych, językowych i kulturowych w takich krajach, jak Belgia, Czechy czy Węgry, ochrona życia nienarodzonego w Irlandii czy prawo do dobrej administracji w Portugalii ${ }^{976}$. Ciekawy problem na tym gruncie może zrodzić się również w związku z Dyrektywą dotyczącą zabezpieczenia i konfiskaty narzędzi służących do popełnienia przestępstwa i korzyści pochodzących z przestępstwa ${ }^{977}$, która może budzić wątpliwość na gruncie systemów konstytucyjnych różnych państw członkowskich Unii, a szczególnie Rumunii, w konstytucji której ochrona prawa własności ma wyjątkowy status i zakres ${ }^{978}$. Szczególne znaczenie dla tego opracowania będzie miał przykład Hiszpanii

975 D. Paris, Limiting..., s. 214 i nast.

${ }^{976}$ L.F.M. Besselink, The Protection of Fundamental Rights Post Lisbon. The Interaction Between the EU Charter of Fundamental Rights, the European Convention on Human Rights (ECHR) and National Constitutions, s. 5 i nast., [online] <http://www.fide2012.eu/index.php?doc_id=94> [dostęp: 5.02.2019].

977 Dyrektywa Parlamentu Europejskiego i Rady w sprawie zabezpieczenia i konfiskaty narzędzi służących do popełnienia przestępstwa i korzyści pochodzących z przestępstwa w Unii Europejskiej, 2014/42/UE z dnia 3 kwietnia 2014, Dz.Urz. L 127 z dnia 29 kwietnia 2014.

${ }_{978}$ Art. 41 Konstytucji Rumunii z 21 listopada 1991 stanowi:

„1) Gwarantuje się prawo własności, jak również wierzytelności wobec państwa. Treść oraz granice tych praw określa ustawa.

2) Własność prywatna, niezależnie od jej podmiotu, jest chroniona ustawą w jednakowy sposób. Obywatele obcy oraz bezpaństwowcy nie mogą nabywać prawa własności gruntów.

3) Nikt nie może zostać wywłaszczony, z wyjątkiem sytuacji konieczności publicznej, określonej zgodnie z ustawą oraz za sprawiedliwym i uprzednim odszkodowaniem.

4) Dla potrzeb robót o znaczeniu ogólnym, władza publiczna może wykorzystać podziemną część każdej nieruchomości z jednoczesnym obowiązkiem wypłacenia właścicielowi odpowiedniego odszkodowania z tytułu strat spowodowanych uszkodzeniem jego gruntu, upraw albo budynków, jak też z tytułu innych strat, za które władza ponosi odpowiedzialność.

5) Odszkodowania przewidziane w ustępach (3) i (4) ustalane są wspólnie z właścicielem, a w przypadku różnicy zdań, na drodze sądowej.

6) Prawo własności zobowiązuje do przestrzegania powinności dotyczących ochrony środowiska oraz zapewnienia dobrosąsiedzkich stosunków, jak też do dopełniania pozostałych obowiązków ciążących na właścicielu w myśl ustawy lub obyczaju. 
i wynikających z konstytucji tego kraju gwarancji prawa do sądu, które przewyższały standard unijny, nie dopuszczając skazania in absentia, i które stały się podstawą pytania prejudycjalnego do TSUE wystosowanego przez tamtejszy Trybunał Konstytucyjny (Tribunal Constitucional de España) w przywoływanej już sprawie Melloni ${ }^{979}$, która będzie jednym z głównych przedmiotów zainteresowania w tym rozdziale ze względu na jej znaczenie dla wykładni art. 53 Karty. Jako że szczegółowa analiza poszczególnych standardów ochrony praw i wolności człowieka zagwarantowanych w Karcie, jak i w porządkach konstytucyjnych państw członkowskich znacznie przekraczałaby zakres tej pracy, uwaga skoncentrowana będzie na porządku polskim. Przytoczoną powyżej listę potencjalnych konfliktów tego rodzaju należy traktować jedynie przykładowo. Również jeśli chodzi o Polskę, analiza nie będzie koncentrować się na problematyce porównania polskich i unijnych gwarancji poszczególnych praw pod kątem ewentualnych materialnych rozbieżności między unijnymi i polskimi standardami. Jest to tematyka niewątpliwie bardzo ciekawa i istotna. „Rzetelne porównanie praw gwarantowanych Kartą i Konstytucją RP wymagałoby [...] co najmniej kilkunastu opracowań dotyczących każdego z nich"980. W pracy tej uwaga koncentruje się na próbie poszerzenia gamy mechanizmów rozwiązywania potencjalnych konfliktów między unijnym a polskim standardem ochrony praw człowieka, gdy ten drugi jest wyższy, która będzie mogła mieć zastosowanie zawsze, gdyby do takiego konfliktu doszło. Celem tej pracy nie jest ich poszukiwanie, lecz sformułowanie zasady ogólnej, służącej rozwiązywaniu tego rodzaju kolizji, jeśli zaistnieją.

Aby rozważania te nie miały jednak charakteru czysto teoretycznego, można podkreślić, że jeśli zgodzić się z Leonardem F.M. Besselinkiem, to przykładów dostarczyć mogłyby niektóre prawa socjalne i ekonomiczne wyżej chronione na podstawie polskiej Konstytucji niż w Karcie ${ }^{981}$. Jednakże specjalny status praw przewidzianych w obejmującym je tytule Karty, o czym była mowa, i ich co do zasady programowy charakter, a także art. 1 ust. 2 Protokołu nr 30 do niego się odnoszący, minimalizują niebezpieczeństwo zaistnienia takiego konfliktu na ich gruncie. Ciekawym przykładem faktycznego zaistnienia takiego konfliktu była niezgodność instytucji ENA, co ostatecznie doprowadziło do zmiany art. 55 Konstytucji, mieszczącego się w Rozdziale II, w którym zawarto

7) Majątek legalnie nabyty nie podlega konfiskacie. Domniemuje się legalne nabycie majątku.

8) Dobra przeznaczone, wykorzystywane lub pochodzące z wykroczeń albo przestępstw mogą być konfiskowane tylko na warunkach określonych ustawą" (za: Konstytucja Rumunii, tłum. A. Cosma, Warszawa 1996).

${ }_{979}$ TSUE, Stefano Melloni p. Ministerio Fiscal, C-399/11, wyrok z 26 lutego 2013.

980 M. Pyziak-Szafnicka, Karta Praw..., s. 21.

${ }^{981}$ L.F.M. Besselink, The Protection..., s. 6. 
konstytucyjne gwarancje praw i wolności jednostki. Przykładu takiego potencjalnego konfliktu z zagwarantowanymi konstytucyjnie prawami i wolnościami jednostki może dostarczyć również wspomniana Dyrektywa 2014/42/UE dotycząca konfiskat mienia związanego z przestępstwem. Już niemal od początku prac nad nią budziła ona kontrowersje na gruncie zgodności z przewidzianymi w polskim porządku prawnym gwarancjami praw człowieka, $w$ tym przede wszystkim z zasadą domniemania niewinności ${ }^{982}$. Nie można wykluczyć, że jeszcze bardziej jaskrawych przykładów obniżania konstytucyjnych standardów ochrony praw człowieka, których nie da się rozwiązać w sposób taki, jak np. kwestii ENA, dostarczy przyszłość.

Nie można wykluczyć, że obowiązki implementacyjne nałożone na Polskę przez prawo unijne zagrożą polskim konstytucyjnym standardom ochrony praw człowieka i uchwalone w ich efekcie prawo polskie nie będzie tym standardom odpowiadać. Możliwe jest również, że jakieś prawo pochodne Unii obowiązujące w Polsce bezpośrednio, wydane zgodnie z wymogami prawa pierwotnego i spełniające minimalne standardy ochrony praw jednostki, którymi związana jest Unia, będzie kolidowało z wyższym niż standard przewidziany w Karcie standardem ochrony konkretnego prawa czy wolności wynikającym z Konstytucji RP. Ta pierwsza sytuacja ziściła się w związku z ENA i została odzwierciedlona w wyroku TK w sprawie P 1/o5. Możliwość zaistnienia tego drugiego niebezpieczeństwa dostrzegł zaś Trybunał Konstytucyjny w wyroku z 16 listopada $2011^{983}$. Oba te wyroki będą istotnym punktem odniesienia w tym rozdziale.

Głównym zadaniem stawianym w tym rozdziale będzie podjęcie próby zarysowania rozwiązania potencjalnego konfliktu między prawem unijnym lub

${ }_{982}$ A. Mościcka, Zajęcie mienia bez wyroku skazującego. Co z domniemaniem niewinności?, „Dziennik. Gazeta Prawna" z 27 sierpnia 2014, [online] <http://www.prawnik.pl/prawo/prawo-w-praktyce/artykuly/817858,zajecie-mienia-bez-wyroku-skazujacego-co-z-domniemaniemniewinnosci.html> [dostęp: 5.02.2019]; A.H. Ochnio, Konfiskata korzyści z przestępstwa - nowe rozwiazania w prawie Unii Europejskiej (część I), „Prokuratura i Prawo” 2016, nr 4; idem, Konfiskata korzyści z przestępstwa - nowe rozwiąania w prawie Unii Europejskiej (część II), „Prokuratura i Prawo" 2016, nr 5 .

${ }^{983}$ TK, sprawa Sk 45/o9, wyrok z 16 listopada 2011. Patrz też np.: P. Bogdanowicz, P. Marcisz, Szukajac granic kontroli - glosa do wyroku TK z 16.11.2011 r. (SK 45/og), "Europejski Przegląd Sądowy" 2012, nr 9; A. Chmielarz, Kontrola...; E. Etynkowska, Glosa aprobujaca do wyroku Trybunału Konstytucyjnego z dnia 16 listopada 2011 roku, Sygn. akt SK 45/og, "Przegląd Prawa i Administracji" 2012, nr 90; J. Galster, A. Knade-Plaskacz, Glosa do wyroku Trybunału Konstytucyjnego $z$ dnia 16 listopada 2011 r. (sygn. Akt SK 45/og), "Przegląd Sejmowy” 2012, nr 6 (113); A. Harast, Zasada pierwszeństwa prawa unijnego a zgodność przepisów prawa UE z polskim prawem w kontekście rozporzadzenia nr 1896/2006, "Edukacja Prawnicza” 2012, nr 4 (133); T. Jaroszyński, Glosa do wyroku z 16 XI 2011, SK 45/og, "Państwo i Prawo” 2012, nr 9; J. Kisielińska, Glosa aprobująca do wyroku TKz 16.11.2011 r., SK 45/og, "Edukacja Prawnicza” 2013, nr 4 (142); J. Łubecki, Stwierdzenie wykonalności orzeczenia sądu zagranicznego według rozporzadzenia 44/2001 a obowiązek wykazania prawomocności tego orzeczenia, „Monitor Prawniczy” 2012, nr 14. 
mieszczącym się w zakresie jego zastosowania prawem polskim a standardem ochrony praw jednostki zagwarantowanym przez Konstytucję RP, przy jednoczesnym zachowaniu fundamentalnych zasad, na których oparte jest prawo polskie, jak i prawo Unii. Porządki te nie będą traktowane rozłącznie, lecz przez pryzmat ich integracji wynikającej z członkostwa Polski w Unii. Rozdział ten będzie próbą wskazania niekonfliktowej drogi rozwiązywania problemu takiej potencjalnej niezgodności, przy zachowaniu podstawowych zasad i wartości, na których opierają się polski i unijny systemy prawne, a które wydają się być możliwe do pogodzenia zarówno z literalnym brzmieniem prawa polskiego i unijnego, jak i z ich interpretacją wypracowaną dotychczas przez TK, jak i TSUE.

Szczególna uwaga poświęcona zostanie pojęciu tożsamości konstytucyjnej, które to pojęcie w ramach dialogu sędziowskiego między TK a TSUE opartego na właściwym wykorzystaniu procedury pytania prejudycjalnego może, zdaniem autora, pomóc zmniejszyć konfliktowy potencjał rozstrzygania ewentualnej niezgodności między standardem unijnym a wyższym od niego standardem konstytucyjnym. Właściwie stosowane przepisy zobowiązujące Unię do poszanowania tożsamości konstytucyjnej Polski jako państwa członkowskiego Unii, mogą stanowić istotny element pozwalający pogodzić ze sobą prima facie wykluczające się wzajemnie zasady, takie jak autonomia i wynikające z niej pierwszeństwo, jedność i skuteczność prawa UE z jednej strony oraz status Konstytucji RP jako najwyższego prawa w Polsce i ranga zawartych w niej gwarancji praw człowieka $z$ drugiej strony.

\section{Powołanie się $w$ pytaniu prejudycjalnym do TSUE na tożsamość konstytucyjną RP}

W obliczu tego, o czym mowa była w poprzednim rozdziale, wydaje się, że należy poszukać jeszcze innych, kiedy wszystkie znane już zawioda, dróg niekonfliktowego rozwiązywania takiej potencjalnej kolizji, które pozwoliłyby pogodzić ze sobą fundamentalne zasady prawa unijnego i polskiego bez konieczności zmieniania żadnego z tych praw ${ }^{984}$, a tym bardziej bez niebezpieczeństwa

${ }^{984} \mathrm{~W}$ zakresie rozwiązania sprowadzającego się do zmiany prawa wskazać można przykład wspominanej już wcześniej sprawy P 1/o5, w której TK odroczył na okres osiemnastu miesięcy utratę mocy obowiązującej przez niezgodną z Konstytucją ustawę implementującą decyzję ramowa, powołując się na wynikający również z Konstytucji obowiązek przestrzegania przez Polskę wiążącego ją prawa międzynarodowego oraz na łączącą nasz kraj i inne państwa należące do UE wspólnotę zasad ustrojowych. W czasie tych osiemnastu miesięcy doszło do zmiany 
kar wobec Polski ze strony Unii w związku z niewypełnianiem przez nią zobowiązań traktatowych, czy też bez konieczności wystąpienia Polski z Unii albo wykluczenia z niej naszego kraju.

Droga, która zaprezentowana zostanie poniżej, podobnie jak inne drogi wskazywane przez TK w uzasadnieniu wyroku w sprawie Sk 45/o9 - również wiąże się z procedurą pytania prejudycjalnego, która to procedura otwiera przestrzeń dla prowadzenia sędziowskiego dialogu i wzajemnego dostrzeżenia oraz uwzględnienia argumentów formułowanych zarówno przez TSUE, jak i przez TK w zakresie stania na straży prawa UE przez pierwszy z tych trybunałów oraz stania na straży Konstytucji przez drugi z nich. Do centralnej roli urasta tu pojęcie tożsamości konstytucyjnej oraz obowiązku Unii do jej poszanowania, który to obowiązek zawarty jest w art. 4 ust. 2 TUE, a także potwierdzony w Preambule do Karty oraz znajdujący oparcie w innych przepisach unijnego prawa pierwotnego, o których będzie mowa w dalszych częściach tego rozdziału. Pojęcie tożsamości konstytucyjnej nie pojawia się expressis verbis $\mathrm{w}$ art. 4 ust. 2 TUE. Artykuł ten stanowi, że:

Unia szanuje równość Państw Członkowskich wobec Traktatów, jak również ich tożsamość narodowa, nierozerwalnie związaną z ich podstawowymi strukturami politycznymi i konstytucyjnymi, w tym w odniesieniu do samorządu regionalnego i lokalnego. Szanuje podstawowe funkcje państwa, zwłaszcza funkcje mające na celu zapewnienie jego integralności terytorialnej, utrzymanie porządku publicznego oraz ochronę bezpieczeństwa narodowego. W szczególności bezpieczeństwo narodowe pozostaje w zakresie wyłącznej odpowiedzialności każdego Państwa Członkowskiego.

Można jednak przyjąć, że pojęcie tożsamości konstytucyjnej, nawet jeśli nie jest jego ekwiwalentem ${ }^{985}$, to co najmniej zawiera się w pojęciu tożsamości narodowej, sprowadzając się do tych fundamentalnych elementów tożsamości narodowej, które mogą być wyrażone w języku prawa i jako takie zostały wyrażone i zawarte przez ustrojodawcę w Konstytucji ${ }^{986}$, stanowiąc o jej toż-

odpowiednich przepisów Konstytucji, która to zmiana sprzeczność wyeliminowała. Nie można jednak wykluczyć takiej sytuacji, że zarówno przepisy unijne, jak i krajowe będą miały taki status, że zmiana żadnych z nich nie będzie możliwa, choćby ze względu na uwarunkowania polityczne, ale również ze względów prawnych - takich jak spójność prawa unijnego albo krajowego.

${ }^{985}$ Praktyka orzecznicza sprawia, że wielu autorów pojęcia te traktuje jako synonimiczne (patrz: K. Kowalik-Bańczyk, Tożsamość narodowa - dopuszczalny wyjątek od zasady prymatu? [w:] S. Dudzik, N. Półtorak (red.), Prawo Unii Europejskiej a prawo konstytucyjne państw członkowskich, Warszawa 2013, s. 45-46 i podana tam literatura).

${ }^{986}$ Oczywiście nie wszystkie możliwe do wyrażenia w języku prawa elementy tożsamości narodowej muszą się znajdować w Konstytucji. To czy się w niej znajdują zależy od woli ustrojodawcy. 
samości $^{987}$. Takie podejście pozwala na pewne ustabilizowanie rozważań na temat tożsamości narodowej i jej prawnego znaczenia i uciec od zbyt daleko posuniętej arbitralności i doraźności w rekonstruowaniu tego pojęcia. Odbiciem tego faktu jest skoncentrowanie uwagi sądów, w tym TSUE, na tożsamości konstytucyjnej państw członkowskich w sprawach dotyczących art. 4 ust. 2 TUE jako najbardziej funkcjonalnym z prawnego punktu widzenia wyrazie tożsamości narodowej ${ }^{988}$. Istniejąca Konstytucja, wraz z zawartym w niej systemem zasad i wartości, w tym tych z jej perspektywy fundamentalnych (toż-

987 Por. np.: L.F.M. Besselink, National and Constitutional Identity Before and After Lisbon, „Utrecht Law Review” 2010, nr 6 (3); autor ten podkreśla również, że nie wszystkie regulacje konstytucyjne są przejawem tożsamości konstytucyjnej państwa, a jedynie niektóre, i to tylko one znajdują się w uprzywilejowanej pozycji względem prawa unijnego (ibidem, s. 48).

988 Por.: G. van der Schyff, The Constitutional Relationship between the European Union and its Member States: The Role of National Identity in Articla 4(2) TEU, „European Law Review” 2012, nr 37, s. 567-568, 572 i nast.; warto jednak pamiętać, że inne składniki tożsamości narodowej mogą mieć również znaczenie w kontekście art. 4 ust. 2 TUE i można sobie wyobrazić, że będą one podnoszone przez różne organy państw członkowskich w różnych trybach, w tym w postępowaniach przed TSUE. Nawet jeśli w państwach, w których ustrojach przewidziano rolę sądu konstytucyjnego, o jakiej mowa w tej pracy, i to on będzie odgrywał rolę centralną, należy jednak pamiętać, że sąd taki czy szerzej władza sądownicza powinny być uznawane za jedynie podmiot rekonstruujący na podstawie konstytucji, wyrażoną w niej tożsamość państwa. Działanie innych władz powinno i może nie tylko mieścić się w ramach tożsamości konstytucyjnej, ale również ją współkształtować i doprecyzowywać, stanowiąc swoiste przedłużenie tekstu konstytucji (K. Whittington, Political Foundations of Judicial Supremacy: The Presidency, the Supreme Court, and Constitutional Leadership in U.S. History, Princeton 2007, s. 291; w kontekście unijnym por. np.: G. van der Schyff, The Constitutional..., s. 573 i nast.). Co więcej, różnorodność państw członkowskich Unii jest głębsza niż różnorodność modeli kontroli konstytucyjności i obejmuje również systemy, w których brak pisanej konstytucji, co nie świadczy oczywiście, że państwa takie, jak Wielka Brytania czy do pewnego stopnia Szwecja nie miałyby mieć tożsamości narodowej czy konstytucyjnej, którą Unia powinna szanować (por. np.: G. van der Schyff, The Constitutional..., s. 576 i nast.). Punktem zainteresowania tej pracy jest jednak Polska jako państwo członkowskie Unii. Rola TK i sądów konstytucyjnych w scentralizowanych systemach kontroli konstytucyjności jest szczególna, to one ostatecznie są zobowiązane do badania, czy aktywność innych władz, w tym szczególnie ustawodawczej, mieści się w ramach ustrojowych zawartych w ustawie zasadniczej. Tożsamość konstytucyjna, jako te elementy tożsamości narodowej, które zostały wyrażone przez ustrojodawcę w ustawie zasadniczej i ujęte przez to $\mathrm{w}$ formę systemu prawnego, maja, jak się wydaje wyjątkowe znaczenie, przede wszystkim pod kątem ich funkcjonalności w postępowaniach sądowych. Mają one bowiem charakter prawny i są ujęte w system prawny, a więc mają określone miejsce w hierarchii norm prawnych oraz są co do zasady spójne i zupełne. Ponadto istnieją określone, kompetentne organy do ich stosowania i interpretowania, a także przewidziane do tego procedury. Wreszcie są częścią kultury prawnej, która nie ma arbitralnego charakteru, lecz jest tworzona przez funkcjonowanie tych norm zarówno w ramach wspomnianych procedur przed kompetentnymi do tego organami, jak i w nauce prawa. Co najważniejsze, za tak rozumianą tożsamością konstytucyjną stoi legitymizacja w postaci woli narodu/ustrojodawcy, której obowiązująca konstytucja jest trudnym do podważenia wyrazem i dowodem. 
samościowych) jest najbardziej namacalnym wyrazem tożsamości narodowej. Jak ujął to Paweł Sarnecki, Konstytucja to akt wyrażający "tożsamość, tradycje i dążenia polityczne narodu, zorganizowanego w państwo" ${ }^{\prime \prime 89}$.

Nie bez znaczenia jest tutaj aspekt suwerennościowy, w związku z którym mówi się czasem również o obowiązku poszanowania przez Unię tożsamości państwowej państw członkowskich, związanej z możliwością zachowania przez nie odrębności państwowej i zachowania podstawowych funkcji państwowych ${ }^{990}$. Ten aspekt będzie widoczny w rozważaniach TK. Wiąże on "tożsamość konstytucyjną przede wszystkim z zasadą suwerenności obudowaną szerokim spektrum postanowień konstytucyjnych, w tym także postanowień zawartych w preambule. Suwerenność zatem wyraża się w nieprzekazywalnych kompetencjach organów władzy państwowej, stanowiących o tożsamości konstytucyjnej państwa" ${ }^{\prime \prime 91}$. Nie ten aspekt będzie miał centralne znaczenie dla tezy tej pracy, która nie skupia się na zagadnieniu suwerenności, lecz na konflikcie standardów ochrony praw człowieka, bez wchodzenia w dyskusję suwerennościową. Tożsamość konstytucyjna będzie więc w tej pracy analizowana w kontekście wspólnotowym - operacjonalizującym różnice w standardach ochrony praw człowieka w ramach Unii, a nie izolacjonistycznym - dopisującym kolejny rozdział do sporu o suwerenność państw członkowskich i granice integracjii92.

Kontekst integracji europejskiej był tym, który w największym stopniu zmobilizował sądy konstytucyjne wielu państw członkowskich do podobnych rozważań. Wnioski, do jakich one dochodziły, były nierzadko dość odległe od siebie, szczególnie jeśli chodzi o charakter elementów składających się na tożsamość konstytucyjną. Wszystkie jednak stawały ostatecznie na stanowisku, że w ramach ich ustrojów prawnych istnieje coś takiego jak tożsamość konstytucyjna, że to one są kompetentne do jej rekonstruowania z przepisów konstytucyjnych i podkreślały, że Unia tożsamość tę musi szanować. Pełna analiza porównawcza przekraczałaby zakres tej pracy. Warto jednak pamiętać, że to właśnie sądy konstytucyjne państw członkowskich stały się forpocztą pojęcia tożsamości konstytucyjnej w europejskiej przestrzeni prawnej. Na dobre do europejskiej debaty konstytucyjnej wprowadził je niemiecki FTK w 2009 r.

989 P. Sarnecki, Artykut 126, [w:] L. Garlicki (red.), Konstytucja Rzeczypospolitej Polskiej. Komentarz, t. 1, Warszawa 1999, s. 9.

${ }^{990} \mathrm{~K}$. Wójtowicz, Poszanowanie tożsamości konstytucyjnej państw członkowskich Unii Europejskiej, "Przegląd Sejmowy” 2010, 4 (99), s. 13.

${ }^{991}$ K. Wójtowicz, Sądy konstytucyjne..., s. 128.

992 Por. np.: W. Sadurski, 'Solange, chapter 3': Constitutional Courts in Central Europe - Democracy - European Union, EUI Working Paper, LAW 2006, nr 40; R. Toniatti, Sovereignty Lost, Constitutional Identity Regained, [w:] A. Saiz Arnaiz, C. Alcoberro (red.), National Constitutional Identity and European Integration, Cambridge-Antwerp-Portland 2013, s. 66. 
przy okazji swojego wyroku w sprawie Traktatu z Lizbony ${ }^{993}$, choć używał go już znacznie wcześniej, przynajmniej od czasu wyroku Solange II ${ }^{994}$. Pojęcie to figuruje w tym wyroku 32 razy, co sprawia, że nie można przejść obok niego obojętnie ${ }^{995}$. Później FTK odwoływał się do tego pojęcia w innych orzeczeniach z wyrokiem w sprawie TL na czele, lecz nie tylko w nim (będzie o niektórych $z$ tych orzeczeń mowa $w$ tym rozdziale), dalej rekonstruując jego znaczenie i zakres ${ }^{996}$.

Zdaniem Krzysztofa Wójtowicza zasługa za spopularyzowanie kwestii tożsamości konstytucyjnej w kontekście integracji europejskiej spoczywa również na francuskiej Radzie Konstytucyjnej997, która odwoływała się do tego pojęcia począwszy od $2006 \mathrm{r}$. w różnych orzeczeniach dotyczących prawa unijnego (głównie implementacji unijnych dyrektyw) ${ }^{998}$. Opierając się na orzecznictwie Rady i FTK, można zresztą mówić o dwóch modelach podejścia do tożsamości konstytucyjnej w sensie materialnym, na tle których stanowisko polskiego TK może być uznane jako w pewnym sensie droga pośrednia. Jak twierdzi Jan-Herman Reestman, modele francuski i niemiecki opierają się na dwóch różnych rozumieniach podstawowej więzi, jaka spaja społeczeństwa, i która stanowi o zestawie idei, wokół których narody w tych państwach członkowskich się identyfikująa99. Jego zdaniem więź, jaka spaja naród niemiecki, składa się ze wspólnej historii, języka i kultury, podczas gdy więź, jaka spaja naród francuski, to wola przynależności do jednego państwa jako wspólnoty politycznej. Od-

${ }^{993}$ FTK, 2 BvE 2/o8, 2 BvE 5/o8, 2 BvR 1010/o8, 2 BvR 1022/o8, 2 BvR 1259/o8, 2 BvR 182/o9, orzeczenie z 30 czerwca 2009.

${ }^{994}$ FTK, 2 BvR 197/83, orzeczenie 22 października 1986, pkt 105.

995 J.-H. Reestman, The Franco-German Constitutional Divide. Reflections on National and Constitutional Identity, "European Constitutional Law Review” 2009, nr 5 (3), s. 375.

${ }_{996}$ Więcej - patrz np.: A. Kustra, Kelsenowski..., s. 284 i nast.; C. Tomuschat, The Defence of National Identity by the German Constitutional Court, [w:] A. Saiz Arnaiz, C. Alcoberro (red.), National Constitutional Identity and European Integration, Cambridge-Antwerp-Portland 2013.

${ }_{997}$ K. Wójtowicz, Sądy konstytucyjne..., s. 125.

${ }_{998}$ Zdaniem francuskiej Rady Konstytucyjnej transpozycja unijnych dyrektyw (gdyż tego rodzaju przepisów dotyczyła sprawa) nie może być sprzeczna z regułami lub zasadami nieodłącznie związanymi z tożsamością konstytucyjną Francji, chyba że ustawodawca wyraził na to zgodę (Francuska RK, decyzja nr 2006-540 DC z 27 lipca 2006, 19ème considérant; por. też: Francuska RK, decyzja nr 2006-543 DC z 30 listopada 2006, 6ème considérant czy Francuska RK, decyzja nr 2011-631 DC z o9 czerwca 2011, 45ème considérant); jak podkreśla Danuta Kabat-Rudnicka, również francuskiej RK nie obce jest, istotne z perspektywy tej pracy „zawężenie rozumienia terminu tożsamość konstytucyjna do kwestii najważniejszych, czy też najbardziej istotnych, definiujących jądro konstytucji" (D. Kabat-Rudnicka, Tożsamość narodowa jako czynnik kształtujacy relacje pomiędzy Unią Europejska a państwami członkowskimi, „Annales Universitatis Paedagogicae Cracoviensis Studia Politologica" 2016, nr XVII, s. 121).

${ }_{999}$ J.-H. Reestman, The Franco-German..., s. 378; por. także: K. Wójtowicz, Poszanowanie..., s. $12,14,16-21$. 
zwierciedla to różny katalog elementów składających się, zdaniem FTK i Rady Konstytucyjnej, na tożsamość konstytucyjną Niemiec i Francji1000. Nie wchodząc głębiej w te rozważania, na potrzeby tej pracy trzeba zauważyć, że w obu przypadkach gwarancje praw i wolności człowieka zajmują poczesne miejsce wśród elementów składających się na tożsamość konstytucyjną tych państw.

\subsection{Tożsamość konstytucyjna z perspektywy Konstytucji RP i orzecznictwa TK}

Pojęcie tożsamości konstytucyjnej ani żaden jego ekwiwalent nie występują explicite w polskiej ustawie zasadniczej. Nie ma więc również żadnej konstytucyjnej definicji tożsamości konstytucyjnej ani katalogu regulacji konstytucyjnych, które należałoby do niej zaliczyć. Tym niemniej, właśnie w kontekście integracji europejskiej, TK podjął próbę zarysowania zakresu tego pojęcia w polskim porządku prawnym i wskazał kluczowe elementy, które jego zdaniem składają się na polską tożsamość konstytucyjną. Zostaną one w tym miejscu wskazane i krótko omówione, jednak jedynie w wymiarze, w jakim jest to konieczne z perspektywy tej pracy.

Na wstępie należy zauważyć, że pojęcie tożsamości konstytucyjnej, czy też jak wolą niektórzy, tożsamości konstytucji, jest niezwykle złożone i może być podstawą do bardzo różnych rozważań oraz prowadzić do różnych wniosków. Może mieć w związku z tym znaczenie dla bardzo wielu wymiarów prawa konstytucyjnego. Rozważania nad tymi pojęciami sięgają w polskiej doktrynie prawa konstytucyjnego czasów znacznie poprzedzających przystąpienie Polski do Unii Europejskiej. Ten najstarszy nurt wiąże się z przekonaniem, że tożsamość konstytucyjna (vel tożsamość konstytucji) ma być swoistym wewnętrznym gwarantem czy też wyrazem wewnętrznej integralności konstytucji, zabezpieczającym ją przed zmianami sprzecznymi z jej integralnością. Prowadzi ich to w efekcie do wniosku o relatywnej niezmienialności niektórych postanowień ustawy zasadniczej ${ }^{1001}$ nawiązującej w jakimś stopniu do znanej od Carla Schmitta koncepcji tzw. „implikowanych zakazów zmiany konstytucji” ${ }^{1002}$. Jest

${ }^{1000}$ Ibidem, s. 378 i nast.; więcej na temat niemieckiej i francuskiej tożsamości konstytucyjnej - patrz np.: K. Wójtowicz, Sądy konstytucyjne..., s. 125-126; M. Zirk-Sadowski, Tożsamość konstytucyjna a prawo europejskie, "Analizy Natolińskie” 2012, nr 1 (53), s. 12 i nast.

1001 Por. przed.: L. Garlicki, Normy konstytucyjne relatywnie niezmienialne, [w:] J. Trzciński (red.), Charakter i struktura norm Konstytucji, Warszawa 1997, s. 148, oraz L. Garlicki, Aksjologiczne podstawy reinterpretacji konstytucji, [w:] M. Zubik (red.), Dwadzieścia lat transformacji ustrojowej w Polsce, Warszawa 2010.

1002 Patrz przede wszystkim: C. Schmitt, Verfassungslehre, Berlin 1928, s. 98 i nast.; Schmitt argumentował: „Także kompetencja do zmiany modyfikacji postanowień konstytucyjnych jest - 
to, jak się wydaje, najbardziej zakorzenione podejście do tożsamości konstytucji w polskiej nauce prawa konstytucyjnego, znane już przynajmniej od czasów Stefana Rozmaryna i rozważań, jakie czynił on na gruncie Konstytucji PRL z 1952 r. ${ }^{1003}$ Nawet jeśli jego rozważania przedawniły się co do treści (a więc wskazywanych przez niego elementów tożsamości konstytucyjnej ówczesnego państwa polskiego i jego socjalistycznego ustroju ${ }^{1004}$ ), to $w$ wymiarze $w$ jakim zwracał on uwagę na konieczność zachowywania spójności aksjologicznej ustawy zasadniczej przy dokonywaniu jej ewentualnych zmian, zachowują one w dużym stopniu aktualnośćcon.

Inni podkreślają znaczenie tożsamości konstytucyjnej jako zabezpieczenia przed taką interpretacją jej przepisów, która zaprzeczyłaby zawartej i wyrażonej w niej aksjologii, ujętej w system powiązanych ze sobą, a nie rozłącznych regulacji. Jak pisze Aleksandra Dębowska, „posługiwanie się w procesie wykładni norm konstytucyjnych konstrukcją tożsamości konstytucyjnej ma stanowić granicę dla interpretatora konstytucji, która powinna zapobiegać wydobywaniu z ustawy zasadniczej tego, czego w niej nie wyrażono"1006. Tożsamość konstytucyjna ma więc sprzyjać integralności konstytucji i spójności wyrażonych w niej zasad, pozwalającej zachować stabilność ustrojową i pewną niezależność ugruntowanego w konstytucji ładu polityczno-prawnego od różnych, doraźnych zmian politycznych ${ }^{1007}$.

Zdaniem jeszcze innych, tożsamość konstytucyjna ma być wyrazem pewnej swoistości i odrębności narodu, którą ten zawarł w swej konstytucji, a który szczególnie w obliczu przynależności do szerszej wspólnoty w ten sposób definiuje swoją odrębność. Jak ujął to Marek Zirk-Sadowski: „Tożsamość konstytucyjna to rozpoznawanie swojej odrębności kulturowej, narodowej poprzez refleksję nad prawami podstawowymi akceptowanymi w danym społeczeń-

\footnotetext{
tak jak każda kompetencja ustanowiona przez konstytucję - konstytucyjnie uregulowaną właściwością do działania, ma więc charakter ograniczony co do zasady. Nie może więc rozsadzać ram tej regulacji konstytucyjnej, z której wynika [...]. Kompetencja do »zmiany konstytucji«, udzielona z mocy unormowania konstytucyjnego, oznacza dopuszczalność zastępowania jednych lub wielu postanowień konstytucyjnych innymi postanowieniami konstytucyjnymi, ale tylko pod warunkiem zachowania identyczności i kontynuacji konstytucji jako całości [...]" (za: L. Garlicki, Normy konstytucyjne..., s. 139).

${ }^{1003}$ Patrz przed.: S. Rozmaryn, Konstytucja jako ustawa zasadnicza PRL, Warszawa 1967, s. $274-276$.

${ }^{1004}$ L. Garlicki, Aksjologiczne..., s. 92.

${ }^{1005}$ L. Garlicki, Normy konstytucyjne..., s. 153 i nast.

1006 A. Dębowska, Tożsamość konstytucji RP z 1997 r.jako granica dopuszczalnej wykładni jej norm, [w:] S. Biernat (red.), Konstytucja Rzeczypospolitej polskiej w pierwszych dekadach XXI wieku wobec wyzwań politycznych, gospodarczych i społecznych, Warszawa 2013, s. 95.

${ }^{1007}$ Ibidem, s. 95.
} 
stwie, narodzie"1008. Owa odrębność ma służyć jako podwalina do budowania tożsamości w ramach wspólnoty, jaką jest Unia. Jak autor ten konkluduje „konstruowanie własnej tożsamości odbywa się poprzez odkrywanie różnicy pomiędzy sobą a innymi, [...] dopiero owa tożsamość prowadzi do uznania naszej pełnoprawności"1009.

\subsubsection{Wyrok w sprawie K 32/o9}

Kolejny bardzo ważny wymiar, w którym pojawia się to pojęcie, to wymiar bardziej formalny, a mniej materialny, związany z integracją w ramach Unii i wspomnianą problematyką suwerennościową. Ogromne znacznie ma tu zarówno wewnętrzny wektor wypływających z tożsamości konstytucyjnej konsekwencji, taki jak zakaz przekazania określonych kompetencji organom zewnętrznym ${ }^{1010}$, a także wektor zewnętrzny, związany z obowiązkiem po stronie Unii do poszanowania tożsamości narodowej i konstytucyjnej należących do niej państw. To właśnie na gruncie integracji europejskiej do tożsamości konstytucyjnej RP najobszerniej odniósł się TK. Uczynił to w sposób na tyle doniosły, że można za Mirosławem Granatem skonkludować, że w wyroku w sprawie zgodności TL z Konstytucja, TK wprowadził pojęcie tożsamości konstytucyjnej do swego acquis ${ }^{1011}$.

Jak czytamy w uzasadnieniu wyroku w sprawie zgodności TL z Konstytucja, TK podziela "wyrażony w doktrynie pogląd, że kompetencje objęte zakazem przekazania, stanowią o tożsamości konstytucyjnej, a więc odzwierciedlają wartości, na których opiera się Konstytucja"1012. Tym samym, co będzie charakterystyczne dla kontekstu odwołania się do tożsamości konstytucyjnej w tym wyroku, Trybunał zwrócił przede wszystkim uwagę na wewnętrzny (choć posiadający też walor zewnętrzny - suwerennościowy) wektor pojęcia tożsamości konstytucyjnej, wiążąc je z tymi regulacjami konstytucyjnymi, kompetencji do zmiany których Polska nie może przekazać podmiotowi zewnętrznemu i które nie mogą tym samym zostać w żaden sposób zmodyfikowane w związku z członkostwem Polski w UE. Trybunał wyraził zdecydowane stanowisko, że:

Tożsamość konstytucyjna jest [...] pojęciem wyznaczającym zakres „wyłączenia spod kompetencji przekazania materii należących (...) do »twardego jądra«, kardynalnych

${ }^{1008}$ M. Zirk-Sadowski, Tożsamość..., s. 1.

1009 Ibidem, s. 32.

1010 Por. np.: K. Wojtyczek, Przekazywanie..., s. 284 i nast.

1011 TK sprawa K 33/12, wyrok z 26 czerwca 2013, zdanie odrębne sędziego TK Mirosława Granata.

1012 TK, sprawa K 32/o9, wyrok z 24 listopada 2010, pkt III 2.1 uzasadnienia. 
dla podstaw ustroju danego państwa" [...], których przekazanie nie byłoby możliwe na podstawie art. 90 Konstytucji ${ }^{1013}$.

W wymiarze materialnym, a więc odnośnie do treści tożsamości konstytucyjnej RP, Trybunał zaznaczył, że elementy składające się na tożsamość konstytucyjną RP to najbardziej fundamentalne postanowienia Konstytucji, które należą do jej "twardego jądra"1014. Definicja ta ma mocno formalny charakter. W dalszej części uzasadnienia do tego wyroku, pozostając w kontekście zakazu przekazania kompetencji, Trybunał wskazał te elementy, a przynajmniej część z nich.

Niezależnie od trudności związanych z ustaleniem szczegółowego katalogu kompetencji nieprzekazywalnych, należy zaliczyć do materii objętych całkowitym zakazem przekazania postanowienia określające zasady naczelne Konstytucji oraz postanowienia dotyczące praw jednostki wyznaczające tożsamość państwa, w tym w szczególności wymóg zapewnienia ochrony godności człowieka i praw konstytucyjnych, zasadę państwowości, zasadę demokracji, zasadę państwa prawnego, zasadę sprawiedliwości społecznej, zasadę pomocniczości, a także wymóg zapewnienia lepszej realizacji wartości konstytucyjnych i zakaz przekazywania władzy ustrojodawczej oraz kompetencji do kreowania kompetencji [... $]^{1015}$.

Kontekst, w jakim TK dokonał rekonstrukcji elementów składających się na tożsamość konstytucyjną RP, nie oznacza jednak, że ma ona znaczenie tylko dla zakazu przekazania kompetencji organizacji międzynarodowej. Wydaje się, że ustalenia te są na tyle ogólne, że są równie doniosłe dla wszelkich innych potencjalnych zastosowań tożsamości konstytucyjnej. Zarówno tych, które zasygnalizowane zostały przed chwila, lecz także takich, jak te, które będą proponowane w dalszej części tego rozdziału.

Znaczenie rozważań o tożsamości konstytucyjnej RP jako granicy wyznaczonej przez Konstytucję władzom polskim, jeśli chodzi o zakres kompetencji, których nie moga zrzec się na rzecz kogokolwiek innego, nawet jeśli byłaby to organizacja międzynarodowa, której członkiem będzie Polska, nie jest również statyczne. Należy podkreślić, że nie dotyczy jedynie momentu przekazania tych

${ }^{1013}$ Ibidem, pkt III 2.1 uzasadnienia; takie podejście TK prowadzi do możliwości odczytywania funkcji art. 4 ust. 2 TUE jako narzędzia sprzyjającego głębszej kontroli zasady kompetencji wyraźnie przyznanych Unii, poprzez wskazanie granicy, której - wykonując je - Unia nie może przekroczyć (por.: K. Wójtowicz, Zachowanie tożsamości konstytucyjnej państwa polskiego w ramach UE - uwagi na tle wyroku TK z 24.11.2010 r. (K 32/og), "Europejski Przegląd Sądowy" 2011, nr 11, s. 4; A. Wróbel, Tożsamość narodowa, czyli różnorodność w jednorodności, "Europejski Przegląd Sądowy" 2012, nr 8, s. 1).

1014 TK, sprawa K 32/o9, wyrok z 24 listopada 2010, pkt III 2.1 uzasadnienia.

1015 Ibidem, pkt III 2.1 uzasadnienia. 
kompetencji. Dotyczy również ich wykonywania. Wykonywanie kompetencji przekazanych organizacji międzynarodowej nie może doprowadzić do naruszenia tożsamości konstytucyjnej również w ramach dynamicznego charakteru relacji między porządkiem unijnym i krajowym, która - jak podkreślał to TK podlega ewolucji wraz ze zmianami w prawie unijnym ${ }^{1016}$.

TK podkreślił również, że jego zdaniem: „Odpowiednikiem pojęcia tożsamości konstytucyjnej w europejskim prawie pierwotnym jest pojęcie tożsamości narodowej"1017, wprost w ten sposób nawiązując do art. 4 ust. 2 TUE. $\mathrm{O}$ ile więc co do zasady „TK, podobnie jak niektóre inne europejskie sądy konstytucyjne, skorzystał z okazji, jaką stworzyło doprecyzowanie pojęcia »tożsamość narodowa « w zmienionym Traktacie o Unii Europejskiej, by określić swoje stanowisko co do sposobu rozumienia zasady kompetencji przyznanych Unii Europejskiej, a w szczególności granic tego przyznania"1018, o tyle można domniemywać, że gdyby TK podjął się próby rekonstrukcji pojęcia polskiej tożsamości narodowej/konstytucyjnej bezpośrednio w związku z art. 4 ust. 2 TUE, również poza tym podstawowym kontekstem (dotyczącym kompetencji przekazanych, a więc związanym z doktryną ultra vires) a - jak zostało to nazwane w tej pracy - na jego przedpolu, to wymienione powyżej elementy również by się w niej znalazły. Z perspektywy tej pracy nie jest nawet istotne, czy powyższe wyliczenie ma charakter zamknięty i czy to już wszystkie elementy tożsamości konstytucyjnej RP. Zważywszy na sposób sformułowania tego katalogu przez TK, jest niemal oczywiste, że wyliczenie to nie ma charakteru enumeratywnego i katalog elementów składających się na tożsamość konstytucyjną RP może być dalej rozwijany ${ }^{1019}$, podobnie jak na przestrzeni lat rozwijały go w swoim orzecznictwie sądy konstytucyjne innych państw członkowskich z FTK na czele ${ }^{1020}$.

Kluczowy z perspektywy tej pracy jest fakt, że nie można mieć wątpliwości, że wśród elementów nienaruszalnej i niemogącej być modyfikowaną ze

${ }^{1016}$ Ibidem, pkt III 2.3 uzasadnienia.

1017 Ibidem, pkt III 2.1 uzasadnienia.

${ }^{1018}$ K. Wójtowicz, Zachowanie..., s. 4.

1019 Por.: A. Kustra, Kelsenowski..., s. 290; powstanie takiego enumeratywnego katalogu nie byłoby ani możliwe, ani wskazane. Musi on powstawać stopniowo, odzwierciedlając dynamikę problemów prawnych, do których będzie mógł mieć zastosowanie, a nawet odzwierciedlając dynamikę procesów społecznych, która może wpływać w jakimś stopniu na jej treść. TK prawidłowo więc stworzył formalną zasadę ogólną, zgodnie z którą tożsamość konstytucyjna/narodowa ma być identyfikowana i wskazał podstawowe jej składniki materialne, pozostawiając ich listę otwartą (por. np.: G. van der Schyff, The Constitutional..., s. 575-576).

${ }^{1020}$ Patrz przed.: FTK, 2 BvR 197/83, orzeczenie z 22 października 1986 oraz FTK, 2 BvE 2/o8, 2 BvE 5/o8, 2 BvR 1010/o8, 2 BvR 1022/o8, 2 BvR 1259/o8, 2 BvR 182/o9 orzeczenie z 30 czerwca 2009; FTK, 2 BvR 2735/14, orzeczenie z 15 grudnia 2015; FTK, 2 BvR 890/16, orzeczenie z 6 września 2016.; por. np.: A. Kustra, Kelsenowski..., s. 284 i nast. 
względu na fakt członkostwa Polski w UE tożsamości konstytucyjnej RP znajdują się "postanowienia dotyczące praw jednostki wyznaczające tożsamość państwa, w tym w szczególności wymóg zapewnienia ochrony godności człowieka i praw konstytucyjnych"1021. Nie może to dziwić, zważywszy na konstytucyjną rangę art. 30. Analogii dostarczają także orzeczenia sądów konstytucyjnych innych państw członkowskich, które również powszechnie zaliczają konstytucyjne gwarancje praw człowieka do tożsamości konstytucyjnej swoich państw. Ponadto, już w kontekście granic wykładni prounijnej, TK zaliczał do nich wyraźne brzmienie norm konstytucyjnych i funkcje gwarancyjne Konstytucji. Już w wyroku dotyczącym akcesji podkreślił, że:

Normy Konstytucji w dziedzinie praw i wolności jednostki wyznaczają minimalny i nieprzekraczalny próg, który nie może ulec obniżeniu ani zakwestionowaniu na skutek wprowadzenia regulacji wspólnotowych. Konstytucja pełni w tym zakresie swą rolę gwarancyjną, z punktu widzenia ochrony praw i wolności w niej wyraźnie określonych, i to w stosunku do wszystkich podmiotów czynnych w sferze jej stosowania $^{1022}$.

\subsubsection{Wewnętrzne znaczenie tożsamości konstytucyjnej RP (dla krajowego systemu prawnego) i zewnętrzne znaczenie tożsamości konstytucyjnej RP ( $w$ ramach systemu unijnego)}

Autorowi tej pracy najbliższe jest takie rozumienie tożsamości konstytucyjnej $R P$, które sprowadza się do systemu podstawowych zasad i wartości w niej wyrażonych, stanowiących fundament ustroju państwa. Na tożsamość tę składałyby się wszystkie fundamentalne zasady ustroju konstytucyjnego RP, z których zmiana czy usunięcie choćby jednej, zmieniałoby ten ustrój. Szczególnie doniosła jest tu w sposób oczywisty zasada godności człowieka i wynikające z niej gwarancje praw człowieka. Autorowi tej pracy dalekie jest więc takie rozumienie tożsamości konstytucyjnej RP, które koncentrowałoby się wokół kwestii, które odróżniałyby Konstytucję RP i oparty na niej ustrój od konstytucji innych państw. Stosując analogię do tożsamości człowieka, nie ma dla niej większego znaczenia to, czy jeśli elementy te uznamy za jego tożsamość konstytuujące, istnieją inne podmioty, które również przynależą do tej samej wspólnoty narodowej, etnicznej, kulturowej, mają tę samą płeć, kolor skóry, oczu itp. Podobnie dla faktu, że gwarancje praw człowieka czy inne elementy składają się na tożsamość konstytucyjną RP nie ma znaczenia, czy składają

1021 TK, sprawa K 32/o9, wyrok z 24 listopada 2010, pkt III 2.1 uzasadnienia.

1022 TK, sprawa K 18/o4, wyrok z 11 maja 2005, pkt III 6.4 uzasadnienia. 
się one na tożsamość konstytucyjną innych państw. Nie ma też dla tego faktu większego znaczenia, czy tak samo rozumiane, szczególnie w zakresie określenia minimalnego standardu, poszczególnych gwarancji tych praw, gwarancje praw człowieka składają się na tożsamość konstytucyjną innych państw ${ }^{1023}$.

Dla tożsamości konstytucyjnej RP jako takiej nie jest więc najważniejsze to, co odróżnia tożsamość polską od jakiejkolwiek innej. Te cechy dystynktywne są jedynie funkcją tożsamości konstytucyjnej. Tożsamość konstytucyjna jest to przede wszystkim zbór fundamentalnych wartości i służących ich wyrażeniu i realizacji instytucji stanowiących o konstytucyjnym porządku w Polsce. Jest to, parafrazując Zdzisława Kędzię, „»wspólny mianownik« integrujący rozmaite rozwiązania konstytucyjne ${ }^{\prime 1024} \mathrm{i}$ leżący u ich podstaw. Wyrazem tożsamości konstytucyjnej są więc co do zasady wszystkie postanowienia ustawy zasadniczej. Nie wszystkie stanowią jednak o jej treści. Niektóre są jedynie jej pochodnymi, czy też derywatami. O treści tożsamości konstytucyjnej RP stanowią te postanowienia Konstytucji, które TK trafnie określił jej „twardym jądrem” i z których najważniejsze wskazał we wspominanym uzasadnieniu do wyroku w sprawie TL. Nie ulega wątpliwości, co kluczowe z perspektywy tej pracy, że zasada godności człowieka i jej ochrona sytuują się w tym "twardym jądrze" ${ }^{\prime 1025}$.

Oczywiście cechy odróżniające polską tożsamość konstytucyjną od tożsamości innych państw mają niezwykle istotne znaczenie, szczególnie w kontekście integracji unijnej i art. 4 ust. 2 TUE. To one bowiem będą szczególnie widocznymi elementami tożsamości konstytucyjnej, które będą musiały być poszanowane w przypadku Polski, a które niekoniecznie muszą, z racji na swą partykularność, być odzwierciedlone w unijnym porządku prawnym, opartym na wspólnych tradycjach konstytucyjnych państw członkowskich. Pozostałe elementy tej tożsamości, te pokrywające się z elementami składającymi się na tożsamość pozostałych państw członkowskich, również muszą być przez Unię poszanowane. Dzieje się to jednak niejako z definicji. To właśnie na nich - jako

${ }^{1023}$ Tym niemniej kwestie związane z odmiennościami danego narodu czy państwa na poziomie tożsamości konstytucyjnej nie należy zupełnie lekceważyć w aspekcie, nazwijmy go, funkcjonalnym. Takie poczucie wspólnoty, oparte na elementach tożsamości tej wspólnoty może mieć ważny wymiar polityczny, organizacyjny i mobilizacyjny również w ramach Unii Europejskiej. Więcej na ten temat - patrz np.: W. Jóźwicki, Rzeczpospolita dobrem wspólnym wszystkich obywateli jako uzasadnienie wymogu wierności obywateli wobec niej w kontekście integracji europejskiej, [w:] S. Biernat (red.), Konstytucja Rzeczypospolitej polskiej w pierwszych dekadach XXI wieku wobec wyzwań politycznych, gospodarczych i społecznych, Warszawa 2013; K. Nicolaïdis, We, the Peoples of Europe..., „Foreign Affairs” 2004, nr 6 (83); J.H.H. Weiler, Czy Europa potrzebuje konstytucji? Demos, telos i orzeczenie Niemiec w sprawie Traktatu z Maastricht, "Nowa Europa” 2005, nr 1 (1); idem, Europa końca wieku: czy nowe szaty maja swojego cesarza?, "Nowa Europa” 2007, nr 1 (5).

1024 Z. Kędzia, Uwagi o aksjologii Konstytucji, [w:] A. Rzepliński (red.), Prawa człowieka w społeczeństwach obywatelskich, Warszawa 1993, s. 23.

${ }^{1025}$ Por. np.: A. Dębowska, Tożsamość konstytucji..., s. 94. 
wspólnych tradycjach konstytucyjnych państw członkowskich - cała integracja, a szczególnie unijne gwarancje praw człowieka, się opierają. W ten sposób można więc wyodrębnić wewnętrzny wymiar pojęcia tożsamości konstytucyjnej, który ma znaczenie przede wszystkim dla samego krajowego sytemu prawnego (o różnorodnej funkcji - np. wykładniczej), w ramach którego takie samo znaczenie mają wszystkie elementy tożsamości konstytucyjnej państwa, oraz zewnętrzny jej wymiar, który sprowadzałby się do jej elementów dystynktywnych - partykularnych dla danego państwa członkowskiego. W tym drugim wymiarze tożsamość konstytucyjna urastałaby do rangi kategorii prawa wspólnotowego zakorzenionej w prawie krajowym (konstytucji). Poprzez obowiązek jej poszanowania wywierałaby skutki na gruncie prawa unijnego, jej zakres byłby jednak definiowany na gruncie systemu krajowego.

Jak słusznie podkreśla Marek Safjan:

Podstawowa trudność, która pojawia się przy próbach optymalizacji koncepcji tożsamości konstytucyjnej jako konstruktu służącego skorygowaniu relacji pomiędzy prawem europejskim a systemem krajowym wynika z niedookreślonego i otwartego charakteru tego pojęcia. Stanowisko zakładające, że wszystkie zasady i reguły określające istotne cechy systemu konstytucyjnego, a w tym wszelkie konstrukcje przyjęte w odniesieniu do treści, hierarchii i możliwych ograniczeń praw podstawowych, należą automatycznie do pojęcia tożsamości konstytucyjnej, wykluczałoby racjonalne stosowanie tej koncepcji i ustanawiałoby de facto niemożliwą do pokonania przeszkodę dla tworzenia jednolitej przestrzeni prawnej w zintegrowanej Europie. Wydaje się więc, że należy przeprowadzić dystynkcję pomiędzy koncepcją tożsamości konstytucyjnej, ustalaną w ramach konkretnego systemu prawnego i dla jego potrzeb, a koncepcją tożsamości konstytucyjnej, ustalaną jako pojęcie i konstrukt prawa europejskiego, który może pełnić w pewnych sytuacjach rolę swoistej klauzuli ograniczającej zasięg stosowania wspólnych mechanizmów prawa europejskiego ${ }^{1026}$.

Co należy również mocno zaakcentować, dla określenia tożsamości konstytucyjnej RP niezwykle istotna jest rola: po pierwsze TK, a po drugie doktryny prawa konstytucyjnego. Mówiąc ogólnie, tożsamość konstytucyjna zakodowana jest w ustawie zasadniczej. Jej matrycą inkarnacji jest jednak przede wszystkim prawna kultura konstytucyjna.

Kultura konstytucyjna jest wartością i dobrem wspólnym, pozostającym w szerokiej przestrzeni publicznej demokratycznego państwa prawa, a nie tylko w orzecznictwie sądowym. Rolą sądu konstytucyjnego jest stymulowanie swoistego procesu sublimacji tych wartości w orzecznictwie, nie zaś ich wymyślanie i narzucanie społeczeństwu,

${ }^{1026}$ M. Safjan, Wprowadzenie..., s. 108. 
ale aplikowanie standardu demokratycznego do zadań i sytuacji, z których składa się $[\ldots]$ codzienna praktyka konstytucyjna ${ }^{1027}$.

Ten wymiar aktywności instytucji państwowych, w tym przede wszystkim TK jeśli chodzi o możliwość rekonstruowania tego, co składać by się miało na tożsamość konstytucyjna, jest zresztą w kontekście teoretycznych rozważań nad pojęciem tożsamości konstytucyjnej znany od bardzo dawna, a przynajmniej od czasów Edmunda Burke'a, który odwoływał się do tego pojęcia, podkreślając proces jego powstawania poprzez faktyczne funkcjonowanie konstytucji i wyłanianie się tego, co należy zaliczyć do jej tożsamości przez proces jej ciągłej interpretacji i stosowania ${ }^{1028}$.

Elementem takiej codziennej praktyki konstytucyjnej jest przede wszystkim aktywność TK. Szczególnie istotnym jej aspektem jest aktywność związana z członkostwem Polski w Unii. Nowym jej wymiarem może stać również mechanizm wykorzystania pytania prejudycjalnego i obowiązku poszanowania przez Unię tożsamości konstytucyjnej w celu ochrony wyższego niż unijny konstytucyjnego standardu ochrony praw i wolności człowieka, o którym mowa w tej pracy. Również jednak na tym gruncie TK powinien ograniczać swoją rolę do sublimacji wartości w ramach interpretacji postanowień Konstytucji składających się na jej tożsamość konstytucyjna, a nie aspirować do ich wymyślania czy tworzenia. W ramach tej sublimacji, szczególnie jeśli działałby w wymiarze zewnętrznym/unijnym, powinien także uwzględniać uwarunkowania wynikające z faktu członkostwa Polski w Unii związane przede wszystkim z autonomicznym charakterem unijnego porządku prawnego. Będzie to wiązało się z koniecznością zachowania przez TK pewnej możliwie daleko idącej powściągliwości, o której będzie jeszcze mowa szerzej. Mówiąc krótko,

${ }^{1027}$ M. Safjan, Wyzwania dla państwa prawa, Warszawa 2007, s. 83.

1028 J. Jacobsohn, Constitutional Identity, "The Review of Politics" 2006, nr 68, s. 364; proces wyłaniania się tożsamości konstytucyjnej poprzez wydobywanie jej rozumienia i organizowania jej elementów w spójną strukturę, który dzieje się głównie przez aktywność odpowiednich organów władzy sądowniczej (co do zasady sądów konstytucyjnych w systemach o scentralizowanej kontroli konstytucyjności) wydaje się charakteryzować europejski namysł nad tym pojęciem. Oczywiście jednak proces odkrywania, a przede wszystkim formowania się tożsamości konstytucyjnej nie musi wcale ograniczać się do analizy prawa. Ważna jest również perspektywa nauk społecznych i humanistycznych, szczególnie takich, jak psychologia i socjologia, które wytworzyły skomplikowane koncepcje rozwoju tożsamości indywidualnej, jak i grupowej, opartych na szerokim spektrum teorii rozpościerających się między biegunami koncepcji romantycznych i egzystencjalistycznych (więcej - patrz np.: ibidem, s. 396-371). Pojęcie tożsamości konstytucyjnej funkcjonuje w nauce również poza kontekstem europejskim czy unijnym, a tym bardziej poza kontekstem relacji państw członkowskich z Unią (więcej na temat tego zagadnienia na przykładach konstytucji Indii, Irlandii, Izraela i USA - patrz: J. Jacobsohn, Constitutional Identity, Harvard 2010). 
powściągliwość ta miałaby się przejawiać w ostrożnym zakreślaniu granic domagającej się poszanowania tożsamości konstytucyjnej RP, również gdy chodzi o składające się na nią standardy ochrony praw i wolności człowieka. Jak się wydaje jedynie w takim wypadku wniosek, o jakim mowa w tym rozdziale, wiążący się z oczekiwaniem od TSUE uwzględnienia wymogów poszanowania tożsamości konstytucyjnej Polski na gruncie prawa unijnego, będzie mógł być uznany za rzetelny i godny uwzględnienia.

TK wydaje się podmiotem najbardziej kompetentnym do tej roli. Jak słusznie podkreśla Aleksandra Kustra, szczególnie w

przypadku konstytucji, w których ustrojodawca nie zdefiniował tożsamości konstytucyjnej poprzez wyraźne wyłączenie danej materii z możliwości jej zmiany, nadanie treści temu pojęciu będzie należało do sądu konstytucyjnego. W procesie wykładni norm konstytucyjnych zmierzającym do ustalenia, które z nich są szczególnie istotne i wyznaczają tożsamość danej konstytucji, sąd konstytucyjny może się jednak spotkać z zarzutem arbitralności. Stąd też sądy konstytucyjne, które nie mają oparcia normatywnego w tzw. przepisach niezmienialnych, powinny unikać w orzeczeniach formułowania in abstracto nawet obszernych egzemplifikacji tego typu spraw ${ }^{1029}$.

Dlatego też formułowana w tej pracy propozycja, uwzględniająca szczególną rolę TK i jego relacji do TSUE, wydaje się szczególnie uzasadniona. Gdyby bowiem TK nie zdecydował się na jej wdrożenie, wszelkie inne podmioty, które w ramach różnych postępowań mogłyby formułować argumentację opartą na tożsamości konstytucyjnej, byłyby znacznie bardziej zagrożone różnego rodzaju pokusami o charakterze politycznym. Abstrakcyjne rozważania TK na temat tożsamości konstytucyjnej nie mogłyby tego niebezpieczeństwa wyeliminować. Pytanie prejudycjalne w sytuacji konkretnego konfliktu standardów byłoby zaś doskonałą okazją do doprecyzowywania zakresu tożsamości konstytucyjnej RP a casu ad casum, z jednoczesnym zastosowaniem wynikających stąd konsekwencji dla prawa polskiego i unijnego.

\subsection{Tożsamość narodowa/konstytucyjna z perspektywy prawa unijnego i orzecznictwa TSUE}

Art. 4 ust. 2 TUE (bądź jego poprzednik w wersji nadanej mu przez Traktat z Maastricht ${ }^{1030}$ ) zobowiązujący Unię do poszanowania tożsamości narodowej/konstytucyjnej państw członkowskich znajdował sporadyczne zastosowa-

1029 A. Kustra, Kelsenowski..., s. 290.

1030 Art. 6 ust. 3 (Traktat o Unii Europejskiej, zawarty w Maastricht 7 lutego 1992, Dz.Urz. C 191 z 29 lipca 1992). 
nie w dotychczasowym orzecznictwie TSUE. Nie wszystkie z wyroków, które się do niego odnosiły, zostaną szczegółowo omówione w tym opracowaniu. Uwaga poświęcona będzie tym orzeczeniom, które mają najistotniejsze znacznie z perspektywy tematyki tego opracowania. Poniżej podjęta zostanie próba omówienia szczególnie tych orzeczeń dotyczących tożsamości konstytucyjnej państw członkowskich, które pozwalają na ukazanie pewnych tendencji i sformułowanie wniosków istotnych z perspektywy tezy tej pracy. Podobnie nie cała złożoność problematyki związanej z obowiązkiem Unii do poszanowania tożsamości konstytucyjnej w swej różnorodnej aktywności (prawotwórczej, sądowniczej, administracyjnej) oraz zaangażowania różnych instytucji (TSUE, Komisji, Parlamentu) będzie poddana tu analizie ${ }^{1031}$, a jedynie te zagadnienia, które są konieczne z perspektywy prezentowanej w tej pracy propozycji współpracy między TK a TSUE w przedmiocie poszanowania wyższego niż unijny, konstytucyjnego standardu ochrony jakiegoś prawa czy wolności jednostki.

Jak jeszcze w 2012 r. zauważał Krzysztof Wójtowicz: „W orzecznictwie TS nie znajdujemy rozwiniętego odniesienia się do zagadnienia poszanowania tożsamości narodowej"1032. Do dziś sytuacja ta uległa niewielkiej zmianie. Zachowała również trafność obserwacja, że do tej pory TSUE wypowiadał się na ten temat na ogół w sytuacjach, kiedy "starał się ważyć konieczność respektowania swobód traktatowych i innych podstawowych dla Unii wartości z obowiązkiem poszanowania tożsamości narodowej"1033. W dużej mierze traktował więc tożsamość konstytucyjną w kategoriach podobnych do porządku publicznego, jako dopuszczalnej podstawy ograniczenia swobód traktatowych. Jak wiadomo jednak korzystanie przez państwa z sytuacji derogacyjnych otwiera prawo państw członkowskich na unijne standardy praw człowieka, które znajdują wobec niego zastosowanie w związku z art. 51 ust. 1 Karty. W pracy tej obowiązek poszanowania tożsamości konstytucyjnej państw będzie analizowany w szerszym kontekście - jako podstawa do zwolnienia państw członkowskich ze wszelkiego rodzaju zobowiązań wynikających z prawa unijnego, a jednocześnie w zakresie węższym - ograniczonym jedynie do składających się na tożsamość konstytucyjną krajowych gwarancji praw człowieka.

Mimo rzadkiego stosowania art. 4 ust. 2 TUE problematyka obowiązku poszanowania przez Unię tożsamości państw członkowskich była przedmiotem dość ożywionej dyskusji zarówno przedstawicieli nauki prawa Unii Europejskiej, jak i prawa konstytucyjnego poszczególnych państw członkowskich. Poszukując genezy pojęcia tożsamości konstytucyjnej na gruncie prawa unijnego:

\footnotetext{
1031 Więcej - patrz przed.: E. Cloots, National Identity in EU Law, Oxford 2015.

1032 K. Wójtowicz, Sady konstytucyjne..., s. 119.

1033 Ibidem.
} 
można albo ograniczyć się do bliższej perspektywy czasowej związanej z wprowadzeniem do języka traktatów UE pojęcia tożsamości narodowej, albo też próbować dostrzec początki tej koncepcji we wczesnej fazie kształtowania się orzecznictwa konstytucyjnego związanego z integracją europejska, w którym podkreślano potrzebę ochrony fundamentalnych elementów porządków konstytucyjnych państw członkowskich ${ }^{1034}$.

W tej pierwszej perspektywie momentem zwrotnym byłby Traktat z Maastricht, który ustanowił UE i jego art. 6 ust. 3, który był poprzednikiem aktualnego art. 4 ust. 2 TUE. W tej drugiej perspektywie należy podkreślić, że takie pojęcia, jak "tożsamość konstytucji” czy "tożsamość porządku konstytucyjnego” funkcjonowały zarówno w doktrynie prawa konstytucyjnego, jak i w orzecznictwie państw członkowskich znacznie wcześniej ${ }^{1035}$, co pokazał również przykład Polski. W kontekście integracji europejskiej, zanim na dobre zagościło w orzecznictwie sądów konstytucyjnych państw członkowskich w pierwszej dekadzie XXI wieku, pojawiało się w nim również wcześniej. Podkreślić należy tu rolę FTK i wyrok Solange ${ }^{1036}$. Inne sądy konstytucyjne, jak np. włoski (Corte Costituzionale) $)^{1037}$, nie pozostawały jednak za nim daleko w tyle ${ }^{1038}$.

W ramach dyskusji nad obowiązkiem poszanowania przez Unię tożsamości konstytucyjnej państw członkowskich pojawiały się głosy o destrukcyjnym i osłabiającym integrację potencjale tego przepisu, które nabrały w ostatnich latach na sile w obliczu wydarzeń w niektórych państwach członkowskich ${ }^{1039}$. Z drugiej strony podkreślano, że może być on podstawą do funkcjonowania Unii w oparciu o tzw. zasadę pluralizmu konstytucyjnego (constitutional plura-

${ }^{1034}$ A. Kustra, Kelsenowski..., s. 280.

1035 Ibidem, s. 279-280.

${ }^{1036}$ FTK, 2 BvL 52/71, orzeczenie z 22 maja 1974.

${ }^{1037}$ Mam na myśli przede wszystkim orzeczenie w sprawie Frontini (włoski TK, sprawa 183/1973, wyrok z 27 grudnia 1973), które posłużyło konstytucjonaliście Paolo Barile do ukucia terminu controlimiti, który to nota bene w orzecznictwie samego włoskiego TK w zasadzie się nie pojawia (więcej - patrz: G. Piccirilli, The 'Taricco Saga': the Italian Constitutional Court Continues its European Journey, "European Constitutional Law Review”, s. 3-4, [online] <https://www.cambridge.org/core/journals/european-constitutional-law-review/article/taricco-saga-the-italianconstitutional-court-continues-its-european-journey/F9BEECCF1oD1B633 ${ }_{4} 65 \mathrm{~A}_{27} \mathrm{D}_{22} \mathrm{OE}_{7} \mathrm{~B}_{1} \mathrm{C}_{3}>$ [dostęp: 5.02.2019]; por. też wyrok w sprawie Granital (włoski TK, sprawa 170/1984, wyrok z 5 czerwca 1984).

${ }^{1038}$ Więcej na te tematy - patrz np.: A. Kustra, Kelsenowski..., s. 28o i nast.; więcej nt. orzecznictwa sądów konstytucyjnych różnych państw członkowskich na ten temat - patrz np.: M. Claes, Negotiating Constitutional Identity or Whose Identity is it Anyway? [w:] M. Claes; M. de Visser; P. Popelier; C. van de Heyning (red.), Constitutional Conversations in Europe. Actors, Topics and Procedures, Antwerp 2012, s. 222-226.

1039 Patrz np.: Z. Körtvélyesi, B. Majtényi, Game of Values: The Threat of Exclusive Constitutional Identity, the EU and Hungary, "German Law Journal" 2017, nr 7 . 
lism $)^{1040}$ czy wieloszczeblowego konstytucjonalizmu (multilevel constitutionalism) $)^{1041}$, a ostatnio nawet kosmopolitycznego konstytucjonalizmu (cosmopolitan constitutionalism) $)^{1042}$, w czym dopatrywano się siły projektu europejskiego. Podstawowym kontekstem analizy było odżycie, dzięki klauzuli poszanowania tożsamości konstytucyjnej państw członkowskich, sporu wokół kwestii suwerenności ${ }^{1043}$, dyskusji wokół zakresu przekazania kompetencji (kompetenz-kompetenz), czy też relacji między Unią a państwami członkowskimi w kontekście wyłaniania się unijnej tożsamości konstytucyjnej i unijnego narodu (demos) $)^{1044}$. Praca ta nie zmierza do ponownej analizy tych kwestii. Cel, jaki jest w niej postawiony sprowadza się do próby poszerzenia przestrzeni współpracy w oparciu o art. 4 ust. 2 TUE i uniknięciu pewnych potencjalnych konfliktów między prawem unijnym a krajowym w zakresie gwarancji praw człowieka i ewentualnych negatywnych skutków tego rodzaju konfliktów. Cel ten jest więc w dużej mierze pragmatyczny, a nie teoretyczny, i nie koncentruje się na próbie wpisywania zaprezentowanego w nim rozwiązania w konkretny model teoretycznoprawny ${ }^{1045}$. Propozycja zawarta $w$ tej pracy nie jest więc kolejnym argumentem w ramach doktryny, którą najpowszechniej określa się mianem pluralizmu konstytucyjnego, który ostatecznie sprowadzałby się do twierdzenia, że sądy krajowe są uprawnione do ograniczania stosowania prawa unijnego i zasady pierwszeństwa prawa unijnego, gdyby to naruszało tożsamość konstytucyjną tych państw ${ }^{1046}$, i do tego, że dotychczas absolutna zasada prymatu prawa

${ }^{1040}$ Patrz np.: M. Avbelj, J. Komárek (red.), Constitutional...; M.P. Maduro, Interpreting...; N. Walker, The Idea...; podsumowanie różnych podejść do pluralizmu konstytucyjnego i ich krytyka - patrz np.: R. Bifulco, Europe and Constitutional Pluralism: Prospects and Limitations, „Italian Journal of Public Law" 2018, nr 10 (2).

${ }^{1041}$ Patrz np.: I. Pernice, Multilevel....

1042 Patrz np.: M. Kumm, The Jurisprudence of Constitutional Conflict: Constitutional Supremacy in Europe before and after the Constitutional Treaty, "European Law Journal” 2005, nr 3 (11); idem, The Cosmopolitan....

${ }^{1043}$ Wprowadzenie tego pojęcia do Traktatu z Maastricht miało na celu przede wszystkim zagwarantowanie suwerenności narodowej państw członkowskich w obliczu powstania nowej, ponadnarodowej organizacji (A. Kustra, Kelsenowski..., s. 281); por. też: R. Toniatti, Sovereignty.... 1044 Więcej - patrz np.: K. Lenaerts, Wartości Unii Europejskiej a pluralizm konstytucyjny, "Europejski Przegląd Sądowy" 2014, nr 9; A. Kustra, Koncepcje pluralizmu prawnego a problem ustalenia ostatecznego strażnika legalności prawa w Unii Europejskiej, „Ruch Prawniczy, Ekonomiczny i Socjologiczny" 2008, nr 1; idem, Sady konstytucyjne a ochrona tożsamości narodowej i konstytucyjnej państw członkowskich, [w:] S. Dudzik, N. Półtorak (red.), Prawo Unii Europejskiej a prawo konstytucyjne państw członkowskich, Warszawa 2013, s. 54-57; K. Nicolaïdis, We, the ...; J.H.H. Weiler, Europa końca....

${ }^{1045}$ Więcej na temat rozważań nad niektórymi z takich modeli - patrz np.: A. Kustra, Kolizje norm konstytucyjnych $i$ wspólnotowych w ujęciu teoretycznoprawnym, „Europejski Przegląd Sądowy" 2007, $\mathrm{nr} 5$.

1046 Tak np.: M. Kumm, The Jurisprudence..., s. 262, 303; A. von Bogdandy, S. Schill, Overcoming Absolute Primacy; Respect for National Identity under the Lisbon Treaty " Common Market Law Review" 2011, nr 48, s. 1417, 1419, 1449-1450. 
unijnego staje się ze względu na obowiązek zawarty w art. 4 ust. 2 TUE zasadą względną ${ }^{1047}$. Jest ona w pewnym sensie argumentem na przedpolu pluralizmu konstytucyjnego, czy pewną miękką jego wersją, gdzie rola sądów krajowych jest niezwykle doniosła, lecz gdzie konsekwencje wynikające z członkostwa w Unii i z prawa unijnego zobowiązują je do podejmowania współpracy z TSUE i dopiero ich wspólne orzeczenie w przedmiocie poszanowania tożsamości konstytucyjnej należy uznać za prawidłowe wypełnienie obowiązku po stronie Unii do poszanowania tożsamości konstytucyjnej państw członkowskich i państw członkowskich do lojalnej współpracy. Dzięki temu pewien wyłom w prawie unijnym na rzecz poszanowania tożsamości tych państw nie będzie podważał sensu stricto zasady pierwszeństwa, lecz będzie pewnym ograniczeniem zasady jego jedności (jednolitości stosowania), choć nie ulega wątpliwości, że obie te zasady są ze sobą ściśle powiązane.

Należy podkreślić, że odmiennie jak w prawie polskim, pojęcie tożsamości narodowej od niemal 25 lat jest expressis verbis wyrażone na poziomie unijnego prawa pierwotnego, i to właśnie ten fakt stał się ważnym impulsem dla sądów konstytucyjnych państw członkowskich do wypracowywania w ramach ich porządków prawnych pojęcia tożsamości konstytucyjnej ${ }^{1048}$. Tym niemniej również na poziomie prawa unijnego brakuje definicji legalnej tego pojęcia. Jego dogmatyczna wykładnia wiąże się z innymi przepisami unijnego prawa pierwotnego. Mam tu na myśli przede wszystkim art. 4 ust. 3 TUE i sformułowany w nim obowiązek lojalnej współpracy państw członkowskich i Unii w zakresie wykonywania obowiązków wynikających z traktatów; art. 5 TUE i wynikającą z niego możliwość działania Unii wyłącznie w zakresie kompetencji jej przyznanych $\mathrm{w}$ traktatach; art. 6, przesądzający o tym, że Unia uznaje prawa, wolności i zasady określone w KPP i art. 67 ust. 1 TUE, zgodnie z którym Unia stanowi przestrzeń wolności, bezpieczeństwa i sprawiedliwości w poszanowaniu praw podstawowych oraz różnych systemów i tradycji prawnych Państw Członkowskich; art. 51 ust. 1 i art. 53 KPP ${ }^{1049}$, które były już w tym kontekście wspominane. Pełna analiza dogmatyczna tego pojęcia nie będzie przedmiotem tej pracy. Analiza orzecznictwa TSUE nie będzie mieć na celu odniesienia się do wszystkich aspektów rozumienia tego pojęcia zarówno w sensie materialnym, a więc rozstrzygnięć takich, jak to, czy TSUE bliżej do francuskiego, czy też niemieckiego modelu rozumienia tego pojęcia ${ }^{1050}$, jak i formalnym, a więc

1047 G. Martinico, O. Pollicino, The Interaction between Europe's Legal Systems. Judicial Dialogue and the Creation of Supranational Laws, Cheltenham-Northampton 2012, s. 194.

${ }^{1048}$ A. Kustra, Kelsenowski..., s. 281.

1049 Por.: ibidem, s. 282.

1050 Zdaniem niektórych w orzecznictwie TSUE można w tej materii zauważyć pewną ewolucję, integrującą na różne sposoby charakterystyczne dla różnych sądów konstytucyjnych państw członkowskich podejścia, i zmierzającą ku uznaniu, „że tożsamość narodową tworzy 
wszystkich możliwych konsekwencji, jakie mogą z tego obowiązku wynikać dla Unii ${ }^{1051}$. Uwaga skoncentrowana będzie na tym wymiarze tego orzecznictwa, które pozwoli odpowiedzieć na pytanie, czy i jeśli tak, to na jakich zasadach, a przynajmniej na podstawie jakich warunków brzegowych, składający się na nią wyższy niż unijny standard gwarancji praw człowieka "może potencjalnie stanowić - akceptowalne przez UE - uzasadnienie niestosowania przepisów prawa UE na terenie państwa członkowskiego. Innymi słowy, czy tożsamość narodowa oraz konstytucyjna są - z perspektywy art. 4 (2) TUE - dopuszczalnymi wyjątkami od zasady pierwszeństwa"1052 lub jednolitości stosowania prawa UE.

\subsubsection{Sprawa Omega}

Bardzo istotne znaczenie dla rozumienia przez TSUE zasady poszanowania tożsamości konstytucyjnej państw członkowskich, szczególnie w kontekście tej pracy, ma wyrok w sprawie Omega ${ }^{1053}$. Chodziło w niej o ograniczenia w możliwości prowadzania przez zarejestrowaną w Niemczech spółkę działalności polegającej na organizowaniu gier typu laser tag (jest to rodzaj sportu podobny do paintballu, który bywa nazywany "laserowym paintballem”; polega na zdobywaniu punktów poprzez trafienie innego gracza urządzeniem imitującym broń palną z opcją podczerwieni LED). Należy pamiętać, że sprawa ta została rozstrzygnięta jeszcze przed nadaniem Karcie mocy prawnej przez TL. Jak pokazują rozważania co do dopuszczalności pytania, poczynione przez TSUE na gruncie tej sprawy, w aktualnym stanie prawnym i na obecnym etapie rozwoju orzecznictwa TSUE odnośnie do stosowania unijnych praw podstawowych nie powinno jednak budzić wątpliwości, że Karta mogłaby znaleźć w takiej sprawie zastosowanie w ramach sytuacji typu ERT ${ }^{1054}$.

zbiorowa świadomość tkwiąca w narodzie rozumianym zarówno jako wspólnota kulturowa, jak i polityczna (państwowa)" (A. Kustra, Kelsenowski..., s. 283); więcej - patrz np.: A. von Bogdandy, S. Schill, Overcoming....

1051 Więcej - patrz np.: A. Kustra, Kelsenowski..., s. 279-297.

1052 Ibidem, s. 291.

${ }^{1053}$ TSUE, Omega Spielhallen-und Automatenaufstellungs-GmbH p. Oberbürgermeisterin der Bundesstadt Bonn, C-36/o2, wyrok z 14 października 2004.

1054 Rozważając, czy sprawa ta miała unijny charakter, co jest warunkiem dopuszczalności orzekania przez TSUE, ten ostatni oparł się na dość wątłej podstawie. Transgraniczny element w niej obecny był bowiem jedynie potencjalny. Spółka Omega, która chciała prowadzić przedmiotową działalność w Niemczech, była zarejestrowana w tym właśnie kraju. Otrzymała zakaz tej działalności zanim podpisała jakąkolwiek umowę (dotyczącą dostawy odpowiednich urządzeń i franczyzy z podmiotem z innego kraju członkowskiego). Ponieważ jak stwierdził jednak TSUE, „z akt sprawy wynika, że w momencie wydania zarządzenia z dnia 14 września 1994 r. Omega nie zawarła jeszcze formalnie umów na dostawę urządzeń i franchisingowej ze spółką mającą siedzibę w Zjednoczonym Królestwie, to wystarczy stwierdzić, że zarządzenie 
Powołując się na swoje wcześniejsze orzecznictwo, w tym na sprawę ERT, TSUE zauważył zresztą ten kontekst, szczególnie w wymiarze znaczenia EKPCz dla sprawy.

Zgodnie z utrwalonym orzecznictwem prawa podstawowe stanowią integralną część ogólnych zasad prawa, których poszanowanie zapewnia Trybunał i których źródłem są tradycje konstytucyjne wspólne dla Państw Członkowskich, jak również wskazówki znajdujące się w dokumentach międzynarodowych dotyczących ochrony prawa człowieka, przy których tworzeniu Państwa Członkowskie współpracowały lub do których przystąpiły. Europejska Konwencja o ochronie praw człowieka i podstawowych wolności ma w tym kontekście szczególne znaczenie [... $]^{1055}$.

Odwołanie to służyło jednak Trybunałowi głównie do podkreślenia uniwersalnej doniosłości ochrony godności ludzkiej, i faktu, że charakteryzuje ona zarówno unijny, jak i krajowe porządki prawne, nie zaś do rekonstrukcji na potrzeby tej sprawy unijnego standardu w tej materii. Posłużyło mu także do potwierdzenia dopuszczalności wyciągania z zasady ochrony godności ludzkiej w różnych państwach członkowskich Unii, różnych konsekwencji, szczególnie gdy chodzi o poziom jej ochrony, co może mieć wpływ na zakres stosowania prawa unijnego.

Nota bene pojęcie tożsamości konstytucyjnej czy narodowej w tym orzeczeniu expressis verbis się nie pojawia. Tym niemniej podkreślenia wymaga, że trybunał luksemburski stwierdził w tym wyroku, że w odniesieniu do swobody świadczenia usług ${ }^{1056}$, która leżała u podstaw tej sprawy, a która - jak powszechnie wiadomo - jest jedną z fundamentalnych zasad prawa UE i całej europejskiej integracji:

Nie jest [...] niezbędne, aby przepis o charakterze ograniczenia wydany przez organy Państwa Członkowskiego odpowiadał koncepcji wspólnej dla wszystkich Państw Członkowskich, jeżeli chodzi o sposoby ochrony określonego prawa podstawowego lub uzasadnionego interesu. Wprawdzie w [...] wyroku w sprawie Schindler Trybunał uczynił odwołanie do względów moralnych, religijnych lub kulturowych, które

to może w każdym razie, mając na uwadze jego przyszłościowy charakter i treść zakazu, jaki ustanawia, ograniczyć rozwój przyszłych kontaktów pomiędzy obiema stronami. Nie wydaje się więc oczywiste, by pytanie postawione przez sąd odsyłający, dotyczące wykładni przepisów Traktatu ustanawiających swobodę świadczenia usług i przepływu towarów, nie miało żadnego związku z treścią i przedmiotem sporu przed sądem krajowym" (ibidem, pkt 21). Doprowadziło go to do uznania pytania za dopuszczalne (ibidem, pkt 21).

1055 Ibidem, pkt 33.

1056 Jeśli chodzi o swobodę przepływu towarów, to zgodnie ze swą doktryną TSUE skupił się na swobodzie świadczenia usług, jako że uznał, iż ta pierwsza jest "drugorzędna w stosunku do drugiej i można ją z tą drugą połączyć" (ibidem, pkt 26). 
prowadzą Państwa Członkowskie do poddania organizacji gier zakładowych i innych gier pieniężnych ograniczeniom, jednak nie zamierzał formułować, na podstawie tej wspomnianej wspólnej koncepcji prawnej, żadnego ogólnego kryterium oceny proporcjonalności każdego przepisu krajowego, który ogranicza wykonywanie działalności gospodarczej ${ }^{1057}$.

Co należy podkreślić w kontekście tego opracowania, ograniczenie swobód dokonane przez władze niemieckie wynikało wprost z chęci stania na straży wyższego standardu ochrony praw jednostki, niż zapewniało to prawo unijne oraz prawa pozostałych państw członkowskich. Przekonanie oparte na właściwym dla niemieckiego porządku konstytucyjnego rozumieniu zasady godności człowieka, które nie dopuszczało nawet symulowanego aktu zabójstwa człowieka, nie znajdowało odzwierciedlenia w prawie unijnym ani w prawach państw członkowskich, gdzie gry typu laser tag były dozwolone. Trybunał kontynuował:

W niniejszym przypadku należy podnieść, po pierwsze, że, zdaniem sądu odsyłającego, zakaz wykorzystywania do celów handlowych gier rozrywkowych polegających na symulacji aktów przemocy w stosunku do osób, w szczególności przez przedstawianie uśmiercania ludzi, odpowiada poziomowi ochrony godności ludzkiej, do którego zapewnienia na terytorium Republiki Federalnej Niemiec dąży konstytucja krajowa ${ }^{1058}$.

W związku z powyższym trybunał luksemburski doszedł do wniosku, że:

należy odpowiedzieć na postawione pytanie w ten sposób, że prawo wspólnotowe nie stoi na przeszkodzie wydaniu przez władze krajowe zakazu prowadzenia działalności gospodarczej polegającej na wykorzystywaniu do celów handlowych gier opartych na symulacji zabijania ludzi, uzasadnionego ochroną porządku publicznego w związku z naruszeniem w ramach tej działalności godności ludzkiej ${ }^{1059}$.

Trybunał stwierdził więc, dokonując tym samym wykładni przepisów unijnego prawa pierwotnego gwarantującego swobody świadczenia usług, że prawo wspólnotowe nie stoi na przeszkodzie, by niemiecki prawodawca ograniczył swobodę świadczenia usług w zakresie pewnego rodzaju usług, jakimi było prowadzenie gier typu laser tag, ze względu na zasadę godności człowieka oraz standard ochrony, jaki tej wartości gwarantuje niemiecka konstytucja, przy jednoczesnej dopuszczalności tych usług i ich swobodnego przepływu na terenie

${ }^{1057}$ Ibidem, pkt 37. Takie podejście Trybunał stosował również w innych sprawach, gdzie swoboda świadczenia usług kolidowała z gwarnacjami praw dziecka (TSUE, Dynamic Medien Vertriebs GmbH p. Avides Media AG, C-244/o6, wyrok z 14 lutego 2008).

1058 TSUE, Omega Spielhallen-und Automatenaufstellungs-GmbH p. Oberbürgermeisterin der Bundesstadt Bonn, C-36/o2, wyrok z 14 października 2004, pkt 39.

1059 Ibidem, pkt 41. 
innych państw członkowskich. Trybunał nie znalazł więc w tak uzasadnionym ograniczeniu naruszenia zasady pierwszeństwa, jedności i skuteczności prawa wspólnotowego. Trybunał nie zawiesił też ani tym bardziej nie podważył zasady swobody świadczenia usług. Tak ją jednak zinterpretował, aby w zakresie, w jakim w tej sprawie czyniło to prawo niemieckie, nie była ona, czy też wynikające z niej konsekwencje, stosowana w Niemczech. Trybunał doszedł do wniosku, że „zarządzenia z dnia 14 września 1994 r. nie można uznać za stanowiące nieuzasadnione naruszenie swobody świadczenia usług"1060. Pokreślił także, że ograniczenia wprowadzone przez niemieckiego prawodawcę nie były ekstensywne, a więc były proporcjonalne ${ }^{1061}$, co również należy zauważyć, i co będzie miało znaczenie $w$ dalszej części rozważań. Zachowanie przez TSUE kompetencji do oceniania proporcjonalności środka krajowego, wynikającego z krajowego standardu ochrony praw człowieka, stanowi pewien istotny etap w ramach sekwencji orzekania, o której mowa w tym rozdziale.

Należy wszakże mocno podkreślić, że ta sprawa nie miała typowego charakteru dla omawianej tu problematyki. Mieliśmy wprawdzie do czynienia ze specyficznym, opartym na krajowym, konstytucyjnym rozumieniu godności człowieka i jej ochrony, które zostało uwzględnione w interpretacji zasady swobody przepływu usług tak, że wprowadzenie ze względu na nie ograniczeń tej swobody w danym państwie, nie powinno być uznane za z tą swobodą sprzeczne. Trybunał oparł się jednak przy tym nie na koncepcji tożsamości konstytucyjnej państw członkowskich (choć istniały już do tego niekwestionowane podstawy prawne, jako że była ona obecna w unijnym prawie pierwotnym od czasu Traktatu z Maastricht), lecz wyłącznie na klauzuli porządku publicznego jako podstawie dopuszczalnego odstępstwa przez państwo członkowskie od unijnych swobód. To właśnie niedopuszczenie do naruszenia porządku publicznego legło u podstaw zarządzenia zakazującego spółce Omega prowadzenie gier typu laser tag ${ }^{1062}$.

Należy zwrócić uwagę na pewne podobieństwa, jakie mogą łączyć koncepcję tożsamości konstytucyjnej i możliwości jej zastosowania z klauzulą porządku publicznego. Niewykluczone, że przydatne okaże się zastosowanie pewnych, wypracowanych na gruncie stosowania klauzuli porządku publicznego $\mathrm{w}$ kontekście derogacji od unijnych swobód i zasad ich dopuszczalności, jak choćby obowiązku wąskiego rozumienia opartych na niej wyjątków czy innych elementów metodologii jej stosowania przez TSUE ${ }^{1063}$. Analogia ta będzie mogła

${ }^{1060}$ Ibidem, pkt 40.
${ }^{1061} \mathrm{Ibidem}$, pkt $37-38$.
$1062 \mathrm{Ibidem}$, pkt 7 .
${ }^{1063}$ Jak wskazują Armin von Bogdandy i Stephan Schill, szczególnie pomocne mogłoby tu być orzecznictwo TSUE w sprawach takich, jak: TSUE, Roland Rutili p. Ministre de 
być może w jakimś stopniu w przyszłości pomóc w doprecyzowaniu znaczenia i zasad zastosowania wobec państw członkowskich pewnych wyjątkowych, opartych na art. 4 ust. 2 TUE, zwolnień z obowiązków, jakie wiążą je w związku z członkostwem w Unii ${ }^{1064}$. Co wszakże bardzo ważne, funkcja, jaka w tej pracy przypisywana jest art. 4 ust. 2 TUE i tożsamości konstytucyjnej państw członkowskich, jest znacznie szersza i dotyczy nie tylko unijnych swobód czy innych przepisów prawa unijnego, które zawierają klauzulę porządku publicznego (jak np. art. 34 ust. 1 Rozporządzenia Bruksela I ${ }^{1065}$ ), lecz wszelkich przepisów prawa unijnego. Praca ta opiera się na koncepcji autonomicznego charakteru pojęcia tożsamości konstytucyjnej i obowiązku jej poszanowania przez Unię, stąd analogie tego rodzaju mogłyby mieć jedynie ograniczone znaczenie.

l'intérieur, 36-75, wyrok z 28 października 1975, pkt 26-28; TSUE, Regina p Pierre Bouchereau, 30-77, wyrok z 27 października 1977, pkt 33 i nast.; TSUE, Omega Spielhallen-und Automatenaufstellungs-GmbH p. Oberbürgermeisterin der Bundesstadt Bonn, C-36/o2, wyrok z 14 października 2004, pkt 30; TSUE, Ministerul Administrației şi Internelor - Direcția Generală de Paşapoarte Bucureşti p. Gheorghe Jipa, C-33/o7, wyrok z 10 lipca 2008, pkt 23; TSUE, Komisja Wspólnot Europejskich p. Wielkiemu Księstwu Luksemburga, C-319/o6, wyrok z 19 czerwca 2008, pkt 50.

${ }^{1064}$ Na marginesie można zauważyć, że pojęcie porządku publicznego jest również dobrze znane w prawie polskim i w kategoriach najogólniejszych należy powiedzieć, że „przesłanką zastosowania klauzuli jest możliwość naruszenia podstawowych zasad polskiego porządku prawnego" (N. Rycko, Klauzula porządku publicznego a normy konstytucyjne, [w:] S. Biernat (red.), Konstytucja Rzeczypospolitej polskiej w pierwszych dekadach XXI wieku wobec wyzwań politycznych, gospodarczych i społecznych, Warszawa 2013, s. 275). Należy również podkreślić, „że zakresem pojęcia porządku publicznego nie zostały objęte wszystkie normy składające się na polski system prawny, a jedynie normy najbardziej istotne. Ustalenie tych norm ustawodawca świadomie pozostawił doktrynie i orzecznictwu" (ibidem, s. 275). To również upodabnia nieco ten koncept do prezentowanego tu rozumienia tożsamości konstytucyjnej, której treść rekonstruowana jest głównie przez orzecznictwo TK i doktrynę, a na którą nie składają się wszystkie normy konstytucyjne, a jedynie te najistotniejsze. Tym niemniej znowu pojęć tych zdecydowanie nie wolno utożsamiać. Różna jest przede wszystkim ich ranga: tożsamość konstytucyjna wynika z samej Konstytucji, źródło - tożsamość konstytucyjna nie została expressis verbis wyrażona w żadnym przepisie prawa polskiego; oraz zakres - tożsamość konstytucyjna ma znaczenie w kontekście wszelkich dziedzin prawa.

1065 Rozporządzenie Rady (WE) nr 44/2001 z 22 grudnia 2000 w sprawie jurysdykcji i uznawania orzeczeń sądowych oraz ich wykonywania w sprawach cywilnych i handlowych, Dz.Urz. L 12 z 16 stycznia 2001, ze zm.; nota bene TSUE aktualnie klauzulę tę interpretuje wąsko i pozostawia państwom małą swobodę w korzystaniu z niej (B. Hess, T. Pfeiffer, M. Bever, Interpretation of the Public Policy Exception as referred to in EU Instruments of Private International and Procedural Law, s. 30-37, [online] <http://www.europarl.europa.eu/RegData/etudes/ STUD/2011/453189/IPOL-JURI_ET(2011)453189_EN.pdf> [dostęp: 5.02.2019]); co do zasady wszelkie odstępstwa ze względu na porządek publiczny, czy to od unijnych swobód, czy to od przewidującego taką możliwość prawa pierwotnego pozostają pod ścisłą kontrolą TSUE, który raczej nie jest skłonny pozostawiać w tej materii państwom szerokiego pola manewru (C. Kessedjian, Public Order in European Law, „Erasmus Law Review” 2007, nr 1 (1). 
Mimo że tożsamość konstytucyjna nie pojawia się w niej expressis verbis, przywołanie sprawy Omega było konieczne, jako że stała się ona i zastosowane $\mathrm{w}$ niej rozumowanie podstawą do pierwszego istotnego, a więc skutecznego zastosowania przez TSUE obowiązku poszanowania przez Unię tożsamości konstytucyjnej państw członkowskich w sprawie Sayn-Wittgenstein ${ }^{1066}$.

\subsubsection{Sprawa Michaniki (opinia)}

Jak słusznie zauważa Krzysztof Wójtowicz, w sensie koncepcyjnym, gdy chodzi o rozumienie obowiązku poszanowania przez Unię tożsamości konstytucyjnej państw członkowskich, prekursorską rolę odegrał Rzecznik Generalny Miguel Poiares Maduro ${ }^{1067}$ w opinii, jaką przedstawił w sprawie Michaniki ${ }^{1068}$, mimo że w wyroku TSUE nie podniósł tej kwestii. Odwołania do obowiązku poszanowania przez Unię tożsamości konstytucyjnej państw członkowskich zdarzały się również w opiniach rzeczników w innych sprawach ${ }^{1069}$. Ze względu na to,

1066 TSUE, Ilonka Sayn-Wittgenstein p. Landeshauptmann von Wien, C-208/o9, wyrok z 22 grudnia 2010.

${ }^{1067}$ K. Wójtowicz, Sady konstytucyjne..., s. 124.

1068 TSUE, Michaniki AE p. Ethniko Symvoulio Radiotileorasis i Ypourgos Epikrateias, C-213/o7, opinia Rzecznika Generalnego M. Poiaresa Madura przedstawiona w dniu 8 października 2008.

1069 Patrz np.: TSUE, Kingdom of the Netherlands p. Council of the European Union, C-58/94, opinia Rzecznika Generalnego A.G. Tesauro przedstawiona w dniu 28 listopada 1995, pkt 19; TSUE, Królestwo Hiszpanii p. Eurojustowi, C-16o/o3, opinia Rzecznika Generalnego M. Poiaresa Madura przedstawiona w dniu 16 grudnia 2004, pkt 24, 35-36; TSUE, Unión General de Trabajadores de la Rioja UGT-RIOJA p. Juntas Generales del Territorio Histórico de Vizcaya i in., C-428/o6, C-429/o6, C-430/o6, C-431/o6, C-432/o6, C-433/o6 i C-434/o6, opinia Rzecznika Generalnego Juliane Kokott przedstawiona w dniu 8 maja 2008, pkt 54; TSUE, Unión de Televisiones Comerciales Asociadas (UTECA), C-222/o7, opinia Rzecznika Generalnego Juliane Kokott przedstawiona w dniu 4 września 2008, pkt 93; TSUE, Anton Las p. PSA Antwerp NV, C-202/11, opinia Rzecznika Generalnego Niila Jääskinena przedstawiona w dniu 12 lipca 2012, pkt 58-61; TSUE, Angelo Alberto Torresi i Pierfrancesco Torresi p. Consiglio dell'Ordine degli Avvocati di Macerata, C-58/13 i C-59/13, opinia Rzecznika Generalnego Nilsa Wahla przedstawiona w dniu 10 kwietnia 2014, pkt 97-105; TSUE, RegioPost GmbH \& Co. KG p. Stadt Landau in der Pfalz, C-115/14, opinia Rzecznika Generalnego Paola Mengozziego przedstawiona w dniu 9 września 2015, pkt 82-85; TSUE, Postępowanie karne przeciwko Gavrilowi Covaciemu, C-216/14, opinia Rzecznika Generalnego Yves'a Bota przedstawiona w dniu 7 maja 2015, pkt 39; TSUE, Remondis GmbH \& Co. KG Region Nord p. Region Hannover, C-51/15, opinia Rzecznika Generalnego Paola Mengozziego przedstawiona w dniu 30 czerwca 2016, pkt 40-41; TSUE, Samira Achbita i Centrum voor gelijkheid van kansen en voor racismebestrijding p. G4S Secure Solutions NV, C-157/15, opinia Rzecznika Generalnego Juliane Kokott przedstawiona w dniu 31 maja 2016, pkt 31-32, 125, 141; TSUE, Asma Bougnaoui Association de défense des droits de l'homme (ADDH) p. Micropole SA, C-188/15, opinia Rzecznika Generalnego Eleanor Sharpston przedstawiona w dniu 13 lipca 2016; TSUE, Konrad Erzberger 
że nie znajdowały ostatecznie odzwierciedlenia w wyrokach albo zostawały w nich traktowane zdawkowo, lecz przede wszystkim ze względu na to, że nie miały tak przełomowego charakteru, nie będą $w$ tym rozdziale, $z$ pewnymi jedynie wyjątkami, omawiane.

Sprawa Michaniki dotyczyła przesłanek wykluczenia przedsiębiorcy z udziału w zamówieniu w ramach procedury udzielania zamówień publicznych na roboty budowlane, co było objęte unijną dyrektywą, która jednak pozostawiała w tym zakresie pewną swobodę państwom. Pytanie skierowane do TSUE przez grecką Radę Stanu (Symvoulio tis Epikrateias) sprowadzało się do kwestii, czy państwo członkowskie może dodać podstawę wykluczenia $\mathrm{z}$ udziału w postępowaniach o udzielenie zamówienia publicznego na roboty budowlane do wykazu znajdującego się w art. 24 dyrektywy 93/37/EWG i ewentualnie na jakich warunkach ${ }^{1071}$. Kwestia ta nie była nowa. Co ważne z perspektywy tej pracy, szczególnym aspektem niniejszej sprawy było to, że krajowy środek normatywny, stanowiący podstawę takiego wykluczenia wynikał z przepisów konstytucyjnych ${ }^{1072}$, których szerszy kontekst dotyczył ochrony celów interesu ogólnego związanych z funkcjonowaniem systemu demokratycznego i gwarancją pluralizmu prasy ${ }^{1073}$.

Nie wchodząc w szczegóły tej sprawy, należy zwrócić uwagę na mające ogólne - systemowe - znaczenie rozważania Rzecznika na temat obowiązku poszanowania przez Unię tożsamości konstytucyjnej państw członkowskich. Podkreślił on w swej opinii, że niewątpliwie spoczywający na Unii obowiązek poszanowania tożsamości konstytucyjnej państw członkowskich, wyrażony w art. 4 ust. 2 TUE, a wcześniej w wersji, jaką otrzymał w wyniku wejścia w życie Traktatu z Maastricht, w jego art. 6 ust. 3, tak naprawdę spoczywał na Unii zawsze i jest zakorzeniony w jej naturze, co podkreśla fakt, że pojęcie to funkcjonowało i było stosowane na forum TSUE jeszcze przed wejściem w życie Traktatu z Maastricht ${ }^{1074}$. Rzecznik podkreślił, że:

p. TUI AG, opinia Rzecznika Generalnego Henrika Saugmandsgaarda Øe przedstawiona 4 maja 2017, pkt 88, 101-103; TSUE, Vera Egenberger p. Evangelisches Werk für Diakonie und Entwicklung e.V., C-414/16, opinia Rzecznika Generalnego Evgeniego Tancheva przedstawiona 9 listopada 2017, pkt 94-95.

1070 Dyrektywa Rady z 14 czerwca 1993 dotycząca koordynacji procedur udzielania zamówień publicznych na roboty budowlane, Dz.Urz. L 199.

1071 TSUE, Michaniki AE p. Ethniko Symvoulio Radiotileorasis i Ypourgos Epikrateias,

C-213/o7, wyrok z 16 grudnia 2008, pkt 26.

1072 Ibidem, pkt 5-6.

1073 Ibidem, pkt 22.

1074 TSUE, Anita Groener p. Minister Edukacji i City of Dublin Vocational Education Committee, C-379/87, wyrok z 28 listopada 1989. 
Obowiązek ten spoczywa na Unii od początku. Wynika on z istoty projektu europejskiego zainicjowanego na początku lat pięćdziesiątych, który polega na pogłębianiu integracji przy zachowaniu politycznej egzystencji państw. Dowodem tego jest fakt, że został on wyraźnie wyrażony po raz pierwszy przy okazji rewizji traktatów, kiedy przewidywane postępy integracji sprawiły, że - w oczach założycieli - konieczne stało się jego przypomnienie ${ }^{1075}$.

Takim przypomnieniem i wyrazem tego obowiązku na poziomie prawa było właśnie dodanie do TUE odpowiednich przepisów w Traktacie z Maastricht i później z Lizbony. Co warto także zauważyć, miał on, w podobnej wersji jak aktualnie, znaleźć się też w Traktacie konstytucyjnym (art. I-5) ) $^{1076}$.

Rzecznik podkreślił, że jedną z zasadniczych konsekwencji obowiązku poszanowania przez Unię tożsamości konstytucyjnej państw członkowskich jest to, że „zachowanie tożsamości konstytucyjnej [...] może [...] stanowić słuszny interes, mogący co do zasady uzasadniać ograniczenie obowiązków nałożonych prawem wspólnotowym"1077. Powołując się na orzecznictwo TSUE, Rzecznik Maduro zauważył, że z uważnej analizy obowiązku poszanowania przez Unię tożsamości konstytucyjnej państw członkowskich

wynika, że państwo członkowskie, w niektórych przypadkach i bezsprzecznie pod kontrolą Trybunału [UE - przyp. aut.], może domagać się ochrony swojej tożsamości narodowej, aby uzasadnić odstępstwo od stosowania podstawowych swobód przepływu. Po pierwsze, może wyraźnie powołać się na nią jako zgodny z prawem i autonomiczny powód odstępstwa. Trybunał uznał bowiem wyraźnie, że ochrona tożsamości narodowej „stanowi uprawniony cel respektowany we wspólnotowym porządku prawnym"1078.

Na szczególne podkreślenie zasługuje tu sklasyfikowanie obowiązku poszanowania tożsamości konstytucyjnej jako autonomicznego względem jakichkolwiek innych (w tym porządku publicznego). Cały czas jednak obowiązek ten pozostaje silnie powiązany ze sposobem realizacji unijnych swobód.

Rzecznik podkreślił także pewną swobodę po stronie państw do określania tego, co składa się na ich tożsamość konstytucyjną. „Ochrona krajowej tożsamości konstytucyjnej może również dawać państwu członkowskiemu możliwość, w określonych granicach, ustalania własnego rozumienia słusznego interesu, który może uzasadniać ograniczenie którejś z podstawowych

1075 TSUE, Michaniki AE p. Ethniko Symvoulio Radiotileorasis i Ypourgos Epikrateias, C-213/o7, opinia Rzecznika Generalnego M. Poiaresa Madura przedstawiona w dniu 8 października 2008, pkt 31 .

1076 Ibidem, pkt 31.

1077 Ibidem, pkt 33.

1078 Ibidem, pkt 32. 
swobód przepływu"1079. Przywołując orzeczenie w sprawie Omega, Rzecznik przypomniał, że:

Dlatego też Trybunał odpowiedział państwu członkowskiemu, które powoływało się na konieczną ochronę zasady zachowania godności człowieka gwarantowanej konstytucją krajową w celu uzasadnienia ograniczeń w swobodnym świadczeniu usług, że godność ludzka jest chroniona we wspólnotowym porządku prawnym jako ogólna zasada prawna. Niemniej jednak Trybunał uznał, że państwo członkowskie ma dużą swobodę w określaniu treści i zakresu prawa do zachowania godności ludzkiej zgodnie z własną koncepcją ochrony należnej takiemu prawu podstawowemu przyjętą na swoim terytorium, przy uwzględnieniu specyfiki krajowej. W konsekwencji fakt, że pozostałe państwa członkowskie nie podzielają koncepcji prawa podstawowego przyjętej przez dane państwo członkowskie, nie oznacza, że państwo to nie może się na nią powoływać, aby uzasadnić ograniczenie w swobodnym świadczeniu usług ${ }^{1080}$.

Jak zauważył to już w jednej ze swych wcześniejszych opinii Rzecznik Maduro, to władze krajowe są jego zdaniem bardziej kompetentne do określania zakresu tego, co należy uznawać za tożsamość konstytucyjną państw członkowskich. Szczególna rola należy się w tym procesie sądowi konstytucyjnemu.

Niewątpliwie należy przyznać władzom krajowym, a w szczególności sądowi konstytucyjnemu, odpowiedzialność za zdefiniowanie charakteru szczególnych uwarunkowań krajowych, które mogą uzasadnić taką różnicę w traktowaniu. Są oni bowiem bardziej kompetentni, aby zdefiniować tożsamość konstytucyjną państw członkowskich, której poszanowanie Unia przyjęła za swoje zadanie [...]. Trybunałowi jednakże pozostaje obowiązek sprawdzenia, czy dokonana ocena jest zgodna z podstawowymi prawami i celami, których poszanowanie zapewnia Unia w ramach wspólnotowych ${ }^{1081}$.

Tym niemniej tożsamości konstytucyjnej państwa nie należy utożsamiać z konstytucją tego państwa jako taką. Jak podkreślił Rzecznik Maduro:

zachowanie tożsamości konstytucyjnej państw członkowskich nie może być rozumiane jako bezwzględne poszanowanie wszystkich krajowych zasad konstytucyjnych. Gdyby tak było, konstytucje krajowe mogłyby stać się instrumentem umożliwiającym państwom członkowskim uwolnienie się od prawa wspólnotowego w określonych

1079 Ibidem, pkt 32.

1080 Ibidem, pkt 32.

1081 TSUE, Cristiano Marrosu, Gianluca Sardino p. Azienda Ospedaliera Ospedale San Martino di Genova e Cliniche Universitarie Convenzionateoraz Andrea Vassallo p. Azienda Ospedaliera Ospedale San Martino di Genova e Cliniche Universitarie Convenzionate, C-53/o4 i C-18o/o4, opinia Rzecznika Generalnego M. Poiaresa Madura przedstawiona w dniu 20 września 2005, pkt 40 . 
dziedzinach. Co więcej, wynikiem takiego podejścia mogłaby być dyskryminacja między państwami członkowskimi w zależności od treści, jaką każde z nich nadałoby swojej konstytucji krajowej ${ }^{1082}$.

Konstatacja ta wydaje się naturalna, zarówno w obliczu charakteru Unii i istoty jej autonomicznego porządku prawnego, jak i w obliczu art. 4 ust. 3 TUE, który zaraz po tym, gdy wyrażony został obowiązek po stronie Unii poszanowania tożsamości konstytucyjnej państw członkowskich, podkreśla obowiązek lojalnej współpracy między państwami członkowskimi oraz obowiązek ciążący na państwach członkowskich do zapewnienia wykonywania zobowiązań wynikających z Traktatów lub aktów instytucji Unii ${ }^{1083}$. Jak podkreślił Rzecznik Maduro: „Tak samo jak prawo wspólnotowe uwzględnia tożsamość konstytucyjną państw członkowskich, krajowe prawo konstytucyjne musi dostosować się do wymogów wspólnotowego porządku prawnego"1084. Na marginesie można zauważyć, że rozważania te nie doprowadziły Rzecznika do wniosku o możliwości modyfikacji względem Grecji obowiązków wynikających z dyrektywy unijnej ${ }^{1085}$.

W wyroku TSUE w tej sprawie ${ }^{1086}$ kwestia tożsamości konstytucyjnej w ogóle się nie pojawia. W kontekście tej pracy podkreślić należy, że - co nie powinno być trudne do przewidzenia w obliczu doktryny Simmenthal - choć wyrok ten nie był w sprawie przytoczony, w sprawie Michaniki przepisy rangi konstytucyjnej nie mogły być uznane za uzasadniające podważenie zobowiązań wynikających z prawa unijnego. TSUE zastosował jednak próbę możliwie

1082 TSUE, Michaniki AE p. Ethniko Symvoulio Radiotileorasis i Ypourgos Epikrateias, C-213/o7, opinia Rzecznika Generalnego M. Poiaresa Madura przedstawiona w dniu 8 października 2008, pkt 33 .

1083 Por.: K. Wójtowicz, Sądy konstytucyjne..., s. 125.

1084 TSUE, Michaniki AE p. Ethniko Symvoulio Radiotileorasis i Ypourgos Epikrateias, C-213/o7, opinia Rzecznika Generalnego M. Poiaresa Madura przedstawiona w dniu 8 października 2008, pkt 32.

${ }^{1085}$ Rzecznik stwierdził: „[w] niniejszej sprawie krajowe zasady konstytucyjne mogą zostać uwzględnione w zakresie, $\mathrm{w}$ jakim mieszczą się w zakresie swobodnego uznania, jakim dysponują państwa członkowskie, aby zapewnić zachowanie zasady równego traktowania narzuconej dyrektywą. Korzystanie z tego swobodnego uznania musi jednak pozostać w granicach wyznaczonych wspomnianą zasadą i samą dyrektywą. Zatem krajowa zasada konstytucyjna jest istotna - w niniejszej sprawie - dla określenia kontekstu krajowego, w którym zasada równego traktowania kandydatów ubiegających się o zamówienie publiczne musi być stosowana, dla ustalenia w tymże kontekście, jakie jest ryzyko konfliktu interesów, a wreszcie dla dokonania oceny, jaką wagę należy przykładać do zapobiegania takim konfliktom w krajowym porządku prawnym, a zatem na jakim poziomie normatywnym powinna ona zostać wykorzystana" (ibidem, pkt 34).

1086 TSUE, Michaniki AE p. Ethniko Symvoulio Radiotileorasis i Ypourgos Epikrateias, C-213/o7, wyrok z 16 grudnia 2008. 
miękkiego ich pogodzenia. Najwłaściwszym sformułowaniem będzie chyba stwierdzenie, że zachęcił do precyzyjniejszego wyjaśnienia zarówno przepisów krajowych, jak i unijnych ${ }^{1087}$, tak, aby je ze sobą pogodzić, i sam, zgodnie ze swoją kompetencja, doprecyzował rozumienie tych drugich ${ }^{1088}$. Choć nie odwołał się do kwestii tożsamości konstytucyjnej i obowiązku jej poszanowania, to również w odniesieniu do zwykłych regulacji konstytucyjnych, znajdujących zastosowanie w tej sprawie, Trybunał podkreślił, że chociaż państwa członkowskie cieszą się pewną dyskrecjonalnością we wprowadzaniu określonych przez dyrektywę środków, mających na celu ochronę wynikających z prawa unijnego zasad równego traktowania oferentów i przejrzystości, to jednak środki krajowe muszą spełniać test proporcjonalności, a środki wprowadzone w tym wypadku przez Grecję ocenił pod tym kątem negatywnie ${ }^{1089}$.

Szczególnie ważne dla konceptualizacji pojęcia tożsamości konstytucyjnej na gruncie prawa unijnego, dokonanej przez Rzecznika Maduro, wydają się trzy rzeczy. Po pierwsze, to po stronie państwa leży uprawnienie do powoływania się na tożsamość konstytucyjną i obowiązek jej poszanowania przez Unię, prowadzący do uchylenia pewnych, ciążących na nim zobowiązań wynikających z prawa unijnego. Po drugie, to po stronie państwa leży określanie zakresu regulacji konstytucyjnych składających się na jego tożsamość konstytucyjną. Nie całe bowiem konstytucje i wszystkie zawarte w nich regulacje mogą się takim statusem cieszyć. Wreszcie po trzecie, co jak się wydaje wymaga największego zniuansowania, powinno się to dziać we współpracy z (a nawet, jakiego to sformułowania użył Rzecznik - pod kontrolą) TSUE ${ }^{1090}$. Jak słusznie podsumowuje Aleksandra Kustra:

Przyjęcie stanowiska rzecznika Maduro wyrażonego w opinii w sprawie Michaniki prowadziłoby do rewolucyjnej zmiany w pojmowaniu zasady supremacji prawa UE. Taka zmiana wiązałaby się też ze „zdjęciem z piedestału” zasad efektywności i jednolitego stosowania tego prawa oraz zrównoważeniem ich zasadą poszanowania tożsamości narodowej i konstytucyjnej państw członkowskich, zasadą rządów prawa oraz zasadą ochrony praw podstawowych. Wpływ traktatowego pojęcia tożsamości narodowej na zmianę orzeczniczej koncepcji zasady pierwszeństwa może być więc znaczący. Praktyczne odwołanie się do tożsamości narodowej (konstytucyjnej) w odniesieniu do zasady pierwszeństwa polegałoby na stwierdzaniu niekonstytucyjności (niezgodności z przepisami konstytucyjnymi tworzącymi tożsamość konstytucyjną) przepisu prawa UE, na jego niestosowaniu na terytorium państwa członkowskiego,

${ }^{1087}$ E. Cloots, National..., s. 341.

1088 TSUE, Michaniki AE p. Ethniko Symvoulio Radiotileorasis i Ypourgos Epikrateias,

C-213/o7, wyrok z 16 grudnia 2008, przed. pkt 37-49.

1089 Ibidem, przed. pkt 48, 55, 61 i nast.

${ }^{1090}$ Por. też: G. van der Schyff, The Constitutional..., s. 578-579. 
przy jednoczesnym uznaniu, że takie orzeczenie nie powoduje negatywnych konsekwencji na płaszczyźnie zobowiązań międzynarodowych państwa ${ }^{1091}$.

Jak pokaże omawiane poniżej orzecznictwo, takie pojmowanie znaczenia tożsamości konstytucyjnej nie może cały czas wyjść ze sfery hipotez ${ }^{1092}$. Nie zostało bowiem ani ostatecznie potwierdzone, ani zanegowane przez TSUE. Jak uwidoczni jednak to orzecznictwo, wydaje się, że o ile podejście takie jest dla TSUE do zaakceptowania, to wymaga ono jednak pewnego zniuansowania, pozwalającego zarówno TSUE, jak i sądom konstytucyjnym, na zachowanie pewnych gwarancji co do faktycznej roli w ramach współpracy w tej materii, a nie roli sprowadzającej się albo jedynie do potwierdzania przez TSUE w zakresie konsekwencji dla prawa unijnego tego, co sąd krajowy ustali w zakresie tożsamości konstytucyjnej, albo, z drugiej strony, do pełnej swobody TSUE w ocenianiu zakresu tożsamości konstytucyjnej państwa członkowskiego i jej ewentualnego znaczenia dla prawa Unii. Podejście, o jakim pisze Aleksandra Kustra, w dużym stopniu sprowadzałoby się też do powiązania stosowania art. 4 ust. 2 TUE z doktryną ultra vires. Tymczasem propozycja zawarta w tej pracy ma ukazać takie metody jego wykorzystywania, które mogłyby pomóc zapobiegać, choć jej ostatecznie nie eliminować, konieczności uciekania się do orzeczeń w ramach doktryny ultra vires. Cały czas byłoby możliwe rozwiązanie „atomowe" i oparcie orzeczenia krajowego sądu konstytucyjnego w ramach doktryny ultra vires na naruszeniu przez Unię tożsamości konstytucyjnej tego państwa na etapie późniejszym ( $w$ razie niepowodzenia dialogu). Jednakże dzięki konkluzywnemu dialogowi na temat tej tożsamości i ewentualnego wspólnego zastosowania metod jej poszanowania przez sąd konstytucyjny i TSUE, mogłoby się to stać zbędne.

\subsubsection{Sprawa Sayn-Wittgenstein}

Sposób rozumowania przyjęty w sprawie Omega, a także w pewnym stopniu zaprezentowany przez Rzecznika Maduro w sprawie Michaniki, został potwierdzony (choć ten drugi nie expressis verbis) i rozwinięty przez TSUE w sprawie Sayn-Wittgenstein już bezpośrednio w związku z art. 4 ust. 2 TUE. Sprawa ta dotyczyła Pani Ilonki Sayn-Wittgenstein, urodzonej w Wiedniu, obywatelki austriackiej, która pracowała jako agentka nieruchomości w sektorze nieruchomości luksusowych w Niemczech, pośrednicząc w sprzedażach głównie zamków i pałaców. Ilonka Sayn-Wittgenstein urodziła się jako Ilonka Kerekes i w wieku

${ }^{1091}$ A. Kustra, Kelsenowski..., s. 292.

1092 Por.: ibidem, s. 293. 
lat 47, podczas pobytu w Niemczech, została adoptowana na podstawie niemieckiego prawa przez Lothara Fürsta von Sayn-Wittgenstein. Od tego czasu chciała być znana jako Ilonka Fürstin von Sayn-Wittgenstein i zarejestrowała się pod tym nazwiskiem w Niemczech i w Austrii. Władze regionalne w Wiedniu (Landeshauptmann von Wien) usunęły jednak z jej nazwiska w prowadzonym przez siebie rejestrze zwrot "Fürstin von". Działanie to było poprzedzone orzeczeniem austriackiego Trybunału Konstytucyjnego (Verfassungsgerichtshof) o niekonstytucyjności przenoszenia zagranicznego tytułu szlacheckiego jako części nazwiska przez obywatela Republiki Austriackiej. Wedle Trybunału nazwiska obywateli austriackich nie mogą zawierać w sobie elementów świadczących o posiadaniu arystokratycznych tytułów, co wynika z konstytucyjnej zasady równości. Zasadzie tej została nadana ranga konstytucyjna poprzez akt parlamentu znany jako Adelsaufhebungsgesetz, co doprowadziło do zakazu używania w Austrii jakichkolwiek austriackich i zagranicznych tytułów arystokratycznych. Pani Ilonka Sayn-Wittgenstein stanęła na stanowisku, że jest to sprzeczne z zasadą swobody przepływu osób, zawartą w art. 21 TFUE ${ }^{1093}$.

Doprowadziło to Sąd Administracyjny (Verwaltungsgerichtshof) do zwrócenia się do TSUE $\mathrm{z}$ wnioskiem $\mathrm{w}$ trybie prejudycjalnym z pytaniem: „Czy art. [21 TFUE] stoi na przeszkodzie uregulowaniu, zgodnie z którym właściwe organy państwa członkowskiego odmawiają uznania nazwiska (dorosłego) przysposobionego - w zakresie, $\mathrm{w}$ jakim zawiera ono niedopuszczalny $\mathrm{z}$ mocy przepisów prawa (konstytucyjnego) tytuł szlachecki - które zostało określone w innym państwie członkowskim?"1094.

Jak widać sprawa znowu nie koncentrowała się wokół kwestii praw człowieka i standardów ich ochrony, co w dużej mierze wynikało ze sposobu sformułowania pytania przez sąd pytający. Tym niemniej, w związku z zakresem zastosowania Karty, opartym na jej art. 51 ust. 1, nie powinno ulegać wątpliwości, że unijne prawa podstawowe mogły mieć w tej sprawie zastosowanie. Warto także w tym kontekście zauważyć, że sprawa została rozstrzygnięta już po uzyskaniu przez Kartę mocy prawnej. Jak zauważa Eleanor Spaventa, pojawienie się instytucji obywatelstwa europejskiego rozszerzyło potencjalną strefę wpływu unijnych praw podstawowych w związku z migracją i poszerzeniem przestrzeni dla zaistnienia elementów transgranicznych. Skoro coraz więcej regulacji mogło być uznanych za ograniczenia praw zagwarantowanych $\mathrm{w}$ traktatach, a więc być uznanych za mające charakter derogacyjny, to coraz większy stawał się również zakres potencjalnego zastosowania unijnych praw podstawowych. Przykładem mogą tu być kwestie związane z nazwiskiem, ta-

1093 TSUE, Ilonka Sayn-Wittgenstein p. Landeshauptmann von Wien, C-208/o9, wyrok z 22 grudnia 2010, pkt 19-34.

1094 Ibidem, pkt 35. 
kie jak te ujawnione w sprawie Sayn-Wittgenstein, lecz nie tylko ${ }^{1095}$. Kontekst praw człowieka nie był w tej sprawie nieistotny. Jak się jednak wydaje, został on przez Trybunał niedoceniony. Tym razem, inaczej niż w sprawie Omega, TSUE nie odwołał się w żadnym wymiarze do doktryny ERT.

Trybunał przelotnie jedynie dostrzegł powiązanie sprawy z prawami człowieka. Jak sam przyznał:

Tytułem wstępu należy zauważyć, że nazwisko osoby jest jednym z elementów składowych jej tożsamości i życia prywatnego, które podlegają ochronie na podstawie art. 7 Karty praw podstawowych Unii Europejskiej oraz art. 8 europejskiej Konwencji praw człowieka i podstawowych wolności. Chociaż art. 8 konwencji nie wymienia w sposób wyraźny nazwiska osoby, odnosi się ono jednak do życia prywatnego i rodzinnego tej osoby, będąc środkiem identyfikacji osobowej i związania z rodziną ${ }^{1096}$.

Na tym spostrzeżeniu, wyrażonym niejako en passant, Trybunał jednak poprzestał i skupił się na zasadzie swobody przepływu osób. Niezwłocznie przeszedł do konstatacji, że: „Uregulowanie krajowe, które stawia w gorszej sytuacji niektórych obywateli danego kraju z tego tylko powodu, że skorzystali oni ze swobody przemieszczania się i pobytu w innym państwie członkowskim, stanowi ograniczenie swobód gwarantowanych przez art. 21 ust. 1 TFUE każdemu obywatelowi Unii"1097.

W sprawie tej na szali znalazła się więc znów jedna z fundamentalnych swobód, jaką tym razem była swoboda przepływu osób i jej ograniczenie przez przepisy prawa krajowego, w tym przypadku Austrii, wynikające ze specyfiki austriackiego porządku konstytucyjnego. TSUE stwierdził wyraźnie, że tego rodzaju ograniczenia, jakie wynikały z prawa austriackiego, stały w sprzeczności z tą swobodą. Opierając się na swoim wcześniejszym orzecznictwie, a także na wnikliwej analizie konsekwencji, jakie wynikały dla Pani Ilonki Sayn-Wittgenstein z niemożności posługiwania się nazwiskiem w wersji, jaka została jej nadana w Niemczech, a więc w innym państwie członkowskim Unii ${ }^{1098}$, TSUE stwierdził, że

odmowa uznania w całości przez władze państwa członkowskiego nazwiska obywatela tego państwa, które zostało określone w innym państwie członkowskim, w którym wspomniany obywatel zamieszkuje, i które to nazwisko przez okres 15 lat było wpisane do akt stanu cywilnego w pierwszym z tych państw członkowskich,

${ }^{1095}$ E. Spaventa, The Interpretation..., s. 23.

1096 TSUE, Ilonka Sayn-Wittgenstein p. Landeshauptmann von Wien, C-208/o9, wyrok z 22 grudnia 2010 , pkt 52.

1097 Ibidem, pkt 53 .

${ }^{1098}$ Ibidem, pkt 54-70. 
stanowi ograniczenia swobód zagwarantowanych wszystkim obywatelom Unii W art. 21 TFUE ${ }^{1099}$.

TSUE oparł się przy tym na znanym z wcześniejszego swego orzecznictwa dotyczącego nazwisk w kontekście prawa unijnego ${ }^{1100}$ teście 'poważnej niedogodności' dla osoby korzystającej z uprawnień wynikających z prawa unijnego. Nie każda bowiem niedogodność związana z regulacjami w danym państwie dotycząca nazwisk w kontekście transgranicznym może być uznana za dyskryminację czy inne naruszenie prawa unijnego, a jedynie niedogodność poważna. Do takiej, zdaniem Trybunału, w sprawie Sayn-Wittgenstein doszło ${ }^{1101}$.

Trybunał dostrzegł jednak przedłożone mu uwagi przez rząd Austrii, poparty również przez rządy niektórych innych państw członkowskich ${ }^{1102}$, oparte na przekonaniu, że

rozpatrywane przepisy mają na celu ochronę tożsamości konstytucyjnej Republiki Austrii. Ustawa o zniesieniu szlachectwa co prawda nie stanowi elementu zasady republiki będącego podstawą konstytucji federalnej, ale stanowi ona podstawową decyzję na korzyść formalnej równości wobec prawa wszystkich obywateli, a żaden obywatel austriacki nie powinien zostać wyszczególniony poprzez użycie dodatku do nazwiska mającego formę przedimka szlacheckiego, tytułu lub honoru, których jedyną funkcją jest wyróżnienie osoby posługującej się nimi i które nie mają żadnego związku z zawodem tej osoby lub jej wykształceniem ${ }^{1103}$.

TSUE, odwołując się wprost do sprawy Omega:

uściślił już w tym względzie, że nie jest niezbędne, aby przepis o charakterze ograniczenia wydany przez organy państwa członkowskiego odpowiadał koncepcji wspólnej dla wszystkich państw członkowskich, jeżeli chodzi o sposoby ochrony określonego prawa podstawowego lub uzasadnionego interesu, oraz że niezbędny i proporcjonalny charakter przepisów przyjętych w określonej dziedzinie nie jest wykluczony tylko z tego powodu, że jedno państwo członkowskie wybrało odmienny system ochrony niż przyjęty przez inne państwo $[\ldots]^{1104}$.

1099 Ibidem, pkt 71.

${ }^{1100}$ Patrz przed.: TSUE, Stefan Grunkin i Dorothee Regina Paul, C-353/o6, wyrok z 14 października 2008.

1101 TSUE, Ilonka Sayn-Wittgenstein p. Landeshauptmann von Wien, C-208/o9, wyrok z 22 grudnia 2010, pkt 67-70.

${ }_{1102}$ Ibidem, pkt $72-80$.

${ }^{1103}$ Ibidem, pkt 74 .

${ }^{1104}$ Ibidem, pkt 91. 
W sprawie Sayn-Wittgenstein możliwość ograniczania skuteczności prawa UE przez regulacje krajowe została bezpośrednio powiązana z art. 4 ust. 2 TUE i obowiązkiem Unii do poszanowania tożsamości narodowej państw członkowskich. Trybunał kontynuował: „Należy również przypomnieć, że zgodnie z art. 4 ust. 2 TUE Unia szanuje tożsamość narodową państw członkowskich, obejmującą również ustrój republikański państwa"1105. To właśnie specyficzne rozumienie republikańskiego charakteru ustroju przez państwo austriackie stało się podstawą ograniczenia swobody przepływu osób w postaci uniemożliwienia Pani Ilonce Fürstin von Sayn-Wittgenstein vel Ilonce Sayn-Wittgenstein (gdyż samego faktu adopcji i zmiany nazwiska ani przepisy, ani władze austriackie nie kwestionowały), która nabyła go w wyniku adopcji w Niemczech, posługiwanie się tytułem arystokratycznym wraz z partykułą "von". Takie rozumienie republikańskości jest specyficzne dla Austrii, choć w dużej mierze podzielane też przez niektóre inne państwa członkowskie. Nie jest jednak powszechnie przyjęte na przestrzeni UE i nie jest charakterystyczne dla wszystkich państw członkowskich. Najlepszym dowodem na brak takiej powszechnej zgody jest sam fakt powstania problemu, w wyniku nadania nazwiska wraz z tytulaturą w jednym z państw członkowskich, jakim były Niemcy. Można w tym miejscu przywołać również przykład Polski i stanowisko w tej materii wyrażone w 1998 r. przez Sąd Najwyższy. W odniesieniu właśnie do kwestii możliwości posługiwania się partykułą „von” stwierdził, że: „W warunkach polskich, podobnie zresztą jak i w innych krajach europejskich, genetycznie ukształtowane nazwisko stanowi podlegające ochronie dobro osobiste [...] i niewątpliwie mieści się ono także w konstytucyjnym pojęciu przyrodzonej i niezbywalnej godności człowieka"1106. Dla dokładności należy wszakże pamiętać, że SN mówił tu o genetycznie ukształtowanym nazwisku, podczas gdy w omawianej sprawie mieliśmy do czynienia z nazwiskiem nabytym w wyniku adopcji i to osoby dorosłej. Z wyroku TSUE nie wynika jednak, aby fakt ten miał znaczenie dla rozstrzygnięcia, choć mógł on osłabić, szczególnie godnościowy, a więc oparty na prawach człowieka, wymiar roszczenia Pani Sayn-Wittgenstein ${ }^{1107}$.

${ }^{1105}$ Ibidem, pkt 92.

${ }^{1106}$ SN, Izba Cywilna, sprawa I CKU 204/97, postanowienie z 4 lutego 1998.

${ }^{1107}$ Niektórzy przedstawiciele doktryny stoją na stanowisku, że okoliczność - jak bezkompromisowo to określają - fałszywości tytułu książęcego miała znaczenie dla sprawy (por. np.: G.N. Toggenburg, Die falsche Fürstin': Zum grenzüberschreitenden Verkehr von Adelstiteln vor dem Hintergrund der Unionsbürgerschaft, "European Law Reporter” 2011, nr 3, s. 74 i nast.), a nawet podają w wątpliwość tożsamościowy charakter tak rozumianej zasady republikanizmu w Austrii, jaka wyłania się z tej sprawy. „Nie jest wykluczone, że wpływ na rozstrzygnięcie mogły mieć okoliczności konkretnej sprawy, które nie zostały przytoczone w uzasadnieniu. Można mieć bowiem wątpliwości, czy rzeczywiście ustawa pochodząca sprzed niemal stu lat i o egzotycznej już treści ma obecnie aż takie znaczenie, aby traktować ją jako część tożsamości konstytucyj- 
Co zasługuje na podkreślenie w kontekście tej pracy, w sprawie tej nie mieliśmy do czynienia z próbą zapewnienia przez Austrię wyższego standardu ochrony jakiegoś prawa czy wolności niż miałoby to miejsce na gruncie prawa unijnego, z czego wynikałby konflikt z prawem unijnym, tak jak miało to miejsce w sprawie Omega, a przynajmniej nie mieliśmy z nim do czynienia aż tak otwarcie. Jak zwrócił uwagę L.F.M. Besselink:

składniki konstytucyjnej tożsamości państwa członkowskiego, które mają być poszanowane nie muszą koniecznie dotyczyć praw podstawowych. Powołanie się zatem na obowiązek poszanowania tożsamości konstytucyjnej państwa członkowskiego wcale nie musi służyć interesowi ochrony prawa obywatela; może dotyczyć również ograniczeń praw obywateli. Jest to wyraźnie widoczne w sprawie Sayn-Wittgenstein, w której republikańska tożsamość Austrii była powodem do ograniczenia obywatelskiego prawa do swobody przepływu osób, tak samo jak osoba, której sprawa dotyczyła ograniczona była w prawie posługiwania się w Austrii tytułem szlacheckim, którym mogła posługiwać się w Niemczech ${ }^{1108}$.

Można jednak z drugiej strony zauważyć, że republikański charakter państwa, co mocno podkreślało stanowisko władz austriackich, powiązany jest z zasadą równości, posuniętą tak daleko, że uniemożliwiającą noszenie tytułów, nawet jeśli sprowadzałoby się to jedynie do brzmienia nazwiska. Trochę poszerza to prawnoczłowieczy kontekst tej sprawy. Tego rodzaju rozważania się jednak na gruncie wyroku w sprawie Sayn-Wittgenstein nie pojawiły.

Z drugiej strony można zauważyć, że na gruncie sprawy Omega też niekoniecznie mieliśmy do czynienia jedynie z ochroną wyższego standardu ochrony godności człowieka. Zakaz gier laser tag ograniczał bowiem możliwość korzystania z innych praw i wolności, jak choćby z wolności prowadzenia działalności gospodarczej czy po prostu z wolności tych osób, które chciałyby skorzystać z możliwości wzięcia udziału w grze. Jest to jednak ogólniejszy problem, związany z tym, że często wyższy poziom ochrony danego prawa czy wolności człowieka wiąże się z dalej idącym ograniczeniem innego prawa czy wolności, co wynika z charakteru praw człowieka, korzystanie z których w naturalny sposób poddawane musi być pewnym ograniczeniom ze względu na prawa i wolności innych. Dodatkowa komplikacja wiąże się z charakterem unijnych swobód, z których każda może być powiązana z wieloma klasycznymi prawami i wolnościami jednostki i wyrażona za ich pomocą. Nie wchodząc w szczegółowe rozważania dotyczące powyższych kwestii, można jednak zaryzykować obser-

nej Austrii" (S. Biernat, Kontrowersje dotyczace nazwisk a prawo Unii Europejskiej, [w:] A. Matlak, S. Stanisławska-Kloc (red.), Spory o własność intelektualna: księga jubileuszowa dedykowana profesorom Januszowi Barcie i Ryszardowi Markiewiczowi, Warszawa 2013, s. 75).

${ }^{1108}$ L.F.M. Besselink, The Protection..., s. 7 (tłum. własne). 
wację, że obowiązek poszanowania tożsamości konstytucyjnej może wiązać się z pewnym poszerzeniem swobody państw nie tyle w zapewnianiu takiego czy innego poziomu ochrony konkretnych praw czy wolności człowieka, lecz do pewnej swobody w ważeniu możliwości korzystania z nich. Być może więc, choć za wcześnie tu na jednoznaczne wnioski, obowiązek poszanowania przez Unię tożsamości konstytucyjnej państw członkowskich może w jakimś stopniu otwierać orzecznictwo unijne na wypracowanie podobnego mechanizmu, jakim na gruncie Konwencji jest doktryna marginesu swobody oceny ${ }^{1109}$.

Wracając do sprawy Sayn-Wittgenstein, to wydaje się, że na szczególne podkreślenie z perspektywy tej pracy zasługuje wniosek, że konstytucyjne elementy tożsamości narodowej, które państwo członkowskie do niej zalicza, nawet jeśli nie mają oczywistego charakteru i głęboko zakorzenione są w specyfice tego państwa, to moga prowadzić do ograniczenia w pewnym zakresie pierwszeństwa, jedności i efektywności prawa Unii, a przynajmniej ograniczenia unijnych swobód traktatowych na terenie danego państwa członkowskiego w zakresie niezgodnym z tożsamością konstytucyjną tego państwa ${ }^{1110}$.

W sprawie tej ponownie doszło do pewnej analogii w stosowaniu klauzuli tożsamości konstytucyjnej do klauzuli porządku publicznego. TSUE nie wykorzystał tej sprawy do szerszego rozwinięcia rozumienia pojęcia tożsamości konstytucyjnej i obowiązku jej poszanowania, jaki ciąży na Unii. Zauważył jedynie,

${ }_{109}$ Por. np.: A. Edenharter, Fundamental Rights Protection In The Eu: The ECJ's Difficult Mission To Strike A Balance Between Uniformity And Diversity, „Italian Journal of Public Law” 2018, nr 10 (2); więcej na temat koncepcji marginesu oceny w orzecznictwie ETPCz - patrz np.: A. Wiśniewski, Koncepcja marginesu oceny w orzecznictwie Europejskiego Trybunału Praw Człowieka, Gdańsk 20o8; więcej na temat marginesu oceny w różnych międzynarodowych systemach ochrony praw człowieka - patrz np.: Ł. Gruszczyński, W. Werner (red.), Deference in International Courts and Tribunals: Standard of Review and Margin of Appreciation, Oxford 2014; A. Legg, The Margin of Appreciation in International Human Rights Law: Deference and Proportionality, Oxford 2012.

${ }^{1110}$ Czym innym jest pytanie, czy tożsamość konstytucyjna mogłaby prowadzić do obniżenia minimalnego standardu ochrony praw podstawowych przewidzianych przez prawo unijne, co również nie jest problemem czysto hipotetycznym (przykłady standardów praw chronionych $\mathrm{w}$ krajowych systemach prawnych na niższym poziomie niż w Unii - patrz np.: L.F.M. Besselink, The Protection..., s. 5). Pytanie to pozostaje jednak poza zakresem zainteresowania tej pracy, która nie ma na celu analizy całej złożoności pojęcia tożsamości konstytucyjnej państw członkowskich i jej skutków w ramach obowiązku jej poszanowania przez Unię. Na aktualnym etapie rozwoju orzecznictwa TSUE wydaje się, że nie można wykluczyć tego, aby obowiązek poszanowania przez Unię tożsamości konstytucyjnej państw członkowskich mógł prowadzić również do obniżenia minimalnego standardu ochrony praw podstawowych przewidzianych przez prawo unijne. Tym niemniej już teraz, w obliczu tego, o czym jest mowa w tym rozdziale, a co przemawia za szczególnym statusem wyższego niż unijny standardu ochrony praw człowieka w porządku krajowym, ewentualne powoływanie się na tożsamość w celu obniżenia unijnego standardu ochrony byłoby, jeśli nie niemożliwe, to znacznie trudniejsze i zapewne wiązać by się musiało ze znacznie bardziej rozbudowanym uzasadnieniem ze strony sądu konstytucyjnego, szczególnie w kontekście zasady proporcjonalności. 
że tożsamość ta musi być szanowana i że jej elementem może być republikański charakter państwa, czy raczej szczególny sposób podejścia do zasady równości.

Niemniej jednak osią swego rozumowania uczynił nie bezpośrednio tożsamość narodowa, ale kwestię czy interes państwa może być uzasadniony w świetle pojęcia porządku publicznego, analizowanego we wcześniejszym orzecznictwie oraz czy związany jest z realizacją zasady równości, będącej jednocześnie przestrzeganą w Unii zasadą ogólną prawa oraz podstawowym celem konstytucyjnym państwa ${ }^{1111}$.

Tożsamość konstytucyjna znowu była więc argumentem niejako dodatkowym - wzmacniającym żądanie państwa oparte na ochronie jego porządku publicznego.

Na koniec trzeba również podkreślić, podobne jak w sprawie Omega, odniesienie się w wyroku w sprawie Sayn-Wittgenstein przez Trybunał do zasady proporcjonalności. TSUE wyraźnie stara się, choć nie bez pewnej rezerwy, podkreślać swą kompetencję do ograniczonej możliwości kontroli, jeśli nie nad samym zakresem tego, co państwa zaliczają do swej tożsamości konstytucyjnej, to nad testem proporcjonalności wartości w ten sposób chronionych wobec wartości ograniczanych, przynajmniej w odniesieniu do jednego $\mathrm{z}$ fundamentalnych elementów tego testu, jakim jest wymóg konieczności ${ }^{1112}$. Jak nadmienił w wyroku w tej sprawie TSUE: „Zdaje się, że odmawiając uznania elementów szlacheckich nazwiska takiego jak nazwisko skarżącej w postępowaniu przed sądem odsyłającym, władze austriackie właściwe w zakresie stanu cywilnego nie wykroczyły poza to, co jest niezbędne dla zapewnienia realizacji podstawowego celu konstytucyjnego, do którego dążą"1113.

\subsubsection{Sprawa Runevič-Vardyn}

Sprawa ta jest kolejnym przykładem bezpośredniego i pogłębionego odniesienia się przez TSUE do obowiązku poszanowania przez Unię tożsamości konstytucyjnej państw członkowskich. Sprawa dotyczyła sporu Pani Malgožaty Runevič-Vardyn vel Małgorzaty Runiewicz-Wardyn oraz jej małżonka Pana Łukasza Pawła Wardyna, z których ta pierwsza była obywatelską litewską, a ten drugi obywatelem polskim, z Urzędem Miasta Wilna, a konkretnie wydzia-

${ }^{1111}$ K. Wójtowicz, Sądy konstytucyjne..., s. 122.

1112 Więcej na temat zasady proporcjonalności i składających się na nią elementów - patrz np.: A. Stępkowski, Zasada proporcjonalności w europejskiej kulturze prawnej. Sądowa kontrola władzy dyskrecjonalnej w nowoczesnej Europie, Warszawa 2010.

1113 TSUE, Ilonka Sayn-Wittgenstein p. Landeshauptmann von Wien, C-208/o9, wyrok z 22 grudnia 2010, pkt 93 . 
łem rejestracji stanu cywilnego departamentu prawnego tego urzędu i innymi instytucjami litewskimi. Spór dotyczył odmowy zmiany nazwisk i imion skarżących w postępowaniu przed sądem krajowym figurujących w wydanych im aktach stanu cywilnego ${ }^{1114}$. Malgožata Runevič-Vardyn, urodzona w Wilnie, powołująca się na fakt przynależności do mniejszości polskiej, choć nieposiadająca polskiego obywatelstwa, domagała się uwzględnienia w dokumentach litewskich właściwej jej zdaniem, a więc zgodnej z zasadami polskiej pisowni, wersji jej imienia i nazwiska. Litewskie władze i sądy odmawiały jej tego ${ }^{1115}$ ze względu na zawarty w konstytucji tego państwa przepis stanowiący, że na Litwie językiem urzędowym jest język litewski, i na przepisy kodeksu cywilnego oraz regulujące akta stanu cywilnego i dotyczące dowodów osobistych i paszportów ${ }^{1116}$, a także na orzecznictwo litewskiego Sądu Najwyższego i Trybunału Konstytucyjnego w sprawie pisowni imion i nazwisk w paszportach obywateli litewskich. Stwierdziły, że imię i nazwisko osoby należy wpisywać w paszporcie zgodnie z regułami pisowni języka urzędowego, aby nie doszło do zakwestionowania konstytucyjnego statusu tego języka ${ }^{1117}$. Doprowadziło to wileński sąd (Vilniaus miesto 1 apylinkés teismas) do zadania serii pytań dotyczących interpretacji przepisów TFUE dotyczących zagwarantowanej w jego art. 21 swobody przemieszczania się, a także wynikającego z art. 18 zakazu dyskryminacji ze względu na przynależność państwową oraz przepisów dyrektywy dotyczącej zasady równego traktowania osób bez względu na pochodzenie rasowe lub etniczne ${ }^{1118}$. Ta ostatnia nie znalazła w sprawie zastosowania, jako nieobejmująca swoim zakresem uregulowań krajowych przewidujących, że imiona i nazwiska mogą być zapisywane w aktach stanu cywilnego tego państwa wyłącznie $\mathrm{w}$ formie zachowującej reguły pisowni języka urzędowego ${ }^{1119}$. Wszystkie pytania sformułowane przez sąd odsyłający dotyczyły tego, czy prawo unijne wyklucza, aby regulacje krajowe dopuszczały zapis imion i nazwisk $\mathrm{w}$ dokumentach jedynie zgodnie z zasadami pisowni języka tego państwa ${ }^{1120}$. Gdy chodzi o pytania dotyczące art. 18 i 21 TFUE, TSUE stwierdził, że sytuacja jest objęta prawem Unii, mimo że pierwszy z aktów stanu cywilnego,

1114 TSUE, Malgožata Runevič-Vardyn i Łukasz Paweł Wardyn p. Vilniaus miesto savivaldybès administracija i inni, C-391/o9, wyrok z 12 maja 2011.

1115 Ibidem, pkt 15 i nast.

1116 Ibidem, pkt 7-14.

1117 Ibidem, pkt 27.

${ }^{1118}$ Dyrektywa Rady 2000/43/WE z 29 czerwca 2000 wprowadzająca w życie zasadę równego traktowania osób bez względu na pochodzenie rasowe lub etniczne, Dz.Urz. L 18o z 19 lipca 2000.

1119 TSUE, Malgožata Runevič-Vardyn i Łukasz Paweł Wardyn p. Vilniaus miesto savivaldybès administracija i inni, C-391/o9, wyrok z 12 maja 2011, pkt 36-48.

${ }^{1120}$ Ibidem, pkt 28. 
w którym sprostowania pisowni domagała się skarżąca, stanowiący podstawę całego sporu, który był jej aktem urodzenia z 1977 r., pochodził z okresu znacznie przed przystąpieniem Litwy do Unii, oraz że jak twierdził rząd litewski, jest to sprawa wewnętrzna ${ }^{1121}$. Trybunał odrzucił te argumenty ze względu na to, że żądanie skarżącej nie dotyczyło uznania uprawnień wywodzonych z prawa Unii, które miałyby zostać nabyte przed przystąpieniem Republiki Litewskiej do Unii i wejściem w życie względem niej postanowień dotyczących obywatelstwa Unii, ale aktualnego traktowania obywatela Unii w sposób dyskryminacyjny lub aktualnego ograniczenia jego uprawnień wyprowadzanych z prawa Unii. Trybunał dostrzegł, że skarżąca w postępowaniu przed sądem krajowym nie żąda bowiem zmiany jej aktu urodzenia z mocą wsteczna, lecz by w celu ułatwienia jej swobodnego przemieszczania się jako obywatelki Unii - skarżąca po zawarciu małżeństwa z obywatelem polskim zamieszkała w Belgii, gdzie urodziła syna, który posiada podwójne obywatelstwo litewskie i polskie - właściwe władze litewskie wydały jej świadectwo urodzenia, w którym jej nazwisko panieńskie i imię będą zapisane $\mathrm{w}$ formie zachowującej reguły pisowni polskiej ${ }^{1122}$. Jeśli chodzi o zarzut wewnętrznego charakteru sprawy, TSUE podkreślił, że skarżąca skorzystała z prawa do swobodnego przemieszczania się i przebywania przyznanego jej bezpośrednio w art. 21 TFUE i wnosi o zmianę tych akt $w$ celu ułatwienia jej wykonywania tego prawa ${ }^{1123}$. Trybunał podkreślił także silnie powiązanie sprawy z art. 20 TFUE dotyczącym obywatelstwa Unii i wynikającymi stąd konsekwencjami, szczególnie związanymi z obowiązkiem równego traktowania wszystkich obywateli Unii ${ }^{1124}$. TSUE zaznaczył, że: „Do sytuacji objętych zakresem stosowania ratione materiae prawa Unii należą sytuacje związane z korzystaniem z podstawowych swobód zagwarantowanych przez traktat, w szczególności w zakresie swobody przemieszczania się i przebywania na terytorium państw członkowskich przyznanej w art. 21 TFUE"1125.

Trybunał przyznał, że na obecnym etapie rozwoju prawa Unii przepisy regulujące zapis nazwiska i imienia $w$ aktach stanu cywilnego należą do kompetencji państw członkowskich. Podkreślił jednak, że państwa są „zobowiązane do wykonywania omawianej kompetencji zgodnie z prawem Unii, a w szczególności z postanowieniami traktatu dotyczącymi przyznanej każdemu obywatelowi Unii swobody przemieszczania się i pobytu na terytorium państw członkowskich"1126. Skoro osoby z niej skorzystały (ślub w Polsce, zamieszki-

\footnotetext{
${ }^{1121}$ Ibidem, pkt 52.

1122 Ibidem, pkt 53-54.

${ }^{1123}$ Ibidem, pkt 58 .

1124 Ibidem, pkt 59-61.

${ }^{1125}$ Ibidem, pkt 62.

1126 Ibidem, pkt 63.
} 
wanie w Belgii) ${ }^{1127}$, Trybunał postanowił zbadać w świetle art. 21 TFUE odmowę zmiany przez władze państwa członkowskiego akt stanu cywilnego ${ }^{1128}$. W sprawie tej znowu więc w centrum uwagi znalazła się jedna z unijnych swobód oraz jej właściwa interpretacja w kontekście uregulowań krajowych i tego, czy stanowią one jej ograniczenie, czy nie.

Sprawa znowu związana była z nazwiskiem. TSUE ponownie dostrzegł jedynie zdawkowo prawnoczłowieczy wymiar tej sprawy. Podkreślił, że:

imię i nazwisko osoby jest jednym z elementów składowych jej tożsamości i życia prywatnego, które podlegają ochronie na podstawie art. 7 Karty praw podstawowych Unii Europejskiej oraz art. 8 europejskiej Konwencji o ochronie praw człowieka i podstawowych wolności sporządzonej w Rzymie dnia 4 listopada 1950 r. Chociaż art. 8 konwencji nie mówi o tym wyraźnie, imię i nazwisko odnoszą się jednak do życia prywatnego i rodzinnego osoby, będąc środkiem identyfikacji osobowej i związania $\mathrm{z}$ rodziną ${ }^{1129}$.

Podobnie jak miało to miejsce na gruncie sprawy Sayn-Wittgenstein Trybunał na tym poprzestał i nie zdecydował się na rozstrzyganie tej sprawy na gruncie przepisów gwarantujących prawa człowieka. Podobnie jak zostało to zauważone przy okazji omawiania sprawy Sayn-Wittgenstein, również i tym razem, skoro TSUE stwierdzil, że sprawa ma charakter unijny i wiąże się z uprawnieniami obywateli Unii wynikającymi z unijnego prawa pierwotnego, a konkretnie swobodą przemieszczania się i ewentualnych od niej odstępstw, to znajdują do niej zastosowanie unijne prawa podstawowe, w tym art. 7 Karty. Skoro regulacje krajowe mieściły się w zakresie prawa Unii, TSUE mógł dokonać rekonstrukcji unijnego standardu zagwarantowanego w art. 7 Karty prawa do poszanowania życia prywatnego i rodzinnego i oceny regulacji krajowych przez pryzmat zgodności z nim oraz tego, czy ograniczenia przez nie wprowadzane spełniają wymogi minimalnej ochrony tego prawa przewidzianej przez prawo unijne, a jeśli nie, to czy przekroczenie tego minimalnego standardu może być w jakiś sposób na gruncie prawa unijnego uzasadnione. Takie podejście do sprawy musiałoby jednak wiązać się z dość daleko idącym zmodyfikowaniem pytań skierowanych przez sąd odsyłający, do czego TSUE mógł nie być jeszcze gotowy i co musiałoby się wiązać z silnym uzasadnieniem. Byłoby to też kłopotliwe w obliczu wspominanego wyroku TSUE w sprawie Pelckmans ${ }^{1130}$, jeśli przyjęte w nim rozumowanie miałoby w kategoriach ogólnych oznaczać,

${ }^{1127}$ Ibidem, pkt 64.

${ }^{1128}$ Ibidem, pkt 65.

1129 Ibidem, pkt 66.

1130 TSUE, Pelckmans Turnhout NV p. Walter Van Gastel Balen NV i inni, C-483/12, wyrok z 8 maja 2014 . 
że środki krajowe, które w obliczu rozumienia derogacji od unijnych swobód, jakie wynika z prawa unijnego, nie mogą być za takie uznane, nie są przejawem stosowania prawa unijnego $\mathrm{w}$ rozumieniu art. 51 ust. 1 Karty.

Trybunał skupił się więc na analizie sprawy z perspektywy art. 21 TFUE i swobody przemieszczania się. Opierając się na wyroku w sprawie Sayn-Wittgenstein stwierdził, że można by mówić o jej ograniczeniu tylko wtedy, gdyby oparta na przepisach krajowych "odmowa zmiany wspólnego nazwiska skarżących w postępowaniu przed sądem krajowym na podstawie rozpatrywanego uregulowania krajowego (...) [miała - przyp. aut.] charakter powodujący dla zainteresowanych "poważne niedogodności« na płaszczyźnie administracyjnej, zawodowej i prywatnej"1131. Ocenę czy tak w danej sprawie jest, czy nie, pozostawił co do zasady sądom krajowym ${ }^{1132}$. Sam zauważył jednak, że na gruncie tej sprawy niedogodności związane z transkrypcją miały charakter znikomy, a zaistnienie $\mathrm{w}$ związku tym poważnych niedogodności w korzystaniu z uprawnień wynikających z art. 21 TFUE jest mało prawdopodobne ${ }^{1133}$. Doprowadziło to Trybunał do wniosku, że:

w sytuacji takiej jak ta, której dotyczy postępowanie przed sądem krajowym, nie stanowi ograniczenia swobód przyznanych $w$ art. 21 TFUE każdemu obywatelowi Unii odmowa dokonania przez właściwe władze państwa członkowskiego, na podstawie mającego zastosowanie uregulowania krajowego, zmiany aktu małżeństwa obywatela Unii pochodzącego z innego państwa członkowskiego w taki sposób, by imiona tego obywatela były zapisane $\mathrm{w}$ tym akcie ze znakami diakrytycznymi, tak jak zostały one zapisane $\mathrm{w}$ aktach stanu cywilnego wydanych przez jego państwo członkowskie pochodzenia, i w formie zachowującej reguły pisowni języka urzędowego tego ostatniego państwa ${ }^{1134}$.

Odpowiadając na postawione przez sąd odsyłający pytania, TSUE stwierdził, że rozumienie zasady swobody przepływu osób nie stoi na przeszkodzie dopuszczalności odmowy przez władze krajowe na podstawie krajowych przepisów, zapisu czy też zmiany zapisu nazwiska w formie innej, niż wynikająca z zasad języka urzędowego ${ }^{1135}$.

Uczynił to, mocno podkreślając kontekst i sytuację w tej konkretnej sprawie. Ponadto, czego znaczenie wydaje się istotne z perspektywy tezy stawianej

${ }^{1131}$ TSUE, Malgožata Runevič-Vardyn i Łukasz Paweł Wardyn p. Vilniaus miesto savivaldybès administracija i inni, C-391/o9, wyrok z 12 maja 2011, pkt 76.

${ }^{1132}$ Ibidem, pkt 77-78.

${ }^{1133}$ Ibidem, pkt 79-81.

1134 Ibidem, pkt 82; wniosek ten Trybunał podał jednak później w pewną wątpliwość (ibidem, pkt 92-93).

${ }^{1135}$ Ibidem, pkt 94. 
w tej pracy, uczynił to, podkreślając swobodę sądów krajowych co do oceny powagi niedogodności. Choć, jak się wydaje, dla tej sprawy nie miało to znaczenia, TSUE zdecydował się przypomnieć, że gdyby jednak "sąd krajowy stwierdzil, że odmowa zmiany wspólnego nazwiska skarżących w postępowaniu przed sądem krajowym stanowi ograniczenie w rozumieniu art. 21 TFUE, (...) [to przyp. aut.] zgodnie z utrwalonym orzecznictwem ograniczenie w swobodnym przepływie osób może być uzasadnione jedynie wtedy, gdy jest oparte na obiektywnych względach i proporcjonalne do uzasadnionego celu realizowanego przez prawo krajowe"1136. W sprawie Runevič-Vardyn w ogóle nie mieliśmy więc zdaniem trybunału luksemburskiego sytuacji ograniczenia żadnej z unijnych swobód traktatowych, gdyż środki krajowe nie urosły do poziomu poważnych niedogodności. Tylko gdyby tak było, mogłyby zostać uznane za ograniczenie swobody. Gdyby jednak do takiego ograniczenia miało dojść, TSUE podtrzymał swe wcześniejsze warunki co do jej dopuszczalności.

W kontekście wymogu proporcjonalności trybunał luksemburski zdecydował się też odnieść do kwestii poszanowania tożsamości konstytucyjnej. Przywołał wyrażane w sprawie stanowisko kilku rządów, które twierdziły, że

zasadne jest, by państwo członkowskie czuwało nad ochroną języka urzędowego w celu zachowania jedności narodowej i spójności społecznej. Rząd litewski podkreśla w szczególności, że język litewski stanowi wartość konstytucyjną, która chroni tożsamość narodową, przyczynia się do integracji obywateli, zapewnia wyrażenie suwerenności narodowej, niepodzielność państwa oraz prawidłowe funkcjonowanie służb państwowych i samorządowych ${ }^{1137}$.

TSUE przypomniał także, co w kontekście tożsamości narodowej państw członkowskich zauważył już dawno w sprawie Groener ${ }^{1138}$, o której będzie jeszcze krótko mowa, że prawo Unii nie stoi na „przeszkodzie przyjęciu polityki, która ma na celu ochronę i promocję języka państwa członkowskiego, który jest jednocześnie językiem państwowym i pierwszym językiem urzędowym"1139. Przypomniał też jednym tchem grupę różnych regulacji mniej lub bardziej związanych ze sprawą: "Zgodnie z art. 3 ust. 3 akapit czwarty TUE oraz art. 22 Karty praw podstawowych Unii Europejskiej Unia szanuje bowiem różnorodność kulturową i językową. Zgodnie z art. 4 ust. 2 TUE Unia szanuje tożsamość narodową jej państw członkowskich, do której należy rów-

${ }^{1136}$ Ibidem, pkt 83.

${ }^{1137}$ Ibidem, pkt 84 .

1138 TSUE, Anita Groener p. Minister Edukacji i City of Dublin Vocational Education Committee, C-379/87, wyrok z 28 listopada 1989.

1139 TSUE, Malgožata Runevič-Vardyn i Łukasz Paweł Wardyn p. Vilniaus miesto savivaldybès administracija i inni, C-391/o9, wyrok z 12 maja 2011, pkt 85 . 
nież ochrona języka urzędowego"1140. Zaraz potem TSUE stwierdził, że nawet gdyby uznać środek taki jak ten wprowadzony w tej sprawie, realizujący „cel ochrony języka urzędowego poprzez wprowadzenie wymogu stosowania reguł pisowni przewidzianych w owym języku"1141, za ograniczający swobodę przewidzianą $w$ art. 21 TFUE, to wcale nie musiałby być on uznany za niedopuszczalny na gruncie tego przepisu i mógłby „być uwzględniony przy wyważaniu między uzasadnionymi interesami a [...] prawami przyznanymi w prawie Unii"1142. Oczywiście, podobnie jak podkreślił to już w sprawie Sayn-Wittgenstein, przy zachowaniu kryterium proporcjonalności ${ }^{143}$. Zaraz potem, znowu jakby mimochodem, Trybunał powtórzył raz jeszcze, że "nazwisko osoby jest jednym z elementów składowych jej tożsamości i życia prywatnego, które podlegają ochronie na podstawie art. 7 Karty praw podstawowych Unii Europejskiej oraz art. 8 europejskiej Konwencji praw człowieka i podstawowych wolności"1144. Ta część wywodu TSUE ma mocno nieuporządkowany charakter ${ }^{145}$.

Mimo to na podkreślenie zasługuje szczególnie w kontekście obserwacji poczynionej już na gruncie sprawy Sayn-Wittgenstein, że jeśliby przeformułować nieco problem i oderwać go od perspektywy swobód traktatowych, spór w sprawie mógłby być wyrażony przez stojące z sobą w pewnym konflikcie, co zresztą jest dla norm gwarantujących prawa człowieka charakterystyczne i co w sposób nieunikniony prowadzi do konieczności ich balansowania, prawa człowieka. Chodzi po pierwsze o prawo zagwarantowane $\mathrm{w}$ art. 7 i o prawo zagwarantowane w art. 22 KPP. O ile w sprawie Sayn-Wittgenstein brak nawet takiej sugestii, o tyle tym razem tak bliskie wymienienie tych norm koło siebie, w części wyroku, która ma wyraźnie charakter obiter dicta, może sugerować, że TSUE dopuszcza taką ewentualność, że pewien zakres balansowania, a co za tym idzie określanie minimalnych i maksymalnych (co z perspektywy tezy stawianej w tej pracy szczególnie istotne) standardów ochrony poszczególnych praw człowieka, nawet w zakresie zastosowania prawa unijnego, może być modyfikowany, opierając się na obowiązku poszanowania tożsamości konstytucyjnej państw członkowskich. Jak zauważył TSUE:

${ }_{1140}$ Ibidem, pkt 86.
${ }^{1141}$ Ibidem, pkt 87.
${ }_{1142}$ Ibidem, pkt 87.
${ }^{1143}$ Ibidem, pkt 88.
${ }^{1144}$ Ibidem, pkt 89.

${ }^{1145}$ Sytuacja, w jakiej TSUE zdecydował się na tego rodzaju rozważania, kiedy nie było to konieczne z perspektywy sprawy, a także to, że poczynił je, na pierwszy rzut oka, w dość chaotyczny sposób, nie powinno umknąć uwadze. Obie te okoliczności powinny wpływać nie tyle na krytyczną ocenę wyroku, lecz pozostawiać miejsce na jego odważną interpretację, która nie tylko nie jest sprzeczna z tezą formułowaną w tej pracy, co wręcz ją wzmacnia. 
Jeżeli zostanie wykazane, że odmowa zmiany wspólnego nazwiska pary obywateli Unii, których dotyczy postępowanie przed sądem krajowym, powoduje poważne niedogodności na płaszczyźnie administracyjnej, zawodowej i prywatnej dla nich i dla ich rodziny, do sądu krajowego należeć będzie ustalenie, czy odmowa taka szanuje słuszną równowagę występujących tu interesów, a mianowicie z jednej strony prawo skarżących w postępowaniu przed sądem krajowym do poszanowania ich życia prywatnego i rodzinnego, a z drugiej strony uzasadnioną ochronę przez dane państwo członkowskie jego języka urzędowego i jego tradycji ${ }^{1146}$.

W przypadku wątpliwości co do tej oceny ${ }^{1147}$ mogłyby one stać się podstawą do kolejnego pytania prejudycjalnego, już o innym i znacznie bardziej fundamentalnym znaczeniu, możliwe, że również z udziałem pośrednim lub bezpośrednim właściwszych do takich bardziej ustrojowych rozważań instytucji, takich jak sąd konstytucyjny - a więc być może nawet do pytania prejudycjalnego, którego sformułowanie oparte byłoby na mechanizmie podobnym do tego, którego propozycja zarysowywana jest w tej pracy.

\subsubsection{Sprawa Las}

Do obowiązku poszanowania tożsamości narodowej państw członkowskich TSUE odniósł się również w sprawie Las ${ }^{1148}$. Sprawa ta dotyczyła wykładni art. 45 TFUE, gwarantującego swobodę przepływu pracowników w związku ze sporem między Panem Lasem a jego byłym pracodawca, spółką PSA Antwerp $\mathrm{NV}$, w przedmiocie wypłacenia mu dwu różnych odpraw i ich łącznej wysokości $\mathrm{w}$ następstwie rozwiązania $\mathrm{z}$ nim stosunku pracy w trybie natychmiastowym. Spór wynikał z faktu, że paragrafy umowy dotyczące rozwiązania stosunku pracy nie były sporządzone w języku niderlandzkim i w związku z tym, jak zarzucał skarżący, były

one dotknięte nieważnością zgodnie z sankcją przewidzianą w art. 1o dekretu w sprawie używania języków, skoro PSA Antwerp jest przedsiębiorstwem, którego miejsce prowadzenia działalności znajduje się w regionie obowiązywania języka niderlandzkiego Królestwa Belgii. Doradca prawny A. Lasa wywnioskował z tego, że strony nie są z tego względu związane postanowieniami art. 8 umowy o pracę i że A. Las jest uprawniony do żądania wyższej odprawy od swojego byłego pra$\operatorname{codawcy}^{1149}$.

1146 TSUE, Malgožata Runevič-Vardyn i Łukasz Paweł Wardyn p. Vilniaus miesto savivaldybès administracija i inni, C-391/o9, wyrok z 12 maja 2011, pkt 91.

1147 Ibidem, pkt 92-93.

${ }^{1148}$ TSUE, Anton Las p. PSA Antwerp NV, C-202/11, wyrok z 16 kwietnia 2013.

1149 Ibidem, pkt 11. 
Spór ten doprowadził sąd rozstrzygający sprawę do skierowania do TSUE pytania, czy:

[dekret w sprawie używania języków] narusza art. [45 TFUE] dotyczący swobodnego przepływu pracowników w Unii Europejskiej w zakresie, w jakim nakazuje, pod sankcją nieważności, każdemu przedsiębiorstwu, którego siedziba znajduje się $w$ regionie obowiązywania języka niderlandzkiego, redagowanie w tym języku wszystkich dokumentów dotyczących stosunku pracy, gdy zatrudnia pracownika na stanowisku o charakterze międzynarodowym? ${ }^{1150}$.

Trybunał przypomniał na wstępie, że „przepisy prawa Unii nie stoją na przeszkodzie przyjęciu polityki, która ma na celu ochronę i wspieranie języka urzędowego lub języków urzędowych danego państwa członkowskiego"1151. TSUE podkreślił, że: „Zgodnie z art. 3 ust. 3 akapit czwarty TUE oraz art. 22 Karty praw podstawowych Unii Europejskiej Unia szanuje bowiem różnorodność kulturową i językową. Zgodnie z art. 4 ust. 2 TUE Unia szanuje także tożsamość narodową jej państw członkowskich, do której należy również ochrona języka urzędowego lub języków urzędowych tych państw"1152. TSUE więc znowu, choć nie miało to większego znaczenia dla sprawy, podkreślił związek obowiązku poszanowania tożsamości konstytucyjnej z prawami podstawowymi.

Co ważniejsze, sprawa ta stanowi kolejny przejaw tendencji traktowania obowiązku poszanowania przez Unię tożsamości konstytucyjnej państw członkowskich jako jednej z okoliczności, która może być uznana za dopuszczalne uzasadnienie derogacji od unijnych swobód. Jak podkreślił Trybunał: "cel zakładający popieranie i stymulowanie używania języka niderlandzkiego, który jest jednym z języków urzędowych Królestwa Belgii, stanowi słuszny interes mogący uzasadniać w zasadzie ograniczenie zobowiązań nałożonych przez art. 45 TFUE"1153. Nie jest jednak jedynym takim celem. Rząd belgijski wskazał też inne cele, takie jak ochrona socjalna pracowników i ułatwienia kontroli administracyjnych z tym związanych. Jak podkreślił Trybunał - „miał już okazję uznać, że zaliczają się one do nadrzędnych względów interesu ogólnego mogących uzasadniać ograniczenie wykonywania podstawowych swobód zagwarantowanych przez traktat" ${ }^{\prime \prime 154}$. Znowu więc tożsamość konstytucyjna nie została przez TSUE potraktowana wyjątkowo, lecz jako jedna

1150 Ibidem, pkt 15 .

${ }^{1151}$ Ibidem, pkt 25.

1152 Ibidem, pkt 26.

${ }^{1153}$ Ibidem, pkt 27; por. zgoła odmienne stanowisko Rzecznika Generalnego w tej sprawie: TSUE, Anton Las p. PSA Antwerp NV, C-202/11, opinia Rzecznika Generalnego Niila Jääskinena przedstawiona w dniu 12 lipca 2012, pkt 58-61.

1154 TSUE, Anton Las p. PSA Antwerp NV, C-202/11, wyrok z dnia 16 kwietnia 2013, pkt 28. 
z dopuszczalnych racji stojących za ograniczeniami swobody przepływu pracowników.

Zgodnie więc z przyjętym wcześniej modus operandi, Trybunałowi pozostało jedynie ocenić, czy środki krajowe spełniają kryteria proporcjonalności, a więc ograniczenia tej swobody jedynie w stopniu ściśle koniecznym do osiągnięcia zamierzonych celów ${ }^{1155}$. Zdaniem Trybunału sankcja nieważności umowy nie jest konieczna dla osiągnięcia uprawnionych celów ${ }^{1156}$, w związku z czym na postawione przez sąd odsyłający pytanie, odpowiedział, że:

art. 45 TFUE należy interpretować w ten sposób, że stoi on na przeszkodzie uregulowaniu jednostki sfederowanej państwa członkowskiego [...], nakładającemu na każdego pracodawcę, którego miejsce prowadzenia działalności znajduje się na terytorium tej jednostki, obowiązek sporządzania umów o pracę o charakterze transgranicznym wyłącznie w języku urzędowym owej jednostki sfederowanej pod rygorem nieważności tych umów stwierdzanej przez sąd z urzędu ${ }^{1157}$.

Gdy chodzi o stosowanie testu proporcjonalności, użycie jako rozstrzygającego w tej sprawie kryterium konieczności wydaje się szczególnie doniosłe. Oceniając skutki powołania się państwa na obowiązek Unii do poszanowania poprawnie zidentyfikowanej tożsamości konstytucyjnej, sformułowanego przez uprawniony do tego podmiot, TSUE powinien koncentrować się właśnie na tym aspekcie testu proporcjonalności środków krajowych. Szczególnie w kontekście tego, o czym mowa będzie w dalszej części rozdziału wydaje się, że nie powinien wykraczać poza kwestię konieczności. Jeśli zgodzi się, że dla usunięcia konfliktu między tożsamością konstytucyjną a prawem unijnym konieczne jest niestosowanie tego ostatniego w określonym zakresie $\mathrm{w}$ danym państwie (a nie wystarczy np. wskazanie poprawnej interpretacji prawa unijnego, błędnie zrozumianego przez organy państwa członkowskiego, czy środki krajowe $\mathrm{w}$ istocie nie będą elementem koniecznym dla realizacji tożsamości konstytucyjnej tego państwa ${ }^{1158}$ ), to wprowadzanie dalszych kryteriów, jak np. oceny

1155 Ibidem, pkt 29-32.

1156 Ibidem, pkt 33.

1157 Ibidem, pkt 34

${ }^{1158}$ Dlatego tak istotne jest, podkreślane w tej pracy wielokrotnie, nie tylko prawidłowe zidentyfikowanie tożsamości konstytucyjnej państwa przez odpowiedni do tego organ krajowy (w przypadku Polski TK), ale również wskazanie, w jaki sposób i w jakim zakresie pozostaje ona w sprzeczności z prawem unijnym. Jest to łatwiejsze w przypadku konfliktu bezpośrednio skutecznego unijnego prawa pochodnego z Konstytucją RP, jako że wtedy mamy jeden tylko wzorzec i przedmiot odniesienia. $\mathrm{W}$ takim przypadku, jak w sprawie Las, kiedy mamy do czynienia z regulacją innego rodzaju (nota bene dekret ustanawiający obowiązek sporządzania umów w języku krajowym i konsekwencje jego niedotrzymania wydany był na mocy art. 129 ust. 1 pkt 3 holenderskiej konstytucji, ale sam nie był w niej zawarty; ibidem, pkt 4), która sprzyja realizacji 
czy wartość, do ochrony jakiej zmierza prawo krajowe jest proporcjonalna do wartości realizowanej przez prawo unijne, nie miałoby podstaw w art. 4 ust. 2 TUE. Podobnie jak, co będzie omówione szerzej w dalszej części tego rozdziału, przepis ten nie daje podstaw do stosowania wynikającego z niego obowiązku jedynie do norm prawa pierwotnego Unii, czy tylko do tych przepisów prawa unijnego, od których przewidziane są dopuszczalne odstępstwa, również w żaden sposób nie daje podstaw do wartościowania elementów tożsamości konstytucyjnej, które miałyby podlegać obowiązkowi poszanowania przez Unię albo nie ${ }^{1159}$. Mówi o obowiązku poszanowania przez Unię tożsamości państw członkowskich, a nie niektórych elementów ich tożsamości, określanych za pomocą jakichkolwiek kryteriów.

Zachowanie po stronie TSUE możliwości stosowania testu proporcjonalności sprawia, że roszczenie czy żądanie poszanowania tożsamości konstytucyjnej i wszelkich jej przejawów formułowane przez państwo nie ma charakteru "asa atutowego", jak zdarza się państwom, a szczególnie ich sądom konstytucyjnym sugerować ${ }^{1160}$, który zawsze musi przezwyciężyć pierwszeństwo, jednolitość i efektywność prawa unijnego. Jednakże stosowanie testu proporcjonalności przez TSUE $\mathrm{w}$ związku z obowiązkiem zawartym $\mathrm{w}$ art. 4 ust. 2 TUE wydaje się być bardzo ograniczone. Nie ulega wątpliwości, że wśród kryteriów proporcjonalności mogących mieć zastosowanie w takich sprawach znajduje się konieczność. To, czy jeszcze jakieś inne kryteria będą mogły być

tożsamości konstytucyjnej państwa, ale nie jest jej warunkiem koniecznym, nie można uznać jej za jej element chroniony art. 4 ust. 2 TUE i jako taka musi ustąpić pierwszeństwu, jedności i efektywności prawa unijnego. TK, w przypadku tego rodzaju sytuacji powinien więc w swym odesłaniu bardzo precyzyjnie wskazać, w jaki sposób normy prawa rangi niekonstytucyjnej, mieszczące się w zakresie zastosowania prawa unijnego, są przejawem tożsamości konstytucyjnej RP, który musi być poszanowany, jako jej element konieczny (a nie jedynie jej derywat czy dalsza konsekwencja) niepodlegający pierwszeństwu, jedności i efektywności prawa unijnego. Znowu więc im precyzyjniejsze i lepiej uzasadnione stanowisko sądu odsyłającego (w przypadku problematyki omawianej w tej pracy - stanowisko TK), tym mniejsza zdaje się być swoboda TSUE - również do stosowania testu proporcjonalności (konieczności).

${ }^{1159}$ Inaczej np.: G. van der Schyff, The Constitutional..., s. 580; twierdzi on, że obowiązek poszanowania tożsamości konstytucyjnej państwa członkowskiego jest relatywny i powinien być realizowany przez Unię i TSUE, "tam, gdzie to możliwe” z perspektywy prawa unijnego. Trudno zgodzić się z taką konkluzją. Relatywizowanie w ten sposób obowiązku poszanowania tożsamości konstytucyjnej państw członkowskich i uzależnianie go od "możliwości”, z perspektywy prawa unijnego prowadziłoby do absolutyzacji zasad pierwszeństwa, jednolitości i efektywności prawa unijnego i byłoby równie nieuzasadnione, jak absolutyzowanie za pomocą art. 4 ust. 2 TUE obowiązku poszanowania przez Unię konstytucji państw członkowskich jako takich. Wniosek taki wynika z samego art. 4 ust. 2 TUE, który mówi o obowiązku poszanowania tożsamości konstytucyjnej państw tout court, a nie mówi, że należy to czynić, gdy jest to możliwe albo proporcjonalne sensu stricto.

${ }_{1160}$ Por.: G. van der Schyff, The Constitutional..., s. 579-580. 
stosowane, pozostaje pytaniem otwartym ${ }^{1161}$. Metodologia stosowania tego testu będzie musiała zostać jeszcze dopracowana w orzecznictwie TSUE w relacji do orzecznictwa krajowego. Pamiętać jednak należy, że o ile stosowanie testu proporcjonalności znajduje swoje podstawy odnośnie do derogacji od unijnych swobód ${ }^{1162}$, o tyle odnośnie do tożsamości konstytucyjnej jako uniwersalnego wyjątku od zobowiązań wynikających z prawa unijnego jest znacznie bardziej problematyczne, jeśli w ogóle nie niedopuszczalne ${ }^{1163}$. Stąd sposób, w jaki w sprawach dotyczących art. 4 ust. 2 TUE test proporcjonalności był dotychczas stosowany, będzie musiał być zniuansowany, gdy będziemy mieli do czynienia ze sprawą sensu stricto związaną z zastosowaniem art. 4 ust. 2 TUE w proponowanej w tej pracy roli, a nie w związku z derogacją i mniej lub bardziej expressis verbis wyrażonym powiązaniem argumentu z art. 4 ust. 2 TUE z wymogami porządku publicznego, czy szerzej - dopuszczalności derogacji od unijnych swobód.

\subsubsection{Sprawa Bogendorff von Wolffersdorff}

Sprawa Bogendorff von Wolffersdorff ${ }^{1164}$ dotyczyła sporu między Panem Nabielem Peterem Bogendorff von Wolffersdorff a władzami miasta Karlsruhe w sprawie odmowy zmiany przez nie imion i nazwiska umieszczonych na akcie

${ }^{1161}$ Wydaje się, że wskazywane w doktrynie sposoby stosowania kryterium proporcjonalności przez TSUE w sprawach dotyczących art. 4 ust. 2 TUE nie zawsze są trafne. Tak np. stanowisko TSUE wyrażone w sprawie O'Brien (TSUE, Dermod Patrick O'Brien p. Ministry of Justice, dawniej Department for Constitutional Affairs, C-393/10, wyrok z 1 marca 2012) nie było przejawem stosowania testu proporcjonalności w tej mierze (por.: G. van der Schyff, The Constitutional..., s. 578-579; por. także: D. Leczykiewicz, The 'national identity clause' in the EU Treaty: A Blow to Supremacy of Union Law? [online] <https://ukconstitutionallaw.org/2012/o6/21/dorota-leczykiewicz-the-national-identity-clause-in-the-eu-treaty-a-blow-to-supremacy-of-union-law/> [dostęp: 5.02.2019]), lecz oceny, czy faktycznie pewne elementy konstytucyjnego ustroju państwa są elementem jego tożsamości konstytucyjnej i Unia nie może w nie ingerować, czy też nimi nie są. W sprawie tej, nota bene dokonanie takiej oceny przez TSUE było uzasadnione, jako że argument naruszenia tożsamości konstytucyjnej, sformułowany przez rząd łotewski nie został poparty wskazaniem konkretnych postanowień rangi konstytucyjnej, wyszczególnionych ze względu na ich tożsamościowy charakter wraz ze wskazaniem, w jakim zakresie pozostawałyby one $\mathrm{w}$ sprzeczności z konkretnymi postanowieniami prawa unijnego, lecz na ogólnym przeświadczeniu jakoby „stosowanie prawa Unii do władzy sądowniczej oznaczałoby nieprzestrzeganie tożsamości narodowej państw członkowskich, co byłoby sprzeczne z art. 4 ust. 2 TUE" (TSUE, Dermod Patrick O'Brien p. Ministry of Justice, dawniej Department for Constitutional Affairs, C-393/10, wyrok z 1 marca 2012, pkt 49).

1162 P. Koutrakos, N. Nic Shuibhne, P. Syrpis (red.), Exceptions....

${ }^{1163}$ K. Kowalik-Bańczyk, Tożsamość..., s. 49.

1164 TSUE, Nabiel Peter Bogendorff von Wolffersdorff p. Standesamt der Stadt Karlsruhe i Zentraler Juristischer Dienst der Stadt Karlsruhe, C-438/14, wyrok z 2 czerwca 2016. 
urodzenia skarżącego i wpisania w rejestrze aktów stanu cywilnego elementów tytułów szlacheckich stanowiących część nazwiska, które ten nabył w innym państwie członkowskim ${ }^{1165}$. Skarżący urodził się w Karlsruhe w 1963 r. jako Nabiel Bagdadi, jednak w postępowaniu administracyjnym o zmianę nazwiska uzyskał drugie imię - Peter - oraz nazwisko Bogendorff, po czym w wyniku adopcji, która miała miejsce również w Niemczech, nazwisko jego zostało zmienione na Bogendorff von Wolffersdorff ${ }^{1166}$. W 2001 r. wyjechał do Wielkiej Brytanii, gdzie uzyskał obywatelstwo i na mocy prawa brytyjskiego znowu zmienił nazwisko - na Peter Mark Emanuel Graf von Wolffersdorff Freiherr von Bogendorff1167. Po tym skarżącemu i jego małżonce urodziła się córka, która również ma podwójne obywatelstwo, a jej imiona i nazwisko figurujące w brytyjskim akcie urodzenia i brytyjskim paszporcie to Larissa Xenia Gräfin von Wolffersdorff Freiin von Bogendorff ${ }^{1168}$.

Jednakże urząd stanu cywilnego w Chemnitz - opierając się na przepisach niemieckiego prawa cywilnego - odmówił zarejestrowania córki pod jej brytyjskim nazwiskiem. Skarżący wniósł skargę o wydanie wobec tego urzędu nakazu wpisania do rejestru aktów stanu cywilnego takiego nazwiska jego córki, na co sąd w Dreźnie przystał i w wyniku wydanego przezeń nakazu urząd miasta Chemnitz dokonał wspomnianego wpisu do rejestru ${ }^{1169}$. Później sam skarżący zażądał wpisania do rejestru aktów stanu cywilnego swoich imion i nazwisk, które nabył na mocy prawa brytyjskiego. Skarżący znowu wniósł do sądu, tym razem w Karlsruhe, o wydanie stosownego nakazu zmiany jego aktu urodzenia. Urząd stanu cywilnego miasta Karlsruhe wniósł o oddalenie tego wniosku w oparciu o zarzut niezgodności z podstawowymi zasadami prawa niemieckiego, zawartymi w przepisach niemieckiego prawa cywilnego ${ }^{1170}$. Wzbudziło to watpliwości sądu rejonowego w Karlsruhe (Amtsgericht Karlsruhe), przed którym sprawa stanęła. Były one związane z zakresem stosowania wspomnianych przepisów niemieckiego prawa cywilnego, które były już zresztą wcześniej przedmiotem orzecznictwa TSUE ${ }^{1171}$, co doprowadziło go do skierowania pytania do TSUE, znowu dotyczącego wykładni art. 18 i 21 TFUE w kontekście potencjalnie ograniczających unijne swobody przepisów krajowych:

Czy art. 18 TFUE i 21 TFUE należy interpretować w ten sposób, że organy państwa członkowskiego są zobowiązane do uznania zmiany nazwiska obywatela tego

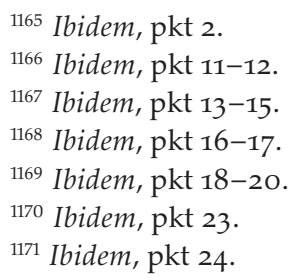


państwa, jeżeli jest on jednocześnie obywatelem innego państwa członkowskiego i w tym państwie członkowskim podczas zwykłego pobytu na skutek zmiany nazwiska, która nie jest związana ze zmianą statusu na gruncie prawa rodzinnego, nabył swobodnie wybrane nazwisko zawierające kilka tytułów szlacheckich, o ile prawdopodobnie nie zaistnieje w przyszłości istotny związek z tym państwem, a w pierwszym państwie członkowskim instytucja szlachty została wprawdzie zniesiona na mocy prawa konstytucyjnego, jednak tytuły szlacheckie noszone w momencie zniesienia instytucji szlachty mogą nadal stanowić część nazwiska? ${ }^{1172}$.

Trybunał zauważył, że sprawa dotyczy zarówno nazwiska, jak i imion ${ }^{1173}$ oraz przypomniał znaczenie art. 20 TFUE obywatelstwa unijnego, podkreślone w podobnym kontekście w wyroku w sprawie Runevič-Vardyn, stwierdzając, że fakt posiadania dwu obywatelstw niczego nie zmienia ${ }^{1174} \mathrm{w}$ kwestii obowiązku takiego samego traktowania wszystkich obywateli Unii wobec prawa $\mathrm{w}$ zakresie stosowania ratione materiae traktatu, bez względu na ich przynależność państwową i bez uszczerbku dla wyraźnie przewidzianych w tym względzie wyjątków ${ }^{1175}$. Ponownie więc na szali znalazły się przepisy unijnego prawa pierwotnego ustanawiające unijne swobody i regulacje krajowe, stanowiące ich potencjalne ograniczenie, które musiały więc zostać ocenione pod kątem tego, czy rzeczywiście stanowią ograniczenie swobody, i jeśli tak, to czy są one dopuszczalne.

Trybunał w tej sprawie podążył drogą wytyczoną w omawianych już wcześniej sprawach Sayn-Wittgenstein i Runevič-Vardyn. Omawianie więc tych powtórzonych ustaleń dotyczących tego, że nazwisko podlega ochronie art. 7 Karty ${ }^{1176}$, czy też tego, jakiego rodzaju regulacje dotyczące nazwiska i w jakich sytuacjach mogą być uznawane za ograniczenia unijnych swobód pod kątem kryterium 'poważnej niedogodności' dla osoby, której sprawa dotyczy w kontekście detali tej sprawy ${ }^{1177}$ nie jest niezbędne. Dość powiedzieć, że Trybunał doszedł do wniosku, że „odmowa uznania przez organy państwa członkowskiego imion i nazwiska obywatela tego państwa członkowskiego, w brzmieniach ustalonych i zarejestrowanych w drugim państwie członkowskim, którego posiada on także obywatelstwo, stanowi ograniczenie przyznanych w art. 21 TFUE każdemu obywatelowi Unii swobód"1178.

\footnotetext{
1172 Ibidem, pkt 25.

1173 Ibidem, pkt 26-27.

${ }^{1174}$ Ibidem, pkt 28-29.

1175 Ibidem, pkt 30.

1176 Ibidem, pkt 35 .

1177 Ibidem, pkt 36 i nast.

1178 Ibidem, pkt 47.
} 
Na szczególną uwagę w kontekście tematu tej pracy zasługuje stanowisko rządu niemieckiego, zgodnie z którym niemieckie przepisy prawa cywilnego tworzą

podstawę prawną umożliwiającą osobie podlegającej prawu niemieckiemu wybranie nazwiska nabytego i zarejestrowanego w innym państwie członkowskim, o ile nie istnieje niezgodność z podstawowymi zasadami prawa niemieckiego. Wspomniany rząd wyjaśnił, że nazwisko to może być wpisane do rejestru aktów stanu cywilnego na podstawie oświadczenia danej osoby w urzędzie stanu cywilnego, w którym osoba ta wskaże, że pragnie nosić nazwisko nabyte w innym państwie członkowskim zamiast nazwiska, które wynika ze stosowania niemieckiego prawa w zakresie statusu osobowego, pod warunkiem że nazwisko zostało nabyte w innym państwie członkowskim w trakcie zwykłego pobytu, czyli pobytu trwającego pewien czas i prowadzącego do pewnej integracji społecznej. Celem tego wymogu jest zapobieżenie temu, by obywatele niemieccy wyjeżdżali - wyłącznie w celu obejścia krajowego prawa w zakresie statusu osobowego - na krótki czas do innego państwa członkowskiego o korzystniejszym ustawodawstwie w celu nabycia nazwiska, jakie chcą nosić1779.

W świetle powyższego Trybunał trochę szerzej niż w poprzednich sprawach odniósł się do kwestii związanych z prawami człowieka, choć znowu nie skoncentrował się na tej kwestii jako rozstrzygającej, a jedynie pomocniczej. Zauważył, że na gruncie EKPCz jest dopuszczalne, aby wprowadzać ograniczenia w swobodzie zmiany nazwiska, w celu ochrony uzasadnionego interesu publicznego ${ }^{1180}$. Doprowadziło to TSUE do konkluzji, choć bez głębszego powiązania zmiany kontekstu analizy z norm praw gwarantujących prawa człowieka, z powrotem do kontekstu swobody przepływu osób, że

dobrowolny charakter zmiany nazwiska nie stanowi sam w sobie naruszenia interesu ogólnego i tym samym nie może uzasadniać jako taki ograniczenia art. 21 TFUE. W związku z powyższym organy niemieckie nie mogą odmówić uznania nazwiska nabytego zgodnie z prawem przez obywatela niemieckiego w innym państwie członkowskim tylko z tego powodu, że ta zmiana nazwiska została dokonana z przyczyn osobistych i bez uwzględnienia powodów wspomnianej zmiany ${ }^{1181}$.

Konieczna była więc ocena, czy racje stojące za ograniczeniami były uzasadnione w inny sposób ${ }^{1182}$.

Niewystarczające dla Trybunału okazało się uzasadnienie, pojawiające się w stanowisku Niemiec, związane z zakazem zbyt długich nazwisk ze wzglę-

\footnotetext{
1179 Ibidem, pkt 53 .

${ }^{1180}$ Ibidem, pkt 54-55.

${ }^{1181}$ Ibidem, pkt 56.

1182 Ibidem, pkt 57-58.
} 
dów praktycznych ${ }^{1183}$. Kluczowe okazało się rozstrzygnięcie, czy ograniczenia takie mogą wiązać się z faktem zniesienia w danym państwie członkowskim przywilejów i wynikającego stąd zakazu noszenia tytułów szlacheckich lub ponownego tworzenia pozorów pochodzenia szlacheckiego. Zdaniem

centralnego biura prawnego miasta Karlsruhe i rządu niemieckiego w sprawie w postępowaniu głównym obiektywny powód umożliwiający uzasadnienie ograniczenia swobodnego przemieszczania się może opierać się na zasadzie równości obywateli niemieckich wobec prawa, a także na wyborze konstytucyjnym polegającym na zniesieniu przywilejów i nierówności związanych z urodzeniem lub ze stanem i na zakazaniu noszenia tytułów szlacheckich jako takich [...]. Uznanie swobodnie wybranego nazwiska, składającego się z kilku tytułów szlacheckich, które zostało nabyte w innym państwie członkowskim i którego uzyskanie nie wynika ze zmiany statusu osobowego w następstwie zastosowania przepisów prawa rodzinnego, oznaczałoby stworzenie nowego tytułu szlacheckiego, co byłoby sprzeczne z niemieckim porządkiem prawnym ${ }^{1184}$.

Niemieckie przepisy, w tym rangi konstytucyjnej, miały prowadzić do zniesienia w Niemczech wszelkich przywilejów i nierówności stanowych. Jak wskazał jednak rząd niemiecki, należy rozróżnić tutaj kwestie tradycyjnego i historycznie ukształtowanego nazwiska oraz kwestię tytułu i ewentualnie wiążącego się z nim przywileju.

O ile tytuły szlacheckie, które rzeczywiście były noszone w momencie wejścia w życie konstytucji weimarskiej, mogą nadal być używane jako elementy nazwiska i mogą być przekazywane ze względu na okoliczność objętą statusem osobowym, o tyle tworzenie nowych tytułów szlacheckich i ich przyznawanie są zakazane. Rząd niemiecki wyjaśnia, że zgodnie z orzecznictwem krajowym nadanie - w następstwie zmiany nazwiska - nazwiska zawierającego tytuł szlachecki jako element nazwiska także objęte jest zakazem przewidzianym w [...] konstytucji weimarskiej oraz że zakazane jest także ponowne tworzenie pozorów pochodzenia szlacheckiego, w szczególności poprzez zmianę nazwiska. Postanowienia te, które zdaniem rządu niemieckiego tworzą część niemieckiego porządku publicznego, mają na celu zagwarantowanie równego traktowania wszystkich obywateli niemieckich ${ }^{1185}$.

W miejscu tym rząd niemiecki powołał się na wyrok w sprawie Sayn-Wittgenstein i przyczyny, jakie w tamtej sprawie doprowadziły TSUE do wniosku

${ }^{1183}$ Ibidem, pkt 59-6o; por też: TSUE, Stefan Grunkin i Dorothee Regina Paul, C-353/o6, wyrok z 14 października 2008, pkt 36.

1184 TSUE, Nabiel Peter Bogendorff von Wolffersdorff p. Standesamt der Stadt Karlsruhe i Zentraler Juristischer Dienst der Stadt Karlsruhe, C-438/14, wyrok z 2 czerwca 2016, pkt 61.

${ }^{1185}$ Ibidem, pkt 62. 
o dopuszczalności pewnych ograniczeń w swobodzie przepływu osób w związku z ograniczeniami dopuszczalności zmian przez nie nazwiska w innym państwie członkowskim ${ }^{1186}$.

W tym zakresie, nawet jeśli - jak podkreśla sąd odsyłający - prawo niemieckie różni się od przepisów prawa austriackiego rozpatrywanych w sprawie, w której wydano wyrok [...] Sayn-Wittgenstein [...], w zakresie, w jakim nie przewiduje ścisłego zakazu używania i przekazywania tytułów szlacheckich, przy czym można je nosić jako integralną część nazwiska, to w niniejszej sprawie należy także przyznać, że art. 109 akapit trzeci konstytucji weimarskiej - rozpatrywany w kontekście niemieckiego wyboru konstytucyjnego - jako element tożsamości narodowej państwa członkowskiego, o której mowa w art. 4 ust. 2 TUE, może być uwzględniony jako element uzasadniający ograniczenie uznanego w prawie Unii prawa do swobodnego przemieszczania się osób ${ }^{1187}$.

Taka argumentacja okazała się dla TSUE przekonująca. Zdaniem Trybunału: „Uzasadnienie dotyczące zasady równości obywateli niemieckich wobec prawa i dotyczące wyboru konstytucyjnego polegającego na zniesieniu przywilejów i nierówności oraz zakazaniu noszenia tytułów szlacheckich jako takich należy interpretować w ten sposób, że odnosi się ono do względów porządku publicznego"1188. Jak stwierdził on już to w swym wcześniejszym orzecznictwie, w omawianych wcześniej wyrokach „szczególne okoliczności, które mogłyby uzasadniać odwołanie do pojęcia porządku publicznego, mogą różnić się w poszczególnych państwach członkowskich lub w określonych okresach"1189. Doprowadziło to Trybunał do jednoznacznej konkluzji, że: „Nie ma [...] watpliwości, że cel odnoszący się do przestrzegania zasady równości jest w świetle prawa Unii słusznym celem"1190.

W obliczu tej oceny pojawił się jednak problem dalszy. Uprawniony cel ograniczeń to jeszcze za mało, żeby ograniczenia uznać za uprawnione. Wymagane jest również, aby były proporcjonalne, a więc przede wszystkim konieczne. Jak podkreślił Trybunał: „Przepisy ograniczające podstawową swobodę mogą być uzasadnione względami porządku publicznego jedynie wtedy, gdy są odpowiednie dla zapewnienia realizacji założonych celów, a także są niezbędne dla ochrony interesów, które mają zapewnić, i gdy cele te nie mogą zostać osiągnięte mniej restrykcyjnymi środkami"1191. Również i tym razem TSUE przy-

\footnotetext{
${ }^{1186}$ Ibidem, pkt 63.

1187 Ibidem, pkt 64 .

${ }^{1188}$ Ibidem, pkt 65.

1189 Ibidem, pkt 68.

1190 Ibidem, pkt 71.

${ }^{1191}$ Ibidem, pkt 72.
} 
pomniał, że środki te nie muszą być na przestrzeni wszystkich państw członkowskich takie same oraz „że niezbędny i proporcjonalny charakter przepisów przyjętych w określonej dziedzinie nie jest wykluczony tylko z tego powodu, że jedno państwo członkowskie wybrało odmienny system ochrony niż ten przyjęty przez inne państwo"1192.

W kontekście tym TSUE przypomniał również, choć bez szerszego odniesienia się do tego zagadnienia, obowiązek po stronie Unii do poszanowania tożsamości konstytucyjnej państw członkowskich ${ }^{1193}$. Dokonał jedynie dość wyczerpującej analizy zniuansowania, jakie wprowadza prawo niemieckie, gdy chodzi o dopuszczalność używania elementów szlacheckich jako części nazwiska lub zakaz ich używania w świetle celu, do zagwarantowania jakiego dąży prawo niemieckie, jakim jest poszanowanie zasady równości ${ }^{1194}$. Doprowadziło to TSUE do konkluzji, że

art. 21 TFUE należy interpretować w ten sposób, że organy państwa członkowskiego nie są zobowiązane do uznania nazwiska obywatela tego państwa członkowskiego w przypadku, gdy posiada on także obywatelstwo innego państwa członkowskiego, w którym nabył to swobodnie wybrane nazwisko zawierające kilka elementów tytułów szlacheckich, które są niedopuszczalne na gruncie prawa pierwszego państwa członkowskiego, o ile zostanie wykazane - czego weryfikacja należy do sądu odsyłającego - że taka odmowa uznania nazwiska jest w tym kontekście uzasadniona względami porządku publicznego, ponieważ jest odpowiednia i niezbędna do zagwarantowania poszanowania zasady równości wszystkich obywateli wspomnianego państwa członkowskiego wobec prawa ${ }^{1195}$.

Na gruncie tej sprawy należy podkreślić raz jeszcze, że TSUE, zgodnie zresztą z brzmieniem skierowanych doń pytań, trzymał się kontekstu interpretacji unijnych swobód i wynikających z nich konsekwencji wobec państw członkowskich w zakresie ewentualnych dopuszczalnych derogacji. Znowu skoncentrował się na dopuszczalności tej ostatniej ze względu na poszanowanie porządku publicznego, a stosując kryteria oceny uzasadnionego celu oraz konieczności środków ograniczających, w sposób podobny jak w poprzednich sprawach zastosował test proporcjonalności ograniczeń. Dał więc po raz kolejny wyraz przekonania o swej kompetencji w tej materii. Argumentację opartą na obowiązku poszanowania przez Unię tożsamości konstytucyjnej państwa członkowskiego potraktował znowu jedynie pomocniczo. Warto jednak podkreślić, że ponownie w sposób dość chaotyczny i pozbawiony rozważań nad

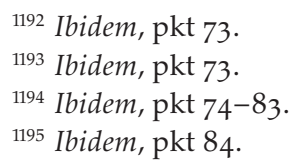


możliwością zastosowania w sprawie unijnych praw podstawowych i bez przeformułowania kwestii w sposób umożliwiający rozstrzygnięcie ewentualnego konfliktu unijnego i krajowego standardu ochrony praw człowieka, zaakcentował prawnoczłowieczy wymiar tej sprawy poprzez odniesienie się do treści prawa zagwarantowanego w art. 7 Karty oraz do orzecznictwa ETPCz.

\subsubsection{Sprawa Coman}

Kwestia poszanowania tożsamości konstytucyjnej jako dopuszczalnej okoliczności stojącej za ograniczeniem unijnych swobód pojawiła się ostatnio na gruncie, choć raczej na marginesie, sprawy Coman ${ }^{1196}$. Warto podkreślić, że pytanie prejudycjalne do TSUE zostało skierowane w tej sprawie przez rumuński Trybunał Konstytucyjny (Curtea Constituțională), co wpisuje się w postulowaną $\mathrm{w}$ tej pracy praktykę stosowania tej procedury dialogu również przez organy tego typu, a nie jedynie zwykłe sądy. Interesująca nas tutaj kwestia, związana z ewentualnym ograniczeniem prawa unijnego ze względu na wchodzącą z nią w kolizję tożsamością narodowa/konstytucyjną państwa członkowskiego, nie została jednak objęta pytaniami rumuńskiego TK. Kwestia ta podniesiona została przez rząd łotewski w przedłożonych TSUE uwagach ${ }^{1197}$. Sprawa ta nie może być więc uznana za przykład postępowania takiego, jakie postulowane jest w tej pracy. Podkreślenia wymaga jednak to, że rumuński TK jest kolejnym organem tego rodzaju, który nie stroni od angażowania TSUE w dialog na drodze pytań prejudycjalnych, co powiększa potencjalne grono aktorów, którzy mogliby w przyszłości skorzystać z wniosków zawartych w tej pracy.

Sprawa Coman ogniskowała się wokół dość delikatnej kwestii, jaką są małżeństwa jednopłciowe. Pan Coman, obywatel Rumunii, w trakcie swego pobytu w Belgii zawarł zgodnie z obowiązującym tam prawem jednopłciowy związek małżeński z Panem Hamiltonem, obywatelem USA. Jednakże władze rumuńskie odmawiały Panu Hamiltonowi, jako obywatelowi państwa trzeciego, przyznania pochodnego prawa pobytu w Rumunii ze względu na to, że prawo rumuńskie nie dopuszcza małżeństw jednopłciowych ${ }^{1198}$. Zdaniem TSUE jednak

odmowa ze strony organów państwa członkowskiego uznania - wyłącznie do celów przyznania pochodnego prawa pobytu obywatelowi państwa trzeciego - małżeństwa zawartego przez niego z obywatelem Unii tej samej płci podczas ich efektywnego pobytu w innym państwie członkowskim, zgodnie z prawem tego ostatniego

1196 TSUE, Relu Adrian Coman i in. p. Inspectoratul General pentru Imigrări i Ministerul Afacerilor Interne, C-673/16, wyrok 5 z czerwca 2018.

1197 Ibidem, pkt 42.

${ }^{1198}$ Ibidem, pkt 9-14. 
państwa, może stanowić przeszkodę w wykonywaniu prawa tego obywatela Unii do swobodnego przemieszczania się i przebywania na terytorium państw członkowskich, ustanowionego w art. 21 ust. 1 TFUE. Konsekwencją takiej odmowy będzie bowiem pozbawienie rzeczonego obywatela Unii możliwości powrotu do państwa członkowskiego, którego przynależność państwową posiada, wraz ze swym małżonkiem ${ }^{1199}$.

\section{Mimo iż rumuński TK tego nie uczynił,}

kilka rządów, które przedłożyły uwagi Trybunałowi, podkreśliło w tej kwestii fundamentalny charakter instytucji małżeństwa oraz wolę niektórych państw członkowskich, by zachować koncepcję tej instytucji jako związku mężczyzny i kobiety, chronionego w pewnych państwach członkowskich normami rangi konstytucyjnej. I tak rząd łotewski wskazał na rozprawie, że jeżeli założyć, iż odmowa w okolicznościach takich, jak w sprawie w postępowaniu głównym uznania małżeństw osób tej samej płci stanowi ograniczenie art. 21 TFUE, to ograniczenie takie jest uzasadnione względami związanymi z porządkiem publicznym i tożsamością narodową, o której mowa w art. 4 ust. 2 TUE ${ }^{1200}$.

Argumentacja ta nie okazała się jednak dla TSUE przekonująca. Przyznał on, opierając się na swym, omawianym w poprzednich podrozdziałach orzecznictwie,

że ograniczenie swobodnego przemieszczania się osób, które - jak w sprawie w postępowaniu głównym - jest niezwiązane z przynależnością państwową zainteresowanych osób, może być uzasadnione, jeżeli opiera się na obiektywnych względach interesu ogólnego oraz jest proporcjonalne do uzasadnionego celu realizowanego przez prawo krajowe [...]. Z orzecznictwa Trybunału wynika, że środek jest proporcjonalny, gdy pozostając zdatnym do osiągnięcia zamierzonego celu, nie wykracza poza to, co jest konieczne do jego osiągnięcia [... $]^{1201}$.

Tymczasem zdaniem Trybunału w przedmiotowej sprawie kryterium proporcjonalności, które w takich sytuacjach w ugruntowanej opinii TSUE traktowane musi być wąsko, ${ }^{1202}$ nie zostało spełnione.

W tej kwestii należy stwierdzić, że obowiązek uznania przez państwo członkowskie małżeństwa osób tej samej płci, zawartego w jednym z państw członkowskich zgodnie z prawem tego państwa, wyłącznie do celów przyznania pochodnego prawa pobytu obywatelowi państwa trzeciego, nie ma wpływu na instytucję małżeństwa w tym pierwszym państwie członkowskim, zdefiniowaną przez prawo krajowe

\footnotetext{
${ }^{1199}$ Ibidem, pkt 40.

1200 Ibidem, pkt 42.

${ }^{1201}$ Ibidem, pkt 41.

1202 Ibidem, pkt 44 .
} 
i należącą [...] do kompetencji państw członkowskich. Nie oznacza on, by państwo członkowskie było zobowiązane do wprowadzenia w swoim prawie krajowym instytucji małżeństwa osób tej samej płci. Sprowadza się on do obowiązku uznania takich małżeństw, zawartych w innym państwie członkowskim i zgodnie z prawem tego państwa, wyłącznie do celów wykonywania praw, które osoby te wywodzą z prawa Unii ${ }^{1203}$.

Takim prawem jest pochodne prawo pobytu, jednak nie inne prawa, jakie małżeństwom może przyznawać prawo krajowe. Dlatego też, zdaniem Trybunału, „tego rodzaju obowiązek uznania wyłącznie do celów przyznania pochodnego prawa pobytu obywatelowi państwa trzeciego nie narusza tożsamości narodowej ani nie zagraża porządkowi publicznemu danego państwa członkowskiego"1204.

Zarówno rząd łotewski, jak przede wszystkim TSUE wpisały się w ten sposób w tendencję do traktowania tożsamości konstytucyjnej jako okoliczności potencjalnie ograniczającej unijne swobody, podobnej do porządku publicznego, a także, że ewentualne ograniczenie konsekwencji wynikających z unijnych swobód ze względu na interes publiczny czy tożsamość konstytucyjną zależne jest od proporcjonalności/konieczności ograniczenia. Ocena tego ostatniego zaś podlega kontroli TSUE. Przeprowadzając na potrzeby tej sprawy test proporcjonalności, TSUE skupiał się na porządku publicznym, nie na tożsamości konstytucyjnej, które potraktował podobnie. Utożsamianie jednego z drugim nie wydaje się jednak uzasadnione w kontekście tej pracy. Jak była o tym mowa, tożsamość konstytucyjna państw członkowskich i obowiązek jej ochrony nie jest odmianą klauzuli porządku publicznego, a jej potencjał jest znacznie większy. Podejście TSUE nie powinno jednak dziwić. Mógł on w dość komfortowy sposób w tej sprawie kontynuować swą wcześniejszą linię orzecznicza, nie modyfikując jej ani nie rozwijając czy doprecyzowując, jednocześnie jednak takiego rozwinięcia czy modyfikacji nie wykluczając w przyszłych sprawach. Kwestia tożsamości konstytucyjnej pojawiła się w sprawie na marginesie, a nie została w sposób precyzyjny sformułowana w pytaniu prejudycjalnym przez wystosowujący je trybunał konstytucyjny państwa członkowskiego. Brak było więc w odesłaniu argumentacji za tym, że przedmiotowe prawo unijne stoi w sprzeczności z konkretnymi regulacjami konstytucyjnymi, które mają rangę tożsamościową, brak było też uzasadnienia dla uznania tożsamości konstytucyjnej państwa członkowskiego za podstawę do modyfikacji zastosowania wobec niego prawa unijnego, w zakresie koniecznym dla poszanowania jego tożsamości konstytucyjnej.

${ }^{1203}$ Ibidem, pkt 45 .

${ }^{1204}$ Ibidem, pkt 46. 


\subsubsection{Sprawy, w których TSUE nie znalazł podstaw do zastosowania przepisów dotyczących poszanowania tożsamości narodowej/ konstytucyjnej państw członkowskich}

\subsubsection{Pierwsze przykłady odwołania się TSUE do obowiązku poszanowania przez Unię tożsamości narodowej/konstytucyjnej państw członkowskich}

Sprawy, w których pojawiło się pojęcie tożsamości narodowej w kontekście jej poszanowania przez Unię były rozstrzygnięte przez TSUE jeszcze przed Traktatem lizbońskim, a więc na gruncie art. 6 ust. 3 ówczesnego brzmienia TUE, jakie zostało mu nadane $\mathrm{w}$ wyniku przyjęcia Traktatu z Maastricht, które to brzmienie było analogiczne, choć nieco bardziej zwięzłe, niż aktualny art. 4 ust. 2 TUE. Po raz pierwszy pojęcie tożsamości konstytucyjnej pojawiło się jednak w orzeczeniu TSUE jeszcze zanim ostatecznie znalazło swój wyraz w prawie pierwotnym Unii. Nie powinno to jednak dziwić, zważywszy że sądy konstytucyjne państw członkowskich już od lat 7o. zwracały uwagę na konieczność respektowania przez Unię i jej prawo „konstytucyjnych struktur państwa, porządku konstytucyjnego czy też tożsamości konstytucji"1205.

W sprawie Groener ${ }^{1206}$ Trybunał stwierdził, że język narodowy (jakim w tym przypadku był język irlandzki) może być uznany za wyraz tożsamości narodowej państwa, nawet jeśli nie jest on używany przez całą ludność tego państwa. Traktaty nie sprzeciwiają się prowadzeniu przez państwa polityki ochrony i wspierania języka narodowego, który jest też pierwszym językiem urzędowym. Polityka taka nie może wszakże naruszać swobody przepływu osób i ograniczeń w możliwości podejmowania pracy. Dlatego też TSUE podkreślił, że wymogi wynikające ze środków wprowadzanych w celu ochrony języka narodowego nie mogą być nieproporcjonalne i powodować dyskryminacji skierowanej przeciwko obywatelom innych państw członkowskich. Rozstrzygając tę sprawę, TSUE stwierdził, że o ile można wymagać od nauczycieli znajomości tego języka, to jedynie w stopniu proporcjonalnym do zamierzonego celu i w sposób niedyskryminujący ${ }^{1207}$.

Już po wejściu w życie Traktatu z Maastricht obowiązek poszanowania przez Unię tożsamości narodowej państw członkowskich pojawił się, również incydentalnie, w sprawie, którą wszczęła przeciwko Luksemburgowi Komisja ${ }^{1208}$. Luksemburg wprowadzał ograniczenia w dostępie do zawodu nauczyciela oby-

${ }^{1205}$ K. Wójtowicz, Sądy konstytucyjne..., s. 124.

1206 TSUE, Anita Groener p. Minister Edukacji i City of Dublin Vocational Education Committee, C-379/87, wyrok z 28 listopada 1989, patrz przed. pkt 18-19.

${ }^{1207}$ Ibidem, pkt 18 i nast.

${ }^{1208}$ TSUE, Komisja p. Wielkiemu Księstwu Luksemburga, C-473/93, wyrok z 2 lipca 1996. 
watelom innych państw członkowskich ze względu na to, że nauczyciele powinni być obywatelami tego państwa po to, aby przekazywać wartości narodowe. Rząd luksemburski utrzymywał, że ze względu na wielkość i szczególną sytuację demograficzną tego kraju, wymóg posiadania przez nauczycieli obywatelstwa luksemburskiego był koniecznym warunkiem zachowania przez Luksemburg tożsamości narodowej ${ }^{1209}$. TSUE nie przystał na ten argument, przyznał jednak, że zachowanie tożsamości narodowej jest uprawnionym celem, szanowanym przez prawo unijne. Ocenił jednak, znowu de facto dokonując testu proporcjonalności, że realizacja tego celu nie może usprawiedliwiać pozbawiania obywateli państw członkowskich dostępu do stanowisk w szkolnictwie. Czym innym są ograniczenia dostępu do stanowisk związanych z bezpośrednim lub pośrednim wykonywaniu uprawnień wynikających z prawa publicznego i pełnieniem zadań mających na celu ochronę ogólnych interesów państwa, gdzie takie ograniczenie mogłoby być uzasadnione ${ }^{1210}$.

1.2.8.2. Przykłady odwołania się TSUE do obowiązku poszanowania przez Unię tożsamości narodowej/konstytucyjnej państw członkowskich na gruncie art. 4 ust. 2 TUE

W wyroku z $2012^{1211}$ na kanwie sporu między Węgrami i Słowacją, dotyczącego możliwości swobodnego wjazdu prezydenta pierwszego z tych państw na terytorium drugiego z nich, Trybunał przywołał argumentację strony słowackiej, że

ponieważ głowa państwa jest depozytariuszem suwerenności państwa, którym kieruje, nie może ona udać się do innego suwerennego państwa bez wiedzy i zgody tego ostatniego. Republika Słowacka przypomina tutaj, że art. 4 ust. 2 TUE stanowi, iż „Unia szanuje równość państw członkowskich wobec traktatów, jak również ich tożsamość narodową", oraz że swoboda przemieszczania się nie może w żadnym razie prowadzić do zmiany zakresu zastosowania traktatu FUE lub przepisów prawa wtórnego ${ }^{1212}$.

Ostatecznie zarzuty strony węgierskiej dotyczące niewpuszczenia prezydenta tego kraju do Słowacji TSUE uznał za bezzasadne ${ }^{1213}$ lub niedopuszczalne ${ }^{1214}$ bez odwołania się do art. 4 ust. 2 TUE.

\footnotetext{
${ }^{1209}$ Ibidem, pkt 32.

${ }^{1210}$ Patrz przed.: ibidem, pkt 33-36.

1211 TSUE, Węgry p. Republice Słowackiej, C-364/10, wyrok z 16 października 2012.

1212 Ibidem, pkt 35 .

${ }^{1213}$ Ibidem, pkt 52, 61

${ }^{1214}$ Ibidem, pkt 71 .
} 
W sprawie O'Brien ${ }^{1215}$ dotyczącej odmowy wypłaty emerytury obliczanej pro rata temporis $\mathrm{w}$ stosunku do emerytury należnej sędziemu zatrudnionemu $\mathrm{w}$ pełnym wymiarze czasu pracy $\mathrm{w}$ świetle przepisów prawa unijnego, regulujących pracę w niepełnym wymiarze godzin ${ }^{1216}$, TSUE nie zgodził się ze stanowiskiem,

zgodnie z którym stosowanie prawa Unii do władzy sądowniczej oznaczałoby nieprzestrzeganie tożsamości narodowej państw członkowskich, co byłoby sprzeczne z art. 4 ust. 2 TUE. Stwierdzić bowiem należy, że zastosowanie wobec sędziów pracujaccych w niepełnym wymiarze czasu pracy i wynagradzanych na podstawie dniówek dyrektywy 97/81 i porozumienia ramowego w sprawie pracy w niepełnym wymiarze czasu pracy nie może mieć wpływu na tożsamość narodowa, lecz ma na celu jedynie umożliwienie im skorzystania z dobrodziejstwa ogólnej zasady równości traktowania, która stanowi jeden z celów tych aktów, jak również ich ochronę przed dyskryminującym traktowaniem pracowników zatrudnionych w niepełnym wymiarze czasu pracy ${ }^{1217}$.

Wyrok w tej sprawie można uznać za przykład rozróżnienia regulacji krajowych, które mogą mieć nawet wysoką rangę w systemie prawnym państwa członkowskiego, w tym ewentualnie rangę konstytucyjną (choć omawiana tu sprawa główna odgrywała się na gruncie prawa brytyjskiego, gdzie trudno o analogicznie jednoznaczną do systemu polskiego klasyfikację norm jako konstytucyjnych bądź nie), ale nie uzasadniającą uznania ich za element tożsamości konstytucyjnej. W podobnym duchu, choć pojęcie tożsamości konstytucyjnej expressis verbis się w tym wyroku nie pojawia, w rozstrzygniętej już po wyrokach w sprawach Omega, a niedługo przed wyrokiem w sprawie Sayn-Wittgenstein, sprawie Wiener Wetten ${ }^{1218}$ TSUE jeszcze raz podkreślił, że zwykłe przepisy rangi konstytucyjnej nadal są co do zasady podległe pierwszeństwu prawa UE, bez wyjątku1219.

W sprawie dotyczącej publikacji ogłoszeń o konkursach w Dzienniku Urzędowym Unii w przywoływanym przez TSUE stanowisku Republiki Włoskiej pojawiło się odwołanie do obowiązku poszanowania przez Unię tożsamości państw członkowskich w kontekście obowiązku publikacji tego rodza-

1215 TSUE, Dermod Patrick O'Brien p. Ministry of Justice, dawniej Department for Constitutional Affairs, C-393/10, wyrok z 1 marca 2012.

${ }^{1216}$ Ibidem, pkt 1-2.

1217 Ibidem, pkt 49 .

1218 TSUE, Winner Wetten GmbH p. Bürgermeisterin der Stadt Bergheim, C-409/o6, wyrok z 8 września 2010.

1219 Por.: M. Taborowski, Polska tożsamość konstytucyjna a prymat prawa UE, [online] <http:// www.obserwatorkonstytucyjny.pl/debaty/polskatozsamosckonstytucyjnaaprymatprawaue/> [dostęp: 5.02.2019]. 
ju ogłoszeń we wszystkich językach Unii ${ }^{1220}$. Art. 4 ust. 2 TUE nie miał jednak znowu istotnego znaczenia dla rozstrzygnięcia. Podkreślić należy także, że $\mathrm{w}$ tej sprawie argument różnorodności językowej został podniesiony przez kandydatów, którzy ubiegali się o pewne stanowiska oferowane przez Unię, i przeciwko Unii, a nie przez państwa członkowskie w celu obrony ich polityki czy stanowionego przez nie prawa. Innymi słowy, koncept ten został powołany nie w celu uzasadnienia środków krajowych stanowiących przeszkodę dla stosowania zobowiązań wynikających z prawa unijnego, ale wyłącznie w ramach prawa unijnego i cechującego je podejścia do kwestii różnorodności językowej na przestrzeni Unii ${ }^{1221}$.

Dość interesująca z perspektywy tej pracy jest natomiast sprawa Torre$\mathrm{si}^{1222} \mathrm{i}$ kontekst, $\mathrm{w}$ jakim pojawia się $\mathrm{w}$ niej art. 4 ust. 2 TUE. Tym razem sprawa dotyczyła bowiem wykładni i ważności unijnej dyrektywy mającej na celu ułatwienie stałego wykonywania zawodu prawnika w państwie członkowskim innym niż państwo uzyskania kwalifikacji zawodowych ${ }^{1223}$, gwarantującej, że każdy prawnik ma prawo do stałego wykonywania działalności wymienionych w dyrektywie, w każdym innym państwie członkowskim, posługując się tytułem zawodowym uzyskanym w kraju pochodzenia, w związku z odmową uwzględnienia wniosków skarżących w postępowaniu głównym - Angelo i Pierfrancesco Torresich - w sprawie wpisu do sekcji specjalnej listy adwokatów, przeznaczonej dla adwokatów posługujących się wydanymi w innych niż Republika Włoska państwach członkowskich tytułami zawodowymi i prowadzących działalność w Republice Włoskiej ${ }^{1224}$. Organ odpowiedzialny za dokonanie wpisu stwierdził, iż sytuacja osoby, tak jak miało to miejsce w tym przypadku, "która po uzyskaniu dyplomu prawa $\mathrm{w}$ danym państwie członkowskim udaje się do innego państwa członkowskiego tylko w celu uzyskania tytułu adwokata, aby następnie niezwłocznie powrócić do pierwszego państwa członkowskiego w celu wykonywania tam zawodu, nie odpowiada celom dyrektywy $98 / 5$ i może stanowić nadużycie prawa"1225.

${ }^{1220}$ TSUE, Republika Włoska p. Komisji Europejskiej, C-566/1o P, wyrok z 27 listopada 2012, pkt 36 .

${ }^{1221}$ Por.: TSUE, Anton Las p. PSA Antwerp NV, C-202/11, opinia Rzecznika Generalnego Niila Jääskinena przedstawiona w dniu 12 lipca 2012, pkt 58.

1222 TSUE, Angelo Alberto Torresi i Pierfrancesco Torresi p. Consiglio dell'Ordine degli Avvocati di Macerata, C-58/13 i C-59/13, wyrok z 17 lipca 2014.

${ }^{1223}$ Art. 3 dyrektywy 98/5/WE Parlamentu Europejskiego i Rady z 16 lutego 1998 mającej na celu ułatwienie stałego wykonywania zawodu prawnika w państwie członkowskim innym niż państwo uzyskania kwalifikacji zawodowych, Dz.Urz. L 77 .

${ }_{1224}$ TSUE, Angelo Alberto Torresi i Pierfrancesco Torresi p. Consiglio dell'Ordine degli Avvocati di Macerata, C-58/13 i C-59/13, wyrok z 17 lipca 2014, pkt 3-12.

1225 Ibidem, pkt 13 . 


\section{Doprowadziło to sąd włoski do skierowania do TSUE dwu pytań:}

1) Czy art. 3 dyrektywy [98/5] w świetle ogólnego zakazu nadużywania prawa i art. 4 ust. 2 TUE dotyczącego poszanowania tożsamości narodowych, należy interpretować w taki sposób, że zobowiązuje on krajowe organy administracji do wpisania na listę prawników z innych państw członkowskich obywateli włoskich, którzy dopuścili się zachowań stanowiących nadużycie prawa Unii, oraz czy powyższy przepis wyklucza praktykę krajową umożliwiającą wspomnianym organom oddalenie wniosku o wpis na listę prawników z innych państw członkowskich, jeżeli występują obiektywne okoliczności pozwalające na stwierdzenie nadużycia prawa Unii, z zastrzeżeniem, po pierwsze, poszanowania zasady proporcjonalności i niedyskryminacji, a po drugie, prawa wszczęcia postępowania sądowego przez osobę zainteresowaną w przypadku ewentualnego naruszenia prawa przedsiębiorczości, a zatem kontroli sądowej działalności organów administracji? 2) W przypadku odpowiedzi przeczącej na [pierwsze pytanie], czy interpretowany w ten sposób art. 3 dyrektywy [98/5] należy uznać za nieważny w świetle art. 4 ust. 2 TUE, w zakresie w jakim pozwala on na obejście przepisów państwa członkowskiego, które uzależniają dostęp do zawodu prawnika od zdania egzaminu państwowego, jeżeli przepis wprowadzający taki egzamin jest zawarty w konstytucji tego państwa i należy do podstawowych zasad ochrony odbiorców usług świadczonych w ramach działalności zawodowej i prawidłowego administrowania wymiarem sprawiedliwości? ${ }^{1226}$.

Jeśli chodzi o pierwsze z pytań, TSUE nie dopatrzył się w zachowaniu skarżących nadużycia praw przysługujących im na mocy prawa unijnego ${ }^{1227}$. Nie odniósł się przy tym do kwestii art. 4 ust. 2 TUE w tym zakresie.

Zdaniem Trybunału celem dyrektywy jest ułatwienie stałego wykonywania zawodu adwokata w państwie członkowskim innym niż to, w którym zostały zdobyte kwalifikacje zawodowe, a sytuacja taka jak w przedmiotowej sprawie jest jedną $\mathrm{z}$ form jego realizacji ${ }^{1228}$.

Gdy zaś idzie o pytanie drugie, to TSUE nie podzielił stanowiska sądu włoskiego (Consiglio Nazionale Forense), zdaniem którego

skutkiem art. 3 dyrektywy 98/5, w zakresie, w jakim zezwala obywatelom włoskim uzyskującym tytuł zawodowy adwokata w państwie członkowskim innym niż Republika Włoska na wykonywanie zawodu w Republice Włoskiej, jest obejście art. 33 ust. 5 konstytucji włoskiej, który uzależnia dostęp do zawodu adwokata od pomyślnego złożenia egzaminu państwowego. W rezultacie, w zakresie, w jakim ten przepis prawa wtórnego Unii zezwala na obejście uregulowania stanowiącego część włoskiej

\footnotetext{
1226 Ibidem, pkt 14 .

1227 Ibidem, pkt 52.

${ }^{1228}$ Ibidem, pkt 47-49.
} 
tożsamości narodowej, narusza on art. 4 ust. 2 TUE, a tym samym należy stwierdzić jego nieważność ${ }^{1229}$.

TSUE dość wąsko zinterpretował znaczenie kwestionowanego art. 3 dyrektywy, które jego zdaniem sprowadza się do tego, że

art. 3 dyrektywy 98/5 dotyczy wyłącznie prawa do osiedlenia się w państwie członkowskim w celu wykonywania tam zawodu adwokata, posługując się tytułem zawodowym uzyskanym w państwie członkowskim pochodzenia. Przepis ten nie reglamentuje dostępu do zawodu adwokata ani wykonywania tego zawodu, posługując się tytułem zawodowym wydanym w przyjmującym państwie członkowskim ${ }^{1230}$.

Jak można z tego rozumieć, prawo unijne mogłoby ewentualnie być uznane za naruszające tożsamość konstytucyjną Republiki Włoskiej, gdyby zmieniało zasady, na jakich we Włoszech można uzyskiwać uprawnienia do wykonywania zawodu adwokata. Doprowadziło to TSUE do wniosku, nota bene - jak nie zgadzając się ze stanowiskiem wyrażonym przez Consiglio Nazionale Forense,

przyznał [sam - przyp. aut.] rząd włoski podczas rozprawy, [...] że w zakresie, w jakim art. 3 dyrektywa 98/5 zezwala obywatelom państwa członkowskiego uzyskującym tytuł zawodowy adwokata w innym państwie członkowskim na wykonywanie zawodu adwokata w państwie, którego są obywatelami, posługując się tytułem zawodowym uzyskanym w państwie członkowskim pochodzenia, nie może w żadnym razie, wpływać na podstawowe struktury polityczne i konstytucyjne ani istotne funkcje przyjmującego państwa członkowskiego w rozumieniu art. 4 ust. 2 TUE ${ }^{1231}$.

Na szczególne podkreślenie zasługuje fakt, że sposób, w jaki sformułowane zostało pytanie, na pierwszy rzut oka może zdawać się podobny do tego, który rekomendowany jest w tej pracy, sprowadzający się do potraktowania obowiązku poszanowania przez Unię tożsamości konstytucyjnej państw członkowskich, jako podstawy do zwolnienia tego państwa z pewnych, sprzecznych z nim obowiązków wynikających z prawa unijnego, w tym prawa pochodnego, nawet w sytuacjach, gdy jest ono przejawem daleko posuniętej harmonizacji.

Tym niemniej należy zwrócić uwagę, że pytania skierowane do TSUE w tej sprawie w sposób istotny różnią się od propozycji zawartej w tej pracy. Po pierwsze, nie zostały one sformułowane przez sąd konstytucyjny, ani nawet nie zostały poparte osadzoną w orzecznictwie sądu konstytucyjnego rekon-

\footnotetext{
1229 Ibidem, pkt 55.

${ }^{1230} \mathrm{Ibidem}$, pkt 56.

${ }^{1231} \mathrm{Ibidem}$, pkt 58.
} 
strukcją zakresu tożsamości konstytucyjnej danego państwa. Brak również jednoznacznego wskazania, w jaki sposób i jakim konstytucyjnym elementom tożsamości tego państwa prawo unijne miałoby się sprzeniewierzać. Jak wielokrotnie była już o tym mowa i co wynika z orzecznictwa TSUE i doktryny Simmenthal, sam fakt, że jakaś regulacja krajowa ma rangę konstytucyjną, to za mało, aby można było uznać ją za umożliwiającą uchylenie się tego państwa od obowiązku stosowania prawa unijnego, a tym bardziej, aby można było ją uznać za podstawę unieważnienia prawa unijnego. Co więcej, należy zwrócić uwagę, że pytania w tej sprawie sformułowane są w sposób, który mógłby wręcz sugerować, że to TSUE miałby dokonać rekonstrukcji tożsamości konstytucyjnej państw członkowskich niejako in abstracto - w oderwaniu od jej konkretnych elementów zidentyfikowanych przez sąd odsyłający, charakterystycznych dla Republiki Włoskiej - składających się ogólnie na tożsamość konstrukcyjną państw członkowskich. Jeśli nie miałby dokonać jej rekonstrukcji, to przynajmniej miałby ocenić czy ogólnie rzecz biorąc, regulacje dotyczące zasad dostępu do zawodu adwokata są elementem tożsamości państw członkowskich Unii, czy nie.

Tak sformułowane pytania wymykają się więc podejściu do tożsamości konstytucyjnej, jakie prezentowane jest w tej pracy. O ile nie można wykluczyć, aby unijne prawo pochodne naruszało tożsamość konstytucyjną wszystkich państw członkowskich jednocześnie, o tyle wydaje się, że właściwszym kontekstem oceny takiej sytuacji byłaby ocena takiego działania Unii przez pryzmat jej kompetencji, co zapewne zbliżałoby tę sytuację do działania ultra vires. Wydaje się, że należałoby takie prawo faktycznie uznać wtedy za nieważne - tak jak wnioskuje sąd odsyłający. Problematyka, której uwaga poświęcona jest w tej pracy, sprowadza się jednak do takich sytuacji, gdy unijne prawo pochodne sprzeniewierza się unikalnym elementom tożsamości konstytucyjnej jakiegoś państwa członkowskiego (w dodatku koncentruje się jedynie na tych elementach tożsamości konstytucyjnej, jakimi są wyższe niż unijne standardy ochrony praw człowieka), co nie ma być podstawą do unieważnienia prawa unijnego, lecz jedynie jego niestosowania w tym państwie, w zakresie, w jakim jest z tożsamością konstytucyjną tego państwa niezgodne. Wydaje się więc, że sposób, w jaki zostały sformułowane pytania w tej sprawie i poziom niedookreślenia w oparciu o partykularny - włoski - wymiar regulacji unijnych w kontekście ich sprzeczności z tożsamością konstytucyjną Republiki Włoskiej oraz ogólnounijny skutek, jakim jest unieważnienie dyrektywy, do jakiego miałoby prowadzić stwierdzenie niezgodności z tak generalnie pojętym obowiązkiem poszanowania przez Unię tożsamości konstytucyjnej państw członkowskich, znacznie odróżniają zachowanie sądu w tej sytuacji, od postulowanego w dalszej części tej pracy. 
Co jednak warto zauważyć, do takiej, jak zostało to określone powyżej, ogólnounijnej koncepcji tożsamości konstytucyjnej państw członkowskich, powiązanej z zakresem podziału kompetencji między tymi pierwszymi a Unią, nolens volens zbliżającą rozumienie obowiązku poszanowania tożsamości konstytucyjnej państw członkowskich do doktryny ultra vires, nawiązał TSUE w swym niedawnym wyroku w sprawie Remondis ${ }^{1232}$, dotyczącej definicji zamówienia publicznego w prawie unijnym. Trybunał przypomniał na marginesie tej sprawy, że "podział kompetencji w państwie członkowskim jest chroniony na podstawie art. 4 ust. 2 TUE, zgodnie z którym Unia powinna uszanować tożsamość narodową państw członkowskich, nierozerwalnie związaną z ich podstawowymi strukturami politycznymi i konstytucyjnymi, w tym $\mathrm{w}$ odniesieniu do samorządu regionalnego i lokalnego"1233, a także, że

nadana przez art. 4 ust. 2 TUE ochrona dotyczy również reorganizacji kompetencji wewnątrz państwa członkowskiego [...]. Takie reorganizacje, mogące przyjąć postać przeniesienia kompetencji z jednego organu władzy publicznej na drugi, zarządzonego przez organ wyższej rangi, lub dobrowolnego przekazania sobie kompetencji przez organy władzy publicznej, mają taki skutek, że organ uprzednio odpowiedzialny zostaje zwolniony z obowiązku i prawa realizacji danego zadania publicznego lub się od nich uwalnia, a innemu organowi ten obowiązek i to prawo zostają przydzielone ${ }^{1234}$.

Potraktowanie art. 4 ust. 2 TUE jako wzmocnienia przepisów dotyczących podziału kompetencji między Unię a państwa członkowskie i zasady pomocniczości pojawiło się niejako en passant, a więc bez jakiegokolwiek rozwinięcia czy pogłębienia również w wyroku w sprawie Albers ${ }^{1235} \mathrm{i}$ jeszcze mniej jednoznacznie w wyroku w sprawie Gmina Wrocław ${ }^{1236}$.

Takie podejście do rozumienia art. 4 ust. 2 TUE wydaje się jednak dość nowe i niekoniecznie najtrafniejsze czy też najpotrzebniejsze, w obliczu istnienia możliwości uczynienia tego samego, do czego mógłby w jego ramach służyć art. 4 ust. 2 TUE, w ramach kontroli unijnego prawa pochodnego przez pryzmat zgodności z prawem pierwotnym, w którym kompetencje Unii zostały wyrażone. Jak wiadomo:

1232 TSUE, Remondis GmbH \& Co. KG Region Nord p. Region Hannover, C-51/15, wyrok z 21 grudnia 2016.

${ }^{1233}$ Ibidem, pkt 40.

1234 Ibidem, pkt 41.

1235 TSUE, Digibet Ltd i Gert Albers p. Westdeutsche Lotterie GmbH \& Co. OHG, C-156/13, wyrok z 12 czerwca 2014, pkt 34 .

1236 TSUE, Gmina Wrocław p. Ministrowi Finansów, C-276/14, wyrok z 29 września 2015, pkt 21-22, 40. 
z pespektywy traktatów, środki do sprawowania kontroli nad respektowaniem przez instytucje unijne zasady przyznania znajdują się w dyspozycji Trybunału Sprawiedliwości [...]. To on generalnie zapewnia "poszanowanie prawa w wykładni i stosowaniu Traktatów" (art. 19 ust. 1 TUE), a ponadto kontroluje legalność aktów unijnych, rozpatrując skargi podnoszące m.in. zarzut braku kompetencji (art. 263 Traktatu o funkcjonowaniu Unii Europejskiej) oraz rozstrzygając o ważności tych aktów w trybie prejudycjalnym (art. 267 TFUE) $)^{1237}$.

O ile można by takie podejście uznać za pewną pomocniczą i dopuszczalną formę swoistej samokontroli Unii przez jej własny sąd pod kątem, czy nie wykracza ona poza swoje kompetencje, o tyle nie powinno to oznaczać, że jest to jedyne dopuszczalne użycie tożsamości konstytucyjnej, szczególnie w obliczu bogatego orzecznictwa, związanego z dopuszczalnością derogacji od unijnych swobód w oparciu o tożsamość konstytucyjną państw członkowskich, czy też w kontekście propozycji związanych z możliwościami zastosowania art. 4 ust. 2 TUE, formułowanych w tej pracy, co jak się wydaje, znacznie lepiej odpowiada funkcji tego przepisu.

Kwestie związane z tożsamością konstytucyjną i obowiązkiem jej poszanowania przez Unię pojawiały się też ostatnio przez Sądem. Nie miały jednak decydującego znaczenia dla rozstrzyganej sprawy, dotyczącej odmowy przez Komisję rejestracji inicjatywy obywatelskiej w ramach polityki spójności, związanej z chęcią zachowania charakteru kulturowego regionów, których cechy etniczne, kulturowe, religijne lub językowe różnią się od cech regionów otaczających. Można odnieść wrażenie, że do kwestii tożsamości konstytucyjnej Sąd odniósł się niejako 'na zapas' - wykluczając ewentualne powoływanie się w tej sprawie na tożsamość konstytucyjna, a przynajmniej wyrażając swoje zdanie na wypadek takiej ewentualności.

Zgodnie z art. 4 ust. 2 TUE, który stanowi w szczególności, że Unia szanuje tożsamość narodową państw członkowskich, nierozerwalnie związaną z ich podstawowymi strukturami politycznymi i konstytucyjnymi, w tym w odniesieniu do samorządu regionalnego i lokalnego, pojęcie „regionu” w rozumieniu art. 174-178 TFUE należy zdefiniować z poszanowaniem rzeczywistej sytuacji politycznej, administracyjnej i instytucjonalnej. Jednakże jednostki administracyjne istniejące w ramach różnych państw członkowskich wykazują między sobą duże zróżnicowanie, zarówno na płaszczyźnie demograficznej i geograficznej, jak i w odniesieniu do ich kompetencji. Przyjęcie unijnych aktów prawnych w dziedzinie polityki spójności wymaga zaś, by prawodawca Unii dysponował porównywalnymi danymi co do poziomu rozwoju każdej z tych jednostek administracyjnych ${ }^{1238}$.

${ }^{1237}$ K. Wójtowicz, Zachowanie..., s. 4.

${ }^{1238}$ Sąd, Balázs-Árpád Izsák i Attila Dabis p. Komisji Europejskiej, T-529/13, wyrok z 10 maja 2016, pkt 70 . 


\subsubsection{Pytania prejudycjalne trybunałów konstytucyjnych państw członkowskich dotyczące obowiązku poszanowania tożsamości narodowej/konstytucyjnej ich państw}

Wśród spraw, w których TSUE ostatecznie nie zastosował art. 4 ust. 2 TUE i obowiązku poszanowania tożsamości konstytucyjnej państw członkowskich na szczególną uwagę zasługują dwa wyroki w sprawach, w których pytania prejudycjalne do TSUE skierowały niemiecki i włoski trybunały konstytucyjne. Mam tu na myśli, po pierwsze, sprawę Gauweiler ${ }^{1239}$, która godna jest uwagi, choćby ze względu na sam fakt, że stanowi pierwszy w historii FTK przypadek skierowania pytania prejudycjalnego do TSUE ${ }^{1240}$. Ponadto, co jeszcze ważniejsze z perspektywy tej pracy, sprawa ta jest jaskrawym przykładem „cichej batalii” o „prawo ostatniego słowa” między FTK a TSUE w procesie ustalania znaczenia tożsamości konstytucyjnej ${ }^{1241}$. Po drugie zaś mam na myśli wyrok TSUE zamykający (przynajmniej na razie ze strony Unii) tzw. sagę Taricco ${ }^{1242}$, która stanowi równie wyraźny przejaw powyższej tendencji. Obie te sprawy, a właściwie sekwencja orzeczeń z nimi związanych, zostaną omówione poniżej i umieszczone w szerszym nieco kontekście pełzającego buntu orzeczniczego przeciwko TSUE, w którym uczestniczą również inne sądy konstytucyjne (jak czeski) czy najwyższe (jak duński) państw członkowskich Unii. O czym również będzie mowa.

W pracy tej pomijam prezentację i analizę przejawów podejścia do kwestii tożsamości konstytucyjnej i obowiązku jej poszanowania przez Unię, nawet jeśli formułowane byłyby przez sądy konstytucyjne państw członkowskich, które zupełnie wymykają się kooperacyjnemu modelowi, jaki budowany jest w tej pracy i ich analiza niewiele by wnosiła do jego konceptualizacji. Mam tu na myśli np. wyrok węgierskiego Trybunału Konstytucyjnego (Alkotmánybíróság), w którym wpisał się on w tendencję traktowania kontroli działań Unii przez sąd konstytucyjny jako formy kontroli ultra vires, obok kontroli przez pryzmat zachowania suwerenności ${ }^{1243}$. Uczynił to w sposób pozbawiony nawet próby nawiązania relacji z TSUE czy osadzenia kwestii

${ }^{1239}$ TSUE, Peter Gauweiler i in. p. Deutscher Bundestag, C-62/14, wyrok z 16 czerwca 2015.

${ }^{1240}$ FTK dołączył tym samym do grona sądów konstytucyjnych, które zdecydowały się na taki krok, a lista których w ostatnich latach istotnie się wydłużyła - o jego odpowiedniki z Litwy, Włoch, Hiszpanii, Francji, Słowenii i Polski. Mimo wszystko trudno jednak mówić o wysypie pytań kierowanych przez tego rodzaju sądy. Jest to nadal raczej praktyka niecodzienna z wyjątkiem przypadków sądów konstytucyjnych Austrii i Belgii (D. Paris, Constitutional..., s. 795).

1241 A. Kustra, Kelsenowski..., s. 293.

1242 TSUE, Postępowanie karne przeciwko M.A.S. i M.B, C-42/17, wyrok z 5 grudnia 2017. ${ }^{1243}$ Węgierski TK, sprawa 22/2016, wyrok z 30 listopada 2016. 
w szerszym kontekście prawa unijnego i wynikających stąd zobowiązań ciążących na Węgrzech ${ }^{1244}$.

\subsubsection{Sprawa Gauweiler}

Sprawa ta koncentrowała się wokół całej serii pytań, dotyczących ważności decyzji Rady Prezesów Europejskiego Banku Centralnego (EBC) z 6 września 2012 w sprawie szeregu szczegółów technicznych bezwarunkowych transakcji monetarnych Eurosystemu prowadzonych na wtórnych rynkach obligacji skarbowych (zwanych dalej "decyzjami w sprawie OMT") i wykładni art. 119 TFUE, 123 TFUE i 127 TFUE, a także art. 17-24 protokołu (nr 4) w sprawie statutu Europejskiego Systemu Banków Centralnych i Europejskiego Banku Centralnego ${ }^{1245}$. Najkrócej rzecz ujmując, dotyczyły one zgodności OMT z prawem unijnym $^{1246}$. W samych pytaniach brak odwołania do pojęcia tożsamości konstytucyjnej. Pojawia się ono jednak w uzasadnieniu odesłania, w dość specyficznym charakterze. Jak słusznie zauważa Aleksandra Kustra:

FTK z rozmysłem zrezygnował [...] ze wskazania w odesłaniu prejudycjalnym również art. 4(2) TUE jako unijnego wzorca kontroli legalności programu OMT. Wyjaśniając tę decyzję, stwierdził, że art. 4(2) TUE nie ma takiego samego zakresu normatywnego ani funkcji jak art. 79(3) UZ (przepisy niezmienialne UZ uznawane za trzon tożsamości konstytucyjnej RFN). Ponadto FTK zaznaczył, że tożsamość konstytucyjną traktuje jako kategorię najwyższej rangi, podczas gdy traktatowa "tożsamość narodowa" ma charakter jednej z wielu konkurencyjnych wobec siebie wartości, które ETS waży w swych orzeczeniach. Innymi słowy, dla FTK "tożsamość konstytucyjna” to swego rodzaju "as w rękawie" ${ }^{\prime 247}$.

Potraktował ją jako czysto wewnętrzną kategorię prawna, opartą na niemieckiej konstytucji, a szczególnie, jak to podkreślał od lat w swym orzecznic-

${ }^{1244}$ Więcej - patrz np.: G. Halmai, National(ist) constitutional identity?Hungary's road to abuse constitutional pluralism, EUI Working Paper, LAW 2017, nr o8; idem, The Hungarian Constitutional Court and Constitutional Identity, VerfBlog, 2017/1/10, [online] <http://verfassungsblog. de/the-hungarian-constitutional-court-and-constitutional-identity/> [dostęp: 5.02.2019]; por. np.: T. Drinóczi, The Hungarian Constitutional Court on the Limits of EU Law in the Hungarian Legal System, Int'1 J. Const. L. Blog, Dec. 29, 2016, [online] <http://www.iconnectblog.com/2016/12/ the-hungarian-constitutional-court-on-the-limits-of-eu-law-in-the-hungarian-legal-system $>$ [dostęp: 5.02.2019].

${ }^{1245}$ Protokół ( $\mathrm{nr} 4$ ) w sprawie statutu Europejskiego Systemu Banków Centralnych i EBC, Dz.Urz. C 326 z 26 października 2012.

1246 TSUE, Peter Gauweiler i in. p. Deutscher Bundestag, C-62/14, wyrok z 16 czerwca 2015, pkt 10 .

1247 A. Kustra, Kelsenowski..., s. 293-294. 
twie, na jej wieczystym charakterze i zakresie. Dał też wyraźnie do zrozumienia, że to on i tylko on jest kompetentny do orzekania w materii tożsamości konstytucyjnej Niemiec i nie musi w tej kwestii współpracować z TSUE. De facto FTK postawił TSUE ultimatum: „stwierdźcie, że OMT jest ultra vires, albo my to zrobimy"1248.

Z uzasadnienia wniosku o odpowiedź na pytanie prejudycjalne, jaki wystosował FTK ${ }^{1249}$ i dość obszernego powołania się w nim na orzecznictwo innych sądów konstytucyjnych państw członkowskich można by odnieść wrażenie, że FTK reprezentuje powszechne w Europie przekonanie tego rodzaju sądów co do rozdzielenia pojęć tożsamości konstytucyjnej i tożsamości narodowej z art. 4 ust. 2 TUE i poddania tej pierwszej jedynie jurysdykcji trybunału krajowego i powiązania jej z doktryną ultra vires. Tymczasem, sądy konstytucyjne państw członkowskich wcale nie są zgodne co do zasadności aż tak jednoznacznego podejścia ${ }^{1250}$. Próba zaproponowania podejścia bardziej zniuansowanego i kooperacyjnego, oparta na orzecznictwie polskiego TK, jest też celem powziętym w tej pracy. Przy czym, co jeszcze raz należy podkreślić, przyjęcie tej propozycji wcale nie musi oznaczać ostatecznej rezygnacji sądu konstytucyjnego z prawa do wypowiedzenia „ostatniego słowa” w kontekście nieposzanowania tożsamości konstytucyjnej i ewentualnego określenia tego jako działanie ultra vires. Odsuwa jednak ten moment, a także sprzyja zapobieganiu ewentualnej konieczności jego postawienia. Traktuje ten krok jako ostateczność - gdy zarysowywane w tej pracy, jak i ewentualnie inne metody kooperacyjne zawiodą. Na konflikt z prawem unijnym i TSUE, w oparciu o doktrynę ultra vires może ewentualnie nadejść czas później. Po wykorzystaniu metod kooperacyjnych i ich niepowodzeniu wybór takiego rozwiązania przez TK czy odpowiedni sąd krajowy innego państwa członkowskiego byłby znaczenie łatwiejszy do uznania - jako wyraz swoistego konstytucyjnego non possumus czy też no pasarán - niż zastosowanie go od razu - bez próby podjęcia jurydycznego dialogu i dojścia w jego ramach do akceptowalnego z punktu widzenia prawa Unii, jak i z punktu widzenia prawa krajowego wspólnego rozwiązania.

Dość jednoznacznie krytyczną ocenę stanowiska zaprezentowanego w tej sprawie przez FTK sformułował w swej opinii w sprawie Rzecznik Generalny TSUE Pedro Cruz Villalón, który mimo wszystko docenił fakt, że kierując swe

${ }^{1248}$ T. Tuominen, C-62/14 Gauweiler: How the ECJ Avoided Stockholm Syndrome but Risks either a Standoff or a Stalemate, [online] <https://acelg.blogactiv.eu/2015/10/26/c-6214-gauweiler-how-the-ecj-avoided-stockholm-syndrome-but-risks-either-a-standoff-or-a-stalemate/> [dostęp: 5.02.2019].

${ }^{1249}$ FTK, 2 BvR 2728/13, 2 BvR 2729/13, 2 BvR 2730/13, 2 BvR 2731/13, 2 BvE 13/13, orzeczenie z 14 stycznia 2014.

${ }^{1250}$ M. Clases, J.-H. Reestman, The Protection of National Constitutional Identity and the Limits of European Integration at the Occasion of the Gauweiler Case , "German Law Journal” 2015, nr 16 (4). 
pierwsze odesłanie do TSUE, FTK przekroczył pewną granicę, wpisując się w tendencję "zagęszczania się" unijnej przestrzeni prawnej, co skutkuje coraz szerszą współpracą między TSUE a sądami konstytucyjnymi państw członkowskich za pośrednictwem procedury z art. 267 TFUE ${ }^{1251}$. Jak gorzko jednak zauważył: „Równocześnie [...] wstępny fragment postanowienia odsyłającego podkreśla wyraźną »wyjątkowość« takiego działania BVerfG. W żadnym razie nie jest oczywiste, czy wniesienie przedmiotowego odesłania prejudycjalnego powinno być postrzegane jako element normalizacji we wskazanym przed chwilą rozumieniu"1252. W swej opinii rzecznik zaprezentował niejako drugi biegun podejścia względem stanowiska FTK do rozumienia i stosowania w ramach Unii pojęcia tożsamości konstytucyjnej, charakterystyczny dla Unii, która uznaje tożsamość konstytucyjną za element traktatowego pojęcia tożsamości narodowej z art. 4 ust. 2 TUE. „Rzecznik generalny odniósł się [...] krytycznie do sugerowanej przez FTK możliwości przeprowadzenia kontroli konstytucyjności programu OMT z perspektywy zachowania tożsamości konstytucyjnej Niemiec. Villalón określił stanowisko FTK zajęte w odesłaniu prejudycjalnym mianem próby »rezerwacji przez FTK tożsamości« dla siebie" ${ }^{\prime 253}$.

Dostrzegł, że odesłanie skierowane przez BVG do TSUE zostało sformułowane „W ramach tego, co [FTK] nazywa kontrolą ultra vires aktów Unii wywierających wpływ na »tożsamość konstytucyjną« Republiki Federalnej Niemiec. BVerfG wychodzi z założenia, że kwestionowany akt EBC jest bezprawny w świetle krajowego prawa konstytucyjnego, a nawet prawa Unii, natomiast przed dokonaniem dalszej oceny przekazuje sprawę do Trybunału Sprawiedliwości, aby ten osądził akt z punktu widzenia prawa Unii"1254. FTK wyraźnie wpisał swe pytania $\mathrm{w}$ wypracowane przez siebie na przestrzeni wielu już lat „orzecznictwo, na podstawie którego sąd ten bada zgodność z Konstytucją aktów instytucji i organów Unii wynikających z oczywistego przekroczenia kompetencji oraz aktów naruszających »tożsamość konstytucyjną《 objętą »klauzulą wieczności w wrażoną w art. 79 ust. 3 Ustawy Zasadniczej z Bonn"1255. Widzi się więc on jako ostateczny arbiter tej kwestii i nie ma większego znaczenia zastrzeżenie, że tego rodzaju kontrola może mieć miejsce tylko jeśli przekro-

${ }^{1251}$ TSUE, Peter Gauweiler i in. p. Deutscher Bundestag, C-62/14, opinia Rzecznika Generalnego Pedra Cruza Villalóna przedstawiona w dniu 14 stycznia 2015, pkt 40; por. np.: M. Claes, Luxembourg, Here We Come? Constitutional Courts and the Preliminary Reference Procedure, "German Law Journal" 2015, nr 16 (4); A. Kustra, The first....

1252 TSUE, Peter Gauweiler i in. p. Deutscher Bundestag, C-62/14, opinia Rzecznika Generalnego Pedra Cruza Villalóna przedstawiona w dniu 14 stycznia 2015, pkt 41.

${ }^{1253}$ A. Kustra, Kelsenowski..., s. 293.

1254 TSUE, Peter Gauweiler i in. p. Deutscher Bundestag, C-62/14, opinia Rzecznika Generalnego Pedra Cruza Villalóna przedstawiona w dniu 14 stycznia 2015, pkt 5.

${ }^{1255}$ Ibidem, pkt 16. 
czenie przez Unię kompetencji miałoby być oczywiste, przy możliwie jak najprzychylniejszym podjęciu do prawa Unii i jedynie, gdyby dotyczyło naruszeń wystarczająco istotnych w kontekście działania przez Unię poza zakresem jej kompetencji (ultra vires) ${ }^{1256}$.

Pierwszy problem z zaprezentowanym przez FTK odesłaniem, jaki dostrzegł Rzecznik, określił mianem funkcjonalnego ${ }^{1257}$. Sprowadzałby się on do tego, że odpowiedź udzielona przez TSUE na pytania skierowane doń przez sąd odsyłający nie miałaby charakteru rozstrzygającego. Jak wynika ze stanowiska FTK, „po zastosowaniu z wynikiem pozytywnym kryterium prawa Unii, do tego samego spornego aktu można ewentualnie zastosować inne kryterium ważności, co leży w gestii BVerfG, a mianowicie konstytucję krajową ${ }^{\prime 258}$. Konkretnie chodzi o zastosowanie przez FTK kryteriów tożsamości konstytucyjnej i działania przez Unię ultra vires ${ }^{1259}$. Pomijając na moment inne konsekwencje, jakie wiązałyby się z przyjęciem tego rodzaju rozumowania, podważałoby ono funkcję pytania prejudycjalnego. Jak zauważył Rzecznik: „skoro sąd krajowy zastrzega sobie ostatnie słowo w kwestii ważności aktu Unii, odesłanie prejudycjalne miałoby w takim przypadku charakter wyłącznie doradczy i w rezultacie doszłoby do podważenia jego funkcji w systemie środków zaskarżenia przewidzianym przez traktaty"1260. Doprowadziło go to do wniosku, że tak sformułowanym pytaniem TSUE w ogóle nie powinien się zajmować. „Podsumowując, sąd krajowy nie powinien móc zwrócić się do Trybunału Sprawiedliwości z odesłaniem prejudycjalnym, jeżeli zawiera ono w swej istocie lub założeniu możliwość postąpienia wbrew uzyskanej odpowiedzi. Nie powinno być to dozwolone, ponieważ nie jest to przypadek, który można by uznać za objęty art. 267 TFUE"1261.

Gdy zaś chodzi o samą tożsamość konstytucyjną, to Rzecznik nie zgadza się z podziałem ról, jaki w zakresie rozstrzygania o jej ewentualnym naruszeniu proponuje FTK, a który w powiązaniu z kontrolą ultra vires ${ }^{1262}$, miałby się sprowadzać do tego, że „W ramach istniejącej relacji opartej na współpracy do Trybunału Sprawiedliwości należy dokonanie wykładni rozpatrywanego środka [chodzi o kwestionowane prawo unijne - przyp. aut.]. Do BVerfG należy natomiast określenie treści nienaruszalnego rdzenia tożsamości konstytucyjnej i weryfikacja, czy rozpatrywany środek (w wykładni ustalonej przez Trybunał)

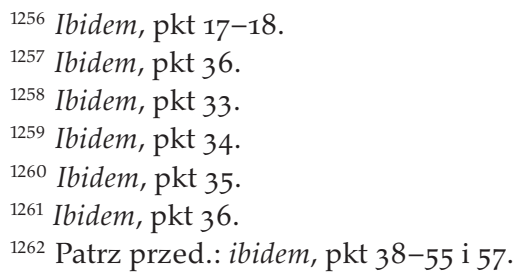


ingeruje w tę treśćn ${ }^{\prime 1263}$. Przyjęcie tego rodzaju rozumowania miałoby zdaniem Rzecznika podważać istotę samej Unii i prowadzić do jej dezintegracji. Jak podkreślił:

wydaje mi się zadaniem niemal niemożliwym zachowanie tej Unii, w dzisiejszej jej postaci, jeżeli zamierza się podporządkować ją bezwzględnemu, ledwie sprecyzowanemu i w praktyce podlegającemu swobodnemu uznaniu każdego z państw zastrzeżeniu, umiejscowionemu w kategorii zwanej „tożsamością konstytucyjną", tym bardziej jeżeli twierdzi się, że jest ona odmienna od "tożsamości narodowej”, o której mowa w art. 4 ust. 2 TUE ${ }^{1264}$.

Przy dwudziestu ośmiu państwach członkowskich, wyposażonych w tak blankietową możliwość kwestionowania prawa Unii, zostałoby ono zdaniem Rzecznika ostatecznie zdegradowane do rangi prawa drugiej kategorii ${ }^{1265}$.

Drugi zasadniczy argument Rzecznika osadzony jest również w samej istocie Unii. Jak podkreślił, tożsamość Unii jest w istocie rzeczy funkcją tożsamości konstytucyjnych państw członkowskich. Przypomina on, że:

Trybunał Sprawiedliwości posługuje się od bardzo dawna pojęciem „wspólnych tradycji konstytucyjnych" państw członkowskich w momencie, gdy poszukuje inspiracji dla systemu wartości, na którym opiera się Unia [...]. W szczególności w tych wspólnych tradycjach konstytucyjnych Trybunał Sprawiedliwości bardzo chętnie poszukiwał fundamentu dla swoistej kultury prawnej, kultury praw Unii. Unia uzyskała dzięki temu nie tylko charakter wspólnoty prawa, lecz również „wspólnoty kultury konstytucyjnej" [...]. Wskazana wspólna kultura konstytucyjna jest częścią wspólnej tożsamości Unii, z tym istotnym w moim mniemaniu skutkiem, że tożsamość konstytucyjna każdego państwa członkowskiego, oczywiście mająca swą specyfikę w koniecznym zakresie, nie może, mówiąc oględnie, być oddalona o lata świetlne od wspomnianej wspólnej kultury konstytucyjnej. Wręcz przeciwnie, właściwie rozumiane otwarte podejście do prawa Unii powinno rodzić w średnim i długim okresie zasadę podstawowej zbieżności pomiędzy tożsamością konstytucyjną Unii oraz poszczególnych państw członkowskich ${ }^{1266}$.

Na gruncie tej uwagi Rzecznika można szczególnie dobitnie zauważyć motywację kryjącą się za tezą tej pracy. Ma ona prowadzić do możliwie integracyjnego podejścia do obowiązku poszanowania przez Unię tożsamości konstytucyjnej państw członkowskich, która przecież zasadniczo jest wspólna. Obowiązek ten nie ma się więc przejawiać w tym, co parafrazując Zygmunta

\footnotetext{
${ }^{1263}$ Ibidem, pkt 56.

1264 Ibidem, pkt 59.

1265 Ibidem, pkt 60.

1266 Ibidem, pkt 62.
} 
Freuda ${ }^{1267}$, nazwać by można pielęgnowaniem narcyzmu małych różnic. Pewien zakres tych różnic jest jednak faktem i jest doniosły. Pozostaje więc konieczność znalezienia jak najlepszej metody ich katalizowania. Jedną z takich metod ma być współpraca zgodna z modelem zarysowanym w tej pracy.

Mówiąc krótko:

W opinii rzecznika generalnego zauważalne jest dążenie do pozbawienia pojęcia tożsamości konstytucyjnej autonomicznego sensu poprzez wskazanie, że nie może być ona pojmowana inaczej niż tożsamość narodowa z art. 4(2) TUE. Ma to uzasadniać m.in. okoliczność, że tradycje konstytucyjne wspólne dla państw członkowskich UE są jedną z wartości tworzących aksjologiczny system, na którym oparto funkcjonowanie UE. Opinia Villalóna dobrze ilustruje stanowisko, zgodnie z którym to do ETS należy ostatnie słowo w procesie ustalania znaczenia tożsamości konstytucyjnej jako jednego z elementów kształtujących znaczenie normatywne art. 4(2) TUE ${ }^{1268}$.

Jak zauważała, jeszcze przed rozstrzygnięciem sprawy przez TSUE, Aleksandra Kustra - jest oczywiste, że podejście takie, jak zaprezentowane przez FTK

budzi sprzeciw ETS, który w postulowanym przez FTK rozumieniu kategorii „tożsamości konstytucyjnej" dostrzega poważne zagrożenie dla swej pozycji jako sądu ostatniego słowa w ramach UE. W tym kontekście sprawę Gauweiler można porównać do sprawy Internationale Handelsgesellschaft. To, czy będziemy mieć do czynienia z kolejnym Solange I (tym razem dotyczącym unijnego standardu przestrzegania tożsamości konstytucyjnej państw członkowskich), pozostaje na razie pytaniem otwartym ${ }^{1269}$.

Wyrok TSUE ostatecznie jednak nie doprowadził do rozstrzygnięcia tych wątpliwości, podobnie zresztą jak późniejsze orzeczenie FTK, gdy sprawa już do niego wróciła, po uzyskaniu odpowiedzi TSUE. Trybunał nie doszedł do wniosku o niezgodności OMT z unijnym prawem pierwotnym ${ }^{1270}$, obwarowując to jednak pewnymi warunkami co do jego rozumienia, które wszakże wcale nie pokrywają się z kwestiami, na które uwagę zwracał w swym odesłaniu FTK. TSUE prawie też nie odniósł się do kwestii tożsamości konstytucyjnej i obowiązku jej poszanowania. Zauważywszy, że na poparcie skarg rozpatrywanych w postępowaniu głównym skarżący „podnieśli, po pierwsze, że decyzje w sprawie OMT stanowią łącznie akt ultra vires, ponieważ nie są one objęte mandatem EBC i są sprzeczne $z$ art. 123 TFUE, oraz po drugie, że decyzje te naruszają zapisaną w Grundgesetz (niemieckiej ustawie zasadniczej) zasadę

1267 Z. Freud, Człowiek imieniem Mojżesz a religia monoteistyczna, Warszawa 1994.

${ }^{1268}$ A. Kustra, Kelsenowski..., s. 293.

1269 Ibidem, s. 294.

1270 TSUE, Peter Gauweiler i in. p. Deutscher Bundestag, C-62/14, wyrok z 16 czerwca 2015, pkt 128 
demokracji, ograniczając w ten sposób niemiecką tożsamość konstytucyjną"1271, do kwestii odniósł się jedynie na marginesie swego rozstrzygnięcia. Niejako mimochodem, i to $\mathrm{w}$ dodatku nie 'od siebie', lecz $\mathrm{w}$ ramach rekonstrukcji stanowiska rządu włoskiego zauważył, że:

spór w postępowaniach głównych jest pozorny i został sztucznie wykreowany. Skargi w postępowaniach głównych są bowiem bezprzedmiotowe z powodu braku wykazania, że dla skarżących w postępowaniach głównych ochrona prewencyjna jest niezbędna lub że grozi im szkoda, ale również dlatego, że podnoszona bezczynność Deutscher Bundestag nie daje się w żaden sposób jako taka zaklasyfikować. Skargi te ponadto powinny zostać uznane przez sąd odsyłający za niedopuszczalne, gdyż dotyczą one aktów Unii o charakterze nieustawodawczym. Dodatkowo sprawa będąca przedmiotem postępowań głównych nie podnosi w rzeczywistości kwestii oczywistego przekroczenia kompetencji dotyczącej niemieckiej tożsamości konstytucyjnej ${ }^{1272}$.

Ostrożnie odpowiadając na pytanie co do zgodności OMT z prawem Unii, wydaje się więc, że TSUE w pewnym sensie uniknął wdawania się w rozważania związane z niemiecką tożsamością konstytucyjną.

FTK z kolei obszernie i wielokrotnie odwoływał się w uzasadnieniu swego wyroku, wydanego już po uzyskaniu odpowiedzi od TSUE, do pojęcia tożsamości konstytucyjnej ${ }^{1273}$. Ostatecznie jednak nie orzekł o niezgodności OMT z niemiecką konstytucją i nie stwierdził naruszenia niemieckiej tożsamości konstytucyjnej przez działanie Unii i jej Trybunału ultra vires. Orzeczenie FTK jest bardzo złożone. Najważniejsze z perspektywy tej pracy jest to, że FTK zaznaczywszy, że jego ocena OMT pod kątem ultra vires byłaby inna niż ta dokonana przez TSUE na gruncie prawa unijnego, stwierdził, że ta ostatnia jednak jest do zaakceptowania i nawet jeśli można by ją uznać za ultra vires, to nie w sposób oczywisty. FTK oparł się więc na dobrze znanym wyroku, wydanym przez siebie na gruncie sprawy Honeywell, gdzie stwierdził, że działanie Unii może być przez niego uznane za ultra vires tylko wtedy, gdy przekroczenie przez Unię kompetencji ma charakter oczywisty ${ }^{1274}$. Zatem jeśli OMT wejdzie w życie, będzie musiało podlegać ciągłemu monitoringowi przez niemieckie organy, co może ostatecznie doprowadzić do kolejnego orzeczenia FTK w tej sprawie. Jeśli jednak będzie funkcjonowało w zgodzie w wyrokiem TSUE i zawartymi w nim wytycznymi, nie będzie mogło być uznane za przejaw wykroczenia Unii poza zakres jej kompetencji, a więc za działanie ultra vires. W pewnym sensie więc

${ }^{1271}$ Ibidem, pkt 6.

1272 Ibidem, pkt 19.

${ }^{1273}$ FTK, 2 BvR 2728/13, 2 BvR 2729/13, 2 BvR 2730/13, 2 BvR 2731/13, 2 BvE 13/13, orzeczenie z 21 czerwca 2016.

${ }^{1274}$ FTK, 2 BvR 2661/o6, orzeczenie z 6 lipca 2010. 
FTK wycofał się, a przynajmniej nie wypełnił swej groźby, zawartej w odesłaniu do TSUE, tym niemniej przyjmując wyrok TSUE, prolongował czy też odroczył możliwość jej spełnienia.

Sprawa ta zakończyła się więc, rzec można remisem, a może wręcz patem. W każdym razie z pewnością nie posunęła do przodu rozumienia pojęcia tożsamości konstytucyjnej ani nie przechyliła szali na korzyść żadnej ze stron, jeśli pozostaniemy w paradygmacie sporu o „ostatnie słowo”. Sprawa ta stała się w dużej mierze - jak określiła to Aleksandra Kustra - „polem bitwy” czy raczej poligonem do zaprezentowania pewnych, jak się wydaje z perspektywy propozycji formułowanych w tej pracy, zbyt jednostronnych interpretacji przedmiotowego problemu - a więc blankietowej rezerwacji tej tematyki przez sąd krajowy w ramach, w pewnym związku z doktryną ultra vires, jaka to interpretacja zdaje się wyłaniać ze stanowiska BVG, oraz próby pozbawienia pojęcia tożsamości konstytucyjnej autonomicznego sensu i poddania go całkowicie pod jurysdykcję TSUE, jaka to interpretacja zdaje się wyłaniać ze stanowiska Rzecznika Villalóna. Co gorsza jednak, sprawa ta nie została wykorzystana do próby znalezienia kooperacyjnego, a nie konfliktowego rozwiązania kwestii podejścia do tożsamości konstytucyjnej. Potwierdziła ona tendencję do przeciągania liny ostatniego słowa między TSUE a krajowymi sądami konstytucyjnymi państw członkowskich, w tym wypadku FTK.

Bez względu jak sprawa ta, przynajmniej na ten moment ${ }^{1275}$, się zakończyła - bez ostatecznego zwycięstwa żadnej ze stron - ani bez względu na to, jak będą kończyć się podobne sprawy, jeśli oba Trybunały kontynuować będą podejście podobne do zaprezentowanego na jej gruncie, należy silnie podkreślić, że obranie drogi takiej, jak proponowane w tej pracy, mogłoby pomóc doprowadzić do znacznie bardziej przejrzystego, funkcjonalnego i sprzyjającego integracji europejskiej, a nie izolacjonistycznego rozwiązania.

Gdyby bowiem FTK, zamiast zastrzegania sobie możliwości badania OMT pod kątem zgodności z niemiecką tożsamością konstytucyjna, po tym, gdy TSUE, niejako w ciemno - nie znając stanowiska FTK w tej materii - wyda orzeczenie dla FTK niezadowalające, zdecydował się na sformułowanie żądania poszanowania tożsamości konstytucyjnej Niemiec przy jednoczesnym precyzyjnym uzasadnieniu, jakie jej elementy domagają się w tej sprawie po-

${ }^{1275}$ FTK skierował niedawno do TSUE kolejne, podobne odesłanie prejudycjalne kontestujące uprawnienia Europejskiego Banku Centralnego, tym razem odnośnie do programu zakupów aktywów sektora publicznego na rynkach wtórnych, w którym kwestia tożsamości konstytucyjnej Niemiec znowu nie pojawia się w samych pytaniach, jest jednak przywoływana w uzasadnieniu (FTK, 2 BvR 859/15, 2 BvR 1651/15, 2 BvR 2006/15, 2 BvR 980/16, orzeczenie z 18 lipca 2017). Sprawa nie doczekała się jednak jeszcze rozstrzygnięcia ze strony TSUE (TSUE, Weiss i in., C-493/17). 
szanowania i w jakim zakresie wiąże się to z koniecznością ograniczenia stosowania prawa unijnego wobec Niemiec w skierowanym do TSUE pytaniu prejudycjalnym, mógłby uzyskać orzeczenie TSUE, które stanowiłoby przejaw poszanowania tej tożsamości. Jeśli zaś takie poszanowanie nie było konieczne, powinien raczej od odwoływania się do tożsamości konstytucyjnej powstrzymać. Trudno bowiem wskazać długoterminowe, systemowe (z perspektywy integracji europejskiej) korzyści zarówno tego, żeby FTK blankietowo straszył TSUE możliwością zastosowania doktryny ultra vires, czy też nowej jej wersji, dotyczącej poszanowania tożsamości konstytucyjnej Republiki Federalnej Niemiec (tym bardziej, jeśli miałoby to doprowadzić TSUE do unieważnienia, a nie jedynie niestosowania względem Niemiec jakiegoś prawa unijnego, które przecież mogłoby nie być niezgodne z tożsamością konstytucyjną innych państw). Niełatwo także określić długoterminowe i systemowe korzyści tego, aby TSUE, niejako w ciemno rozstrzygał o kwestiach prawa unijnego w sposób niepewny (gdyż bez precyzyjnych wskazówek ze strony FTK) powiązanych z tożsamością konstytucyjną Niemiec, popadając coraz głębiej w swoisty syndrom sztokholmski, cechujący zdaniem niektórych orzecznictwo TSUE, przynajmniej od czasu wyroku w sprawie Solange I, sprowadzający się do orzekania w obliczu hipotetycznego zagrożenia odrzucenia orzeczenia TSUE przez FTK w oparciu o bliżej niesprecyzowane kryteriaa ${ }^{1276}$. Trudno wreszcie wskazać korzyści tego, aby ignorował tę (zaanonsowana, ale nie rozwiniętą przez odpowiedni organ krajowy) kwestię, jak ostatecznie uczynił to w sprawie Gauweiler.

Nie wchodząc w rozważania nad relacją między TSUE a FTK, jaka wyłania się, albo się wyłoni być może w przyszłości na gruncie sprawy Gauweiler i jej podobnych, ani tym bardziej nie wchodząc w burzliwą relację między tymi dwoma sądami, jaka ma miejsce właściwie od początku procesu integracji europejskiej, na potrzeby tej pracy należy podkreślić, że orzeczenia w sprawie Gauweiler nie wykluczają możliwości zastosowania zaproponowanej w tej pracy sekwencyjnej współpracy między TK a TSUE, jako mieszczącej się poniekąd na przedpolu ewentualnego sięgnięcia do doktryny ultra vires czy jeszcze dalej idących konsekwencji. Być może natomiast pozwalają nawet jeszcze lepiej dostrzec zalety proponowanego tu mechanizmu.

\subsubsection{Saga Taricco na tle sagi Landtová i sprawy Ajos}

Znajdujący się w gronie sądów, które na jakimś etapie wykluczały możliwość kierowania pytań prejudycjalnych do TSUE, a potem, między innymi w związku

1276 Por.: T. Tuominen, C-62/14 ... 
ze zmianą sytuacji prawnej, modyfikowały swoje stanowisko ${ }^{1277}$, włoski Trybunał Konstytucyjny skierował ostatnio do TSUE pytanie prejudycjalne, w którym podważył orzecznictwo TSUE ${ }^{1278} \mathrm{i}$ w którym po raz pierwszy expressis verbis podniósł kwestię tożsamości konstytucyjnej Włoch ${ }^{1279}$. Podobnie jak FTK w sprawie Gauweiler uczynił to jednak w sposób nieadekwatny z perspektywy tej pracy. Zawarte w odesłaniu trybunału włoskiego powołanie się na tożsamość konstytucyjną nie miało odpowiednio precyzyjnego charakteru, nie zostało też zawarte wprost w postawionych pytaniach, w odwołaniu do tożsamości konstytucyjnej brak jednoznacznego wskazania jej elementów wraz z uzasadnieniem, dlaczego należy je uznać za składające się na tożsamość konstytucyjną Włoch, brak też precyzyjnego wskazania charakteru sprzeczności, jak i zakresu, w jakim prawo unijne miałoby zdaniem włoskiego TK podważać włoską tożsamość konstytucyjną. Włoski TK, jak się więc wydaje, powielił negatywnie ocenioną przed chwilą metodę FTK próby zaszachowania TSUE groźbą orzeczenia o niezgodności jego wyroku, gdy ten wróci do włoskiego TK, poprzez zastosowanie tożsamości konstytucyjnej w kontekście doktryny ultra vires, a mówiąc precyzyjniej w kontekście jej włoskiego ekwiwalentu, jakim jest doktryna controlimiti ${ }^{1280}$.

Saga Taricco rozpoczęła się od wyroku TSUE w sprawie dotyczącej terminów przedawnienia związanych z przestępstwami podatkowymi (VAT), które zgodnie $\mathrm{z}$ włoskimi przepisami proceduralnymi były krótsze niż $\mathrm{w}$ innych państwach członkowskich, a w związku z przewlekłością postępowań we Włoszech często prowadziły do przedawnień ścigania lub karania, skutkując wielokrotnie bezkarnością osób popełniających tego rodzaju przestępstwa ${ }^{1281}$. TSUE, zgodnie z rozumowaniem wyrażanym w swej ugruntowanej linii orzeczniczej, opartym na kryterium efektywności prawa unijnego, doszedł do wniosku, że:

Uregulowanie krajowe w dziedzinie przedawnienia przestępstw karnych, [...], które przewidywało $\mathrm{w}$ chwili zaistnienia okoliczności faktycznych w postępowaniu głównym, że zdarzenie przerywające bieg przedawnienia, zaistniałe w trakcie postępo-

1277 K. Wójtowicz, Sądy konstytucyjne..., s. 140-141; więcej - patrz np.: G. Martinico, O. Pollicino, Italy. The Impact of the European Courts on the Italian Constitutional Court, [w:] P. Popelier, C. van de Heyning, P. van Nuffel (red.), Human Rights Protection in the European Legal Order: the Interaction Between the European and the National Courts, Cambridge-Antwerp-Portland 2011; G. Piccirilli, The 'Taricco Saga'..., s. 9 i nast.

1278 TSUE, Postępowanie karne przeciwko Ivo Taricco i in., C-105/14, wyrok z 8 września 2015.

1279 Włoski TK, sprawa 24/2017, postanowienie z 26 stycznia 2017.

1280 Por. np.: P. Faraguna, The Italian Constitutional Court in re Taricco: "Gauweiler in the Roman Campagna", VerfBlog, 2017/1/31, [online] <http://verfassungsblog.de/the-italian-constitutionalcourt-in-re-taricco-gauweiler-in-the-roman-campagna/> [dostęp: 5.02.2019].

${ }_{1281}$ TSUE, Postępowanie karne przeciwko Ivo Taricco i in., C-105/14, wyrok z 8 września 2015, pkt 18-25. 
wania karnego dotyczącego poważnych oszustw w dziedzinie podatku od wartości dodanej, skutkuje przedłużeniem terminu przedawnienia jedynie o jedną czwartą jego pierwotnego czasu trwania, może stanowić zagrożenie dla obowiązków nałożonych na państwa członkowskie przez art. 325 ust. 1 i 2 TFUE w sytuacji, w której owo uregulowanie krajowe uniemożliwia nałożenie skutecznych i odstraszających sankcji karnych w znacznej liczbie przypadków poważnych oszustw stanowiących zagrożenie dla interesów finansowych Unii Europejskiej lub przewiduje dłuższe terminy przedawnienia w przypadku oszustw stanowiących zagrożenie dla interesów finansowych danego państwa członkowskiego, niż w przypadku oszustw stanowiących zagrożenie dla interesów finansowych Unii Europejskiej, czego sprawdzenie należy do sądu krajowego. Do sądu krajowego należy nadanie pełnej skuteczności art. 325 ust. 1 i 2 TFUE, poprzez powstrzymanie się w razie potrzeby od stosowania przepisów prawa krajowego, które skutkują uniemożliwieniem danemu państwu członkowskiemu przestrzegania obowiązków nałożonych na niego przez art. 325 ust. 1 i 2 TFUE ${ }^{1282}$.

Trybunał nakazał więc w zasadzie sądom włoskim niestosowanie niezgodnych z prawem unijnym - podważających skuteczną ochronę interesów finansowych Unii - przepisów prawa włoskiego.

Doprowadziło to włoski TK do skierowania do TSUE trzech pytań w trybie prejudycjalnym:

1) Czy art. 325 ust. 1 i 2 TFUE należy interpretować w ten sposób, że nakłada on na sąd karny obowiązek niestosowania uregulowania krajowego w przedmiocie przedawnienia, które stoi na przeszkodzie ukaraniu w znacznej liczbie wypadków poważnych oszustw naruszających interesy finansowe Unii, bądź przewiduje krótsze terminy przedawnienia dla oszustw naruszających interesy finansowe Unii, aniżeli terminy przedawnienia dla oszustw naruszających interesy finansowe państwa, nawet jeżeli takie niestosowanie jest pozbawione wystarczająco precyzyjnej podstawy prawnej? [oraz] 2) [...] nawet jeżeli w porządku prawnym państwa członkowskiego przedawnienie należy do materialnego prawa karnego i podlega zasadzie legalności? [oraz] 3) [...] nawet jeżeli takie niestosowanie jest sprzeczne z nadrzędnymi zasadami porządku konstytucyjnego państwa członkowskiego lub z niezbywalnymi prawami człowieka uznanymi w konstytucji państwa członkowskiego? ${ }^{1283}$

W swej argumentacji włoski TK odniósł się do kwestii zagrożenia przez wyrok w sprawie Taricco włoskiej tożsamości konstytucyjnej w zakresie, w jakim chroni ona prawa i wolności jednostki. Włoski TK wyraził pogląd, że „we włoskim porządku prawnym system przedawnienia w sprawach karnych ma

${ }^{1282}$ Ibidem, pkt 66.

1283 TSUE, Postępowanie karne przeciwko M.A.S. i M.B, C-42/17, wyrok z 5 grudnia 2017, pkt 20. 
charakter materialny, a zatem wchodzi w zakres stosowania zasady legalności, o której mowa w art. 25 konstytucji włoskiej. W konsekwencji system ten powinien być uregulowany przez ściśle określone normy obowiązujące w momencie popełnienia danego przestępstwa"1284. Obowiązywanie tego rodzaju przepisów proceduralnych i określone w nich kryteria są elementem gwarancji praw człowieka, a gwarancje te są elementem włoskiej tożsamości konstytucyjnej, która nie może być $w$ żaden sposób podważana przez prawo unijne i nie poddaje się zasadzie pierwszeństwa prawa unijnego ${ }^{1285}$. Pytania skierowane przez włoski TK do TSUE należy więc odczytywać jako swoistą próbę upewnienia się czy TSUE stoi sztywno na stanowisku wyrażonym w wyroku w sprawie Taricco, przy jednocześnie sformułowanej wyraźniej groźbie, że jeśli TSUE pozostanie przy swoim, to sąd włoski może wpisać się w linię orzeczniczą przewidującą możliwość weryfikacji prawa unijnego i sposobu jego interpretacji wyrażonego przez TSUE przez sąd konstytucyjny w ramach włoskiej wersji doktryny ultra vires znanej pod marką controlimiti ${ }^{1286}$.

Niektórzy autorzy twierdzą, że skierowane przez włoski TK pytanie do TSUE można uznać za przejaw dialogu sędziowskiego i przejaw woli współpracy z TSUE, a także gest przyjazny unijnej integracji ${ }^{1287}$. Nawet zwolennicy tej tezy potrafią jednak przyznać, że ostatecznie zagadnienie, do jakiego sprowadza się odesłanie włoskiego TK to pytanie, czy prawo unijne, rozumiane w sposób wyrażony wcześniej przez TSUE, może być stosowane w państwie członkowskim jedynie pod warunkiem, że jest zgodne z tożsamością konstytucyjną danego państwa członkowskiego i że rozstrzygnięcie tej kwestii spoczywa w rękach odpowiedniej instytucji tego państwa członkowskiego ${ }^{1288}$. W swym odesłaniu włoski TK wyraźnie opowiedział się przeciwko jakiemukolwiek przenoszeniu ciężaru w procesie stosowania art. 4 ust. 2 TUE i zapewniania ochrony tożsamościom konstytucyjnym państw członkowskich na rzecz TSUE. Włoski trybunał wyszedł z założenia, że TSUE powierzono przede wszystkim dbanie o jednorodną interpretację prawa unijnego, a więc nie można mu powierzać szczegółowej oceny, czy prawo unijne pozostaje w zgodzie z tożsamością kon-

${ }^{1284}$ Ibidem, pkt 14 .

${ }^{1285}$ Patrz przed.: włoski TK, sprawa 24/2017, postanowienie z 26 stycznia 2017, pkt 8 .

${ }^{1286}$ Więcej na temat doktryny controlimiti i jej orzeczniczego, jak i doktrynalnego zakorzenienia - patrz np.: G. Piccirilli, The 'Taricco Saga'..., s. 3-4.

1287 Tak np.: N. Lupo, The Advantage..., s. 194 i nast.; przyznać należy, że w samym fakcie skierowania pytania do TSUE przez włoski TK można dostrzec pewną życzliwość ze strony tego ostatniego w formie dania TSUE szansy wycofania się z wyroku w sprawie Taricco, a nie aktywowaniu doktryny controlimiti, czego spodziewali się po TK sędziowie włoskich sądów, którzy sprawę przed TK zainicjowali (G. Piccirilli, The 'Taricco Saga'..., s. 6).

${ }^{1288}$ F. Fabbrini, O. Pollicino, Constitutional Identity in Italy: European Integration as the Fulfilment of the Constitution, EUI Working Paper, LAW 2017, nr 06, s. 13. 
stytucyjną każdego z państw członkowskich Unii z osobna ${ }^{1289}$. Stwierdził on wprost, że jest zatem rozsądne, aby w przypadkach, kiedy taka ocena nie jest oczywista, TSUE ustalał znaczenie prawa unijnego i pozostawiał organom krajowym (w przypadku Włoch - tamtejszemu TK) ostateczną ocenę odnośnie do jego zgodności z naczelnymi zasadami krajowego porządku prawnego, a więc z tożsamością konstytucyjną tego państwa ${ }^{1290}$. To ujawnia raczej konfrontacyjną i wpisującą się w spór o "ostatnie słowo" postawę włoskiego trybunału, zbliżoną do opisanego wcześniej stanowiska FTK w sprawie Gauweiler, a także wyraźnie ukazuje, że przedmiotowe odesłanie z jego strony wykracza poza granice kooperacyjnego modelu proponowanego w tej pracy.

Odpowiedź ze strony TSUE należy uznać za częściowe jedynie wyjście naprzeciw oczekiwaniom włoskiego TK, nawet jeśli chodzi tylko o najprostsze ustępstwo względem tego ostatniego, a więc pewną rewizję wyroku w sprawie Taricco. TSUE nie zdecydował się na niezniuansowane podtrzymanie swojego pierwszego wyroku. Modyfikacje, na jakie się zdecydował, nie są jednak ani do końca przejrzyste, ani w pełni spójne. Nie pozwalają mieć pewności co do dalszego rozwoju wydarzeń. W tak zwanym wyroku w sprawie Taricco II ${ }^{1291}$ TSUE, choć nie bez różnego rodzaju zastrzeżeń i prób rozmycia nieco istoty sprawy i jej bardziej generalnego wydźwięku ${ }^{1292}$, w dużej mierze ustąpił przed żądaniem włoskiego TK. TSUE powstrzymał się w swym orzeczeniu od odniesienia się do kwestii ochrony tożsamości konstytucyjnej Włoch, czy też do kwestii ochrony wyższego niż unijny, konstytucyjnie chronionego standardu praw człowieka, który mógłby stanowić jej element. Nie zdecydował się również na podważenie swego wcześniejszego osądu odnośnie do niezgodności włoskich przepisów z prawem unijnym. Wycofał się jednak z żądania automatycznego niestosowania niezgodnych $z$ prawem unijnym przepisów prawa włoskiego. Oparł się przy tym jednak nie na ochronie włoskiej tożsamości konstytucyjnej i konstytucyjnych gwarancji praw człowieka, lecz na unijnych gwarancjach tychże praw.

TSUE przypomniał „znaczenie, zarówno w porządku prawnym Unii, jak i w krajowych porządkach prawnych, jakiego nabiera zasada ustawowej określoności czynów zabronionych i kar w ramach jej wymogów dotyczących przewidywalności, precyzji i niedziałania wstecz mającej zastosowanie ustawy

1289 Por.: D. Paris, Limiting..., s. 221.

1290 Włoski TK, sprawa 24/2017, postanowienie z 26 stycznia 2017, pkt 6.

${ }^{1291}$ TSUE, Postępowanie karne przeciwko M.A.S. i M.B, C-42/17, wyrok z 5 grudnia 2017.

${ }^{1292}$ Więcej - patrz np.: M. Krajewski, 'Conditional' Primacy of EU Law and Its Deliberative Value: An Imperfect Illustration from Taricco II, [online] <http://europeanlawblog.eu/2017/12/18/ conditional-primacy-of-eu-law-and-its-deliberative-value-an-imperfect-illustration-from-taricco-ii/> [dostęp: 5.02.2019]. 
karnej"1293. Oparł się więc na art. 49 Karty, która to zgodnie z ugruntowanym wcześniej orzecznictwem bez wątpienia znajdowała w sprawie zastosowanie ${ }^{1294}$. Rozważania te poparł również odwołaniem do EKPC $z^{1295}$. Odniósł się również do gwarancji zawartych w systemach państw członkowskich. Nie uczynił tego jednak w kontekście partykularnym - tożsamości konstytucyjnej - lecz w kontekście wspólnotowym i podkreślił, że „zasada ustawowej określoności czynów zabronionych i kar należy do tradycji konstytucyjnych wspólnych dla państw członkowskich"1296. Wskazał przy tym przede wszystkim aspekt niedziałania prawa wstecz, a więc niemożności stosowania konsekwencji wyroku w sprawie Taricco do stanów sprzed jego wydania.

TSUE przyznał sądom krajowym pewną swobodę $\mathrm{w}$ przedmiocie niestosowania włoskich przepisów dotyczących przedawnienia. Stwierdził, że

do sądu krajowego należy zbadanie, czy stwierdzenie wymagane przez pkt 58 wyroku Taricco, zgodnie z którym sporne przepisy kodeksu karnego uniemożliwiają nałożenie skutecznych i odstraszających sankcji karnych w znacznej liczbie wypadków poważnych oszustw naruszających interesy finansowe Unii, prowadzi do sytuacji niepewności we włoskim porządku prawnym co do określenia mającego zastosowanie systemu przedawnienia, która naruszałaby zasadę określoności mającej zastosowanie ustawy. Jeśli rzeczywiście tak jest, sąd krajowy nie jest zobowiązany do powstrzymania się od stosowania spornych przepisów kodeksu karnego ${ }^{1297}$.

W praktyce TSUE uznał więc, że opierając się na unijnych gwarancjach praw człowieka sądy krajowe mogą powstrzymywać się od niestosowania przepisów krajowych niezgodnych z prawem unijnym, tak jak zostało to określone w wyroku w sprawie Taricco, do stanów sprzed wyroku w sprawie Taricco, aby w ten sposób zachować unijne gwarancje praw jednostki ${ }^{1298}$. Odnośnie do niemożności niestosowania przepisów krajowych do stanów późniejszych niż wyrok w sprawie Taricco, przewidując, że sądy mogą tak postępować (choć jak się wydaje $\mathrm{w}$ jego ocenie nie powinny), TSUE zaapelował natomiast o interwencję ustawodawczą. Stwierdził, że

jeżeli [...] sąd krajowy miałby uznać, że obowiązek niestosowania spornych przepisów kodeksu karnego napotyka przeszkodę w postaci zasady ustawowej określoności czynów zabronionych i kar, nie byłby zobowiązany do zastosowania się do tego

${ }^{1293}$ TSUE, Postępowanie karne przeciwko M.A.S. i M.B, C-42/17, wyrok z 5 grudnia 2017, pkt 51.
${ }^{1294}$ Ibidem, pkt 52.
${ }^{1295}$ Ibidem, pkt 53-54.
1296 Ibidem, pkt 53.
1297 Ibidem, pkt 59.
1298 Ibidem, pkt 60. 
obowiązku, nawet jeśli umożliwiłoby to usunięcie sytuacji w porządku krajowym, która jest niezgodna z prawem Unii [...]. Ustawodawca krajowy powinien zatem podjąć niezbędne środki ${ }^{1299}$.

Ostatecznie sformułowana przez TSUE odpowiedź na pytanie włoskiego TK jest więc tylko w pewnym stopniu potwierdzeniem wcześniejszego orzeczenia w sprawie Taricco. TSUE potwierdził,

iż art. 325 ust. 1 i 2 TFUE należy interpretować w ten sposób, że nakłada on na sąd krajowy obowiązek niestosowania, w ramach postępowania karnego dotyczącego przestępstw w dziedzinie VAT, przepisów krajowych w przedmiocie przedawnienia należących do krajowego prawa materialnego, które stoją na przeszkodzie nałożeniu skutecznych i odstraszających sankcji karnych w znacznej liczbie wypadków poważnych oszustw naruszających interesy finansowe Unii bądź które przewidują krótsze terminy przedawnienia dla poważnych oszustw naruszających te interesy aniżeli terminy przedawnienia dla oszustw naruszających interesy finansowe danego państwa członkowskiego ${ }^{1300}$.

Obarczył to jednak dającym dość daleko idącą swobodę sądom krajowym zastrzeżeniem: „chyba że takie niestosowanie skutkuje naruszeniem zasady ustawowej określoności czynów zabronionych i kar ze względu na niedostateczną określoność znajdującej zastosowanie ustawy lub z uwagi na działanie wstecz przepisów ustanawiających surowsze warunki odpowiedzialności niż obowiązujące w chwili popełnienia przestępstwa"1301.

Słusznie zauważają Chiara Amalfitano i Oreste Pollicino, że TSUE wykazał się w wyroku Taricco II sporą dozą pojednawczości. Przyznał niemal wprost, że wyrok w sprawie Taricco nie powinien być stosowany do stanów mających miejsce przed jego ogłoszeniem. Podkreślił także, że zasada legalności jest częścią unijnego porządku prawnego i wspólnych tradycji konstytucyjnych państw członkowskich, pozostawił też sporą swobodę sądom krajowym co do tego, jak ją stosować w odniesieniu do konsekwencji wynikających z wyroku w sprawie Taricco. Wyjścia z impasu doszukiwał się raczej w ingerencji ustawodawczej, a nie w podporządkowaniu się włoskim sądom jego orzeczeniu. To wszystko mogło prowadzić do przypuszczeń, że wyrok ten przyjęty zostanie przez włoski TK z satysfakcją ${ }^{1302}$. Tak się jednak nie stało ${ }^{1303}$.

${ }^{1299}$ Ibidem, pkt 6o; por. także: ibidem, pkt 41-42.

${ }^{1300}$ Ibidem, pkt 61.

${ }^{1301}$ Ibidem, pkt 61.

1302 Tak też: M. Bonelli, The Taricco Saga and the Consolidation of Judicial Dialogue in the European Union, "Maastricht Journal of European and Comparative Law" 2018, nr 25 (3), s. 365.

${ }^{1303}$ C. Amalfitano, O. Pollicino, Two Courts, Two Languages? The Taricco Saga Ends on a Worrying Note, [online] <https://verfassungsblog.de/two-courts-two-languages-the-taricco-saga- 
W swym niedawnym orzeczeniu włoski TK przystał na rozumowanie wyrażone przez TSUE odnośnie do niestosowalności konsekwencji wynikających z wyroku w sprawie Taricco do stanów sprzed wydania tego wyroku. Mimo że sprawa dotyczyła takiej właśnie sytuacji, włoski TK jednak na tym nie poprzestał. Dwukrotnie, choć nie było to dla rozstrzygnięcia sprawy konieczne, powrócił do kwestii tożsamości konstytucyjnej Włoch ${ }^{1304}$, nie podążając tym samym za przykładem TSUE, który wolał skupiać się na wspólnych tradycjach konstytucyjnych państw członkowskich, czy też po prostu nie pomijając tej kwestii, jako dla sprawy nierelewantnej. Jak oceniają Chiara Amalfitano i Oreste Pollicino, nawet jeśli w swym wyroku włoski TK formalnie przyznaje, że nie odstępuje od poglądu co do wyłącznej kompetencji TSUE do interpretowania prawa unijnego i do określania, czy ma ono skutek bezpośredni czy też nie ${ }^{1305}$, to jednak otwarcie podważa wyrażone w orzecznictwie stanowisko Wielkiej Izby TSUE, stwierdzając, że art. 325 ust. 1 i 2 TFUE i standard określony w wyroku w sprawie Taricco, nie spełniają krajowego wymogu precyzji przepisów prawa karnego ${ }^{1306}$. Zdaniem włoskiego TK stopnień precyzji wymaganej od przepisów prawa karnego na podstawie art. 25 ust. 2 włoskiej konstytucji wyklucza stosowanie zasady sformułowanej w wyroku w sprawie Taricco, nawet $\mathrm{w}$ formie jaką TSUE nadał jej w wyroku w sprawie M.A.S. i M.B. (Taricco II), a więc bez względu na to, czy czyny popełnione zostały przed publikacją wyroku w sprawie Taricco, czy też po $^{1307}$. Tym samym włoski TK wyraźnie potwierdził aktualność doktryny controlimiti i swojej pozycji w jej ramach odnośnie do ochrony włoskiej konstytucji i jej tożsamości, szczególnie, gdy chodzi o konstytucyjne gwarancje praw człowieka, w sytuacji konfliktu $\mathrm{z}$ prawem unijnym ${ }^{1308}$.

Sprawa - saga Taricco - nie jest jeszcze ostatecznie zamknięta. Wciąż nie jest w pełni jasne, jak przebiegnie krajowa recepcja luksemburskich orzeczeń, choć orzeczenie włoskiego TK wydane już po wyroku Taricco II nie stanowi przejawu satysfakcji z jego strony, a wręcz świadczy o dalszej eskalacji konfrontacyjnego podejścia. Nie wiadomo też jak na recepcję swojego orzeczenia we Włoszech zareagować może TSUE, na co szansa wcale nie musi się zdarzyć

-ends-on-a-worrying-note/> [dostęp: 5.02.2019].

${ }^{1304}$ Włoski TK, sprawa 115/2018, wyrok z 31 maja 2018, pkt 5 i 11.

${ }^{1305}$ Ibidem, pkt 12.

${ }^{1306}$ Ibidem, pkt 11 .

${ }^{1307}$ Jak twierdzą niektórzy, nawet więc jeśli nie zastosował wprost doktryny controlimiti, to zastosował, mniej lub bardziej otwarcie, jej substytut (doktrynę riserva di legge), wyraźnie zabraniając sądom włoskim podporządkowywania się wyrokowi TSUE w sprawie Taricco, nawet wersji złagodzonej w wyroku Taricco II (G. Piccirilli, The 'Taricco Saga'..., s. 15-17).

${ }^{1308}$ C. Amalfitano, O. Pollicino, Two Courts.... 
w jakiejś bardzo odległej przyszłości ${ }^{1309}$. Już teraz można jednak powiedzieć, że bez wątpienia mamy do czynienia z kolejnym dowodnym przykładem napięcia na linii TSUE - trybunały konstytucyjne państw członkowskich i przeciągania przez nie liny, szczególnie, gdy chodzi o ochronę praw człowieka i przewagę standardu krajowego w związku z ochroną przez nie tożsamości konstytucyjnej. Wyrok ten pokazuje również, że TSUE, nawet jeśli nie chce tego otwarcie przyznać, to jednak nie zostaje w pełni usztywniony wobec presji sądów krajowych, w tym przede wszystkim konstytucyjnych, odnośnie do tożsamości konstytucyjnej państw członkowskich i krajowej ochrony praw człowieka, zwłaszcza jeśli miałaby być ona dalej idąca niż w prawie Unii. Efekt wyroków w sprawach Åkerberg-Fransson i Melloni, jeśli chodzi o charakter unijnego standardu praw człowieka w zakresie zastosowania KPP, jak ujęła to Andrea Edenharter, został wraz z wyrokiem w sprawie Taricco II co najmniej rozwodniony ${ }^{1310}$, nawet jeśli nie stało się to wprost i w pełni otwarcie.

W miejscu tym należy również pamiętać o dwu orzeczeniach, które z różnych względów wymykają się modelowi proponowanemu w tej pracy (bądź to nie wiązały się $\mathrm{z}$ interakcją między sądem konstytucyjnym a TSUE $\mathrm{w}$ ramach procedury prejudycjalnej, bądź to w ogóle nie angażowały sądu konstytucyjnego państwa członkowskiego), których doniosłość jest jednak dla tej pracy istotna. Po pierwsze chodzi o orzeczenie czeskiego TK (Ústauní soud České republiky) w sprawie słowackich emerytur, które było pierwszym przypadkiem otwartego zastosowania przez sąd konstytucyjny państwa członkowskiego doktryny ultra vires ${ }^{1311}$. Jest ono szczególnie interesujące w kontekście sagi Taricco, gdyż można odnieść wrażenie, że być może TSUE liczy na podobny rozwój wydarzeń, jak miało to miejsce w sprawie czeskiej ${ }^{1312}$.

Po orzeczeniu czeskiego TK o niewykonalności wyroku TSUE w Czechach, jako stanowiącego akt ultra vires, Najwyższy Sąd Administracyjny Republiki Czeskiej (Nejuyšší správní soud České republiky), który w związku z tym stanął w toczącej się przed nim sprawie przed problemem niezastosowania się do wyroku TSUE, zwrócił się doń z wnioskiem w trybie prejudycjalnym ${ }^{1313}$. W jednym z pytań zapytał TSUE wprost, czy prawo unijne zakazywało mu przyjęcia punktu widzenia wyrażonego przez czeski TK, sprzecznego jego zdaniem z prawem unijnym. „Wojny nuklearnej”, jakim to mianem niektó-

${ }^{1309}$ Tak też np.: C. Amalfitano, O. Pollicino, Two Courts...; potencjał do dalszego rozwoju 'sagi Taricco' dostrzega też: G. Piccirilli, The 'Taricco Saga'..., s. 2.

${ }^{1310}$ A. Edenharter, Fundamental..., s. 394.

${ }^{1311}$ Czeski TK, sprawa Pl. ÚS 5/12, wyrok z 31 stycznia 2012, który był reakcją na wyrok w sprawie: TSUE, Marie Landtová p. Česká správa socialního zabezpečení, C-399/o9, wyrok z 22 czerwca 2011.

${ }_{1312}$ Por. np.: M. Bonelli, The Taricco...; N. Lupo, The Advantage..., s. 196-199.

1313 TSUE, JS, C-253/12, sprawa wycofana 18 lipca 2013. 
rzy określali konfliktowy potencjał sagi Landtová1314, jednak uniknięto. Ostatecznie bowiem roszczenie skarżącej w postępowaniu głównym zostało zaspokojone i Najwyższy Sąd Administracyjny wycofał swoje pytanie, a także zamknął sprawę bez konieczności rozstrzygania. Stało się tak ze względu na to, że czeski parlament dokonał nowelizacji przepisów uznanych przez TSUE za niezgodne z prawem unijnym tak, że niezgodność ta została usunięta ${ }^{1315}$. Podobna sekwencja wydarzeń miała zresztą również miejsce w następstwie innego pytania prejudycjalnego, jakie do TSUE skierował włoski TK ${ }^{1316}$, kiedy potencjalnego konfliktu między prawem unijnym a krajowym uniknięto poprzez ingerencję ustawodawczą ${ }^{1317}$.

Nota bene czeski TK w swym orzeczeniu w rzeczonej sprawie nie wszedł w kwestie dotyczacce czeskiej tożsamości konstytucyjnej i jej ewentualnego pogwałcenia przez TSUE. Było to rozczarowujące ${ }^{1318}$ nie tylko na poziomie teoretycznym (intelektualnym), ale również praktycznym. Przeprowadzenie takiej analizy mogłoby doprowadzić do niezaistnienia kolizji. Gdyby czeski TK stwierdził brak zagrożenia dla czeskiej tożsamości konstytucyjnej (co zresztą potwierdził dalszy rozwój wydarzeń, skoro zmiana prawa krajowego tak, aby było zgodne z prawem unijnym, w sposób w jaki zinterpretował je TSUE, była możliwa bez zmiany konstytucji, a co dopiero bez zmiany jej tożsamości), problemu w ogóle można byłoby uniknąć, podobnie jak zaleca się to w prezentowanym w tej pracy modelu, przewidującym możliwość ustępstwa względem prawa unijnego już na etapie orzeczenia przez TK.

Gdy mowa o podważaniu przez sądy krajowe orzeczeń TSUE, nie sposób pominąć także sprawy Ajos ${ }^{1319}$ i późniejszego orzeczenia duńskiego Sądu Naj-

${ }^{1314}$ R. Zbiral, Nuclear War between the Court of Justice and Czech Constitutional Court (hopefully) averted, [online] <https://verfassungsblog.de/nuclear-war-between-the-court-of-justice-and-czech-constitutional-court-hopefully-averted/> [dostęp: 5.02.2019].

${ }^{1315}$ Więcej - patrz: J. Zemánek, An 'Entirely-Specific' Situation or a Routine Limitation of the National Autonomy? Slovak Pensions XVII of the Czech Constitutional Court, [w:] R. Arnold (red.), Limitations of National Sovereignty through European Integration, Dordrecht 2016, s. 137 .

1316 TSUE, Raffaella Mascolo i in. p. Ministero dell'Istruzione, dell'Università e della Ricerca i Comune di Napoli, C-22/13, od C-61/13 do C-63/13 i C-418/13, wyrok z 26 listopada 2014.

${ }^{1317}$ G. Amato, M. Cartabia, D. de Pretis, S. Sciarra, Constitutional Adjudication Within A European Composite Constitution - A View From The Bench, "Italian Journal of Public Law" 2018, nr 10 (2), s. 501-502; takie rozwiązanie sagi Taricco bywa zresztą proponowane [C. Rauchegger, $\mathrm{Na}$ tional Constitutional Rights and the Primacy of EU Law: M.A.S, "Common Market Law Review" 2018, nr 55 (5), s. 1547], tym razem sprawa może być jednak trudniejsza (G. Piccirilli, The 'Taricco Saga'..., s. 19-20).

${ }^{1318}$ J. Komárek, Czech Constitutional Court Playing with Matches: The Czech Constitutional Court Declares a Judgment of the Court of Justice of the EU Ultra Vires; Judgment of 31 January 2012, Pl. ÚS 5/12, Slovak Pensions XVII , European Constitutional Law Review” 2012, nr 8, s. 336.

1319 TSUE, Dansk Industri (DI) p. Sucession Karsten Eigil Rasmussen, C-441/14, wyrok z 19 kwietnia 2016. 
wyższego (Højesteret), który odmówił wykonania wyroku TSUE, jeśli chodzi o horyzontalny efekt unijnej dyrektywy, ze względu na brak odpowiednich przepisów krajowych i niemożności zinterpretowania istniejących przepisów w sposób przyjazny prawu unijnemu i wyrokowi TSUE bez popadania w wykładnię contra legem ${ }^{1320}$. Duński sąd uczynił to na podstawie aktu akcesyjnego i konstytucji, opierając na nich swą ocenę zakresu kompetencji Unii i jej organów, jak i swojej do dokonywania interpretacji prawa krajowego, nawet pozostającego w związku z prawem unijnym, co spotkało się z dość szeroką krytyką ${ }^{1321}$. Nie wchodząc w szczegóły tego orzeczenia i nieco innego charakteru podmiotów, które brały udział w wydarzeniach niż TK, a więc sąd konstytucyjny, funkcjonujący w modelu scentralizowanej kontroli konstytucyjności, podkreślić należy jednak, że również i ten przykład pokazuje, że podważenie przez sąd krajowy wyroku TSUE, jeśli nie jest on wystarczająco refleksywny względem specyfiki prawa krajowego, szczególnie tego o randze konstytucyjnej, wcale nie jest jedynie hipotetycznym zagrożeniem. Dość otwarcie jeszcze przed omawianym wyrokiem wyraził to prezes duńskiego Sądu Najwyższego Børge Dahl, który stwierdził, że jeśli TSUE będzie zaskakiwać swymi wyrokami sądy krajowe, to może to prowadzić do wzrastającej niechęci ze strony tych ostatnich do korzystania z procedury pytania prejudycjalnego ${ }^{1322}$. Co więcej, również sądy krajowe mogą się podobną niespodzianką odwdzięczyćc1323. Wydaje się, że rozwój wydarzeń w tej sprawie można ocenić jako w najwyższym stopniu konsternujący. Mieliśmy bowiem do czynienia z sytuacją, w której TSUE otrzymał pytanie prejudycjalne, udzielił na nie przejrzystej odpowiedzi, po czym duński Sąd Najwyższy, stanowiący sąd ostatniej instancji w systemie prawnym państwa członkowskiego, otwarcie wyrok TSUE podważył1324. Podejście proponowane $\mathrm{w}$ tej pracy ma się przyczynić do unikania tego rodzaju niespodzianek ${ }^{1325}$.

${ }^{1320}$ Duński SN, sprawa 15/2014, wyrok z 6 grudnia 2016.

${ }^{1321}$ Więcej - patrz przed.: G. Zaccaroni, The Good, The Bad, And The Ugly: National Constitutional Judges And The EU Constitutional Identity, "Italian Journal of Public Law" 2018, nr 10 (2), s. 424 i nast.; M.R. Madsen, H.P. Olsen, U. Šadl, Competing Supremacies and Clashing Institutional Rationalities: the Danish Supreme Court's Decision in the Ajos Case and the National Limits of Judicial Cooperation, „European Law Journal” 2017, $\mathrm{nr} 23$ (1-2) i podana tam literatura.

1322 B. Dahl, Keynote Address, [w:] U. Neergaard, C. Jacqueson (red.), Proceedings: Speeches from the XXVI FIDE Congress, The XXVI FIDE Congress in Copenhagen, 2014, "Congress Publications" Vol. 4, s. 30.

${ }^{1323}$ Por.: M.R. Madsen, H.P. Olsen, U. Šadl, Competing..., s. 140.

${ }^{1324} \mathrm{~J}$. Baquero Cruz, What's Left of the Law of Integration?: Decay and Resistance in European Union Law, Oxford 2018, s. 36.

${ }^{1325}$ Można przy tej okazji również odnotować wyrok, który co do meritum nie okazał się prawu unijnemu ani procesowi unijnej integracji nieprzychylny, jednak obiter belgijski Trybunał Konstytucyjny, uznając przepisy zatwierdzające tak zwany pakt fiskalny, podkreślił, że granicą 
Wracając do sagi Taricco, najsłabszą stroną pytania włoskiego sądu w kontekście propozycji współpracy między TK a TSUE proponowanej w tej pracy, wydaje się być arbitralne stwierdzenie przezeń, że gwarancje praw człowieka, jakich sprawa ta dotyczy, są elementem tożsamości konstytucyjnej Włoch bez żadnego uzasadnienia takiej tezy - tak jakby sam fakt istnienia tych gwarancji we włoskim systemie konstytucyjnym był wystarczający, aby uznać, że składają się one na tożsamość konstytucyjną Włoch, a także bez rozróżnienia, czy to konkretnie określona w przepisach długość ich biegu jest elementem tej tożsamości, czy też sama konieczność ich określenia przez przepisy prawne jest wymogiem rangi tożsamości konstytucyjnej.

Pozostaje to w sprzeczności z fundamentalnym dla prawidłowego, zdaniem autora tej pracy, rozróżnienia między takim wymiarem konstytucyjnych gwarancji praw człowieka, który jest na tyle doniosły, aby można było uznać go za element tożsamości konstytucyjnej państwa i który powinien w związku z tym być przez Unię poszanowany, nawet jeśli miałoby to prowadzić do pewnego nadzwyczajnego zniuansowania konsekwencji wynikających z zasady pierwszeństwa, a przede wszystkim jednolitości stosowania oraz efektywności prawa unijnego, a takim, który nie ma tożsamościowego charakteru i który powinien w związku z tym ustąpić zasadom pierwszeństwa, jedności i efektywności prawa UE. Podejście włoskiego TK, jak się wydaje, pozostaje w sprzeczności do rozróżnienia tożsamościowego (konstytucyjnie) charakteru jedynie niektórych postanowień włoskiej ustawy zasadniczej i wynikających z nich konsekwencji, jakiego trybunał ten dokonał w pewnym zakresie w swym wcześniejszym orzecznictwie, nie twierdząc wówczas, że wszystko co zawarte w konstytucji i wszelkie konsekwencje wynikające z przepisów konstytucji ma tak szczególny charakter ${ }^{1326}$.

Podejście włoskiego TK pozostaje też w sprzeczności z takim właśnie rozróżnieniem odnośnie do konstytucyjnych gwarancji praw człowieka, które jest podstawą proponowanego w tej pracy odpowiedzialnego i powściągliwego dialogu w ramach procedury pytania prejudycjalnego między TK a TSUE w przedmiocie poszanowania wyższych niż unijne, konstytucyjnych standardów praw człowieka, które, co będzie jeszcze poddane bardziej szczegółowej analizie, wyłania się zarówno z orzecznictwa polskiego TK (w sprawie K 32/o9, gdy doprecyzowywał, że na tożsamość konstytucyjną RP składają się „postanowienia

\footnotetext{
dla ewentualnego rozrostu kompetencji unijnych instytucji jest nienaruszalna tożsamość konstytucyjna Belgii (Belgijski TK, sprawa 62/2016, wyrok z 28 kwietnia 2016).

${ }^{1326}$ Por.: włoski TK, sprawa 183/1973, wyrok z 27 grudnia 1973 (Frontini), przed. pkt 9; włoski TK, sprawa 170/1984, wyrok z 5 czerwca 1984 (Granital); a także włoski TK, sprawa 1146/1988, wyrok z 29 grudnia 1988, czy szczególnie w kontekście praw podstawowych: włoski TK, sprawa 232/1989, wyrok z 13 kwietnia 1989 (Fragd), pkt 3.1.
} 
dotyczące praw jednostki wyznaczające tożsamość państwa"1327 a nie wszystkie z nich), jak i FTK (gdy raz podważył możliwość wykonania ENA ze względu na konstytucyjne gwarancje praw człowieka i tożsamość konstytucyjną Niemiec ${ }^{1328}$, a innym razem tego nie uczynił ze względu na to, że gwarancje niemieckie, dalej idące niż w innym państwie członkowskim, nie stanowiły elementu tożsamości konstytucyjnej Niemiec ${ }^{1329}$ ), czy hiszpańskiego TK w związku z wyrokiem w sprawie Melloni ${ }^{1330}$ (który kwestii tożsamości konstytucyjnej w sprawie tej nie podniósł i podporządkował się wyrokowi TSUE ograniczającemu wyższy niż unijny, konstytucyjny standard w Hiszpanii ${ }^{1331}$ ).

\subsubsection{Obowiązek poszanowania przez Unię tożsamości konstytucyjnej państw członkowskich i jego dotychczasowe oraz potencjalne konsekwencje}

Jak pokazują omówione tu sprawy, wkład TSUE w wyjaśnienie treści obowiązku poszanowania przez Unię tożsamości konstytucyjnej państw członkowskich jest raczej skromny, a odwołania do niej mają właściwie charakter pomocniczy. Trudno wyciągnąć z nich ostateczne wnioski co do zakresu tego obowiązku. TSUE raczej nie ingeruje w materialny zakres tożsamości konstytucyjnej państw członkowskich, określany w omawianych sprawach przez poszczególne państwa. Trudno jednak jednoznacznie stwierdzić, czy bierność ta oznacza brak poczucia kompetencji do tego rodzaju prób, czy wiąże się z akceptacją formułowanych dotychczas twierdzeń w tej materii i brakiem konieczności podejmowania polemiki. Z przedstawionego powyżej orzecznictwa TSUE, lecz również z samego brzmienia unijnego prawa pierwotnego, a także ze specyfiki porządków konstytucyjnych państw członkowskich, w tym porządku polskiego i wydanego w jego ramach orzecznictwa TK, zdaje się jednak wynikać po pierwsze, że konstrukcja art. 4 TUE „sugeruje, że to do państw członkowskich powinno należeć wypełnianie treścią pojęcia »tożsamości konstytucyjnej«, skoro mowa jest o kompetencjach zachowywanych przez państwa nie tylko w kategoriach ogólnych, lecz także z odniesieniem do dających się indywidualnie zidentyfikować i właściwych każdemu państwu struktur politycznych"1332. Ujęcie jej w art. 4 ust. 2 TUE sprawia więc, że tożsamość narodowa i składające się na nią elementy, w tym przede wszystkim tożsamość konstytucyjna państw człon-

\footnotetext{
${ }^{1327}$ TK, sprawa K 32/o9, wyrok z 24 listopada 2010, pkt III 2.1 uzasadnienia.

${ }^{1328}$ FTK, 2 BvR 2735/14, orzeczenie z 15 grudnia 2015.

${ }^{1329}$ FTK, 2 BvR 890/16, orzeczenie z 6 września 2016.

1330 TSUE, Stefano Melloni p. Ministerio Fiscal, C-399/11, wyrok z 26 lutego 2013.

${ }^{1331}$ Hiszpański TK, sprawa 26/2014, wyrok z 13 lutego 2014, BOE nr 6o z 11 marca 2014.

1332 K. Wójtowicz, Sądy konstytucyjne..., s. 120.
} 
kowskich, to kategoria prawa unijnego, która ma dla niego skutki. W wymiarze jej treści, prawo unijne odsyła jednak do porządków krajowych. Jest to więc "traktatowe pojęcie o narodowej treści"1333, którą to treść nadają mu odpowiednie organy w poszczególnych porządkach krajowych państw członkowskich ${ }^{1334}$.

Po drugie, wydaje się, że podmiotem najbardziej predystynowanym w polskim systemie konstytucyjnym (i innych, w których również funkcjonuje scentralizowany model kontroli konstytucyjności prawa), do napełniania tego pojęcia treścią jest TK. Nie oznacza to, że inne podmioty nie mogą tego czynić, czy też $\mathrm{w}$ procesie tym współuczestniczyć. Jak miało to miejsce w przytoczonych sprawach, prób powoływania się na art. 4 ust. 2 TUE na forum TSUE moga podejmować się również rządy państw czy też sądy zwykłe. Tym niemniej, jak się wydaje, stanowisko TK $w$ tej mierze miałoby przymiot najwyższego uprzywilejowania i powinno być przez TSUE przyjmowane z najwyższą uwaga, a fakt zajęcia w tej mierze stanowiska przez TK pozostawiałoby trybunałowi luksemburskiemu relatywnie najmniejsze pole manewru na gruncie toczącej się przed nim sprawy. Stanowisko TK mogłoby być uwzględniane pośrednio gdyby inne podmioty, jak np. rząd, w swej argumentacji opartej na tożsamości konstytucyjnej państwa powołały się na orzecznictwo TK, w którym ten przy innej okazji poczyniłby relewantne w sprawie ustalenia dotyczące tożsamości konstytucyjnej RP, albo bezpośrednio - $\mathrm{w}$ ramach proponowanej $\mathrm{w}$ tej pracy metody wykorzystania procedury pytania prejudycjalnego przez sam $\mathrm{TK}^{1335}$.

${ }^{1333}$ K. Kowalik-Bańczyk, Tożsamość..., s. 47.

${ }^{1334}$ Jak bowiem wiadomo, TSUE w myśl artykułu 19 TUE nie ma kompetencji do zajmowania się interpretowaniem prawa krajowego, a zwłaszcza krajowych konstytucji (ibidem, s. 47).

${ }^{1335}$ Gerhard van der Schyff w kategoriach ogólniejszych stwierdza, że artykulacja konstytucyjnej indywidualności państwa członkowskiego w ramach obowiązku poszanowania przez Unię jego tożsamości narodowej stanowi prerogatywę państw członkowskich. Nie różnicuje on przy tym, jaki podmiot miałby to czynić, ani czy w związku z tym jaki podmiot to uczyni, miałaby ta artykulacja mieć mniejszą lub większą moc (G. van der Schyff, The Constitutional..., s. 578). Jak zauważa Elke Cloots, trudno jednoznacznie powiedzieć, kto zdaniem TSUE miałby mieć prawo do zgłaszania roszczenia o poszanowanie tożsamości konstytucyjnej, czy kogo TSUE uważałby za podmiot do tego najodpowiedniejszy. Istnieje przynajmniej kilka dróg, którymi TSUE może podążyć. Po pierwsze może odciąć się od wewnątrzkrajowych niuansów i po prostu zadowalać się wyrażonym w tej materii stanowiskiem rządu czy sądu odsyłającego w postępowaniu przed nim. Z drugiej strony mógłby wdawać się w problematykę wielości podmiotów krajowych wyrażających swe stanowisko co do tożsamości konstytucyjnej danego państwa i oceniać je osobno w każdej sprawie. Niektórzy, w tym autor tej pracy, uważają, że preferencję powinno mieć w tej materii stanowisko wyrażane przez sądy konstytucyjne, inni, że stanowisko wyrażane przez władzę ustawodawczą - jako bezpośrednią emanację suwerena (Narodu), do którego to tożsamości poszanowania verbatim art. 4 ust. 2 TUE zobowiązuje Unię. Jeszcze inni powstrzymują się przed podejmowaniem prób uniwersalnego rozstrzygania tego problemu i wskazywania jednej kategorii instytucji najbardziej do tego kompetentnych (E. Cloots, National..., s. 147-148 i nast.). Być może faktycznie sytuacja może różnić się w zależności od specyfiki danego państwa, 
Wreszcie po trzecie wydaje się, że orzecznictwo TSUE, choć skoncentrowane dotychczas raczej na lepiej mu znanych i silniej ugruntowanych w prawie unijnym kategoriach niż tożsamość konstytucyjna, takich jak porządek publiczny, może mimo wszystko stanowić

zapowiedź poszukiwania nowej równowagi między Unią Europejską a krajowymi porządkami konstytucyjnymi. Wyrażać by się ona miała w odstąpieniu od dążenia do ustanowienia hierarchicznej przewagi prawa unijnego nad krajowym i uznaniu znaczenia krajowych porządków konstytucyjnych, tak jak te interpretują sądy konstytucyjne. Natomiast Trybunał Sprawiedliwości czuwałby nad tym, by nie nadużywano kategorii tożsamości narodowej, poprzez objęcie nią norm konstytucyjnych niezasługujących na to oraz by nie korzystano z niej w sposób nieproporcjonalny ${ }^{1336}$.

Wiąże się to, po czwarte, z widocznym postępującym procesem akceptacji przez TSUE związania Unii obowiązkiem poszanowania tożsamości narodowej/konstytucyjnej państw członkowskich, a także wynikającego z niego podziału kompetencji między Unią a państwami ${ }^{1337}$.

Tym niemniej, jak pokazuje orzecznictwo TSUE, trybunał ten jest dość ostrożny w podejściu do art. 4 ust. 2 TUE. O ile jest powściągliwy, gdy chodzi o ingerowanie w to, co państwa identyfikują jako elementy swej tożsamości

a być może nawet właśnie od jego tożsamości konstytucyjnej. Faktycznie różnorodność państw członkowskich uzasadnia wątpliwości, czy jest możliwe wskazanie jednego rodzaju instytucji, która byłaby najwłaściwsza w każdym państwie członkowskim do określania treści tożsamości konstytucyjnej. Na potrzeby tej pracy, skupiającej się na porządku polskim, nie wydaje się jednak budzić wątpliwości, opierając się na samej Konstytucji RP, jak i na omawianym wcześniej orzecznictwie TK, że w porządku polskim jest on podmiotem do tego właściwym, a nawet najwłaściwszym. Nie można jednak wykluczyć, co w żadnym stopniu nie ogranicza roli TK, o jakiej mowa w tej pracy, że również w sprawach polskich inne podmioty będą mogły powoływać się przed TSUE na obowiązek poszanowania tożsamości konstytucyjnej RP i składającego się na nią wyższego niż unijny, konstytucyjnego standardu ochrony praw człowieka. Nie można też wykluczyć, a nawet można mieć nadzieję, że będą czynić to prawidłowo i że TSUE będzie przystawał na ich argumentację. Będzie to nie tylko niesprzeczne z rolą TK postulowaną w tej pracy, a nawet będzie mogło ją uzupełniać w sytuacjach, w których ze względu na kwestie proceduralne nie będzie mógł on spełnić swojej roli (a więc, gdy nie dojdzie do odpowiedniej sekwencji orzeczniczej, umożliwiającej aktywowanie roli TK). Możliwość uczestnictwa rządu w sprawach toczących się przed TSUE, w tym tych, które nie dotyczą bezpośrednio Polski (ale analizowane w nich prawo unijne może znajdować się w konflikcie z tożsamością konstytucyjną RP, która została już w pewnym zakresie zdefiniowana przez TK) jest znacznie szersza (patrz np.: K. Buczkowska-Mazurek, Procedura zwiazana z udziatem Polski w postępowaniach przed Europejskim Trybunałem Sprawiedliwości, sądem pierwszej instancji oraz Trybunałem EFTA, [online] <https://bs.net.pl/upload/File/pdf/Microsoft\%2oWord\%20-\%2obsnet-92.pdf> [dostęp: 7.02.2019].

${ }^{1336}$ K. Wójtowicz, Sądy konstytucyjne..., s. 123; por także: L.F.M. Besselink, Case C-208/og, Ilonka Sayn-Wittgenstein v. Landeshauptmann von Wien, Judgment of the Court (Second Chamber) of 22 December 2010, "Common Market Law Review" 2012, nr 49 (2), s. 687-689.

1337 Por.: K. Wójtowicz, Sądy konstytucyjne..., s. 123-124. 
konstytucyjnej (co szczególnie uzasadnione wydawałoby się, gdyby dokonane to było wprost przez sąd konstytucyjny, albo przynajmniej w związku z jego orzecznictwem dotyczącym tożsamości konstytucyjnej danego państwa członkowskiego), to jednak stara się nie traktować tożsamości konstytucyjnej państw członkowskich jako jakiejś szczególnej instytucji i pojęcia w pełni autonomicznie rozumianego w ramach unijnego porządku prawnego. Ma to szczególnie doniosłe znaczenie $w$ kontekście rozumienia art. 4 ust. 2 TUE $w$ ramach tezy postawionej w tej pracy, a więc ewentualnej dopuszczalności opierania na nim podstaw do niuansowania absolutnego charakteru zasad pierwszeństwa, jedności i efektywności prawa Unii. W obliczu jednego z kluczowych w tym kontekście pytań: „Czy art. 4(2) TUE może stanowić podstawę prawną do dopuszczenia wyjątku od przyjętej w wyroku Melloni interpretacji art. 53 Karty"1338 - czołowi przedstawiciele doktryny, jak Aleksandra Kustra, podkreślają, że:

Akceptacja takiej tezy przez ETS nie wydaje się obecnie prawdopodobna. Strategia ETS opiera się raczej na adaptowaniu norm konstytucyjnych jako punktów odniesienia dla interpretacji przepisów prawa pierwotnego UE niż na uznawaniu wartości konstytucyjnych państw członkowskich jako samodzielnych i autonomicznych wobec prawa UE podstaw prawnych do przyjęcia wyjątku od zasady pierwszeństwa (a w kontekście analizowanego zagadnienia również od doktryny Melloni) ${ }^{1339}$.

Wniosek taki może wydawać się uzasadniony. Nie stanowi jednak jedynej możliwej interpretacji podejścia prezentowanego dotychczas przez TSUE. Warto zastanowić się również nad tym, czego TSUE do tej pory nie powiedzial, być może dlatego, że nie miał dotychczas okazji, a czemu też otwarcie nie zaprzeczył, nawet w obliczu odmiennego podejścia do rozumienia art. 4 ust. 2 TUE sformułowanego w sprawie Michaniki przez swego własnego Rzecznika Generalnego (Miguela Maduro), czy przez Rzecznika Bota w sprawie Melloni (o czym będzie mowa za chwilę), które współgrałoby z propozycją wyrażoną $w$ tej pracy. Być może taka tendencja w podchodzeniu do art. 4 ust. 2 TUE i obowiązku poszanowania tożsamości konstytucyjnej państw członkowskich, jaka wynika z przeanalizowanych powyżej wyroków TSUE, wiąże się po prostu ze specyfiką spraw, w których dotychczas problematykę tę trybunał ten podejmował, co w dużej mierze wynika również ze sposobu, w jaki czyniły to na jego forum organy krajowe.

Wydaje się, że ze sposobu, w jaki TSUE dotychczas stosował art. 4 ust. 2 TUE, nie wynika wprost, że nie mógłby być on uznany za autonomiczną pod-

${ }^{1338}$ A. Kustra, Kelsenowski..., s. 487 .

${ }^{1339}$ Ibidem. 
stawę do zwolnienia państwa z obowiązków wynikających z prawa unijnego ${ }^{1340}$, w tym do podważenia rozumienia art. 53 wyrażonego w sprawie Melloni czy do zawieszenia stosowania bezpośrednio skutecznego unijnego prawa pochodnego w zakresie, w jakim z tożsamością konstytucyjną danego państwa byłoby ono sprzeczne, szczególnie jeśli w grę wchodziłyby wyższe niż unijne, krajowe gwarancje praw człowieka. Zarówno w sprawie Omega (choć w niej nie ma expressis verbis mowy o tożsamości konstytucyjnej), a także w sprawach Sayn-Wittgenstein, Runevič-Vardyn, Las czy Bogendorff von Wolffersdorff tożsamość konstytucyjna rozpatrywana była w kontekście porządku publicznego i dodatkowego uzasadnienia dopuszczalności derogacji od unijnych swobód. Wynikało to jednak z postawionych w tych sprawach pytań i przede wszystkim z charakteru tych spraw, w których to właśnie unijne swobody znajdowały się na szali jako przeciwwaga dla obowiązku poszanowania tożsamości konstytucyjnej państw członkowskich. W sprawach tych TSUE zdarzało się znajdować taką interpretację owych swobód, która dopuszczała pewne wyjątki od ich skuteczności związane z tożsamością i obowiązkiem jej poszanowania. Podkreślenia wymaga, że tożsamość konstytucyjna występowała tam co do zasady jako samodzielna kategoria, choć wzmacniająca uzasadnienie dopuszczalności derogacji ze względu na porządek publiczny. Nie oznacza to jednak, że należy wykluczyć, iż mogłaby pełnić również tę, a nawet dalej idące funkcje (jak podstawa do zawieszenia stosowania prawa unijnego z nią sprzecznego w danym kraju) w pełni samodzielnie. Brak jak do tej pory wyroku, w którym TSUE odrzuciłby powołanie się na autonomicznie rozumiany obowiązek poszanowania tożsamości konstytucyjnej państwa członkowskiego, w sytuacji jej konfliktu (szczególnie składającego się na nią wyższego niż unijny, konstytucyjnego standardu ochrony jakiegoś prawa czy wolności jednostki) z prawem unijnym, $w$ tym przede wszystkim $z$ unijnym prawem pochodnym.

W istocie rzeczy rację ma Marek Safjan, który twierdzi, że "Sygnały płynące z orzecznictwa TSUE stanowią przesłankę dla tezy, że również w zakresie ustalenia treści i zakresu gwarancji praw podstawowych, stosowanych w odniesieniu do oceny norm prawa krajowego znajdujących się w obszarze stosowania prawa europejskiego, koncepcja tożsamości konstytucyjnej mogłaby przemawiać na rzecz przyjęcia odmiennego standardu konstytucyjnego, jeśli zostałby on uznany za składnik tej tożsamości. Taka interpretacja wykraczałaby poza warunki określone w dotychczasowym orzecznictwie"1341. Nie jest jednak niemożliwa i wydaje się wskazana. Dlatego nic nie stoi na przeszkodzie, aby

${ }^{1340}$ Por.: K. Kowalik-Bańczyk, À la recherche d'une cohérence perdue - Possible Arguments for the Non-application of EU Law in Member States, "Polish Yearbook of International Law" 2013, nr XXXIII, s. 179 i nast.

${ }^{1341}$ M. Safjan, Wprowadzenie..., s. 108. 
tego rodzaju odesłanie, o jakim mowa w tej pracy, sformułować. Można bowiem przyjąć założenie, że "tożsamość konstytucyjna danego systemu prawnego może stanowić uzasadnienie dla zastosowania oceny prawnej odmiennej od tej, która wynikałaby z regulacji europejskiej, a więc także wtedy, gdy [...] przesłanki pierwszeństwa, efektywności i spójności prawa europejskiego nie są spełnione" ${ }^{\prime \prime 342}$.

Pamiętać należy jednak, że takie odwołanie powinno zostać dokonane w sposób powściągliwy i kooperacyjny, aby można mieć nadzieję, że TSUE się do niego przychyli, a także, by sprzyjało ono procesowi integracji europejskiej, a nie go rozsadzało. Wydaje się również, że po raz pierwszy powinien dokonać go organ do tego szczególnie predystynowany, jak sąd konstytucyjny (gdy chodzi o państwa o scentralizowanym systemie kontroli konstytucyjności prawa). Wydaje się także, że tego rodzaju odwołanie byłoby w sposób szczególny uzasadnione w sytuacji, gdyby tym składnikiem tożsamości konstytucyjnej był wyższy niż unijny standard ochrony prawa czy wolności człowieka, a więc gdyby art. 4 ust. 2 TUE przywołany byłby w związku z art. 53 Karty, lecz także z innymi przepisami unijnego prawa pierwotnego, o których będzie jeszcze mowa. Wydaje się więc, że do pewnego stopnia rację mają Armin von Bogdandy i Stephan Schill, gdy twierdza, że art. 4 ust. 2 TUE powinien być rozumiany szerzej - jako dopuszczający w pewnych, ograniczonych okolicznościach, by szczególnie sądy konstytucyjne, powołując się na niego, wytyczały wynikające z konstytucji granice dla zasady pierwszeństwa prawa unijnego (choć w pracy tej ciężar kładziony jest raczej na zasadę jednolitości prawa unijnego) w całym zakresie jej zastosowania ${ }^{1343}$. Również, gdy chodzi o prawo pochodne, w tym takie, które służy pełnej harmonizacji i jest bezpośrednio stosowane. Na marginesie można zauważyć, że wszystkie unijne swobody, które interpretowane były w omówionych sprawach przez TSUE, w których zmodyfikował on ich rozumienie, tak aby zapewnić poszanowanie tożsamości konstytucyjnej państw członkowskich, zgodnie z ugruntowanym orzecznictwem TSUE, same również mogą wywoływać skutek bezpośredni ${ }^{1344}$. Ważne jednak, by te granice, o których piszą von Bogdandy i Schill, wytyczane były nie samodzielnie przez TK czy inne sądy konstytucyjne państw członkowskich, lecz wspólnie - we współpracy z TSUE.

Opisana w tym rozdziale sekwencja takiego orzekania i podział ról w jej ramach między TK a TSUE odzwierciedla fakt, że wprawdzie art. 4 ust. 2 TUE odsyła do porządków krajowych, gdy chodzi o jego treść, to jednak jest prze-

${ }^{1342}$ Ibidem, s. 107.

1343 A. von Bogdandy, S. Schill, Overcoming..., s. 1419; por. także np.: L.F.M. Besselink, National..., s. 36 .

${ }^{1344}$ B. Capik, A. Łazowski, Art. $91 \ldots$, s. 165. 
pisem unijnym i niesie w sobie również przesłanie "europeizujące" kontekst funkcjonowania sądów konstytucyjnych państw członkowskich - w wymiarze konieczności uwzględniania przez nie wiążącego państwa członkowskie prawa unijnego i perspektywy unijnej, gdy wypowiadają się w jego przedmiocie ${ }^{1345}$. Sekwencja taka i współpraca najlepiej odpowiada też podziałowi kompetencji między TK a TSUE, który nie ma nie tylko podstawy dogmatycznej, lecz również zakorzeniony jest w europejskiej kulturze prawnej i opiera się na zidentyfikowanych przez Matthiasa Klatta wynikających z niej kryteriów uzasadniania przewagi po stronie TK czy TSUE, w sytuacji niepełnej jasności co do podziału kompetencji między instytucjami unijnymi a krajowymi. Kryteriami takimi są jego zdaniem, po pierwsze, legitymacja demokratyczna (związana z pozycją obu sądów w ramach ustroju unijnego i krajowego w oparciu o fundamentalne dla nich akty prawne); po drugie, przepisy prawa materialnego leżące u podstaw danej kompetencji (zawarte $\mathrm{w}$ fundamentalnych dla europejskiego - rozumianego integralnie, a więc w naszym przypadku unijnego i krajowego - aktach prawnych, czyli w TUE i TFUE oraz Konstytucji RP); po trzecie, argumentacyjna jakość decyzji (ograniczająca swobodę na dalszych etapach postępowania w ramach opisywanej tu sekwencji, w sytuacji silniej i lepiej osadzonego w przepisach prawa, lecz także we wspólnej, europejskiej kulturze prawnej ${ }^{1346}, \mathrm{w}$ tym metodach argumentacji prawniczej, stanowiska wyrażonego na wcześniejszych etapach wspomnianej tu sekwencji), i wreszcie, last but not least, zasada subsydiarności (a więc wspierającego współudziału TSUE w tych wymiarach, które - jak np. określanie materialnego zakresu tożsamości konstytucyjnej danego państwa - zakorzenione są przede wszystkim w prawie krajowym oraz rola wiodąca TSUE $\mathrm{w}$ tych wymiarach, które - jak np. określanie skutków wynikających z art. 4 ust. 2 TUE dla instytucji unijnych i stanowionego przez nie prawa - zakorzenione są w prawie unijnym - i vice versa ${ }^{1347}$.

Co najważniejsze z perspektywy tej pracy wyłania się z omówionych przed chwilą wyroków TSUE to to, że skoro, choć niechętnie i w sposób nie w pełni uporządkowany, dopuszcza on, by obowiązek poszanowania przez Unię tożsamości narodowej/konstytucyjnej państw członkowskich mógł być uznany, za podstawę zwolnienia państwa członkowskiego z pewnych funda-

${ }^{1345}$ M. Claes, Negotiating..., s. 221.

1346 O szczególnym znaczeniu kultury prawnej i konieczności zakorzenienia w niej metod identyfikowania, czy też dekodowania tożsamości konstytucyjnej RP przez TK, była już mowa. Dla dialogu i współpracy między TK a TSUE, który proponowany jest w tej pracy, równie ważna jest szersza - europejska - kultura prawna, której Polska jest częścią. Tylko w jej ramach możliwe będzie bowiem prowadzenie doniosłego i jurydycznie relewantnego dialogu między TK i TSUE.

${ }_{1347}$ Por.: M. Klatt, Balancing Competences: How Institutional Cosmopolitanism can Manage Jurisdictional Conflicts, "Global Constitutionalism” 2015, nr 4:2, s. 214-217. 
mentalnych zobowiązań wynikających z prawa unijnego, jakimi bez wątpienia są swobody traktatowe, to tym bardziej (a maiori) może i powinien dopuścić, aby tożsamość konstytucyjna mogła prowadzić do zwolnienia tych państw z pewnych zobowiązań, nałożonych na nie przez unijne prawo pochodne (czy to bezpośrednio skuteczne, czy to wymagające implementacji). Na marginesie można zauważyć, że klauzula porządku publicznego, w kontekście której do tej pory TSUE podnosił kwestie związane $z$ obowiązkiem poszanowania przez Unię tożsamości konstytucyjnej państw członkowskich, jest zresztą znana również unijnemu prawu pochodnemu. Tak np. rozporządzenie znane jako „Bruksela I"1348 dotyczące kwestii tak istotnej dla harmonizacji porządków prawnych państw członkowskich w ramach Unii, jak jurysdykcja i uznawanie orzeczeń sądowych oraz ich wykonywania w sprawach cywilnych i handlowych, przewiduje w swym art. 34 ust. 1, że orzeczenia wydanego w innym państwie członkowskim nie uznaje się, jeżeli uznanie byłoby oczywiście sprzeczne z porządkiem publicznym państwa członkowskiego, w którym wystąpiono o uznanie.

Należy w tym kontekście jednak wyraźnie podkreślić, że art. 4 ust. 2 TUE, który zobowiązuje Unię do poszanowania tożsamości konstytucyjnej państw członkowskich, nie wprowadza żadnego zróżnicowania co do sfer, w jakich tożsamość ta miałaby być poszanowana albo nie. Nie mówi więc nic o tym, czy miałaby być ona poszanowana jedynie w ramach realizacji przez Unię określonych kompetencji, ani czy miałaby być poszanowana tylko wtedy, gdy prawo unijne dopuszcza jakąś inną formę derogacji od jego postanowień, jak choćby na podstawie klauzuli porządku publicznego. Art. 4 ust. 2 TUE mówi ogólnie o obowiązku Unii do poszanowania tożsamości konstytucyjnej państw członkowskich przez Unię - a więc we wszystkich jej aktywnościach ${ }^{1349}$. Można oczywiście postawić sobie pytanie, czy w każdym wypadku ewentualnie wynikające stąd konsekwencje powinny być w pełni analogiczne i np. wymagać tak samo przekonującego i silnego uzasadnienia, a nawet, czy charakter kompetencji Unii do regulowania określonych kwestii i sposób ich uregulowania może mieć wpływ na zakres obowiązku poszanowania tożsamości konstytucyjnej państw członkowskich. W omawianych przypadkach mieliśmy do czynienia ze swobodami traktatowymi, a nie precyzyjnymi przepisami prawa pochodnego. Można zgodzić się z niektórymi komentatorami, że zwłaszcza te ostatnie mogą być uznawane za przejaw pewnego konsensu w Unii, którego funkcją jest daleko posunięta harmonizacja i brak swobody po stronie państw członkowskich do jakichkolwiek odstępstw, co w pewnym sensie podnosiłoby

${ }^{1348}$ Rozporządzenie Rady (WE) nr 44/2001 z 22 grudnia 2000 w sprawie jurysdykcji i uznawania orzeczeń sądowych oraz ich wykonywania w sprawach cywilnych i handlowych, Dz. Urz. L 012 z 16 stycznia 2001.

${ }^{1349}$ Por.: G. van der Schyff, The Constitutional..., s. 568-569. 
rangę, przynajmniej jeśli chodzi o jego sztywność, prawa pochodnego względem prawa pierwotnego ${ }^{1350}$. W takich wypadkach TSUE faktycznie mógłby mieć podstawy do mniejszej elastyczności, co mogłoby w jakimś stopniu minimalizować potencjalny zakres zastosowania art. 4 ust. 2 TUE.

Nie można jednak wykluczyć znaczenia art. 4 ust. 2 TUE odnośnie do jakiegokolwiek przejawu realizacji przez Unię swych kompetencji, w tym również odnośnie do prawa pochodnego Unii, w tym prawa bezpośrednio skutecznego, wprowadzającego najwyższy stopień harmonizacji. Choćby ze względu na to, że nie można przecież wykluczyć pewnych wyjątkowych sytuacji, w których np. doszłoby do naruszenia przewidzianego $w$ art. 4 ust. 2 TUE obowiązku po stronie Unii, który mógłby ujawnić się dopiero po pewnym czasie funkcjonowania przepisów unijnych, co byłoby niemożliwe do spostrzeżenia na etapie ich tworzenia ${ }^{1351}$, a więc na etapie wyrażania owego konsensu w formie norm prawnych. Brak możliwości zastosowania proponowanego w tej pracy mechanizmu w takich przypadkach i a priori odrzucenie możliwości uwzględnienia przez TSUE obowiązku poszanowania tożsamości konstytucyjnej odnośnie do niektórych rodzajów przepisów prawa unijnego prowadziłby do utraty szans, jakie się wiążą z zastosowaniem tego mechanizmu. Powodowałoby to podniesienie prawdopodobieństwa ziszczenia się zagrożenia, jakim jest niesubordynacja państw, oparta na znanej ich sądom konstytucyjnym doktrynie ultra vires, i prowadziłoby do otwartego konfliktu.

Należy więc przyjąć, że w niektórych przypadkach obowiązek poszanowania tożsamości konstytucyjnej państwa członkowskiego przez możliwość niestosowania wobec niego pewnych konsekwencji, wynikających z wiążącego je prawa unijnego, może wymagać silniejszego uzasadnienia niż w innych przypadkach i ograniczać się może jedynie do najbardziej doniosłych przejawów naruszenia tożsamości tych państw (szczególną rolę może tu odegrać stosowanie testu proporcjonalności). Jak się jednak wydaje, nie ma takich obszarów prawa unijnego, w których obowiązek nałożony na Unię w art. 4 ust. 2 TUE nie znajdowałby zastosowania. Przepis ten sformułowany jest w sposób

${ }^{1350}$ Por. np.: K. Lenaerts, EU Values and Constitutional Pluralism: The EU System of Fundamental Rights Protection, "Polish Yearbook of International Law” 2014, nr 34; idem, The Court's Outer and Inner Selves: Exploring the External and Internal Legitimacy of the European Court of Justice, [w:] M. Adams, H. de Waele, J. Meeusen, G. Straetmans (red.), Judging Europe's Judges: the Legitimacy of the Case Law of the European Court of Justice, Oxford 2013.

${ }^{1351}$ Tego typu rozumowanie, przy zachowaniu wszelkich różnic co do zakresu, formy i podmiotu uprawnionego do dokonywania kontroli zgodności prawa unijnego z tożsamością konstytucyjną Niemiec zaprezentował FTK w sprawie Gauweiler, akceptując, że aktualnie kwestionowane przepisy unijne nie stanowią zagrożenia dla tożsamości konstytucyjnej Niemiec, rezerwując sobie jednak możliwość weryfikacji tego stanu w przyszłości (FTK, 2 BvR 2728/13, 2 BvR 2729/13, 2 BvR 2730/13, 2 BvR 2731/13, 2 BvE 13/13, orzeczenie z 21 czerwca 2016). 
uniwersalny, brak w nim określenia zakresu kompetencji czy sposobów ich wykonywania przez Unię, które miałyby być nim objęte, a które nie. Odróżnia to ten przepis np. od art. 5 ust. 3 TUE i sposobu, w jaki reguluje on zastosowanie zasady pomocniczości ${ }^{1352}$. Co nie może być też zignorowane, art. 4 ust. 2 TUE po reformie lizbońskiej

figuruje obecnie obok ważnych zasad strukturalnych leżących u podstaw funkcjonowania Unii Europejskiej: zasady kompetencji wyraźnie przyznanych (art. 4 ust. 1 TUE, ujętej też w art. 5 ust. 1 TUE) oraz zasady lojalności (art. 4 ust. 3 TUE, d. art. 10 TWE). Niektórzy autorzy uznaja, że zasada poszanowania tożsamości narodowej od czasu wejścia w życie traktatu z Lizbony stała się wobec tego zasadą określającą działania Unii Europejskiej w jej relacji z państwami członkowskimi. Wcześniejsze jej uplasowanie w art. 6 TUE wiązało ją z zagadnieniem ochrony praw podstawowych, natomiast teraz znajduje się ona wśród zasad "ustrojowych" Unii, określających relacje Unii z jej państwami członkowskimi. Takie umiejscowienie zasady poszanowania tożsamości narodowej wskazywałoby na to, że zasada ta powinna być obok zasady kompetencji przyznanych i zasady lojalności regułą przewodnią - określającą i ograniczającą działania Unii Europejskiej ${ }^{1353}$.

Co należy dodać - wszelkie jej działania, we wszelkich dziedzinach i we wszystkich formach ${ }^{1354}$. Jest to przepis o „uniwersalnym zastosowaniu” względem prawa unijnego, nie obarczony w swej treści żadnymi wyrażonymi wprost ograniczeniami, nawet wymogami proporcjonalności czy konieczności ${ }^{1355}$, choć te ostatnie być może w pewnym stopniu mogą być do niego stosowane, o czym świadczy dotychczasowe orzecznictwo TSUE.

Jak podkreśla Stanisław Biernat, wyroki w sprawach Sayn-Wittgenstein i Runevič-Vardyn, co potwierdziły dowodnie następujące po nich, omówione w tej pracy inne orzeczenia, stanowiły „jakościową zmianę w orzecznictwie ETS. Odwołanie się do zasad konstytucyjnych przeważyło nad swobodami przemieszczania się i pobytu wynikającymi z prawa unijnego"1356. Nic nie stoi na przeszkodzie, aby w sytuacji uzasadnionej względami konstytucyjnymi, a konkretnie względami tożsamości konstytucyjnej państw członkowskich, do podobnego jakościowego przełomu doszło w orzecznictwie TSUE odnośnie do możliwości pewnego, wyjątkowego ograniczenia zasad pierwszeństwa, jedności i efektywności prawa unijnego, również odnośnie do prawa pochodnego

${ }^{1352}$ Por.: G. van der Schyff, The Constitutional..., s. 569.

${ }^{1353}$ K. Kowalik-Bańczyk, Tożsamość..., s. 36.

1354 Por.: S. Platon, Le respect de l'identité nationale des Etats membres: frein ou recomposition de la gouvernance?, "Revue de l'Union européenne” 2012, nr 556.

${ }^{1355}$ K. Kowalik-Bańczyk, Tożsamość..., s. 49.

1356 S. Biernat, Konsekwencje..., s. 75 . 
Unii, a więc również $\mathrm{w}$ obszarach $\mathrm{w}$ najwyższym stopniu zharmonizowanych, nawet jeśli prawo unijne nie pozostawiałoby państwom członkowskim żadnego pola swobody ani nie ustanawiało odnośnie do tych przepisów szczegółowych mechanizmów derogacyjnych. Ta swoboda i mechanizm derogacyjny (bądź quasi-derogacyjny) zostały w prawie unijnym ustanowione w wymiarze generalnym i zawierają się w obowiązku poszanowania przez Unię tożsamości konstytucyjnej państw członkowskich, wyrażonym w art. 4 ust. 2 TUE. W tym duchu, choć może nie aż tak jednoznacznie, komentował już sprawę Melloni Koen Lenaerts, kiedy pisał, że państwa członkowskie muszą respektować pierwszeństwo prawa unijnego, nawet gdy dotyczy to regulacji rangi konstytucyjnej. $Z$ drugiej jednak strony prawo unijne musi pozostawiać przestrzeń do ochrony tożsamości konstytucyjnych państw członkowskich i pewnego różnicowania standardów krajowych, nawet jeśli mamy do czynienia ze skutecznymi przepisami prawa unijnego ${ }^{1357}$.

Faktycznie bowiem "wkomponowanie konstytucyjnych struktur państwa w pojęcie tożsamości narodowej ( $w$ art. 4 ust. 2 TUE) zdaje się przenosić obowiązek, czy może raczej przywilej, nadawania treści temu pojęciu z Trybunału Sprawiedliwości Unii na krajowe sądy konstytucyjne. Nie zaskakuje więc, że niektóre z nich przekształciły »traktatową« tożsamość narodową w tożsamość konstytucyjną"1358. Należy wszakże pamiętać, że cały czas mówimy tu o kategorii zawartej $\mathrm{w}$ art. 4 ust. 2 TUE, a więc $\mathrm{w}$ unijnym prawie pierwotnym. Nawet więc jeśli pewna doza interpretacyjnego ciężaru, gdy chodzi o treść tożsamości każdego z państw członkowskich spoczywa na organach tego państwa, a w przypadku Polski przede wszystkim na TK, to jednak jej znaczenie w ogólnounijnym wymiarze jej stosowania spoczywa na TSUE i to on musi wypracować pewną metodologię i konceptualne ramy do formułowania przez sądy konstytucyjne jak najprecyzyjniejszych i możliwych do zaakceptowania na gruncie prawa unijnego treści charakterystycznych dla porządków konstytucyjnych ich państw, które można będzie uznać za doniosłe i godne poszanowania $\mathrm{w}$ ramach unijnego porządku prawnego.

Wydaje się, że ochrona wyższych niż unijne, choć nie wszystkich - lecz tych, które można zaliczyć do konstytucyjnej tożsamości - standardów ochrony praw i wolności człowieka mogłaby być jedną z pierwszych i najważniejszych kategorii zagadnień $\mathrm{w}$ ramach takiego podejścia do obowiązku poszanowania przez Unię tożsamości konstytucyjnej państw członkowskich. W pewnym sensie zielone światło do tego rodzaju podejścia, choć na razie bardzo delikatnie, TSUE dał w sprawach, o których mowa była w poprzednim podrozdziale. Jako

${ }^{1357}$ K. Lenaerts, Kooperation und Spannung im Verhältnis von EuGH und nationalen Verfassungsgerichten, "Europarecht” 2015, nr 1, s. 24.

${ }^{1358}$ K. Wójtowicz, Sady konstytucyjne..., s. 124. 
pewne 'ciche przyzwolenie' traktować można również niezanegowaną opinię Rzecznika Maduro w sprawie Michaniki. O pewnych przykładach orzeczeń ukazujących specjalny status, jaki ochronie praw człowieka w kontekście krajowym coraz szerzej nadaje TSUE, i konsekwencjami, jakie to za sobą niesie dla tak fundamentalnych zasad, na których opiera się prawo unijne, jak pierwszeństwo, jedność i efektywność, a także zasada wzajemnego zaufania - będzie jeszcze mowa. Podnoszą one prawdopodobieństwo przystania TSUE na taki specyficzny status niektórych krajowych gwarancji praw człowieka.

Jest więc prawda, że sądy konstytucyjne państw członkowskich, w tym polski TK, skorzystały z szansy,

jaką stworzyło ścisłe powiązanie w art. 4 ust. 2 TUE tożsamości narodowej państw członkowskich z ich podstawowymi strukturami politycznymi i konstytucyjnymi. W konsekwencji nie tylko wypełniają treścią pojęcie tożsamości konstytucyjnej, ale przekształcając "traktatową" tożsamość narodową w tożsamość konstytucyjną uzasadniają swoje prawo do kontrolowania zarówno zakresu przekazywanych Unii kompetencji, jak i sposobu korzystania $\mathrm{z}$ nich. W tym ostatnim przypadku mogłoby to nawet polegać na sprawdzeniu, czy stanowione przez Unię akty respektują tożsamość konstytucyjną państwa ${ }^{1359}$.

Wydaje się jednak, że ta aktywność sądów konstytucyjnych jest w pewnym sensie wyizolowana nie tyle od materialnego kontekstu unijnego, co od jego wymiaru formalnego i oderwana od aktywności TSUE oraz przejawiana równolegle do orzecznictwa TSUE w tej materii. Sądy konstytucyjne nie skorzystały - przynajmniej do tej pory - z możliwości powołania się na tożsamość konstytucyjną w pytaniu prejudycjalnym do TSUE w sposób, o jakim mowa w tej pracy. Na razie mamy tu do czynienia ze specyficzną formą dialogu sędziowskiego, przejawiającego się w dwu monologach, których echa odbijają się wzajemnie w orzecznictwie. Brak jednak przykładu, w którym TK, jako najbardziej do tego upoważniony, odwołałby się do tożsamości konstytucyjnej we wniosku do TSUE, a ten jako najbardziej do tego upoważniony, orzekłby o konsekwencjach tego faktu dla prawa unijnego, szczególnie w kontekście zasady jego pierwszeństwa, a właściwie bardziej w kontekście jednolitości jego stosowania. Pytanie takie powinno dotyczyć interpretacji prawa unijnego $\mathrm{w}$ związku $\mathrm{z}$ art. 4 ust. 2 TUE i art. 53 KPP i sprowadzać się do tego, czy można zawiesić stosowanie przepisów prawa unijnego w danym państwie członkowskim (a nie podważać ważność takiego prawa na przestrzeni całej Unii) w zakresie, w jakim jest ono niezgodne z gwarantowanym w jego systemie konstytucyjnym, wyższym niż unijny, składającym

${ }^{1359}$ Ibidem, s. 128. 
się na jego tożsamość konstytucyjną standardem ochrony jakiegoś prawa czy wolności jednostki.

Propozycja rozpoczęcia tego rodzaju dialogu jest właśnie przedmiotem tej pracy. Trudno jednoznacznie wskazać, z czego wynika dotychczasowa niechęć do powzięcia takiego kroku. Być może wypływa ona z pewnej obawy TK i innych sądów konstytucyjnych przed ewentualnym oddaniem inicjatywy TSUE, który mógłby zyskać sytuacyjną przewagę, przejawiającą się w możliwości weryfikowania stanowiska TK, a więc uzyskiwałby rolę rozstrzygającą. Rozumowanie takie wydaje się jednak błędne. W sytuacji samodzielnego orzeczenia przez TK np. o niezgodności z konstytucyjnymi, składającymi się na tożsamość konstytucyjną RP, gwarancjami praw człowieka bezpośrednio skutecznego prawa unijnego, tak jak potencjalnie mogło się to stać w sprawie Sk 45/o9, to i tak TSUE mógłby mieć "ostatnie", a przynajmniej „następne” słowo w ramach procedury naruszeniowej ${ }^{1360}$. Natomiast po tym, gdy TK zwróciłby się do TSUE z pytaniem, sprawa i tak wracałaby przecież do TK, a więc to znowu on byłby "ostatni".

Znacznie lepszym rozwiązaniem, zdaniem autora zgodniejszym z prawem unijnym, ale i Konstytucją RP, a także sprzyjającym wspólnej trosce o obowiązek poszanowania tożsamości konstytucyjnej Polski, który powinien być celem przyświecającym zarówno TK, jak i TSUE, byłoby wystąpienie przez TK do TSUE z pytaniem prejudycjalnym zawierającym powołanie się na tożsamość konstytucyjną. Podkreślić należy, że sekwencja orzekania w takiej sprawie, i to, kto wypowiadałby się później, wcale nie musiałoby oznaczać przewagi sytuacyjnej wynikającej z możliwości wypowiedzenia "ostatniego słowa”. Stopień związania poprzednimi etapami procedury i wypowiedzianymi na ich etapie "słowami"1361 dawałby bowiem obu trybunałom status równorzędnych partnerów w ramach wspólnego (i dzięki temu dającego znacznie wyższą szansę powodzenia) działania zmierzającego do wypełnienia przez Unię obowiązku przewidzianego w art. 4 ust. 2 TUE i wypełniania przez Polskę obowiązku przewidzianego $\mathrm{w}$ art. 4 ust. 3 TUE. Po uzyskaniu odpowiedzi od TSUE, sprawa wracałaby do TK, który to mógłby, w skrajnym przypadku nie zastosować się do wyroku TSUE, uzyskując albo odzyskując w ten sposób pewną przewagę sytuacyjną. Tę jednak znowu odbierałaby mu perspektywa wszczęcia procedury naruszeniowej, która mogłaby zakończyć się na forum TSUE. Najważniejsze

${ }^{1360}$ Choć jak twierdzą niektórzy, tego rodzaju sytuacje wcale nie musiałyby się kończyć skierowaniem ostatecznie skargi przez Komisję przeciwko Polsce (por. np.: P. Bogdanowicz, P. Marcisz, Szukając..., s. 51).

${ }^{1361}$ Zdaniem niektórych możliwość wypowiedzenia „pierwszego słowa” w ramach procedury prejudycjalnej w przedmiocie wrażliwych problemów konstytucyjnych daje istotną przewagę nad TSUE sądom konstytucyjnym państw członkowskich (tak np.: N. Lupo, The Advantage...). 
wydaje się więc skupienie się na walorach kooperacyjnych zaproponowanego tutaj podejścia do pytania prejudycjalnego i obowiązku poszanowania tożsamości konstytucyjnej państw członkowskich, a nie na walce o "ostatnie słowo".

Propozycja współpracy między TK a TSUE w zakresie poszanowania wyższego niż unijny, konstytucyjnego standardu ochrony praw człowieka, składającego się na tożsamość konstytucyjną RP prowadzi więc do odróżnienia funkcji i sposobów realizowania obowiązku po stronie Unii do poszanowania tożsamości konstytucyjnej od doktryny ultra vires, podczas gdy z orzecznictwa sądów konstytucyjnych państw członkowskich wyłania się podobne potraktowanie ich funkcji. Jak podkreśla Aleksandra Kustra: „Po pierwsze, tak jak zakaz działania ultra vires, ochrona tożsamości konstytucyjnej stanowi argument uzasadniający wewnątrzsystemową legitymację sądów konstytucyjnych do badania zgodności norm prawa UE z konstytucją (czy też z normami stanowiącymi o tożsamości danej konstytucji). Po drugie zaś, tożsamość konstytucyjna zaczyna być wykorzystywana jako nowy wzorzec kontroli wobec norm prawa UE"1362. Podążanie tą drogą wydaje się niewskazane, zarówno gdy chodzi o inne sądy konstytucyjne, jak i będący przedmiotem zainteresowania w tej sprawie polski TK, szczególnie, że istnieją możliwe do pogodzenia z jego dotychczasowym orzecznictwem metody rozdzielenia rozumowania opartego na tożsamości konstytucyjnej i potraktowania jej jako jeszcze jednego mechanizmu kooperacyjnego i dającego szansę na pogodzenie wymogów wynikających z prawa unijnego i Konstytucji, niejako na przedpolu zastosowania doktryny ultra vires.

Proponowane tu rozwiązanie nie unieważnia ani nie wyklucza możliwości zastosowania opcji ostatecznej, ale stara się doprowadzić do tego, aby nie było to konieczne. Ostatecznie jednak zachowuje aktualność, bez względu na ocenę takiego stanowiska, to, co TK szczególnie silnie podkreślił w wyroku w sprawie akcesji.

Państwa członkowskie zachowują prawo do oceny, czy prawodawcze organy wspólnotowe (unijne), wydając określony akt (przepis prawa), działały w ramach kompetencji przekazanych i czy wykonywały swe uprawnienia zgodnie z zasadami subsydiarności i proporcjonalności. Przekroczenie tych ram powoduje, że wydane poza nimi akty (przepisy) nie są objęte zasadą pierwszeństwa prawa wspólnotowego ${ }^{1363}$.

Zgodnie $\mathrm{z}$ koncepcją prezentowaną $\mathrm{w}$ tym rozdziale, za taki akt ultra vires można by było również uznać orzeczenie TSUE, które niesłusznie nie wzięłoby pod uwagę wyższego niż unijny polskiego standardu ochrony praw człowieka składającego się na tożsamość konstytucyjną RP, co zosta-

1362 A. Kustra, Kelsenowski..., s. 288.

${ }^{1363}$ TK, sprawa K 18/o4, wyrok z 11 maja 2005, pkt III 10.2 uzasadnienia. 
łoby prawidłowo wskazane w pytaniu prejudycjalnym przez TK, a TSUE nie uwzględniłby skutków tego faktu dla stosowania prawa unijnego w Polsce. Oczywiście stwierdzenie działania ultra vires przywracałoby aktualność całej tematyki odpowiedzialności Polski za niewywiązywanie się ze zobowiązań wynikających z prawa unijnego. Moment ten byłby jednak odsunięty i podjęte zostałyby kroki, które mogłyby sprawić, że do niego nie dojdzie. Procedury naruszeniowej nie trzeba jednak traktować jedynie jako ewentualności związanej z niepowodzeniem proponowanej tu sekwencji współpracy między TK a TSUE. Można ją uznać za jej przedłużenie i swoistą 'dogrywkę ${ }^{1364}$, która pozwalałaby jeszcze raz rozważyć argumenty dotyczące tożsamości konstytucyjnej, które po dodatkowym namyśle i ewentualnie pogłębionym stanowisku wyrażonym przez TK (po otrzymaniu odpowiedzi na pytanie prejudycjalne) na tym etapie mogłyby ostatecznie zostać uwzględnione ${ }^{1365}$.

Tego rodzaju 'dogrywkę' traktować należy jednak jedynie jako swoisty wentyl bezpieczeństwa - rozwiązanie awaryjne, dające wszakże, szczególnie krajowym sądom konstytucyjnym kolejny argument, że ich otwarcie sformułowane i precyzyjne stanowisko, dotyczące poszanowania tożsamości konstytucyjnej tego państwa, skierowane do TSUE $\mathrm{w}$ formie pytania prejudycjalnego, nie wiąże się z utratą przez nie pozycji i roli wynikającej z ich statusu jako organów stojących na straży konstytucji i tożsamości konstytucyjnej państw członkowskich, jakie to obawy mogły stać za różnymi, sprzecznymi z propozycją zawartą w tej pracy, sposobami zastosowania obowiązku poszanowania przez Unię tożsamości konstytucyjnej przez sądy konstytucyjne, z omawianą pod tym kątem w tej pracy sprawą Gauweiler ${ }^{1366}$ na czele. Pamiętając o tym wentylu bezpieczeństwa, należy jednak podkreślić, że: „Naruszenie przez sądy konstytucyjne prawa Unii Europejskiej i uchybienie przyjętym przez państwa członkowskie zobowiązaniom jest z pewnością sytuacją, której należy unikać"1367. Metodą ich unikania ma być właśnie zastosowanie pytania prejudycjalnego w sposób, o którym mowa w tej pracy. Jak w kategoriach ogólnych zauważył bowiem Krzysztof Wójtowicz:

Procedura prejudycjalna, dotycząca konkretnych problemów interpretacyjnych o charakterze konstytucyjnym, powinna doprowadzić do zbliżenia stanowisk Trybunału Sprawiedliwości i sądów konstytucyjnych, przede wszystkim ze względu na wspól-

${ }^{1364}$ Podobnie np.: I. Pernice, The Autonomy..., s. 65.

${ }^{1365}$ Więcej na temat wykorzystywania procedur z art. 258-26o TFUE jako konsekwencji naruszenia prawa unijnego przez sądy krajowe państw członkowskich, w tym przez ich sądy konstytucyjne - patrz: M. Taborowski, Konsekwencje naruszenia prawa UE przez sady krajowe, Warszawa 2012, s. 263-359.

1366 TSUE, Peter Gauweiler i in. p. Deutscher Bundestag, C-62/14, wyrok z 16 czerwca 2015.

${ }^{1367}$ K. Wójtowicz, Sądy konstytucyjne..., s. 155. 
notę wartości leżących u podstaw porządków konstytucyjnych oraz prawa unijnego. Łatwiej bowiem w formie bezpośredniego dialogu ustalić akceptowalną dla obu stron wykładnię, która szanując prawo Unii, jednocześnie respektuje podstawowe zasady porządku konstytucyjnego ${ }^{1368}$.

\subsection{Art. 4 ust. 2 TUE jako wyjątek od rozumienia art. 53 Karty przedstawionego przez TSUE w sprawie Melloni}

Kluczowa dla rozumienia podejścia TSUE do kwestii możliwości stosowania przez państwa członkowskie wyższych standardów praw podstawowych niż przewiduje to Karta w sytuacjach, gdy zgodnie z jej art. 51 ust. 1 znajduje ona zastosowanie, jest sprawa Melloni. Wyrok w sprawie Melloni był już również przywoływany w tej pracy, szczególnie w kontekście wyłaniającej się z orzecznictwa TSUE zasady związanej z mieszanym (mixed) stosowaniem unijnych i krajowych praw podstawowych w zakresie zastosowania Karty. W tym miejscu sprawa ta zostanie omówiona nieco bardziej szczegółowo, w kluczowym z perspektywy tej pracy kontekście, a zatem w zakresie, w którym dokonana w niej interpretacja art. 53 Karty prowadzi do ograniczenia swobody państw członkowskich w stosowaniu wyższego niż unijny standardu ochrony praw podstawowych i tym samym standard ochrony tych praw oparty na Karcie urasta do rangi maksymalnego dopuszczalnego standardu ochrony.

\subsubsection{Sprawa Melloni i unijny standard ochrony praw człowieka jako standard maksymalny w zakresie zastosowania prawa unijnego}

Sprawa ta dotyczyła Pana Stefano Melloniego, który był obywatelem włoskim. W 1996 r. sąd hiszpański zarządził jego ekstradycję. Został on zwolniony za kaucją (w wysokości 5 mln ESP), po zapłaceniu której zniknął. W 2000 r. (co zostało potwierdzone w 2003 r.) został skazany we Włoszech in absentia za oszukańcze bankructwo na 10 lat więzienia. Piąta izba karna Corte suprema di cassazione (Włochy) oddaliła środek odwoławczy wniesiony przez adwokatów Stefano Melloniego i prokurator generalny Republiki przy Corte d'appello di Bologna wydał za nim europejski nakaz aresztowania. Pan Melloni został aresztowany ponownie przez hiszpańską policję w 2008 r., lecz zaskarżył decyzję o wydaniu go władzom włoskim do hiszpańskiego Trybunału Kon-

1368 Ibidem, s. 156. 
stytucyjnego $\mathrm{w}$ trybie recurso de amparo twierdząc, że naruszałoby to prawo zagwarantowane mu w art. 24 ust. 2 hiszpańskiej konstytucji, zakazującym sądzenia in absentia, jeśli nie istnieje już możliwość jakiegokolwiek odwołania od wydanego w takiej sytuacji orzeczenia. Hiszpański TK rozpatrywał wcześniej podobną sprawę obywatela Rumunii i przyznał rację skarżącemu, potwierdzając, że taki właśnie zakaz składa się na zawartą w art. 24 konstytucji Hiszpanii gwarancję prawa do sądu.

Od tego czasu zmianie uległy jednak przepisy unijne dotyczące ENA (stara Decyzja ramowa nr: 2002/584 $4^{1369}$ ). Nowa Decyzja (nr: 2009/299 $9^{1370}$ ) explicite wykluczyła z okoliczności, na podstawie których władze wykonujące ENA mogłyby tego odmówić, sytuację, w której osoba, której on dotyczy, nie uczestniczyła $\mathrm{w}$ procesie. Zostało to jednak obwarowane wymogiem, by osoba ta (zgodnie z nowo dodanym do starej Decyzji art. 4a ust 1 pkt b), „wiedząc o wyznaczonej rozprawie, udzieliła pełnomocnictwa obrońcy, który został wyznaczony przez daną osobę albo przez państwo do tego, aby ją bronić na rozprawie, i obrońca ten faktycznie bronił jej na rozprawie". Wymóg ten w sprawie Pana Melloniego został spełniony, co wykluczało odmowę wykonania ENA w oparciu o regulujące tę instytucję prawo unijne, mimo że naruszyłoby to gwarancje prawa do rzetelnego procesu przewidziane przez konstytucję hiszpańską ${ }^{1371}$.

Na kanwie tej sprawy uwidocznił się więc bezpośrednio kluczowy dla tej pracy problem, jakim jest możliwość stosowania wyższego niż unijny standardu ochrony praw jednostki, który gwarantowany był w tym wypadku przez konstytucję Hiszpanii, a który stał w sprzeczności z pochodnym prawem Unii, w tym wypadku decyzją ramową regulującą kwestie ENA. Jak wspomniano wcześniej decyzje ramowe stanowiły swoisty odpowiednik dyrektyw w dawnym tak zwanym trzecim filarze, wymagały więc transpozycji do prawa krajowego. Przedmiotem pytania skierowanego przez hiszpański TK do TSUE nie było jednak to, czy może on badać prawo implementujące decyzję ramową pod kątem zgodności z konstytucją Hiszpanii, lecz to, czy Hiszpania może zwolnić się z obowiązku przewidzianego $\mathrm{w}$ decyzji ze względu na wyższy niż przewidziany w prawie unijnym standard ochrony praw jednostki wynikający z hiszpańskiej ustawy zasadniczej. Jak łatwo bowiem zauważyć, poziom harmonizacji, jaki przewidywała Decyzja, był bardzo wysoki i nie pozostawiała

${ }^{1369}$ Decyzja ramowa Rady z 13 czerwca 2002 w sprawie europejskiego nakazu aresztowania i procedury wydawania osób między Państwami Członkowskimi, Dz.Urz. L 190 z 18 lipca 2002.

${ }^{1370}$ Decyzja ramowa Rady 2009/299/WSiSW z 26 lutego 2009 zmieniająca decyzje ramowe 2002/584/WSiSW, 2005/214/WSiSW, 2006/783/WSiSW, 2008/909/WSiSW oraz 2008/947/ WSiSW i tym samym wzmacniająca prawa procesowe osób oraz ułatwiająca stosowanie zasady wzajemnego uznawania do orzeczeń wydanych pod nieobecność danej osoby na rozprawie, Dz.Urz. L 81 z 27 marca 2009.

${ }^{1371}$ TSUE, Stefano Melloni p. Ministerio Fiscal, C-399/11, wyrok z 26 lutego 2013, pkt 13-25. 
ona swobody państwom członkowskim, szczególnie, gdy chodzi o okoliczności, ze względu na które władze państwa członkowskiego mogłyby odmówić wykonania ENA.

W obliczu tego, co powiedziane zostało w rozdziale I, nie może budzić wątpliwości kwestia czy sprawa miała charakter unijny, a więc czy znajdowały w niej zastosowanie unijne prawa podstawowe. Kwestia art. 51 ust. 1 Karty nawet nie pojawiła się w wyroku, choć TSUE odrzucił zarzuty niedopuszczalności pytania o charakterze ratione temporis, a nie ratione materiae ${ }^{1372}$. Hiszpański TK zapytał więc, czy:

art. 53 [Karty] interpretowany zgodnie z wykładnią systemową w związku z prawami zawartymi w art. 47 i 48 Karty zezwala państwu członkowskiemu na uzależnienie przekazania osoby skazanej zaocznie od umożliwienia ponownego rozpoznania sprawy zakończonej danym wyrokiem skazującym w państwie wydającym nakaz, poprzez przyznanie w ten sposób tym prawom szerszego poziomu ochrony niż wynikający z prawa Unii Europejskiej, w celu uniknięcia wykładni ograniczającej lub naruszającej prawo podstawowe zawarte w konstytucji państwa członkowskiego? ${ }^{1373}$

Jak zostało to już powiedziane, kryteria, które musiały być spełnione zgodnie z decyzją ramowa, aby mogło dojść do wydania osoby skazanej państwu, w którym doszło do skazania na podstawie ENA, były określone bardzo szczegółowo. Również kwestia dopuszczalności ewentualnego skazania in absentia, stanowiącego podstawę wydania w ramach ENA była bardzo szczegółowo uregulowana. Pierwszym pytaniem, jakie należało sobie więc postawić, było to, czy spełniają one przewidziane w Karcie gwarancje rzetelnego procesu. Gdyby tak bowiem nie było, przepisy decyzji ramowj należałoby uznać za sprzeczne z Karta, co prowadziłoby do ich nieważności. Nie mogłyby więc stać dłużej na przeszkodzie realizacji hiszpańskich gwarancji konstytucyjnych z nimi sprzecznych. Zdaniem Trybunału nie budzi wątpliwości, że przedmiotowe przepisy decyzji, dopuszczające pod pewnymi warunkami skazanie in absentia, spełniały standardy wynikające $\mathrm{z}$ art. 47 i 48 Karty, ani nie naruszały wiążącego Unię standardu ochrony wynikającego $\mathrm{z}$ art. 6 EKPCz oraz jego interpretacji dokonanej przez ETPC $z^{1374}$.

Kluczowe okazało się więc pytanie, czy prawo pochodne Unii, które spełnia wymagane przez unijne prawo standardy ochrony praw jednostki, może być podważone ze względu na wyższy standard obowiązujący w prawie państwa członkowskiego. Odpowiedź TSUE na to pytanie w tym przypadku okazała

\footnotetext{
${ }^{1372}$ Ibidem, pkt 27-34.

${ }^{1373}$ Ibidem, pkt 26.

${ }^{1374}$ Ibidem, pkt 47-54.
} 
się negatywna. Wnioski, do jakich doszedł Trybunał, mają jednak doniosłe znaczenie systemowe. Trybunał jednoznacznie rozwiał nadzieje sądu odsyłającego co do możliwości oparcia dopuszczalności zastosowania wyższego niż unijny standard na podstawie art. 53 Karty w sytuacji takiej, jaka miała miejsce w tej sprawie. "W tym względzie sąd odsyłający bierze pod uwagę przede wszystkim wykładnię, zgodnie z którą art. 53 Karty zezwala w sposób ogólny państwu członkowskiemu na stosowanie standardu ochrony praw podstawowych gwarantowanego konstytucja, jeśli jest on wyższy od standardu wynikającego z Karty, i na sprzeciwienie się w razie potrzeby stosowaniu przepisów prawa Unii"1375. Tymczasem, zdaniem TSUE: „Taka wykładania art. 53 Karty nie może być przyjęta"1376.

Trybunał podjął się w ten sposób obrony fundamentalnych dla unijnego porządku prawnego zasad pierwszeństwa, jedności i skuteczności prawa UE, które byłyby zagrożone przez taką swobodną możliwość interpretacji po stronie państw członkowskich. Zdaniem Trybunału: „Wspomniana wykładnia art. 53 Karty naruszałaby [...] zasadę pierwszeństwa prawa Unii w zakresie, w jakim pozwalałaby, aby państwo członkowskie tworzyło przeszkodę w stosowaniu aktów prawa Unii w pełni zgodnych z Kartą w wypadku braku poszanowania przez te akty praw podstawowych gwarantowanych konstytucją tego państwa"1377. Wyraźnie pobrzmiewa tu echo dobrze znanej doktryny Simmenthal. Jak podkreślił Trybunał: „Z utrwalonego orzecznictwa wynika [...], że na mocy zasady pierwszeństwa prawa Unii, która jest istotną cechą porządku prawnego Unii [...], okoliczność powoływania się przez państwo członkowskie na przepisy prawa krajowego, nawet rangi konstytucyjnej, nie może mieć wpływu na skuteczność prawa Unii na terytorium tego państwa [...]"1378.

Wyrok w sprawie Melloni posłużył TSUE do dokonania dość jednoznacznej wykładni art. 53 Karty, odróżniającej go od podobnie brzmiących klauzul, jak zostały one wcześniej nazwane, „najwyższego uprzywilejowania jednostki", znajdujących się w różnych międzynarodowych aktach prawnych zawierających gwarancje praw człowieka. Trybunał podsumował: „Artykuł 53 Karty potwierdza wprawdzie, że gdy akt prawa Unii wymaga przyjęcia krajowych aktów stosowania, organy i sądy krajowe są uprawnione do stosowania krajowych standardów ochrony praw podstawowych, o ile zastosowanie owych standardów nie podważa poziomu ochrony wynikającego z Karty stosownie do wykładni Trybunału, ani pierwszeństwa, jednolitości i skuteczności prawa

\footnotetext{
1375 Ibidem, pkt 56.

1376 Ibidem, pkt 57.

1377 Ibidem, pkt 58.

1378 Ibidem, pkt 59.
} 
Unii"1379. Nie są jednak do tego uprawnione, gdy prowadziłoby to do podważenia zasad pierwszeństwa, jedności i skuteczności prawa unijnego. O ile w wyrokach w sprawach Åkerberg-Fransson i Siragusa taka właśnie interpretacja art. 53 nie doprowadziła do ograniczenia swobody państw do stosowania swoich, w tym wyższych niż unijne, standardów praw człowieka, o tyle tym razem do tego doszło. Na tym właśnie polega mieszane (mixed) stosowanie unijnych i krajowych praw podstawowych.

W przedmiotowej sprawie sformułowana powyżej zasada doprowadziła TSUE do jednoznacznej konkluzji, że

zezwolenie państwu członkowskiemu na powołanie się na art. 53 Karty w celu uzależnienia przekazania osoby skazanej zaocznie od nieprzewidzianego w decyzji ramowej 2009/299 warunku wymagającego umożliwienia ponownego rozpoznania w państwie wydającym nakaz sprawy zakończonej danym wyrokiem skazującym, aby uniknać naruszenia prawa do sprawiedliwego procesu i prawa do obrony zagwarantowanych konstytucją państwa członkowskiego wykonującego nakaz, prowadziłoby poprzez podważenie jednolitości standardu ochrony praw podstawowych określonego w decyzji ramowej do naruszenia zasad wzajemnego zaufania i wzajemnego uznawania, do których wzmocnienia dąży wspomniana decyzja ramowa, i w konsekwencji do zagrożenia jej skuteczności ${ }^{1380}$.

\subsubsection{Sprawa Melloni a możliwość powołania się na tożsamość konstytucyjną dla realizacji wyższego niż unijny krajowego standardu ochrony praw człowieka}

Pytanie, jakie należy sobie w związku z tym postawić jest takie, czy odpowiedź TSUE mogłaby być w innych nieco okolicznościach inna niż ta, której udzielił w omawianej tu sprawie. Mówiąc ogólniej, czy mogą istnieć okoliczności, które mogłyby doprowadzić do zniuansowania wykładni art. 53 Karty dokonanego przez TSUE, a tym samym do zniuansowania rozumienia przez ten trybunał zasad pierwszeństwa, jedności i efektywności prawa unijnego. Zdaniem autora tej pracy okolicznością taką mogłoby być to, że wyższy niż unijny standard ochrony jakiegoś prawa czy wolności człowieka stanowiłby element składający się na tożsamość konstytucyjną państwa członkowskiego. Co do zasady należy się bowiem zgodzić, że prawo krajowe, nawet rangi konstytucyjnej i nawet zawierające gwarancje praw człowieka, nie może być uznane automatycznie za wystarczającą podstawę do podważenia prawa unijnego. Byłoby to nie do pogodzenia z zasadą pierwszeństwa tego ostatniego, której przestrzeganie

\footnotetext{
${ }^{1379}$ Ibidem, pkt 60.

${ }^{1380}$ Ibidem, pkt 63.
} 
jest wraz z zasadami jednolitości i efektywności prawa unijnego gwarantem autonomii prawa unijnego, bez czego Unia nie mogłaby realizować celów, dla których została powołana. Czym innym jest jednak prawo krajowe, składające się na tożsamość konstytucyjną państwa członkowskiego, do poszanowania której Unia jest zobowiązana na mocy art. 4 ust. 2 TUE.

Należy w tym miejscu zauważyć, że w swym odesłaniu prejudycjalnym w sprawie Melloni hiszpański TK nie zdecydował się na stwierdzenie, że niedopuszczalność skazania in absentia jest tak fundamentalnym elementem hiszpańskiego porządku prawnego, by stanowić element jego tożsamości konstytucyjnej. TK zdecydował się w swym pytaniu powołać jedynie na art. 53 Karty, a pominać odwołanie do art. 4 ust. 2 TUE. Mimo to, a właściwie dlatego właśnie, sprawa ta może być wskazana jako przykład zgodny, a przynajmniej niesprzeczny, z rozumowaniem prezentowanym w tej pracy. Nawet bowiem jeśli ocena taka nie została przez hiszpański TK wyrażona wprost, to należy się zgodzić, że twierdzenie, iż bezwzględny zakaz skazywania in absentia miałby stanowić element hiszpańskiej tożsamości konstytucyjnej, byłoby nieuzasadnione. Zostało to zresztą odzwierciedlone w opinii w sprawie Melloni sporządzonej przez Rzecznika Generalnego Yves'a Bota ${ }^{1381}$. Jak się wydaje, hiszpański TK potwierdził to również w swym orzeczeniu wydanym już po uzyskaniu odpowiedzi od TSUE ${ }^{1382}$. Gdyby więc TK wyraził stanowisko, jakoby bezwzględny zakaz skazywania in absentia był elementem hiszpańskiej tożsamości konstytucyjnej przy użyciu swego autorytetu jako sądu konstytucyjnego Hiszpanii, byłby to przejaw nadużycia jego pozycji, sprzecznego przede wszystkim z art. 4 ust. 3 TUE i niedopuszczalnego w obliczu podstaw prawidłowego funkcjonowania mechanizmu sekwencyjnego orzekania w przedmiocie tożsamości konstytucyjnej i konsekwencji obowiązku jej poszanowania przez Unię, o którym mowa w tym rozdziale.

Rzecznik Bot w opinii w sprawie Melloni słusznie zauważył, że interpretacja art. 53, sprowadzająca się do ochrony zasad pierwszeństwa, jedności i efektywności prawa unijnego nie prowadzi w tej sprawie do naruszenia obowiązku poszanowania przez Unię tożsamości konstytucyjnej państw członkowskich ${ }^{1383}$.

Nie zapominam o tym [wywodził - przyp. aut.], że zgodnie z art. 4 ust. 2 TUE Unia jest obowiązana szanować tożsamość narodową państw członkowskich, "nierozerwalnie związaną z ich podstawowymi strukturami politycznymi i konstytucyjnymi"

${ }^{1381}$ TSUE, Stefano Melloni p. Ministerio Fiscal, C-399/11, opinia Rzecznika Generalnego

Yves'a Bota przedstawiona w dniu 2 października 2012.

1382 Hiszpański TK, sprawa 26/2014, wyrok z 13 lutego 2014, BOE nr 6o z 11 marca 2014.

1383 TSUE, Stefano Melloni p. Ministerio Fiscal, C-399/11, opinia Rzecznika Generalnego Yves'a Bota przedstawiona w dniu 2 października 2012, pkt 137. 
[...]. Zauważam także, że w preambule do karty przypomniano, że w swoim działaniu

Unia powinna szanować tożsamość narodową państw członkowskich ${ }^{1384}$.

Co szczególnie godne podkreślenia w kontekście tezy stawianej w tej pracy, Rzecznik stwierdził ponadto, że: „Państwo członkowskie, które uznałoby, że przepis prawa wtórnego narusza jego tożsamość narodowa, mogłoby więc zaskarżyć ten przepis na podstawie art. 4 ust. 2 TUE [... $]^{\prime 1385}$. Wprawdzie brak tu rozwinięcia, w jaki sposób miałoby do tego dojść, ani jaka dokładnie miałaby być rola poszczególnych organów państw członkowskich, w tym ich sądów konstytucyjnych (kontekst tej sprawy, a także fakt, że to hiszpański Trybunał Konstytucyjny był w tej sprawie sądem odsyłającym w sposób szczególny podnosi rangę tej sprawy dla tezy formułowanej w tej pracy), ani jaka miałaby być rola TSUE. Jasno jednak wynika z Opinii Rzecznika Bota, że obowiązek poszanowania tożsamości konstytucyjnej państw członkowskich nie musiałby się sprowadzać jedynie do derogacji od unijnych swobód traktatowych, lecz również do uchylenia się od zobowiązań wynikających z unijnego prawa pochodnego, nawet tak wysoce zharmonizowanego jak ENA, i że państwo poprzez jego organy mogłoby domagać się poszanowania swej tożsamości.

Wedle oceny Rzecznika:

W niniejszej sprawie nie mamy jednak do czynienia z taką sytuacją. Wymiana stanowisk, jaka miała miejsce zarówno przed Tribunal Constitucional, jak i przed Trybunałem przekonuje, że określenie zakresu prawa do rzetelnego procesu i praw do obrony w wypadku wyroków wydanych zaocznie nie może naruszyć tożsamości narodowej Królestwa Hiszpanii ${ }^{1386}$.

Jak kontynuował Rzecznik:

ustalenie tego, co stanowi „absolutną treść” prawa do obrony, jest nadal przedmiotem dyskusji nawet wewnątrz Tribunal Constitucional, Królestwo Hiszpanii samo bowiem wskazało na rozprawie, opierając się w szczególności na istniejących w prawie hiszpańskim wyjątkach od ponownego rozpoznania sprawy po wyroku wydanym zaocznie, że kwestia udziału oskarżonego w rozprawie nie jest elementem tożsamości narodowej Królestwa Hiszpanii ${ }^{1387}$.

Zdaniem Rzecznika nie należy „mylić tego, co mieści się w wymagającej koncepcji ochrony prawa podstawowego z naruszeniem tożsamości krajowej

\footnotetext{
${ }^{1384}$ Ibidem, pkt 138 .

1385 Ibidem, pkt 139.

${ }^{1386}$ Ibidem, pkt 140.

${ }^{1387}$ Ibidem, pkt 141 .
} 
lub, ściślej rzecz ujmując, tożsamości konstytucyjnej państwa członkowskiego. Z pewnością w niniejszej sprawie chodzi o prawo podstawowe chronione konstytucją hiszpańską, której wagi nie sposób nie doceniać, nie oznacza to jednak, że należy tu rozważać stosowanie art. 4 ust. 2 TUE $^{\prime \prime 1388}$. W omawianej opinii Rzecznik wyraźnie rozróżnił więc standard ochrony wynikający z konstytucji danego państwa członkowskiego, od standardu ochrony wynikającego z konstytucji danego państwa członkowskiego, który jest elementem jego tożsamości konstytucyjnej. Krótko mówiąc, nie każdy konstytucyjny standard ochrony jakiegoś prawa czy wolności człowieka musi, z samego tego faktu, być uznany za element tożsamości konstytucyjnej danego państwa, do poszanowania której zobowiązuje Unię art. 4 ust. 2 TUE. Podobnego rozróżnienia można dopatrywać się, o czym była już i będzie jeszcze mowa, w orzecznictwie TK. Nawet jeśli nie wynika to z niego jednoznacznie, to przynajmniej nie można takiej ewentualności wykluczyć.

Sam TSUE $\mathrm{w}$ wyroku w omawianej sprawie rozważania dotyczące art. 4 ust. 2 TUE pominąl, ale wydaje się to uzasadnione w obliczu braku ze strony hiszpańskiego sądu konstytucyjnego, który skierował w tej sprawie pytanie do TSUE, powołania się na hiszpańską tożsamość konstytucyjną. Fakt poczynienia takich rozważań przez Rzecznika Generalnego TSUE może być jednak uznany za zwiastun, że rozwiązanie takie, gdyby było faktycznie uzasadnione tożsamością konstytucyjną jakiegoś państwa członkowskiego, mogłoby być przez TSUE uznane za dopuszczalne.

Hiszpański TK zna, choć może nie wyraził tego aż tak bezpośrednio jak polski, niemiecki czy odpowiednie organy innych państw członkowskich, koncepcję tożsamości konstytucyjnej, na którą miałyby się składać jedynie najistotniejsze postanowienia konstytucji.

Dobrą ilustracją takiej praktyki "cichego nawiązania” do samej istoty koncepcji tożsamości konstytucyjnej jest - wydana jeszcze w 2004 r. (...) - deklaracja hiszpańskiego TK (...) dotyczaca ratyfikacji Traktatu konstytucyjnego. W deklaracji tej [hiszpański - przyp. aut.] TK stwierdził, że wykładnia art. 93 Konstytucji [który stanowi hiszpańską klauzulę integracyjną (...) - przyp. aut.] musi wychodzić z założenia, że przeniesienie wykonywania kompetencji na rzecz Unii Europejskiej i - w konsekwencji - włączenie prawa wspólnotowego do hiszpańskiego porządku prawnego nakładają konieczne ograniczenie suwerennych kompetencji Państwa, możliwe jedynie $\mathrm{w}$ przypadku, gdy prawo europejskie jest zgodne z podstawowymi zasadami społecznego i demokratycznego państwa prawnego ustanowionego przez Konstytucję $e^{1389}$.

${ }^{1388}$ Ibidem, pkt 142.

1389 A. Kustra, Kelsenowski..., s. 294-295. 
W sprawie Melloni hiszpański TK jednak na tożsamość konstytucyjną Hiszpanii w żadnej formie się nie powołał. Jak to już wskazano, należy to uznać za rozwiązanie prawidłowe. $Z$ całą pewnością lepsze niż blankietowe - ostrzegawcze - choć jak się później okazało w istocie rzeczy, na gruncie danej sprawy nieprzydatne, powołanie na tożsamość konstytucyjną przez FTK w sprawie Gauweiler. Niepodnoszenie argumentu zbędnego, czy w danej okoliczności nierelewantnego, należy uznać za przejaw rzetelnego i kooperatywnego dialogu.

W sprawie tej hiszpański TK nie powołał się na tożsamość konstytucyjną Hiszpanii ani w odesłaniu do TSUE, ani w wyroku wydanym ostatecznie po uzyskaniu odpowiedzi od TSUE. TK podporządkował się wyrokowi TSUE i „zmodyfikował swoją dotychczasową linię orzeczniczą dotyczącą wyroków wydawanych in absentia, dostosowując swe orzecznictwo do poziomu ochrony gwarantowanego Kartą ${ }^{\prime \prime 390}$. Wyrok ten był jednak przyjęty dość krytycznie przez hiszpańską doktrynę, a także wydany został przy trzech zdaniach odrębnych. Sytuacja, przed jaką stanął hiszpański TK była tym trudniejsza, że z jego dotychczasowego orzecznictwa wynikało jednoznacznie, że zakaz skazywania in absentia stanowi, jeśli nie twarde jądro to element rdzenia prawa zagwarantowanego w art. 24 ust. 2 Konstytucji. Ostatecznie hiszpański TK zreinterpretował ten standard, obniżając go, tak aby odpowiadały mu przepisy dotyczące ENA ${ }^{1391}$.

Co istotne z perspektywy tej pracy, hiszpański TK podkreślił w końcowych fragmentach uzasadnienia do omawianego tu orzeczenia "znaczenie wyroku ETS w sprawie Melloni dla modyfikacji pojęcia istoty konstytucyjnego prawa do rzetelnego procesu sądowego, ale z drugiej - wskazał, że orzeczenie ETS musi być odczytywane w zgodzie z przyjętą przez TK ogólną koncepcją relacji między hiszpańską konstytucją a prawem UE, która została przedstawiona w deklaracji TK $1 / 2004^{11392}$. Była ona ${ }^{1393}$ wspomniana przed chwilą jako przejaw "cichej" rekonstrukcji tożsamości konstytucyjnej Hiszpanii w kontekście zakresu nieprzekazywalnych kompetencji w ramach integracji europejskiej i obowiązku Unii do respektowania zasad podstawowych demokratycznego państwa socjalnego, ustanowionych przez konstytucję hiszpańską ${ }^{1394}$. Jak podkreśla Aleksandra Kustra: „Deklaracja ta stanowi orzeczniczy fundament określenia konstytucyjnych warunków uczestnictwa Hiszpanii w procesie integracyjnym ${ }^{\prime 1395}$. W ten

${ }^{1390}$ Ibidem, s. 488.

${ }^{1391}$ Więcej na ten temat - patrz np.: ibidem, s. 489-496; A. Torres Pérez, Melloni in Three Acts: From Dialogue to Monologue, "European Constitutional Law Review” 2014, nr 10 (2); M. Rodríguez-Izquierdo Serrano, The Spanish Constitutional Court and Fundamental Rights Adjudication After the First Preliminary Reference, "German Law Journal" 2015, nr 16 (6).

1392 A. Kustra, Kelsenowski..., s. 493.

${ }^{1393}$ Hiszpański TK, sprawa 1/2004, uchwała z 13 grudnia 2004, BOE nr 3 z 4 stycznia 2005.

${ }^{1394}$ M. Safjan, Wprowadzenie..., s. 108.

1395 A. Kustra, Kelsenowski..., s. 493-494. 
sposób hiszpański TK przyznał już niemal wprost, że obniżenie przezeń wspomnianego standardu ochrony praw człowieka było możliwe ze względu na to, że nie wiązało się to z naruszeniem tożsamości konstytucyjnej Hiszpanii. Choć tego otwarcie już nie dopowiedział ${ }^{1396}$, można się jednak spodziewać, że w sytuacji konfliktu prawa unijnego $\mathrm{z}$ regulacją konstytucyjną mającą rangę elementu tożsamości konstytucyjnej Hiszpanii, stanowisko zarówno hiszpańskiego TK, jak i TSUE mogłoby i powinno być inne.

\subsubsection{Wyjątki od rozumienia art. 53 Karty a inne przepisy unijnego prawa pierwotnego}

Wyrok w sprawie Melloni można uznać za jednoznaczny wyraz stanowiska TSUE, zgodnie z którym Karta oprócz tego, że stanowi nieprzekraczalny, minimalny standard ochrony praw jednostki, którego państwa nie mogą obniżyć stosując prawo unijne, stanowi również w określonych przypadkach standard maksymalny. Jeśli bowiem standard minimalny wynikający z Karty jest przez prawo UE spełniony, to może ona w ramach swoich kompetencji kształtować sytuację prawną jednostki poprzez stanowione przez siebie prawo, a wyższe niż unijne standardy ochrony praw jednostki w państwach członkowskich nie mogą stać temu na przeszkodzie, gdyż byłoby to sprzeczne z pierwszeństwem, jednością i efektywnością prawa unijnego. Z wyroku tego wynika wyraźnie, że

nawet jeżeli konstytucja państwa członkowskiego gwarantuje wyższy standard ochrony praw człowieka, to w sytuacji, gdy ten podwyższony standard uniemożliwia efektywność prawa UE na terenie państwa członkowskiego, odmawia mu się skuteczności. Prawo krajowe nie może zatem przewidywać niższego standardu ochrony praw podstawowych niż Karta, ale nawet jeśli przewiduje standard wyższy, to zostanie uznane za nieskuteczne, gdy podważa pierwszeństwo, skuteczność lub jednolitość prawa UE ${ }^{1397}$.

Jak się jednak wydaje, co widoczne było szczególnie w opinii Rzecznika wyrażonej w sprawie Melloni, i co jest odzwierciedlone również, choć nie explicite w sekwencji wszystkich następujących po sobie orzeczeń w tej sprawie, w tym w ostatecznym orzeczeniu hiszpańskiego TK, sytuację zasadniczo zmienić mogłoby powołanie się w związku z art. 53 Karty na art. 4 ust. 2 TUE. Podobnie luksemburską interpretację art. 53 Karty rozumie L.F.M. Besselink, kiedy twierdzi, że „różnorodne standardy ochrony praw podstawowych nie

${ }^{1396}$ Wydaje się jednak, że dał do zrozumienia; patrz: hiszpański TK, sprawa 1/2004, uchwała z 13 grudnia 2004, BOE nr 3 z 4 stycznia 2005, para. 3 .

${ }^{1397}$ A. Kustra, Kelsenowski..., s. 495. 
mogą być ze sobą godzone jednoznacznie jedynie na mocy klauzul takich, jak art. 53 Karty i EKPCz, lecz przez odniesienie do art. 4 ust. 2 TUE. Uwzględnienie odmiennego standardu jest więc zależne od tego, czy stanowi on element tożsamości konstytucyjnej danego państwa członkowskiego"1398. Ujawniony w sprawie Melloni konflikt między wyższym niż unijny, konstytucyjnym standardem ochrony prawa jednostki nie został uznany za podstawę do zwolnienia Hiszpanii ze sprzecznych z nim zobowiązań wynikających z unijnego prawa pochodnego ze względu na ciążący na Unii obowiązek poszanowania tożsamości konstytucyjnej. Dobrze wpisuje się to w prezentowaną w tej pracy tezę, skoro ten wyższy standard nie został uznany przez odpowiednie do tego organy (z hiszpańskim TK na czele) za element tożsamość konstytucyjnej Hiszpanii. Rozstrzygnięcie tej sprawy wcale nie wyklucza jednak, aby w sytuacji, gdy wyższy niż unijny standard ochrony będzie elementem tożsamości konstytucyjnej państwa członkowskiego, za taką podstawę uznany został, szczególnie w kontekście łącznego zastosowania art. 53 Karty i art. 4 ust. 2 TUE ${ }^{1399}$. Sprawa Melloni może być nawet uznana za dobry przykład powściągliwości orzeczniczej koniecznej dla prawidłowego funkcjonowania proponowanego w tej pracy mechanizmu, a więc przykład nieformułowania zbyt daleko idących roszczeń, kiedy nie byłoby to uzasadnione. $\mathrm{W}$ pewnym sensie (ostatecznie zakończoną bezkonfliktowo) przeciwną tendencję pokazała np. sekwencja orzeczeń TSUE i FTK w sprawie Gauweiler.

Znaczenie art. 4 ust. 2 TUE $w$ związku z art. 53 odzwierciedla jeszcze bardziej odmienne, wynikające z wyroku w sprawie Melloni, podejście do ograniczonej dopuszczalności stosowania przewidzianych przez prawo państw członkowskich minimalnych standardów ochrony praw człowieka, przy braku tego rodzaju zastrzeżeń odnośnie do minimalnego standardu gwarantowanego przez EKPCz. Nie wchodząc w tym miejscu w pogłębione rozważania na ten temat, standard konwencyjny jest uznawany przez prawo unijne jako niepodważalny standard minimalny, który prawo Unii, mimo że ta nie jest stroną Konwencji, musi spełniać. Do rozróżnienia takiego dochodzi, mimo że w art. 53 Karty Konwencja wymieniona jest w jednym rzędzie z konstytucjami państw członkowskich. Należy zwrócić jednak uwagę na obecność w Karcie również art. 52 ust. 3, który jasno rozstrzyga, że poziom ochrony praw podstawowych zagwarantowanych w Karcie, o ile są one zagwarantowane również w Konwencji, nie może być niższy niż w Konwencji. Czyni to z Konwencji również w ra-

${ }^{1398}$ L.F.M. Besselink, The Protection..., s. 46 (tłum. własne).

${ }^{1399}$ Podobnie: A. Torres Pérez, Melloni in ..., s. 327-328; Por. też: A. Torres Pérez, Constitutional Identity and Fundamental Rights: The Intersection between Articles 4(2) TEU and 53 Charter, [w:] A. Saiz Arnaiz, C. Alcoberro (red.), National Constitutional Identity and European Integration, Cambridge-Antwerp-Portland 2013. 
mach porządku unijnego, podobnie jak ma to miejsce w porządkach krajowych, źródło bezwzględnie wiążącego, minimalnego standardu ochrony, który nie może być obniżany, swobodnie może być jednak podnoszony.

Tymczasem nie ma w Karcie tego rodzaju przepisu, który by jednoznacznie i bez względu na okoliczności wykluczał możliwość ograniczania przez prawo UE standardów ochrony praw jednostki wynikających z konstytucji państw członkowskich. Nawet jeśli więc wykładnię art. 53, jakiej dokonał odnośnie do krajowych standardów TSUE w prawie Melloni przyjać jako zasadę, to nie można wykluczyć istnienia od niej jakichkolwiek wyjątków. Taką ewentualną rolę odgrywa art. 4 ust. 2 TUE. Znajduje on ponadto również, a z perspektywy prawa unijnego przede wszystkim, poparcie w innych przepisach unijnego prawa pierwotnego. Na pierwszym miejscu należy wymienić Preambułę do Karty, która nie będąc wiążąca, stanowi istotne źródło inspiracji interpretacyjnej. Czytamy w niej, że: „Unia przyczynia się do ochrony i rozwoju [...] wspólnych wartości, szanując przy tym różnorodność kultur i tradycji narodów Europy, jak również tożsamość narodową Państw Członkowskich [...]”. Powiązanie art. 4 ust. 2 TUE z Kartą za pomocą Preambuły do Karty jest bardzo wyraźne. Można zatem zaryzykować twierdzenie, że ewentualne powołanie się na obowiązek poszanowania przez Unię tożsamości konstytucyjnej w formie odstępstwa od doktryny Melloni i wyrażonej w niej interpretacji art. 53 Karty, należy uznać za szczególnie właściwą metodę wykorzystania art. 4 ust. 2 TUE.

Zgodnie z linią orzeczniczą TSUE, poprzez którą stara się on ugruntować swoją rolę jako ostatecznego strażnika praw podstawowych w ramach unijnego porządku prawnego ${ }^{1400}$ na podstawie przyjętej przezeń wykładni art. 51 ust. 1 Karty, a sprowadzającej się do tego, że:

Poszanowanie praw podstawowych chronionych na mocy karty jest [...] konieczne, w sytuacji gdy przepisy krajowe mieszczą się w zakresie zastosowania prawa Unii. Nie mogą więc występować sytuacje podlegające prawu Unii, w których wspomniane prawa podstawowe nie miałyby zastosowania. Stosowanie prawa Unii oznacza więc jednoczesne zastosowanie praw podstawowych chronionych na mocy karty ${ }^{1401}$.

Tym niemniej w kontekście omawianym w tym miejscu, należy pamiętać również o tym, że art. 51 ust. 1 Karty wspomina też o zasadzie pomocniczości. „Umieszczenie zasady pomocniczości jako czynnika wpływającego na zakres zastosowania Karty, ma na celu umocnienie poszanowania zadań i kompetencji UE oraz kompetencji i zadań państw członkowskich, a ponadto zachowanie tożsamości i swoistości ochrony praw podstawowych w porządkach prawnych

${ }^{1400}$ Por.: A. Andreangeli, Ne bis..., s. 1840.

${ }^{1401}$ TSUE, Åklagaren p. Hans Åkerberg Fransson, C-617/10, wyrok z 26 lutego 2013, pkt 21. 
państw członkowskich"1402. Ma to również znaczenie w kontekście efektu, jaki niosą ze sobą łączne konsekwencje art. 51 ust. 1 i 53 KPP.

Uwagę należy zwrócić także na art. 52 ust. 4 Karty, który jak się wydaje również dopuszcza możliwość pewnych odstępstw w wyjątkowych, uzasadnionych przypadkach od zasady wyrażonej w art. 53 Karty oraz jej rozumienia przez TSUE. Przepis ten stanowi, że: „W zakresie, w jakim niniejsza Karta uznaje prawa podstawowe wynikające ze wspólnych tradycji konstytucyjnych Państw Członkowskich, prawa te interpretuje się zgodnie z tymi tradycjami". Na pierwszy rzut oka może się wydawać, że przepis ten jedynie potwierdza status unijnych praw podstawowych jako wywodzących się z tradycji konstytucyjnych państw członkowskich, i przez to uwydatnia wspominaną już w tej pracy wspólnotę aksjologiczną na przestrzeni Unii, gdy chodzi o prawa człowieka. Tym niemniej zgodnie z Wyjaśnieniami dotyczącymi Karty przepis ten wiąże się wprawdzie z art. 6 ust. 3 TUE „i należycie uwzględnia podejście Trybunału Sprawiedliwości do wspólnych tradycji konstytucyjnych [...]”. Tym niemniej: "Zgodnie z tą zasada, a nie ze sztywnym podejściem »najniższego wspólnego mianownika«, takie prawa zawarte w Karcie powinny być interpretowane w sposób zapewniający wysoki poziom ochrony, odpowiedni dla prawa Unii i zgodny ze wspólnymi tradycjami konstytucyjnymi"1403. O ile przepis ten faktycznie więc zwraca uwagę na wspólność i konwergencję unijnych i krajowych standardów ochrony praw człowieka, o której była zresztą mowa, o tyle podkreśla również, że wspólności tej nie należy rozumieć w kategoriach najniższego wspólnego mianownika, co wyraźnie podkreśla doniosłość poszanowania podejścia do ochrony praw człowieka w państwach członkowskich, szczególnie jeśli miałaby ona się przejawiać w zapewnianiu ochrony dalej idącej niż w innych państwach czy w samej UE. To właśnie podejście do ochrony praw człowieka w ramach Unii jako do promocji ochrony, opartej na najmniejszym wspólnym mianowniku, jakiej przejawem jest de facto wyrok w sprawie Melloni, nawet jeśli miałoby się to sprowadzać jedynie do obszarów w pełni zharmonizowanych, było podstawą jego krytyki z perspektywy prawa praw człowieka ${ }^{1404}$. Krytyka ta nie okaże się jednak w pełni zasłużona, o ile w przyszłości TSUE dopuści pewne modyfikacje doktryny Melloni, w tym przede wszystkim jeśli dopuści takie modyfikacje jak te, proponowane w tej pracy.

Na znaczenie art. 52 ust. 4 Karty i jego potencjał w związku z art. 4 ust. 2 zwracał uwagę również Marek Safjan. Art. 52 ust. 4 Karty mógłby służyć jako ar-

\footnotetext{
1402 A. Wróbel, Art. 51..., s. 1309.

${ }^{1403}$ Wyjaśnienia dotyczące Karty Praw Podstawowych, Dz.Urz. C 303 z 14 grudnia 2007, s. 34 .

${ }^{1404}$ Patrz np.: A.-L. Chané, A. Hauser, J. Jaraczewski, W. Jóźwicki, Z. Kędzia, M.A. Šimáková, H. Suchocka, S. Wallace, EU Engagement..., s. 94 i podana tam literatura.
} 
gument za szczególnym potraktowaniem krajowych standardów praw człowieka w kontekście art. 4 ust. 2 TUE nawet przy wąskim jego rozumieniu - a więc takim, które nie było przedmiotem analizy w tej pracy jako zdaniem autora nie najwłaściwsze i które ograniczałoby się do wewnątrzunijnego wymiaru obowiązku poszanowania tożsamości konstytucyjnej państw członkowskich.

Postanowienia pierwotnego prawa europejskiego, w tym przede wszystkim art. 4 TUE oraz art. 52 ust. 4 KPP pozwalają [...] na sformułowanie pewnych wskazówek. Tożsamość konstytucyjna w wąskim znaczeniu tego terminu oznaczałaby tożsamość narodową, do której odwołuje się wprost art. 4 ust. 2 TUE [...]. W szerszym znaczeniu pojęcie to może być wzbogacone o te elementy systemu prawnego, które wynikają z utrwalonych tradycji konstytucyjnych, do których odwołuje się art. 52 ust. 4 KPP. Trzeba jednak podkreślić, że pojęcie tradycji konstytucyjnych w rozumieniu przywołanego przepisu i tradycji konstytucyjnych w relacji do konkretnego systemu prawnego nie jest w pełni tożsame. W pierwszym wypadku "tradycje konstytucyjne" stanowią element wspólnego dziedzictwa państw członkowskich, w drugim wypadku - jako składnik "tożsamości konstytucyjnej” - są one odnoszone do najważniejszych wartości i cech danego systemu prawnego warunkowanych kultura, historią i doświadczeniami konkretnego społeczeństwa ${ }^{1405}$.

W obszarze wolności, bezpieczeństwa i sprawiedliwości należy również wskazać ust. 1 art. 67 TFUE ustanawiającego tę przestrzeń, o którym będzie jeszcze mowa. Nie można również zapominać, że godność człowieka i wynikająca z niej ochrona praw człowieka są fundamentalnymi wartościami, na jakich opiera się Unia zgodnie z art. 2 TUE, a także są one elementami jej tożsamości (jak twierdzą niektórzy - również konstytucyjnej ${ }^{1006}$ ). Jak widać więc

${ }^{1405}$ M. Safjan, Wprowadzenie..., s. 107-108.

${ }^{1406}$ W. Sadurski, European Constitutional Identity?, EUI Working Paper, LAW 2006, nr 33; w kontekście tym nie można też nie dostrzec słynnej sagi Kadi (Sąd Pierwszej Instancji, Yassin Abdullah Kadi p. Radzie Unii Europejskiej i Komisji Wspólnot Europejskich, T-315/o1, wyrok z 21 września 2005; TSUE, Yassin Abdullah Kadi i Al Barakaat International Foundation p. Radzie Unii Europejskiej i Komisji Wspólnot Europejskich, C-402/o5 P i C-415/o5 P, wyrok z 3 września 2008; TSUE, Komisja Europejska i in. p. Yassin Abdullah Kadi, C-584/1o P, C-593/1o P i C-595/10 P, wyrok z 18 lipca 2013), w której TSUE przejawił pogląd, że rządy prawa i związane z nimi nierozerwalnie gwarancje praw człowieka są elementem tożsamości konstytucyjnej Unii i nie mogą być podważane nawet przez zobowiązania międzynarodowe, które byłyby wiążące dla Unii (więcej - patrz np.: K. Lenaerts, The Kadi Saga and the Rule of Law within the EU, "SMU Law Review" 2014, nr 67). Nie wchodząc w szczegóły i złożoność serii orzeczeń w sprawie Kadi, można jednak zauważyć, że skoro TSUE dostrzega możliwość swoistej własnej wersji rozumowania à la doktryna ultra vires w ramach swej aktywności na styku prawa unijnego i prawa międzynarodowego, nie powinien bezkrytycznie wykluczać takiego rozumowania w ramach wewnętrznych relacji w Unii ze strony sądów konstytucyjnych państw członkowskich na styku prawa unijnego i prawa krajowego. Szczególnie jeśli miałaby ona doprowadzić do podniesienia standardu ochrony jakiegoś prawa czy wolności jednostki (których ochrona jest elementem unij- 
sporo przepisów prawa unijnego tworzy przyjazny kontekst dla funkcjonowania w oparciu o art. 4 ust. 2 TUE mechanizmu opisywanego $w$ tej pracy, zmierzającego do współpracy w przedmiocie jego stosowania jako autonomicznej podstawy do zwolnienia państwa członkowskiego ze zobowiązań ciążących na nim na mocy prawa unijnego dla poszanowania jego tożsamości konstytucyjnej, gdy elementem tej tożsamości są zagwarantowane w tym państwie wyższe niż unijne gwarancje praw człowieka.

\section{Ochrona praw człowieka jako dopuszczalny wyjątek od zasady wzajemnego zaufania w orzecznictwie TSUE}

Szczególny status gwarancji praw człowieka i poszanowania dla godności osoby ludzkiej, z której wszystkie one wynikaja, został także odzwierciedlony przez TSUE na gruncie orzecznictwa nie bezpośrednio związanego z tematyką tej pracy. Ze względu na jego doniosłość w kontekście dopuszczalności pewnych wyjątków od sztywnego rozumienia fundamentalnych zasad prawa unijnego związanych z jego autonomicznością oraz pewnego rodzaju zbieżność z rozumowaniem przedstawionym w tej pracy - sprowadzającym się do szczególnego potraktowania kwestii poszanowania praw człowieka w kontekście pierwszeństwa, jedności i efektywności prawa Unii - zostanie ono w tym miejscu zarysowane. Co należy wszakże podkreślić, w wyrokach, o których będzie poniżej mowa, nie pojawia się ani problematyka art. 53 Karty, ani tym bardziej art. 4 ust. 2 TUE. W wyrokach tych TSUE zaprezentował natomiast stanowisko, które stanowi przejaw pewnego zniuansowania ogólnych zasad, na jakich opiera się prawo unijne, ze względu na ochronę praw człowieka, co jest zbieżne z tezą

\footnotetext{
nej tożsamości konstytucyjnej) na przestrzeni Unii, nawet jeśli miałoby to ograniczać się tylko do jednego państwa i nawet jeśli miałoby wiązać się z pewnym ograniczeniem zasad pierwszeństwa, jedności i efektywności prawa Unii; po bardziej przekrojową próbę analizy unijnej tożsamości konstytucyjnej w relacji, a nawet w pewnej kontrze do rozwijającej się aktualnie linii orzeczniczej sądów konstytucyjnych państw członkowskich w przedmiocie narodowych tożsamości konstytucyjnych, obarczoną jednak niepewnością co do jej elementów składowych, patrz: G. Zaccaroni, The Good..., gdzie jako elementy tożsamości konstytucyjnej Unii, wynikające z orzecznictwa TSUE wskazane są: zakaz dyskryminacji ze względu na wiek i jego horyzontalne oddziaływanie, zasada kompetencji powierzonych oraz ochrona interesu finansowanego Unii (ibidem, s. 424 i nast.); pewną formą poszukiwania tożsamości konstytucyjnej UE jest również poszukiwanie jej konstytucyjnego rdzenia (więcej - patrz np.: D. Sarmiento, The EU's Constitutional Core, [w: A. Saiz Arnaiz, C. Alcoberro (red.), National Constitutional Identity and European Integration, Cambridge-Antwerp-Portland 2013).
} 
stawianą w tej pracy. Sprawy te nie wiązały się expressis verbis z zasadą autonomiczności czy pierwszeństwa prawa Unii, lecz z bardzo ściśle z nimi powiązaną zasadą wzajemnego zaufania państw członkowskich. Sprawy te toczyły się w obszarach zharmonizowanych w stopniu wysokim, a nawet najwyższym (polityka azylowa i ENA), a jakie ma to konsekwencje dla relacji między unijnymi a krajowymi standardami ochrony praw człowieka, była szczegółowo mowa.

\subsection{Sprawa N.S.}

Wyrok w sprawie N.S. ${ }^{1407}$ był już omawiany w tej pracy pod kątem luksemburskiego rozumienia art. 51 ust. 1 Karty, jak i w kontekście Protokołu nr 30. Wtedy zarysowany został też stan faktyczny. Teraz wystarczy przypomnieć, że w wyroku tym TSUE przesądził, że nawet w zakresie swobody, jaką pozostawiało państwom członkowskim Rozporządzenie Dublin II $^{1408}$, są one związane unijnymi gwarancjami praw człowieka. Art. 3 ust. 2 Rozporządzenia stanowi między innymi, że „każde państwo członkowskie może rozpatrzyć wniosek o udzielenie azylu wniesiony do niego przez obywatela państwa trzeciego, nawet jeżeli za takie rozpatrzenie nie jest odpowiedzialne na podstawie kryteriów ustanowionych w niniejszym rozporządzeniu". Nie oznacza to jednak, że musi taki wniosek rozpatrzyć. Rozporządzenie to zostało przyjęte w celu zapobiegania odsyłaniu osób ubiegających się o azyl z jednego kraju do drugiego, a także zapobiegania nadużyciom systemu poprzez składanie kilku wniosków o udzielenie azylu przez jedną osobę. W związku z tym w rozporządzeniu tym również określono obiektywne i hierarchiczne kryteria służące do ustalenia dla każdego wniosku o azyl państwa członkowskiego odpowiedzialnego za jego rozpatrzenie. Państwo tych kryteriów niespełniające mogło wniosek rozpatrzyć, jednak nie musiało, mogąc odesłać wnioskodawcę do państwa odpowiedzialnego do rozpatrzenia wniosku, którym jest co do zasady państwo, w którym osoba ubiegająca się o azyl przekroczyła granicę Unii.

Dopuszczalność przekazania osoby wnioskującej o azyl do innego państwa członkowskiego niż to, w którym wniosek taki by ona złożyła, w sposób naturalny oparta jest na zasadzie wzajemnego zaufania, w tym jeśli chodzi o zapewnienie odpowiednich standardów ochrony praw i wolności człowieka. Jak

${ }^{1407}$ TSUE, N.S. p. Secretary of State for the Home Department oraz M.E., A.S.M., M.T., K.P., E.H. p. Refugee Applications Commissioner, Minister for Justice, Equality and Law Reform, C-411/10 i C-493/10, wyrok z 21 grudnia 2011.

${ }^{1408}$ Rozporządzenie Rady (WE) nr 343/2003 z 18 lutego 2003 ustanawiające kryteria i mechanizmy określania państwa członkowskiego właściwego dla rozpatrywania wniosku o azyl, wniesionego w jednym z państw członkowskich przez obywatela państwa trzeciego, Dz.Urz. L 50 z 25 lutego 2003. 
podkreślił Trybunał: „należy domniemywać, iż traktowanie osób ubiegających się o azyl w każdym państwie członkowskim jest zgodne $\mathrm{z}$ wymogami określonymi w karcie, w konwencji genewskiej, a także w EKPC"1409. Jak zostało to wyjaśnione, w zakresie swobody do rozpatrzenia wniosku państwa pozostają jednak związane Kartą i zawartymi w niej gwarancjami praw człowieka. Objęcie takiej osoby unijną ochroną praw człowieka nie miało w tej sprawie jedynie wymiaru teoretycznego czy hipotetycznego. Mimo zasady wzajemnego zaufania Trybunał zauważył, że nie można "jednak wykluczyć, że w praktyce wystąpią poważne trudności w funkcjonowaniu wspomnianego systemu [ochrony praw człowieka - przyp. aut.] w określonym państwie członkowskim i w związku z tym zaistnieje poważne niebezpieczeństwo, iż w razie transferu do tego państwa członkowskiego osoby ubiegające się o azyl będą traktowane w sposób, którego nie dałoby się pogodzić z ich prawami podstawowymi"1410. Trybunał podkreślił, że w sytuacji, w której pojawiają się poważne obawy, iż w odpowiedzialnym państwie członkowskim występują systemowe nieprawidłowości w zakresie procedur azylowych i warunków przyjmowania osób ubiegających się o azyl, wiążące się z nieludzkim lub poniżającym traktowaniem $\mathrm{w}$ rozumieniu art. 4 Karty, taki transfer byłby niezgodny z przepisami prawa unijnego dopuszczającymi przekazanie w związku z ich interpretacją zgodną z KPP ${ }^{1411}$.

Trybunał dokonał więc w sprawie N.S. oceny sytuacji w państwie, do którego miałoby zostać dokonane przekazanie osoby wnioskującej o azyl, jaką w tym wypadku była Grecja. Dokonał tego, opierając się na orzecznictwie EKPCz, a konkretnie wyroku w sprawie M.S.S. ${ }^{142}$, w którym ETPC z uznał między innymi, że Królestwo Belgii, wydając osobę wnioskującą w Belgii o status azylanta, naruszyło art. 3 EKPCz, zakazujący tortur i nieludzkiego traktowania,

po pierwsze, narażając skarżącego na niebezpieczeństwa wynikające z nieprawidłowości procedury azylowej w Grecji z tego względu, że władze belgijskie wiedziały lub powinny były wiedzieć, iż nie istniała jakakolwiek gwarancja starannego rozpatrzenia jego wniosku o udzielenie azylu przez władze greckie, i, po drugie, posiadając pełną wiedzę w tym względzie, naraziło skarżącego na to, że warunki zastosowania wobec niego środka detencyjnego i jego warunki bytowe będą równoznaczne z poniżającym traktowaniem ${ }^{1413}$.

${ }^{1409}$ TSUE, N.S. p. Secretary of State for the Home Department oraz M.E., A.S.M., M.T., K.P., E.H. p. Refugee Applications Commissioner, Minister for Justice, Equality and Law Reform, C-411/10 i C-493/10, wyrok z 21 grudnia 2011, pkt 8 o.

${ }^{1410}$ Ibidem, pkt 81 .

${ }^{1411}$ Ibidem, pkt 86.

1412 ETPCz, M.S.S. p. Belgii i Grecji, skarga 30696/o9, wyrok z 21 stycznia 2011.

1413 TSUE, N.S. p. Secretary of State for the Home Department oraz M.E., A.S.M., M.T., K.P., E.H. p. Refugee Applications Commissioner, Minister for Justice, Equality and Law Reform, 
Przy czym TSUE podkreślił także, że powyższe nieprawidłowości w Grecji mają charakter systemowy i że były znane władzom belgijskim oraz że prowadzą do poważnego naruszenia praw człowieka ${ }^{1414}$.

Doprowadziło to TSUE do wniosku,

że w przypadkach takich jak rozpatrywane przez sądy krajowe w celu umożliwienia Unii i jej państwom członkowskim przestrzegania ich obowiązków dotyczących ochrony praw podstawowych osób ubiegających się o azyl na państwach członkowskich, w tym na sądach krajowych, ciąży obowiązek niedokonania transferu osoby ubiegającej się o azyl do „odpowiedzialnego państwa członkowskiego" [...], jeżeli nie mogą one pominąć faktu, iż systemowe nieprawidłowości w zakresie procedury azylowej i warunków przyjmowania osób ubiegających się o azyl w tym państwie członkowskim stanowią poważne i udowodnione powody, aby przypuszczać, że wnioskodawca zetknie się z rzeczywistym niebezpieczeństwem bycia poddanym nieludzkiemu lub poniżającemu traktowaniu w rozumieniu art. 4 karty ${ }^{1415}$.

W ten sposób ochrona praw człowieka stała się dla TSUE podstawą do podważenia zasady wzajemnego zaufania. W sprawie N.S. szczególne znaczenie dla podważenia tej zasady miało stwierdzenie problemów przestrzegania zakazu tortur i nieludzkiego traktowania o charakterze systemowym w innym państwie członkowskim. Należy również zauważyć, że TSUE dość szeroko zakreślił dopuszczalność podważenia domniemania przestrzegania przez inne państwo członkowskie unijnych gwarancji praw człowieka opartego na zasadzie wzajemnego zaufania. W zasadzie wystarczające było stwierdzenie istnienia problemu o charakterze systemowym w zakresie przestrzegania nieprzekraczalnego minimum zagwarantowanego w Karcie (w tym wypadku w jej art. 4), aby to domniemanie wzruszyćc ${ }^{1416}$. Wymóg systemowego charakteru naruszeń mógł jednak obrócić się przeciw jednostce, gdyby była ona zagrożona naruszeniami, które takiego charakteru nie mają. TSUE doprecyzował tę kwestię w swym późniejszym orzecznictwie, o czym będzie za chwilę mowa.

W miejscu tym należy wyraźnie podkreślić istotne znaczenie, jakie dla wyroku w sprawie N.S. miało orzecznictwo ETPC $z$, w tym przede wszystkim wyrok w sprawie M.S.S. ${ }^{1417}$ Wprawdzie relacja między TSUE a ETPCz nie jest przedmiotem analizy w tej pracy, nie sposób nie dostrzec jednak

\footnotetext{
C-411/10 i C-493/10, wyrok z 21 grudnia 2011, pkt 88.

${ }^{1414}$ Ibidem, pkt 89-93.

${ }^{1415}$ Ibidem, pkt 94.

${ }^{1416}$ Por.: A.-L. Chané, A. Hauser, J. Jaraczewski, W. Jóźwicki, Z. Kędzia, M.A. Šimáková, H. Suchocka, S. Wallace, EU Engagement..., s. 95.

${ }^{1417}$ ETPCz, M.S.S. p. Belgii i Grecji, skarga 30696/o9, wyrok z 21 stycznia 2011.
} 
jednej z najistotniejszych obaw, jakie TSUE żywi względem Konwencji, w kontekście ewentualnego przystąpienia do niej przez Unię, która już wprost wiąże się z tematem tej pracy. Chodzi o ewentualną próbę obchodzenia przez państwa członkowskie art. 53 Karty i sposobu, w jaki TSUE go zinterpretował za pomocą odwołania do art. 53 Konwencji. Pozostawiając na marginesie zasadność tego zarzutu ${ }^{1418}$, należy przypomnieć, że TSUE stwierdził w Opinii 2/13, iż:

W zakresie, w jakim art. 53 EKPC zastrzega zasadniczo uprawnienie dla układających się stron do ustalenia wyższych standardów ochrony praw podstawowych niż te zagwarantowane we wspomnianej konwencji, należy zapewnić koordynację między tym postanowieniem i art. 53 karty praw podstawowych w wykładni nadanej mu przez Trybunał, aby uprawnienie przyznane w art. 53 EKPC państwom członkowskim pozostało ograniczone - w odniesieniu do praw uznanych w karcie praw podstawowych, które to prawa odpowiadają prawom zagwarantowanym w EKPC - do tego, co konieczne, by uniknąć sytuacji, w której poziom ochrony przewidziany w karcie praw podstawowych, jak również pierwszeństwo, jednolitość i skuteczność prawa Unii zostałyby zagrożone ${ }^{1419}$.

W obliczu braku regulacji zapewniających taką koordynację, TSUE między innymi z tego właśnie względu uznał uzgodnione instrumenty akcesyjne za niezgodne $z$ prawem unijnym ${ }^{1420}$. W kontekście przystąienia Unii do EKPCz TSUE podkreślał też dobitnie znaczenie zasady wzajemnego zaufania, o czym będzie jeszcze mowa. Stanowisko to jest przejawem bardzo silnego, i jeszcze do niedawna w zasadzie bezkompromisowego podejścia TSUE do sposobu, w jaki zinterpretował on w sprawie Melloni art. 53 Karty w kontekście możliwości po stronie państw członkowskich do promocji wyższych niż unijne gwarancji praw człowieka.

ETPCz w sprawie M.S.S. nie odniósł się do tych kwestii, nie podjął się również badania prawa unijnego jako źródła naruszenia Konwencji. Przypomniał swoją dobrze ugruntowaną "doktrynę Bosphorus" ${ }^{\prime 1421}$. Państwa strony Konwencji nie są pozbawione możliwości przystępowania do umów międzynarodowych i organizacji międzynarodowych ${ }^{1422}$, nie wyłącza to jednak ich odpowiedzialności za przestrzeganie praw zagwarantowanych w Konwencji ${ }^{1423}$. Działania podejmo-

${ }^{1418}$ Na temat jego pozorności patrz np.: P. Gragl, The Reasonableness..., s. 37 i nast.

1419 TSUE, Opinia 2/13 wydana w dniu 18 grudnia 2014, pkt 189.

${ }^{1420}$ Ibidem, pkt 190.

${ }^{1421}$ ETPCz, Bosphorus Hava Yolları Turizm ve Ticaret Anonim Şirketi p. Irlandii, skarga 45036/98, wyrok z 30 czerwca 2005.

${ }^{1422}$ Ibidem, pkt 152.

${ }^{1423}$ Ibidem, pkt 153. 
wane przez państwa strony Konwencji, stanowiące realizację zobowiązań wynikających z członkostwa w takiej organizacji, należy uznać za dopuszczalne, jeśli organizacja ta zapewnia równoważną ochronę praw człowieka. ETPCz przyjmuje, że Unia zapewnia równoważną ochronę praw człowieka, w związku z tym można przyjąć, że gdy państwa członkowskie wypełniają obowiązki wynikające z prawa unijnego, nie mając przy tym żadnej swobody, to nie naruszają obowiązków wynikających z Konwencji. Domniemanie to może być podważone jedynie wtedy, gdyby ochrona praw podstawowych w danej sytuacji okazałaby się jawnie niewystarczająca $^{1424}$. Taka sytuacja nie miała jednak do tej pory miejsca, choć ostatnio ETPCz zbliżył się do takiej konkluzji, podnosząc prawdopodobieństwo tego, że w przyszłości do tego dojdzie ${ }^{1425}$. To aktywowałoby odpowiedzialność państwa ${ }^{1426}$. Państwo pozostaje natomiast w pełni odpowiedzialne za wszelkie działania poza zakresem obowiązków wynikających z członkostwa w takiej organizacji, a więc również wtedy, kiedy ich międzynarodowe zobowiązania pozostawiają im margines swobody co do sposobu ich wykonywania.

W sprawie M.S.S. ETPCz doszedł do wniosku, że skoro Belgia miała swobodę co do tego, czy skorzystać z możliwości przekazania osoby ubiegającej się o azyl do Grecji, jaka pozostawiało jej przedmiotowe prawo unijne, to doktryna Bosphorus nie znajdowała zastosowania ${ }^{1427}$. Podobne rozumowanie ETPCz zaprezentował w sprawie Tarakhel ${ }^{1428}$. Na gruncie orzecznictwa ETPCz można zaobserwować tendencję, w ramach której, co szczególnie doniosłe w obliczu Opinii 2/13, dostrzega on różne okoliczności prowadzące do niemożności zastosowania domniemania równorzędnej ochrony z doktryny Bosphorus i w związku ze swoboda, jaką pozostawia państwom prawo unijne, ETPCz weryfikuje sposób, w jaki państwa te je stosuja, przez pryzmat zgodności z Konwencją ${ }^{1429}$.

Wyrok TSUE w sprawie N.S. jest wyraźną odpowiedzią na wyrok ETPCz w sprawie M.S.S. i kolejną cegiełką w skomplikowanej relacji między TSUE a ETPCz, co wykracza poza ściśle pojmowaną tematykę tej pracy, koncentrującą się na unijnych i krajowych gwarancjach praw człowieka i relacji

\footnotetext{
${ }^{1424}$ Ibidem, pkt 154-157.

${ }^{1425}$ ETPCz, Avotinšs p. Łotwie, skarga 17502/o7, wyrok z 26 maja 2016.

${ }^{1426}$ Co Europejska Komisja Praw Człowieka wyraźnie powiedziała już w sprawie X p. Niemcom, skarga 235/56, decyzja z 10 czerwca 1958.

${ }_{1427}^{127}$ ETPCz, M.S.S. p Belgii i Grecji, skarga 30696/o9, wyrok z 21 stycznia 2011, pkt 340.

${ }^{1428}$ ETPCz, Tarakhel p. Szwajcarii, skarga 29217/12, wyrok z 4 listopada 2014.

${ }^{1429}$ Patrz przede wszystkim: ETPCz, Michaud p. Francji, skarga 12323/11, wyrok z 6 grudnia 2012; ETPCz, M.S.S. p. Belgii i Grecji, skarga 30696/o9, wyrok z 21 stycznia 2011; ETPCz, Schipiani i inni p. Włochom, skarga 38369/o9, wyrok z 21 lipca 2015; por.: A. Bodnar, Standard "równoważnej ochrony" w odniesieniu do ochrony praw człowieka po opinii Trybunału Sprawiedliwości 2/13, "Europejski Przegląd Sądowy" 2015, nr 12.
} 
między nimi. Trzeba wszakże pamiętać, że wszystkie państwa członkowskie Unii są stronami Konwencji i odgrywa ona w ramach ich porządków prawnych istotną rolę, jako źródło gwarancji praw i wolności. W niektórych państwach ranga Konwencji równa się nawet konstytucji (jak np. w Austrii). Sprawa N.S. pokazała więc wagę gwarancji praw człowieka dla unijnego porządku prawnego, których ochrona może prowadzić nawet do pewnych wyłomów w fundamentalnych dla unijnego porządku zasadach, takich jak zasada wzajemnego zaufania. O ile w wyroku tym szczególne znaczenie miał kontekst relacji między prawem unijnym a Konwencją, o tyle w wyroku w sprawie Pál Aranyosi i Robert Căldăraru ${ }^{1430}$, o której mowa będzie za chwilę, kontekst konwencyjny znowu odegrał ważną rolę, tym razem jednak ciężar nacisku na TSUE w kierunku dokonania wyłomu w zasadzie wzajemnego zaufania za względu na ochronę praw człowieka wiązał się przede wszystkim z krajowymi - konstytucyjnymi - gwarancjami praw i wolności człowieka i postawą krajowego sądu konstytucyjnego.

W obu przypadkach wyłom w zasadzie wzajemnego zaufania był tak doniosły, że stał się podstawą, już niedługo po wydaniu przez TSUE wyroku w sprawie N.S., do sformułowania koncepcji opierającej się na kolejnej transmutacji doktryny Solange, tym razem nazwanej "horyzontalnym Solange" ${ }^{\prime 1431}$. Dopuszczenie do takiego horyzontalnego Solange, a więc do oceniania poziomu ochrony praw jednostki w jednym państwie członkowskim przez inne państwo członkowskie i uzależniania od tej oceny wykonania zobowiązań wynikających z prawa unijnego - prowadzi ostatecznie do kolejnej wersji wertykalnego Solange - uzależniania wykonania prawa unijnego od tego, czy zawiera ono mechanizmy umożliwiające jego niewykonanie, a w razie czego niewykonywania go ze względów konstytucyjnych ${ }^{1432}$. Do tej pory, zarówno w sprawie N.S., jak i w sprawie Pál Aranyosi i Robert Căldăraru, o której będzie mowa za chwilę, udało się takie unijne mechanizmy znaleźć, co szczególnie w drugiej $z$ tych spraw wymagało dokonania przez TUSE nowatorskiej interpretacji jednego z przepisów decyzji ramowej dotyczącej ENA. Gdyby jednak tak się nie stało, ochrona praw człowieka i tożsamość konstytucyjna państw członkowskich mogłaby posłużyć państwom za podstawę niewykonania prawa unijnego i stać się przejawem wertykalnej kontroli unijnych praw podstawowych przez państwa członkowskie.

${ }^{1430}$ TSUE, Pál Aranyosi i Robert Căldăraru p. Generalstaatsanwaltschaft Bremen, C-404/15 i C-659/15, wyrok z 5 kwietnia 2016.

${ }^{1431}$ I. Canor, My brother's keeper? Horizontal solange: "An ever closer distrust among the peoples of Europe", "Common Market Law Review" 2013, nr 50 (2).

${ }^{1432}$ Por.: K. Tuori, From Copenhagen to Venice, [w:] C. Closa, D. Kochenov (red.), Reinforcing Rule of Law Oversight in the European Union, Cambridge 2016, s. 232. 


\subsection{Sprawa Pál Aranyosi i Robert Căldăraru}

Sprawa Pál Aranyosi i Robert Căldăraru dotyczyła obywatela węgierskiego Pála Aranyosiego - za którym węgierski sędzia śledczy wystawił dwa nakazy aresztowania po to, aby umożliwić przeprowadzenie przeciwko niemu postępowania karnego w przedmiocie dwóch kradzieży z włamaniem, których popełnienie na Węgrzech zostało mu zarzucone, oraz obywatela rumuńskiego - Roberta Căldăraru - za którym to ENA wystawił sąd rumuński, w celu wykonania orzeczonej przeciw niemu w tym kraju kary roku i ośmiu miesięcy pozbawienia wolności za prowadzenie pojazdu bez prawa jazdy. Zarówno Pál Aranyosi, jak i Robert Căldăraru zostali odnalezieni w Niemczech. Stąd też do organów tego kraju należało rozpatrzenie nakazów aresztowania. Wyższy sąd krajowy w Bremie (Hanseatisches Oberlandesgericht in Bremen) zdecydował się w obu sprawach wystąpić $\mathrm{z}$ analogicznymi pytaniami prejudycjalnymi do TSUE. Ten rozpoznał obie sprawy łącznie.

Sąd odsyłający stanął na stanowisku, że gdyby doszło do wykonania nakazów zarówno Pál Aranyosi na Węgrzech, jak i Robert Căldăraru w Rumunii byliby pozbawiani wolności w warunkach, które naruszają prawa podstawowe, w szczególności postanowienia KPP zakazujące nieludzkiego lub poniżającego traktowania lub karania. Sąd w Bremie oparł swoje stanowisko na niedawnych wyrokach przeciwko Węgrom i Rumunii, w których ETPCz uznał, że państwa te naruszyły EKPCz ze względu na przeludnienie więzień. W sprawie Varga ${ }^{1433}$, którą ETPCz uznał za pilotażową po otrzymaniu 450 podobnych skarg, a więc uznał, że problem ma charakter systemowy, związany z deficytami w traktowaniu więźniów w więziennictwie węgierskim, a nie jedynie jednostkowy, orzekł, że państwo węgierskie naruszyło art. 3 EKPCz poprzez osadzenie skarżących w zbyt małych i przeludnionych celach. W przypadku Rumunii zaś sąd odsyłający oparł swe stanowisko na wyrokach w sprawach Voicu ${ }^{1434}$, Bujorean ${ }^{1435}$, Constantin Aurelian Burlacu ${ }^{1436}$ oraz Mihai Laurențiu Marin ${ }^{1437}$, w których państwo to zostało skazane za naruszenie art. 3 EKPC poprzez osadzenie skarżących w zbyt małych i przeludnionych celach, bez dostatecznego ogrzewania, brudnych i pozbawionych możliwości skorzystania z prysznica z ciepłą wodą. Również odnośnie do więziennictwa rumuńskiego można wyciągnąć więc wniosek, że problem ma charakter systemowy.

${ }^{1433}$ ETPC $z$, Varga i in. p. Węgrom, skargi 14097/12, 45135/12, 73712/12, 34001/13, 44055/13 i 64586/13, wyrok z 10 marca 2015.

${ }^{1434}$ ETPCz, Voicu p. Rumunii, skarga 22015/10, wyrok z 10 czerwca 2014.

1435 ETPCz, Bujorean p. Rumunii, skarga 13054/12, wyrok z 10 czerwca 2014.

1436 ETPCz, Constantin Aurelian Burlacu p. Rumunii, skarga 51318/12, wyrok z 10 czerwca 2014 .

${ }^{1437}$ ETPCz, Mihai Laurențiu Marin p. Rumunii, skarga 79857/12, wyrok z 10 czerwca 2014. 
Doprowadziło to sąd niemiecki do zadania Trybunałowi dwóch pytań w trybie prejudycjalnym:

1) Czy art. 1 ust. 3 decyzji ramowej [dotyczącej ENA] należy interpretować w ten sposób, że przekazanie w celu wykonania kary jest niedopuszczalne, jeżeli istnieją poważne podstawy wskazujące na to, że warunki pozbawienia wolności w państwie wydającym nakaz naruszają prawa podstawowe danej osoby i ogólne zasady zagwarantowane $\mathrm{w}$ art. 6 TUE, czy też należy go interpretować $\mathrm{w}$ ten sposób, że państwo wykonujące nakaz $\mathrm{w}$ tych przypadkach może lub musi uzależnić rozstrzygnięcie o dopuszczalności przekazania od uzyskania gwarancji, że zostaną zapewnione odpowiednie warunki pozbawienia wolności? Czy państwo wykonujące nakaz może lub musi sformułować $\mathrm{w}$ tym względzie konkretne wymagania minimalne w stosunku do gwarantowanych warunków pozbawienia wolności?

2) Czy art. 5 i art. 6 ust. 1 decyzji ramowej należy interpretować w ten sposób, że organ sądowy wydający nakaz jest także uprawniony do udzielenia gwarancji, iż zostaną zapewnione odpowiednie warunki pozbawienia wolności, czy też uprawnienie to regulują krajowe przepisy dotyczące podziału kompetencji państwa członkowskiego wydającego nakaz? $?^{1438}$

Jeśli chodzi o art. 51 ust. 1 Karty, nie może budzić wątpliwości, że sprawa mieści się w zakresie zastosowania Karty. Trybunał podkreślił, że „poszanowanie art. 4 karty, dotyczącego zakazu nieludzkiego lub poniżającego traktowania i karania, jest wiążące, jak wynika z art. 51 ust. 1 karty, dla państw członkowskich, a w rezultacie dla ich sądów, gdy wykonują one prawo Unii, co ma miejsce, gdy wydający nakaz organ sądowy i wykonujący nakaz organ sądowy stosują przepisy krajowe przyjęte w wykonaniu decyzji ramowej [...]"1439. Trybunał podkreślił także bezwzględny charakter prawa zagwarantowanego w art. 4 Karty wynikający z obowiązku ochrony godności człowieka (art. 1 Karty), jak i jego związek art. 3 EKPCz, zawierającym analogiczną do art. 4 Karty gwarancję. Podkreślił także ich wysokie znaczenie w hierarchii wartości chronionych przez Unię, jak i przez jej państwa członkowskie ${ }^{1440}$.

Doprowadziło go to do stwierdzenia, że gdy istnieją uzasadnione obawy co do niebezpieczeństwa naruszenia praw podstawowych osób, przeciwko którym został wystawiony ENA w innym państwie członkowskim, do którego miałyby zostać one wydane, organ sądowy państwa wykonującego nakaz ma prawo dokonać oceny tego rodzaju niebezpieczeństwa ${ }^{1441}$ i ewentualnie odmówić jego wykonania. Trybunał stwierdził, że:

${ }^{1438}$ TSUE, Pál Aranyosi i Robert Căldăraru p. Generalstaatsanwaltschaft Bremen, C-404/15 i C-659/15, wyrok z 5 kwietnia 2016, pkt 46.

${ }^{1439}$ Ibidem, pkt 84 .

${ }^{1440}$ Ibidem, pkt $85-87$.

${ }^{1441}$ Ibidem, pkt 88 . 
W tym celu wykonujący nakaz organ sądowy powinien na wstępie oprzeć się na obiektywnych, wiarygodnych, dokładnych i należycie zaktualizowanych danych o warunkach pozbawienia wolności panujących w wydającym nakaz państwie członkowskim, które dowodzą istnienia nieprawidłowości, czy to systemowych lub ogólnych, czy dotyczących niektórych grup osób, czy też niektórych ośrodków penitencjarnych. Dane te mogą wynikać w szczególności z międzynarodowych orzeczeń sądowych, takich jak wyroki ETPC, orzeczeń sądowych wydającego nakaz państwa członkowskiego oraz decyzji, sprawozdań i innych dokumentów sporządzanych przez organy Rady Europy lub pochodzących z systemu Organizacji Narodów Zjednoczonych ${ }^{1442}$.

Ocena ta nie może mieć jednak charakteru abstrakcyjnego. „Po stwierdzeniu istnienia [...] niebezpieczeństwa konieczne jest jeszcze następnie, by wykonujący nakaz organ sądowy dokonał oceny w sposób konkretny i dokładny, czy istnieją poważne i sprawdzone podstawy, aby uznać, że zainteresowana osoba będzie narażona na to niebezpieczeństwo ze względu na warunki jej pozbawienia wolności rozważane w wydającym nakaz państwie członkowskim"1443. Aby to stwierdzić, konieczna jest więc również współpraca między organami sądowymi obydwu państw członkowskich na podstawie decyzji ramowej ustanawiającej nakaz aresztowania ${ }^{1444}$. Stwierdzenie, że osoba objęta nakazem będzie narażona na naruszenia jej praw zagwarantowanych w art. 4 Karty, uniemożliwia państwu to stwierdzającemu wykonanie nakazu ${ }^{1445}$.

W porównaniu do wyroku w sprawie N.S. wydaje się, że ostatecznie wymóg dotyczący zagrożenia naruszeniem praw człowieka w innym państwie, zawarty w sprawie Pál Aranyosi i Robert Căldăraru jest korzystniejszy z perspektywy jednostki. Problemy systemowe są w nim uznane za okoliczność podnosząca prawdopodobieństwo zagrożenia dla praw człowieka. Nie są jednak warunkiem koniecznym dla odmowy wykonania ENA. Jak stwierdził TSUE, przekazania należy odmówić „w obliczu obiektywnych, wiarygodnych, dokładnych i należycie zaktualizowanych danych świadczących o istnieniu nieprawidłowości, czy to systemowych lub ogólnych, czy dotyczących niektórych grup osób, czy też niektórych ośrodków penitencjarnych, w odniesieniu do warunków pozbawienia wolności w wydającym nakaz państwie członkowskim"1446. Dlatego też

wykonujący nakaz organ sądowy powinien sprawdzić w sposób konkretny i dokładny, czy istnieją poważne i sprawdzone podstawy, aby uznać, że osoba objęta europejskim nakazem aresztowania wydanym w celu przeprowadzenia postępowania

\footnotetext{
${ }^{1442}$ Ibidem, pkt 89.

${ }^{1443}$ Ibidem, pkt 92.

${ }^{1444}$ Ibidem, pkt 95-103.

${ }^{1445}$ Ibidem, pkt 104

${ }^{1446}$ Ibidem, pkt 104
} 
karnego lub wykonania kary pozbawienia wolności będzie ze względu na warunki jej pozbawienia wolności we wskazanym państwie narażona na rzeczywiste niebezpieczeństwo nieludzkiego lub poniżającego traktowania w rozumieniu art. 4 Karty praw podstawowych Unii Europejskiej w razie przekazania do wspomnianego państwa członkowskiego ${ }^{1447}$.

Pewne wątpliwości na gruncie tej sprawy rodziła kwestia rozbieżności w różnych wersjach językowych tego wyroku. Wersja niemiecka czy polska sugerowały wyraźnie, że wyliczenie różnych typów nieprawidłowości (systemowych, ogólnych itd.) jasno wskazywało, że wyszczególnienie to ma charakter alternatywny, a nie kumulatywny (co w wersji polskiej wzmocnione było jeszcze użyciem spójnika współrzędnego rozłącznego „czy”), oraz że wskazane rodzaje nieprawidłowości są jedynie przykładami kategorii nieprawidłowości, a nie ich wyczerpującą listą. Za rozstrzygającą należy więc w każdej sprawie uznawać sytuację konkretnej osoby i to czy istnieją poważne i sprawdzone podstawy, aby uznać, że osoba objęta ENA byłaby rzeczywiście narażona w państwie wystawiającym nakaz na naruszenie jej praw. Wersje angielska, czeska, duńska, francuska, grecka, portugalska czy włoska mogły natomiast sugerować coś zgoła odmiennego, a więc, że jedynie w ramach wymienionych w wyroku grup nieprawidłowości, a więc jedynie w przypadku nieprawidłowości systemowych, ogólnych, dotyczących niektórych grup osób, albo dotyczących niektórych ośrodków penitencjarnych mogłoby dojść do niewykonania ENA ${ }^{1448}$.

Jak podkreślają niektórzy ${ }^{1449}$, późniejsze orzecznictwo TSUE ${ }^{1450}$ potwierdziło, że prawidłowa była interpretacja pierwsza, a nawet, że za odmową wykonania ENA mogłyby potencjalnie stać względy indywidualne, a nie koniecznie systemowe problemy w państwie wystawiającym ENA ${ }^{1451}$, choć istnienie względów ogólnych i systemowych stanowi istotne uprawdopodobnienie zagrożenia dla jednostki. Znaczenie gwarancji praw człowieka w kontekście klauzuli

1447 Ibidem, pkt 104 .

1448 Por.: D. Halberstam, The Judicial Battle over Mutual Trust in the EU: Recent Cracks in the Façade, VerfBlog, 2016/6/o9, [online] <http://verfassungsblog.de/the-judicial-battle-over-mutual-trust-in-the-eu-recent-cracks-in-the-facade/> DOI: <http://dx.doi.org/10.17176/201606o9093714> [dostęp: 7.02.2019]; J. Polakiewicz, Accession to the European Convention on Human Rights (ECHR) - An Insider's View Addressing One By One the CJEU's Objections in Opinion 2/13, "Human Rights Law Journal" 2016, nr 1-6, vol. 36, s. 16; A.-L. Chané, A. Hauser, J. Jaraczewski, W. Jóźwicki, Z. Kędzia, M.A. Šimáková, H. Suchocka, S. Wallace, EU Engagement..., s. 95.

1449 J. Polakiewicz, Accession..., s. 16.

1450 TSUE, Postępowanie karne p. Piotrowi Kossowskiemu, C-486/14, wyrok z 29 czerwca 2016; TSUE, C.K. i in. p. Republika Slovenija, C-578/16 PPU, wyrok z 16 lutego 2017.

${ }^{1451}$ W sprawie C.K. stan osoby, której dotyczył ENA sprawił, że sam jej transport urastałby do rangi tortury, ze względu na to wykonanie ENA było niemożliwe (TSUE, C.K. i in. p. Republika Slovenija, C-578/16 PPU, wyrok z 16 lutego 2017, pkt 76 i nast.). 
praw człowieka w decyzji ramowej dotyczącej ENA (tym razem naruszenia istotnej treści zagwarantowanego w art. 47 Karty prawa do skutecznego środka prawnego i dostępu do bezstronnego sądu), jako potencjalnego wyjątku od zasady wzajemnego zaufania TSUE podkreślił również w niedawnej sprawie Celmer ${ }^{1452}$. TSUE pokazał $w$ ten sposób, że gwarancje praw człowieka, również tych, które nie mają charakteru bezwzględnego, jak ma to miejsce w przypadku zakazu tortur i nieludzkiego i poniżającego traktowania (choć $\mathrm{w}$ ich bezwzględnym wymiarze - składającym się na istotną treśćc ${ }^{1453}$ ), i sposób, w jaki są one zagwarantowane w Unii, mogą w wyjątkowych okolicznościach stać się podstawą do odstąpienia od zasady wzajemnego zaufania. W sprawie tej TSUE podkreślił znaczenie systemowych i ogólnych nieprawidłowości w państwie członkowskim, z którego pochodzi nakaz, oraz ich potencjalnego wpływu na sytuację konkretnej osoby, której to oceny miałby dokonywać sąd decydujący o wykonaniu ENA.

Orzecznictwo to wyraźnie pokazuje ewolucję podejścia TSUE w kierunku przyjaznym prawom człowieka i ich ochronie, nawet jeśli miałoby to prowadzić do powstawania pewnych wyłomów w zasadzie wzajemnego zaufania. TSUE przyznaje państwom coraz dalej idącą możliwość weryfikowania, czy wykonanie przez nie prawa unijnego nie doprowadzi do naruszenia praw człowieka. Na razie czyni to na podstawie prawa unijnego. Trudno jednak nie dostrzec kontekstu krajowego i pewnego rodzaju groźby, jaka być może jest elementem dodatkowo skłaniającym TUSE do ustępstw. O ile bywa on określany mianem unijnego sądu praw człowieka, to jednak przede wszystkim jest unijnym sądem strzegącym autonomii prawa unijnego ${ }^{1454}, \mathrm{w}$ ramach której to ambiwalencji na ogół przeważają racje stania na straży autonomii i jej podstaw ${ }^{1455}$. Omawiane tu orzecznictwo TSUE jest w pewnym sensie reakcją na presję, jaką wywiera nań ETPCz. W znacznie większym stopniu wydaje się być jednak reakcją na presję, jaką w tej materii wywierają krajowe porządki prawne i stojące na straży zawartych w nich gwarancji praw człowieka sądy konstytucyjne państw członkowskich.

W sprawie Pál Aranyosi i Robert Căldăraru, podobnie jak w sprawie N.S. nie mieliśmy do czynienia z problemem, jakim jest zwolnienie państwa członkowskiego z pewnych zobowiązań wynikających z prawa unijnego ze wzglę-

${ }^{1452}$ TSUE, Minister for Justice and Equality (Défaillances du système judiciaire), C-216/18 PPU, wyrok z 25 lipca 2018.

${ }^{1453}$ Ibidem, pkt 59.

1454 TSUE, Opinia 2/13 wydana w dniu 18 grudnia 2014.

${ }^{1455}$ Czego najlepszym dowodem jest Opinia 2/13, która zablokowała przystąpienie Unii do EKPCz (por.: D. Halberstam, ,It's the Autonomy, Stupid!' A Modest Defense of Opinion 2/13 on EU Accession to the ECHR, and the Way Forward, "German Law Journal" 2015, nr 16 (1). 
du na wyższy niż unijny standard ochrony praw człowieka (ewentualnie stanowiący element jego tożsamości konstytucyjnej). To unijne gwarancje praw podstawowych jako standard minimalny w zakresie zastosowania Karty legły $\mathrm{u}$ podstaw rozstrzygnięcia $\mathrm{w}$ tych sprawach. To ze względu na nieprzekraczalny, minimalny standard ochrony prawa do wolności od tortur i nieludzkiego traktowania, za niedopuszczalne TSUE uznał przekazywanie w ramach polityki azylowej czy wydawanie na podstawie ENA podmiotów uprawnionych do korzystania z gwarancji art. 4 Karty Unii do państw niewypełniających standardów art. 4 Karty. Karta wykorzystana została więc do zapewnienia minimalnego standardu ochrony praw w niej przewidzianych na przestrzeni Unii w zakresie prawa unijnego i posłużyła jego prawidłowej interpretacji. Nie doszło więc do sytuacji, w której to państwo członkowskie chciałoby zapewnić standard wyższy niż prawo Unii, a to ostatecznie stałoby mu w tym na przeszkodzie, co jest przedmiotem zainteresowania $\mathrm{w}$ tej pracy.

Tym niemniej, w kontekście tezy stawianej w tej pracy, należy zwrócić uwagę na pewne novum w tendencji do szczególnego traktowania gwarancji praw podstawowych w kontekście zasad, takich jak wzajemne zaufanie czy pierwszeństwo, jednolitość i efektywność prawa unijnego, jakie wyłania się z orzecznictwa TSUE. W sprawie Pál Aranyosi i Robert Căldăraru szczególnie wyraźnie przejawiła się ona w postaci innowacyjnej interpretacji decyzji ramowej regulującej kwestię ENA ${ }^{1456} \mathrm{i}$ zawartych w niej przepisów umożliwiających niewykonanie nakazu. Jak wiadomo ENA jest podstawową instytucją europejskiej przestrzeni sądowej i wiąże się z fundamentalną zasadą wzajemnego zaufania między państwami członkowskimi Unii, bez której nie mogłaby ona funkcjonować. Jej doniosłość i niechęć TSUE do jej modyfikacji dobitnie pokazał wyrok w sprawie Melloni ${ }^{1457}$. Doniosłość tej zasady trybunał luksemburski potwierdzał wielokrotnie, choćby we wspominanej Opinii $2 / 13^{1458}$, w której między innymi właśnie ze względu na niebezpieczeństwo podważenia wzajemnego zaufania między państwami, jakie mogłoby przynieść ze sobą przystąpienie Unii do Konwencji, orzekł o niezgodności wynegocjowanych warunków przystąpienia ${ }^{1459} \mathrm{z}$ prawem unijnym ${ }^{1460}$. Trybunał przypomniał w swojej Opinii, że

1456 Decyzja ramowa 2002/584/WSiSW, Dz.Urz. L 190 z 18 lipca 2002 zmieniona Decyzją ramową 2009/299/WSiSW, Dz.Urz. L 81 z 27 marca 2009.

${ }_{1457}$ TSUE, Stefano Melloni p. Ministerio Fiscal, C-399/11, wyrok z 26 lutego 2013.

1458 TSUE, Opinia 2/13 wydana w dniu 18 grudnia 2014.

${ }^{1459}$ Fifth Negotiation Meeting Between the CDDH Ad Hoc Negotiation Group and The European Commission On the Accession of the European Union to The European Convention On Human Rights. Final report to the CDDH, 47+1(2013)oo8rev2 z 10 czerwca 2013.

1460 TSUE, Opinia 2/13 wydana w dniu 18 grudnia 2014, pkt 191-195. 
zasada wzajemnego zaufania między państwami członkowskimi ma w prawie Unii fundamentalne znaczenie, gdyż umożliwia ona utworzenie i utrzymywanie przestrzeni bez granic wewnętrznych. Zasada ta wymaga w szczególności w odniesieniu do przestrzeni wolności, bezpieczeństwa i sprawiedliwości, by każde z tych państw uznawało - z zastrzeżeniem wyjątkowych okoliczności - iż wszystkie inne państwa członkowskie przestrzegają prawa Unii, a zwłaszcza praw podstawowych uznanych $\mathrm{w}$ tym prawie $[\ldots]^{1461}$.

TSUE oparł się w sprawie Pál Aranyosi i Robert Căldăraru na prawie unijnym i na interpretacji prawa unijnego w sposób zgodny z Kartą. Dokonał tego poprzez interpretację tak zwanej „klauzuli praw podstawowych”, w jaką wyposażona jest przedmiotowa decyzja ramowa (w art. 1 ust. $3^{1462}$ ). Do tej pory jednak stronił od takiej interpretacji tego przepisu i ochrona praw podstawowych nie była uznawana za dopuszczalną podstawę niewykonania nakazu. Nie jest bowiem ona wymieniona ani w art. 3 Decyzji, gdzie mowa o podstawach do obligatoryjnej odmowy wykonania ENA, ani w jej art. 4, gdzie mowa o podstawach do fakultatywnej odmowy jego wykonania. Tym niemniej, zważywszy na rangę ochrony praw człowieka, szczególnie widoczną na gruncie tej sprawy w związku z fundamentalnym i nieograniczalnym (absolutnym) charakterem prawa zagwarantowanego w art. 4 Karty, a także w ramach szerszej tendencji związanej z podnoszeniem rangi ochrony praw człowieka w ramach unijnego porządku prawnego, TSUE zmodyfikował swoje stanowisko. W miejscu tym należy podkreślić także, że już od pewnego czasu zarówno państwa członkowskie, takie jak Niemcy czy Irlandia ${ }^{1463}$, a także Parlament Europejski ${ }^{1464}$, który oparł się w tym zakresie na wcześniejszej opinii Komisji ${ }^{1465}$, bezskutecznie promowały stanowisko zmierzające do umożliwienia odmowy wykonania ENA, gdyby jego wykonanie miało prowadzić do naruszenia praw człowieka. Od pewnego czasu pojawiały się nawet w niektórych państwach członkowskich orzeczenia

${ }^{1461}$ Ibidem, pkt 191.

1462 Przepis ten stanowi, że: „Niniejsza decyzja ramowa nie skutkuje modyfikacją obowiązku poszanowania praw podstawowych i podstawowych zasad prawa zawartych w art. 6 Traktatu o Unii Europejskiej".

${ }^{1463}$ D. Halberstam, European Arrest Warrant: the CJEU Tries to Find a Balance Between Efficiency and Protection of Human Rights, "EU Law Blog", [online] <https://ukaelblog.wordpress. $\mathrm{com} / 2016 / 05 / 27 /$ european-arrest-warrant-the-cjeu-tries-to-find-a-balance-between-efficiency-and-protection-of-human-rights/> [dostęp: 7.02.2019]. W tym kontekście warto pamiętać również o wyroku Sądu Apelacyjnego w Szczecinie (sprawa II AKa 1/o9, wyrok z 26 marca 2009), o którym była już mowa wcześniej.

${ }^{1464}$ Rezolucja Parlamentu Europejskiego z 8 września 2015 w sprawie sytuacji w zakresie praw podstawowych w Unii Europejskiej (2013-2014) (2014/2254(INI)), P8_TA(2015)O286, para. 155 .

${ }_{1465}$ Rezolucja Parlamentu Europejskiego z 27 lutego 2014 zawierająca zalecenia dla Komisji w sprawie przeglądu europejskiego nakazu aresztowania [2013/2109(INL)]. 
sądów, w których poddawały one weryfikacji czy wydane osoby, za którymi wystawiano ENA nie są narażone na naruszenie ich praw człowieka i czy ze względu na to nie należałoby nakazu nie wykonać1466.

Nie można w tej sprawie zapominać o kontekście strasburskim. Niewątpliwie sprawa Pál Aranyosi i Robert Căldăraru była swego rodzaju kontynuacją rozwiązywania potencjalnych komplikacji na gruncie relacji między prawem unijnym a EKPCz, jakie ujawniły się na gruncie omawianych już spraw M.S.S. (i Tarakhel) oraz N.S. Gdyby TSUE nie zdecydował się na dopuszczenie pewnych wyjątków, związanych z ochroną praw podstawowych, opierając się na "klauzuli praw podstawowych", zawartej w art. 1 ust. 3 decyzji ramowej, mogłoby to doprowadzić do poważnych konsekwencji w relacji między prawem unijnym a EKPCz, a także między Unią a jej państwami członkowskimi. Orzecznictwo ETPCz dotyczące systemowego charakteru naruszeń zakazu tortur i nieludzkiego i poniżającego traktowania na Węgrzech i w Rumunii było na tyle ugruntowane, że nie sposób spodziewać się, by ETPCz łatwo zmienił zdanie w tej materii. Jednocześnie, w obliczu swego orzecznictwa dotyczącego prawa unijnego niepozostawiającego państwom członkowskim żadnej swobody (a z takim mielibyśmy do czynienia, gdyby TSUE pozostał przy zawężającej interpretacji "klauzuli praw podstawowych"), można by się spodziewać, że gdyby sprawa trafiła ostatecznie do Strasburga, to ETPCz musiałby zastosować tym razem doktrynę Bosphorus. Mogłoby to doprowadzić, o ile uznałby, że w tym wypadku ochrona praw człowieka w prawie Unii byłaby jawnie niewystarczająca, do podważenia domniemania ochrony równorzędnej, jakim cieszy się prawo unijne. Aktualne orzecznictwo ETPC z wydane już po Opinii 2/13 pokazuje, że ewentualność taka wcale nie jest wykluczona, a powściągliwość trybunału strasburskiego w podważaniu domniemania równoważnej ochrony zawartego w doktrynie Bosphorus może się niebawem skończyćc ${ }^{1467}$. Jak stwierdził to bowiem wprost ETPCz na gruncie sprawy Avotinšs, nawet zasada wzajemnego uznawania wyroków nie może prowadzić do naruszenia praw człowieka zagwarantowanych w Konwencji ${ }^{1468}$.

Oczywiście, zgodnie z tym co napisane zostało wcześniej, jako że Unia nie jest stroną Konwencji, odpowiedzialność za takie naruszenie ciążyłaby na państwie członkowskim. Utrata przez prawo Unii statusu prawa zapew-

${ }^{1466}$ Więcej - patrz np.: J. Polakiewicz, Accession..., s. 16.

1467 Patrz wyrok w sprawie: ETPCz, Avotinš p. Łotwie, skarga 17502/o7, wyrok z 26 maja 2016; por. także: L.R. Glas, J. Krommendijk, From Opinion 2/13 to Avotinš̌: Recent Developments in the Relationship between the Luxembourg and Strasbourg Court, Forthcoming, "Human Rights Law Review" 2017, nr 17(2), [online] <https://papers.ssrn.com/sol3/papers.cfm?abstract_id=2871263> [dostęp: 7.02.2019]; oraz: A. Bodnar, Standard "równoważnej....

${ }^{1468}$ Patrz przed.: ETPCz, Avotinš p. Łotwie, skarga 17502/o7, wyrok z 26 maja 2016, para. 114 i nast. 
niającego ochronę równorzędną prowadziłaby do daleko idących komplikacji również w najważniejszym z perspektywy tej pracy wymiarze, jakim są relacje Unii z państwami członkowskimi w przedmiocie ochrony praw człowieka, szczególnie w związku z sytuacją, w jakiej zobowiązania wynikające z prawa unijnego postawiłyby je w kontekście ciążących na nich zobowiązaniach wynikających z Konwencji, o komplikacjach na gruncie prawa unijnego już nie wspominając.

Dokonując interpretacji decyzji ramowej w tej sprawie Trybunał faktycznie chronił przede wszystkim prawa w zakresie, $w$ jakim zagwarantowane jest ono również w KPP. Ponadto, zezwalając państwom na pewne ograniczenie zasady wzajemnego uznawania wyroków, zapobiegł jednak jednocześnie powstaniu poważnego problemu, który mógłby zrodzić się na gruncie ochrony prawa do wolności od tortur i nieludzkiego traktowania na podstawie gwarancji przewidzianych przez prawo krajowe. Gdyby bowiem TSUE nie zdecydował się na taką interpretację "klauzuli praw podstawowych” zawartej w decyzji ramowej i wykluczył jakiekolwiek inne, wynikające z potrzeby ochrony praw podstawowych wyjątki umożliwiające odmowę wykonania ENA, niż te które expressis verbis wynikają z odpowiednich przepisów Decyzji, mógłby narazić się na spełnienie scenariusza, w którym państwo członkowskie odrzuciłoby taką interpretację Decyzji w oparciu o doktrynę ultra vires i przekroczenie przez Unię swych kompetencji poprzez ograniczenie gwarancji praw człowieka, wynikających z regulacji krajowych w stopniu naruszającym tożsamość konstytucyjną państw, czy też szerzej - naruszającym podział kompetencji między Unię i państwa członkowskie. Byłoby to dodatkowo poparte autorytetem ETPC $z^{1469}$.

Trzeba zwrócić uwagę, że argumentacja w wyroku w sprawie Pál Aranyosi i Robert Căldăraru nie ograniczała się jedynie do oceny sytuacji z perspektywy prawa unijnego. Istotną rolę odgrywały tu również krajowe gwarancje praw człowieka, na które powołała się strona odsyłająca. Jak zauważył Trybunał:

Decyzja ramowa została transponowana do niemieckiego porządku prawnego na mocy $\S \S 78-83 \mathrm{k}[\ldots]$ (ustawy o międzynarodowej pomocy prawnej w sprawach

${ }^{1469}$ Na marginesie warto podkreślić, że w swym orzecznictwie dotyczącym kwestii związanych z prawem unijnym i doktryną Bosphorus ETPCz chętnie powtarza słynny passus ze sprawy Loizidou [ETPCz, Loizidou p. Turcji (Zagadnienia wstępne), skarga nr 15318/89, wyrok z 23 marca 1995, para. 75] o roli Konwencji, jako „konstytucyjnego instrumentu europejskiego porządku publicznego" w zakresie praw człowieka (patrz: ETPCz, Bosphorus Hava Yolları Turizm ve Ticaret Anonim Şirketi p. Irlandii, skarga 45036/98, wyrok z 30 czerwca 2005, para. 156; ETPCz, Michaud p. Francji skarga 12323/11, wyrok z 6 grudnia 2012, para. 103; ETPCz, Avotinš p. Łotwie, skarga 17502/o7, wyrok z 26 maja 2016, para. 103; por. także: ETPCz, M.S.S. p. Belgii i Grecji, skarga 30696/o9, wyrok z 21 stycznia 2011, para. 338-340). 
karnych) z dnia 23 grudnia 1982 r., zmienionej [...] (ustawą o europejskim nakazie aresztowania) z dnia 20 lipca 2006 r. (BGBl. 2006 I, s. 1721) (zwanej dalej „IRG”) ${ }^{1470}$.

Należy podkreślić, że paragraf 73 tej ustawy mówi: „W braku odpowiedniego wniosku współpraca sądowa i przekazywanie informacji są niedopuszczalne, jeśli naruszają istotne zasady niemieckiego porządku prawnego. W przypadku wniosku na mocy części ósmej, dziewiątej i dziesiątej współpraca sądowa jest niedopuszczalna, jeśli narusza zasady wymienione w art. 6 TUE"1471. Sąd odsyłający przywołał te przepisy i stwierdził, że

przekazanie należałoby uznać za niedopuszczalne w razie zaistnienia przeszkody dotyczącej przekazania na podstawie § 73 IRG. Przy uwzględnieniu zaś obecnie dostępnych informacji sąd odsyłający jest przekonany, że istnieją wiarygodne wskazówki, iż w razie przekazania węgierskiemu organowi sądowemu P. Aranyosi mógłby być poddany warunkom pozbawienia wolności naruszającym art. 3 EKPC i prawa podstawowe oraz ogólne zasady prawa ustanowione w art. 6 TUE ${ }^{1472}$.

Niebezpieczeństwo, czy też groźba, sprowadzająca się do niewykonania nakazu w oparciu o prawo krajowe, gdyby Decyzja tego nie umożliwiała, jest tu wyrażona wprost.

Analizując wyrok w sprawie Pál Aranyosi i Robert Căldăraru, nie można zapomnieć również o orzeczeniu FTK z grudnia $2015^{1473}$, które jak się wydaje stanowiło po pierwsze reakcję FTK na wyrok TSUE w sprawie Melloni, a na które reakcja, choć niewypowiedzianą wprost, stał się z kolei wyrok w sprawie Pál Aranyosi i Robert Căldăraru ${ }^{1474}$. Szczególna uwaga, z jaką TSUE podchodził do niemieckiego porządku prawnego w wyroku w sprawie Pál Aranyosi i Robert Căldăraru była niewątpliwie w dużej mierze spowodowana orzeczeniem FTK, które ze względu na stanowisko w nim wyrażone przez niektórych zostało okrzyknięte mianem Solange III ${ }^{1475}$. 15 grudnia 2015 r. FTK unieważnił wydaną przez sąd niemiecki decyzję o wykonaniu ENA wystawionego przez sąd włoski wobec obywatela USA. Sprawa dotyczyła obywatela amerykańskiego skazanego przez sąd we Florencji na 30 lat więzienia za udział w grupie

1470 TSUE, Pál Aranyosi i Robert Căldăraru p. Generalstaatsanwaltschaft Bremen, C-404/15 i C-659/15, wyrok z 5 kwietnia 2016, pkt 24.

${ }^{1471}$ Ibidem, pkt 27.

${ }^{1472}$ Ibidem, pkt 42.

${ }^{1473}$ FTK, 2 BvR 2735/14, orzeczenie z 15 grudnia 2015.

${ }^{1474}$ Por. np.: Y. Nakanishi, Completion of EU Measures through Court Decisions: The Example of the European Arrest Warrant, "Hitotsubashi Journal of Law and Politics" 2017, nr 45, s. 15-19; wpływ orzeczenia FTK z 15 grudnia 2015 na wyrok w sprawie Pál Aranyosi i Robert Căldăraru jest dość powszechnie dostrzegany w doktrynie (patrz np.: D. Paris, Constitutional..., s. 818).

${ }^{1475}$ Ibidem, s. 16. 
przestępczej zajmującej się przemytem narkotyków. Obywatel ten zdecydował się skierować do FTK skargę konstytucyjna, twierdząc, że wykonanie nakazu naruszyłoby jego prawa człowieka, szczególnie jego godność chronioną przez art. I niemieckiej ustawy zasadniczej, jako że wyrok przeciwko niemu wydany został przez sąd włoski in absentia, że nie wiedział o toczącym się przeciwko niemu postępowaniu i że skazany został jako rzekomy członek grupy przestępczej, a nie w oparciu o zindywidualizowaną winę.

FTK dokonał unieważnienia decyzji o wykonaniu tego nakazu ze względu na ochronę konstytucyjnych praw człowieka, wynikających ze stanowiącej o tożsamości konstytucyjnej Niemiec ochronie godności człowieka. Doszedł do wniosku, że zasada winy oraz indywidualnej i osobistej odpowiedzialności (Schuldprinzip) wynika z godności człowieka i jest objęta zakresem art. 1 niemieckiej konstytucji i że jako taka jest niepodważalna w związku z art. 23 ust. 1 oraz 79 ust. 3 niemieckiej ustawy zasadniczej. Dla niepodważalnego charakteru tej zasady nie mogą mieć znaczenia nawet zobowiązania, jakie nakłada na Niemcy prawo unijne wraz z zasadami wzajemnego zaufania, pierwszeństwa czy jedności prawa unijnego. FTK przywołał tu wprowadzoną w wyroku w sprawie TL zasadę kontroli prawa unijnego przez pryzmat zgodności z tożsamością konstytucyjną Niemiec (Identität-Kontrolle) ${ }^{1476}$ i doszedł do wniosku, że ze względu na charakter gwarancji praw i wolności człowieka, jakie w tym wypadku zostały przez postępowanie przed włoskimi sądami naruszone, które to gwarancje stanowią element tożsamości konstytucyjnej Niemiec, nakaz ten nie może zostać wykonany. Należy w tym miejscu podkreślić, że sprawa ta tylko pozornie jest analogiczna do sprawy Melloni. Naruszenia praw człowieka wynikające $\mathrm{z}$ wyroku in absentia tym razem szłyby znacznie dalej niż w sprawie Melloni. Byłyby one tak daleko posunięte, że naruszałyby nie tylko pewne szczególnie wysokie gwarancje standardu rzetelnego procesu, które na gruncie hiszpańskiej konstytucji obejmowały całkowity zakaz wydawania wyroków in absentia, lecz tym razem prowadziłyby do naruszenia tego, co jak się wydaje, można by zaliczyć do istoty prawa do rzetelnego procesu. Ponadto, wydaje się również, że na gruncie prawa unijnego, w związku z dopuszczalnymi okolicznościami odmowy wykonania nakazu, można byłoby twierdzić, że nie powinien on zostać wykonany ${ }^{1477}$. FTK nie oparł jednak swego orzeczenia na prawie unijnym. Skoncentrował się na konstytucji, jej tożsamości i zasadzie winy (Schuldprinzip), o której decyzja ramowa nie wspomina. Odnośnie

1476 Patrz przed.: FTK, 2 BvE 2/o8, 2 BvE 5/o8, 2 BvR 1010/o8, 2 BvR 1022/o8, 2 BvR 1259/o8, 2 BvR 182/o9, orzeczenie z 30 czerwca 2009, pkt 240 i 332.

${ }_{1477}$ Mam tu na myśli przede wszystkim art. 4a wprowadzony do Decyzji ramowej 2002/584/WSiSW, Dz.Urz. L 190 z 18 lipca 2002, zmienionej Decyzją ramową 2009/299/ WSiSW, Dz.Urz. L 81 z 27 marca 2009. 
do prawa unijnego stanął na stanowisku, że również w nim (w decyzji ramowej) zawarte są gwarancje praw podstawowych i godności człowieka i że jest to tak oczywiste, że nie ma potrzeby kierowania w tej kwestii pytania prejudycjalnego do TSUE. Wyrok TSUE w sprawie Pál Aranyosi i Robert Căldăraru pokazał, że w pewnym sensie FTK miał rację, choć nie można mieć pewności, czy bez tego rodzaju presji ze strony krajowego sądu konstytucyjnego TSUE zdecydowałby się na nową interpretację "klauzuli praw podstawowych", jako dającej podstawę do niewykonania ENA, czego od lat, mimo różnych sugestii, nie czynił. Warto w tym miejscu również podkreślić, że siłę presji wywieranej na TSUE FTK zwiększyl, powołując się na orzecznictwo innych sądów konstytucyjnych państw członkowskich, podkreślając, że również one stają na straży nieprzekazywalnego zakresu suwerenności, którego Unia naruszyć nie może ${ }^{1478}$.

Na marginesie warto zwrócić uwagę, że w wyroku tym, w stopniu znacznie wyższym niż w innych swych orzeczeniach, FTK oddzielił kontrolę stosowania prawa unijnego przez pryzmat tożsamości konstytucyjnej Niemiec oraz jego kontrolę $\mathrm{w}$ ramach doktryny ultra vires. Trudno jednoznacznie odpowiedzieć, dlaczego tak uczynił. Być może wiązało się to z faktem, że, jak była o tym mowa, kontrola $\mathrm{w}$ ramach doktryny ultra vires została przez niego samego znacznie ograniczona w sprawie Honeywell, gdzie stwierdził, że działanie Unii może być przez niego uznane za ultra vires tylko wtedy, gdy przekroczenie przez Unię kompetencji ma charakter oczywisty ${ }^{1479}$. Być może więc poprzez rozgraniczenie kontroli w ramach doktryny ultra vires i kontroli opartej na tożsamości konstytucyjnej poszukiwał nowego narzędzia, którego zastosowanie nie byłoby uwarunkowane tak wysoko postawionymi wymaganiami ${ }^{1480}$.

Co godne podkreślenia z perspektywy tej pracy, to okoliczność, że rozgraniczenie takie w pewnym stopniu otwiera orzecznictwo tego trybunału na propozycję formułowaną w tym tekście, która opiera się na traktowaniu zastosowania kontroli opartej na doktrynie ultra vires jako ostatecznego rozwiązania, gdyby wszelkie inne kooperacyjne rozwiązania się nie powiodły, przy czym za

${ }^{1478}$ FTK, 2 BvR 2735/14, orzeczenie z 15 grudnia 2015, para. 47; bardziej przekrojowo o różnych wariacjach doktryn controlimiti, ultra vires i tożsamości konstytucyjnej, a także ich wspólnych elementów w orzecznictwie sądów konstytucyjnych państw członkowskich patrz np.: D. Paris, Limiting..., s. 210-213.

${ }^{1479}$ FTK, 2 BvR 2661/o6, orzeczenie z 6 lipca 2010.

1480 Jeśli wyrok w sprawie Honeywell można nazwać swoistym odwrotem czy częściową kapitulacją ze strony FTK w ramach relacji z TSUE wokół doktryny ultra vires, o tyle doktrynę tożsamości konstytucyjnej można odebrać jako nowy rozdział sporu o suwerenność i jej zachowanie w ramach Unii poprzez formę kontroli jej aktów przez FTK; por.: D. Thym, Attack or Retreat? Evolving Themes and Strategies of the Judicial Dialogue between the German Constitutional Court and the European Court of Justice, [w:] M. Claes, M. de Visser, P. Popelier, C. van de Heyning (red.), Constitutional Conversations in Europe. Actors, Topics and Procedures, Antwerp 2012, s. 237-246. 
jedno z rozwiązań kooperacyjnych uznaje się kontrolę prawa unijnego przez pryzmat zgodności z tożsamością konstytucyjną państwa - oczywiście pod warunkiem, że będzie ona dokonywana w ramach dialogu i współpracy między krajowym sądem konstytucyjnym i TSUE. Pewne konceptualne rozdzielenie kontroli prawa unijnego przez pryzmat zgodności z tożsamością konstytucyjną Niemiec i kontroli prawa unijnego przez pryzmat doktryny ultra vires uchyla trochę drzwi dla koncepcji przyjmowanej w tej pracy. Nadal jednak, co znacznie ogranicza jej stosowalność w ramach niemieckiego porządku konstytucyjnego, wyraźnie widać, że FTK stoi na stanowisku, zgodnie z którym uważa się za podmiot kompetentny do samodzielnego dokonywania kontroli stosowania prawa unijnego w Niemczech przez pryzmat zgodności z tożsamością konstytucyjną Niemiec. Co więcej, nieobarczonego wymogiem oczywistości ze sprawy Honeywell. Nie ma więc większego znaczenia, czy kontrola przez pryzmat zgodności z tożsamością konstytucyjną i kontrola w ramach doktryny ultra vires są kategoriami rozłącznymi, czy ta pierwsza jest rodzajem tej drugiej. Tak czy owak trudno doszukać się w orzecznictwie Trybunału w Karlsruhe zwiastunów ewentualnej akceptacji dialogicznego podejścia do tej pierwszej, takiego jak proponowane w tej pracy.

Ewentualnym zwiastunem akceptacji przynajmniej jednego z elementów proponowanego $\mathrm{w}$ tej pracy sekwencyjnego mechanizmu może być natomiast orzeczenie wydane przez FTK 6 września $2016^{1481}$, a więc już po wyroku TSUE w sprawie Pál Aranyosi i Robert Căldăraru. FTK badał w niej skargę konstytucyjną wniesioną przez obywatela chorwackiego i irlandzkiego, oskarżonego o zabójstwo w Wielkiej Brytanii, za którym sąd tego państwa wystawił ENA. Sąd w Berlinie, gdzie został on aresztowany, przychylił się do nakazu. Zdaniem skarżącego było to jednak nie do pogodzenia z gwarancjami praw i wolności człowieka wynikającymi z niemieckiej konstytucji, jako że opierając się na zasadach postępowania w Wielkiej Brytanii sąd mógłby z jego ewentualnego milczenia i odmowy składania zeznań wyciągnąć wnioski o charakterze obciążającym go. Tymczasem, jak twierdził, prawo do zachowania milczenia jest elementem gwarancji praw człowieka w Niemczech i stanowi element tożsamości konstytucyjnej tego państwa. Na tej podstawie wniósł skargę konstytucyjną do FTK, licząc na rozstrzygnięcie analogiczne do tego z 15 grudnia 2015.

FTK przyznał, że osobie oskarżonej w procesie karnym przysługuje prawo do odmowy składania zeznań obciążających samego siebie (Grundsatzes der Selbstbelastungsfreiheit), co zawiera w sobie prawo do swobodnego wyboru, czy w ogóle składać zeznania czy nie, przez co nikt nie może być ani zmuszany do obciążania samego siebie, ani w żaden sposób przyczyniać się do skaza-

${ }^{1481}$ FTK, 2 BvR89o/16, orzeczenie z 6 września 2016. 
nia. FTK przyznał również, że prawo to wynika z zasady godności człowieka. Stwierdził jednakże, że naruszenie art. 1 konstytucji niemieckiej miałoby mieć miejsce jedynie wtedy, gdyby doszło do ingerencji w istotę tego prawa. FTK orzekł, że ekstradycja na podstawie ENA nie jest niedopuszczalna ze względu na sam fakt, że prawo do nieskładania zeznań obciążających samego siebie nie jest zagwarantowane $\mathrm{w}$ prawie proceduralnym państwa wystawiającego nakaz $\mathrm{w}$ tym samym stopniu, jak ma to miejsce $\mathrm{w}$ procedurze niemieckiej w związku z konstytucyjnymi gwarancjami praw i wolności człowieka. Zdaniem FTK fakt, że w ramach brytyjskiej procedury karnej milczenie oskarżonego może, w określonych okolicznościach, być użyte na jego niekorzyść, stoi w sprzeczności z prawem oskarżonego, aby nie obciążać samego siebie, jakie wynika z niemieckich przepisów proceduralnych i z niemieckiej konstytucji. Tym niemniej, nie prowadzi to do naruszenia podstawowych zasad konstytucyjnych, które są wyjęte spod wpływu integracji europejskiej i stanowią dla niej granice. Tylko gdyby doszło do naruszenia istoty praw i wolności, można by było mówić o naruszeniu art. 1 konstytucji, co byłoby nie do pogodzenia z tożsamością konstytucyjną Republiki Federalnej Niemiec. Tym razem jednak sytuacja taka nie zachodzi, nakaz powinien więc zostać wykonany.

Elementem, który w tej sprawie zasługuje na podkreślenie, a który współgra z koncepcją prezentowaną w tej pracy, jest stanowisko FTK, zgodnie z którym nie wszystkie uprawnienia wynikające z konstytucyjnych gwarancji praw człowieka są jednocześnie składnikami tożsamości konstytucyjnej tego państwa, nawet jeśli wszystkie wynikają z zasady godności człowieka. Na tożsamość konstytucyjną składają się tylko te gwarancje i tylko ten ich zakres, które mają fundamentalne znacznie dla porządku konstytucyjnego i które stanowią o istocie ochrony godności człowieka w ramach tego porządku.

\section{Szczególna rola sądów w mechanizmie sekwencyjnego dialogu między TK a TSUE umożliwiającego zapewnienie przestrzegania w Polsce wyższego niż unijny konstytucyjnego standardu ochrony praw czlowieka}

Dostrzegając kluczową rolę TK i TSUE w ramach proponowanej w tej pracy koncepcji współpracy między nimi w przedmiocie poszanowania przez Unię wyższych niż unijne, konstytucyjnych gwarancji praw człowieka, stanowiących element tożsamości konstytucyjnej państwa członkowskiego, jakim jest Polska, należy także zwrócić uwagę na rolę innych podmiotów, które mogłyby uła- 
twiać, a w związku z pewnymi ograniczeniami proceduralnymi, wręcz warunkują możliwość zaistnienia sekwencji orzeczniczej, w ramach której TK i TSUE taką współpracę mogłyby podjaćc. Do szczególnej rangi urasta w tej mierze rola sądów zwykłych. Poprawne rozumienie przez nie i świadomość wynikających z nich konsekwencji art. 51 ust. 1 Karty oraz jej art. 53, lecz także innych przepisów prawa unijnego, jak art. 267 TFUE czy kluczowy z perspektywy tej pracy art. 4 ust. 2 TUE, a także prawidłowe rozumienie specyfiki unijnego porządku prawnego związanej z jego autonomicznością oraz wynikających stąd zasad, na jakich się on opiera, jest kluczowe do tego, aby mogły one odgrywać systemową rolę i wyławiać oraz prawidłowo kierować wnioski do TK we wszystkich zasługujących na to przypadkach i przez to umożliwiać przeprowadzenie dialogu między TK a TSUE, o jakim mowa w tej pracy.

O ile prawo unijne komplikuje w pewnym stopniu relację między sądami polskimi a TK, co było już omawiane w poprzednich rozdziałach, o tyle z drugiej strony należy podkreślić, że ratyfikowane „umowy międzynarodowe wiążące Polskę oraz prawo UE nie regulują bezpośrednio legitymacji w postępowaniu przed $\mathrm{TK}^{\prime \prime} 1482$. W mocy pozostają więc regulacje krajowe, szczególnie te osadzone w Konstytucji. „Należy jednak mieć na uwadze, że w odniesieniu do sądów może pojawić się kwestia konkurencyjności legitymacji do zainicjowania postępowania przed TK w drodze pytania prawnego lub wystapienia z pytaniem prejudycjalnym do TSUE"1483. Członkostwo Polski w Unii i wynikające stąd konsekwencje, sprawiaja, że

kompetencja do wnoszenia pytań prawnych powinna być rozpatrywana w świetle art. 267 TFUE, upoważniającego każdy sąd państwa członkowskiego UE (a obligujący sąd, którego orzeczenia nie podlegają zaskarżeniu) do wystąpienia z pytaniem prejudycjalnym w sprawie wykładni Traktatów lub ważności prawa pochodnego UE. Sąd może zwłaszcza stanąć przed dylematem, czy w pierwszej kolejności ma skierować pytanie prawne do TK dotyczące zgodności aktu normatywnego z Konstytucją RP, czy pytanie prejudycjalne do TSUE [... $]^{1484}$. Należałoby przyjąć, że wystąpienie równoległych wątpliwości co do konstytucyjności pochodnego prawa unijnego lub implementującego je prawa krajowego oraz dotyczących ważności prawa pochodnego powinno uzasadniać uprzednie skierowanie pytania prejudycjalnego. Rozstrzygnięcie TSUE o nieważności rozporządzenia unijnego otwiera drogę do rozstrzygnięcia zawisłej przed sądem sprawy z pominięciem tego rozporządzenia, a zarazem bez konieczności angażowania TK. Z kolei stwierdzenie nieważności dyrektywy nie prowadzi per se do wyeliminowania z systemu prawnego przepisów ustawowych ją im-

1482 A. Mączyński, J. Podkowik, Art. 191. [Legitymacja podmiotowa do występowania do TK], [w:] M. Safjan, L. Bosek (red.), Konstytucja. Komentarz, t. II, Warszawa 2016, s. 1226.

1483 Ibidem.

${ }^{1484}$ Więcej - patrz np.: A. Kustra, Kelsenowski..., s. 39 i nast. 
plementujących, a co za tym idzie - nie uzasadnia ich niezastosowania w sprawie. Ewentualna odmowa zastosowania przepisu implementującego z uwagi na nieważność prawa pochodnego UE wchodziłaby w grę dla aktów podustawowych. Prejudycjalny wyrok TSUE może jednak uzasadniać skierowanie pytania prawnego do TK w sprawie konstytucyjności przepisów implementujących nieważną dyrektywę, w konsekwencji prowadząc do wyeliminowania ustawy implementującej z porządku prawnego. Orzeczenie o ważności prawa pochodnego UE nie zamyka natomiast sądowi drogi do zakwestionowania ich zgodności z Konstytucją RP. W świetle zasady nadrzędności Konstytucji RP (art. 8 ust. 1) nie można interpretować przepisów kompetencyjnych zawartych w Konstytucji RP, nawet z powołaniem się na obowiązek przestrzegania wiążącego prawa międzynarodowego (art. 9), w sposób wyłączający lub ograniczający jej supremację w systemie prawa ${ }^{1485}$. Ograniczeniem tego rodzaju byłby m.in.: brak możliwości skutecznego wniesienia przez sąd pytania prawnego i jego merytorycznego rozpoznania przez TK, w związku z rozstrzygnięciem o ważności aktu prawa pochodnego. Zatem art. 193 Konstytucji RP należałoby interpretować w sposób przyjazny prawu unijnemu, a zatem nieblokujący sądowi możliwości występowania z pytaniem prejudycjalnym [...]. Z kolei art. 267 TFUE należałoby interpretować w sposób nieograniczający kompetencji sądu konstytucyjnego - jako strażnika nadrzędności Konstytucji RP ${ }^{1486}$.

Sądy krajowe są jednocześnie sądami unijnymi i spoczywa na nich obowiązek zapewnienia przestrzegania pierwszeństwa, jedności i efektywności

${ }^{1485}$ W wyroku w sprawie K 18/o4 TK wskazał płaszczyzny, na których przejawia się nadrzędność Konstytucji nad prawem unijnym, czy mówiąc szerzej: „nadrzędność Konstytucji w stosunku do całego porządku prawnego, w obszarze suwerenności Rzeczypospolitej Polskiej [...]. Po pierwsze, proces integracji europejskiej związany z przekazywaniem kompetencji w niektórych sprawach organom wspólnotowym (unijnym) ma oparcie w samej Konstytucji Rzeczypospolitej Polskiej. Mechanizm przystąpienia Rzeczypospolitej do Unii Europejskiej znajduje wyraźną podstawę prawną w regulacjach konstytucyjnych. Jego ważność i skuteczność uzależniona jest od spełnienia konstytucyjnych elementów procedury integracyjnej, w tym również - procedury przekazywania kompetencji. Po drugie, nadrzędność Konstytucji znajduje potwierdzenie w konstytucyjnie określonym mechanizmie kontroli konstytucyjności Traktatu akcesyjnego oraz aktów stanowiących jego integralne składniki. Mechanizm ten został oparty na tych samych zasadach, na jakich Trybunał Konstytucyjny orzekać może o zgodności z Konstytucją ratyfikowanych umów międzynarodowych. W takiej sytuacji przedmiotem kontroli stają się także, jakkolwiek pośrednio, inne akty prawa pierwotnego Wspólnot i Unii Europejskiej stanowiące załączniki do Traktatu akcesyjnego. Po trzecie, przepisy (normy) Konstytucji jako aktu nadrzędnego i stanowiącego wyraz suwerennej woli narodu nie mogą utracić mocy obowiązującej bądź ulec zmianie przez sam fakt powstania nieusuwalnej sprzeczności pomiędzy określonymi przepisami (aktami wspólnotowymi a Konstytucją). W takiej sytuacji suwerenny polski ustrojodawca konstytucyjny zachowuje prawo samodzielnego zadecydowania o sposobie rozwiązania tej sprzeczności, w tym również o celowości ewentualnej zmiany samej Konstytucji" (pkt III 7 uzasadnienia).

${ }_{1486}$ A. Mączyński, J. Podkowik, Art. 193. [Pytanie prawne], [w:] M. Safjan, L. Bosek (red.), Konstytucja. Komentarz, t. II, Warszawa 2016, s. 1250. 
prawa unijnego oraz zapewniania przestrzegania unijnych praw podstawowych w związku z zakresem zastosowania Karty. Muszą więc one stosować unijne gwarancje praw podstawowych do prawa pochodnego Unii stosowanego w państwach członkowskich. Co więcej, muszą odmawiać zastosowania takich przepisów krajowych, które mieszczą się w zakresie zastosowania prawa unijnego, jeśli byłyby one sprzeczne z Karta, a w razie potrzeby korzystać $\mathrm{w}$ tej materii z procedury pytania prejudycjalnego do TSUE. Nie mogą zostać tej kompetencji pozbawione przez prawo krajowe i ewentualnie zawarte w nim wymogi dotyczące unieważniania takiego prawa krajowego przez sądy konstytucyjne. Scentralizowany system hierarchicznej kontroli prawa w państwach członkowskich, na którego szczycie w Polsce stoi TK, nie może podważać również, co do zasady, scentralizowanego systemu hierarchicznej kontroli prawa w Unii, na którego szczycie stoi TSUE. Rozumienie art. 51 ust. 1 oraz art. 53 Karty doprowadziło do istotnej ekspansji standardu unijnego, nawet nie tyle ratione materiae czy personae, gdyż w tej kwestii art. 51 ust. 1 Karty przyniósł niewielką zmianę względem stanu rzeczy sprzed wejścia Karty w życie, co w kwestii charakteru standardu unijnego, jako silnie wiążącego państwa członkowskie i nie pozostawiającego im swobody do stosowania standardów wyższych niż przewidziane przez prawo unijne, gdyby miało to prowadzić do konfliktu z zasadami pierwszeństwa, jedności i efektywności prawa unijnego. Doprowadziło to do sytuacji pewnej ostrożności, czy wręcz podejrzliwości wielu sądów konstytucyjnych państw członkowskich, gdy chodzi o stosowanie Karty, które wynikało nie tylko z trudności precyzyjnego ustalenia treści normatywnej art. 51 ust. 1 Karty, lecz jeszcze bardziej z problemu interpretacji jej art. 53, jakiej dokonał TSUE ${ }^{1487}$.

Rozumienie art. 53 pozwala na pewną swobodę państwom członkowskim. Chodzi przede wszystkim o dopuszczalność, jak zostało to określone, mieszanego (mixed) stosowania unijnych i krajowych standardów, gdy te drugie nie zagrażają zasadom pierwszeństwa, jedności i efektywności prawa unijnego. Powinno być to odzwierciedlone w orzecznictwie sądów zwykłych. Co więcej zgodnie z postawioną w tej pracy tezą, wyjątkiem od rozumienia art. 53 przedstawionego w wyroku w sprawie Melloni powinna być również sytuacja, gdy wyższy niż unijny, konstytucyjny standard ochrony praw człowieka, podważający pierwszeństwo, jedność i efektywność prawa unijnego stanowi element tożsamości konstytucyjnej państwa członkowskiego. Dostrzeżenie tego faktu przez sądy krajowe, a przynajmniej uzasadnione podejrzenie, że taka sytuacja ma miejsce, jest niezwykle istotne, chociaż ostateczne rozstrzygnięcie o tym, co mieści się w zakresie tożsamości konstytucyjnej RP powinno należeć nie do nich, lecz do TK. Powinno to również być odzwierciedlone w postępowaniu

1487 A. Kustra, Kelsenowski..., s. 48o. 
sądów: konkretnie w tym, jaką procedurę współpracy orzeczniczej i z jakim podmiotem wybiorą - czy zwrócą się z pytaniem prejudycjalnym do TSUE, czy też z pytaniem prawnym do TK.

W sytuacjach, w których sądy krajowe byłyby przekonane, a nawet jedynie miały co do tego podejrzenie, że konstytucyjne standardy ochrony praw człowieka w zakresie zastosowania Karty są wyższe od unijnych i że ich ochrona na gruncie konstytucji może mieć na tyle fundamentalny charakter, że uzasadniałoby to uznanie ich za element polskiej tożsamości konstytucyjnej, powinny, zdaniem autora, móc skorzystać z procedury zwrócenia się najpierw do TK z wnioskiem o weryfikację prawa krajowego, nawet jeśli mieści się ono w zakresie prawa unijnego i nawet jeśli mieści się ono w zakresie dalece zharmonizowanego prawa unijnego. Podobnie powinny one w analogicznej sytuacji, zdaniem autora, móc skorzystać z procedury pytania prawnego $\mathrm{w}$ celu zwrócenia się najpierw do TK z wnioskiem o weryfikację bezpośrednio skutecznego prawa unijnego. To pierwsze nie wiąże się z przeszkodami natury formalnej. TK badał już w różnych trybach zgodność prawa polskiego mieszczącego się $\mathrm{w}$ zakresie zastosowania prawa unijnego. To drugie może rodzić pewne wątpliwości formalne. Jednakże, jak zostało to wykazane w poprzednim rozdziale, procedura pytania prawnego dla kontroli konstytucyjności unijnego prawa pochodnego jest na gruncie Konstytucji RP możliwa na takiej samej zasadzie, jak kontrola takiego prawa w trybie skargi konstytucyjnej.

W obu tych wypadkach na TK spadłaby znacznie większa odpowiedzialność, dotycząca nie tylko możliwości skorzystania z szansy na dialog z TSUE, który proponowany jest w tej pracy, jaką dałoby mu zwrócenie się w tego rodzaju sprawach przez sąd krajowy do niego zamiast do TSUE, lecz również dotycząca niemożności wykorzystywania tego rodzaju sytuacji, gdyby sąd zwykły się pomylił i sprawa nie miała charakteru uzasadniającego udział TK. Współpraca i chęć dania TK szansy do podjęcia dialogu z TSUE w przedmiocie poszanowania tożsamości konstytucyjnej RP ze strony sądów zwykłych nie powinna być wykorzystywana do umacniania izolacjonistycznie pojmowanej pozycji TK względem TSUE. Powinna służyć zainicjowaniu sekwencji orzekania, która miałaby służyć w równym stopniu realizacji zasady konstytucjonalizmu i ochrony tożsamości konstytucyjnej RP oraz zasady pierwszeństwa, jedności i efektywności prawa unijnego i zasady lojalnej współpracy w ramach Unii. Wydaje się, że TK przejawił w swym orzecznictwie zwiastuny takiej otwartości. Dokonał tego zarówno w sprawie K 61/13, w której skierował pytanie prejudycjalne do TSUE, dostrzegając unijny charakter sprawy, mimo że formalnie badane przez niego przepisy pochodziły od polskiego ustawodawcy i uwzględniając wyrok w sprawie Melki i Abdeli ${ }^{1488}$, jak i w sprawie Sk 45/o9,

${ }^{1488}$ TK, sprawa K 61/13, postanowienie z 7 lipca 2015, pkt 3.1.3 uzasadnienia. 
gdzie poszukiwał niekonfliktowych metod rozwiązania problemu, który mógłby zaistnieć w przypadku niekonstytucyjności bezpośrednio skutecznego unijnego prawa pochodnego, podkreślając swoje zobowiązanie do skierowania w takiej sytuacji odesłania prejudycjalnego do TSUE. Nawet jeśli potencjalny zakres i rodzaj pytań prejudycjalnych w ramach rozważań TK poczynionych na gruncie orzeczenia w sprawie Sk 45/og nie wyczerpywał, zdaniem autora, wszystkich możliwości, nic nie stoi na przeszkodzie, aby uzupełnić je o możliwość sformułowania pytania prejudycjalnego, o jakim mowa w tej pracy.

\subsection{Rola sądów w mechanizmie sekwencyjnego dialogu odnośnie do prawa polskiego mieszczącego się w zakresie zastosowania prawa unijnego}

Gdy chodzi o prawo polskie mieszczące się w zakresie zastosowania prawa unijnego, jak się wydaje pewną furtkę dla elastyczności sądów krajowych w tej dziedzinie zostawił sam TSUE w omawianych wcześniej wyrokach w sprawach Melki i Abdeli oraz A. p. B. Zdaniem niektórych przedstawicieli doktryny wyrok w sprawie Melki i Abdeli stanowił przejaw pewnego złagodzenia oczekiwań wobec sądów krajowych wynikających z wyroku w sprawie Simmenthal na korzyść krajowych sądów konstytucyjnych ${ }^{1489}$. Na gruncie wyroku w sprawie Simmenthal TSUE stwierdził wyraźnie, że

sprzeczne z wymogami wynikającymi z samej natury prawa wspólnotowego byłyby wszelkie przepisy obowiązujące w krajowym porządku prawnym oraz wszelka praktyka legislacyjna, administracyjna lub sądowa, powodujące ograniczenie skuteczności tego prawa poprzez odmowę przyznania sądowi, w którego kompetencji leży jego zastosowanie, uprawnienia do uczynienia, w momencie stosowania tego prawa, wszystkiego, co niezbędne do pominięcia krajowych przepisów ustawowych stojących na przeszkodzie pełnej skuteczności prawa wspólnotowego ${ }^{1490}$.

Tymczasem po wyroku w sprawie Melki i Abdeli, co potwierdził wyrok w sprawie A. p. B., nie ma wątpliwości, że sądom zwykłym wolno kierować do krajowych sądów konstytucyjnych, zamiast po prostu niestosować prawa krajowego, wnioski prowadzące do kontroli prawa krajowego, nawet takiego, którego treść ogranicza się do transpozycji bezwzględnie wiążących przepisów dyrektyw unijnych ${ }^{1491}$. Warunkiem, jaki sformułował TSUE, jest zapewnienie,

${ }^{1489}$ D. Paris, Case Note..., s. 404.

1490 TSUE, Amministrazione delle Finanze dello Stato p. Simmenthal SA, C-106/77, wyrok z 9 marca 1978, pkt 22.

${ }^{1491}$ TSUE, A. p. B. i in., C-112/13, wyrok z 11 września 2014, pkt 40-43. 
"by sąd krajowy miał swobodę z jednej strony stosowania wszelkich niezbędnych środków w celu zapewnienia tymczasowej ochrony sądowej praw gwarantowanych w porządku prawnym Unii, a z drugiej strony odstąpienia od stosowania, po zakończeniu takiego postępowania wpadkowego, krajowego przepisu ustawowego, który uważa za sprzeczny z prawem Unii"1492.

TSUE dopuszcza więc w pewnym sensie zawieszenie czy też, jak kto woli, odroczenie natychmiastowego zastosowania przez sąd krajowy, będący również sądem unijnym, zasady pierwszeństwa. Umożliwia to powstanie przestrzeni dla przeprowadzenia kontroli konstytucyjności przepisów krajowych mieszczących się w zakresie prawa Unii. To właśnie, jak twierdzą niektórzy, osłabia czy podważa zasadę pierwszeństwa ${ }^{1993}$. Zdaniem autora tej pracy raczej ją uelastycznia, tym samym, przy odpowiednim wykorzystywaniu tej elastyczności, ją wzmacniając ${ }^{1494}$. Skierowanie pytania najpierw do TK wcale nie musi bowiem prowadzić do podważenia pierwszeństwa, jedności i efektywności prawa unijnego, szczególnie w dłuższej perspektywie. Przeciwnie, w dłuższym rozrachunku może ją wzmocnić, otwierając przestrzeń dialogu między TK a TSUE, takiego jak ten, o którym mowa w tej pracy - zmierzającego do wspólnego zastosowania, gdy z obu stron okaże się to uzasadnione i na warunkach dla obu stron akceptowalnych, art. 4 ust. 2 TUE i uniknięcia w ten sposób ewentualnego konfliktu, który ostatecznie mógłby się zakończyć znacznie gorszymi konsekwencjami dla pierwszeństwa, jedności i efektywności prawa unijnego, a nawet dla całego projektu europejskiego.

Przedmiotem zainteresowania w tym miejscu nie jest pogłębione rozważanie na temat wszelkich aspektów i konsekwencji ani mieszanego (mixed) stosowania gwarancji praw człowieka, ani też szczegółowa analiza prowadząca do całościowej oceny dopuszczalności kierowania do TK przez sądy pytań prawnych, w celu ewentualnego unieważnienia przepisów krajowych ze skutkiem erga omnes zamiast jedynie ich niestosowania przez sądy, w związku z ich niezgodnością z prawem unijnym, w tym przede wszystkim z KPP, czy też priorytetowego kierowania pytań prejudycjalnych do TSUE. Wymagałoby szerokiej analizy na tle różnych, rozpiętych wokół opcji francuskiej i austriackiej, modeli integracji do systemów krajowych prawa unijnego, a przede wszystkim Karty. Uelastycznienie podejścia do zasady pierwszeństwa, związane $\mathrm{z}$ umożliwieniem zastosowania sekwencji orzekania w przedmiocie wyższych niż unijne krajowych standardów ochrony praw człowieka składających się na

${ }^{1492}$ Ibidem, pkt 40.

${ }^{1493}$ Por.: D. Paris, Case Note..., s. 404.

${ }^{1494}$ M. Belov, The Functions of Constitutional Identity Performed in the Context of Constitutionalization of the EU Order and Europeanization of the Legal Orders of EU Member States, "Perspectives on Federalism" 2017, nr 9 (2), s. E-85. 
tożsamość konstytucyjną, nie powinno jednak być rozumiane jako odejście w jakimkolwiek stopniu od fundamentalnej dla unijnego porządku prawnego zasady pierwszeństwa. Na pewno ani w wyroku w sprawie Melki i Abdeli, ani w sprawie A. p. B., TSUE nie wyraził na to w żaden sposób zgody, a sprawa ta $\mathrm{w}$ swej istocie przede wszystkim potwierdza prawo sądów krajowych do zwracania się z pytaniami prejudycjalnymi do TSUE na dowolnym etapie postępowania, bez względu na przepisy krajowe ${ }^{1495}$. Należy zauważyć, że TSUE nie odniósł się do specyfiki kontroli konstytucyjności we Francji czy w Austrii. Nie wchodził więc w krajowe partykularyzmy, które się na gruncie tych spraw ujawniły. Fakt, że w dwu tak różnych sytuacjach skupił się na ograniczeniach, jakie wynikają z prawa unijnego dla scentralizowanej kontroli konstytucyjności prawa w państwach członkowskich pokazuje, że ugruntowana zasada pierwszeństwa, tak jak jest ona znana od wyroku w sprawie Simmenthal, zachowuje $w$ istocie swą moc ${ }^{1496}$. Tym niemniej, nie wyklucza to możliwości funkcjonowania w państwach członkowskich scentralizowanego systemu kontroli konstytucyjności prawa i dokonywania w różnym zakresie przez sądy konstytucyjne państw członkowskich kontroli konstytucyjności prawa krajowego, które mieści się w zakresie zastosowania prawa unijnego.

Propozycja formułowana w tej pracy nie ma prowadzić do osłabienia zasady pierwszeństwa, lecz ma służyć minimalizacji niebezpieczeństwa zaistnienia kolizji między krajowymi i unijnymi gwarancjami praw człowieka, a także konfliktu w tej materii między TK a TSUE. Nie idzie tak daleko w przychylnej prawu krajowemu i przewidzianym przez nie procedurom kontroli prawa, jak chciałby tego na przykład włoski $\mathrm{TK}^{1497}$. Polskie sądy, choć za wskazane należy uznać lepsze przyswojenie sobie przez nie znaczenia art. 51 ust. 1 Karty, jak była o tym mowa, i tak nie przejawiają tendencji do występowania do TSUE z pytaniami dotyczącymi zgodności z Kartą mieszczącego się w jej zakresie zastosowania prawa polskiego. Nawet jeśli to robią, to na ogół dość nieporadnie. Dzięki odesłaniu w sprawie K 61/13 bardziej kooperacyjny okazał się w tej materii TK. Nawet więc jeśli ostatecznie (oczywiście przy spełnieniu wszystkich zastrzeżeń i warunków zapewnienia tymczasowej ochrony sądowej praw gwarantowanych w porządku prawnym Unii, o jakich mówił TSUE, a o których szczegółowo była mowa w podrozdziale II. 3) sądy krajowe będą kontynuowały

${ }^{1495}$ M. Bonelli, The Taricco..., s. 367.

${ }^{1496}$ Por.: D. Paris, Case Note..., s. 404-405.

${ }^{1497}$ Przełamując swe wcześniejsze stanowisko, wyraził on niedawno obiter pogląd, że w przypadku wątpliwości co do zgodności badanych przepisów z włoską ustawą zasadniczą, kontrola konstytucyjności prawa włoskiego powinna zawsze poprzedzać zwrócenie się przez sąd zwykły z pytaniem prejudycjalnym do TSUE (włoski TK, sprawa 269/2017, wyrok z 7 listopada 2017), który to pogląd znalazł już odzwierciedlenie w praktyce sądowej we Włoszech (więcej - patrz np.: G. Piccirilli, The 'Taricco Saga'..., s. 18-19). 
tendencję do zwracania się do TK z pytaniami prawnymi odnośnie do wszystkich przepisów prawa polskiego, również tych, które są przejawem stosowania prawa unijnego, nie jedynie w sytuacjach, gdy będzie istniało podejrzenie, że prawo to narusza standardy konstytucyjne ochrony praw i wolności człowieka, $\mathrm{w}$ tym standardy potencjalnie wyższe niż unijne i przez to stające $\mathrm{w}$ sprzeczności z pierwszeństwem, jednością i efektywnością prawa unijnego, to niekoniecznie będzie musiało to doprowadzić do podważenia zasady pierwszeństwa. Wszystko będzie w rękach TK, który oceni, czy te konstytucyjne standardy mają charakter, który sprawia, że stanowią one o tożsamości konstytucyjnej RP i skierować oparte na tym pytanie prejudycjalne do TSUE, czy też tak nie jest, i wtedy będzie mógł skierować pytanie analogiczne do tego, jakie wystosował w sprawie K 61/13. Będzie więc mógł wybrać najodpowiedniejsze kroki $\mathrm{w}$ procesie dialogu między nim a TSUE.

\subsection{Rola sądów w mechanizmie sekwencyjnego dialogu odnośnie do bezpośrednio skutecznego pochodnego prawa unijnego}

Zapewnienie przez sądy krajowe bezpośredniej skuteczności niewymagającego transpozycji prawa unijnego jest jedną z naturalnych konsekwencji zasady efektywności tego prawa związanej z autonomicznością unijnego porządku prawnego, wpracowaną w orzecznictwie Trybunału w Luksemburgu, począwszy od wyroku w sprawie van Gend \& Loos ${ }^{1498}$. Zasada skutku bezpośredniego jest, podobnie jak zasada pierwszeństwa, oparta na orzecznictwie luksemburskim i dotyczy przepisów prawa unijnego zawartych w różnych rodzajach aktów prawnych. Nigdy nie doczekała się kodyfikacji w prawie pierwotnym. „Nie ulega wątpliwości, iż celem sędziów luksemburskich było wzmocnienie pozycji praw jednostek przez umożliwienie dochodzenia roszczeń na podstawie prawa UE bezpośrednio przed sądami krajowymi. W ten sposób oczywiście wzmocniona została jednocześnie efektywność prawa UE"1499.

Bez wchodzenia w zbędne z perspektywy tej pracy szczegóły dość powiedzieć, że kryteria, jakie musi spełnić prawo unijne, by mogło być bezpośrednio stosowane, są powszechnie znane i dobrze ugruntowane w orzecznictwie luksemburskim. Przepis taki powinien być jasny, niebudzący wątpliwości, bezwarunkowy i niezależny od dalszych działań Unii lub państw członkow-

${ }^{1498}$ TSUE, NV Algemene Transport- en Expeditie Onderneming van Gend \& Loos p. Netherlands Inland Revenue Administration, ETS, 26/62, wyrok z 5 lutego 1963.

${ }^{1499}$ B. Capik, A. Łazowski, Art. $91 \ldots$, s. 163 i nast. 
skich $^{1500}$. Skutek bezpośredni mogą mieć zarówno przepisy prawa pierwotnego Unii, a także regulacje zawarte aktach prawa pochodnego, przede wszystkim w rozporządzeniach unijnych. Podstawowym instrumentem unijnego prawa pochodnego, które nie wymaga transpozycji, a którego transpozycja jest wręcz zabroniona, jest właśnie unijne rozporządzenie. Jak wynika $z$ art. 288 TFUE rozporządzenia wiążą w całości i podlegają bezpośredniemu stosowaniu na płaszczyźnie krajowej. Mimo że w związku z tym brak elementu krajowego, takiego jak w przypadku prawa unijnego wymagającego implementacji, TK, choć w ograniczonym zakresie, uważa się za władny do kontrolowania konstytucyjności takiego prawa. Podstaw do tego dostarczają mu przepisy art. 188 pkt $5 \mathrm{w}$ związku z art. 79 oraz art. 193 Konstytucji RP.

Co wymaga szczególnego podkreślenia w tym miejscu, to to, że jak zauważył TSUE już w sprawie Factortame ${ }^{1501}$, obowiązek zapewnienia ochrony prawnej wywodzonej z bezpośrednio skutecznych przepisów prawa wspólnotowego należy do sądów krajowych. Ewentualne odstępstwo od tego obowiązku wiązałoby się z podważeniem zasady pierwszeństwa w sposób jeszcze bardziej jaskrawy niż w sytuacji, o której była mowa w poprzednim podrozdziale. Na gruncie tematyki poruszanej w tej pracy należy zauważyć, że orzecznictwo TK nie stanowi jakiejś zasadniczej przeszkody dla respektowania statusu bezpośrednio skutecznego prawa unijnego w Polsce. Jak było to już wspomniane, TK potwierdził podstawowe konsekwencje bezpośredniego skutku prawa UE wyrażone w orzecznictwie TSUE, szczególnie w swych wyrokach dotyczących traktatu akcesyjnego i TL. TK nie podważa też statusu unijnego prawa pochodnego w polskim porządku prawnym, który opiera się na przepisach art. 90 ust. 1 i 91 ust. 3 Konstytucji. Tym niemniej poważny problem rodzi się, gdy chodzi o zasadę pierwszeństwa bezpośrednio skutecznego w Polsce prawa unijnego względem Konstytucji. O ile bowiem TK uznaje pierwszeństwo prawa unijnego względem ustaw i aktów normatywnych niższego rzędu, co bezdyskusyjnie potwierdza art. 91 ust. 3 Konstytucji, o tyle nie jest skłonny uznać pierwszeństwa prawa unijnego względem ustawy zasadniczej.

Zaprezentowana $\mathrm{w}$ tej pracy propozycja rozwiązywania potencjalnego konfliktu między wyższym niż unijny konstytucyjnym standardem ochrony praw człowieka a standardem unijnym znajduje pełne zastosowanie również w sytuacjach, gdyby taki konflikt ujawnił się w związku z bezpośrednio skutecznym prawem unijnym obowiązującym w Polsce. Jak była o tym mowa, kom-

${ }^{1500}$ Więcej na ten temat w kontekście konstytucyjnym - patrz np.: ibidem, s. 163 i nast.

1501 TSUE, The Queen p. Secretary of State for Transport, ex parte: Factortame Ltd i in., C-213/89, wyrok z 19 czerwca 1990. 
petencja TK do kontroli prawa pochodnego UE pod kątem jego zgodności z Konstytucją sprowadza się jedynie do ograniczonej grupy postępowań przez Trybunałem. Dotychczas kontrola taka miała miejsce jedynie raz w trybie skargi konstytucyjnej. W trybie tym nie ma mowy o udziale sądów powszechnych, administracyjnych ani Sądu Najwyższego. Skarga konstytucyjna może być bowiem wniesiona dopiero po wyczerpaniu drogi prawnej na ich forum, przez każdego, czyje konstytucyjne prawa i wolności zostały naruszone przez akt normatywny zastosowany wobec niego przez te sądy.

Warto jednak pamiętać, że zgodnie z zaprezentowanym w poprzednim rozdziale rozumowaniem przyjętym przez TK w sprawie Sk 45/o9, skarga konstytucyjna nie jest jedyną możliwą do zastosowania procedura, w ramach której TK mógłby zostać uznany za kompetentny do kontroli bezpośrednio skutecznego prawa unijnego. Drugą z nich jest procedura pytania prawnego. Otwiera to przestrzeń dla aktywności sądów powszechnych, administracyjnych czy nawet Sądu Najwyższego, które już na etapie toczącego się przed nimi postępowania mogłyby zwrócić się do TK z pytaniem prawnym w przedmiocie bezpośrednio skutecznego prawa unijnego, na podstawie którego orzekają w danej sprawie, budzącego wątpliwości co do zgodności z konstytucyjnymi gwarancjami praw i wolności jednostki (czy też z innymi przepisami Konstytucji, co wszakże pozostaje poza zakresem zainteresowania w tej pracy). Co do zasady, sądy polskie, jako sądy unijne, w razie wątpliwości co do ważności danego bezpośrednio skutecznego prawa unijnego powinny zwrócić się z pytaniem prejudycjalnym do TSUE, który mógłby to prawo unieważnić jako niezgodne z Karta, a więc w ramach unijnej hierarchii aktów prawnych. Unieważnienie go albo wykładnia rozwiewająca wątpliwości co do zgodności tego prawa z Konstytucją rozwiązywałaby problem. Przedmiotem zainteresowania $\mathrm{w}$ tej pracy jest jednak, co należy jeszcze raz podkreślić, takie prawo unijne, które spełnia wymogi wynikające z unijnych gwarancji praw i wolności człowieka, jest więc zgodne z prawem unijnym wyższego rzędu, w tym z Kartą, ale które jednocześnie nie spełnia konstytucyjnych, wyższych niż unijne gwarancji praw człowieka.

W takim wypadku prawidłowym adresatem pytania prawnego powinien być, zdaniem autora tego opracowania, TK, który to mógłby ocenić, czy faktycznie dany standard konstytucyjny jest przez dane prawo unijne naruszony, a także mógłby ocenić, czy ochrona tego standardu w zakresie, w jakim jest naruszony, stanowi wymóg mieszczący się w zakresie tożsamości konstytucyjnej RP. Ewentualnie mogłoby to zostać jeszcze zweryfikowane za pomocą pytania prejudycjalnego skierowanego przez TK do TSUE odnośnie do ewentualnej nieważności tego aktu ze względu na niezgodność z Kartą albo w przedmiocie 
jego wykładni (jak zapowiadał to TK w sprawie Sk 45/og). Gdyby to jednak nie wystarczyło, TK mógłby jako organ do tego najbardziej kompetentny wystąić z pytaniem prejudycjalnym do TSUE, zmierzającym do uwzględnienia standardu konstytucyjnego na podstawie art. 4 ust. 2 TUE i zawartego w nim obowiązku poszanowania przez Unię tożsamości konstytucyjnej państw członkowskich. Oczywiście jeśli standard konstytucyjny miałby mieć charakter to uzasadniający. W takiej sytuacji nie mielibyśmy do czynienia z podważaniem stricte zasady pierwszeństwa prawa unijnego, a jedynie z jej ewentualnym uelastycznianiem poprzez pewien wyłom $\mathrm{w}$ zasadzie jednolitości stosowania prawa unijnego.

Również odnośnie do bezpośrednio skutecznego prawa unijnego istnieje więc przestrzeń dla aktywności sądów zwykłych, zmierzającej do umożliwienia odpowiedniej sekwencji orzekania przez TK i TSUE, o której mowa w tym rozdziale, umożliwiającej im dialog i rozpisane na etapy wspólne orzekanie o kwestiach związanych z tożsamością konstytucyjną. Tym razem jednak sądy zwykłe powinny być znacznie bardziej ostrożne, dokonując wyboru czy stosując prawo unijne opierać się po prostu na art. 91 ust. 3 Konstytucji i nie stosować niezgodnego z nim prawa polskiego (które nawet jeśli miałoby rangę ustawową mogłoby być wyrazem konstytucyjnego standardu ochrony praw człowieka i zmierzać do jego realizacji), czy kierować pytanie prejudycjalne do TSUE dotyczące ważności bądź interpretacji prawa unijnego w związku z Kartą czy też, nie wykluczając sprzeczności takiego prawa unijnego z tożsamością konstytucyjną RP, angażować w to jeszcze TK. Wymagałoby to pogłębionej znajomości i dużego wyczucia po stronie tych sądów zarówno odnośnie do prawa unijnego, jak i Konstytucji oraz zawartych w nich gwarancji praw jednostki. W razie pomyłki sądów zwykłych, które przeoczyłyby bezpośrednio skuteczne prawo pochodne, które naruszałoby konstytucyjne, wyższe niż unijne gwarancje praw człowieka, składające się na tożsamość konstytucyjną RP, ewentualnie istniałaby jeszcze możliwość naprawienia tego błędu poprzez procedurę skargi konstytucyjnej. Zważywszy profesjonalny charakter sądów i ich ustrojową rolę, wydaje się jednak ważne, aby czuwały one nad tym, stosując prawo unijne. Dlatego, jak się wydaje, bezpieczniejszym dla tożsamości konstytucyjnej RP rozwiązaniem jest, by sądy zaryzykowały skierowanie pytania prawnego do TK, a nie pomijały ten krok. Nieuzasadnione czy niekonieczne skorzystanie z procedury pytania prawnego mogłoby zostać naprawione przez TK - zarówno samodzielnie (poprzez stwierdzenie niedopuszczalności pytania albo uznania kwestionowanych przepisów za zgodne z Konstytucją), ewentualnie poprzez zwrócenie się przez TK z pytaniem prejudycjalnym do TSUE. Pominięcie TK mogłoby jednak doprowadzić do skutków trudniejszych do usunięcia, prowadzących w efekcie do naruszenia tożsamości konstytucyjnej RP. 


\subsection{Potencjalna rola innych organów w obliczu ewentualnych trudności ze stosowaniem sekwencyjnego mechanizmu orzekania o tożsamości konstytucyjnej RP}

Warto zauważyć, że podstawowym utrudnieniem dla TK do występowania w funkcji przewidzianej dla niego w tej pracy mogłaby być zasada skargowości. Z zasady tej wynikają trzy podstawowe konsekwencje. Po pierwsze oznacza ona, że TK nie może orzekać bez wniosku, pytania prawnego czy skargi skierowanej do niego przez uprawniony podmiot, czyli nie może podjać postępowania z własnej inicjatywny ani z urzędu. Po drugie, TK może rozpoznawać sprawę wyłącznie w ramach wyznaczonych przez wnioskodawcę, a tym samym nie może wyjść poza granice wniosku, pytania prawnego lub skargi. Dotyczy to zarówno wskazanych wzorców kontroli, jak i przedmiotu kontroli. Wreszcie po trzecie, TK ma obowiązek rozpoznania każdego wniosku (pytania prawnego, skargi), który do niego wpłynie. Nie może zatem pozostawić sprawy bez rozpoznania ${ }^{1502}$. Z perspektywy tej pracy najważniejsza wydaje się być pierwsza z wymienionych tu konsekwencji zasady skargowości, co zaanonsowane zostało już przed chwilą. Pewne problemy mogą się zrodzić również na gruncie drugiej z nich.

Zasada skargowości ujęta była we wszystkich dotychczasowych stanach prawnych dotyczących postępowań w przedmiocie kontroli konstytucyjności inicjowanej zarówno skarga, wnioskiem, jak i pytaniem prawnym, a więc dotyczy wszystkich postępowań, w ramach których TK dokonuje badania hierarchicznej zgodności norm. W obliczu tego faktu bardzo ważne jest, aby podmioty kierujące swoje skargi, wnioski czy pytania do TK były świadome niuansów dotyczących stosowania unijnych i krajowych standardów ochrony praw jednostki. Najistotniejsze natomiast jest, aby TK nie był przez nie pomijany, jeśli miałby odegrać rolę w procesie zmierzającym do poszanowania tożsamości konstytucyjnej RP w ramach dialogu z TUSE. W kontekście tezy stawianej w tej pracy, oprócz postępowania w trybie skargi konstytucyjnej szczególnie doniosłe znaczenie ma unijna świadomość sądów polskich w związku z kierowanymi przez nie pytaniami prawnymi. Od właściwie sformułowanych wniosków, a przede wszystkim pytań i skarg w znacznym stopniu zależeć będzie możliwość po stronie TK podjęcia i możliwie całościowego podejścia do zagadnień

1502 A. Mączyński, J. Podkowik, Art. 191..., s. 1226. Więcej na temat zasady skargowości w postępowaniu przed TK - patrz np.: E. Łętowska, J. Królikowski, A. Łyszkowska, J. Sokólska-Warchoł, Zasada skargowości - watpliwości i uwarunkowania na tle acquis constitutionnel, [w:] K. Budziło (red.), Księga XXV-lecia Trybunału Konstytucyjnego. Ewolucja funkcji i zadań Trybunału Konstytucyjnego - założenia a ich praktyczna realizacja, Warszawa 2010; K. Wojtyczek, Zasada skargowości w procedurze kontroli norm przed polskim Trybunatem Konstytucyjnym , „Przegląd Sejmowy” 2003, nr 1 . 
omawianych w tej pracy. Znów podkreślić należy, ponownie używając metafory Ewy Łętowskiej, znaczenie podmiotów „podających piłkę”, tym razem Trybunałowi Konstytucyjnemu. Prawidłowe "podania” znacznie ułatwią mu odegranie przewidzianej dla niego roli. Nieprawidłowe "podania" mu to utrudnią, jednak jak się wydaje, nie uniemożliwią. Uniemożliwi mu to jedynie brak "podania”, a więc pomijanie go, przede wszystkim przez sądy, poprzez nieuzasadnioną rezygnację ze skierowania pytania prawnego do TK na rzecz samodzielnego zastosowania przez nie prawa unijnego czy skierowania jedynie pytania prejudycjalnego wprost do TSUE.

Jak się wydaje, w ramach drugiej ze wspomnianych konsekwencji zasady skargowości, a więc związania TK zakresem wniosku, TK będzie mógł naprawić pewne niedociągnięcia wnioskodawców, pytających i skarżących, sprowadzające się do pominięcia prawa unijnego jako przedmiotu kontroli w przypadku inicjowania kontroli prawa polskiego mieszczącego się w zakresie zastosowania prawa unijnego czy pominięcia prawa unijnego wśród wzorców kontroli. Należy bowiem zauważyć, że zasada skargowości nie przeszkodziła TK w skierowaniu pytania prejudycjalnego do TSUE $\mathrm{w}$ sprawie $\mathrm{K}$ 61/13, mimo że prawo unijne nie było wskazane we wniosku RPO ani jako przedmiot, ani jako wzorzec kontroli. Pojawiło się ono we wniosku jedynie w kontekście interpretacyjnym, jako że zaskarżone prawo polskie miało charakter transponujący przepisy dyrektywy. Wydaje się więc, że TK stoi na, niewypowiedzianym wprost, a jedynie implicite stanowisku, że zasada skargowości nie ogranicza możliwości stwierdzenia przez TK unijnego charakteru sprawy i skierowania w związku z tym pytania w trybie prejudycjalnym do TSUE.

Wydaje się, że uzasadnienia dla braku ograniczenia możliwości wystąpienia przez TK z pytaniem prejudycjalnym do TSUE, nawet jeśli prawo unijne nie zostało wskazane we wniosku jako wzorzec czy przedmiot kontroli w kontekście zasady skargowości, nie trzeba szukać daleko, np. w rozważaniach dotyczących wypracowanych przez TK metod niuansowania omawianej tu konsekwencji zasady skargowości ${ }^{1503}$. Wydaje się, że wystarczy zauważyć, że zwrócenie

1503 "Jeżeli inicjator postępowania wiąże kwestionowaną treść normatywną z pewnym redakcyjnie wyodrębnionym fragmentem ustawy, podczas gdy do zrekonstruowania tej treści trzeba wziąć pod uwagę także inny (niewskazany przez niego) fragment tej samej ustawy, to nic nie stoi na przeszkodzie, aby Trybunał poddał kontroli wszystkie przepisy ustawy, z których wynika kwestionowana treść normatywna. W europejskiej kulturze prawnej ugruntowana jest bowiem zasada falsa demonstratio non nocet, w myśl której decydujące znaczenie ma istota sprawy, a nie jej oznaczenie (por. wyroki w sprawach: K 3/98, K 14/o2 i P 11/o2). Orzecznictwo TK odnosi powyższe założenia nie tylko do przedmiotu kontroli, lecz w zasadzie także do jej wzorców (por. wyrok w sprawie SK 41/o1). Nie stanowi to jednak przeszkody w ujmowaniu wzorca konstytucyjnego wskazanego przez inicjatora postępowania w powiązaniu z innymi, »dookreślającymi« przepisami Konstytucji, takimi jak art. 2 (klauzula państwa prawnego) czy art. 31 
się z pytaniem prejudycjalnym do TSUE jest zupełnie innym postępowaniem, rzec by można o charakterze wpadkowym, będącym elementem innego porządku i wynikającym z innego rodzaju zobowiązań, jakie wiążą TK w związku z członkostwem Polski w UE, niż postępowania oparte na Konstytucji, objęte zasadą skargowości. Procedura pytania prejudycjalnego dotyczy TK i całego prawa polskiego w związku z członkostwem naszego kraju w Unii i jest uregulowana w unijnym prawie pierwotnym. To art. 267 TFUE nadaje uprawnienie, a w określonych sytuacjach ustanawia obowiązek, zwracania się do TSUE z pytaniami prejudycjalnymi przez sądy i trybunały państw członkowskich. TFUE jako umowa międzynarodowa ratyfikowana w specjalnym trybie, składająca się na unijne prawo pierwotne ma wyższy status w hierarchii źródeł prawa niż ustawa, w której to jest wyrażona zasada skargowości.

Takie podejście do uprawnienia i obowiązku TK do kierowania pytań prejudycjalnych do TSUE w znacznym stopniu minimalizowałoby niebezpieczeństwo, że kierowane doń wnioski, a w kontekście tematu tej pracy przede wszystkim skargi i pytania prawne, nie byłyby w pełni poprawne z perspektywy prawa unijnego i nie w pełni odzwierciedlałyby wszelkie niuanse związane z art. 51 ust. 1 Karty, jej art. 53, a także z art. 4 ust. 2 TUE i ich relacją wobec przepisów konstytucyjnych regulujących status prawa unijnego w Polsce i zasady konstytucjonalizmu. Dzięki podejściu cechującemu się nieobjęciem kwestii związanych z pytaniami prejudycjalnymi do TSUE zasadą skargowości w tym wymiarze, TK zyskałby możliwość eliminowania ewentualnych błędów podmiotów inicjujących przed nim postępowanie i mógłby je naprawiać poprzez ewentualne samodzielne kierowanie do TSUE pytań prejudycjalnych i określanie zakresu regulacji unijnych znajdujących w danej sprawie zastosowanie. Jak zostało to już zauważone, błędem, którego naprawić natomiast by nie mógł, byłoby pominięcie TK.

W obliczu doniosłości jak najpoprawniejszego formułowania wniosków, skarg i pytań prawnych do TK należy również podkreślić potencjalną rolę Rzecznika Praw Obywatelskich, który na podstawie art. 63 ust. 2 ustawy o organizacji i trybie postępowania przed Trybunałem Konstytucyjnym ${ }^{1504}$ oraz art. 16 ust. 2 pkt 3 ustawy o Rzeczniku Praw Obywatelskich ${ }^{1505}$ może zgłosić udział w postępowaniu przed TK i brać w nim czynny udział ${ }^{1506}$. W razie potrze-

ust. 3 (granice dopuszczalnych ograniczeń wolności i praw)" (Informacja o istotnych problemach wynikajacych $z$ działalności i orzecznictwa Trybunału Konstytucyjnego, Warszawa 2006, s. 21-22).

${ }^{1504}$ Ustawa z 30 listopada 2016 o organizacji i trybie postępowania przed Trybunałem Konstytucyjnym, Dz.U. poz. 2072.

${ }^{1505}$ Ustawa z 15 lipca 1987 o Rzeczniku Praw Obywatelskich, Dz.U. z 2014 poz. 1648 ze zm.

1506 „Przyznając Rzecznikowi w takim wypadku formalną pozycję uczestnika postępowania, ustawodawca nie rozstrzygną kwestii, czy w tej roli może on rozszerzyć wzorzec kontroli wskazany przez skarżącego. Owa niejasność regulacji ustawowej stała się przyczyną rozbież- 
by, gdyby wnioskodawcy, a w kontekście tej pracy przede wszystkim skarżący czy pytający nie dostrzegli problemu, na którym koncentruje się ta praca, to właśnie Rzecznik mógłby odegrać rolę ułatwiającą Trybunałowi podjęcie kwestii ochrony wyższych niż unijne, konstytucyjnych gwarancji praw i wolności w kontekście tożsamości konstytucyjnej RP w związku z obowiązkiem poszanowania tejże przez Unię i jej instytucje. Taka jego rola pozostawałaby bez wątpienia w zgodzie z jego ustrojową pozycją i funkcją, jako organu stojącego na straży wolności i praw człowieka i obywatela określonych w Konstytucji RP (art. 208) oraz w innych aktach normatywnych (art. 1 ustawy o RPO). Szczególnie przydatne mogłoby okazać się zaangażowanie Rzecznika w wymiarze materialnym, a więc dla prawidłowego zidentyfikowania i prawidłowej oceny $\mathrm{w}$ świetle omawianych $\mathrm{w}$ tej pracy przepisów i zasad prawa unijnego i konstytucyjnego charakteru oraz zakresu ewentualnej kolizji między wyższym niż unijny, konstytucyjnym standardem ochrony praw człowieka a prawem unijnym i jego ocena przez pryzmat tego, czy stanowi on element tożsamości konstytucyjnej RP, czy też nie.

\section{Podsumowanie}

Zdaniem niektórych „próbą minimalizacji fragmentacji europejskiej przestrzeni prawnej powinno być znalezienie wspólnego wzorca kontroli prawa pochodnego albo jej zupełne zaniechanie ${ }^{\prime \prime 1507}$. Dotyczy to zarówno bezpośredniej kontroli takiego prawa, jak i pośredniej, poprzez kontrolę aktów krajowych, implementujących pochodne prawo unijne. Faktycznie fragmentacja unijnego porządku prawnego byłaby zjawiskiem niewskazanym i przeciwnym całemu projektowi europejskiej integracji. Powściągliwość (deferencja) przy podejmowaniu kontroli unijnego prawa pochodnego przez krajowe sądy konstytucyjne, nawet przez pryzmat zgodności z tak fundamentalnymi regulacjami, jak za-

ności w orzecznictwie [...]. Przez pewien czas dominował pogląd, że RPO przez zgłoszenie swego udziału w sprawie nie zyskuje prawa rozszerzenia zakresu skargi, lecz jedynie możliwość wspierania jej, w szczególności poprzez przedstawianie nowych argumentów prawnych (por. wyroki w sprawach: SK 17/oo, SK 2/O1 i SK 19/o1)" (Informacja o istotnych problemach wynikajacych $z$ działalności i orzecznictwa Trybunału Konstytucyjnego, Warszawa 20o6, s. 22). Trybunał odstapił jednak "od powyższej, restrykcyjnej linii orzeczniczej, dopuszczając możliwość uzupełnienia skargi konstytucyjnej przez RPO poprzez wskazanie dodatkowych wzorców kontroli (por. wyroki w sprawach: SK 21/o2 i SK 64/o3; podobnie - wcześniej - w sprawie SK 15/oo)" (ibidem, s. 22). W obliczu rozłącznego, jak się wydaje, charakteru procedury pytania prejudycjalnego i postępowań objętych zasadą skargowości, rola Rzecznika przejawiająca się w możliwości uzupełniania wzorców kontroli nie byłaby jednak kluczowa.

${ }^{1507}$ J. Maśnicki, Kontrola konstytucyjności..., s. 77. 
warte w krajowych konstytucjach gwarancje praw człowieka, wydaje się więc wysoce wskazana. Różny stopień tej powściągliwości wydaje się jednak uzasadniony w zależności zarówno od przedmiotu, jak i charakteru wzorca kontroli. Najwyższy stopień powściągliwości wskazany byłby zapewne przy kontroli prawa unijnego bezpośrednio skutecznego, w wysokim stopniu zharmonizowanego. Mniejszy przy kontroli prawa polskiego, które mieści się w zakresie zastosowania prawa unijnego. W tym zakresie też przydatne byłoby pewne zróżnicowanie odnośnie do prawa krajowego, którego treść jest całkowicie zdeterminowana przez prawo unijne oraz prawa krajowego, które implementuje prawo unijne przy dużej swobodzie pozostawionej przez Unię państwom, aż po prawo krajowe, które jedynie luźno mieści się w zakresie prawa unijnego poprzez zasadę efektywności tego ostatniego. Takie zróżnicowanie wynika zresztą z orzecznictwa samego TSUE, jak była o tym mowa w ostatnich trzech rozdziałach tej pracy i w ostatnim przypadku skutkuje nawet dopuszczalnością tak zwanego mieszanego (mixed) stosowania unijnych i krajowych gwarancji praw człowieka. Wydaje się jednak, że w odniesieniu do żadnych przepisów prawa unijnego, nawet tych, których charakter uzasadniałby najdalej posuniętą powściągliwość, całkowite zaniechanie kontroli konstytucyjności, szczególnie przez pryzmat zgodności z konstytucyjnymi gwarancjami praw i wolności człowieka, należałoby uznać za niemożliwe. Byłoby to sprzeczne z zasadą konstytucjonalizmu i statusem gwarancji praw człowieka w polskim porządku konstytucyjnym, a także z zasadą poszanowania przez Unię tożsamości konstytucyjnej państw członkowskich.

Zakres tej powściągliwości zależy również od wzorców kontroli, a mianowicie czy miałyby to być po prostu normy konstytucyjne, czy też normy konstytucyjne o fundamentalnym znaczeniu dla konstytucyjnego ustroju państwa, a więc składające się na jego tożsamość konstytucyjna, a jeśli tak, to czy składające się na nią w sposób konieczny i stanowiące jej istotowy element, czy też będące jedynie jej funkcją czy derywatami (służącymi jej realizacji, ale nie stanowiącymi o jej istocie $)^{1508}$. Jak się wydaje co do zasady, te pierwsze po-

${ }^{1508}$ Wszystkie okoliczności prowadzące do wspomnianej w tym i poprzednim akapicie "powściągliwości" można określić też sensu largo kryteriami proporcjonalności, które będą mogły odgrywać rolę podczas badania, czy górę w konkretnej sprawie powinny wziąć zasady pierwszeństwa jednolitości i efektywności prawa unijnego czy tożsamość konstytucyjna państwa członkowskiego i normy ją realizujące (por. np.: G. van der Schyff, The Constitutional..., s. 580-582); choć ze względów poruszanych już wcześniej trudno zgodzić się z perspektywa, z której Gerhard van der Schyff, choć nie bezalternatywnie (ibidem, s.581-582), podchodzi do stosowania testu proporcjonalności. Jego perspektywa prowadzi do absolutyzacji, jak zostało to określone wcześniej, zasad pierwszeństwa, jedności i efektywności prawa Unii. Prowadzi go to do stwierdzenia, że ocena proporcjonalności miałaby sprowadzać się do tego, że im dotkliwsze miałyby być konsekwencje nieposzanowania przez Unię tożsamości konstytucyjnej jakiegoś 
winny ustąpić takim wartościom, jak pierwszeństwo, jednolitość i efektywność prawa unijnego, co odzwierciedlone jest w prawie unijnym w art. 4 ust. 3 TUE, a w prawie konstytucyjnym w jakimś stopniu odzwierciedlone jest w art. 9 Konstytucji ${ }^{1509}$, a co wynika z autonomicznego charakteru unijnego systemu prawnego, który jest warunkiem powodzenia procesu integracji w ramach UE. Te drugie zaś powinny móc znaleźć zastosowanie również jako wzorzec kontroli dla prawa UE (choć nie uniwersalny, ale partykularny - mający skutki dla konkretnego państwa członkowskiego), co odzwierciedlone jest w art. 4 ust. 2 TUE $\mathrm{i}$ innych przepisach unijnego prawa pierwotnego, o których była mowa w tym rozdziale, a w prawie konstytucyjnym wyrażone przede wszystkim w art. 8 Konstytucji, lecz także w przepisach regulujących członkostwo Polski w Unii, i nawet jeśli nie prowadzić do nieważności prawa unijnego, to do jego niestosowania w danym państwie członkowskim.

Marek Safjan zastanawiając się nad zakresem zastosowania unijnych praw podstawowych wobec państw członkowskich, jeszcze przed wyrokiem w sprawie Melloni, zwracał uwagę na doniosłość pytania o to, do jakiego stopnia interpretacja i stosowanie unijnych praw podstawowych może być modyfikowane w wyniku uwzględniania indywidualnych tradycji konstytucyjnych poszczególnych państw członkowskich. Pytał, czy zakres zastosowania

państwa, tym silniej powinno być to uzasadnione ze względu na prawo Unii, a czasem z tego względu niedopuszczalne (ibidem, s. 581).

${ }^{1509}$ Należy pamiętać, że przepis ten ma taką samą rangę jak art. 8 Konstytucji. Jak słusznie zauważa Krzysztof Wójtowicz: „Zamieszczenie art. 9 w Rozdziale I Konstytucji RP - Rzeczpospolita wskazuje, iż przestrzeganie przez Polskę wiążącego ją prawa międzynarodowego jest nie tylko obowiązkiem konstytucyjnym, ale stanowi jedną z zasad systemu prawnego i ustroju państwa. Jest to przepis o pełnej wartości normatywnej właściwej innym naczelnym zasadom konstytucyjnym" (K. Wójtowicz, Art. 9..., s. 325). Skoro tak, jest ona równa, a przynajmniej znajduje się w tej samej kategorii zasad, jak zasada suwerenności. Być może nawet można by ją uznać za element tożsamości konstytucyjnej RP i przez to podnieść rangę wymogu poszanowania prawa unijnego i zasad jego pierwszeństwa, jedności i efektywności w Polsce, który rozciągałby się również na przepisy rangi konstytucyjnej, jednak jedynie te, które tej tożsamości nie stanowią (o ile trudno, aby prawo unijne zagrażało tożsamości konstytucyjnej RP w zakresie, w jakim za jej element uznane byłoby poszanowanie jego pierwszeństwa, jedności i efektywności, o tyle poszanowanie tych wartości mogłoby zagrażać innym elementom tej tożsamości, takim jak suwerenność czy godność ludzka i wynikające z niej, niepodważalne gwarancje praw człowieka). Aktualnie jednak wydaje się, że brak jest podstaw do stawiania tezy o tożsamościowym charakterze art. 9 na gruncie Konstytucji RP. Przede wszystkim brak do tego podstaw w orzecznictwie TK. Przepis ten, nawet gdyby ograniczyć go jedynie do wymiaru unijnego, nie znalazł się w zidentyfikowanym dotychczas katalogu elementów składających się na tożsamość konstytucyjną RP. TK przesądził też, że Konstytucji RP został jednoznacznie zagwarantowany status najwyższego prawa w RP, nawet jeśli regulacji tej towarzyszy "nakaz respektowania i przychylności wobec właściwie ukształtowanych oraz obowiązujących na terytorium Rzeczypospolitej Polskiej unormowań prawa międzynarodowego (art. 9 Konstytucji)" (TK, sprawa Sk 45/o9, wyrok z 16 listopada 2011, pkt III 2.6 uzasadnienia). 
Karty mógłby być różnicowany, z uwagi na odmienne konstytucyjnie zagwarantowane standardy ochrony praw człowieka. Pozytywna odpowiedź na to pytanie mogłaby prowadzić do pewnego zachwiania jednorodnego zastosowania unijnych praw podstawowych ${ }^{1510}$. Wyrok w sprawie Melloni rozwiał te wątpliwości i odrzucił, co do zasady, taką możliwość. Tym niemniej jak może się wydawać, pewna modyfikacja i pewne zawężenie szerokiego zakresu zastosowania unijnych praw podstawowych mogłyby mieć miejsce w bardzo ograniczonej kategorii sytuacji - w których ów wyższy, krajowy standard ochrony nie tyle, że wynikałby po prostu z regulacji krajowych, nawet o randze konstytucyjnej, lecz gdyby stanowił element tożsamości konstytucyjnej tego państwa członkowskiego. $W$ takiej sytuacji państwo to powinno móc stosować wyższy standard, nawet jeśli wiązałoby się to z pewnym ograniczeniem zastosowania się przez nie do pewnych zobowiązań wynikających z prawa unijnego, wbrew zasadom pierwszeństwa, jedności i efektywności tego prawa, a właściwie nie tyle wbrew nim, co w ich ramach przy pewnej ich elastyczności (szczególnie odnośnie do jednolitości stosowania). Postępowanie zmierzające do zwolnienia państwa ze zobowiązań ciążących na nim na gruncie prawa unijnego powinno mieć charakter dialogiczny i zapewniać udział odpowiednich organów tego państwa (jakim w omawianym w tej pracy polskim przypadku jest TK) oraz TSUE zgodnie $\mathrm{z}$ ich kompetencjami i w ramach przewidzianych $\mathrm{w}$ prawie unijnym procedur.

Praca ta koncentruje się na Polsce. Nie oznacza to jednak, że metoda w niej proponowana nie jest możliwa do zastosowania mutatis mutandis również w ramach innych porządków konstytucyjnych państw członkowskich Unii. Pewne zalety podejścia zaprezentowanego $\mathrm{w}$ tej pracy pokazane zostały też na tle wybranych orzeczeń innych sądów konstytucyjnych państw członkowskich. Jak zauważa Aleksandra Kustra,

mimo stosunkowo wąskiego geograficznie kręgu sądów konstytucyjnych, które zdecydowały się wyraźnie nawiązać do pojęcia tożsamości konstytucyjnej, wzorzec ten podobnie jak zakaz działania ultra vires - ma potencjalnie uniwersalny charakter. W każdym państwie członkowskim, w którym funkcjonuje scentralizowany model kontroli konstytucyjności prawa, sąd konstytucyjny może bowiem dążyć do wyznaczenia nieprzekraczalnych granic integracji (przynajmniej w ramach porządku konstytucyjnego gwarantowanego obowiązującą w danym czasie ustawą zasadniczą). Oczywiście łatwiej to zrobić sądom konstytucyjnym tych państw, których konstytucje zawierają tzw. przepisy niezmienialne. Przykład Polski dowodzi jednak, że brak takiej „klauzuli wieczności” nie stanowi większej przeszkody. Ponadto, podobnie jak w przypadku zakazu działania ultra vires, sąd konstytucyjny nie musi de facto używać

${ }^{1510}$ M. Safjan, Areas of..., s. 15. 
terminu "tożsamość konstytucyjna” w swym rozstrzygnięciu, by realnie nawiązać do tej koncepcji. Wystarczy, że wskaże - podobnie jak włoski SK - konstytucyjne controlimiti, a więc nieprzekraczalne w ramach danej konstytucji unormowania, których nie może naruszać proces integracji ${ }^{1511}$.

Jak podkreślił Marek Safjan: „Warunkiem tworzenia się nowej kultury prawnej zjednoczonej Europy jest dialog sądów krajowych i sądów UE. Prowadzenie prawniczej dysputy umożliwiają m.in. pytania prejudycjalne. Warto, byśmy w Polsce odważniej korzystali z tej instytucji"1512. Wedle Giuliano Amato najważniejszymi wymogami wobec sędziów konstytucyjnych w procesie godzenia europejskiego pluralizmu i jednolitości jest szukanie rozwiązań dopuszczalnych proceduralnie, osadzonych w obowiązującym prawie i praktycznie osiągalnych $^{1513}$. Być może taką właśnie odważną metodą skorzystania z instytucji odesłania prejudycjalnego do TSUE, spełniającą również wymogi postawione przez Giuliano Amato, byłoby sformułowanie w nim przez TK zarzutu, że kontrolowane przez niego prawo unijne (przy wszystkich ograniczeniach, o których była mowa w tym i poprzednich rozdziałach) narusza tożsamość konstytucyjną RP. Szczególne znaczenie i rangę w tej materii powinno mieć powołanie się na pewne, wyższe niż unijne, standardy ochrony praw i wolności człowieka, składające się na tożsamość konstytucyjną. Dzięki tego rodzaju współpracy art. 4 ust. 2 TUE mógłby być stosowany w najlepszy sposób uwzględniający w maksymalnym stopniu zarówno okoliczności wewnętrzne, związane z partykularyzmem ustrojów konstytucyjnych państw członkowskich, jak i zewnętrzne, związane $\mathrm{z}$ autonomicznością unijnego porządku prawnego. Pozwalałoby to na to, aby różnorodność państw członkowskich mogła się pomieścić i być moderowana w ramach jednego sytemu prawnego, zawierającego w sobie mechanizmy dialogicznego zarządzania dywergencją, jakim jest art. 4 ust. 2 TUE, w związku z innymi przepisami prawa unijnego, a także poprzez odesłanie, jakie art. 4 ust. 2 TUE czyni do krajowych porządków prawnych. $W$ ten sposób poszerzona zostałaby przestrzeń unijnej integracji i współpracy, a zmniejszone zostało, choć nie zostałoby jednak w pełni wyeliminowane, niebezpieczeństwo otwartego konfliktu i fragmentacji ( $w$ ramach

${ }^{1511}$ A. Kustra, Kelsenowski..., s. 294.

1512 M. Safjan, Europa sędziów. Europa dialogu, [w]: „Na wokandzie” 2011, nr 7, [online] <https://nawokandzie.ms.gov.pl/numer-7/opinie-7/europa-sedziow-europa-dialogu.html> [dostęp: 7.02.2019].

${ }^{1513}$ G. Amato, M. Cartabia, D. de Pretis, S. Sciarra, Constitutional Adjudication..., s. 499. Nota bene, jego zdaniem, przy korzystnej ocenie, która nie w pełni podzielana jest w tej pracy, sagi Taricco, rozstrzygnięcia polskiego TK w sprawach unijnych przypominają włoskie, jednakże sprzed pięćdziesięciu lat, bez odzwierciedlenia ewolucji, jaką przeszedł szczególnie w ostatnich latach włoski TK (ibidem, s. 500). 
zastosowania doktryny ultra vires), czy wręcz, w dłuższej perspektywie, dezintegracji Unii i jej systemu prawnego.

Można zgodzić się z Aleksandrą Kustrą, że tego typu rozwiązanie stanowiłoby pewien przełom $w$ orzecznictwie zarówno na poziomie krajowym, jak i unijnym, a szczególnie na ich styku. Podobne pojmowanie znaczenia tożsamości konstytucyjnej należy aktualnie "tylko do sfery hipotez. Ze względu na dosyć krótki okres funkcjonowania tego pojęcia w orzecznictwie sądów konstytucyjnych należy się spodziewać, że z upływem czasu wyklarują się bardziej precyzyjne standardy przeprowadzania kontroli pod kątem naruszenia tożsamości konstytucyjnej"1514. Celem tego rozdziału było możliwie precyzyjne przedstawienie jednej z hipotez, co do możliwości znalezienia metod przeprowadzania tej kontroli, w ramach "odważniejszego" korzystania z procedury pytania prejudycjalnego przez polski TK i ocena jej zalet w kontekście pogłębiania i poszerzania integracji europejskiej poprzez dialogiczne metody współpracy między TK a TSUE, zamiast podążania przez nie ścieżkami kolizyjnymi, a także próba oceny kompatybilności zaproponowanych rozwiązań z dotychczasowym orzecznictwem zarówno TK, jak i TSUE.

Zalety zaprezentowanego rozwiązania z pewnością nie rozwiązują wszystkich problemów w ramach batalii o "ostatnie słowo" w przedmiocie tożsamości konstytucyjnej, jaka ciszej lub w sposób bardziej otwarty toczy się na forach sądów konstytucyjnych państw członkowskich Unii i TSUE. Rozwiązanie to nie zapewnia też ostatecznego wyeliminowania możliwości zaistnienia kolizji między unijnymi a krajowymi porządkami prawnymi, czy też otwartego sporu dotyczącego ewentualnych działań Unii ultra vires. Zalety zaprezentowanego $\mathrm{w}$ tej pracy rozwiązania polegają głównie na tym, że stanowi ono jeszcze jeden mechanizm dialogu i współpracy, pozwalający ograniczyć niebezpieczeństwo konfliktu i minimalizującego przestrzeń zastosowania rozwiązań kolizyjnych. Unieważnia, przynajmniej w jakimś zakresie, spór o ostatnie słowo - skoro będzie ono uzgodnione i tożsame zarówno po stronie TK, jak i TSUE, a więc stanie się słowem 'wspólnym'. Wtedy nie będzie miało większego znaczenia, kto je jako ostatni wypowie. W ramach zaprezentowanego tu sposobu użycia instytucji pytania prejudycjalnego do TSUE w zasadzie znika sens sporu o ostatnie słowo. Znaczenie sekwencji orzekania i podziału w jej ramach ról między TK, opiera się na tym, że to, kto wypowiada ostatnie słowo, okazuje się nie prowadzić do jakiejś zasadniczej przewagi nad tym, kto dialog inicjuje, jako że każde kolejne słowo w ramach owej sekwencji jest w dużym stopniu związane słowami poprzednio wypowiedzianymi. Paradoksalnie więc to "pierwsze słowo" ma większą, a przynaj-

${ }^{1514}$ A. Kustra, Kelsenowski..., s. 293. 
mniej równą wartość do "ostatniego". Dla dobra integracji europejskiej wydaje się, że „batalia o prawo ostatniego słowa” powinna zostać zastąpiona wspólnym namysłem i metodami kooperacyjnego dochodzenia przez TSUE i sądy konstytucyjne państw członkowskich, w ramach sekwencyjnej współpracy orzeczniczej. Prowadziłoby to do doprecyzowywania rozumienia pojęcia tożsamości konstytucyjnej oraz napełniania go treścią w kontekście problemów wynikłych na gruncie konstytucyjnych ustrojów poszczególnych państw członkowskich i do traktowania jej jako autonomicznej podstawy do zwolnienia danego państwa z niezgodnych z jego tożsamością konstytucyjną obowiązków wynikających z prawa unijnego, przy jednoczesnym jak najdalej idącym poszanowaniu zasad pierwszeństwa, jedności i efektywności prawa unijnego, nie ograniczając znaczenia art. 4 ust. 2 jedynie do kontekstu dopuszczalności derogacji od unijnych swobód. W takiej sytuacji nie mielibyśmy do czynienia z podważaniem stricte zasady pierwszeństwa prawa unijnego, a jedynie z jej ewentualnym uelastycznianiem poprzez pewien wyłom $w$ zasadzie jednolitości stosowania prawa unijnego. Takie uelastycznienie nie prowadziłoby do jej osłabienia. Przeciwnie, chroniłoby ją przed jej złamaniem (np. przez orzeczenie krajowego sądu konstytucyjnego, opartego na doktrynie ultra vires), a więc ostatecznie by ją wzmacniało ${ }^{1515}$.

Jak wspomniano, gwarancje konstytucyjnych praw i wolności znalazły się w katalogu elementów, które składają się zdaniem TK na tożsamość konstytucyjną RP. Podobnie zresztą ma to miejsce w przypadku orzecznictwa sądów konstytucyjnych wielu innych państw członkowskich UE ${ }^{1516}$. Fakt zaliczenia konstytucyjnych gwarancji praw i wolności jednostki do tożsamości konstytucyjnej RP jako kategorii elementów na nią się składających nie oznacza jednak, że każde ewentualne naruszenie wyższego niż unijny konstytucyjnego standardu przez prawo pochodne UE musiałoby się wiązać z koniecznością orzekania o jego niestosowaniu na terenie naszego kraju. Zarysowana w tej pracy propozycja sekwencji orzekania, aby mogła działać, wymaga od obu stron pewnej powściągliwości i formułowania postulatów czy żądań, możliwych do zaakceptowania dla drugiej strony i możliwych do pogodzenia z wymogami prawa, na straży którego stoją, a więc odpowiednio unijnego, gdy

${ }^{1515}$ Podobnie np.: F.-X. Millet, The Respect for National Constitutional Identity in the European Legal Space. An Approach to Federalism as Constitutionalism, [w:] L. Azoulai (red.), The Question of Competence in the European Union, Oxford 2014; choć autor ten skupia się głównie na swoistej rekompensacie, jaka miałaby jego zdaniem wiązać się z uelastycznieniem prawa unijnego w tym przede wszystkim pewnym osłabieniem „uświęconej” zasady pierwszeństwa - poprzez wzmocnienie legitymizacji Unii w oczach jej obywateli i wzmocnienie tym samym effet utile prawa unijnego (ibidem, s. 276).

${ }^{1516}$ Patrz np.: A. Kustra, Kelsenowski..., s. 279 i nast.; K. Wójtowicz, Sądy konstytucyjne..., S. 125 i nast. 
chodzi o TSUE, i konstytucyjnego, gdy chodzi o TK. Należy mocno podkreślić, że art. 4 ust. 2 TUE, zobowiązujący Unię do poszanowania tożsamości konstytucyjnej państw członkowskich, poprzedza art. 4 ust. 3, który z kolei zobowiązuje państwa członkowskie do lojalnej współpracy przy realizowaniu celów Unii ${ }^{1517}$. Obustronna powściągliwość ${ }^{518}$ jest więc w równym stopniu zakorzeniona w samym tekście TUE. Dla prawidłowego funkcjonowania zaproponowanego $\mathrm{w}$ tej pracy mechanizmu należy więc uznać, że nie wszystkie wyższe niż unijne, wynikające z Konstytucji standardy ochrony praw i wolności człowieka mogłyby służyć za podstawę takiego zwolnienia czy zawieszenia obowiązków wynikających z prawa unijnego. Taką rolę mogłyby odgrywać tylko te elementy konstytucyjnych gwarancji, które stanowią element tożsamości konstytucyjnej RP. Zakres tego zwolnienia również byłby wąski. Musiałby spełniać podstawowe wymogi proporcjonalności, a więc przede wszystkim ograniczać skuteczność prawa unijnego jedynie w wymiarze koniecznym dla osiągnięcia poszanowania wyższego niż unijny, stanowiącego element tożsamości konstytucyjnej RP standardu ochrony jakiegoś prawa czy wolności człowieka.

Jak wspomniano, art. 53 Karty byłby zbyt słabą podstawa, aby sam fakt zawarcia w danym systemie konstytucyjnym wyższego niż unijny standardu ochrony praw człowieka wystarczył, żeby miał być on poszanowany nawet jeśli podważałoby to pierwszeństwo, jedność i efektywność prawa unijnego. Wymagania wynikające $\mathrm{z}$ konieczności odwołania się w tego rodzaju przypadkach do art. 4 ust. 2 TUE wiążą się z koniecznością znacznie dalej idącego uzasadnienia doniosłości dla danego systemu konstytucyjnego konkretnego standardu ochrony praw jednostki. TK w wyroku w sprawie K 32/og stwierdził, że na tożsamość konstytucyjną RP składają się „postanowienia dotyczące praw jednostki wyznaczające tożsamość państwa"1519. Sformułowanie to należy więc zdaniem autora tej pracy rozumieć tak, że wcale nie wszystkie konsekwencje konstytucyjnych gwarancji praw i wolności należy uznać za składające się na tożsamość konstytucyjną RP, a jedynie te z nich, które faktycznie wyznaczają

${ }^{1517}$ Na marginesie można jednak zauważyć, że o ile art. 4 ust. 3 TUE i zapisany w nim obowiązek lojalnej współpracy prowadzi co do zasady do konkluzji związanych z obowiązkami państw stron do wspierania Unii w realizacji celów Unii zapisanych w traktatach, o tyle lojalna współpraca jest pojęciem dwukierunkowym. Nie ma więc przeszkód ku temu, aby ze zobowiązania do niej wyciągać również konsekwencje wobec Unii, w tym te dotyczące jej obowiązku do poszanowania tożsamości konstytucyjnej państw członkowskich.

${ }^{1518} \mathrm{O}$ ile art. 4 ust. 2 TUE jest koronnym przykładem swoistego samoograniczenia i zachęty do tego rodzaju powściągliwości, o tyle również dzięki innym przepisom, można powiedzieć, że przenika ona unijne traktaty. Jeśli chodzi o państwa członkowskie, to w wielu konstytucjach odzwierciedlona jest w tak zwanych "klauzulach europejskich", choć wynikająca z nich logika samoograniczenia nie wydaje się być aż tak silna (więcej - patrz np.: N. Lupo, The Advantage..., s. 188 i nast.).

1519 TK, sprawa K 32/o9, wyrok z 24 listopada 2010, pkt III 2.1 uzasadnienia. 
tożsamość państwa. Tego rodzaju rozróżnienie na gruncie konstytucyjnych gwarancji praw człowieka zdaje się być również odzwierciedlone w orzecznictwie innych sądów konstytucyjnych, jak choćby FTK w wyrokach dotyczących ENA z 15 grudnia $2015^{1520}$ i 6 września 2016 $6^{1521}$, czy hiszpańskiego TK na kanwie sprawy Melloni ${ }^{1522}$. Szczegółowa analiza czy w konkretnym przypadku mamy do czynienia z takim właśnie tożsamościowym standardem ochrony praw lub wolności jednostki musiałaby być dokonywana a casu ad casum, w kontekście ewentualnej sprzeczności z nim prawa unijnego.

Podejście takie znajdowałoby, jak się wydaje, oparcie także w zaprezentowanym powyżej orzecznictwie TSUE, a przynajmniej nie można go uznać na gruncie tego orzecznictwa za wykluczone. Przede wszystkim trzeba zwrócić tu uwagę na sprawę Omega, która w sposób szczególny wyeksponowała znaczenie zasady godności człowieka i jej rozumienia, prowadzącego w różnych państwach członkowskich do różnego zakresu jej ochrony i konieczności poszanowania sposobu jej ochrony $\mathrm{w}$ związku z obowiązkiem poszanowania tożsamości konstytucyjnej państw członkowskich. Nawet jeśli to ostatnie pojęcie nie pojawia się w wyroku w tej sprawie, to nie ulega wątpliwości, że zasada godności człowieka i jej odmienne rozumienie, gwarantujące wyższy poziom ochrony w Niemczech niż na pozostałym obszarze Unii może być zaliczone do tożsamościowych elementów tamtejszego systemu konstytucyjnego. Z orzecznictwa FTK wynika, że zasada godności człowieka, należąca zresztą do niezmienialnych, a więc najbardziej fundamentalnych postanowień niemieckiej konstytucji, i wynikające z niej prawa i wolności jednostki, stanowi kluczowy element tamtejszego porządku konstytucyjnego i zalicza się do regulacji składających się na tożsamość konstytucyjną Niemiec ${ }^{1523}$. Nawet jeśli w sprawie Omega, jak i późniejszych wyrokach, w których TSUE wprost stosował art. 4 ust. 2 TUE, jego znaczenie ograniczało się jedynie do uzasadnienia dopuszczalności derogacji od unijnych swobód, to nic nie stoi na przeszkodzie, aby znalazł on zastosowanie również odnośnie do innych przepisów prawa unijnego, w tym bezpośrednio skutecznego prawa pochodnego. Przecież przepisy gwarantujące unijne swobody, jak wynika z orzecznictwa TSUE, też mogą wywoływać skutek bezpośredni ${ }^{1524}$, a w dodatku są zawarte w prawie wyższego rzędu w ramach unijnej hierarchii źródeł prawa niż prawo pochodne. Nawet

${ }^{1520}$ FTK, 2 BvR 2735/14, orzeczenie z 15 grudnia 2015.

${ }^{1521}$ FTK, 2 BvR 89o/16, orzeczenie z 6 września 2016.

1522 Hiszpański TK, sprawa 26/2014, wyrok z 13 lutego 2014, BOE nr 60 z 11 marca 2014.

${ }^{1523}$ Patrz przed.: FTK, 2 BvR 197/83, orzeczenie z 22 października 1986; FTK, 2 BvE 2/o8, 2 BvE 5/o8, 2 BvR 1010/o8, 2 BvR 1022/o8, 2 BvR 1259/o8, 2 BvR 182/o9, orzeczenie z 30 czerwca 2009; FTK, 2 BvR 2735/14, orzeczenie z 15 grudnia 2015; FTK, 2 BvR 890/16, orzeczenie z 6 września 2016.

1524 B. Capik, A. Łazowski, Art. 91 ..., s. 165. 
jeśli prawo pochodne należałoby uznać za sztywniejsze i mniej podatne na wyjątki w jego stosowaniu niż prawo pierwotne ze względu na poziom harmonizacji, jaki ono wprowadza, to jednak brak podstaw do uznania go za wyjęte spod takiej ewentualności.

Brak powołania się przez hiszpański TK na tożsamość konstytucyjną Hiszpania w sprawie Melloni wpisuje się w zaprezentowaną powyżej linię argumentacyjna, spełnia również wymogi odpowiedzialnego dialogu sędziowskiego między sądem konstytucyjnym państwa członkowskiego a TSUE. Można bowiem domniemywać, że zakaz skazywania in absentia mieści się wprawdzie w gwarantowanych przez hiszpańską konstytucję standardach ochrony praw i wolności jednostki, nie jest jednak aż tak fundamentalnym ich elementem, aby można zaliczyć go do tożsamości konstytucyjnej. Tym samym wyższy standard jest oczywiście dopuszczalny w Hiszpanii zawsze, gdy nie stoi w sprzeczności z zasadami pierwszeństwa, jedności i skuteczności prawa UE. W sytuacji, w której byłby jednak z nimi sprzeczny, musi im ustąpić, a wystarczający musi być standard gwarantowany przez prawo $\mathrm{UE}^{1525}$.

W tym kontekście na zwrócenie uwagi zasługuje, że wybór, jakiego TK dokonał w sprawie P 1/o5, o charakterze swoistej, jak mogliby to określić niektórzy, kapitulacji względem prawa unijnego, czyli sugestii zmiany Konstytucji tak, aby prawo unijne nie było z nią niezgodne, również dobrze wpisuje się w prezentowany w tej pracy sposób myślenia. Wydaje się, że TK słusznie zarekomendował tego rodzaju ustępstwo na rzecz prawa unijnego, jako że taki absolutny zakaz ekstradycji polskiego obywatela trudno byłoby uznać za składający się na tożsamość konstytucyjną RP. Przy tym należy zwrócić uwagę, że zmiana dokonana w art. 55 Konstytucji RP była dobrze dostosowana do wymogów wynikających z prawa unijnego, a nie z jakichkolwiek innych względów. Nowe brzmienie art. 55 Konstytucji dobrze odzwierciedla fakt, że ekstradycja nadal nie jest dopuszczalna, chyba że będzie dokonana właśnie ze względu na zobowiązania wynikające $z$ prawa unijnego. Przy czym prawo to pozwala domniemywać, przede wszystkim w związku z zasadą wzajemnego zaufania między państwami, a szerzej, ze względu na wspólnotę tradycji konstytucyjnych, jakie leżą u podstaw integracji europejskiej, że wszelkie, potencjalnie tożsamościowo (konstytucyjnie) istotne prawa obywatela polskiego będą chronione, w związku z czym tożsamość konstytucyjna RP nie zostanie naruszona. Służą temu przede wszystkim gwarancje zawarte w samej decyzji ramowej dotyczącej ENA. Gdyby jednak okazało się, że może być zagrożona, to prawo

${ }^{1525}$ Dlatego też sekwencja orzeczeń w sprawie Melloni nie powinna, jak twierdzą niektórzy (np.: M. Almhofer, J. Hartlieb, Article 53..., s. 159), prowadzić do obaw po stronie sądów konstytucyjnych do kierowania do TSUE pytań prejudycjalnych, w tym dotyczących obowiązku poszanowania tożsamości konstytucyjnej państw członkowskich, o jakich mowa w tej pracy. 
unijne zawiera również mechanizmy temu zapobiegające (w tym kontekście do szczególnej rangi urasta wyrok w sprawie Pál Aranyosi i Robert Căldăraru).

Podział ról proponowany w tej pracy sprowadza się w istocie do tego, że TK orzekałby o elementach składających się na tożsamość konstytucyjną RP, TSUE zaś określałby skutki tego faktu z perspektywy prawa UE. Jak swe rozważania na temat art. 4 ust. 2 TEU konkludują Armin von Bogdandy i Stephan Schill: „[...] odpowiedź na pytanie, kto ma ostateczną władzę decydować w kwestiach tożsamości konstytucyjnej jest taka, że nie ma definitywnej odpowiedzi, jako że nie ma ostatecznego arbitra w złożonym systemie europejskiego sądownictwa konstytucyjnego. Wynikający stąd potencjał konfliktu jest tamowany przez wzajemny obowiązek współpracy" ${ }^{\prime \prime 1526}$. Zaproponowana w tym rozdziale sekwencja orzekania ma właśnie służyć takiej współpracy. Fakt zajmowania określonego miejsce w jej ramach - a więc możliwość wypowiadania ostatniego albo pierwszego słowa - nie ma decydującego znaczenia. Decydujące znaczenie ma zakres wypowiedzi każdego z dwu trybunałów w kontekście ich kompetencji oraz roli i pozycji w ramach unijnego i krajowego porządku konstytucyjnego. Sądy te powinny więc wzajemnie szanować swoją kompetencję i legitymizację szczególnie, gdy jej zastosowanie wiąże się z wywoływaniem skutków poza podstawowym zakresem ich aktywności, a więc przez TK skutków dla prawa unijnego i przez TSUE dla prawa krajowego. Może to sprawić, aby metody konfliktowe, jak doktryna ultra vires, które można określić za Andreasem Voßkuhle nadzwyczajnymi mechanizmami hamującymi, nigdy się nie ziściły. Ten ostatni twierdzi, że są one najbardziej efektywne, gdy nie są stosowane. Są skuteczne ze względu na to, że istnieją i istnieje możliwość ich zastosowania, która rodzi obawę i powściągliwość przed zbyt jednostronnym podejściem do wrażliwych kwestii ${ }^{1527}$. Wydaje się jednak, że lepiej uniknąć logiki groźby i szachowania, a lepiej otwarcie rozstrzygać sporne kwestie w ramach dialogu. To jeszcze bardziej minimalizuje niebezpieczeństwo konieczności uciekania się do mechanizmów nadzwyczajnych niż jedynie obawa przed ich wykorzystaniem przez drugą stronę. Obawa ta zresztą zawsze pozostaje w przypadku, gdyby któryś trybunał na jakimś etapie sekwencji zachował się nierzetelnie.

Należy również pamiętać, że gdyby zaproponowana tu sekwencja orzekania w podstawowym jej zakresie nie przyniosła spodziewanego efektu, istnieje jeszcze możliwość jej ekstraordynaryjnego kontynuowania. Wprawdzie działoby się to już w ramach etapu, który można by nazwać 'konfliktowym', gdyż toczyłby się on w ramach ujawnionego konfliktu między TK a TSUE oraz otwar-

1526 A. von Bogdandy, S. Schill, Overcoming..., s. 1452 (tłum. własne).

${ }^{1527}$ A. Voßkuhle, Multilevel Cooperation of the European Constitutional Courts: Der Europäische Verfassungsgerichtsverbund, "European Constitutional Law Review” 2010, nr 6 (2), s. 195. 
tej kolizji między prawem unijnym a Konstytucją RP, a konkretnie zawartymi w niej gwarancjami praw człowieka, cały czas jednak byłaby możliwa kontynuacja dyskusji nad tożsamością konstytucyjną i obowiązkiem jej poszanowania przez Unię, być może już nie w sposób tak bezpośredni jak w pierwszym - opisanym w tej pracy - etapie, lecz wciąż na podstawie wypowiedzi w jego ramach sformułowanych, a uzupełnionych o wyrok TK po uzyskaniu odpowiedzi na pytanie prejudycjalne od TSUE. Chodzi tu o taką sytuację, w której TSUE nie zdecydowałby się przystać na stanowisko TK dotyczące poszanowania tożsamości konstytucyjnej RP albo przystałby na nie w stopniu nie do zaakceptowania z perspektywy tożsamości konstytucyjnej i TK wydałby orzeczenie, o jakim mówił, jako o ostatecznej ewentualności w wyroku w sprawie Sk 45/og, czyli o niestosowalności danego prawa unijnego w Polsce. Takim kolejnym etapem byłaby procedura naruszeniowa, która ostatecznie mogłaby zakończyć się znowu na forum TSUE, który mógłby zweryfikować swoje wcześniejsze stanowisko w obliczu wyroku wydanego przez TK po uzyskaniu odpowiedzi od TSUE. Tego rodzaju 'dogrywka' wydaje się jednak etapem bardzo niewskazanym ze względu na swój konfliktowy charakter. Konieczność jej zastosowania oznaczałaby popełnienie jakiegoś błędu podczas stosowania opisanej w tej pracy sekwencji w jej podstawowym wymiarze. 


\section{Zakończenie}

Zasadniczym celem, jaki przyświecał tej pracy było odnalezienie i pokazanie pewnych metod niekonfliktowego rozwiązywania niektórych - dotyczących wyższych niż unijne, konstytucyjnych standardów ochrony praw człowieka ewentualnych kolizji między prawem unijnym a prawem polskim i potencjalnych kompetencyjnych sporów między polskim TK a TSUE $w$ tej materii. W pracy tej podjęta została próba pokazania dostępnej drogi rozwiązywania takich sporów poprzez współpracę i podział ról między TK a TSUE w specyficznej sekwencji orzekania, otwierającej oba sądy na faktyczny i bezpośredni dialog i dochodzenie przez nie do wspólnego stanowiska („wspólnego słowa”) zamiast spierania się o to, który z nich miał będzie "słowo ostatnie" i decydujące. Na pewno nie udało się w tej pracy rozwiązać wszystkich dylematów i wątpliwości, a także wskazać wyjść ze wszystkich kłopotliwych sytuacji, jakie mogą powstać na linii relacji między tymi dwoma trybunałami, gdy chodzi o kontrolowanie prawa obowiązującego w Polsce przez pryzmat praw człowieka. Wydaje się jednak, że umiejętne, powściągliwe i oparte na wzajemnym zaufaniu, samoograniczeniu i wspólnych wartościach korzystanie z pojęcia tożsamości konstytucyjnej w kooperatywnej sekwencji orzekania może skutkować przyjazną współpracą między obydwoma trybunałami oraz sprzyjać trwałości i pogłębianiu się integracji europejskiej przy udziale w niej Polski, a także sprzyjać realizacji jak najwyższych standardów praw człowieka, którymi cieszyć się będą mogli wszyscy, którzy znajdą się pod władzą obowiązującego w Polsce prawa.

„Tożsamość konstytucyjna [...] jest koncepcją nadal ewoluującą. Pojęcie tożsamości konstytucyjnej, z powodu silnego zakotwiczenia w traktatowej klauzuli poszanowania tożsamości narodowej, może jednak potencjalnie służyć za narzędzie powodujące istotne zmiany w postrzeganiu relacji między sądami konstytucyjnymi a ETS"1528. Być może więc warto, aby zamiast w kierunku wewnątrzsystemowym, czy to $\mathrm{w}$ izolacjonistycznie pojmowanym wymiarze unijnym, zbliżającym jej rozumienie do klauzuli porządku publicznego w kontekście derogacyjnym, jak mogłoby to na pierwszy rzut oka wynikać z orzecz-

${ }^{1528}$ A. Kustra, Kelsenowski..., s. 296. 
nictwa TSUE, czy też w kierunku wewnątrzsystemowym w izolacjonistycznie pojmowanym wymiarze krajowym, służącym do legitymizacji kontroli konstytucyjności prawa unijnego w związku z doktryną ultra vires, tożsamość konstytucyjna ewoluowała w kierunku pojęcia autonomicznego, o ogólnosystemowym znaczeniu (cechującym się podejściem do unijnego systemu prawnego jako całości - składającej się z prawa unijnego i z prawa krajowego) opartym na art. 4 ust. 2 TUE i porządkach konstytucyjnych państw członkowskich, do których przepis ten odsyła.

Zaprezentowane $\mathrm{w}$ tej pracy podejście nie jest niewątpliwie pozbawione trudności, wad czy pewnego potencjału, jeżeli nie do konfliktu, to przynajmniej do nieporozumień między sądami krajowymi - w tym wypadku TK - oraz unijnymi - TSUE. Jest przede wszystkim ograniczone w swym zakresie. Koncentruje się na najbardziej, jak się wydaje, drażliwym wymiarze potencjalnego konfliktu, jakim jest ochrona praw człowieka, szczególnie w sytuacji, gdyby prawo krajowe zawierało w sobie gwarancje dalej idące. Nawet w tym wymiarze nie jest jednak rozwiązaniem idealnym, pozwalającym rozwiązać wszelkie problemy wynikające ze złożonej unijnej architektury konstytucyjnej oraz unijnych mechanizmów ochrony praw człowieka.

Głównymi zaletami tego rozwiązania są zdaniem autora, po pierwsze, zminimalizowanie przestrzeni potencjalnego konfliktu między TK a TSUE w przedmiocie ochrony praw człowieka, który mógłby przejawić się w postaci wzajemnie nieakceptowalnych orzeczeń, które ostatecznie mogłyby doprowadzić do konsekwencji urastających do sankcji względem Polski, a w skrajnych przypadkach do wykluczenia albo wystąpienia Polski z Unii. Po drugie, za zaletę taka, jak się wydaje szczególnie istotną z perspektywy jednostki ${ }^{1529}$, lecz również z perspektywy wspólnoty politycznej opartej na Konstytucji RP, należy uznać możliwość zapewnienia przestrzegania wyższych niż unijne, fundamentalnych dla tej wspólnoty standardów praw człowieka, nawet jeśli miałoby to w jakimś wymiarze podważyć zasadę pierwszeństwa, a właściwie głównie zasadę jednolitości stosowania prawa unijnego. Wydaje się to uzasadnione również z perspektywy wspólnoty, jaką jest Unia. Jest ona także oparta na wartościach poszanowania godności osoby ludzkiej i poszanowania praw człowieka. Powinna więc sprzyjać realizacji standardów jak najwyższych. Po trzecie wreszcie, podstawową zaletą tego rozwiązania zdaje się być zaangażowanie trybunałów o najwyższym autorytecie w kwestii praw człowieka, jak i najbardziej kompetentnych do prowadzenia konstytucyjnego dialogu i współpracy sprzyjającej budowie unijnego konstytucjonalizmu, z uniknięciem potencjalnie dla tego

${ }^{1529}$ Por.: M. Cartabia, Fundamental Rights and the Relationship among the Court of Justice, the National Supreme Courts and the Strasbourg Court, [w:] Van Gend en Loos 1963-2013. Conference Proceedings, Luxemburg, 13 May 2013, s. 160-161. 
systemu rozsadzającego sporu o miano „najwyższego arbitra”, czy też „sądu ostatniego słowa".

Byłoby to możliwe dzięki prowadzonemu przez TK i TSUE dialogowi sędziowskiemu sensu stricto, poprzez wydawanie w ramach jednej (ewentualnie dwóch) procedury formalnie i merytorycznie powiązanych orzeczeń. Ze względu na merytoryczny podział ról między nimi odbywałoby się to $\mathrm{w}$ ramach sekwencji, a nie hierarchii orzekania. Praca ta miała więc służyć wskazaniu nowej płaszczyzny bezpośredniego dialogu sędziowskiego. Nie miał on bowiem ograniczać się do de facto dwu monologów, wzajemnie w mniejszym lub większym stopniu wysłuchiwanych, ale jednak monologów, w których sąd konstytucyjny miałby wskazywać granice integracji, TSUE miałby je szanować lub próbować je obchodzić, a sąd konstytucyjny je ewentualnie znowu przesuwać, czy też uciekać się do rozwiązania, które toutes proportions gardées można by nazwać "atomowym”, a więc ostatecznym, radykalnym i w skali systemowej destrukcyjnym dla integracji europejskiej, przejawiającym się w zastosowaniu doktryny ultra vires.

Sądy konstytucyjne powinny aktywnie współtworzyć wraz z Trybunałem Sprawiedliwości UE europejską przestrzeń prawną. Z jednej strony wskazywanie przez nie konstytucyjnych granic integracji, winno być uważane za element kształtowania tradycji konstytucyjnych, które winien uwzględniać w swej działalności orzeczniczej Trybunał Sprawiedliwości UE. Z drugiej strony, na upowszechnienie zasługuje stanowisko tych sądów konstytucyjnych, które relacje z prawem Unii opierają na domniemaniu zgodności przepisów tego prawa oraz ich wykładni dokonanej przez Trybunał Sprawiedliwości, z wartościami i zasadami, które znajdują wyraz w postanowieniach konstytucji ${ }^{1530}$.

Tego rodzaju, znany dotychczas, "dialog" jest niewątpliwie niezwykle ważny i potrzebny. Tym niemniej dialog między TK i TSUE może odgrywać ważna, a może nawet ważniejsza, rolę również w formie bezpośredniej - poprzez procedurę pytania prejudycjalnego - i służyć nie tyle wskazywaniu granic ingerencji, co ich poszerzaniu, poprzez pewne niuansowanie zastosowania unijnych praw podstawowych oraz zasad pierwszeństwa, jedności i efektywności prawa unijnego w związku z obowiązkiem poszanowania przez Unię tożsamości konstytucyjnych państw członkowskich, pozwalającym uniknąć rozwiązań konfliktowych czy kolizyjnych ${ }^{1531}$.

${ }^{1530}$ K. Wójtowicz, Sądy konstytucyjne..., s. 159.

${ }^{1531}$ Takich jak jednostronne orzekanie przez TK o niestosowaniu danego prawa unijnego w Polsce czy nakładanie przez TSUE kar na Polskę w ramach procedury naruszeniowej, że o rozwiązaniach jeszcze dalej idących, pojawiających się jednak w rozważaniach TK i TSUE, takich jak wystąpienie, czy też wykluczenie Polski z UE bądź sprzeczna z polską tożsamością 
Możliwość takiego elastycznego podejścia otwiera art. 4 ust. 2 TUE i jego właściwe stosowanie. Jego prawidłowe zastosowanie wydaje się możliwe jedynie w ramach współpracy między TK a TSUE, poprzez procedurę pytania prejudycjalnego. Próbą zaproponowania takiego odważnego zastosowania tej procedury, gdy będzie to uzasadnione, był właśnie sekwencyjny, a nie hierarchiczny mechanizm orzekania o tożsamości konstytucyjnej RP i jej skutkach $\mathrm{w}$ ramach prawa unijnego, o którym mowa w tej pracy. Zdaniem autora tego opracowania stanowi on kolejną potencjalną odsłonę tego, o czym pisał Joseph Weiler, gdy bez przesady określał procedurę pytania prejudycjalnego jako "genialny" mechanizm w ramach polityczno-prawnej kultury, na której opiera się projekt integracji europejskiej wcielony w Unię Europejską ${ }^{1532}$. Dla jego prawidłowego funkcjonowania konieczne jest jednak powściągliwe z niego korzystanie i powściągliwe korzystanie w jego ramach $\mathrm{z}$ sekwencyjnych przewag, jakimi mogą cieszyć się oba trybunały. Powinny one unikać pokusy zbyt dalekiego umacniania swej roli i kompensowania faktu, że nawet jeśli nie będzie się miało "ostatniego słowa”, to będzie się miało słowo rozstrzygające. TK powinien więc powściągliwie zakreślać indywidualne ramy polskiej tożsamości konstytucyjnej w wymiarze zewnętrznym (unijnym) i zakres składających się na tę tożsamość gwarancji ochrony praw człowieka. Gdy już się jednak na to zdecyduje, powinien jak najstaranniej twierdzenie takie uzasadnić, nie pozostawiając TSUE $\mathrm{w}$ tej materii przestrzeni do wątpliwości, szczególnie w obliczu spodziewanych ustępstw, jakie ten ostatni miałby uczynić na rzecz polskiej konstytucji, kosztem prawa unijnego i jego pierwszeństwa, jedności i efektywności. TSUE powinien zaś powściaggliwie, i tym bardziej powściągliwie, im stanowisko TK byłoby mocniejsze, stosować test proporcjonalności, gdy chodzi o ocenę chronionych w ramach tożsamości konstytucyjnej wartości kosztem zobowiązań wynikających z prawa unijnego. W zasadzie badanie proporcjonalności przez TSUE powinno koncentrować się na teście konieczności.

Pojęcie "tożsamość konstytucyjna” [...] ma charakter samoistnej konstrukcji prawa europejskiego. Z tego punktu widzenia na pierwszy plan wysuwa się przede wszystkim obowiązek prawodawcy europejskiego respektowania cech immanentnych danego systemu konstytucyjnego [...]. Tak jak każde pojęcie prawa europejskiego czy to funkcjonujące na poziomie pierwotnego prawa europejskiego, czy też prawa wtórnego - podlega ono interpretacji przez TSUE. Taka ocena nie musi być więc

konstytucyjną zmiana Konstytucji RP albo niepotrzebna i nieuzasadniona w skali całej Unii modyfikacja prawa unijnego, ze względu na polski, konstytucyjny partykularyzm.

1532 Patrz: J.H.H. Weiler, The Political and Legal Culture of European Integration: An Exploratory Essay, "International Journal of Constitutional Law” 2011, nr 9 (3-4), s. 690. 
w pełni zbieżna z oceną przyjmowaną w systemie krajowym, ponieważ uwzględnia ona cele związane z funkcjonowaniem zintegrowanej przestrzeni prawnej UE ${ }^{1533}$.

To, że w ramach zaproponowanej tu sekwencji orzekania stanowisko TK dotyczące tożsamości konstytucyjnej RP i obowiązku jej poszanowania przez Unię będzie weryfikowane przez TSUE jest naturalną konsekwencją faktu, że klauzula, o której tu mowa (zawarta w art. 4 ust. 2 TUE), swą formalną podstawę ma w prawie unijnym. Tożsamość konstytucyjna państw członkowskich jako taka zawarta jest i wyrażona w konstytucyjnych fundamentach ich ustroju. Jej treść nie jest więc w żaden sposób zakorzeniona w prawie UE. Co najwyżej prawo UE jest wyrazem wspólnych elementów tożsamości państw ją tworzących. Tożsamość każdego z tych państw w jej całej złożoności jest zawarta w konstytucjach państw członkowskich. Interpretacja tożsamości konstytucyjnej przez TSUE nie powinna więc dotyczyć składników tożsamości konstytucyjnej poszczególnych państw, ale konceptualizacji tego pojęcia na potrzeby prawa UE i określenia skutków obowiązku poszanowania tożsamości konstytucyjnej, a także do stworzenia pewnych ram, w których odpowiednie organy państw członkowskich mogłyby w konkretnych przypadkach się na nią powoływać. $W$ ten sposób tożsamość konstytucyjna służyłaby jako narzędzie pomagające koordynować różnorodność porządków konstytucyjnych państw członkowskich Unii w ramach złożonej konstytucyjnej struktury samej Unii, pozwalając zachować zasadę pierwszeństwa prawa unijnego przy jednoczesnym poszanowaniu doniosłych i prawowitych narodowych partykularyzmów ${ }^{1534}$.

TSUE powinien, im lepiej TK wywiąże się ze swego zadania, tym powściągliwiej oceniać zasadność na gruncie prawa unijnego konsekwencji związanych ze zwolnieniem danego państwa z pewnych zobowiązań wynikających z prawa unijnego. Usytuowanie na późniejszym etapie sekwencji w istocie nie powinno być traktowane jako przewaga "ostatniego słowa”, lecz jako ograniczenie - związanie "poprzednim słowem” - wypowiedzianym w zakresie bliższym jego kompetencji przez TK.

Należy [...] podkreślić, że ocena TSUE odnosząca się do zakresu komponentów pojęcia tożsamości konstytucyjnej powinna w takich wypadkach przyjmować za punkt wyjścia koncepcję, która jest definiowana i określana przez konkretny system konstytucyjny danego państwa członkowskiego, najczęściej za pośrednictwem orzecznictwa sądownictwa konstytucyjnego. Wyłącznie w ramach otwartego, opartego o racjonalne argumenty i racje dialogu sądowego jest możliwe znalezienie konsensu w wypadku rozbieżności. Postulat elastyczności i otwierania się na racjo-

${ }^{1533}$ M. Safjan, Wprowadzenie..., s.109.

${ }^{1534}$ Por.: M. Belov, The Functions..., s. E-78. 
nalny dyskurs sądowy musi być adresowany zarówno do sędziów konstytucyjnych, jak i do sędziów europejskich ${ }^{1535}$.

Podobnie TK, do którego sprawa by wróciła po odpowiedzi na pytanie prejudycjalne, powinien czuć się bardziej związany odpowiedzią TSUE, w związku ze wspomnianym unijnym charakterem sprawy, nawet jeśli będzie ona dla niego niepomyślna, im silniej będzie ona uzasadniona i osadzona w prawie i im rzetelniej ukaże bezzasadność albo chociaż nieproporcjonalność sformułowanego przez TK żądania, opartego na tożsamości konstytucyjnej RP.

Już w 1986 r. Mauro Cappelletti i David Golay dopatrywali się uzasadnienia doniosłości i skuteczności orzecznictwa TSUE przede wszystkim w sile jego rozumowań i argumentacji. Twierdzili, że w przeciwieństwie do amerykańskiego Sądu Najwyższego, a także do sądów konstytucyjnych państw członkowskich, TSUE nie ma władzy, która nie byłaby ostatecznie zakorzeniona w jego prestiżu oraz intelektualnej i moralnej sile wyrażanych przez niego stanowisk ${ }^{1536}$. Właśnie na tego rodzaju przewagach powinna opierać się relacja między TK a TSUE, które właśnie na podstawie takich wartości powinny budować swój autorytet i pozycję względem siebie, a właściwie swą wspólną pozycję. Tylko wtedy będziemy mogli z obu stron mieć do czynienia z dobrowolnym posłuszeństwem, a właściwie z uzgadnianiem wspólnego stanowiska przy poszanowaniu i posłuchu w ramach podziału kompetencji między nimi na różnych etapach w ramach opisanej w tej pracy sekwencji orzeczeń. Pozwalałoby to budować szeroką - w skali Unii - i dwuwektorowa, używając pojęcia spopularyzowanego przez Josepha Weilera, konstytucyjną tolerancję̨ ${ }^{1537}$, a więc tolerancję i poszanowanie nie tylko dla konstytucyjnych porządków państw członkowskich, ale także dla unijnego konstytucjonalizmu. Ostatecznym arbitrem w tego rodzaju sprawach nie powinien być ten trybunał, który mniej czy bardziej izolacjonistycznie wykorzysta sytuacyjną przewagę wynikającą z możliwości wypowiedzenia ostatniego czy jedynego słowa w danej sprawie, lecz ten, który przedstawi bardziej przekonujące argumenty ${ }^{1538}$. Najlepiej, aby okazały się one przekonujące również dla obu stron potencjalnego konfliktu, którego dotyczy ta praca (TK i TSUE) i aby pozwoliły go uniknąć poprzez porozumienie i wspólne stanowisko.

${ }^{1535}$ M. Safjan, Wprowadzenie..., s.109.

${ }^{1536}$ M. Cappelletti, D. Golay, The Judicial Branch in the Federal and Transnational Union: Its Impact on Integration. Integration Through Law, [w:] M. Cappelletti, M. Seccombe, J. Weiler (red.), Volume 1: Methods, Tools and Institutions, Book 2: Political Organs, Integration Techniques and Judicial Process, Berlin-New York 1986.

${ }^{1537}$ Patrz przed.: J.H.H. Weiler, Czy...; idem, Europa....

1538 Por.: M. Krajewski, ,Conditional'.... 
Szczegółowe kryteria rzetelności i obustronnej powściągliwości (deferencji) pozostają jeszcze do wypracowania - o niektórych z nich wspomniano $\mathrm{w}$ tej pracy. Są one jednak w dużej mierze nieuchwytne i pozostają związane z poszanowaniem wspólnej europejskiej kultury prawnej i argumentacyjnej. Na wspólnej kulturze prawnej przecież cały projekt, jakim jest Unia Europejska, jest oparty. Kolejną zaletą zaproponowanej tu metody, tym razem już nie o charakterze materialnym, jak wspomniane powyżej główne jej zalety, lecz o charakterze formalnym, jest również to, że jeśli doszłoby na jakimś jej etapie do błędu, czy też pomyłki, to zawsze istnieje jeszcze możliwość przeprowadzenia, mówiąc językiem sportowym, swoistej „dogrywki”, w ramach zastosowania procedury naruszeniowej, kiedy zarówno strona polska, jak i TSUE moga jeszcze "dać się przekonać" i zmodyfikować swoje stanowisko. W ramach tej procedury sprawa nie musiałaby zresztą dotrzeć do samego TSUE. Komisja jako podmiot ją wszczynający i decydujący o nadaniu jej biegu przed TSUE mógłby od tego odstąpićn ${ }^{1539}$. Ewentualne włączenie się tego podmiotu do sporu między TK a TSUE byłoby działaniem poza proponowanym tu mechanizmem, opierającym się na dialogu i współpracy między dwoma trybunałami, stąd nie jest w tej pracy analizowane. Jest ono jednak możliwe, nawet jeśli miałoby mieć bardziej polityczny, a mniej jurydyczny charakter.

Oczywiście nie można wykluczyć, że kwestia obowiązku poszanowania tożsamości konstytucyjnej będzie pojawiała się również w sprawach, w których nie będziemy mieli do czynienia ze współpracą między TSUE a TK, a nawet takich, które będą wpisywać się w tendencję, jaką orzecznictwo TSUE przejawiało w tej materii do tej pory - a więc w sprawach dotyczących dopuszczalności derogacji od unijnych swobód, poza scenariuszem proponowanym w tej pracy. Nie można wykluczać sytuacji, że na tożsamość konstytucyjną powoływać się będą $w$ różnych postępowaniach przed TSUE sądy czy rządy, co zresztą miało niejednokrotnie miejsce $\mathrm{w}$ omawianych $\mathrm{w}$ poprzednim rozdziale sprawach. Oczywiście kwestia pozostaje otwarta, czy rząd taki powołałby się na tożsamość

${ }^{1539}$ Podobnie jak np. stało się to w przypadku orzeczenia FTK w sprawie Solange I. Mimo że niektórzy deputowani do Parlamentu Europejskiego domagali się kontynuowania przez Komisję postępowania $\mathrm{z}$ art. 258, ta ostatecznie nie podjęła dalszych czynności w tej sprawie, mimo że wyraziła stanowisko, iż wspomniane orzeczenie FTK, w którym ten rezerwował sobie prawo do badania prawa pochodnego, stanowiło niedopuszczalną ingerencję $\mathrm{w}$ kompetencje zastrzeżone dla trybunału luksemburskiego. W wyniku wymiany korespondencji z rządem niemieckim Komisja poprzestała jednak na deklaracji o uważnym śledzeniu rozwoju sytuacji i ewentualnym zastosowaniu procedury naruszeniowej w przyszłości (więcej - patrz: M. Taborowski, Konsekwencje..., s. 283-284). Nota bene dotychczas kwestia odpowiedzialności państwa za naruszenie prawa unijnego przez sąd konstytucyjny tego państwa nie była przedmiotem postępowania przed TSUE. Nic nie stoi jednak na przeszkodzie, aby tak się stało w obliczu art. 4 ust. 3 zd. trzecie TUE w związku z art. 258-26o TFUE (więcej - patrz: K. Wójtowicz, Sądy konstytucyjne..., s. 147-156). 
konstytucyjną swego państwa w związku z jej rekonstrukcją dokonaną ewentualnie przy innych okazjach przez sąd konstytucyjny, czy nie. Nie wchodząc głęboko w te rozważania, jako mieszczące się poza zakresem tej pracy, można jednak powiedzieć, że w obliczu tego, co zostało powiedziane o ustrojowej roli TK, jakiekolwiek powołanie się innego podmiotu na tożsamość konstytucyjną w oderwaniu, a tym bardziej wbrew orzecznictwu TK, byłoby znacznie słabsze do utrzymania i swoboda oceny po stronie TSUE byłaby znacznie większa.

Podkreślić jednak należy, że w żadnej z omawianych spraw TSUE nie odrzucił otwarcie powołania się na tożsamość konstytucyjną przez sąd konstytucyjny państwa członkowskiego. Do tej pory bowiem żaden z nich otwarcie nie skierował doń takiego wniosku (nie licząc sprawy Gauweiler czy Taricco, w których odwołanie się do tożsamości konstytucyjnej nie miało formy, jakiej oczekuje się w obliczu rozważań zawartych w tej pracy, od wniosku TK, a więc nie zawierało precyzyjnego wskazania na treść i zakres tożsamości konstytucyjnej państwa członkowskiego, która domagałaby się poszanowania, ani precyzyjnego wskazania, które i w jakim zakresie przepisy prawa unijnego ją naruszają). Gdyby jednak jakikolwiek sąd konstytucyjny państwa członkowskiego skierował do TSUE pytanie prejudycjalne dotyczące poszanowania jego tożsamości konstytucyjnej przejawiającej się w ochronie wyższego niż unijny standardu ochrony praw człowieka, o jakim mowa w tej pracy i w sposób, o którym w niej mowa, to wydaje się, że TSUE byłby znacznie bardziej ograniczony w możliwości nieprzystania na stanowisko sądu konstytucyjnego, niż miało to miejsce w omawianych przypadkach odrzucania stanowisk wyrażanych przez inne podmioty w sprawach, w których argument z tożsamości konstytucyjnej TSUE odrzucał. Stosowanie takiego jak do tej pory podejścia do art. 4 ust. 2 TUE nie stoi na przeszkodzie, aby w szczególnych sytuacjach i przy udziale specjalnych podmiotów potraktować ten przepis szerzej i nadać mu rangę autonomiczna, skutkującą jego potencjalnym zastosowaniem wobec wszelkich przepisów prawa unijnego.

Nie można także wykluczyć, że TK pójdzie inną drogą. Być może znajdzie się w gronie innych sądów konstytucyjnych państw członkowskich, które w wyższym stopniu przejawiają takie tendencje (jak choćby FTK, o którego aktywności związanej z traktowaniem tożsamości konstytucyjnej jako odmiany doktryny ultra vires była mowa w tej pracy; czy jeszcze bardziej konfrontacyjne, jak np. sądy czeski ${ }^{1540}$ czy węgierski ${ }^{1541}$ ), i wybierze kierunek samodzielnego orzekania w sprawach unijnych, a więc dotyczących również unijnego prawa pochodnego i mieszącego się w jego zakresie prawa polskiego, o pogwałceniu przez nie polskiej tożsamości konstytucyjnej. Takie rozwiązanie nie

${ }^{1540}$ Czeski TK, sprawa Pl. ÚS 5/12, wyrok z 31 stycznia 2012.

${ }^{1541}$ Węgierski TK, sprawa 22/2016, wyrok z 30 listopada 2016. 
wydaje się jednak wskazane. Wydaje się również, że tendencja przejawiająca się szczególnie w ostatnim orzecznictwie TK w sprawach unijnych, dowodzi (a przynajmniej dowodziła) jego prounijnego i kooperacyjnego nastawienia ${ }^{1542}$. Rozwiązanie izolacjonistyczne wiązałoby się z utratą wszystkich potencjalnych korzyści, o których mowa była w tej pracy.

Jak zauważają między innymi Armin von Bogdandy i Stephan Schill, orzecznictwo TSUE dotyczące tożsamości konstytucyjnej nie wyklucza możliwości, aby to krajowe sądy konstytucyjne same dokonywały kontroli jej poszanowania w odniesieniu do aktów Unii. Jest to inherentna cecha jednego z podejść do integracji europejskiej, jakim jest tzw. pluralizm konstytucyjny ( $w$ różnych wariantach wspominany w tej pracy). Zdaniem przedstawicieli takiego podejścia, zgodnie z konstytucją krajowa, krajowy sąd konstytucyjny może interpretować krajowy obowiązek ochrony tożsamości konstytucyjnej danego państwa inaczej niż TSUE i klauzula zawarta w art. 4 ust. 2 TUE może być rozumiana jako unijna ratyfikacja dla tych, wynikających z tożsamości konstytucyjnych państw członkowskich, granic integracji. Możliwa dywergencja między TSUE a sądami konstytucyjnymi państw członkowskich mogłaby być widziana jako akceptowalna cena za heterarchiczną strukturę konstytucyjną Unii, która jest, zdaniem tych autorów, znacznie bardziej odpowiednia dla unijnej pluralistycznej architektury prawnej niż struktura hierarchiczna. Jak twierdza, taka struktura mogłaby się wszakże utrzymać tylko wtedy, gdy sądy konstytucyjne poważnie traktowałyby zasadę lojalnej współpracy. Wymagałoby to od sądów krajowych zarówno bardzo wąskiego interpretowania takich konstytucyjnych wyjątków, lecz także jak najdalej posuniętej, dobrze znanej orzecznictwu TK, zasady prounijnej wykładni Konstytucji ${ }^{1543}$.

${ }^{1542}$ Podobnie zresztą jak od początku odnosił się do ewentualnego uznawania przez siebie za będące przejawem działania przez Unię ultra vires orzeczeń TSUE (co szczególnie doniosłe w kontekście proponowanej tu sekwencji orzekania i ewentualnej reakcji TK na wyrok TSUE nieprzychylający się do poglądu TK w przedmiocie obowiązku po stronie Unii do poszanowania tożsamości konstytucyjnej RP, przejawiającej się w składającym się na nią, kolidującym z prawem unijnym, wyższym standardzie ochrony jakiegoś prawa czy wolności człowieka). Już w wyroku w sprawie traktatu akcesyjnego TK dostrzegł, że „ze szczególnie złożoną i delikatną sytuacją możemy mieć do czynienia wówczas, gdy zarzut wykroczenia poza przyznane kompetencje dotyczy Trybunału Sprawiedliwości UE. W wyroku K 18/o4 Trybunał Konstytucyjny wypowiedział się na ten temat w sposób wyważony, by nie powiedzieć - ostrożny. Z jednej strony uznał, że nie może czynić przedmiotem dokonywanej przez siebie bezpośredniej oceny konstytucyjności wypowiedzi orzeczniczych TSUE. Dotyczy to zarówno konkretnych orzeczeń, jak i wyinterpretowanej z konkretnych orzeczeń »stałej linii orzecznictwa« TSUE. Z drugiej strony stwierdził, że wykładnia prawa wspólnotowego (unijnego) dokonywana przez TSUE winna mieścić się w zakresie funkcji i kompetencji przekazanych przez państwa członkowskie na rzecz Unii" (K. Wójtowicz, Traktat..., s. 513).

${ }^{1543}$ A. von Bogdandy, S. Schill, Overcoming..., s. 1449-1450; patrz też: podana tam literatura. 
Zdaniem autora tej pracy dla dobra czy wręcz dla przetrwania unijnego projektu, zanim można by zdecydować się na dopuszczenie $w$ jego ramach na taką, czy jeszcze dalej posuniętą dywergencję, czy jak mówią wspomniani autorzy - heterarchię, jeszcze bardziej wskazane byłoby podjęcie próby współpracy między TK a TSUE w tej materii, rozszerzającej jak najdalej się da granice integracji i osiąganie, nawet jeśli nie pełnej konwergencji, to dywergencji w najwyższym możliwym stopniu współkontrolowanej zarówno przez najbardziej do tego uprawnione podmioty krajowe (w przypadku Polski - TK) z jednej strony, i podmioty unijne (TSUE) z drugiej strony. Jeszcze raz należy powtórzyć, że zadaniem, jakie zostało postawione w tej pracy, była próba zaproponowania schematu sekwencji orzekania przez TK i TSUE zmierzającego do jak najdalej posuniętego poszerzenia przestrzeni poszanowania w ramach Unii konstytucyjnych standardów ochrony praw człowieka oraz zasady konstytucjonalizmu i tożsamości konstytucyjnej przy jak najdalej posuniętym poszanowaniu zasad autonomiczności oraz pierwszeństwa, efektywności i jednolitości prawa unijnego. Jak podkreśla wielu komentatorów w unijnym porządku konstytucyjnym konflikty o charakterze konstytucyjnym, szczególnie dotyczące podziału kompetencji na tym poziomie i o tym charakterze, są nieuniknione, a analiza orzecznictwa nie daje odpowiedzi jak je ostatecznie rozwiązać ${ }^{1544} \mathrm{czy}$ wyeliminować. Do tej pory nie powstała żadna w pełni przekonująca matryca systemowego rozstrzygania tego rodzaju konfliktów kompetencyjnych, a kwestionowana jest nawet sama możliwość jej powstania ${ }^{1545}$. Dlatego też w pracy tej nie podjęto próby zmierzającej ku całościowemu, systemowemu rozwiązaniu tych problemów, nawet jeśli miałaby się sprowadzać jedynie do potencjalnego konfliktu między TK a TSUE. Podjęta została próba postawienia pewnego kroku w tym kierunku. Praca ta miała wskazać możliwość podziału, koordynacji i wzajemnego poszanowania kompetencji przez TK i TSUE w ramach sekwencji orzekania w przedmiocie bez wątpienia o konstytucyjnej randze, jaką są gwarancje praw i wolności człowieka, która to problematyka ogniskuje większość węzłowych problemów ${ }^{1546} \mathrm{w}$ przedmiocie ich potencjalnej kolizji kompetencyjnej w ogóle. Współpraca ta miałaby prowadzić do poszerzenia przestrzeni konwergencji, a przynajmniej współkontrolowanej dywergencji w tej materii, minimalizując, choć jej nie eliminując w całości, przestrzeń konfliktu i dywergencji izolacjonistycznej. Feci, quod potui, faciant meliora potentes.

${ }^{1544}$ Por. np.: M. Kumm, The Jurisprudence....

${ }_{1545}$ M. Klatt, Balancing..., s. 197; I. Pernice, The Autonomy..., s. 61 i podana tam literatura.

${ }^{1546}$ M. Klatt, Balancing..., s. 198. 


\section{Bibliografia $^{1547}$}

Adam, R., Safjan, M., Tizzano, A., Zarys prawa Unii Europejskiej, Warszawa 2014.

Almhofer, M., Hartlieb, J., Article 53 of the Charter of Fundamental Rights of the EU: Recent Developments, „European Yearbook of Human Rights” 2014, nr 14.

Amalfitano, C., Pollicino, O., Two Courts, Two Languages? The Taricco Saga Ends on a Worrying Note, [online] <https://verfassungsblog.de/two-courts-two-languages-the-taricco-saga-ends-on-a-worrying-note/> [dostęp: 5.02.2019].

Amato, G., Cartabia, M., de Pretis, D., Sciarra, S., Constitutional Adjudication Within A European Composite Constitution - A View From The Bench, "Italian Journal of Public Law" 2018, nr 10 (2).

Andreangeli, A., Ne bis in idem and administrative sanctions: Bonda, "Common Market Law Review" 2013, nr 50 (6).

Arnold, R., Germany. The Federal Constitutional Court of Germany in the Context of the European Integration, [w:] P. Popelier, C. van de Heyning, P. van Nuffel (red.), Human Rights Protection in the European Legal Order: the Interaction Between the European and the National Courts, Cambridge-Antwerp-Portland 2011.

Arnull, A., Protocol (No 30) on the Application of the Charter of Fundamental Rights of the European Union to Poland and the United Kingdom, [w:] S. Peers, T. Harvey, J. Kenner, A. Ward (red.), The EU Charter of Fundamental Rights. A Commentary, Oxford 2014.

Avbelj, M., Komárek, J. (red.), Constitutional Pluralism in the European Union and Beyond, Oxford 2012.

Baquero Cruz, J., What's Left of the Charter? Reflections on Law and Political Mythology, „Maastricht Journal of European and Comparative Law" 2008, t. 15.

Baquero Cruz, J., What's Left of the Law of Integration?: Decay and Resistance in European Union Law, Oxford 2018.

Baranowska, G., Bodnar, A., Gliszczyńska-Grabias, A. (red.), Ochrona praw obywatelek i obywateli Unii Europejskiej. 20 lat - osiagnięcia i wyzwania na przyszłość, Warszawa 2015.

Barcz, J., Traktat z Lizbony. Wybrane aspekty prawne działań implementacyjnych, Warszawa 2012.

Barents, R., The Autonomy of Community Law, Haga-Londyn 2004.

${ }^{1547} \mathrm{~W}$ bibliografii nie umieszczono wykazu aktów prawnych przywoływanych w przypisach. 
Barnard, C., The 'Opt-Out' for the UK and Poland from the Charter of Fundamental Rights: Triumph of Rhetoric over Reality? [w:] S. Griller, J. Ziller (red.), The Lisbon Treaty. EU Constitutionalism without Constitutional Treaty, Wiedeń-Nowy Jork 2008.

Beck, G., The Court of Justice, Legal Reasoning, and the Pringle Case - Law as the Continuation of Politics by other Means, "European Law Review" 2014, nr 39 (2).

Beck, G., The Problem of Kompetenz-Kompetenz: a Conflict Between Right and Right in Which There is no Praetor, "European Law Review” 2005, nr 1.

Belling, V., Supranational Fundamental Rights or Primacy of Sovereignty? Legal Effects of the So-Called Opt-Out from the EU Charter of Fundamental Rights, "European Law Journal" 2012, $\mathrm{nr} 18$ (2).

Belov, M., The Functions of Constitutional Identity Performed in the Context of Constitutionalization of the EU Order and Europeanization of the Legal Orders of EU Member States, „Perspectives on Federalism” 2017, nr 9 (2).

Besselink, L.F.M., Case C-208/og, Ilonka Sayn-Wittgenstein v. Landeshauptmann von Wien, Judgment of the Court (Second Chamber) of 22 December 2010, "Common Market Law Review" 2012, nr 49 (2).

Besselink, L.F.M., National and Constitutional Identity Before and After Lisbon, „Utrecht Law Review" 2010, nr 6 (3).

Besselink, L.F.M., The Protection of Fundamental Rights Post Lisbon. The Interaction Between the EU Charter of Fundamental Rights, the European Convention on Human Rights (ECHR) and National Constitutions, [online] <http://www.fide2012.eu/index. php?doc_id=94> [dostęp: 5.02.2019].

Biernat, S., Członkostwo Polski w Unii Europejskiej w świetle orzecznictwa Trybunału Konstytucyjnego, [w:] S. Biernat, S. Dudzik, Doświadczenia prawne pierwszych lat członkostwa Polski w Unii Europejskiej, Warszawa 2011.

Biernat, S., Czy Karta Praw Podstawowych Unii Europejskiej obowiazuje w Polsce? [w:] P. Kardas, T. Sroka, W. Wróbel (red.), Państwo prawa i prawo karne. Ksiega jubileuszowa Profesora Andrzeja Zolla, Warszawa 2012.

Biernat, S., Kontrowersje dotyczace nazwisk a prawo Unii Europejskiej, [w:] A. Matlak, S. Stanisławska-Kloc (red.), Spory o własność intelektualną: księga jubileuszowa dedykowana profesorom Januszowi Barcie i Ryszardowi Markiewiczowi, Warszawa 2013.

Biernat, S., Pierwsze pytanie prejudycjalne Trybunatu Konstytucyjnego, „Europejski Przegląd Sądowy" 2015, nr 9.

Bifulco, R., Europe and Constitutional Pluralism: Prospects and Limitations, "Italian Journal of Public Law" 2018, nr 10 (2).

Biłgorajski, A., Rozdział II. Źródła prawa, [w:] R.M. Małajny, Polskie prawo konstytucyjne na tle porównawczym, Warszawa 2013.

Bobek, M., The Impact of the European Mandate of Ordinary Courts on the Position of Constitutional Courts, [w:] M. de Visser, C. van de Heyning (red.), Constitutional Conversations in Europe, Cambridge 2012.

Bockel van, B., Wattel, P., New Wine into Old Wineskins: the Scope of the Charter of Fundamental Rights of the EU after Akerberg Fransson, "European Law Review" 2013, nr 38 . 
Bodnar, A., Res Interpretata: Legal Effect of the European Court of Human Rights' Judgments for other States Than Those Which Were Party to the Proceedings, [w:] Y. Haeck, E. Brems (red.), Human Rights and Civil Liberties in the $21^{\text {st }}$ Century, Dordrecht 2014.

Bodnar, A., Standard "równoważnej ochrony" w odniesieniu do ochrony praw człowieka po opinii Trybunatu Sprawiedliwości 2/13, "Europejski Przegląd Sądowy” 2015, nr 12.

Bogdandy von, A., Kottmann, M., Antpöhler, C., Dickschen, J., Hentrei, S., Smrkolj, M., Reverse Solange - Protecting the Essence of Fundamental Rights against EU Member States, "Common Market Law Review" 2012, nr 2 (49).

Bogdandy von, A., Schill, S., Overcoming Absolute Primacy; Respect for National Identity under the Lisbon Treaty, "Common Market Law Review” 2011, nr 48.

Bogdanowicz, P., Marcisz, P., Szukając granic kontroli - glosa do wyroku TK z 16.11.2011 r. (SK 45/og), "Europejski Przegląd Sądowy” 2012, nr 9.

Bonelli, M., The Taricco Saga and the Consolidation of Judicial Dialogue in the European Union, "Maastricht Journal of European and Comparative Law" 2018, nr 25 (3).

Bosek, L., Ochrona godności człowieka w prawie Unii Europejskiej a konstytucyjne granice przekazywania kompetencji państwa, "Przegląd Sejmowy” 2008, nr 2.

Buczkowska-Mazurek, K., Procedura zwiazana z udziałem Polski w postępowaniach przed Europejskim Trybunałem Sprawiedliwości, sadem pierwszej instancji oraz Trybunałem EFTA, [online] <https://bs.net.pl/upload/File/pdf/Microsoft\%2oWord\%20-\%20 bsnet-92.pdf> [dostęp: 7.02.2019].

Búrca de, G., After the EU Charter of Fundamental Rights: The Court of Justice as a Human Rights Adjudicator?, "Maastricht Journal of European and Comparative Law” 2013, nr 20.

Búrca de, G., The Drafting of the European Union Charter of Fundamental Rights, "European Law Review" 2001, nr 26.

Búrca de, G., The Road Not Taken: The European Union as a Global Human Rights Actor, "American Journal of International Law" 2011, nr 4 (105).

Burgorgue-Larsen, L., L'identité constitutionnelle en question(s), [w:] L. Burgorgue-Larsen (red.), L'identité constitutionnelle saisie par les juges en Europe, Paryż 2011.

Canor, I., My brother's keeper? Horizontal solange: "An ever closer distrust among the peoples of Europe”, "Common Market Law Review" 2013, nr 50 (2).

Capik, B., Łazowski, A., Art. 91. [Pierwszeństwo ratyfikowanej umowy przed ustawami], [w:] M. Safjan, L. Bosek (red.), Konstytucja. Komentarz, t. II, Warszawa 2016.

Cappelletti, M., Golay, D., The Judicial Branch in the Federal and Transnational Union: Its Impact on Integration. Integration Through Law, [w:] M. Cappelletti, M. Seccombe, J. Weiler (red.), Volume 1: Methods, Tools and Institutions, Book 2: Political Organs, Integration Techniques and Judicial Process, Berlin-New York 1986.

Cartabia, M., Fundamental Rights and the Relationship among the Court of Justice, the National Supreme Courts and the Strasbourg Court, [w:] Van Gend en Loos 1963-2013. Conference Proceedings, Luxemburg, 13 May 2013.

Chalmers, D., Looking Back at ERT and its Contribution to an EU Fundamental Rights Agenda, [w:] M.P. Maduro, L. Azoulai (red.), The Past and Future of EU Law: The Classics of EU Law Revisited on the 5oth Anniversary of the Rome Treaty, Oxford-Portland 2010. 
Chalmers, D., Davies, G., Monti, G., European Union Law: Cases and Materials, Cambridge 2010.

Chané, A.-L., Hauser, A., Jaraczewski, J., Jóźwicki, W., Kędzia, Z., Šimáková, M.A., Suchocka, H., Wallace, S., EU Engagement with Other European Regional Organisations (Work Package No.5 - Deliverable No. 5.2), Fostering Human Rights Among European Policies, Large-Scale FP7 Collaborative Project GA No. 3200oo, [online] <http:// www.fp7-frame.eu/frame-reps-5-2/> [dostęp: 28.12.2018].

Chmielarz, A., Kontrola konstytucyjności prawa pochodnego Unii Europejskiej, "Przegląd Sejmowy" 2012, $\mathrm{nr}_{4}$ (111).

Chmielewski, J., Pojęcie nadrzędnego interesu publicznego w prawie administracyjnym, Warszawa 2015.

Claes, M., Luxembourg, Here We Come? Constitutional Courts and the Preliminary Reference Procedure, "German Law Journal" 2015, nr 16 (4).

Claes, M., Negotiating Constitutional Identity or Whose Identity is it Anyway? [w:] M. Claes; M. de Visser; P. Popelier; C. van de Heyning (red.), Constitutional Conversations in Europe. Actors, Topics and Procedures, Antwerp 2012.

Claes, M., The National Courts' Mandate in the European Constitution, Oxford, Portland 2006.

Clases, M., Reestman, J.-H., The Protection of National Constitutional Identity and the Limits of European Integration at the Occasion of the Gauweiler Case, "German Law Journal" 2015, nr 16 (4).

Cloots, E., National Identity in EU Law, Oxford 2015.

Co to jest EFSF i ESM? [online] <http://www.mf.gov.pl/documents/764034/1417826/23_ efsf-esm.pdf> [dostęp: 28.12.2018].

Craig, P., de Búrca, G., EU Law: Text, Cases, and Materials, Cambridge 2015.

Czapliński, W., Kilka uwag w kwestii możliwości wycofania się przez Polskę z protokołu polsko-brytyjskiego, "Studia Europejskie” 2012, nr 1.

Dahl, B., Keynote Address, [w:] U. Neergaard, C. Jacqueson (red.), Proceedings: Speeches from the XXVI FIDE Congress, The XXVI FIDE Congress in Copenhagen, 2014, "Congress Publications" Vol. 4.

Dallen, R.M., An Overview of European Community Protection of Human Rights, with Some Special References to the U.K., "Common Market Law Review" 1990, nr 27 (4).

Danwitz von, T., Paraschas, K., A Fresh Start for the Charter: Fundamental Questions for the Application of the European Charter of the Fundamental Rights, "Fordham International Law Journal" 2012, 35.

Degener, R., Garlicki, L., Art. 46 [moc obowiąująca oraz wykonanie wyroków], [w:] L. Garlicki (red.), Konwencja o Ochronie Praw Człowieka i Podstawowych Wolności. Komentarz do artykułów 19-59, Warszawa 2011.

Denman, D., (Opinion) The Charter of Fundamental Rights, „European Human Rights Law Review" 2010, nr 4.

Denman, D., The EU Charter of Fundamental Rights: How Sharp are its Teeth?, "Judicial Review" 2014, nr 3.

Dębowska, A., Tożsamość konstytucji RP z 1997 r.jako granica dopuszczalnej wykładni jej norm, [w:] S. Biernat (red.), Konstytucja Rzeczypospolitej polskiej w pierwszych deka- 
dach XXI wieku wobec wyzwań politycznych, gospodarczych i społecznych, Warszawa 2013.

Domańska, M., Implementacja dyrektyw unijnych przez sądy krajowe, Warszawa 2014.

Dougan, M., Judicial Review of Member State Action under the General Principles and the Charter: Defining the "Scope of Union Law", "Common Market Law Review" 2015, nr $52(5)$.

Dougan, M., The Treaty of Lisbon 2007: Winning Minds, Not Hearts, "Common Market Law Review" 2008, nr 45.

Douglas-Scott, S., Constitutional Law of the European Union, Harlow-Nowy Jork 2002.

Drinóczi, T., The Hungarian Constitutional Court on the Limits of EU Law in the Hungarian Legal System, Int'1 J. Const. L. Blog, Dec. 29, 2016, [online] <http://www.iconnectblog.com/2016/12/the-hungarian-constitutional-court-on-the-limits-of-eu-law-in-the-hungarian-legal-system> [dostęp: 5.02.2019].

Dybowski, M., Prawa fundamentalne w orzecznictwie ETS, Warszawa 2007.

Edenharter, A., Fundamental Rights Protection In The Eu: The ECJ's Difficult Mission To Strike A Balance Between Uniformity And Diversity, „Italian Journal of Public Law” 2018, nr 10 (2).

Editorial Comments: Ultra vires - has the Bundesverfassungsgericht shown its teeth?, "Common Market Law Review" 2013, nr 50 (4).

Eeckhout, P., The EU Charter of Fundamental Rights and the Federal Question, "Common Market Law Review" 2002, nr 39 (5).

Etynkowska, E., Glosa aprobujaca do wyroku Trybunału Konstytucyjnego z dnia 16 listopada 2011 roku, Sygn. akt SK 45/og, "Przegląd Prawa i Administracji” 2012, nr 90.

Fabbrini, F., Pollicino, O., Constitutional Identity in Italy: European Integration as the Fulfilment of the Constitution, EUI Working Paper, LAW 2017, nr o6.

Faraguna, P., The Italian Constitutional Court in re Taricco: "Gauweiler in the Roman Campagna", VerfBlog, 2017/1/31, [online] < http://verfassungsblog.de/the-italianconstitutional-court-in-re-taricco-gauweiler-in-the-roman-campagna/> [dostęp: 5.02.2019].

Fontanelli, F., The Implementation of European Union Law by Member States Under Article 51(1) of the Charter of Fundamental Rights, "Columbia Journal of European Law" 2014, $\mathrm{nr} 20(2)$.

Freeman, M., Prawa człowieka, Warszawa 2007.

Freud, Z., Człowiek imieniem Mojżesz a religia monoteistyczna, Warszawa 1994.

Galster, J., Knade-Plaskacz, A., Glosa do wyroku Trybunału Konstytucyjnego z dnia 16 listopada 2011 r. (sygn. Akt SK 45/og), "Przegląd Sejmowy” 2012, nr 6 (113).

Garlicki, L., Aksjologiczne podstawy reinterpretacji konstytucji, [w:] M. Zubik (red.), Dwadzieścia lat transformacji ustrojowej w Polsce, Warszawa 2010.

Garlicki, L., Art. 53. [Ochrona uznanych praw człowieka], [w:] L. Garlicki (red.), Konwencja o Ochronie Praw Człowieka i Podstawowych Wolności. Komentarz do artykułów 19-59 oraz protokołów dodatkowych, Warszawa 2011.

Garlicki, L., Normy konstytucyjne relatywnie niezmienialne, [w:] J. Trzciński (red.), Charakter i struktura norm Konstytucji, Warszawa 1997. 
Garlicki, L., Ochrona praw jednostki w XXI wieku (globalizacja - standardy lokalne - dialog między sq̨dami), [w:] „Abstrakty i tezy” LVI Zjazd Katedr i Zakładów Prawa Konstytucyjnego, Lublin 29-31 maja 2014.

Garlicki, L., Polskie prawo konstytucyjne. Zarys wykładu, Warszawa 2014.

Garlicki, L., Sądy a Konstytucja Rzeczypospolitej Polskiej, "Przegląd Sądowy” 2016, nr 7-8.

Glas, L.R., Krommendijk, J., From Opinion 2/13 to Avotinšs: Recent Developments in the Relationship between the Luxembourg and Strasbourg Court, Forthcoming, "Human Rights Law Review" 2017, nr 17 (2), [online] <https://papers.ssrn.com/sol3/papers. cfm?abstract_id=2871263> [dostęp: 7.02.2019].

Gontarski, W., Grabowska, G., Glosa do postanowień Sądu Najwyższego z dnia 28 listopada 2013 r.: I KZP 14/13 i I KZP 15/13 oraz do wyroków Sądu Najwyższego: z dnia 3 grudnia 2013 r., V KK 82/13 i z dnia 8 stycznia 2014 r., IV KK 183/13, LEX 193496.

Górski, M., Glosa do postanowienia SN z dnia 28 listopada 2013 r., I KZP 15/13, LEX 188532.

Górski, M., Skutek Karty Praw Podstawowych Unii Europejskiej po wejściu w życie Traktatu z Lizbony w orzecznictwie Europejskiego Trybunału Praw Człowieka, Trybunału Konstytucyjnego Rzeczypospolitej Polskiej i Trybunału Sprawiedliwości Unii Europejskiej, [w:] S. Dudzik, N. Półtorak (red.), Prawo Unii Europejskiej a prawo konstytucyjne państw członkowskich, Warszawa 2013.

Gragl, P., The Accession of the European Union to the European Convention on Human Rights, Oxford-Portland 2013.

Gragl, P., The Reasonableness of Jealousy: Opinion 2/13 and EU Accession to the ECHR, "European Yearbook on Human Rights", Wiedeń 2015.

Groussot, X., Pech, L., Fundamental Rights Protection in the European Union post Lisbon Treaty, Robert Schuman Fondation Policy Paper, "European Issue” nr 173 z 14 czerwca 2010, [online] <http://www.robert-schuman.eu/en/doc/questions-d-europe/ qe-173-en.pdf> [dostęp: 28.12.2018].

Gruszczyński, Ł., Werner, W., (red.), Deference in International Courts and Tribunals: Standard of Review and Margin of Appreciation, Oxford 2014.

Grzeszczak, R., Szmigielski, A., Sadowe stosowanie Karty Praw Podstawowych UE w odniesieniu do państw członkowskich - refleksje na podstawie orzecznictwa Trybunału Sprawiedliwości i praktyki sądów krajowych, "Europejski Przegląd Sądowy” 2015, nr 10.

Gutowski, M., Kardas, P., Sądowa kontrola konstytucyjności prawa. Kilka uwag o kompetencjach sądów powszechnych do bezpośredniego stosowania konstytucji, "Palestra” 2016, nr 4 .

Halberstam, D., European Arrest Warrant: the CJEU Tries to Find a Balance Between Efficiency and Protection of Human Rights, "EU Law Blog", [online] <https://ukaelblog. wordpress.com/2016/o5/27/european-arrest-warrant-the-cjeu-tries-to-find-a-balance-between-efficiency-and-protection-of-human-rights/> [dostęp: 7.02.2019].

Halberstam, D., 'It's the Autonomy, Stupid!' A Modest Defense of Opinion 2/13 on EU Accession to the ECHR, and the Way Forward, "German Law Journal" 2015, nr 16 (1).

Halberstam, D., The Judicial Battle over Mutual Trust in the EU: Recent Cracks in the Façade, VerfBlog, 2016/6/o9, [online] <http://verfassungsblog.de/the-judicial-battle-over-mutual-trust-in-the-eu-recent-cracks-in-the-facade/> DOI: <http://dx.doi. org/10.17176/20160609-093714> [dostęp: 7.02.2019]. 
Halmai, G., National(ist) Constitutional Identity? Hungary's Road to Abuse Constitutional Pluralism, EUI Working Paper, LAW 2017, nr o8.

Halmai, G., The Hungarian Constitutional Court and Constitutional Identity, VerfBlog, 2017/1/10, [online] <http://verfassungsblog.de/the-hungarian-constitutionalcourt-and-constitutional-identity/> [dostęp: 5.02.2019].

Harast, A., Zasada pierwszeństwa prawa unijnego a zgodność przepisów prawa UE z polskim prawem w kontekście rozporządzenia nr 1896/2006, "Edukacja Prawnicza” 2012, nr 4(133).

Hess, B., Pfeiffer, T., Bever M, Interpretation of the Public Policy Exception as referred to in EU Instruments of Private International and Procedural Law, [online] <http:// www.europarl.europa.eu/RegData/etudes/STUD/2011/453189/IPOL-JURI_ ET(2011)453189_EN.pdf> [dostęp: 5.02.2019].

Horsley, T., EU Law, Sunday Trading Restrictions ... and the Charter? [online] <http://europeanlawblog.eu/?p=2372> [dostęp: 28.12.2018].

Jacobs, F., Human Rights in the European Union: the Role of the Court of Justice, "European Law Review" 2001, nr 26.

Jacobs, F.G., Wachauf and the Protection of Fundamental Rights in EC Law, [w:] M.P. Maduro, L. Azoulai (red.), The Past and Future of EU Law: The Classics of EU Law Revisited on the 5oth Anniversary of the Rome Treaty, Oxford-Portland 2010.

Jacobsohn, J., Constitutional Identity, Harvard 2010.

Jacobsohn, J., Constitutional Identity, "The Review of Politics” 2006, nr 68.

Jacqué, J.-P., The Explanations Relating to the Charter of Fundamental Rights of the European Union, [w:] S. Peers, T. Harvey, J. Kenner, A. Ward (red.), The EU Charter of Fundamental Rights. A Commentary, Oxford 2014.

Jarosz, M., Pierwszeństwo kontroli konstytucyjności a prawo UE - uwagi na tle wyroku TS w sprawach Melki i Abdeli, "Europejski Przegląd Sądowy” 2011, nr 8.

Jaroszyński, T., Glosa do wyroku z 16 XI 2011, SK 45/og, "Państwo i Prawo” 2012, nr 9.

Jaroszyński, T., Rozporządzenie Unii Europejskiej jako składnik systemu prawa obowiązujacego w Polsce, Warszawa 2011.

Jaśkowski, M., Konsekwencje prawne Protokotu nr 30 w sprawie stosowania Karty praw podstawowych Unii Europejskiej do Polski i Zjednoczonego Królestwa, "Zeszyty Prawnicze Biura Analiz Sejmowych" 2013, nr 4 (40).

Jirásek, J., Application of the Charter of Fundamental Rights of the EU in the United Kingdom and Poland according to the Lisbon Treaty, Brno 2008.

Joseph, S., Castan, M., The International Covenant on Civil and Political Rights: Cases, Materials, and Commentary, Oxford 2013.

Jóźwicki, W., Art. 5. Zakaz nadużywania postanowień Paktu oraz ochrona uznanych praw i wolności człowieka, [w:] Z. Kędzia, A. Hernandez-Połczyńska (red.), Międzynarodowy Pakt Praw Gospodarczych, Socjalnych i Kulturalnych. Komentarz, Warszawa 2018.

Jóźwicki, W., Protocol 16 to the ECHR. A Convenient Tool for Judicial Dialogue and Better Domestic Implementation of the Convention?, [w:] E. Kużelewska, D. Kloza, I. Kraśnicka, F. Strzyczkowski (red.), European Judicial Systems as a Challenge for Democracy, Cambridge-Antwerp-Portland 2015.

Jóźwicki, W., Rzeczpospolita dobrem wspólnym wszystkich obywateli jako uzasadnienie wymogu wierności obywateli wobec niej w kontekście integracji europejskiej, [w:] S. Biernat 
(red.), Konstytucja Rzeczypospolitej polskiej w pierwszych dekadach XXI wieku wobec wyzwań politycznych, gospodarczych i społecznych, Warszawa 2013.

Jurczyk, T., Prawa jednostki w orzecznictwie Europejskiego Trybunału Sprawiedliwości, Warszawa 2009.

Kabat-Rudnicka, D., Tożsamość narodowa jako czynnik ksztattujacy relacje pomiędzy Unia Europejska a państwami członkowskimi, "Annales Universitatis Paedagogicae Cracoviensis Studia Politologica" 2016, nr XVII.

Kaila, H., The Scope of Application of the Charter of Fundamental Rights of the European Union in the Member States, [w:] P. Cardonnel, A. Rosas, N. Wahl (red.), Constitutionalizing the EU Judicial System: Essays in Honour of Pernilla Lindh, Oxford 2012.

Kania, E., MS: w zeszłym roku do sądów trafito ponad 14 mln spraw, „Rzeczpospolita”, [online] <http://www.rp.pl/artykul/990665-MS--w-zeszlym-roku-do-sadow-trafilo-ponad-14-mln-spraw.html\#ap-1> [dostęp: 28.12.2018].

Kessedjian, C., Public Order in European Law, "Erasmus Law Review” 2007, nr 1 (1).

Kędzia, Z., Uwagi o aksjologii Konstytucji, [w:] A. Rzepliński (red.), Prawa człowieka w społeczeństwach obywatelskich, Warszawa 1992.

Kędzia, Z., Wprowadzenie, [w:] Z. Kędzia, A. Hernandez-Połczyńska (red.), Międzynarodowy Pakt Praw Gospodarczych, Socjalnych i Kulturalnych. Komentarz, Warszawa 2018.

Kisielińska, J. Glosa aprobująca do wyroku TK z 16.11.2011 r., SK 45/og, "Edukacja Prawnicza" 2013, $\mathrm{nr}$ 4(142).

Klatt, M., Balancing Competences: How Institutional Cosmopolitanism can Manage Jurisdictional Conflicts, "Global Constitutionalism" 2015, nr 4:2.

Knook, A., The Court, the Charter, and the Vertical Division of Powers in The European Union, "Common Market Law Review" 2005, nr 42.

Komárek, J., Czech Constitutional Court Playing with Matches: The Czech Constitutional Court Declares a Judgment of the Court of Justice of the EU Ultra Vires; Judgment of 31 January 2012, Pl. ÚS 5/12, Slovak Pensions XVII, "European Constitutional Law Review” 2012, nr 8.

Koncewicz, T.T., Podolska, A., Karta Praw Podstawowych w sadach polskich. Mit, marzenie czy rzeczywistość, „Palestra” 2014, nr 3-4.

Konstytucja Austrii, tłum. P. Czarny, B. Naleziński, Warszawa 2004.

Konstytucja Rumunii, tłum. A. Cosma, Warszawa 1996.

Korenica, F., The EU Accession to the ECHR. Between Luxembourg's Search for Autonomy and Strasbourg's Credibility on Human Rights Protection, Cham-Nowy Jork 2015.

Kornobis-Romanowska, D., Kompetencje wspólnotowe sądów krajowych - przegląd zagadnień, [w:] D. Kornobis-Romanowska (red.), Stosowanie prawa wspólnotowego w prawie wewnętrznym z uwzględnieniem prawa polskiego, Warszawa 2004.

Körtvélyesi, Z., Majtényi, B., Game of Values: The Threat of Exclusive Constitutional Identity, the EU and Hungary, "German Law Journal" 2017, nr 7.

Koutrakos, P., Does the United Kingdom Have a General Opt out from the EU Charter of Fundamental Rights?, "European Law Review” 2014, nr 39.

Koutrakos, P., Nic Shuibhne, N., Syrpis, P., (red.), Exceptions from EU Free Movement Law Derogation, Justification and Proportionality, Oxford-Londyn-Portland 2016. 
Kowalik-Bańczyk, K., À la recherche d'une cohérence perdue - Possible Arguments for the Non-application of EU Law in Member States, "Polish Yearbook of International Law” 2013, nr XXXIII.

Kowalik-Bańczyk, K., Konsekwencje przyjeccia protokołu polsko-brytyjskiego dotyczacego stosowania Karty Praw Podstawowych, [w:] A. Wróbel (red.), Karta Praw Podstawowych w europejskim i krajowym porządku prawnym, Warszawa 2009.

Kowalik-Bańczyk, K., Protokół w sprawie stosowania Karty Praw Podstawowych Unii Europejskiej do Polski i Zjednoczonego Królestwa, [w:] A. Wróbel (red.), Karta Praw Podstawowych Unii Europejskiej. Komentarz, Warszawa 2013.

Kowalik-Bańczyk, K., Tożsamość narodowa - dopuszczalny wyjątek od zasady prymatu? [w:] S. Dudzik, N. Półtorak (red.), Prawo Unii Europejskiej a prawo konstytucyjne państw członkowskich, Warszawa 2013.

Krajewski, M., 'Conditional' Primacy of EU Law and Its Deliberative Value: An Imperfect Illustration from Taricco II, [online] <http://europeanlawblog.eu/2017/12/18/conditional-primacy-of-eu-law-and-its-deliberative-value-an-imperfect-illustration-from-taricco-ii/> [dostęp: 5.02.2019].

Krzywoń, A., Glosa do postanowienia Sądu Najwyższego z dnia 28 listopada 2013 r. (sygn. akt I KZP 15/13), "Zeszyty Naukowe Sądownictwa Administracyjnego" 2014, nr 1 (52).

Książkiewicz, M., Stosowanie Karty Praw Podstawowych Unii Europejskiej: Protokół brytyjski i Sprawozdania ze stosowania KPP UE, "Rocznik Integracji Europejskiej” 2012, nr 6.

Kühn, Z., Wachauf and ERT: On the Road from the Centralised to the Decentralised System of Judicial Review, [w:] M.P. Maduro, L. Azoulai (red.), The Past and Future of EU Law: The Classics of EU Law Revisited on the 5oth Anniversary of the Rome Treaty, Oxford-Portland 2010.

Kumm, M., The Cosmopolitan Turn in Constitutionalism: On the Relationship Between Constitutionalism in and Beyond the State, [w:] J.L. Dunhoff, J.P. Trachtmann (red.), Ruling the World? Constitutionalism, International Law and Global Governance, Cambridge 2009.

Kumm, M., The Jurisprudence of Constitutional Conflict: Constitutional Supremacy in Europe before and after the Constitutional Treaty, "European Law Journal” 2005, nr 3 (11).

Kustra, A., "Euronowelizacja” w projektach ustaw o zmianie Konstytucji RP. Próba oceny, "Przegląd Sejmowy" 2011, nr 3.

Kustra, A., Kelsenowski model kontroli konstytucyjności prawa a integracja europejska. Studium wptywu, Toruń 2015.

Kustra, A., Kolizje norm konstytucyjnych i wspólnotowych w ujęciu teoretycznoprawnym, „Europejski Przegląd Sądowy" 2007, nr 5.

Kustra, A., Koncepcje pluralizmu prawnego a problem ustalenia ostatecznego strażnika legalności prawa w Unii Europejskiej, "Ruch Prawniczy, Ekonomiczny i Socjologiczny" 2008, nr 1.

Kustra, A., Polemika. Wokót multicentryczności systemu prawa, „Państwo i Prawo” 2006, z. 6.

Kustra, A., Sady konstytucyjne a ochrona tożsamości narodowej i konstytucyjnej państw członkowskich, [w:] S. Dudzik, N. Półtorak (red.), Prawo Unii Europejskiej a prawo konstytucyjne państw członkowskich, Warszawa 2013.

Kustra, A., Sądy konstytucyjne a procedura prejudycjalna przed Trybunałem Sprawiedliwości Unii Europejskiej, "Przegląd Sejmowy” 2012, nr 4. 
Kustra, A., The First Preliminary Questions to the Court of Justice of the European Union Referred by Italian Corte Costituzionale, Spanish Tribunal Constitucional, and French Conseil Constitutionnel, "Comparative Law Review” 2013, nr 16.

Laskowska, M., Taborowski, M., Obowiazzek wykładni przyjaznej prawu Unii Europejskiej - między otwartością na proces integracji a ochrona tożsamości konstytucyjnej, [w:] S. Dudzik, N. Półtorak (red.), Prawo Unii Europejskiej a prawo konstytucyjne państw członkowskich, Warszawa 2013.

Lauterpacht, H., International Law and Human Rights, Londyn 1950.

Leczykiewicz, D., "Effective Judicial Protection" of Human Rights After Lisbon: Should National Courts be Empowered to Review EU Secondary Law?, "European Law Review” 2010, $\mathrm{nr} 3$.

Leczykiewicz, D., The 'national identity clause' in the EU Treaty: A Blow to Supremacy of Union Law? [online] <https://ukconstitutionallaw.org/2012/06/21/dorota-leczykiewicz-the-national-identity-clause-in-the-eu-treaty-a-blow-to-supremacy-of-union-law/> [dostęp: 5.02.2019].

Legg, A., The Margin of Appreciation in International Human Rights Law: Deference and Proportionality, Oxford 2012.

Lenaerts, K., Gutiérrez-Fons, J.A., The Place of the Charter in the EU Constitutional Edifice, [w:] S. Peers, T. Harvey, J. Kenner, A. Ward (red.), The EU Charter of Fundamental Rights. A Commentary, Oxford 2014.

Lenaerts, K., EU Citizenship and the European Court of Justice's 'stone-by-stone' Approach, "International Comparative Jurisprudence" 2015, nr 1.

Lenaerts, K., EU Values and Constitutional Pluralism: The EU System of Fundamental Rights Protection, "Polish Yearbook of International Law” 2014, nr 34.

Lenaerts, K., Exploring the Limits of the EU Charter of Fundamental Rights, "European Constitutional Law Review" 2012, nr 3.

Lenaerts, K., Kooperation und Spannung im Verhältnis von EuGH und nationalen Verfassungsgerichten, „Europarecht” 2015, nr 1.

Lenaerts, K., Respect for Fundamental Rights as a Constitutional Principle of EU, "Columbia Journal of European Law" 2000, nr 1.

Lenaerts, K., The Court of Justice of the European Union and the Protection of Fundamental Rights, "Polish Yearbook of International Law” 2011, nr XXXI.

Lenaerts, K., The Court's Outer and Inner Selves: Exploring the External and Internal Legitimacy of the European Court of Justice, [w:] M. Adams, H. de Waele, J. Meeusen, G. Straetmans (red.), Judging Europe's Judges: the Legitimacy of the Case Law of the European Court of Justice, Oxford 2013.

Lenaerts, K., The Kadi Saga and the Rule of Law within the EU, "SMU Law Review” 2014, nr 67.

Lenaerts, K., Trybunał Sprawiedliwości Unii Europejskiej a ochrona praw podstawowych, „Europejski Przegląd Sądowy” 2013, nr 1.

Lenaerts, K., Wartości Unii Europejskiej a pluralizm konstytucyjny, „Europejski Przegląd Sądowy" 2014, nr 9.

Lord Goldsmith Q.C., A Charter of Rights, Freedoms and Principles, "Common Market Law Review" 2001, nr 38 (5). 
Lupo, N., The Advantage of Having the "First Word" in the Composite European Constitution, „Italian Journal of Public Law" 2018, nr 10 (2).

Łętowska, E., Multicentryczność wspótczesnego systemu prawa i jej konsekwencje, „Państwo i Prawo" 2005, z. 4.

Łętowska, E., Multicentryczność współczesnego systemu prawa i wykładnia jej przyjazna, [w:] L. Ogiegło, W. Popiołek, M. Szpunar (red.), Rozprawy prawnicze. Ksiegga pamiątkowa Profesora Maksymiliana Pazdana, Kraków 2005.

Łętowska, E., Królikowski, J., Łyszkowska, A., Sokólska-Warchoł, J., Zasada skargowości - watpliwości i uwarunkowania na tle acquis constitutionnel, [w:] K. Budziło (red.), Ksiega XXV-lecia Trybunału Konstytucyjnego. Ewolucja funkcji i zadań Trybunału Konstytucyjnego - założenia a ich praktyczna realizacja, Warszawa 2010.

Łubecki, J., Stwierdzenie wykonalności orzeczenia sądu zagranicznego wedtug rozporzadzenia 44/2001 a obowiązek wykazania prawomocności tego orzeczenia, „Monitor Prawni-

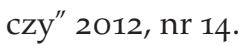

Madsen, M.R., Olsen, H.P., Šadl, U., Competing Supremacies and Clashing Institutional Rationalities: the Danish Supreme Court's Decision in the Ajos Case and the National Limits of Judicial Cooperation, "European Law Journal” 2017, nr 23 (1-2).

Maduro, M.P., Interpreting European Law: Judicial Adjudication in a Context of Constitutional Pluralism, "European Journal of Legal Studies” 2007, nr 1 (2).

Maliszewska-Nienartowicz, J., Naruszenie obowiązku notyfikacji przepisów technicznych a zasada pierwszeństwa prawa UE - glosa do postanowienia SN z 28.11.2013 r. (I KZP 15/13), "Europejski Przegląd Sądowy” 2014, nr 6.

Martinico, G., Pollicino, O., Italy. The Impact of the European Courts on the Italian Constitutional Court, [w:] P. Popelier, C. van de Heyning, P. van Nuffel (red.), Human Rights Protection in the European Legal Order: the Interaction Between the European and the National Courts, Cambridge-Antwerp-Portland 2011.

Martinico, G., Pollicino, O., The Interaction between Europe's Legal Systems. Judicial Dialogue and the Creation of Supranational Laws, Cheltenham-Northampton 2012.

Maśnicki, J., Kontrola konstytucyjności instrumentów implementujacych prawo pochodne Unii Europejskiej, „Państwo i Prawo” 2015, z. 6.

Mączyński, A., Podkowik, J., Art. 188. [Trybunat Konstytucyjny; właściwość rzeczowa], [w:] M. Safjan, L. Bosek (red.), Konstytucja. Komentarz, t. II, Warszawa 2016.

Mączyński, A., Podkowik, J., Art. 191. [Legitymacja podmiotowa do wystepowania do TK], [w:] M. Safjan, L. Bosek (red.), Konstytucja. Komentarz, t. II, Warszawa 2016.

Mączyński, A., Podkowik, J., Art. 193. [Pytanie prawne], [w:] M. Safjan, L. Bosek (red.), Konstytucja. Komentarz, t. II, Warszawa 2016.

Miąsik, D., 5.6 Zasada efektywności a interpretacja przepisów prawa, [w:] A. Wróbel (red.), Stosowanie prawa Unii Europejskiej przez sądy, t. 1, Warszawa 2010.

Mik, C., Karta Praw Podstawowych: wyznaczniki standardów ochrony, [w:] J. Barcz (red.), Ochrona praw podstawowych w Unii Europejskiej, Warszawa 2008.

Millet, F.-X., The Respect for National Constitutional Identity in the European Legal Space. An Approach to Federalism as Constitutionalism, [w:] L. Azoulai (red.), The Question of Competence in the European Union, Oxford 2014. 
Mościcka, A., Zajęcie mienia bez wyroku skazującego. Co z domniemaniem niewinności?, „Dziennik. Gazeta Prawna" z 27 sierpnia 2014, [online] <http://www.prawnik.pl/ prawo/prawo-w-praktyce/artykuly/817858,zajecie-mienia-bez-wyroku-skazujacego-co-z-domniemaniem-niewinnosci.html> [dostęp: 5.02.2019].

Murphy, C., Bulletin on the EU Charter of Fundamental Rights: An Introduction (Part 1), „European Human Rights Law Review” 2016, nr 21 (1).

Nakanishi, Y., Completion of EU Measures through Court Decisions: The Example of the European Arrest Warrant, "Hitotsubashi Journal of Law and Politics” 2017, nr 45.

Nicolaïdis, K., We, the Peoples of Europe..., "Foreign Affairs” 2004, nr 6 (83).

Nowak, M., U.N. Covenant on Civil and Political Rights: CCPR Commentary, Kehl 2005.

O'Donovan, D., 'The Way of the World', International Economic Law and National Constitutions: Irish Constitutional Sovereignty and the Eurozone Crisis, [w:] F. De Londras, S. Mullally (red.), "The Irish Yearbook of International Law” 2013, t. 8.

Ochnio, A.H., Konfiskata korzyści z przestęstwa - nowe rozwiąania w prawie Unii Europejskiej (część I), "Prokuratura i Prawo” 2016, nr 4.

Ochnio, A.H., Konfiskata korzyści z przestępstwa - nowe rozwiąania w prawie Unii Europejskiej (część II), "Prokuratura i Prawo” 2016, nr 5.

Olszówka, M., Zinkiewicz, A., Kompetencje Trybunału Konstytucyjnego w zakresie orzekania w sprawie konstytucyjności prawa Unii Europejskiej, [w:] D. Harasimiuk, M. Olszówka, A. Zinkiewicz (red.), Prawo Unii Europejskiej i porządek konstytucyjny państw członkowskich. Problem konkurencji i wzajemnych relacji, Warszawa 2014.

Orator, A., The Decision of the Austrian Verfassungsgerichtshof on the EU Charter of Fundamental Rights: An Instrument of Leverage or Rearguard Action?, "German Law Journal" 2015, vol. 16, nr 6.

Paprocka, A., Wptyw orzecznictwa ETPCz na rozumienie konstytucyjnych praw $i$ wolności w Polsce - kilka uwag na marginesie orzecznictwa Trybunatu Konstytucyjnego, [w:] M. Zubik (red.), XV lat obowiązywania Konstytucji RP z 1997 r. Ksiega jubileuszowa dedykowana Zdzisławowi Jaroszowi, Warszawa 2012.

Paris, D., Case Note: Constitutional Courts as Guardians of EU Fundamental Rights? Centralised Judicial Review of Legislation and the Charter of Fundamental Rights of the EU European Court of Justice (Fifth Chamber), Judgment of 11 September 2014, "European Constitutional Law Review" 2015, nr 11.

Paris, D., Constitutional Courts as European Union Courts: The Current and Potential Use of EU Law as a Yardstick for Constitutional Review, "Maastricht Journal of European and Comparative Law" 2017, nr 24 (6).

Paris, D., Limiting the 'Counter Limits'. National Constitutional Courts and the Scope of the Primacy of EU Law, „Italian Journal of Public Law” 2018, nr 10 (2).

Pernice, I., Multilevel Constitutionalism in the European Union, "European Law Review” 2002, $\mathrm{nr} 27$ (5).

Pernice, I., The Autonomy of the EU Legal Order - Fifty Years After Van Gend, [w:] Van Gend en Loos 1963-2013. Conference Proceedings, Luxemburg 13 May 2013.

Pernice, I., The Treaty of Lisbon and Fundamental Rights, [w:] S. Griller, J. Ziller (red.), The Lisbon Treaty. EU Constitutionalism without Constitutional Treaty, Wiedeń-Nowy Jork 2008. 
Piccirilli, G., The 'Taricco Saga': the Italian Constitutional Court Continues its European Journey, "European Constitutional Law Review", [online] <https://www.cambridge. org/core/journals/european-constitutional-law-review/article/taricco-saga-the-italian-constitutional-court-continues-its-european-journey/F9BEECCF1oDıB63 $\mathrm{B}_{46}{ }_{5} \mathrm{~A} 27 \mathrm{D} 620 \mathrm{E}_{7} 81 \mathrm{C}_{3}>$ [dostęp: 5.02.2019].

Platon, S., Le respect de l'identité nationale des Etats membres: frein ou recomposition de la gouvernance?, "Revue de l'Union européenne” 2012, nr 556.

Polakiewicz, J., Accession to the European Convention on Human Rights (ECHR) - An Insider's View Addressing One By One the CJEU's Objections in Opinion 2/13, "Human Rights Law Journal" 2016, nr 1-6, vol. 36.

Półtorak, N., Zakres związania państw członkowskich Karta Praw Podstawowych Unii Europejskiej, "Europejski Przegląd Sądowy” 2014, nr 9.

Pyziak-Szafnicka, M., Karta Praw Podstawowych UE w orzecznictwie Trybunatu Konstytucyjnego, "Europejski Przegląd Sądowy” 2016, nr 8.

Quinn, G., The European Union and the Council of Europe on the Issue of Human Rights: Twins Separated at Birth?, "McGill Law Journal” 2000-2001, nr 46.

Rauchegger, C., National Constitutional Rights and the Primacy of EU Law: M.A.S, "Common Market Law Review" 2018, nr 55 (5).

Ravasi, E., Human Rights Protection by the ECtHR and the ECJ. A Comparative Analysis in Light of the Equivalency Doctrine, Leiden 2017.

Reestman, J.-H., The Franco-German Constitutional Divide. Reflections on National and Constitutional Identity, "European Constitutional Law Review” 2009, nr 5 (3).

Relacja z konferencji "Niezależność sądów i niezawisłość sędziów gwarancja praworządności i praw człowieka”, "Krajowa Rada Sądownictwa. Kwartalnik” 2012, nr 2 (15).

Rodríguez-Izquierdo Serrano, M., The Spanish Constitutional Court and Fundamental Rights Adjudication After the First Preliminary Reference, "German Law Journal” 2015, nr 16 (6).

Rosas, A., The Applicability of the EU Charter of Fundamental Rights at National Level, „European Yearbook of Human Rights" 2013, nr 13.

Rosas, A., When is the EU Charter of Fundamental Rights Applicable at National Level?, "Jurisprudence" 2012, nr 19.

Rozmaryn, S., Konstytucja jako ustawa zasadnicza PRL, Warszawa 1967.

Rycko, N., Klauzula porzadku publicznego a normy konstytucyjne, [w:] S. Biernat (red.), Konstytucja Rzeczypospolitej polskiej w pierwszych dekadach XXI wieku wobec wyzwań politycznych, gospodarczych i społecznych, Warszawa 2013.

Sadurski, W., European Constitutional Identity?, EUI Working Paper, LAW 2006, nr 33.

Sadurski, W., 'Solange, chapter 3': Constitutional Courts in Central Europe - Democracy European Union, EUI Working Paper, LAW 2006, nr 40.

Safjan, M., Areas of Application of the Charter of Fundamental Rights of the European Union: Fields of Conflict?, EUI Working Paper, LAW 2012, nr 22.

Safjan, M., Dialog czy konflikt? O relacji Trybunału Sprawiedliwości Unii Europejskiej i sądów konstytucyjnych w dziedzinie zastosowania praw podstawowych, "Zeszyty Naukowe Sądownictwa Administracyjnego" 2015, rok XI, nr 1 (58). 
Safjan, M., Europa sędziów. Europa dialogu, [w]: „Na wokandzie” 2011, nr 7, [online] <https://nawokandzie.ms.gov.pl/numer-7/opinie-7/europa-sedziow-europa-dialogu. html> [dostęp: 7.02.2019].

Safjan, M., Konstytucja a Karta Praw Podstawowych. Dylematy wyboru właściwego standardu ochrony, [w:] P. Radziewicz, J. Wawrzyniak (red.), Konstytucja, rzad, parlament: księga jubileuszowa Profesora Jerzego Ciemniewskiego, Warszawa 2014.

Safjan, M., Wprowadzenie, [w:] M. Safjan, L. Bosek (red.), Konstytucja RP. Komentarz, t. 1, Warszawa 2016.

Safjan, M., Wyzwania dla państwa prawa, Warszawa 2007.

Sakowicz, A., Zasada ne bis in idem w prawie karnym w ujęciu paneuropejskim, Białystok 2011.

Sanetra, W., Bezpośrednie stosowanie Konstytucji RP przez Sąd Najwyższy, „Przegląd Sądowy" 2017, $\mathrm{nr} 2$.

Sarmiento, D., The EU's Constitutional Core, [w:] A. Saiz Arnaiz, C. Alcoberro (red.), National Constitutional Identity and European Integration, Cambridge-Antwerp-Portland 2013.

Sarmiento, D., Who's Afraid of the Charter? The Court of Justice, National Courts and the New Framework of Fundamental Rights Protection in Europe, "Common Market Law Review" 2013, nr 50 (5).

Sarnecki, P., Artykut 126, [w:] L. Garlicki (red.), Konstytucja Rzeczypospolitej Polskiej. Komentarz, t. 1, Warszawa 1999.

Sarnecki, P., Artykut 9, [w:] L. Garlicki, M. Zubik (red.), Konstytucja Rzeczpospolitej Polskiej. Komentarz, t. 1, Warszawa 2016.

Saul, B., Kinley, D., Mowbray, J., The International Covenant on Economic, Social and Cultural Rights. Commentary, Cases Materials, Oxford 2014.

Schmitt, C., Verfassungslehre, Berlin 1928.

Schütze, R., European Union Law, Cambridge 2015.

Schyff van der, G., The Constitutional Relationship between the European Union and its Member States: The Role of National Identity in Articla 4(2) TEU, "European Law Review" 2012, nr 37.

Sędek, J., Konferencja "Niezależność sądów i trybunałów jako gwarancja praw i wolności człowieka", Warszawa, 5 marca 2016 r., "Palestra” 2016, nr 5.

Skrzydło, J., Karta Praw Podstawowych UE w praktyce brytyjskiej, „Europejski Przegląd Sądowy" 2015, nr 10.

Snyder, F., The Effectiveness of European Community Law: Institutions, Processes, Tools and Techniques, "The Modern Law Review” 1993, nr 56 (1).

Spaventa, E., The Interpretation of Article 51 of the EU Charter of Fundamental Rights: the Dilemma of Stricter or Broader Application of the Charter to National Measures, European Parliament STUDY, PE 556.930.

Stępkowski, A., Zasada proporcjonalności w europejskiej kulturze prawnej. Sądowa kontrola władzy dyskrecjonalnej w nowoczesnej Europie, Warszawa 2010.

Stone Sweet, A., A Cosmopolitan Legal Order: Constitutional Pluralism and Rights Adjudication in Europe, "Journal of Global Constitutionalism" 2012, $\operatorname{nr} 1$ (1).

Szewczyk, M.J., Glosa do postanowienia SN z dnia 28 listopada 2013 r., I KZP 15/13, LEX 195443. 
Szpunar, M., Kilka uwag systematyzujących na temat zakresu zastosowania Karty Praw Podstawowych UE, „Europejski Przegląd Sądowy” 2015, nr 10.

Szydło, M., Art. 22. [Dopuszczalność ograniczenia wolności działalności gospodarczej], [w:] M. Safjan, L. Bosek (red.), Konstytucja RP. Komentarz, t. 1, Warszawa 2016.

Taborowski, M., Konsekwencje naruszenia prawa UE przez sądy krajowe, Warszawa 2012.

Taborowski, M., Polska tożsamość konstytucyjna a prymat prawa UE, [online] <http:// www.obserwatorkonstytucyjny.pl/debaty/polskatozsamosckonstytucyjnaaprymatprawaue/> [dostęp: 5.02.2019].

Thorson, B., Individual Rights in EU Law, Cham 2016.

Thym, D., Attack or Retreat? Evolving Themes and Strategies of the Judicial Dialogue between the German Constitutional Court and the European Court of Justice, [w:] M. Claes, M. de Visser, P. Popelier, C. van de Heyning (red.), Constitutional Conversations in Europe. Actors, Topics and Procedures, Antwerp 2012.

Toggenburg, G.N., Die ,falsche Fürstin': Zum grenzüberschreitenden Verkehr von Adelstiteln vor dem Hintergrund der Unionsbürgerschaft, "European Law Reporter" 2011, nr 3.

Tomuschat, C., The Defence of National Identity by the German Constitutional Court, [w:] A. Saiz Arnaiz, C. Alcoberro (red.), National Constitutional Identity and European Integration, Cambridge-Antwerp-Portland 2013.

Toniatti, R., Sovereignty Lost, Constitutional Identity Regained, [w:] A. Saiz Arnaiz, C. Alcoberro (red.), National Constitutional Identity and European Integration, Cambridge-Antwerp-Portland 2013.

Torres Pérez, A., Constitutional Identity and Fundamental Rights: The Intersection between Articles 4(2) TEU and 53 Charter, [w:] A. Saiz Arnaiz, C. Alcoberro (red.), National Constitutional Identity and European Integration, Cambridge-Antwerp-Portland 2013.

Torres Pérez, A., Melloni in Three Acts: From Dialogue to Monologue, „European Constitutional Law Review" 2014, nr 10 (2).

Torres Pérez, A., The Federalizing Force of the EU Charter of Fundamental Rights, "International Journal of Constitutional Law" 2017, nr 4.

Trzcińska, A., Europejski Mechanizm Stabilności jako stabilizator w planowanej unii finansowej, [online] <https://www.nbp.pl/badania/seminaria/1oiv2013.pdf> [dostęp: 28.12.2018].

Tuominen, T., C-62/14 Gauweiler: How the ECJ Avoided Stockholm Syndrome but Risks either a Standoff or a Stalemate, [online] <https://acelg.blogactiv.eu/2015/10/26/c6214-gauweiler-how-the-ecj-avoided-stockholm-syndrome-but-risks-either-a-standoff-or-a-stalemate/> [dostęp: 5.02.2019].

Tuori, K., From Copenhagen to Venice, [w:] C. Closa, D. Kochenov (red.), Reinforcing Rule of Law Oversight in the European Union, Cambridge 2016.

Tuori, K., The European Financial Crisis: Constitutional Aspects and Implications, EUI Working Paper, LAW 2012, nr 28.

Villalón, P.C., 'All the guidance', ERT and Wachauf, [w:] M.P. Maduro, L. Azoulai (red.), The Past and Future of EU Law: The Classics of EU Law Revisited on the 5oth Anniversary of the Rome Treaty, Oxford-Portland 2010.

Voßkuhle, A., Multilevel Cooperation of the European Constitutional Courts: Der Europäische Verfassungsgerichtsverbund, "European Constitutional Law Review” 2010, nr 6 (2). 
Walker, N., The Idea of Constitutional Pluralism, EUI Working Paper, LAW 2002, nr 1.

Ward, A., Art. 51, [w:] S. Peers, T. Harvey, J. Kenner, A. Ward (red.), The EU Charter of Fundamental Rights. A Commentary, Oxford 2014.

Weiler, J.H.H., Czy Europa potrzebuje konstytucji? Demos, telos i orzeczenie Niemiec w sprawie Traktatu z Maastricht, "Nowa Europa” 2005, nr 1 (1).

Weiler, J.H.H., Europa końca wieku: czy nowe szaty maja swojego cesarza?, "Nowa Europa” 2007, $\operatorname{nr} 1(5)$.

Weiler, J.H.H., Fundamental Rights and Fundamental Boundaries: on the Conflict of Standards and Values in the Protection of Human Rights in the European Legal Space, [w:] J.H.H. Weiler (red.), The Constitution of Europe, Cambridge 1999.

Weiler, J.H.H., The Political and Legal Culture of European Integration: An Exploratory Essay, "International Journal of Constitutional Law" 2011, nr 9 (3-4).

Weiler, J.H.H. (red.), The Constitution of Europe, Cambridge 1999.

Weiler, J.H.H., Lockhart, N.J.S., "Taking rights seriously" Seriously: The European Court and its Fundamental Rights Jurisprudence - part I, "Common Market Law Review" 1995, $\operatorname{nr} 32$ (1).

Whittington, K., Political Foundations of Judicial Supremacy: The Presidency, the Supreme Court, and Constitutional Leadership in U.S. History, Princeton 2007.

Wieruszewski, R., Artykut 5. Podstawowe zasady interpretacji postanowień Paktu, [w:] R. Wieruszewski (red.), Międzynarodowy Pakt Praw Obywatelskich (Osobistych) i Politycznych. Komentarz, Warszawa 2012.

Wieruszewski, R., Postanowienia Karty Praw Podstawowych w świetle wiążacych Polskę umów międzynarodowych i postanowień Konstytucji RP z 1997 r., [w:] J. Barcz (red.), Ochrona praw podstawowych w Unii Europejskiej, Warszawa 2008.

Wieruszewski, R., Rola i znaczenie Karty Praw Podstawowych Unii Europejskiej dla ochrony praw człowieka, "Przegląd Sejmowy” 2008, nr 2 (85).

Wildhaber, L., Precedent in the European Court of Human Rights, [w:] P. Mahoney, H. Petzold (red.), Protecting Human Rights: The European Perspective, Köln 2000.

Wiśniewski, A., Koncepcja marginesu oceny w orzecznictwie Europejskiego Trybunału Praw Człowieka, Gdańsk 2008.

Wojtyczek, K., Przekazywanie kompetencji państwa organizacjom międzynarodowym, Kraków 2007.

Wojtyczek, K., Trybunat Konstytucyjny w europejskim systemie konstytucyjnym, „Przegląd Sejmowy" 2009, nr 4 (93).

Wojtyczek, K., Zasada skargowości w procedurze kontroli norm przed polskim Trybunałem Konstytucyjnym, "Przegląd Sejmowy” 2003, nr 1.

Wójtowicz, K., Art. 9. [Zasada przestrzegania prawa międzynarodowego], [w:] M. Safjan, L. Bosek (red.), Konstytucja. Komentarz, t. 1, Warszawa 2016.

Wójtowicz, K., Poszanowanie tożsamości konstytucyjnej państw członkowskich Unii Europejskiej, "Przegląd Sejmowy” 2010, 4 (99).

Wójtowicz, K., Sądy konstytucyjne wobec prawa Unii Europejskiej, Warszawa 2012.

Wójtowicz, K., Traktat akcesyjny, [w:] M. Derlatka, L. Garlicki, M. Wiącek (red.), Na straży państwa prawa. Trzydzieści lat orzecznictwa Trybunału Konstytucyjnego, Warszawa 2016. 
Wójtowicz, K., Zachowanie tożsamości konstytucyjnej państwa polskiego w ramach UE uwagi na tle wyroku TK z 24.11.2010 r. (K 32/og), "Europejski Przegląd Sądowy” 2011, nr 11.

Wronkowska, S., Podstawowe pojęcia prawa i prawoznawstwa, Poznań 2003.

Wronkowska, S., Ziembiński, Z., Zarys teorii prawa, Poznań 2001.

Wróbel, A., Art. 51. Zakres zastosowania, [w:] A. Wróbel (red.), Karta Praw Podstawowych Unii Europejskiej. Komentarz, Warszawa 2013.

Wróbel, A., O niektórych problemach sądowego stosowania Karty Praw Podstawowych, [w:] A. Wróbel (red.), Karta Praw Podstawowych w europejskim i krajowym porządku prawnym, Warszawa 2009.

Wróbel, A., Tożsamość narodowa, czyli różnorodność w jednorodności, „Europejski Przegląd Sądowy" 2012, nr 8.

Wróblewski, M., Karta Praw Podstawowych UE w orzecznictwie Trybunału Konstytucyjnego - stan obecny i perspektywy, "Europejski Przegląd Sądowy” 2015, nr 10.

Wróblewski, M., Karta Praw Podstawowych Unii Europejskiej w polskim sq̨downictwie problemy i wyzwania, "Krajowa Rada Sądownictwa” 2015, nr 2 (27).

Wróblewski, M., Bojarski, Ł., Schindlauer, D., Wladasch, K., Karta Praw Podstawowych Unii Europejskiej jako żywy instrument. Podręcznik dla prawników, Warszawa 2014.

Wyrozumska, A., Inkorporacja Karty Praw Podstawowych do prawa UE: status Karty w prawie UE, zakres obowiazywania i stosowania, główne problemy interpretacyjne z uwzglednieniem stanowiska polskiego, [w:] J. Barcz (red.), Ochrona praw podstawowych w Unii Europejskiej, Warszawa 2008.

Wyrozumska, A., Znaczenie prawne zmiany statusu Karty Praw Podstawowych Unii Europejskiej w Traktacie lizbońskim oraz Protokołu polsko-brytyjskiego, "Przegląd Sejmowy" 2008, nr 2(85).

Wyrzykowski, M., Wiele hałasu o nic? Racjonalizowanie irracjonalności na przykładzie Protokotu polsko-brytyjskiego do Karty Praw Podstawowych UE, [w:] J. Wawrzyniak, M. Laskowska (red.), Instytucje prawa konstytucyjnego w dobie integracji europejskiej. Ksiega jubileuszowa Marii Kruk-Jarosz, Warszawa 2009.

Wyrzykowski, M., Wprowadzenie: granice władzy i granice interpretacji, [w:] J. Barcz (red.), Ochrona praw podstawowych w Unii Europejskiej, Warszawa 2008.

Zaccaroni, G., The Good, The Bad, And The Ugly: National Constitutional Judges And The EU Constitutional Identity, "Italian Journal of Public Law" 2018, nr 10 (2).

Zbiral, R., Nuclear War between the Court of Justice and Czech Constitutional Court (hopefully) averted, [online] <https://verfassungsblog.de/nuclear-war-between-the-court-of-justice-and-czech-constitutional-court-hopefully-averted/> [dostęp: 5.02. 2019].

Zemánek, J., An 'Entirely-Specific' Situation or a Routine Limitation of the National Autonomy? Slovak Pensions XVII of the Czech Constitutional Court, [w:] R. Arnold (red.), Limitations of National Sovereignty through European Integration, Dordrecht 2016.

Zirk-Sadowski, M., Tożsamość konstytucyjna a prawo europejskie, "Analizy Natolińskie” 2012, $\mathrm{nr} 1(53)$.

Zubik, M., "Akt normatywny" jako przedmiot kontroli Trybunału Konstytucyjnego, "Gdańskie Studia Prawnicze" 2014, t. XXXI. 


\section{Orzecznictwo}

\section{A. Polskie sądy i trybunały}

\section{Trybunał Konstytucyjny}

Sprawa U 15/88, wyrok z 7 czerwca 1989.

Sprawa K 11/oo, wyrok z 4 kwietnia 2001.

Sprawa K 36/oo, wyrok z 8 października 2002.

Sprawa K 11/03, wyrok z 27 maja 2003.

Sprawa 33/03, wyrok z dnia 21 kwietnia 2004.

Sprawa K 18/03, wyrok z 3 listopada 2004.

Sprawa P 1/05, wyrok z 27 kwietnia 2005.

Sprawa K 18/04, wyrok z 11 maja 2005.

Sprawa Tw 26/05, postanowienie z 27 września 2005.

Sprawa P 37/05, wyrok z 19 grudnia 2006.

Sprawa SK 98/o6, postanowienie z 9 maja 2007.

Sprawa K 41/05, wyrok z 2 lipca 2007.

Sprawa Kp 8/o9, wyrok z 3 grudnia 2009.

Sprawa U 6/o8, postanowienie z 17 grudnia 2009.

Sprawa Sk 26/o8, wyrok z 5 października 2010.

Sprawa Kp 1/o9, wyrok z 13 października 2010.

Sprawa Kp 1/o9, wyrok z 13 października 2010, zdanie odrębne sędziego TK Stanisława Biernata.

Sprawa K 32/o9, wyrok z 24 listopada 2010.

Sprawa P 14/10, wyrok z 5 lipca 2011.

Sprawa Sk 45/o9, wyrok z 16 listopada 2011.

Sprawa P 46/11, wyrok z 22 maja 2013, zdanie odrębne sędzi TK Teresy Liszcz.

Sprawa P 11/12, wyrok z dnia 25 czerwca 2013.

Sprawa K 33/12, wyrok z 26 czerwca 2013.

Sprawa K 33/12, wyrok z 26 czerwca 2013, zdanie odrębne sędziego TK Mirosława

Granata.

Sprawa Sk 65/12, wyrok z 25 lutego 2014.

Sprawa K 23/11, wyrok z 30 lipca 2014.

Sprawa P 50/13, wyrok z 21 października 2014. 
Sprawa K 52/13, wyrok z 10 grudnia 2014.

Sprawa Sk 17/13, postanowienie z 13 stycznia 2015.

Sprawa P 4/14, wyrok z dnia 11 marca 2015.

Sprawa P 40/13, wyrok z 21 kwietnia 2015.

Sprawa Ts 350/14, postanowienie z 5 maja 2015.

Sprawa K 61/13, postanowienie z 7 lipca 2015.

Sprawa Ts 350/14, postanowienie z 1 października 2015.

Sprawa P 32/12, wyrok z 21 października 2015.

Sprawa K 32/14, postanowienie z 3 listopada 2015.

Sprawa P 102/15, postanowienie z 4 listopada 2015.

Sprawa K 47/15, wyrok z 9 marca 2016.

Sprawa P 19/14, postanowienie z dnia 15 grudnia 2016.

Sprawa K 61/13, postanowienie z 17 maja 2017.

\section{Sąd Najwyższy}

Izba Cywilna, sprawa I CKU 204/97, postanowienie z 4 lutego 1998.

Izba Karna, sprawa II KZ 27/04, postanowienie z 8 czerwca 2004.

Izba Pracy, Ubezpieczeń Społecznych i Spraw Publicznych, sprawa III PK 83/o4, wyrok z 7 marca 2005.

Izba Cywilna, sprawa I CK 834/o4, postanowienie z 28 czerwca 2005.

Izba Karna, sprawa III KK 243/o6, postanowienie z 7 lutego 2007.

Izba Pracy, Ubezpieczeń Społecznych i Spraw Publicznych, sprawa III SK 1/10, wyrok z 14 kwietnia 2010.

Izba Pracy, Ubezpieczeń Społecznych i Spraw Publicznych, sprawa III SK 52/10, wyrok $z$ dnia 7 lipca 2011.

Izba Karna, sprawa I KZP 12/12, uchwała z 29 października 2012.

Izba Karna, sprawa III KK 74/13, postanowienie z 21 sierpnia 2013.

Izba Karna, sprawa I KZP 15/13, postanowienie z 28 listopada 2013.

Izba Karna, sprawa V KK 82/13, wyrok z 3 grudnia 2013.

Izba Karna, sprawa IV KK 183/13, wyrok z 8 stycznia 2014.

Izba Pracy, Ubezpieczeń Społecznych i Spraw Publicznych, sprawa I PK 276/13, wyrok z 9 maja 2014.

Izba Pracy, Ubezpieczeń Społecznych i Spraw Publicznych, sprawa II PK 273/13, wyrok z 23 maja 2014 .

Izba Cywilna, II CSK 517/14, wyrok z 24 listopada 2015.

Izba Cywilna, sprawa IV CSK 270/15, wyrok z 16 marca 2016.

Izba Pracy, Ubezpieczeń Społecznych i Spraw Publicznych, sprawa II PK 199/16, wyrok z 12 lipca 2017.

\section{Sądy powszechne}

Sąd Apelacyjny w Szczecinie, sprawa II AKa 1/o9, wyrok z 26 marca 2009. 
Sąd Apelacyjny we Wrocławiu, Wydział I Cywilny, sprawa I ACa 1337/11, wyrok z 29 października 2012.

Sąd Apelacyjny w Katowicach, III Wydział Pracy i Ubezpieczeń Społecznych, sprawa III AUa 497/12, wyrok z 15 listopada 2012.

Sąd Apelacyjny w Białymstoku, II Wydział Karny, sprawa II AKzw 665/13, postanowienie z 17 kwietnia 2013.

Sąd Apelacyjny w Gdańsku, III Wydział Pracy i Ubezpieczeń Społecznych, sprawa III AUa 208/13, wyrok z 19 kwietnia 2013.

Sąd Apelacyjny w Białymstoku Wydział I Cywilny, sprawa I Acz 1479/13, postanowienie z 5 grudnia 2013.

Sąd Rejonowy Wrocław Śródmieście we Wrocławiu, sprawa X P 20/16, wyrok z 3 sierpnia 2016.

\section{Sądy administracyjne}

WSA w Warszawie, sprawa IV SA/Wa 1968/o9, wyrok z 29 kwietnia 2010.

NSA, sprawa II FNP 3/11, wyrok z 21 października 2011.

NSA, sprawa I OSK 810/11, wyrok z 19 lipca 2012.

WSA w Lublinie, sprawa III SA/Lu 476/13, wyrok z 17 listopada 2013.

NSA, sprawa I ONP 1/14, postanowienie z 30 maja 2014.

NSA, sprawa I ONP 3/14, postanowienie z 22 sierpnia 2014.

NSA, sprawa II ONP 4/14, postanowienie z 22 sierpnia 2014.

NSA, sprawa II ONP 5/14, postanowienie z 22 sierpnia 2014.

WSA w Kielcach, sprawa I SA/Ke 496/14, wyrok z 29 grudnia 2014.

NSA, sprawa I OSK 1502/13, wyrok z 24 lutego 2015.

NSA, sprawa II GSK 935/14, wyrok z 22 maja 2015.

WSA w Warszawie, sprawa V SA/Wa 1217/15, wyrok z 6 sierpnia 2015.

WSA w Warszawie, sprawa V SA/Wa 1214/15, wyrok z 12 sierpnia 2015.

NSA, sprawa II OSK 107/14, wyrok z 24 września 2015.

\section{B. TSUE}

\section{Trybunał Sprawiedliwości UE}

NV Algemene Transport- en Expeditie Onderneming van Gend \& Loos p. Netherlands Inland Revenue Administration, ETS, 26/62, wyrok z 5 lutego 1963.

Flaminio Costa p. ENEL, C-6/64, wyrok z 15 lipca 1964.

Internationale Handelsgesellschaft $\mathrm{mbH}$ p. Einfuhr- und Vorratsstelle für Getreide und Futtermittel, 11/70, wyrok z 17 grudnia 1970.

Roland Rutili p. Ministre de l'intérieur, 36-75, wyrok z 28 października 1975.

Rewe-Zentralfinanz eG i Rewe-Zentral AG p. Landwirtschaftskammer für das Saarland, C-33/76, wyrok z 16 grudnia 1976. 
Regina p. Pierre Bouchereau, 30-77, wyrok z 27 października 1977.

Amministrazione delle Finanze dello Stato p. Simmenthal SA, C- 106/77, wyrok z 9 marca 1978.

SpA Eridania - Zuccherifici nazionali i SpA Societa italiana per l'industria degli zuccheri p. Ministro per l'agricoltura e le foreste, Ministro per l'industria, il commercio e l'artigianato i SpA Zuccherifici meridionali, 230/78, wyrok z 27 września 1978.

Rewe-Zentral AG p. Bundesmonopolverwaltung für Branntwein, C 120/78, wyrok z 20 lutego 1979.

Ursula Becker p. Finanzamt Münster-Innenstadt, C-8/81, wyrok z 19 stycznia 1982.

Zuckerfabrik Franken GmbH p. Republice Federalnej Niemiec, 77/81, wyrok z 18 lutego 1982.

Sabine von Colson i Elisabeth Kamann p. Land Nordrhein-Westfalen, C-14/83, wyrok z 10 kwietnia 1984 .

Cinéthèque SA and others p. Fédération nationale des cinémas français, C-6o i 61/84, wyrok z 11 lipca 1985.

Marthe Klensch i inni p. Secrétaire d'État a l'Agriculture et a la Viticulture, C-201/85 i C-202/85, wyrok z 25 listopada 1986.

Foto-Frost p. Hauptzollamt Lübeck-Ost, C-314/85, wyrok z 22 października 1987.

Hubert Wachauf p. Republika Federalna Niemiec, C-5/88, wyrok z 13 lipca 1989.

Anita Groener p. Minister Edukacji i City of Dublin Vocational Education Committee, C-379/87, wyrok z 28 listopada 1989.

The Queen p. Secretary of State for Transport, ex parte: Factortame Ltd i in., C-213/89, wyrok z 19 czerwca 1990.

Massam Dzodzi p. państwu belgijskiemu, C-297/88 i C-197/89, wyrok z 18 października 1990.

Peter Kaefer i Andréa Procacci p. Państwu Francuskiemu, C-100/89 i C-101/89, wyrok z 12 grudnia 1990.

Zuckerfabrik Süderdithmarschen AG p. Hauptzollamt Itzehoe i Zuckerfabrik Soest GmbH przeciwko Hauptzollamt Paderborn, C-143/88 i C-92/89, wyrok z 21 lutego 1991.

Elliniki Radiophonia Tiléorassi AE i Panellinia Omospondia Syllogon Prossopikou p. Dimotiki Etairia Pliroforissis i Sotirios Kouvelas i Nicolaos Avdellas et al., C-260/89, wyrok z 18 czerwca 1991.

The Society for the Protection of Unborn Children Ireland Ltd p. Stephen Grogan and others, C-159/90, wyrok z 4 października 1991.

The Queen p. Ministry of Agriculture, Fisheries and Food, ex parte Dennis Clifford Bostock, C-2/92, wyrok z 24 marca 1994.

Bernard Keck i Daniel Mithouard, C-267/91 i C-268/91, wyrok z 24 listopada 1994.

Komisja p. Wielkiemu Księstwu Luksemburga, C-473/93, wyrok z 2 lipca 1996.

Friedrich Kremzow p. Republik Österreich, C-299/95, wyrok z 29 maja 1997.

Vereinigte Familiapress Zeitungsverlags- und vertriebs $\mathrm{GmbH}$ p. Heinrich Bauer Verlag, C-368/95, wyrok z 26 czerwca 1997.

Daniele Annibaldi p. Sindaco del Comune di Guidonia, Presidente Regione Lazio, C-309/96, wyrok z 18 grudnia 1997 . 
Kjell Karlsson i inni p. Szwecji, C-292/97, wyrok z 13 kwietnia 2000.

Postępowanie karne p. Jean-Pierre Guimont, C-448/98, wyrok z 5 grudnia 2000.

Bernard Connolly p. Komisji Wspólnot Europejskich, C-274/99, wyrok z 6 marca 2001.

Rudy Grzelczyk p. Centre public d'aide sociale d'Ottignies-Louvain-la-Neuve, C-184/99, wyrok z 20 września 2001.

Mary Carpenter p. Secretary of State for the Home Department, C-6o/oo, wyrok z 11 lipca 2002.

Unión de Pequeños Agricultores p. Radzie Unii Europejskiej, C-5O/oo P, wyrok z 25 lipca 2002.

Baumbast i R p. Secretary of State for the Home Department, C-413/99, wyrok 17 września 2002.

Roquette Frères SA p. Directeur général de la concurrence, de la consommation et de la répression des fraudes, and Commission of the European Communities, C-94/oo, wyrok z 22 października 2002.

Ángel Rodríguez Caballero p. Fondo de Garantía Salarial (Fogasa), C-442/oo, wyrok z 12 grudnia 2002.

Joachim Steffensen, C-276/o1, wyrok z 10 kwietnia 2003.

Rechnungshof p. Österreichischer Rundfunk i innym oraz Christa Neukomm i Joseph Lauermann p. Österreichischer Rundfunk, C-465/oo, C-138/o1, C-139/o1, wyrok z 20 maja 2003.

Eugen Schmidberger, Internationale Transporte und Planzüge p. Republik Österreich, C-112/oo, wyrok z 12 czerwca 2003.

Booker Aquacultur Ltd i Hydro Seafood GSP Ltd p. The Scottish Ministers, C-20/oo i C-64/oo, wyrok z 10 lipca 2003.

Carlos Garcia Avello p. państwu belgijskiemu, C-148/o2, wyrok z 2 października 2003.

RTL Television GmbH p. Niedersächsische Landesmedienanstalt für privaten Rundfunk, C-245/O1, wyrok z 23 października 2003.

Herbert Karner Industrie-Auktionen $\mathrm{GmbH}$ p. Troostwijk $\mathrm{GmbH}, \mathrm{C}-71 / 02$, wyrok z 25 marca 2004.

Wolff \& Müller GmbH \& Co. KG p. José Filipe Pereira Félix, C-6o/o3, wyrok z 12 października 2004.

Omega Spielhallen-und Automatenaufstellungs-GmbH p. Oberbürgermeisterin der Bundesstadt Bonn, C-36/o2, wyrok z 14 października 2004.

Kunqian Catherine Zhu i Man Lavette Chen p. Secretary of State for the Home Department, C-200/02, wyrok z 19 października 2004.

Postępowanie karne przeciwko Marcel Burmanjer, René Alexander Van Der Linden i Anthony De Jong, C-20/03, wyrok z 26 maja 2005.

Werner Mangold p. Rüdiger Helm, C-144/o4, wyrok z 22 listopada 2005.

The Queen, na wniosek International Air Transport Association i European Low Fares Airline Association p. Department for Transport, C-344/o4, wyrok z 10 stycznia 2006.

A-Punkt Schmuckhandels GmbH p. Claudia Schmidt, C-441/o4, wyrok z dnia 23 lutego 2006.

Laserdisken ApS p. Kulturministeriet, C-479/o4, wyrok z 12 września 2006.

Fidium Finanz AG p. Bundesanstalt für Finanzdienstleistungsaufsicht, C-452/o4, wyrok z 3 października 2006. 
Republika Federalna Niemiec p. Parlamentowi Europejskiemu i Rada Unii Europejskiej, C-38o/o3, wyrok z 12 grudnia 2006.

Ministero dell'Industria, del Commercio e dell'Artigianato p. Lucchini SpA, C-119/o5, wyrok z 18 lipca 2007.

Josefa Velasco Navarro p. Fondo de Garantía Salarial (Fogasa), C-246/o6, wyrok z 17 stycznia 2008.

Productores de Música de España (Promusicae) p. Telefónica de España SAU, C-275/o6, wyrok z 29 stycznia 2008.

Dynamic Medien Vertriebs GmbH p. Avides Media AG, C-244/o6, wyrok z 14 lutego 2008.

Komisja Wspólnot Europejskich p. Wielkiemu Księstwu Luksemburga, C-319/o6, wyrok z 19 czerwca 2008.

Ministerul Administrației şi Internelor - Direcția Generală de Paşapoarte Bucureşti p. Gheorghe Jipa, C-33/o7, wyrok z 10 lipca 2008.

Yassin Abdullah Kadi i Al Barakaat International Foundation p. Radzie Unii Europejskiej i Komisja Wspólnot Europejskich, C-402/05 P i C-415/o5 P, wyrok z 3 września 2008.

Stefan Grunkin i Dorothee Regina Paul, C-353/o6, wyrok z 14 października 2008.

Michaniki AE p. Ethniko Symvoulio Radiotileorasis i Ypourgos Epikrateias, C-213/o7, wyrok z 16 grudnia 2008.

Sopropé - Organizações de Calçado Lda p. Fazenda Pública, C 349/o7, wyrok z 18 grudnia 2008.

Postępowanie karne przeciwko Frede Damgaard, C-421/o7, wyrok z 2 kwietnia 2009. Seda Kücükdeveci p. Swedex GmbH \& Co. KG, C-555/o7, wyrok z 19 stycznia 2010. Janko Rottman p. Freistaat Bayern, C-135/o8, wyrok z dnia 2 marca 2010.

Raffinerie Mediterranee (ERG) SpA, Polimeri Europa SpA i Syndial SpA p. Ministero dello Sviluppo economico and Others oraz ENI SpA p. Ministero Ambiente e Tutela del Territorio e del Mare and Others, C-379/o8 i 380/o8, wyrok z 9 marca 2010.

Aziz Melki i Sélim Abdeli, C-188/10 i C-189/10 wyrok z 22 czerwca 2010.

Winner Wetten GmbH p. Bürgermeisterin der Stadt Bergheim, C-409/o6, wyrok z 8 września 2010.

J. McB. p. L.E., C-40o/10, wyrok z 5 października 2010.

Krasimir Asparuhov Estov i inni p. Ministerski savet na Republika Bulgaria, C-339/10, postanowienie z 12 listopada 2010.

Marc Michel Josemans p. Burgemeester van Maastricht, C-137/o9, wyrok z 16 grudnia 2010.

DEB Deutsche Energiehandels- und Beratungsgesellschaft $\mathrm{mbH}$ p. Bundesrepublik Deutschland, C-279/o9, wyrok z 22 grudnia 2010.

Ilonka Sayn-Wittgenstein p. Landeshauptmann von Wien, C-208/o9, wyrok z 22 grudnia 2010.

Claude Chartry p. państwu belgijskiemu, C-457/o9, postanowienie z 1 marca 2011.

Gerardo Ruiz Zambrano p. Office national de l'emploi (ONEm), C-34/o9, wyrok z 8 marca 2011.

Malgožata Runevič-Vardyn i Łukasz Paweł Wardyn p. Vilniaus miesto savivaldybės administracija i inni, C-391/o9, wyrok z 12 maja 2011. 
André Rossius i Marc Collard p. państwu belgijskiemu - Service public fédéral Finances, C-267/1o i C-268/10 postanowienie z 23 maja 2011.

Marie Landtová p. Česká správa socialního zabezpečení, C-399/o9, wyrok z 22 czerwca 2011.

Postępowania karne przeciwko Magatte Gueye i Valentín Salmerón Sánchez, C-483/o9 i C-1/10, wyrok z 15 września 2011.

Hubert Pagnoul p. państwu belgijskiemu, C-314/10, postanowienie z 22 września 2011. Murat Dereci i inni p. Bundesministerium für Inneres, C-256/11, wyrok z 15 listopada 2011.

N.S. p. Secretary of State for the Home Department oraz M.E., A.S.M., M.T., K.P., E.H. p. Refugee Applications Commissioner, Minister for Justice, Equality and Law Reform, C-411/10 i C-493/10, wyrok z 21 grudnia 2011.

Dermod Patrick O'Brien p. Ministry of Justice, dawniej Department for Constitutional Affairs, C-393/10, wyrok z 1 marca 2012.

Postępowanie karne przeciwko Łukasz Marcin Bonda, C-489/10, wyrok z 5 czerwca 2012.

Anton Winkow p. Naczałnik Administratiwno-nakazatełna dejnost, C 27/11, wyrok z 7 czerwca 2012.

Fortuna sp. z o.o. i in. p. Dyrektorowi Izby Celnej w Gdyni, C-213/11, C-214/11 i C-217/11, wyrok z 19 lipca 2012.

Węgry p. Republice Słowackiej, C-364/10, wyrok z 16 października 2012.

Yoshikazu Iida p. Stadt Ulm, C-40/11, wyrok z 8 listopada 2012.

Thomas Pringle p. Government of Ireland, Ireland i The Attorney General, C-370/12, wyrok z 27 listopada 2012.

Republika Włoska p. Komisji Europejskiej, C-566/1o P, wyrok z 27 listopada 2012.

Iwona Szyrocka p. SiGer Technologie GmbH, C-215/11, wyrok z 19 grudnia 2012.

Åklagaren p. Hans Åkerberg Fransson, C-617/10, wyrok z 26 lutego 2013.

Stefano Melloni p. Ministerio Fiscal, C-399/11, wyrok z 26 lutego 2013.

Anton Las p. PSA Antwerp NV, C-202/11, wyrok z 16 kwietnia 2013.

Gena Ivanova Cholakova p. Osmo rayonno upravlenie pri Stolichna direktsia na vatreshnite raboti, C-14/13, postanowienie z 6 czerwca 2013.

ET Agrokonsulting-o4-Velko Stoyanov p. Izpalnitelen direktor na Darzhaven fond «Zemedelie» - Razplashtatelna agentsia, C-93/12, wyrok z 27 czerwca 2013.

Komisja Europejskiej i in. p. Yassin Abdullah Kadi, C-584/1o P, C-593/1o P i C-595/10 P, wyrok z 18 lipca 2013.

JS, C-253/12, sprawa wycofana 18 lipca 2013.

Texdata Software GmbH, C-418/11, wyrok z 26 września 2013.

Nagy Sándor p. Hajdú-Bihar Megyei Kormányhivatal, Lajos Tiborné Böszörményi, Róbert Gálóczhi-Tömösváry, Magdolna Margit Szabadosné Bay p. Mezőgazdasági és Vidékfejlesztési Hivatal i Józsefné Ványai p. Nagyrábé Község Polgármesteri Hivatal, C-488/12, C-489/12, C-49o/12, C-491/12 i C-526/12, postanowienie z 10 października 2013.

Michael Schwarz p. Stadt Bochum, C-291/12, wyrok z 17 października 2013.

Jiří Sabou p. Finanční ředitelství pro hlavní město Prahu, C-276/12, wyrok z 22 października 2013. 
Sociedade Agrícola e Imobiliária da Quinta de S. Paio Lda p. Instituto da Segurança Social IP, C-258/13, postanowienie z 28 listopada 2013.

Association de médiation sociale p. Union locale des syndicats CGT i inni, C-176/12, wyrok z 15 stycznia 2014.

Cruciano Siragusa p. Regione Sicilia, C-206/13, wyrok z 6 marca 2014.

O. p. Minister voor Immigratie, Integratie en Asiel, oraz Minister voor Immigratie, Integratie en Asiel p. B., C-456/12, wyrok z 12 marca 2014.

Emiliano Torralbo Marcos p. Korota SA and Fondo de Garantía Salarial, C-265/13, wyrok z 27 marca 2014.

Urszula Leśniak-Jaworska i Małgorzata Głuchowska-Szmulewicz p. Prokuratura Okręgowa w Płocku, C-520/13, postanowienie z 27 marca 2014.

Digital Rights Ireland Ltd p. Minister for Communications, Marine and Natural Resources i inni oraz Kärntner Landesregierung i inni, C-293/12 i C-594/12 wyrok z 8 kwietnia 2014.

Postępowanie zainicjowane przez Robert Pfleger i inni, C-390/12, wyrok z 30 kwietnia 2014.

Pelckmans Turnhout NV p. Walter Van Gastel Balen NV i inni, C-483/12, wyrok z 8 maja 2014.

Érsekcsanádi Mezőgazdasági Zrt p. Bács-Kiskun Megyei Kormányhivatal, C-56/13, wyrok z 22 maja 2014.

Wolfgang Glatzel p. Freistaat Bayern, C-356/12, wyrok z 22 maja 2014.

Ryszard Pańczyk p. Dyrektor Zakładu Emerytalno-Rentowego Ministerstwa Spraw Wewnętrznych i Administracji w Warszawie, C-28/14, postanowienie z 12 czerwca 2014 .

Digibet Ltd i Gert Albers p. Westdeutsche Lotterie GmbH \& Co. OHG, C-156/13, wyrok z 12 czerwca 2014 .

Víctor Manuel Julian Hernández i inni p. Reino de España (Subdelegación del Gobierno de España en Alicante) i inni C-198/13, wyrok z 1o lipca 2014.

Angelo Alberto Torresi i Pierfrancesco Torresi p. Consiglio dell'Ordine degli Avvocati di Macerata, C-58/13 i C-59/13 wyrok z 17 lipca 2014.

Juan Carlos Sánchez Morcillo i María del Carmen Abril García p. Banco Bilbao Vizcaya Argentaria SA, C-169/14, wyrok z 17 lipca 2014.

A. p. B. i in., C-112/13, wyrok z 11 września 2014.

Liivimaa Lihaveis MTÜ p. Eesti-Läti programmi 2007-2013 Seirekomitee, C-562/12, wyrok z 17 września 2014.

Elisabeta Dano i Florin Dano p. Jobcenter Leipzig, C-333/13, wyrok z 11 listopada 2014.

Stylinart sp. z o.o. p. Skarb Państwa - Wojewoda Podkarpacki i Skarb Państwa - Prezydent Miasta Przemyśla, C-282/14, postanowienie z 11 grudnia 2014.

Opinia 2/13 wydana w dniu 18 grudnia 2014.

W.P. Willems i in. p. Burgemeester van Nuth i in, C-446/12 do C-449/12, wyrok z 16 kwietnia 2015.

Kernkraftwerke Lippe-Ems GmbH p. Hauptzollamt Osnabrück, C-5/14, wyrok z 4 czerwca 2015.

Peter Gauweiler i in. p. Deutscher Bundestag, C-62/14, wyrok z 16 czerwca 2015. 
Postępowanie karne przeciwko Ivo Taricco i in., C-105/14, wyrok z 8 września 2015.

Gmina Wrocław p. Ministrowi Finansów, C-276/14, wyrok z 29 września 2015.

Thierry Delvigne p. Commune de Lesparre Médoc i Préfet de la Gironde, C-650/13, wyrok z 6 października 2015.

Pál Aranyosi i Robert Căldăraru p. Generalstaatsanwaltschaft Bremen, C-404/15 i C-659/15, wyrok z 5 kwietnia 2016.

Dansk Industri (DI) p. Sucession Karsten Eigil Rasmussen, C-441/14, wyrok z 19 kwietnia 2016.

Halina Grodecka p. Józefowi Konieczce i in., C-50/16, postanowienie z 2 czerwca 2016.

Nabiel Peter Bogendorff von Wolffersdorff p. Standesamt der Stadt Karlsruhe i Zentraler Juristischer Dienst der Stadt Karlsruhe, C-438/14, wyrok z 2 czerwca 2016.

Postępowanie karne p. Piotrowi Kossowskiemu, C-486/14, wyrok z 29 czerwca 2016.

JZ p. Prokuraturze Rejonowej Łódź-Śródmieście, C-294/16 PPU, wyrok z 28 lipca 2016.

Postępowanie karne przeciwko Gianpaolowi Paolettiemu i in., C-218/15, wyrok z 6 października 2016.

Remondis GmbH \& Co. KG Region Nord p. Region Hannover, C-51/15, wyrok z 21 grudnia 2016.

C.K. i in. p. Republika Slovenija, C-578/16 PPU, wyrok z 16 lutego 2017.

RPO, C-39o/15, wyrok z 7 marca 2017.

Postępowanie karne przeciwko M.A.S. i M.B, C-42/17, wyrok z 5 grudnia 2017.

Soufiane El Hassani p. Ministrowi Spraw Zagranicznych, C-403/16, wyrok z 13 grudnia 2017.

Relu Adrian Coman i in. p. Inspectoratul General pentru Imigrări i Ministerul Afacerilor Interne, C-673/16, wyrok z 5 czerwca 2018.

Minister for Justice and Equality (Défaillances du système judiciaire), C-216/18 PPU, wyrok z 25 lipca 2018.

Weiss i in., C-493/17 (sprawa w toku).

\section{Sąd UE}

Yassin Abdullah Kadi p. Radzie Unii Europejskiej i Komisji Wspólnot Europejskich, T-315/o1, wyrok z 21 września 2005.

Manfred Danzer i Hannelore Danzer p. Radzie Unii Europejskiej, T-47/o2, wyrok z 21 czerwca 2006.

Balázs-Árpád Izsák i Attila Dabis p. Komisji Europejskiej, T-529/13, wyrok z 10 maja 2016.

\section{Opinie Rzeczników Generalnych TSUE}

Christos Konstantinidis p. Stadt Altensteig - Standesamt i Landratsamt Calw - Ordnungsamt, C-168/91, opinia Rzecznika Generalnego Francisa Jacobsa przedstawiona w dniu 9 grudnia 1992. 
Michaniki AE p. Ethniko Symvoulio Radiotileorasis i Ypourgos Epikrateias, C-213/o7, opinia Rzecznika Generalnego M. Poiaresa Madura przedstawiona w dniu 8 października 2008.

Kingdom of the Netherlands p. Council of the European Union, C-58/94, opinia Rzecznika Generalnego A.G. Tesauro przedstawiona w dniu 28 listopada 1995.

Królestwo Hiszpanii p. Eurojustowi, C-16o/o3, opinia Rzecznika Generalnego M. Poiaresa Madura przedstawiona w dniu 16 grudnia 2004.

Cristiano Marrosu, Gianluca Sardino p. Azienda Ospedaliera Ospedale San Martino di Genova e Cliniche Universitarie Convenzionateoraz Andrea Vassallo p. Azienda Ospedaliera Ospedale San Martino di Genova e Cliniche Universitarie Convenzionate, C-53/04 i C-180/o4, opinia Rzecznika Generalnego M. Poiaresa Madura przedstawiona w dniu 20 września 2005.

Unión General de Trabajadores de la Rioja UGT-RIOJA p. Juntas Generales del Territorio Histórico de Vizcaya i in., C-428/o6, C-429/o6, C-430/o6, C-431/o6, C-432/o6, C-433/o6 i C-434/o6, opinia Rzecznika Generalnego Juliane Kokott przedstawiona w dniu 8 maja 2008.

Birgit Bartsch p. Bosch und Siemens Hausgeräte (BSH) Altersfürsorge $\mathrm{GmbH}$, C-427/o6, wyrok z 23 września 2008, opinia Rzecznika Generalnego Eleanor Sharpston przedstawiona w dniu 22 maja 2008.

Unión de Televisiones Comerciales Asociadas (UTECA), C-222/o7, opinia Rzecznika Generalnego Juliane Kokott przedstawiona w dniu 4 września 2008.

Gerardo Ruiz Zambrano p. Office national de l'emploi (ONEm), C-34/o9, opinia Rzecznika Generalnego Eleanor Sharpston przedstawiona w dniu 30 września 2010.

N.S. p. Secretary of State for the Home Department oraz M.E., A.S.M., M.T., K.P., E.H. p. Refugee Applications Commissioner, Minister for Justice, Equality and Law Reform, C-411/10 i C-493/10, opinia Rzecznika Generalnego Vericy Trstenjak przedstawiona w dniu 22 września 2011.

Postępowanie karne przeciwko Łukasz Marcin Bonda, C-489/10, opinia Rzecznika Generlanego Juliane Kokott przedstawiona w dniu 15 grudnia 2011.

Åklagaren p. Åkerberg Fransson, C-617/10, opinia Rzecznika Generalnego Pedra Cruza Villalóna przedstawiona w dniu 12 czerwca 2012.

Anton Las p. PSA Antwerp NV, C-202/11, opinia Rzecznika Generalnego Niila Jääskinena przedstawiona $\mathrm{w}$ dniu 12 lipca 2012.

O. p. Minister voor Immigratie, Integratie en Asiel i Minister voor Immigratie, Integratie en Asiel p. B., C-456/12 oraz S. p. Minister voor Immigratie, Integratie en Asiel i Minister voor Immigratie, Integratie en Asiel p. G., C-457/12, opinia Rzecznika Generalnego Eleanor Sharpston przedstawiona w dniu 12 grudnia 2013.

Angelo Alberto Torresi i Pierfrancesco Torresi przeciwko Consiglio dell'Ordine degli Avvocati di Macerata, C-58/13 i C-59/13, opinia Rzecznika Generalnego Nilsa Wahla przedstawiona w dniu 10 kwietnia 2014.

Peter Gauweiler i in. p. Deutscher Bundestag, C-62/14, opinia Rzecznika Generalnego Pedra Cruza Villalóna przedstawiona w dniu 14 stycznia 2015. 
Postępowanie karne przeciwko Gavrilowi Covaciemu, C-216/14, opinia Rzecznika Generalnego Yves'a Bota przedstawiona w dniu 7 maja 2015.

RegioPost GmbH \& Co. KG p. Stadt Landau in der Pfalz, C-115/14, opinia Rzecznika Generalnego Paola Mengozziego przedstawiona w dniu 9 września 2015.

Samira Achbita i Centrum voor gelijkheid van kansen en voor racismebestrijding p. G4S Secure Solutions NV, C-157/15, opinia Rzecznika Generalnego Juliane Kokott przedstawiona w dniu 31 maja 2016.

Remondis GmbH \& Co. KG Region Nord p. Region Hannover, C-51/15, opinia Rzecznika Generalnego Paola Mengozziego przedstawiona w dniu 30 czerwca 2016.

Asma Bougnaoui Association de défense des droits de l'homme (ADDH) p. Micropole SA, C-188/15, opinia Rzecznika Generalnego Eleanor Sharpston przedstawiona w dniu 13 lipca 2016.

Konrad Erzberger p. TUI AG, opinia Rzecznika Generalnego Henrika Saugmandsgaarda Øe przedstawiona 4 maja 2017.

Vera Egenberger p. Evangelisches Werk für Diakonie und Entwicklung e.V., C-414/16, opinia Rzecznika Generalnego Evgeniego Tancheva przedstawiona 9 listopada 2017.

\section{Europejska Komisja Praw Człowieka}

X p. Niemcom, skarga 235/56, decyzja z 10 czerwca 1958.

\section{ETPCz}

Engel i in. p. Niderlandom, skargi nr 5100/71, 5101/71, 5102/71, 5354/72, 5370/72, wyrok z 8 czerwca 1976.

Bosphorus Hava Yolları Turizm ve Ticaret Anonim Şirketi p. Irlandii, skarga 45036/98, wyrok z 30 czerwca 2005.

M.S.S. p. Belgii i Grecji, skarga 30696/o9, wyrok z 21 stycznia 2011.

Michaud p. Francji skarga 12323/11, wyrok z 6 grudnia 2012.

Povse p. Austrii, skarga 3890/11, wyrok z 18 czerwca 2013.

Bujorean p. Rumunii, skarga 13054/12, wyrok z 10 czerwca 2014.

Constantin Aurelian Burlacu p. Rumunii, skarga 51318/12, wyrok z 10 czerwca 2014.

Mihai Laurențiu Marin p. Rumunii, skarga 79857/12, wyrok z 10 czerwca 2014.

Voicu p. Rumunii, skarga 22015/10, wyrok z 10 czerwca 2014.

Tarakhel p. Szwajcarii, skarga 29217/12, wyrok z 4 listopada 2014.

Varga i in. p. Węgrom, skargi 14097/12, 45135/12, 73712/12, 34001/13, 44055/13 i 64586/13, wyrok z 10 marca 2015.

Schipiani i inni p. Włochom, skarga 38369/o9, wyrok z 21 lipca 2015.

Avotinšs p. Łotwie, skarga 17502/o7, wyrok z 26 maja 2016. 


\section{E. Sądy i trybunały innych państw}

\section{Austriacki Trybunał Konstytucyjny}

Sprawa U 466/11 ua, wyrok z 14 marca 2012.

\section{Belgijski Trybunał Konstytucyjny}

Sprawa 62/2016, wyrok z 28 kwietnia 2016.

\section{Brytyjski Sąd Najwyższy}

HS2 Action Alliance Limited v The Secretary of State for Transport, (2014) UKSC 3, wyrok z 22 stycznia 2013.

\section{Czeski Trybunał Konstytucyjny}

Sprawa Pl. ÚS 5/12, wyrok z 31 stycznia 2012.

\section{Duński Sąd Najwyższy}

Sprawa 15/2014, wyrok z 6 grudnia 2016.

\section{Francuska Rada Konstytucyjna}

Decyzja nr 2006-540 DC z 27 lipca 2006.

Decyzja nr 2006-543 DC z 30 listopada 2006.

Decyzja nr 2011-631 DC z o9 czerwca 2011.

\section{Hiszpański Trybunał Konstytucyjny}

Sprawa 1/2004 uchwała z 13 grudnia 2004, BOE nr 3 z 4 stycznia 2005. Sprawa 26/2014, wyrok z 13 lutego 2014, BOE nr 6o z 11 marca 2014.

\section{Niemiecki Federalny Trybunał Konstytucyjny}

2 BvL 52/71, orzeczenie z 22 maja 1974 (Solange I).

2 BvR 197/83, orzeczenie z 22 października 1986 (Solange II). 
2 BvE 2/o8, 2 BvE 5/o8, 2 BvR 1010/o8, 2 BvR 1022/o8, 2 BvR 1259/o8, 2 BvR 182/o9, orzeczenie z 30 czerwca 2009.

2 BvR 2661/o6, orzeczenie z 6 lipca 2010 (Honeywell).

1 BvR 1215/o7, orzeczenie z 24 kwietnia 2013.

2 BvR 2728/13, 2 BvR 2729/13, 2 BvR 2730/13, 2 BvR 2731/13, 2 BvE 13/13, orzeczenie z 14 stycznia 2014 (Gauweiler).

2 BvR 2735/14, orzeczenie z 15 grudnia 2015 (Solange III).

2 BvR 2728/13, 2 BvR 2729/13, 2 BvR 2730/13, 2 BvR 2731/13, 2 BvE 13/13, orzeczenie z 21 czerwca 2016 (Gauweiler).

2 BvR 890/16, orzeczenie z 6 września 2016.

2 BvR 859/15, 2 BvR 1651/15, 2 BvR 2006/15, 2 BvR 980/16, orzeczenie z 18 lipca 2017.

\section{Węgierski Trybunał Konstytucyjny}

Sprawa 22/2016, wyrok z 30 listopada 2016.

\section{Włoski Trybunał Konstytucyjny}

Sprawa 183/1973, wyrok z 27 grudnia 1973 (Frontini). Sprawa 170/1984, wyrok z 5 czerwca 1984 (Granital).

Sprawa 1146/1988, wyrok z 29 grudnia 1988.

Sprawa 232/1989, wyrok z 13 kwietnia 1989 (Fragd).

Sprawa 24/2017, postanowienie z 26 stycznia 2017.

Sprawa 269/2017, wyrok z 7 listopada 2017.

Sprawa 115/2018, wyrok z 31 maja 2018. 


\section{Niektóre inne źródła}

Co to jest EFSF i ESM? [online] <http://www.mf.gov.pl/documents/764034/1417826/23_ efsf-esm.pdf> [dostęp: 28.12.2018].

European Union Agency for Fundamental Rights, Fundamental rights: challenges and achievements in 2014, Luxembourg: Publications Office of the European Union, 2015, [online] <http://fra.europa.eu/sites/default/files/fra-annual-report-2014_en.pdf> [dostęp: 28.12.2018].

European Union Agency for Fundamental Rights, Fundamental Rights Report 2016, Luxembourg: Publications Office of the European Union, 2016, [online] <http:// fra.europa.eu/sites/default/files/fra_uploads/fra-2016-fundamental-rights-report-2016-2_en.pdf> [dostęp: 28.12.2018].

House of Commons, European Scrutiny Committee, The Application of the EU Charter of Fundamental Rights in the UK: A State of Confusion. Forty-third Report of Session 2013-14. Report, together with Formal Minutes, HC 979, Londyn 2014, [online] <http:// www.publications.parliament.uk/pa/cm201314/cmselect/cmeuleg/979/979.pdf> [dostęp: 28.12.2018].

House of Lords Constitution Committee, Session 2007-08: $6^{\text {th }}$ Report, European Union (Amendment) Bill and the Lisbon Treaty: Implications for the UK Constitution, Cm 7417, Londyn 2008, [online] <https://www.gov.uk/government/uploads/system/ uploads/attachment_data/file/243382/7417.pdf> [dostęp: 28.12.2018].

Informacja o istotnych problemach wynikających $z$ działalności i orzecznictwa Trybunału Konstytucyjnego, Warszawa 2006.

Informacja o istotnych problemach wynikajacych $z$ działalności i orzecznictwa Trybunału Konstytucyjnego w 2015 roku, Trybunał Konstytucyjny Wydawnictwa, Warszawa 2016, [online] http://trybunal.gov.pl/fileadmin/content/dokumenty/publikacje/informacje_o_problemach/Informacja2015.pdf [dostęp: 28.12.2018].

Naczelny Sąd Administracyjny, Informacja o działalności sądów administracyjnych w 2013 roku, Biuro Orzecznictwa Naczelnego Sądu Administracyjnego, Warszawa, 23 kwietnia 2014, [online] <http://www.nsa.gov.pl/sprawozdania-roczne.php> [dostęp: 28.12.2018].

Naczelny Sąd Administracyjny, Informacja o działalności sądów administracyjnych w 2015 roku, Warszawa 2016, [online] <www.nsa.gov.pl/download.php?id=335\&mo$\mathrm{d}=\mathrm{m} / 11 /$ pliki_edit.php $>$ [dostęp: 28.12.2018]. 
Odpowiedź sekretarza stanu w Ministerstwie Spraw Zagranicznych - z upoważnienia prezesa Rady Ministrów - na interpelację nr 18706 w sprawie zastrzeżeń do Karty Praw Podstawowych, [online] <http://www.sejm.gov.pl/sejm7.nsf/InterpelacjaTresc.xsp?key=6CD471D2> [dostęp: 28.12.2018].

Opinia Doradczego Komitetu Prawnego przy Ministrze Spraw Zagranicznych z 21 maja 2008 r. dotyczacej skutku prawnego Protokotu w sprawie stosowania Karty Praw Podstawowych Unii Europejskiej w stosunku do Polski i Zjednoczonego Królestwa, „Przegląd Legislacyjny" 2011, nr 1.

Opinia [Rady Legislacyjnej] z 17 marca 2008 r. w sprawie skutków prawnych Karty Praw Podstawowych, RL-0303-8/o8, [online] <http://radalegislacyjna.gov.pl/dokumenty/opinia-z-17-marca-2008-r-w-sprawie-skutkow-prawnych-karty-praw-podstawowych> [dostęp: 28.12.2018].

Podręcznik europejskiego prawa o niedyskryminacji, Fundamental Rights Agency, [online] < fra.europa.eu/sites/default/files/fra.../1510-FRA_CASE_LAW_HANDBOOK_PL.pdf> [dostęp: 28.12.2018].

Sprawozdanie roczne, Biuro Orzecznictwa Naczelnego Sądu Administracyjnego, Warszawa, kwiecień 2015, [online] <http://www.nsa.gov.pl/sprawozdania-roczne.php> [dostęp: 28.12.2018]. 


\title{
Summary
}

\section{Protection of a Constitutional Fundamental Rights Standard Higher than European Union's and of Polish Constitutional Identity.}

\author{
Constitutional Tribunal \\ and Court of Justice of the European Union: \\ From a Hierarchical Towards a Sequential Model of Adjudication
}

The book attempts to investigate and propose a solution aimed at minimizing potential conflict between the European Union's fundamental rights protection standards and constitutional ones, when the latter are higher, but obligations stemming from EU law and Polish membership of the community demand limiting them. The author proposes a braver application of the referral for preliminary judgment procedure to the Court of Justice of the European Union (CJEU) by the Polish Constitutional Court (CC). In such a referral, the CC would invoke art. 4(2) TEU and the obligation expressed within it requiring the $\mathrm{EU}$ to respect the constitutional identity of its member states in connection with art. $53 \mathrm{ChFR}$, as well as in light of other EU law and domestic (constitutional) law provisions in situations in which EU law would not compromise constitutional standards as such, but standards belonging to Polish constitutional identity.

The dissertation attempts to develop a possible cooperative mechanism for arriving at a conclusion regarding which standards should preponderate. The aim is also to present the advantages of such a mechanism in comparison to an isolationist approach aligning constitutional identity protection with the ultra vires doctrine and putting it on another level in the well-known sovereignty conundrum. Moreover, the book also seeks to balance the competences of the CC and the CJEU in that endeavour, as well as trying to show convincing arguments for this and make them cooperate and mutually respect their competences and positions in their respective legal systems through a sequence - not a hierarchy - of adjudication.

This all leads to the development of a sequential and non-hierarchical mechanism of adjudication, within which the "last word" dispute is replaced with an attempt at reaching judgments that are as satisfying as possible for both the EU and domestic legal contexts, and which are commonly agreed on by the CJEU and CC. Within this 
procedure, the gravity shifts from the "last word" court to the "first word", provided that such a judicial stand and the reasoning contained in it meets certain requirements, which are also highlighted in the book.

The book does not favour any of the different philosophical and theoretical approaches to EU and European constitutionalism. It does not support constitutional pluralism in any of its denominations nor constitutional patriotism in any of its denominations or any other EU constitutional theory. It offers a cooperative mechanism which may, in the eyes of the author, limit the collision zone between EU and domestic law without the need to subsume any of the theoretical approaches. In that sense, it is focused on avoiding conflict and resulting from this necessity to establish certain hierarchies before it emerges. The book's aim is thus more pragmatic than theoretical.

The book is divided into an Introduction and Concluding Remarks, with four chapters in between. The first of these chapters analyses the scope of application of EU fundamental rights to the Member States, according to the EU Charter of Fundamental Rights and the CJEU's jurisprudence. It shows how the application of EU fundamental rights is, in the eyes of the CJEU, oriented around the principle of the effectiveness of EU law and how it spreads the EU standard. The second chapter shows Polish courts' practice in that regard. It criticizes Polish courts' current, rather unreflective approach to that issue and shows the dangers that stem from this fact. Finally, it contains suggestions as to how the courts should improve. The third chapter shows the status of EU law in Poland and the CC's approach to it, which does not conform to the strict reading of the principles of autonomy, primacy, unity and effectiveness of EU law that the CJEU promotes. It also explores the CC's claim to preserve scrutiny competence, albeit limited, also over EU law. The fourth chapter develops the aforementioned sequential mechanism of cooperation of the CJEU and the CC in assuring respect of domestic fundamental rights protection standards higher than the EU's, which belong to the constitutional identity of the state, as well as ensuring the highest respect possible for the primacy, unity and effectiveness of EU law. It also attempts to show that applying this mechanism might bring effects that are beneficial for European integration. It does so against the background of some other Member States' constitutional courts' jurisprudential developments, especially those (like the German Federal Constitutional Court or the Italian one) directly engaging the CJEU, which do not share the approach presented in the book and thus lead to losing the cooperative benefits which the sequential adjudication mechanism proposed in the book offers. 


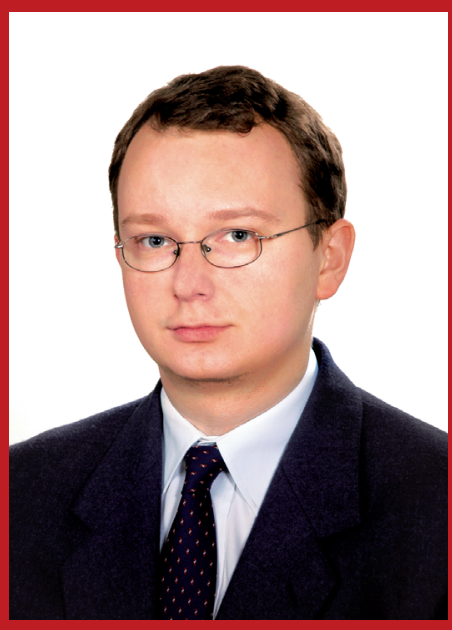

WŁADYSłAW JÓŹWICKI - doktor nauk prawnych, adiunkt w Zakładzie Prawa Konstytucyjnego WPiA UAM. W 2011 roku ukończył magisterskie studia prawnicze na WPiA UAM. W 2009 roku ukończył magisterskie studia w zakresie nauk politycznych w INP UW. W 2006 roku ukończył także studia na Uniwersytecie Middlesex w Londynie, uzyskując tytuł $B A$ in Political and International Studies with Foint Degree. W roku akademickim 2018/2019 trzy miesiące spędził jako Visiting Research Fellow na Wydziale Prawa Uniwersytetu Kopenhaskiego w instytucie iCourts (Danish National Research Foundation's Centre of Excellence for International Courts). Absolwent European Inter-University Centre w Wenecji Academy of Human Rights (2016 i 2017) oraz European University Institute we Florencji Academy of European Law zarówno w dziedzinie prawa unijnego (2013), jak i prawa praw człowieka (2013). W 2015 roku przez dziewięć miesięcy ekspert w dziedzinie prawa konstytucyjnego w Biurze Prawa i Ustroju Kancelarii Prezydenta RP oraz członek Prezydenckiego Programu Eksperckiego „Laboratorium Idei”. Członek polskich i międzynarodowych zespołów badawczych. Autor licznych publikacji naukowych.

Jego badania koncentrują się przede wszystkim wokół problematyki konstytucyjnej, unijnej i międzynarodowej ochrony praw i wolności jednostki, relacji pomiędzy tymi systemami oraz metod rozwiązywania potencjalnych konfliktów między nimi, a także wokół problematyki sądownictwa konstytucyjnego, unijnego konstytucjonalizmu oraz naczelnych zasad ustrojowych, w tym przede wszystkim zasady dobra wspólnego.

Koncepcja pracy jest jasna, przemyślana i konsekwentnie realizowana. Autor wykazuje wszechstronną i głęboką znajomość omawianych zagadnień, a praca prezentuje bardzo wysoki poziom merytoryczny. Jest wartościowa nie tylko naukowo, ale może być pomocną wskazówką dla sędziów, w jaki sposób należy rozwiązywać problemy wskazane w rozprawie.

prof. dr hab. Krzysztof Wójtowicz, UWr

Praca poświęcona jest zagadnieniom ważnym, aktualnym, lecz przy tym spornym i trudnym. [...] praca zasługuje na jednoznacznic pozytywną ocenę. Autor wybrał trudną, interdyscyplinarną problematykę i znakomicie sobie z nią poradził. Koncepcja pracy - jasna oraz przemyślana - została przez Autora konsekwentnie zrealizowana. Praca prezentuje wysoki poziom zarówno pod względem formalnym, jak i merytorycznym.

dr hab. Aleksandra Kustra-Rogatka, UMK

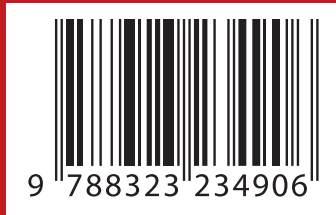

ISBN 978-83-232-3490-6 ISSN 0083-4262 